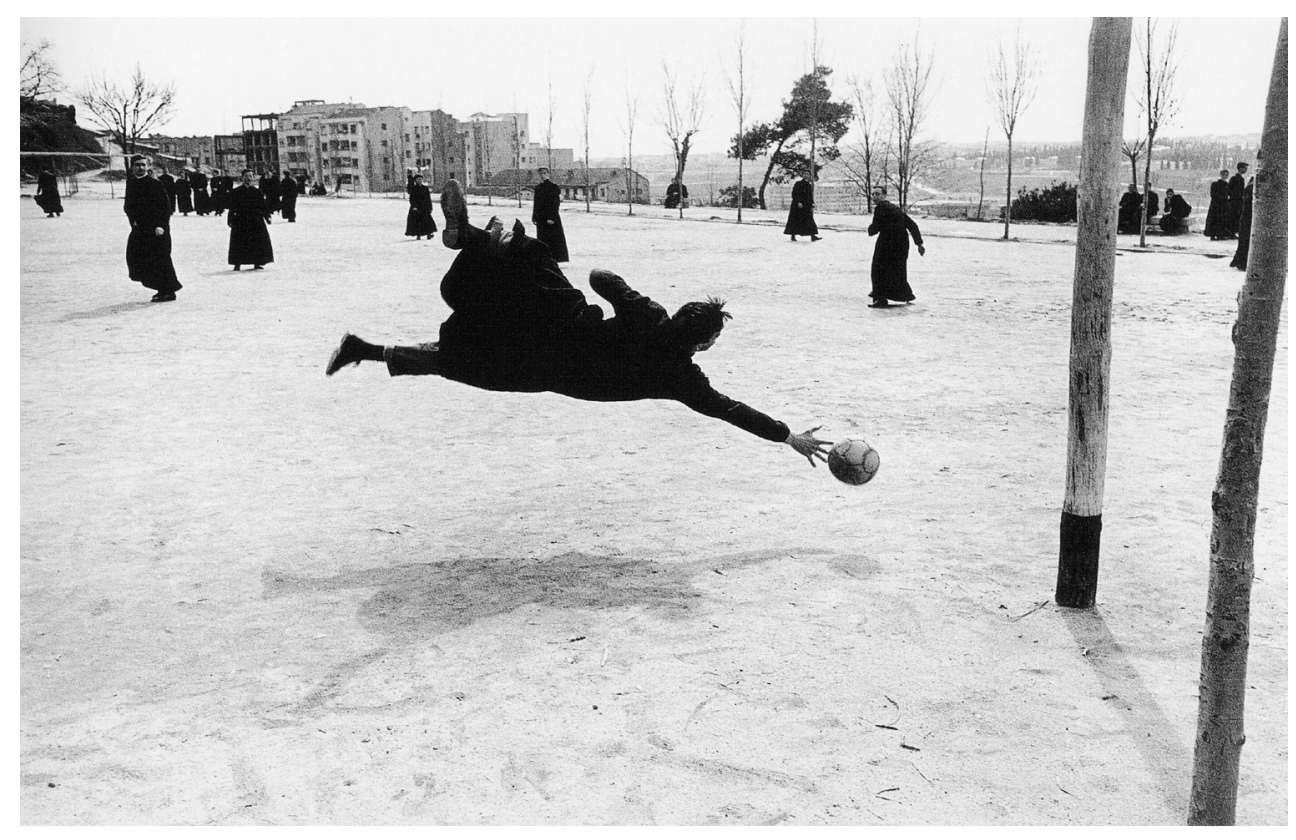

\title{
EL ROBLE EN EL PÁRAMO La trayectoria fotográfica de Ramón Masats
}

Tesis Doctoral presentada por: Jaime Fuster Pérez Dirigida por: Dr. David Pérez Rodrigo 





\section{ÍNDICE}

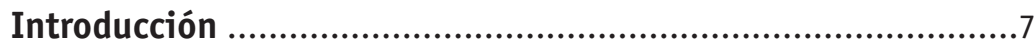

1. La era de Franco: una breve aproximación histórica............19

1.1. LA REALIDAD INTERNACIONAL: EL BLOQUEO ........................... 19

1.2. LA ESTÉTICA FRANQUISTA .............................................21

1.2.1. La influencia del gusto personal de Franco y su vinculación con la fotografía .................................................... 21

1.2.2. La iconografía católico-folclórico-imperial.......................22

1.2.3. La ideologización de la historia..................................24

2. La fotografía oficial de principios de los años cincuenta: el contexto en el que Masats se forma........................................27

2.1. LAS ASOCIACIONES FOTOGRÁFICAS.....................................28

2.1.1. El estatus del fotógrafo aficionado ............................. 32

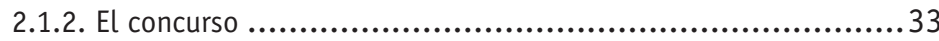

2.2. LA FOTOGRAFÍA SEUDOARTÍSTICA ..................................... 37

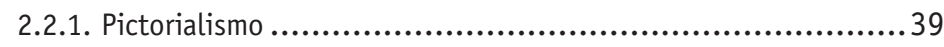

2.2.2. La fotografía pretendidamente "pura" ............................50

3. La aceptación internacional. Cambios en la política interior

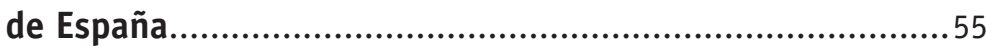

3.1. LA BATALLA IDEOLÓGICA ................................................59

3.2. UN ARTE PARA LA EXPORTACIÓN ......................................62 62

4. La crisis ideológica que precede a la renovación ....................69

4.1. LUIS NAVARRO (LUIS CONDE VÉLEZ), LO NAÏF..............................70

4.2. FRANCESC CATALÀ-ROCA, LA INFLUENCIA NACIONAL. .....................75

5. La fotografía joven, el cambio de la generación de Masats .. 81

5.1. LA AGRUPACIÓN FOTOGRÁFICA DE CATALUÑA .........................83

5.2. AFAL ............................................................. 86

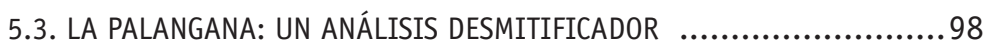

5.4. INFLUJOS COSMOPOLITAS Y PROTAGONISTAS.......................... 107 
5.4.1. Oriol Maspons.................................................... 110

5.4.2. Gonzalo Juanes............................................... 112

5.4.3. Xavier Miserachs................................................ 114

5.4.4. La aportación extranjera....................................... 114

5.5. UN ANEXO SOBRE LA RELACIÓN ENTRE LA DICTADURA Y LA FOTOGRAFÍA JOVEN: EL CASO DE DELEITOSA Y EL COMPROMISO SOCIAL ............ 121

6. Acervo conceptual de Ramón Masats: rasgos de una poética . 139

6.1. EL NOMBRE DEL ENEMIGO: SALONISMO .............................. 140

6.1.1. El antipictorialismo como respuesta a la modernidad .......... 152

6.1.2. Contra el tecnicismo aséptico.................................. 157

6.2. EL FOTÓGRAFO ES EL OBRERO DE LA CÁMARA .......................... 164

6.2.1. El profesionalismo fotográfico ................................ 165

6.2.2. La tensión entre instinto e intelecto ........................... 171

6.2.3. La esquizofrenia del autor profesional ......................... 175

6.3. ARTE Y UTILIDAD: EL VALOR COMUNICATIVO ........................... 186

6.4. UN COMPROMISO ÉTICO ............................................... 194

6.5. ¿INTERVENCIÓN 0 PURISMO? .......................................... 202

7. Análisis de una praxis partiendo del propio autor ........... 209

7.1. EN TORNO A LA IMAGEN TÓPICA..................................... 209

7.2. LA LLAMADA FOTOGRAFÍA DE FORMAS .............................. 221

7.2.1. La Barceloneta y Las Ramblas .................................. 240

7.2.2. El regreso a la no figuración en la etapa en color............... 259

7.3. EL REPORTAJE ................................................... 272

7.4. EL LIBRO COMO SOPORTE Y UNIDAD NARRATIVA ...................... 290

7.4.1. La narratividad de las series fotográficas ....................... 290

7.4.2. Los Sanfermines $(1956$ - 1963) ................................ 306

7.4.3. La colección Palabra e Imagen de Lumen: una referencia ineludible.. 320

7.4.4. Neutral Corner (1962) .......................................... 330

7.4.5. Viejas historias de Castilla la Vieja (1964) ...................... 347

7.4 6. Un proyecto descartado......................................... 359

7.5. EL ABANDONO DE LA FOTOGRAFÍA Y EL SALTO AL DOCUMENTAL Y A LA TELEVISIÓN: UNA NUEVA INVESTIGACIÓN........................... 362

Conclusiones ......................................................... 387

Cronología............................................................. 395

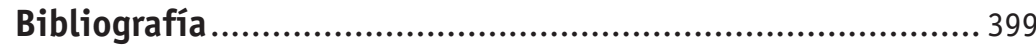

Resúmenes......................................................... 413 


\section{INTRODUCCIÓN}

Se suele identificar metafóricamente el periodo de la dictadura franquista con un páramo cultural yermo y seco, caracterizado por la ausencia de cualquier rastro de vida intelectual y/o creativa. Este desértico panorama quedará determinado por el exilio, el ostracismo y la propia depuración operada desde las instituciones dominadas por el Régimen. Sin embargo, sin restar validez general a esta apreciación, la misma requiere unas ciertas puntualizaciones. En este sentido, cuando recientemente Julián Marías reflexionaba sobre la cantidad y la calidad de la producción intelectual generada en parte del citado periodo proponía la introducción de una nueva figura: desde su punto de vista la existencia del páramo no invalidaba la presencia de una peculiar vegetación ${ }^{1}$.

$\mathrm{Si}$, partiendo de esta apreciación, tuviéramos que escoger una especie vegetal que por sus características representara a Ramón Masats, no nos cabe duda de que la misma sería la de un roble o una encina. Todo aquel que haya conversado con Masats y haya oído desplegar sus reflexiones a mazazos, con esa cavernosa y poderosa voz, o haya observado los ademanes firmes de sus enormes brazos y manos mientras sus negros y penetrantes ojos analizan con curiosidad, comprenderá rápidamente que a Masats sólo lo puede representar una entidad vegetal enorme, fértil, frondosa, en ocasiones nudosa y áspera, pero sin duda un árbol sólido, macizo, terco y muy, muy longevo. La obra de Masats se extiende con coherencia y firmeza, llegando hasta nuestros días con la misma frescura y potencia de hace cincuenta años. De ahí que no nos dejen de sorprender la vitalidad y la vigencia de sus imágenes, llenas de espontaneidad y de energía pero, al mismo tiempo, nunca improvisadas ni accidentales.

A veces es complicado poder justificar completamente nuestras motivaciones pues no todas las reflexionamos y las meditamos convenientemente. En nuestro caso, seleccionar a Ramón Masats como tema de nuestra tesis doctoral ha sido fruto de una mezcla de impulsos, unos meramente prácticos o racionales, otros emocionales y, por último, los más determinantes, de pura intuición.

Por nuestra formación académica, titulado en la Escuela Superior de Fotografía del C.E.U. San Pablo y licenciado en Ciencias de la Información, rama Imagen y Sonido, así como por nuestros intereses creativos 0 , incluso, profesionales, después de haber trabajado seis años como Operador de Cámara en los informativos de Canal-9, siempre nos ha seducido el reportaje fotográfico. Se trata de nuestro campo de actuación, el marco de referencia, el ámbito creativo donde nos encontramos más cómodos y donde nos manejamos con más soltura. A su vez, crecimos fotográficamente al amparo de Cartier-Bresson, admirando profundamente a Doisneau, a Haas, a Salgado o a Robert Capa. Y en estos términos buscábamos nuestro sujeto/objeto de investigación. Éste debía ser un reportero puro, un fotógrafo que compartiera más o menos los mismos referentes que nosotros para asegurar la mutua comprensión que ofrece el usar el mismo lenguaje y los mismos conceptos. Asimismo, buscábamos un autor todavía en activo, o recientemente retirado: ello podría facilitarnos parte de la documentación que requiere un trabajo de esta índole, a la par que podría permitirnos conocer y entrevistar a auténticas leyendas vivas de

1 Marías, Julián, "La vegetación del páramo", en AA. VV., España años 50. Una década de creación, Madrid, SEACEX, 2004, pág. 17. 


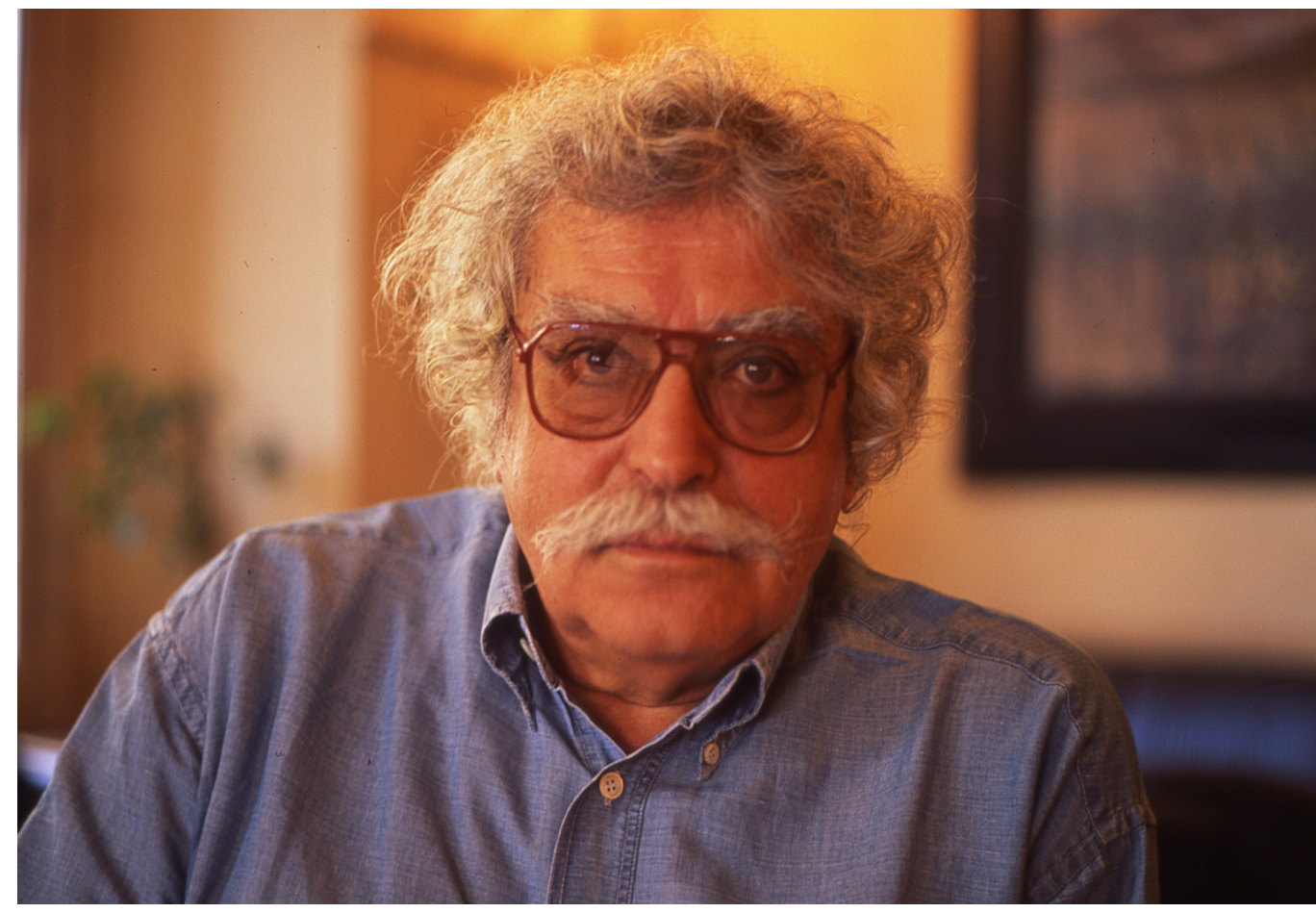

Retrato de Ramón Masats tomado en nuestra primera entrevista el día 17 de julio de 1999 en el Círculo de Bellas Artes de Madrid.

nuestra Historia Fotográfica. Sólo por eso, por conocerlos en persona, por ir a sus estudios o a sus casas, por charlar amigablemente sobre fotografía, ya nos parecía estimulante. De hecho, no sólo nos serviríamos de sus conocimientos y su memoria histórica para nuestra tesis. Un reportero con experiencia tiene muchas cosas que enseñar... algunas aprovechables para nuestra investigación, otras provechosas no sólo para nuestro propio trabajo -nuestros reportajes personales-, sino también para nuestra percepción de la fotografía en la historia y en la actualidad.

Una vez delimitado este marco -reporteros españoles vivos- analizamos la conocida Historia de la fotografia en España, de Publio López Mondéjar², para empezar a delimitar el perfil de nuestros candidatos. El periodo histórico de los años cincuenta y sesenta parecía ser el más interesante. En él concurren dos aspectos que conviene destacar. En primer lugar, los fotógrafos surgidos durante estos años se convirtieron en una generación de ruptura y choque con la generación anterior, reivindicando el reportaje puro en clara oposición a la fotografía pictorialista y concursística. Por ello, nuestro autor no sólo sería interesante por sí mismo, sino también como representante de una generación y de una época. En segundo lugar, la mayoría de los componentes de este segmento artístico todavía sigue en activo lo que nos permitiría conocerlos personalmente.

Consultamos con Koldo Chamorro, fotógrafo especializado en reportaje aunque perteneciente a una generación posterior, sobre qué autor estudiar, y él nos sugirió a Masats. Sabíamos que una tesis es un trabajo largo, absorbente y que requiere de una entrega total para su consecución, de ahí que la sintonía con nuestro autor debía ser absoluta. Creo recordar que una de las primeras fotos que vimos de Masats fue la del toro agonizante en Pamplona. Conocíamos escasamente la 
obra de éste, pero aquella imagen nos impresionó profundamente. La víctima ante los verdugos, la intuida mirada del animal a la multitud en silencio, acusadora, rabiosa, digna. Podía interpretarse como la agonía de la España de la posguerra, del franquismo...

Una rápida consulta al catálogo editado con motivo de la exposición Cuatro direcciones. Fotografía Contemporánea Española 1970-1990³, nos permitió confirmar nuestra primera impresión. Cuando vimos la foto del seminarista jugando al fútbol o la del perrito con su amo apoyando los pies en su lomo... sabíamos que teníamos delante a nuestro autor, nuestro sujeto/objeto de investigación. Después de diversas gestiones, nos pusimos en contacto con él, meses antes de su primera exposición antológica en el Círculo de Bellas Artes de Madrid, en 1999. De la primera entrevista que mantuvimos con él extrajimos diversas conclusiones:

1) No conserva casi nada: ni artículos, ni revistas, ni cartas. Lo tiró todo cuando abandonó la fotografía y pasó al cine y la televisión en 1967.

2) Tiene mala memoria. No le gusta reflexionar sobre el pasado y está en activo. Sólo le importa el futuro, de ahí que datos, fechas y eventos tengan que ser traídos a colación por nosotros. Masats no nos sirve como base documental fiable.

3) No le gusta hablar sobre sí mismo. Ello hace que sea muy difícil obtener de él información válida, no obstante es franco, sincero y sin compromisos que satisfacer ni oídos que alagar. Asimismo, es encantador en su aparente brutalidad y en su grandeza, con esa voz grave y esos ojos profundos...

Pese a estas dificultades supimos que haríamos nuestra tesis doctoral sobre él.

El fotógrafo Ramón Masats Tartera nació en 1931 en Caldes de Montbui. Su infancia y su juventud se le fueron entre los malos estudios y las aspiraciones a joven promesa de atletismo nacional, ayudadas por su fornida constitución, los entrenamientos en Montjuïc y las jornadas de natación en el puerto de Barcelona, en pleno invierno... Su familia regentaba un negocio propio, la pesca salada, que obligó a Masats a trabajar desde muy joven, dados sus desiguales resultados académicos. Madrugones intempestivos, carga y descarga de camiones llenos de pescado... Poco hacía prever que, años más tarde, Masats se convertiría en uno de los mejores fotógrafos españoles de los años cincuenta y sesenta. Su única preparación estética, como presume Chema Conesa en la introducción del catálogo de La memoria construida ${ }^{4}$, se ceñía a la estibación de los salazones: el bacalao y las anchoas colocadas meticulosamente en la furgoneta del negocio de su padre, una manera de aprender a componer en el espacio tan evidente como estricta. La geometría y la composición aplicada al aprovechamiento máximo de la carga de una furgoneta de reparto.

Su incorporación a la fotografía se produjo por casualidad, como no podía ser de otro modo. Durante el servicio militar, como se aburría mucho, Ramón leía. Masats siempre había leído y lo hacía compulsivamente, irracionalmente. Masats devoraba todo lo que caía ante sus ojos -leyó todas las obras de teatro de Shakespeare antes de los diecisiete años-. Y quiso la casualidad que cayera ante sus ojos un número de la recién aparecida revista Arte Fotográfico. Esa afortunada anécdota ocurrió en 1953 y sólo una década más tarde Masats declinará el ofrecimiento de realizar una exposición individual en la Galería Juana Mordó, probablemente la mejor galería de arte de España en aquellos años. Allí realizará una exposición colectiva junto a Carlos Saura, pero una individual nunca.

¿Qué llevó a Masats de cargar bacalao a exponer junto a Saura en la Galería Juana Mordó, en sólo diez años de intervalo? ¿Qué le indujo a renunciar a exponer individualmente?

3 AA. VV., Cuatro direcciones. Fotografía Contemporánea Española 1970-1990, Madrid, Museo Nacional Centro de Arte Reina Sofía, Ministerio de Cultura/Lunwerg, 1991.

4 Ramón Masats, La memoria construida, Madrid, Dirección General de Archivos y Bibliotecas, Consejería de las Artes, Comunidad de Madrid, 2002. 
Hay actitudes como la constancia, el sacrificio o la mera resistencia física aprendidas durante la juventud que probablemente ayudaron a templar el carácter de Masats. Su innata inteligencia y sensibilidad también. Pero lo que siempre ha reivindicado Masats ha sido su intuición. Ramón Masats reniega vehementemente de cualquier vinculación, plástica o estética, con autor o movimiento alguno. Él se autodenomina "intuitivo", más o menos con aquel significado que Konrad Lorenz atribuyó al término, en el que el instinto, dirigido por un programa genético, justifica parte del comportamiento de los animales y del hombre. A su vez, Masats admira a los grandes y en ocasiones ha "vibrado en sintonía" con alguno de ellos, pero siempre por pura coincidencia. El presente trabajo pretende aclarar tales extremos.

No podemos olvidar que Ramón Masats constituye por sí solo una figura trascendental en nuestra Historia de la Fotografía tanto por su numerosa obra - por el impacto que la misma ha supuesto para nuestra memoria colectiva-, como por su vigencia en la actualidad. Pocos autores han conseguido construir la memoria visual de un país con un trabajo tan despojado del rico y variopinto anecdotario que nos constituye $y$, a la vez, tan lleno de verdad y autenticidad. De una gran sencillez y una aparente naturalidad, la obra de Masats se yergue firme y sin fisuras, asumiendo tanto los conceptos teóricos de sus coetáneos, como revelando líneas de investigación propias. Esta dualidad, colectiva e individual, dificulta cualquier intento de clasificación en género y especie del conjunto de su producción. Podría decirse que Masats es un fotógrafo especializado en reportaje, un humanista, pero rápidamente habría que objetar que también trabaja la abstracción y las imágenes plásticas. Quizás podría argumentarse que Masats se especializó en captar instantes vivos y de gran expresividad, aunque igualmente habría que añadir que también ha investigado las posibilidades narrativas de los grupos de imágenes, ampliando el lenguaje fotográfico para llegar a un híbrido entre el cine y la imagen estática. La obra de Masats se extiende durante más de cincuenta años de actividad y prosigue febrilmente en la actualidad a pleno rendimiento. Es un maestro en blanco y negro y domina como pocos los complejos códigos del color. Asimismo, es un erudito que revindica la intuición como fundamento de su obra y un fotógrafo que defiende la palabra impresa de su amada biblioteca por encima de sus imágenes fotográficas. Masats está lleno de contradicciones, de matices y facetas que son asumidas con total naturalidad por él mismo y que no hacen más que otorgarle una mayor fascinación e interés.

La justificación de la necesidad de estudiar su obra y su figura se evidencia tanto por la oportunidad de aprender y comprender sobre/con sus imágenes, como por la posibilidad de contribuir al reconocimiento de un autor fundamental en la fotografía mundial. Masats representa a una generación que, aglutinada en torno a AFAL (la Agrupación Fotográfica Almeriense), representó la vanguardia, la renovación, la revolución de la fotografía española en la época franquista. Este periodo histórico tuvo tanta trascendencia que ha suscitado varias tesis doctorales: la realizada por Maria Dolors Tàpias, bajo la dirección de Francisco Caja, con el título Barcelona Blanc i Negre de X. Miserachs, y el reportaje urbano en la Barcelona de los años sesenta (leída en 1991) y la realizada por Laura Terré, dirigida también por Francisco Caja, El grupo fotográfico Afal (1956/1963). Estudio del periodo y aproximación a sus ideas estéticas (leída en la Universidad de Barcelona en 1998). Ambas tesis coincidían en reconocer la falta de estudios existentes sobre la fotografía realizada en el periodo histórico comprendido entre los años cincuenta y principios de los setenta en España. Años, precisamente, de formación y maduración de la obra de Masats y de todos sus compañeros de revolución. Las razones alegadas para la existencia de esas lagunas históricas son diversas, aunque bien pudieran obedecer a un agravio generacional. La generación posterior a Masats -a AFAL- se reunió en torno a la revista Nueva Lente. Ella no sólo aglutinó un nutrido grupo de fotógrafos, sino también asentó el discurso de los principales críticos, comisarios e investigadores de la Historia de la Fotografía Española desde finales de los años setenta hasta principios de los noventa. Todos éstos olvidaron durante casi quince años a la generación de fotógrafos anteriores a ellos mismos, dejando una laguna de grandes proporciones que espera ser subsanada poco a poco, y a cuya recuperación pretendemos contribuir. 
Mucho ha cambiado la popularidad de Masats desde que iniciamos la tesis en 1998 hasta nuestros días. De técnico con un excelente prestigio, conocido y reconocido exclusivamente en ámbitos profesionales especializados, a clásico incuestionable y jurado en certámenes nacionales, pasando por invitado habitual en exposiciones colectivas antológicas, entrevistado en revistas especializadas en fotografía pero también en radio, televisión y prensa, representante de la fotografía española más actual en exposiciones internacionales... Masats es considerado hoy un maestro de pleno derecho por su trayectoria histórica así como por las nuevas imágenes que sigue generando de manera incansable.

Como ya hemos comentado, la primera vez que contactamos con Masats fue en la primavera de 1999, un par de meses antes de su gran exposición antológica en el Círculo de Bellas Artes de Madrid, producida dentro del Festival Internacional de Fotografía PhotoEspaña. Aquella muestra supuso el descubrimiento de Masats por el gran público. A ello contribuyó el magnífico catálogo editado con textos de Carlos Saura, Caballero Bonald y Publio López Mondéjar. Poco más tarde, el 23 de abril de 2001, se le entregó el Premio de Cultura de la Comunidad de Madrid en la modalidad de fotografía. El premio también incluía una exposición (cuya inauguración tuvo lugar el 3 de diciembre de 2002 en el Canal de Isabel II: La memoria construida, comisariada por Chema Conesa) y la publicación de un catálogo con textos de Francisco Umbral y el propio Chema Conesa. Finalmente, el cénit de su carrera (por el momento) culminó el 16 de noviembre de 2004 cuando se le concedía el premio Nacional de Fotografía otorgado por el Ministerio de Cultura. El jurado estuvo presidido por el director general de Bellas Artes del Ministerio de Cultura, Julián Martínez, e integrado por el director del Centro Andaluz de Fotografía, Manuel Falces; la directora de la revista Exit, Rosa Olivares; el pintor y escultor Rafael Canogar; el director de la Escuela de Cinematografía de Madrid, Fernando Méndez-Leite; el profesor de Historia de la Fotografía de la Universidad de Castilla-La Mancha Horacio Fernández, y el ganador de la edición anterior, Carlos Pérez Siquier. La concesión del premio se argumentó por la atemporalidad y, por tanto, la vigencia de la obra de Masats. Como era de suponer, a partir del Premio Nacional la explosión de actividades que Masats realiza se dispara y es casi imposible llevar razón de todas ellas, por ello sólo nos hemos hecho eco de los hitos más importantes de su carrera, obviando una infinidad de actos, mesas redondas, conferencias, exposiciones, entrevistas y publicaciones en los que Masats ha sido requerido recientemente.

Vista la importancia alcanzada por nuestro autor en el panorama fotográfico actual, parece inexcusable la necesidad de un trabajo de investigación en profundidad pero, a pesar de todo lo dicho, éste no se ha llegado a producir hasta el momento, ya que la obra de Masats nunca se ha abordado con la suficiente extensión y rigor. Todos los textos que tratan sus imágenes se limitan a repetir una serie de manidos e imprecisos tópicos que no hacen justicia a un artista tan multicefálico y complejo como apuntábamos más arriba.

Como se puede comprobar en el índice elaborado, la ESTRUCTURA DE LA TESIS presenta tres amplios bloques generales:

-Contextualización histórica.

-Conceptos de la poética de Masats.

-Análisis de la obra.

La articulación de la contextualización histórica atiende a varios estratos de aproximación. Esta distribución por niveles trascurre de lo general a lo particular: es decir, dado el peculiar momento histórico que vive Masats en su periodo de formación, y dada la inevitable y decisiva influencia que los aspectos extrafotográficos tuvieron en su obra, nos vemos obligados a referirnos a todos aquellos acontecimientos para, poco a poco, iniciar la aproximación a nuestro autor. Por ello, el primer capítulo se centra en las circunstancias políticas, sociales y económicas existentes en la España de la dictadura franquista. La obra de Ramón Masats 
se inicia a partir de 1953, cuando el periodo más duro de la posguerra acaba. Es un momento de cambios políticos vitales tanto a nivel internacional como nacional. Ningún autor del momento se mantendrá al margen de las implicaciones y consecuencias de hechos históricos tan determinantes como la propia existencia de la dictadura franquista o el nuevo orden internacional gestado después de la II Guerra Mundial. Este reparto geopolítico traerá consigo el inicio de la guerra fría, pero para nuestro país supondrá el fin de la autarquía y la posterior aceptación de España por parte de la Comunidad Internacional a través de su definitivo ingreso en la 0.N.U.

A continuación (apartado 1.2.) nos centramos de un modo general en la vertiente plástica y en las ideas estéticas de la iconografía oficial franquista. No nos cabe la menor duda de que una dictadura totalitaria como la que sufrió España durante casi cuarenta años -centrada en el poder unipersonal y autoritario de Franco- llegó a todas las parcelas de la sociedad: desde las económicas, políticas o sociales, hasta las artísticas y culturales. Siguiendo la lógica aproximativa a nuestro tema, el siguiente nivel (acotado en el capítulo 2) ya se ciñe a la fotografía, aunque por el momento siga aludiendo a la fotografía oficial del Régimen: si existió una estética franquista capaz de generar una determinada literatura y arquitectura, es evidente que también debió existir una fotografía dirigida, apoyada y organizada desde el aparato ideológico franquista. Habría que determinar si estas premisas son correctas y establecer, exactamente, las características y particularidades de este tipo de fotografía. ¿Qué autores fueron los más representativos?, ¿qué instituciones u organizaciones apoyaron y fomentaron su implantación?, ¿cómo estaba organizado el entramado fotográfico? En resumen, ¿cuál fue la fotografía oficial de régimen de Franco? Enfrentarnos a estas cuestiones supone observar cómo las mismas ideas estéticas examinadas en el apartado anterior se aplican a la fotografía oficial del Régimen de un modo siniestramente coherente. De este modo hemos repasado con concisión el escenario vigente al comienzo de la revolución que Masats y sus compañeros de generación llevan a cabo. Este análisis de la situación previa nos permite entender mejor el sentido de la transformación efectuada por la generación de Masats, así como saber contra qué luchaban, hecho que posibilita situar mejor sus nuevos planteamientos fotográficos.

El siguiente apartado analiza la sublevación fotográfica propiamente dicha. Una vez más repetimos el esquema: primero los motivos políticos y sociales que permitieron el cambio (capítulo 3) y, a continuación, cómo afectaron esos cambios de orientación política al panorama cultural y artístico. Ya hemos comentado el ingreso de España en la 0.N.U. Conocido es que los pintores españoles coetáneos a Masats -por ejemplo el grupo El Paso- se aprovecharon de las operaciones de cosmética que, de cara al exterior, realizó la dictadura franquista. Esta relativa apertura ¿facilitó el tránsito de ideas fotográficas entre el resto del mundo y España?, ¿cuáles fueron los cauces de esa entrada de nuevas ideas? Por último, también analizamos los antecedentes que plantearon la necesidad del cambio a nivel fotográfico (capítulo 4). Así vemos que, a pesar de que la fotografía siempre ha mantenido un estatus un tanto marginal dentro de la cultura y el arte, de alguna manera el tránsito hacia la superación del franquismo fue una necesidad común que se debió a las mismas circunstancias y se originó casi al mismo tiempo en muchos aspectos de la sociedad.

Llegados a este punto, una vez repasados los condicionamientos políticos y sociales, y revisados los cambios que asimismo gozaron otras manifestaciones artísticas o culturales, abordamos el estudio de la generación de Masats y de la revolución que protagonizó. A pesar de que la práctica fotográfica requiere de una gran independencia y hasta de una áspera soledad, Masats siempre ha sido una persona gremial. Ha tenido conciencia de pertenencia a un grupo con el que compartir información, defender unas ideas, promocionar su obra y relacionarse socialmente. ¿Cuáles fueron el resto de los protagonistas de la vanguardia? y ¿cuáles los motivos que los 
empujaron al cambio? Aunque Masats tuvo su primer contacto con la fotografía en el Casino de Comercio de Tarrasa, donde aprendió las bases técnicas del medio, para estudiar la figura histórica de Masats nos centramos en el resto de las asociaciones fotográficas a las que perteneció y en los autores y obras que pudieron influirlo. Todo ello aparece reflejado en el capítulo 5 . Dentro de éste, los tres primeros subcapítulos recogen el paso de Masats por las otras tres asociaciones fotográficas a las que perteneció y que, por otro lado, son las más representativas del momento. Hemos concedido un número importante de páginas a esta sección por distintos motivos: las dos primeras asociaciones son paradigmáticas y trascendentales en aquel momento fotográfico y en la propia formación de Masats. Su paso por la Agrupación Fotográfica de Cataluña y AFAL, y los contactos y amistades resultantes, así como el enfrentamiento interno con alguno de sus compañeros, marcará definitivamente la trayectoria fotográfica de nuestro autor, hecho que habrá que explicar con detalle. El motivo para conceder tantas páginas a su paso por la tercera agrupación (la Real Sociedad Fotográfica de Madrid), y dentro de ella su adscripción al grupo La Palangana, es ligeramente diferente. Al contrario de lo sucedido con las otras agrupaciones, la pertenencia a la asociación más importante de la capital de España no influirá determinantemente en la obra de Masats, es más La Palangana nunca protagonizará ningún papel destacado ni relevante, opinión completamente contraria a los análisis históricos tradicionales que sí le otorgan un rol destacado en la revolución fotográfica de los años cincuenta y sesenta en España: será, por ello, necesario contradecir esta postura y justificar debidamente nuestra teoría. Dentro de este capítulo también hemos prestado atención a aquellas personalidades significativas de las que Masats aprendió, ya estuvieran vinculadas a estas agrupaciones o provinieran del extranjero. Por último, analizamos la percepción que de esta transformación fotográfica surgida en el seno de la sociedad española mantenía la propia Dictadura.

La siguiente gran área temática que abordamos se refiere a los conceptos estético-fotográficos que Masats maneja de un modo más o menos consciente. El orden de los subcapítulos no está tan jerarquizado como los precedentes, aunque, de alguna manera, los primeros apartados corresponden a los conceptos que surgen como reacción y oposición a los principios de la fotografía de corte oficial franquista, mientras que los siguientes responden a las reflexiones que, debido a los antecedentes, las influencias extranjeras o las propias aportaciones de autores nacionales, se van planteando Masats y sus compañeros de generación. En cualquier caso, aunque estos conceptos tendrán implicaciones prácticas trascendentes, no será hasta el último gran bloque temático donde analizaremos la obra de Masats y veremos cómo, desde un punto de vista artístico y plástico, esos conceptos confluyen en la misma. Para ello, vamos a profundizar en las actividades, los manifiestos, las exposiciones, los anuarios, los catálogos y, muy especialmente, en los libros realizados por nuestro autor.

El repaso de la obra más representativa e interesante de Masats nos permitirá descubrir sus aportaciones personales a la fotografía moderna. Este último bloque está dividido en tres grandes grupos ordenados de modo cronológico: en primer lugar, la fotografía más abstracta (representada en sus primeros trabajos en blanco y negro $\mathrm{y}$, paradójicamente, en sus últimas diapositivas en color), a continuación la fotografía de reportaje (que atiende a sus principales libros en blanco y negro ordenados según la fecha de realización) y, por último, una breve introducción a su etapa como realizador audiovisual. No obstante, cabe recordar aquí que la obra de Masats no se ciñe exclusivamente a lo citado. Todo lo contrario, su obra es inmensamente mayor, fruto de su gran labor como profesional de la fotografía.

La catalogación detallada de la obra de Masats resulta absolutamente imposible por varias circunstancias. La más evidente porque Masats no dispone de los originales de todas las fotografías que ha tomado en su vida. Como muestra de ello dos simples ejemplos: algunos de estos originales han sido donados, como un reportaje sobre Cuba que fue regalado a las autoridades 
culturales de la isla; otros robados, como un reportaje completo sobre Arcos de la Frontera que le propuso hacer el representante de turismo francés en España, Bernard Lelong. Lelong desapareció sin pagar a Masats y llevándose las diapositivas originales, material que nunca se ha recuperado.

En realidad, hemos decidido renunciar a entrar en el inventariado exhaustivo porque consideramos de mucha más utilidad la contextualización y el análisis de aquellas obras realmente representativas, importantes y fundamentales en su carrera, es decir, aquellas que ejemplifican con mayor claridad los conceptos que Masats asimiló. Este es el motivo por el que nos limitaremos a reflexionar sobre aquellas obras realmente innovadoras o significativas, sin olvidar referenciar el resto de trabajos. De este modo, podremos ofrecer una panorámica conceptual lo más detallada y comprensiva de su obra. Nuestra investigación, por tanto, no se detendrá en trabajos menores como las fotografías realizadas para la edición ilustrada de Don Quijote o en encargos como los efectuados por el Ministerio de Turismo. De igual modo, sus libros en color -tan parecidos entre ellos- han sido considerados desde una perspectiva unitaria y sin entrar en el análisis de sus contenidos. Asimismo, somos plenamente conscientes de la existencia de una extensa obra audiovisual que escapa a nuestro objetivo investigador: la producción fotográfica de Masats. Sus dieciocho años como realizador y coordinador de series documentales en Televisión Española han generado un número extraordinario de horas de grabación. Dada la extensión y, especialmente, la especificidad del medio audiovisual consideramos que sería necesaria una nueva tesis doctoral que tratara ese material con profundidad. A pesar de ello, no hemos resistido la oportunidad de introducir someramente el periodo y hemos comentado con el autor alguna de sus obras más representativas.

En cierto modo, es lógico que sus imágenes en blanco y negro de la época franquista hayan eclipsado las fotografías de estos últimos años: su joven producción mantuvo el carácter de feroz disidencia contra la fotografía adormecida del franquismo y esa insurrección ya justificaría por sí su importancia. A su vez, estas fotografías, sin renunciar a un elevado interés artístico, reflejan una sociedad desaparecida, de ahí que sea inevitable que las mismas se hayan convertido en documentos de una época. Por otro lado, los libros de Masats publicados en aquel momento han devenido obras imprescindibles, clásicos de gran originalidad y potencia creativa. También es cierto que todos los conceptos fotográficos que Masats manejará el resto de su vida se consolidarán en esos primeros años de formación. Precisamente por ello tiene tanta importancia situar su producción fotográfica en el contexto en el que se produjo, con los valores y preocupaciones de origen. La mejor manera de comprender su obra es manejar las FUENTES DIRECTAS que influyeron claramente en Masats. Debido al aislamiento internacional al que se vio sometido el país por sus simpatías con las potencias del eje en la II Guerra Mundial, la carencia de artículos de importación era manifiesta. No sólo cámaras o materiales fungibles, en el caso de los fotógrafos, también los libros y las revistas extranjeras únicamente pudieron llegar a través de un lento goteo y muchas veces bajo el brazo de los propios fotógrafos. Esta dramática circunstancia, unida a la pobre producción de revistas especializadas en fotografía a nivel nacional, representadas únicamente por Arte Fotográfico (editada a partir de 1952) y por el boletín bimensual de la Asociación Almeriense de fotografía, AFAL (creado en el año 1956), permiten abarcar la práctica totalidad del material básico que podía manejar Ramón Masats en aquellas fechas. En las dos revistas publicará nuestro autor textos o fotografías. De hecho, los jóvenes renovadores utilizarán ambas revistas, aunque Arte Fotográfico fuera más reaccionaria y respetuosa con el salón. De cualquier modo, Arte Fotográfico también tendrá su papel, quizá de manera involuntaria, en la renovación que se cuajaba por toda España. Las dos publicaciones sacarán a la luz entrevistas, artículos de opinión, rumores, peleas dialécticas, enfados, sesudos análisis. En una palabra, pasión por la fotografía. Aquel fue el crisol que Masats utilizó para fraguar sus cimientos. Unas bases que han permanecido 
inamovibles en su fondo hasta el presente y que explican algunos actos quizá incomprensibles desde nuestra perspectiva actual, tal y como sucede con el rechazo de la fotografía artística en favor de la fotografía utilitaria o la defensa de la intuición por contraposición al intelecto. Pretendemos, pues, conocer lo que Masats conoció, leer lo que él leyó, compartir las reflexiones de sus compañeros de revolución, aprender, de algún modo, siguiendo el mismo proceso que pudo seguir nuestro autor... Realmente no nos interesa enfrentarnos tanto al autor/influencia eventual como a la repercusión que tuvo dicho binomio en el propio Masats durante su época de formación. En este sentido, poco importa la evolución posterior de los autores extranjeros o nacionales, o si renegaron de la obra de esos años. Sólo queremos destacar la percepción que Masats tuvo de ellos en aquel preciso momento.

Asumiendo la dificultad que este hecho conlleva intentaremos ceñirnos a los textos originales de la época aunque, en ocasiones, sean reediciones posteriores o compilaciones de obras sobre textos antológicos de fotografía. Los manifiestos, las entrevistas, las críticas... todos los artículos que ayuden a dibujar aquel panorama de cambio serán detalladamente comentados, asumiendo el peligro de que, quizás, la bibliografía pudiera quedar excesivamente sesgada hacia los textos originales de la época en ligero detrimento de la bibliografía actual, más orientada hacia el ámbito de la crítica de arte y a sus vinculaciones con la fotografía.

Esta labor de recopilación de la documentación original se ha complementado con todo un conjunto de ENTREVISTAS A MASATS Y A SUS COMPAÑEROS DE GENERACIÓN, así como a aquellos colaboradores y figuras históricas relevantes en relación al tema que nos ocupa. Evidentemente, el autor con el que hemos mantenido un mayor número de entrevistas es el propio Masats. Cabe destacar que, aunque las constantes conversaciones telefónicas o las revisiones de las mismas que le hemos ido enviando durante todos estos años justificarían que consideráramos todo este material como una larguísima entrevista, en conjunto le hemos visitado en siete ocasiones que se han dilatado a lo largo de ocho años:

-17 de julio de 1999: Círculo de Bellas Artes de Madrid.

-20 de marzo de 2000: cursillo de fotografía en el Círculo de Bellas Artes de Madrid.

-17 de noviembre de 2000: rueda de prensa para presentar su película Topical Spain en Barcelona.

-4 de septiembre de 2002 y 15 de diciembre de 2003: domicilio particular en Madrid.

-25 de marzo de 2004: conferencia en el Colegio Mayor Rector Peset de Valencia.

-20 de octubre de 2004: mesa redonda junto a Carlos Pérez Siquier y Publio López Mondéjar en el Museo de Arte Contemporáneo Esteban Vicente de Segovia.

-27 de diciembre de 2006: domicilio particular en Madrid.

Las otras personalidades entrevistadas han sido:

-Carlos Pérez Siquier, 27 de abril de 2002: domicilio particular en Almería.

-Esther Tusquets y Oriol Maspons, 31 de octubre de 2004: domicilio particular de Esther Tusquets en Barcelona.

-Francisco Ontañón, 28 de enero de 2005: contacto telefónico.

-Koldo Chamorro, 21 de marzo de 2003: domicilio particular en Pamplona.

-Lluis Clotet, 9 de noviembre de 2004: contacto telefónico.

-Óscar Tusquets, 6 de febrero de 2005: contacto telefónico.

-Salvador Pons, 2 de enero de 2007: domicilio particular en Denia.

Todas las citas y referencias extraídas de estas entrevistas se insertarán en nuestro texto de la siguiente manera: nombre y apellidos del autor más el lugar de la entrevista y la fecha; seguido del texto entrecomillado con el mismo tamaño, el mismo interlineado y el mismo sangrado que nuestros textos originales, pues consideramos que estas entrevistas son material original y fuentes de primera mano de considerable valor. 
Cada autor ha sido seleccionado por incidir sobre un aspecto determinado de la obra y figura de Masats. Evidentemente, nos hubiera gustado contar con la opinión y el testimonio de todos los protagonistas, sin embargo no ha podido ser así en algunos casos. José María Artero -cofundador de AFAL- murió en 1991, Miserachs y Paco Gómez lo hicieron en 1998. A Gabriel Cualladó lo conocimos en diciembre de 2002 en la inauguración de la exposición de Masats en el Canal de Isabel II. Hablamos de la posibilidad de una entrevista sin saber que, lamentablemente, fallecería pocas semanas después. Otros autores, simplemente, han declinado hablar con nosotros, como es el caso de Joan Colom, Ricard Terré o Leopoldo Pomés, o lo han intentado pero por causa de la edad no se han visto capaces de recordar con la suficiente fluidez y frescura, como sucedió con Gonzalo Juanes.

De cualquier modo, creemos que la selección de autores entrevistados es suficiente para reconstruir, contrastar y aportar información necesaria y de primerísima mano. Carlos Pérez Siquier representa el alma viva de AFAL y es el autor que mejor conoce aquel movimiento. Esther Tusquets nos ayudó a analizar y comprender la entidad de la colección Palabra e Imagen de la editorial Lumen donde Masats publicó dos de sus libros más importantes Neutral Corner y Viejas Historias de Castilla la Vieja. Oriol Maspons tuvo un papel fundamental en la importación de conceptos desde París aunque también escribió manifiestos, conectó personalidades diversas e intervino directamente en el destino de Masats, tal y como podremos comprobar. A Francisco Ontañón se le atribuye la famosa fotografía que dio nombre al grupo La Palangana, convirtiéndose en uno de sus integrantes desde el principio y de pleno derecho: él nos ha ayudado a desmitificar un grupo al que también perteneció Masats y que no tuvo más producción, como tal, que la tan cacareada fotografía de la palangana. Koldo Chamorro fue comisario de una exposición de Masats sobre Los Sanfermines, que tuvo lugar en Pamplona en 1985. Chamorro, de una generación posterior a la de nuestro autor, conoce su obra perfectamente y como fotógrafo especializado en el reportaje analiza sus imágenes y su figura con un criterio de excepción. Además, Koldo Chamorro es, en parte, responsable de nuestra elección de Masats como tema de nuestra tesis y, por lo tanto, está implicado en este proyecto desde el principio. Lluis Clotet y Óscar Tusquets maquetaron juntos los libros que Masats realizó por encargo de la editorial Lumen. Dada la complejidad de la puesta en página (especialmente de Neutral Corner), su testimonio ayuda a revelar todos los aspectos formales y narrativos de las citadas obras. Óscar Tusquets, además, ha teorizado sobre la utilidad de la obra de arte, uno de los conceptos fundamentales de Masats y mantiene una estrecha amistad con nuestro autor. Salvador Pons, por último, fue el primer director de la segunda cadena de Televisión Española y una figura trascendental en todo el periodo televisivo de Masats.

Ahora bien, nuestras fuentes originales no se limitan tan sólo a estas entrevistas. En algunos casos las conversaciones telefónicas o las entrevistas presenciales han continuado en forma epistolar, como es el caso de la correspondencia mantenida con Francisco Ontañón (22 de junio de 2005) y con Oriol Maspons (23 de octubre de 2004). Antoni Civantos i Lambea, presidente del Museo de la Agrupación Fotográfica de Cataluña, tuvo la amabilidad de escribirnos el 24 de marzo de 2004 para facilitarnos varios datos, entre ellos la fecha de ingreso de Masats a su asociación. A su vez, el pintor Joaquín Rubio Camín, fundador de La Palangana, nos escribió el 16 de enero de 2005 y, por último, Miguel Delibes, autor de los escritos de Viejas Historias de Castilla la Vieja, nos envió el 17 de mayo de 2005 unas letras que atesoramos con fervor.

Queremos aprovechar este momento para agradecer la paciencia y la amabilidad mostrada por todos ellos, aunque es de justicia reconocer que, en cuanto les comentábamos que las entrevistas versaban sobre Ramón Masats, todos han respondido encantados de colaborar en la investigación que llevábamos a cabo sobre su amigo y compañero.

Con todo este material hemos planteado un texto concebido como el guión de un documental audiovisual: de este modo las citas bibliográficas actúan como si fueran imágenes o entrevistas de archivo, ya publicadas y conocidas (aunque hemos comentado la dificultad de conseguir 
los textos de época). Las referencias a las entrevistas son intercaladas de manera que, a veces se complementan, otras confirman lo señalado $y$, en otros momentos, cuestionan o contradicen lo apuntado. Nuestros comentarios, por ello, funcionan a la manera de un locutor omnisciente que relaciona e hilvana las entrevistas y las citas, aportando comentarios, opiniones personales y conclusiones. De este modo se establece un coloquio ficticio a varias bandas, una estructura artificial que enfrenta voces de diferentes épocas y desde diferentes espacios, articuladas a modo de diálogo en torno a un único discurso, fluido y coherente, discretamente orquestado y ejecutado por nosotros. En cualquier caso, se ha respetado la voz original de los personajes entrevistados. Gracias a ello, podemos conocer mejor a nuestros protagonistas: a través de su particular modo de expresarse, su vocabulario, sus giros y hasta sus muletillas y, además dotamos al texto de una falsa apariencia de realidad directa y objetiva. Preferimos aprovechar la frescura y el dinamismo del testimonio directo aun a riesgo de poder perder una cierta dosis de precisión y rigor en el discurso. Con todo, el análisis histórico y el exhaustivo vaciado bibliográfico utilizado en otros muchos momentos de nuestro trabajo compensa la posible espontaneidad y familiaridad de la entrevista. Esta construcción, inspirada en el documental audiovisual, se justifica por el objeto mismo de la tesis: se trata de un lenguaje que Masats practica y entiende perfectamente y que nos ha parecido el más adecuado para tratar su propia obra y figura. La gran labor de montaje que Masats desarrolla en sus libros y en sus documentales tiene su equivalencia en la urdimbre de nuestro trabajo: deconstruir la realidad para, una vez analizada y asimilada, reconstruirla de nuevo, modificándola y alterándola levemente para así poder aportar nuestra personal luz con el mayor rigor y autenticidad posibles. Para controlar veladamente todo el proceso, aparentando no obstante la mayor objetividad, nos hemos visto obligados a utilizar algunos ardides periodísticos: dirigir y conducir férreamente las entrevistas centrando el objeto de investigación y evitando que los entrevistados cobren mayor protagonismo y eludan las respuestas directas; preguntar a menudo sabiendo las respuestas de antemano; seleccionar respuestas en función de nuestro hilo argumental; plantear conflictos o enfrentamientos que ayuden a avanzar la historia que pretendemos articular; introducir algunas anécdotas que, al mismo tiempo que aportan información interesante, aligeran los contenidos y permiten una lectura más amena...

Junto a ello, el hecho de fundamentar parte de nuestra argumentación mediante el uso de las entrevistas, responde a una motivación generada por el interés de nuestro director de tesis, David Pérez, hacia la reivindicación de la contribución teórica de los productores plásticos. A pesar de que los textos de artista hayan sido tradicionalmente minusvalorados y hayan perdido legitimidad desde el ámbito de la teoría e historia del arte, cabe defender su carácter divulgativo y/o informativo. En este sentido, no hay que olvidar que la aportación teórica del propio autor enriquece la obra de arte, al situarnos en el espacio de la propia vivencia artística. Con ello no se pretende en modo alguno sustituir la obra por el texto de artista, ni siquiera privilegiar la mirada del propio artista sobre su obra, sino complementarla, multiplicar su sentido, confirmar su carácter contradictorio y plural. La supuesta falta de rigor de los textos de artista, la presunta incapacidad del propio artista para teorizar y articular razones y argumentos, vincularían irremediablemente lo artístico al arrebato intuitivo e irreflexivo, impidiendo la defensa de las propias decisiones y la justificación de sus propias opciones. De este modo, el presente trabajo se integra dentro de un proyecto investigador que, contando con el apoyo de la Universidad Politécnica de Valencia y la Conselleria d'Empresa, Universitat i Ciència (subvenciones otorgadas en los años 2006 y 2007), está empezando a dar frutos como el que ahora se muestra.

Finalmente, no querríamos concluir esta introducción sin agradecer una vez más la colaboración, el cariño y la profesionalidad con que Masats nos ha atendido durante todos estos años. Masats y Paloma, su mujer, nos han abierto su casa, su archivo, sus vidas y hasta algunos pequeños secretos inconfesables... haciendo el difícil tránsito de la investigación más amable 
y divertido. Nuestro director, David Pérez, ha sido un implacable corrector. Severo en el fondo pero cómplice desde el principio, David se ha entregado completamente al proyecto, confiando en nosotros y aportando la necesaria serenidad y perspectiva. Koldo Chamorro nos animó desde el principio, nos sugirió líneas de investigación, nos facilitó contactos oportunos, nos aportó su personal visión sobre Masats y el periodo investigado... En resumen, nos prestó su ayuda y apoyo en todo momento de una manera incondicional, contaminándonos de su entusiasmo en los momentos más difíciles. La tesis rezuma su sabiduría y no podemos más que agradecerle el regalo de su amistad. Entre otros pretextos, la tesis también nos ha servido para reencontrarnos con Dolores Devesa, "Doloretes". Cada vez que hemos visitado a Masats en Madrid nos hemos alojado en su casa. Los viajes se convertían en unas auténticas excursiones culturales con visitas a exposiciones o presentaciones de libros, largas conversaciones sobre el desarrollo de la tesis, sobre cine o fotografía, que disfrutamos de un modo inolvidable. Maria Àngels Manuel y Joan Martínez-Mora se sumaron a nuestra causa e intentaron por todos los medios posibles ponernos en contacto con Leopoldo Pomés. No pudo ser, pero no queremos perder la oportunidad de agradecer su comprensión, su apoyo y su amistad. Asimismo, hemos compartimos con Ana Casado las respectivas tesis, dándonos ánimo y aliento mutuamente para aguantar esta carrera de fondo que se ha dilatado durante tantos años.

En realidad, hemos tenido a toda la familia y a los amigos pendientes de nuestro trabajo de investigación durante este largo periodo de tiempo: todos han aguantando nuestros monólogos interminables, una y otra vez. De algunos hemos abusado, presentándonos sin previo aviso en su casa con la excusa de una entrevista a un autor, a otros los hemos enviado a alguna exposición para que nos recogieran el catálogo o nos buscaran ciertos libros, siempre imprescindibles y todos agotados. También hemos tomado prestado ordenadores portátiles, magnetofones e impresoras durante años. Todos han comprendido la importancia de nuestro esfuerzo y han compartido nuestra ilusión... y eso no debería agradecerse en una sola frase. Así, pues, nuestro reconocimiento a: Álex, Ana, Ángel, Celia, Clara, Copo, David, Dídac, Elena, Fran, Gabi, Gema, Inma, Isabel, Joanot, Jose, Juan, Juliana, Loli, Luisa, Lluis, Maite, María, M. ${ }^{a}$ Ángeles, M. ${ }^{a}$ Carmen, Maribel, Marisol, Maru, Pepe, Pilar, Quico, Ramón, Raquel, Roberto, Rodón, Salva, Tomás, Vicent, Vicent M. a ... A todos ellos, gracias y lo siento.

Con todo, mi mayor agradecimiento (qué sería yo sin ti) a Cris. 


\section{CAPÍTULO 1}

\section{La era de Franco: una breve aproximación histórica}

La fotografía en la España posterior a la Guerra Civil y a sus más inmediatas consecuencias, económicas y sociales, se halla inmersa en un estado de agradable y bucólica catalepsia. El paciente está clínicamente muerto, sumido en un profundo trance, una alucinación llena de gasas y vaporosas damas, de idílicos paisajes brumosos, de insípidas marinas y ruinosos castillos, símbolos de una patética grandeza y de una perdida historia de conquistas e imperios que tanto agradaba a la ideología gobernante.

Con la victoria militar del bando franquista la vida cultural española quedó violentamente aplastada. La mayoría de escritores, artistas, científicos e intelectuales debieron exiliarse en el extranjero o llevar una vida discreta y semiclandestina para evitar la cárcel y los penosos procesos de depuración. Ellos y sus obras fueron perseguidos por las autoridades franquistas, que llegaron a elaborar un índice de más de tres mil libros prohibidos. Efectivamente, el franquismo significó el fin del gran momento cultural que España había vivido en el primer tercio del siglo XX y que había culminado en la II República. Asimismo, supuso la anulación de las culturas particulares de Cataluña, el País Vasco y Galicia.

El franquismo, por el contrario, retornó al remoto pasado del Cid y de Hernán Cortés, del Quijote y de Santa Teresa de Jesús. Su mirada se volvió a los primitivos valores castrenses, patrióticos y tradicionales. Se revalorizó la arquitectura de El Escorial, la retratística de los místicos, la idealización de Castilla y del paisaje castellano. La educación primaria y secundaria quedó en manos de la Iglesia, que impuso el pensamiento tradicional católico y un arte religioso vinculado al credo del falangismo.

El régimen de Franco favoreció, por tanto, una filosofía (y hasta una ciencia) católica y tradicional, cuyas tesis básicas harían de la Contrarreforma la contribución sustancial de España a la historia, y del catolicismo, el elemento que debía vertebrar a España y devolverle su sentido como nación. La vanguardia, estética o literaria se persiguió mediante la censura o simplemente se denostó, sospechosa de contener ponzoñosas ideas contra Franco, surgidas de la conspiración judeomasónica y comunista, y de responder a frivolidades liberales de un occidente corrupto, inmoral y ateo.

\subsection{LA REALIDAD INTERNACIONAL: EL BLOQUEO}

El principal problema de esta España filofascista y totalitaria devino en 1945 cuando sus socios ideológicos y comerciales perdieron la II Guerra Mundial. Franco tuvo que replantear su situación internacional e incluso alterar -aunque fuera de cara al exterior- su política nacional, ya que el bando ganador aisló por primera vez al Estado Español debido a sus alianzas con los países derrotados en la guerra.

Desde 1943 el franquismo comprendió que la Guerra Mundial no iba a ser ganada por las potencias del Eje, una de las cuales, Italia, ya había sucumbido. Inició, entonces, un rápido desmarcaje. 
“Se abandonó la no-beligerancia para ir a la neutralidad. Se retiró la División Azul del frente del Este. En 1944 había ya acuerdos económicos con los aliados, que valdrían el discurso de Churchill, favorable a Franco, y el 3 de noviembre del próximo año Franco podía afirmar: «Nunca España ha sido fascista o nazi»"1.

La razón de esta afirmación: el fascismo no tenía al catolicismo como principio básico. Desde 1945, la esencia católica del Régimen pasó a ser su primera credencial ante el exterior.

El nuevo orden internacional vertebrado por la 0.N.U. -la Organización de Naciones Unidas creada en abril de 1945-, no admitía países como la España de Franco, fundados sobre principios fascistas y culpables de colaboración con la Alemania de Hitler y la Italia de Mussolini. La 0.N.U. rechazó el 19 de junio de 1945 la admisión de España. El 1 de Marzo de 1946 Francia cerró la frontera con España. El 12 de diciembre de 1946 la Asamblea General de Naciones Unidas aprobó una resolución por la que condenaba al Régimen español y recomendaba la ruptura de relaciones con el mismo. La práctica totalidad de países, salvo la Santa Sede, Portugal, Suiza y la Argentina de Perón, retiraron los embajadores de Madrid desde finales de 1946 hasta noviembre de 1950. España pagaba, por tanto, un precio considerable por la dictadura de Franco: su aislamiento internacional.

“El inocuo ostracismo internacional tuvo dentro España el efecto de confirmar la imagen que el régimen proyectaba de sí mismo como inevitable e inamovible. Los Falangistas y otras personas ligadas a Franco por redes de corrupción y complicidad en la maquinaria represora, quedaron aún más convencidos de que su futuro estaba a salvo con el Generalísimo. El Caudillo ya había previsto esta situación cuando habló con Martín Artajo al final de la Segunda Guerra Mundial"².

De la ineficacia de este bloqueo, al margen del significado simbólico que tuvo como gesto moral, nos habla la propia supervivencia de la Dictadura que, no obstante, supo aprovechar esta ruptura con el exterior para terminar más concienzudamente con los núcleos residuales de resistencia política y militar.

La situación, no obstante, comenzará a verse mitigada a comienzos de la década de 1950 cuando la posición anticomunista de la Dictadura sea instrumentalizada desde Estados Unidos, dentro del contexto de la guerra fría. En relación con ello este momento representó un viraje artístico muy visible, ya que acusó una fuerte reorientación hacia el mundo cultural anglosajón, lo que llevó a curiosísimos aspectos de mimetismo, generalmente basado en la divulgación de lo inglés y americano conocido a través del cine. En la cinematografía propia predominaban entonces los temas familiares y católicos en vez de los temas bélicos del periodo anterior.

“El período del aislamiento internacional (...) significó (...) una vigorización de los aspectos nacionalistas, típicos o castizos, así como de lo tradicional (...) La tendencia a la marginación de los aspectos más o menos "modernos" ligados a la comunicación falangista con Italia y Alemania, acentuaba la cerrazón artística, básicamente académica o castiza, de esta época, y ello estimuló la aparición en su seno de los primeros intentos de rebelión plástica" ${ }^{3}$.

Hay que situar en este contexto la aparición radicalmente contestataria, tanto en lo que concierne al lenguaje artístico como a la significación política del grupo Dau al set en Cataluña.

1 Cirici, Alexandre, La estética del franquismo, Barcelona, Gustavo Gili, 1977, pág. 45.

2 Preston, Paul, Franco, Caudillo de España, Barcelona, Grijalbo, 2002, págs. 603-604.

3 Cirici, Alexandre, op. cit., pág. 46. 


\subsection{LA ESTÉTICA FRANQUISTA}

\subsubsection{La influencia del gusto personal de Franco y su vinculación con la fotografía}

El régimen de Franco duró casi cuarenta años. En tan largo periodo de tiempo el franquismo sólo mantuvo inalterada la presencia del Generalísimo y su poder personal y autoritario, que llegó a todas las parcelas de la vida militar, religiosa, política y cultural de España. Es por ello que despierta interés la preparación estética o artística del hombre que marcó la cultura de esta época.

Franco, militar africano, pese a que dedicó sus ocios a la pintura, no se sabe que tuviera formación artística. Ávalos, el escultor del Valle de los Caídos, obra concebida y alentada directamente por el Caudillo, afirmó que aunque Franco era capaz de apreciar las obras grandiosas y hermosas no era propiamente un "entendido" en arte. Otro testimonio que dudaba de la preparación artística de Franco era fray Justo Pérez de Urbel (abad mitrado del Valle de los Caídos), aunque, evidentemente, alababa su buen gusto.

Durante la guerra, su conocimiento de la arquitectura histórica debió incrementarse ya que, por necesidades de espacio y también de prestigio, sus cuarteles generales se instalaron siempre en antiguos palacios (Sevilla, Cáceres, Salamanca, Burgos).

\footnotetext{
“Por otra parte, la exaltación patriótica de la Iglesia le llevó a participar en grandes ceremonias en las catedrales y templos importantes. Mejor aún debió ser su familiaridad con el marco de El Pardo y el uso de los Sitios Reales. Todo ello influyó en el gusto de Franco, para el cual nada que no fuera antiguo era distinguido, del que todas las fotografías que de su persona se conservan ninguna es al lado de un objeto de diseño moderno, del que en sus habitaciones de El Pardo, aparte de la radio y la televisión, no se ve ningún mueble u obra de arte de nuestra época"4.
}

De hecho, no sólo le molestaba la modernidad. Como reacción a la II República, Franco no quiso jamás que su régimen tuviera connotaciones intelectualistas. El escritor monárquico José María Pemán observó cómo en los discursos de Franco jamás hubo espacio para la literatura o la cita de ningún autor. La generación del 98 le incomodaba particularmente.

“Nuestra generación -diría en Sevilla el 28 de abril de 1956- había salido al mundo tras la generación del 98 y no podía conformarse con el pesimismo y resignación de sus autores" ${ }^{\prime \prime}$.

Tal era el recelo de Franco por los intelectuales liberales que, en consonancia con sus obsesiones personales, los llegó a identificar con los masones y los comunistas, enemigos tradicionales del Régimen y, por ende, de España.

Sobre la opinión de Franco respecto a la fotografía cabe destacar un curiosísimo artículo aparecido en Arte Fotográfico con ocasión del nombramiento de "Su Excelencia el Jefe del Estado" como "Aficionado de Honor a la fotografía", otorgado por la I Asamblea Nacional de Fotografía, celebrada en Madrid.

“(...) Su excelencia dedicó unas primeras frases a ponderar la importancia que actualmente ya tiene la producción fotográfica en España, así como también que conocía la parte que en este esfuerzo se debía a los hombres que en esta manifestación industrial están vinculados.

Examinó a continuación el panorama económico del país en los últimos años, con alusión a los quebrantos habidos en las fuentes de nuestras divisas, centradas principalmente en el renglón de agrios, que 
se perdieron la mitad, y a la mala cosecha de aceite, lo cual exigió que las necesidades más apremiantes se vieran precisadas a nutrirse exclusivamente de los productos de minería. Por fortuna la situación ha entrado en una fase de optimismo que, junto con una política crediticia a corto, medio y largo plazo, hará posible alcanzar una mayor elasticidad en nuestro comercio exterior. En este nuevo cambio, como en tantos otros sectores de la economía, la producción fotográfica se verá beneficiada tan pronto como sea posible (...) Expresó, por último, su antigua afición a la fotografía, a la que siente no poder prestar mayor atención por sus tareas de gobierno, reiterando la gran simpatía que siente por esta actividad, que no sólo es recreativa, sino trascendental en muchos aspectos de la técnica y de la ciencia" ${ }^{\prime \prime}$.

No deja de ser significativo que el nombramiento sea de "Aficionado de Honor a la fotografía". Como estudiaremos más tarde, la figura del aficionado es muy determinante en la época. Podría haber sido simplemente "fotógrafo de honor", pero el sonsonete "aficionado" no es casual en una España abarrotada de asociaciones de fotografía y nutrida exclusivamente de "aficionados".

Por otro lado, Franco aprovecha la coyuntura para comentar las malas cosechas de la agricultura -compensadas eso sí, por la minería- pero menciona tres términos que, posiblemente, permiten adivinar el concepto que de la fotografía tenía "Su Excelencia": recreativa, técnica y científica. Como en el resto de su línea de pensamiento, no le concede ni un ápice de creatividad ni de contenido artístico al medio fotográfico. La fotografía es una mera distracción: se llegará a definir como una actividad deportiva, un pasatiempo. Como jugar al mus o pescar. En realidad, en el texto queda denominada como una "manifestación industrial", como el aceite o las naranjas (quizá por la cantidad de dinero que mueven las cámaras y los materiales fungibles), pero que sólo tiene su importancia real en muchos aspectos de la técnica y de la ciencia. Resulta irónico que el artículo apareciera en la revista Arte Fotográfico, publicación llena de las más peregrinas elucubraciones y los más encendidos debates sobre la artisticidad del medio, sobre sus posibilidades y sus aspiraciones y que, además, proclamaba su fidelidad al Régimen desde los primeros ejemplares. Ya en el número 3 (marzo de 1952) aparecía una fotografía de Franco dedicada a la revista con el siguiente pie:

“«Arte fotográfico» se engalana con la presencia en sus páginas de la figura de nuestro Caudillo, Generalísimo Franco, al que rendimos tributo de gratitud por el regalo de su autógrafo que, al prestigiarnos nos anima a seguir nuestra labor de enaltecimiento de la fotografía española, de la que él es un destacadísimo representante. Su colección de fotografías en color es dilatada y de una sorprendente calidad. La fotografía, con la caza y la pesca, ocupa alguna que otra vez el poco tiempo que le deja libre su grave quehacer. Noble afición que se honran en compartir con él todos los fotógrafos españoles"7.

\subsubsection{La iconografía católico-folclórico-imperial}

En verdad el franquismo nunca fue un todo homogéneo e indivisible. Más bien al contrario, toda la Dictadura se desarrolló con un vaivén de influencias y tensiones, algunas internas, dentro de las familias de poder cercanas a Franco, otras externas, dependientes de la política internacional, de las relaciones con países extranjeros, aliados o enemigos, y de sus destinos. El resultado de este juego de fuerzas fue la consolidación personal de Franco. Éste aprovechó todas las crisis políticas desde 1937 para robustecer su poder, distribuyendo cuotas de influencia entre las distintas familias políticas y, así, evitar gobiernos "monocolores". De cualquier modo, en el período de guerra se consolidaron dos corrientes básicas: la vinculada al mundo nacional-católico y la

6 Anónimo, "Su excelencia el Jefe del Estado recibe el nombramiento de «Aficionado de Honor a la fotografía», otorgado por la I Asamblea Nacional de Fotografía, celebrada en Madrid", en Arte Fotográfico, n 66, año VI, agosto 1957, págs. 602-603.

7 Anónimo, (sin título), Arte Fotográfico, n³ 3, año I, marzo 1952, pág. 67. 
dependiente del fascismo falangista. Por un lado, el sector nacional-católico defendía la idea -derivada de Menéndez Pelayo y Ramiro de Maeztu- de que el catolicismo constituía el elemento esencial de la nacionalidad española y de la unidad nacional. La defensa del catolicismo habría sido el fundamento de la grandeza imperial española (reconquista de la península, expulsión de los moriscos, conquista de América, conversión de los indígenas...) que el nuevo régimen venía a restaurar. Por tanto las figuras de Isabel la Católica y de Felipe II se convertirán en el principal referente de aquel pasado medieval e imperial. Por otro lado, en el sector falangista, articulado en torno a la obra de Dionisio Ridruejo, Eugenio Montes, Mourlane Michelena, Foxá y otros, y en revistas como Jerarquía (1936-1938), inspirada por Fermín Yzurdiaga y Ángel María Pascual, Vértice y Escorial, primó el gusto por la cultura greco-latina (influencia de d’Ors), la idealización de Castilla y del paisaje castellano, la reivindicación de Velázquez y El Greco, la exaltación del heroísmo militar y la vindicación del arte religioso. Sin embargo, en el ámbito privado se alimentará una cultura del folclore y de las tradiciones costumbristas.

“El núcleo central de la actividad artística estuvo basado, como en Italia, en la selección e integración de los artistas mediante el encargo. Pero el bando falangista puso el mayor énfasis en las dos direcciones mismas que el nazismo, la del arte monumental para el poder y la del arte folclórico-familiar para la esfera privada, con alguna diferencia señalada respecto al modelo alemán, causada por el especial espíritu de radical represión sexual mantenido, por encima de todo, a causa de la gran autoridad del nacional-catolicismo"s.

La explicación de esta dualidad folclórico-imperial responde a la necesidad de la Falange de eliminar los conceptos de lucha de clases, de obrero y de todo aquello que insinuara conflicto 0 pluralidad. El estado seríamos todos, sin intereses particulares ni egoísmos, sacrificados si fuera menester en el beneficio colectivo, sumisos a su totalidad, unidos en una gran nación. Gracias al arte propagandístico, se crea el mito de la unidad nacional y del Imperio: Imperio-histórico perdido hacía siglos, e Imperio-Estado sin clases sociales, preindustrial. En él, la tradición católica campesina, la artesanía y el folclore sustituían literalmente a la fábrica y al obrero, sospechosos de haber apoyado a los republicanos en la contienda.

“El campo va a vivir la contradicción de ser, por un lado, el punto de referencia en cuanto a valores y modelos de vida del franquismo, que exalta continuamente el medio rural, y singularmente el campo castellano y sus virtudes de sacrificio, abnegación, valores religiosos, modelo familiar patriarcal, ausencia de propósitos emancipadores o colectivistas, frente a una ciudad que representaba la degeneración de esos valores, el cosmopolitismo, la pérdida de la religión, etc., al menos hasta los años sesenta, cuando la emigración hacia la ciudad en el proceso de industrialización es imparable" ${ }^{\prime \prime}$.

Por otra parte, a la clase media se le tenía que dar una sensación de protagonismo histórico como complemento de la negación de las clases sociales. Era preciso que no se viesen los hilos que, desde el gran capital, movían las decisiones fundamentales del sistema socioeconómico y que, paralelamente, no se percibiese la potencialidad autónoma de la clase obrera. Para borrar la visión de las clases en conflicto era necesario apoyar cualquier hecho que reforzara la idea del concepto de unidad. Todo ello se acabó resolviendo en la sacralización de lo que fue llamado "nacional", dando a esta palabra una identificación emotiva con el estado. 
“Para la proyección artística y literaria, el concepto de Imperio tuvo un gran papel. En todas partes estaba inscrita la frase: «Por el Imperio hacia Dios», y la arquitectura, como la escultura monumental, tomaban morfologías que respondían claramente al concepto de lo imperial. Nadie sabía exactamente lo que esta idea de Imperio representaba. Para unos era la voluntad de reconstruir la unidad política de lo que había sido el antiguo Imperio de Castilla, para lo cual se utilizaba otra palabra de Unidad, ésta forjada en su día por Ramiro de Maeztu, la «Hispanidad»"10.

Esta visión alentaba las formas artísticas imperiales con la intención de evocar la época más poderosa de la antigua expansión americano-filipina. Para otros con menos fantasía y menos locas esperanzas, el Imperio era la irradiación del estado. En cuanto a la identificación con una realidad sin clases sociales y alejada del pluralismo liberal, el arte se encargó de idealizar las formas de vida pre-industrial: el folclore, la artesanía, la tradición católica campesina, doméstica y familiar, las familias numerosas, las cofradías, los gremios, es decir, todo lo que ayudase a idealizar las formas pretéritas de una sociedad muy atada a convenciones estables.

La existencia del proletariado con todo lo que comporta en el nivel icónico (cadenas de montaje, grandes fábricas humeantes, degradación del ambiente físico) era incómoda para el estado:

“¿Qué pasa entonces con la industria? Se ha disfrazado de «Artesanía». La colección de libros La riqueza en la mano demuestra que es posible hacer un capital, a título particular, sin utillaje ni especiales inversiones previas; por supuesto, tampoco es necesario contratar obreros. Para eso están el palomar, el gusano de seda, el colmenar, o la cría de canarios y periquitos (...) Como puede verse, también predominan las industrias tradicionales y de subsistencia, en las que, con desarrollos a pequeña escala, no resulta fácil la aparición de proletariado organizado"11.

\subsubsection{La ideologización de la historia}

La retórica imperial reconstruía completamente las lecturas que de la Guerra Civil se pudieran concluir. En ellas los vencedores se consideraban herederos directos de los grandes héroes nacionales, como cuando Franco fue investido con el título de Gran Almirante de Castilla en 1948:

“Hacía mucho tiempo que la maquinaria propagandística de su régimen lo había presentado como el Cid del siglo XX; en aquel momento le había arrebatado a su hermano Ramón el título de Cristóbal Colón del siglo $X X^{\prime \prime 12}$.

Los enemigos de España llevaban turbante y plumas como los moros y los paganos. De esta manera la guerra estaba legitimada por la historia, auspiciada por designios divinos. La misma fuerza que habría guiado a Isabel la Católica contra el moro, guiaría al Caudillo contra los comunistas, los ateos... La "nueva España" se levanta sobre las virtudes y hazañas de la "España eterna". El carácter de "españoles auténticos" reivindicado por los sublevados pretendería manifestarse en su capacidad para recrear los momentos más gloriosos de la historia patria. De hecho, la Guerra Civil se consideraba la guerra contra la anti-España, una "guerra preventiva" para evitar que "los rojos" regalaran el país al comunismo soviético. 
El Alcázar remite al cerco infructuoso de Tarifa; la Guerra Civil, en su conjunto, se presenta como una "guerra de liberación", como nueva reconquista contra el infiel; los sitios de Oviedo, Nuestra Señora de la Cabeza, el Cuartel de Simancas en Gijón, etc., se asimilan a los grandes cercos de la historia española: Sagunto, Numancia, Zaragoza, Gerona...

\begin{abstract}
“Hay, pues, unas correspondencias tipológicas entre la historia antigua y la historia moderna, paralelas a las que los iconógrafos descubrieron, hace mucho tiempo, entre los episodios y figuras del Antiguo y del Nuevo Testamento (...), la cruzada y sus episodios permiten evocar a todos los enemigos tradicionales «de España». Los republicanos («los rojos») se identificaban con los árabes medievales, los turcos, los protestantes ingleses y centroeuropeos, los indios paganos de América, etc. Así la iconografía «oficial» del Nuevo Régimen se amplía de modo inusitado, incluyendo reconstrucciones historicistas de todos los grandes momentos del «Imperio»"13.
\end{abstract}

Evidentemente, no toda la historia convenía al Régimen, ya que aunque disfrazada de saber empírico, la historiografía franquista era una mera consigna ideologizada:

\begin{abstract}
“Desde luego, el régimen rechazó siempre las tesis de Américo Castro sobre la confluencia de las culturas cristiana, islámica y judía en la formación de España. Además, el siglo XVIII, tan estimado por la tradición liberal, fue ahora marginado y el XIX, abiertamente rechazado (salvo la guerra de Independencia de 1808-1813) como siglo de liberalismo que había desembocado en la República marxista y masónica de 1931-1936: «el siglo XIX -dijo Franco en un discurso el 21 de junio de 1950-, que quisiéramos eliminar de nuestra historia, es la negación del espíritu español»"14.
\end{abstract}

Cabe destacar, por tanto, que todos los movimientos artísticos y culturales franquistas estaban aglutinados bajo un denominador común: su sentido político subsidiario, su afán legitimador y propagandístico.

“Desde las consignas de Eugenio d’Ors en torno al arte angélico (...) hasta la explícita dependencia de arte y poder político que había promulgado Jiménez Caballero desde 1935 en Arte y Estado; desde las molduras clásicas y los elementos neoherrerianos de la monumentalidad arquitectónica hasta el cartelismo o la ilustración gráfica, todo quiso valer como instrumento de inoculación de una verdad política e histórica"15.

A pesar de toda la retórica oficial, la realidad de la estética franquista en una España azotada por la guerra y la posterior hambruna, no llegó a las expectativas creadas. Apenas si tuvo resonancia en la reconstrucción arquitectónica. Desde luego, se intentó programar una estética a imagen y semejanza de Alemania e Italia, pero ésta no llegó a cuajar como un estilo homogéneo y duradero.

“En la España franquista de posguerra no llegó a haber, por consiguiente, sino unos cuantos atisbos de estilo imperial, cuya apoteosis fue, además, la erección de la cruz monumental del Valle de los Caídos, lo que da idea por sí mismo del peculiar carácter del fascismo español, el nacional-catolicismo irredento de un Imperio, ya calificado en su época histórica más pujante como «nebuloso», precisamente por su falta de acomodo a las circunstancias impuestas por el poder efectivo de la realidad moderna" ${ }^{16}$.

13 Bonet Correa, Antonio, op. cit., págs. 240-241.

14 Fusi, Juan Pablo, op. cit., pág. 107.

15 Gracia García, Jordi, “Artes y letras de supervivencia”, en Hernández Sandoica, Elena (Dir.), op. cit., pág. 128.

16 Calvo Serraller, Francisco, op. cit., pág. 55. 
En efecto, incluso entre 1940 y 1945, cuando se vive intensamente el fervor triunfalista y los más exaltados intelectuales falangistas tienen en sus manos todo el aparato de propaganda y difusión, fracasa la creación de un estilo que apenas se atisba en algunos casos aislados. El academicismo más convencionalmente conservador se impuso rápidamente sobre cualquier ilusión previa de fabricar un estilo imperial, cuyos resultados prácticos resultan comparativamente ridículos:

“Incluso en el terreno de la arquitectura, fundamental en un momento volcado a la reconstrucción, apenas fueron edificados monumentos con estas características y en cuanto a las artes plásticas, tan sólo conservamos algunos ejemplos en el campo de la ilustración gráfica y unas cuantas excepciones en pintura y escultura, cuya importancia a nivel general es verdaderamente insignificante (...) todos ellos académicos acreditados de la preguerra, empeñados en su gran mayoría en una pintura entre costumbrista y folclórica"17.

17 Calvo Serraller, Francisco, op. cit., págs. 34-35. 


\section{CAPÍTULO 2}

\section{La fotografía oficial de principios de los años cincuenta: el contexto en el que Masats se forma}

En 1952, con veintiún años, Ramón Masats Tartera hacía el servicio militar en los juzgados militares de Lérida y como se "aburría" en exceso, Masats leía, leía mucho. En ese mismo año empezó a editarse una revista de fotografía nueva, Arte Fotográfico, y quiso la casualidad que cayera en sus manos un ejemplar de la misma. Llevado por la curiosidad, Masats se interesó por las técnicas y las fotografías que allí contempló.

“Masats había aterrizado en el mundo fotográfico por un azar literal: mientras hacía la «mili», le tocó en una tómbola una cámara Retina"1.

(R. Masats, Valencia, 25 de marzo de 2004) -“Mi incorporación a la fotografía no fue fruto de la casualidad, fue fruto de que me aburría en la mili. Un día me compré una revista, que se llamaba Arte Fotográfico, y dije: «Pues mira, se pueden hacer fotos. Se puede uno expresar con la fotografía». Arte Fotográfico ha sido una revista que luego ha sido muy vilipendiada, pero que a nosotros nos ayudó mucho. Luego, en la mili, cuando me compré la revista, me compré una cámara, una Retina II, y durante muchos años he tenido que decir que la cámara me había tocado en una tómbola. La cámara me la compré con dinero que le chorizaba a mi padre. Cuando volví a casa... ¿Cómo justificaba que me había comprado una cámara? Ya no podría haberle robado nunca más -cosa que no me interesaba-. Entonces dije que me había tocado en una tómbola, y hasta que no murió mi padre en el 1992, he tenido que contar esto".

Cuando Masats pretende profundizar en los conocimientos sobre el mundo que acaba de descubrirse ante sus ojos, comprueba que no hay en toda España ninguna escuela, ningún instituto o universidad -pública o privada- donde estudiar fotografía. ¿Dónde podría Masats aprender a manejar las máquinas, o dónde podría aprender los secretos del cuarto oscuro?

La respuesta la hallamos en las asociaciones de fotógrafos aficionados. En ellas se encontraba la infraestructura imprescindible (locales, laboratorios, bibliotecas...) para que los aficionados pudieran descubrir y aprender las técnicas fotográficas básicas. Y con esa intención se inscribió Masats en la sección de fotografía del Casino de Comercio de Tarrasa. Masats ya pertenecía a esta institución antes de ir al servicio militar y se interesó por la sección de fotografía a su regreso.

Manuel Santos resume las consecuencias que este sencillo acto -el hecho de inscribirse en una agrupación fotográfica- hubieran podido comportar para Masats o para cualquier otro fotógrafo aficionado español en los años cincuenta.

“La imposibilidad de alternativas claras conducían al novel fotógrafo siempre al mismo círculo: la enseñanza era realizada, no en escuelas sino en asociaciones o clubs. La promoción y venta de la obra, en suma la búsqueda de los clientes, quedaban reemplazadas por el Concurso. La crítica fotográfica por el Jurado. La revista Arte Fotográfico garantizaba la difusión del evento, y el plagio sustituía a la tradición"².

1 Miserachs, Xavier, Criterio fotográfico. Notas para un curso de fotografía, Barcelona, Omega, 1998, pág. 185.

2 Santos, Manuel, “Fotografía contemporánea española 1970-1990”, en el catálogo de la exposición Cuatro direcciones. Fotografía Contemporánea Española 1970-1990, Madrid, Museo Nacional Centro de Arte Reina Sofía, Ministerio de Cultura/ Lunwerg, 1991, pág. 35. 


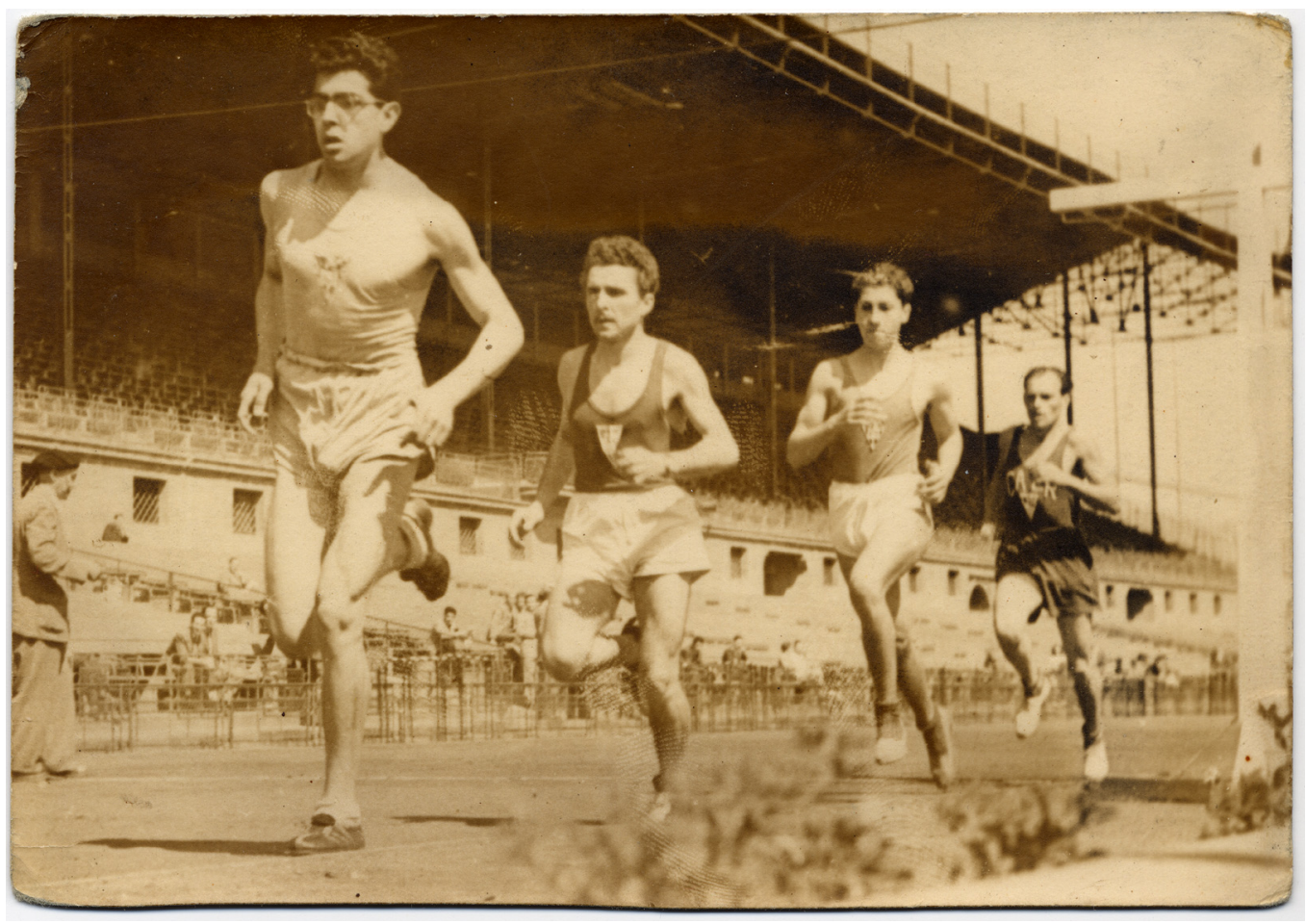

Retrato de Masats en una carrera de atletismo, 1950.

A continuación estudiaremos con atención este implacable proceso que, inexorable, hubiera conducido al plagio a Masats, evidentemente, si Masats no hubiera sido Masats...

\subsection{LAS ASOCIACIONES FOTOGRÁFICAS}

¿Un Casino de Comercio, escuela de fotografía?

Efectivamente, el Casino de Comercio de Tarrasa tenía una oferta muy diversa. En él se organizaban bingos (que aunque prohibidos por las autoridades franquistas se consentían en navidades), fiestas sociales de lo más diverso, bailes de gala en fechas señaladas, etc. Masats disfrutaba de sus instalaciones ya antes de interesarse por la fotografía. Entre sus estructuras se cobijaban clubes de ajedrez, de billar... y la sección de fotografía. Cabe destacar que los socios del Casino de Comercio de Tarrasa pertenecían, como el propio Masats, a una clase social media, de pequeños burgueses, de empresarios con pequeños negocios, como el caso de la pesca salada del padre de Masats. No era un club aristocrático en absoluto, sino más bien, popular. Pero no era, ni mucho menos, la única institución que entre sus muchas actividades albergaba una oferta fotográfica: peñas deportivas, agrupaciones excursionistas... cualquier colectivo con fines recreativos o sociales, valía como marco para una sección de entusiastas aficionados a la fotografía.

Las asociaciones surgían por doquier. Prácticamente, cualquier ciudad, cualquier pueblo, disfrutaba de sus propios aficionados reunidos en torno a su propia asociación. 
“SOCIEDADES FOTOGRÁFICAS ESPAÑOLAS. Con insistencia se nos solicitan nombres y domicilios de las Sociedades Fotográficas españolas, y con objeto de atender dichas peticiones, y para divulgar también el conocimiento de las mismas, damos a continuación relación de las más conocidas por nosotros:

Real Sociedad Fotográfica de Madrid.-Príncipe, 16- Madrid.

Agrupación Fotográfica de Cataluña.-Duque de la Victoria, 14- Barcelona.

Sociedad Fotográfica de Zaragoza.-Pl. de Sas, 7- Zaragoza.

Foto Club de Valencia.-Embajador Vich, 7- Valencia.

Sociedad Fotográfica de Guipúzcoa.-Apartado 86- San Sebastián.

Nuevo Club Deportivo de Bilbao.-Alameda de Recalde, 18- Bilbao.

Sociedad Fotográfica de Alicante.-Ángel Lozano, 14- Alicante.

Agrupación Fotográfica de Igualada.

Asociación Fotográfica Vallisoletana.

Agrupación Fotográfica de Mallorca.-Gral. Goded, 67- Palma de Mallorca.

Agrupación Fotográfica de Arenys de Mar.-Plaza de José Antonio, 11- Arenys de Mar (Barcelona).

Agrupación Fotográfica de León.-Lope de Vega, 4- León.

Agrupación Fotográfica Canaria.-Italia, 53- Las Palmas de Gran Canaria.

Foto Club del Círculo Artístico de Ciudadela.

Agrupación Fotográfica de Sitges.-San Francisco, 9- Sitges (Barcelona).

Agrupación Fotográfica de Gavá.-Rambla, 55- Gavá (Barcelona).

Sección Fotográfica de Fomento Hortense.-Alta Mariné, 15- Horta (Barcelona).

Foto Cine Club.-Gral. Zubillaga, 3- Oviedo.

Ágora. Foto Cine Club.-M. Pidal, 5- Oviedo.

Foto Club de Novelda.-José Antonio, 45- Novelda (Alicante).

Agrupación Fotográfica «San Juan Bautista».-Plaza de Martínez Anido,5- San Adrián de Besos (Barcelona). Foto Club Alcira.-Santa Teresa, 12- Alcira (Valencia).

Club Fotográfico de Molins de Rei.-Enrique Granados, 17- Molins de Rei (Barcelona).

Grupo Fotográfico del Centro Cultural y Artístico «Ebusus».-Paseo Vara de Rey- Ibiza.

Grupo Fotográfico del Centro Excursionista de la Comarca de Bagés.-Urgel, 14- Manresa.

Cámara Club Sabadell.-Rambla Caudillo, 95- Sabadell.

Peña Guara.-Sección Fotográfica-Coso Alto, 59- Huesca"3.

El panorama nacional se veía circunscrito, prácticamente, a las asociaciones, ya que el fotógrafo aislado carecía de cualquier posibilidad de aprender o de medrar, de aquí la importancia que adquieren en la contextualización de la época. En origen, el modelo que seguían las distintas asociaciones fotográficas era el de la decana Royal Photographic Society de Londres, fundada en el remoto 1853, aunque, como veremos, venidas a menos.

“La primera sociedad fotográfica de una cierta envergadura se creó en Madrid a partir de la sección fotográfica del Círculo de Bellas Artes, fundada por Manuel Suárez Espada, que pasó a denominarse, en diciembre de 1899, Sociedad Fotográfica de Madrid. Sus principales actividades giraban en torno a excursiones, proyecciones y concursos. Entre sus miembros se encontraban Antonio Cánovas, Luis de Ocharán, José Ortiz Echagüe y Santiago Ramón y Cajal.

La Sociedad Fotográfica de Madrid se convertiría en 1907 en la Real Sociedad Fotográfica, verdadero motor impulsor del movimiento pictorialista en nuestro país hasta bien entrados los años veinte, en que aparecían otras asociaciones compartiendo el mismo empeño"4. 
En 1923 se creó la Sociedad Fotográfica de Zaragoza y en 1928 se fundó el Foto Club de Valencia. Esta asociaciones fueron el detonante para que el agrupacionismo se extendiera, como hemos visto, por toda España. El caso de Cataluña fue especialmente prolífico en el movimiento asociativo pues en su territorio había más de cincuenta asociaciones fotográficas operativas en los años cincuenta. A la propia Agrupación Fotográfica de Cataluña pertenecían mil doscientos socios en el año 1958, mientras que en la Real Sociedad Fotográfica de Madrid sólo tenía inscritos ciento veinticinco socios el mismo año.

“Hay que hacer referencia al Club Fotográfico Barcelonés, que a finales del siglo XIX, contaba ya con
más de tres mil miembros, y a la Unión Fotográfica de Barcelona, fundada en 1918, que editaba la
revista Lux, y cuya dirección técnica estaba a cargo de Rafael Areñas. El movimiento no alcanzó es-
tabilidad hasta la aparición de la Agrupación Fotográfica de Cataluña, de Barcelona, fundada en 1923
por Claudi Carbonell, Josep Demestres, Salvador Lluch y Joaquín Pla Janini"5.

La función específica de las agrupaciones consistía en crear una infraestructura de la que se podía servir el aficionado en su proceso de aprendizaje. Xavier Miserachs nos ha legado un testimonio de primera mano del ambiente que se respiraba en la Agrupación Fotográfica de Cataluña en aquellos años.

“Alguien que advirtió mi pasión, me desaconsejó seguir mi solitario aprendizaje y opinó que progresaría con más rapidez en el marco de algún club de aficionados. Dejé el curso por correo, y en septiembre me hice socio de la Agrupación Fotográfica de Cataluña.

La entidad disponía de laboratorios convenientemente equipados, con varias ampliadoras cada uno, que los socios podían alquilar por horas (...)

Iba con frecuencia a la Agrupación, recorría una y otra vez las exposiciones que en su sala se celebraban, admirando el virtuosismo de las fotografías expuestas tras su presentación a concurso, intentando adivinar el criterio del jurado en la adjudicación de premios, los recursos técnicos y materiales empleados. Hojeaba también las revistas disponibles en la biblioteca, copiaba de ellas alguna fórmula de revelador, esperando vagamente que resultara mágica para mejorar la calidad de mis trabajos. Solía acercarme a la entidad a la salida de la escuela, a última hora de la tarde, y así coincidía en la sede con la hora de las tertulias de veteranos y virtuosos. No me atrevía a sentarme con ellos, mi ignorancia y mi timidez de adolescente me lo impedían, pero desde una prudente distancia acomodaba y afinaba mi oído para oír sus deliberaciones sobre las cámaras que empleaban, la combinación de filme y revelador que daba más finura al grano, el filtro para resaltar nubes" ${ }^{\prime 6}$.

Asimismo, las agrupaciones fotográficas promovían el contacto entre los aficionados que, de otro modo, hubieran permanecido absolutamente aislados. La principal herramienta con la que contaban las asociaciones para relacionarse con sus miembros y con las otras asociaciones era mediante la publicación de boletines, como el boletín de la Agrupación Fotográfica de Cataluña o el de la Real Sociedad Fotográfica de Madrid. Estos modestos boletines pretendían llegar a ser una auténtica revista: aumentando constantemente el número de sus reproducciones y sus ilustraciones, editando números especiales, etc. Pero la revista por antonomasia -prácticamente la única leída por todas las asociaciones fotográficas y por todos los aficionados- era Arte Fotográfico. Cuando en 1952 apareció la citada revista lo hizo sobre la tradición de una serie de revistas que siempre habían

5 Fontcuberta, Joan, “La fotografía catalana de 1900 a 1940: el camino hacia la modernidad”, en Naranjo, Juan; Fontcuberta, Joan; Formiguera, Pere; Terré Alonso, Laura y Balsells, David, Introducción a la Historia de la Fotografía en Cataluña, Barcelona, MNAC/Lunwerg, 2000, pág. 82.

6 Miserachs, Xavier, op. cit., pág. 180. 


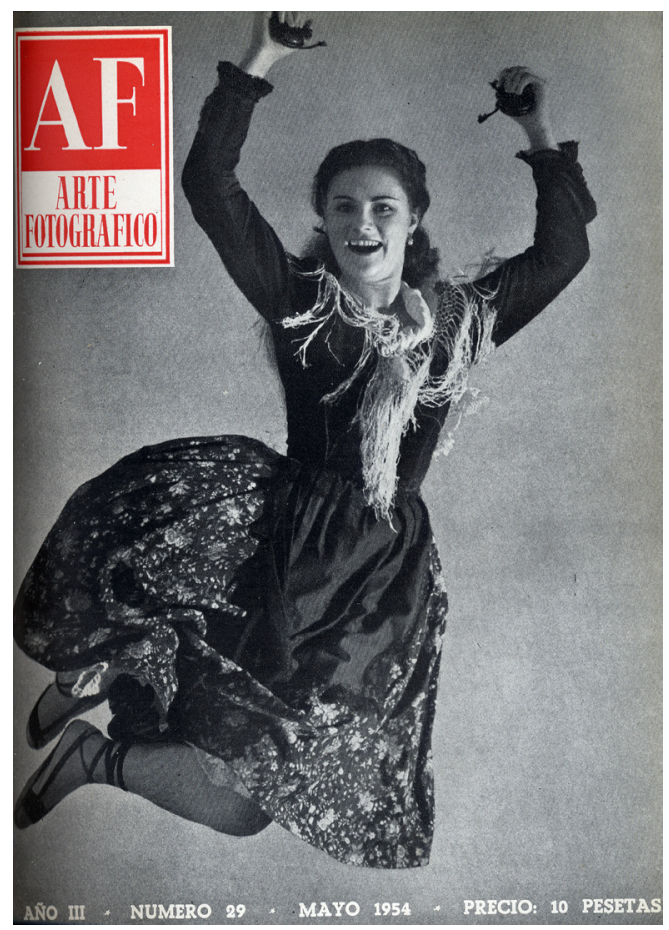

A. Palau Claveras, “La Jota”. Portada de Arte Fotográfico, n 29, mayo 1954.

funcionado como órganos oficiales de la Real Sociedad Fotográfica de Madrid. La primera revista se llamó La Fotografía y nació con los albores del siglo (1901-1913). Legítima heredera suya fue la revista Sombras, nacida en 1944 y desaparecida el mismo año de publicación de Arte Fotográfico, 1952, y aunque Arte Fotográfico ya no fue oficialmente el órgano de "la Real", sabido es que, de hecho, siguió funcionando tácitamente como tal. Editada en Madrid y dirigida por Ignacio Barceló:

“Arte Fotográfico se convirtió muy pronto en el auténtico portavoz del asociacionismo fotográfico de cariz inoperante y adicto al régimen"7.

La revista llegó a alcanzar un éxito editorial espectacular -no igualado hasta nuestros díasa pesar de no contar, en sus inicios, con más de doce reproducciones fotográficas por número. Sus tiradas fluctuaban entre quince y veinte mil ejemplares, llegando a alcanzar la espectacular cifra de veinticinco mil ejemplares en su número trescientos de 1976.

El ambiente que encontrará Masats en la sección de fotografía del Casino de Comercio de Tarrasa es parecido al que meses más tarde encontrará en la Agrupación Fotográfica de Cataluña, en Barcelona (se inscribió el 4 de julio de 1956 con el $n^{0}$ de socio 1545) y, años más tarde (1958), en la Real Sociedad Fotográfica de Madrid. La realidad de las agrupaciones era más bien triste y decadente. La falta de espacio de sus locales, la pobreza de sus medios y la parquedad de sus bibliotecas nos sirven para situarnos en un ambiente caduco que olía a viejo y a cerrado. No obstante, como veremos, será dentro de la propia Agrupación Fotográfica de Cataluña donde se producirán los primeros choques entre los viejos académicos y la nueva generación de fotógrafos. 
"Sumida en una profunda crisis tras la Guerra Civil, la AFC se debatía entre las concepciones más tradicionales y los aires rupturistas que, al principio tímidamente, empezaban a ventilarse de la mano de las nuevas incorporaciones. Básicamente se cruzaban dos tipos de dialécticas: en lo sociológico, la que oponía el amateurismo con aquellos que aspiraban a alcanzar un estatus profesional $y$, en lo estético, el recrudecimiento de la vieja querella filosófica entre la búsqueda de la belleza y la búsqueda de la verdad, es decir, la confrontación entre una fotografía «artística» versus otra «documental»"8.

\subsubsection{El estatus del fotógrafo aficionado}

Conviene no olvidar que las sociedades fotográficas o los fotoclubs fueron creados en su origen para impulsar el desarrollo científico y artístico de la fotografía, y reunieron tanto a los profesionales como a los aficionados. Pero progresivamente los profesionales fueron desapareciendo para dejar paso a la figura omnipresente del aficionado. Recordemos cómo el propio Franco era nombrado "aficionado de honor a la fotografía". Se suponía que únicamente los fotógrafos aficionados podían aspirar a ser "artistas", puesto que los profesionales jamás llegarían a esta categoría, sometidos a las necesidades del cliente y de la venta de su producto:

“En cierta manera se les negaba esta posibilidad a causa de su profesionalidad que, a juicio de los nue-
vos «artistas de domingo», impedía por completo la posibilidad de entrar en el tránsito creativo que
requiere toda obra de arte. Se recupera así el sentido mítico del artista, alejado del mundo real, que
seguía recreando escenarios idílicos y modelos plásticos convencionales, escenarios de un bucolismo
trasnochado y composiciones clásicas y pictóricas que incluso la pintura ya había olvidado"9.

El estatus de la fotografía y de los fotógrafos españoles de 1952 es éste: la inmensa mayoría son aficionados, pequeños burgueses de clase media o profesionales liberales que dedican sus horas libres, de manera diletante, a su pasatiempo favorito: fotografiar. Para ello organizan excursiones de fin de semana, salidas en grupos dispersos al campo los domingos por la mañana para lanzarse a la caza de una imagen "artística".

\footnotetext{
“Mantenía, eso sí, cierta prudente distancia sobre la «artisticidad» de estas prácticas, que se pregonaban a los cuatro vientos como «fotografía artística». A ser sincero, mis dudas eran más sociológicas que fundamentadas en conocimientos de arte. Me resultaba difícil entender que tenderos, médicos, empleados de banca, sastres, etc., fueran vanidosos artistas de 7 a 9 de la tarde en las tertulias de la Agrupación, y se dedicaran los domingos por la mañana, en caso de buen tiempo, a producir excelso arte. Tenía yo todavía fe en el arte, y me resistía a admitir que pudiera salir de un ocasional hobby. Las agrupaciones de aficionados mantenían una ilusión que tenía algo de comedia, la de participar en la aventura de un arte que se les escapaba una y otra vez por el colador cultural en que se sustentaban"10.
}

No hace falta señalar cómo ese carácter, de distracción y de ocupación del tiempo de ocio, marcará el planteamiento previo de la obra y los proyectos estéticos de los aficionados, fundamentalmente porque no existen. No hay una reflexión que preceda al acto fotográfico. No se medita críticamente sobre el resultado obtenido. No se pretende desarrollar una línea de investigación que lleve a una profundización. No se plantea evolución alguna. La triste realidad de la fotografía asociacionista es que consolida únicamente el plagio acrítico:

8 Fontcuberta, Joan, "Izas, rabizas y colipoterras: un álbum furtivo”, en Balsells, David y Ribalta, Jorge, Joan Colom. Fotografias de Barcelona, 1958-1964, Madrid/Barcelona, Ministerio de Educación, Cultura y Deporte/Lunwerg, 2004, pág. 45.

9 Formiguera, Pere, op. cit., pág. 152.

10 Miserachs, Xavier, op. cit., pág. 182. 
“Como seguidoras aventajadas de esta doctrina hay que citar a las agrupaciones fotográficas de Reus, Lleida, Terrassa, Igualada, Manresa, y a muchísimas otras que resultaría largo enumerar. Todas ellas participaron en un juego perverso que pretendía confundir el arte con la producción lúdica y diletante propia del «amateurismo»"11.

Toda esta actividad se mantiene al margen de las políticas museísticas y de subvenciones estatales o privadas, puesto que no interesan en absoluto las obras que allí se originan. La fotografía española, por su parte, tampoco pretende integrarse en la sociedad y se mantiene hermética, desvinculada de cualquier otra actividad cultural, intelectual o artística.

Aparte de la falta de interés de las obras producidas por los fotógrafos aficionados de un primer momento, hay otras razones estructurales que condenaban a las fotografías a ser contempladas únicamente en el interior de las agrupaciones de aficionados. No existe un mercado fotográfico que pudiéramos equiparar al mercado artístico. Los motivos son diversos: recordemos, entre otros, que las cartillas de racionamiento están vigentes hasta el año 1952. Estamos pues, a finales de la posguerra y en plena autarquía. No es época ésta de grandes lujos. Además, tradicionalmente la fotografía como proceso de reproducción técnico, ha atrofiado el "aura" -tal como la entendía Walter Benjamin-. Este "aura" es lo que fundamenta el valor cultural, la "autenticidad" del objeto único, de la pieza. Es el principal elemento valorado en el mercado del arte.

Otra razón -para que el mercado artístico desconfíe de la fotografía como mercancía única y como signo diferencial- es la popularización de los medios de producción fotográficos. Las técnicas se simplifican y se mecanizan, las máquinas se abaratan y se generalizan. Cualquiera puede ser fotógrafo. Cualquiera puede apretar un botón. ¿Dónde queda el genio del autor, la intervención manual, la huella? La fotografía presenta, pues, un estatus indefinido en donde se reniega del profesionalismo y el fotógrafo se convierte en un aficionado de domingo aspirante a artista, pero de espaldas al mercado, a las instituciones y automarginado de la propia sociedad.

\subsubsection{El concurso}

¿Cuál será entonces la aspiración máxima del fotógrafo aficionado en el interior de las asociaciones? ¿Dónde le llevarán sus enconados esfuerzos de fin de semana? La respuesta es que a ganar un premio en uno de los cientos de concursos fotográficos que se convocaban por toda la geografía nacional. Efectivamente, el concurso fue una actividad constante en las agrupaciones fotográficas, convertido en una tradición histórica mantenida desde la década de los años veinte.

“La actividad de estas agrupaciones fotográficas se centra fundamentalmente en los concursos, muchos de ellos mensuales y, al orgullo de resultar vencedor se unía la ventaja de ser invitado por todos a comer, realizándose así unas reuniones «gastronómicas». La fotografía se convierte en una forma de relación social. Las charlas, tertulias o salidas a fotografiar juntos los domingos estaban a la orden del día. La fotografía más que como una forma de expresión, es concebida como una afición. Ángel Ruiz, primer presidente de la Sociedad Fotográfica de La Coruña decía que: «la afición, el entusiasmo, la práctica continuada en una especie de amistosa y deportiva competencia nos animaba a conseguir una obra más perfecta, más original, o que ofreciese más dificultades. Se compulsaban los resultados de distintos reveladores, virajes, reductores: Oh! Farmer cuantas sorpresas...»"12.

11 Formiguera, Pere, op. cit., pág. 154.

12 Suárez Canal, Xosé Luis, “Lo caduco y lo nuevo", en el catálogo de la exposición Cuatro direcciones... op. cit., pág. 17. 


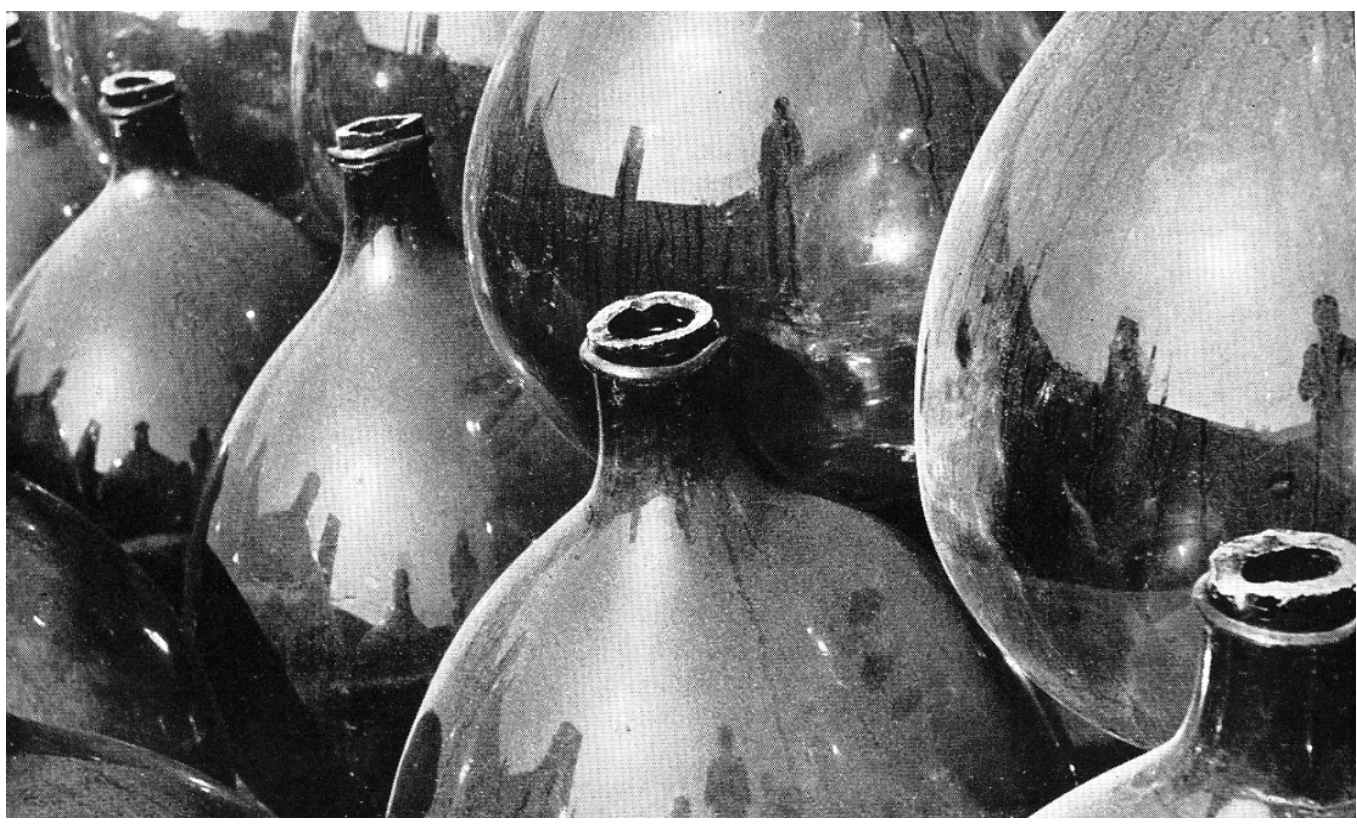

Jose March Argerich, "Vidrio", 1957. Premio de Honor en el VII Concurso Nacional de Fotografía, organizado por la Agrupación Fotográfica San Juan Bautista de San Adrián de Besós.

El concurso se convirtió en el sustituto del cliente, de la venta de la obra, del rendimiento económico y del mercado. Este hecho acentúa, si cabe, su carácter endogámico.

“En este sentido, cada vez fueron haciéndose más importantes las dotaciones crematísticas de los concursos. Se decía que de este modo se compensaban mejor los altos gastos que ocasionaba la actividad fotográfica (...) Una vez que la situación económica fue mejorando a lo largo de los 60, las empresas o entidades se volcaron hacia un patrocinio fácil. Se estabilizó un auto-mercado sobre el que subsistieron muchos fotógrafos (...) limitándose a una labor de autofagocitación, de consumo de los propios pseudoproductos generados por ella misma"13.

Los concursos surgían por doquier -convocados por cualquier institución como ayuntamientos o peñas excursionistas-, pero los concursos con más prestigio para el fotógrafo siempre surgían con el respaldo organizativo de las agrupaciones de fotógrafos aficionados legalmente constituidas.

“Arte Fotográfico iba a convertirse en el altavoz de todas las actividades concursísticas del país, dando la falsa sensación de que recogía la totalidad de la producción fotográfica de aquellos años"14.

La propia revista comenta orgullosa cómo gracias a ella ha crecido el número de concursos en los últimos años. De hecho la revista reservaba un $40 \%$ de sus contenidos a los concursos: las bases, los fallos y los comentarios de los mismos. 
“La cantidad de concursos y salones nacionales que tenemos a la vista rebasa con mucho el número de los celebrados en las mismas fechas en años anteriores. La afición a la fotografía crece de forma hasta ahora insospechada, y en este crecimiento o resurgimiento creemos tener buena parte, ya que nuestra Revista ha reavivado en muchos de nuestros lectores la pasión por la fotografía activa y ha ayudado a crear en más de una población clubs o peñas fotográficas de las que carecían, aun existiendo numerosos cultivadores del arte de la luz"15.

Se identifica de forma absoluta el concurso con la asociación. En aquel periodo es inconcebible el uno sin el otro. Los concursos o salones fotográficos se convertían en el único lugar donde se cotejaba obra ajena y donde se comparaba el nivel entre los fotógrafos, compitiendo. Esta circunstancia provocaba que antiguos concursantes anclados en el pasado de las entidades se erigieran, gracias a la veteranía, en jueces (llamados "jurados clasificadores") de nuevos concursantes; y que compañeros de la misma asociación, de la misma formación y de idénticas aspiraciones estéticas, se juzgaran los unos a los otros, dificultando enormemente cualquier posibilidad renovadora y consolidando el inmovilismo.

\footnotetext{
“Hay que hacer notar la similitud entre instituciones eclesiales/militares y las asociaciones fotográficas. Ambas participaban de un claro sentido jerárquico, que en las asociaciones estaba marcado por la escalera ascendente de premios, las condecoraciones/medallas honoríficas como las FIAP, y finalmente por la admisión en el Cuerpo de Jurados Diplomados, extraña institución creada para garantizar la calidad de los dictámenes de los Concursos"16.
}

Las rígidas estructuras de la asociación propiciaban un anquilosamiento de sus juntas directivas que a su vez perpetuaban unos gustos y unas costumbres específicas. En efecto, la propia dinámica concursística propiciaba el estancamiento y la obsesiva repetición en todos los aspectos, fueran temáticos, formales o estilísticos. La propia concepción del salón llevaba implícito su fracaso como opción creativa.

\begin{abstract}
“Dado el gran número de esta clase de acontecimientos, la diversidad de sus «rangos» -desde locales a internacionales- $\mathrm{y}$ «tipos» - de tema obligatorio o libre- y por la asequibilidad de las condiciones de participación disponen al concurso como medio óptimo para la libre y abundante concurrencia de los fotógrafos aficionados. Parece, pues, que el auténtico móvil y la verdadera pretensión de todo fotógrafo aficionado que participe en el concurso no fuese otro que el de la libre expresión y la difusión de una obra creativa hecha para ser mostrada. No obstante, la realidad del concurso en España lo convierte en una especie de «meritaje», un proceso de acumulación de premios, prestigio, y reconocimiento entre los compañeros del «mundillo fotográfico» que con un poco de suerte servirán para el salto a la «fotografía profesional». La dualidad amateur/ profesional se hace insalvable y aún más, se convierte a la primera en un mero tránsito y al concurso en el método de formación como sucedáneo de inexistentes centros pedagógicos oficiales, y muy pocos privados, dedicados a la enseñanza de la fotografía"17.
\end{abstract}

El concurso se convierte en una escuela de formación técnica, en el examen final de unos estudios que se han venido impartiendo en las tertulias, los debates y los consejos que se han intercambiado entre los propios socios aficionados. Pero no sólo se juzgarán los conocimientos

15 Barceló, Ignacio, "Salones y concursos", en Arte Fotográfico, nº 6, año I, junio 1952, pág. 193.

16 Santos, Manuel, op. cit., pág. 57.

17 Mira, Enric, La vanguardia fotográfica de los años setenta en España, Alicante, Instituto de Cultura "Juan Gil Albert", Diputación Provincial de Alicante, 1991, pág. 25. 
técnicos del aficionado, también se valorará una estética y una moral concreta. En los concursos se generará una ideología, en absoluto casual o inocente, sino más bien determinada por el Régimen.

\begin{abstract}
“Algunas se crean, para no herir susceptibilidades, con el beneplácito de personas allegadas al Régimen. Así la Agrupación Fotográfica Gallega para conseguir su legalización hubo de poner en la presidencia al Presidente de la Audiencia y como vocales, al comisario de Policía y al Comandante del Estado Mayor. Los comités de honor de algunos salones estaban presididos por el Gobernador Civil, el presidente de la Diputación, el Obispo de la Diócesis, el Gobernador Militar, el Alcalde de la ciudad y así hasta doce personas, ninguna de ellas vinculadas al mundo de la fotografía"18.
\end{abstract}

Para poder fundar una asociación fotográfica había que contar con una aprobación oficial del Gobierno que, asimismo, participaba directamente en el control de la asociación por medio de la presencia, en su junta directiva, de un miembro de la Seguridad del Estado, ya fuera civil, militar o policía:

\begin{abstract}
“Los nuevos responsables culturales, a través del Departamento de Plástica de la Dirección General de Prensa y Propaganda, además de ejercer la censura en las obras de arte, se encargaron de convocar los Salones Nacionales de Fotografía, que dependían de la sección fotográfica, dirigida por Augusto Vallmitjana, muy cercano a la Agrupación Fotográfica de Cataluña. Dichos salones, junto a las agrupaciones y a las revistas especializadas, influyeron decisivamente en la obra de la nueva generación pictorialista, deudora de un folclorismo de andar por casa, que enfatizaba los valores de la España «viril», frente a la Europa «fabril y liberal». Consecuentemente, los epígonos del tardopictorialismo exaltan en sus obras, la paz, la dicha, el honor y la «armonía sin angustias» de la vida rural y campesina. Algo que se mantendría durante varios lustros como el leimotiv de la obra de los más caracterizados epígonos del movimiento, como José Loygorry, J. Domingo Bisbal, Manuel Cuadrada, Miguel Tubáu, Diego Gálvez, Rafael Gómez Teruel, Josep Massó, Pere Sender, José Veiga Roel o José Núñez Larraz. Algunos de ellos -Pere Sender, José Veiga Roel o Núñez Larraz- sirvieron de puente con el realismo practicado por la generación siguiente" ${ }^{\prime 19}$.
\end{abstract}

El estado fomenta los salones, los considera un juego pueril. De este modo neutraliza enemigos potenciales. Es plenamente consciente de su servilismo, de sus veleidades artísticas -que aspiraban a la idealización y poetización de la realidad- y de sus estructuras arcaizantes. El estado rompe los cristales que pudieran reflejar una España herida que contradijera la versión oficial que tantos esfuerzos había costado articular a la propaganda franquista. El concurso se instituirá como un mecanismo sancionador que legitimará o no las obras presentadas. Las que no se acoplen a sus normas o tendencias estéticas, simplemente no ganarán. De este modo, se "educa" al fotógrafo aficionado que aspira a sintonizar con un jurado no preparado estéticamente, políticamente dirigido, que a su vez tiene mentalidad y formación de concursante.

Es cierto que los fotógrafos nunca fueron conscientes de la manipulación política que los concursos propiciaban, pero algunos, los más jóvenes, los que después protagonizarían la revolución en la que se vio inmerso Masats, sí se dieron cuenta de que la recepción de nuevas inquietudes creativas y de otras expresiones fotográficas estaba virtualmente imposibilitada en los concursos fotográficos: 


\begin{abstract}
“Esencialmente, el mecanismo sancionador que define el propio carácter del concurso se hace efectivo mediante la estipulación de unas bases o reglas del juego, a las que se pliegan los concursantes y el mismo jurado en tanto que elemento ejecutivo de aquella normativa que concede los premios según su criterio. De este modo, (...) pensamos que es la misma constitución del concurso, como procedimiento competitivo, de donde arrancan los males y vicios que (...) aquejaron gran parte de la fotografía en nuestro país"20.
\end{abstract}

\title{
2.2. LA FOTOGRAFÍA SEUDOARTÍSTICA
}

Si bien hemos presentado el contexto social que enmarcaba el salonismo, queda por perfilar el tipo de fotografía que representaba. Cuál es su origen, sus pretensiones estéticas...

En 1956 se realizó una exposición fotográfica en la Biblioteca Española de París comisariada por Oriol Maspons y presentada por la Agrupación Fotográfica de Cataluña a través del Club Les 30×40 de París. En ella participó Masats (es la primera vez que Masats expone en el extranjero) aunque su nombre no puede figurar en el programa por ser una incorporación de última hora. Con motivo de la exposición, Oriol Maspons escribió un artículo en la revista AFAL que completó con un texto de Daniel Masclet aparecido en la revista CINE-PHOTO-MAGACINE. Gracias a ese artículo podemos conocer la opinión que merece la fotografía española a un coetáneo ajeno al ambiente salonista. Un extranjero que observa la fotografía española desde una prudente distancia, de manera crítica y comprometida. Aunque Masclet reconoce la grata sorpresa que le produce la exposición -pues pudiera ser el principio de una "ráfaga de aire fresco" un intento de "cambiar de ropaje"-, el autor realiza un breve diagnóstico de la fotografía española que conoce hasta ese momento, que no deja lugar a dudas:

“En otro tiempo, la fotografía española estuvo representada por dos grandes maestros: Savignac y Ortiz-Echagüe. El primero era el mejor de los dos, el más sencillo, el más fotógrafo, el más profundo... El segundo era demasiado pictórico y muy aficionado al folclore... Publicó, incluso, varias obras sobre el paisaje y las costumbres de su país. Pero su folclore era demasiado artificioso, «teatral», cosa que se notaba enseguida. Más tarde hubo un largo periodo de inactiva decadencia, durante el cual España fue, con Bélgica e Inglaterra, una de las naciones Fotográficamente muertas en Europa.

¡Qué tremendo retraso! Sobre las paredes de los salones internacionales y entre los bromuros de las demás aportaciones, se encontraban algunas pruebas en tintas grasas, anticuadas demostraciones al aceite, empañadas y sucias, gomas bicromatadas amarillentas y desvaídas: eran la participación española, anquilosada en un pictorialismo de hacía cuarenta años..."21.

Con la excepción de Ortiz Echagüe, que seguirá exponiendo internacionalmente, la fotografía española de principio de los años cincuenta se encuentra completamente alejada de cualquier contacto con el extranjero. Arte Fotográfico fue uno de los causantes del estado en el que se encontraba la fotografía española de aquel momento, pues realmente se convirtió en el rasero por el que se comparaban todos los aficionados con pretensiones de ganar un concurso. Arte Fotográfico era el libro de texto de la escuela fotográfica franquista que marcaba rigurosamente lo que valía y lo que no valía.

“Por un lado va a introducir una serie de artículos, muchos de ellos traducidos de revistas extranjeras, y por otro se va a convertir en la revista que establezca los cánones que hay que cumplir para ganar los concursos. Va a ser la referencia de la concursística nacional. Un buen aficionado debe saber cuáles son los temas artísticos para no ser acusado de ignorante y poder tener acceso a la gloria local o nacional. A partir de escenas cotidianas había que obtener imágenes de cuidada y equilibrada composición, que

20 Mira, Enric, op. cit., pág. 26.

21 Masclet, Daniel, "Fotografía Española en París", en Afal, nº 6, noviembre-diciembre, 1956, sin paginar. 
tuvieran gran belleza plástica. Imágenes «exquisitas», según ellos, a las que se llegaba a través de un buen positivado y de un título sugerente: Satisfacción, Fantasía Otoñal, Flora, Bonjour, Contraluz, Espejo de Mar, Luces de Otoño, etc. (...) Los hechos humanos no tenían cabida dentro del realismo poético al que aspiraban las agrupaciones (...) Por lo único que se interesaban era por fotografiar algo que, aunque no tuviera sentido temático, mereciera la pena por la coherencia de sus partes, por su equilibrio, o por el ritmo de sus zonas blancas y negras, mostrando así una consumada pericia y visión artística pura"22.

Estos cánones no interesaban en absoluto a nadie fuera de las propias asociaciones. Como recoge el propio Ignacio Barceló:

“En alguna ocasión hemos apuntado desde este mismo lugar la ausencia de la fotografía española en las páginas de los anuarios que se publican en varias naciones europeas y en aquellos que ven la luz en Norteamérica"23.

Los motivos que aporta para justificar esta escasez en el extranjero son:

"Las tarifas de Correos puestas en vigor hace unos meses son prohibitivas para los aficionados"24.

"Cuando las obras vuelven a España hay que retirarlas de la Aduana, previo pago de los derechos correspondientes" 25 .

En cualquier caso, la realidad es que la fotografía española anterior a 1956, todavía sumida en la autarquía, y con una producción plenamente pictorialista y concursista, no interesaba al resto del mundo. España está "fotográficamente muerta". Pero esta falta de interés no sólo se sufre en el extranjero, también aparece en los propios círculos artísticos y culturales del interior del país.

La naturaleza documental de la fotografía sospechosa ante el Régimen, sobre todo después del ensayo fotográfico de E. Smith en Deleitosa (publicado el 9 de abril de 1951 en la revista Life bajo el título de "Spanish Village: It Lives in Ancient Povery and Faith"), la ruptura total con la incipiente vanguardia fotográfica anterior a la Guerra Civil y las propias estructuras salonísticas automarginadoras dentro de un país asimismo aislado... configuaban un contexto en el que parecía imposible que la fotografía no desapareciese ahogada entre los concursos, el pictorialismo y la técnica academicista. Para conocer el tipo de fotografía existente en España a principios de los años cincuenta vamos a seguir la clasificación que propone Antonio Ollé Pinell (Barcelona, 1897-1981).

Éste fue un artista polifacético, fotógrafo y grabador. También fue pintor, ensayista y crítico fotográfico (inmerso de pleno en la estética salonista). En 1954 publicó El arte de la fotografía y posteriormente, en 1957, una Enciclopedia de la fotografía con prólogo de Claudio Carbonell ${ }^{26}$. Según sus textos, la fotografía de los años cuarenta y principios de los cincuenta se encontraba agrupada básicamente en: fotografía científica (usada en medicina o geografía, con técnicas de radioscopia, micrografía, fotométrica); fotografía publicitaria o cartelística; fotografía documental (ocupada de la fijación exacta, perfecta y rápida de la realidad para ser publicada en la prensa diaria, la revista ilustrada, el documental cinematográfico...) y fotografía "artística" (destinada a las "más elevadas empresas").

La fotografía artística es la que pretendían producir los aficionados en los salones de las agrupaciones fotográficas y, según aleccionaba Antonio Ollé Pinell en 1954, se dividía en dos núcleos diferenciales: la fotografía "pictórica" y la fotografía "pura". La estética pictorialista exigía:

22 Suárez Canal, Xosé Luis, op. cit., pág. 17.

23 Barceló, Ignacio, "Trato de favor", en Arte Fotográfico, n 37, año IV, enero 1955, pág. 1.

24 Barceló, Ignacio, ibidem.

25 Barceló, Ignacio, “Aduanas", en Arte Fotográfico, n 8, año I, agosto 1952, pág. 281.

26 Ollé Pinell, Antonio, Enciclopedia de la fotografía, Barcelona, Gassó Hnos., 1957. 
“(...) disimular la naturaleza mecánica del procedimiento y la de expresar con el mismo temas de índole pictórico en su aspecto descriptivo y anecdótico. Es decir, que bajo este aspecto la Fotografía viene a ofrecer al Arte pictórico una técnica más de expresión plástica, como lo eran el Dibujo y el Grabado"27.

\subsubsection{Pictorialismo}

Para introducir el tardopictorialismo que imperaba en España a mediados de los años cincuenta hay que retrotraerse a los orígenes del propio pictorialismo (casi sesenta años antes) para entender, quizás, las motivaciones que llevaron a los fotógrafos a perpetuar un estilo tan peculiar durante tanto tiempo. Aunque es posible que las razones de esta pervivencia no fueran estrictamente estéticas o artísticas y sean debidas a las circunstancias políticas que regían el destino de España.

Uno de los principales motivos por el cual apareció el pictorialismo fue, entre otras razones, la reacción que motivó en los sectores más elitistas la popularización de la fotografía: el abaratamiento y la simplificación de todo el proceso fotográfico.

“El gran público deja de comprar fotografías, para comprar los medios de ejecutarlas. Al lado de los fotógrafos industriales, de los reporteros y de los retratistas, se desarrolla una nueva clase de practicantes, los aficionados, para los cuales la fotografía no está sometida a las obligaciones profesionales, sino que se convierte en una diversión, en un instrumento de placer"28.

Fue en 1888 cuando, desde Estados Unidos, llegó aquel inocente mensaje “Clic Clac Kodak”. Una legión ingente de aficionados surgió como competencia directa de los profesionales. Esta aparición, supuso una importante recesión económica entre los fotógrafos profesionales así como una profunda transformación de la industria, la práctica y el mercado fotográfico. A pesar del abaratamiento de las nuevas cámaras y de la sencillez de los nuevos materiales -como la nueva emulsión sobre película- lo cierto es que los precios seguían siendo demasiado altos para las clases obreras y no eran sino la clase media y la nueva burguesía los que nutrieron las filas de los primeros aficionados a la fotografía. Como cabe suponer los resultados estéticos de los nuevos invitados a participar de la fotografía fueron de lo más variopinto. Circunscritas al ámbito familiar, eran fotografías anecdóticas, sin ninguna pretensión de trascendencia, realizadas por fotógrafos con apenas técnica y/o nula preparación estética.

"Una de las principales objeciones que se formularon a la fotografía para considerarla como un medio de expresión fue su extremada impersonalidad. La fotografía era entendida tan sólo como un proceso mecánico-químico de registro de la luz sobre una superficie. Al fotógrafo se le valoraba como una pieza más de un engranaje, cuya función era limitadamente pasiva"29.

Pero la reacción del pictorialismo no fue sólo contra los aficionados, de hecho al final fue un movimiento asumido y perpetuado por ellos, en realidad fue una reacción contra la estandarización impuesta por el progreso de la industria fotográfica.

“La figura entre mágica y alquímica del fotógrafo de mediados del siglo XIX fue reemplazada por una prosaica legión de aficionados, dispuestos a comerse el mundo, con la única habilidad de mirar a través del visor y apretar el obturador" ${ }^{\prime \prime 3}$.

27 Ollé Pinell, Antonio, El arte de la fotografia, Barcelona, E. Meseguer, 1954, pág. 13.

28 Mélon, Marc, "Más allá de lo real: la fotografía artística", en Lemàgny, J.C. y Roville, André, Historia de la fotografía, Barcelona, Martínez Roca, 1988, pág. 84.

29 Gili, Marta, “El pictorialismo", en el catálogo de la exposición, Idas y Caos. Aspectos de las vanguardias fotográficas en España, Madrid, Ministerio de Cultura, Dirección General de Bellas Artes y Achivos, 1984. pág. 123.

30 Fontcuberta, Joan, "La fotografía catalana...", op. cit., pág. 78. 
El ataque del pictorialismo arremetió, asimismo, contra la asepsia y la perfección fría de la fotografía aplicada o científica, acusada de deshumanizada y surgida como consecuencia de la industrialización, la tecnología y la ciencia:

“Una cierta categoría de aficionados y de profesionales se cree en el deber de reaccionar contra la proliferación de imágenes consideradas como vulgares, puesto que carecen de todo control estético. La mayoría de ellos pertenece a la nueva clase dirigente. Quieren imponer una etiqueta de clase, un estatuto social, una elección política, un pensamiento filosófico, unas afinidades estéticas. En una palabra buscan una representación. Bajo la égida del progreso y de la ciencia, la fotografía se había convertido en la representación por excelencia de la clase liberal. Ahora seduce, aunque por otros motivos, a la nueva burguesía en ascensión. Dado que la ciencia ha puesto la fotografía al alcance de todos, hay que situar ahora la imagen mecánica bajo los auspicios de un maestro susceptible de avalar los privilegios de algunos, un maestro situado en las antípodas de la ciencia y que lleva un nombre mágico y prestigioso: el arte ${ }^{\prime \prime 31}$.

Se trataba de reivindicar un fotografía humanizada, artesana, con la impronta personal de la intervención manual:

“En oposición a la fotografía como réplica aséptica de la realidad se afirmaba una fotografía como vivencia espiritual y estética; en oposición a la fotografía como simple documento se afirmaba la fotografía de creación; en oposición a una fotografía servil y funcional se afirmaba una fotografía como experiencia de libertad creadora; en oposición a una fotografía banal y de consumo se afirmaba la nobleza y dignidad de los procesos fotográficos" ${ }^{\prime 2}$.

La intervención manual se materializaba en el uso de las impresiones nobles -es decir, gomas bicromatadas, bromóleos, aunque también se usarán papeles al carbón, fresones, etcétera- que conferían a las imágenes dos importantes características:

“Una enorme posibilidad de intervención en el proceso y de control del resultado, lo que requería un equilibrio de sensibilidad y destreza en el dominio técnico en el momento de preparar emulsiones y utilizar tórculos; y, por otra parte, una apariencia plástica que confundía a los que esperaban confrontarse con fotografías convencionales" ${ }^{\prime \prime 3}$.

No interesaba, pues, la definición de la imagen, la cantidad de detalles o la exactitud de los tonos fotográficos - pretensiones propias de las fotografías documentalistas, con aspiración de fidelidad a la realidad-:

“De esta rebelión frente a la angostura de los primitivos medios y prácticas, nacieron posteriormente los diferentes métodos de positivado pigmentario, también de naturaleza científica, pero más maleables, más adaptables al temperamento y a la idea personal de interpretación de cada aficionado" ${ }^{\prime 34}$.

La fotografía pictorialista valoraba la calidad de los soportes, las texturas o el color de la imagen, que permitían una personal y artística interpretación del mundo y de la realidad:

31 Mélon, Marc, op. cit., pág. 85.

32 Fontcuberta, Joan, “La fotografía catalana...", op. cit., pág. 78.

33 Fontcuberta, Joan, "La fotografía catalana...", op. cit., pág. 79.

34 Carbonell, Claudio, "Prólogo. La fotografía al servicio del Arte”, en Ollé Pinell, Antonio, op. cit., 1957, pág. 8. 
“Los procesos pigmentarios que permitían la acción directa del autor sobre la imagen final, eliminando detalles molestos, realzando las luces altas o introduciendo efectos de pincelada -procedimientos que en apariencia pueden ser contradictorios con una práctica documental- se utilizaban más como una forma de añadir un plus de artisticidad a la fotografía, reclamando esa posibilidad del medio de ir más allá del simple registro de la realidad, que como una forma de negar esa realidad, materia prima de la imagen." ${ }^{135}$

Hay que tener en cuenta que dos elementos resumen los signos de identidad pictorialistas: la obra única y la obra creativa, y los dos elementos confluirán en el uso de los procedimientos pigmentarios. Por un lado, las técnicas pigmentarias requerían de largas y complicadas preparaciones de los materiales a utilizar:

“(...) unido a lo costoso del procedimiento, hacía muy difícil la reproducción, de tal manera que la copia de un solo negativo se convertía en ejemplar único"36.

Y, por otro lado, la placa de cristal no era más que un boceto de la imagen final, el positivado, lleno de las máximas intervenciones y manipulaciones posibles que hacia que se convirtiera en la verdadera obra:

“Cuyo resultado final, es decir la fotografía propiamente dicha, era montada y presentada en el formato y con los materiales adecuados para sugerir en el espectador la idea de «cuadro», de "pintura», de «obra de arte» que es lo que se pretendía" ${ }^{37}$.

La realidad fría y científica, el detalle fotográfico, será rechazado sistemáticamente por el pictorialismo. Esta repulsa vendrá motivada, en parte, por el convencimiento de que, gracias al descubrimiento de la fotografía y a su empleo en diversos campos como la óptica, la astronomía, la arqueología, la física...

“(...) la realidad ha sido conquistada por entero. Una idea errónea, claro está, pero muy defendible al final del siglo XIX. Los aficionados a la fotografía se dan cuenta de que ésta ha agotado casi el programa que Arago le asignó en 1839. (...) Ya lo lamente o lo alabe, el público del siglo XIX reconoce al realismo fotográfico su excelencia en cuanto a la reproducción del detalle. Ahora bien, en ciertos espíritus, esa perfección cualitativa tiende a crear la ilusión de una «perfección» cuantitativa semejante, esto es, una totalidad"38.

Por tanto, los pictorialistas pretenden acceder a la realidad de "otro modo", personalizando la mirada del aséptico objetivo, independizándose del referente. Para ello no sólo utilizan los procesos nobles, como ya hemos visto, también dispondrán de una batería de "técnicas de distanciamiento": desde los famosos "objetivos de artista" -llenos de aberraciones ópticas que aprovechan los fotógrafos para desenfocar el molesto detalle-, a un interminable surtido de filtros, pantallas, gasas, tramas o bastidores. Incluso pueden tratarse de pantallas naturales, como la lluvia, la niebla, la bruma o la nieve. No hay que olvidar que el pictorialismo, en origen, nace como respuesta a una serie de reflexiones estéticas y deontológicas sobre el propio medio, sobre la legitimidad de la representación fotográfica y en defensa de un estatus artístico para la fotografía. Aunque parezca surgir de un complejo de inferioridad de la fotografía frente a otras artes ya reconocidas, como el dibujo y la pintura, lo

35 Zelich, Cristina, op. cit., pág. 22.

36 Cancer Matinero, José Ramón, “Introducción”, en el catálogo de la exposición, Fotografía pictorialista valenciana, Valencia, Generalitat Valenciana, 1992, pág. 86.

37 Cancer Matinero, José Ramón, ibidem.

38 Mélon, Marc, op. cit., pág. 93. 
cierto es que los pictorialistas no pretendían imitar a la pintura, sino situarse a su nivel, disfrutar de su misma categoría y prestigio. El valor artístico de la fotografía fue tan cuestionado que la mayoría de los artistas que la utilizaron, muchas veces como documentación o apoyo a sus pinturas, esculturas o dibujos, tardaron tiempo en reconocer que la utilizaban o directamente se negaron a hacerlo. Casi desde su origen la fotografía era considerada como un mero sistema de reproducción de la realidad. En su crítica al salón de 1859 Baudelaire arremetía contra las aspiraciones artísticas de la fotografía:

\begin{abstract}
“Como la industria fotográfica era el refugio de todos los pintores fracasados, demasiado poco capacitados o demasiado perezosos para acabar sus estudios, ese universal entusiasmo no sólo ponía de manifiesto el carácter de la ceguera y de la imbecilidad, sino que también tenía el color de la venganza.(...) Si se permite que la fotografía supla al arte en algunas de sus funciones pronto, gracias a la alianza natural que encontrará en la necedad de la multitud, lo habrá suplantado o totalmente corrompido. Es necesario, por tanto, que cumpla con su deber, que es el de ser la sirvienta de las ciencias y de las artes, pero la muy humilde sirvienta, lo mismo que la imprenta y la estenografía, que ni han creado ni suplido a la literatura" ${ }^{\prime 39}$.
\end{abstract}

El pictorialismo trataba, pues, de alcanzar el reconocimiento de la fotografía como parte de las Bellas Artes con todo lo que ello implicaba: mercado del arte, estructuras administrativas, intereses financieros... Desde un punto de vista comercial una imagen única, firmada y personalizada, recupera el aura que más tarde definirá Walter Benjamin, convirtiéndose en un artículo de lujo que puede contrarrestar la producción del aficionado, a la par que marca una categoría privilegiada tocada por el arte.

La primera vez que apareció el término fue en el título del libro de Henry Peach Robinson (1830-1901), Pictorial Effect in Photography:

“En eso reside el gran proyecto del pictorialismo, en considerar la fotografía como una de las bellas artes.

Los orígenes de la palabra pictorialismo confirman la naturaleza de su proyecto. El término deriva de la expresión inglesa pictorial photography, en la que pictorial es un calificativo que proviene de la palabra picture, que significa «imagen» o «cuadro», y no pintura, que la lengua inglesa traduce por painting. Ciertas traducciones como «fotografía pintoresca», «fotografía pictórica» o «pictoricismo» resultan, por consiguiente, inadecuadas. La presencia de la palabra picture en la denominación inglesa del movimiento recuerda cuál fue su objetivo inicial: dar a conocer la fotografía como una imagen entre las demás imágenes" 40 .

Fue una corriente artística de carácter internacional, extraordinariamente prolífica, que aunque nació en Europa, rápidamente se extendió a Estados Unidos. En Europa las asociaciones impulsoras del movimiento pictorialista fueron fundamentalmente: la Wiener Kamera Club de Viena, el Linked Ring Brotherhood de Londres, L' Association Belge de Phographie de Bruselas y el Photo-Club de París. Asimismo, el pictorialismo entró en Estados Unidos de la mano de Alfred Stieglitz, fundador del grupo Photo-Secession. Hay que destacar el carácter elitista e incluso aristocrático de estas asociaciones. Pertenecer a una de ellas, entrar en su restringidísimo círculo, era un honor concedido a unos pocos privilegiados, puesto que estas asociaciones pretendían, no sólo velar por la calidad de sus fotografías, sino que también defender el estatus artístico y social de los propios fotógrafos. De hecho, los socios eran personas acomodadas, ricas y poderosas:

39 Baudelaire, Charles, "Salón de 1859. El público moderno y la fotografía", en Salones y otros escritos sobre arte, Madrid, Visor,1996, págs. 232-233.

40 Mélon, Marc, op. cit., pág. 87. 
“(...) muchos de sus afiliados son alcaldes o diputados y pertenecen a la magistratura o al ejército. Algunas, como la Asociación Belga de Fotografía, que goza de la protección del rey Leopoldo II y elige como presidente honorífico al príncipe Alberto, mantiene las mejores relaciones con los poderes políticos" ${ }^{\prime 1}$.

La fecha oficial del comienzo de pictorialismo se sitúa en 1891. En ese año se organizó la primera exposición del Kamera Club de Viena con aspiraciones más artísticas que técnicas. En ella participó Alfred Stieglitz, el mismo que en 1902 convertirá a Nueva York en el centro del pictorialismo internacional, fundando -junto a Edward Steichen y otros-, la agrupación Photo-Secession y editando la revista Camera Work. Stieglitz organizó en 1910 una magna exposición (600 fotografías) en la Albright Knox Art Gallery de Búfalo, con la que consiguió el reconocimiento internacional de la fotografía.

Aunque siempre subyaciera el concepto de la fotografía como arte, lo cierto es que aparecieron una gran diversidad de tendencias cobijadas bajo el genérico término de pictorialismo, dada la amplia distribución de territorio que alcanzó. Esta heterogeneidad se acentuó por la gran diversidad cultural de los distintos países que modificaron y acoplaron el movimiento a sus características propias. Precisamente, con la disolución de la Photo-Secession y la desaparición de la revista Camera Work en 1917, Alfred Stieglitz, su director, dio por superado el movimiento pictorialista en favor de una fotografía directa, libre de cualquier deuda pictórica. Aunque, ciertamente, esta transición no fue tajante y el pictorialismo se mantuvo durante años conviviendo con la fotografía realista.

En España el pictorialismo fue introducido a principios del siglo XX a través de las publicaciones extranjeras, en las que colaboraban fundamentalmente Antonio Cánovas del Castillo y Vallejo, Kaulak, (Madrid, 1862-1934) y Ortiz Echagüe (Guadalajara, 1886 - Madrid, 1980). El pictorialismo se instauró en España con varios años de retraso, y ese retraso se mantuvo en su disolución de manera desproporcionada. No será hasta final de los años cincuenta que el pictorialismo entrará en crisis, a favor de una fotografía directa y realista, reivindicada por Masats entre otros.

“El pictorialismo español del primer tercio del siglo XX se desarrolla en dos etapas, marcadas por el cambio generacional y delimitadas por la creación de nuevas instituciones en los años veinte: Sociedad Fotográfica de Zaragoza (1922), Agrupació Fotogràfica de Catalunya (1923) y Foto Club de Valencia (1928) (...) La división entre el novecientos y la Guerra Civil se realiza en dos grandes grupos con límite en 1920. Entre ambos períodos se producen diferencias estéticas, técnicas y temáticas. En el primero tuvo la hegemonía Madrid, y la revista de relevancia fue La fotografía, editada por la Sociedad Fotográfica de Madrid; en el segundo la tuvo Barcelona y se editaron una decena de publicaciones, entre ellas Lux, Criterium y Arte Fotográfico"42.

En sus inicios la fotografía pictorialista en España tuvo muchas concomitancias con la fotografía artística que se realizaba en el resto de Europa, pero pronto adquirió características específicas. Los puntos en común con el pictorialismo internacional los hallamos en aquellas obras acordes con el simbolismo y el art nouveau. El art nouveau aportó una pátina de aquel excesivo preciosismo de la decoración de finales del siglo XIX, mientras que el simbolismo añadió al ornamento una intención de trascendencia. El simbolismo utilizaba las imágenes como alegorías de temas místicos, pretenciosamente sublimes: 
“Ninfas en el bosque, mujeres con largas túnicas... son algunos de los motivos que aparecen con frecuencia en las imágenes. Pero lo que define también al simbolismo es esa voluntad de trascender el tema para llegar a un mensaje: el rayo de sol que se filtra a través de los árboles representa a la Divinidad del mismo modo que las mujeres retratadas pasan a ser símbolo de la Belleza" 43 .

Paralelamente, en su intento de equipararse al arte, hubo influencias de la pintura más académica y clásica, aquella inspirada en temas históricos o sacados de nuestra literatura más universal como los trabajos de Luis de Ocharán sobre El Quijote, el de Antonio Cánovas con su ilustración de la dolora de Campoamor ¡Quién supiera escribir!, etc. Otra inspiración para la fotografía de la época fue la pintura de género, retratos, escenas familiares... y por supuesto la pintura religiosa. La fotografía pictorialista se llenó de iglesias, escenas bíblicas, monjes, claustros procesiones y monaguillos.

La aparición masiva de asociaciones de fotografía y de nuevas publicaciones especializadas marcan el advenimiento de una segunda generación de fotógrafos pictorialistas:

“En 1923 se creó en Barcelona la Agrupación Fotográfica de Cataluña, entre cuyos miembros se encontraban Joaquín Pla Janini y Claudi Carbonell. También ese mismo año se creó la Sociedad Fotográfica de Zaragoza en la capital aragonesa y cinco años más tarde, en 1928, se fundó el Foto Club de Valencia por iniciativa, entre otros, de Vicente Peydró. Estas tres asociaciones dieron un nuevo impulso a la fotografía pictorialista, canalizando la obra de un buen número de aficionados. Evidentemente, la creación de estas asociaciones respondía a la necesidad de aunar esfuerzos e iniciativas que hasta ese momento se hallaban dispersas. Fue también el detonante para que el agrupacionismo y el salonismo se extendieran por toda la geografía española"44.

En España la fotografía artística acabó refugiándose en las agrupaciones de aficionados que, anacrónicamente, mantuvieron su práctica hasta finales de los años cincuenta.

“Buena parte de los pictorialistas más destacados eran amateurs militantes, es decir, que hicieron del «amateurismo» una causa. En general procedían de familias acomodadas y desempeñaban profesiones liberales. Consideraban la fotografía una actividad demasiado noble para embrutecerla mercantilizándola"45.

Por tanto, en España se renunció a participar del mercado del arte: no había galerías, ni coleccionistas. Ser aficionado se convirtió en una condición indispensable para ser un auténtico pictorialista. Se perdió, por consiguiente, parte del sentido que originó el movimiento fotográfico en Europa hacía casi sesenta años. Identificar a la obra pictorialista con una pintura o un dibujo, dotarla de aura, convertirla en "pieza" para imbuirla del mismo estatus y, lógicamente, del mismo mercado del resto de las artes. Este solitario tardopictorialismo, absolutamente desfasado y caduco, repitió una y otra vez los mismos temas y los mismos esquemas creativos: folclore, escenas de género y paisajes bucólicos llenos de ruinas que evocaban aquel pasado glorioso del imperio español que, como ya hemos señalado, tanto agradará a la estética franquista.

Los aficionados, ajenos a la manipulación a la que serían sometidos por parte del Régimen, se debatían buscando la artisticidad del medio fotográfico. Unos lo justificaban mediante los temas escogidos, otros mediante la manipulación y el tratamiento pigmentario de los originales. 


\begin{abstract}
“No siempre hubo unanimidad en torno al concepto de fotografía artística. Quizás el debate más relevante fue el que se estableció entre los que defendían la artisticidad del medio recurriendo a los temas de la pintura y, por extensión, a los de la historia, la mitología y la literatura, y los que, por el contrario, opinaban que independientemente del tema fotografiado lo que probaba la capacidad de la fotografía de ir más allá de una simple reproducción mecánica de la realidad era la posibilidad de manipulación que algunos procesos específicos de impresión le brindaban. La intervención de la mano del autor individualizaba y personalizaba cada imagen de tal modo que dejaba de ser una mera descripción para convertirse en evocadora de sentimientos e impresiones" 46 .
\end{abstract}

Temáticamente, y en perfecta consonancia con la ideología franquista, surge un interés mayoritario por el paisaje y el costumbrismo por parte de los nuevos aficionados pictorialistas que, desde una perspectiva formal, apostarán por un uso casi generalizado de la goma bicromatada y, sobre todo, del bromóleo transportado. Resulta paradójico observar cómo coinciden dos aspectos aparentemente contradictorios en este tipo de fotografía. Por un lado, se observa un contenido eminentemente documental, a veces incluso antropológico, pero al mismo tiempo el tratamiento de las imágenes está absolutamente manipulado, y no sólo mediante procedimientos pigmentarios de lo más variado. En realidad muchas de las imágenes son complejas puestas en escena, con modelos vestidos por el fotógrafo para la ocasión, contratados y en actitudes forzadas:

“Pero si algo imprimió realmente un carácter propio al pictorialismo español fue el regeneracionismo, que se origina en los círculos intelectuales vinculados a la generación de 98 . Su influencia determinaría una revisión del paisaje, al igual que suscitaría el interés de las ciudades castellanas, ampliado con la incorporación de los principales protagonistas de estos escenarios: los campesinos y los tipos castellanos.

Impulsados por un interés etnográfico y antropológico, en busca de una esencia de lo español a través de sus tipos, tradiciones y paisajes, en clara relación con el ideario de la generación del 98 y, posteriormente, del regionalismo, un buen número de fotógrafos recorre el país y sus lugares más recónditos. Como también ilustra la monumental España tipos y trajes. Se produce una curiosa mezcla de fotografía con un pretendido carácter documental pero realizada a menudo con técnicas pigmentarias y en las que el fotógrafo, en el momento de la toma, intervenía a modo de director de escena colocando a los personajes" ${ }^{\prime \prime 7}$.

No sorprende descubrir cómo las imágenes costumbristas que se recrean son fundamentalmente rurales frente a las fotografías realizadas en las ciudades. La modernidad, las fábricas o la industria quedarán relegadas en favor de los trajes típicos, los pueblecitos tranquilos, los pastorcillos y sus rebaños y los riachuelos espejeantes. La discusión estética sobre la artisticidad de la fotografía se remonta a sus orígenes, como ya hemos visto. Pero el motivo real por el cual se decidió apoyar al pictorialismo, desde los instrumentos de control franquista, no se debe al resultado de ningún debate estético. El motivo es evidentemente político.

“En el ambiente de exaltación patriótica propiciado por la victoria militar de 1939, el arte era concebido como algo meramente ceremonial, puesto al servicio del Estado y del Imperio, entre pompier, reverencial y azul. La estética del franquismo, definida por hombres como Giménez Caballero, José María Pemán, Eugenio Montes, García Valdecasas o Laín Entralgo, era un confuso amasijo de retórica, que se acercaba mucho al catálogo de valores del pictorialismo de la anteguerra: grandeza y unidad de la Patria, exaltación de la raza, de la tradición y de una catolicidad barroca y herrumbrosa. No es nada 
extraño que la doctrina cultural del franquismo se apropiase de la estética de este movimiento, cuya prolongada vigencia sólo puede entenderse por el decidido apoyo que se le ofreció desde las más altas instancias oficiales del nuevo Régimen" 48 .

Este tipo de fotografía que idealizaba la España eterna, era la que se alentaba, o se premiaba, en los salones y concursos fotográficos; no porque se hubiera gestado en el interior de ningún movimiento propiciado por el estado (ya hemos visto que el pictorialismo es bastante anterior al régimen de Franco), sino porque, de todos los movimientos precedentes éste es el más inofensivo y acorde con la ideología dominante. Aquellas "técnicas de distanciamiento" que idealizaban o poetizaban sus referentes eran providenciales para un régimen al que no le interesaba en absoluto que la penosa realidad de la autarquía, el racionamiento y el estraperlo trascendiera. De modo que el franquismo se apropió del pictorialismo y lo utilizó en su propio interés, probablemente a pesar de algunos de los propios fotógrafos:

“Unos fotógrafos anclados, en su mayoría, en el preciosismo decorativista que tanto convenía a los propósitos de un Régimen que buscaba ocultar la realidad del país, mediante un arte -y la fotografía vivía plenamente el prejuicio artístico de sí misma-, al que se reservaba un papel ceremonial y enmascarador. En este sentido, el tardopictorialismo fue la aportación fotográfica nacional a la autarquía, en la misma medida en que fue producto de ésta"49.

La trayectoria de Ortiz Echagüe es paradigmática en lo concerniente a la manipulación y apropiación del pictorialismo por parte del aparato ideológico franquista. Ortiz Echagüe (1886-1980) fue de todos los autores pictorialistas el que más distinciones y premios cosechó. Miembro del jurado del Salón de Londres, Socio de Honor de varias sociedades fotográficas (Real Sociedad Fotográfica de Madrid, Sociedad Fotográfica de Zaragoza, Agrupación Fotográfica de Cataluña, Agrupación Fotográfica de Igualada, Agrupación Fotográfica de León) y de varias asociaciones extranjeras, su obra se desarrolló a lo largo de setenta años sin ningún tipo de desviación ni evolución aparente:

“El prolongado período pictorialista, que fue brillantemente contestado antes de la Guerra Civil por Pere Català Pic, Aurelio Grasa, Nicolás Lecuona y tantos otros, volvió a resurgir de las cenizas de posguerra en la glorificación por Ortiz Echagüe de la España mística y trabajadora con que soñaba el general Franco"50.

Desde su primera imagen, “El Sermón en la aldea” (1903), captada a los dieciséis años, hasta sus últimas fotografías tomadas en 1973, su estilo y sus concepciones estéticas no sufrieron alteraciones esenciales. Como ya vimos, Echagüe fue uno de los pioneros en la importación del pictorialismo a principios del siglo XX e, incluso, publicó su primer libro antes del golpe de estado militar: Spahische Köpfe, fue publicado en Alemania en 1930. La edición española se titulará España, tipos y trajes (1933), y alcanzará la cifra de doce ediciones de más de setenta mil ejemplares en total. Por tanto, cuando años más tarde Echagüe concluya su monumental tetralogía (España, pueblos y paisajes que vio la luz en 1938 -con nueve ediciones-, España mística se publicó en 1943 -con cuatro ediciones- y Castillos y alcázares lo hizo en 1956 -con otras cinco ediciones-), su estilo, su técnica, su temática y sus referencias ya estarán perfectamente consolidadas. De hecho, durante la Guerra Civil su archivo desapareció y sus imágenes fueron utilizadas por el bando republicano para ilustrar el pueblo campesino, exaltándolo. 


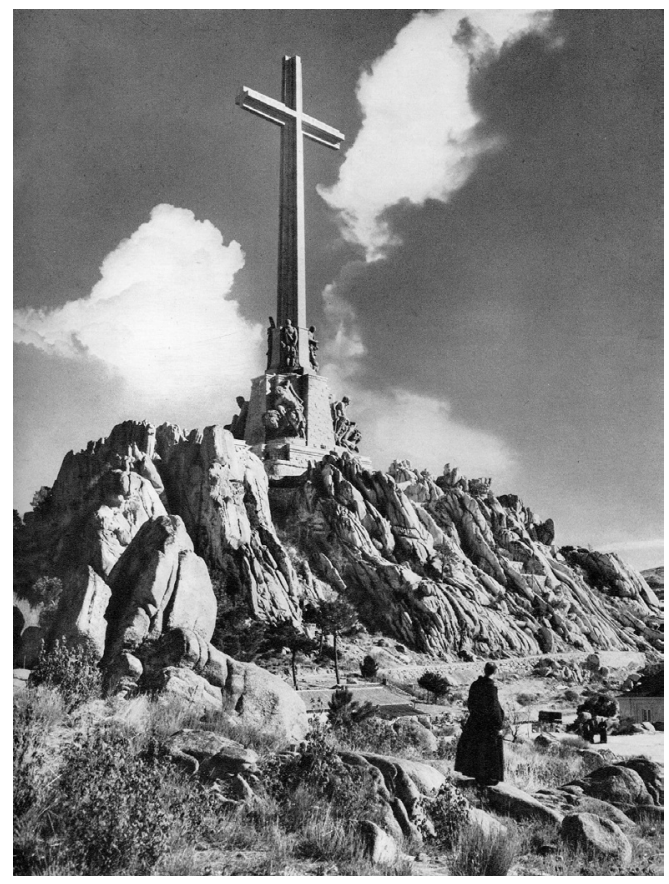

José Ortiz Echagüe, "El valle de los caídos", 1943. Primera fotografía de su libro La España Mística.

“Durante la Guerra Civil española, pude liberar de la zona comunista a los tres meses de iniciada e incorporado al ejército nacional, realicé la campaña. A la liberación de Madrid encontré mi casa saqueada y, naturalmente, desaparecido todo mi laboratorio y archivo fotográfico. Después de activas pesquisas encontré éste en un centro de juventudes libertarias casi completo. Mis fotografías sobre temas populares habían sido utilizadas por los comunistas para ilustrar artículos periodísticos exaltando las virtudes del pueblo. Nunca hubiera imaginado semejante destino" ${ }^{151}$.

El hecho de que Echagüe fuera militar y luchara en el bando nacional durante la Guerra Civil y que posteriormente dirigiera dos grandes empresas (en 1923 funda “Construcciones Aeronáuticas, S. A." [CASA] y en 1950 es requerido por el presidente del Instituto Nacional de Industria para presidir la SEAT) quizá ha generado una sesgada interpretación de su obra:

“Es interesante ver cómo las polémicas sobre su adscripción a diversos movimientos o la discusión sobre la validez de la utilización de las técnicas pigmentarias, a menudo han opacado e impedido un acercamiento a la obra de Ortiz Echagüe. Igualmente su condición de militar y después de industrial de éxito (relativo en un país poco dispuesto a reconocer la labor de estos pioneros), en la España de Franco, han generado una corriente crítica sobre la intencionalidad política de su obra, que nosotros no compartimos y que la correcta datación de sus obras contradice" ${ }^{\prime \prime 2}$.

51 Ortiz-Echagüe, José "Mi vida fotográfica", en Ortiz-Echagüe, José; Vielba, Gerardo, José Ortiz-Echagüe. Sus fotografías, Madrid, Incafo, Colección clásicos de la fotografía española, 1978, págs. 7-8.

52 Levenfeld, Rafael y Vallhonrat Valentín, “Ortiz Echagüe 1886-1980", en Ortiz Echagüe, fotografías 1903-1964, Madrid, Tf. Editores/La Fábrica, Espacio de Cultura,1998, págs. 30-31. 
Como puede observarse, ha sucedido algo similar, salvando las distancias, a lo acaecido con la obra de Leni Riefenstahl (Berlín, 1902 - Baviera 2003) y el régimen de Hitler. ¿Cómo sustraerse en las imágenes de Riefenstahl del nazismo y de la barbarie que provocó? Con independencia de ello, y sin entrar en un debate que daría, él solo, para otra tesis doctoral, José Ortiz Echagüe se convirtió en la representación pura de la España franquista y su estilo, anacrónico y anticuado, fue mantenido artificialmente gracias a ello.

“Acabada la contienda Ortiz Echagüe continuó con su afición tras la recuperación de su archivo. Pero también sus fotografías de tipos y trajes fueron recuperadas ideológicamente. Esto fue si cabe más sencillo, en ellas se daban cita por igual la tradición, el realismo, la identidad nacional, la austeridad y, sobre todo, la espiritualidad perdida; no cabía duda que en el arte de Ortiz Echagüe era fácil encontrar todos estos valores que se exaltaban en aquellos momentos, además de la belleza, la verdad y la bondad, características esenciales de la retórica estilística de la Nueva España del Régimen de Franco"53.

La obra de Echagüe fue fagocitada por el franquismo aunque la manipulación a la que se vio sometida no fue involuntaria ni inconsciente, dado que Echagüe colaboró con el franquismo y se benefició de él. Echagüe era la perfecta encarnación de los valores franquistas. Su vida y su obra constituían el perfecto ejemplo para las nuevas generaciones. Sus gestas militares, sus aventuras como pionero de la aviación y sus condecoraciones se declamaban en las biografías y las entrevistas que concedía, mitificando al personaje, convirtiéndolo en un héroe, en un titán. Echagüe se transforma en una figura legendaria: militar, medio monje y eremita que artesanalmente elabora sus propios materiales para corporeizar su obra al margen de cualquier veleidad. Una obra que resalta las antiguas señas de identidad del Imperio (los castillos) y del pueblo (el folclore y el tipismo), siendo profundamente religiosa, espiritual y católica. Como puede deducirse fácilmente, todos los tópicos franquistas, estudiados en las primeras páginas de este trabajo, se materializan en José Ortiz Echagüe.

“Esta profunda identificación entre la obra de Ortiz Echagüe y el espíritu nacional del franquismo fue insistentemente subrayada por algunos de los miembros más representativos de las nuevas élites intelectuales. «A través de su obra -escribió fray Justo Pérez de Urbel, en 1948-vemos desfilar al hombre de todas las provincias y también de todos los tiempos, el que ha hecho esa historia descomunal que supera los más locos extravíos de la poesía épica. Así vemos al héroe de Numancia y al conquistador americano, al repoblador anónimo de la reconquista, a don Quijote, a Hernán Cortés...». Todavía en 1962, Miguel Tubáu insistía en argumentos similares: «Y ahí está el secreto del maestro, palpitando al compás de un sentimiento patriótico puesto al servicio del arte de la fotografía, sin desviaciones $\mathrm{y}$, a la vez, sin concesiones a liberalismos de importación»" ${ }^{\prime 4}$.

La obra de Ortiz Echagüe contribuirá a la construcción de un estereotipo nacional que se utilizará tanto en el interior de España como en los libros o las exposiciones que vieron la luz en el extranjero.

“De todos es conocidos la situación en la que quedó el país (...) Evidentemente ese ambiente no era el que se debía transmitir, ni difundir y, de hecho, una de las consignas del nuevo régimen político fue ocultar la realidad del país. Para ello las imágenes de tipos y trajes de Ortiz Echagüe hicieron

53 Vega, Jesusa, “La fotografía, Ortiz Echagüe y el simulacro de España”, en el catálogo de la exposición José Ortiz Echagüe en la colecciones del Museo Nacional de Antropología, Madrid, Ministerio de Educación, Cultura y Deporte, Secretaría de Estado de Cultura, Secretaría General Técnica, Subdirección General de Información y Publicaciones, 2002, pág. 66. 54 López Mondéjar, Publio, op. cit., págs. 178-179. 
un gran servicio ya que se transformaron en la imagen «real» de España, a través de un proceso de simulación, es decir, se convirtieron, siguiendo a Baudrillard, en la hiperrealidad de España.(...) Es más, la hiperrealidad se construye a través de imágenes tan perfectas y acabadas que no son penetrables, el espectador ante ellas es pasivo, es decir, elimina la crítica y no duda de ella. $Y$ eso precisamente es lo que ha ocurrido con las imágenes de Ortiz Echagüe hasta nuestros días: su simulacro de España ha eliminado el análisis y ha llevado a la fascinación, porque la realidad tiene contradicciones pero el simulacro no, todo está codificado incluso la recepción alienante, en este caso, de evocadora nostalgia.

Es ahí donde creo que radica la perversidad de estas fotografías, en el uso que se hizo de ellas"55.

Cabe destacar que, obviamente, esta lectura de la politización de la fotografía pictorialista en general -y la de Ortiz Echagüe en particular- es bastante reciente. La opinión que Ortiz Echagüe suscitó a los jóvenes renovadores en aquel momento fue, cuando menos, de respeto. Lo consideran un clásico al que hay que superar. Así lo demuestran los textos de la época como éste de Luis Navarro:

“Ante todo no sigas a nadie. No hay nadie tan grande que pueda valer lo suficiente para que sigas sus huellas. Admira a Misonne, a Bodine, a Echagüe, a Weston, a Steichen. Y sigue un camino diferente al suyo. ¿No lo hay? Ábrelo. La cámara fotográfica es un buen machete para abrirse paso entre la vegetación de la jungla" ${ }^{\prime \prime 6}$.

0 éste, más sorprendente, de Oriol Maspons -uno de los principales ideólogos de la renovación fotográfica-, que aclara bastante su opinión sobre el academicismo:

“A no dudar confunde Vd. lo académico con lo clásico o no matiza la enorme diferencia de lo que es un clásico, un auténtico clásico, que puede serlo sin necesidad de estar muerto (como Edward Steichen, Weston, Brassaï o Cartier-Bresson) y el académico, empeñado en hacer belleza siguiendo unas normas fácilmente trasmisibles por la enseñanza. Para que no me tilde de repetir siempre nombres extranjeros, que a $\mathrm{Vd}$. tan poca gracia le hacen, me tomaré la libertad de ponerle un ejemplo con nombres de españoles. La fotografía española ha tenido un solo clásico que es José Ortiz Echagüe y muchos académicos entre los que destacan el Dr. Pla Janini, Antonio Campañá y otros. De los fotógrafos de nuestros días es aún prematuro fijar su calidad total" ${ }^{\prime 57}$.

El reconocimiento de la obra de Ortiz Echagüe por parte de, prácticamente, todos los fotógrafos españoles de la era de Franco, incluso los más evolucionados y críticos, hizo que incluso la junta directiva del -por entonces, ya desaparecido- grupo AFAL, José M. a Artero y Carlos Pérez Siquier, le publicaran un homenaje con ocasión de la edición del Anuario de la fotografía española $1973^{58}$, el primero de los cinco anuarios de la fotografía, Everfoto. En él aparece un extenso artículo de ocho páginas escrito por Gerardo Vielba, con cuatro fotos a toda página, en el que se repasa nuevamente la vida y la obra de Ortiz Echagüe. El artículo en cuestión contrasta profundamente con el resto del anuario que pretende acaparar la totalidad de la fotografía moderna española de ese mismo año. Desde nuestra perspectiva es incomprensible que una publicación con voluntad de vanguardia y novedad cometa tal anacronismo. Aunque, tal vez, la

55 Vega, Jesusa, op. cit., págs. 66-67.

56 Conde Vélez, Luis (Luis Navarro), “Carta a un aficionado joven”, en Arte Fotográfico, n 22, año II, octubre 1953, pág. 475. 57 Maspons, Oriol, “Carta abierta para D. Raimundo Costa Terradellas”, en Afal, n 10, julio-agosto, 1957, sin paginar. 58 Vielba, Gerardo, “Homenaje. José Ortiz Echagüe, fotógrafo de España”, en Artero García, José M. ${ }^{a}$ y Pérez Siquier, Carlos, Anuario de la fotografía española 1973, León, Everest, 1972, págs. 8-16. 
respuesta a tal incoherencia tenga más a ver con cuestiones político-diplomático-sociales -que permitieran la continuidad, difusión y apoyo del proyecto de los anuarios-, que con cuestiones meramente estéticas. Tal vez fuera una concesión política que evitara la oposición activa a los anuarios.

Con todo, ya veremos más adelante qué es lo que se rechaza del pictorialismo. Aunque es posible que tenga mucho que ver con esa repetición de fórmulas artísticas "fácilmente transmisibles por la enseñanza". 0 con su sentido artificioso y teatral... 0, simplemente, con el hecho de ser una fotografía antigua y vieja que choca frontalmente con la modernidad

\subsubsection{La fotografía pretendidamente "pura"}

Siguiendo aquella clasificación de Antonio Ollé Pinell (en la que dos corrientes aglutinaban la fotografía artística: pictorialismo y fotografía pura), veremos ahora cómo la fotografía "pura" -en tanto que Arte- renunciará a las manipulaciones pigmentarias de la fotografía pictórica, despreciando todo recurso que no sea exclusivamente fotográfico:

“La anécdota, el asunto, pasó a segundo plano; cualquier motivo, cualquier cosa era bastante para conseguir una maravilla fotográfica; el caso era que se le viera bien, con luces ajustadas, bien moldeadoras, desde un punto de vista original; el movimiento podía ser violento sin malograr la nitidez y la calidad material del objeto, mejor cuanto más fiel y crudo (...) objetivismo y dinamismo por encima de todo (...) En la fotografía pura adquieren valor anecdótico las cualidades materiales de las cosas (...) las principales son: el sentimiento y la valoración de la luz; el movimiento y las calidades de la materia.

Evidentemente que la luz, el movimiento y las calidades materiales ya eran tenidas en cuenta en el concepto pictórico, pero en sentido auxiliar y secundario, en cambio, la fotografía pura los eleva a sujeto principal, y en esto consiste, más que en otra cosa, la diferencia entre ambos conceptos de arte fotográfico" ${ }^{\prime \prime 59}$.

Como se ve, la fotografía "pura" no aspira a nada más que a un aséptico ejercicio técnico. Sólo importa la luz, el movimiento y la definición óptica, la materia. El objeto, el asunto, no tiene ninguna importancia. Y por supuesto, cualquier valoración o interpretación de la realidad ni se concibe. Para ello ya está el pictorialismo, encargado de maquillarla, de idealizarla. La fotografía "pura" es un sistema óptico para captar exclusivamente materia, luz y movimiento. Realmente no se puede limitar más un medio de expresión. No alberga ninguna capacidad comunicativa, ninguna utilidad. Ni falta que hace, mientras los tonos negros salgan profundos y las luces brillantes.

Pero cuidado, cualquier intento de experimentación o "exageración" es sospechoso de "mal gusto" y debe evitarse. Hay que erradicar de base cualquier veleidad renovadora:

“Naturalmente, al caer en exageraciones se produjeron desviaciones del sentido común, y así ángulos visuales atrevidos se convirtieron en extravagantes; los estudios de calidades, en documentos fríos y banales de materias muchas veces desagradables en su naturaleza, y la fijación de un movimiento, en la manifestación absurda de un desequilibrio, por más real que fuese ${ }^{\prime \prime 60}$.

La dictadura de Franco truncó cualquier proyecto de modernidad y sólo aquellas tendencias no implicadas en la creación de vanguardia, ajenas a cualquier intento de renovación plástica, subsistieron. No deja de ser significativa la ausencia total de referencias, en el texto de Antonio 
Ollé, a cualquiera de los textos estéticos que se divulgaban, en aquella misma época, año 1954, fuera de nuestras fronteras. Todos los movimientos artísticos gestados en aquel periodo, o incluso anteriores al mismo, simplemente se desconocen. Los profesionales sólo podían ser científicos, publicistas o periodistas. El reportaje era una mera traslación de la realidad al papel, sin ninguna pretensión estética o creativa, sólo se concibe en el contexto de la prensa gráfica, cuya única función era la de difundir un evento o servir de documento histórico.

La fotografía "pura" estaba destinada al aficionado, defendida desde los jurados de los salones, colgada de sus muros. Esta cerrazón no sólo era producto del aislacionismo internacional, recordemos que estamos en plena autarquía. Años mas tarde, ya en 1958, cuando empiezan a conocerse las obras de Cartier-Bresson o de Steichen y su The Family of Man, la lectura que Thomas Höpke extrae de este tipo de fotografía está completamente tergiversada, calificándola de "sentimentalista" y "literaria".

“El mayor ídolo fotográfico lo constituyen actualmente las fotos de Cartier-Bresson y la Exposición The Family of Man, de Steichen. Hemos superado ya la puesta de sol en el estanque y la barba de los guardabosques, y ahora encontramos nuestros motivos en las tabernas de los puertos, patios traseros, cuevas con música de jazz, cementerios. Y al hacerlo no nos damos cuenta que seguimos permaneciendo fieles a nuestros antiguos métodos fotográficos, que ahora continuamos fotografiando sentimentalismos, aunque ahora, por así decirlo, con signo negativo. Que no falte en ninguna revista burguesa un mendigo cojeando o alguna «amenacita» de tipo atómico. Eso da una sensación de escalofrío muy agradable por la espalda. Las fotos éstas tienen su razón de ser, de eso no cabe duda, porque se nos dice como con altavoz su mensaje: un repatriado de Rusia sollozando a su regreso, una dama distinguida ante un montón de estiércol, la pareja de novios ante la «seta» atómica. Y al rendir tributo a este fetichismo del «mensaje», no nos damos cuenta de que todas esas fotos ni siquiera merecen el nombre de tal, pues en el fondo no son más que ilustraciones de textos literarios" ${ }^{\prime \prime 1}$.

De esta manera, el fotógrafo, haciendo "foto-literatura", se convierte en un mero intermediario, según Höpker, que no depende de sus conocimientos compositivos para hacer una buena imagen, sino de la suerte al escoger el objeto fotografiado:

“La foto literaria renuncia, en general, a la parte estética y, por tanto, a la especial «dignidad» óptica"62.

Por el contrario, la foto "puramente de forma", el equivalente a la foto "pura" de Ollé Pinell...

“Se habría liberado de todo contenido literario y sería fotografía en el sentido más puro de la palabra, teniéndola que comprender no intelectual y racionalmente, sino con los sentidos, o sea, sólo por su observación (...) La forma es el efecto conjunto de líneas, superficies, curvas, de tonos grises, de lo claro y lo oscuro, del color y de la luz. Cada forma aislada, y cada conjunto de formas, tiene una fuerza expresiva especial, un cierto contenido original que puede producir en el observador sensible determinadas sensaciones y representaciones" ${ }^{\prime \prime 3}$.

En este caso, también se nos advierte contra los abusos o las experimentaciones.

61 Höpker, Thomas, “¿Hacia dónde? Tareas y caminos de la fotografía actual”, en Arte Fotográfico, n 79, año VII, julio 1958, pág. 576.

62 Höpker, Thomas, “¿Hacia dónde? Tareas y caminos de la fotografía actual (conclusión)”, en Arte Fotográfico, n 80 , año VII, agosto 1958, pág. 659.

63 Höpker, Thomas (agosto 1958), op. cit., pág. 657. 
“De ningún modo debemos caer en una completa abstracción y falta de objetividad, siempre tiene que poder reconocerse el objeto original. $Y$ ese es precisamente el atractivo específico de la fotografía, el que un motivo que vemos a diario -transformado en imagen de forma adecuada- adquiera posibilidades de expresión completamente nuevas" ${ }^{\prime 64}$.

Como síntoma del retraso ideológico y conceptual es curiosa la anécdota de cómo, en 1958, los fotógrafos españoles redescubrieron otro uso de la fotografía: la de ser reproductora de cuadros y esculturas. En la revista Arte Fotográfico aparece un artículo entusiasta al respecto de una exposición en la que:

“Ante la imposibilidad de desplazar las diversas piezas que componen la colección del Museo, sin evitar el riesgo artístico que tal operación reportaría, se recurrió a la feliz idea de exponer en tan memorable acto el conjunto de ampliaciones murales, demostrativas en diversos aspectos del galardonado Museo (...)

Tan interesante experiencia nos ha suscitado el considerar cuan útil podría ser en esta nueva faceta de la fotografía (...) para poder exhibir, en su función cultural y educativa, los más preciados tesoros artísticos del Patrimonio Nacional, sin excesivo coste y con nulo riesgo. ¿Será un día verdad tanta belleza...?"65.

Como ya hemos comentado, el desconocimiento de los textos críticos y de la bibliografía que hoy consideramos como clásica, era casi absoluto. En un anuncio de venta de libros por correo de una librería de Barcelona aparece un listado con la bibliografía esencial que podría haber manejado el fotógrafo del año 1955:

“El enfoque. F.W. Frerk

La luz natural. Edwin Smith.

Los filtros. C. I. Jacobson.

El retrato. Hugo van Wadenoyen

La exposición. C. I. Jacobson.

El momento preciso. Alex Strasser.

Efectos de contraluz. Hugo van Wadenoyen.

El paisaje. Hugo van Wadenoyen.

Los interiores con la luz natural. Hugo van Wadenoyen.

Una sola lámpara. Hugo van Wadenoyen.

La segunda lampara. Hugo van Wadenoyen.

La composición. A. Kraszna-Kraus.

Procesos de laboratorio. C. I. Jacobson.

Los negativos como se mejoran. F. W. Frerk.

Ampliaciones. C. I. Jacobson.

Código del principiante. Marcel Natkin.

Niños al aire libre. Hugo van Wadenoyen.

Juegos y deportes. Lancelot Vining.

Los grupos. (vol. doble.) Gordon Catling.

Fórmulas. C. I. Jacobson.

Niños en interiores. Hugo van Wadenoyen.

Instantáneas mejores. Hugo van Wadenoyen.

64 Höpker, Thomas (agosto 1958), op. cit., pág. 660.

65 C. L., “Una nueva faceta utilitaria en la fotografía española”, en Arte Fotográfico, n 79, año VII, julio 1958 , pág. 611. 
Retoque de ampliaciones. (vol. doble) A. Frouin

El bebé. W. Suschitzky.

Retratos bellos. W. Nurberg.

El retoque de negativos. (vol. doble) A. Roumanés.

Copias por contacto. B. Mautner.

Las cámaras miniatura. P. W. Harris.

La Leica. W. D. Emanuel"66.

Se puede observar que casi todos los libros o son manuales de técnica fotográfica o recetarios compositivos. Son libros de diferentes géneros, llenos de tópicos y de fórmulas, con reglas de composición, iluminación... No deja de sorprender que casi todos los autores sean extranjeros. Pero la temática es completamente inofensiva para el régimen. 


\section{CAPÍTULO 3}

\section{La aceptación internacional. Cambios en la política interior de España}

El primer contacto de Masats con el mundo de la fotografía tuvo lugar en un momento histórico muy intenso, que sin duda influyó determinantemente en su obra. A continuación analizaremos el contexto político del final de la autarquía, y las consecuencias sociales y culturales que reportó para Masats y para toda su generación.

El absoluto rechazo por parte de la comunidad internacional al gobierno franquista duró siete años. Siete años de casi total ostracismo tanto a nivel político y económico como cultural. Pero con la aparición de la guerra fría la posición ideológica y geográfica de España interesó de nuevo a la comunidad internacional y a Estados Unidos en particular. La amenaza fascista había desaparecido por completo después de la virtual demolición de los países del eje, para ser inmediatamente sustituida por la agresiva política expansionista de los países comunistas. España, un país pequeño, aislado y todavía no recuperado de su propia Guerra Civil, no tenía ninguna posibilidad de suscitar algún tipo de amenaza militar o ideológica. Que Franco tuviera un pasado o un presente filofascista no era mayor problema. Era un tema agotado mundialmente. Sin embargo, lo que Franco profesaba de manera explícita y activa era el anticomunismo. La situación geográfica de España, situada estratégicamente entre dos continentes y a la entrada del Mediterráneo, era atractiva para Estados Unidos. Por ello España fue aceptada por la comunidad internacional y admitida, por fin, en la Organización de las Naciones Unidas:

\footnotetext{
“Gracias al ataque alemán a la Unión Soviética, Franco había presentado su idea de dos guerras separadas: la guerra en el oeste, en la cual los intereses españoles indicaban la no-beligerancia, y la guerra del este, la intervención en la cual resultaba un imperativo ideológico, «Rusia tiene la culpa de nuestra Guerra Civil», declaró Serrano Suñer en los balcones de la Sede Central de Movimiento. «El exterminio de Rusia es una demanda de la historia». En julio de 1941 la División Azul, con 18.694 hombres, había partido hacia el frente ruso"1.
}

Con el advenimiento de la guerra fría la teoría de las "dos guerras", otrora un obstáculo, se transformó en una carta de triunfo. Antes de la era de los misiles intercontinentales la importancia de España para los planes estratégicos norteamericanos era evidente y, además, la idea de España como "reserva espiritual" anticomunista era atractiva para el Congreso. Asimismo, la Santa Sede se erigió en adalid diplomático del Estado Español como prebenda a su sumisión y entrega. La Iglesia, que ejerció una censura sobre la moral de los espectáculos y de los libros mucho más rígida que la censura política del Régimen, mantuvo su prensa y creó su propia escuela de periodismo, sus emisoras de radio y sus editoriales:

“En todo caso, y como advertía una entrega de Mis chicas, revista para niñas (...) «Antes de leer un libro consulta con un sacerdote»"2.

1 Carr, Raymond, España 1808-1975, Barcelona, Ariel, 1990, pág. 769.

2 Gracia García, Jordi, “La estética del miedo”, en Hernández Sandoica, Elena (Dir.), La España de Franco (1939-1975). Cultura y vida cotidiana, Madrid, Síntesis, Colección Historia de España 3er. Milenio, 2001, pág. 27. 
En la Universidad, con bastantes cátedras ocupadas por religiosos y pensadores católicos, la filosofía católica de raigambre tomista reemplazó al pensamiento de Ortega como filosofía oficial. Fue otra de las fuerzas que presionaron para conseguir la aceptación internacional del régimen de Franco, maquillado de semi-demócrata y tolerante. En el interior las consignas de Carrero Blanco eran sensiblemente diferentes:

“(...) orden, unidad y aguantar. El régimen tenía que actuar «sobre la base de que es moral y lícito imponerse por el terror cuando éste se fundamenta en la justicia y corta un mal mayor» (...) Terror, palizas y escarmientos fueron, en efecto, los métodos empleados para sofocar los intentos de reorganización de sindicatos y partidos obreros alentados por la expectativa de la inminente caída de Franco que acompañó el fin de la Guerra Mundial"3.

De cara al exterior la operación cosmética supuso la eliminación de los rasgos más decididamente fascistas del Régimen y la aprobación de algunas leyes que suavizaron su significación totalitaria.

“La finalidad declarada de esa campaña retórica de «cosmética constitucional», de «cambio aparente de fachada» era mejorar la imagen del régimen y satisfacer así mínimamente la sensibilidad democrática de los aliados victoriosos, pero sin reducir un ápice su poder omnímodo y vitalicio. Se trataba, según el propio testimonio privado de Franco, de una «política de depuración del mimetismo» respecto del eje sin llegar a «uncirnos en el carro democrático». Y todo ello sin cambios sustanciales: «No conviene ceder para que no se tome por debilidad»"4.

El 13 de julio de 1945 se promulgó el Fuero de los Españoles, una especie de carta de derechos. El día 17 el gobierno aprobó una amnistía parcial. El 20 de julio Franco formó un nuevo gobierno: para la cartera en aquella circunstancia más importante, la de Exteriores, nombró a un significado católico, Alberto Martín Artajo; eliminó, además, el Ministerio del Movimiento. El 11 de septiembre se suprimió oficialmente el saludo fascista. El día 18 España evacuó Tánger. El 22 de octubre el nuevo gobierno promulgó la Ley de Referéndum Nacional, que contemplaba que por primera vez algunas leyes pudieran ser sometidas al referendo de los españoles. El voto, evidentemente, sólo era para los hombres, los "cabezas de familia":

“El 26 de julio de 1947, tras ser aprobada precisamente en referéndum (votó sí el 78\% de un censo de 16 millones, con una participación del 93\%), se promulgó la Ley de Sucesión, que definía a España como «un Estado católico, social y representativo que, de acuerdo con su tradición, se declara constituido en Reino»"5.

El franquismo enfatizaba, por tanto, la significación católica de España y de su régimen. La Iglesia, duramente castigada en la zona republicana, había bendecido la sublevación como "cruzada". La recatolización del país había sido objeto casi fundacional del nuevo régimen:

3 Juliá, Santos, Un siglo de España. Política y sociedad, Madrid, Marcial Pons, Ediciones de Historia,1999, pág. 166.

4 Moradiellos, Enrique, "La etapa del predominio del nacional-catolicismo (1945-1959)", en Hernández Sandoica, Elena (Dir.), La España de Franco (1939-1975). Cultura y vida cotidiana, Madrid, Síntesis, Colección Historia de España 3er. Milenio, 2001, pág. 104.

5 Fusi, Juan Pablo y Palafox, Jordi, España (1808-1996) El desafio de la modernidad, Madrid, Espasa Calpe, 1998, pág. 305. 


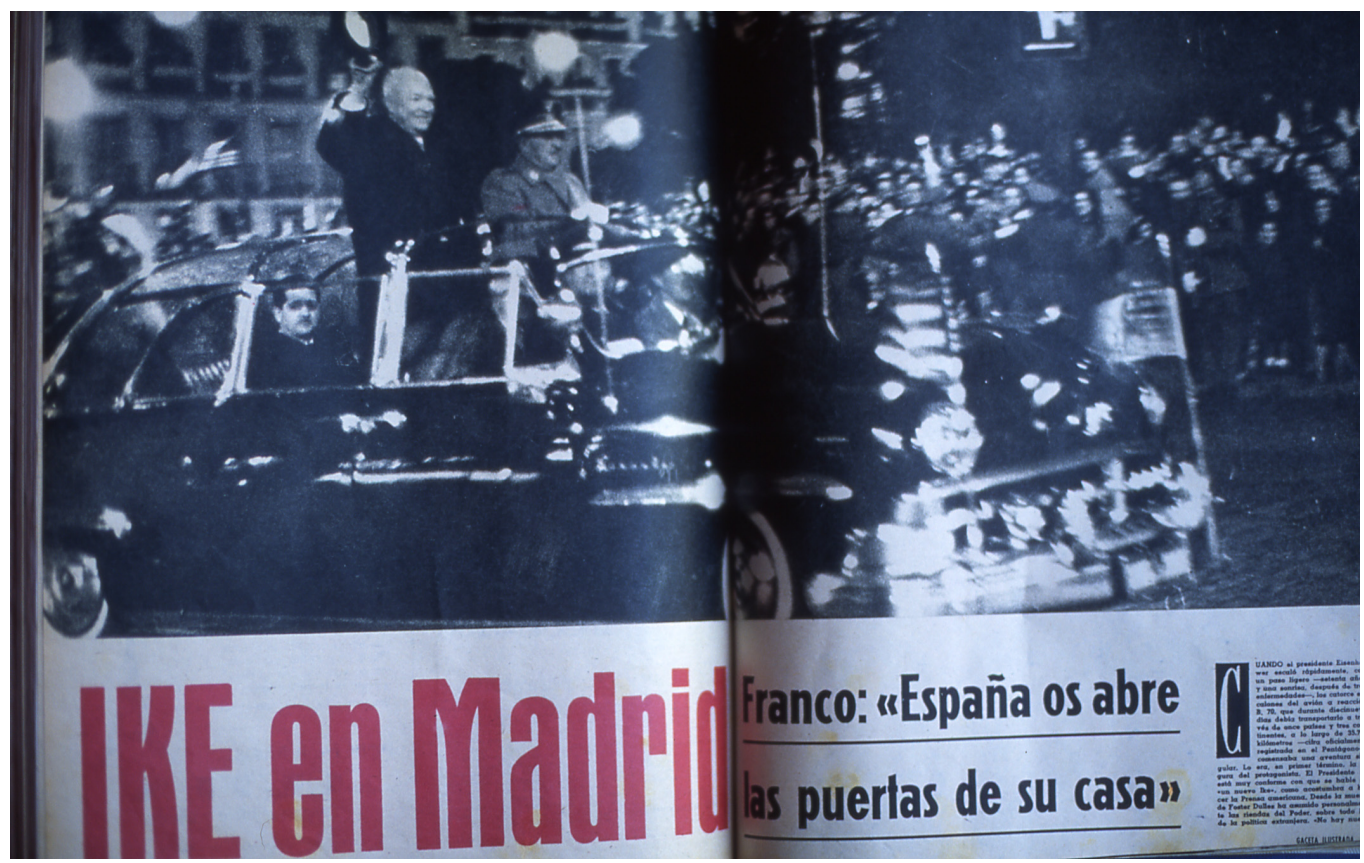

Reportaje gráfico sobre la llegada de Eisenhower aparecido en Gaceta Ilustrada, n 168, 26 de diciembre de 1959, págs. 10-24.

“Por decreto de 3 de mayo de 1938 se había autorizado el retorno de la Compañía de Jesús. España fue solemnemente consagrada a la causa Católica en 1939. Las festividades religiosas volvieron a ser celebradas con fasto especial.

Toda la legislación laicista de la II República fue derogada. La Iglesia recibió el monopolio de la educación"6.

Franco hizo numerosas concesiones a la Iglesia: el Concordato convertía a España en un estado jurídicamente católico:

“En realidad, no le quedaba otra alternativa: en 1945 ni el ejército ni Falange servían para establecer relaciones con el exterior; la única que podía desempeñar ese papel era la Iglesia" ${ }^{\text {"7. }}$

Pero los acuerdos fueron especialmente satisfactorios para el Régimen español:

“Aparecer unido en espíritu con su católico pueblo no le haría daño alguno a los ojos de los católicos estadounidenses y europeos y lo acercaría al codiciado Concordato con el Vaticano. No podía haber máscara más eficaz para un régimen tan cruelmente represivo"8.

Era, pues, un refuerzo moral excepcional de cara a la consecución del que desde 1946 era el

8 Preston, Paul, Franco, Caudillo de España, Barcelona, Grijalbo, 2002, pág. 673. 
objetivo esencial de la diplomacia franquista, encabezada por Martín Artajo: la ruptura del aislamiento internacional. En noviembre de 1952, la Naciones Unidas rescindieron su resolución de 1946 y los embajadores retornaron a España. En 1953 se llegó al acuerdo con los Estados Unidos relativo al establecimiento de bases en España a cambio de la promesa de un préstamo sustancial:

“En diciembre de 1955, España fue admitida en la 0.N.U. con sólo concesiones de fachada a las exigencias de democratización de su dictadura personal (el Fuero de los Españoles en 1945), el Caudillo había sido aceptado por la democracia más grande del mundo merced a su propia valoración de si: el centinela de occidente. Cuando en 1959, Franco recibió el abrazo del general Eisenhower a los acordes de La rosa amarilla de Texas, pudo decir: «Ahora he ganado la Guerra Civil»"${ }^{9}$.

Como puede sospecharse, todos estos acontecimientos tuvieron una gran resonancia en el interior del país. En el pulso de poder que se produce en la política nacional, la Falange radical y sectaria es la gran perdedora en favor del Opus Dei y de sus ministros tecnócratas. Éstos promulgan una leve pero decidida liberalización de la universidad y de la economía que busca la integración en Europa. La consigna de modernización y desarrollo económico conllevará cambios trascendentales en la actitud autoritaria del Estado Español. La antigua autarquía se manifiesta como inviable. Es necesaria una apertura de las fronteras, de la comunicación con el exterior, y también una apertura informativa.

Junto a esta "normalización" de las relaciones internacionales se producen algunos cambios políticos en el interior que, si no afectan a la estructura y orientación generales del Régimen, sí implican una redistribución del poder y cambios parciales en algunos sectores. Reducido al mínimo el lastre de Falange, los ministros del Opus Dei, a los que se conoce habitualmente con el nombre de "tecnócratas" -aunque realicen una política por completo ideológica- inician una serie de reformas que cambian la fisonomía del país y buscan su desarrollo. Estabilización, o ajuste, primero; desarrollo, después: estos serán los dos ejes de una renovación que finalmente chocará de nuevo con la rigidez de la estructura política. Pese a ello la modernización buscará la integración en Europa a través del saneamiento y desarrollo de la economía, de la elevación del nivel de consumo, de la apertura de las fronteras, de la transformación de algunos modelos de comportamiento y costumbres, de la apertura informativa...

Todo ello unido a una represión notable y efectiva. En este sentido, la crisis en el marco de la cual se lleva a cabo la estabilización económica y el Primer Plan de Desarrollo alienta la resistencia obrera, cuyas huelgas son reprimidas con contundencia. Las reformas iniciadas por Ruiz Giménez en la Universidad dan origen a una oleada de reivindicaciones que pondrán en aprietos a las instituciones educativas superiores.

“El SEU (Sindicato Español Universitario), que estaba penetrado de estudiantes izquierdistas, bastantes militantes del PCE, salta por los aires en sucesivas voladuras que se quiere controladas y que finalmente resultan siempre explosivas.

Esta penetración (que fue rasgo característico del movimiento sindical, y no sólo del sindicato universitario, en los años cincuenta) podía producir efectos sorprendentes a nivel cultural.

Por ejemplo, la publicación de revistas como Acento cultural (1959), editada por el Departamento Nacional del SEU y dirigida por Carlos Vélez, y Cuadernos de Arte y Pensamiento (1959), editada por el SEU de la Facultad de Filosofía y Letras de la Universidad Complutense de Madrid y dirigida por César García Martín"10.

9 Carr, Raymond., op. cit., pág. 682.

10 Bozal, Valeriano, "Arte del siglo XX en España II. Pintura y escultura 1939-1990", Summa Artis. Historia general del arte, Tomo XXXVII, Madrid, Espasa Calpe, 1995, pág. 253. 
Hay que destacar que muchos de los implicados en estas revueltas estudiantiles eran hijos de los mismos tecnócratas, pues no todo el mundo tenía acceso a una educación universitaria.

\subsection{LA BATALLA IDEOLÓGICA}

Con la relativa apertura informativa y con los conatos de liberalización se hizo patente la necesidad de renovar unas estructuras y un pensamiento obsoletos. Poco a poco, siquiera fuera de forma subrepticia, el marxismo y el existencialismo calaron en un estrato intelectual cada vez más crítico con las ideas franquistas, falangistas y religiosas. Quienes impulsan la renovación ideológica habían vivido la guerra siendo niños y carecían de una vivencia directa o indirecta de lo que condujo a la misma. Todos ellos poseen la conciencia innovadora que los anima a romper con la inercia localista. La visión de una España idealizada y deformada bajo el prisma de la retórica épica, imperial y mística, dejó paso a una mirada de la realidad inmediata y cotidiana que evidenció la grave situación social. Intelectuales, artistas y escritores se comprometieron moralmente con la denuncia de una realidad penosa e hiriente. El neorrealismo italiano, la novela objetiva, la "generación realista de la posguerra", fueron las formas de expresión de una cultura crítica y cada vez más liberal.

Hay que destacar que este despertar del opiáceo sueño en que se hallaba sumergida España ocurrió en ámbitos muy concretos y selectos ya que la cultura popular siguió en manos del régimen de Franco. De hecho, el clima cultural del Régimen quedó definido mucho más por la subcultura de consumo de masas que por la propia cultura oficial:

“Por una razón esencial: porque esa cultura de masas, una subcultura carente de preocupaciones políticas e intelectuales pero de gran popularidad y difusión pública, favorecía, vía el entretenimiento y la evasión, la integración social y la desmovilización del país, objetivos políticos del nuevo régimen"11.

Dicho de otro modo, sólo la vanguardia intelectual en España se llamaba realismo. Pero este realismo crítico era más que una moda literaria. Era, forzando los términos, la expresión de la sensibilidad e ideología de las nuevas generaciones españolas, las que protagonizaron en 1956 y en 1963-1968 la rebelión universitaria contra el franquismo. Efectivamente, en 1956 antiguos falangistas aparecían unidos en una acción común con nuevos comunistas: una novedad que derrumbaba barreras y mezclaba los campos divididos por la guerra. Los incidentes de febrero de 1956 marcaron la aparición de una nueva generación que comenzaba a organizarse como oposición al Régimen sin que importara el campo en que hubieran militado ellos mismos o sus padres durante la Guerra Civil.

\footnotetext{
“Además del grupo comunista, la Agrupación Socialista Universitaria se presentó el día 1 de abril con un manifiesto que comenzaba con una insólita identificación: «Nosotros, hijos de los vencedores y de los vencidos», con el propósito nunca oído antes, «de reconciliarnos con España y con nosotros mismos»"12.
}

Este rechazo ideológico del movimiento universitario evidenciaba la repulsa al franquismo de los futuros dirigentes.

\footnotetext{
“De hecho, según las encuestas realizadas en la Universidad de Madrid, a finales de los años sesenta parece evidente que los universitarios españoles eran mayoritariamente demócratas por convicción e incluso
}

11 Fusi, Juan Pablo, Un siglo de España, La cultura, Madrid, Marcial Pons, Ediciones de Historia, 1999, pág. 109. 12 Juliá, Santos, op. cit., pág. 173. 
marxistas de intención: más del 70\% se sentían influidos por autores como Herbert Marcuse o Jean Paul Sartre, algo más del 50\% seguían a Bertrand Russell o Joaquín Ruiz-Giménez, en tanto que menos del $10 \%$ compartían la ideología de dos intelectuales del régimen (Fueyo Álvarez y Muñoz Alonso)"13.

Como vemos, el compromiso con sus contemporáneos se focalizó a través de las dos grandes corrientes filosóficas que corrían por Europa, el existencialismo y el marxismo clásico:

“Las páginas de Acento y Cuadernos de Arte y Pensamiento (...) están llenas de reflexiones que se reclaman del realismo y se mueven en un horizonte difuso de marxismo y existencialismo: el marxismo de Lukács y los "clásicos" de la Academia de Ciencias de la URSS, por una parte, el existencialismo sartiano más orientado al análisis de los acontecimientos concretos (literarios, filosóficos, sociales, políticos, etc.), por otra"14.

Todo esto quiere decir que ya no era posible el monolitismo de los años cuarenta. El debate se hizo más complejo y menos abstracto, contó con nuevos ingredientes y perspectivas diferentes a las tópicas de la inmediata posguerra: las vinculadas a la realidad social, la realidad inmediata y cotidiana, y a su análisis. Paradójicamente algo cambió también en Falange, o por lo menos en parte de ella, ya que algunos de los responsables de este nuevo cambio proceden de los medios intelectuales de primera hora:

La politización del arte tuvo, tal y como ya hemos señalado, dos polos teóricos principales: el marxismo y el existencialismo. Si el primero destacaba el carácter social y productivo de la persona, el existencialismo incidía directamente sobre el compromiso moral del individuo llevado a una situación límite en la cual se revelaba la verdadera identidad de las cosas.

“El nexo de unión se establece a través de la concepción sartiana del artista libre y comprometido, de la moralidad cívico-política, de la noción de testimonio y denuncia que era común a ambos. Las diferencias se afirmaban a partir de la respectiva defensa de la individualidad, propia del existencialismo y del informalismo, y de la articulación social, propia del marxismo y del realismo"15.

La cultura liberal, no toda ella en el exilio, representada por historiadores, escritores, críticos de arte o filósofos (hombres como Julián Marías, Zubiri, Laín Entralgo, Emilio García Gómez, Dámaso Alonso, Lapesa, Caro Baroja, Ramón Carande, José A. Maravall, Díez del Corral, Rodríguez Huéscar, Garagorri, López Aranguren, Antonio Tovar, Lafuente Ferrari, Chueca Goitia), irá adquiriendo paulatinamente una mayor vigencia. La misma lógica de la docencia superior hizo que la Universidad (en la que enseñaban Laín, Maravall, Díez del Corral, Aranguren, Vicens Vives, Fuentes Quintana, Carlos Ollero...) no pudiera marginarse de la evolución del pensamiento moderno. Varios escritores (Cela, con La Familia de Pascual Duarte y La colmena; Dámaso Alonso, con Hijos de la ira; Carmen Laforet, con Nada; Miguel Delibes, Álvaro Cunqueiro, Josep Pla, Torrente Ballester; Antonio Buero Vallejo, autor de Historia de una escalera; los poetas Gabriel Celaya, Blas de Otero y José Hierro) iniciaron pronto la búsqueda de formas de expresión propias y exigentes y produjeron obras de calidad y valía muy estimables. Las mismas necesidades de la demanda cultural obligaron a mejoras evidentes en la oferta y variedad de la cultura de masas. La libertad comercial permitió la difusión de parte muy considerable de la literatura y del cine internacionales, siquiera fuera bajo los condicionamientos impuestos por la censura.

13 Moradiellos, Enrique, “La fase autoritaria del desarrollismo tecnocrático (1959-1969)”, en Hernández Sandoica, Elena (Dir.), 2000, op. cit., pág. 163.

14 Bozal, Valeriano, op. cit., pág. 254.

15 Bozal, Valeriano, op. cit., pág. 260. 
Desde finales de los años cincuenta y a lo largo de los sesenta, las nuevas generaciones de intelectuales, artistas y escritores -divorciados ya radicalmente del franquismo- fueron construyendo una verdadera contracultura crítica y libre.

Algunos escritores (Sánchez Ferlosio, Aldecoa, Carmen Martín Gaite) iniciaron la novela "objetiva", con obras excelentes de prosa y técnicas narrativas claras y precisas. La llamada "generación realista de la posguerra", que irrumpió ya en los años sesenta (Juan y Luis Goytisolo, Martín Santos, García Hortelano, Juan Marsé, el dramaturgo Alfonso Sastre, poetas como Gil de Biedma, José Ángel Valente, Ángel González, Claudio Rodríguez...), hizo una literatura profundamente social sobre temas como la sordidez de la vida obrera y el conformismo político y moral de la burguesía.

En cine, Juan A. Bardem y Luis García Berlanga introdujeron las formas del neorrealismo italiano. En una entrevista con Vittorio De Sica, publicada en Arte Fotográfico, Vicente A. Pineda pregunta al director italiano sobre el sentido de su filmografía. Éste ofrece algunas claves para entender todo el movimiento humanista de posguerra:

“Le hago notar que, a mi entender, las constantes de sus películas, como director, son la solidaridad social, el amor cristiano y la poesía cotidiana. Enseguida precisa:

-Creo que los tres factores están en mi obra, porque yo trato de comunicar el amor a la Humanidad. Siempre he intentado invitar con mis películas a pensar y acercar al prójimo en una fraternidad cristiana. Mejorar la humanidad, si esto es posible; ese ha sido el pensamiento que me ha guiado"16.

El productor Elías Querejeta aprovechó la "liberalización” que supuso la llegada de Fraga Iribarne al Ministerio de Información para lanzar, hacia 1965, un "nuevo cine español" (La caza, de Saura; Nueve cartas a Berta, de Basilio Martín Patino, etc.).

“Dicho de otro modo, el franquismo perdió la batalla de las ideas. Desde principios de los años sesenta, la cultura "establecida" (que no oficial) era una cultura liberal. La cultura crítica, por una parte, se radicalizaba; por otra, se regionalizaba. Desde mediados de dicha década, al régimen de Franco no le quedaba sino la cultura de masas (deportes, toros, cine y teatro comerciales, la literatura de bestsellers, radio, y desde 1956-1960, la televisión)"17.

El uso que hizo el Régimen de esta cultura de masas llegó a límites absurdos. Así, por ejemplo, en 1950 la selección española de futbol triunfaba frente a Inglaterra y en 1964 sobre Rusia, triunfo que permitió la victoria del campeonato de Europa. Estos hechos constituyeron para la propaganda oficial, masiva, poco menos que un ajuste de cuentas con aquellas naciones con las que España había tenido conflictos históricos. El divorcio entre el pensamiento español y el régimen de Franco era ya abismal. Prácticamente, la totalidad de la amplia producción que las ciencias sociales desarrollaron desde finales de los sesenta giró en torno a un tema dominante: la democracia en España, su fracaso histórico, la construcción de un nuevo orden estable y duradero.

-En aquella época la vanguardia intelectual española se posicionó entre el existencialismo, el realismo y el marxismo. ¿Te vinculas a alguna de estas corrientes?

(R. Masats, Madrid, 17 de junio de 1999) -“Ten en cuenta que yo no soy nada intelectual, y si en este momento no soy intelectual en aquel momento muchísimo menos. Siempre he sido

16 Pineda, Vicente A., "Trascendencia del creador y servidumbre del actor. Diálogo abierto con Vittorio De Sica”, en Arte Fotográfico, nº 79, año VII, julio 1958, pág. 623.

17 Fusi, Juan Pablo y Palafox, Jordi, op. cit., pág. 318. 
muy intuitivo. Hombre, uno tiene sus formas de pensar... Me gusta mucho leer y tal..., pero no te puedo decir que yo fuera un intelectual y que fuera muy consciente de que pudiera hacer existencialismo o marxismo, en absoluto".

-Por ejemplo Neutral Corner parece recoger un claro influjo existencialista. Son fotos tan dramáticas, es un libro tan seco, tan oscuro...

(R. Masats, Madrid, 17 de junio de 1999) -“Pero eso no es por teorías... al fin y al cabo esto son teorías, en principio literarias. El tema era así, el boxeo era así. Yo sólo reflejaba una realidad. El intuitivo lo que hace es reflejar esta realidad y si esta realidad no le gusta, pues con muchísima más razón. A parte de que sí estaba un poco influenciado por lo que hablábamos con Ignacio Aldecoa, que era una persona muy crítica con el boxeo y a la vez muy cerca del boxeo, que le interesaba muchísimo; que es un poco la misma postura que tengo yo con los toros. Soy crítico desde fuera pero me gustan los toros. Con el boxeo me pasa lo mismo, a pesar de que me parece peor el boxeo que los toros".

Este posicionamiento a favor de la intuición será puesto de relieve por Maspons al aludir al carácter laborioso de Masats y a su enorme capacidad con la cámara.

(0. Maspons, Barcelona, 20 de octubre de 1999) -“Ramón en aquella época vendía bacalao y estaba en el mercado. Era muy brutote, pero tenía mucho afán de aprender, de culturizarse, sin hacer el cursi. Ramón es un hombre de aquellos que fue absorbiendo cultura, y en cuanto se fue a Madrid se hizo amigo de poetas, de Aldecoa, de pintores, como Saura... e inmediatamente se empezó a culturizar, era una verdadera esponja.

Y libros... conocía los mismos que yo. Conocía bien a Cartier-Bresson, veíamos libros... Pero quiero decir que no había necesidad de ir a una escuela para aprender fotografía.

Era un hombre que aprendió lo mismo que yo, pero mejor y más deprisa. Me quedaba asombrado lo deprisa que tiraba, lo deprisa que revelaba. Trabaja con una intensidad con la que yo nunca he podido trabajar, ni Xavier Miserachs, ni Colita. Se va solo... Porque es un lobo estepario... Ahora no, porque se ha puesto en la obligación de enseñar a su hijo, pero antes nunca había trabajado con nadie. ¡Y con una intensidad...! Se iba de viaje por España y se levantaba a las seis de la mañana, a las siete se iba del hotel y se acostaba a las ocho de la tarde. Cuando trabaja, trabaja con mucha más dedicación... ¡No, no es cuestión de dedicación!, es cuestión de ser trabajador. Es un obrero de la cámara, un tío de estos que empiezan la jornada... Él había trabajado en una cosa muy obligada, como era el pescado, y se tenían que ir al mercado a buscar el bacalao a las cuatro de la mañana. Llevaba una vida de saber dominar el tiempo, no de quedarse en cama y esto... ¡Es de una eficacia! Por eso puede hacer los libros para Lunwerg, que lo engañan y lo estafan.

Tiene mucho carácter, es muy decidido, mucho más que yo. Es un tipo que toma decisiones, no es un «cagaductes» como yo. Lo que me hace gracia de Ramón Masats, y siempre se lo digo, es que cada vez que lo veo está más culto y más sofisticado, cada vez más intelectualizado de izquierdas. Aunque tuvo época de anarquista. Se incorporó muy bien en Madrid".

\subsection{UN ARTE PARA LA EXPORTACIÓN}

A partir de la década de 1950 el Régimen comienza a tomar unas nuevas iniciativas a nivel artístico. La primera Bienal Hispanoamericana de arte de 1951 fue una importante exposición de todos los países de América Latina. La selección se hizo con la gente más joven, descartando a los académicos más conservadores y a los "grandes" artistas:

“Tanto por la selección de obras, que incluía nombres de la Vanguardia histórica -algunos de los cuales eran afectos al régimen franquista, como Cossío o el propio Dalí, pero no todos, pues también estuvieron representados en ella Maruja Mallo, Oteiza y Juan Manuel Caneja, este último recién salido 
de la cárcel-, como por la incorporación de los jóvenes vanguardistas más radicales, entre los que encontramos a varios representantes de "Dau al Set" -Tàpies y Tharrats-, la Bienal mostró un criterio revolucionario respecto a lo que venía siendo la postura oficial"18.

La Bienal supondrá un precedente para el cambio de criterio que hasta aquel momento había predominado en las exposiciones oficiales. En éstas, no lo olvidemos, se valoraba el academicismo más conspicuo y retardatario, sin permitir ni una leve fisura por la que abrir brecha. La Bienal, al hacer pública su preferencia por las obras que correspondiesen a nuevos planteamientos, estableció una nueva jerarquía renovadora. Fue, efectivamente, como un aldabonazo en la vida artística de España: una especie de rendición de cuentas colectiva de toda la modernidad dispersa (recuento de fuerzas, balance de situaciones, estado de conciencia). Este cambio institucional coincidirá con la llegada ministerial de Ruiz-Giménez y propiciará un intenso debate en torno a la legitimidad o no del arte abstracto.

En este contexto surgirán grupos como Parpalló, El Paso y el Equipo 57. De estos será el de El Paso, el que logrará suscitar a partir de 1957 la atención de la crítica europea y americana. Saura, Millares, Feito, Chirino... después de esa generación de artistas nacidos en los años veinte a los que cabe unir nombres como los de Tàpies o Chillida, no ha habido un grupo español tan exitoso como ése en el panorama internacional.

El Paso se convirtió en la máxima representación del arte español de la época. El mismo pretendía recuperar la memoria histórica de la vanguardia -rota por la Guerra Civil- y apostar paralelamente por un cosmopolitismo que buscaba la conexión con la vanguardia internacional. Su enemigo era el academicismo del arte realista, herencia del siglo XIX. Enemigo que persistía en el interior del propio país, inmerso en una realidad esquizoide: de puertas a fuera se mostraba a la vanguardia y de puertas a dentro sólo se veía un convencionalismo academicista. Efectivamente, mientras que la Bienal Hispanoamericana de 1951 significaba un soplo de aire nuevo, las “Exposiciones Nacionales" de 1950 y 1952 ofrecían una realidad muy distinta.

“En estas últimas, dentro de una factura bastante convencional, cuando no directamente académica, predominaban las obras de figuración realista al servicio de temas tradicionales, como bodegones, paisajes y retratos, reservándose las vivencias más ideologizadas para los asuntos religiosos, los épicos, los costumbristas o los intimistas, concebidos todos ellos en una línea ortodoxa, que entonces, a tenor de los acontecimientos, era, sobre todo, la propia de un pensamiento pequeño-burgués muy conservador. Por lo demás, la propia nómina de artistas participantes, salvo alguna excepción, estaba en consonancia con las direcciones artísticas citadas"19.

En este cambio de orientación expositiva internacional destaca la figura de Luis González Robles, funcionario del Ministerio de Asuntos Exteriores, Jefe de los Servicios de Exposiciones de la Oficina de Relaciones Culturales, que dará un cambio de rumbo al apostar de forma decidida por el arte nuevo. No hay que olvidar tampoco al propio Director General de Relaciones Culturales del Ministerio, José Miguel Ruiz Morales, que presentó en París (1959) la exposición 13 peintres espagnols actuels, en la que estuvieron presentes, entre otros, Canogar, Cuixart, Feito, Saura, Millares, Palazuelo, Lucio Muñoz, Rivera y Viola, es decir, los principales representantes del grupo El Paso y otros artistas del informalismo español. A su vez un año antes, Venecia se había convertido en plataforma de esa nueva generación:

18 Calvo Serraller, Francisco, España medio siglo de arte de vanguardia 1939-1985, Madrid, Ministerio de Cultura, Dirección General del Libro y Bibliotecas, 1985, pág. 52.

19 Calvo Serraller, Francisco, op. cit., pág. 58. 
“La Bienal de Venecia se convirtió en el escaparate de los nuevos artistas españoles y en el marco de su éxito, especialmente en su edición de 1958. De este modo, el Estado adoptaba una fisonomía bifronte: radicalmente renovadora en el exterior, conservadora en el interior. Esta política no podía por menos de ir acompañada de una cierta esquizofrenia de los artistas. Enemigos del régimen en su vida diaria y en su actividad pública en el interior, parecían sus colaboradores en el exterior"20.

\section{Al respecto, el citado Bozal apunta:}

“De todos modos, la tensión esquizofrénica a la que aludo fue más notable (...) precisamente porque el arte era en los años cincuenta una actividad civil y moralmente política. Un régimen como el del General Franco politizaba todo aquello que tocaba, la vida social y cultural toda, y el arte de vanguardia se definía en uno de sus parámetros, y no el menor, en atención a su oposición al régimen: la cultura, y el arte con ella, era antifranquismo. Su antifranquismo propendía a convertir las obras en instrumentos de transformación social y política, imágenes que debían ayudar a la formación de la conciencia, denunciar las situaciones de injusticia, testimoniar las relaciones de dominación"21.

Debido a ello, lo sorprendente fue el éxito de los artistas jóvenes en un país carente de tradición, crítica, museos... Sin duda, el triunfo se debió en gran parte a las gestiones del Ministerio de Asuntos Exteriores. El patrocinio oficial de los artistas jóvenes se debe leer dentro del contexto del momento: había una confluencia por parte del pensamiento institucional con los jóvenes vanguardistas. Se trataba de una actualización o recuperación de la tradición del mejor arte español de todos los tiempos, ahora con un enfoque vanguardista.

Hay una serie de circunstancias del informalismo, como son el tremendismo, el misticismo, la monocromía y el gesto dramático, que pueden ser relacionadas con la llamada "veta brava española". Con esta síntesis, y a través de la recuperación de Velázquez o Goya, el grupo El Paso consiguió alcanzar el éxito.

“Vamos hacia una plástica revolucionaria -en la que estén presentes nuestra tradición dramática y nuestra directa expresión-, que responda históricamente a una actividad universal (...) Propugnamos un arte recio y profundo, grave y significativo"22.

Curiosamente, el misticismo y el tremendismo informalistas coincidirán en un aspecto con la fotografía pictorialista de posguerra. Los dos supondrán, a los ojos de las autoridades, la exaltación de una España legendaria e imperial, con un pasado brillante y con un presente que, heredero de aquellas glorias, se inspira en la religión, el folclorismo, el mundo rural y el costumbrismo. Lo que llama la atención es que mientras uno significaba el alma de la vanguardia en la España de finales de los cincuenta y principios de los sesenta, el otro era un lastre, un anacronismo del siglo XIX. El anteriormente citado Ortiz Echagüe nos resulta una vez más útil como ejemplo de fotógrafo exportado por el franquismo para generar en el extranjero una imagen, un estereotipo de la España franquista que, disfrazado de antropología, falseaba la realidad y la convertía en políticamente correcta.

“En 1934 empieza a reunir y seleccionar las pruebas de archivo para una nueva obra: «España, pueblos y paisajes» (...) Ampliada luego, llega a incluir 400 láminas en su novena edición, totalizando los 90.000 
ejemplares, gran parte de los cuales salen al extranjero, pues es ésta la obra de Ortiz Echagüe que mayor popularidad logra, sobre todo como síntesis y visión del aspecto particular de España"23.

Revisando su extenso curriculum, nos llaman la atención las fechas y los lugares elegidos para sus exposiciones. Iniciada su carrera en 1915, con un primer premio del Concurso Nacional del Círculo de Bellas Artes, se suceden varios premios en Washington, Boston, Dublín, Nueva York, Viena, California, así como tres exposiciones personales en el extranjero anteriores a la Guerra Civil: Turín (1928), Berlín (1929) y Londres (1935). La Guerra Civil y la autarquía se hacen patentes en su trayectoria ya que entre 1935 y 1948 se interrumpen sus apariciones internacionales. Sin embargo, una vez acabada la II Guerra Mundial retoma su proyección internacional: primero en Italia y luego, a partir de 1951, en EE.UU y el resto del mundo: Turín (1948), Milán (1949), Northwest Photographic Salon (1951), Smithsonian Institution de Washington (1952), Méjico (1953), Johannesburgo (1955), Londres, Newcastle, Manchester y Liverpool (1958-1959), Kentucky (1959)... Se podría considerar que la cima de su carrera la encontramos en 1960, si atendemos al reconocimiento internacional de su obra y a su identificación con el arte de la verdadera España, la España histórica que representaban Goya y Velázquez. Después de pasear su obra por medio mundo, expuso 80 fotografías en el Metropolitan Museum de Nueva York:

“Colgadas en medio de las fotos, tomadas en su gran mayoría por José Ortiz Exhagüe, se mostraban algunos famosos aguafuertes de Goya, a título de ensayo, «y muchos de los espectadores, pasando la mirada de unos a otros, no acertaban a decir cuáles eran más impresionantes»"24.

Éste será el gran triunfo de la fotografía de exportación franquista.

“En este contexto también es más comprensible la frustración que sintió W. Eugene Smith ante los resultados de su trabajo en Deleitosa: quiso desenmascarar a Franco a través de un reportaje fotográfico documentando «hasta el máximo la pobreza y el miedo causados» por él (...) Pero Smith no se dio cuenta de que el sistema que empleó no era eficaz para desmontar el simulacro que Franco había creado y paseado por Europa y Estados Unidos. El sistema fue precisamente la proyección internacional de Ortiz Echagüe como único artista fotógrafo, de interés y calidad, que existía en España, a través de exitosas exposiciones. El momento culminante fue la exposición Spectacular Spain abierta en The Metropolitan Museum de Nueva York desde febrero a mayo de 1960: los positivos se intercalaron con estampas de Goya. No cabía duda, los dos eran artistas geniales que supieron visualizar la verdad de la España de su tiempo"25.

Ahora bien, con independencia de esta utilización, lo que del informalismo español llamó la atención en el extranjero fue el descubrimiento de un arte reivindicativo, un arte que representaba un soplo de libertad en la dictadura franquista. Con todo, no debemos olvidar que estas obras no tienen por sí mismas dicho sentido. Es más, su interpretación requería una educación visual y pictórica de la que carecían incluso los propios compañeros de promoción, novelistas o ensayistas:

“Hay que tener en cuenta, por una parte que el enlace del arte español con la vanguardia internacional, tras años de aislamiento, se produjo cuando triunfaba clamorosamente en todo el mundo el

23 Vielba, Gerardo, "Personalidad y estilo de un fotógrafo singular", en Ortiz-Echagüe, José; Vielba, Gerardo, José OrtizEchagüe. Sus fotografías, Madrid, Incafo, 1978, pág. 21.

24 Vielba, Gerardo, op. cit., pág. 13.

25 Vega, Jesusa, "La fotografía, Ortiz Echagüe y el simulacro de España", en el catálogo de la exposición José Ortiz Echagüe en la colecciones del Museo Nacional de Antropología, Madrid, Ministerio de Educación, Cultura y Deporte, 2002, págs. 67-68. 


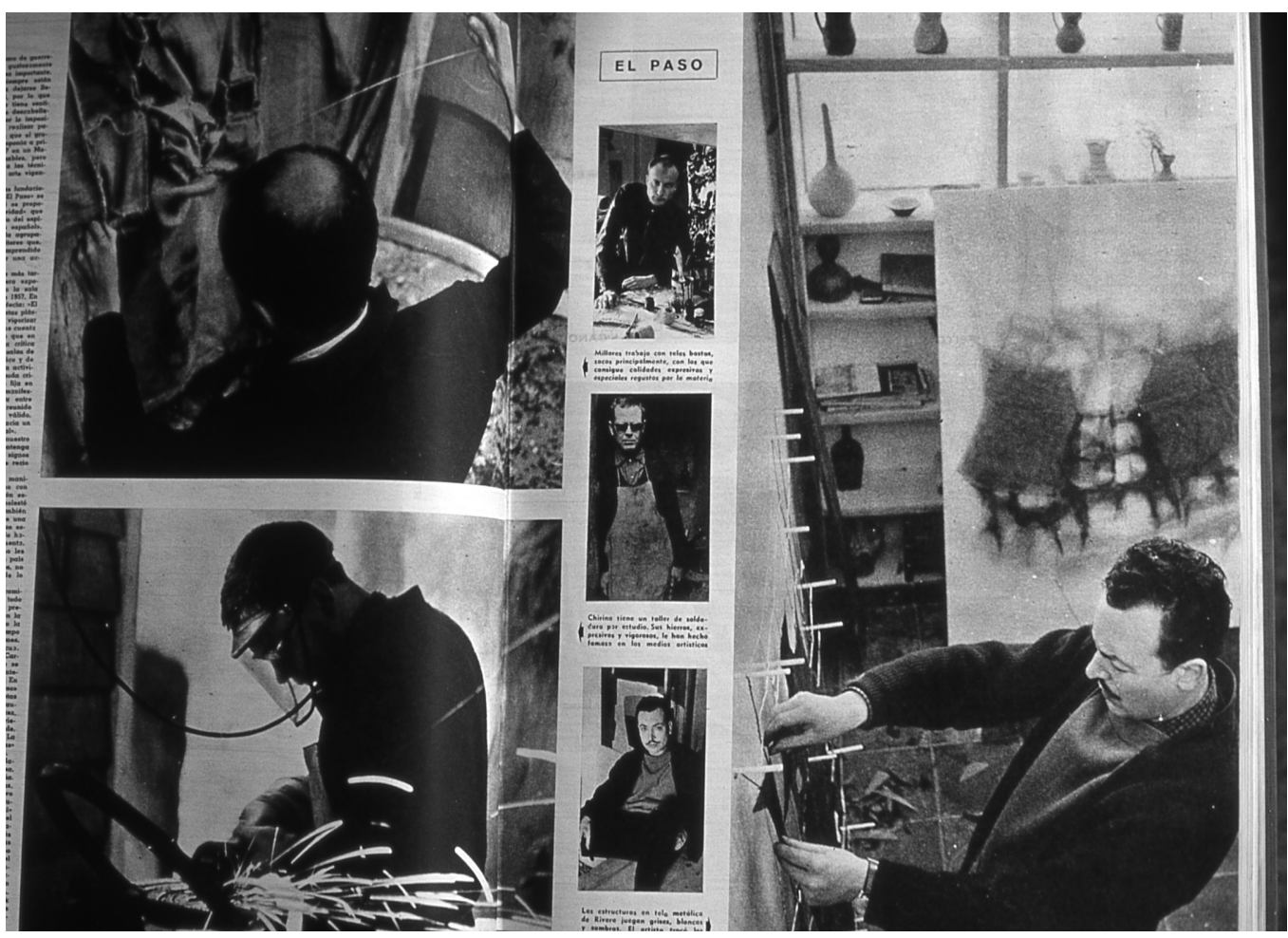

Masats, Ramón y Ramírez de Lucas, J. (texto), “Se ha disuelto El Paso", en Gaceta Ilustrada, n 185, 23 de abril de 1960, págs. 29-35.

informalismo, pero también por otra, que el arte no representativo, anicónico, ofrecía una plataforma más dúctil y ambigua, cuya elasticidad se adecuaba mejor a un contexto tan especial y complejo como el de la postguerra franquista. Dentro de la mítica abstracción, cabía, en efecto, casi todo, incluso lo procedente de aspiraciones ideológicas más diversas y encontradas" ${ }^{26}$.

A pesar del esfuerzo pedagógico de la nueva crítica, consciente de la oscuridad lingüística del expresionismo abstracto, la crisis del informalismo se produce por la crisis de la vanguardia y porque al quererse comprometer con la realidad y denunciar los problemas sociales, lo abstracto comenzará a perder valor frente a la pujanza del realismo crítico.

“La estética neorrealista del cine italiano, la que estaban adoptando los nuevos cineastas con tan buenos resultados como Calle mayor o Muerte de un ciclista, o las mismas consignas del PCE en la clandestinidad, estaban apelando a la recrudización del realismo español"27.

Denuncia, testimonio y conciencia fueron términos utilizados con abundancia por los artistas y los críticos en aquellos años, aunque más en las conversaciones privadas y en las tertulias que en los textos escritos, salvo cuando se publicaban en el extranjero. De cualquier

26 Calvo Serraller, Francisco, op, cit., pág. 52.

27 Gracia García, Jordi, “Virajes del medio siglo”, en Hernández Sandoica, Elena (Dir.), op. cit, 2001, pág. 267. 


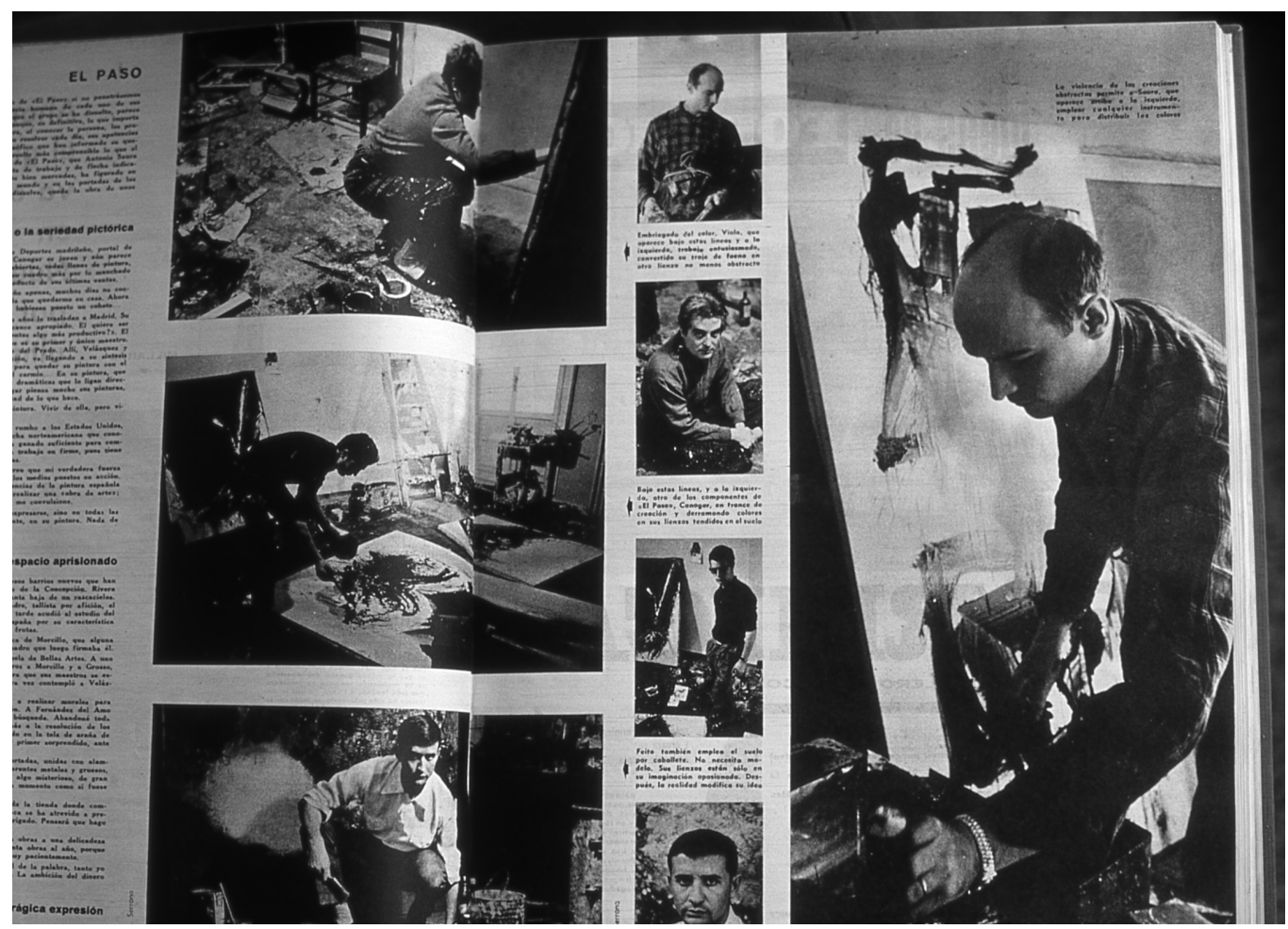

Masats, Ramón y Ramírez de Lucas, J. (texto), "Se ha disuelto El Paso", en Gaceta Ilustrada, n 185, 23 de abril de 1960, págs. 29-35.

modo, y desde una perspectiva actual, parece que no se llegó a manipular ni a instrumentalizar absolutamente el informalismo (a pesar de los intentos de Luis González Robles), ni se puso en peligro su alta calidad.

“Por lo demás, es falso que estos artistas, presentados en el extranjero a través de canales oficiales, pero en absoluto franquistas en su ideología y en sus obras, sirvieran para "blanquear" la imagen del régimen de la dictadura. Muy por el contrario, si atendemos a lo que sobre ellos se escribió en la prensa especializada mundial, fueron bien recibidos y premiados porque representaban, por primera vez, esa España reprimida, potencialmente revolucionaria; porque, dicho sea de una vez por todas, representaban el antifranquismo español que fluía a través de las grietas de un régimen cada vez más tambaleante"28.

-El grupo El Paso, fue tan apoyado por el Gobierno, y por el Ministerio de Asuntos Exteriores porque compartía en parte el ideario de la generación del 98 y porque suponía una especie de revisitación de los clásicos (Goya, Velázquez), aunque de una forma moderna...

(R. Masats, Madrid, 17 de junio de 1999) -“Hombre, españoles sí eran, en su forma de hacer... Pero yo creo que aquí cada uno jugó a lo que le interesaba. A España le interesaba dar una visión de apertura en el arte abstracto, que no perjudica en absoluto y a ellos les interesaba salir a las exposiciones de Brasil, Italia y todo esto. Quiero decir que creo que fue un juego inteligente 
y positivo para las dos partes. Pero no creo que el Estado permitiera eso por este planteamiento de tipo artístico, sino que se planteó... Bueno esta gente... Porque no eran tontos... Estaba un comisario, que no sé si ya ha muerto, que se llamaba Luis González Robles, que era un tipo muy entendido en arte, muy inteligente, que fue un poco el que tuvo la idea de aprovecharse de El Paso. Y El Paso fue lo suficientemente inteligente como para decir: -Mientras no me señalen un camino para seguir artísticamente, si lo que yo hago honestamente se puede mostrar en el extranjero, pues también me voy a aprovechar de ello. Lo que sí es evidente es que González Robles se daría cuenta de que la pintura esa era muy española y muy representativa, y que los entendidos del extranjero se darían cuenta de que era auténtica".

-Usted hizo una exposición con el grupo El Paso. ¿Consiguió ponerse a rebufo de todo ese apoyo institucional?

(R. Masats, Madrid, 17 de junio de 1999) -“No, en absoluto. Mi relación con el grupo fue, Gaceta Ilustrada que era la revista para la que trabajaba y que me encargó un reportaje sobre El Paso. Entonces yo fui e hice el reportaje. Hubo una cierta comunicación con algunos de ellos, con algunos menos, pero me adoptaron como fotógrafo, sobre todo por parte de Antonio Saura. Aparte de esto, les interesaba que yo hiciera reproducciones de sus cuadros. Porque claro, una vez hecho el reportaje, pues alguna vez hacía alguna foto y tal, pero era cosa mía. Lo que sí les hacía eran fotos de sus cuadros y eso hizo que siguiera la relación con ellos. También me gustaban como gente inteligente y sensible, y cuando hacía alguna cosa se lo enseñaba... Por aquel entonces hicieron una exposición y me dijeron que les gustaría que expusiera con ellos, pero ya está". 


\section{CAPÍTULO 4}

\section{La crisis ideológica que precede a la renovación}

Ramón Masats protagonizó algunos de los momentos más significativos de la renovación fotográfica de un modo tremendamente activo, participando en todas las agrupaciones implicadas, exponiendo en los momentos más significativos y junto a los componentes más determinantes, convirtiéndose a través de sus imágenes en uno de los principales símbolos de su generación ${ }^{1}$... Pero no fue un caso aislado, sino el resultado de un proceso jalonado de exhibiciones, nombres propios o colectivos, agrupaciones fotográficas y revistas en donde el propio Masats se constituyó, por propios méritos, en una de las principales referencias.

Al respecto, una de las primeras reflexiones que se realizaron en torno al periodo que nos disponemos a estudiar (1952-1957), efectuada desde una brevísima perspectiva temporal (apenas cinco años) -tan breve que casi pudiera pertenecer a las postrimerías del propio periodo-, corresponde a la realizada por Aquiles Pujol (sobrenombre de Josep Maria Casademont) en la revista Arte Fotográfico en 1962. En ella Casademont elabora una detallada recapitulación histórica de aquellos años, repasando nombres y exposiciones que, si bien no completan absolutamente todo el cuadro o incluso añaden algún nombre que no ha llegado hasta nuestros días, sí enmarcan lo que podría constituirse como un índice bastante aproximado de los protagonistas de la crisis y la evolución de la fotografía española de los años cincuenta.

“En aquel tiempo (empecemos por el principio) éramos muy pocos los que abogábamos por un profundo cambio en nuestra fotografía. El primero de ellos -destacado colaborador de esta Revista hasta su prematura muerte-, el nunca bastante llorado amigo Luis Navarro, cuyo nombre y apellido ostenta tan merecidamente el mejor trofeo de fotografía de vanguardia.

Este comentarista también perteneció a aquel grupo; con él inmediatamente, Oriol Maspons -el de ideas más claras de todos nosotros-, Marcel Giró- que hoy está en el Brasil y a quien no tuve el gusto de tratar personalmente-, Bella Costa -tal vez más en la intención que en los resultados-, Ricardo Terré, Javier Miserachs e inmediatamente después Ramón Masats. Esto, por lo que hace a la línea de fuego del primer momento.

Aquí, un inciso importante: por aquellas fechas, Francisco Català-Roca había ya celebrado su primera exposición en la antigua y hoy desaparecida Sala Caralt, de Barcelona, y había también ganado la primera convocatoria del premio de dicha ciudad -la primera y la última, con todos los respetos que se merecen quienes la han ganado después que él-. Por otra parte, por aquel entonces Leopoldo Pomés había celebrado ya también su Exposición en Galerías Layetana.

Sin embargo, en este comentario no deseamos implicar a Català-Roca ni a Pomés, por ser hombres formados al margen totalmente de la fotografía de competición y sin vinculación ninguna -irarísimo fenómeno en este país!- con el Salón y el Concurso... Ciñéndonos, pues, a aquellos nombres pioneros de la modernidad (pioneros en definitiva, de algo cuya trascendencia y características ellos mismos no conocían a priori), formados, no obstante, en el ambiente de la entidad fotográfica al uso, debemos hacer mención en este punto a la primera muestra colectiva llevada a cabo por Ricardo Terré, Javier Miserachs y Ramón Masats. Ésta tuvo lugar en los salones de la A.F.C. y constituyó un auténtico 
impacto. Tanto, que no tardó mucho en seguir su ejemplo por otro trío: el formado por Juan Cubaró, Francisco Ontañón y Valentín Galí.

También ésta tuvo lugar en la A.F.C., y aunque tal grupo pudo ser considerado en su momento como una nueva edición, sin mejorar, de aquella primera, hoy, con la perspectiva del tiempo, podemos darnos cuenta de que significó en realidad como un enlace hacia los Colom y otros nombres importantes de la actualidad"'2.

Luis Navarro y Català-Roca no pertenecen a la generación de Masats. Sus respectivas aportaciones a la historia de la fotografía -sus textos y sus obras- son anteriores, independientes de la gran cantidad de acontecimientos, de las influencias y los contactos, que hacen que varios autores se reconozcan entre ellos como un grupo, un colectivo o una generación. Luis Navarro y Català-Roca no se beneficiaron del fin de la autarquía, ni de los contactos con la fotografía extranjera, ni del apoyo de ningún grupo para construir sus baterías retóricas. Luis Navarro muere en 1953, poco después de que Masats acabe el servicio militar (posiblemente todavía leyera sus textos en la revista Arte Fotográfico). Català-Roca, nueve años mayor que Masats, llevará una vida paralela, independiente... Veremos cómo el poso de conocimiento y la personalidad de estos autores influirán decisivamente en la nueva generación que estaba a punto de tocar a las puertas de la modernidad, una generación que seguirá ese camino que, según Casademont, inició Luis Navarro, continuó Oriol Maspons, se concretó en la primera exposición de Xavier Miserachs, Ricard Terré y el propio Masats, discurrió por la exposición de Juan Cubaró, Francisco Ontañón y Valentín Galí, y culminó en la figura de Joan Colom.

\subsection{LUIS NAVARRO (LUIS CONDE VÉLEZ), LO NAÏF}

Luis Navarro, que firmaba sus artículos con el seudónimo de Luis Conde Vélez, fue uno de los pioneros en la crítica de la fotografía oficial española. Precursor del movimiento revolucionario en el que participará Masats, fue colaborador de la revista Arte Fotográfico durante sus primeros años, 1952 y 1953, fecha esta última en la que morirá prematuramente. En sus textos publicados en la revista arremetió contra la grandilocuencia de la fotografía de los salones, ridiculizó sus manidos temas y denunció la apremiante necesidad de una renovación, de una evolución urgente de la actitud de los fotógrafos españoles, de los jurados de los concursos... Por todo ello, tras su muerte, se organizó un concurso que llevó su nombre y que pretendía representar la fotografía más vanguardista del momento. Concurso que ganaron, por cierto, Miserachs en 1954, el propio Masats en 1957, Francisco Gómez (1959), Leonardo Cantero (1960) y Gabriel Cualladó (1961), todos ellos miembros de la nueva generación.

La historiografía sitúa a Luis Navarro como el punto de inflexión entre la vieja fotografía y la nueva generación. Su apuesta por la renovación es la principal aportación al clima de cambio que se iba a desarrollar en los años posteriores, y por ello ya estaría justificado su inclusión en esta contextualización histórica del periodo. Pero creemos que sus aportaciones no se ciñen, exclusivamente, a esta reivindicación. En el detallado estudio de todos sus escritos en la revista Arte Fotográfico que hemos llevado a cabo, queda patente cómo Luis Navarro introduce postulados tan importantes como la subjetividad de la mirada, que también desarrollará el doctor Otto Steinert, o cómo ante la pretenciosidad de la fotografía de salón defiende la cotidianidad y hasta el posible error técnico, temas estos que -en otro universo creativo, y con otras pretensiones completamente distintas, mucho más sofisticadas y conceptualizadas-, desarrollará posteriormente 
William Klein. Estos autores nunca conocieron los escritos de Luis Navarro y viceversa. Ello no obsta para que Luis Navarro fuera el primero que reflexionara en voz alta sobre estas cuestiones en España y que, al hacerlo, sembrara un germen, una duda, en las nuevas generaciones y que esta duda posteriormente facilitara la introducción de los conceptos más complejos y fundamentados del extranjero:

“Creo que simplemente había detectado y advertido que la fotografía de concurso había entrado en un notable amaneramiento estilístico, un virtuosismo temáticamente reiterativo, un preciosismo exclusivamente destinado a seducir a un jurado"3.

Cabe destacar que los textos de Luis Navarro carecen prácticamente de citas de autores (aunque sí nombra a Misonne, Bodine, Echagüe, Weston y Steichen, no los analiza, ni comenta sus obras. Apenas los menciona como consagrados a los que no hay que copiar) ${ }^{4}$. Por tanto, suponemos que su crítica y sus exigencias de renovación son fruto de una reflexión propia. Una vez más, se llegó a estas conclusiones de una manera intuitiva. Por una "vibración en sintonía" con postulados que recorrían, discretamente, los salones fotográficos españoles, a espaldas de los consagrados, los viejos, los pictorialistas. Algo que también sucederá en el resto de manifestaciones artísticas del momento

Como decíamos, en un excelente artículo, citado en casi todas las fuentes que trabajan sobre la década de los cincuenta, fechado en 1952, Luis Navarro señalaba:

“Nuestros artistas fotógrafos son viejos y no han sabido renovarse (...) El artista fotógrafo español se limita a repetir una, dos, mil, cinco mil veces la misma fotografía del mismo caserío y de los mismos árboles que otros produjeron antes que él. Como los cangilones de una noria, va, viene, sube, baja sin moverse jamás de las inmediaciones del mismo eje (...) Entraña una tragedia la circunstancia de que un hombre viva un tiempo posterior al suyo; pero es mayor la tragedia de quien vive un tiempo anterior"

Y un año después nuestro autor insistía:

“Los nuevos sentimientos no tienen valor con viejos modos de expresión, ni los nuevos modos de expresión que no vayan acompañados de sentimientos nuevos (...) Vamos hacia las puertas que nos abre una generación de artistas fotógrafos, de jóvenes que saben ver con ojos nuevos y que actualmente vacilan ante la angustia de lo que representa una época pasada y la esperanza de un tiempo inédito para sus vuelos"6.

Luis Navarro defendía la necesidad de una búsqueda personal en la realización de fotografías. La originalidad como premisa de autenticidad en oposición a las estrictas normas compositivas o técnicas que, implacables, asfixiaban la creatividad de los aficionados. Asimismo, defiende una nueva manera de mirar, de interpretar el mundo. Esta sola mirada ya supone un avance, una creación diferente, independientemente de su materialización física y de su acabado final:

3 Miserachs, Xavier, Criterio fotográfico, Notas para un curso de fotografía, Barcelona, Omega, 1998, pág. 181.

4 Conde Vélez, Luis (Luis Navarro), “Carta a un aficionado joven”, en Arte Fotográfico, n 22, año II, octubre 1953, pág. 475.

5 Conde Vélez, Luis (Luis Navarro), "El momento fotográfico español”, en Arte Fotográfico, n 12, año I, diciembre 1952, pág. 488.

6 Conde Vélez, Luis (Luis Navarro), “Lo nuevo en fotografía”, en Arte Fotográfico, n 14, año II, febrero 1953, pág. 81. 
“El fotógrafo no reproduce, caballero: interpreta. Ante un mismo tema, no habrá dos fotógrafos que produzcan dos obras iguales (...) Cada uno de ellos lo verá con ojos dispares. El temperamento de cada uno se reflejará inevitablemente en su obra. Y sucederá así porque, en resumen, cada uno de ellos tiene un alma propia y exclusiva (...) no será la imagen de un árbol lo que leguemos en cada caso a las generaciones venideras, sino el modo que tenemos de verlo, de interpretarlo. Nuestro legado será nuestro modo de mirar, de ver"7.

La fotografía deja de ser un medio aséptico que refleja fielmente la realidad. La mirada nunca puede ser objetiva, por mucho que esté traducida por un medio tan tecnificado y mecanizado como es la fotografía. La aportación del hombre no será la caligrafía o el trazo del pincel, supuestos completamente pictorialistas, sino la mirada. El fotógrafo es autor por el mero hecho de mirar.

Para que se diera esa renovación era necesario cambiar la mentalidad de los jurados en aquel ambiente de concursos y salones, y, caso de no conseguirlo, la única opción como autor era la de liberarse de su yugo para alcanzar la autonomía personal en el juicio y creación fotográfica. Esta necesidad de originalidad y de liberación justificaba cualquier tipo de experimentación o evolución, llegando a redefinir el concepto de "error", no como un fallo, sino como un punto de partida nuevo:

“QQué es “fotografía moderna"? (...) Arte fotográfico moderno es eso que usted siente, eso que vibra y aletea en usted cuando quiere hacer una fotografía que no se parezca a ninguna otra, que tenga unas características esenciales distintas a todas las fotografías que usted ha visto. En suma que responda a una orientación personal y a los dictados de un anhelo exclusivo, que sea reflejo de un yo"8.

"En arte puro no puede haber concreciones, porque el arte es espíritu, no materia, y para el espíritu no hay posibilidad de concreciones. Todo cuanto tales leyes podrían producir había sido producido ya. Ya no había modo humano de crear nada nuevo sin salirse de los senderos que esas leyes señalaban. Un sendero solamente conduce desde un punto determinado a otro punto determinado. Ya habíamos llegado a nuestro destino. El sendero había muerto. Y luego, ¿qué? ¿Podíamos volver atrás, recorrer el mismo camino en sentido inverso?

Por otra parte, tales leyes tenían (tienen, pues viven aún, aunque olvidadas, jafortunadamente!, por muchos) muy poco en cuenta el espíritu. Se atenían a dictaminar sobre la parte concreta y material del arte (...) Pero, ¿por qué son "errores" las obras de los artistas fotógrafos modernos? Es preciso aclararlo de modo urgente. Son errores porque contradicen todas las reglas tradicionales de expresión estética. Esta es la teoría más divulgada. Y este es el verdadero error, el único error. Se dice que contradicen las leyes. ¿Qué leyes? (...) La ley es respuesta, no interrogación ni mandato.

Como consecuencia, no será posible afirmar en vista de la evolución temática de la fotografía que comete error por ignorancia de las leyes. Lo que hace la fotografía es crear unas nuevas leyes estéticas, arrinconar las antiguas, desoírlas. Esas leyes no pueden servir para juzgar la producción fotográfica actual porque no han evolucionado con ella. Las leyes sociales evolucionan, se modifican a medida que la vida social humana se transforma, modifica y evoluciona. Las leyes fotográficas parecen haberse momificado. Y lo malo es que aún aspiran a vivir (...) Falta, por regla general, amplitud de criterio, modernidad de visión, comprensión espiritual, dinamismo, en una palabra a la vieja crítica. Lo que la separa de las corrientes modernas es precisamente su posición ante el error, el error interpretado como generador de arte o el error que nace de una deseo de romper, de violar, de anular lo caduco. ¡Bendito error, característica representación de la actitud de las nuevas respecto a la tradición, ese error que crea, reforma y es fecundo y vivo hasta el punto de adquirir fuerza y categoría de verdad!"9.

7 Conde Vélez, Luis (Luis Navarro), "Grandeza y miseria de la fotografía", en Arte Fotográfico, nº 18, año II, noviembre 1953, págs. 272-273.

8 Conde Vélez, Luis (Luis Navarro), "El I salón de fotografía moderna", en Arte Fotográfico, nº 18, año II, junio 1953, pág. 295.

9 Conde Vélez, Luis (Luis Navarro), “Fecundidad del error”, en Arte Fotográfico, n² 21, año II, septiembre 1953, págs. 448-450. 
La modernidad, la originalidad, la necesidad de innovación llevan a depurar un estilo, un camino solitario, despojándolo de influencias y de injerencias externas que, tal y como ya hemos señalado con anterioridad ("No hay nadie tan grande que pueda valer lo suficiente para que sigas sus huellas"), impidan la expresión auténtica y libre del autor.

\begin{abstract}
“No importa que, acaso, tus obras no gusten a nadie. No es preciso que obtengan esa aprobación general que es adulación. Para que todos las acepten como obras valiosas y dignas será preciso que posean las mismas cualidades que poseen las de los modelos imitados. Pero entonces no serán creación, sino repetición, eco de voces de otros, no el sonido de tus cantos (...) Están llenas las bibliotecas de libros que hablan de fotografía y que reproducen las obras de los que llamamos «los grandes maestros». Estudia sus características (...) Entonces, desmóntalas, desármalas, déjalas reducidas a sus elementos esenciales aislados para examinarlos y calibrarlos (...) Y luego, cuando lo hayas hecho y tengas seguridad de conocer a fondo aquella técnica, di: -Esto es lo que no haré jamás.

El estudio de las fotografías que otros produjeron solamente deberá servirte para olvidarte de ellas de modo instantáneo"10.
\end{abstract}

Luis Navarro aboga por la recuperación de la sencillez, la espontaneidad y la modestia en contraposición a la complejidad, la artificiosidad y la pretenciosidad de la fotografía concursística. Es decir, libera al aficionado de la obligación impuesta por los concursos fotográficos de entrar, o al menos intentarlo, en la "Historia del Arte". Nadie tiene por qué ser un genio para poder fotografiar a su familia o a sus amigos. Simplemente tiene que disfrutar haciéndolo. Desaparece, por tanto, el imperativo de la competición, el ser mejor que nadie para poder gozar de la fotografía. Contra severidad y trascendencia, el mero disfrute...

\begin{abstract}
“Hay un amplio sector de aficionados a la fotografía que la cultiva de un modo intrascendental, de un modo humilde, natural, sencillo. Ese sector es el que obtiene el placer puro de la fotografía, porque vive sin apetencias de gloria o grandes esplendores. Y es precisamente ese sector el que se ve olvidado, el que obtiene por toda respuesta un encogimiento de hombros desdeñoso por parte de las Sociedades fotográficas, cuando es digno de obtener un cariño aleccionador que le encauce hacia el perfeccionamiento de esa misma sencillez..., sin que por ello pierda su intrascendencia"11.
\end{abstract}

Desaparece, pues, la ampulosidad y la gradiosidad de cartón piedra. Lo groseramente evidente quedará devaluado en pro de la sutileza, de la sugerencia y la "insinuación":

“La grandilocuencia ha recibido un golpe de muerte. Una voz íntima y recóndita suena en su lugar. Es decir, no suena, porque es voz que no puede sonar sino en las reconditeces del alma, donde los sonidos no existen. Los grandes paisajes en que se abarca todo un ancho panorama, en que se veía un río, un campo segado, un rebaño en la ladera de un montículo, una aldea y, al fondo, un mar resplandeciente y espejeante, se amustian ya, como flor amarillenta y vieja, entre las páginas del pasado. El primer sustituto de esta grandilocuencia de expresión fue la «insinuación», el tema suscitador en que la idea se apuntaba de modo somero: el sombrero de copa, los guantes de cabritilla, el monóculo y la hoja impresa en que se leía un nombre, nos hablaban de una función de ópera (...) La fotografía entona hoy un canto a lo pequeño, a lo baladí, a lo recóndito, a lo que carece de grandiosidad"12.

10 Conde Vélez, Luis (Luis Navarro), "Carta a un aficionado...", op. cit., pág. 475

11 Conde Vélez, Luis (Luis Navarro), “El placer puro de la fotografía”, en Arte Fotográfico, n 19, año II, julio 1953, pág. 324.

12 Conde Vélez, Luis (Luis Navarro), "Fecundidad del error", op. cit., pág. 449. 
Otra trampa que cegaba la apertura de miras era la obsesión por la calidad técnica en la valoración de la fotografía. Luis Navarro critica la perfección fría y aséptica. El corazón debe sustituir a tanta racionalidad:

\begin{abstract}
“Por sí misma la perfección técnica carece de valor. Para que lo adquiera es preciso que se ponga al servicio del propósito inicial del fondo de la obra, que sea variable, maleable, cambiante, no rígida y dura, como suele serlo cuando quiere adquirir valor por sí misma"13.

“La pintura cerebral, la poesía cerebral, la música cerebral, la escultura cerebral han producido obras perfectas. La perfección es ajena al arte. Puede ser perfecta una obra de ingeniería, de arquitectura, de mecánica. No puede ser perfecto y artístico a un mismo tiempo un cuadro. Ni lo puede ser una poesía, ni una sinfonía. La perfección cierra las puertas al espectador, lo deja fuera de sí, lo rechaza (...) Quien tenga vocación podrá producir obras imperfectas, obras inacabadas (...) Y serán arte porque el espectador no se sentirá ajeno a ellas, porque verá que puede poner algo de su yo que llene lagunas y complete la intención del autor (...) La vocación dicta actitudes que brotan del corazón. Es el corazón, no el cerebro, donde nace la inspiración. El cerebro alberga los gérmenes de la perfección. La perfección obtura puertas"14.
\end{abstract}

Como hemos visto, Luis Navarro reivindicará la imperfección, el error, la irracionalidad, el instinto, lo sencillo, lo impulsivo pero auténtico y naïf... Todo ello como reacción a aquellos recetarios de las sociedades graníticas y rancias, preocupadas sólo por la competición y el estatus social de "artistas". Esta misma reivindicación la hace suya Ramón Masats, como respuesta a mucha de la fotografía intelectualizada que se realiza hoy día en nuestro país. Así, en el curso de fotografía que realizó en el Círculo de Bellas Artes de Madrid, casi cincuenta años más tarde que Luis Navarro, comenta:

(R. Masats, Madrid 20 de marzo de 2000) -“Con gran alegría por mi parte, sucede que en ARC0... La alegría que me llevé cuando el último día de la feria, el fotógrafo que más vendió fue el fotógrafo gallego, Virxilio Vieitez. Es un fotógrafo absolutamente naïf, que no tenía ninguna noción de que estaba haciendo nada importante. Él se ganaba la vida haciendo fotos... absoluto naïf. Bueno, pues... ¡Es el fotógrafo que más se vendió en ARCO! Era el fotógrafo más útil. ¡Tiene una honestidad! Además, es muy bueno como fotógrafo. A mí me gusta muchísimo. Y es sencillamente lo que era... Venía una mujer y le decía: -0iga, para mandarle una foto a mi padre que me he comprado una radio y quiero que él la vea-. Y sale la señora puesta así, mirando a la cámara y con la radio. ¡Esto tiene una inocencia! Por parte de la señora... y por parte del fotógrafo, que en ningún momento se podía imaginar que lo que estaba haciendo... - le ha pasado a muchísimos naïf - tuviera el valor y la trascendencia que ha tenido. Y la alegría que me llevé cuando Juanma Castro Prieto, el día anterior... ¡Venga a positivar! Y yo le decía: - ¿Pero qué estás haciendo? Y él me decía: -¡Es que lo vende todo!- Y cuando el último día fui allí... ¡Por las paredes, por los suelos... es que se lo llevaban todo...! ¡Qué alegría, coño! Frente a tanta tontería (...) Para mí lo importante es en primer lugar la foto, lo que es la foto. En segundo lugar, o a la par, la intención del fotógrafo. Creo que tanto la intención del fotógrafo, sin ninguna presunción, y la fotografía, sin ninguna presunción, es lo que le da valor a la obra. Luego... que esta obra, a través de su hija, que haya visto la posibilidad de comercializarla, o sacar un dinero, y de reivindicar lo buen fotógrafo que era su padre, y lo hayan descubierto los de la fotobienal de Vigo, le hayan hecho una promoción fuera de los cauces que tenía el hombre... Esto me parece ya... Es una cosa que está completamente aparte del fin por el que este hombre hizo las fotografías. A mí lo que me parece mal es hacer fotografías para ser ex-

13 Conde Vélez, Luis (Luis Navarro), “El XII Salón Internacional de Arte Fotográfico”, en Arte Fotográfico, n²0, año II, agosto 1953, pág. 404.

14 Conde Vélez, Luis (Luis Navarro), “Carta a un aficionado...", op. cit., pág. 473. 
hibidas en tal museo, o en la misma galería de Juana de Aizpuru. Pero ella se ha dado cuenta que podía sacar un beneficio económico. Yo creo que ella ha tenido un planteamiento como de un fotógrafo naïf, que es lo que es. Frente a fotógrafos tan evolucionados según sus conceptos, poner un fotógrafo naïf, económicamente le ha explotado en las manos."

Como vemos, es exactamente la misma idea de fotografía inocente, que tiene Luis Navarro, la única diferencia entre uno y otro sea, quizá, que Masats admira a un profesional y Luis Navarro sólo piensa en los aficionados. En efecto, Luis Navarro nunca pensó que la renovación pudiera efectuarse fuera de las propias asociaciones fotográficas, ya que era difícil imaginar otro contexto donde perviviera el propio medio fotográfico. Su propuesta trataba de cambiar los criterios de los concursos y de las asociaciones, no llegar a superarlas con la profesionalización.

\subsection{FRANCESC CATALÀ-ROCA, LA INFLUENCIA NACIONAL}

La única figura española que reconocerán Masats, Maspons y toda su generación fue la de Francesc Català-Roca (Valls, 1922 - Barcelona, 1998), hijo del fotógrafo Pere Català i Pic. Él se convirtió en el eslabón, el puente entre la estética formalista de los años treinta y la fotografía testimonio de los cincuenta. Supuso el único contacto con las vanguardias fotográficas de la República, anteriores a la Guerra Civil. Quienes habían protagonizado los movimientos más avanzados y prometedores de la historia de la fotografía en los ámbitos de la publicidad, el cartelismo, el foto-reportaje o la fotografía de autor, prácticamente habían desaparecido de la esfera pública. Muchos de ellos tuvieron que exiliarse por razones políticas -como Josep Renau o José Suarez-, otros habían muerto -como Nicolás de Lekuona-, y la mayoría había abandonado su trabajo anterior, por propia voluntad o a la fuerza -como el paradigmático caso de Agustí Centelles, fotógrafo con un estupendo trabajo sobre la Guerra Civil, absolutamente desconocido hasta la transición democrática-. Pues bien, en el caso de Català-Roca, su formación vendrá de la mano de su padre, el fotógrafo Català Pic, no de ninguna asociación fotográfica. Gracias, en parte, a esta base proporcionada por su padre, llegará -una vez más, intuitivamente- a las mismas posiciones conceptules que algunos de los más importantes autores de su época.

\footnotetext{
“Hombre dotado de una gran sentido del humor, Català-Roca llegaría de forma intuitiva a una filosofía de la creación fotográfica que sucintamente podría resumirse como que en fotografía «ver es crear» y que «es más importante captar que hacer», sentencias en perfecta sintonía con importantes ideólogos del panorama internacional coetáneo como Cartier-Bresson o Minor White"15.
}

En 1948 se independizó de su padre y empezó a trabajar por su cuenta. A pesar de que desarrollaría una visión propia de la fotografía, su influencia emergería en algunas de sus imágenes más sorprendentes y fascinantes.

“Català-Roca es un humanista. Sus suites y secuenciaciones fotográficas muestran y definen la rea-
lidad que capta, a la que ama y conoce. De esos momentos, de esas fotografías que son producto de
la atenta espera de algo que es obligatorio que suceda (porque cuando se conoce el medio, no puede
sorprenderte una parte y la aíslas). De entre esas fotografías, me gusta repetir: hay muchísimas que
destacan. Algunas austeras, otras graciosas, elegantes, y otras incluso algo extrañas: no hay que
olvidar que Català-Roca se formó junto a su padre, su maestro, el fotógrafo Pere Català i Pic, que le

15 Joan Fontcuberta, "De la posguerra al siglo XXI", en Sánchez Vigil, Juan Miguel (coordinador), "La fotografía en España. De los orígenes al siglo XXI", Summa Artis. Historia general del Arte, Tomo XLVII, Madrid, Espasa Calpe, 2001, pág. 413. 
introdujo en el universo de las vanguardias: Francesc, a los quince años y siendo su ayudante, pudo contemplar en Barcelona una exposición de Man Ray, organizada por su padre"16.

Aunque conocía los movimientos vanguardistas que se habían gestado en el extranjero con autores como Man Ray o Steinert, Català-Roca decidió que su fotografía no sería la de estudio ni la fotografía construida. Por el contrario, trasladó su campo de trabajo a la calle. Català-Roca fue el primero en articular un estilo documental que permitió la plasmación de una sociedad que se transformaba de forma traumática y acelerada:

“Cada foto de Català-Roca es un meticuloso estudio de composición, luz y perspectiva, elementos todos
ellos perfectamente equilibrados, conjugados en unos encuadres muy particulares y composiciones com-
plejas. Vinculado al Grupo R, se comprometió con el ideal moderno que proponían los arquitectos catala-
nes. También retrató a toda la intelectualidad de su época: literatos escritores, compositores, etc."17.

Català-Roca era la prueba palpable de que fuera del cerco de las asociaciones fotográficas era posible una fotografía nueva. Con una actitud absolutamente independiente evitó el aislamiento endogámico de los fotógrafos de salón. Català-Roca contactó no sólo con intelectuales y artistas, sino también con los arquitectos del Grupo $\mathrm{R}$-ajenos al mundo fotográfico-, quienes se adelantaron algunos años al "deshielo" que propició el fin de la autarquía y que posteriormente ${ }^{18}$ la joven fotografía española también revindicaría.

“El 21 de agosto de 1951 se fundó el Grupo R (...) «Con el nombre de Grupo R se constituye en la ciudad de Barcelona una Asociación que tendrá por objeto el estudio de los problemas del arte contemporáneo y en especial de la arquitectura».

Sus objetivos eran variados: desde el rechazo a la arquitectura académica que los centros de poder trataban de imponer, al estudio del conocimiento de la obra de los maestros del movimiento moderno, así como la dignificación de la profesión, dando a conocer sus propios proyectos, en la creencia de que la utopía reformista del movimiento moderno podía transformar la sociedad"19.

A su vez, Català-Roca fue un fotógrafo profesional que interesaba a la cultura y a la intelectualidad de su época. Precisamente fue su actitud vital lo que más impresionó a Masats y a su generación: su decisión, determinación y empeño en hacer de la fotografía una forma de ganarse la vida de modo absolutamente coherente. Esta coherencia llegó a tal extremo que Català-Roca nunca diferenció en su obra las fotografías funcionales -realizadas por encargo-, de las fotografías artísticas -más personales-. De modo que, aunque años más tarde Masats, Miserachs, Maspons, Ubiña y otros harán suya esta decisión de profesionalizarse, se verán imposibilitados en mantener esa actitud y se verán forzados a diferenciar su obra personal de su obra como "mercenarios".

La exposición de biombos de Català-Roca en la Sala Caralt de Las Ramblas de Barcelona en 1953 ofrecía una fotografía nueva, alejada de la producción repetitiva de los salones, que llamará poderosamente la atención de los jóvenes fotógrafos, igual que las fotografías que Català-Roca presentó en el pabellón español de la Exposición Universal de Bruselas de 1958.

16 Revenga, Luis, Francesc Català-Roca. Una mirada necesaria, Madrid, La Fábrica/Tf. Editores, 1998, pág. 4.

17 Rodríguez, Mafalda, "Los cincuenta olvidados", en el catálogo de la exposición España años 50. Una década de creación, Madrid, SEACEX, 2004, pág. 95.

18 Probablemente el primer signo del cambio fotográfico español fue en octubre de 1956, durante la exposición de la Agrupación Fotográfica de Cataluña en la Bibliothèque de Paris, organizada por Oriol Maspons y Les 30x40.

19 Giménez, Emilio, “La segunda modernidad (arquitectura española de los cincuenta), en el catálogo de la exposición España años 50, op. cit., pág. 132. 


\begin{abstract}
“Su trabajo se me antojaba mucho más libre y carente de prejuicios que la fotografía de concurso, me pareció ver en él una amplitud de miras y una voluntad de proyección cultural, un afán de comunicar contando bien y sin retórica cosas sencillas, con una técnica casi perfecta pero nunca aparente, un proceder completamente al margen de lo que solía verse y dogmatizarse en la agrupación. En cierto modo, la exposición de Català-Roca fue para mí la primera relativización de la autoridad de los maestros del concurso, la primera sospecha de que podían existir otras vías para una fotografía de calidad totalmente al margen del circuito de los premios y honores. Sin saber todavía por qué, me resultaba más fácil entroncar la línea de Català-Roca con las fotos vistas en la revista D`Ací i d’Allà, que con las de los virtuosos de la Agrupación. Intuía que la citada línea era más compacta, más contundente, que escapaba de poder ser más reducida a las magnitudes de "visión", "composición" y "técnica" con que los jurados analizaban y eventualmente premiaban -todavía lo hacen- las fotos presentadas (...) Si Català influyó mucho en nosotros, fue sin ninguna voluntad de hacerlo. Fuimos nosotros quienes vimos en él y su forma de entender la fotografía un camino lógico y comprometido, una salida natural, ética y valiente, a las indecisiones y dudas que nos atenazaban. Català hacía una fotografía que nos interesaba por su calidad, por su temática, y por la voluntad de insertar su trabajo en el clima cultural de la época. Sus fotografías solían verse reproducidas en Revista y en Destino, las dos únicas publicaciones locales que trataban con cierta profundidad, al límite de lo que permitía la dictadura, temas literarios, cinematográficos, plásticos, religiosos, dos revistas que se ocupaban de cultura. Català documentaba la actualidad desde dentro, su propio trabajo era cultura, dejando testimonio iconográfico del tiempo que le había tocado vivir, de sus contemporáneos anónimos o famosos, de actividades triviales o relevantes. Para nosotros, esta actitud y las magníficas imágenes que producía chocaban frontalmente con la atemporalidad de la fotografía de concurso, de imágenes deliberadamente no comprometidas con su época, que parecían huir del tiempo en su reiteración formal y temática. El compromiso de Català era el de un profesional, el de alguien tan interesado en la fotografía como nosotros, pero que había decidido hacer de ella su medio de vida (...) Ninguno de nosotros siguió a pies juntillas su estilo ni sus recursos técnicos, lo que nos impresionó de él fue la persona"20.
\end{abstract}

A finales de los años cincuenta Català-Roca recibió el encargo de la Dirección General de Turismo de realizar fotografías por toda España para una campaña de promoción turística. Aunque realizó el trabajo con profesionalidad para satisfacer al cliente, el encargo le permitió retratar, para su propia producción, imágenes de una España en plena posguerra. Imágenes de pobreza y esperanza, pero no exentas de un elevado sentido del humor. Efectivamente, su obra no refleja la realidad desde una perspectiva crítica, no se compromete socialmente, ni denuncia un momento histórico tan sombrío como es la posguerra. Como dice Carlos Cánovas:

“En todo caso su testimonio no entraña una crítica acerba. Como corresponde a su momento, se mueve con frecuencia en un decir que es no decir, o en un no decir «significante», sin renunciar a toques de humor que aligeran el contenido crítico de sus imágenes"21.

Además de su influencia temática, es decir, la recuperación de la realidad y la calle como el gran tema fotográfico, y de la influencia de su actitud vital como profesional y como testimonio de su tiempo, Català-Roca también será el precursor a la hora de buscar una vía concreta para exhibir su obra a traves del libro. Aunque nunca renunció tajantemente a colgar su producción en las paredes de una sala de exposiciones (recordemos que su primera exposición fue en 1953 en la Sala Caralt de Barcelona), el formato preferido para mostrar su obra fue la publicación impresa.

20 Miserachs, Xavier, op. cit., págs. 181-183.

21 Cánovas, Carlos, "Entre dos rupturas", en Formiguera, Pere y Cánovas, Carlos, Tiempo de silencio. Panorama de la fotografía de los años 50 y 60, Barcelona, Departament de Cultura de la Generalitat de Catalunya/Fundació Caixa de Catalunya, 1992, pág. 16. 
Desde su primer libro, La sagrada Familia, editado en 1952 con textos de César Martinell, hasta el final de su carrera, publicó unos setenta volúmenes de temática muy diversa, que abarcan desde su obra documental personal, hasta la ilustración de libros de Miró, Llorenç Artigas, Gargallo, Clavé, Picasso, Chillida y otros artistas.

“De hecho, la obra de Francesc Català-Roca podría dividirse, a grandes rasgos, en estos dos mundos. El popular, que encontraba por la calle y que sabía captar como nadie, y el de difusión editorial de las obras de los grandes artistas del momento, con los que el fotógrafo estuvo siempre en contacto a través de su relación con el Grup R, La Revista, Destino y otros foros culturales del momento"22.

Este modo de difundir su ingente producción a través de revistas y libros fue una de las enseñanzas que mayor influencia alcanzaría en la generación de fotógrafos posterior. En el fondo supone un cambio de mentalidad respecto al estatus del fotógrafo, que renuncia expresamente al arte, para revalorizar su capacidad comunicativa y defender su carácter profesional. Oriol Maspons reivindicará a Català-Roca y sus biombos en una de las pocas referencias a fotógrafos españoles efectuada en sus entrevistas desde París.

“La fotografía mural de decoración arquitectónica y otras aplicaciones, como los biombos de Català-Roca y sus proyectos de decoración de techos, atrae cada día a más artistas que la mejoran sin cesar"23.

El propio Joan Colom reconoce que lo que más admiró de Català-Roca fue su actitud, su independencia y su estatus de profesional y cómo ese estatus le permitió mantenerse al margen de las asociaciones fotográficas:

“JR ¿Y Català-Roca?

JC Sólo recuerdo haberlo visto en actos muy concretos. No era una presencia habitual en la Agrupación [Fotográfica de Cataluña] en aquel momento. Él ya era una institución.

JR ¿Tiene que ver eso con el hecho de que él ya era un profesional, mientras que Maspons o

Miserachs no se profesionalizaron hasta más tarde, en los años sesenta?

JC Sí, claro"24.

Por tanto, el libro se convertirá, como veremos, en uno de los rasgos paradigmáticos de la fotografía de aquellas décadas, como reacción, un vez más, a la postura salonista y su costumbre de colgar las fotos como si fueran cuadros.

-A Francesc Català-Roca lo han mencionado como el primero que tiende un poco a romper...

(R. Masats, Madrid, 17 de junio de 1999) - “Es cierto, fue un poco..., no pertenecía a nuestra generación, aunque por muy pocos años, creo que era seis o siete años mayor que nosotros... ¿En que año nació?".

$-1922$.

(R. Masats, Madrid, 17 de junio de 1999) -“Él, es verdad, que fue un poco el que empezó a hacer un tipo de fotografía distinta a la de los demás. Era, digamos, un poco la transición entre los viejos y nosotros -más cerca de nosotros que no de los viejos-. Una persona muy indepen-

22 Formiguera, Pere, “La segunda ruptura, La fotografía catalana de los años cincuenta y sesenta”, en Naranjo, Juan; Fontcuberta, Joan; Formiguera, Pere; Terré Alonso, Laura y Balsells, David, Introducción a la Historia de la fotografía en Cataluña, Barcelona, MNAC y Lunwerg, 2000, pág. 156.

23 Maspons, Oriol, "Cómo hago mis fotografías, por Guy Bourdin”, en Arte Fotográfico, n 70, año VI, octubre 1957, pág. 824.

24 Ribalta, Jorge, "Entrevista a Joan Colom", en el catálogo de la exposición, El carrer. Joan Colom a la Sala Aixelà, 1961, Barcelona, MNAC, 1999, pág. 119. 
diente, muy amable. Cuando hablabas con él era muy agradable, siempre muy atento, una gran persona y un gran fotógrafo... pero muy independiente. Él no pertenecía a grupos ni a nada, pertenecía a sí mismo. Tienen razón, podría decirse que fue el precursor de este movimiento, pero nunca nos fijamos en él para nuestras fotos. La verdad es que nunca nos fijamos en nadie. No era una cosa como eso que ha ocurrido con los pintores que se reúnen en un café, discuten y teorizan sobre la pintura. Nosotros hablábamos poco de la fotografía, nos enseñábamos cosas, opinábamos de lo que hacía uno y otro, pero una teoría, unos principios fundacionales, un manifiesto... nunca jamás".

La influencia de Català-Roca no se ciñe exclusivamente a la contemplación de su obra y de su modo de plantearse la fotografía, realizada siempre con la intención de ser publicada. Los contactos con Masats fueron frecuentes, manifestando la mutua simpatía que se profesaban. Un ejemplo de ellolo encontramos en las declaraciones aparecidas en la revista AFAL a raíz de la primera exposición de Masats junto a Terré y Miserachs:

“Terré, Miserachs y Masats nos han presentado una Exposición de verdadera fotografía actual. Los tres, a través de sus fotos, me convencieron de que saben lo que buscan"25.

De hecho, tanto le gustaba la obra de Masats que años más tarde le proporcionó el contacto para que trabajase en el Ministerio de Información y Turismo como fotógrafo.

-Yo es que creo que hasta que no hicisteis la primera exposición con Terré y Miserachs no hubo mucha exposiciones de fotos con tema urbano.

(R. Masats, Madrid, 15 de diciembre de 2003) -“Català-Roca sí tenía".

-Sí, es cierto, pero tenía más arquitectura... era más monumental. Aunque es cierto que también había reportaje. Pero claro, él estaba a caballo entre un generación y la otra.

(R. Masats, Madrid, 15 de diciembre de 2003) -“Fíjate que la última exposición que se ha hecho de él se llama Barcelona-Madrid. Yo creo que hacía más ciudad que yo, aunque Català-Roca hacía también mucho campo. Seguramente él hacía un cincuenta campo y un cincuenta ciudad, y yo estoy en un cuarenta-sesenta o en un treinta-setenta".

-Supongo que cuando empezaste a trabajar para el Ministerio de Turismo harías más campo que ciudad...

(R. Masats, Madrid, 15 de diciembre de 2003) -“Català-Roca es el que me presentó en Turismo. Hice una exposición en el Ateneo de Madrid y Català-Roca cogió al que entonces era el encargado de Turismo -era amigo suyo y luego fue amigo mío-, Salvador Pons, valenciano de Oliva, y lo llevó a ver mi exposición. Fue Paco Català el que me proporcionó el contacto". 


\section{CAPÍTULO 5}

\section{La fotografía joven, el cambio de la generación de Masats}

A principios de los años cincuenta tal y como ya hemos constatado con anterioridad, los fotógrafos se encuentran aislados, encerrados en sus agrupaciones, todavía ajenos a las tensiones creativas que renovarían poco a poco la sociedad española y cuyo germen ya palpitaba en otras esferas sociales, más inquietas y renovadoras. Parecía imposible que surgiera un aire nuevo de entre las propias asociaciones, encerradas en un asfixiante círculo vicioso, y demasiado cerca de las autoridades militares, administrativas, ideológicas y estéticas. Pero, afortunadamente, distintas voces surgieron críticas ante el yermo panorama fotográfico, denunciando su anacronismo y su inmovilismo creativo.

Como veremos en este apartado, la causa del cambio se localiza, no ya en una mera reacción vanguardia-clasicismo, sino en una causa más difusa, más global y multifacial: el cambio generacional. Éste se concretará en una oposición abierta, directa y militante contra la generación anterior, sus modos de expresión, sus sociedades jerarquizadas, sus estructuras, sus aspiraciones y sus formas de entender el hecho fotográfico.

El rechazo a la fotografía tradicional se generó simultáneamente en distintas partes de España. Desde Cataluña el propio Ramón Masats (1931), Oriol Maspons (1928), Xavier Miserachs (1937-1998), Ricard Terré (1928), Francisco Ontañón (1930), Joan Colom (1921) o Leopoldo Pomés (1931); desde Almería José María Artero (1921-1991) y Carlos Pérez Siquier (1930); desde Madrid Gabriel Cualladó (1925-2003) -aunque nacido en Massanassa (Valencia)- y Paco Gómez nacido en Pamplona (1922-1998), Gonzalo Juanes (1923) de Gijón y Alberto Schommer nacido en Vitoria (1928)... Aquellos jóvenes fotógrafos se encontraban incómodos en las vetustas asociaciones fotográficas (por ello todos pasarán por AFAL). Ellos, que sólo habían sufrido la Guerra Civil como niños o adolescentes, y que no tuvieron contacto directo con las causas que condujeron al conflicto, responderían por fin, al mismo cambio generacional que comenzaba a producirse en otros ámbitos sociales y culturales.

Este cambio generacional fue consecuencia, como ya hemos señalado, de la relativa apertura al exterior con la que la diplomacia franquista pretendía romper el aislamiento internacional. Sin embargo, no hemos de olvidar un hecho:

\footnotetext{
“El cambio político, que había tenido una cierta incidencia en otros campos de la creación, apenas influyó en el de la fotografía, dramáticamente enclaustrada en el universo endogámico y en el pueril amaneramiento esteticista de agrupaciones y salones. No obstante, el fin de la autarquía supuso el agotamiento de la tradición regionalista y nacionalista y, consecuentemente, el de la justificación ideológica en la que se basaban buena parte de los presupuestos artísticos del tardopictorialismo" ${ }^{11}$.
}

El cambio de mentalidad de la nueva fotografía fue radical y absoluto: estéticamente heterogéneos, geográficamente dispersos, temáticamente plurales lo que uniría a Masats, a Pérez Siquier o a Gabriel Cualladó fue el rechazo a la fotografía establecida, rígida y acartonada de las asociaciones fotográficas tradicionales. Negaron a las instituciones oficialistas, a los concursos, a 
Los maestros consagrados, a la estética pictorialista o tecnicista, a los aficionados domingueros con espíritu de artista, a los prepotentes y grandilocuentes, a los localistas, a los indiferentes al drama de la humanidad, a los idealizadores de la realidad...

Era tan importante denunciar los puntos de fuga y las reglas de oro -dogmas férreos de la fotografía oficial- como conseguir la profesionalización. Dejar de concursar para empezar a publicar. La disidencia exigía un revolución total, estética, social y vital. La postura personal era tan analizada, admirada o criticada, como la propia obra del autor.

“En nuestro intento de dar unas pinceladas genéricas sobre la figura del fotógrafo, la imposibilidad de adscribirle a cualquier grupo o estamento social existente. Cualquier intento de definición en este plano tiene que hacerse por negación: no es un aristócrata ni un hortera; no es un artista en el sentido tradicional de productor de excelsas piezas únicas, sin ser tampoco un industrial; no es un intelectual pero está bastante enterado de todo; no es ni un técnico ni un humanista... ni un burgués ni un paria...

Es, en resumen, un declassé, un individuo difícilmente encasillable, sin un colectivo afín donde encontrar eco y sintonías (...)

No es tampoco un escalador social, ni un venido a menos. Se mueve con cierta desenvoltura entre todos los estamentos, a pesar de ser consciente de que ninguno es el suyo. Está siempre de paso, es un turista social"2.

Como vemos, el estatus social del "aficionado artista" se denostó para reivindicar la inaprensible aunque, por otro lado, absolutamente definida figura del "obrero de la cámara".

“Esta oposición de tradición y vanguardia se puede establecer en otra clave, la de los «jóvenes» y los «viejos», es decir, una clave generacional (...) No es fácil reconstruir el contexto y los debates que dominaron en el ambiente fotográfico de la época. Una simple traducción de estos debates a términos de reacción y progreso sería probablemente inexacta en la medida en que el debate en curso mezclaba posiciones estéticas, un conflicto generacional y posiblemente también, aunque de manera difusa, cuestiones de orden social o ideológico (...) Este conflicto se puede también plantear, en cierta medida, entre los fotógrafos aficionados y los fotógrafos profesionales y, en este sentido, la confrontación enlazaría con un postulado que identifica la vanguardia fotográfica con una renuncia a la autonomía artística, a favor de una inmersión de la fotografía en los medios de producción. Esta comprensión, autodenominada vanguardista en su momento, se define por oposición a los hábitos de los círculos de aficionados, en los que la fotografía permanece aristocráticamente aislada de la vida social, imitando ociosamente el lenguaje de una pintura académica trasnochada"3.

Joan Fontcuberta recoge las posibles concomitancias entre la joven fotografía española y el movimiento neorrealista italiano con autores como Mario Giacomelli, Luigi Comencini, Toni Del Tin... y sobre todo con el llamado Grupo Friulano que contaba entre sus fotógrafos a nombres como Gianni Berengo-Gardin, Fulvio Roiter, Nino Migliore o Italio Zannier. Aunque los propios fotógrafos han rechazado esta influencia en repetidas ocasiones, admitiendo parecidos formales pero distanciándose en las cuestiones de fondo, las causas de este paralelismo las encuentra Fontcuberta en razones sociales, históricas y, una vez más, generacionales. Ambos colectivos padecen:

2 Miserachs, Xavier, Profesiones con futuro: Fotógrafo, Barcelona, Grijalbo, 1995, pág. 41.

3 Ribalta, Jorge,"Entrevista con Joan Colom", en El carrer. Joan Colom a la Sala Aixelà, 1961, Barcelona, MNAC, 1999, págs. 104-105. 
“Una parecida sensibilidad, una parecida posguerra, y una parecida frustración colectiva. Tanto italianos como españoles destilan la amargura y la impotencia fruto de unas circunstancias históricas recibidas como herencia de la generación anterior" ${ }^{\prime \prime}$.

De cualquier modo, el concepto de "generación" fue asumido conscientemente por los jóvenes renovadores gracias a los contactos que establecieron entre ellos en el interior de las asociaciones fotográficas. Recordemos que la fotografía no existía, prácticamente, al exterior de ellas.

\subsection{LA AGRUPACIÓN FOTOGRÁFICA DE CATALUÑA}

En el caso de Masats la primera asociación en la que conocería otros jóvenes contestatarios fue la Agrupación Fotográfica de Cataluña:

“Ramón Masats entró como Socio de la Agrupación Fotográfica de Catalunya con en número de Socio 1545 el 4 de julio de 1956 (según datos del Libro de Socios consultado). La fecha de la Baja no consta"5.

En Tarrasa prácticamente sólo aprendió a revelar, ya que allí casi todos los socios eran salonistas empedernidos. Más tarde, escribió su primera carta a Pérez Siquier y se hizo socio de AFAL (agosto de 1957) -donde realmente se aglutinó toda la fotografía española cómplice en el golpe de estado fotográfico que se estaba llevando a cabo-. Posteriormente (a finales de 1957 cuando se instaló en Madrid para trabajar) se hizo socio de la Real Sociedad Fotográfica de Madrid, donde formaría el grupo disidente "La Palangana". Pero, en primera instancia, fue en la Agrupación Fotográfica de Cataluña donde Masats se encontró con Oriol Maspons, Xavier Miserachs, Ricard Terré, Joan Colom, Galí, Sender, Tharrats, García Pedret, Casademont, Joan Cubaró, Julio Ubiña y Francisco Ontañón.

No sería difícil destacar de entre el resto de compañeros de asociación, los más críticos, discrepantes y rebeldes. Como ya hemos visto, la juventud fue uno de sus signos distintivos más significativos. Encontrar compañeros con posturas y opiniones comunes debió confirmar los primeros impulsos, basados más en profundas intuiciones que en razonamientos lógicos o en fundamentos teóricos. Como explica Xavier Miserachs:

“Sintonicé en seguida con alguno de los más jóvenes que por allí andaban, especialmente con Oriol Maspons, con quien realicé productivas excursiones fotográficas a Cadaqués -en la época en que todavía hacía falta el policial Salvoconducto de Zona Fronteriza-, visité la sorprendente exposición de Leopoldo Pomés en la Galería Layetana en 1954 -Pomés, conectado con el grupo Dau al Set, iba totalmente por libre, con una fotografía no por descuidada menos misteriosa- $y$, sobre todo, empecé a hablar con Oriol de fotografía sin mencionar la técnica, a tratar sólo de la imagen y su contenido comunicativo, a desprendernos ambos del hábito de valorar una foto como optante a premio en un concurso" 6 .

La obra y la vida de Masats no hubiera sido la misma sin los contactos, los vínculos y las amistades de la agrupación catalana. La influencia personal de Maspons, por ejemplo, será decisiva en su trayectoria. Gracias a Maspons conocerá, en un primer momento, la fotografía que se

4 Fontcuberta, Joan “De la posguerra al siglo XXI", en Sánchez Vigil, Juan Miguel (coordinador), "La fotografía en España. De los orígenes al siglo XXI", Summa Artis. Historia general del Arte, Tomo XLVII, Madrid, Espasa Calpe, 2001, pág. 417.

5 Antoni Civantos i Lambea, Presidente del Museo de la Agrupación Fotográfica de Cataluña, correspondencia con el autor, 24 de marzo de 2004.

6 Miserachs, Xavier, Criterio fotográfico. Notas para un curso de fotografía, Barcelona, Omega, 1998, págs. 182-183. 
generaba más allá de los Pirineos, pero también, por su mediación, contactará con AFAL, con la revista Gaceta Ilustrada...

Oriol Maspons nos regala -en la correspondencia que cruzamos con él- una descripción del Masats que conoce en un primer momento que no tiene desperdicio. En ella habla de la admiración que ya siente por sus primeras fotografías, de su afición al atletismo, de su adscripción social y de una furgoneta legendaria... cuyo olor todavía rememora Maspons cuarenta años después:

“Masats ya empezó haciendo las fotos que hubiéramos querido hacer nosotros, o sea Xavier Miserachs y yo, y como que ninguno de los dos éramos envidiosos siempre nos fue bien con él.

Masats estaba cachas ( $y$ ahora voy a ser indiscreto pues no sé si le agradará que se sepa). Masats hacía atletismo que era una tontería de correr pero sin hacer carreras y así no ganaba nunca a nadie y no ganaba dinero. Al no poder apostar dinero perdía interés. Yo no he conocido nunca a nadie más que hiciera atletismo porque sí. Claro, lo dejó.

En aquella época trabajaba en el mercado, en una acreditada parada de bacalao de sus padres y se levantaba de madrugada para ir a buscar bacalao con una furgoneta que tenía que a cinco metros de donde estuviera aparcada se encontraba por el olor. Olía tanto que no sé ni la marca. En el espacio de carga tenía unas mantas y las utilizaba de picadero con alguna de las clientas preferidas a las que debía especial atención personal. A Xavier Miserachs y a mí nos hacía mucha gracia pensar lo que debía contar la adulterina clienta al llegar a su casa oliendo como una loca a «Eau de morue n ${ }^{\circ}$ ».

Xavier y yo nos distinguíamos de Ramón en que él no era pijo en absoluto. En cambio Xavier y yo sí. Llevábamos el preceptivo reloj ROLEX, desde 1959. Xavier jugaba al tenis, iba a esquiar y tenía un coche MINI trucado para correr rallys en cuesta, y a los dos nos gustaban las pijas. A Ramón no.

Un día que yo estaba de foto fija en un película en la que intervenía una guapa argentina, Analia Gadé, y me vio saliendo con ella, pues a mí me gustaba mucho, me riñó y me dijo: “Qué manía de salir con las vedettes, yo siempre procuro salir con una maquilladora o con una peluquera y me va muy bien pues son más agradecidas»-. Y seguramente tenía razón. Pero es que yo era pijo, y él no, las peluqueras jodían más, no lo dudo"7.

En octubre de 1956 Masats participó en la exposición de la Agrupación Fotográfica de Cataluña en la Bibliothèque Espagnole de París, organizada por Oriol Maspons y Les 30×40 (aunque su nombre no pudo figurar en el programa por ser una incorporación de última hora). Esa fue la primera exposición de Masats en el extranjero. Maspons junto con Roger Doloy (presidente del Club 30x40) pretenden dar una imagen nueva de la fotografía española en la exposición de París y, por ello, realizan una selección muy rigurosa de las fotografías expuestas. Esta selección, y por tanto la exclusión de los fotógrafos más arcaicos y repetitivos, precipitará la expulsión de Maspons de la Agrupación Fotográfica de Cataluña meses más tarde.

Efectivamente, la Agrupación Fotográfica de Cataluña representará el salonismo más rancio y más intolerante de todo el panorama nacional e interpretará como una amenaza a sus estructuras la nueva fotografía producida por jóvenes como Masats o como Xavier Miserachs. La estrategia de supervivencia del salonismo no será simplemente la de negar la evidencia, o la de silenciar los nuevos valores en alza, por el contrario, intentará anexionársela y someterla a su propio status quo y, por ello, creará los premios Luis Navarro de Fotografía de Vanguardia, precisamente Masats ganó en su quinta convocatoria (24 de Abril de 1957). Ese prestigioso galardón conllevó una tertulia -o un "coloquio"-, en la Agrupación Fotográfica de Cataluña que fue metódicamente transcrito en el correspondiente boletín de la agrupación. En él ${ }^{8}$ Masats manifestó, por primera vez en

7 Oriol Maspons, correspondencia con el autor, 23 de octubre de 2004.

8 E.V.P., “Coloquios en la A.F.C., con D. Ramón Masats”, Boletín de la A.F.C., junio 1957, pág. 89. 


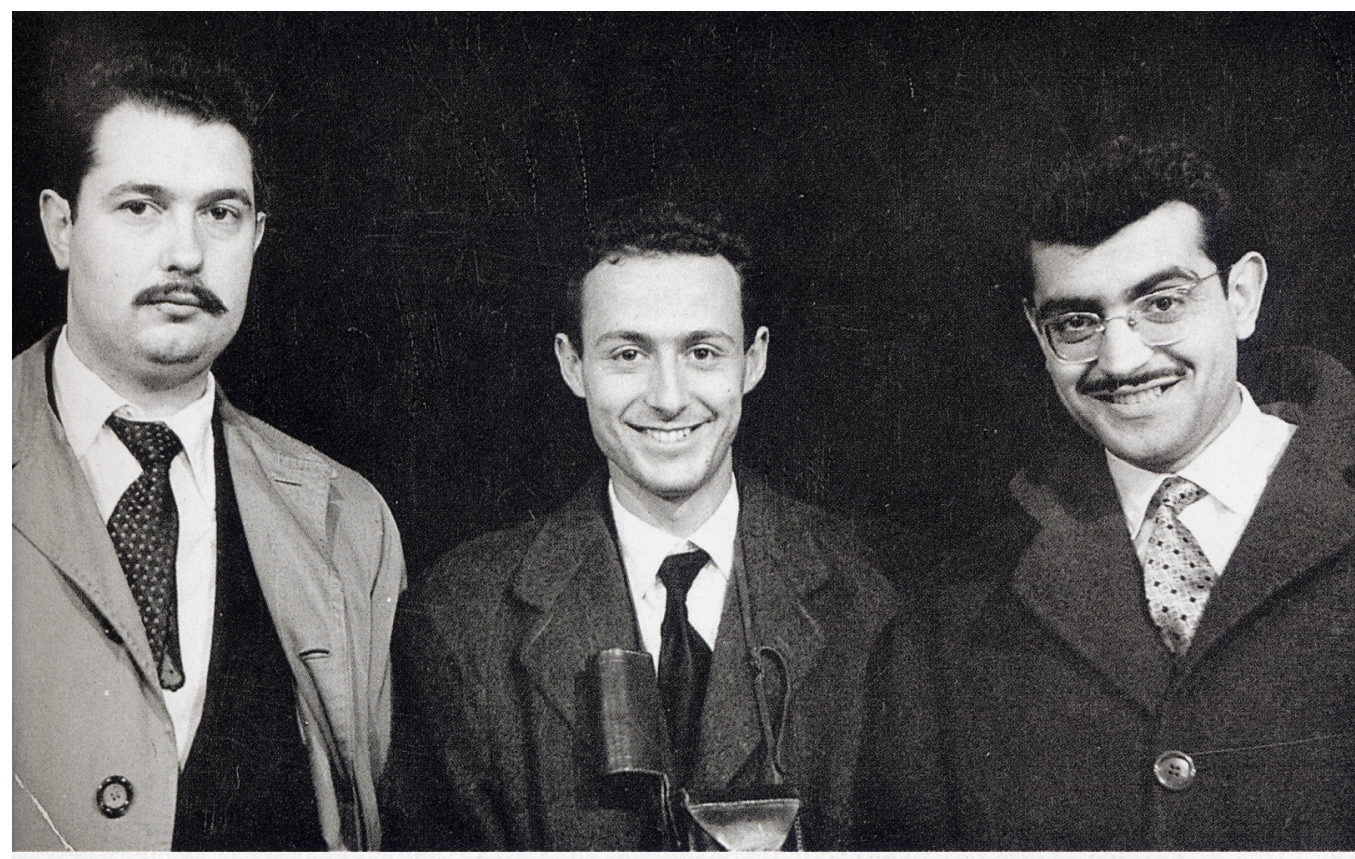

TERRE MISERACHS

MASATS

Fotografía de Julio Ubiña tomada en la Agrupación Fotográfica de Cataluña 1957.

público sus opiniones sobre su manera de entender la fotografía. Ya veremos cómo muchos de los novedosos conceptos que importa Maspons desde París, son asumidos por el propio Masats.

Otro de los encuentros más productivos, surgido de los contactos y las charlas en la Agrupación, fue la amistad nacida entre Masats, Terré y Miserachs. Con ellos hizo dos exposiciones que los situaron en la vanguardia de la renovación fotográfica, la primera de ellas en el interior de los muros de la Agrupación Fotográfica de Cataluña...

(R. Masats, Madrid, 15 de diciembre de 2003) -“El otro día vi a Terré en una exposición en Barcelona, vino de La Coruña, y estuvimos comiendo con él y con Chema Conesa (que es el comisario de la exposición del Canal de Isabel II que llevé a Pontevedra). Y entonces él me dijo: «¿Tú no te acuerdas cómo nos conocimos?»; «Pues no, no me acuerdo» -él tiene una memoria fabulosa-; «Pues mira, estaba viendo una exposición en la Agrupación Fotografía de Cataluña y estabais Javier Miserachs y tú comentando unas fotografías, y yo, discretamente, desde un poquito detrás (de modo que no me veíais), iba escuchando lo que decíais. Y estaba tan de acuerdo con vosotros que me presenté». Y a partir de este momento formamos un grupo de amigos".

Las referencias a los encuentros son cruzadas y recíprocas. Todas ellas destilan la misma alegría, la misma simpatía y amistad de un grupo jóvenes que, como fotógrafos, se encontraron en su camino de oposición ante el pictorialismo y ante el salón fotográfico:

“En la Agrupación había conocido a Ricard Terré y a Ramón Masats (...) Masats había aterrizado en el mundo fotográfico por un azar literal: mientras hacía la «mili», le toco en una tómbola una cámara Retina. Empezó a experimentar con ella, se apasionó con la magia del proceso, y acudió a la Agrupa- 
ción con la intención de aprender más. Masats, vital, sin formación estética previa, tenía un instinto fotográfico extraordinario, ningún prejuicio teórico coartaba su aproximación a la realidad, jamás he vuelto a encontrar a alguien que comprenda tan rápidamente para qué sirve una cámara"9.

De esta época Masats recuerda con agrado las excursiones fotográficas junto a los compañeros de agrupación los domingos por la mañana. Debían ser los domingos puesto que el resto de la semana se dedicaba a trabajar en el mercado, en el puesto de pesca salada de su padre. En estas excursiones desarrollará sus primeras fotografías del puerto de Barcelona y el barrio de la Barceloneta.

La primera exposición colectiva de Masats junto a Miserachs y Ricard Terré, se inauguró en abril de 1957, en la sala de exposiciones de la Agrupación Fotográfica de Cataluña. En aquella ocasión Las Ramblas de Barcelona fueron el motivo que centraron la atención de Masats. Precisamente esta exposición, que ya estudiaremos detalladamente, fue la que motivó que Carlos Pérez Siquier conociera a Masats -con Oriol Maspons como intermediario- y le propusiera inscribirse en AFAL, la Asociación Fotográfica Almeriense. Hay que resaltar que la acogida de la exposición por parte de la mayoría de los socios de la Agrupación Fotográfica de Cataluña fue bastante fría -cuando no de absoluta incomprensión-. En verdad, la Agrupación Fotográfica de Cataluña tan sólo proporcionó el marco para los contactos entre los jóvenes fotógrafos, pero, como entidad, nunca defendió las posturas renovadoras, es más, como ya hemos comentado, llegó a expulsar al principal teórico de la joven generación, Oriol Maspons. Por tanto, suponer que la revolución surgió de la Agrupación Fotográfica de Cataluña sería un error. Realmente sí fueron algunos miembros de esta agrupación los que alzaron las primeras voces discrepantes, pero lo hicieron a pesar de la institución que de forma coyuntural los reunió:

“El «arte» en fotografía -afirmaba recientemente, Miserachs- era su monopolio (de la Agrupación Fotográfica de Cataluña), y nuestra sospecha primera y confirmación posterior de que había otra forma de integrar la fotografía en el mundo cultural, más universal y, además, más útil, creó una enorme incomodidad. De hecho, emplear la expresión Fotografía Moderna había sido un intento eufemístico de dar cabida dentro del status quo, a la misma fotografía «artística», pero formalmente más atrevida. Naturalmente, no se trataba de eso, y por ello acabamos abandonando las agrupaciones fotográficas"10.

Masats frecuentó la Agrupación Fotográfica de Cataluña apenas un año y medio, ya que en noviembre de 1957 se trasladó a Madrid y no volvió por la agrupación catalana. El mérito de la Agrupación Fotográfica de Cataluña fue, simplemente, el de poseer una infraestructura suficiente para poner en contacto a talentos y personalidades dispersas, ya que nunca apoyó realmente a los jóvenes renovadores. Todo lo contrario del recibimiento que se les brindó en Almería. Ese fue precisamente el valor de AFAL: reconocer la capacidad y el esfuerzo de unos fotógrafos que pretendían renovar la fotografía española de su época.

\subsection{AFAL}

La primera noticia que tendrán los impulsores de AFAL de Ramón Masats les llegará de la mano de Oriol Maspons, que en una carta a Carlos Pérez Siquier (con fecha 21-03-1957) lo presenta entusiasmado: 
“Apunta ahora un nombre: Ramón Masats. El fotógrafo aficionado español más completo. Es una bomba. Ahora se va a París a hablar con Ernst Haas y Cartier-Bresson para ver si se mete en Magnum"11.

José María Artero conoce la obra de Masats gracias a su primera exposición -junto a Miserachs y a Terré- realizada en la Agrupación Fotográfica de Cataluña el 13 de abril de 1957. Artero escribe una carta a Terré en la que constata la inmediata sintonía de los tres jóvenes fotógrafos con el ideario de AFAL:

\begin{abstract}
"AFAL, como portavoz que quiere ser de una auténtica fotografía, debe estar alerta al engaño, debe orientar, diferenciar, exigir, señalar en suma, el camino. No sé si tenemos suficiente formación para ello, pero si nadie se ha atrevido a hacerlo, nosotros no podemos seguir esta conducta conformista, la juventud se nos rebela. Y aún reconociendo que muchas de las fotos de los tres, pecan de salonísticas, por exceso de preparación, sin dejar nada al azar, la exposición constituye una verdadera revolución en el ambiente nacional; revolución que está en línea directa con la postura de AFAL"12.
\end{abstract}

Aunque la exposición colectiva pasa antes por Madrid (apenas duró ocho días en mayo 1957), obligados, quizá, por la presentación de la misma -publicada en la revista Arte Fotográfico ${ }^{13}$-, rápidamente se publica otro monográfico en la revista $A F A L^{14}$-dedicada prácticamente en exclusiva a la exposición-, y no pasa mucho tiempo hasta que la primera exposición, Terré, Miserachs, Masats, llega a la sala de exposiciones de AFAL en Almería (en concreto, en Junio de 1957). En Agosto Masats escribe su primera carta a Pérez Siquier y se hace socio de AFAL.

(Carlos Pérez Siquier, Almería, 27 de abril de 2002) -“Yo a Masats lo vi y me interesó mucho. Lo vi como un fotógrafo eminentemente intuitivo, que tampoco había bebido de la cultura ni era un hombre intelectual en aquella época (como todos nosotros). Pero él tenía lo que para mí es lo más importante en un fotógrafo, que es saber mirar, la percepción de la mirada, y saber seleccionar, quitar toda la paja e ir muy directo a las cosas, con una gran agilidad y con un ojo muy vivo y muy certero. Y creo que de aquella época... para mí era el que más me interesó".

- ¿El cambio empezó primero en AFAL y se trasladó después a la Real Sociedad Fotográfica de Madrid?

(R. Masats, Madrid,17 de junio de 1999) -“No, yo creo que fue simultáneo. Yo soy poco de pensar y mirar atrás, mi memoria es muy frágil porque no la he cultivado en estos sentidos. Soy poco nostálgico, así como tampoco soy de mirar adelante. Soy, más bien, no del día a día pero sí del semana en semana. A través de revistas y conversaciones me doy cuenta de cosas en las que no había pensado. Pero no fue AFAL el inductor, ni la Agrupación Fotográfica de Cataluña, ni la Real Sociedad, o sea algunos miembros de estas sociedades, las que influyeron en AFAL, sino que, yo creo, que fue simultáneo. Y desde luego, fue AFAL el que aglutinó, digamos, este movimiento fotográfico, y le dio una unión. Entonces muchos fotógrafos, que casi ni nos conocíamos ni nada -como por ejemplo, Gonzalo Juanes de Gijón y otros fotógrafos-, a través de la revista AFAL nos pusimos un poco en contacto. Fue muy importante la revista AFAL".

La agrupación Fotográfica de Almería (AFAL), se fundó en enero de 1950, y aunque em-

11 Terré, Laura, El grupo fotográfico Afal (1956/1963). Estudio del periodo y aproximación a sus ideas estéticas, tesis presentada en el Departamento de Diseño e Imagen, Facultad de Bellas Artes, Universidad de Barcelona, 1998 , pág. 67. 12 Suárez Canal, Xosé Luis, "Lo caduco y lo nuevo", en el catálogo de la exposición, Cuatro direcciones. Fotografía Contemporánea Española 1970-1990, Madrid, Museo Nacional Centro de Arte Reina Sofía, Ministerio de Cultura/Lunwerg, 1991, pág. 19.

13 Maspons, Oriol, "Cómo hacen sus fotografías Terré, Miserachs y Masats", en Arte Fotográfico, n 64, año VI, abril 1957, pág. 294.

14 AA. VV., “Terré, Miserachs, Masats", en AFAL, n 8, marzo-abril 1957, sin paginar. 


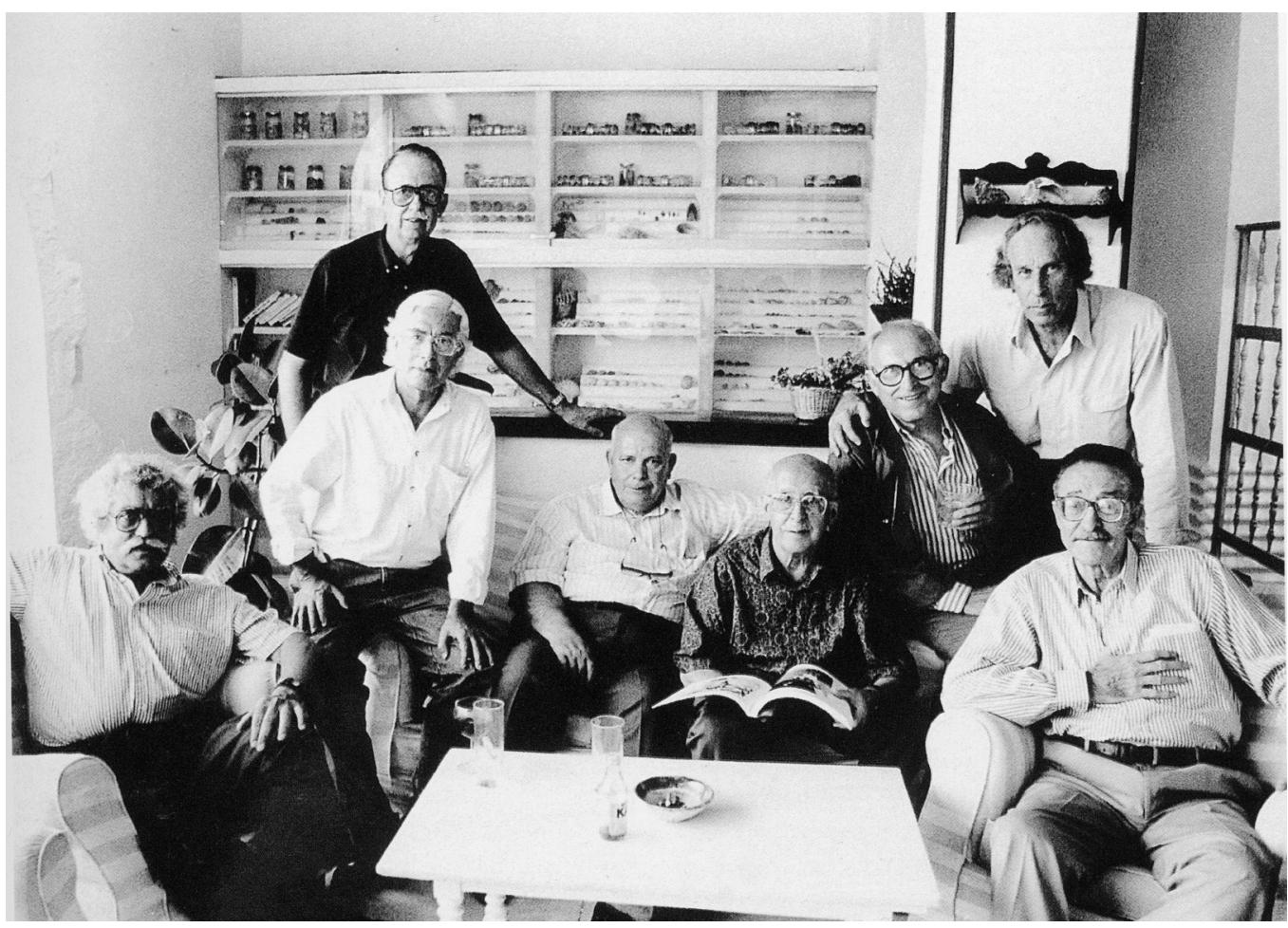

Miembros de AFAL reunidos en Almería en 1990. De izquierda a derecha, Masats, Terré, Pérez Siquier, Cualladó, Paco Gómez, Maspons, Schommer y Artero.

pezó siendo una agrupación idéntica a la miríada de agrupaciones fotográficas que cubrían el panorama nacional, cinco años más tarde, cuando José María Artero y Carlos Pérez Siquier se convirtieron en presidente y secretario del grupo, empezaron a dinamizar la anquilosada fotografía española.

El grupo almeriense, supo sacar partido de sus aparentes desventajas: Por un lado, su novísima constitución les permitió obviar tranquilamente a los "viejos" salonistas. Les proporcionó la suficiente serenidad para no tener que batallar en casa constantemente -aunque sí mantuvieran esta actitud beligerante hacia el salonismo del resto de España-. Por otro lado, su alejamiento geográfico -a priori, otro importante problema- les facilitó la suficiente discreción para evitar las rencillas internas entre fotógrafos de distintas ciudades y distintas agrupaciones.

-¿El milagro de AFAL se pudo hacer por estar precisamente en Almería?

(Carlos Pérez Siquier, Almería, 27 de abril de 2002) -“Sí, efectivamente, en eso estoy de acuerdo. No se hubiera podido hacer por las individualidades. Hubiera habido una guerra entre unos y otros. $Y$ José María Artero y yo tuvimos la suerte que nos llevábamos muy bien. Éramos los que hicimos AFAL. Había dos o tres colaboradores, pero se puede decir que no contaban mucho en el tema".

-Además no tenían que pelearse con ninguna sociedad establecida.

(Carlos Pérez Siquier, Almería, 27 de abril de 2002) -“Exactamente, bueno... había una agrupación fotográfica en Cataluña, igual que estaba la Real Sociedad Fotográfica de Madrid... y Oriol se tuvo que pelear con ellos. Ramón tampoco quiso entrar por allí -pasaba de la Agrupación Fotográfica de Cataluña-, y nosotros teníamos que guerrear con los socios de la Agrupación 
Fotográfica de Cataluña. Dijimos: «la agrupación va a seguir funcionando, y van a seguir con sus concursos y sus cosas, pero va a haber una especie de escisión que va a ser el grupo AFAL y ese grupo va a ser constituido por algunos de Almería y algunos de otros sitios». Los que seleccionaban las fotos estaban constituidos por una comisión que no la formábamos nosotros, sino que estaba formada por catalanes, franceses, vascos y madrileños. De forma que si la foto tuya, de mi amigo, que estás aquí todos los días tomando vino y tal... no gusta, no soy yo el responsable. De esta forma nos quitamos de en medio eso, que hubiera sido el cisma, que hubiera roto enseguida las relaciones... Todo eso era ficticio, porque los que seleccionábamos las fotos éramos nosotros. El órgano decisorio en la sombra lo llevábamos con mucha autoridad nosotros dos. Claro, eso en Madrid y Barcelona hubiera sido mucho más difícil, y además la ciudad pequeña te permite una mayor aproximación y una mayor dedicación".

Con el tiempo, AFAL se convirtió en referencia máxima de la fotografía en España:

\begin{abstract}
“Conscientes de las naturales limitaciones que comporta el aislamiento de su provincia, y con el fin de potenciar sus acciones, se proponen como primer objetivo atraer hacia sí a todos aquellos inconformistas que ya empezaban a aparecer dispersos por nuestro territorio. Catalanes, castellanos, vascos, valencianos se unen con este puñado de andaluces en una misma actitud vital hacia la fotografía. Son nombres que han hecho historia en nuestro medio de expresión. AFAL consigue de esta forma reunir a lo más destacado de la joven fotografía española y constituirse en su instrumento de comunicación. Su Comité Directivo queda constituido como sigue: Presidente: José M. a Artero García, de Almería; Secretario: Carlos Pérez Siquier, de Almería; Consejeros: Oriol Maspons y Casades, de Barcelona, Gonzalo Juanes Cifuentes, de Gijón, Ricardo Terré Marcellés, de Vigo, y Gabriel Cualladó Candel, de Madrid"15.
\end{abstract}

(Carlos Pérez Siquier, Almería, 27 de abril de 2002) -“José María Artero llevaba más bien la parte de edición y yo llevaba los contactos y el hacer adeptos a AFAL. El procedimiento que seguíamos era: yo veía un fotógrafo que me interesaba en una revista determinada... veía que tenía cierta intencionalidad o que era culto con arreglo a aquella época -donde se hacía una fotografía de domingo o de concurso- y entonces le enseñaba lo que hacíamos en AFAL, el manifiesto que hicimos desde la revista..., y lo implicábamos. $Y$ todos, realmente, como se encontraban muy huérfanos de apoyo en sus respectivas ciudades, pues se hicieron socios de AFAL y eso es lo que nos permitió crear un grupo más compacto. Porque el problema de provincias era que aquí, en Almería, había nada más que dos o tres fotógrafos que podían tener una categoría quizá internacional, y para hacer algo sólido teníamos que contar con otros elementos que estaban dispersos por otras ciudades".

Oriol Maspons reconocerá su afiliación muchos años más tarde:

“Els del grup AFAL, d'Almeria, eren molt simpàtics i vaig treballar amb ells amb alegria. Ens hi divertíem. Els enviava coses que no havien vist mai. Els enviava fotografíes de noies, cosa que ningú feia llavors. Els agradava el mateix que a mi. Eren una mica més literaris que nosaltres"16.

Otros miembros que progresivamente fueron incorporándose a la agrupación serán: Joan Cubaró, Juan Dolcet, Xavier Miserachs, Julio Ubiña, Francisco Gómez, Francisco Ontañón, Alberto Schommer, Joan Colom, Leonardo Cantero, Gerardo Vielba...

15 Pérez Siquier, Carlos, “Presencia del «Grupo AFAL» en la fotografía internacional de los años 50/60", en Pérez Siquier, Carlos y Artero, José María, Grupo Afal: 1956-1991, Almería, Almediterránea/Junta de Andalucía, 1991, págs. 17-18.

16 Balsells, David, "Memòries i amnèsies. Extractes d'una conversa amb Oriol Maspons", en Maspons, Oriol; Balsells, David y Permanyer, Lluís, L'instant perdut, Barcelona, Fundació “La Caixa”/Lunwerg, 1995, pág. 12. 
“Desde en n. ${ }^{\circ}$ 1, de Enero de 1956, expresamos nuestra intención y en su editorial se decía: «...Nuestra ambición es ser bastante más que una mera hoja volante para uso exclusivo de socios. Cabrán en nuestras páginas aficionados de El Ferrol, Huelva, Castellón y Gerona... Seremos un pequeño portavoz independiente de las inquietudes de todos los grupos fotográficos que coincidan con nosotros»"17.

Las coincidencias serían meramente la oposición al salonismo y la intención renovadora y cosmopolita. Evidentemente, la selección de personalidades que componen el grupo AFAL se hizo como una reunión de individualidades que, de forma aislada, no hubieran podido llegar a manifestarse, ahogadas por la fotografía oficial. Ésas serán prácticamente la únicas concomitancias, pues los miembros de AFAL tenían fuertes personalidades y vehementes caracteres, que los mantuvieron relativamente independientes en cuanto a sus gustos, estilos y maneras de fotografiar. Así lo confirma el propio Masats.

-Pero era un grupo muy heterogéneo. No fue una única corriente, sino que fue una manera de enfrentarse al salonismo y punto.

(R. Masats, Madrid,17 de julio de 1999) -“Sí, era lo que nos unía tanto a los que hacíamos reportaje como a otros, como por ejemplo a Leopoldo Pomés, que aunque también hacía reportaje era más conocido como retratista. Hacía retratos de una forma completamente distinta".

Aunque fuera el antipictorialismo lo que unió a aquel grupo tan heterogéneo de fotógrafos, lo cierto es que AFAL se vertebró sobre la base de unas premisas muy concisas y claras, motivadas como reacción al salonismo. Por un lado, asumieron un estatus nuevo: el fotógrafo como autor, sincero, auténtico; con un compromiso ético con clara vocación testimonial de su sociedad y su tiempo a través de una mirada natural, sencilla y genuina. Por otro lado, la fotografía debía tener una función utilitaria -como oposición al arte inútil del salonismo-. La aséptica belleza formal pictorialista, unida a la perfección técnica será rechazada en favor del concepto y su expresión. Esa comunicación y expresión del concepto justificará la técnica utilizada -siempre y cuando sean soluciones formales (ópticas y químicas) exclusivamente fotográficas, respetando la especificidad del medio-, así como también justificará la aparición de series o grupos - publicados en forma de libros o reportajes en revistas ilustradas-, que serán mucho más valorados que las fotos sueltas. Las fotos sueltas pueden ser fruto del azar, pero las series, reflejan más la intención del autor, su intención ideológica o estética. Enric Mira efectuará una clara aproximación a las aportaciones de AFAL:

“1) Radical oposición al formalismo academicista de la poética pictorialista que había resurgido durante la posguerra y que alimentaba una fotografía guiada por criterios de composición pictórica así como una excesiva valoración de la técnica: «¿Qué debemos pues oponer al concepto de fotografía moderna? Sencillamente: fotografía pictórica. Esos son los elementos radicalmente opuestos: la fotografía que quiere vivir imitando malamente la pintura del siglo pasado y la fotografía de nuestro tiempo» (Editorial «Nuestra postura», AFAL, $\mathrm{n}^{\circ} 4$ ).

2) Reivindicación, como consecuencia de lo anterior, del estatus de la fotografía como una forma de expresión artística con identidad propia -técnica y temática- capaz de generar una estética propia no hipotecada por los cánones de la pintura: «Consideramos la fotografía como una manifestación artística que admite parentescos, concomitancias y afinidades con otras más o menos próximas, pero con peculiaridades que la hacen independiente, soberana de su propio campo de expresión y con posibilidades inéditas» (Editorial «Nuestra postura», AFAL $n^{\circ} 4$ ).

3) Confección de una nueva propuesta fotográfica de vocación documentalista: «... AFAL una nueva voz, libre de prejuicios, que intenta sacar a la fotografía española de su desván de anticuario

17 Artero, José María, “La revista AFAL y aquellos locos fotógrafos de los 50/60", en Pérez Siquier, Carlos y Artero, José María, op. cit., pág. 10. 
¡Ganemos la calle! ¡Captemos la humanidad que nos rodea! ¡Demos nuestra vida a las cosas y seres que con nosotros conviven! Reflejemos en nuestra obra, concretamente, «nuestro tiempo» (AFAL, n ${ }^{\circ} 6$ Editorial «Un año ya»). De este modo «ser del tiempo en que se vive» se traduce, en términos de poética, comprendiendo la fotografía como reflejo de ese tiempo y en términos de ética, exigiendo del fotógrafo, fiel a su época, el compromiso con los problemas vitales de sus contemporáneos: «sin concesiones ni escapismo alguno, con toda su cruda autenticidad de documento humano, vital, cálida, tremendamente sincera...» (AFAL, $\mathrm{n}^{0} 5$ Editorial «Insistiendo»); o como lo expresaba G. Juanes «el creador de imágenes jamás puede sentirse ajeno a los problemas vitales de sus contemporáneos» (AFAL, $\left.n^{0} 7\right)^{\prime 18}$.

Carlos Pérez Siquier explica cómo realizaban la minuciosa selección de miembros y cómo respetaban cualquier corriente estilística contemporánea mientras el autor tuviera una clara intención renovadora y su obra tuviera vocación de novedad y originalidad. En realidad, Pérez Siquier contradice a Enric Mira en su análisis, pues en AFAL no se concreta una única tendencia documentalista. Daba igual que el autor hiciera fotografía "humanista" o por el contrario fotografía "subjetiva", mucho más abstracta, seguidora (en algunos casos, no en el de Masats) de las teorías del doctor Otto Steinert y su Subjective Photography. Era un criterio de selección más intuitivo que teórico o racional que, en modo alguno, coartaba al autor escogido mientras comulgara con la modernidad.

(Carlos Pérez Siquier, Almería, 27 de abril de 2002) -“Yo entonces trabajaba en un banco, estaba de secretario del director. El director trabajaba tarde, en vez de entrar a las ocho, entraba a las nueve o nueve y pico, y yo, de ocho a nueve, me dedicaba a escribir a todos los fotógrafos que consideraba interesantes. Y no había día que no escribiera cinco o seis cartas... Si no, eso no se hubiera podido haber hecho. Entonces conseguimos primero a Oriol, y lo incorporamos al comité directivo, y luego me puse en contacto... cuando vi la exposición de Terré, Masats, Miserachs, les escribí también... Realmente nosotros lo hicimos de una forma intuitiva y por un amor a una fotografía más culta, más intelectual, más humanista que entroncaba con lo que habíamos visto en revistas como Life, o los franceses como el club fotográfico Les 30x40 de París. De cualquier modo, lo que tenía el grupo AFAL era que no tenía una determinada tendencia. En aquel momento estaba el neorrealismo, la fotografía humanista, la Familia del Hombre... y eso influía mucho en nosotros, pero la fotografía podía tener muy diversas manifestaciones y, de hecho, lo que no hicimos fue encorsetar y decir: «vamos a apostar por los que hacen una fotografía de reportaje social, humano», sino que podía entrar la fotografía subjetiva con las tendencias de 0tto Steinert y tal... Los fotógrafos... cada uno tenía que ser personal, pero con una cierta inquietud y con un interés determinado y, de hecho, la fotografía de Maspons era más frívola, la de Ramón Masats era más fresca, con un ojo mas certero. La mía estaba más relacionada con la que hacía Ramón. Hacía reportaje humano, sobre todo, y como no tenía medios para salir de Almería, me centré más en hacer lo de la Chanca".

El grupo fotográfico francés Les 30x40, la revista Life, el libro The Family of Man, Otto Steinert... las referencias extranjeras son constantes y prolijas. La vocación cosmopolita incuestionable. AFAL importó las más destacadas publicaciones y catálogos de exposiciones internacionales que apenas cruzaban nuestras fronteras:

“Para impulsar intelectualmente el medio fotográfico inician la difusión de los principales artículos aparecidos en las más importantes publicaciones internacionales que apenas eran conocidas en nues-

18 Mira Pastor, Enric, "El documentalismo Fotográfico en España durante los años 50 y 60", en el catálogo de la exposición, Benlloch, P.; Mira, E. y Ortega, A.T., Fotógrafos Valencianos Años 60, Valencia, Generalitat Valenciana, 1992, págs. 10-11. 
tro país y propician su intercambio: «La gazzete de la fotografia, Ferrania, Vita Fotografica, Rivista Fotografica Italiana, Photo-Ciné-Revue, Lerte de París, Jeune Photographie, Camera, Photorama, Clic, Foto, Ilustrated y Pictures Post, Popular Photography, U.S. Camera, Photography...»"19.

Pero la apertura al mundo no se ceñirá exclusivamente a la importación de artículos de revistas. El ansia de contactos con el exterior, promueve que incorporaran exposiciones extranjeras que circularán por toda España.

“A partir de este momento el aislacionismo que existía va a ir desapareciendo poco a poco, a pesar de la reacción contraria y violenta de los medios oficiales de la fotografía que se «encierran en un academicismo burgués y estéril». A la falta de información se va a responder con la publicación de artículos extraídos de revistas extranjeras y con la información de exposiciones que van a dar a conocer nuevas tendencias fotográficas: la joven fotografía belga, el grupo la ventana de México, la exposición de Otto Steinert, etc." ${ }^{20}$.

La exposición de Steinert en Madrid fue objeto de una gran atención por parte de AFAL, pues publicó un número especial de la revista que incluía una reproducción de toda la obra expuesta y una serie de textos inéditos. La exposición circuló por varias galerías del país y logró, por primera vez, el reconocimiento oficial de la Dirección General de Bellas Artes a la fotografía.

Si bien AFAL había participado, de alguna manera, en la tradición asociacionista convocando salones de fotografía ${ }^{21}$, nunca lo hizo con el premio como fin en sí mismo -como hacía el salonismo-, sino como un medio de descubrir y recuperar fotógrafos olvidados por la fotografía oficialista. AFAL convocó a autores jóvenes y desconocidos que serían reivindicados desde las respectivos actividades de la agrupación. Aún así, los Salones de Invierno fracasaron como instrumento para descubrir en masa nuevos talentos de la fotografía española ajenos al "salón", pues, más allá del círculo de agrupaciones fotográficas no existía prácticamente fotografía alguna y el número de "descubrimientos" fue escaso. Ya, desde 1958, AFAL renunciaría de plano a la trampa de los concursos para volcar todos sus esfuerzos en la proyección internacional de sus miembros, organizando exposiciones itinerantes por Europa. Para ello establecieron una serie de contactos con grupos extranjeros como La Góndola en Venecia o la Bussola en Milán; con el Poeo-Cine Clube Bandeirante de Sao Paulo (Brasil); Le Cercle Royal Photographique de Charleroi en Bélgica o el ya citado grupo parisino de Les $30 \times 40$.

Gracias a estos contactos y a la buena acogida que tuvieron en estas agrupaciones extranjeras -sorprendidas por la nueva fotografía que se estaba despertando en España- fueron invitados a participar en numerosos eventos europeos. Diecisiete componentes de AFAL -entre ellos Masats- consiguieron exponer 112 obras en el prestigioso Salón International Albert I (Bélgica, 13 de abril 1958) con gran éxito:

19 Pérez Siquier, Carlos, op. cit., pág. 18.

20 Suárez Canal, Xosé Luis, op. cit., pág. 20.

21 AFAL convocó cuatro premios: de ellos el más acorde con los modos salonistas fue su I Gran Salon de Invierno (1956) -aunque incluso aquí ganaría un fotógrafo desconocido como era Carlos Pérez Siquier-. Los Salones de Invierno posteriores: II Salón de Invierno (enero 1957), III Salón de Invierno (enero 1958) y, el último, Salón Nacional de Fotografía de Invierno (enero 1959), fueron diametralmente opuestos al salonismo. No sólo ganaron autores jovencísimos (Maspons, Schommer y Rubio Camín), sino que además en su II Salón de Invierno se editó un catálogo-antología (antecesor directo del gran Anuario de 1958), donde se obviará a los salonistas, se recopilará una antología de textos que recogen el ideario de AFAL y se impulsará a unos jóvenes y desconocidos autores, presentados como los mejores fotógrafos de vanguardia de España. 
“Del éxito de esta participación española habla el texto de la carta que con fecha 24/6/1958 es recibida del «Cercle Royal»:

«Les expresamos nuestro máximo agradecimiento por la gran colaboración que su grupo ha aportado. De todo el mundo seguimos recibiendo eco del mismo. Así, esta semana, la revista holandesa Focus le ha consagrado un largo artículo. El diario L'Independance publica una crítica consagrada a la participación de AFAL. Deberían tener en cuenta de que el hecho de la publicación de esta crítica fotográfica en un diario no especializado y no obligado a nosotros por ninguna razón es altamente interesante...»"22.

Patrocinada por la revista suiza Camera, trece miembros expusieron veinte obras en la italiana II Bienal Internacional de la Fotografía en Pescara durante septiembre de 1958 -cuyo catálogo reprodujo las imágenes de Masats, Maspons y Terré, la de este último en la portada-. También serán requeridos para exponer en Sao Paulo, Brasil, por el Poeo-Cine Club Bandeirante. Posteriormente, siete miembros de AFAL expondrán en la Galería de Arte Moderno de Milán, en la muestra "Fotógrafos de la nueva generación".

“En el Popular Photography italiano, se expresa la «enorme sorpresa que ha causado el envío español, quien superando un clasicismo estéril -por el que era conocido hasta ahora- ha presentado una fotografía profundamente realista y viva»" ${ }^{\prime 2}$.

Por mediación de Oriol Maspons y bajo el patrocinio del embajador en París, José Rojas y Moreno, los miembros de AFAL expondrán junto con el grupo Les 30x40 en la Biblioteca Española de París el 4 de diciembre de 1959 (en esta ocasión Masats exhibirá trece obras). La exposición conjunta aparece destacada en amplios reportajes en Point de Vue-Images du Monde, Ciné-Photo, Kodeco, Photo-Cinéma, el semanario L'Arts así como en un extenso reportaje de la televisión francesa. Esta exposición tuvo un largo periplo pues fue solicitada por la Ibero-Ameririkanische Bibliothek de Berlín occidental en el mes de abril de 1960 para recorrer toda Alemania, desde Munich hasta las dos zonas de Berlín, a través de sus colegios, institutos y universidades. ¡La exposición llegó hasta Moscú! (abril 1960).

“No es pues de extrañar que siendo el clima internacional propicio a estos «toma y daca» culturales, fuese relativamente fácil organizar para la Exposición que conjuntamente con «Les 30x40» de París presentamos en la capital francesa, una tournée interesante por el continente. En otro lugar de este mismo número se da público conocimiento del estado de nuestra relación con Italia, en donde es parte importante el recorrido que hará esta Exposición. Nuestros muchos amigos de Bélgica verían con gusto la posibilidad de hacerla circular por Países Bajos y Alemania 0ccidental. Y finalmente para empezar este denso recorrido europeo, hacemos el anuncio oficial de que en este momento las fotografías están en Rusia, para su inmediata exhibición dentro del país.

¿Qué impacto producirán en aquellas gentes la Semana Santa de Terré y de Ubiña, los Hermanos Fosores y el Seminario de Masats, los toros de Oriol y de Cantero, los melancólicos grises de Cualladó, el solanesco velatorio en La Chanca, de Pérez Siquier...? España, siempre piedra de escándalo. De nuevo, otra vez, españoles en Moscú. Nunca para resolver definitivamente nada; sólo para decir: esto somos, aquí estamos (...)

¡Ah! Pero ésta es precisamente nuestra máxima satisfacción. Que en alguna parte, representando a España, hemos llegado antes que el fútbol. ¡Que no es pequeña satisfacción!"24.

22 Pérez Siquier, Carlos, op. cit. pág. 18.

23 Pérez Siquier, Carlos, ibidem.

24 Artero, José María (firmado como El Director), "Españoles en Moscú", en AFAL, n 23, marzo-abril 1960, sin paginar. 
Junto a ello, la labor editorial de la agrupación fue admirable. Para cumplir con su objetivo de llegar al máximo número de lectores, se amplió la tirada de la revista AFAL de 200 ejemplares a 2500 , sin ningún tipo de subvención o ayuda oficial y casi sin publicidad:

“Jamás, por otra parte, nuestro amigo personal el Delegado de Información y Turismo almeriense, nos dio un maldito duro por los muchos anuncios del Patronato Oficial de Turismo que insertamos número tras número y ni Ayuntamiento, ni Diputación, ni Caja de Ahorros, ni los Organismos similares a los que ahora reparten el dinero a manos llenas apenas suena la palabra cultura, tuvieron el menor «detalle» con AFAL"25.

De la revista se editaron treinta y seis números entre enero de 1956 y mayo de $1963^{26}$.

“De forma paralela a estos acontecimientos la pequeña publicación del Grupo «Revista Afal», editada por modestísimos medios económicos y técnicos - compuesta manualmente con cuerpos de letra, fotograbados en cobre, impresa con una anticuada Minerva Plana-, adquiere una mayor difusión, 2500 ejemplares, que son distribuidos internacionalmente. Se convierte en edición bilingüe, francés y castellano y crea corresponsalías fijas en París, Bruselas, Londres y Milán..." ${ }^{27}$.

La trayectoria y los contenidos de la revista fueron resumidos por Gerardo Vielba en 1988:

“En enero de 1956, la Agrupación Fotográfica Almeriense, nacida al calor de la organización de un Salón de Fotografía del Mar que venía celebrándose desde el principio de la década, publica el $n^{\circ} 1$ de su Boletín, AFAL (sigla del nombre social), luego crecido en revista y destinado a remover el marasmo fotográfico español. Por lo pronto y durante un cierto tiempo, ello no se percibe, pues no es mucho más atractivo -aunque sí mucho más nutrido- que la mayor parte de la veintena que por entonces se editan por las agrupaciones fotográficas de España: unas cincuenta páginas casi enteramente de texto, y alguna imagen ciertamente anodina [...Los de AFAL] pronto se definen (...) y enderezan el rumbo hacia el logro de una fotografía más libre y profunda al mismo tiempo (...) También incluyen artículos sobre diversos aspectos artísticos (arquitectura, pintura, arte abstracto...) y literarios. Y, desde luego, cine"28.

La distribución de la revista alcanzó unas dimensiones espectaculares sobre todo teniendo en cuenta sus fuentes de financiación:

“Hasta el fin, en 1963, seguimos componiendo un «afiche» que decía: «La revista AFAL no está subvencionada por ningún Organismo, ni por determinada Casa comercial, ni patrocinada por Agencia de publicidad alguna. La revista AFAL sale casi cada dos meses por el esfuerzo desinteresado de un puñado de aficionados a la fotografía y la aportación económica de sus suscriptores y anunciantes». Más de un tercio de sus ejemplares llegaba puntualmente a fotógrafos y Sociedades de Francia, Italia, Portugal, Inglaterra, Bélgica, Suiza, Méjico, Brasil... e Indochina"29.

En 1958 AFAL lanzó a la calle el Anuario de la fotografía española 1958. En total coherencia con la vocación cosmopolita del grupo su prólogo fue traducido a cuatro idiomas: inglés, francés,

25 Artero, José María, “La revista AFAL y aquellos locos ...", op. cit., pág. 11.

26 Aunque el último número se publicó en mayo de 1963, la fecha de portada es la de junio/diciembre de 1962.

27 Pérez Siquier, Carlos, op. cit., pág. 19.

28 Vielba, Gerardo, "Ese grupo... esa «escuela»...", en Casademont, J. M.; Formiguera, P. y Vielba G., Fotógrafos de la escuela de Madrid, Ministerio de Cultura/MEAC, 1988, pág. 14.

29 Artero, José María, "La revista AFAL y aquellos locos...", op. cit., págs. 11-12. 
alemán e italiano. El anuario se convirtió en un hito fundamental para la fotografía española. Publicaron cuarenta y ocho autores, entre ellos: el propio Masats (con un total de nueve imágenes) Català-Roca, Gabriel Cualladó, Cubaró Ciriquian, Galí Riera, Francisco Gómez, Gonzalo Juanes, Xavier Miserachs, Nicolás Muller, Oriol Maspons, Pérez Siquier, Leopoldo Pomés, Schommer, Ricardo Terré, Julio Ubiña...

En el propio texto introductorio del anuario -escrito por José María Artero- aparece reflejada la percepción que de sí tiene la propia AFAL, en el contexto de la fotografía española del año 1958. AFAL es consciente de que su anuario supone un hito, un punto de inflexión en el panorama de la fotografía nacional. Panorama sumergido en una "crisis" inducida por el propio grupo:

\begin{abstract}
“Para nosotros, crisis es ese momento decisivo, que no puede prolongarse mucho, en el cual una situación adquiere equilibrio inestable y a partir de la cual se debe mejorar con relación a una situación anterior. Es pues como un examen o juicio de todo un proceso, un estado transitorio, una especie de muda de crecimiento, un punto de inflexión en una curva estadística. Al decir que en la fotografía española hay crisis de valores, de ideas, de procedimientos, de realizaciones, no queremos significar que se deba perder la esperanza de una renovación, sino precisamente todo lo contrario. Pensamos que la fotografía española se ha detenido a recapacitar sobre su trayectoria anterior y ha comprendido que seguía un camino que no llevaba a ninguna parte; que la adhesión incondicional y continuada a unos cánones de composición pictórica que habían dejado de tener vigencia para la fotografía hace bastantes años en todo el mundo civilizado y casi apenas tienen valor ya en la propia pintura, era estéril; que la fotografía como pura concepción académica conducía a producciones frías, deshumanizadas, que eran poco más que distracciones esotéricas, un vano divagar sin contenido íntimo, sin meta próxima ni lejana; que se renunciaba voluntariamente a toda trascendencia para caer en el inoperante y ridículo onanismo estético que supone «el arte por el arte».

Por eso afirmamos y nos complacemos en señalar esta crisis, este momento crucial de la fotografía española, optimistas ante su previsible desarrollo y evolución. Tímidamente al principio, más y más decididamente después y ya ahora casi en masa, la fotografía española ha despertado del letargo esteticista en que estaba sumida y se ha lanzado a la práctica de una fotografía, al menos más espontánea. Con una gran inexperiencia, pero con el mayor entusiasmo; con una gran falta de base, pero con la máxima sinceridad"30.
\end{abstract}

Una vez más se reafirma, a modo de manifiesto, que la fotografía pictorialista es estéril, deshumanizada, anticuada, ridícula... y se reconocen a sí mismos como los responsables directos del cambio, postulando una fotografía sincera, espontánea, que se proyecta a todo el mundo civilizado desde España. Efectivamente, si ya la revista había ayudado a difundir la renovación fotográfica que se estaba aglutinando en torno a AFAL, el Anuario de la fotografía española de 1958 confirmó las expectativas generadas por los jóvenes fotógrafos españoles en el resto del mundo. Desde Nueva York, el mismísimo Edward Steichen (jefe del departamento de fotografía del MOMA que comisariara la legendaria exposición que marcó toda la generación de Masats, The Family of Man) compra varias fotografías del anuario, pagadas a 10 dólares la copia ${ }^{31}$. Desde Suiza, CartierBresson -el otro gran referente de la joven generación fotógrafo de la agencia Magnum- acusa recibo del anuario, complacido por la sorpresa que le produce la contemplación de sus imágenes, igual que Daniel Masclet desde París, Paolo Monti desde Italia:

30 Artero, José María, “Introducción”, en Anuario de la fotografía española 1958, Almería, AFAL, 1958, sin paginar. 31 Los autores seleccionados por Edward Steichen son: Ricardo Terré, Oriol Maspons, Cortés Vázquez, Leopoldo Pomés, José María Artero, Bargues, Jesús Aguirre y Carlos Pérez Siquier. Recordemos, asimismo, que la obra existente en el M0MA perteneciente a Masats no fue adquirida en esta primera compra, sino con posterioridad. 
“La invitación de Edward Steichen a ocho fotógrafos pertenecientes a AFAL para su exposición Maestros de la fotografía, desde sus comienzos hasta el presente, así como la inclusión de las fotos de alguno de ellos en las tres exposiciones Subjektive hechas por Otto Steinert, o la publicación de una foto de Terré, como único fotógrafo español, en su libro sobre la historia del «autorretrato» en 1960, es el espaldarazo final y el reconocimiento de esa fotografía por la que apostaban y que definía «una visión actual del hombre y su entorno», según palabras de José María Artero"32.

Toda esta explosión de actividades internacionales y nacionales, todos los intercambios, todas las exposiciones y las publicaciones, tan elogiadas en el extranjero, no merecieron ni una línea, ni un párrafo, ni un comentario de los medios especializados y oficialistas de la cultura española, ni por supuesto de la revista Arte Fotográfico:

\begin{abstract}
“Porque dicho sea suavemente y sin ánimo de molestar, ¿no resulta hasta cierto punto gracioso que tengamos tantos, tan buenos e importantes acuses de recibo del ANUARIO 58 de todo el mundo y que dentro de nuestras fronteras solo la prensa no especializada se haya ocupado de él? Repasando de memoria -por lo que podemos incurrir en alguna omisión a favor que estamos dispuestos a reconocer encantados-, ni un solo Boletín, publicación oficiosa, revista, etc., de España específicamente fotográfica ha comentado expresamente, en pro o en contra, el hecho importante de la aparición del ANUARIO y lo que ello representa, aun cuando hubiera sido un fracaso rotundo o una garrafal equivocación en vez de merecer el reconocimiento universal de los que por el ancho mundo son «alguien» en fotografía" ${ }^{\prime 3}$.
\end{abstract}

Carlos Pérez Siquier define la situación en unos términos muy similares, pues aunque desde todo el mundo acusan recibo del anuario:

“En España, en los medios especializados y oficialistas de la cultura se mantiene una conspiración de silencio" ${ }^{\prime 3}$.

Con todo, la edición del anuario se convirtió en el mayor logro de AFAL... y también en el catalizador que precipitó su desaparición. Sus gastos de edición y distribución golpearon la precaria línea de flotación económica de la agrupación que nunca se recuperó del choque y $A F A L$ sucumbió finalmente, tras larga agonía, en 1963:

“Trastocada definitivamente su débil economía por los altos costes del Anuario, con escasa publicidad,
pues los anunciantes preferían revistas menos intelectuales y más técnicas, y sin ningún apoyo de
organismos o entidades culturales que no querían problemas con la censura, AFAL fue languideciendo
hasta alcanzar su último número - 36 - en diciembre de 1963. La felicitación para el nuevo año 1964
no podía ser más expresiva: un entierro y una tumba con la inscripción $A F A L$ ”.

(Carlos Pérez Siquier, Almería, 27 de abril de 2002) -“El gran valor de AFAL, y en esto estoy seguro, es que en aquellos años, en el año cincuenta y ocho o cincuenta y nueve, AFAL desde Almería apostó por unos fotógrafos de fuera, que fueron seis u ocho, que fueron los caballos ganadores. Todos por los que apostamos, aquellos jóvenes, al final se hicieron maduros y dejaron un rastro. Son fotógrafos sólidos que han escrito libros y que han triunfado. Todos: Miserachs, Cualladó, Schommer -que se incorporó un poco más tarde-, Terré -que sigue todavía trabajando

32 Suárez Canal, Xosé Luis, op. cit., pág. 19.

33 Anónimo, "AFAL en el mundo", en $A F A L$, n 19, julio-agosto 1959, sin paginar.

34 Pérez Siquier, Carlos, op. cit., pág. 20.

35 Santos, Manuel, op. cit, pág. 38. 
a pesar que tiene setenta y cinco o setenta y seis años-, Oriol... Ese fue el factor importante de AFAL, que en su momento hizo una revolución y tuvo un medio de comunicación como fue la revista, con una voluntad de servicio a la fotografía. Conectó con los grupos más importantes internacionales y esos fotógrafos han perdurado con el paso del tiempo, han sido intemporales. Lo que demuestra que estábamos en el camino de la verdad, que fuimos auténticos y apostamos por lo que tenía un valor trascendente".

Xavier Miserachs resume las consecuencias que para él tuvo la aparición de la revista AFAL en el panorama nacional.

\begin{abstract}
“José María Artero y Carlos Pérez-Siquier, los principales y más dinámicos impulsores de la publicación, invitaban - desde la propia revista pero también con una febril y personal actividad epistolar- a establecer a través del nuevo medio una red de comunicación que permitiera tratar la fotografía como un hecho cultural, a mandar artículos y fotos sobre temas ajenos al mundo de los concursos (...) A la publicación se debieron dos logros para mí incuestionables y que, en mi caso particular, afectaron notablemente mi juvenil entorno fotográfico.

Por una parte, a través de Afal supe que éramos más de los previstos los que esperábamos de la fotografía otra cosa que llenar de trofeos una estantería. En los más diversos y dispersos puntos del país aparecieron sintonías, y muchas de ellas se convirtieron para mí en duraderas amistades.

$Y$, por otra, Afal puso en evidencia, aun sin estar entre sus objetivos, el talante acultural y retrógrado de las estructuras y actividades en que se desenvolvía la fotografía amateur. Tanto las sociedades y agrupaciones, como las revistas y publicaciones, acusaron la aparición de Afal con desasosegado nerviosismo, vieron al recién llegado como algo profundamente desestabilizador, interpretaron como sedición nuestra simpatía por el nuevo medio y las ideas que desde él se proponían"36.
\end{abstract}

Este fue el legado de AFAL a la historia de fotografía española: el descubrimiento, apoyo y difusión de una serie de fotógrafos, entre ellos Masats, que han trascendido y se han constituido, por méritos propios, en alguno de los mejores fotógrafos de nuestra historia -no sólo de aquel periodo, también de la actualidad-. Por otro lado, a AFAL debemos el que la fotografía "a pelo" $y$ "sin artificios" 37 , llegara a considerarse como un "hecho cultural".

"Su proyección llegó a ser tan importante, que todos los grupos renovadores surgidos en España -el Mussol, de Tarrasa; El Forat, de Valencia, o la propia La Palangana, de Madrid-, llegaron a reclamarse, con más o menos fundamento, como miembros de Afal. En este sentido, puede afirmarse que fue éste el más influyente y decididamente renovador, de los movimientos fotográficos aparecidos en el deprimido panorama cultural español de la posguerra. A través suyo se dieron a conocer los más notables representantes de la vanguardia documental española, como Masats, Maspons, Miserachs, Ontañón, Terré, Colom, Gómez, Cualladó, Pomés, Schommer o Pérez Siquier"38.

(R. Masats, Valencia 25 de marzo de 2004) -“A Carlos Pérez Siquier yo lo admiro mucho... Porque que en aquella época -¡Almería... que aquello era el fin del mundo!- hiciera una revista tan buena... (porque para mí no se ha hecho una revista mejor que $A F A L$ en este país). ¡Conseguir que escribiera Cartier-Bresson...! ¡Que le cedieran fotos todo el mundo...! Para mí eso tiene un mérito fabuloso. Y luego como fotógrafo también me gusta mucho".

36 Miserachs, Xavier, Criterio fotográfico..., op. cit., pág. 184.

37 El 25 de marzo de 2004, Ramón Masats impartió una conferencia en el Colegio Mayor Peset, dentro de la "I Semana de fotoperiodismo de Valencia", titulada, A pelo, la fotografía sin artificios, organizada por la escuela de fotografía EFTI de Valencia.

38 López Mondéjar, Publio, op. cit., pág. 234. 
La relación entre AFAL y Masats fue de admiración mutua. Por un lado, a pesar de su gran independencia, Masats siempre se ha definido como perteneciente a AFAL: publicó artículos cuando se los solicitó la revista, cedió imágenes y contactos, concedió entrevistas y apoyó definitivamente a la agrupación desde sus posibilidades. Por otro lado, este apoyo tuvo su correspondencia, y se vio reflejada en el gran número de actividades organizadas por AFAL a los que fue invitado y en la gran cantidad de páginas que la revista dedicó a difundir su obra. Ya han quedado recogidas las exposiciones internacionales de AFAL en las que participó Masats, igual que su contribución en el anuario de 1958, pero la publicación de su obra, o las críticas a sus fotografías, o incluso sus propios textos, fue mucho más profusa. Para demostrarlo pueden consultarse los números de la revista 8, 9, 21, 23, 25, 27, 28, 30 y 34, aparecidos entre los meses de mayo-junio de 1957 y enero-febrero de 1962.

No obstante, el hecho de que Masats perteneciera al mismo tiempo a la Real Sociedad Fotográfica de Madrid -y que en su interior formara parte de un grupo como La Palangana-, y que, además, publicara en bastantes ocasiones en la revista Arte Fotográfico, fue visto con recelo desde AFAL. A pesar de la buena sintonía entre AFAL y Masats, la relación entre ambos no siempre fue todo lo fluida que se pudiera desear.

Con ello lo que se ponía de manifiesto era la disputa de fondo entre AFAL y Arte Fotográfico, y por extensión entre AFAL y La Real Sociedad Fotográfica de Madrid, o lo que es lo mismo, entre la fotografía de vanguardia, militante y revolucionaria y otra sospechosamente más conformista. Masats se vio inmerso en un fuego cruzado y su carácter absolutamente independiente y poco predispuesto a las sutilezas de la diplomacia contribuyeron a generar no pocas confusiones.

\subsection{LA PALANGANA: UN ANÁLISIS DESMITIFICADOR}

Abordar el estudio de la relación de Masats con la Escuela de Madrid, y más concretamente su relación con el primer grupo de disidentes dentro de la Real Sociedad Fotográfica -La Palangana-, nos ha supuesto un verdadero ejercicio de desmitificación. Cuando preguntamos a Ramón Masats por su paso por la Real y por La Palangana, su lacónica respuesta nos deja helados.

-Y lo de La Palangana...

(R. Masats, Madrid, 4 de septiembre de 2002) -“Eso son cuatro domingos que nos reunimos para hacernos unos vinos y ya está".

Sin embargo, casi todos los autores que se han referido al periodo de los años cincuenta en España destacan la labor renovadora de La Palangana. Esto es así, aunque también es cierto que los nombres de los componentes fundadores bailan constantemente en una sinfonía imprecisa y tampoco se concreta ninguna actividad, exposición, catálogo o manifiesto que justifique la importancia del grupo como tal.

De este modo, Josep Vicent Monzó compara La Palangana con el grupo El Paso:

“La importancia del grupo La Palanga, formado en Madrid en 1959 por Francisco Gómez, Gabriel Cualladó, Leonardo Cantero, Gerardo Vielba, Juan Dolcet y Fernando Gordillo, se puede comparar con lo que supuso el grupo El Paso para la pintura española y aunque durara muy poco y se fragmentara, formaba parte de una nueva generación de autores que se enfrentaron directamente con el arte establecido para contribuir, a través de su libertad artística, a la consecución de los cambios que la sociedad civil estaba protagonizando"39.

39 Monzó, Josep Vicent, "La fotografía: España en blanco y negro", en el catálogo de la exposición, Los años jóvenes 1960-70, Alicante, Caja de Ahorros del Mediterráneo, 2004, pág. 122. 


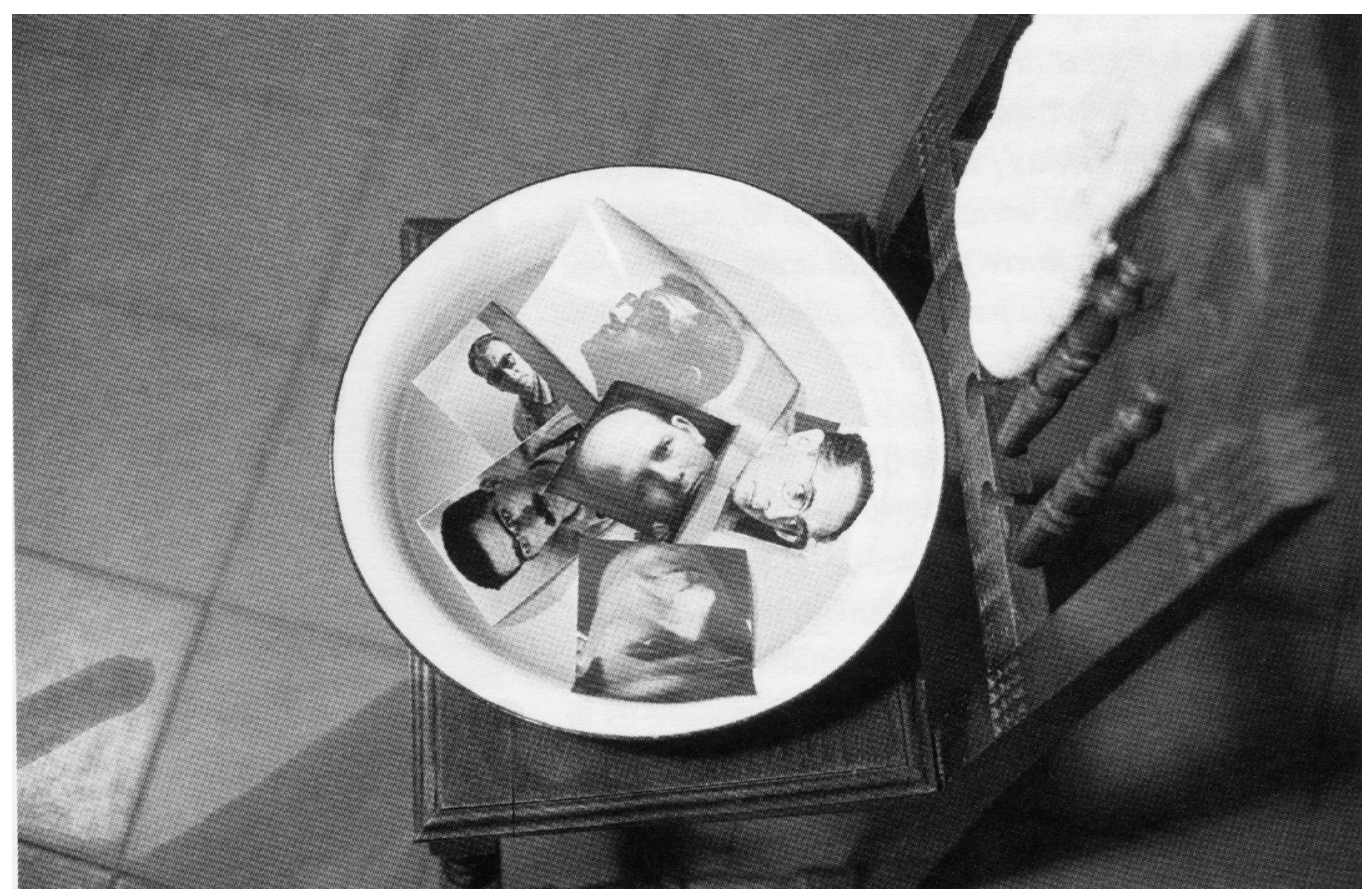

Francisco Ontañón, “La palangana”, 1959, donde aparecen Francisco Gómez, Gabriel Cualladó, Leonardo Cantero, Joaquín Rubio-Camín, Francisco Ontañón y Masats.

Como ya veremos, el nombre del grupo se le ocurrió a Masats a partir de una fotografía realizada por Francisco Ontañón en 1959. Por tanto, la fotografía es la única prueba material de la existencia del grupo. Las personas que en ella aparecen y que, por consiguiente, conforman el núcleo inicial son: Francisco Gómez, Gabriel Cualladó, Leonardo Cantero, Joaquín Rubio-Camín, Francisco Ontañón y el propio Masats.

Josep Vicent Monzó, sin embargo, añade tres autores que no aparecen en la fotografía que dio lugar al nombre del grupo (Gerardo Vielba, Juan Dolcet y Fernando Gordillo) y no menciona a Joaquín Rubio Camín, ni a Francisco Ontañón y ni siquiera se acuerda de Masats; olvido heredado de Joan Fontcuberta que, en su correspondiente capítulo sobre la fotografía de la posguerra hasta nuestros días de la conocida obra Summa Artis, apunta:

“El grupo de Madrid.-Mientras tanto en Madrid se producía un proceso similar en la Real Sociedad Fotográfica de Madrid, que acogería por su parte a otra nutrida hornada de autores: Francisco Gómez (1918-?), Gabriel Cualladó (1925), Leonardo Cantero (1907-1955) y Gerardo Vielba (19211992), de entre ellos saldría en 1957 el grupo La Palangana, nombre acuñado humorísticamente a partir de una foto irónica que hace 0ntañón de los seis integrantes del grupo dentro de una palangana en referencia a las cubetas y baños químicos del cuarto oscuro. Posteriormente se agregaría Juan Dolcet (1948), Fernando Gordillo (1933), Rafael Romero (1916) y Rafael Sanz Lobato $(1932)^{\prime \prime 4}$. 
Como vemos, tampoco nombra a Joaquín Rubio Camín, insiste en añadir a Gerardo Vielba al grupo primigenio y, además, se equivoca en la fecha de formación del grupo, datándola en 1957. Publio López Mondéjar, por su parte, también varía el grupo inicial -olvidando a Francisco Ontañón e incluyendo a Gerardo Vielba- y también fecha la aparición de La Palangana en 1957:

“Contrariamente a Barcelona, la renovación fotográfica madrileña se inició intramuros de la Real Sociedad Fotográfica, en cuyos miembros más atentos e informados causó un fuerte impacto el trabajo de Ramón Masats, que se había instalado en Madrid en 1957. El propio Masats, junto a Gabriel Cualladó, Gerardo Vielba, Leonardo Cantero, Paco Gómez o el pintor asturiano Joaquín Rubio Camín, participó en la creación del efímero grupo La Palangana (1957), al que pronto se incorporaron Juan Dolcet, Rafael Romero, Paco Ontañón y Gonzalo Juanes"41.

Hay que precisar que Gerardo Vielba no aparece en la foto realizada por Ontañón. Fotografía que, recordemos, está fechada en 1959. Además, Gonzalo Juanes nunca se vinculó con La Palangana ya que apenas coincidió unas semanas con Masats en Madrid a finales de 1957. Masats le llamó por teléfono para avisarle de que acababa de instalarse en Madrid y le explicó su plan para profesionalizarse. Ni siquiera se vieron en persona. Masats llegaba para ejercer como fotógrafo profesional y Gonzalo Juanes se iba a Asturias a trabajar como ingeniero industrial, lo que llenaba de dudas y sana envidia a Gonzalo Juanes, que era consciente que se dirigía a una ciudad de provincias donde carecería de compañeros de inquietudes fotográficas, de interlocutores válidos con quien compartir sus reflexiones en torno a la fotografía ${ }^{42}$.

Manuel Santos, a su vez, también menciona a Masats y en las notas aclara que fue éste el que le puso el nombre al grupo -a partir de la foto de Francisco Ontañón-:

“Nombre jocoso sugerido por Ramón Masats a semejanza de los grupos italianos El Navío y La Góndola"43.

Junto a ellos, Santos añade una frase que es, cuando menos, discutible y que evidentemente da lugar a confusión:

"Los miembros de La Palangana expusieron en muchas ciudades europeas con AFAL, y consiguieron muchos premios" ${ }^{\prime 4}$.

El origen de todo el equívoco parece encontrarse en unas declaraciones que Óscar Berdugo recogió de Gabriel Cualladó en 1985. En ellas se aclara qué elementos conformaron el grupo apareciendo en la famosa foto de La Palangana realizada por Ontañón en 1959: Francisco Gómez, Gabriel Cualladó, Leonardo Cantero, Joaquín Rubio Camín, Francisco Ontañón y el propio Masats. También reconoce que la principal actividad del grupo consistía en reunirse a la salida de la Real Sociedad Fotográfica de Madrid. No obstante, se atribuyen a La Palangana una serie de acciones que no le fueron propias:

“La formación del grupo fue anterior a la creación de los Salones de Fotografía actual que te he nombrado antes. Francisco Gómez y yo nos conocimos cuando empecé a frecuentar la Real. Poco después, ya te he dicho que conocimos a Ramón Masats, que nos dejó impresionados con sus fotografías. Leonardo Cantero era ya un fotógrafo de larga experiencia y también coincidimos con él. Poco después

41 López Mondéjar, Publio, op. cit., pág. 235.

42 Esta información la hemos obtenido gracias a diversas conversaciones telefónicas mantenidas con el autor a lo largo de 2004.

43 Santos, Manuel, op. cit., pág. 58.

44 Santos, Manuel, op. cit., pág. 39. 
conocí a un pintor asturiano llamado Joaquín Rubio-Camín. Estaba muy interesado en la fotografía y se incorporó al grupo. Desde entonces nos reuníamos Masats, Cantero, Gómez, Rubio-Camín y yo. El punto de cita era la Real, pero luego continuábamos hablando en cualquier sitio, de fotografía, de proyectos, de lo que se hacía por ahí, de lo que nos gustaba...

Transcurrido algún tiempo, vino de Barcelona Francisco Ontañón, procedente de un grupo de fotógrafos catalanes formado por Galí, Ontañón y Cubaró. Se incorporó inmediatamente al grupo, al que, en broma Masats había bautizado con el nombre de La Palangana.

Empezamos a establecer contactos y a difundir nuestras obras en Alemania, Francia, Bélgica y otros países. El doctor Karl Pawek, bajo el patrocinio de la revista Stern, comenzó a organizar exposiciones inspiradas en la famosa exposición de Steichen, "La familia del hombre", e incluyó nuestra obra en ellas. En fin, empezábamos a movernos. Poco después se incorporaron al grupo Gerardo Vielba y Juan Dolcet"45.

Como vimos con anterioridad, fue AFAL la que en un primer momento organizó las exposiciones en Francia, Alemania, Bélgica, Moscú, Italia... Asimismo, fue AFAL quien publicó el anuario de 1958 (anuario que AFAL distribuyó por todo el mundo y que propició que Edward Steichen comprara fotos de sus miembros). Por último, fue AFAL quien reivindicó a Otto Steinert y lo puso en contacto con sus fotógrafos que finalmente expusieron en el extranjero invitados por Steinert... Por otro lado, es cierto que Gabriel Cualladó participó en la exposición organizada por el doctor Karl Pawek ${ }^{46}$, Exposición Mundial de la Fotografía, pero los otros dos fotógrafos españoles seleccionados -junto a otros 261 fotógrafos de 30 países- no pertenecen a La Palangana, ni siquiera son de Madrid. Realmente, hubo cuatro exposiciones mundiales de esta índole: 1964, 1968, 1972 y 1977 y parece que la exposición en la que participó Cualladó fue la primera, junto a Ricard Terré y Xavier Miserachs ${ }^{47}$.

A su vez, Francisco Ontañón ${ }^{48}$ no recuerda -sobre La Palangana- si el nombre se lo puso él o Masats, aunque sí que él realizó una fotografía de sus componentes como si estuvieran revelándose en una palangana. Ontañón nos cuenta que la Real Sociedad Fotográfica de Madrid era el lugar de concentración, pero luego se iban a un bar que había al lado de la calle Príncipe, que era la calle donde estaba la sede de la Real. El bar tenía un saloncito en su interior, con mesas de mármol, y allí hablaban sobre fotografía, comían o se tomaban unas copas; y coincide con Masats en opinar que ésa fue toda la actividad de La Palangana. Al citarle el contenido de la entrevista entre Óscar Berdugo y Gabriel Cualladó su reacción es de perplejidad. La Palangana nunca publicó ni expuso nada como grupo. Sólo hablaban de fotografía, se reunían y se divertían como amigos. Ontañón considera que Cualladó se ha confundido con AFAL, que sí tuvo toda esa actividad.

“Mi memoria me dice que el nombre lo puse yo, pero puedo estar equivocado, me da igual, si otro dice que fue él, para él la pelota y la palangana.

A este grupo no se añadió nadie más, pues no había tiempo para ello porque se disolvió, toda vez que el médico nos prohibió tomar alcohol a varios.

No cabía nadie más en la Palangana y no hicimos ninguna exposición, pues nuestro pasatiempo era ver los libros que compraba Gabriel, hablar de fotografía y de mujeres" ${ }^{\prime \prime 9}$.

45 Berdugo, Óscar, "Diálogo con Gabriel Cualladó", en Gabriel Cualladó Fotografías, Madrid, Museo de Arte Contemporáneo, Ministerio de Cultura, 1985, pág. 6.

46 En España fue organizada por la Comisaría General de Exposiciones de la Dirección General de Bellas Artes del Ministerio de Educación y Ciencia, en colaboración con el instituto Alemán de Madrid, siendo presentada en Sevilla, Granada, Valencia, Barcelona y Madrid.

47 Exposición Mundial de la Fotografía, Hamburgo, Gruner + Jahr GmbH, sin fechar. Nos referimos a las fotos 189 (Ricard Terré), 138 y 191 (Xavier Mixerachs) y 507 (Gabriel Cualladó).

48 Conversación telefónica mantenida con Francisco Ontañón el 28 de enero de 2005.

49 Francisco Ontañón, correspondencia con el autor, 22 de junio de 2005. 
No debemos olvidar que Cualladó se gastó una fortuna en libros de fotografía y que tenía la biblioteca en un chalet. Su proveedor era una empresa, Ateneum, que traía los libros de importación. Cualladó los tenía todos, ya que su propio negocio de transportes funcionaba económicamente muy bien. Ontañón estuvo una temporada viviendo en ese chalet de Cualladó y revelaba en su cuarto oscuro, encima de unas tablas colocadas sobre la bañera.

Cualladó estaba muy vinculado a la Real Sociedad Fotográfica, llegando a tener un cargo importante en su seno. Tenía un concepto más amateur de la fotografía que ellos. De todo el grupo inicial de La Palangana Ontañón nos explica que Leonardo Cantero vivía de rentas, Paco Gómez era sastre, Rubio Camín era pintor, Cualladó se dedicaba al transporte y Ontañón y Masats eran los únicos fotógrafos profesionales.

“Ese grupo de seis fue el principio que evidentemente tuvo influencia en diversos miembros de la Sociedad Fotográfica. Posteriormente, algunos se aproximaron a La Palangana y dijeron pertenecer a ella. Simplemente por «arrimo». Era cuestión de amistad e ideas comunes, nada más.

Masats era un gran creador nato e inconformista con lo que se «cocía» en la mayor parte de los miembros de la Sociedad Fotográfica, donde por cierto, nos conocíamos todos (...)

Ni Masats ni nadie abandonó La Palangana: sencillamente se consumió con el tiempo. Ahora sólo quedamos vivos 3 de aquellos seis iniciales" ${ }^{\prime \prime}$.

\section{¿Cuáles fueron, por tanto, las actividades que como colectivo realizó La Palangana?}

“Ontañón hizo una fotografía de una palangana conteniendo los seis retratos de los componentes del grupo, fingidamente recién revelados, en el diario de la noche El Alcázar se publicó con un comentario lleno de buen humor al pie: «... Se proponen organizar exposiciones, reunirse en coloquios amistosos y no hablar nunca de técnica fotográfica (...) en el reglamento, que han aprobado ellos mismos, hay una cláusula que dice que esta sociedad no podrá ser nunca ampliada. Porque, como se demuestra en la fotografía, tienen que caber en una palangana (...) Salvo en caso de defunción de alguno de los componentes.» Todo ello culmina en 1959, y pronto, tras un intensa, pero corta actuación abrirán un hueco sin necesidad de la macabra justificación necrológica, pues, para el II SALÓN INTERNACIONAL DE TERRASA, que el Grupo Fotográfico del Casino del Comercio ha organizado para 1963 mediante invitación a grupos de vanguardia de distintos países, habiendo sido elegido por España el de La Palangana, el Grupo concurre ya sin la aportación de Masats... Veamos cómo salteadamente, lo cuenta Gabriel: «Ya por aquellas fechas (primeros años sesenta) Gerardo Vielba y Juan Dolcet eran nuevas aportaciones humanas al grupo. En cambio, Ramón Masats empezó a separarse atraído por el cine y la televisión"51.

Desde 1959 (dos años después de la llegada de Masats a Madrid, en noviembre de 1957, por lo que cabe suponer que las reuniones empezarían antes de la publicación de la foto) hasta 1963 sólo es invitada, como colectivo, para exponer en el II Salón Internacional de Terrasa y ya, para entonces, sin contar con la participación de Masats ${ }^{52}$. Esta única exposición -de parte del colectivo de La Palangana- no parece suficiente como para justificar la importancia que los historiadores de la fotografía española le han atribuido. Tal vez la relevancia de grupo se debiera a su consideración como antecedente de la Escuela de Madrid.

50 Joaquín Rubio Camín, correspondencia con el autor, 16 de enero de 2005.

51 Vielba, Gerardo, op. cit., págs. 18-19.

52 Su ausencia fue debida, según Vielba, a que Masats empezaba abandonar la fotografía para dedicarse al cine. Efectivamente, Ramón Masats hizo la fotografía del cortometraje de once minutos La suerte, dirigida por Mario Camus en 1963 , aunque recordemos que en 1964 publicó Viejas Historias de Castilla la Vieja y todavía en 1967 publicó su Don Quijote de la Mancha. 


\begin{abstract}
“Pocos meses más tarde, Rubio Camín, Masats, Ontañón y Juanes abandonaron las reuniones informales del grupo, mientras se agregaban Fernando Gordillo y algunos miembros del futuro grupo La colmena, como Carlos Hernández Corcho, Rafael Sanz Lobato, Sigfrido de Guzmán o Felipe Hernández Tarabillo. Entre el posibilismo reformista del núcleo inicial y la actitud más bronca e insumisa de los componentes de La colmena, se produjo una síntesis formal y conceptual, que acabaría conformando esa dudosa -y a veces, sospechosa- poética de lo rural, que caracterizó buena parte de la obra de lo que luego daría en denominarse, Escuela de Madrid"53.
\end{abstract}

Efectivamente, el membrete Escuela de Madrid ha sido aplicado a toda la generación de Cualladó. Precisamente la primera mención escrita del término la hizo Josep Maria Casademont desde Barcelona, al respecto del polémico Trofeo Luis Navarro de Fotografía de Vanguardia que obtiene Gabriel Cualladó en 1961 (con su puntual fotografía Niña peinándose).

“El VIII Trofeo Luis Navarro ha tenido un ganador de la escuela de Madrid (algún día diremos qué entendemos bajo este nombre): Gabriel Cualladó Candel"54.

Esta mención vuelve a repetirse al finalizar el año en la referencia de una exposición de Dolcet en la sala Aixelà:

“Hemos visto a un Juan Dolcet evidentemente evolucionado respecto a su producción anterior, rehuyendo, no obstante, el sumarse incondicionalmente a la «escuela de Madrid»..." ${ }^{\prime 55}$.

Sin embargo, ni el propio Cualladó cree que existieran características comunes que permitieran esa definición...

"Yo pienso que no, desde luego. En realidad éramos un grupo de fotógrafos completamente distintos entre nosotros, incluso entre los del grupo La Palangana. No se parece nada la fotografía de Ramón Masats a la mía. 0 la de Gómez a la de Cantero. La denominación Escuela de Madrid se generó en Barcelona, pienso que no sólo tomando como un conjunto de fotógrafos que vino después: Sigfrido de Guzmán, Hernández Corcho, Rafael Lobato... Quizá olvide alguno. Este segundo grupo fue englobado junto con nosotros en esta denominación. Yo creo que lo único que denota es que en Madrid se estaba haciendo entonces una fotografía interesante y que habíamos conseguido romper aquellos corsés tan rígidos en que se movía la fotografía hasta entonces" ${ }^{\prime \prime 56}$.

(R. Masats, Madrid, 20 de marzo de 2000) - "Esto es de Leonardo Cantero, es uno de los aficionados que pertenecen a lo que se llamó, la Escuela de Madrid: que nunca sé lo que es. Son nombres que se inventa la gente que tiene que poner etiquetas a todo, yo no sé por qué".

Como hemos visto, parece que la Escuela de Barcelona fue la que bautizó a la Escuela de Madrid... por razones meramente geográficas o, mejor dicho, geopolíticas. Parece que hay una ausencia absoluta de elementos comunes entre los componentes de los distintos grupos. Sin embargo, Enric Mira encuentra ciertas concomitancias entre los miembros de la Escuela de Madrid, que podrían justificar el término, y los fotógrafos catalanes:

53 López Mondéjar, Publio, op. cit., pág. 235.

54 Anónimo (Josep Maria Casademont), “El VIII Trofeo Luis Navarro y el IX «Aplec» de sociedades catalanas en Seo de Urgel", en Arte Fotográfico, nº 115, año X, julio 1961, pág. 583.

55 Anónimo (Josep Maria Casademont), "Fotografías de Juan Dolcet en la sala Aixelà", en Arte Fotográfico, n 120, año

X, diciembre 1961, pág. 1089.

56 Berdugo, Óscar, op. cit., pág. 6. 
“Uno de los rasgos más característicos del hacer fotográfico de la Escuela de Madrid es el de la marcada presencia del autor que hace de la imagen fotográfica testimonio de la realidad exterior una forma de testimonio del mundo interior. Esta dimensión psicológica de auto-testimonio supone una serie de rasgos concretos a la hora de concebir y plasmar la imagen fotográfica. En este sentido, se tiende a una imagen meditada y estática -distanciada-, guiada por el máximo cuidado en el encuadre y en sus cualidades técnicas y formales. El fotógrafo se halla a la busca -espera- de la situación en la que, ubicados los personajes, se imbriquen con ella en una unidad expresiva equilibrada. Por ello, la realidad, plasmada en una evocación rural, será siempre de contenido personal y humano, haciendo del retrato-ambiente el género que aúna los valores más específicos de la Escuela de Madrid.

En el estilo practicado por los catalanes nos encontramos con una concepción del fotógrafo como estricto testigo de la realidad que debe ser testimoniada de la manera más fiel, pura y directa... no interpretada subjetivamente. La realidad es acotada básicamente como realidad sociológica, en vez de la dimensión personal y psicológica se opta por la del sujeto inmerso en una trama social no rural sino urbana. A los valores temáticos se subordinan los aspectos formales y técnicos de la imagen. En aras a un mejor testimoniaje habrá que acercarse a la realidad e implicarse con ella, con su acción. Esto hizo que la serie fotográfica fuese tomada, entre los fotógrafos catalanes, como el mejor medio de reflejar el dinamismo cambiante de la realidad social"57.

Por su parte, Publio López Mondéjar analiza las posibles diferencias entre uno y otro "colectivo".

“Mientras los fotógrafos catalanes mantuvieron una estrecha cercanía con los círculos culturales más avanzados de Barcelona, los madrileños -miembros en su mayoría, de las clases más representativas del franquismo sociológico-, se mantenían enclaustrados en el universo endogámico de la Real Sociedad Fotográfica. Aislados del ambiente cultural de su ciudad, los componentes de la escuela de Madrid permanecieron anclados en un melifluo lirismo, que en muy pocos casos trascendió una estomagante "alabanza de aldea", o el reflejo de una realidad idealizada por el aliento pretendidamente poético de sus autores. No obstante, justo es señalar que acabaron siendo los protagonistas de un movimiento renovador que, pese a sus limitaciones, supuso un intento honesto de romper el pueril academicismo de la época" ${ }^{158}$.

Nuestra opinión es que, probablemente, la principal característica que permitiera polarizar a los fotógrafos y aglutinarlos en torno a los grupos de las dos "capitales" de España sea la profesionalización. Excepto Ricard Terré todos los fotógrafos catalanes relevantes fueron profesionales -siguiendo el ejemplo de Català-Roca-. Por el contrario, ningún fotógrafo madrileño se atrevió a dejar su empleo para dedicarse a la fotografía con total exclusividad. Ninguno abandonó el ámbito del aficionado y posiblemente sea esta la causa real de las diferencias apuntadas por los dos autores citados.

Francisco Ontañón nos ha comentado en más de una ocasión que la fotografía en Cataluña empezaba como en toda España, "saliendo los domingos de excursión a ver qué pescabas". Pero luego... con el tiempo, aquello no les satisfacía y necesitaban dedicarle más tiempo... hasta que llegaban a la profesionalización. Cualladó nunca necesitó dar ese paso. Sobre Ramón Masats, este último destaca precisamente su intención de profesionalizarse:

“Al poco tiempo, conocí a Ramón Masats, que llegaba de Barcelona, cargado con una caja de 18×24 hecha en Los Sanfermines. Quería ser un profesional. Él era entonces un fotógrafo amateur, que provenía de una agrupación fotográfica catalana. Aquella ambición le costó mucho trabajo. Se convirtió en un miembro más de la R.S.F. Empezamos entonces a renovar el ambiente de la R.S.F. Creamos, con Gerardo 
Vielba, lo que llamamos Salones de Fotografía Actual. Pretendíamos con ello facilitar el conocimiento de la fotografía que se estaba haciendo en Europa y América. Creo que conseguimos un cambio total en las fotografías que se estaban haciendo en el mundo concursístico" ${ }^{\prime \prime 2}$.

El planteamiento fotográfico de Cualladó sigue anclado en el concurso. Su universo fotográfico no superó a la agrupación, sino que pretendió conseguir una evolución sin salir al exterior de sus muros. De hecho, esta exposición de intenciones y logros parece sacada de aquel ideario que manifestara Luis Navarro en 1952 y 1953. Por el contrario, la obligación de satisfacer las necesidades de las revistas y de las editoriales, los contactos profesionales con escritores, editores y pintores, marcaron la pauta de los fotógrafos catalanes. La finalidad última de la publicación obligaba a un planteamiento completamente diferente a la hora de enfrentarse a un tema. Por ello trabajan pensando en series fotográficas y no en fotos únicas -más propias de un concurso-, por ello trabajan la ciudad -donde se produce la noticia o bulle la sociedad-y no el campo -cada vez más despoblado y con menos interés informativo-.

Sobre el membrete de la Escuela de Madrid, Francisco Ontañón nos ha señalado en conversaciones mantenidas con él que, siendo catalán, cuando se hace una antológica sobre fotografía catalana se le llama para que colabore como integrante de la Escuela de Barcelona. A su vez, cuando se hace una exposición sobre fotografía madrileña, también se le invita como perteneciente a la Escuela de Madrid. Ontañón considera que esta necesidad de poner etiquetas es una herencia de la Historia del Arte, pero que no tiene ningún sentido profundo.

Es posible que el motivo de la exagerada relevancia de la Escuela de Madrid y de La Palangana en la Historia de la Fotografía Española, se deba a la necesidad política de atribuir a la capital de España algún mérito, algún protagonismo en esta revolución fotográfica que estamos estudiando y de la que forma parte indiscutible Ramón Masats. Como hemos visto, Masats perteneció a las tres agrupaciones fotográficas: la de Barcelona, Almería y Madrid. En todos los casos hemos visto cuáles fueron sus primeros contactos y sus principales vínculos. ¿Pero qué es lo que motivaba el afán asociativo de Masats? Probablemente un hecho, no hay que olvidarlo, que resulta sintomático de una situación como la que atravesaba el arte español del momento, plagado de grupos y colectivos de muy diversa índole que surgen como reacción a la represión política y su consiguiente falta de información.

Cada agrupación fotográfica tuvo su cronista particular y, si bien Miserachs y Maspons nos han legado testimonios sobre la Agrupación Fotográfica de Cataluña y Carlos Pérez Siquier ha hecho lo propio sobre AFAL, en el caso de la Real Sociedad Fotográfica el testimonio más interesante será el de Gabriel Cualladó.

“Cuenta Cualladó, en unas notas rememorativas muy posteriores (leídas en una Mesa redonda sobre fotografía en el M.E.A.C. en mayo de 1982): «Empecé a frecuentar la sociedad casi al mismo tiempo que Francisco Gómez y pronto hicimos amistad (...) Conocimos a Leonardo Cantero. Nosotros éramos unos principiantes y Leonardo era ya un fotógrafo con una larga experiencia, nuestras inclinaciones fotográficas eran coincidentes en muchos sentidos (...) Poco después de esta exposición (se refiere a la de Terré-Miserachs-Masats ya comentada) vino a Madrid Masats con el deseo de abrirse camino en el campo profesional. Como tarjeta de presentación traía un reportaje que había hecho en Los Sanfermines (...) Recuerdo que ese día nos fuimos a un café para ver con detenimiento aquel trabajo. A mí me dejó impresionado la gran belleza de aquellas imágenes. Me recordaba mucho lo que hasta entonces había visto de Cartier-Bresson, tanto en los encuadres, en la oportunidad del disparo e incluso en el positivado de tonos grises plata"60. 
Como ya hemos visto, Cualladó resalta las intenciones de profesionalizarse de Masats, pero también describe con todo detalle sus imágenes, su belleza, el tipo de positivado, la sorpresa al contemplarlas... y el contexto en el que fueron admiradas por primera vez. Fuera de la Real Sociedad Fotográfica, en un café. Parece que el uso que Masats hacía de las agrupaciones fotográficas no era el más ortodoxo, lo que no es de extrañar después de su paso por la Agrupación Fotográfica de Cataluña, agrupación con la que había vivido los molestos silencios tras su exposición junto a Terré y Miserachs, la expulsión de Maspons...

El ambiente que buscaba Masats en la Real Sociedad Fotográfica lo describe muy bien él mismo.

- ¿Tú piensas que en la actualidad el documentalismo es menos asociativo que antiguamente, que es un poco más individualista?

(R. Masats, Valencia, 25 de marzo de 2004) -“No lo sé, no tengo yo tanto contacto. Yo no soy muy aficionado a las escuelas, pero creo que una de las grandes cosas que hace una gran escuela de fotografía -yo me di cuenta de eso cuando fui a Madrid-, es el poner en contacto gente. Esto es muy importante. Para mí lo más importante es el contacto entre los alumnos, el interés que puedan tener entre ellos, y en segundo lugar la biblioteca. Es decir, la información visual (no la información hablada de un profesor que te cuenta...) y para mí eso es muy importante. En tercer lugar -y que me perdonen- son los profesores. Yo creo que sí, que los jóvenes siguen agrupándose, la gente seguirá contándose sus cosas, si han descubierto algún fotógrafo, seguirán contándoselo unos a otros, seguirá existiendo..."

Masats busca compañeros, colegas con quien compartir un mismo lenguaje y unas mismas inquietudes. Masats buscaba fotógrafos y encontró amigos que superaban con mucho el ámbito fotográfico, tal y como recoge el citado Cualladó:

“Desde entonces nos reuníamos el grupo que se había formado compuesto por Masats, Cantero, Gómez, Rubio Camín y yo. El punto de cita era la Real, pero después continuaba la charla bien en un bar o algún restaurante; estas tertulias se prolongaban y en muchas ocasiones terminaban en el domicilio de alguno de nosotros" ${ }^{\prime \prime 1}$.

Los detalles de la relación entre Masats y sus amigos no han trascendido, y tampoco tienen mucha importancia, aunque como vemos los guiños y las complicidades han perdurado más de cuarenta años:

“Desde que volví a mi tierra y dejé Madrid, donde viví 26 años; veo muy poco a Masats, pero mi admiración es total. Tuve un trato intenso, semana a semana nos veíamos todas las tardes de domingo, en el Barrio de la Concepción madrileño, donde yo vivía. A su hijo primero Óscar lo entretuve tardes enteras cuando tenía solamente meses"62.

Esa intensa relación supuso grandes alegrías y también algún agravio involuntario, que aunque anecdótico, nos revela parte del carácter de Masats y de la concepción que tenía de las distintas asociaciones a las que perteneció.

- ¿A qué asociación fotográfica te vinculas más, a la de Madrid, la de Barcelona o la de Almería? Porque el Premio Negtor tenía una parte destinada a una asociación fotográfica y tú se la diste a la Real Sociedad Fotográfica de Madrid, con el consiguiente enfado de Carlos Pérez Siquier.

(R. Masats, Madrid, 4 de septiembre de 2002) -“¿Ah sí?, ¿se cabreó Carlos Pérez Siquier porque no les puse...? Sí... algo hubo de eso, alguien se cabreó. Siempre se cabreaba conmigo la 
gente. Pero lo de Almería no me acordaba yo. Ahora que lo dices, tenían razón. Tenía que haber puesto AFAL, pero no se me ocurrió. Lo que pasa es que, para mí, la Asociación Fotográfica de Almería no existe. Para mí existe la revista AFAL, y existen Pérez Siquier y José María Artero, pero como agrupación fotográfica me da absolutamente igual. Es decir, ni conozco la sede, el local, ni conozco nada de la agrupación. Es AFAL, la revista. Tengo más vinculación con la revista, pero tampoco te puedo decir que fuera más intensa que la que tenía en Madrid con Gabriel Cualladó, con Paco Gómez...; en Barcelona con Oriol Maspons o Miserachs, aunque en aquel momento ya no estaba en la Agrupación Fotográfica de Cataluña porque cuando el Negtor yo ya estaba en Madrid, y a Oriol lo habían tirado y nos habíamos ido de la Agrupación Fotográfica de Cataluña. Yo conozco el local de Madrid, iba aquí. Mi agrupación fotográfica era la de Madrid. A nivel personal tenía más vinculación con Gabriel Cualladó y con Paco Gómez o Leonardo Cantero..."

-Ellos también pertenecían a AFAL.

(R. Masats, Madrid, 4 de septiembre de 2002) -“Si".

-Es que cuando fui a Almería a hablar con Carlos Pérez Siquier me comentó que la asociación realmente renovadora e importante fue AFAL.

(R. Masats, Madrid, 4 de septiembre de 2002) - “Es verdad, aglutinó la fotografía española”.

Una vez puestas por Masats cada asociación en su lugar, no queremos cerrar este epígrafe sin dar cuenta del desagravio público que ofreció Masats a Carlos Pérez Siquier durante la mesa redonda que tuvo lugar en Segovia, en el Museo de Arte Contemporáneo Esteban Vicente en 2004. Cuando Carlos Pérez Siquier hace referencia a los apuros económicos por los que atravesó la revista AFAL, Masats recuerda la entrevista que mantuvimos con él y se apresta a intervenir:

(R. Masats, Segovia, 20 de octubre de 2004) -“Perdón, perdón. Hablando de esto de dinero. Yo quiero pedirte perdón porque... para nosotros -para mí personalmente- AFAL no era el Boletín de la Agrupación Fotográfica Almeriense. A mí me dieron un premio (que era el premio Negtor) que llevaba implícito, aparte del dinero -que para mí me vino muy bien, eran quince mil pesetas-, Llevaba un dinero también para una agrupación fotográfica. En ese momento, cuando me preguntaron qué agrupación fotográfica, puse la Agrupación Fotográfica de Madrid (que sé que no necesitaba el dinero) y no puse la Agrupación Fotográfica de Almería porque no se me ocurrió que aquello que estabais haciendo era el Boletín de la Agrupación Fotográfica Almeriense. Con lo cual lo siento mucho y te pido perdón. Fue porque no era un boletín de una agrupación fotográfica. Vosotros manumilitari os metisteis allí, hicisteis lo que os salió de los... las narices... hicisteis una gran labor. Pero yo, en aquel momento no era consciente de que $A-F-A-L$ quería decir «Agrupación Fotográfica de Almería»".

(Carlos Pérez Siquier, Segovia, 20 de octubre de 2004) -“Bueno... se te perdonan todos tus pecados".

(R. Masats, Segovia, 20 de octubre de 2004) -“Me parece muy bien".

Hay que destacar que Ramón Masats, actualmente, sigue pagando la cuota como socio de la Real Sociedad Fotográfica de Madrid.

\subsection{INFLUJOS COSMOPOLITAS Y PROTAGONISTAS}

-Comenta Publio López Mondéjar su independencia creativa, su falta de maestros o influencias.

(R. Masats, Madrid, 17 de junio de 1999) -“Hombre, me gustaba mucha gente; me gustaba William Klein, y sigue gustándome, pero sobre todo el que más me gusta es Cartier-Bresson, pero nunca hemos querido imitar".

- ¿Es decir que inventaron la fotografía, su manera de fotografiar?

(R. Masats, Madrid, 17 de junio de 1999) -“No, no inventamos la fotografía... inventamos lo que nos gustaba". 
-Pero de todas maneras cada uno inventó la suya, quiero decir que era un grupo muy heterogéneo. No fue una única corriente, sino que fue una manera de enfrentarse al pictorialismo y punto.

(R. Masats, Madrid, 17 de junio de 1999) -“Sí, era lo que nos unía tanto a los que hacíamos reportaje como a otros, como por ejemplo a Leopoldo Pomés, que aunque también hacía reportaje era más conocido como retratista. Hacía retratos de una forma completamente distinta".

Es difícil aclarar las posibles influencias de Ramón Masats después de unas declaraciones como éstas. De hecho, Masats es un autor tremendamente independiente, que ha renegado siempre de cualquier intelectualismo o de cualquier influencia ajena a su asombrosa capacidad de intuición, a su rapidez y a su autenticidad. No obstante, Masats jamás se encerró en sí mismo. No permaneció aislado del panorama fotográfico de su momento ${ }^{63}$. Por el contrario, siempre perteneció a asociaciones fotográficas: Tarrasa, Agrupación Fotográfica de Cataluña, AFAL y Real Sociedad Fotográfica de Madrid; y en ellas siempre mantuvo una postura tremendamente activa, participando en sus respectivas publicaciones, agrupándose con sus compañeros con ideas estéticas afines y creando grupos "disidentes", como los acabados de analizar. Por tanto, Masats fue un hombre perfectamente integrado en el ambiente fotográfico de mediados de los años cincuenta. Y de todos esos contactos, de los escritos de sus amigos -como Oriol Maspons o Gonzalo Juanes-, de los debates y las discusiones en las agrupaciones fotográficas, de las revistas AFAL y Arte Fotográfico, de la contemplación de revistas extranjeras como Life o Paris Macht, o de libros, como The Family of Man, se destilaría, en parte, su manera de entender la fotografía.

En concreto, la tarea de la importación fotográfica fue posible porque, aunque la década de los cincuenta no aportó ningún cambio sustancial en el destino político del país, la aceptación por parte de los Estados Unidos del nuevo papel de la España de Franco -como un peón más en el bloque defensivo occidental- no solo acabó con el bloqueo diplomático anterior, sino que permitió de hecho una mayor permeabilidad internacional dentro de la vida del país.

(R. Masats, Madrid, 17 de julio de 1999) -“Es cierto que coincide eso que dices, yo nunca lo había pensado. Nosotros no éramos conscientes de ello en absoluto, a lo mejor sí nos influenció la apertura de pintores, y de escritores posiblemente también, pero de pintores sobre todo. Pero yo no creo que tuviera nada que ver con la apertura de Franco. Yo no soy consciente de que esta pseudoliberalización tuviera influencia en nosotros. Por ejemplo, yo estoy convencido de que el catálogo de The Family of Man hubiese llegado exactamente igual. A mí me parece que Oriol trajo dos o tres catálogos de la exposición desde París, porque tenía mucha relación con París e iba mucho a París. No creo que si no hubiera habido esa pseudoliberalización Oriol hubiera dejado de traerlo. Además no era un libro subversivo en absoluto".

(0. Maspons, Barcelona, 20 de octubre de 1999) - “Yo, en plena Dictadura, me iba a un quiosco de Las Ramblas y compraba un periódico que se llamaba Telexpres, fíjate que ya ni existe, y le decía: -Lo quiero «relleno»-, y me metían el Playboy dentro. ¡En Las Ramblas podías comprar el Playboy! Un poco caro, pero lo tenías. Y luego nosotros nos íbamos continuamente a Perpiñán a ver cine de la Nouvelle Vague, a ver cine francés de éste. Había otros que se iban a ver cine porno, yo no. Y luego íbamos a librerías y comprábamos lo que nos daba la gana, y traíamos cosas para los amigos. Yo al menos compré tres o cuatro veces la Historia de España de un autor francés muy bueno, que deshacía un poco la historia oficial... Quiero decir que no estaba tan cerrado".

63 Véase, al respecto, nuestro trabajo de investigación Influencias foráneas en la fotografia española de los años cincuenta. Ramón Masats como paradigma leído en 2003 en el Departamento de Comunicación Audiovisual, Documentación e Historia del Arte de la Facultad de Bellas Artes de la Universidad Politécnica de Valencia. 


\begin{abstract}
“Espiábamos los Vogue americanos atrasados de nuestras amigas más «pijas» y descubríamos a Richard Avedon e Irving Penn. Por el Jardin des Modes traído por alguna parienta enteradilla que había viajado a Francia nos enterábamos del trabajo de Frank Horvat y Harry Meerson. Cuando la censura franquista dejaba distribuir en España Paris Match, disfrutábamos de los reportajes de Walter Carone y Toni Saulnier... Los más recalcitrantes defensores de la «fotografía artística» de la Agrupación llegaron a calificar de marica a Oriol porque siempre iba con ejemplares de Vogue y Marie Claire bajo el brazo"64.
\end{abstract}

De esta manera -aunque con restricciones- se produjo un mayor fluido de información que, lógicamente, repercutió en la vida cultural y artística. Ésta halló ciertos resquicios para tratar de homologarse al resto de los países de Europa occidental. En este sentido, es significativo el talante decididamente cosmopolita que adoptan casi todos los movimientos vanguardistas españoles de esta década, fueran pictóricos, arquitectónicos o fotográficos, desde la Escuela de Altamira o El Paso, hasta el grupo AFAL. Ciertamente, ninguno de estos movimientos alcanzó una adecuada proyección social, inconcebible en tiempos de una férrea censura ideológica, pero, al menos, la posibilidad de salir al extranjero facultaba la información. Como ya se ha señalado, el grupo artístico Dau al Set desempeñó un papel pionero en este lento proceso cultural. Uno de los participantes directos de aquella aventura, el pintor Antoni Tàpies -que llegaría a convertirse en figura clave del informalismo europeo- nos ha dejado un relato del ambiente intelectual y artístico que se respiraba en la Barcelona de fines de los cuarenta en vísperas de la fundación de Dau al Set. En su Memòria personal, Tàpies traza un valioso panorama de las circunstancias históricas en las que un joven pintor con inquietudes trata de labrarse una formación intelectual en medio de una cultura oficial chabacana y de una información censurada. Gracias al minucioso inventario de recuerdos podemos asistir al descubrimiento de las grandes figuras de la vanguardia histórica, como Picasso y Miró; los libros hallados y, sobre todo, el contacto con algunas figuras singulares, como Joan Brossa, J. V. Foix y Joan Prats... En el terreno estrictamente pictórico, Tàpies nos relata asimismo su fascinación ante las obras de Klee, Miró, Schwitters, Marcel Duchamp, etc.:

\footnotetext{
“Tot això fou com un altre doll de noves idees que es posaven en marxa dintre meu, bé que amb molt d'endarreriment degut a tots els anys de tancament del nostre país. Si haguéssim viscut en una situació normal, potser les hauria assimilades abans i amb resultats més positius.

Tant de patrioterisme $\mathrm{i}$ fals orgull que pretenia que el franquisme ens havia fet progressar tant $i$ que fins havia donat artistes que triomfaven pel món, oblidava que res no s'hauria pogut aconseguir sense l'entroncament amb les generacions republicanes d'abans de la guerra i la influencia que ens arribava de l'estranger"65.
}

Esta conclusión de Tàpies sintetiza las dos preocupaciones esenciales de los jóvenes artistas que entonces buscaban intuitivamente una salida del cerco impuesto: por un lado, la recuperación de la memoria histórica, cercenada por la guerra y la represión; por otro, el ansia cosmopolita más acentuada. Desgraciadamente, en el plano fotográfico que nos ocupa, no fue posible la recuperación histórica de fotógrafos de la anteguerra, pero sí se mantuvo el cariz aperturista, y, por ello, aunque Luis Navarro fuera el pionero en exigir la renovación fotográfica y Català-Roca aportara su actitud como figura referencial en España, sólo fueron aquellos fotógrafos que salieron al extranjero los que podrá llenar realmente de contenidos ese vacío de la fotografía española de los años cincuenta. De entre todos ellos Oriol Maspons será uno de los más influyentes. 


\subsubsection{Oriol Maspons}

Oriol Maspons Casades (Barcelona 1928) fue, sin duda, el mayor crítico de la fotografía española de su época. Maspons se convertirá en la figura determinante en la renovación de sus coetáneos gracias a sus viajes a París. En 1955 se trasladó a esta ciudad donde residió dos años. Trabajaba en una compañía de seguros, pero frecuentaba los ambientes fotográficos de la capital. Sus entrevistas con Brassaï, Cartier-Bresson, Robert Doisneau y Guy Bourdin lo pusieron en contacto con la más alta fotografía francesa y, por tanto, mundial:

“Oriol Maspons marchó a París para un stage en la sede francesa de la empresa aseguradora donde trabajaba, y rápidamente se conectó con el mundo fotográfico de la capital francesa, muy especialmente con el dinámico grupo Club Photographique Les 30×40. Aprovechando que yo tenía un tío materno viviendo allá, le visité en algunas ocasiones, y pude comprobar la familiaridad de su trato con el citado grupo, a través del que se había conocido a Doisneau, Cartier- Bresson y Brassaï, de quienes yo no tenía ninguna noticia previa, y cuyo trabajo me impresionó enormemente" ${ }^{\prime 66}$.

- ¿Puede decirse que hiciera de puente entre Francia y España?

(0. Maspons, Barcelona, 20 de octubre de 1999) -“Sí, claro, esto sí. Yo al llegar a Francia me di cuenta de que se podía ser fotógrafo sin ser un desgraciado. Porque en España, en aquel momento, sólo había un fotógrafo, que era Francesc Català-Roca, en su contexto. Y luego había otro, que era Ramón Valles Compte, que era, digamos, un poco de moda para señoras bien, pero era muy bueno porque hacía dye-transfer en color y sólo trabajaba con material americano. Valles Compte era el puente con Estados Unidos. Y luego Català-Roca, en lo asequible, en lo que nos gustaba a nosotros. Y no había más. También traía revistas. Había una revista francesa excelente, que todavía existe, que se llamaba Photo, y luego veíamos el Paris Match y la americana Life".

El recuerdo de Maspons sobre su periodo parisino está trufado de nombres que constituirán los pilares de las influencias que estudiaremos a continuación.

“Treballava per a la companyia d'assegurances Le Continent, que era prop de la borsa. No sabia el francès i el vaig aprendre allà a empentes i rodolons. Aviat em vaig fer amic de Roger Doloy, del Club $30 \times 40, i$ allò va ser un corrent d'aire fresc (...)

Al Club 30x40 vaig trobar una cultura fotográfica molt desenvolupada en relació amb el que coneixia a Espanya. El club tenia prestigi entre els fotògrafs. Per allà passaven Cartier-Bresson, André Thevenet, Masclet, que era com un Papa... Tenien un nivell molt alt. Per a mi, el reportage era la quintaessència de la fotografia, tot i que també em podien interessar altres treballs de tipus més artístic com, de vegades, els de Doisneau o Brassaï.

Aquests fotògrafs que vaig conèixer a París van ser les meves influències decisives: Daniel Masclet, Robert Doisneau, Henri Cartier-Bresson... També m'agradava molt Richard Avedon. La meva admiració anava cap a la fotografia útil, l'agència Magnum, la moda... Aleshores la fotografia artística no tenia cap tradició. Dels americans m'agradava molt William Klein, que vaig anar a veure amb Miserachs a País, uns anys després. Ens va rebre d'una manera molt simpàtica. En tinc fotografies per aquí..."67.

Sus entrevistas con los fotógrafos extranjeros desde París le permiten introducir conceptos nuevos y renovados que por su importancia merecen un análisis muy detallado. Parece que las mismas - publicadas puntualmente en Arte Fotográfico- actúan como un catéter que gota a gota,

66 Miserachs, Xavier, Criterio fotográfico..., op. cit., págs. 183-184.

67 Balsells, David, "Memòries i amnèsies. Extractes d'una conversa amb Oriol Maspons", en Maspons, Oriol; Balsells, David y Permanyer, Lluís, op. cit., págs. 9-10. 
permite reflotar a ese enfermo terminal que era la fotografía española de los años cincuenta. Las entrevistas -realizadas entre 1955 y 1958- recogen las biografías y obras de sus "maestros", pero no son textos meramente enciclopédicos. Maspons aprovecha la oportunidad para criticar la situación española haciendo gala de su cáustica mofa. También interviene y comenta... destilando un tipo de estética fotográfica nueva, que vibraba en sintonía con las inquietudes de los jóvenes fotógrafos de la época. El concepto de "vibración en sintonía" remarca cómo, en más de una ocasión, se llegó intuitivamente a las mismas conclusiones desde diversos ámbitos que no estaban previamente en contacto, mediante un proceso de convergencia cultural o de intertextualidad tácita. Ya vimos cómo intervenían factores generacionales en el cambio de mentalidad de parte de la sociedad española.

La labor de Maspons fue ingente y no se ciñó en conectar a la fotografía española con la francesa. El inquieto Maspons asumió, asimismo, unas responsabilidades que no se ceñían, únicamente, a las propias de un simple fotógrafo. Conocido tanto por los renovadores como por los tradicionalistas, tuvo un papel indiscutible como agitador y provocador. Desde esta perspectiva, lo que hizo de Maspons un hito fueron tanto sus conocimientos como su peculiar modo de expresarlos, lo que le llevó, incluso, a ser expulsado de la Agrupación Fotográfica de Cataluña tras varios artículos en donde atacaba verbalmente a los compañeros de agrupación más retrógados.

Por otro lado, Maspons fue el primero de los renovadores en reconocer la figura de Català-Roca:

\begin{abstract}
“Maspons, que trabajaba en una compañía de seguros, había coincidido unas vacaciones en Ibiza con Català-Roca, y había regresado con gran admiración por el fotógrafo y un montón de magníficas fotografías. Yo había empezado la carrera de medicina. Cuando nuestros bolsillos lo permitían, íbamos a cenar a la mesa colectiva del restaurante Estevet, donde solía hacerlo Català-Roca. Entre la locuacidad, el sentido del humor, y el rico anecdotario de Català -todo ello conservado hasta hoy- y la mordacidad y el espíritu crítico de Maspons -hoy corregido y aumentado- estas cenas eran para mí una maravilla"68.
\end{abstract}

El caso de la reivindicación de Català-Roca parece sencillo, ya que Català-Roca había ganado el premio que la ciudad de Barcelona concedía en 1950, había publicado su libro La sagrada Familia en 1952 y había expuesto en la sala Caralt de Barcelona en 1953. Sin embargo, la Historia de la Fotografía Española siempre agradecerá a Maspons que descubriera el talento de Joan Colom. Talento que, dado el carácter reservado de Colom, hubiera pasado completamente desapercibido. Maspons, por el contrario, era una caja de resonancia, un provocador nato, un espíritu inquieto, cuya incesante hiperactividad le llevó a atribuirse competencias más propias de un editor, 0 incluso de un "investigador privado", que de un simple fotógrafo.

Su papel en la editorial Lumen y en la colección Palabra e Imagen fue muy significativo (justificado, quizá, por la gran amistad entre Maspons y Esther y Óscar Tusquets), pues no sólo descubrió a Colom, sino que también presentó a Colita a la editorial, realizó varios de los libros de la colección -como Toreo de Salón (1963), La caza de la perdiz roja (1963) y Poeta en Nueva York (1976) - y revisó las pruebas de imprenta del libro de Ramón Masats, Neutral Corner (1962).

\footnotetext{
“Oriol (...) andaba loco por las chicas guapas (seguro que él las denominaría de otro modo) y las retrataba mejor que nadie en nuestro país. Hizo tres libros para Palabra e Imagen -el de Cela, el de Delibes y Poeta en Nueva York, de Lorca- y las fotos de uno de los libros más hermosos editados en Lumen, Arquitectura gótica catalana, con texto de Alexandre Cirici. A través de Oriol conocimos a Joan Colom (...) y a Colita"69.
}

68 Miserachs, Xavier, Criterio fotográfico..., op. cit., págs. 183-184.

69 Tusquets Blanca, Esther, Confesiones de una editora poco mentirosa, Barcelona, RqueR, 2005, pág. 52. 
La figura de Maspons será muy rica, compleja y multiforme: ejerció de periodista, crítico, ensayista, fotógrafo profesional... y, además, fue comisario de la exposición que en 1956 se realizó en la Biblioteca Española de París (presentada por la Agrupación Fotográfica de Cataluña a través del club Les 30x40 de París). A su vez, recomendó a Masats a la dirección de Gaceta Ilustrada de Madrid -después de un acuerdo con Masats práctico y comercial-, así como también lo presentó a Carlos Pérez Siquier de AFAL.

\subsubsection{Gonzalo Juanes}

Otro autor que de alguna manera influyó en Masats, aunque de un modo completamente distinto al de Maspons, y que verbalizó alguno de los conceptos que manejó Masats y toda su generación, fue Gonzalo Juanes.

Gonzalo Juanes Cifuentes (Gijón, 1923) era ingeniero industrial y gracias a un destino de la empresa para la que trabajaba (Sociedad Española de 0xígeno) también pudo visitar el extranjero y cumplir con la vocación cosmopolita y el cariz aperturista de las principales figuras teóricas de su generación. De hecho, coincidió en París durante varios meses con Oriol Maspons. Ya se conocían por la correspondencia que habían cruzado cuando Maspons le solicitó fotografías para la exposición en la Bibliothèque Espagnole de París en 1956. No tardaron en trabar una gran amistad y Gonzalo Juanes llegó a compartir el apartamento de Maspons durante su estancia parisina. También aprovechó los contactos de Maspons para conocer de primera mano los fotógrafos más importantes de Francia a través del club Les 30×40.

Gonzalo Juanes conoció personalmente a Ramón Masats en octubre de 1957 -aprovechando una estancia de veinte días en Barcelona por motivos laborales-. Prácticamente fue la única ocasión en la que se vieron las caras los dos fotógrafos. Fueron presentados por Maspons, que nuevamente lo había acogido en su casa. De esa primera cita Gonzalo Juanes recuerda cierta furgoneta de reparto con un olor a pescado legendario. Cuando recientemente hablé con Gonzalo Juanes por teléfono al respecto de su relación con Masats, éste me comentó que sólo se habían visto unos pocos días en su vida, hacía muchos años, y que lo recordaba muy joven y con el pelo negro. Su relación fue prácticamente epistolar (no conserva las cartas) o a través de los textos que publicó en la revista AFAL. Igual que la relación que mantuvo con Maspons, Gabriel Cualladó - Carlos Pérez Siquier. Este aislamiento se debió, en el fondo, a que Gonzalo Juanes nunca fue fotógrafo profesional. Aunque Gonzalo Juanes se trasladó a Madrid en 1952 buscando un ambiente cultural propicio para sus ambiciones creativas, finalmente ejerció de ingeniero industrial. A partir de 1957 su empresa lo destinó a Gijón donde se encontró fotográficamente exiliado.

Las personalidades de Masats y Gonzalo Juanes son completamente diferentes. Masats es extrovertido, decidido, optimista, intrépido. Un hombre de acción, directo y poco dado a las reflexiones teóricas y a los arrepentimientos. Gonzalo Juanes es un intelectual puro, tremendamente severo en su autocrítica, inseguro y categórico al mismo tiempo, depresivo, austero y lleno de sutilezas. Tan discreto, que su obra - grave y misteriosa- no ha sido prácticamente mostrada en su conjunto hasta la actualidad ${ }^{70}$.

Sin embargo, y pese a las diferencias de personalidad, e incluso a las propias contradicciones estilísticas con las que nos encontraremos, Gonzalo Juanes y Ramón Masats se profieren una admiración mutua. A Gonzalo Juanes le fascina la aparente facilidad con la que resuelve Masats sus fotografías. Lo considera el mejor reportero de su generación. El más próximo a su ideal de fotógrafo -aunque, paradójicamente, sea implacable en su crítica a su modo de plantearse sus propios trabajos-, y Masats, por su parte, recurre a Gonzalo Juanes -y por ende a todos sus cono-

70 Juanes, Gonzalo y Terré Alonso, Laura, Gonzalo Juanes... ese declinar de la luz..., Barcelona, Lunwerg/Ayuntamiento de Gijón, 2003. 
cimientos teóricos- para que realice una crítica de su libro más personal, Los Sanfermines.

Gonzalo Juanes desarrolló una gran labor teórica, a pesar de las manifiestas reticencias que él mismo profesa a hablar de fotografía y no practicarla. Sus teorías fotográficas quedan patentes desde su primer texto publicado en AFAL en enero-febrero de $1957^{71}$, así como desde el publicado en Arte Fotográfico en el mismo año ${ }^{72}$. Pero sobre todo, su ideario quedará recogido en los artículos críticos referidos a los libros fotográficos de William Klein, New York ${ }^{73}$, e Irvin Penn, Moments Preserved ${ }^{74}$, publicados en AFAL, y ello sin olvidar el último artículo dedicado al libro de Oriol Maspons La caza de la perdiz roja ${ }^{75}$.

La labor crítica y teórica de Gonzalo Juanes se detuvo justo cuando AFAL acabó su trascendental trayectoria y dejó de publicarse. De hecho, el artículo sobre el libro de Maspons, aparecido finalmente en la revista Imagen y Sonido, estaba concebido para publicarse en AFAL, junto con otro artículo que quedó inédito debido al cierre de la revista: una crítica sobre el Neutral Corner de Masats que nunca vio la luz. Fue el laborioso Maspons quién propuso a Pérez Siquier la conveniencia de contratar a Gonzalo Juanes para que realizara estas críticas sobre los libros de Lumen que empezaban a publicarse. Pero éste no fue el único proyecto inconcluso. Laura Terré recoge cómo a Gonzalo Juanes le hacía mucha ilusión realizar una crítica del libro de Masats Los Sanfermines:

“Del que cree que es el mejor libro editado en España en los últimos veinticinco años"76.

De hecho, como ya hemos comentado, es el propio Masats el que envía un ejemplar del libro a Gonzalo Juanes para que realice su crítica. Gonzalo Juanes tuvo la amabilidad de fotocopiarnos la dedicatoria que Masats le escribió en su ejemplar.

“Para Gonzalo Juanes con la amistad de Ramón. ¡Espero una justa crítica en AFAL, un abrazo!”.

La crítica nunca se publicó, ni siquiera ha quedado constancia de que se hubiera llegado a realizarse en su momento. Simplemente no existe. Dado que Gonzalo Juanes continua en activo, y que este trabajo inacabado aparece en todos los textos que estudian el periodo y/o su obra, nos atrevimos a proponerle que nos realizara la crítica para nuestra tesis. A lo que Gonzalo Juanes contestó:

“Te confirmo lo adelantado por teléfono. No soy capaz de satisfacer tu demanda a pesar de varios intentos infructuosos. No logro conectar mi mente de hoy con la que tenía hace unos cuarenta años, época en la que hice para AFAL una crítica no publicada del libro de Ramón Masats Los Sanfermines. Imposible ahora «recrear» aquello. Criticar la obra en visión de hoy no tiene sentido: la Fotografía y nosotros mismos hemos evolucionado mucho. Sí puedo decir que Los Sanfermines conserva los valores fotográficos de entonces"77.

Por tanto, deberán ser los textos de la época los que nos guíen a través de los conceptos que desarrolló Gonzalo Juanes y que compartió, en mayor o menor medida, Ramón Masats.

71 Juanes, Gonzalo, “Gonzalo Juanes Cifuentes", en AFAL, nº 7, enero-febrero 1957, sin paginar.

72 Juanes, Gonzalo, "Cómo hago mis fotografías", en Arte Fotográfico, nº 66, año VI, junio 1957, págs. 475-512.

73 Juanes, Gonzalo, "Anotaciones sobre el New York", en AFAL, n² 24, mayo-junio 1960, sin paginar.

74 Juanes, Gonzalo, "Moments Preserved (Comentarios a un libro de Irving Penn)", en AFAL, n 35, marzo-abril 1962,

sin paginar.

75 Juanes, Gonzalo, "La caza de la perdiz roja, de Oriol Maspons", en Imagen y Sonido, n 1, Junio 1963.

76 Juanes, Gonzalo y Terré Alonso, Laura, op. cit., pág. 147.

77 Gonzalo Juanes, correspondencia con el autor, 27 de diciembre de 2004. 


\subsubsection{Xavier Miserachs}

Otro gran fotógrafo que ha teorizado sobre la generación de Masats fue Xavier Miserachs (Barcelona 1937-1998). Sin embargo, el caso de Miserachs es completamente distinto al de los dos compañeros anteriores, ya que Miserachs casi no tiene textos originales publicados en los años cincuenta o sesenta.

Miserachs y Masats compartieron amistades (Maspons, Casademont, Terré, y todo el grupo AFAL), agrupaciones fotográficas (la AFC y AFAL), exposiciones (las dos TMM en 1957 y 1959 respectivamente, y todas las originadas en el entorno AFAL), premios (el Luis Navarro de Vanguardia: Miserachs ganó el primer año, en 1954, y Masats en 1957), encargos (La oficina de Turismo Francesa encarga un reportaje sobre París a 10 fotógrafos españoles en 1962, entre los que se cuentan Miserachs y Masats), editoriales (editorial Lumen donde Miserachs publicó Los Cachorros) y hasta revistas (Gaceta Ilustrada donde ambos trabajaron como fotógrafos durante varios años). Por todo ello se puede decir que las vidas fotográficas de Miserachs y Masats fueron relativamente parejas. Los dos se convirtieron en fotógrafos profesionales que publicaron en libros y revistas en el mismo periodo histórico, compartiendo los mismos conceptos fotográficos.

Sin embargo, la importancia de Miserachs estriba en que ha sido el único de su generación que ha intentado sistematizar todos los conceptos que surgieron en aquel momento, recopilándolos en una serie de libros publicados entre 1995 y 1998, con una intención eminentemente pedagógica ${ }^{78}$. Estos libros nos son de una gran utilidad, puesto que Miserachs ha sido el único de aquella generación que ha continuado reflexionando en voz alta, trasladando aquellos conceptos - generados en los años cincuenta y sesenta-, para interpretarlos desde la actualidad. Evidentemente su testimonio hay que analizarlo teniendo en cuenta de estas circunstancias y hemos de ser conscientes de las ventajas e inconvenientes que conlleva el paso del tiempo. No son los textos originales que pudieran haber influido en Masats, no están escritos en el mismo contexto ni en las mismas circunstancias. Sin embargo, están escritos por un testigo que vivió en primera persona aquellos tiempos de cambio. Es la interpretación subjetiva de unos hechos y de unos años realizada por uno de sus protagonistas. Interpretación que coincide, en muchos casos, con las reflexiones que el propio Masats plasma en sus testimonios.

Después de conocer la gran actividad social y comunicativa de la generación de Masats (las reuniones semanales, las cartas, las visitas de los diferentes miembros, las cenas, las excursiones fotográficas, las exposiciones conjuntas...) sería muy pretencioso suponer que las influencias se Masats se ciñen exclusivamente a estos autores. Éstas, quizá, sean las cabezas más visibles. Por ello conviene no olvidar la biblioteca y la hemeroteca de Gabriel Cualladó, y los debates que pudieran generar las nuevas adquisiciones, que seguro pondría en común con sus amigos y compañeros de la Palangana en cualquiera de sus conversaciones de café.

\subsubsection{La aportación extranjera}

Sin duda, y como el propio Masats reconocía en el sucinto comentario que abría este apartado, uno de los autores más influyentes de su generación fue Henri Cartier-Bresson (1908-2004). Toda una constelación de fotógrafos aceptará sus tesis publicadas en el libro Images à la sauvette en 1952. Su título en la versión americana crearía escuela, The Decisive Moment (cada momento tiene un instante decisivo que lo resume y explica). Así pues, si el fotógrafo es capaz de captar ese instante, habrá conseguido condensar toda una historia en una sola imagen. En 1958, Oriol Maspons (quién si no) publica una extensa entrevista con Henri Cartier-Bresson en Arte Fotográfico -seis años después de la publicación de su primer libro-. En ella Maspons olvida, por una vez, su ácida ironía para declararse incondicional y absolutamente fascinado por la obra y la figura del "maestro". Ya, en esta entrevista, descubre toda su batería retórica, sus formas de trabajar, sus metas: 


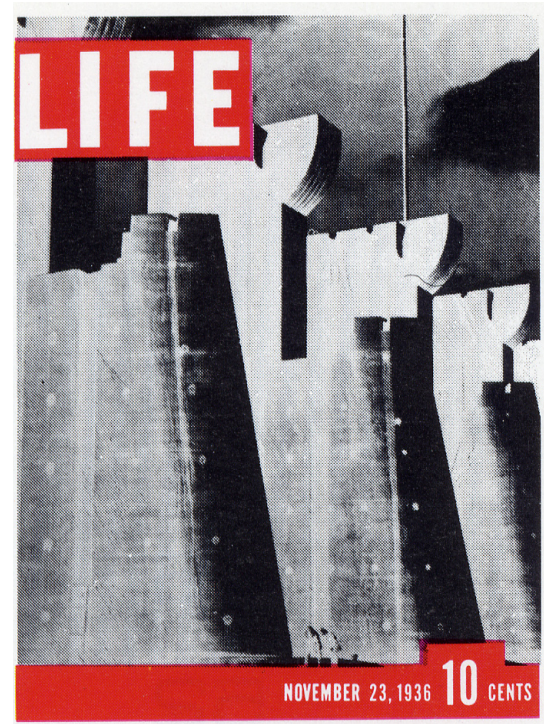

Life, $\mathrm{n}^{0} 1,1936$.

“La obra de Cartier-Bresson, a sus cincuenta años, es monumental. Desde 1930 ha seguido sin variación una línea de conducta que empezó en él y ha formado la escuela fotográfica, el «academicismo» si se quiere, más grande que ha existido. El «Cartierbressonismo» ha influido en la mayor parte de los reporteros profesionales de toda nuestra época "79.

Todos ellos reconocen la habilidad de Cartier-Bresson para hacerse "invisible", para captar la realidad retenida en una fracción de segundo. Sin embargo la contestación a los postulados de Cartier-Bresson no se hace esperar y en las antípodas estilísticas, William Klein nacido en Nueva York en 1928 y con una sólida preparación artística y sociológica, publica una serie de libros sobre ciudades: New York (1956), Rome (1958), Moscow (1964) y Tokyo (1964), donde el autor se cuestiona la necesidad de respetar las normas que había impuesto Cartier-Bresson y se dedica a transgredirlas de manera sistemática, en aras de una mayor fuerza expresiva y un mayor plasticidad. Aquella libertad creativa que reivindicaba a gritos toda la generación de Masats, aquella auténtica revolución formal exigida por Luis Navarro, culminó en 1956 con la obra de William Klein, New York. Ese libro supuso la constatación para la joven fotografía española de que lo nuevo y lo trasgresor no eran elucubraciones vacías, nacidas como reacción a la estética salonista, sino que realmente suponían una vía de encuentro con la vanguardia europea y mundial.

“Otra visita fue William Klein, joven, alto y fuerte, con cara de muy inteligente. Hace un poco de todo: al lado de su libro «New-York» y el todavía mejor «Roma», con fotografías movidas, desenfocadas y estupendas, hace fotos de moda para «Vogue» con una distinción y pulcritud inmejorables, diseña las portadas de la revista italiana «Domus», tiene su estudio lleno de grandes cuadros en los que no hay más que ensayos tipográficos, va a hacer cine y prepara un nuevo libro «Moscú». Es el tipo que más me impresionó. Hace de todo y todo lo hace fantástico, nuevo" ${ }^{100}$.

79 Maspons, Oriol, "Cómo hago mis fotografías por Henri Cartier-Bresson", en Arte Fotográfico, n ${ }^{81}$, año VII, septiembre 1958, pág. 769.

80 Miserachs, Xavier, "Oriol y yo hemos ido a París", en AFAL, n 30, mayo-junio, 1961, sin paginar. 


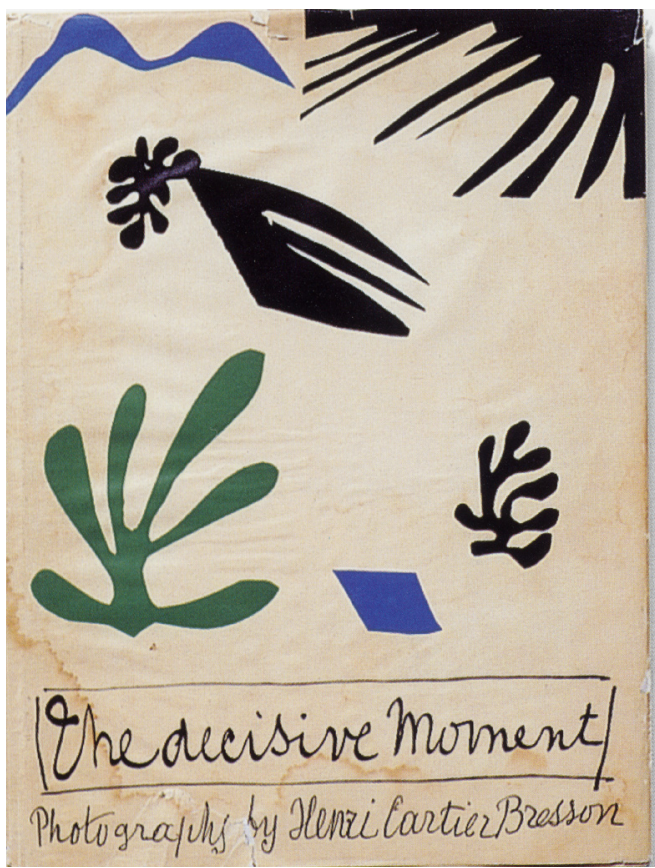

Henri Cartier-Bresson, The decisive moment, 1952.

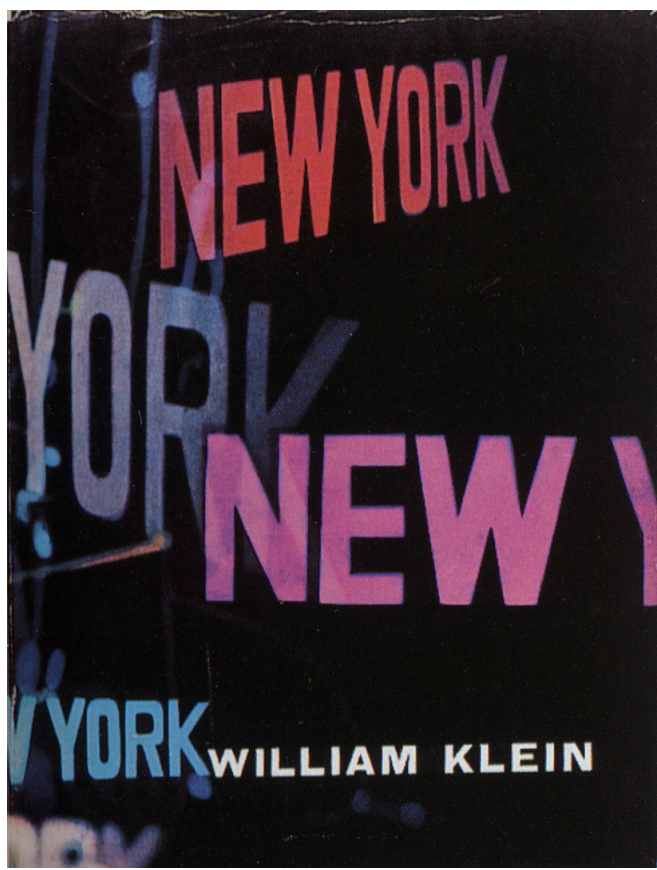

William Klein, New York, 1956.

La contestación a Cartier-Bresson no dependerá tan sólo de Klein. En 1952 Minor White crea y edita la revista Aperture. En 1958 Robert Frank publica en París Les Américains (necesitó un año más para poder publicarlo en Nueva York). Frank renunciaba explícitamente a la objetividad y negaba la teoría del instante decisivo de Cartier-Bresson. Para él la fotografía era un viaje solitario y los momentos que realmente debían mostrarse eran los que se sucedían entre los instantes decisivos bressonianos, los momentos triviales en apariencia pero cargados de significado bajo la óptica necesariamente subjetiva del fotógrafo. A Frank tampoco le interesa la belleza sino un severo realismo, por sórdido que pueda parecer; tampoco le preocupa ni la limpieza técnica ni la pureza formal, sino la espontaneidad absoluta. Las consecuencias, es decir, las imperfecciones o accidentes que podrían recordar las fotografías de los aficionados, son perfectamente aceptadas.

En una antología de la fotografía que hizo Masats en el curso de fotografía que organizó el Círculo de Bellas Artes de Madrid en marzo de 2000, Frank ocupaba un lugar destacado, aunque confiesa que no tiene una influencia directa en su obra. Ello se debe a que ni Masats ni otros autores de su generación tuvieron acceso a su libro, Les américains, hasta años más tarde.

(R. Masats, Madrid, 20 de marzo de 2000) -“Esta diapositiva es de Robert Frank, que hizo un libro que se llama Les Américains que le dio una sensibilidad... no solamente en las personas, también en los detalles, las ventanas...".

(Koldo Chamorro, Pamplona, 21 de marzo de 2003) -“`Y además es muy coherente, porque cuando se habla de la generación Beat -que es contemporánea de él-, y que yo creo que no es una generación que aparezca espontáneamente sin ninguna explicación, sino que hay una serie de motivos en el ámbito cultural, que son los que desencadenan o los que propician que surja la generación Beat. Claro, la generación Beat está desde Allen Ginsberg hasta Robert Frank, porque Robert Frank tuvo muchísima relación personal con Jack Kerouac. Y Ramón está un poco 


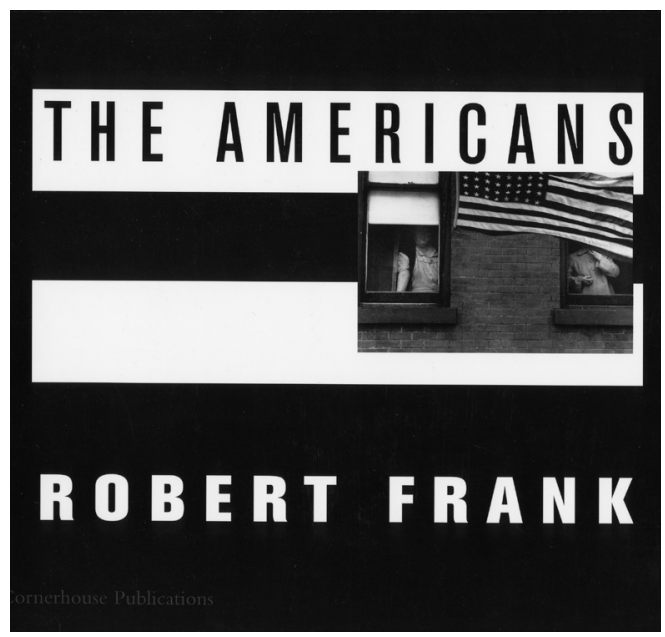

Robert Frank, The Americans. Portada de la edición de 1993.

en esta onda de intentar redefinir el mundo: quizá porque ese mundo está terminando de hacerse... Desde el año cincuenta hasta el sesenta y ocho, en que el hombre llega a la luna, hay diecinueve años y ocurren un montón de acontecimientos. Además, casualmente, el movimiento Beat es el que señala un antes y un después... cosa que, desde el punto de vista histórico, sólo se le ha dado un valor anecdótico, más casual que la trascendencia que realmente tiene. Yo, con esto, no quiero decir que sea realmente lo que marca con una claridad absoluta el antes y el después, pero sí que es bastante sintomático que hay un grupo de personas que empiezan a plantearse de verdad el mundo de otra forma, y yo creo que a partir de aquí aparecen un montón de nuevos conceptos de lo que es entender el mundo. A partir de ese momento aparece la palabra ecología, por ejemplo, o estando en la guerra fría aparece el tema de la globalización, o la estrategia generalizada de los parques temáticos, etcétera. La generación Beat son los que rompen con lo que se suponía que era la ortodoxia y no casualmente en el año cincuenta y cinco aparece The Family of Man, que de algún modo establece un antes y un después, pero más metido en el mundo de la fotografía, desde una visión tranquila de lo que se supone que tiene que ser la fotografía políticamente correcta... En ese sentido, yo creo que el trabajo de Ramón es sumamente interesante, y con el tiempo se le va recuperar y se va entender cúal es la importancia de su obra. Pero bueno, esta es una cuestión que... hay que estar preparados para poderlo entender, y quitarse muchos prejuicios y muchos juicios que han estado enturbiando qué es lo que hay que reflexionar y cómo".

- ¿Puede ser que tu punto de vista estuviera filtrado por la generación Beat?

(R. Masats, Madrid, 27 de diciembre de 2006) -“No, porque los Beat fueron posteriores a 1957. Me da la sensación que Jack Kerouac y todos estos tardaron en llegar aquí. Yo me acuerdo que me leí a Kerouac porque me lo recomendó Carlos Saura a principio de los sesenta. Pero no creo que me influyera en nada. Yo creo que influyó en Oriol y Miserachs, en las fiestas de Cadaqués, y con las niñas monas. Es un tipo de fotografía más frívolo -aunque los Beat no eran nada frívolos-. Era muy importante el viaje como una forma de vivir, mucho más libertino y agradable, con mucha sensualidad, aunque luego se suicidaron todos. Eran gente auténtica que luego se vulgarizó bastante con los hippies, las florecitas y el ir en pelotas por el campo. Pero los de Barcelona estaban más cerca de este ambiente. Aquí, en Madrid, era todo más carpetovetónico. El hirsuto de barba, con boina... el paleto, digamos". 
-La gauche divine sí estaba más en esa línea.

(R. Masats, Madrid, 27 de diciembre de 2006) -“"Era gente muy interesante, mucho más que los de la movida madrileña, que sólo ha producido a un director de cine (Almodóvar) y a un pintor. En Cataluña habían arquitectos, escritores, pintores, fotógrafos, eran más auténticos, a parte de su aparente frivolidad".

Sobre la posible influencia o no de esa generación Beat, nos llama la atención un comentario de Jesús García de Dueñas al respecto de su película Topical Spanish (1970).

(Jesús García de Dueñas, Barcelona, 17 de noviembre de 2000) -“La película es notable, pero justamente es notable por lo que tiene de característico Ramón Masats como creador cinematográfico, y es su cualidad de creador fronterizo. Es evidente que Ramón Masats, cuyas raíces están en Barcelona y en el Mediterráneo, se integró perfectamente en el mundo mesetario y garbancero que representábamos los que en aquel momento hacíamos el cine español de los años setenta. Y esa integración fue absolutamente fácil, cordial y extraordinaria".

De forma paralela a los Beat, en 1951 Otto Steinert fundaba el movimiento de la "Subjektive Fotografie" en torno a tres exposiciones itinerantes presentadas en 1951, 1954 y 1958. Con independencia de los correspondientes catálogos, en 1952 y 1954 se publicarán dos libros monográficos con textos programáticos fundamentales donde se reivindicará la individualidad del autor y su compromiso con la realidad. Según Steinert, el fotógrafo siempre interpreta la vida de una manera parcial, propia, "subjetiva". Tesis contraria a los postulados objetivistas de CartierBresson. Aunque el propio Masats reconoce que no influyó en su manera de fotografiar, gracias a Steinert, consiguieron exponer en Bruselas, en el Palacio de Bellas Artes del Sarre.

(R. Masats, Madrid, 20 de marzo de 2000) -“Éstas son unas fotos que están dentro de la teoría de un profesor, que la explicaba muy bien, que yo la entiendo vagamente, pero que no os puedo explicar, de la fotografía subjetiva de Otto Steinert. (¡Lo que perdéis por mi ignorancia lo ganáis por mi sinceridad!) Estuvo hasta bastante avanzado, porque recuerdo que Ricard Terré y yo expusimos en una exposición de Otto Steinert de fotografía subjetiva. Fíjate lo alejado que está mi fotografía de reportaje de estas cosas".

En el caso de Masats, William Eugene Smith (1918-1978) nacido en Wichita, Kansas, no fue una influencia directa ${ }^{81}$. No asumió ni sus planteamientos estéticos ni sus intenciones testimoniales. Sin embargo, para entender la relación entre la generación de Masats y la Dictadura (basada en el recelo y la susceptibilidad y materializada en la censura, la manipulación de los salones de fotografía, en el aprovechamiento del pictorialismo y la idealización poética de la realidad) resulta ineludible tener en cuenta la figura de este fotógrafo americano. Su reportaje sobre el pueblo de Deleitosa (publicado en la revista Life en 1951 y al que dedicamos el próximo epígrafe) causó un gran impacto a nivel internacional y motivó las protestas oficiales del gobierno español al gobierno estadounidense.

Eugene Smith podría considerarse como el prototipo del fotógrafo de reportaje comprometido con su tiempo y con sus congéneres. La distorsión en la información aparecida en la prensa sobre el suicidio de su padre, dejó a Smith con dudas sobre el papel y la influencia de los medios de comunicación americanos. Convencido de la obligación de la fotografía para acabar con las desgracias de la humanidad, utilizó todas las armas a su disposición para proclamar sus denuncias. Recorrió todos los soportes, del Newsweek al New York Times, y desde 1946 a 1955 trabajó para Life, con reportajes como "Country Doctor" (1948) o el mencionado "Spanish Village" (1951) que tantos disgustos dio a la administración franquista. También trabajó con la agencia Black Stary y con la mismísima Magnum. Los años sesenta son los de su militancia más activa,

81 Aunque Gabriel Cualladó sí que reconocerá explícitamente su admiración y el influjo que Eugene Smith supondría para su obra. 
con la autofinanciación de proyectos como el de Pittsburg o el de Minamata, y con la edición de revistas de comunicación, actividad que unirá a la de la impartición de conferencias.

Finalmente, para completar este panorama de influjos cabe destacar la celebración en 1955 de la exposición "The Family of Man", concebida y comisariada por Edward Steichen en el MOMA de Nueva York. En España fue recibida por la joven fotografía como la "Biblia" o como "libro de cabecera", términos utilizados por todos los autores de la generación de Masats sin excepción alguna, apreciación que confirma todas sus posturas y reacciones contra lo caduco. La exposición nunca llegó a España, pero el catálogo -que por cierto, se sigue editando hoy en día-, constituyó la mayor referencia para muchos fotógrafos de la época. Fue recibido por Masats y toda su generación como la constatación de una serie de ideas acerca de la fotografía que ellos estaban experimentando de forma casi clandestina en España.

-Ramón Masats me comentó que tu trajiste el libro de The Family of Man.

(0. Maspons, Barcelona, 20 de octubre de 1999) -“Sí, bueno claro, como yo iba y venía de París, pues traje el libro The Family of Man. Este libro influyó mucho en Xavier Miserachs, sí, sí, nos marcó mucho a todos. Nos dijo a Ramón y a mí... todos pensamos: «¡No ves cómo tenemos la razón, no ves cómo es esto lo que nosotros queremos, no ves cómo es esto lo que vale!». Fue nuestra Biblia, es como si dijera: «Mira qué caso nos hacen que nos han hecho este libro». Aquel libro iba con todas nuestras aspiraciones. En un momento dado fue el «libro de cabecera»".

A su vez, no hay que olvidar la entrada de las revistas extranjeras como Life y Look que tuvieron una divulgación masiva hasta su desaparición con la llegada de la televisión. El modelo de las revistas ilustradas supuso la evolución de los arcaicos conceptos de la fotografía documental y del fotoperiodismo, para imponer el revolucionario concepto del reportaje moderno. En 1957 Gabriel Cualladó nos describe, en un texto lleno de sinceridad, los primeros momentos de caos y desconcierto que supusieron la entrada de las revistas extranjeras en el panorama nacional. Era tal el contraste conceptual con el exterior que en un primer momento cuestionó, decepcionado, la nueva fotografía que se abría ante sus ojos.

\footnotetext{
“Mi «educación» fotográfica se inició contemplando las obras premiadas en nuestros Salones Nacionales y que reproducía y sigue reproduciendo nuestra revista Arte Fotográfico. Conocido lo que aquí se hacía, tuve curiosidad por ver cómo sentían la fotografía en otros países, y adquirí el anuario U.S. Camera. La primera vez que ojeé sus páginas me sentí completamente decepcionado. No comprendía aquella clase de fotografía. A pesar de ello no la rechacé; comprendía que los editores que habían hecho aquella selección eran personas muy competentes y, por tanto, si no todas las obras eran buenas, si debía haber bastantes de una calidad notable. Poco tiempo después tuve ocasión de adquirir el Photography Annual, el Year Book y el anuario alemán. Después de examinar, estudiar todos estos libros detenidamente comprendí que la fotografía española se había detenido no sé en qué época y que se había negado a acompañar a la humanidad en su camino a través de los años.

Después he tenido ocasión de comprobar que una serie de tópicos y fórmulas rígidas eran, y en muchos casos siguen siendo, por desgracia, los principios básicos en que se apoyan cuantos se dedican a realizar fotografía artística. Yo he bebido en esta misma fuente; me he acostumbrado al principio a ese sabor; pero plenamente convencido de que llevaba una camino equivocado, un sendero que no me conducía a ninguna parte, me detuve, volví atrás, y actualmente trato de hallar el camino de la fotografía joven, expresiva, emotiva, humana, artificiosa, abstracta... no me importa qué clase de fotografía, sólo quiero y aspiro a que caiga de lleno en nuestros días, que diga lo que tenga que decir de una forma actualizada" 82 .
} 


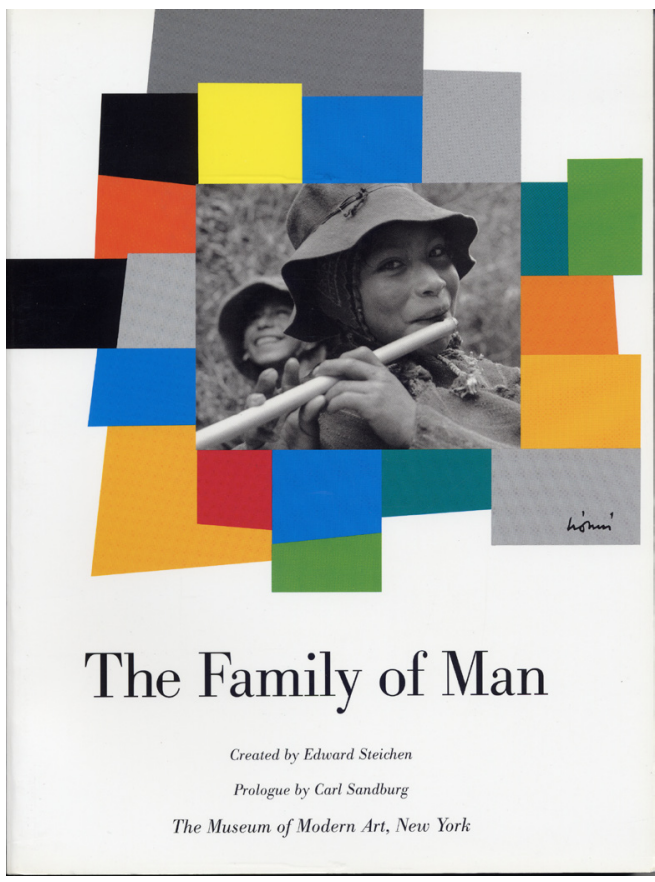

Edward Steichen, The Family of Man, 1955. Portada del catálogo.

De todas esta influencias y referencias, sólo dos fueron compartidas sin discusión por todo el colectivo de fotógrafos inmersos en el cambio fotográfico: The Family of Man y la obra y figura de Cartier-Bresson. Por un lado, The Family of Man suponía una visión personal del reportaje que todos ansiaban, incluso para su trabajo profesional. Y, por otro lado, Cartier-Bresson se presenta ya como un clásico, una figura incontestable, cuya obra no es discutida ni debatida. Está por encima del bien y del mal, algo inalcanzable, perteneciente a un universo creador superior. Por el contrario, Robert Frank o William Klein sí suscitaron interpretaciones varias, provocando reacciones encontradas entre los jóvenes fotógrafos. Por lo tanto, no se puede constatar que su influencia fuera unánime, ni generalizada.

“Otras obras de referencia fueron: los reportajes de carácter humanista de Eugene Smith (sólo para algunos fotógrafos, como Cualladó y Ontañón) (...) y las teorías y exposiciones de la fotografía subjetiva de 0tto Steinert. También la obra y el tratamiento editorial de los fotógrafos Robert Doisneau, Brassaï, Izis, Werner Bishop, Marc Riboud, etc., y la creación de la Agencia Magnum, como proyecto paradigmático. El trabajo de Robert Frank no llegó a todos los fotógrafos de AFAL en ese momento, fue de gusto más minoritario (...) También tuvieron su importancia las ediciones de anuarios fotográficos alemanes, japoneses y americanos, así como la participación en los concursos de fotografía más importantes en el momento. En el cambio de década, algunos fotógrafos de AFAL admiran el trabajo de sus colegas italianos de La Góndola y La Bussola, pero tampoco se trata de una referencia unánime.

La relación con el Club Photographique Les $30 \times 40$ más que una influencia formal o temática, fue un apoyo en todo lo que concierne a la gestión y a la difusión de la obra de AFAL en el extranjero"83. 
Por su parte, Ramón Masats siempre reconocerá, dentro de los matices y salvedades que después estudiaremos, cómo vibraba en sintonía con William Klein y cómo admiraba a CartierBresson y a Steichen y su The Family of Man. Entre otras cosas porque Robert Frank tardó mucho más tiempo en llegar a España. Su libro Les Américains, no llegó tan temprano como el New York de William Klein, tal y como ya hemos comentado. Debido a este hecho, analizaremos con detalle estos autores en las páginas siguientes, obviando aquellos otros que, aunque teniendo Masats conocimiento de su obra, no encontramos concomitancias ni referencias suficientes como para justificar una influencia directa en su obra.

Ahora bien... después de todo lo dicho, en relación con las influencias de Ramón Masats, no queremos olvidar la advertencia que nos hace Koldo Chamorro respecto a las posibles referencias 0 intertextualidades de los auténticos fotógrafos.

(Koldo Chamorro, Pamplona, 21 de marzo de 2003) -“Hay mucho ir chupando rueda, y bueno eso se ve, y cuando alguien viene y te dice: «Cuéntame algo de ti». Yo lógicamente, intento no hacerlo, pero les cuentas algo y siempre están intentando ponerte en referencia a alguien. Y yo no sé... Claro, yo entiendo que Ramón te diga: «Sí, bueno, Cartier me interesa mucho». ¿Pero es que a quién no le interesa Cartier? Pero que Cartier haya incidido de tal forma... que tu trabajo no tenga explicación nada más que con Cartier-Bresson... A mí me parece fuera de lugar cuando hablamos de fotógrafos".

En cualquier caso, lo que queda fuera de duda es que toda la generación de Masats asumió un talante completamente universalista, buscando fuera de nuestras fronteras modelos y ejemplos desconocidos en España.

\subsection{UN ANEXO SOBRE LA RELACIÓN ENTRE LA DICTADURA Y LA FOTOGRAFÍA JOVEN: EL CASO DE DELEITOSA Y EL COMPROMISO SOCIAL}

Como acabamos de reseñar la relación entre la Dictadura y los fotógrafos jóvenes, en el conjunto de los cuales se incluye Masats, se basa en un mutuo recelo y en una permanente suspicacia. A ello contribuirá el papel asumido por la censura, así como la constatación de un fenómeno como el protagonizado por Eugene Smith a raíz de su reportaje sobre el pueblo de Deleitosa. Según hemos señalado, Smith fue perfectamente consciente del inmenso poder comunicativo de las revistas ilustradas en la opinión pública -recordemos que todavía no se había implantado la televisión-. A su vez, asumió la responsabilidad de controlar su obra, consciente de que la fotografía era un material delicado susceptible de ser manipulado, no sólo en el momento de su ejecución, sino también en la paginación, la contextualización y sobre todo en los pies de página:

“-¿Cuál era su objetivo cuando trabajaba para revistas de circulación masiva?

Las revistas como Life eran los mejores vehículos para la obra de un fotógrafo. Incluso si no se conseguía tanto como se hubiera deseado, era la mejor posibilidad de influir sobre la gente. Cuando fui a Minamata, encontré en esa pequeña aldea japonesa dos personas que tenían álbumes completos con recortes de mi obra. Ésa es la clase de influencia que me parece muy importante. Un libro no consigue llegar a esa cantidad de personas. Puede durar más, pero el reportaje El médico rural ha durado desde 1948 hasta hoy. Creo que el mundo ha empeorado con la desaparición de algunas revistas excelentes y otras menos excelentes ${ }^{184}$.

Con todo, esa conciencia del poder de influencia de los medios de comunicación de masas, esa agresividad en la defensa de la responsabilidad ética y moral del fotógrafo con la humanidad, no la compartirá nunca Ramón Masats. Aquella posición de mártir por la libertad de expresión y por la denuncia de los regímenes autoritarios era impensable asumirla en plena dictadura de Franco. 
“El fotógrafo debe asumir la responsabilidad de sus obras y los efectos de éstas. Pero cuando su obra sea una deformación (esto es a veces intangible, pero otras, chocantemente evidente), será también proporcionalmente un crimen contra la humanidad. Aun en temas poco importantes hay que adoptar esta actitud, pues las fotografías (y la leyenda al pie) son lo que moldean opinión"85.

En este contexto debe ser entendido el reportaje sobre el pueblecito extremeño de Deleitosa, publicado el 9 de abril de 1951 en la revista ilustrada Life bajo el título de "Spanish Village: It Lives in Ancient Poverty and Faith". Un año antes, en 1950, dicha revista americana tenía la intención de publicar un reportaje sobre los problemas de aprovisionamiento de alimentos de la España franquista, precisamente en un momento de controversia política sobre la idoneidad de ayudar económica y militarmente a una dictadura de corte filofascista que podía actuar como un seguro aliado contra la Unión Soviética en el marco de la guerra fría. Life obtuvo la autorización del gobierno español para el citado reportaje con cierta celeridad, ya que se trataba de una revista de reconocido prestigio internacional con millones de lectores. El gobierno de Franco consideró que un documental fotográfico pondría en evidencia los efectos que el bloqueo internacional producía sobre los españoles y presionaría al gobierno de los Estados Unidos para conceder las urgentes ayudas económicas.

Eugene Smith entró en Hendaya el 5 de mayo de 1950. La intencionalidad de Smith era completamente distinta a las consideraciones del gobierno franquista. En realidad, estaba completamente en contra de que su país ayudara al régimen de Franco. Pretendía describir la pobreza, el miedo y la opresión engendrado por un régimen autoritario. El reportaje de Eugene Smith denunciaba a la Dictadura con unas fotografías -y unos pies de foto- completamente parciales y militantes:

“Éste trabajaba como un director cinematográfico. Más que encontrar los asuntos y retratarlos, como era regla de los fotógrafos documentales, Smith preparaba cuidadosamente las escenas y las hacía repetir una y otra vez hasta darse por satisfecho (...) La preparación de las fotos tenía como objetivo, como es lógico, conseguir las mejores imágenes posibles, pero también era una consecuencia de la falta de objetividad de Smith, que sólo buscaba fotografías que demostraran la injusticia del Gobierno de Franco"86.

El plan de Eugene Smith para denunciar e, incluso, colaborar en la derrota de Franco, así como en la pervivencia de la Dictadura y en su aceptación por los Estados Unidos y la 0.N.U., se verá abocado al fracaso:

“En este contexto también es más comprensible la frustración que sintió W. Eugene Smith ante los resul-
tados de su trabajo en Deleitosa: quiso desenmascarar a Franco a través de un reportaje fotográfico docu-
mentando «hasta el máximo la pobreza y el miedo causados» por él (...) Pero Smith no se dio cuenta de
que el sistema que empleó no era eficaz para desmontar el simulacro que Franco había creado y paseado
por Europa y Estados Unidos. El sistema fue precisamente la proyección internacional de Ortiz Echagüe
como único artista fotógrafo, de interés y calidad, que existía en España, a través de exitosas exposicio-
nes. El momento culminante fue la exposición Spectacular Spain abierta en The Metropolitan Museum de
Nueva York desde febrero a mayo de 1960: los positivos se intercalaron con estampas de Goya. No cabía
duda, los dos eran artistas geniales que supieron visualizar la verdad de la España de su tiempo"87.

85 Smith, William Eugene, "Fotoperiodismo", publicado originariamente en Photo Notes, junio 1948, recogido ahora en Fontcuberta, Joan, Estética fotográfica. Selección de textos, Barcelona, Blume, 1984, pág. 179.

86 Fernández, Horacio, Variaciones en España. Fotografía y arte 1900-1980, Madrid, La Fábrica/Fundación MARCO/CAAM, 2004, pág. 110.

87 Vega, Jesusa, "La fotografía, Ortiz Echagüe y el simulacro de España", en el catálogo de la exposición José Ortiz Echagüe en la colecciones del Museo Nacional de Antropología, Madrid, Ministerio de Educación, Cultura y Deporte, 2002, págs. 67-68. 


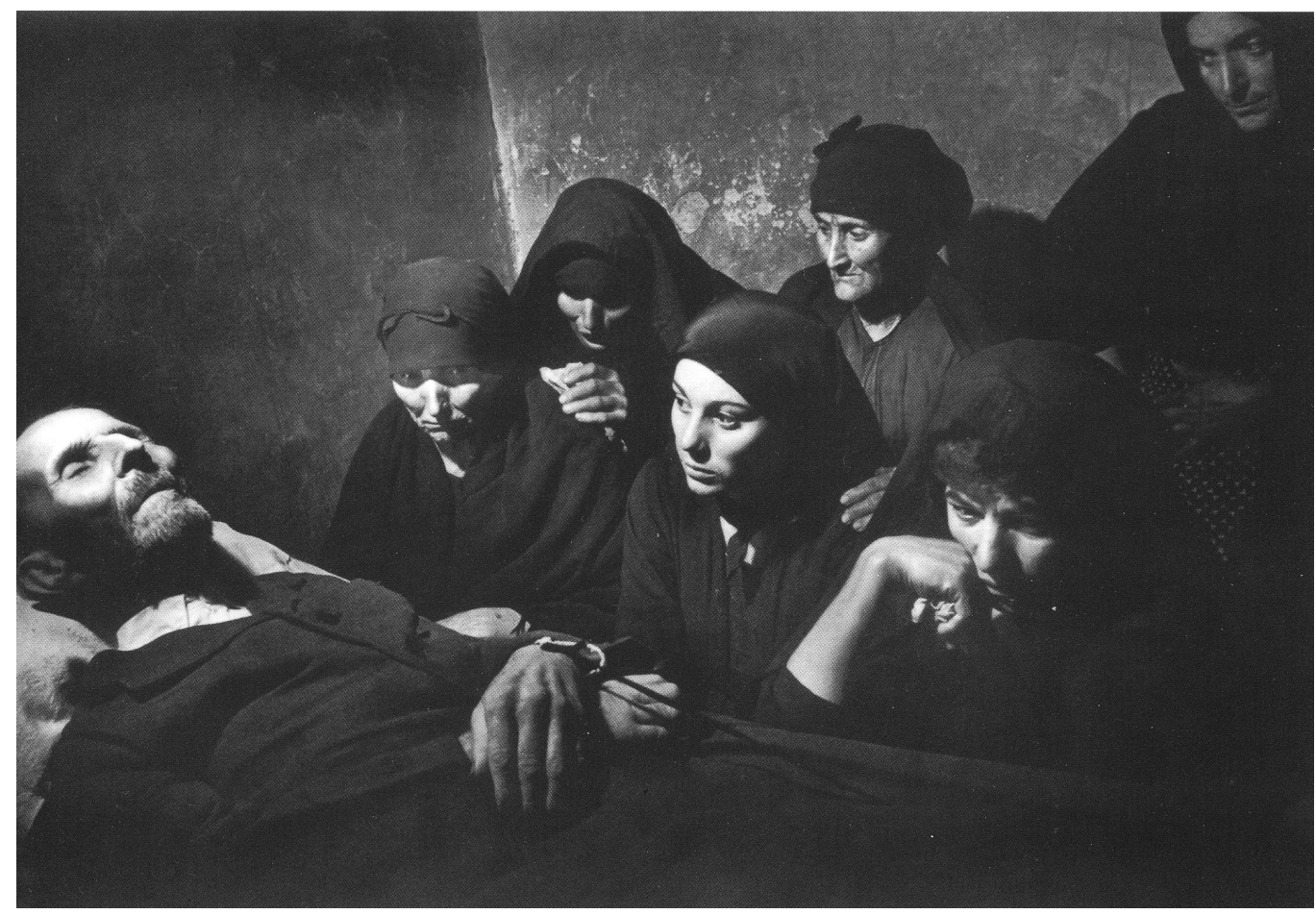

Eugene Smith, "The Wake", imagen perteneciente al reportaje "Spanish Village: It Lives in Ancient Poverty and Faith", 1950.

Por otro lado, la repuesta de Life ante las protestas de la administración española no fue, precisamente, defender a E. Smith ni a su particular postura ante Franco:

“Sino encargar un nuevo reportaje a Dmitri Kessel, once páginas a todo color de promoción del turismo en España, sin ninguna carga política o crítica. Para entonces, los préstamos de Estados Unidos al Gobierno español ya habían sido concedidos y la España de Franco era una nación amiga y aliada"88.

De cualquier modo, este trabajo, considerado un clásico en la fotografía de reportaje, suscitó una considerable admiración en muchos países, mientras que fue objeto de censura por la dictadura franquista. Hasta las exposiciones sobre Eugene Smith que tuvieron lugar en el Museo Nacional de Arte de Catalunya (MNAC) de Barcelona en la primavera de 1999, sus fotos sobre Deleitosa nunca habían sido mostradas en público en España. Como muestra de la enojada contestación española rescatamos dos artículos de la época. El primero se publicó en Arte Fotográfico en 1952, apenas un año después de la publicación del reportaje de Smith en Life:

“Irritante y lamentable.- Nos hemos visto desagradablemente sorprendidos al contemplar en el «Ehrentafel» o «Cuadro de Honor» de esta exposición, ampliado a gran escala y citado como modelo a seguir en el reportaje gráfico, el publicado por la revista americana «Life» hace algún tiempo, bajo el título «Spanish Village». Ancient poverty and Faith (Pueblo Español. Vieja miseria y Religión). Se 


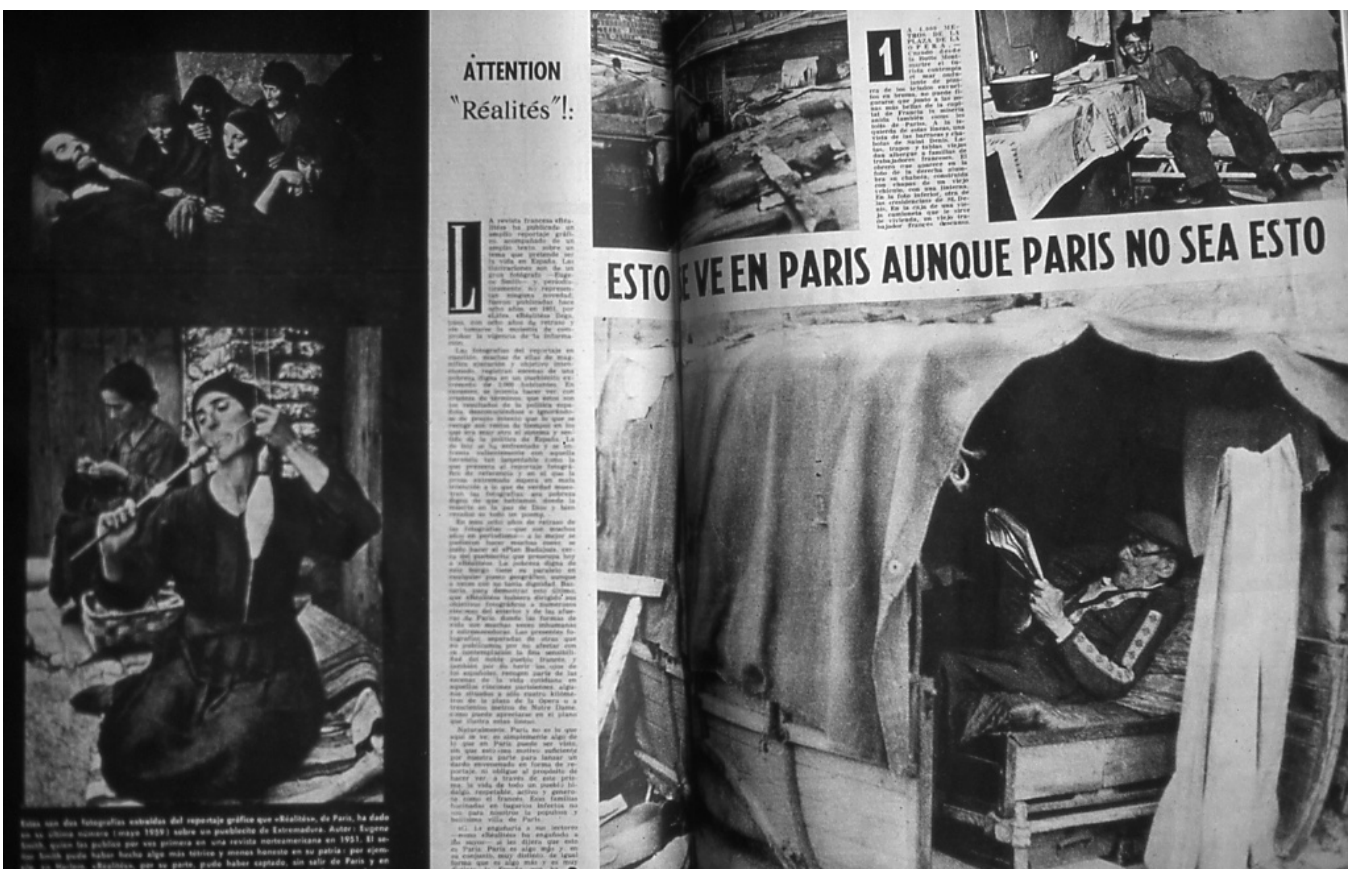

“ATTENTION «Réalités»!: Esto se ve en París aunque París no sea esto", Gaceta Ilustrada, n 140, 13 de junio 1959.

trata de una serie de fotografías «organizadas» en un pueblo de Extremadura por el norteamericano W. Eugene Smith. Fotografías bastante malas, por cierto, de campesinos sudorosos y famélicos, niños raquíticos y harapientos, curas a destiempo, guardias civiles y demás tópicos de la propaganda antiespañola.

Para ser más objetivos que el «Life», y en honor a la verdad, diremos que una foto de la serie, eso sí, solamente una desde el punto de vista fotográfico, es magnífica: la de un muerto rodeado de sus parientes, si bien la composición y efectos de luz que en ella observamos nos hacen pensar demasiado en un muy calculado «régie» o escenificación.

Reportaje éste malicioso y tendencioso y por ello en ningún caso ni para nadie modelo a imitar, ya que la primera condición del reportaje es que ha de ser objetivo y desapasionado" ${ }^{89}$.

Resulta curioso observar que la única imagen del reportaje que gusta al crítico es la del entierro. Posiblemente la más pictorialista de toda la serie. No deja de ser significativo que la revista Arte Fotográfico apoye la postura oficial y denuncie el reportaje de Smith calificándolo de "malicioso y tendencioso", a la par que lo acusa de estar "organizado" y manipulado y de contener unas fotografías simplemente malas. La revista recuerda que el reportaje de E. Smith no ha de suponer "modelo a imitar" para nadie, pues no es objetivo ni desapasionado, condición -según su criterio- indispensable del género del reportaje. Esta recomendación intenta evitar -educando convenientemente- que nuevos reporteros se lancen por España a buscar imágenes que hieran la sensibilidad del público. Queda patente aquí la función de la revista como catalizadora de una estética muy determinada y como

89 De la Fuente Ruiz, Antonio, “La exposición mundial de la fotografía Lucerna (Suiza)", en Arte Fotográfico, n 7, año I, julio 1952, pág. 267. 


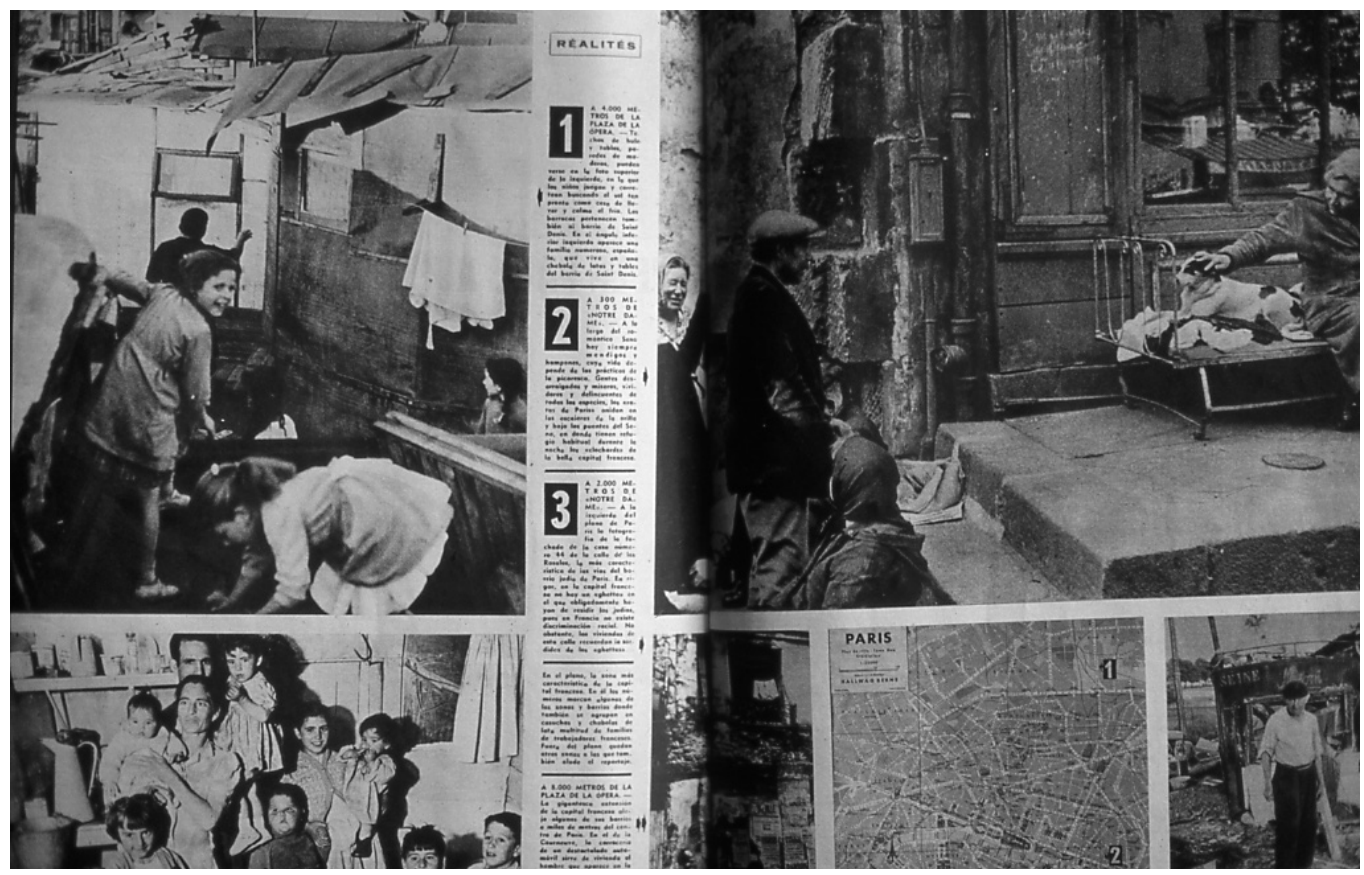

“ATTENTION «Réalités»!: Esto se ve en París aunque París no sea esto", Gaceta Ilustrada, n 140, 13 de junio 1959.

formadora de criterio de los fotógrafos de la época. Años más tarde se recogen los frutos de esta labor pedagógica, al aparecer acuñado el término "tremendismo", que frecuentemente es utilizado para repudiar el reportaje de denuncia o social, dado que el mismo se identifica con el mal gusto.

Ocho años más tarde de su publicación en Life Eugene Smith repuso su trabajo sobre Deleitosa en una revista francesa, Réalités. La airada respuesta española no se hizo esperar y la revista Gaceta Ilustrada replicó el mismo mes de publicación con otro reportaje sobre la miseria parisina. El argumento esgrimido por la revista española destaca la parcialidad del reportaje, su falta de honestidad y de actualidad, su malicia y su intencionalidad. El reportaje de Gaceta Ilustrada -tomado como testimonio histórico-, pone de manifiesto no sólo la actitud de la revista, sino también la actitud del propio Gobierno ante el reportaje de Smith:

“El señor Smith pudo haber hecho algo más tétrico y menos honesto en su patria: por ejemplo, en Harlem. «Réalités», por su parte, pudo haber captado, sin salir de París y en estos mismos días del año de gracia de 1959, lo que el lector verá por las fotos que siguen"90.

La reacción española ante el reportaje de E. Smith, reeditado en Reálités, consiste en publicar, a su vez, fotografías de la miseria en París, acompañadas con un mapa que explica detalladamente la ubicación exacta de cada toma, la distancia a los monumentos más representativos, la impresión que se llevarían los turistas si se encontraran con esas estampas... 
“La revista francesa «Réalités» ha publicado un amplio reportaje gráfico acompañado de un amplio texto sobre un tema que pretende ser la vida en España. Las ilustraciones son de un gran fotógrafo -Eugene Smith- $y$, periodísticamente no representan ninguna novedad: fueron publicadas hace ocho años, en 1951, por «Life». «Réalités» llega, pues, con ocho años de retraso y sin tomarse la molestia de comprobar la vigencia de la información.

Las fotografías del reportaje en cuestión muchas de ellas de magnífica ejecución y objetivo intencionado, registran escenas de una pobreza digna en un pueblecito extremeño de 3000 habitantes. En resumen, se intenta hacer ver, con crudeza de términos, que estos son los resultados de la política española, desconociéndose o ignorándose de propio intento que lo que se recoge son restos de tiempos en los que era muy otro el sistema y sentido de la política de España. La de hoy se ha enfrentado y se enfrenta valientemente con aquella herencia tan lamentable como la que presenta el reportaje fotográfico de referencia y en el que la prosa extremada supera en mala intención a lo que de verdad muestran las fotografías: esa pobreza digna de que hablamos, donde la muerte en la paz de Dios y bien rezados es todo un poema.

En esos ocho años de retraso de las fotografías -que son muchos años en periodismo- a lo mejor se pudieron hacer muchas cosas, se pudo hacer el «Plan Badajoz» cerca del pueblecito que preocupa hoy a «Réalités». La pobreza digna de este burgo tiene su paralelo en cualquier punto geográfico, aunque a veces con no tanta dignidad. Bastaría para demostrar esto último que «Réalités» hubiera dirigido sus objetivos fotográficos a numerosos rincones del interior y de las afueras de París donde las formas de vida son muchas veces inhumanas y estremecedoras. Las presentes fotografías separadas de otras que no publicamos por no afectar con su contemplación la fina sensibilidad del noble pueblo francés y también por no herir los ojos de los españoles, recogen parte de las escenas de la vida cotidiana en aquellos rincones parisienses, algunos situados a sólo cuatro kilómetros de la plaza de la Ópera o a trescientos metros de Notre Dame como puede apreciarse en el plano que ilustra estas líneas.

Naturalmente, París no es lo que aquí se ve: es simplemente algo de lo que en París puede ser visto sin que esto sea motivo suficiente por nuestra parte para lanzar un dardo envenenado en forma de reportaje, ni obligue al propósito de hacer ver, a través de este prisma la vida de todo un pueblo hidalgo, respetable, activo y generoso como el francés. Esas familias hacinadas en tugurios infectos no son para nosotros la populosa y bellísima villa de París.

«G.i.» engañaría a sus lectores -como «Réalités» ha engañado a los suyos- si les dijera que esto es París. París es algo más y, en su conjunto, muy distinto, de igual forma que es algo más y es muy distinta la España que ha querido mostrar "Réalités»"

El primer artículo de Arte Fotográfico quizá pasó desapercibido para Masats, pues la fecha de su publicación coincide con las primeras lecturas de éste de la revista. Sin embargo el publicado por Gaceta Ilustrada seguro que sí lo conoció. De este modo, Masats debió entrar en contacto con la obra de Eugene Smith en el año 1959. Probablemente no conocería todo el conjunto de fotografías publicadas sobre Deleitosa, pero seguro que este artículo, aparecido en la revista donde el propio Masats estaba trabajando, llamó su atención. Es decir que, como mínimo, Masats conocía las posibilidades de denuncia de la fotografía y las consecuencias que este uso podía acarrear:

"La labor de ocultación, idealización o "poetización" de la realidad, ejercida por la fotografía artística de la posguerra, se completó con la labor de los funcionarios de la censura, impuesta por las autoridades para velar por la pureza de las costumbres y salvaguardar los valores morales del Movimiento Nacional. Desde la Ley de Prensa de Serrano Suñer de 1938, la censura fue obligatoria para todo tipo de publicaciones, espectáculos y obras de arte. En fotografía, esa labor era competencia de la 
Dirección General de Prensa y Propaganda. En unos años en que la ortodoxia nacionalcatólica insistía obsesivamente en la moralidad, la censura se centró en la veda severa de cualquier tímido exceso en esta materia, aparte de la prohibición absoluta de toda publicación que atentase contra los principios fundamentales del régimen. La censura llegó a ser tan asfixiante, que el desnudo permaneció proscrito en salones y concursos, hasta bien entrados los sesenta. Consecuentemente, los fotógrafos no trataron este género hasta las vísperas de la transición democrática, y excepcional resulta encontrar un desnudo fotográfico en los años cuarenta y cincuenta, con la salvedad de alguna obra estimable de 0tho Lloyd o Nicolás Muller, formados fotográficamente fuera de España. Hubo que esperar hasta 1958 para encontrar los desnudos de Ramón Bargués publicados en el anuario Afal de aquel año, tras un pulso tenaz con los funcionarios de la Administración"92.

Casi todos se toparían con la censura, por ejemplo Oriol Maspons cuando fue a las Hurdes:

(0. Maspons, Barcelona, 20 de octubre de 1999) -“Nosotros estábamos siempre expuestos a pequeños retoques de la censura. Ya lo sabíamos... en aquella época me censuraron fotos de publicidad... Y también hacíamos autocensura. Yo estuve en las Hurdes y no pude hacer nada a pesar de mi autocensura, la Guardia Civil me vigilaba y estaba prohibido hacer fotos" ${ }^{\prime 93}$.

\begin{abstract}
“Vaig anar a Las Hurdes el 1960. Carles Barral volia fer un llibre que que s'havia de titular Caminando por las Hurdes. El llibre va sortir i va ser molt atacat per malintencionat i això (...) Estaven molt aïllats i patien d'una mena de degeneració endogàmica (...) Jo era conscient del valor crític de fer aquestes fotografíes i de la intenció crítica de l'encàrrec. Em semblava important i necessari que allò se sabés i es veiés, perquè era una situació que no es podia aceptar" ${ }^{\prime \prime 4}$.
\end{abstract}

Algo similar sucederá con Joan Colom -con sus fotografías del barrio chino de Barcelona-, con Carlos Pérez Siquier -y con portadas de la revista AFAL, con artículos enteros de la misma 0 con los desnudos del anuario de 1958-, con Ramón Masats -y su imagen de los micrófonos de Franco-... Ellos se convirtieron en el germen de la modernización, en los primeros autores que se lanzaron al vacío de lo políticamente molesto. Oriol Maspons en su artículo "Salonismo", da una pista, evidentemente entre líneas, que es muy significativa del contexto social en el que se produce la renovación:

“Debería crearse un carnet de superfotógrafo aficionado... (otro papel sellado en la cartera, vaya asco). Se acabó el hablar del Matagranol o del Pepefinol momificado, ahora hay que aprovechar lo que la fotografía tiene de burocrático" ${ }^{\prime 95}$.

A pesar de todo, Joan Fontcuberta duda de la intencionalidad de denuncia política de la joven fotografía española. La publicación de los reportajes, y por lo tanto la permisividad de la censura, parecen avalar este argumento. Actualmente los propios testimonios de los autores, tomados en democracia, sin ninguna presión por parte del Estado y en plena libertad de expresión, refuerzan la tesis de la no beligerancia directa contra la Dictadura.

92 López Mondéjar, Publio, op. cit., págs. 182-183.

93 La película pseudo-documental de Luís Buñuel "Las Hurdes, tierra sin pan" (1932) estuvo prohibida incluso por la República española. Censurada y perseguida, aún hoy día sigue siendo denostada o ensalzada hasta extremos insospechados. Motivó el recelo de las autoridades y de los propios hurdanos que desconfiaban de cualquier fotógrafo que visitara la zona.

94 Balsells, David, "Memòries i amnèsies. Extractes d'una conversa amb Oriol Maspons”, en Maspons, Oriol; Balsells, David y Permanyer, Lluís, op. cit., pág. 16.

95 Maspons, Oriol, "Salonismo", en Arte Fotográfico, n 61, año VI, enero 1957, pág. 3. 
“Cabría polemizar no obstante sobre su verdadera dimensión crítica. Algunas interpretaciones historiográficas sostienen que muchos jóvenes autores de ese momento se ensañaron desempolvando las tristes estampas de la España negra como una forma de contradecir la fachada de progreso y desarrollo que el régimen pretendía transmitir. Pero de hecho no podía haber una verdadera «denuncia», primero porque la censura la hubiera cortado de raíz, segundo porque los autores tampoco demostraron en su momento una especial voluntad crítica y tercero porque hubo una cierta tolerancia oficial respecto a esa documentación «distorsionada» que se explicaría por la imposibilidad de darle una resonancia masiva; la ausencia de medios de difusión suficientes confinaba estos trabajos a una audiencia muy reducida y de prácticamente nula incidencia en el extranjero"96.

Las pretensiones de los jóvenes fotógrafos del momento no contemplaban una denuncia social explícita, ni una oposición al Régimen -debido, sin duda alguna, a la propia imposibilidad de ser publicados sus trabajos por la censura- aunque sí sostuvieron una reivindicación de la autenticidad, de la libertad de mirar, del potencial comunicativo de la fotografía, de su capacidad para emocionar. En una entrevista realizada por Jorge Ribalta a Joan Colom se recoge:

“JR ¿Eras conciente del potencial crítico y de denuncia de tus imágenes respecto a la situación política y social del momento, en el sentido de que mostrabas situaciones de marginalidad y pobreza en un periodo de falta de libertades?

JC En aquel momento, no pensé mucho en todo eso. Cuando hice la exposición no era consciente de las cosas que se podían derivar de ella. Me di cuenta más tarde, cuando se publicó el libro y se desencadenó un escándalo, seguido de una demanda judicial (...) Yo no sabía que estaba haciendo fotografía social en aquel momento. Yo sólo hacía fotografía y buscaba imágenes que me emocionasen (...) Yo hago la calle. Con mis fotografías yo busco ser una especie de notario de una época"97.

- ¿Tuvisteis algún problema con la censura de Franco en algún libro. Por ejemplo en el libro de Colom?

(Esther Tusquets, Barcelona, 31 de octubre de 2004) -“Lo de Izas lo arregló personalmente Cela con Fraga. Si no, no hubiera pasado la censura nunca en la vida. De los libros de narrativa extranjera mutilaban muchísimos. Los libros de Seix Barral de Biblioteca breve, los libros de Lumen, estaban censurados".

$-¿$ Y de libros de fotografía?

(Esther Tusquets, Barcelona, 31 de octubre de 2004) -“No. De fotografía no. Prohibieron uno de dibujos. Uno de Juan Ballesta, el dibujante, que se llamaba El rico, y uno de Cesc que fue personalmente a Madrid, pero no lo consiguió arreglar; y de narrativa mucha, pero de fotografía no".

“En septiembre del 63 recibimos la autorización de censura, salvo para la cubierta y una foto, que fueron aprobadas pocos meses después. Creo que la amistad de Cela con Fraga, gallego como él, jugó un papel importante. El libro se editó íntegro en el 64. Era inconcebible en la España de aquellos años, ocasionó un escándalo, en algunas librerías se negaron, por razones morales, a venderlo, y constituyó, como he dicho, el primer pequeño bestseller de un pequeño editor" ${ }^{\prime \prime 8}$.

96 Fontcuberta, Joan, “De la posguerra al siglo XXI”, en Sánchez Vigil, Juan Miguel (coordinador), op. cit., pág. 417. 97 Ribalta, Jorge, "Entrervista con Joan Colom", en El carrer. Joan Colom a la Sala Aixelà, 1961, Barcelona, MNAC, 1999, pág. 122.

98 Tusquets Blanca, Esther, op. cit, pág. 48. 
- ¿Crees que AFAL fue tan revolucionaria porque no tenía el lastre de las autoridades de la censura que la ignoraron por estar en una provincia periférica sin mucha influencia social en el país?

(R. Masats, Madrid, 17 de julio de 1999) -“Es que AFAL no tenía problemas con la censura, quiero decir que la censura, que muchas veces era muy imbécil, otras veces se daba cuenta que el poner un desnudo en una revista minoritaria de Almería no tenía tampoco tanta importancia, casi nadie se enteraba. Lo único que podían censurar era algún desnudo o alguna cosa, lo otro, las fotos en las que aparecía un poco de miseria y tal, estoy convencido que lo consideraban como costumbrismo, no como una denuncia. Pues bueno..., la Chanca está ahí, mira qué gracioso, qué bonito las paredes blancas y todo eso, creo que no eran conscientes de ello".

La anécdota de la censura de estos desnudos todavía la recuerda vívidamente Carlos Pérez Siquier, orgulloso por haber conseguido publicarlas a pesar de los problemas con las autoridades.

(C. Pérez Siquier, Almería, 27 de abril de 2002) -“El censor, que era el Delegado del Ministerio de Información y Turismo, era un hombre muy medroso y en cuanto veía algo enseguida lo mandaba a Madrid. Nosotros publicamos en el anuario de AFAL unos desnudos abstractos, completamente abstractos. Nos costó un viaje a Madrid para que el jefe de la censura nos los autorizara, quitó alguno y al final por amistad conseguimos publicarlos. Era una cosa asombrosa lo que podían llegar a censurar, nos costó un trabajo enorme y no pudimos poner todas las fotos. Por el hecho de habernos censurado tanto, tengo la sensación que me pasé, porque le di más importancia a las fotos de la que tenían, y son reiterativas. Hay demasiadas".

Efectivamente, hay cuestiones como la libertad creativa, según ya hemos comentado, o como el reconocimiento de la subjetividad y la búsqueda de la honestidad en las que sí coinciden con E. Smith.

\begin{abstract}
“Aquellos que creen que el fotorreportaje es «selectivo y objetivo, pero puede interpretar la materia fotografiada», muestran una falta absoluta de entendimiento respecto a los problemas y al funcionamiento propios de la profesión. El fotoperiodista no puede tener más que un enfoque personal: le es imposible ser totalmente objetivo. Honesto, sí; objetivo, no (...) los fotógrafos Lisette Model, Cartier-Bresson y Gjon Mili se elevan por encima de la pericia técnica. Sin embargo, cada uno de ellos, si hubiese de manejar el mismo material, sería capaz de dar al mundo una interpretación individual, excelente (...) ¿Cuál es la verdad objetiva? Tal vez todos estos fotógrafos expresan la verdad, siendo la verdad «Muchas cosas para mucha gente»" ${ }^{\prime 99}$.
\end{abstract}

José María Artero comenta al respecto:

“No buscábamos premios en Salones fotográficos, sino Muestras y Exposiciones de una visión nueva en la vida, captada naturalmente con intención, porque ante el mismo objeto y detrás de dos cámaras iguales hay dos fotógrafos distintos, pero sin "mala intención", sin una idea de utilización posterior de la realidad captada que fuera más allá de sus valores fotográficos. Y Doña Censura no entendió nunca esta sencilla y honrada postura y nos cohibía, nos limitaba o peor aún, nos empujaba a la autocensura, empecinada en que ocultábamos una segunda intención heterodoxa"100.

En el año 1960 Carlos Pérez Siquier escribe un artículo sobre el grupo francés Les 30x40. En él, Pérez Siquier filtra un comentario que puede arrojar una luz sobre su concepción del compromiso moral de la fotografía, e incluso, muy sutilmente, de su opinión sobre la Dictadura: 
“Pero el reproche más grande que he de hacer a «Les 30x40» es su indiferencia a los problemas humanos, sociales y hasta políticos del pueblo francés (...) La fotografía debe ser, ante todo, testimonio, reflejo auténtico de una época o de un pueblo. Todo fotógrafo-reporter contrae la ineludible obligación moral de interpretarnos la realidad de su país, por muy triste o muy esperanzadora que sea.

En la Radiotelevisión francesa me preguntaron que si la razón de que las fotos españolas en relación a las francesas, acusasen una mayor profundidad y dolor, era debido a la denuncia de un problema social inexistente en Francia. ¡Qué tontería! El problema social es común a todos los países. Puede ser un problema de transportes, de alimentación, de mecanización, acaso de felicidad... En todos los rincones existe y puede ser explicado. Los franceses no han querido verlo en su país. Buena parte de los españoles sin embargo, nos lo han mostrado, no con ánimo de complacencia en el dolor, sino como medio de curación por el conocimiento"101.

Ese “problema social" español, que no padece Francia, es, sin ninguna duda, Franco. Evidentemente, el periodista francés considera la denuncia de la Dictadura como la causa de la profundidad y el dolor de fotografía española. Sin embargo, Pérez Siquier lo supone una tontería. Probablemente considere anecdótica a la propia Dictadura. En este texto es posible rastrear la influencia de la exposición y el catálogo de The Family of Man y su ingenua ideología: esos "problemas" universales que apunta Pérez Siquier son casi el índice del catálogo de la famosa exposición.

“Maspons por su parte reconocía que se inspiró «un poco» en el neorrealismo italiano, pero también que nunca pretendió «hacer denuncia social»"102.

En la actualidad Carlos Pérez Siquier aporta argumentos que aclaran la postura de los fotógrafos españoles ante el uso de la fotografía como denuncia social.

- ¿Ese tipo de fotografía que hacía usted y Ramón, tenía alguna pretensión de denuncia o compromiso social?

(C. Pérez Siquier, Almería, 27 de abril de 2002) -“Yo creo que no, porque podía haber cogido... El barrio de la Chanca es muy marginal y con una situación, por una parte sostenida, honestamente sostenida dentro de las carencias de la época, pero luego había una parte que era realmente catastrófica, que eran las cuevas donde vivía la gente con enfermedades y en situaciones realmente penosas, y eso yo lo soslayé. Entre otras cosas porque nunca se podría haber publicado. En la época franquista la revista AFAL estaba completamente censurada. Pasaba por dos filtros, uno de aquí local y cuando había alguna duda se consultaba con Madrid. Y hasta nuestra correspondencia estaba muchas veces intervenida porque teníamos relaciones con Francia. Yo he llegado a estar muchas veces en comisaría y estuve a punto de estar en la cárcel porque decían que mandaba información y fotos a revistas francesas contrarias al Régimen. Tal es así, que en una fecha yo quise ser profesor de fotografía en la Escuela de Artes y Oficios y necesité certificado de buena conducta, y cuando fui no me lo dieron. Yo insistí, y dijeron que yo era persona no adicta al Régimen, de tendencia más bien liberal... y no me dejaron. Con lo cual si yo hubiera hecho ese trabajo de denuncia, o Ramón también lo hubiera hecho, no hubiera tenido oportunidad de publicarlo. Por eso no nos planteamos esa cuestión. Sencillamente lo que yo traté de coger era la gente en su humanidad, la dignidad de las personas, su vivir cotidiano, pero no con una idea de denuncia, y yo creo que él tampoco. Porque, además, aquellos temas que cogió, como lo de Los Sanfermines, tenían una mirada crítica pero satírica, socarrona, como es él. Tiene un humor soterrado. Él, evidentemente, siempre había gustado mantener una postura de hombre rebelde, 
de contestatario y sarcástico. Y ese sarcasmo se le nota en la fotografía de Los Sanfermines. El Neutral Corner sí tiene un sentido crítico de lo que es el boxeo y sus destrozos, en eso sí puede ser una denuncia, porque la censura le permitió trabajar, no vio problema en ello. Pero el tratar de hacer algo político de la situación de Cataluña, de marginación o de independentismo... eso no lo ha tocado él".

“Pérez Siquier se refirió al colectivo manifestando que «éramos los Rolling Stones en la fotografía española» (...) recordó cómo eran sometidos a la actividad censora no sólo los textos sino también las imágenes (...) la censura prohibió un artículo sobre «El dictador», de Chaplin (...) la correspondencia que mantenían con Francia «sabíamos que era abierta», concluyó." ${ }^{103}$.

La actitud de rechazo y oposición a la fotografía oficial franquista parece un enfrentamiento político, sin embargo tiene un origen fundamentalmente estético: su "libertad" es la libertad de la mirada, de la expresión. Necesitan sacudirse de encima los rígidos corsés salonistas que aprisionan a un medio de comunicación puro, como consideran que es la fotografía. Tampoco el propio Joan Colom, con su trabajo sobre el barrio chino de Barcelona, tendrá la intención de denuncia social que preside la obra de E. Smith, a pesar de que en una primera lectura pareciera lo contrario:

“Sin embargo, en el caso de Colom, esta lectura del trabajo en términos de instrumentalidad política sería inadecuada. Al menos de entrada, puesto que en esos años el debate alrededor del concepto de «fotografía social» en el contexto barcelonés parece más de orden estético que ideológico. Este debate posiblemente ilustra las dificultades de articular un discurso explícitamente político en el contexto de la época"104.

Josep Maria Casademont también matiza el concepto de fotografía social en los años cincuenta y principios de los sesenta en España. En esta línea, parafrasea a Joan Fuster y a su concepto de poesía social (en un texto aparecido en la revista del Monasterio de Monserrat Serra D'0r). Casademont habla de la fotografía social española y su nivel de denuncia o protesta, y reconoce que no existe prácticamente ningún fotógrafo español que realmente esté implicado 0 comprometido socialmente. La única salida que encuentra el fotógrafo para comprometerse con su tiempo será mediante su actitud vital, siempre y cuando considere el carácter utilitario de la fotografía y practique la libertad de pensamiento.

“Hacer una fotografía cuyo tema sea la denuncia. Como dice Fuster: una fotografía -perdón: una poesía- de engagement, es decir, que implique una postura social de protesta y compromiso (...) Yo tampoco conozco muchos fotógrafos sociales españoles. Ni siquiera Joan Colom..., al menos en el sentido hasta aquí apuntado. Y me quedo con lo que dice Castellet... y tal vez como él pueda afirmar que la fotografía social -perdón: la poesía social- no lo sea tanto por el tema como por la actitud del autor (...) Dije en su momento, refiriéndome a Joan Colom, que en él, más importante que el carácter del tema (sigo creyendo que Colom no está engagé en ninguna postura de protesta) era el hecho de habérselo propuesto.

Lo importante en él (lo importante en lo que yo creo que debe entenderse por fotografía social) no está en que el tema o asunto lo sea, sino en el hecho de que el fotógrafo adquiera un sentido adecuado de pudor hacia la obra inútil"105.

103 García, Pilar, "Una muestra fotográfica rescata la historia de Afal en su 50 aniversario", en Ideal, 3 de marzo de 2006, pág. 53.

104 Ribalta, Jorge, op. cit., pág. 110.

105 Pujol, Aquiles (Josep Maria Casademont), “Fotografía social”, en Arte Fotográfico, n 127, año XI, julio 1962 , pág. 662. 


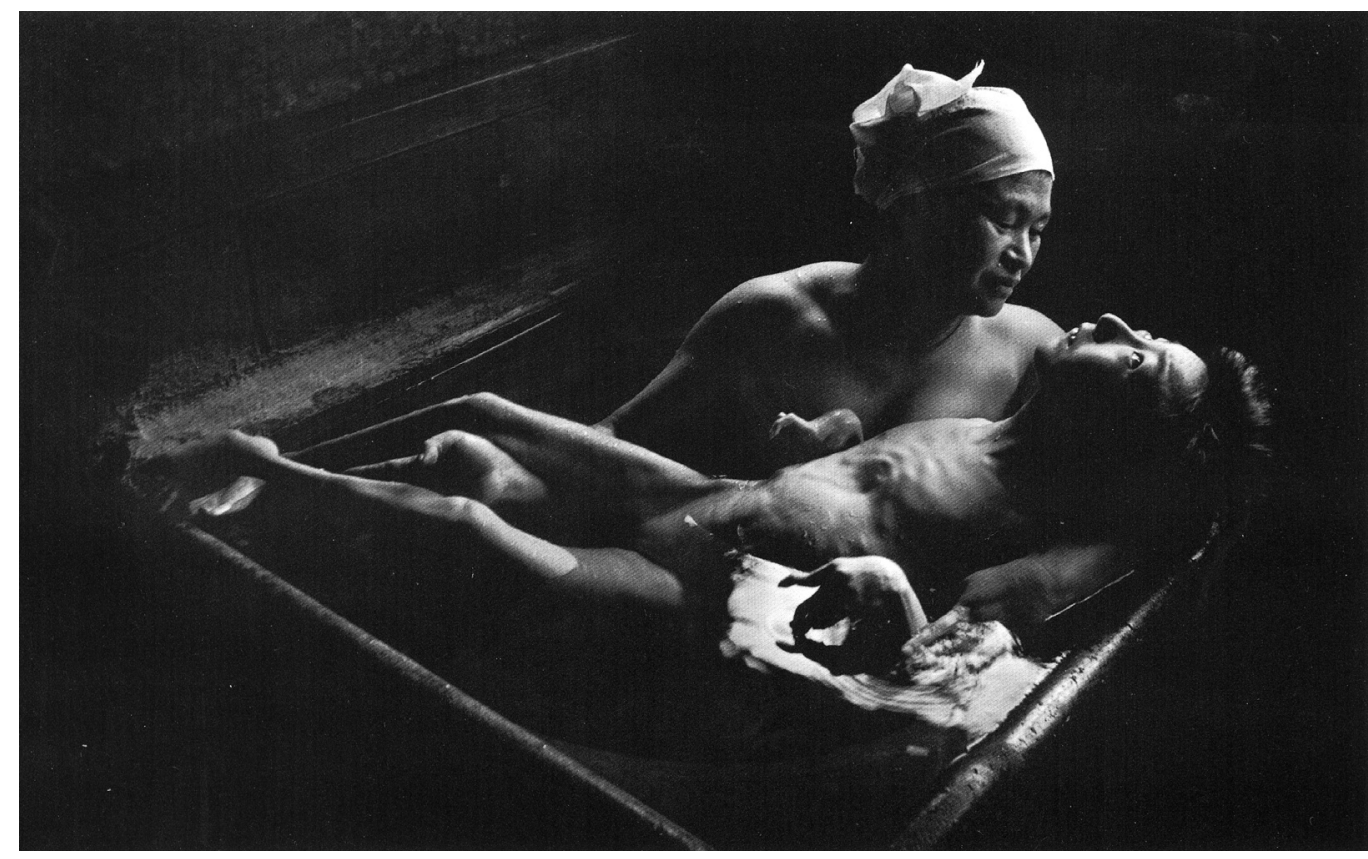

Eugene Smith, "El baño de Tomoko", 1972. Perteneciente al reportaje sobre Minamata.

Parece evidente que hubo muchas circunstancias históricas que pudieron favorecer la elección del reportaje como medio de expresión frente a otros géneros como el paisaje o la abstracción (Masats se planteó al principio de su carrera hacer paisajes en los Pirineos buscando abstracciones y experimentando con la geometría, ya que la "fotografía de forma" nunca la abandonará completamente), aunque sin duda la asunción del reportaje documental implicaba una toma de postura.

“Los fotógrafos optaron por centrarse en captar aquello que les rodeaba, luchando contra una fotografía de asuntos deprimentes, en lugar de prestarse al servicio del régimen o de ser testigos del boom económico de principios de los sesenta. El componente crítico que el tiempo ha otorgado a esas fotografías no se corresponde con una búsqueda consensuada de mejora social y política en ese momento, a pesar de lo que pudieran sugerir estas fotografías una vez traspasadas nuestras fronteras. Si bien era mayoritario en los fotógrafos el sentido de rechazo frente a la tradición, era un espíritu crítico contra el propio medio fotográfico, más que contra el sistema político"106.

- ¿Tú conocías lo que había hecho Eugene Smith sobre Deleitosa?

(R. Masats, Madrid, 20 de marzo de 2000) -“No, en absoluto, aquí en España ese Life estuvo prohibidísimo, yo no lo he conocido hasta muchos años después".

$-¿$ ¡ la idea de que la fotografía se puede utilizar para denunciar...?

(R. Masats, Madrid, 20 de marzo de 2000) - "Yo soy bastante pesimista, yo creo que no sirve. No sirve para nada. Para lo único que sirve es para que mandes dinero a donde la gente se está

106 Rodríguez, Mafalda, "Los cincuenta olvidados”, en España años 50. Una década de creación, Madrid, SEACEX, 2004, pág. 101. 


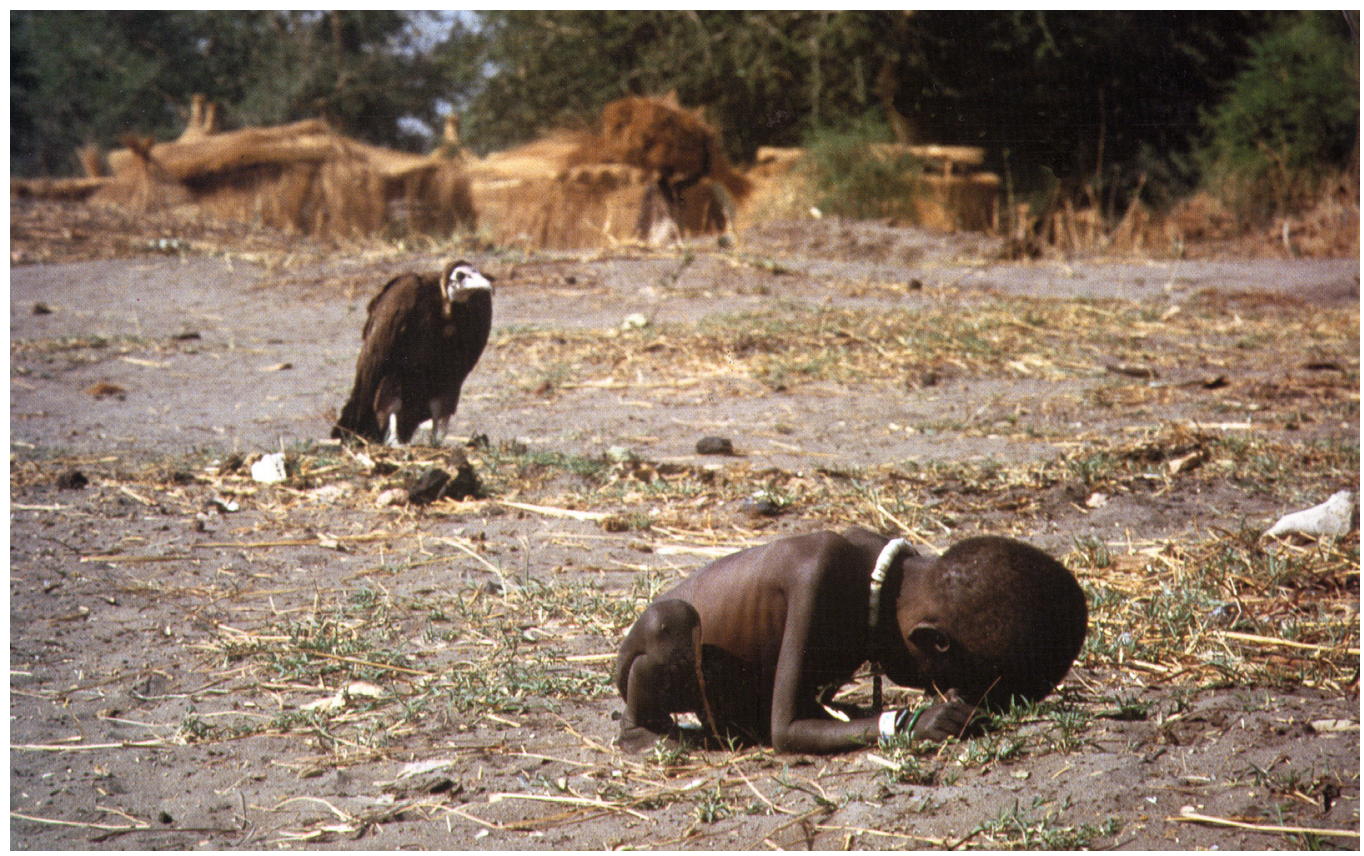

Kevin Carter, "El buitre y el niño", 1994. Premio Pulitzer.

muriendo y el jefe de la tribu se lo quede para él, y el Jefe del Estado se lo quede también para él. Tenéis que daros cuenta. Lo que pasa es que se dice con la boca pequeña, pero todo eso que se da para las inundaciones... cuando hablas con la gente de allí te dicen que no ha llegado casi nada. Para lo único que sirve la imagen de catástrofes es para desarrollar un sentimiento que se llama caridad. Y creo que con la caridad no se soluciona nada".

-Pero, por ejemplo, lo de la tragedia de Minamata...

(R. Masats, Madrid, 20 de marzo de 2000) - “Yo creo que los japoneses ya estaban trabajando en lo que tenían que hacer, y creo que lo que hizo Eugene Smith no sirve. No sirve en un tanto por ciento muy elevado, no es que sea absolutamente inútil. Aparte que llega un momento de insensibilidad... Además, es mucho más efectivo en televisión que en fotografía".

$-¿$ ¿Y la fotografía de guerra?

(R. Masats, Madrid, 20 de marzo de 2000) -“¿'Tú conoces alguna guerra que...? ¡Ni Vietnam! En algún momento se dijo que los americanos se habían ido de allí por la presión de los medios. ¡La presión era que les estaban matando demasiados americanos! Venían demasiados ataúdes con americanos muertos. Pero las fotos... como información me parece muy bien, pero creo que sirve para muy poco. Y lo de Deleitosa no sirvió de nada... Al cabo de dos días vino Eisenhower... porque les interesaba, más que el fascista de Franco, les interesaba que era anticomunista. Frente a las barbaridades y lo mal que lo hizo el fascismo... ¿Qué hay que hacer? Que viva bien el pueblo español, para que en un momento determinado no se levante contra Franco que es nuestro bastión anticomunista. ¡Y es así! Hay que ser conscientes de las limitaciones.

Recuerdo que había una exposición en la FNAC de unos fotógrafos franceses sobre las mi- 
serias de la guerra. Cada fotografía tenía una pequeña explicación. Había una de un chaval muy famélico en el borde de una carretera, en la cuneta de la carretera. Y el fotógrafo contaba que había hecho esta foto, ellos iban hacia otro sitio y cuando volvieron se dieron cuenta que el chaval ya había muerto. Y entonces el fotógrafo reflexionaba y tal, y un espectador había puesto: ¡Eres un hijo de puta! ¿Qué puede hacer un fotógrafo...? Quiero decir, el drama de los fotógrafos... Y sabéis que uno se suicidó. Uno que hizo una foto en la que también hay un niño que está en las últimas; y hay un buitre que está esperando que el niño muera para comérselo, y el fotógrafo se suicidó. Yo no sé si el niño se salvó, me imagino que no. La cosa que les queda a los fotógrafos... ¿Qué haces en ese momento...? Eso debe ser horroroso para ellos.

De todos modos yo, como espectador, nunca he sentido delante de una fotografía lo que sentí con un texto que leí en El País, en una columna de Manolo Vicent. Nunca he sentido la tristeza...

Llegaba a un sitio en un jeep. En aquel momento un niño lo mira con unos ojos que decían todo y no expresaban nada, ni le pedían nada en absoluto. Dio una vuelta al campamento, se volvió a montar en el jeep y la mirada del niño cuando vio que se marchaba. Solamente esta tontería, y a mí me ha producido más emoción que cualquier fotografía de niños famélicos. Creo que llega un momento que por saturación... El dicho chino de que una imagen vale mil palabras es una estupidez. Para mí como la palabra no hay nada. Puede haber pequeñas excepciones, pero en un noventa y nueve por ciento, para mí, la palabra es muy superior incluso a la música, que posiblemente para mí, sea el segundo".

Parece claro que la postura de Masats ante la Dictadura de Franco no fue ni de enfrentamiento, ni de sometimiento o alabanza. Masats consiguió mantenerse al margen, independiente. Aunque aquella imagen de Franco ante los micrófonos puede inclinar la balanza. El carácter de Masats pudo más que la prudencia y realizó esta fotografía tan comprometida en la que cara del dictador quedaba tapada por los folios de un discurso. Esa imagen fue censurada (autocensurada, mejor dicho) y nunca fue publicada durante la Dictadura.

“¿Significa eso que en aquel momento su fotografía era una toma de posición política?

[Masats] No éramos directamente políticos, no éramos activistas. Pero al hacer una fotografía realista, lo que reflejábamos tenía necesariamente un mensaje político"107.

-Es posible que hayas tenido una fotografía crítica y después hayas evolucionado a una fotografía más amable. Es decir un paso de la fotografía en blanco y negro, más crítica; a la fotografía en color, más amable.

(R. Masats, Madrid, 17 de julio de 1999) -“Yo no lo sé hasta que punto. Posiblemente sea cierto; pero por ejemplo, de las fotografías de la exposición sólo hay dos censuradas, una en blanco y negro y una en color. Censuradas por publicación: una es la de Franco tapado por micrófonos mientras está leyendo, que fue un reportaje que hice y la revista no quiso publicarla, y luego hay otra en color de una cabeza de toro en Benidorm, que cuando hice el libro sobre España alguien de la editorial dijo que esa fotografía no podía ir. Luego se ha publicado en el libro Toro (Lunwerg, 1998), pero fue censurada en el libro de La España Diversa (Luna Wennberg, 1982). A pesar de ello posiblemente tengas razón".

(Koldo Chamorro, Pamplona, 21 de marzo de 2003) -“Estando gran parte de la vida activa de Ramón sometido a una época histórica que es la que fue -con todas las perversiones que tuvo-, que es el franquismo, las fotos de Ramón no puede decirse que sean estrictamente franquistas".

-Ni antifranquistas.

107 Arnalte, Arturo, "Ramón Masats. Los grandes fotógrafos españoles con Descubrir el Arte", en Descubrir el Arte, n 93, año VIII, 2006, pág. 46. 


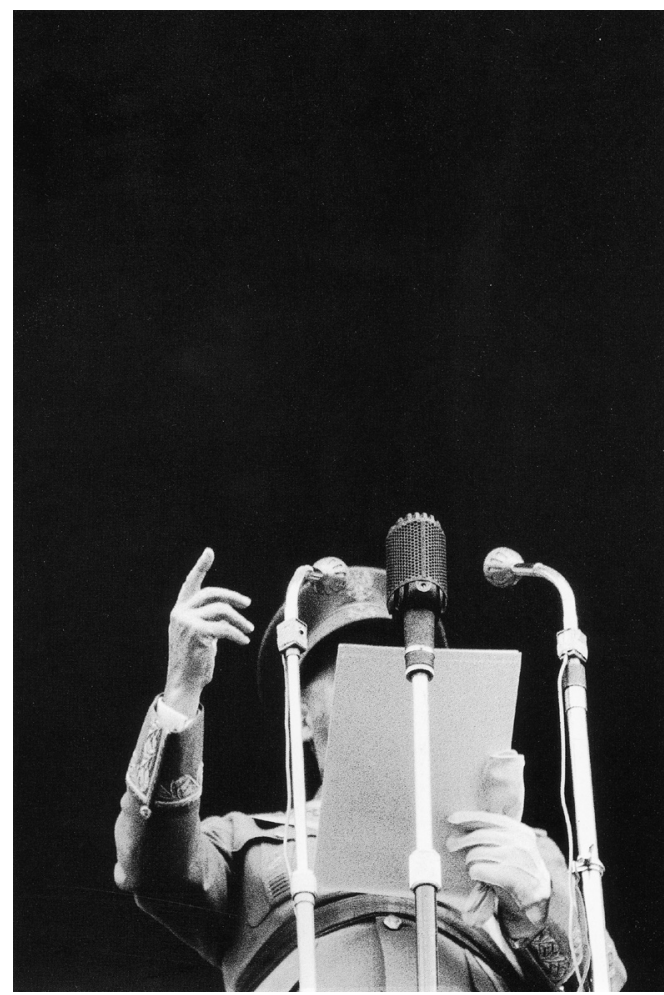

Ramón Masats, "Francisco Franco", 1958.

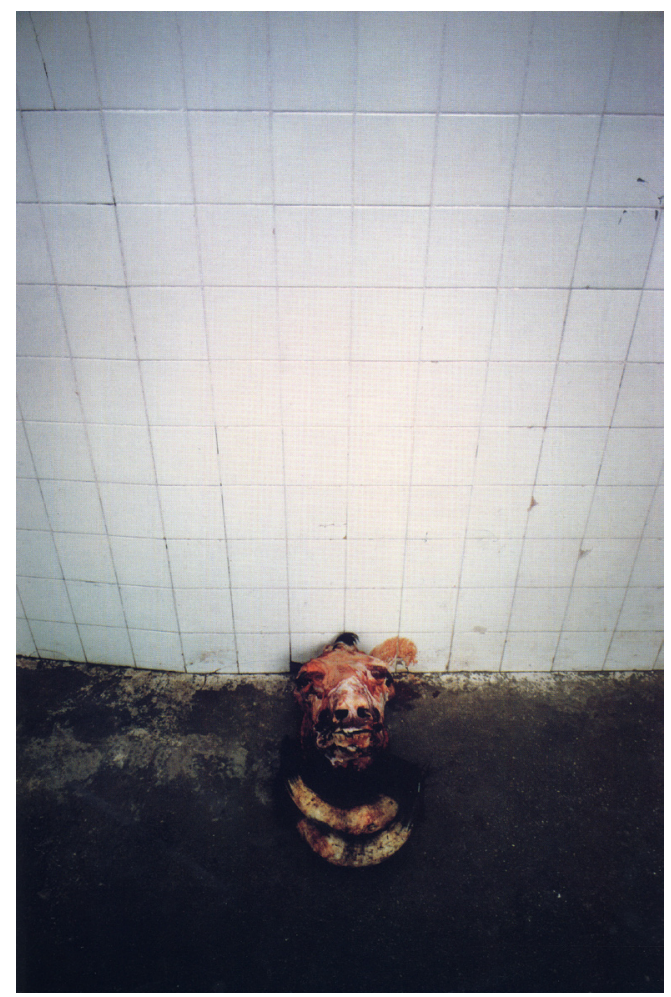

Ramón Masats, “Benidorm (Alicante)”, 1982.

(Koldo Chamorro, Pamplona, 21 de marzo de 2003) -“Son fotos de España, y eso es un gran beneficio. Cosa que otros fotógrafos de la época cayeron, y no voy a dar nombres, pero se les ve el plumero, se ve mucho el franquismo. Y claro, esto lo puede conseguir una persona que tiene un gran amueblamiento conceptual, porque sino caes. $Y$ eso es lo que hace a Ramón incómodo, porque políticamente es incorrecto. Se escapa de una ley no escrita, pero pactada, de que uno tenía que ser lo que tenía que ser. Y eso es muy importante".

- ¿Y qué tenía que ser, antifranquista?

(Koldo Chamorro, Pamplona, 21 de marzo de 2003) -“No, no es una cuestión de ser antifranquista, ni de ser franquista, la cuestión es contar lo que era este país. El país era lo que era, y la presencia de Franco, con todo el dolor que podía generar, era un presencia meramente anecdótica. La España que cuenta Ramón, era una España despojada en ese sentido, incluso en el político".

-Entonces... Ramón era políticamente incorrecto porque no estaba definido.

(Koldo Chamorro, Pamplona, 21 de marzo de 2003) -“Era una persona libre”.

-Objetivo.

(Koldo Chamorro, Pamplona, 21 de marzo de 2003) -“Objetivo no, era libre. Objetivo aquí no hay nadie. Aquí todos somos subjetivos. Sólo la elección de un tema ya te está determinando. Era libre en el sentido de que no estuvo atrapado por las redes... No hizo esa España de miseria, de ajetreo de masas aplaudiendo al Caudillo... Es una España que está ahí. Es una España dura, pobre pero digna. Y en muchos fotógrafos de su época es una España un poco indigna, se ve mucho la pobreza, un poco el esperpento". 


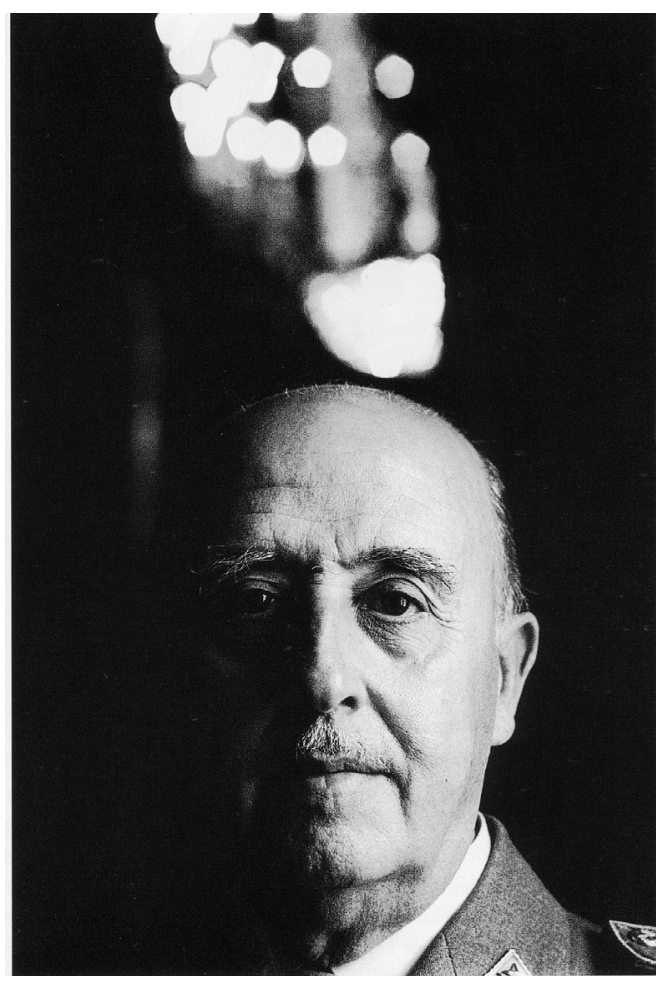

Ramón Masats, "Franco", 1964.

Hay una curiosa anécdota en la que Masats cuenta cómo, con ocasión de un encargo profesional, mantuvo un breve contacto directo con Franco. En la anécdota queda patente el desparpajo de Masats y cómo gracias a su carácter se sobrepone a la impresión de visitar El Pardo para fotografiar al mismísimo Caudillo.

(R. Masats, Barcelona, 17 de noviembre de 2000) -“Esta foto te explicaré cómo la hice. Me encargaron unas fotos unos arquitectos. Quisieron decorar la central de la Caja de Ahorros de Huelva. Me pidieron que hiciera fotografías de Huelva para, después, hacer grandes ampliaciones en blanco y negro. Yo me fui a Huelva. Hice las fotos. Les hice la faena y me dijeron que las querían a dos metros por tres. Entonces había pocos laboratorios que ampliaran tales tamaños, y me lo hizo Paco Català-Roca, que tenía un estudio -aparte de su obra personal-, que si le pedíamos cosas los fotógrafos amigos, nos las hacía. Cuando estuvieron hechas todas las ampliaciones -y ya estaba todo montado-, al director de la Caja de Ahorros de Huelva se le ocurrió decir que: «este fotógrafo que le gustaba tanto...» que hiciera un retrato de Franco para ponerse en su despacho. A mí me llamaron diciéndome si me importaba hacer un retrato de Franco. Cuál sería mi sorpresa, cuando, al cabo de una semana, me llamaron de El Pardo diciéndome que tal día, a tal hora, me espera Franco para hacerle una foto. Yo cogí mi Hassel, me fui para allá, y la gente en recepción me dijo: «Espérese aquí, si acaso vaya preparando el equipo...» Yo preparé el equipo y cuando acabé, salió Franco y me dijo: «¿Qué quiere que haga?», «Pues mire, siéntese aquí y le haremos las fotografías». El hombre se sienta, pongo la Hassenblad con un 150 para hacer un retrato y tal, saco el fotómetro de mano, me acerco a él, le mido la luz, y cuando vuelvo a la cámara para mirar por el visor, toda la luz me ha cambiado. Vuelvo coger el fotómetro, vuelvo a medir la luz... y la luz cambiaba, porque había nubes, y yo tenía que cambiar el diafragma y tal... 
Y Franco me mira y me pregunta: «¿Por qué mira tanto la luz?». «Es que hay nubes y cuando sale el sol tiene un diafragma y cuando hay nubes tiene otro». Y dijo: «¡Ah bueno!, pues no coja el fotómetro que yo le iré avisando». Y Franco me iba diciendo: «Ahora saldrá el sol». Y le ponía entre $5^{\prime} 6$ y 8 . «Espere un momento que ahora se nubla». Y abría el diafragma. Y me tenías allí, haciendo el retrato, y Franco diciéndome qué diafragma tenía que poner. $Y$ eso es lo que pasó con esta foto". 


\title{
CAPÍTULO 6
}

\section{Acervo conceptual de Ramón Masats: rasgos de una poética}

El "texto" que exponemos a continuación -publicado en 1957- es el primero que se conoce de Ramón Masats. Aunque no está escrito de su puño y letra, y su ironía y sentido del humor -característicos de sus escritos posteriores- no se perciban, en él se pueden rastrear alguno de los conceptos que desarrollaremos a continuación y que marcarán toda su carrera:

\begin{abstract}
“El coloquio con Ramón Masats, ganador del V trofeo Luis Navarro, prometía ser movidillo, y, en verdad, que hubo de todo, y para todos. Tirios y troyanos esgrimieron sus argumentos, y, una vez más, se abogó por una u otra tendencia. Diremos, no obstante, que Masats parece estar ya de vuelta de muchas de esas cosas que, en boca de algunos supone el «tremendismo». Inició su exhibición con la foto galardonada. Siguieron a ésta otras de su etapa «abstracta» (no figurativa) y a continuación nos mostró las obras de más reciente factura, entre las que se hallaban algunas de carácter puramente «decorativo» (sin anécdota) y varias de marcada tendencia moderna, tal como se entiende el modernismo en fotografía más allá de nuestras fronteras. Quizá lo más «flojo» de sus ampliaciones sea la técnica y la composición, pero ello está de acuerdo con la opinión que sustenta: Ni composición, ni calidades, ni luces hacen que una fotografía sea buena, sino el «alma» que encierra, la emoción que pueda producir al que contempla. El reportaje -afirma- es arte cuando deja traslucir el «alma». Su justificada carencia de medios dialécticos dificultó en algún momento sus respuestas a las preguntas formuladas por esteticistas más elocuentes. Sin embargo, creímos asimilar su pensamiento y su postura en esta etapa actual: La fotografía debe ser, ante todo, humanidad, o documento humano, verismo, y no falseamiento de la realidad. Ningún otro arte puede captar el momento con tanta autenticidad. El reportaje es pues, hijo de nuestra época. Se debe, por tanto, realizar con hondo sentido humano, y sin mixtificaciones de índole técnica o de encuadre.

Los asistentes siguieron con gran interés el transcurso de esta entrevista que aunó a la justa curiosidad que despierta conocer las opiniones de un ganador del Premio de «Vanguardia» el aliciente de una polémica, suscitada hace tiempo, y contra la cual nada tenemos que objetar, siempre y cuando la discusión discurra dentro de los justos límites de la corrección y la ecuanimidad"1.
\end{abstract}

Lo primero que se puede comprobar tras la lectura del texto es cómo se alude a un conflicto entre "tirios y troyanos": dos tendencias fotográficas opuestas e irreconciliables (no olvidemos que la expresión "tremendismo" se usa de un modo despectivo para calificar a los fotógrafos que realizan fotos de "niños con mocos", aunque Masats parece superar esa consideración). A él se le aplican otros términos como: "abstracto", "decorativo", de "marcada tendencia moderna" influida desde el extranjero... etiquetas, todas ellas, que él siempre negará, aunque le faltaran herramientas dialécticas para hacerlo elocuentemente -como dice el transcriptor-, o desgana en utilizarlas para explicar su obra -como opinamos nosotros-.

Como vemos se rastrean algunos conceptos de importancia fundamental en el Masats de formación. Unos conceptos que mantendrá prácticamente inalterables durante toda su vida aunque quizá los matizará con los años y con la experiencia. Caben resaltar los términos "documento

1 E.V.P., “Coloquios en la A.F.C., con D. Ramón Masats”, Boletín de la A.F.C., junio 1957, pág. 89. 
humano", "verismo" o "no falseamiento de la realidad". Aunque no son menos importantes el "momento", la "autenticidad", la modernidad, la renuncia a la idolatría de la técnica o al encuadre...

Vamos a desarrollar todos los conceptos que aparecen en este primer texto y algunos otros que se planteará más adelante. Intentaremos averiguar qué interpreta, qué entiende Masats por todos ellos, con quién los comparte, hasta qué punto son determinantes en su obra... No seguiremos un orden cronológico en la exposición de las ideas estéticas, pues prácticamente todas ellas se generaron simultáneamente en el mismo periodo y la diferencia de algunos meses en la publicación de tal artículo o en la aparición de aquel libro trascendental no nos parece significativa. Por otro lado, las diferentes aportaciones de los diversos autores que desarrollan y matizan los conceptos que intuitivamente maneja Masats se solapan temporalmente. Masats es absolutamente consecuente con sus ideas (hasta en sus contradicciones) y por ello nuestra exposición seguirá un orden argumental en el que veremos cómo unos conceptos se entroncan con otros de un modo casi previsible.

Desde esta perspectiva estudiaremos, en primer lugar, a qué renuncia, qué niega, contra qué reacciona. Esta negación de conceptos es tan importante para entender la obra de Masats, como las nuevas aportaciones que éste asume. De hecho, la radicalización de alguna de sus posturas sólo se entenderá como respuesta a todo contra lo que Masats y sus compañeros de generación reaccionan.

\title{
6.1. EL NOMBRE DEL ENEMIGO: SALONISMO
}

Como ya hemos señalado, Oriol Maspons se convirtió en el mayor crítico de la fotografía española de su época. Su crítica, mordaz e hiriente, apabullaba por lo elocuente y contundente. Una sátira lúcida que no dudaba en ridiculizar lo consagrado, abofeteando intelectualmente gracias a su genial sentido del humor. Así contestaba uno de los críticos habituales de Arte Fotográfico, Argilaga, reaccionario de pro, a Oriol Maspons después de que éste arremetiera contra su manera de entender la fotografía.

\begin{abstract}
“Oriol Maspons (así firma), haciendo gala de una ironía muy de «La codorniz», afirma -claro está que a vía de ejemplo- que «a un señor que le guste la zarzuela es muy difícil que posea el eclecticismo necesario para que comprenda el sentido moderno que puede animar cualquier medio de expresión», asegurando, a renglón seguido «que si a Argilaga no le gusta la zarzuela merecería que le gustase». $\mathrm{Si}$ alguien le ve la «gracia», que puede que la tenga, que levante el dedo (...) No está, por otra parte, del todo mal su desenfado, e incluso su facilidad para hacer «frases» $y$, es de suponer igualmente, para hacer «fotos»"2.
\end{abstract}

La cita de Argilaga, ejemplifica perfectamente el carácter y el estilo del genial Maspons, peleón, reivindicativo y "toca-narices" profesional, que no dudaba en atacar a nivel personal al rival para hacer valer sus tesis. Argilaga "piropea" lo que de Maspons mejor nos sirve, "su facilidad para hacer «frases»". En efecto, Oriol Maspons tuvo el atino de nominar al "otro", al enemigo, dándole un espejo en el que mirarse a la cara y descubrir su propio nombre: salonismo. Y, por supuesto, en su propio terreno: la revista Arte Fotográfico. En ella plasmó el que probablemente sea el artículo de crítica fotográfica más influyente y que más pasiones levantó, en uno y otro sentido, en su generación. De hecho, el clima de enfrentamiento ideológico entre los clubes fotográficos y el ideario renovador, llegó a su punto culminante con la publicación de aquel artículo (tanto que, junto a su actitud de acoso al salonista y junto a otros textos de 
similar contenido, motivó que en 1958 Maspons fuera expulsado de la Asociación Fotográfica de Cataluña en el transcurso de la II Reunión de Sociedades Fotográficas Catalanas que tuvo lugar en Gavà). Sin embargo, el artículo actuó como un auténtico manifiesto generacional, siendo revindicado por casi todos sus compañeros, asumiendo su peculiar terminología en su vocabulario habitual.

“En principio deseo fijar mi posición; no me declaro enemigo de los Concursos y salones de fotografía. Sería ridículo negar la gran importancia que han adquirido en España, y no puedo oponerme, pero sí juzgar el gusto de los demás. Sirva, pues, este escrito de simple comentario.

Las ventajas a que los Concursos conducen son claras: estimulan al principiante; el cotejo de sus obras con las de los iniciados le obligan a la autocrítica y automáticamente al plagio, y muy pronto por poco que se esfuerce, le llueven a cada fallo copas y medallas (...) El «salonista» llega a un estado en que se siente «gloria local», admirado por sus familiares y compañeros de oficina, que constituyen el público en las salas de exposición, ya que la fotografía de salón a nadie más interesa (...) No se puede considerar que la fotografía «tipo» de salón, es artística por el solo hecho de que el autor tenga este íntimo deseo y ponga todos sus conocimientos a ese fin (...) La fotografía de salón suena a pianola. Si algunas veces pueden atraer sus calidades técnicas, superficiales, es siempre a causa de la falta de importancia del sujeto fotografiado, que es en realidad quien debería dominar.

«La fotografía artística va a lo ridículo por el camino de lo pretencioso.» Esta frase también. Ejemplo claro de que los trucos, sean gráficos o gramaticales, no tienen mucho alcance (...) Estos «artistas de la luz», estas «prestigiosas personalidades» que invaden los Jurados, siempre a petición de alguien que quiere irresponsabilizarse, valoran las obras, encasillándolas en una serie de cualidades y composiciones prefijadas. Son formas «a adoptar» que por ellas mismas no pueden emitir ni reflejar ninguna emoción (...) Y a veces, también, vemos las fotografías que vienen a sustituirlas.

Son las fotografías «modernas», de salón, cómo no, que siguen estando a la altura de las circunstancias, nutriéndose igualmente de los principios propios a la pintura, pero aprovechándose esta vez de la pintura que viene haciéndose los treinta últimos años. La revolución renueva, pues, la forma pero no el fondo del problema. El caso es el mismo, la fotografía de salón sigue siendo pictórica. Sigue cazando en coto ajeno. En 1957, tan poco fotográfico es un bromóleo, que estuvo muy justificado en su época, como una fotografía que pretenda ser cubierta, a lo 1930, o una foto trucada en color de Irvin Pen, que imita una pintura impresionista"3.

Aunque en 1957 Maspons ya había vuelto de su periplo en París, no le hace ninguna falta citar en su artículo a ninguno de los autores que entrevistó en su viaje. Creo que su opinión sobre el mundillo fotográfico es anterior a su contacto con el exterior. Maspons llegó a la conclusión de que la fotografía que se hacía en España se encontraba en un estado "anormal", pues todo el colectivo encontraba como única motivación el concurso y el premio. El problema estriba en el hecho de que, por su propia dinámica "el salón" sólo permitía el plagio, sacrificando la ética en su consecución. Los jurados enseñan y dirigen las obras de los principiantes, y si éstos quieren conseguir algún premio, deberán someterse a sus normas. Los neófitos sólo conocen las obras de los veteranos y éstos sólo se conocen entre sí. Un círculo cerrado, completamente endogámico, que no interesaba a nadie de fuera del "mundillo". Los "salonistas" (a partir de este artículo se llamarán siempre así) se preocupaban únicamente por cuestiones técnicas y/o relativas a los estatus y las jerarquías artísticas. Su fotografía estaba vacía de emoción, muerta, llena de "formulario compositivo"...

3 Maspons, Oriol, “Salonismo", en Arte Fotográfico, nº 61, año VI, enero 1957, pág. 3. 
Ricard Terré llega incluso a calificar a la fotografía salonista (asimilando el término de Maspons) como fotografía "social", aunque también podría haberla llamado gastronómica, pues recordemos que en muchas ocasiones se invitaba a comer al afortunado ganador del salón:

\begin{abstract}
“Sin embargo, a mi entender, la que origina el problema fotográfico español (...) Es precisamente la Salonista como se le viene llamando, SOCIAL como debería denominarse. Para los practicantes no es más que un carnet con categorías para un casino donde en lugar de jugar a los naipes se juega a las fotos, finalidad puramente externa, es en lo externo donde el ejecutante busca su razón de ser; ya que va destinada a la Sociedad, a ésta con sus reglas es a quien le corresponde comprarla a su gusto. Aspiración estética reducida a la moda imperante que pueda impresionar a los jurados formados, mitad molde y mitad impresión, por ignorancia (...) No se entienda que el problema está en las Sociedades Fotográficas, sino en la forma que están organizadas. Tampoco pretendo un cambio en ellas, ya que el mal lo producen sus órganos, los consagrados. Debo hacer constar y ello es cierto, que resuelta del todo incompatible la mezcla de la fotografía social con la fotografía libre, íntima de cada fotógrafo, la fotografía verdad, llana, casi tímida sin aspiración al ARTE, contenta sólo con ser FOTOGRAFÍA"4.
\end{abstract}

Terré coincide con Maspons no sólo en la denuncia del estatus de la fotografía salonista -considerada como un distracción igual que los juegos de naipes por los aficionados e, incluso, por el más insigne de todos ellos, el propio Franco-, sino también en su crítica a los jurados y a la estructura de las asociaciones fotográficas.

Por otro lado, y siguiendo con el texto de Maspons, la fotografía debería preocuparse por el "espíritu del tiempo y de su operador", y no por pictorialismos, sean del siglo pasado o de los últimos treinta años. Maspons arremete aquí contra lo que sucederá años más tarde: la imitación de la pintura "clásica" será sustituida por la imitación de la pintura "moderna" o, incluso, por la imitación de los "temas" de la fotografía renovadora. Las postales bucólicas fueron sustituidas por ancianitas a la puerta de casa, pero no se asumió el fondo de la vanguardia. La imitación, el plagio y la copia siempre serán despreciadas por la fotografía auténtica.

“Convertir la fotografía en una simple diversión y desprenderla de su capacidad de comunicación y denuncia fue el gran pecado de aquellas entidades, que tuvieron una vida activa y floreciente hasta bien entrada la década de los setenta, momento en que, a causa de su inoperancia, iniciaron una larga e irreversible agonía provocada por un autoconsumo feroz y la más absoluta incapacidad de trascender los muros reclusorios de sus sedes para instalarse en la calle, donde hervía la realidad" ${ }^{\prime \prime}$.

Seis meses después del artículo de Maspons apareció una tímida respuesta por parte del sector conservador (representado en este caso por Raimundo Costa Terradellas, secretario de la Agrupación Fotográfica de Cataluña) defendiendo al salonismo, y que -con clara referencia al epígrafe del artículo de Maspons- se titula “Salones! Sí...”. Aunque el artículo en cuestión apareció publicado en el Boletín de la Agrupación Fotográfica de Cataluña en primera instancia, la revista AFAL vuelve a publicarlo junto con la inevitable respuesta de Oriol Maspons. Es decir, que Arte Fotográfico publica el primer artículo de Oriol Maspons, "Salonismo", asimismo, el Boletín de la Agrupación Fotográfica de Cataluña publica la contestación, “¡Salones! Sí...” y

4 Terré, Ricardo, "Fotografía social fotografía libre”, en AFAL, Boletín de información exclusivamente para socios, enerofebrero, 1959.

5 Formiguera, Pere, “La segunda ruptura. La fotografía catalana de los años cincuenta y sesenta", en Naranjo, Juan; Fontcuberta, Joan; Formiguera, Pere; Terré Alonso, Laura y Balsells, David, Introducción a la historia de la fotografía en Cataluña, Barcelona, MNAC/Lunwerg, 2000, pág. 154. 
finalmente la revista $A F A L$ reúne a las dos partes en "Un artículo y una respuesta", texto que incluye la respuesta de Oriol Maspons: "Carta abierta para D. Raimundo Costa Terradellas":

“La lectura del artículo ;Salones! Sí... que nuestro amigo y consocio R. Costa Terradellas publicó en el número de Agosto del Boletín de la Agrupación de Cataluña, nos había movido a escribir unos renglones a manera de contestación. Pero la llegada de una carta abierta de nuestro también amigo, consocio y catalán Oriol Maspons, nos induce a dejar para mejor ocasión nuestro escrito e insertar el artículo de Costa y la respuesta de Maspons" ${ }^{\text {. }}$

La introducción continúa posicionándose junto a Maspons, pero intenta evitar el conflicto personal y advierte que no publicarán más cartas que se dediquen a hacer "demagogia personal", en vez de "edificar sólidos argumentos". Esta advertencia se entiende mejor si leemos el principio del artículo de Maspons, en donde éste se deja llevar por su verbo fácil, su humor y su natural sarcasmo:

“Muy Sr. mío: En la circular para los señores socios de nuestra Agrupación Fotográfica de Cataluña del último mes de agosto, grita Vd. eufóricamente ¡Salones! Sí..., con un énfasis que casi diría digno de mejor causa, inútil al menos, ya que aunque Vd. dijese ¡Salones! No..., grito que sería muy original, pues aún nadie lo ha lanzado, los salones continuarían tal y como son, ni mejores ni peores. He de suponer que le es a Vd. tan difícil comprender lo que escriben los demás como intentar expresar sus ideas en castellano inteligible cosa que evidentemente se resiste a sus aptitudes a juzgar por sus escritos en nuestro Boletín mensual"7.

Del artículo, “Salones! Sí...”, rescataremos algunas citas y después veremos las correspondientes respuestas de Maspons. Con respecto a la evolución del reportaje fotográfico en revistas y periódicos, es curioso que Costa opine que:

“Hace más de diez años esta evolución se está realizando a pasos agigantados y todos han puesto su granito"8.

\section{A lo que Maspons replica:}

“Hablando de la situación en que se encuentra la fotografía española, ignoro a qué velocidad de crucero juzga Vd. debe avanzar una evolución. Encontraría curiosísimo que cualquier cosa que avance «a pasos agigantados» durante más de diez años, como Vd. dice, no haya llegado a su destino. Rebájeme los «pasos de gigante» y déjeme en dos años lo que Vd. juzga once o doce, que al final será Vd., quien pretenda tomar por «menores» a sus esforzados lectores. ¡Hace diez años! Bella época de la artística revista "SOMBRAS»" .

Parece claro que Maspons considera que la revolución fotográfica se ha iniciado hace apenas dos años, en 1955. Esta fecha tiene dos coincidencias interesantes. Por un lado, es justo cuando él mismo empieza a colaborar con la revista Arte Fotográfico con sus entrevistas desde París y, curiosamente, también coincide con el fin de la autarquía. 
Costa arremete contra el ansia profesionalista de Maspons pero este tema nos merece un apartado exclusivo que desarrollaremos con posterioridad. Por otro lado, es curioso que Costa no hable sobre el pictorialismo, sino sobre los pintores y sus obras. Habla del arte reconocido con una mezcla de complejo y de resentimiento:

“De los caminos pictóricos, ¿por qué pronunciamos y escribimos tanto sobre la palabra pictórico, cuando los pintores sólo nos recuerdan para sus fines de propaganda?¿Por qué no dejamos de apuntar en ese sentido y vamos a lo nuestro?"10.

Aquí Maspons comprende que la pintura y la fotografía no son enemigos ni rivales en nada.

“iAh, los pintores! Vd. huye de ellos hace tiempo, despiertan en Vd. una curiosa agresividad (complejito). Yo conozco a muchos: buenos, menos buenos y hasta académicos. Nunca me ha preocupado si tienen prejuicio contra la fotografía. Lo que sí comprendo es que no acepten el «gato por liebre» de la fotografía de arte. Ellos están de vuelta de estos trucos y los hacen mejor ya hace muchos años. Muchos pintores se interesan por la mejor fotografía, especialmente todos los modernos, J.J. Tharrats, por ejemplo, sin tocar una cámara posee seguramente la más interesante selección de libros y reproducciones fotográficas de España y tiene un criterio fotográfico que para sí quisiéramos muchos fotógrafos. Un día le oí decir ante un grupo de pintores que prefería una buena imagen fotográfica a una pintura académica"11.

Costa realiza una aseveración tan simple que prácticamente no recibe respuesta:

"Vemos los esfuerzos inútiles que se hacen para llegar a un «expresionismo», y que en el mismo se refleje el alma; lo único que capta la cámara son gesticulaciones más o menos afortunadas, pero nunca ese algo sublime que es el alma, que no está al alcance de un disparo fotográfico"12.

Como decíamos, Maspons contesta de manera breve pero incisiva $y$, sin duda, hiriente con el comentario de Costa.

“Pretender obligar a los pobres vanguardistas y a los «iluminados» a que fotografíen «almas de verdad» es muy fuerte. Vd. con los gestos no se conforma e incluso llega a la conclusión de que el alma «no está al alcance de un disparo fotográfico». Audaz conclusión; mi mente inmadura no alcanza a tanto"13.

Medio año después de escribir este artículo (1958), y por culpa de la polémica que suscitó, Maspons será expulsado de la Asociación Fotográfica de Cataluña en el transcurso de la II Reunión de Sociedades Fotográficas Catalanas que tuvo lugar en Gavà (Barcelona) y que, de alguna manera, intentaba representar una reacción contra la vanguardia.

- ¿Por qué lo tiraron de la Agrupación Fotográfica de Cataluña?

(0. Maspons, Barcelona, 20 octubre de 1999) -“Porque los machacaba todo el rato con que las fotos que hacían para los salones no tenían ningún interés ni artístico ni de nada, que eran una ficción. También porque yo iba siempre con revistas de moda debajo del brazo. Llevaba el Elle... y dijeron que era maricón porque llevaba revistas de mujer debajo del brazo.

10 Costa Terradellas, Raimundo, “`Salones! Sí...”, op. cit., sin paginar.

11 Maspons, Oriol, "Carta abierta...", op. cit., sin paginar.

12 Costa Terradellas, Raimundo, “¡Salones! Sí...”, op. cit., sin paginar.

13 Maspons, Oriol, "Carta abierta...", op. cit., sin paginar. 
Hicimos una exposición en París, que la organicé yo y El 30×40 en la embajada de España. Una exposición donde había fotos de Masats, Ontañón... y también de la Asociación Fotográfica de Cataluña ${ }^{14}$. Cuando llegaron las fotos de la agrupación tuvimos que eliminar unas cuantas porque eran horrorosas (eran de aquellos contraluces del pastor con la pajita en la boca), además porque tampoco teníamos ninguna obligación de llenar el salón, y tampoco teníamos tanto espacio. Lo decidimos entre Roger Doloy y yo, que éramos los comisarios, porque yo sólo, quizás no me habría atrevido. Y cuando les dije que habíamos tenido que quitar algunas fotos... ¡Se pusieron tan histéricos que me expulsaron de la agrupación! Me dijeron que yo no tenía derecho a escoger las fotos. Te imaginas lo que es un comisario de una exposición que no pueda escoger las fotos...

Una cosa que pasaba en la Agrupación Fotográfica de Cataluña era que no se podía decir que una foto era «mala». Se podía decir que «no me gusta» pero estaba prohibido decir que era «mala», y te decían que no podías criticar una foto «sin estar el autor presente». Yo, claro, les gritaba y les decía incultos e ignorantes. No... lo que peor me supo de mi expulsión fue que ninguno de mis amigos, ni Xavier Miserachs ni nadie, dijera nada. Aunque yo sabía que el nivel de las reuniones bajaría cuando yo me fuese, que es lo que pasó".

A Maspons lo expulsaron por culpa de la intolerancia de unas estructuras arcaicas, amenazadas por su constante reivindicación de lo moderno.

"A l'Agrupació no s'admetien crítiques; deien que tot havia de ser respectat i que no es podia criticar perquè es podia ofendre la gent. Jo m'esperava d'ells més tolerància cap a la crítica i el diàleg. Jo defensava la fotografia moderna, fins i tot dins del salonisme"15.

- ¿Y qué se siente contestando a los consagrados? Por ejemplo a un José Ortiz Echagüe, y diciéndole: -Mire usted, a mí lo que hace usted me parece que está un poco pasado. ¿No tenían ninguna duda?

(R. Masats, Madrid, 17 de junio de 1999) -“No, no teníamos ninguna duda que el salonismo de Oriol Maspons, y todo el ambiente aquél..., es decir, había fotografía profesional de los fotógrafos profesionales que publicaban en las revistas, o había lo que Oriol Maspons llamó muy certeramente "salonismo", es decir, hacer fotografías para ser presentadas a un salón de fotografía, ser premiadas y todo esto. Y la contestación... ¡Hombre, no les sentó nada bien a los viejos! Nos miraban como rebeldes".

-Creo que Oriol Maspons tuvo sus más y sus menos y lo echaron de la Asociación Fotográfica de Cataluña.

(R. Masats, Madrid, 17 de junio de 1999) -“Bueno... no sé si lo echaron o nos fuimos porque no teníamos nada que hacer allí. En el fondo nos daba absolutamente igual, la Agrupación Fotográfica de Cataluña sirvió un poco para aglutinarnos y conocernos todos, pero a partir de ahí ya no nos interesaba en absoluto".

La postura de Masats ante el salonismo quedó absolutamente clara desde el principio. Antes incluso de que el concepto fuera bautizado por Maspons. No debemos olvidar que Masats siempre ha tenido un enorme afán por descubrir imágenes nuevas en motivos próximos. Ese interés por la imagen inédita y por la investigación visual, esa curiosidad por la innovación y la originalidad en sus fotografías -a pesar de la cotidianidad y de la proximidad física de sus sujetos- chocará frontalmente contra

14 La exposición de la Agrupación Fotográfica de Cataluña, a la que ya nos hemos referido, tuvo lugar en octubre de 1956 en la Bibliothèque Espagnole de París.

15 Balsells, David, "Memòries i amnèsies. Extractes d'una conversa amb Oriol Maspons”, en Maspons, Oriol; Balsells, David y Permanyer, Lluís, L'Instant perdut, Barcelona, Fundació “La Caixa”, Lunwerg, 1995, pág. 12. 
la anodina repetición del salonismo, contra la anquilosada normativa de su estética y de sus jurados. Su fuerte carácter le llevará a un enfrentamiento, incluso personal, con algunos de sus compañeros de asociación. Cuando le pregunté a Ramón Masats al respecto me contestó socarronamente:

(R. Masats, Madrid, 17 de junio de 1999) -“Yo creo que fue para tocar los cojones a los pictorialistas. Yo me acuerdo de que antes de la Asociación Fotográfica de Cataluña estuve en una parte fotográfica que había en el Casino de Comercio de Tarrasa. Allí fue donde empecé, donde me enseñaron a revelar y todo esto, o sea que antes de pasar a la Agrupación Fotográfica de Cataluña, la primera relación que tuve con gente, que eran salonistas casi todos, fue en Tarrasa. Entonces hacían concursos, e hicieron un concurso sobre animales. Yo me acuerdo que lo que hice fue un primer plano del blanco y negro del pelaje de una vaca, entonces se cabrearon mucho. $Y$ yo les decía: «iPero esto es una parte de una vaca!», y ellos me decían: «iNo, esto es abstracto!», y tal... Yo creo que en el fondo también me gustaba hacer cosas de éstas".

La expresión "cosas de éstas" es bastante ambigua pero parece claro que hace referencia a dos cuestiones. Por un lado, explica que su primera fotografía era más abstracta, más formal y plástica que su periodo de reportaje puro posterior -y quizá más conocido-. Pero también hace alusión a su actitud de hostigamiento al salonismo. Y es que la situación del panorama fotográfico nacional era desoladora. La renovación no podía consentir aquel anacronismo que suponía el pictorialismo; aquel miedo a evolucionar que defendía (todavía en 1955) Joaquín Pla Janini (1879-1970), a la sazón, presidente de la Agrupación Fotográfica de Cataluña -agrupación en la que se inscribirá al año siguiente, el 4 de julio de 1956, Ramón Masats-:

"Los viejos maestros pueden codearse con las mejores obras que hoy se realizan, sobre todo las ejecutadas con los procedimientos llamados pigmentarios, que hoy debido al modo de ser del aficionado, se puede decir inexplicablemente están desterrados, cuando en realidad es el único medio de poner de manifiesto la capacidad y gusto artístico del mismo.

La mayor parte de las herejías en el arte han comenzado con el grito de reforma, y en muchas ocasiones han terminado mutilando y deformando aquello que deseaban enderezar (...) Son muchas las ocasiones que se impresionan clisés de objetos que se dicen modernos, y aunque en realidad lo sean, no hacemos otra cosa que reproducir lo que otro u otros han creado, por tanto, nuestra obra no tiene nada de original, probablemente será extravagante, porque la hemos visto de una manera anormal y pocas veces es agradable a la vista de los demás"16.

Como ya hemos visto, la opinión de Masats y su toma de postura ante el salonismo es muy inicial, mientras todavía era un aficionado principiante en Tarrasa. De hecho, cuando Masats habla de su primera época se excusa por haber participado en los salones.

-Tú llegaste a hacer fotografía salonista.

(R. Masats, Madrid, 20 de marzo de 2000) -“ ${ }$ Cuidado! Al principio... pero no era exactamente fotografía salonista. Lo que hacía eran mis fotos... y las llevaba a los salones. Porque en aquel momento... es decir, cuando estás empezando en una cosa, cometes muchos errores, y tienes derecho a cometer muchos errores. Yo los cometí. No hacía fotos para los salones, porque es evidente que nunca jamás me dieron un premio. Pero sí las presentaba en los salones. Todo esto fue antes de la caída del caballo que ocurrió con la vuelta de Oriol Maspons de París, de ver The Family of Man, las cosas que hacía William Klein, Cartier-Bresson... Es decir, de ver otras cosas y decir: «Esto es lo que yo considero que es la fotografía...». Entonces cambias. Pero sí, participé en salones y nunca gané nada en absoluto". 
Esta afirmación no es enteramente cierta. Sí participó en los salones, y también ganó, aunque cuando se presentó fue casi siempre por motivos meramente económicos, como si fuera un encargo profesional. Como veremos, el profesionalismo será la postura que marcará casi toda su obra y la posicionará frente al salonismo. Por tanto, Masats siguió concursando, pero como profesional. Y con la mentalidad de éste, Masats instauró, en una ocasión, un nuevo estatus, una nueva categoría, la del "profesional de los salones". En ella -una vez aprendido el estándar que se repite una y otra vez- aplicará su creatividad a una fórmula ex profeso para contentar a su cliente, el jurado.

Aunque Oriol Maspons acuñara el término salonismo en 1957 y Masats asumiera su concepto en esa fecha (e incluso lo intuyera antes, cuando guerreaba contra los aficionados de Tarrasa), habrá que esperar a 1960 para disfrutar de las palabras del propio Masats contra el jurado salonista. Con motivo de la publicación en Arte Fotográfico de una serie de entrevistas a los ganadores del Premio Negtor de 1960, el propio Masats -ganador del primer premio de esa edición- nos deja un testimonio impagable en un texto, convertido casi en un manifiesto personal, en donde se explaya a gusto y deja bien clara su opinión sobre el salonismo, la fotografía "seudoartística" y los jurados -por contraposición al profesionalismo-.

El texto viene presentado por un escrito del propio director de la revista, Ignacio Barceló, en el que muestra su orgullo y satisfacción porque se han cumplido sus expectativas de futuro en lo concerniente a su apuesta personal por Masats, hecho que ya había quedado plasmado dos años antes en un monográfico de la propia revista dedicado a las fotos de Masats sobre Los Sanfermines. En la entrevista citada es curiosa la diferencia de tonos existente entre Masats y su entrevistador: mientras uno se muestra halagador y satisfecho durante toda la entrevista (igual que el propio Barceló en su editorial), el otro se muestra crítico y severo, y ambas actitudes transcurren paralelas, convirtiendo todo el texto en un auténtico despropósito. En especial, cuando se insiste, una y otra vez, en las consabidas preguntas sobre la técnica, cuestiones que son contestadas apáticamente por Masats. Estas diferencias tan chocantes tienen una razón lógica que el redactor explica detalladamente: en realidad no se trata de una entrevista en directo con Masats. Su ausencia de Madrid por las vacaciones de verano obliga a la revista a enviarle un cuestionario escrito que él lee con calma y detenimiento en la soledad de la casa de sus padres. Por eso sus palabras son tan sopesadas y meditadas. $Y$ precisamente por ello adquieren el valor de un manifiesto, de una declaración de intenciones explícita:

“-Sabemos, por propia experiencia, que cuando se envía una obra a un Concurso se confía siempre en un premio, pues si no se tuviera esa ilusión no se enviaría la obra. Al enviar sus tres obras al «Negtor»¿en cuál de las tres tenía más confianza, y por qué? Con respecto a sus tres obras, ¿cree usted que la elegida por el Jurado es la mejor de las tres?¿Qué ve usted en ella que no esté en las otras dos?

-Esta pregunta es de muy compleja contestación. Indiscutiblemente, al concurrir se hace siempre para ganar. Yo mandé al «Premio Negtor» tres fotografías. Una era mi preferida; una foto que para mí es importante y a mi pleno gusto. La segunda me gusta pero bastante menos que la anterior; es mucho más fácil de conseguir y, sobre todo, de ver. La tercera la mandé pensando en el jurado que yo creía iba a juzgar las fotos. Es la que menos me gusta de las tres. A una Exposición personal mía no la presentaría. Lo siento de verás, pero ésta es la que ha ganado el premio.

Naturalmente sé que esta afirmación mía se presta a mucha polémica posterior. Intentaré explicarme.

Está comprobado que, fotográficamente, la repetición ilimitada de algo, sean hombres, corderos, cruces de cementerio o bolas de billar, con una iluminación efectista, produce una impresión seudoartística completamente primaria y facilona. Este es el caso que estamos comentado. Lo único verdaderamente mío fue el dejar reposar a los corderos para que éstos estuvieran tranquilos y quietos, y luego llamarles la atención bruscamente con una gran voz que les hiciera mirar hacia mí. Es lo único que reconozco mío de la fotografía. Bien poca cosa, por cierto. 


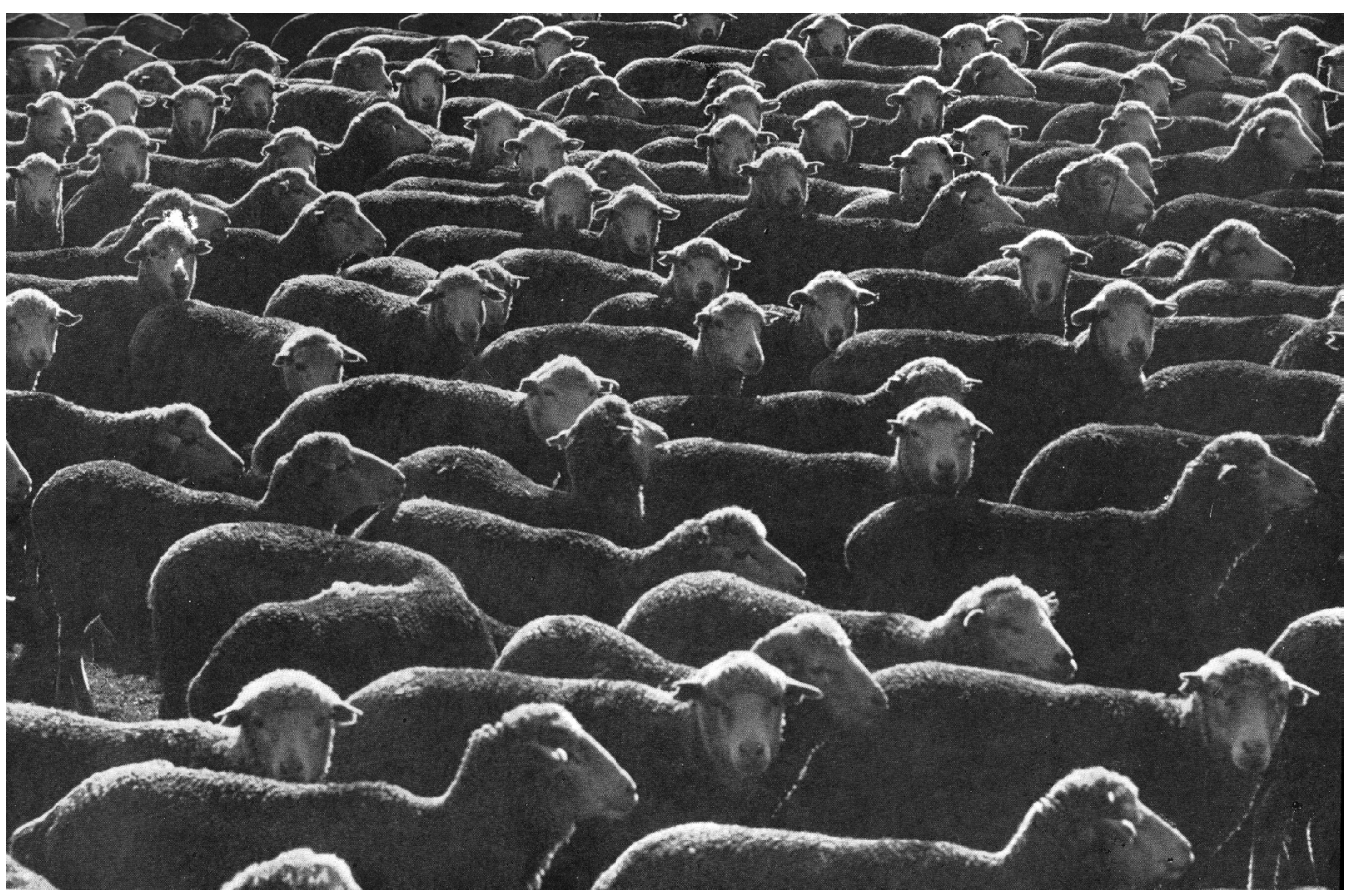

Ramón Masats, "Soria", Premio Negtor 1960. Esta fotografía nunca volverá a ser publicada ni reproducida por Masats.

Soy profesional, y el Concurso iba dirigido a aficionados y profesionales. Como profesional, debo poner todos los medios no solo fotográficos, sino de conocimiento de la mentalidad del cliente (en este caso concreto, el jurado), para que se me acepte y recompense debidamente un determinado trabajo. Desgraciadamente no puedo vivir aún de la fotografía que a mí me gusta, y tengo que ajustarme a lo que se me pide. Esto no es crítica alguna para la Casa Negtor. Solo que creo que tiene mal enfocado el modo de elegir los jurados. Jamás he creído que un buen Presidente de una Sociedad Fotográfica tenga que ser necesariamente un buen fotógrafo, ni tampoco buen crítico. Generalmente se elige para este cargo a personas que, por su gran personalidad humana y rectitud de carácter, son merecedoras de representar a la Entidad lo más dignamente posible y dar justa solución a los conflictos burocráticos e internos que a la misma se le representen. Generalmente estos asuntos les absorben su tiempo libre, y por ello están fuera de la evolución natural en todo arte. Por otra parte, aquí en España, salvo una o dos excepciones, como mucho, carecemos de verdaderos críticos fotográficos. Hay que buscarlos, por ahora, fuera de nuestras fronteras, pero creo que por caminos distintos a los seguidos hasta hoy. Sólo así, el «Premio Negtor», el más importante, sin discusión, de cuantos se celebran en España, además de mostrar las ya sabidas calidades de la marca, puede ser una verdadera escuela de enseñanza fotográfica para los que empiezan.

- ¿Quiere usted decir a nuestros lectores las circunstancias en que obtuvo el negativo, dónde y cómo fue? ¿Vio en seguida en el asunto la gran obra que buscaba?

- La fotografía está tomada durante un reportaje que, por encargo del Suplemento Dominical de «Ya», hice en tierras de Soria, sobre la trashumancia.

-Muchos lectores se interesan siempre por los datos técnicos de las obras, porque en ellos siempre encuentran algo que les hace mejorar su propia técnica. ¿Qué cámara, que objetivo, película y revelador utilizó? 
-Los datos técnicos que puedo facilitarle son algo vagos, como todo reportero, no tomo nota, ni siquiera mentalmente, de los mismos. Debo ajustarme rápidamente a cada problema que se presenta sin preocuparme de más. La cámara fue una Leica $M-3$, y el objetivo creo recordar fue un tele, no recuerdo si un Summarex de 85 milímetros o un Héctor de 135 milímetros. La película fue Plus X, revelada con Pheidone: naturalmente, de la velocidad y diafragma es imposible acordarme. Puse, por instinto, el que convenía en aquel momento.

-Y a propósito de técnica, usted que la domina perfectamente, a juzgar por la obra premiada, ¿la cree necesaria para el triunfo del fotógrafo o estima que debe prestarse más atención al asunto?¿Qué tanto por ciento destina usted a la técnica y qué tanto por ciento al asunto?

-Creo la técnica imprescindible para lograr algo en cualquier expresión artística. Ahora bien, la técnica puede ser tan compleja como sea preciso para exponer una idea. Acepto las fotos cortas de revelado, con grano, excesivo contraste, etc., siempre que sea para mejor valorar la idea del autor. Creo la técnica importantísima, pero no necesariamente la técnica tradicional. Cualquiera es buena si apoya la forma plástica que se quiere expresar. La creo tan importante como para concederle un treinta por ciento del valor total de la fotografía"17.

Por primera vez la falta de locuacidad de Masats desaparece y, como decíamos, el texto presenta las características de un manifiesto personal fresco y ágil, lleno de sinceridad e incluso de pedagogía. Con una intencionalidad evidente, moralizante y ejemplarizante, Masats calcula los riesgos y se lanza a un ataque directo al corazón del salonismo, con la única necesidad de dejar en paz su conciencia. Hay que recordar que el premio "Negtor" era uno de los premios mejor dotados económicamente de toda España (15000 pesetas) y, por lo tanto, uno de los más prestigiosos. Masats podía haber evitado el enfrentamiento mientras se embolsaba el dinero, podía haberse dejado alabar durante una buena temporada por su éxito en el concurso... Sin embargo, Masats saca arrestos y aprovecha la repercusión del premio para hacer una declaración de principios, siendo perfectamente consciente de la polémica que iba a levantar.

Para empezar explica cómo ha presentado tres fotografías al concurso. Dos de su agrado y una tercera del gusto que supone al jurado. Es decir, da la oportunidad al jurado de escoger entre fotografía auténtica (innovadora, moderna, difícil de conseguir y sobre todo de ver) y fotografía salonista: anacrónica, formulista, recetaría, repetitiva. Lamenta que esta última, finalmente, sea la escogida por el jurado. Después de manifestar su decepción, se permite el lujo de descubrir la receta que ha utilizado para efectuar el truco que tanto ha impresionado al jurado: repetición ilimitada + luz efectista = impresión pseudoartística. Sin embargo, Masats da una vuelca de tuerca más y se reconoce como profesional, como un buen experto que conoce la mentalidad de sus clientes y actúa en consecuencia. Analiza el jurado y, como profesional, se torna aficionado salonista para satisfacerlo, por lo menos, en una foto de las tres que presentó. En realidad Masats no arremete contra los aficionados. Muchos de sus amigos lo son y él mismo practicaba la fotografía como diletante hasta no hacía mucho. Masats es consciente de que hay aficionados que realizan una fotografía excelente. El problema del salonismo estriba en los jurados. Ellos son los que se equivocan, ellos son los que anulan a los jóvenes renovadores que surgen en las asociaciones. Achaca su torpeza a su falta de preparación estética, a su poca sensibilidad y predisposición hacia la vanguardia, la modernidad y la autenticidad. Sugiere buscar jurados competentes en el extranjero, puesto que en España no hay más de uno o dos...

Evidentemente, la furibunda contestación llegó con el siguiente número de la revista Arte Fotográfico. El señor Ernesto Gasso Grau -perteneciente al jurado que acaba de premiar a Masats- le

17 Masats, Ramón, “Los 4 primeros premios contestan. Al habla con Ramón Masats, "Premio Negtor 1960»", en Arte Fotográfico, nº 105, año IX, septiembre 1960, págs. 800-801. 
escribe una "carta abierta" donde da recibo del bofetón dialéctico que les ha propinado Masats. De entre sus líneas se destila la indignación de un jurado que, en vez de obtener agradecimiento y lisonja por parte de concursante al que acaba de subir a los altares y al que acaba de otorgar 15000 pesetas de la época, recibe ingratitud y crítica por su mal gusto:

“Tenía razón cuando afirmaba que sus opiniones sobre su «Negtor» se prestaban a muchas polémicas posteriores. Verdaderamente, ha conseguido dar la "campanada"; pero déjeme decirle, Sr. Masats, que su proceder choca con mi idea de la Ética y las normas de la convivencia social.

Me pone usted en un dilema: ¿A cuál de los dos Masats he de creer? ¿Cuándo ha dicho usted la verdad? ¿Al hacer la fotografía y mandarla al concurso o ahora, al descubrirnos una pretendida disconformidad con el jurado, al que ha tomado el número mandándole una obra «tan mala», que usted no habría exhibido en una Exposición particular?

$\mathrm{Ni}$ a usted, como autor, ni a mí, como Jurado, nos conviene la segunda versión. Me quedo, pues, con la primera.

Nada hay más despreciable para un artista que incurrir en una falsedad en su obra. Todos sabemos que la sinceridad debe ser en todo momento la fuerza principal que mueve la función creadora (...)

No cabe comparación entre las fotografías de pedido y las obras para Concurso. Usted se gana la vida vendiendo fotos; pero su profesión no es ganar Concursos, y dudo que su posición económica justifique caer en el vicio de «agradar» al Jurado, vicio tantas veces reprochado a los «salonistas».

Pero tengo otra razón para creer que la fotografía ganadora le gusta. Una foto casi igual a la premiada fue usada por usted como felicitación de Navidad y mandada a sus amigos y conocidos. Me cuesta admitir que mande a sus amistades las fotos de desecho.

De ser cierto que su foto no le gusta (y esta foto va a gustar a todo el mundo), cabría suponer que Masats, el estupendo fotógrafo Masats, es un pésimo juez de sus fotos y, me temo, un mal crítico de las obras de los demás. En este caso nos encontraríamos ante un fenómeno de unilateralidad de criterio bastante frecuente en las personas que acostumbran a exigir mucho de ellas mismas y que casi las incapacita para juzgar las obras de los otros.

Igualmente podríamos también suponer que ha existido una tergiversación de la verdad «a posteriori» he analizado los motivos que pueden haberlo inducido a ello y no me gustan. No son dignos de usted.

El dilema final es éste: ¿Se ha sincerado usted entonando un «mea culpa» o nos ha obsequiado con una estratagema de guardarropía? La verdad clara y limpia sólo la sabrá usted. A mí, sea cual sea esta verdad, me ha quedado la desilusión de haber visto apagarse una estrella"18.

Es precisamente en el profesionalismo donde Ernesto Gasso hace hincapié para deslegitimar a Masats. En principio Masats se ha vendido al profesionalismo, ahogando su creatividad y su sinceridad, sacrificándolas para agradar al cliente. Lo cierto es que nunca más Masats volverá a positivar esta fotografía. No aparecerá en ninguna antológica ni en ningún libro posterior. Quedará para la historia como la única foto, reconocida por el propio Masats, de "virtudes" pictorialistas.

Junto a ello, parte del Premio Negtor consistía en un viaje a la Photokina de ese mismo año, con todos los gastos pagados. La revista AFAL pidió a Masats un texto sobre las novedades de la feria alemana y sobre el viaje en general. Este texto lo aprovechará Masats para reagrupar filas y hacer frente común al ambiente salonista. Cuando presenta a su compañero de viaje José Homs escribe:

18 Gasso Grau, Ernesto, “Carta abierta a don Ramón Masats «Premio Negtor 1960»”, en Arte Fotográfico, n 161, año IX, octubre 1960, pág. 906. 


\begin{abstract}
“Por si no lo conocen personalmente, les diré que Homs es un tipo estupendo, muy elegantón él y cuya única preocupación es hacer buena fotografía para hacer la pascua a sus contertulios de Tarrasa. Y a fe que lo consigue. Con el mismo fin se compró un capuchón último modelo para la Rollei y un sombrero con una pluma de estos tiroleses. Me dejó que llevase un ratito el sombrero y hemos vuelto más amigos que antes"19.
\end{abstract}

Como principio de intenciones no está nada mal. Tácticas psicológicas para hacer rabiar al enemigo, esos contertulios de Tarrasa que Masats conocía tan bien. Y como las posturas son irreconciliables, las personalidades se enfrentan. Así, Masats confiesa sus desavenencias con Álvaro Esquerdo:

“Esquerdo es un señor que siempre está diciendo «Mi obra», muy ufano. Al subir al avión no discutimos porque nos sentamos en sitios diferentes, pero al llegar al aeropuerto y subirnos al taxi que nos llevó a Colonia, empezamos a manifestar nuestras profundas discrepancias. Así pasamos ocho días. Ya se sabía. Cuando estábamos juntos, bronca. Ya nos conocíamos de antes, de la A. F. de Cataluña"20.

La actitud era tan importante como la propia obra. Si el autor era petulante, grandilocuente y hablaba de su trabajo como de "mi obra", ya era suficiente como para considerarlo sospechoso.

Unos meses después de haber ganado el Premio Negtor se vuelve a presentar a otro concurso. En esta ocasión al Salón Internacional de Fotografía, Mafe-Perutz Galerías Preciados, organizado por la Real Sociedad Fotográfica de Madrid en 1960. De este modo contesta con humor y ironía a los que le atacan por concurrir como profesional:

“-No es corriente ver tu nombre en los Catálogos de los Salones Fotográficos. ¿Por qué te has decidido a participar en éste?

Por 15000 razones. Aprovecho esta ocasión para declarar públicamente que lamento ser tan pervertido.

- ¿Piensas seguir acudiendo a Salones de aquí y de allá o piensas reservarte sólo para los que tengan premios en metálico?

No pienso reservarme sólo a los monetarios. Mandaré a los Salones nacionales o extranjeros que económicamente o personalmente crea interesantes para mí"21.

Evidentemente el entrevistador conoce la polémica de las declaraciones del Negtor de Masats y le sigue preguntado con la espera de que diga alguna manifestación jugosa. Aquí Masats se muestra prudente:

“-¿Qué premio esperabas conseguir? La verdad ¿eh?

Pues mira, yo creo que todo el que participa espera alcanzar el primero.

$-¿$ Con esta foto o con otra?

Me parece que lo que tú quieres es que me coja el toro. Pues bien; con otra.

-Desde la fecha de la foto premiada has hecho centenares más. ¿Por qué elegiste ésa que para todos es ya antigua?

Elegí ésta y tres más hechas posteriormente. Las cuatro me gustan más o menos y cuando mando a un Salón, no tengo en cuenta el orden cronológico de las mismas, sino otros factores.

-Visto el Salón ¿cuál hubiera sido tu fallo?

19 Masats, Ramón, “Photokina 60", en AFAL, $\mathrm{n}^{\circ}$ 27, noviembre-diciembre 1960, sin paginar.

20 Ibidem.

21 Anónimo, "Salón internacional de fotografía, Mafe-Perutz Galerías Preciados, organizado por la Real Sociedad fotográfica de Madrid", en AFAL, n² 27, noviembre-diciembre 1960, sin paginar. 
No quiero eludir la respuesta, pero la verdad es que el día de la inauguración, como pasa siempre en las inauguraciones, estuve hablando de otras cosas con una serie de amigos interesantes, pensando en volver solo, después del fallo, para verlo con tranquilidad. Se me pasó el tiempo y el día de la entrega de premios que pensaba ir para verlo despacio, estuve enfermo y no pude asistir. Por lo tanto, no he visto el Salón con detenimiento y menos los premios. Sólo recuerdo en este momento la fotografía premiada de Cualladó, pues está hecha en mi boda, y el primer premio de Vielba que me llamó enseguida la atención y así lo comenté con su autor"22.

Lamentablemente sólo consiguió un quinto premio en este concurso, con el que cobró 1000 pesetas, y con una fotografía que, como ya vemos, tampoco era su preferida (probablemente su apuesta de foto ganadora fuera la de Peñaranda). Es curioso comprobar como Masats siguió concursando a pesar de no tener ninguna probabilidad de ganar. Parece que hay un momento en que Masats se da cuenta de que hay ciertas imágenes que no se pueden publicar en las revistas donde trabaja y que la única manera de darles salida, de que el mundo las contemple, sea en los concursos. Es como una costumbre relicta de su época de aficionado. De hecho, hay varias costumbres de aficionado que Masats conservará. No hay que olvidar que éste empezó en la fotografía como aficionado en una agrupación fotográfica y que siempre tendrá reminiscencias que recordarán sus orígenes. Curiosamente, Masats coincide con Miserachs en algunos "tics" de aficionado:

\begin{abstract}
“Arrastré al profesionalismo muchos tics de amateur, como también lo hicieron mis compañeros procedentes de este campo. Meticulosidad y lentitud en el tiraje, y obsesión por un perfecto acabado, por ejemplo. Pero donde más se notó nuestra procedencia, donde más afectó nuestra ulterior trayectoria, fue en nuestro constante entusiasmo por la actividad, por la satisfacción que nos producía disponer de la oportunidad y los medios para producir algunas buenas fotos, por la sensación que teníamos de seguir gozando con nuestro oficio. Tuvimos que esperar a tener algún desengaño importante, algún apuro económico gordo, algún cliente desaprensivo, para caer en la realidad de que aquello era un trabajo como cualquier otro.

Recordaré para siempre el comentario del fotógrafo y buen amigo Gianni Ruggiero, muchos años más tarde, en una festiva y divertida ocasión veraniega en que Oriol Maspons y yo sacamos nuestras cámaras para registrar la situación, fotografiar a las chicas guapas presentes, etc., sin otro ánimo que el de divertirnos y obsequiar a nuestros anfitriones con alguna fotografía para el recuerdo: «En el fondo, sois todavía unos amateurs» sentenció.

Denotaba, asimismo, nuestra formación de aficionados la ambición de abarcar todos y cada uno de los géneros de la fotografía. Nos interesaba «toda» la fotografía, o por lo menos toda la destinada a ser reproducida en artes gráficas. Cualquier inicial especialización habría sido sentida como una traumática amputación de los demás géneros posibles. Pero esta forma de pensar en sí tenía un trasfondo económico, a la dureza de la renuncia podría unirse la imposibilidad de mantenerse en un solo campo, y la indefinición genérica, estar igualmente dispuesto para un fregado que para un barrido, permitía pescar trabajos en varios terrenos"23.
\end{abstract}

\title{
6.1.1. El antipictorialismo como respuesta a la modernidad
}

Maspons también lideró la lucha contra el pictorialismo. Su argumento, y el de sus entrevistados, es sencillamente la modernidad. Como ya vimos, el pictorialismo fue un movimiento de finales del XIX y principios del XX. Según Maspons ya no tenía sentido practicar aquel tipo de fotografía en sus días:

22 Ibidem.

23 Miserachs, Xavier, Criterio fotográfico. Notas para un curso de fotografía, Barcelona, Omega, 1998, págs. $188-189$. 


\begin{abstract}
“A no dudar confunde Vd. lo académico con lo clásico o no matiza la enorme diferencia de lo que es un clásico, un auténtico clásico, que puede serlo sin necesidad de estar muerto, (como Edward Steichen, Weston, Brassaï o Cartier-Bresson) y el académico, empeñado en hacer belleza siguiendo unas normas fácilmente trasmisibles por la enseñanza. Para que no me tilde de repetir siempre nombres extranjeros, que a Vd. tan poca gracia le hacen, me tomaré la libertad de ponerle un ejemplo con nombres de españoles. La fotografía española ha tenido un solo clásico que es José Ortiz Echagüe y muchos académicos entre los que destacan el Dr. Pla Janini, Antonio Campañá y otros. De los fotógrafos de nuestros días es aún prematuro fijar su calidad total"24.
\end{abstract}

Recordemos que aunque tuviera respeto por Ortiz Echagüe y lo calificara como un clásico al mismo nivel que Weston o Brassaï, al resto de pictorialistas los tacha de académicos, llenos de normas y de trucos "fácilmente trasmisibles por la enseñanza". Maspons opina que el pictorialismo es un puro anacronismo:

“Sougez también hizo bromóleos, muy bellos, pero de esto hace ya muchos años. No es que se avergüence de ello, claro está, como seguramente no se avergonzaría tampoco de haber bailado en aquella época el «charlestón». Pero si hoy no los sigue haciendo es simplemente porque comprende que no está de acuerdo con el espíritu de la época en que vive"25.

Otro motivo para el rechazo visceral del pictorialismo se sitúa en el encorsetamiento de la creatividad de los artistas. Toda la normativa compositiva, heredera de la pintura clásica e impuesta desde el salonismo, queda abolida en aras de la libertad, de la creatividad y de la originalidad. La maestría empieza siempre desde la renovación y la ruptura:

“En otro tiempo, poco tiempo, yo creí en las leyes, en las reglas, en las fórmulas, en los «puntos fuertes», en las «diagonales», en «divinas proporciones»... Hoy no creo más que en la Vida y la Belleza. Es el objeto mismo que me descubre sus propios «encuadres», siempre renovados, jamás impuestos (...) Pues la diferencia entre los maestros... y los otros, es la independencia; a los primeros, todo les está permitido. Pero si uno no se toma este permiso, nadie se lo dará"26.

Al respecto de la fotografía en color, Guy Bourdin comenta cómo el pictorialismo gusta a la mayoría, siendo por ello un movimiento que no es de su agrado. Está demasiado aceptado socialmente y corremos el riesgo de buscar la aceptación general en vez de buscar nuestra propia satisfacción. Tema que remite a la cuestión de los concursos y de los salones de fotografía:

“El color en fotografía - dice- tardará unos años en dar resultados satisfactorios. No es la química que falla. Es la falta de educación estética de los fotógrafos que no está a punto. Dentro de cada fotógrafo hay un antipintor. Esto hace que el fotógrafo no sea suficientemente ágil para apreciar lo que en color es fotográfico.

Me molesta el fotógrafo pictorialista, porque siempre hace la fotografía para gustar a los demás. Hoy, «hacer Cartier-Bresson» es pictorialismo, porque ahora ya ha dejado de disgustar (estamos en París) y forma parte del gusto de una mayoría a quien dirigirse.

24 Maspons, Oriol, "Carta abierta...", op. cit., sin paginar.

25 Maspons, Oriol, “Cómo hago mis fotografías, por Emmanuel Sougez", en Arte Fotográfico, nº 63, año VI, marzo 1957, pág. 208.

26 Maspons, Oriol, “Cómo hago mis fotografías, por Daniel Masclet", en Arte Fotográfico, n 49, año V, enero 1956, págs. 32-61. 
Siempre es la idea de gustarse a sí mismo, sinceramente, la que da las mejores fotografías. Un artista debe ser ególatra, al extremo de no tener vergüenza de hacer imágenes que puedan ser banales para los demás, si es que se siente seguro de lo que hace"27.

El propio Brassaï, que quizás sea junto a Man Ray el fotógrafo de reconocido prestigio más próximo a los movimientos artísticos de las vanguardias históricas, reconoce en un sincero ejercicio de autocrítica, la necesidad de liberarse de la cultura pictórica para poder ejercer la fotografía de una manera íntegra. La paradoja aparece cuando Brassaï critica su formación visual como un lastre. Son necesarios ojos nuevos para una forma nueva de mirar. Por ello envidia la incultura visual de los jóvenes americanos, libres de tradición y de historia:

“Lo más difícil para un fotógrafo actual es liberarse de la «cultura de pintor» que a todos nos afecta. Si bien es verdad que Degas y otros pintores han recibido influencias de la fotografía sin perjudicarles, a los fotógrafos no nos ocurre lo mismo, pues debemos transformar nuestro sentido estético mal acostumbrado.

Véase sino cómo a los jóvenes norteamericanos les es más fácil llegar a ser fotógrafos integrales.

Yo veo en mí, en mis fotografías, influencias varias.

Fotografiando una barca, por ejemplo, me veo seducido por una impresión que luego, traducida, me doy cuenta coincide con la que tuve la primera vez que vi el cuadro de una barca de Van Gogh. Si yo no conociese la barca de Van Gogh, quizá con mi sensibilidad sola sería capaz de crear algo; ahora me es ya más difícil, pues caigo en el plagio involuntario. Van Gogh está en mí"28.

En el fondo lo que se está planteando es la necesidad de encontrar un lenguaje propio y genuino de la fotografía. Esta búsqueda se iniciará partiendo de la premisa de una renuncia explícita a cualquier influencia de otras artes. Por tanto, la pintura debe ser eliminada de la mentalidad del fotógrafo. Esta fobia llevará a los fotógrafos a rechazar cualquier concepto que remita a la misma:

“En fotografía ha quedado demostrado (...) que las imágenes creadas sin más finalidad que la de producir un placer estético, difícilmente pueden zafarse de las influencias canónicas de otras artes"29.

Este argumento conducirá, como ya veremos, a evitar el "arte por el arte", dirigiendo los pasos de la fotografía hacia la funcionalidad y la profesionalización de los fotógrafos. De modo que no se trata de un rechazo a los pintores (el propio Masats tiene como amigos a varios integrantes del grupo El Paso, entre los que destaca Saura), es más bien un rechazo a que la fotografía se vea sometida a las estructuras, los usos y las costumbres de la pintura. Todo ello como reacción a la fotografía pictorialista. No obstante, exponer en un museo, valorar y vender los originales como objetos artísticos e, incluso, considerarse los propios fotógrafos como artistas... de todo ello sospecharán Masats y su generación, aún hoy, por su vinculación con la pintura:

“Sentiría mucho que la fotografía sólo fuese eso: encontrar un tema, montar el trípode (que bien podría ser el caballete de pintor con tela y todo) y disparar el obturador (...) Puedo asegurar que si la fotografía hubiese seguido por este camino de contemplación, intervención, para dar paso a la

27 Maspons, Oriol, “Cómo hago mis fotografías, por Guy Bourdin”, en Arte Fotográfico, n 70, año VI, octubre 1957, pág. 824. 28 Maspons, Oriol, "Cómo hago mis fotografías, por Brassaï", en Arte Fotográfico, n 72, año VI, diciembre 1957, págs. 959 y 1000.

29 Anaxágoras (Josep Maria Casademont), “La II de T.M.M. Una muestra de arte vivo", en AFAL, n 21, noviembre-diciembre 1959, sin paginar. 
creación (procedimiento que tanto nos acerca a los pintores), la fotografía repito, no estaría ni mucho menos en donde está ahora. Ni como medio de expresión ni como arte (...) la fotografía en el mundo nunca ha estado mejor que ahora. Sólo es de desear que así siga, a pesar de los concursos"130.

Sobre la postura antipictorialista y el rechazo a que la fotografía utilice los recursos y modos del arte museístico tradicional, David Balsells y Jorge Ribalta destacan la dificultad de encontrar ampliaciones fotográficas de la época. Ello se debe al poco valor, como obra original, que daban los propios autores a sus obras:

\begin{abstract}
“A pesar de su relativa proximidad en el tiempo, no es frecuente poder ver originales de esta época. Lo más habitual es que los fotógrafos de esta generación se deshiciesen de las copias o que no las considerasen buenas para exponer y que hoy, a la hora de mostrar su trabajo de esta época hagan copias nuevas (...)

El papel de la página impresa en la nueva vanguardia fotográfica de los años cincuenta establece una complejidad especial en la noción de obra original en lo referente a la fotografía de este periodo. Pensemos en el enorme protagonismo de los medios impresos a partir de los años cuarenta, determinante en la comprensión pública de la fotografía, y su expansión como medio de comunicación de masas. Oriol Maspons habla aún hoy del hecho de que deja de hacer muchas fotografías por no tener donde publicarlas y, lamentándose de la desaparición de las revistas y los libros fotográficos, alude a la necesidad de un encargo para hacer una imagen (...) los fotógrafos de la nueva vanguardia son indiferentes, cuando no contrarios, a tal noción de original (...) La idea implícita sería que una fotografía es una especie de imagen en potencia, que puede materializarse en copias que variarían según las circunstancias y cuyo destino final sería no tanto la exposición como la publicación. La tarea del fotógrafo consistiría, en este sentido, en la creación de un archivo de negativos" ${ }^{\prime \prime 1}$.
\end{abstract}

A pesar de ello, ese rechazo de las formas y los modos de la pintura tradicional no es exclusivo de la fotografía y un ejemplo de este hecho lo encontramos en la declaraciones de William Klein sobre el mercado fotográfico actual:

“WK: (...) [Man Ray] Murió antes de su reconocimiento, iy hace nada se ha vendido un Man Ray por un millón de dólares!

$E D: ¿$ Le parece a usted exagerado?

WK: No hay que olvidar que yo me formé en el taller de Léger, quien se reía de los coleccionistas, las galerías, el mercado, etc. Opinaba que el arte debía ser asequible y, de alguna manera, industrial. A algunos discípulos, yo entre ellos, nos daba maquetas para que las pintáramos a escala. Decía que lo importante en la pintura no era la pincelada y que, por consiguiente, una vez terminada la maqueta de una obra, cualquiera podía hacerla. Una de las cosas que más me sedujo de la fotografía era el hecho de que la foto en sí misma no valiera gran cosa, que fuera una simple hoja de papel que, en aquella época, sólo costaba unos francos.

ED: Pero, usted estará atento al mercado, no le queda más remedio que velar por sus intereses.

WK: Aquí ya voy a ser malísimo.¡Me parece totalmente ridículo que por el hecho de que una foto haya sido revelada hace treinta y cinco años, un museo o un galerista pueda pretender que tiene un enorme valor! Claro que, bien pensado, tampoco está tan mal..."32.

30 Maspons, Oriol, “Cómo hago mis fotografías, por Bernard Valette”, en Arte Fotográfico, n 68, año VI, agosto 1957, pág. 648.

31 Balsells, David y Ribalta, Jorge, Joan Colom. Fotografias de Barcelona, 1958-1964, Madrid, Barcelona, Ministerio de Educación, Cultura y Deporte/Lunwerg, 2004, pág. 124.

32 Klein, William y Daviron Eric, William Klein habla con Eric Daviron, Madrid, La Fábrica/Fundación Telefónica, Colección conversaciones con Fotógrafos, 2003, págs. 23-24. 
El argumento esgrimido es muy parecido al de Óscar Tusquets cuando se pregunta por el sentido de la fotografía en las galerías de arte o en los departamentos de fotografía de los museos y concluye que los usos y modos pictóricos son grotescos en fotografía:

“En la fotografía y, sobre todo, en el diseño industrial, la distinción entre original y copia es absurda por definición y da lugar a las situaciones más ridículas. En una copia fotográfica aún podemos suponer una directa intervención del creador en la elección del papel, en el revelado, en la elección del contraste, en algún retoque..., pero estas habilidades son cada vez menos habituales entre los grandes fotógrafos -Robert Mapplethorpe no tiraba personalmente ninguna de sus copias- $y$, con las enormes perspectivas que se abren por la acelerada evolución de la manipulación digital de originales, parecen cada vez menos imprescindibles. Por este motivo es totalmente contradictoria la pretensión de trasladar la fotografía de arte de masas a arte de galería. La copia única que comporta la destrucción del negativo, o la edición limitada, numerada y firmada por el artista, no son más que intentos cursis de aproximar la fotografía a las limitaciones de la pintura"33.

El propio Masats me confesaba sorprendido cómo los coleccionistas buscaban y valoraban muchísimo más las ampliaciones de los años cincuenta que las que pudiera realizar él mismo hoy en día. Su sorpresa se fundamenta en que, según su propia opinión, él positiva mucho mejor ahora que hace cincuenta años. Sobre la animadversión hacia todo lo que oliera a museo, galería o salón comenta:

-¿Tú te consideras artista o artesano?

(R. Masats, Madrid, 4 de septiembre de 2002) -“Yo me considero artesano. A veces hay gente que me considera artista, pero yo me considero un artesano que de vez en cuando hace una foto y hay algo ahí dentro que me dice que he hecho una buena foto. ¿Esto es arte? No lo sé. No me preocupa ser un artista, lo que sí me preocupa es ser un buen profesional, un buen artesano. Cuando dejé la fotografía, creo que fue en el año 1967 o así, Juana Mordó, que era la galerista más importante que había en este momento en Madrid, me propuso exponer en su galería, y aunque unos años antes expuse en el Ateneo de Madrid, en aquel momento estaba mucho más radicalizado y le dije que no. Le propuse que hiciera la exposición de unas personas que me habían enseñado unas fotografías que me parecían estupendas, de unos cuerpos desnudos de mujer con bolas, no se si eran bolas de billar o no. Distribuidas por el cuerpo. Era muy bueno. Lo expuso con mucho éxito Juana Mordó. Y para mí en ese momento hubiese sido un orgullo haber expuesto en esa galería pero no lo hice".

-Pero expusiste en 1964 con Antonio Saura...

(R. Masats, Madrid, 4 de septiembre de 2002) -“Pero era una colectiva. En el caso anterior hubiera sido una individual mía. Y le dije que no".

$-¿$ ¿Y por qué?

(R. Masats, Madrid, 4 de septiembre de 2002) -“Porque en aquel momento yo estaba muy influenciado en una cosa que sigo pensando, que es que el primordial objetivo de la fotografía es ser reproducida, no colgada en la pared. Ahora pienso que si además de ser reproducida puede estar expuesta en la pared... No hay que ser tan radical como era yo en aquel momento. En eso coincido mucho con Avedon. Lo leí posteriormente y me hizo mucha ilusión, me hizo mucha gracia el que Avedon pensara esto también. ¡Vamos que pensáramos igual!".

-Es curiosa tu postura... En el sentido de que te consideres un artesano, y en realidad puedas exponer en los museos junto a Saura, o de que te consideres un intuitivo y realmente seas un lector empedernido con una formación cultural importante... No sé si es una postura tuya... 
(R. Masats, Madrid, 4 de septiembre de 2002) -“No, siempre he tenido, no a nivel fotográfico, sino a nivel personal, admiración por el trabajo manual. La gente que sabe hacer cosas con las manos... Los artesanos para mí siempre han sido muy importantes".

-Y además le has tenido un poco de manía a los artistas.

(R. Masats, Madrid, 4 de septiembre de 2002) -“Hay una frase de Josep Pla, que dice que él se fía poco de la gente que va muy de artista, refiriéndose a Eugenio d’Ors, y tiene toda la razón. A mí la gente ampulosa, es algo que no... ¿Yo soy un artista? Me da igual, no lo sé, no me importa. Lo que sí sé, y de eso sí estoy orgulloso, es que soy un buen profesional. Lo otro lo dejo en la duda. Lo dejo en la consideración de los demás".

\subsubsection{Contra el tecnicismo aséptico}

La técnica no era concebida a principios de los años cincuenta como un mero instrumento a la hora de elaborar una imagen fotográfica. Las calidades tonales, el grano de la emulsión, el enfoque, la velocidad de exposición o la definición eran trabajadas no como un mero medio sino como el fin último de la imagen. Los "defectos" técnicos devaluaban absolutamente las fotografías, pero la mera corrección técnica también las justificaba. En aquella época la gran mayoría de los aficionados desconocía la técnica mínima para fotografiar: se carecía de bibliografía básica, no existían academias donde preparase, tampoco había posibilidad de realizar estudios oficiales... De ahí que las asociaciones fotográficas asumieran un papel relevante a la hora de educar a los aficionados en las cuestiones técnicas. El concurso, por tanto, se convirtió en el examen práctico donde los alumnos demostraban los conocimientos adquiridos en la "escuela" salonista.

“Es lamentable ver que en un gran porcentaje de las fotos presentadas en los salones españoles todo se supedita a una buena técnica, tanto que ahoga a la idea, si es que ésta existe. El resultado es la fotografía artificial, monótona y relamida, que estamos acostumbrados a ver ${ }^{\prime \prime 3}$.

Maspons aprovecha la oportunidad, ya en 1955, en la sección "Cómo hago mis fotografías" de la revista Arte Fotográfico, para arremeter contra la obsesión tecnicista de los salonistas:

“Hay estilos muy fotográficos, no se les puede negar esta cualidad, en que la técnica más estricta es imprescindible. ¿Es posible imaginar una foto de Weston, Man Ray o Sudre carente de ella? Son fotógrafos de imágenes estáticas pero formando un mundo aparte de lo pictórico, oliendo a fotografía por los cuatro costados -pues, ¿a qué han de oler?-, a pesar de dar exposiciones seguramente superiores a medio segundo.

En otros la técnica estricta no es imprescindible. Como artistas fotógrafos, creo se apoyan en bases más puramente fotográficas que la técnica, para valorizar, aunque sólo sea en parte, sus fotos. Como Brassaï, como Cartier-Bresson, Doisneau o Haas, a los que les es dado el privilegio de prescindir hasta cierto punto, de ella, para centrar por completo la fuerza enorme de sus imágenes en la expresión, el movimiento, la belleza de un ambiente, en un momento oportuno visto con inteligencia fotográfica.

Aquí está lo mejor, lo genial, lo nuevo, la aportación de valor que puede dar la fotografía a las Bellas Artes en general (...) el momento fugaz ordenado con belleza, o simplemente bello sin ordenar; pero auténtico, que es honradamente lo que ha de distinguirla del plano cinematográfico, que normalmente se crea con ficción.

Así quisiera hacer mis fotografías. No envidio, pues, el vulgarismo técnico que han alcanzado 
nuestros Salones Internacionales. Un cesto con cebollas, o un plato con dos huevos, incluso con una mosca encima si me apuran, puede tener unos blancos maravillosos y unos negros (la mosca) impresionantes; pero si nos acostumbrásemos a considerar la fotografía, en el Arte, como un medio más de representación gráfica, descubriríamos lo pobre y anodina que resulta por comparación, en la mayoría de los casos, con los demás procedimientos con los que injustamente se la quiere hacer competir en igualdad de condiciones temáticas" ${ }^{\prime 35}$.

En este artículo Maspons fundamenta lo que posteriormente caracterizará al resto de su crítica: cita de autores clásicos fundamentales en la historia de la fotografía, pero extranjeros y, por lo tanto, de difícil acceso en el final de la autarquía; alarde de su finísimo sentido del humor (la mosca); y reivindicación de lo "auténtico". Dos años más tarde, en su entrevista a Sabina Weiss, fotógrafa suiza, escribe:

“La fotografía publicada la escogí entre muchas de niños. Precisamente porque a pesar de reunir una serie de notables defectos técnicos su interés no queda disminuido en nada.

La fotografía de este tipo debe ganar su puesto en el mundo de las imágenes, no por competencia en lo estético, sino por su privilegio de autenticidad"36.

En efecto, el rechazo a la fría técnica se produce como reacción ante el anquilosamiento y la falta de autenticidad de la fotografía salonista. No se rechaza de un modo tajante y definitivo, pero deja de considerarse como un valor. Ni tan siquiera a un rasgo pretendidamente estético se le consiente su posición de privilegio. Relegada a un segundo término la técnica se subordina siempre a otros conceptos, como la fuerza expresiva, la honestidad, la intensidad, la cultura...

“Por mucha técnica que aprenda, las ansias comunicativas que le empujaron a elegir la profesión se verán frustradas e impotentes si, por falta de formación cultural, luego se da cuenta de que no tiene nada que comunicar, que no comprende dónde aplicar lo aprendido e incurre en un estéril virtuosismo (...) En el discurso fotográfico, la técnica es sólo caligrafía, ortografía y sintaxis. El mensaje es cultura. Por ello, no me canso de repetir que el perfeccionamiento técnico debe ir siempre acompañado de un buen bagaje cultural, que permita al fotógrafo la comprensión del mundo que le rodea, condición indispensable para ser capaz de contárselo a los demás"37.

Gonzalo Juanes también explica su rechazo a la técnica utilizando un recurso muy didáctico. Explica las consecuencias implícitas en la elección de un elemento tan prosaico como significativo, el tipo de papel fotográfico:

\footnotetext{
“Empleo el papel brillante no por snobismo, sino porque se presta mal a las mistificaciones; es, simplemente, lo que debe ser: un vehículo de la imagen (...) Que este tipo de papel denota los defectos de la imagen (grano de la emulsión, movidos...) creo que es una ventaja para los fotógrafos honestos (...) Para la mayoría de las fotos que yo hago el grano ni quita ni pone, el virtuosismo a secas tampoco. Lo que cuenta (...) es el contenido.

La fotografía es el medio de expresar algo y no un fin en sí misma. Naturalmente, me refiero a un «algo» interesante" ${ }^{\prime 38}$.

35 Maspons, Oriol, "Cómo hago mis fotografías", en Arte Fotográfico, n 45, año IV, noviembre 1955, pág. 692.

36 Maspons, Oriol, "Cómo hago mis fotografías, por Sabina Weiss", en Arte Fotográfico, n 62, año VI, febrero 1957,

37 Miserachs, Xavier, Profesiones con futuro: Fotógrafo, Barcelona, Grijalbo, 1995, págs. 108-109.

38 Juanes Cifuentes, Gonzalo, “Cómo hago mis ...", op. cit., pág. 472.
} pág. 112. 


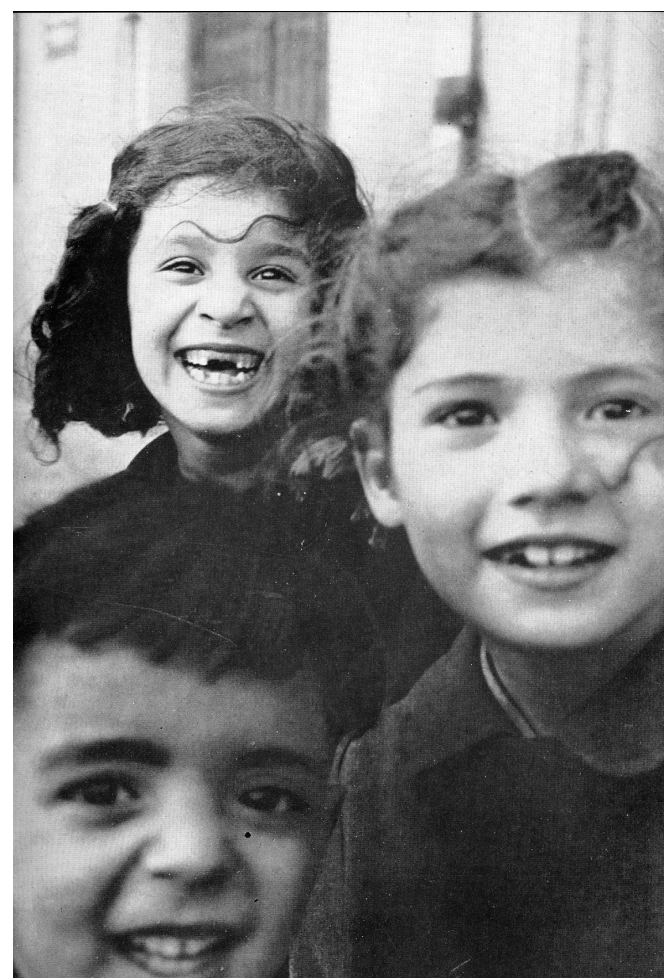

Sabina Weiss, "Desdentada", publicada en Arte Fotográfico, $\mathrm{n}^{\circ}$ 62, febrero 1957.

En la carta que respondió Masats a la revista Arte Fotográfico con ocasión del primer Premio Negtor (1960), aparece una breve reflexión con respecto a la importancia que confiere Masats a la técnica en su obra. Hay que destacar que es la propia revista la que pregunta a Masats por la técnica, cuestión a la que él responde con un tono sarcástico e irónico, sobre todo al porcentualizar el valor de una fotografía. Pese a que ya hemos hecho referencia a ese texto creemos oportuno volver sobre el mismo y reiterar lo señalado por nuestro autor:

“Creo la técnica imprescindible para lograr algo en cualquier expresión artística. Ahora bien, la técnica puede ser tan compleja como sea preciso para exponer una idea. Acepto las fotos cortas de revelado, con grano, excesivo contraste, etc., siempre que sea para mejorar la idea del autor. Creo la técnica importantísima, pero no necesariamente la técnica tradicional. Cualquiera es buena si apoya la forma plástica que se quiere expresar. La creo tan importante como para concederle un treinta por ciento del valor total de la fotografía" ${ }^{\prime 2}$.

Masats supedita completamente la técnica a la idea del fotógrafo. La subordina a la libertad creativa y al concepto, considerando válida cualquier desviación de la técnica tradicional mientras refuerce la expresividad del autor. Paralelamente a ello, el rechazo a la técnica cobra nuevo sentido por razones de carácter moral: 
“¿Qué es lo que yo trato de introducir? La «importancia» y la «intensidad». Son unos de los grandes secretos. Una de las llaves, la belleza fotográfica debe ser «intensificada» para hacerla oír a los sordos, ver a los ciegos, alcanzar a los pobres. Mas el «vigor» corriente no es la «intensidad», sólo es una calidad óptica material; buenos negros, buenos blancos, ¡nada! Mientras que la «intensidad» es, además, una energía espiritual. Una fotografía, para ser bella, para ser «una obra», debe ser intensa, un poco en el sentido en que se habla de un «motor trucado»" 40 .

Como vemos, la "autenticidad" es una cualidad casi espiritual que exige del autor un compromiso ético, una implicación y una entrega completa. No sirven los trucos que tapen nuestras carencias.

“Honestidad no es solamente el pacto que hace el autor con el medio para no traicionar los principios de la fotografía, como piensan otros autores de la época. La honestidad del autor empieza en la selección del tema, comprometiéndose con aquello que realmente le interesa, lo que le obligará a buscar soluciones originales para su plasmación. No existe un tema de moda que sea «honesto»"41.

Ni trucos en la selección del tema, ni en la realización del mismo. La honestidad y la autenticidad implican una gran espontaneidad, sencillez y pureza. No vale aprender una serie de fórmulas compositivas para repetirlas indefinidamente y así resolver los problemas que se nos planteen.

“En la fotografía hay un nuevo tipo de plasticidad producto de las líneas que, instantáneamente, van siendo trazadas por los movimientos del sujeto. Trabajamos en unicidad con el movimiento como algo premonitorio de cómo la vida misma se desarrolla y mueve. Pero dentro del movimiento hay un momento en el cual los elementos que se mueven logran un equilibrio. La fotografía debe capturar este momento y conservar estático su equilibrio (...)

La composición debe ser una de nuestras preocupaciones constantes, pero en el momento de fotografiar sólo podemos hacerla brotar intuitivamente, pues hemos salido a la captura del instante fugaz y todas las interrelaciones involucradas están en movimiento. Aplicando la Regla de Oro: el único par de circunferencias de que dispone el fotógrafo es el par de ojos que tiene. Cualquier análisis de tipo geométrico, cualquier reducción de la fotografía a un esquema, sólo puede ser hecho (debido a su naturaleza misma) después que la fotografía haya sido tomada, revelada y copiada, y luego podrá ser utilizado solamente para un examen post mortem de la fotografía. Espero que nunca veamos llegar el día en que las tiendas de fotografía vendan artefactos en serie en forma de pequeñas rejillas geométricas para colocar en nuestros visores; y que la Regla de Oro nunca sea impresa en nuestro vidrio esmerilado"42.

Esta reivindicación de la espontaneidad, de lo intuitivo, podría salir de los labios del propio Ramón Masats, empeñado en apartar a su fotografía de cualquier pretensión intelectual o artificiosa. Todo lo contrario a lo impuesto desde el mundo salonista, lleno de normas y reglas compositivas. Precisamente, al respecto de la reducción de la fotografía a un mero "esquema", se refirió Masats en el comentario a unas fotografías del propio Cartier-Bresson:

40 Maspons, Oriol, "Cómo hago mis fotografías, por Daniel Masclet...", op. cit., pág. 61.

41 Terré Alonso, Laura, "La fotografía según Gonzalo Juanes durante el periodo AFAL", en Juanes, Gonzalo y Terré Alonso, Laura, Gonzalo Juanes... ese declinar de la luz..., Barcelona, Lunwerg/ Ayuntamiento de Gijón, 2003. pág. 24.

42 Cartier-Bresson, Henri, "Henri Cartier-Bresson (1948). El instante decisivo”, en Fontcuberta, Joan, Estética fotográfica. Selección de textos, Barcelona, Blume, 1984, págs. 195-196. 


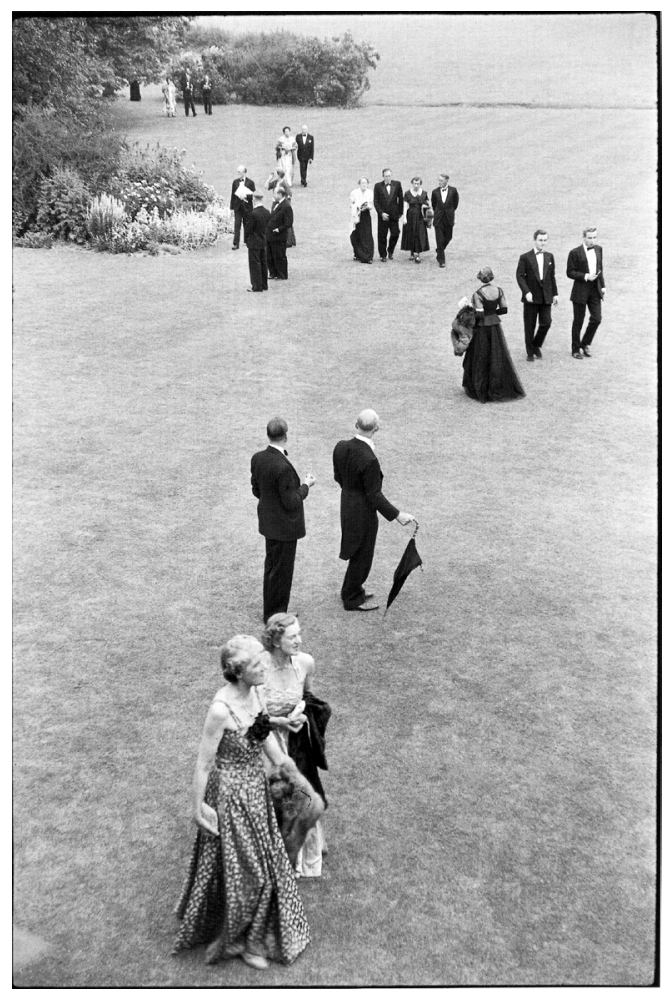

Henri Cartier-Bresson, "Entrada a la ópera de Glyndebourne, Inglaterra", 1953.

(R. Masats, Madrid, 20 e marzo de 2000) -“Esto es Cartier-Bresson. Sólo he puesto dos fotos de él en esta recopilación por error. Ésta es de una casa de citas de Alicante. Por un error mío no he puesto más fotos. Ésta es otra... ¡Qué importancia tiene el paraguas! Una cosa tan sencilla. Si quitas el paraguas... Es más del cincuenta por ciento de la foto. Lo primero que tenéis que aprender es a ver, luego... las cámaras y las ópticas... Lo importante es ver. Yo no soy muy aficionado... Creo, por supuesto, que todas las fotografías tienen que tener un ritmo interno; pero estas cosas que se señalan como unos triángulos, «Y por aquí va la fuga...» y todo eso... todo esto son unos conceptos pictóricos absolutamente anticuados que nunca me han preocupado. Pero... ¡la armonía que tiene y centrada en este paraguas! Verdaderamente me parece una foto muy sencilla y muy hermosa. La realidad es tan rica (...) Lo que sí tienes que hacer es prever lo que puede pasar. Hay que mirar qué cosas te pueden incidir dentro de la fotografía. Es importante saber prever lo que va a pasar por el cuadro para esperar".

Frente a la grandilocuencia del salonismo, frente a su pretenciosidad y su artificiosidad, Maspons ensalza la normalidad, la modestia, el recato. Sabe que sus objetivos y sus instrumentos son otros. El espectáculo de la vida, la cotidianidad, esos pequeños detalles que confieren verdad a unas imágenes sinceras, auténticas:

“«Brassaï posee este don raro que tantos artistas desprecian: una visión normal. Henry Miller»

Este hallazgo de Henry Miller, el de que un artista pueda tener una visión normal, es quizá la virtud más espectacular de la fotografía propiamente fotográfica (...) Esta «visión», que da fotografías aparentemente tomadas al azar por un hombre que no ha querido darles otro valor que el inherente a los fenómenos, nos impresiona por la autoridad que de ellas se desprenden. 
Cartier-Bresson es para mí el fotógrafo con «visión normal» más grande que ha existido.

Brassaï está, para mí también, a la cabeza de otra escala de valores (...) Brassaï, nos miente sin recato, como el bueno de Doisneau"43.

En su entrevista a Sabina Weiss, Maspons retoma la realidad como exigencia de la modernidad. Los tiempos de la idealización y de la poetización del pictorialismo han pasado:

"Sabe que la fotografía trata de apaciguar el hambre que siente nuestra época de realidades. Y creo que es por este solo hecho, la realidad que trasciende en sus imágenes, hace que éstas sean aceptadas tan unánimemente por el público" ${ }^{\prime 4}$.

La autenticidad es un valor de difícil concreción. Independiente del tema o de los materiales utilizados, parece responder a una actitud determinada que podría situarse entre la sinceridad, la inquietud, la valentía y la honestidad con uno mismo:

“-Jamás he creído ni en temas clásico ni modernos; sólo creo que cambia la visión del fotógrafo que debe adaptarse a su tiempo. Todo es siempre igual, sólo cambia el hombre y su forma de ver. Los grandes maestros de mil ochocientos y pico, Cameron, Atget, Nadar, etc., han sido seguramente superados, pero sólo por el factor tiempo y la lógica evolución técnica. Me gusta compararlos con los nuevos maestros, y, desde luego, sus fotografías resisten perfectamente la comparación, ya que poseen la fuerza y verdad que sólo pueden transmitir los verdaderos artistas, y todo ello por una sola razón: fueron sinceros"45.

Como se puede comprobar, el propio Masats no acierta a definirlo, aunque es posible que la inquietud sea una condición indispensable para conseguir la autoría.

“-Ustedes, tal vez sin quererlo, hacían fotos de autor.

-Teníamos una inquietud que era como buscar una autoría"46.

En una de nuestras entrevistas se nos ofrecen pistas y ejemplos de autores "auténticos". Aunque todos los autores citados son actuales, Masats los escoge premeditadamente alejados de su estilo fotográfico para que no haya ninguna confusión con los motivos que le inducen a admirarlos.

(R. Masats, Madrid, 20 de marzo de 2000) -“Es realmente una contradicción. Es algo que... La autenticidad, la gente que es auténtica a mí me... García Álix es uno de los mejores fotógrafos de España. Me lo encontré cuando le dieron el premio Nacional de Fotografía y le dije que si todos los premios nacionales tuvieran su autenticidad y su clase otro gallo cantaría. Si habéis visto su libro, él empezó haciendo $35 \mathrm{~mm}$ y luego ha hecho $6 \times 6$. La técnica suya en el positivado... Es un fotógrafo que no sé cómo resultaría si positivara esos temas tan duros que fotografía, con el sistema tan duro que tengo yo para positivar. Ha hecho un contraste, por supuesto pensado, pero creo que retrata lo que él ve, pero lo positiva como él es. Es un tío muy dulce, no tiene nada que ver con la dureza de los temas que trata. Trata unos temas verdaderamente duros, y en lugar de darles más dureza a través del revelado o del positivado y la película que gasta... En lugar de darles más dureza lo que hace es suavizarlos. Fotografía unos temas duros, que a él le interesan, pero los revela con la dulzura que él tiene. Pero es cierto. Alberto García Álix no tendría que

43 Maspons, Oriol, "Cómo hago mis fotografías, por Brassaï", op. cit., págs. 959 y 1000.

44 Maspons, Oriol, "Cómo hago mis fotografías, por Sabina Weiss", op. cit., pág. 112.

45 Masats, Ramón, “Los 4 primeros premios contestan. Al habla con Ramón Masats...", op. cit., pág. 801.

46 Amestoy, Ignacio, "Ramón Masats. Maestro del reportaje gráfico", en El Mundo. El Mentidero, n 5794, año XVII, 23 de octubre de 2005. 
gustarme pero me gusta mucho porque es auténtico. ¿Me entiendes?"

-Entonces, ¿Cuál es el denominador común... la autenticidad?

(R. Masats, Madrid, 4 de septiembre de 2002) -“Yo creo que sí. Como me puede gustar Witkin. Me gusta mucho. ¿Sabes quién es Witkin? Un podrido que no tiene nada que ver conmigo, pero es un tío auténtico, también me gusta mucho. Este tipo de fotos que están tan manipuladas... Es que si te pasas hay que pasarse mucho. No sé si tendré que ir al psicólogo porque me gustan mucho estas cosas.

(R. Masats, Madrid, 20 de marzo de 2000) -“Con Mappelthorpe también. Como todos sabéis era homosexual, era muy descarado y fotografió el miembro masculino con una sensibilidad, igual que sus flores. También hizo pornografía. Es lo más pornográfico en homosexual que puede haber. A mí me gusta muchísimo. Quiero decir que yo no soy homosexual, pero me parece un tío de una honestidad y un valor impresionante. Sobre todo tuve la suerte de ver en unos documentales que hizo Paloma Chamorro en la segunda cadena... Creo que fueron tres programas -ahora no sé si fueron de media hora sobre Mappelthorpe- y fue una maravilla cómo el hombre lo explicaba todo... ¡Impresionante! Y como fotógrafo, creo que pocas fotos hay más alejadas de lo que hago yo, y pocas vidas están tan alejadas como la suya y la mía. Y a pesar de ello le tengo una gran admiración. Y como más representativo tengo esta foto que a mí me parece sensacional. El tío que ha sido capaz de vestir a un tío de la tercera planta de El Corte Inglés, porque va maqueado de El Corte Inglés, y por supuesto, miembros de este tamaño, incluso mayores, en Mappelthorpe es frecuente. En el ambiente en el que estaba metido... casi todos están desnudos, en pelotas. Pues dándose... yo te doy, tú me das, tú me chupas, yo te chupo -en fin, para qué os voy a contar-. Pero la idea de vestir de esta manera tan hortera y sacar este cacho mango... a mí me parece una idea cojonuda vamos. Incluso con ese cachito de camisa saliéndose... me vais a perdonar pero a mí esta fotografía de Mappelthorpe me deja..."

- ¿Tú te acuerdas de la crítica que hiciste de la Photokina en 1960?

(R. Masats, Madrid, 4 septiembre de 2002) -“¡joder, sí que estás documentado! Yo es que soy poco de mirar hacia atrás".

-Comentabas de un autor del que decías: "Tiene una falta de alma que asusta".

(R. Masats, Madrid, 4 septiembre de 2002) -“Fijate que todos los que te he citado tienen alma. Witkin es un podrido maravilloso. García Álix... lo que pasa con García Álix es que tiene un gran defecto y es que es español. Ha habido una exposición de Nan Goldin, que no he podido ir porque estaba recién operado, que se ha metido en el mundo de las drogas y tal. Yo he visto fotos de esta señora, será un icono mundial, pero no es fotógrafo. Me parece absolutamente vacía, un invento de estos que se hacen los posmodernos".

En realidad la cita de Masats de la Photokina a la que aludíamos en el diálogo mantenido con él no dice la palabra, "alma", sino "inquietud", término que actúa como sinónimo de "autenticidad" y "honestidad":

“En la tercera va Ernst Haas. Muchas de sus fotos en color ya son conocidas nuestras. Nueva York, Venecia y sus ya clásicas fotos movidas de toros, carreras de caballos, rodeos y últimamente esquí acuático. Pero además de esto ha presentado unas cosas completamente diferentes, hechas en su estudio de Nueva York con flores, plantas y luces artificiales que son verdaderamente estupendas y completamente diferentes a lo que de él conocíamos todos. Creo están hechas para publicidad y aportan algo verdaderamente nuevo al concepto de fotografía en color.

¡Ave María Purísima! No se les ha ocurrido nada mejor que poner a su lado a Fritz Henle que, como siempre, presenta unas fotos en color correctísimas y enfocadísimas, pero con una falta de inquietud que asusta" 47 .

47 Masats, Ramón, “Photokina 60...", op. cit., sin paginar. 
Como puede observarse, la coherencia de Masats se mantiene inalterable durante cuarenta años, dado que sigue manejando exactamente los mismos conceptos, aunque quizá menos radicalizado por el paso de los años, pero no por ello menos revelador. Conceptos tan resbaladizos y subjetivos como "inquietud" o "autenticidad" que, pese a su vaguedad y difícil delimitación, no pueden quedar soslayados.

\subsection{EL FOTÓGRAFO ES EL OBRERO DE LA CÁMARA}

Como contraste con la generación salonística anterior, preñada de aficionados a la fotografía, la generación de Masats y más concretamente los fotógrafos catalanes (Leopoldo Pomés, Paco Ontañón, Xavier Miserachs, Oriol Maspons y el propio Masats) deciden dar un paso adelante en el ejercicio de la fotografía y resuelven profesionalizarse. Las razones para llegar a tan radical decisión son de lo más variada, pero tal vez estuvieran motivadas por la contemplación del catálogo de la exposición The Family of Man y las posteriores reflexiones que provocó:

“He contado un sinfín de veces el choque que representó para mí la contemplación y exhaustivo estudio del catálogo de "The Family of Man», el descubrimiento de la fotografía como vehículo comunicativo de alcance universal. Si me hubiera hecho falta algo para desterrar para siempre la tentación de la «fotografía artística», para borrar el crédito que ésta pudiera mantener ante mí, el catálogo de esta exposición habría bastado. Pero las quinientas y algo excelentes fotografías que se me ofrecían movían a otras lecturas, a otras reflexiones. Aquellas imágenes habían nacido para Life, para Picture Post, para las agencias Black Star, Rapho o Magnum, tras ellas no había un aficionado de domingo, sino un profesional que las había concebido con voluntad de verlas en tinta de imprenta, para quien el único premio que importaba era una doble página en Life. Comunicar, contar, sugerir enseñar, mostrar, de una forma universalmente comprensible, parecían ser las últimas motivaciones de quienes las habían tomado, y yo, maravillado y con los ojos atónitos, recibía perfectamente el mensaje" ${ }^{\prime \prime}$.

Esta decisión marcó tanto a los fotógrafos catalanes que incluso Miserachs llegó a afirmar:

“Estábamos locos por el control y manipulación de la imagen, sabíamos mucho y conseguíamos maravillas, pero no fuimos fotógrafos hasta que todo nuestro arte y nuestra ciencia fue útil a alguien: hasta que apareció el cliente" 49 .

Josep Maria Casademont también ponía el acento en la necesidad de realizar fotografías de calidad desde el ámbito de la profesionalización. Fotografías que gracias a los medios de comunicación interesasen más allá de las agrupaciones fotográficas y llegaran a toda la sociedad, sobre todo al mundo de la cultura y el arte. Respecto a la segunda exposición de Terré Miserachs y Masats no hay que olvidar que fue concebida cuando Masats ya es un fotógrafo profesional y cuando Miserachs empieza a fantasear con la idea de seguirle en su modo de vida:

“Ha sido la primera vez que en Barcelona -y en España- una exposición fotográfica ha logrado interesar más allá de los límites estrictos de la afición, despertando la atención de amplios sectores de la cultura y del arte, corrientemente ajenos a la actividad fotográfica nacional (...) el verdadero meollo 
de la fotografía de hoy [es] que el fotógrafo dirigiese, también de una vez para siempre, su atención a la publicidad, a la prensa, y a la ilustración, sin desesperar por ello de hacer, en cada una de estas artes aplicadas, verdadero arte con letra mayúscula.

En suma: sustituir el pomposo «artista de la cámara», por el modesto pero fértil concepto de "obrero de la cámara»"

Este concepto, por tanto, reúne dos voluntades: por un lado, la ambición de comunicar a través de la fotografía impresa - gracias a la profesionalización- y, por otro, que esa comunicación sea realizada por un autor íntegro, es decir, alguien que imprima a su trabajo una gran personalidad, que cuente con una opinión propia, con una originalidad y una visión nueva y viva, como para que interese a la cultura y al arte, utilizando únicamente las herramientas propias de la fotografía.

\subsubsection{El profesionalismo fotográfico}

Masats adquiere la mentalidad de profesional muy joven. Aunque sus primeros trabajos del puerto de Barcelona y del barrio de la Barceloneta son eminentemente diletantes (basados en el excursionismo de fin de semana), el planteamiento de su primera exposición junto a Terré y Miserachs en 1957 (con sus fotos sobre Las Ramblas de Barcelona), así como su proyecto al abordar el reportaje de Los Sanfermines (viajó por primera vez en julio de 1956) son completamente profesionales. La selección que presenta Masats a la exposición conjunta con Terré y Miserachs no será una recopilación de diversas imágenes, de distintos temas, fotografiados a lo largo de sus años de aficionado, sino que será un reportaje de un tema concreto, realizado ex profeso, en un espacio limitado y hasta con unos periodos de tiempo completamente reales y competitivos en el mundo editorial -apenas tres o cuatro fines de semana-. Por otro lado, la primera vez que Masats decide viajar a Pamplona se lo plantea casi como un experimento. Él intuye que se maneja con soltura en dos géneros distintos de fotografía: el reportaje humano y la fotografía que puede ser calificada como de "forma", y decide probar con un tema de reportaje para escoger después a cuál de las dos vertientes se dedica profesionalmente: a fotografiar paisajes y formas abstractas en los Pirineos o al reportaje puro. (Más adelante veremos que finalmente encontrará un camino intermedio). Desde esta perspectiva, los dos reportajes actúan como ensayos generales, es decir, como demostraciones de lo que Masats efectuará después en el mundo profesional.

La razón por la que Masats se planteó saltar al mundo de la fotografía profesional apenas iniciada su andadura como aficionado es bastante prosaica y práctica: la manera de entender el negocio de la bacaladería de su padre no correspondía con las ideas de Ramón y la relación entre su padre y él no era muy cordial. Masats no tenía otra manera de ganarse la vida y, visto que la fotografía no se le daba mal, fantaseaba con la posibilidad de trabajar como fotógrafo profesional. Hay que pensar que Masats era el primogénito de su familia, seis años mayor que su hermana pequeña, Francina. En la cultura catalana era l'hereu (el heredero en el que el padre deposita toda su fortuna y todas sus expectativas) y, por ello, el responsable de continuar con el negocio familiar).

(R. Masats, Barcelona, 17 de diciembre de 2000) -“Yo no tenía ganas de seguir con la faena de mis padres que eran bacaladeros. Hasta los veintiséis años yo fui bacaladero... y yo era el heredero. Entonces... «l'hereu no quiere seguir la faena y se va...» y quedarme en Barcelona era un poco violento para todos. Me fue muy bien irme a Madrid, y por eso me fui".

Probablemente su padre nunca entendería la afición de su hijo (recordemos que Masats tuvo 
que robarle el dinero para comprarse su primera cámara) y tampoco coincidieron en la gestión del negocio familiar que llevaban entre ambos.

- Hay un hito personal que creo que ha influido en tu trabajo. Tu relación con tu padre, Anicet Masats, que hace que te dediques a la fotografía profesionalmente, ya que supongo que si tú hubieras tenido una relación estupenda... hubieras estado encantado de llevar la tienda de bacalao...

(R. Masats, Madrid, 15 de diciembre de 2003) -“No sé hasta que punto hubiese seguido en la pesca salada o no".

-Claro, si hubieras tenido una relación personal más fluida a lo mejor no hubieras tenido que abandonar la pescadería y nunca te hubieras dedicado a hacer fotografía profesionalmente.

(R. Masats, Madrid, 15 de diciembre de 2003) - "Puede ser".

-Es lo que me contaste ayer. Le dijiste a Oriol que ya no aguantabas a tu padre y por eso te viniste a Madrid, para poner tierra por medio.

(R. Masats, Madrid, 15 de diciembre de 2003) -“Puede ser, sí".

-0 cuando le quitaste el dinero para la cámara... Desde siempre tuviste una relación de carácter bastante encontrado.

(R. Masats, Madrid, 15 de diciembre de 2003) -“Si”.

-Es que cada vez que mencionas a tu padre es para decir: “¡Es que no me dejaba... y nos peleábamos...!".

(R. Masats, Madrid, 15 de diciembre de 2003) -“Sí, eso es cierto".

-Me comentó Koldo Chamorro que te ofrecieron entrar en la Magnum.

(R. Masats, Madrid, 17 de junio de 1999) -“No exactamente, yo con mi descaro, me fui con fotografías mías a París a ver a la Magnum, y ellos me dijeron que les parecían bien pero que ellos fotos sueltas no les interesaban; que pensara en un buen reportaje sobre España, o sobre un tema concreto de España y que fuera allí y ya veríamos. Entonces yo estaba trabajando en la pesca salada de mi padre, yo no tenía perras para hacer esto y le dije a mi padre que me ayudara económicamente, y me dijo que me dejara de leches...".

“Apunta ahora un nombre: Ramón Masats. El fotógrafo aficionado español más completo. Es una bomba. Ahora se va a París a hablar con Ernst Haas y Cartier-Bresson para ver si se mete en Magnum"51.

Por tanto, su padre, acaso involuntariamente, precipitó los acontecimientos y "ayudó" a Masats a encontrar el incentivo y la motivación que le llevaría al profesionalismo, hecho sin el cual quizá Masats nunca hubiera llegado a iniciar su prolífica trayectoria fotográfica. De cualquier modo, conviene no olvidar que fue el propio Oriol Maspons el que recomendó a Masats a los directivos de la revista Gaceta Ilustrada, donde, de hecho, comenzó su vida profesional.

(R. Masats, Valencia, 25 de marzo de 2004) -“Yo me fui a Madrid en 1957. He vivido aquí desde entonces. Cuando me dediqué profesionalmente a la fotografía me vine. Llegó un momento en que, en el negocio de mi familia, mi padre y yo queríamos ir por caminos diferentes y la fotografía me estaba tirando mucho. Quería hacerme profesional. Había una revista muy importante en España, que era como un Paris Match de aquella época. Era bastante gráfica e importante: Gaceta Ilustrada (para mí era la mejor que había en España). Tenía la dirección entre Madrid y Barcelona. Era una cosa extraña: aunque el que firmaba como director estaba en Madrid la delegación de Barcelona hacía casi más de dirección que 


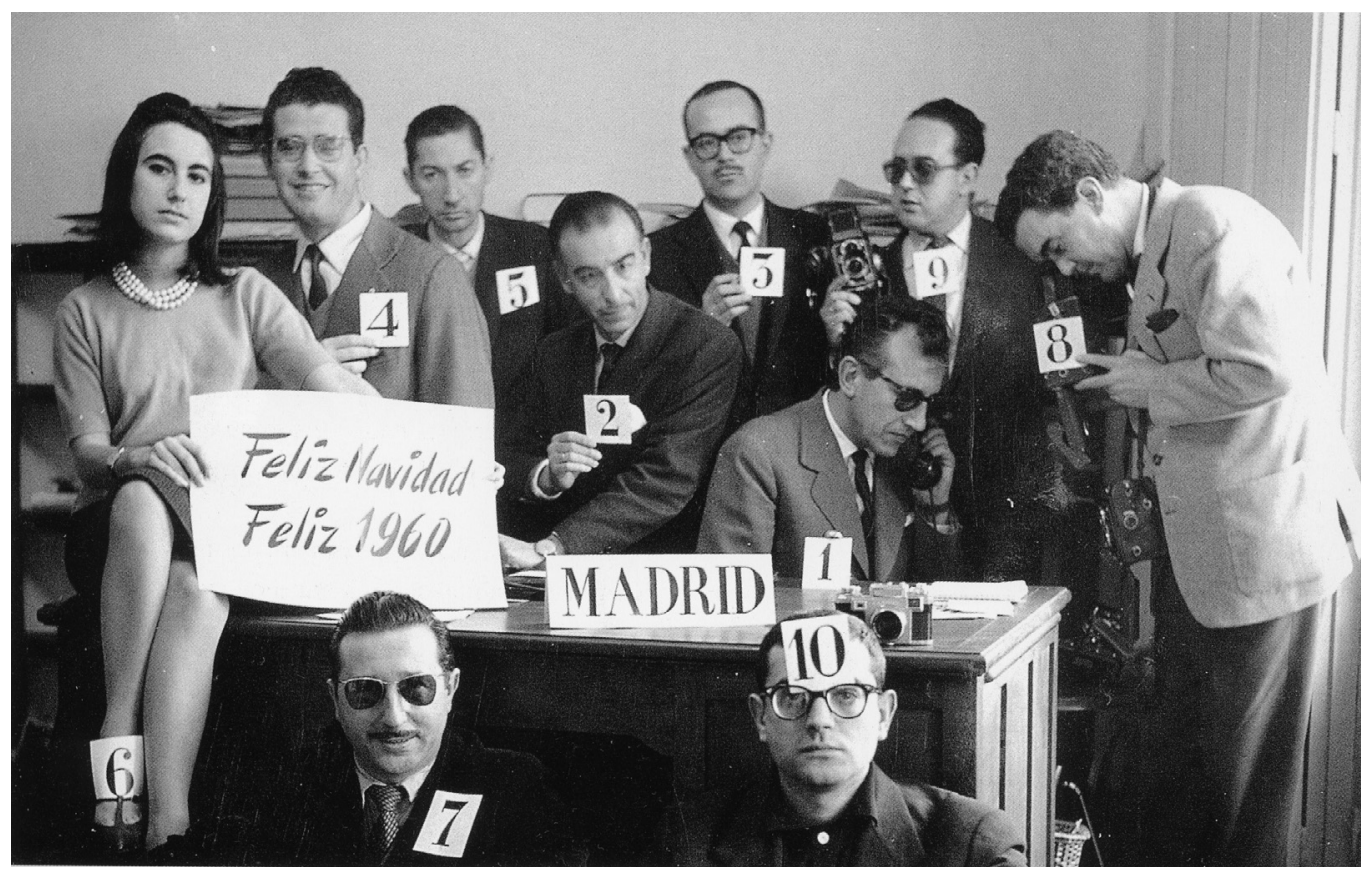

Redacción de Gaceta Ilustrada en 1959. Masats con el número 10.

Madrid. Daba igual. Entonces le pedí ayuda a Oriol Maspons (Oriol Maspons trabajaba ya como fotógrafo profesional en la revista, pero vivía en Barcelona). Hablé con él y me dijo: «¡Hombre, aquí ya estoy yo...!», y yo le dije: «Sí, eso es evidente». "Pero en Madrid... yo creo que podrías trabajar en Gaceta. Hablaré con el director». Consultó con el director. Y el director dijo: "Si es un buen fotógrafo y me enseña cosas que me gustan y tal... pues ya hablaremos...». Oriol me concertó una entrevista y yo cogí mis fotos de aficionado -y un reportaje que había empezado a hacer sobre Los Sanfermines- y me vine a Madrid. El hombre las vio y le gustaron, pero me dijo que fijo no podía hacerme. Yo nunca he querido estar fijo en ningún trabajo, ni en fotografía, ni en televisión. He preferido la libertad frente a la seguridad. Pero en aquel momento me dijo el director: «Si vienes a Madrid te daremos trabajo». Entonces yo fui a Madrid -me establecí con medios muy precarios- y empecé a colaborar con la revista. A partir de aquí, las fotografías que me encargaban eran del sur de España. Digamos que el norte de España estaba cubierto por Oriol Maspons y los fotógrafos catalanes que tenían allí su asentamiento, y eso ha hecho que gran cantidad de mis fotografías sean del sur de España. Del norte de España, sobre todo de Cataluña, tengo poquísimas fotografías. Luego ya ha habido un camino hacia la forma de vivir y la estética andaluza ¡Y para mí Andalucía...! Yo diría que casi un sesenta por ciento de mis fotografías son andaluzas. Luego, cuando he vuelto otra vez a la fotografía, esta vez en color, ha pasado exactamente lo mismo. La editorial Lunwerg con la que he estado trabajando casi veinte años tenía una delegación en Madrid y otra en Barcelona. Y a partir de aquí he vuelto otra vez a Andalucía, cosa que no me importa en absoluto".

(Esther Tusquets, Barcelona, 31 de octubre de 2004) -“Masats se había ido a Madrid... y decía -que es una cosa que no he acabado de entender nunca- que se había ido porque era muy 
amigo de Miserachs y de Maspons y no quería competir con ellos. Parecía que tres fotógrafos eran demasiados para esta ciudad y por eso se fue a Madrid".

De este modo, se puede decir que hubo un reparto del territorio para evitar la competencia entre los propios amigos, ya que como hemos visto, el salto al profesionalismo no fue exclusivo de Masats. También Maspons, Miserachs o Francisco Ontañón se arriesgaron con valentía a hacer de su afición su modo de vida.

“Masats había tomado la decisión de instalarse como fotógrafo en Madrid, Maspons acababa de dejar los seguros para profesionalizarse como fotógrafo. En junio me fui a la «mili» (...) con el macuto repleto de dudas sobre mi futuro profesional y vocacional. Cuando la terminé -en primavera de 1961 (...) las dudas se habían esfumado, iba a ser fotógrafo, era ya fotógrafo"

Francisco 0ntañón nos contaba por teléfono la aventura de renunciar de un modo completamente irresponsable a un trabajo estable para dedicarse por entero a una pasión mucho más arriesgada, pero infinitamente más satisfactoria. Ontañón trabajó trece años en el Banco Hispano Americano de Barcelona. Dentro del banco hacía sus pinitos y fotografiaba, como aficionado, temas como "la entrega de los regalos de los Reyes Magos a los hijos de los empleados" y otros eventos de este tipo. Cuando Ramón Masats se fue a trabajar a Madrid, la agencia de prensa Europa Press le pidió que recomendara a un fotógrafo para su plantilla. Masats, que conocía a Ontañón de la Agrupación Fotográfica de Cataluña, pensó que su perfil correspondía con las necesidades de la agencia y llamó a Ontañón para que fuera a trabajar a Madrid. Ontañón sólo se lo pensó lo justo. Nunca había trabajado fuera de Barcelona. Cogió un avión y se fue hacia Madrid. Cuando llegó al aeropuerto lo estaban esperando responsables de la agencia y lo llevaron directamente al rodaje de una película de Benito Perojo. Comenta que le temblaban las piernas de la emoción de todo aquel ajetreo. En cuanto revelaron las fotos le propusieron que se quedara a vivir inmediatamente en Madrid y que trabajara para la agencia. Ontañón se volvió a Barcelona para consultarlo con la familia y, finalmente, para despedirse del banco. En el banco se creían que se iba a pedir unos días de excedencia o unos meses, ya que estaba fijo, pero él se dio de baja y quemó las naves con el asombro y la incredulidad de sus compañeros. Se volvió a Madrid para un traslado definitivo. Los primeros días vivió en un hotel y después en pensiones.

Su segundo encargo fueron las inundaciones de Ribadelgado, donde la ruptura de una presa había arrastrado a muchos habitantes de la zona. No aparecían los cadáveres y fotografió la búsqueda de los buzos. Fotografió cualquier tema. Comenta que aunque todavía no se había inventado la palabra paparazzi (de hecho nunca se dedicaron a perseguir a la gente) había una sección vinculada a la "vida social" donde fotografió la boda de Balduino y Fabiola o la del príncipe Juan Carlos. También trabajó en Gaceta Ilustrada (gracias a un trabajo sobre el Coto de Doñana que realizó por encargo de Gaceta le dieron el Premio Nacional del Periodismo Gráfico) y en Actualidad Española (donde destaca un reportaje sobre los animales que se introducen en las turbinas de los reactores de Torrejón de Ardoz, con texto de Félix Rodríguez de la Fuente). Esa falta de especialización fue característica de todo el colectivo de nuevos fotógrafos. Masats nos comentaba orgulloso cómo ha hecho de todo. Desde reproducir cuadros, a hacer de paparazzi en la boda de La Chunga.

(R. Masats, Valencia, 25 de marzo de 2004) -“Es decir, la escuela que es el estar en una revista 0 en un periódico, en donde un día tienes que hacer un retrato y otro tienes que reproducir un cuadro... es fabuloso. Te da un oficio que es importantísimo. Esa es mi opinión". 


\begin{abstract}
“Nuestra irrupción en el mercado coincidió con el incipiente desarrollo preconizado por los ministros «tecnócratas» de Franco. Tuvimos trabajo para sobrevivir y pudimos ganar nuestra independencia material y mental inmediatamente, pero, eso sí, a base de servir igual para un barrido que para un fregado.

Dar la vuelta a España en un Seat 600 para fotografiar las instalaciones industriales de una compañía azucarera. Ir a Mallorca, alojarme en casa de Camilo José Cela, y orientado por él realizar el cartel de convocatoria de un premio literario. Vivir un mes en Oviedo para, desde allá, realizar la ilustración de un libro sobre el arte prerrománico asturiano. Éstos fueron algunos de los primeros encargos culturalmente enriquecedores que tuve, trabajos que llevaban a pensar que el fotógrafo es un privilegiado" 53 .
\end{abstract}

Maspons, por su lado, revindicaba desde su particular tribuna de Arte Fotográfico la categoría de profesional de la fotografía como oposición a la legión de aficionados salonistas que llenaban las asociaciones fotográficas. Esta reivindicación laboral apareció por la fascinación que produjo la contemplación crítica de las revistas ilustradas de la época y también por la lectura de The Family of Man, libro lleno de profesionales y de "obreros de la cámara" que alcanzaron la categoría de maestros ejerciendo sinceramente su oficio. Por contraste, en España el número de profesionales preparados era irrisorio. En su entrevista a Emmanuel Sougez comenta irónico al respecto del "Grupo de los 15" francés:

\begin{abstract}
“Teniendo en cuenta que el «Grupo de los 15» está constituido, creo que exclusivamente, por profesionales, si en España se quisiera crear un grupo parecido, velando ante todo por la calidad de sus miembros y compuesto por fotógrafos reporteros, de modas, ilustradores y galería, no puedo menos que creer que se llamaría el "Grupo de los dos o tres»" ${ }^{14}$.
\end{abstract}

La clave para entender en su totalidad el concepto de profesional, tal como lo defendía Maspons o tal y como lo practicaban Miserachs y Masats, es la autoría. Un auténtico profesional debía imprimir un sello personal a su trabajo (que ellos nunca llamarían obra) de manera que ese trabajo fuera identificable con su autor con tan sólo leer e interpretar las imágenes como un texto visual, sin necesidad de leer las referencias de los pies de página o la firma. A partir de esta generación de fotógrafos la fotografía española comprende que no existe la objetividad de la fría máquina, que nuestra visión responde a una construcción, que nosotros siempre completamos la realidad de las imágenes fotográficas e incluso de la propia percepción sensorial a partir de nuestra experiencia, que a través del encuadre ya se está seleccionando, determinando y descontextualizando:

“El fotógrafo se enfrenta con la realidad (...) El fotógrafo la observa, espía, acecha, intenta la forma de leerla, de comunicarse con ella (...) En realidad está estudiando el tema, realcionándose con él, haciéndole cosquillas para que se «exprese», se manifieste en una forma adecuada para hacer llegar la imagen en la mejor forma al espectador (...) Está relacionándose con el tema en términos de conocimiento o reconocimiento, de sensibilidad, de afecto, de ideología, de forma. Esta relacionándose culturalmente con él (...) El carácter cultural de esta relación es el responsable de que dos fotógrafos ante el mismo tema realicen imágenes completamente distintas" ${ }^{\prime \prime 5}$.

53 Miserachs, Xavier, Profesiones con futuro..., op. cit., pág. 31.

54 Maspons, Oriol, "Cómo hago mis fotografías, por Emmanuel Sougez...", op. cit., pág. 208.

55 Miserachs, Xavier, Profesiones con futuro..., op. cit., págs. 33-34. 
Este hecho cobra tanta importancia que el protagonista de una imagen deja de ser -en un alto porcentaje- el objeto fotografiado y se traslada al propio fotógrafo que interpretó esa realidad. El teórico que posiblemente más incidiera en este trascendental punto es Otto Steinert y sus famosas exposiciones Subjetive fotografie ${ }^{56}$.

“La noción de fotografía «subjetiva» abraza todos los dominios de la creación personal, desde el fotograma abstracto hasta el reportaje, que parte del análisis psicológico para desembocar en la imagen (...) nuestro movimiento «subjetive fotografie», consiste en una acentuación del factor personal en el acto creador de la fotografía" 57 .

En el catálogo de la exposición antológica que se celebró en España de la mano de AFAL se habla del resultado de la concepción personal del mundo material, del enriquecimiento de este mundo gracias a la sensibilidad del hombre espectador que trasforma en imagen el asunto tratado...

La percepción es una mezcla de los estímulos sensitivos, filtrados o dirigidos o matizados por la experiencia. Por tanto, vemos desde lo que somos y/o según cómo somos. Ante un mismo hecho, por ejemplo un accidente de tráfico, no percibirá igual un guardia civil, un médico, un mecánico o alguien que ya haya sufrido uno. La mirada de cada cual está matizada por una experiencia y por unos conocimientos particulares. Por otro lado, existen reglas, más o menos universales y estrictas, de ordenación perceptiva, las leyes de la Gestalt, que también influyen y modifican la mirada (leyes de cierre, semejanza, agrupación...), leyes que ponen de relieve cómo el cerebro simplifica las imágenes y tiende a reconocer las más sencillas, ordenándolas según la geometría. De este modo, el cerebro tiende a reconocer los elementos que ya había percibido con anterioridad y que ya había experimentado, y más si son elementos geométricos sencillos. Esta experiencia puede ser vivida directamente o a través de la lectura de textos escritos o iconográficos (fotografía, video o televisión). Debido a ello se puede afirmar que cuanto más se ha vivido, leído o visto, más cultura visual y más posibilidades existen para responder a los problemas que se plantean a la hora de resolver una imagen.

(R. Masats, Madrid, 4 de septiembre de 2002) -“Sí, estoy de acuerdo contigo, pero creo que es un cincuenta por ciento. Cincuenta lo que pones tú y cincuenta lo que pone la realidad. Es decir, tú, en un momento determinado, has dicho que es mucho más lo que tú das que lo te da la realidad. Yo lo pondría mitad y mitad. Todo lo demás estoy de acuerdo. De todos modos (...) yo creo que para mentir tienes que ser consciente que mientes. Ser subjetivo no quiere decir que mientas, sino que es «tu» verdad. Pero para mentir tienes que ser consciente, y eso es en lo que no estoy de acuerdo con lo que hace Fontcuberta. En su mentira sí estoy de acuerdo, pero en la mentira de la fotografía no".

No obstante, el control de la autoría debe ser tan estricto que todo debe ser manejado por el fotógrafo de forma voluntaria y consciente, renunciando incluso a que el azar pueda intervenir en la toma de la imagen:

“QQue cómo hago mis fotografías? (...) Nunca al azar (...)

Comprendo que me voy en línea recta, al huir de todo artificio, retórica o simbolismo fotográfico, a una fotografía sencilla, de modesta apariencia, intencionadamente en tono menor (...) Pero estoy convencido de que el camino de la humildad es un buen camino. Además, al buscar esta fotografía casi íntima, conseguiremos algo profundamente subjetivo dentro del objetivismo a que la misma naturaleza de la fotografía nos obliga" ${ }^{15}$.

56 Recordemos que hubo tres exposiciones: Subjetive fotografie $n^{\circ} 1$ (1951), Subjetive fotografie $n^{\circ} 2$ (1954) y Subjetive fotografie $n^{0} 3$ (1958).

57 Steinert, Otto, “Fotografía subjetiva”, en el catálogo de la exposición Otto Steinet, exposición antológica 1950-1960, Almería, AFAL/Dirección General de Bellas Artes, 1960.

58 Juanes Cifuentes, Gonzalo, “Cómo hago mis ...", op. cit., pág. 472. 


\title{
6.2.2. La tensión entre instinto e intelecto
}

Gonzalo Juanes escribió en la revista AFAL un minucioso análisis del libro New York. Probablemente fuera el primer fotógrafo español que conociera de la existencia del libro en un portafolio publicado en la revista italiana DOMUS, en cuyas portadas Klein solía colaborar. Juanes describe el sofisticado lenguaje fotográfico de Klein, donde aúna su gran intelectualización y reflexión, con su intuición y objetividad del medio fotográfico. Es decir, compatibiliza un material, aparentemente objetivo, con una finalidad completamente personal. En esta obra Juanes encuentra una nueva funcionalidad para la fotografía: ni documento objetivo, ni obra de arte colgada en un museo. Klein utiliza la fotografía, la paginación, el grafismo y los textos para expresar su punto de vista, su subjetividad. Aquí, el control por parte del autor es total. Desde la toma de la imagen, hasta su disposición en la página del libro. Todo está escrupulosamente planeado por Klein, incluyendo el azar:

\begin{abstract}
“Estoy convencido de que de posible documental de una ciudad, el libro «NEW-YORK» no tiene más que el título.

A mi manera de ver, el libro que estamos comentando hay que juzgarlo como la expresión de lo que el autor del mismo piensa sobre la gran ciudad estadounidense. Así Klein no fotografía todo lo que hay en Nueva-York, ni siquiera todo lo que es típico de la gran urbe, sino tan sólo lo que es significativo a sus ojos, aquello que mejor puede expresarnos la impresión subjetiva que él tiene de la gran ciudad"59.
\end{abstract}

Lo que más admira Gonzalo Juanes de Klein es lo cerebral e intelectual que resulta su obra. No deja de recordar que su obra no obedece a la casualidad y que no es irreflexiva ni impulsiva. Es todo eso, pero dirigido y canalizado por un auténtico intelectual de la fotografía:

\begin{abstract}
“Aquí es donde empecé a fijarme en la obra de este creador de imágenes, para quien la fotografía no es sino el medio de que se vale para materializar sus especulaciones intelectuales (...) ya he dicho que no es tanto un reportero interesado en informarnos sobre el mundo exterior, como un intelectual que mira en su propio interior, a sus reacciones frente al mundo circundante (...) La perfecta unidad -del libro y el folleto- que forman ambos componentes y el hecho de que su unión consiga un tan alto grado de expresividad, se debe a que ambos son fruto de la mente de un hombre muy cultivado intelectualmente, cosa no demasiado frecuente en nuestro mundo fotográfico"60.
\end{abstract}

De igual manera, Xavier Miserachs exige del fotógrafo profesional-autor, del humilde "obrero de la cámara", una gran preparación intelectual y cultural para dotar a las imágenes de un mayor contenido significativo, de una mayor trascendencia, de una mayor comunicabilidad:

“Lo que sí me atrevo a afirmar es que lleva mucha ventaja quien tiene una amplia curiosidad ideológica y formal hacia el mundo que le rodea, y el hábito de buscar en él pistas y detalles significantes, de hacer lo que suele conocerse como «sacar punta» a las cosas. No cabe duda de que un nivel cultural alto ayudará mucho a ampliar la gama temática y la profundidad y precisión de los signos que faciliten la comunicación"61.

La disciplina de la cámara desnuda, sin trucos pictóricos, conduce a un camino de autoconocimiento. Sólo podemos fotografiar aquello que amamos u odiamos, aquello por lo cual sentimos algo, aquello que no nos deja indiferentes. La visión que tenemos del mundo, es la visión que

59 Juanes, Gonzalo, “Anotaciones sobre el New York”, en $A F A L, n^{\circ} 24$, mayo-junio 1960, sin paginar.

60 Juanes, Gonzalo, ibidem.

61 Miserachs, Xavier, Profesiones con futuro..., op. cit., pág. 39. 
tenemos de nosotros mismos. Está condicionada, como hemos visto, por nuestra experiencia, nuestros conocimientos, nuestro carácter. De ahí la importancia de la sinceridad y de la autenticidad. No podemos mentir a los demás sin mentir antes a nuestra propia conciencia:

“Lo que cuenta en primer lugar, es el hombre, pues un hombre no puede hacer una fotografía de mejor calidad que él mismo, y la mayor parte de los fotógrafos, el 90 por 100, no son ni la mitad de buenos que sus cámaras. Debemos, pues, en principio, perfeccionar sin cesar, sin fatiga, al fotógrafo, al hombre que manda a la máquina"62.

Por tanto, la máquina no importa, la técnica menos. Hablar de reveladores, objetivos o tipos de papel es completamente estéril si no se educa al hombre, cuya principal misión, además, será fotografiar a sus semejantes:

“Para nosotros el mundo sólo existe en función del grado de conciencia que de él tengamos, y esto se reduce a un problema puramente interior. El hombre es, pues, el punto central, la $\mathrm{X}$ de esta ecuación. La fotografía es sólo la técnica que permitirá resolverla"63.

La implicación de los fotógrafos con su obra debe ser total y absoluta. De hecho lo que se valorará de ellos no serán ni técnicas sofisticadas ni aparatosas puestas en escena. La mirada del fotógrafo, su manera de interpretar el mundo, ése es el campo de batalla. El fotógrafo deberá recuperar su propia mirada, liberándose de todas las miradas prestadas, liberándose de los estereotipos adquiridos y de las imágenes contaminadas por otros autores. De este modo, podrá alcanzar una mirada pura y limpia. Partiendo de ella, de sus huellas -que son las imágenes- se podrá rastrear todo su mundo interior, la manera con que su inteligencia organiza la realidad, consecuencia directa de la experiencia del fotógrafo, de su formación y de su preparación. Por ello reclama Daniel Masclet una mayor preparación de los fotógrafos, de los ojos que miran y ven, porque sabe que cuanto más sofisticados y más cultivados sean, ofrecerán imágenes más sugerentes, más complejas intelectualmente, con una mayor polisemia, aunque sean de construcción y ejecución sencillas, aunque sean concebidas desde una "visión normal". Ésa es la habilidad de Masats. Sacudirse los estereotipos de encima para encontrarse a sí mismo y toparse con una mirada intensa, provocadora, dotada con la suficiente ambigüedad para que nuestro intelecto complete los significados y encuentre nuevas interpretaciones.

Masats siempre se ha considerado como un fotógrafo meramente intuitivo y directo, poco dado a las teorías o las sofisticaciones. De hecho, siempre ha disfrutado de una maliciosa delectación al revindicar sus orígenes como bacaladero en contextos supuestamente cultos, posiblemente como provocación y pose vital, como modo de eludir hastiosas preguntas sobre su obra. Al respecto, le hemos oído decir infinidad de veces que de no haber ejercido de fotógrafo hubiera sido regente de una pesca salada. A pesar de ello, para Gonzalo Juanes sólo hay un reportero español que se acerque a la grandeza de Klein. Nuestro Ramón Masats. Sólo él tiene aquellas características que admiraba de la obra de Klein:

“Trazo fuerte, precisión, vitalidad, penetración sicológica (...) Modo de hacer opuesto a toda retórica, directo, descarnado, aparentemente elemental, deliberadamente emparentado en ciertas ocasiones con el de los rudimentarios fotógrafos «al minuto»"64.

62 Maspons, Oriol, "Cómo hago mis fotografías, por Daniel Masclet...", op. cit., pág. 32.

63 Maspons, Oriol ,"Cómo hago mis fotografías, por Bernard Valette...", op. cit., pág. 688.

64 Juanes, Gonzalo, "Anotaciones sobre el New York...", op. cit., sin paginar. 
Pero, ¿qué hay de intelectual en Masats? ¿Dónde está ese raciocinio frío que reflexione y medite la obra?

\begin{abstract}
“[Masats] está muy seguro de sí mismo, no por haber pensado mucho sobre lo que debe hacer sino por no haber pensado casi nada. Tiene un excepcional instinto reportero y eso le salva. Yo me temo que Masats, a pesar de ser tan buen reportero, llega a caer en vulgar, precisamente por exceso de despreocupación intelectual" ${ }^{\prime \prime 5}$.
\end{abstract}

De hecho, la diferencia fundamental entre Masats y Klein, según Gonzalo Juanes, es la diferencia de sus planteamientos. Mientras que Masats atiende a la realidad, al reportaje veraz, donde el acontecimiento marca el momento decisivo de Cartier-Bresson, Klein atiende a su propio yo, a su mundo interior:

“Klein estaba llamado a plasmar un ambiente, un matiz sutil de la realidad que pasaba desapercibido en el tiempo corriente, pero que quedaba subrayado en la fotografía mediante el tratamiento plástico de las imágenes. La fotografía de Masats se fundamenta en otro tipo de búsqueda: el momento oportuno (...) el objeto mismo dándose a ver gracias a la intuición (no a la expresividad) del fotógrafo"66.

No cabe duda de que la figura de Masats es hoy en día mucho más completa que en el año 1958, cuando Gonzalo Juanes escribió estas cartas. Aunque el tiempo puede alterar la percepción de la realidad de un momento histórico, en ocasiones dota a la crítica de una mayor perspectiva sobre el autor y sobre toda su obra, lo que permite incluso llegar a contradecirlo.

\begin{abstract}
“Todo es tan espontáneo, tan poco literario, en la obra de este artista, que una de las principales sorpresas que depara la irrupción en su intimidad es su voluminosa biblioteca. Más que la de un fotógrafo, parece la de un poeta. Cuando no viaja en pos de sus fotografías, Masats lee. «Una imagen no vale más que mil palabras. Palabra e Imagen son cosas diferentes y cada una ocupa su sitio»"67.
\end{abstract}

(Koldo Chamorro, Pamplona, 21 de marzo de 2003) -“Ramón también plantea otra cosa muy interesante. Hay mucha gente que se toma los oficios o las profesiones como un concepto y él, en cambio, determina muy claramente que es una actitud. Y eso le permite, de algún modo, escaparse de ese «estado natural» de que el fotógrafo es un tipo que sólo sabe de fotografía y que lo único que le interesa es la fotografía hasta niveles de desesperación absoluta. 0 sea, saber cuándo se fabricó no sé que lente y cuántos grupos de lentes tiene no sé que objetivo... En cambio a él le interesa mucho más leer. ¿Por qué? Pues porque él sabe que en la medida en que, de algún modo, alimenta su conocimiento, su conocimiento se realimenta a su vez en el trabajo. Y eso hace que a medida que pasa el tiempo sea un poco más escéptico, y eso es bueno".

-Masats renegaba de su formación intelectual, de que su fotografía se viera enriquecida por sus lecturas.

(Koldo Chamorro, Pamplona, 21 de marzo de 2003) -“Sí, eso está muy bien, y yo no se lo voy a discutir, pero entiendo que a medida que uno tiene más información, evidentemente, se es más escéptico y coordina mejor lo que quiere hacer. Es decir, qué es lo que quiere contar y cómo lo quiere contar. Yo mantengo la teoría de que la imagen se edita primero en la cabeza,

65 Juanes, Gonzalo, correspondencia con Pérez Siquier (22-05-58), en Terré, Laura, op. cit., pág. 494.

66 Terré, Laura, op. cit., pág. 495.

67 Memba, Javier, “En el estudio de Ramón Masats, el fotógrafo alquimista”, en Descubrir el Arte, n 89, año VIII, 2006, pág. 111. 
en la mente de uno. Porque sabe qué imagen quiere, tanto por su construcción visual, como por sus contenidos de narración internos. Qué es lo que quieres contar y cómo contarlo. Porque si no tienes la imagen en la cabeza es muy difícil que la encuentres. A no ser que funciones con aquello de que la casualidad me sorprenda... Eso no es cierto".

-¿Tú realmente crees, como creía Gonzalo Juanes, que William Klein es un intelectual mientras que Ramón es un mero intuitivo?

(Koldo Chamorro, Pamplona, 21 de marzo de 2003) -“Aquí hay una cosa tópica y clásica de este país, y es que, desde el punto de vista cultural, llevamos mucho tiempo totalmente colonizados por lo que se hace fuera. $Y$ esa colonización es muy dolorosa porque impide que se valore a la gente que es. Si Masats hubiera sido americano, ahora habría cuarenta mil libros de él, y yo que sé. Como no es americano, que se pudra. Entonces hay que ponerlo en referencia «respecto de». Respecto al trabajo de William Klein... Me parece interesante, dentro de lo que podría ser particular como forma de entender el mundo. Me parece que sí, que hay un aporte, pero también y contemporáneo de él está Robert Frank y Cartier-Bresson. Partiendo del hecho de que la obra de uno es un autorretrato, cada cual elige determinadas opciones o estrategias para hacer su autorretrato. Hay quienes van más de boceto, con las ideas preconcebidas, sabiendo exactamente que es lo que quiere, cómo lo quiere... Y hay otras personas que en cambio no. Tienen un marco general y dicen «Yo me ubico aquí, y voy a trabajar básicamente a partir de lo que ya sé, pero de un modo más intuitivo». ¿Esa intuición, en qué se manifiesta? Pues que a lo mejor es un poco más ingenua, y más limpia, también, desde el punto de vista de la construcción visual de la imagen. Pero esto no es ningún handicap en sí, es una forma de entender el mundo. Yo, desde el principio, he dicho que en la obra de Masats hay una cosa muy importante, y es el tratamiento que da a los espacios. $\mathrm{Y}$ hay muy poca gente que lo haga. Por poner otro ejemplo, con otro tratamiento del espacio, totalmente distinto, está Cartier-Bresson. Los espacios en Cartier-Bresson son tan importantes como la organización o distribución de los personajes. Ahora... ¿Es un handicap ser intuitivo? Yo creo que no.

La intuición no es un destino, ni es una ocupación total... la luz que hay en Ramón Masats, no es una cosa que uno se encuentra... Hay una decisión previa. ¿Por qué? Bueno, porque en aquel momento quiere trabajar mucho el tema de las siluetas... y en el libro del Quijote hay buenas pruebas de ello. Ramón tiene que elegir la hora a la que las siluetas se pueden recortar, una hora de luz potente. Y claro, tienes que tener la imagen metida en la cabeza para saber en qué lugar del escenario vas a crear la escenificación. La tienes que tener en la cabeza, porque sino, no consigues las siluetas ni consigues nada. ¿Y ahí qué es lo que hay de intuitivo? La idea, pero después hay todo un proceso de elaboración muy complejo. Y a mí no me vale mucho que digan... «No, es intuitivo». Pues bueno... La intuición tiene muy mala defensa como argumento. Por eso yo siempre digo que, independientemente de los temas, la forma de trabajar de un fotógrafo se ve en las hojas de contacto. Tú, y cualquiera, ve hojas de contacto y se da cuenta de que la foto que se edita, que evidentemente el fotógrafo, si es fotógrafo, ya la tiene en la cabeza, es la última de la serie. ¿Por qué pasa eso? Porque cuando tú sabes que la imagen está ahí segura... Quiero decir... Es al contrario de lo que se pueda pensar. Hay que hacer los bocetos y las posibilidades de lo que es la imagen definitiva, para que una vez que la tengas, tú puedas reflexionar para saber cómo se ha construido esa imagen, aunque la tuvieras en la cabeza, porque eso te ayudará a construir otras imágenes en la cabeza. Claro, cuando a Eugene Smith le mandaban a fotografiar algo, y le medían la película, Eugene Smith se subía por las paredes. Porque la estrategia suya era precisamente esta. Ir viendo, ir viendo... Él ya sabía qué imagen iba a hacer, pero claro, antes iba cogiendo todos los bocetos...

Aquí, como es un criterio taxonómico, tenemos que decir que «Ramón es un fotógrafo intuitivo». Bueno, yo, que me perdone, tengo mis dudas. Porque todos somos intuitivos. Y luego, 
aparte de la intuición, depende de la formación que tengas, serás más sólido o menos. Ramón es muy sólido y otros lo dudo, porque siempre van a ver qué es lo que encuentran, no van a buscar. «Voy al mercado a ver qué encuentro. Vuelvo a casa a ver qué me he encontrado. ¡Hay huevos!». $Y$ resulta que tienes dos docenas de huevos en la nevera".

\subsubsection{La esquizofrenia del autor profesional}

(Koldo Chamorro, Pamplona, 21 de marzo de 2003) -“Hasta muy final de los años setenta el estatus del fotógrafo no se sabía muy bien lo que era. Estaba en la duda entre lo que era el oficio, el artesanato, el artista, el no sé qué... Analizándolo desde el punto de vista de la artesanía, el que hubiera gente con formación era bastante inquietante y era inoportuno. Xavier Miserachs era médico: pero claro, nunca decía que era un médico que no ejerció nunca. ¿Por qué? Pues porque era inapropiado. Claro, un médico que trabaja con un periodista y el periodista le dice: «iChaval, haz aquella foto!». Es jodido... Entonces, uno ha intentado ser discreto. Yo me he pasado la vida diciendo a mis alumnos: «Mira, antes de hacer fotos, lee, estudia y después ya harás las fotos. Pero primero tienes que saber un montón de cosas, porque en la medida que sepas, tus imágenes van a ser más sólidas». Ramón pertenece a esta generación. Esto no quiere decir que no tenga una formación solidísima -se ve en su trabajo-, ahora, él ha sido discreto. Yo no. Yo he salido a la calle y he dicho que hay que defender el estatus. Y yo, cuando digo estatus, no estoy hablando que si el fotógrafo es un «artista» o es un «genio». No. Simplemente que yo, por ejemplo, pueda hablar de tú a tú con un físico nuclear, porque sé lo suficiente de física nuclear para que el lenguaje, el vocabulario que este hombre usa, yo lo pueda entender, que me resulte comprensible. ¿Si no de qué voy a hablar? Tengo que saber lo suficiente de música para que, si hablo con un músico, sepa de qué va y pueda aprender. Porque él es el que va a enseñar. Claro, me va a enseñar si yo tengo la suficiente curiosidad y formación mínima para que él me pueda explicar".

-Sobre el estatus del fotógrafo en los años sesenta...

(Oriol Maspons, Barcelona, 31 de octubre de 2004) -“Era perfecto, mejor no podía ser, y ahora no se repetirá, por descontado. Ahora he hecho un libro de nenas, de titis ${ }^{68}$, y he pedido un escrito de presentación y me han dicho que sí enseguida: José Luis de Villalonga, Paco Umbral... todos dicen que sí enseguida. Eso lo pide un fotógrafo de hoy en día y no lo tiene".

(Esther Tusquets, Barcelona, 31 de octubre de 2004) - “¿Te lo dicen porque son de otra generación y tú también?"

(Oriol Maspons, Barcelona, 31 de octubre de 2004) -“Puede que sí, no lo sé. Pero nos tienen simpatía, nos aprecian".

- Me comentabas que cuando Ramón Masats se fue a Madrid enseguida hizo amistad con escritores y pintores...

(Oriol Maspons, Barcelona, 31 de octubre de 2004) -“Sí, hizo contactos con la gente intelectual de allí. Por eso te dije que Ramón era más rojo que yo. Porque sus amistades eran más rojas que yo".

(Esther Tusquets, Barcelona, 31 de octubre de 2004) -“Pero es que tú, rojo no eres nada en absoluto".

(Oriol Maspons, Barcelona, 31 de octubre de 2004) -“Nada. Yo era gauche divine. Un ejemplo perfecto de la gauche divine. Era políticamente incorrecto, eso siempre, todavía lo soy ahora".

(Esther Tusquets, Barcelona, 31 de octubre de 2004) -“Mucho".

(Oriol Maspons, Barcelona, 31 de octubre de 2004) -“Mucho, todo lo que puedo. Y eso, el ser políticamente incorrecto era una defensa contra la dictadura franquista, porque no podía estar po- 
líticamente correcto con Franco. Ahora sí. Todo el mundo es políticamente correcto, qué angustia. Hablas con una persona que parece normal y resulta que es políticamente correcto. ¡Qué horror!"

-Entonces aprovechasteis ese momento en que socialmente teníais un estatus elevado.

(Oriol Maspons, Barcelona, 31 de octubre de 2004) -“ ${ }$ Hombre, aprovecharnos...! Nos lo encontramos y nos parecía normal".

Óscar Tusquets nos comenta telefónicamente que los arquitectos eran amigos de los fotógrafos y que entre sí también eran muy amigos. Había muy buen ambiente en ese sentido. Sobre el reconocimiento social de los fotógrafos de aquella época opina que cada profesión tiene su momento, que lo tuvieron los fotógrafos, también los arquitectos, y hoy en día tienen ese nivel de prestigio los cocineros.

-¿Y por qué hoy es imposible?

(Oriol Maspons, Barcelona, 31 de octubre de 2004) -“Sí. Yo creo que hoy en día es imposible. Igual que sería imposible hacer un libro de nenas como el que he hecho sin que todas pusieran la mano y cobraran. En lo que se notaba mucho era en lo de la gauche divine. Aunque Rosa Regàs diga que no (es una tía que para mí no es aceptable en nada, sólo ha sido buena madre, pero nada más). Ésta ha tenido la cara de decir en público que lo de Bocaccio y todo aquello no era clasista, que podía entrar quien quisiera. ¡Sí, en la época de Boccacio hubiéramos aceptado a Marta Sánchez...! La hubiéramos enviado a hacer puñetas, pero rápidamente. Y yo tengo la prueba de que todos éramos unos pijos. ¡Todos, absolutamente todos decían «papá y mamá», nadie decía «papi y mami»! A Xavier Miserachs le molestaba mucho que le dijeran pijo, pero a mí no me ha molestado nunca... porque lo éramos ¿verdad?".

(Esther Tusquets, Barcelona, 31 de octubre de 2004) -“Sí, sí, éramos pijos. Yo soy un poco de carácter... pero bueno..."

(Oriol Maspons, Barcelona, 31 de octubre de 2004) -“Aquí en Barcelona era definitivo. Los que decían «padre y madre» eran «lletraferits» -intelectuales-, los de «papá y mamá» eran gente de carrera, y los de "papi y mami» eran los currantes, los «menestrals»".

$-Y$, sin embargo, Masats era una excepción. Él era un currante.

(Esther Tusquets, Barcelona, 31 de octubre de 2004) -“Pero es que Ramón no sería característico de la gauche divine".

(Oriol Maspons, Barcelona, 31 de octubre de 2004) -“No, Ramón no era de la gauche divine. Y otro tío que tampoco era gauche divine, y era divertido, era Leopoldo Pomés. ¿Y sabes por qué no era gauche divine? Porque vio que perdíamos mucho el tiempo y él se dedicó a labrarse un porvenir y a ganar dinero y hacía cosas para ganar dinero. Pero no le interesó nunca porque éramos una panda de vagos".

(Esther Tusquets, Barcelona, 31 de octubre de 2004) -"Pero sí lo era..."

(Oriol Maspons, Barcelona, 31 de octubre de 2004) -“De espíritu... pero Colita no tiene ninguna fotografía donde aparezca Leopoldo Pomés. Hacía dinero y negocios con la gente de la gauche divine, pero no se dedicaba a perder el tiempo y a hacer el gilipollas como nosotros".

Aunque coincido con Maspons en que Masats no es característico de la gauche divine, lo cierto es que la propia Rosa Regàs lo cita y lo incluye en el grupo de fotógrafos vinculados a ese coletivo. Probablemente debido a que todos los veranos Masats volvía de vacaciones a Cataluña y probablemente se reuniera con sus amigos fotógrafos en la Costa Brava.

“Colita, Xavier Miserachs, Oriol Maspons, Català-Roca, Masats o Pomés apareixien de sobte a la casa, a la llibreria, al restaurant, com si sabessin quan i com havia nascut aquell infant, aquell llibre o aquell edifici" ${ }^{\prime \prime}$.

69 Regàs, Rosa, "La Gauche Divine”, en el catálogo de la exposición Gauche Divine, Barcelona, Lunwerg, Ministerio de Educación, Cultura y Deporte, 2000, pág. 22. 


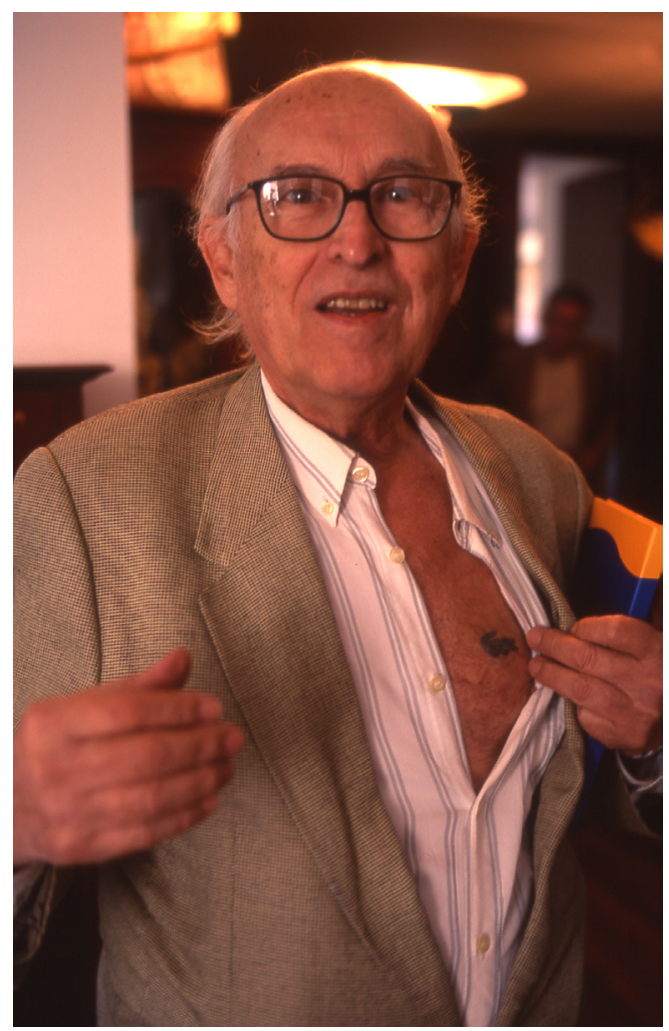

Oriol Maspons nos enseña su tatuaje del cocodrilo de Lacoste en casa de Esther Tusquets.

El nuevo estatus del fotógrafo profesional potenciaba la autoría y la creación personal con mucha intensidad. El obrero de la cámara debía poseer una sólida preparación cultural, técnica y humana; una vocación cosmopolita y moderna incuestionable, arropada por la más exquisita honestidad y el mayor respeto ético a la realidad, a su trabajo y a sí mismo, y todo ello puesto al servicio del cliente. Sin embargo, veremos que los problemas para conservar la autoría serán generadores de un sinfín de conflictos deontológicos:

“La pasión por la comunicación a través de imágenes nos llevó a la decisión de intentar vivir de ello. El futuro era de una incertidumbre total, pero en la base de nuestra decisión estaba el compromiso de progresar en el conocimiento de la fotografía desde la práctica diaria, y también desde ella dar a conocer que la fotografía útil no tenía por qué estar marginada del mundo de la cultura. Nuestro eventual talento como fotógrafos iba a manifestarse en el marco del servicio a nuestros clientes, de ningún modo íbamos a adoptar la esquizofrénica postura, luego tan frecuente, del servilismo y la docilidad en la vulgaridad del trabajo comercial, para dar rienda suelta a nuestro genio en una producción paralela e inútil de superior rango cultural"70.

Esta sensación de esquizofrenia -que pretende evitar Miserachs-, y/o de bicefalia, es decir, de contraposición entre una obra profesional, alimenticia y vulgar (Koldo Chamorro acuñará más tarde el término de fotografía mercenaria) y otra obra personal -más creativa y elevada- pero no 
remunerada ni reconocida laboralmente, la siguen padeciendo muchos fotógrafos en la actualidad. Ello pone de relieve que esta batalla que se inicia en España con la generación de Masats, todavía no ha sido resuelta en absoluto:

“La reivindicación del fotógrafo a opinar (...) le otorgará el estatus de autor. Es decir, se constata la falacia de la fotografía: no hay una verdad única sino muchas verdades superpuestas y el autor-fotógrafo tiene el derecho y la responsabilidad de proponer una interpretación propia de la realidad. Esto representaría una fuente inagotable, todavía no resuelta, de conflictos profesionales, deontológicos y de reconocimiento social, y explicaría fenómenos como la aparición de agencias tipo Magnum (fundada en 1947 por Capa, Seymour, Cartier-Bresson y otros), que precisamente pretenden preservar el marco de libertad del fotógrafo versus los condicionamientos por parte del mundo editorial, y la acuñación de categorías ad hoc características también de aquellos momentos (sin que, en cierta medida, hayan perdido vigencia) como las de "documentalismo social", "fotografía humanística", "fotografía comprometida", etc."

Aquí reside, tal y como ya hemos reseñado, la clave de Masats y de toda la generación de fotógrafos catalanes a la que pertenece: conseguir la profesionalización. El profesionalismo será el principal objetivo a alcanzar y, sin embargo, será precisamente en ese punto donde se verán más cuestionados, empezando por los salonistas. Éstos pretendían defender su condición de aficionados -amenazada por el nuevo estatus del fotógrafo profesional- argumentando que el aficionado disfruta de una libertad creativa de la cual carece el profesional, sometido al condicionamiento del cliente, del producto y del mercado editorial. Por ello, Raimundo Costa considera que:

"Entre el profesionalismo y el amateur hay un abismo, aunque el profesional pueda ser amateur y viceversa, esta tendencia bastante acentuada es popular en cierto países. El asunto profesional y dignificación del mismo es de lógica pura; pero de esto a querer imponer que todos los amateurs seamos o vayamos a un campo que no es propio, es casi incomprensible.

La única saludable tendencia según ciertos sectores, es que los amateurs hagamos fotografía «no salonista». ¿Y eso por qué?¿Por qué ese empeño? Los profesionales, en particular los interviuvados extranjeros, coinciden en que sus mejores fotos son las de amateur, pero ésas no se las pagan tan bien en las Redacciones; por ese motivo nosotros estamos muy bien en el plan amateur, porque no queremos ser profesionales, y lo mismo que ellos desean ver sus fotos en revistas ilustradas, periódicos, etc., nosotros las deseamos ver en Boletines y Salones, y cuantas más mejor"72.

La contestación recibida de manos de Maspons nos sirve para entender mejor su interés en la fotografía producida bajo el profesionalismo:

“Nadie pretende, creo yo, que los amateurs vayan a un campo que no les sea propio. Sólo se desea
informarles, para que puedan escoger por ellos mismos su «alimento cerebral», que la fotografía pro-
fesional de hoy ha dado al arte fotográfico su máximo esplendor, ya que ha convertido en lenguaje lo
que antes era sólo objeto decorativo y que este nuevo lenguaje puede usarlo todo el mundo sin temor
de abandonar el techo que les cobija que de puro viejo se hunde. El señalar un nuevo camino no es
obligar a nadie que lo siga; si alguien lo coge o es que lo cree bueno, o es porque ya andaba extraviado
antes de que se lo ofrecieran"73.

71 Gili, Marta, "Miserachs en su marco histórico", en Dupuy, Alain y Gili, Marta, Xavier Miserachs, 1 segundo y 25 centésimas, Barcelona, Fundació "la caixa", 1992, pág. 19.

72 Costa Terradellas, Raimundo, “'Salones! Sí...", op. cit., sin paginar.

73 Maspons, Oriol, "Carta abierta...", op. cit., sin paginar. 
Es decir, que lo que más valora Masponsde la fotografía que se publica en las revistas ilustradas es su comunicatividad, su utilidad expresiva. Lo que antes era un objeto decorativo inútil, hoy es un lenguaje que todo el mundo entiende. Por eso es vendible, si es buena:

\begin{abstract}
"Ahora bien, coincido en que la fotografía «de arte», es la más difícil de colocar, precisamente porque a nadie interesa. $Y$ no porque el gran público no tenga formación suficiente, ya que hay revistas destinadas a todos los sectores de cultura y ninguna quiere cargar con el muerto. Ni en las mismas publicaciones de arte, en donde la fotografía como lenguaje es aceptada, se tragan hoy día «la artística» (Réalités, L'Oeil, Diorama, Goya, etc. $)^{74}$.
\end{abstract}

El propio Maspons nos confirma de nuevo que la fotografía salonista o pictorialista no interesa a nadie. Pervive encerrada en las asociaciones, rechazada, olvidada, marginada por los propios centros culturales y por las publicaciones especializadas en arte -en concreto en las mismas revistas donde sí se acepta la fotografía comunicativa-. Justamente, es en la revista Réalités, que menciona Maspons, donde aparecerá la reedición del reportaje de Eugene Smith realizado en Deleitosa y que tantas protestas provocará de la revista española Gaceta Ilustrada. Este uso de la fotografía como medio de comunicación de masas lo estudiaremos detalladamente con posterioridad. No obstante, aunque Miserachs defendiera incansablemente la autoría dentro del campo profesional y Maspons encontrara la comunicación como la principal virtud de ese nuevo estatus social, la verdad es que, como ya hemos comentado, el conflicto entre la autoría y el profesionalismo ha quedado lejos de resolverse, como demuestra una anécdota del propio Miserachs:

“Una editorial (...) me encargó un extenso trabajo sobre un área geográfica concreta (...) Los libros, de unas doscientas páginas, contenían más de un centenar de fotografías que ocupaban no menos del $85 \%$ de la superficie de papel, y el resto lo ocupaban pies de foto y un texto de un escritor prestigioso (...) Supe que el escritor que todos deseábamos para el texto andaba muy ocupado y no acababa de comprometerse a aceptar el encargo. La situación seguía siendo la misma cuando, en una reunión, se convino que mi trabajo estaba ya completo y terminado (...) Contento, uno de ellos exclamó:

-¡Fantástico!, ¿ya tenemos el contenido del libro! Ahora sólo falta el autor...

Sin perder la calma, y aprovechando la confianza, di un golpe en la mesa, me levanté, y solté aproximadamente el siguiente discurso:

-Reclamo un poco de respeto, tanto para mi persona como para mi trabajo. Si opináis que el contenido del libro está listo, el único autor hasta el momento soy yo. Mis fotos no son la mera decoración para un texto presuntamente genial que todavía ha de empezar a escribirse (...) La reivindicación de que nuestro trabajo es también cultura (...) creo que es una de las más importantes asignaturas pendientes de nuestra profesión y un constante motivo de roces con los clientes"75.

Anécdotas aparte, lo cierto es que ha habido una gran cantidad de fotógrafos que han sufrido la sentenciosa afirmación de Raimundo Costa y han acabado realizando su obra más personal al margen de su trabajo profesional. Actualmente, las razones que encuentran los fotógrafos profesionales son muy diversas, pero se centran en responsabilizar al mundo editorial de la escasez de publicaciones con planteamientos originales y novedosos. Es decir, de propuestas con verdadero interés fotográfico, motivadoras creativamente, tanto a nivel personal como profesional. Las causas de esa pobreza son variadas: desde la consabida falta de presupuesto $-\mathrm{y}$ por tanto de tiempo para plantear y realizar trabajos absolutamente inéditos y originales-, hasta la mera 
competencia entre los medios - que les lleva a la copia y a repetición-, pasando por otros motivos más inquietantes como puede ser la aparición de estereotipos espectaculares o folclóricos que cautivan la mirada impidiendo la generación de imágenes nuevas, o la indefinición del estatus profesional/ social del fotógrafo que entra en competencia directa con intermediarios como editores, directores de arte, maquetadores, redactores... Algunas de estás razones nos resultan familiares y nos recuerdan los motivos de la absoluta falta de originalidad y la aburrida repetición de la fotografía salonista. Koldo Chamorro analiza el problema desde una perspectiva vigente, pero que, sin lugar a dudas, nos sirve para entender el contexto en el que se movían aquellos primeros fotógrafos profesionales, muchos de los cuales siguen en activo en la actualidad, como el propio Ramón Masats.

(Koldo Chamorro, Pamplona, 21 de marzo de 2003) -“El otro gravísimo problema es que hay una especie de fractura, que yo entiendo que es por comodidad y por poco sentido común, y es que... antes, cuando éramos evidentemente más pobres, la financiación de un proyecto era más complicada, era más largo todo. Pero ahora, que se supone que tenemos dinero... yo no veo que ese tipo de proyectos para hacerlos con profundidad... Es, hoy día, inconcebible. Te tienes que pensar un tema para hacerlo en dos días. Entonces... ¿Dónde están los medios? Antes a lo mejor es que no había más remedio, solamente había dinero para trabajar dos días. Pero es que ahora no. Hay dinero, pero se trabaja muy malamente, con lo cual se está reforzando por comodidad la reutilización de estereotipos. Es decir, «Hay que resolver como sea y rápidamente». Yo me pregunto... ¿En el mundo editorial... cuántos libros hay explicando un poco lo que es España? ¿Cuántos libros hay interesantes? ¿Cuántas editoriales, hoy en día, pueden afrontar el que alguien venga y cuente lo que es España? Yo creo que ninguna. ¿Por qué? Porque España es un tópico y es un tópico que está determinado claramente por una empresa que se llamaba El escudo de oro, que hacía postales. ¡Punto, y no hay más vueltas que dar! Y si se escapa de ese marco de referencia, aquello no funciona. Con lo cual, la gran mayoría de los libros, acaban siendo libros suntuarios y totalmente inútiles. Lo que se llama en inglés table book. Es decir, libro para poner encima de la mesa de café, y no se usa. Solamente es para uso de decoración suntuaria. Y claro, esta especie de pobreza hace que los editores de libros de fotografía no sepan ya qué es una imagen. Buscan temas que sean más o menos conocidos (...) ¿Qué pasa con los libros espectáculo? Es como si intentases, con mucho esfuerzo, tesón y constancia, escribir de nuevo El Quijote. ¿Para qué te vas a poner de nuevo a pensar si ya está escrito, y lo hizo Cervantes maravillosamente bien? ¿Te vas a poner de nuevo a escribir las obras de Shakespeare? Si ya están escritas. Búscate otra cosa (...) Yo vi la exposición... -que es un trabajo que me interesa mucho- La tierra vista desde el cielo. Yo vi la exposición en París. La hicieron en la calle... y me gustó mucho porque estaba perfectamente dimensionada la cantidad de imágenes que había. Y cuando vi el libro me decepcionó profundamente. Porque hay tal acumulación, hay tanta ambición, que se desmorona todo. Con la mitad de imágenes hubiera quedado perfecto. Ése es el criterio. Y no es un problema del fotógrafo, es un problema del editor".

- ¿El problema puede generarse por una especie de intrusismo laboral?

(Koldo Chamorro, Pamplona, 21 de marzo de 2003) -“Tú a un dentista vas a que te quite una caries, y el dentista te crea una dentadura, te pone una ortodoncia. Aquí no. Yo llevo tiempo trabajando con guión. Y... evidentemente intentas mejorar el asunto. Pero claro, cuando lo mejoras, vas, iy te riñen! Entonces... ¿qué haces? Antes de empezar a ejecutar el guión me voy a ver al director de arte y al director de fotografía, para saber qué es lo que piensan. Y no quiero que me cuenten gran cosa. Le miro los zapatos, le miro qué camisa lleva, miro los papeles de encima de la mesa, qué libros tiene en la estantería y tal... Me hago una idea del editor, y digo: «Ya sé... éste, postales». ¡Pues venga, postales! Y ése funciona con el estereotipo. No quiere que le haga una foto que le genere dudas. Si la pone en doble página o la pone en la derecha o la izquierda. 
¡Como le haga eso, me degüella! Y es más. Si haces alguna foto -que yo siempre las hago- que va allá de... y se la presentas, es la primera foto que a la hora de editar te la tiran. Y yo tengo el caso de un trabajo en Salamanca. Las mejores imágenes tiradas al suelo".

-En realidad, es como si tuvieran miedo de innovar.

(Koldo Chamorro, Pamplona, 21 de marzo de 2003) -“Claro, esto se tiene que parecer a aquello y aquello y aquello".

-Es lo que pasaba con los concursos salonistas, que los jurados siempre premiaban las mismas imágenes, y se repetían y repetían "como los cangilones de una noria". Aquello que decía Luis Navarro:

“Nuestros artistas fotógrafos son viejos y no han sabido renovarse (...) El artista fotógrafo español se limita a repetir una, dos, mil, cinco mil veces la misma fotografía del mismo caserío y de los mismos árboles que otros produjeron antes que él. Como los cangilones de una noria, va, viene, sube, baja sin moverse jamás de las inmediaciones del mismo eje"76.

(Koldo Chamorro, Pamplona, 21 de marzo de 2003) -“Sí, es que aparte de la presencia del estereotipo, está el concepto de la competencia. Aparece una revista que viene con un diseño, que usa una tipografía... y entonces todo el mundo va a hacerle saqueo y a pillarle, y todas las revistas se parecen. No hay ninguna que interese. Se juntan muchos elementos y no se puede saber cuál es el elemento que actúa a modo de arrastre. Hay otro factor con el que se encuentran los editores y es que las casas actuales tienen noventa metros cuadrados. Tienen un nivel de ocupación limitado. Tú no puedes hacer grandes libros, porque el gran libro no lo puedes meter en ningún sitio. Con lo cual, hay que ir a fórmulas estrictamente funcionales. Eso está bien, siempre y cuando el editor entienda cuándo tiene encima de la mesa la maqueta de un libro especial y cuándo tiene un libro común. Cuando tiene que encargar un libro de creación como Dios manda y cuándo tiene que hacer un libro de catálogo de máquinas de coser.

Luego hay otra historia que es muy vieja... ¿Cuál es el estatus del fotógrafo? Y aquí la culpa principal es de los propios fotógrafos -bajo mi punto de vista-. Quiero decir, que el fotógrafo va entre la duda de si es un «artista» o si es un «autor» o si es un señor que, bueno... vive de la fotografía. El dentista del ejemplo anterior, es un señor que no alardea de que es dentista. Cumple con su trabajo, lo hace lo mejor que puede, y luego se queda con la satisfacción de haberlo hecho bien. Aquí no. Aquí, todo el mundo tiene que figurar en la lista de «los cuarenta principales» de ese momento, y estamos en la época de «primavera-verano». Y claro, te tienes que preocupar de estar en esta lista porque sino, no eres nadie. Claro, eso es muy terrible, porque tú no estás haciendo lo que tienes que hacer, sino que estás siempre pensando... a ver qué es lo que puede agradar a los demás o cómo epato a los demás. Bueno... Cada cual es cada cual. Puedes hacer lo que quieras, pero es una mala vía. Y eso -que es muy confuso- hace que el criterio de los editores sea también muy confuso y el estereotipo sea cada vez más confuso y tal... ¿Dónde está el punto de luz? No lo sé. Pero lo que sí que digo es que la generación de Ramón pasó de un conflicto brutal, que era el salonismo, con toda la estupidez y el carácter inútil que se le daba, a intentar defender la función del fotógrafo como autor. Y digo, «autor», en letras minúsculas, pero con personalidad, con criterio... Y ahora se encuentran con que ese autor, que ha intentado ser «autor», muy capaz, muy ordenado, muy meticuloso y con muchísima constancia, lo convierten en «artista». $Y$ eso es un paso realmente muy doloroso. Ahora mismo, y es una comparación un poco perversa, el concepto que se tiene de la cultura y de

76 Conde Vélez, Luis (Luis Navarro), “El momento fotográfico español”, en Arte Fotográfico, n 12, año I, diciembre 1952, pág. 488. 
todas las manifestaciones culturales, es un concepto de espectáculo. Y el salonismo también tenía el mismo criterio. Era un espectáculo en el cual se mezclaban la parte de la habilidad técnica -que siempre ha tenido la fotografía como sistema de interposición- con las partes más o menos cautivas de la estética, que ahora siguen siendo iguales. ¿Ahora se pone de moda el nuevo objetivismo? Venga, pues todo el mundo haciendo por ahí paisajes, con más o menos coherencia, pero también con cierto vértigo.

Entonces la propuesta sería. ¿Por qué, si se han hecho productos culturales como Neutral Corner, ahora no somos capaces de hacer un tipo de proyecto así? ¿Por qué un libro sólo tiene cierta posibilidad de aparecer en el mercado si trata temas pintorescos o espectaculares? Además, son libros cautivos de una tradición establecida sobre el criterio del estereotipo. ¿Por qué no se pueden hacer otro tipo de cosas? A mí me sorprende que, en aquel momento, Ramón fuera capaz de hacer este tipo de libros, como el Neutral Corner. Un trabajo tan bien ubicado. Yo es lo que más valoro de Ramón, la seriedad, la honestidad y la importancia de su obra".

¿Cómo ha influido toda esta polémica en la obra de Masats? ¿Realmente ha conseguido escapar del agorero Raimundo Costa y su perversa maldición? Lo primero que hemos de recordar es que, con excepción de las primeras fotos del puerto de Barcelona, y posiblemente de las últimas imágenes realizadas en sus más recientes viajes ${ }^{77}$, toda su obra está realizada por completo en el marco de su trabajo profesional. Masats hace del encargo la excusa ideal para utilizar la cámara y transformarse en fotógrafo. Esta condición de profesional no ha dejado de reivindicarla en todas las ocasiones que ha podido. Siempre que sale a colación recuerda que es un fotógrafo profesional y que esto nunca le ha supuesto ni un problema ni una cortapisa. Lo considera más bien una forma de motivación, aunque con su ironía y su sentido del humor de por medio nunca se sabe:

(R. Masats, Valencia, 25 de marzo de 2004) -“Nunca jamás se ha creído nadie que yo soy un vago total. Y si no se lo ha creído nadie es porque yo he trabajado muchísimo: en primer lugar, porque me gustaba y, en segundo lugar, porque tenía que vivir de mi trabajo. Ahora puedo realizar lo que más me gusta en el mundo a mi edad, que es leer. Y siempre les pido a mis amigos que... (porque cuando dejo en el sofá aquel agujero que se hace allí donde leo... que ya parece lo de la madre de Psicosis) siempre les pido a los amigos que cuando haya una boda un bautizo o lo que sea, que me lo digan, que me saquen de mi rincón y cojo las cámaras y con mucho gusto hago fotografías. Porque una de las cosas que yo creo es que te puede surgir una buena fotografía en una cosa tan banal como es una boda. Donde no puedes hacer buenas fotografías es sentado en tu casa leyendo. Pero en cualquier hecho, hasta el más nimio o el más vulgar, siempre tienes ocasión de sacar una buena fotografía. Y esta foto es de la boda de la hija de un amigo mío. Y esta otra es premonitoria, porque se está escapando y a los cuatro meses ya se habían divorciado. El sentido de la anticipación es importante fotográficamente".

-Entonces, ¿todas las fotos las haces por encargo o haces fotos tuyas, las tienes guardadas y a lo mejor algún día las publicas?

(R. Masats, Madrid, 17 de junio de 1999) -“No, yo soy bastante radical y las fotos que hago, mayormente, las hago por encargo. $Y$ cuando digo encargo... obligo a mis amigos a que me saquen para fotografiar temas tan intranscendentes como una boda o un bautizo. Yo les digo: «Sacadme», y ellos me sacan y me lo paso muy bien. Pero coger la cámara y hacer esto y tal... no".

$-¿$ Y no crees que cuando haces un trabajo de encargo puedes perder un poco tu creatividad y

77 Masats ha viajado mucho al extranjero estos últimos años. Fue a Egipto con ocasión de su boda con su segunda mujer, Paloma, y, bajo el patrocinio del Instituto Cervantes, ha viajado desde 2002 por Moscú, Atenas, Estambul, Roma, Milán, Bremen, Viena... para presentar su exposición antológica. 
tu entidad porque dependas un poco del que te encarga? Lo digo por la discusión entre fotógrafo aficionado/profesional, ya que parece que el fotógrafo aficionado hace siempre las fotos que le dan la gana, mientras que el profesional...

(R. Masats, Madrid, 17 de junio de 1999) -“No lo creo. Lo que te marca el encargo es el tema. Para mí nunca ha sido un límite, ni un corsé. 0 a lo mejor es que el corsé me viene bien. Pero, creo yo, que de cualquier encargo se pueden hacer fotografías interesantes, que a lo mejor luego no se corresponden con el encargo o no se publican; o tú mismo decides que no se publican pero que es buena como fotografía. Por ejemplo, la fotografía de Menéndez Pidal subiendo las escaleras con su retrato. Aquello fue un encargo de Gaceta Ilustrada y consideré que no era una fotografía para ser publicada en Gaceta Ilustrada. Pero sí que era una buena fotografía para luego ser expuesta. Quiero decir que en un encargo haces también lo que te vas encontrando".

(R. Masats, Madrid, 4 de septiembre de 2002) -“Cuando estoy trabajando, o estoy haciendo un libro, muchas veces hago fotografías personales, que sé que para el libro no van a valer. Pero sí me valen a mí".

-Pero las exposiciones son recientes.

(R. Masats, Madrid, 4 de septiembre de 2002) -“En color sí, en B/N son ya muy antiguas. Esto siempre ha sido así. Lo que te decía antes de cuando voy a un bautizo. Digamos que un bautizo es igual que un libro. Yo lo que voy es a reflejar cómo es este bautizo y que quede bien. Que tengan constancia del bautizo los padres. Pero si durante este hecho hay una foto que yo la veo y me hace clic... Yo la hago y me la quedo para mí. Me pasa exactamente igual que en los libros. Eso no quiere decir que fotos que aparecen en los libros no pueden ser expuestas. Muchas de las imágenes de los libros aparecen después en las exposiciones, individualmente sirven. Con los documentales no puedes pensar en planos aislados y luego pegado uno con otro, sino que es todo un conjunto lo que tienes que pensar".

-Es que me da la sensación de que las mejores fotos las puedes hacer no cuando estás trabajando sino cuando de repente ves algo...

(R. Masats, Madrid, 20 de marzo de 2000) -“Ves algo cuando estás buscando algo. Yo normalmente no veo fotos y digo: «¡Huy, qué foto más bonita!». No, normalmente cuando voy por la calle no tengo el concepto de que soy fotógrafo".

$-¿$ Y si te encuentras algo de repente?

(R. Masats, Madrid, 20 de marzo de 2000) - “ ¡Qué se joda, peor para él! No me preocupa. Si es una cosa bonita la disfruto, pero no tengo la necesidad de reflejarla, de imprimirla. Sobre todo porque si tuviera una cámara e hiciera la foto la relación entre esta cosa... esta luz, esta forma, esta cara, las manos de un hombre o una mujer, lo que fuera no lo viviría tan intensamente como sin la cámara. La cámara -sigo pensando para mí- es un condón. Es como una cosa que te quita la realidad... Me gusta mucho ir por la calle con una cámara, pero es una cosa distinta. Creo que no es bueno ir siempre con una cámara y ver la vida siempre a través de una deformación de tipo profesional. Te pierdes muchas cosas, te pierdes sonidos... te limita. Lo que sí es evidente es que cuando yo llevo una cámara o hago una cosa, me gusta mucho hacerlo intensamente. Cuando empecé tenía más afán por ir... Pero la verdad es que nunca he ido con la cámara colgada a todas horas. Lo que sí que hacía eran excursiones los domingos por la mañana. Nos reuníamos con amigos y lo hacíamos como aficionados, pero tampoco iba con la cámara a todos lados. Nunca he sido como los japoneses o los turistas, que lo único que les interesa es ver que han estado en un sitio. Es decir, lo importante no es el sitio o lo que disfrutas, si no la representación que de este hecho tendrás tú luego en tu casa. Esto a mí me parece una barbaridad y una deformación. Ahora solamente trabajo y cojo la cámara cuando los amigos me sacan. Si no, el placer de leer puede sobre el placer de fotografiar".

Por lo tanto, Masats encuentra, desde la absoluta honestidad, un camino híbrido, una solu- 
ción al problema de la profesionalización. Él realiza obra personal al mismo tiempo que contenta al cliente. Si éste es suficientemente receptivo para comprender y aceptar la obra de Masats e integrarla en su encargo, no hay problema alguno. En caso contrario, Masats retendrá la imagen hasta mejor ocasión. Ya comentamos que Masats siguió concursando después de ofender a los jurados salonistas que lo habían premiado. Aunque era imposible que volviera a ganar después de tan humillante afrenta Masats seguía presentando sus obras obstinadamente, quizás para tener oportunidad de enseñar unas imágenes que no conseguía publicar, pero estas fotografías siempre fueron tomadas durante la realización de reportajes destinados, por ejemplo, a Gaceta Ilustrada o a cualquier otro cliente que le ofreciera un encargo. Sin embargo, Masats también hace autocrítica y reconoce que no toda su obra está realizada al mismo nivel de autoría y que, aunque él siempre ha buscado imágenes válidas a su criterio, a veces el conjunto del libro, la maquetación, la edición o el guión del trabajo, no le han satisfecho de igual modo.

(R. Masats, Madrid, 4 de septiembre de 2002) -“Uno, desgraciadamente, está metido en el mundo editorial y en las exposiciones... Es decir, los que mandan son los intermediarios. El que manda ahora en una exposición es el comisario. El que manda en una editorial es el director de arte. El que manda en las patatas no es ni el que cultiva las patatas, ni el que las vende en el mercado. En todos los órdenes es el intermediario el que lo organiza todo. Y los intermediarios... en un noventa y nueve coma noventa y nueve, son todos mediocres. Quieren hacer prevalecer sus conceptos y sus ideas, y el que te vaya a hacer un libro querrá hacer "su» libro, darle su sello de intermediario".

(R. Masats, Valencia, 25 de marzo de 2004) -“Yo creo que hay una generación de fotógrafos jóvenes en España fabulosa. Me permito ser chauvinista, que uno de los defectos que tenemos en España es no ser chauvinistas. España es un país en el que la gente es muy visual. De la misma forma que tenemos fantásticos pintores, tenemos fantásticos fotógrafos. Lo que pasa es que la fotografía necesita detrás un apoyo de tipo económico, de las revistas o las editoriales, que en España no tenemos. Y por las razones que sean aquí no ha venido una guapa señorita judía americana a descubrir la fotografía española -cosa que sí ha pasado en otros países, que incluso yo pienso que son inferiores fotográficamente-. Tenemos la obligación de ser chauvinistas y defender lo nuestro, que es cojonudo. Ahora, los que quieran ser fotógrafos... tengo que decir que lo tienen crudo. Tendréis que luchar mucho. De aquella época se podrá decir lo que se quiera, pero si eras un buen fotógrafo se reconocía tu trabajo. De mi época no creo que haya quedado ningún fotógrafo desconocido, pero hoy en día puede pasar, sobre todo por una razón -como me decía el otro día César Lucas, que ya sabéis que es jefe de fotografía del grupo Zeta-. Él me decía: «Mira, Ramón, desgraciadamente el valor fotográfico que se valora en este momento es que seas barato». Esto te lo dice todo. En la fotografía se ha metido el mundo del intermediario. Hagas la fotografía que hagas el intermediario, que es el director de arte hace lo que le sale de los cojones. Corta por aquí y por allí. A mí me han llegado a decir: «Ramón no me hagas las fotos tan bien compuestas porque no me dejas cortar». Es decir, su misión es cortar y transformar aquello en otra cosa, con lo cual, si eres barato... con que le des una imagen ya el tío hace "arte". Yo soy optimista en la calidad, pero no soy optimista en el futuro desarrollo de los jóvenes. Lo lamento pero es así. ¡Ojalá me equivoque!".

“Cuando entregamos nuestras fotos, nos hacemos responsables de su encuadre, de su graduación tonal,
de la composición interna de las mismas. Alterar estos términos presupone un atrevimiento basado en
la convicción de que la labor del diseñador está por encima de la nuestra, es de rango «artístico» su-
perior, y por tanto está en condiciones de colonizarla sin miramiento alguno. Es labor del fotógrafo se-
ñalar con el dedo estos abusos, y advertir al cliente sobre ellos... si vuelve a encargarnos trabajos"78. 78 Miserachs, Xavier, Profesiones con futuro..., op. cit., pág. 159. 
(Oriol Maspons, Barcelona, 31 de octubre de 2004) -“Los únicos enemigos del fotógrafo han sido siempre: el diseñador (porque siempre nos han tenido envidia los directores de arte), luego el grabador y el impresor. Los editores no (...) Yo recuerdo las discusiones que yo tenía con Carlos Barral cuando hacía las portadas estas que ahora resulta que están muy bien, las portadas de la Biblioteca breve. ¡Como él era tan literato! Yo le discutía diciéndole: -Pero si tu no tienes ni idea de imagen. Era tan poeta que no iba al cine, parecía que no había visto nunca ninguna película".

(Esther Tusquets, Barcelona, 31 de octubre de 2004) - “ ${ }$ Pero si fue el primer editor que se ocurrió hacer una colección con fotografía en la cubierta!"

(Oriol Maspons, Barcelona, 31 de octubre de 2004) -“Sí, por supuesto. Fue cuando yo empecé. Fue el primero. Joan Marsé me ha enviado un texto -porque yo le hice las dos portadas de su primeros libros- y me dice que su personaje la tiene identificada con la chica ésta del coche..."

(Esther Tusquets, Barcelona, 31 de octubre de 2004) -“Del libro de Últimas tardes con Teresa".

(Oriol Maspons, Barcelona, 31 de octubre de 2004) -“Sí, Susan. Pero quiero decir, que esta gente sí eran tíos agradecidos".

- Hoy en día parece que el director de arte ha adquirido tanto poder que toma decisiones sin tener en cuenta al fotógrafo.

(Oriol Maspons, Barcelona, 31 de octubre de 2004) -“Eso pasaba sobre todo con la foto publicitaria, porque los directores de arte eran unos envidiosos y nos tenían celos, y ahora han triunfado. Ahora en las agencias de publicidad sólo hay un fotógrafo que por las mañanas reparte pizzas y por las tardes hace de fotógrafo, pero no hay tíos de nombre. Ni uno. A mí me lo pronosticó Xavier Miserachs. Yo me dediqué más a revistas y él se quiso dedicar a la publicidad y lo hacía muy bien. Un día me dijo que no haríamos nada porque nos encontraban demasiado sabios, demasiado cultos. Que habláramos de tú a tú con Miguel Delibes o Camilo José Cela nos les hacía ninguna gracia.

Eso de que pusieran las fotos como sellos de correos, muy pequeñitas, en la misma página «por la composición». ¡Tú crees que hay derecho en que un fotógrafo tenga su foto con una medida de sello de correos! Pero el grafista lo hacía porque estéticamente era la moda, poner fotos como manchas".

Sobre la manipulación de los intermediarios, Masats opina que ello no afecta exclusivamente al ámbito fotográfico, sino que desgraciadamente se extiende a todos las esferas creativas.

(R. Masats, Madrid, 4 de septiembre de 2002) -“Y eso ocurre en muchos sitios, en casi todos. Algunos directores de cine tienen aún la facultad de poder controlar el montaje de sus películas. Cada vez más, afortunadamente, en Estados Unidos y aquí en España también. Pero hay muchísimos que el que manda es el productor, que es el que impone el final y todas esas cosas. Y eso es así. En pintura... ¿cuántos pintores tienen éxito y a partir de este momento tienen que repetirse porque la galería no les permite cambiar, porque si cambia de estilo no vende? Es decir les cortan la producción. Y eso ocurre con los escritores... con todo. Los libros de Lumen son libros auténticos míos, de autor, Los Sanfermines también, incluso yo hice la maquetación del libro y gané el premio Ibarra al libro mejor editado del año. Pero aparte de estos tres libros... El Toro, también puede considerarse que sí, pero tienes tú razón: que todos los demás libros son libros de encargo que yo he hecho como profesional, o porque me interesaba por mi trabajo, o porque me da la oportunidad de viajar. Ahora bien, de entre todas las fotos comerciales que tengo que hacer siempre hay alguna que me ha interesado como foto absoluta a mí". 


\subsection{ARTE Y UTILIDAD: EL VALOR COMUNICATIVO}

El concepto del utilitarismo se generó simultáneamente en una gran variedad de círculos creativos a principio de los años sesenta. Desde el diseño o la arquitectura se preconizaba la funcionalidad de los nuevos proyectos como reacción a estéticas meramente formalistas. El arte por el arte se vio absolutamente devaluado y desprestigiado entre diversos autores que, por el contrario, revindicaron la perfecta concordancia entre la funcionalidad de un objeto y su diseño. Y ello hasta tal extremo que la utilidad fue el motivo determinante para justificar la existencia del objeto artístico.

El autor español de aquella generación que quizá más ha reflexionado sobre este aspecto es Óscar Tusquets (Barcelona, 1941). Estas dos escuetas reseñas -la fecha y el lugar de nacimiento- son especialmente trascendentes para comprender su inclusión en el desarrollo del concepto de "utilidad" y ello pese a ser diez años más joven que Masats. Al respecto, hemos de recordar que el cambio generacional protagonizado por Masats y su quinta ${ }^{79}$ se origina en Cataluña, donde los fotógrafos abrieron, a machetazos, la espesura para llegar a la profesionalización.

Con todo, conviene tener en cuenta que Óscar Tusquets no es fotógrafo:

“Arquitecto por formación, pintor por inclinación y diseñador por vocación, Óscar Tusquets es el prototipo del artista que se hubiera encontrado como pez en el agua en el Renacimiento" ${ }^{\prime 80}$.

A estas tareas cabría añadir las de editor, escritor... aunque quizás sea el propio Masats el que mejor nos presente a Óscar Tusquets. Éste le pidió un texto para su Enciclopedia de Óscar Tusquets ${ }^{81}$ y no es casualidad, en absoluto, que la voz que escogerá Masats para definir a su amigo sea precisamente el término "útil":

“Útil. Adjetivo. Dícese del arquitecto que realiza su obra con creatividad y sentido común, proporcionando al personal mucho bienestar físico y provecho sensual con sus diseños.

Si además escribe de puta madre, desarrollando sus originales planteamientos con ingenio y claridad no exenta de ironía, al margen de tendencias papanatas y badulaques y dándose en llamar Óscar Tusquets y Blanca, mándesele un abrazo con admiración y respeto.

Y si además pinta, consultar IMPRESCINDIBLE"82.

Masats olvida en esta definición el aspecto que más nos incumbe de este autor, ya que Óscar Tusquets fue también director de arte, maquetador, seleccionador de fotógrafos y supervisor de la parte gráfica y del diseño de la colección Palabra e Imagen de la editorial Lumen -dirigida por su hermana Esther Tusquets-. Posteriormente analizaremos con detalle esta colección y los libros que Ramón Masats realizará en su seno, pero queremos adelantar que toda la colección se realizó bajo premisas funcionalistas, como destacan Oriol Maspons y Esther Tusquets:

(Esther Tusquets, Barcelona, 31 de octubre de 2004) -“Los grafistas opinaban que daba igual que una cosa se leyera o no. Las letras eran tan pequeñas o estaban colocadas de modo que no se leía nada. № hacían caso a los fotógrafos y a mí me tenían cabreada siempre y me quejaba de que las cosas no se veían".

79 Dada la precocidad de Esther y Óscar Tusquets que, debido a diversos avatares familiares, empezaron a dirigir la editorial Lumen con veintidós y diecisiete años respectivamente, se les puede considerar de la misma generación.

80 Tusquets Blanca, Óscar, Más que discutible. Observaciones dispersas sobre el arte como disciplina útil, Barcelona, Tusquets, 2002, pág. 3.

81 En su enciclopedia hay 471 entradas relacionadas con la biografía y el universo creativo de Tusquets, de ellas 64 voces están elegidas y escritas por personalidades destacadas del mundo de la cultura. Entre los participantes destacan Guillermo Cabrera Infante, Rafael Moneo, Fernando Savater, Mario Vargas Llosa o el propio Masats.

82 Masats, Ramón, “Útil”, en Capella, Juli, Álbum/Enciclopedia de Óscar Tusquets, Barcelona, Electa, 2003, pág. 203. 
(Oriol Maspons, Barcelona, 31 de octubre de 2004) -“Era una cuestión de estética para ellos, pero nosotros los fotógrafos éramos mucho más racionalistas e íbamos en contra del formalismo. Yo todavía lo llevo dentro. Cuando empezaron Óscar Tusquets, Pep Bonet y Cristian Cirici a hacer de arquitectos, odiaban el formalismo. Decían que el único coche que se podía aceptar era el dos caballos. Y entonces les dije yo: -Es que no habéis subido en helicóptero. Los helicópteros sí que están bien por dentro. No hay nada añadido. Realmente no tienen formalismos y es increíble que se pueda hacer una cosa sin ningún formalismo. Eran tan de esta manía que si alguien llevaba un reloj cuadrado lo criticaban porque decían que si las piezas de dentro son todas redondas... ¿por qué el reloj es cuadrado? Creo que era Pep Bonet que decía que si los zapatos son una cosa que van por el suelo... ¿por qué los hacen brillantes? Lo encontraban todo poco racionalista. Decían que los coches eran un porquería todos porque todos estaban hechos con razones que no tenían nada que ver con la cosa práctica".

-Entonces a la hora de maquetar también pensabais así.

(Oriol Maspons, Barcelona, 31 de octubre de 2004) -“ ${ }_{\mathrm{i}}$ Hombre claro! Tuvimos suerte con Óscar Tusquets que se metió en todo esto".

Años más tarde de la edición de aquel hito de la fotografía española que supuso la colección Palabra e Imagen de Lumen, el argumento utilitarista le servirá como detonante a Óscar Tusquets para escribir varios libros llenos de reflexiones como la siguiente:

“Cuando, como diseñador, se me pregunta repetidamente si se debe privilegiar la función o la estética, respondo que esta disyuntiva no existe y que la cuestión está mal planteada, pues en un objeto útil la estética es indisociable de su uso" ${ }^{\prime \prime 3}$.

0 esta otra, exactamente en la misma línea:

“Somos hijos del racionalismo, de las simplezas de la Bauhaus que aseguran que la belleza va indefectiblemente unida a la utilidad; que son sinónimos" ${ }^{\prime \prime 4}$.

Como vemos, el subtítulo del libro del que están extraídas estas afirmaciones es de lo más revelador: Observaciones dispersas sobre el arte como disciplina útil. El propio Masats coincide con argumentos que parecen salidos de las mismas páginas del citado libro.

(R. Masats, Madrid, 20 de marzo de 2000) -“No sé sí me gusta más el color o el blanco y negro, de verdad. Sí, estoy en contra de se diga que el blanco y negro sea más artístico que el color. El blanco y negro es más fácil que el color y tiene esa cosa nostálgica... como el restaurante que cocina con carbón, o el que escribe con estilográfica, o los barcos de madera y a vela... Sí, está muy bien. Pero yo tengo la teoría de que una cosa, cuanto mejor funciona, más bonita es. Es decir, para mí el Concorde es de una belleza excepcional. Y hay muchas cosas que cuanto más eficientes son, más bonitas son. La eficiencia lleva a una estética y eso para mí está muy claro. A mí siempre me han gustado mucho los radiadores. Como en la foto del boxeador de Neutral Corner.

Recuerdo el primer documental que hice. Fue sobre el Museo del Prado. Era en blanco y negro, estoy hablando del año sesenta y cinco, fue el primero que hice... Y estaba la gente mirando, estaban los cuadros... Era un documental donde se veía por dónde iba a ir yo haciendo documentales más tarde, muy influenciado por mis fotos. Y recuerdo que terminaba con una cosa que poquísima gente ha podido ver: los cerrojos de las puertas que había en aquel momento en el Museo del Prado. Claro, no los puede ver la gente porque se ven cuando se cierran. Pero noso- 
tros sí los vimos. A veces mientras guardábamos el equipo se iba el público, y también quisimos hacer algunas cosas sin gente. $Y$ me di cuenta... Son unos portalones enormes y estaban llenos de nudos que se metían en los bastidores de la pared. ¡Eran de una belleza...! El documental del Museo de Prado lo terminé sobre la puerta cerrada. No tenía nada que ver con el Museo del Prado, pero era un poco el concepto de que está muy bien la pintura y tal, pero que las cosas eficientes tienen una belleza que para mí es muy importante".

(R. Masats, Madrid, 27 de diciembre de 2006) - “iPorque cuando el pueblo se pone a pretender hacer Arte hace unas barbaridades! Sobre todo en Valencia, ¡Porque en Valencia hacéis unas casas! ¿Es verdad o no? Yo no me quiero meter con los valencianos pero... ¡en cuanto ganan dinero! Cuando no tienen dinero tienen una casa muy sencilla, muy lógica y muy eficiente, pero en cuanto ganan dinero enseguida le meten todo. Son falleros, esto es verdad. Creo que en las formas taurinas igual. Cuando la gente quiere hacer algo conscientemente artístico la caga, igual que las casas de los valencianos. Si vas a una casa de un torero verás una serie de vírgenes o las cabezas de los toros disecadas. ¡De un mal gusto! Es normal, son gente humilde que se han dedicado al toro por el dinero y cuando empiezan a ganar dinero se compran una finca, una dehesa, iy se hacen una casa fastuosa! Y eso podía haberlo reflejado en el libro Toro, pero no me dio por ahí".

Oriol Maspons y Josep Maria Casademont fueron los primeros en revindicar el arte aplicado y la fotografía utilitaria, llegando a prolongar el concepto útil para identificarlo absolutamente con el término comercial. La línea argumental es muy sencilla: un verdadero autor debe realizar un producto cultural útil para ser bueno -el producto y él mismo-, ya que sólo entonces se podrá vender y ponerse al alcance del público:

“Arte y utilidad ¿pueden ir juntos? Deberían ir juntos y a veces van juntos (...) Porque solamente por estúpido tradicionalismo no se da la importancia que en realidad tiene la aparición de auténticos descubrimientos de formas nuevas en arte, como son, por ejemplo, la carrocería del automóvil Studebaker modelo 1955 o del Alfa Romeo «Sprint» (...) Porque es un error creer que la fotografía aplicada a fines utilitarios, por el solo hecho de ser «comercial» no tiene interés estético, o artístico para otros. A tal punto es error, que estaría más cerca de la verdad quien hoy día sostuviera lo contrario.

La fotografía «utilitaria» (fea palabra en verdad), la de modas, ilustración de reportajes escritos, de reportaje puro con pies explicativos, la fotografía publicitaria de las grandes revistas, la fotografía mural de decoración arquitectónica y otras aplicaciones, como los biombos de Català-Roca y sus proyectos de decoración de techos, atrae cada día a más artistas que la mejoran sin cesar, ya que tiende más que nunca a la creación y a la búsqueda de las máximas posibilidades de aplicación, dictadas por la época, que exige a todas las otras artes, nuevas formas para necesidades nuevas" ${ }^{\prime 85}$.

Recordemos que la negra sombra del salonismo planea sobre estas palabras. Por ello se dota de ese espíritu de modernidad y de actualidad al racionalismo utilitarista, como reacción al tradicionalismo.

“Es posible que este concepto tan utilitario que venimos exponiendo no convenza a los esteticistas y que se nos acuse de un comercial divorciado del arte. No nos apeamos, sin embargo, de él y no precisamente porque no nos importe que se nos acuse de comerciales -que esta acusación nos importaría mucho si fuese fundada-, sino porque estamos firmísimamente convencidos de que, en nuestra era, ningún arte puede llamarse tal como valor de creación, si no responde al sentido de llenar una función determinada. En otras palabras, que no creemos que la estética actual pueda prescindir de una base esencialmente utilitaria, sin la cual cualquier actividad artística podría llegar incluso a carecer de justificación" ${ }^{\prime 86}$.

85 Maspons, Oriol, “Cómo hago mis fotografías, por Guy Bourdin”, op. cit., pág. 824.

86 Anaxágoras (Josep Maria Casademont), op. cit., sin paginar. 
En 1998 Xavier Miserachs escribió Criterio fotográfico, un auténtico y sincero manifiesto personal ante el actual panorama fotográfico español. El principal argumento que focaliza el texto sigue siendo aquella obstinada lucha contra el salonismo, el pictorialismo y toda la fotografía que tenga alguna pretensión artística. Miserachs contraataca con las armas que, según él, son consustanciales a la esencia de la propia fotografía: su utilidad y funcionalidad, puesto que:

“Un género que se autoproclama «inútil», como hace la «fotografía creativa», difícilmente podrá ser juzgado con criterios de eficacia. No busca resultados, no le importa que sus exposiciones y publicaciones sean tediosas, crípticas, incomprensibles para el público, que intelectuales competentes piensen y opinen que para lo que produce ya estaba bien la pintura. El único criterio de eficacia es conseguir o mantener su predominio en los centros de poder"87.

Parece que con los años el enemigo va cambiando de ropaje. De hecho, todos los fotógrafos de la generación de Masats coinciden en apuntar a la fotografía "creativa", la fotografía "artística" -aquella producida exclusivamente para ser colgada en un museo-, como la heredera del implacable salonismo, precisamente por su falta de utilidad.

“En las artes utilitarias podemos relativizar el peso de la función, podemos ironizar sobre ella, pero en cuanto la perdemos de vista, cortamos el cordón umbilical que nos da vida, caemos en la arbitrariedad, todo es posible $y$, con esta libertad absoluta, ya sabemos lo que le pasa al arte: que se vuelve soporífero, o sea "de vanguardia»" 88 .

Por ello, todos siguen reivindicando al humilde profesional:

“Me duele que cuando en general se escribe o habla de fotografía artística, se circunscribe al terreno aficionado y se omite totalmente la labor de los profesionales periodistas, publicitarios, de estudio, de moda, etc." ${ }^{\prime \prime 9}$.

Masats también tiene muy clara esa relación entre la fotografía "artística" actual y el rancio salonismo:

(R. Masats, Madrid, 20 de marzo de 2000) -“Para mí la fotografía tiene que ser útil para algo, puede ser para lo que sea, y su fin es éste. $Y$ es lo que un movimiento artístico, en estos momentos, le está rechazando. Estoy absolutamente en contra de la fotografía que yo considero inútil. Lo que están haciendo en este momento todos estos que dicen que la misión de la fotografía es colgarla en un museo es volver a lo que era el salonismo. Los salones de fotografía no servían para nada más que para mirarse el ombligo, el suyo y el tuyo. Yo te miro tu ombligo, tú me miras el mío, y tú me dices: ¡Qué bello es tu ombligo!, y yo te digo: ¡Qué bello es tu ombligo, incluso qué redondo! Es absolutamente inútil. Como comparaba mi amigo Xavier Miserachs, es como hacer fósiles para un museo de historia natural. Los fósiles no hay que hacerlos. ¡Se encuentran, ya están hechos! Entonces sí tiene su función colgarlos en un museo de Historia Natural. El hacer arte para los museos a mí me parece absolutamente horroroso, y en fotografía... aparte de inútil, desorienta a muchísima gente. Me parece vergonzoso".

Aunque Masats nunca se ha considerado un purista estricto, lo cierto es que siempre ha reivindicado la independencia del medio fotográfico. Masats es consciente de los costes y obliga-

87 Miserachs, Xavier, Criterio fotográfico..., op. cit. pág. 33.

88 Tusquets Blanca, Óscar, Más que discutible..., op. cit., pág. 194.

89 Francisco Ontañón, correspondencia con el autor, 22 de junio de 2005. 
ciones de la simple fotografía. La fotografía requiere una gran disciplina, un gran autocontrol, lo que conlleva el reconocimiento de límites a la propia creatividad en aras de la utilidad, límites a partir de los cuales el sentido de la fotografía se diluye... No todo vale.

(R. Masats, Madrid, 20 de marzo de 2000) -“Para mí no sólo vale el reportaje. Incidiendo en la utilidad de la fotografía, estoy convencido que Chema Madoz está de acuerdo en este concepto, puesto que, desde un tipo de fotografía que podría decirse que no es nada útil, ha hecho publicidad para la modista Purificación García. Y, además, es una publicidad hecha con una inteligencia y una sensibilidad suya, propia. Le sirve lo que está haciendo para la producción de las cosas de Purificación García. Es decir, no ha hecho una cosa, en el encargo, diferente de las cosas que hace normalmente. Puro Chema Madoz y funcionando para publicidad. Para mí fotografía es mostrar fotográficamente una idea o una cosa, que no puede ser mostrada mejor por otro medio, ni por la literatura, ni por la música, ni por la pintura, ni por nada... Imagínate, lo que hace Chema Madoz en pintura no tiene razón de ser. El gran valor de lo suyo es que es absolutamente fotográfico. La fotografía tiene muchas limitaciones; pero esas limitaciones, si eres consciente de ellas, son la gloria de la fotografía. En sus limitaciones está su grandeza. La fotografía es esto... un papel fotográfico... y ya está. No porque piense que es limitada me meta a rascar el negativo. Yo no digo que esto no sea válido. Digo que como fotografía a mí no me vale. Tú lo que necesitas, a lo mejor, es hacer vídeo. ¡Pues haz vídeo! No te limites. Hay unos vídeos estupendos que destruyen la forma, el color, el ritmo... sobre todo en los vídeos musicales, aunque en la publicidad ya se está cogiendo todo esto. Ves una creación, una imaginación... La fotografía tiene sus limitaciones y en sus limitaciones está su grandeza. Está en el espacio fotográfico, esto es lo que hay".

“QQué función tiene la fotografía para usted?

Aparecer en revistas y libros. En eso coincido con Richard Avedon que dice que hace las fotos para los libros. Luego si se exponen y se venden, le parece muy bien. También pensaba así Irving Penn. Ahora la gente va a las galerías y, aunque parecen estupendas las formas artísticas, creo que la fotografía es para ser impresa.

¿Aunque sea etiquetando una botella de vino Valderiz, como sucede con una fotografía suya de una mujer pintando el suelo de La Mancha?

Claro, porque es un arte útil. Cuando el enólogo Telmo Rodríguez me lo propuso, me encantó la idea, porque la fotografía tiene que ser útil"90.

Óscar Tusquets coincide con Masats a la hora de buscar razones que avalen la tesis utilitarista y funcional de la fotografía, popularizándola, alejándola del elitismo y la cursilería de las Bellas Artes. Tusquets no se limita únicamente a defender la serialidad de la fotografía -y del diseño industrial-, sino que llega, incluso, a cuestionar el valor de la obra original en las mismas artes tradicionales, razonamiento heredado directamente de los postulados de la Bauhaus.

\footnotetext{
"He tratado de hacer ver cómo, en las Bellas Artes tradicionales -escultura, pintura y arquitectura-, la reproducción tiene su razón de ser, y el dominante fetichismo por la obra Original parece desproporcionado, pero si en algunas artes esta actitud roza la caricatura, es en las que se definen como artes seriadas. Me refiero, en concreto, a la fotografía y al diseño industrial; disciplinas paradigmáticas de la Modernidad, del arte en la era de la producción mecánica, de la popularización de la Cultura, de la supresión de las barreras elitistas del Arte Burgués, del Arte para el Pueblo con el que soñaba la Bauhaus" ${ }^{\prime \prime 1}$.
}

90 Lario, Ores, “Fotografía de la memoria”, en Expansión. Fuera de Serie, n 111, 21 de septiembre 2006, pág. 5. 91 Tusquets Blanca, Óscar, Todo es..., op. cit., pág. 32. 
-Lo de la utilidad de la foto... ¿Tiene algo que ver con la Bauhaus y con las experiencias artísticas del diseño aplicado a la vida cotidiana?

(R. Masats, Madrid, 20 de marzo de 2000) -“'La Bauhaus racionalizó una cosa que ya existía desde Atget. Él hacía fotografías para vendérselas a los pintores de París, para que pudieran pintar después sus cuadros sin salir a la calle. Quiero decir que, posiblemente, la Bauhaus racionalizó una forma normal de funcionar".

“El consenso entre la mayoría de fotógrafos de aquel momento en el hecho de que el vehículo natural de la imagen fotográfica es la página impresa. Los tirajes fotográficos -las copias o ampliaciones de un determinado negativo- 0 , en su caso, las diapositivas quedan desprovistos del aura de "originales" para convertirse en meros materiales intermedios de cara a este destino último de la impresión. Impresión que se traducirá en un afán de comunicación y difusión o, en lo que es lo mismo, en la hegemonía de la dimensión social sobre la estética"92.

Como vemos, esta utilidad de la fotografía que será reivindicada por toda aquella generación y por el mismo Masats, no se centrará exclusivamente en la mera reproducción de la realidad como documento para facilitar el trabajo de los pintores o como herramienta en la restauración de las artes tradicionales, o como elemento decorativo, por citar algunos de los usos que han aparecido a lo largo del presente trabajo. Del sinfín de posibilidades que la fotografía ofrece a la vida cotidiana hay una utilidad a la que se le concederá una especial importancia: su capacidad comunicativa. Cuanto más comunicativas, expresivas, informativas -no sólo en su concepción, también en su soporte, en su canal, en el medio de transporte de esa información-, sean las fotografías, más trascendentes, frescas y vivas se mostrarán. Ésta será la quintaesencia de la fotografía de Masats, su razón de ser.

“No hay nada más aburrido que las siempre desiertas, salas del departamento de fotografía en cualquier museo de arte contemporáneo. Aquellas instantáneas que tanto pudieron atraernos en un libro, en un Vogue, en un Harpers, en un Geographic, en una valla publicitaria, en cualquier periódico..., aparecen en esas paredes mucho mejor reproducidas, pero... como muertas" ${ }^{\prime \prime 3}$.

Desde la perspectiva que otorga esta apreciación la primera toma de conciencia real de la potencia comunicativa de la fotografía tendría lugar con ocasión de la llegada a España de los primeros ejemplares del catálogo de la exposición fotográfica de The Family of Man. Paradójicamente, fue una exposición, o más bien su catálogo, lo que descubrió las posibilidades expresivas y el alcance de las revistas ilustradas. Revistas que ocupaban el nicho social e icónico que más tarde comprenderán los dominios absolutos de la televisión.

José María Artero, uno de los padres de AFAL junto con Carlos Pérez Siquier, adquirió el catálogo de la exposición en abril de 1957, un año después de su distribución en España. La revista AFAL hace una presentación del catálogo y publica un fragmento de la introducción de Steichen y el prólogo de Carl Sandburg en el número 10, de julio de 1957. Pérez Siquier y Artero no disimulan el retraso de su conocimiento, pero es tal su entusiasmo por el catálogo que lo presentan con la ceremonia de una novedad:

\footnotetext{
“Han pasado varios meses de la primera vez que lo leímos y aún nos dura el asombro: el libro de Steichen, The Family of Man, nos cayó como una bomba, como venido de otro planeta (...) Nosotros sa-
} 
bemos de antemano que muchos, muchísimos importantes aficionados sonreirán ante nuestro ingenuo entusiasmo y pensarán que tratamos de descubrir la pólvora, ya que las primeras ediciones del libro se distribuyeron en España hace ahora un año. Sirvan pues esta líneas de reproche a todas aquellas grandes Sociedades y organizaciones que con mejores contactos con las novedades fotográficas conocieron en su día la aparición y venta en España y no lo comunicaron.

Cuando alguien os hable, después, de que la fotografía es arte únicamente cuando imita a la pintura, (enseñadle) este grandioso poema fotográfico" ${ }^{\prime \prime 4}$.

Este es el legado de The Family of Man a la joven fotografía española de los años cincuenta. Los fotógrafos del momento descubrieron en sus páginas lo que de un modo balbuceante ya adivinaban intuitivamente en la contemplación de las revistas ilustradas. Al contemplar el libro comprendieron por qué les repelía el salonismo y toda su estética y parafernalia oficial. Asimismo, descubrieron los motivos por los que renunciaban al pictorialismo:

"Por culpa exclusivamente de The Family of Man, sin otro motivo, Xavier Miserachs abandonó la carrera de medicina en quinto curso y con notas excelentes, todo notables. Yo me cabreé con él. Le rogaba que esperara el fin de su carrera. Pero no quiso, tenía prisa, quizás intuyó su muerte y quiso disfrutar de lo que le quedaba de vida"95.

Descubierta la capacidad comunicativa de la fotografía -su nivel testimonial y documental- no extraña la calificación del libro como "poema fotográfico", poema que debe ser leído e interpretado, no sólo contemplado o disfrutado plásticamente. Apreciar únicamente las calidades o las composiciones hubiera sido no haber entendido nada de lo que allí se contaba. En el fondo, y siguiendo la comparación que se propone, es como valorar la hermosura caligráfica de las letras de un libro, o la calidad del papel en el que se escribe, o la belleza formal o sonora de las palabras... sin entender absolutamente nada del contenido del texto en sí.

“Contar, comunicar, explicar, aumentar el conocimiento de otros a través de la experiencia propia, explorar con la cámara lo que el ojo no consigue «ver», documentar lo que va a perderse irremisiblemente... éste es el trabajo del fotógrafo"96.

Ontañón, por ejemplo, nos comenta telefónicamente que siempre ha entendido la fotografía para ser publicada, nunca para ser expuesta. Una vez más, subraya la importancia del potencial comunicativo de la fotografía. Una imagen podía ser vista por varios millones de personas. Aquello no tenía parangón. Con un telefoto podían transmitir fotos a todo el mundo. Esa virtud y utilidad son tan grandes que no se puede comparar con la fotografía conceptual o decorativa de la actualidad (una vez más seidentifica el salonismo con la fotografía artística de nuestros días).

"Cuando comparo la fotografía a un lenguaje, lo hago consciente de que puedo estar cometiendo una ligereza (...) Pero no por ello dejo de rendirme a la evidencia de que nos hallamos ante un vehículo comunicativo de una potencia y capacidad excepcionales. Acepto la falsedad de la frase «una imagen vale más que mil palabras», falsedad derivada de la comparación de entidades no equivalentes, pero sí creo que evita muchas, e informa, además, en un «canal» al que difícilmente podría llegar la palabra. Una fotografía lleva, en lo más profundo de su imagen, un «documento», por elemental que sea. Ésta es su grandeza"97.

94 Siquier, Pérez y Artero, José María, “The Family of Man”, en AFAL n 10, julio-agosto 1957, sin paginar.

95 Oriol Maspons, correspondencia con el autor, 23 de octubre de 2004.

96 Miserachs, Xavier, Profesiones con futuro..., op. cit., pág. 22.

97 Miserachs, Xavier, Profesiones con futuro..., op. cit., pág. 19. 
Recordemos la anécdota que contaba el propio E. Smith de cómo, mientras realizaba su famoso reportaje sobre el dramático envenenamiento de mercurio, se encontró con varios álbumes completos con recortes de fotos suyas en un lugar del mundo tan alejado y pequeño como la aldea de Minamata. A esa posibilidad de universalidad en la distribución o difusión de una imagen publicada es precisamente a lo que hace referencia Ontañón, a la capacidad de influir en la opinión pública de la sociedad.

“Esto explicaría que durante este tiempo la publicación pase a ocupar el papel de unidad expresiva de los fotógrafos y que la historia correspondiente deba efectuarse enumerando títulos de obras editadas. No ha de extrañar a nadie que una revista como Life (iniciada en 1936) y el modelo que encarna, seguido en Europa por revistas como Paris-Match, Stern, Época, etc. se aprovechen de ello para alcanzar su máximo esplendor"98.

Al respecto de las exposiciones que se realizaron en aquel periodo, Ontañón comenta que ellos no tenían ningún apego en exponer. Era como un muestreo. Cuando exponían lo hacían por la satisfacción de ver sus obras a gran tamaño y con mucha calidad, ya que en aquella época se perdía mucha resolución en las reproducciones de los libros y las revistas. Según Ontañón, el tamaño es fundamental en un exposición. Cuanto más grande es la ampliación más gana la exposición pero más se alejaba de la publicación. En la actualidad, como han desaparecido las revistas ilustradas del estilo de Life o Look, se ha pasado de la foto para publicar a la foto para exponer, mucho más limitada en su difusión geográfica y en su alcance efectivo.

De este modo, la potencia comunicativa alejaba a la fotografía de las artes plásticas mientras que la comunicación planteaba inevitablemente una serie de compromisos morales: no sólo entre el fotógrafo y el cliente -la revista o la editorial que realizaba el encargo-, sino también entre el fotógrafo y el público -el potencial receptor del mensaje fotográfico-, o entre las propias personas fotografiadas, como ya veremos. Nuevamente esas responsabilidades éticas, deontológicas o morales contrastaban con la vacua esterilidad del salonismo:

“Yo más que funcional la llamaría descriptiva, ilustrativa o editorial: fotografía con finalidad. Qué mejor finalidad para una imagen que ilustrar al mundo. Alejada siempre de la idea de hacer «arte» dejemos esto para los salonistas; cambiar páginas de literatura de texto por imágenes. ¿Has visto la Familia del Hombre? Creo que es el máximo exponente de la fotografía funcional: hecha en función de ilustrar el mundo; la fotografía ilustrativa, sublime exponente de lo que puede llegar a hacerse estéticamente, poéticamente con una cámara en las manos. La mayoría de las obras han ilustrado revistas famosas, hechas $\sin$ aspiraciones artísticas. Seguramente han logrado una perfección estética que las han hecho trascendentales.

Fotografía narrativa que no fue creada para ser colgada en un salón o aparecer en las páginas de un boletín. Obras de unos profesionales casi toda, sólo así dándole una finalidad a la producción de birrias del arte olvidando el salón y el concurso, trabajando, no queriendo hacer arte, creo que sería el medio de ir produciendo algo, algo nuestro, la significación de la fotografía en España tiene que ser para toda la fotografía, para TODA. Y diría menos la de Salón, de esa de la que no vale la pena ni hablar, creo que ya está bien donde está"99.

98 Gili, Marta, "Miserachs en...", op. cit., pág. 20.

99 Cubaró, correspondencia con Pérez Siquier (02-11-57), en Terré, Laura, op. cit., pág. 120. 


\title{
6.4. UN COMPROMISO ÉTICO
}

Aunque en un determinado momento Masats llegara a plantearse si iba a dedicarse a realizar reportaje humano o fotografía de formas abstractas, lo cierto es que hay un denominador común en toda la producción de Masats: el humanismo. Humanismo que no será patrimonio exclusivo suyo, todo lo contrario. Su generación al completo asumirá el mismo compromiso con sus congéneres y con su sociedad. De ahí que hasta en las composiciones más abstractas de Masats siempre aparezcan referencias a lo humano. Parte de la responsabilidad de esa corriente humanística recae nuevamente en el catálogo de The Family of Man. Cuando Edward Steichen volvió de la guerra y se le confió el desarrollo del departamento de fotografía del Museum of Modern Art de Nueva York, inaugurado por Beaumont Newhall, tuvo una revelación:

\begin{abstract}
"Steichen había presentado ya varias exposiciones de fotografías sobre la guerra, pero las reacciones demasiado superficiales del público le habían dejado insatisfecho. Llegó a la conclusión de que había que considerar, con una mentalidad positiva, «que la vida es una cosa maravillosa, que la gente es maravillosa y, sobre todo, hasta qué punto la gente es la misma en todo el mundo»"100.
\end{abstract}

Después de su inauguración, en enero de 1955, la exposición inició su periplo europeo en Berlín ese mismo año, a una década de la liberación de la ciudad por las tropas soviéticas y norteamericanas. La exposición fue un triunfo. Unos diez millones de visitas en sesenta y nueve países. Se necesitaron seis ediciones de la exposición para responder a la demanda. En la introducción al catálogoSteichen insistía sobre la gran idea de "la unidad esencial del género humano a través del mundo". Evidentemente, la exposición adolece de unos fundamentos maniqueos y simplistas. Este planteamiento vino determinado por una circunstancia histórica muy dramática -como fue la posguerra de la II Guerra Mundial- pero es que además, toda aquella visión paternalista, inocentona e idealista, estaba organizada y orquestada con el lastre de la mirada, el pensamiento y la intención del todo poderoso hombre blanco occidental. El responsable de esta lectura fue el propio Steichen, de ningún modo los fotógrafos participantes, que sometidos a la maquetación, la selección y la ordenación, fueron absolutamente manipulados y utilizados en pro de una ideología sospechosamente cándida. Tanto que motivó las lógicas protestas de algunos de ellos.

\footnotetext{
“Presente en Moscú, donde se suceden las muchedumbres, Steichen refuerza su humanismo universal, afirmando que, «de todos los pueblos que he visitado, el pueblo ruso es el que más se parece al pueblo americano».

Fue en París, en 1956, donde la prensa se mostró más elogiosa. Sin embargo, ese mismo año, en una colección de estudios titulada Mythologies, el filósofo Roland Barthes ajusta las cuentas a la ideología sospechosa que se confiesa y se disimula en una tal manifestación: «El fracaso de la fotografía me parece aquí flagrante. Reproducir la muerte o el nacimiento no enseña, a decir verdad, nada. Sólo eterniza los gestos del hombre para desactivarlos mejor». La realidad se halla en la situación histórica de una madre bantú o esquimal determinadas, en las injusticias que se ceban sobre ellas, en los progresos que podrían hacer, no en la exaltación de una «maternidad» general y abstracta. Barthes analiza así el motivo de que las fotografías demasiado bien captadas y demasiado hábilmente cargadas de significación nos decepcionen, al detener en seco nuestra imaginación" ${ }^{\prime 101}$.
}

100 Osman, Colin, "La fotografía segura de sí misma (1930-1950)", en Lemàgny, J.C. y Roville, André, Historia de la fotografía, Barcelona, Martínez Roca, 1988, pág. 184.

101 Osman, Colin, op. cit., págs. 184-185. 
Esta crítica nunca llegó a la generación de Masats. No hubo recelo alguno en el mensaje de la exposición. Tampoco fueron conscientes de la responsabilidad del editor en la construcción del contenido ni en el mensaje final del libro. Hubiera sido impensable ese sofisticado nivel de lectura en un ambiente tan atrasado como el de la España de 1957. Por el contrario, en lo concerniente a contenidos, la exposición influyó decisivamente en los jóvenes fotógrafos. La intención moralizante de la obra, su función de compromiso ético con el Hombre o, mejor dicho, con toda la Humanidad, contrastaba directamente con el ideario oficial franquista en el que primaban las ideas autoritarias de superioridad y de diferencia con el extranjero, de patriotismo exclusivista y endogámico.

\begin{abstract}
“Hacer fotografía no es hacer buenas fotos. Hacer fotografía, es hacer humanidad; es dar al hombre motivos para sentirse feliz de ser hombre, darle motivos de sentirse agradecido a Dios por tener toda esta maravilla de la Naturaleza. Hacer fotos es mirar largamente y con profundidad a nuestros hermanos, todos estos hombres que pasan a nuestro lado y nos son -en principio- indiferentes, mirarlos y sacar conclusiones, y presentarlos con cariño, con respeto a su integridad espiritual. Es escribir en cada negativo una página de humanidad que nos haga vibrar a nosotros creadores, o bien receptores. Te das cuenta, que para poder hablar con verdad, con profundidad, se necesitan muchos requisitos. Porque un fotógrafo -y son palabras de Masats en una visita que me hizo hace unos días- debe hablar con sus fotos, no hacer literatura"102.
\end{abstract}

La herencia de The Family of Man se rastrea años más tarde cuando Carlos Pérez Siquier realiza una crítica sobre el grupo Les 30×40, el alter ego de AFAL en Francia. AFAL y Les 30x40 compartieron exposiciones, revistas y otros contactos para promocionarse y apoyarse mutuamente, pero nunca tuvieron las mismas inquietudes éticas ni el mismo compromiso moral con su tiempo y sus congéneres que proclamaba la histórica exposición.

“Pero el reproche más grande que he de hacer a «Les 30x40» es su indiferencia a los problemas humanos, sociales y hasta políticos del pueblo francés (...) La fotografía debe ser, ante todo, testimonio, reflejo auténtico de una época o de un pueblo. Todo fotógrafo-reporter contrae la ineludible obligación moral de interpretarnos la realidad de su país, por muy triste o muy esperanzadora que sea"103.

Después de conocer el catálogo, muchos de los fotógrafos del momento dejan de hablar de reportaje para hablar de "Fotografía Humana". Algunos hablan simplemente de "el HOMBRE como tema". Ello hace que, en su mayoría, centren su trabajo en los temas humanos, tomados directa o indirectamente, a través del paisaje humano o de naturalezas muertas:

“La fotografía actual ha tomado claro viraje después de la guerra, y su objeto principal es la búsqueda de la verdad (...) ¿Puede uno soñar mejor asunto, tema eterno, que el hombre?... El hombre en su trabajo, en sus ocios, en sus alegrías, en sus penas... Separar toda una pequeña secuencia en la vida que pasa... Esta es nuestra misión, por la cual somos los mejores equipados entre todas las artes. Cada uno puede en ello sobresalir según sus gustos y preferencias; el tema es inagotable"104.

(Koldo Chamorro, Pamplona, 21 de marzo de 2003) - “Y yo creo que, en definitiva, lo que pasa con Ramón es que trabajando el reportaje en realidad no trabajaba con el reportaje. Trabaja sobre una fotografía que vamos a llamar de tipo humanístico. Y es lo que a Ramón le confiere

102 Schommer, correspondencia con Pérez Siquier (02-11-57), en Terré, Laura, op. cit., pág. 120.

103 Pérez Siquier, Carlos "Fotografías de Francia", en $A F A L, n^{\circ} 23$, marzo-abril 1960, sin paginar.

104 Varga, André, “Opiniones a distancia, por Miguel Tubau”, en Arte Fotográfico, n 83, año VII, noviembre 1958 , pág. 948. 
ese punto de extrañeza respecto a gente contemporánea de él (...) Él mira a través del hombre, pero lo que mira es la humanidad. Mira la humanidad y el territorio de la humanidad. Es una humanidad que, evidentemente, tiene un calendario de acontecimientos, por una parte, y es una humanidad que va a dejar tras de sí una serie de rastros, de huellas y de indicios que tienen tanto interés como el contenido de esa humanidad; es decir del calendario. Claro, yo pienso que en ese viaje que ha hecho Ramón -un viaje bastante solitario- al final lo que le pasó es que no encontró interlocutores que entendieran lo que estaba haciendo. Esa carencia es lo que, de algún modo, le ha dado ese nivel de extrañeza que él posee en el conjunto de su obra. Claro, es un nivel de extrañeza que, cuando ahora mismo, cuando lo observamos, evidentemente, tenemos más información que ellos en aquel momento, respecto a lo que afecta especialmente a la escritura fotográfica (...) Hablar de que él es un fotógrafo humanista... A mí me parece quizás excesivamente rimbombante. Quiero decir, que eso del humanismo ya sabemos que es un lugar común, confuso, utópico y peligroso en definitiva. Pero sí, a él lo que le interesa es el hombre y el teatro de operaciones en el cual se desarrolla el hombre, y que en muchas imágenes ambos están al mismo nivel y que uno no tiene explicación sin la presencia del otro. ¡0jo!, que cuando hablo del teatro hablo del espacio de escenificación, no estoy hablando de la articulación visual de lo que entendemos por teatro. Y prueba de ello es que todas las escenificaciones de Ramón son muy limpias. Ni falta ni sobra".

En cualquier caso, el resultado final de ese humanismo es bien distinto, y ello a pesar de la influencia ejercida por el catálogo de Steichen:

“Las series que componen el trabajo de los fotógrafos de AFAL - pensemos en las imágenes de Semana
Santa de Terré, la serie La Chanca de Pérez Siquier, las imágenes de cualquier serie de reportaje de
Masats, etc.- son más crudas, más directas, más humorísticas. La grave impresión que deja el libro
de Steichen (sea por la introducción de fotografías antiguas, algunas de ellas de valor documental
importante, que encierran el peso del pasado, sea por la solemnidad de los textos que las acompañan)
no se experimenta al seguir una a una las fotos de los fotógrafos citados. El punto picante del humor
se siente en las series españolas. Es quizá ese punto que Steichen no dejó transparentar en el proyecto
porque necesitaba la gravedad casi religiosa de un acto de desagravio a favor de la humanidad entera.
Los fotógrafos españoles poseen esa ingenuidad que parece no conocer todavía el mal, o cuya costum-
bre infantil frente a él les ha hecho crecer sin prejuicios. Pensemos en la imagen de la bizca de Terré.
Es una fotografía tremendamente humana, pero transgresora. Una imagen que ha nacido al límite de
los pactos del buen gusto, que no consigue el consenso, pues en vez de mover a la pena mueve a la
sonrisa. Una forma particular de narrar la humanidad, cuya épica es sustituida por una poética de lo
cotidiano, sencilla y humorística"105.

Desde nuestro punto de vista es precisamente esa falta de solemnidad, esa ironía y escepticismo, lo que salva a los trabajos de Masats y a los de sus compañeros de generación de lo que hubiera podido ser una mojigatería cargante. Por el contrario, la sonrisa los dota a todos ellos de una fresca atemporalidad y de una cierta violación de lo establecido y lo conveniente. Ahora bien, ese sentido del humor no entra en contradicción con un gran respeto al público (al lector de las fotografías) y, por supuesto, a la propia persona fotografiada. Hay una gran dignidad y ternura en los sujetos fotografiados de Masats. Como ya vimos, no asume el compromiso de denuncia de las injusticias sociales que hacía E. Smith, puesto que con la represión franquista hubiera sido imposible. Ya comentamos que no hay intención de denuncia en los trabajos de Joan Colom sobre la prostitución, ni en los de Pérez Siquier sobre los barrios marginales de Almería. Pero, a pesar de ello, sí mantienen un nivel de compromiso ético y respeto. 


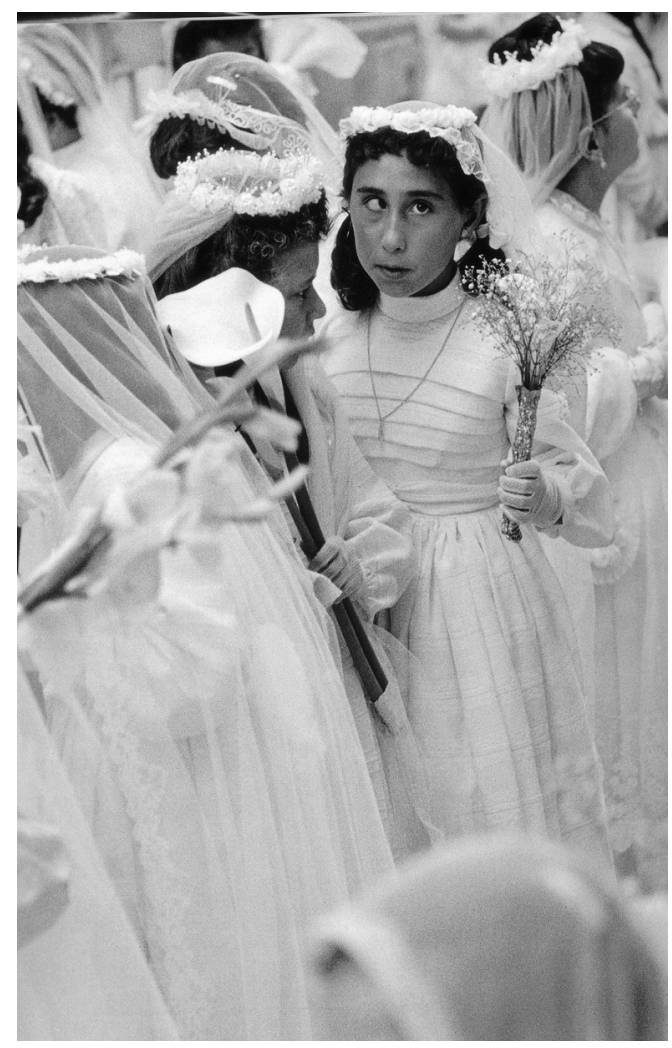

Ricard Terré, "Serie Semana Santa. Sant Boi de Llobregat", 1957.

“Soy bastante irónico, nada malicioso. En mis primeros años con la cámara iba por la Barceloneta y había mucha miseria. Pero no la fotografiaba porque me parece muy fácil mostrar la mugre y la pobreza"106.

Henry Cartier-Bresson fue uno de los autores que mayor influencia tuvo en Masats y todos sus compañeros de generación. Sus estrictas normas del juego, su disciplina rígida, aparecen fielmente transcritas en una entrevista realizada por Oriol Maspons en 1958, cuando Cartier-Bresson ya cuenta con veinte años de experiencia:

“Cartier-Bresson deja de publicar una imagen a partir del momento en que para aprovecharla ha de dejar de ampliar la totalidad de su superficie del clisé $24 \times 36$ (...) Cartier-Bresson encuadra, telemetra y dispara sin tener que acercarse 0 alejarse del sujeto, pues conoce perfectamente lo que abarca el ángulo de su objetivo de cinco centímetros y el encararse la máquina a los ojos es sólo para telemetrar (cosa que hace siempre) y disparar. La composición ya la tiene hecha de antemano (...) La sensación de verdad que se desprende de sus fotografías ha sido a mi juicio, la causa del extraordinario triunfo de Cartier-Bresson en todo el mundo. Sus personajes son simples y vivos, ninguna preparación ha mediado jamás en sus escenas. Nunca ha usado un «flash» ni ha tocado un trípode, su única máquina ha sido la Leica con diversas ópticas"107.

106 Lario, Ores, op. cit., pág. 5.

107 Maspons, Oriol, “Cómo hago mis fotografías, por Henri Cartier-Bresson”, en Arte Fotográfico, n 81, año VII, septiembre 1958, págs. 770-772. 


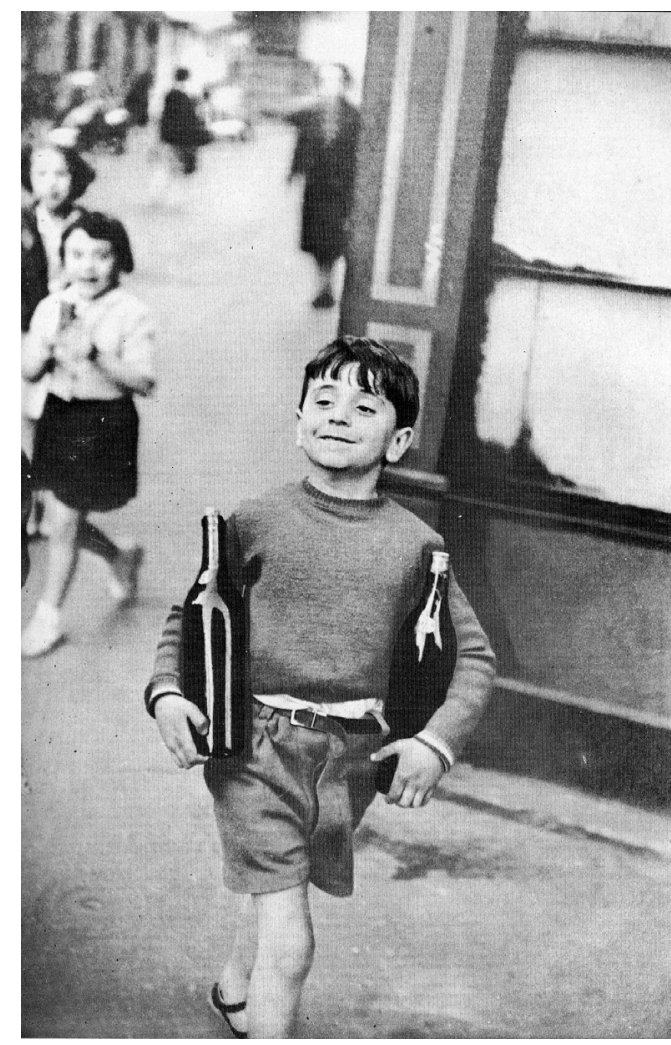

Henri Cartier-Bresson, "El niño de la calle Mouffetard", publicada en Arte Fotográfico, n 81, septiembre 1958.

Como afirma Maspons, este tipo de "normas" (el respeto al formato -más tarde se descubrirá que limaba incluso el portanegativos para que se vieran los orificios de la película-, el respeto a la luz encontrada, el uso de un solo objetivo cuyas proporciones son parecidas a las del ojo humano...) son asumidas por toda una generación de fotógrafos. Sin embargo, el maestro indiscutible que es Cartier-Bresson hoy, y que era reconocido de inmediato por Masats y por sus compañeros hace medio siglo, no llegó, como era de suponer, a toda la fotografía española. Una vez más, los salonistas se cerraban en banda ante la obra de uno de los fotógrafos más importantes del siglo XX. En un curioso artículo, Argilaga, aquel salonista de pro que vapuleara dialécticamente Oriol Maspons, critica la entrevista de Maspons a Cartier-Bresson. Decimos curioso porque, de forma prudente, Argilaga no cita en ningún momento a Maspons ni a Cartier-Bresson en todo su escrito...

“Porque no quiero líos y por ser, además, poco amigo de polémicas que, por lo general, poco ayudan a aclarar las cosas, sobre todo cuando de los puntos de vista sustentados se hace poco menos que cuestión personal"108.

Sin embargo, queda claro que se refiere al artículo de Maspons publicado unos meses antes, porque describe perfectamente la foto de Cartier-Bresson:

108 Argilaga, "Tertulia fotográfica. La realidad «desnuda» no es tema de arte", en Arte Fotográfico, n 85, año VIII, enero 1959, pág. 33. 


\begin{abstract}
“Tampoco acertamos con el motivo determinante que exige, para no quitar «veracidad» ni «realismo» a las obras así captadas, el que tengan que positivarse lamentablemente «torcidas» y con una caída total de verticales, un desagradable desfoque que sólo deja «limpia», a lo mejor, una figura de muchacho «sin pies», que será -no lo dudamos- todo lo dinámica y expresiva que se quiera, pero que en cuanto a presentación cabría hacer no pocos distingos para catalogarla como obra de arte"109.
\end{abstract}

Argilaga considera la obra de Cartier-Bresson fruto de la casualidad, técnicamente incorrecta, por las urgencias a la hora de disparar y demasiado real.

“El arte (con permiso) constituye casi siempre un «falseamiento» de la realidad, porque ésta pocas veces resulta «grata». Se hace, pues, preciso «embellecerla» «idealizarla», «pulirla»; de lo contrario, puede incluso devenir repelente. Una prueba obtenida a «destajo» casi nunca resulta «artística» (...) El arte, para ser tal, no precisa de la «verdad»"110.

La realidad ocupará un lugar de privilegio en la nueva fotografía. Los seguidores de CartierBresson admiran que en sus imágenes, casi siempre frontales y directas, las personas fotografiadas actúan indiferentes a la cámara. La realidad surge intacta. Para ello el fotógrafo debe ser muy discreto:

“Enemigo de darse a conocer o que le reconozcan, hace de su incógnito un «capital profesional», que le permite pasar inadvertido por todas partes, le ayuda a ello su aspecto inofensivo"111.

Esta defensa del anonimato como parte de su utilería fotográfica contribuye a su leyenda: ausencia de autorretratos publicados, ataque con un cortaplumas a un fotógrafo que pretendió fotografiarlo en la inauguración de una exposición... Cartier-Bresson es consciente del pacto, del vínculo que une al sujeto fotografiado con el fotógrafo, responsable de la imagen final:

\footnotetext{
“Una mano de seda y un ojo de lince es lo que deberíamos tener todos. No es bueno llegar a codazos y empujones, ni tampoco las fotografías deben tomarse con la ayuda de la luz del flash, por lo menos por respeto a la luz que se halla presente, aunque haya muy poca o nada. A no ser que un fotógrafo observe condiciones como éstas, corre el riesgo de convertirse en una persona insoportablemente agresiva"112.
}

Estos consejos, eminentemente prácticos, tienen un trasfondo estético, pero sobre todo ético. Por un lado, consiguen la aproximación al sujeto de una forma invisible; por otro, remarcan la no intervención como lo específico del reportaje. Evitar el flash ayuda a que no seamos detectados cuando hagamos la foto. De este modo, nuestro sujeto no se alertará y no alterará su comportamiento -al ser consciente del objetivo de la cámara- y tampoco se verá amenazado ni atacado. Asimismo, nunca adulteraremos la luz que había en la escena: la respetaremos y no la falsearemos, de ahí que desaparecen también los filtros de colores. Usar un cincuenta ayuda a pasar desapercibidos: no es un teleobjetivo que llama la atención por su tamaño y que apunta como un arma, ni señala como un dedo índice, faltando el respeto y agrediendo a la persona retratada. Al igual que sucedía con los filtros de colores, el uso de un teleobjetivo implica la

109 Argilaga, "Tertulia fotográfica...", op. cit., pág. 35.

110 Ibidem.

111 Maspons, Oriol "Cómo hago mis fotografías, por Henri Cartier-Bresson...", op. cit., pág. 770.

112 Cartier-Bresson, Henri, "Henri Cartier-Bresson (1948)...", op. cit., pág. 192. 
alteración de la realidad al verse aplastada la perspectiva, por ello tampoco se admite un gran angular, dado exagera y modifica la escala real de la escena deformando la visión de la misma. A su vez, pintar las partes cromadas de la cámara sirve al mismo propósito: ser discreto, no ser detectado y no intervenir en la escena.

“No quiero decir más sino que prefiere beber té, que Kandinsky le entristece o que suele pintar de negro las piezas cromadas de sus máquinas fotográficas"113.

Un objetivo o dos, un cuerpo de cámara... Equipo reducidísimo, sin trípode, sin aparatosas bolsas de accesorios... Todo ello no sólo para encubrir al fotógrafo y que éste tenga el aspecto de "señor que pasaba por ahí", sino también para que pueda además olvidarse de la tecnología y concentrarse en el "Hombre". Dicho de otro modo:

“Para captar la vida en «flagrante delito» como hace Cartier-Bresson, se sirve, además, de su gran capacidad física de manejo de la cámara, de su extraordinaria capacidad psicológica, compuesta de una rapidez de reflejos que le permite aprovechar todas las ocasiones que le dicta su enorme conocimiento del hombre como ser de reacciones previsibles. Este conocimiento del hombre le permite prever y anticiparse, en cierto modo, al acontecimiento que brillará en la expresión de una cara y que será ciertamente fugaz. Explicando esto me decía: -Una vez estaba en Valencia presenciando una corrida de toros; fotográficamente me «entendía» bien con el público y los toreros antes de comenzar la lidia; pero cuando llegó el momento de fotografiar la corrida me encontré perdido. Yo no entiendo de toros, no conozco a los animales y no puedo sacar buenas fotografías, porque no sabía lo que iba a hacer el toro antes de hacerlo"114.

En esta anécdota queda implícito el núcleo de la obra de Cartier-Bresson: el Hombre y/o la Humanidad como tema. Igual que Steichen con su The Family of Man, igual que E. Smith, igual que la obra del propio Masats.

“Él dice: «Hay mil maneras de describir al hombre en su alegría, su pena y sus luchas. Cuando alguna tendencia se me reprocha siempre lejos de mi ánimo, ni yo ni nadie será capaz de afirmar que los personajes de mis fotos son puramente imaginarios y que todo su parecido con personas reales es pura coincidencia...» «Yo estaba allí, y he aquí la vida en ese momento tal como yo la vi.» (...) Sin pretender hacer Arte, pues él sólo me afirma que el motivo de toda su vida ha sido «dar a la fotografía su más legítima función, la de manera de ver y testimoniar de su época, dejando de buscar en vano su razón de ser en lo que acabó llamándose la pintura de los pobres»"115.

\section{Como afirma el propio Cartier-Bresson:}

“Nunca he estado interesado en el aspecto documental de la fotografía, excepto como expresión poética. Sólo me interesa la fotografía que surge de la vida"116.

(Koldo Chamorro, Pamplona, 21 de marzo de 2003) - “Otra cosa, en la que he coincido mucho con Ramón, es en cómo enfrentarte a determinados modos de hacer imágenes, que son

113 Delpire, Robert, “Henri Cartier-Bresson”, en Arte Fotográfico, n 84, año VII, diciembre 1958, pág. 1021.

114 Maspons, Oriol, “Cómo hago mis fotografías, por Henri Cartier-Bresson”, op. cit., pág. 771.

115 Ibidem.

116 Hill, Paul y Cooper, Thomas, Diálogo con la fotografía, Barcelona, Gustavo Gili, 2001, pág. 79. 
excesivamente dolorosos para el sujeto que te cede la imagen. Hay que ser muy respetuoso. Tú no puedes trabajar con un teleobjetivo porque no te puedas aproximar a las personas. 0 te ven, te identifican y saben qué es lo que estás haciendo, o no hagas las fotos. Sabiendo también que luego esas imágenes cuentan. Yo mantengo desde hace mucho tiempo que la imagen común que se utiliza en la prensa, es un tipo de imagen fundamentalmente policial. Porque la policía te puede identificar en una manifestación, o en lo que sea. Lo que pasa es que hay tanta información que la policía llega un momento en que si tuviera un ordenador se le rompería, ¿me entiendes? Pero, de hecho, es lo que pasa, y eso la gente lo sabe. En la historia de la cultura occidental hemos pasado de la no existencia de la imagen privada a su existencia, y cómo el poder está manipulando toda esa privacidad, rompiéndola a través de los programas de contenido rosa, o no sé que. Claro, la privacidad hace que las personas sean menos controlables. Y ahí la fotografía ha tenido mucha importancia. Ha sido peligrosa para la gente. Yo siempre he defendido el derecho a la privacidad. Por eso nunca he ido a sitios, nunca he trabajado en sitios donde la privacidad fuera realmente privada".

-Ramón comenta que la Judicatura está cambiando el reportaje fotográfico, al impedir a los fotógrafos fotografiar por la calle.

(Koldo Chamorro, Pamplona, 21 de marzo de 2003) -“Evidentemente, si tú lees a Aristóteles o Jenofonte o Platón... te das cuenta de que a nivel legislativo está todo hecho. Ahora lo único que se hace es marear la perdiz. Eso hace que las relaciones sean mucho más penosas. Pero a la vez ha ocurrido otra cosa, y es que hemos pasado de cierta inocencia, sociológicamente entendida, a comprender que hay una perversión y una manipulación. Y claro, uno no quiere verse sometido ni a manipulaciones ni a perversiones. La perversión nace ya desde lo que pueda pensar el fotógrafo, la forma de mirar... la imagen, cómo se edita la imagen, cómo se extrae del conjunto de negativos y cómo se usa. Hay mucha gente que mete mano y al final... ¿Quién es el responsable? ¿El fotógrafo que pensó la imagen, o el paginador que cortó la imagen, o el editor que la metió en no sé que libro o no sé en donde? Todo eso ha hecho que la gente pierda la inocencia. Trabajar en España en el año treinta y uno, era relativamente sencillo, porque la gente era inocente, ahora es más complicado, evidentemente. Es más complicado en determinados ámbitos. Allá donde el espacio público entre en conflicto con el espacio privado. El tema de las playas es muy claro. Aparentemente es un espacio público, pero no, es un espacio de uso estrictamente privado. $Y$ eso crea muchos conflictos, como también puede ocurrir en las fiestas. Yo siempre pongo el caso de la feria de Sevilla, que es una fiesta estrictamente privada. Si tú no perteneces a una caseta, no puedes entrar. Irás con alguien que te invite, pero tú solo no puedes entrar. Hay una contemplación muy clara de lo que es un espacio privado. Yo entro como fotógrafo, y a mí me presentan como fotógrafo: y a partir de ahí se dispara una alarma y la gente actúa, sobreactúa en función de mi presencia como fotógrafo. Ahora, si yo voy como amigo y no como fotógrafo, la gente actúa de otro modo. Esto ha hecho que el tipo de imágenes de no ficción, donde trabajamos con la gente, en sus espacios culturales de hábito y costumbre, cada vez sea más complicado tomarlas".

-Siempre fuiste muy respetuoso con la gente.

(R. Masats, Madrid, 27 de diciembre de 2006) -“Yo es que siempre he sido muy respetuoso con las personas".

-Si hubiera habido más fotógrafos como tú, no hubiéramos llegado al extremo en que no se puede hacer reportaje.

(R. Masats, Madrid, 27 de diciembre de 2006) -“Seguramente. No lo sé. No es sólo cuestión de qué temas trates sino cómo están hechos, la factura. Cuando hay un poco de inteligencia y tratas los temas con humor, o de una forma sensata...". 


\section{5. ¿INTERVENCIÓN O PURISMO?}

El purismo de Cartier-Bresson y la no intervención directa ejercieron una matizada influencia sobre Masats. La libertad creativa de éste le impedirá aceptar cualquier norma como un dogma de fe. Gobernado por un gran compromiso con respecto a la sinceridad y la autenticidad, las imágenes de Masats se ajustan a la realidad, como las de Cartier-Bresson, pero en Masats sí aparece explicitamente el autor. Éste rechaza cualquier invisibilidad y participa de la imagen y de la realidad, creándola, modificándola y permitiéndose algunas frivolidades meramente plásticas, como sucede con las fotos movidas de toros o el tronco invertido de Las Ramblas. ¡Girar una fotografía y ponerla boca abajo sería inaudito en Cartier-Bresson! En vez de ser verdad absoluta e inalterada, la imagen se convierte en una honesta veracidad.

(Koldo Chamorro, Pamplona, 21 de marzo de 2003) -“Yo, hace poco, hablando con una gente que trabajan en el cine haciendo documentales y todo esto... Me comentaban el gravísimo problema de escoger un tema nuevo para hacer un documental. ¿Cuál? Quiero... yo qué sé el que. Vas, miras, y hay por lo menos ochenta documentales que lo tratan. Algunos con mejor fortuna y otros con menos, pero los tienes. Claro, el gran problema al que hemos llegado es que, evidentemente, todo está contado. Ha habido una pretensión de objetividad, que no ha existido nunca, pero que ha limitado un poco el ámbito. Es decir, que uno no podía implicarse en el asunto, y cuando uno se implicaba al final venían a acusarlo a uno de manipulador como ocurrió con Eugene Smith. Y yo creo que es todo lo contrario. Tienes que implicarte, ser muy subjetivo y empezar a contar un poco el territorio... que es un territorio intersticial, muy difícil de ver, que es lo que existe entre la verdad y la mentira. Y claro, es un territorio que lo tienes tú en tu casa, no lo tienes en la península de Kamchacka. No te tienes que ir tan lejos, lo tienes aquí. Claro, eso también desorienta mucho, porque el tema de la fotografía, como profesión, es un poco los últimos coletazos de lo que pudo ser, dentro del romanticismo, el aventurero. Y tiene eso de la tierra inhóspita, la tierra por descubrir, el tema por descubrir, el primero que llega... Claro, eso ya no existe. $Y$ cuando hay alguien que lo hace, y lo hace con discreción, como ha pasado con Ramón, políticamente es incorrecto $\mathrm{y}$, además, es incorrecto porque como lo ha hecho bien, no recibe las salpicaduras del régimen político, que evidentemente era muy atosigante. Que es lo que hicieron un poco todos, que es la España de las moscas, de la pandereta... Y yo no veo en las fotos de Ramón ese ánimo que ha habido en las fotos de la época, y también en las de mi generación".

Masats comenta al respecto de la intervención y de la subjetividad:

(R. Masats, Madrid, 20 de marzo de 2000) -“Doisneau falsificaba muchas fotos. Hay una serie, en un escaparate de un anticuario, que hay un cuadro de una señora estupenda, y notas las miradas de unos y de otros... Y sobre todo la mirada de un policía, al que le dijo : «Pon mala cara...» ¿Hasta qué punto es válido o no es válido? No lo sé. No tiene importancia si esto ocurre realmente y tú lo recreas. Me parece válido. Mientras no falsifiques yo creo que sí".

\footnotetext{
“Doisneau, excepcionalmente, prepara sus fotografías, ya sea provocando la escena o haciendo actuar a modelos improvisados. Muy exigente en el resultado, ni él mismo ha de notar que lo que ocurre es falso; ni nunca lo que «sucede» debe parecer sensacional ni inesperado en el ambiente en que se desarrolle. Ha de ser solamente un acto normal, repetido con oportunidad.

A mis reproches por esta debilidad, respondió Doisneau que, a pesar de todo, su manera de actuar está muy de acuerdo con su carencia de normas y principios"117.
}

117 Maspons, Oriol, “Cómo hago mis fotografías, por Doisneau”, en Arte Fotográfico, n 59, año V, noviembre 1956, pág. 823. 


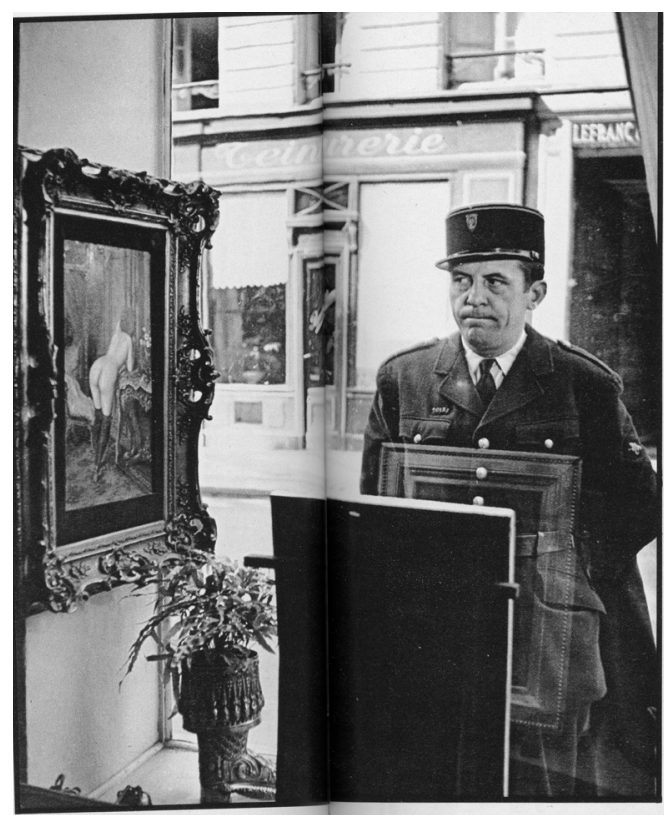

Robert Doisneau, “Desnudo en escaparate”, 1947.

Esta carencia de dogmas, esta libertad creativa, es la que impide a Masats someterse a las estrictas leyes de Cartier-Bresson. Una oportunidad para comprobar la participación y la intervención de Masats en el momento de disparar la cámara, la tenemos en la publicación de los contactos de la fotografía de "Peñaranda", en la revista AFAL. Aquí aparece descrito, con todo lujo de detalles, cómo la fotografía está directamente provocada, orquestada y dirigida.

“(...) La foto es buena, de acuerdo. Pero ¿cómo «vio» esa foto su autor? ¿Le bastó apretar el disparador y todo se le dio por añadidura? ¿Resultó más bien laboriosa la tarea de eliminar falsos encuadres y aceptar sólo el bueno? En tantas ocasiones, estas preguntas no tienen contestación posible; unas veces por conocer al autor, sabemos que sufrió hasta obtener la «obra bien hecha» y otras, también por conocer al autor, sabemos que fue verdad eso de la flauta y la casualidad. Pero en este caso concreto tuvimos la fortuna de saciar nuestra curiosidad, porque el autor estaba con nosotros y más asequible que nunca.

Junto a la foto final, la hermosa foto final, damos la historia gráfica de su logro. No es (fíjate bien, amigo lector) una cualquiera o una especial de las varias hechas sobre el mismo tema, sino precisamente «la última». Y esto es lo importante, porque revela que el autor supo, inmediatamente, que después de esa YA NO HABÍA MÁS QUE HACER. La gradación se aprecia perfectamente a lo largo de la serie, cuya numeración indica su continuidad, dirección y sentido. Había tema. ¡Y qué tema! Hubiera sido difícil no verlo, pero ya no era tan fácil determinar «qué hacer» con ese asunto. Masats fue buscando; disparando y buscando; fijó con palabras a los chicos que salían de la escuela, les gritó alguna broma de las suyas que los concentró ante su cámara y sin duda otra broma más gruesa les haría romper en carcajadas. ¡Ya está! ¡Esa era «su foto», la que buscaba intuitivamente desde que halló la plaza de Peñaranda! YA NO HABÍA MÁS.

¡Qué fácil! dirán algunos. ¡Qué difícil! digo yo. ¡Qué fácil apretar una y otra vez el botón hasta conseguir una buena foto! ¡Qué difícil saber encontrar lo que el oscuro instinto nos empuja a buscar! 


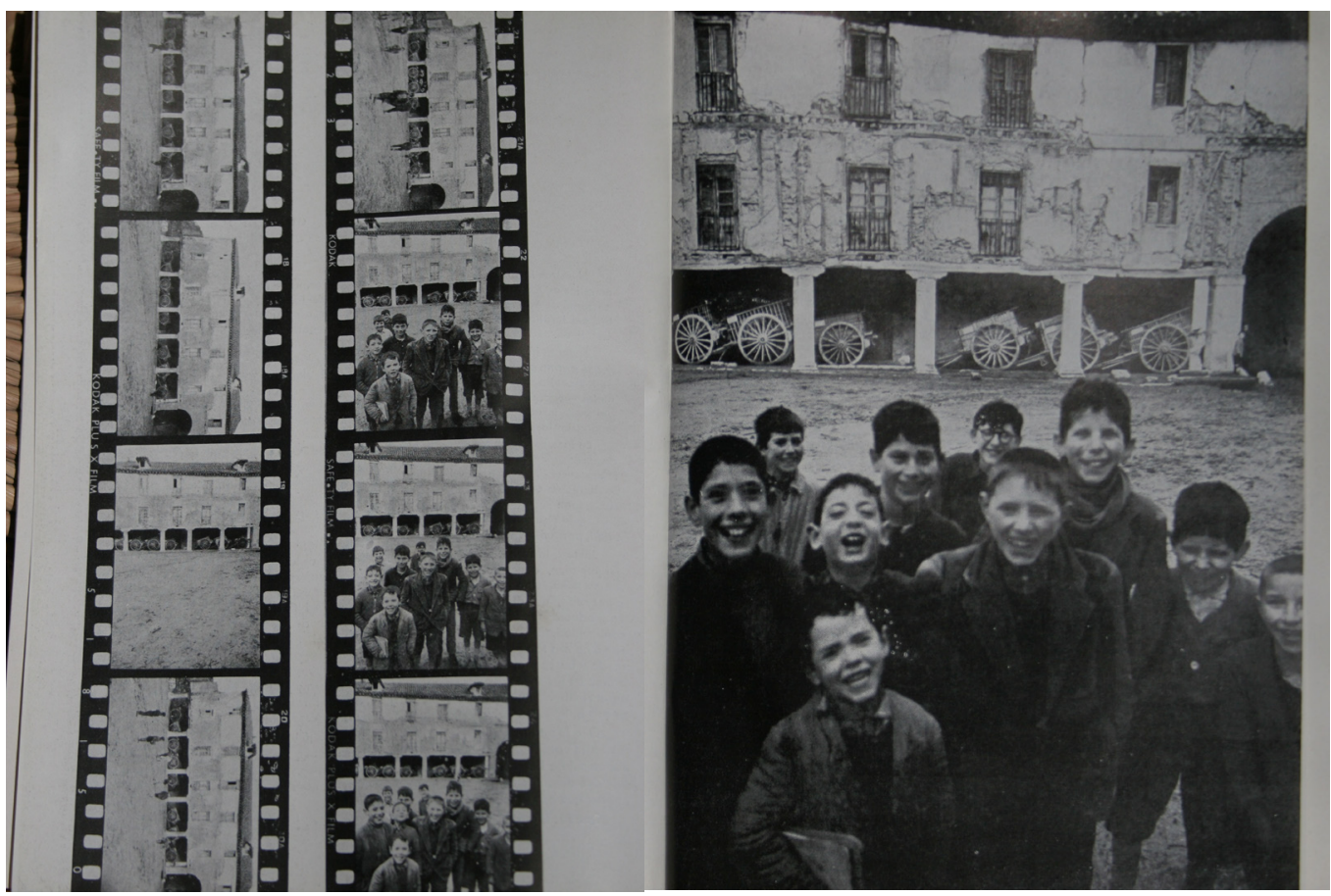

Ramón Masats, contactos de "Peñaranda" publicados en AFAL, n² 28, enero-febrero 1961, sin paginar.

¡Qué fácil disparar muchas fotos y luego elegir la que mejor nos quede! ¡Qué difícil detenerse en el momento oportuno, no pasarse de la raya, alcanzar la meta y saber que esa es la meta que buscamos.

¡Qué fácil! Dirán algunos. ¡Qué difícil! digo yo"118.

(R. Masats, Madrid, 20 de marzo de 2000) -“Normalmente me gusta coger las cosas tal cual, pero de vez en cuando, también considero que está bien que se te ocurra una cosa para mejorar una foto, no soy tan purista para negarlo. Antes, estaba comentando sobre un fotógrafo del que habréis oído hablar, Oriol Maspons. Se ha cogido una cabreo grande con una exposición que ha habido en Barcelona de un fotógrafo muy importante norteamericano que se llama Eugene Smith. En el folleto contaban que muchas de las fotografías de Eugene Smith estaban montadas, estaban preparadas. Incluso llevaba algún flash para poner luces...Y esto a Oriol Maspons le parecía una falsificación de la realidad. Sobre todo con unas fotos que hizo sobre una intoxicación gravísima que hubo, por comer pescado contaminado, en Japón, en Minamata. Hizo un reportaje muy bueno con niños que nacieron con malformaciones. A pesar de que convivía con los pescadores, y estaba muy metido, muchas de las fotografías estaban preparadas. Es decir: «Ahora tú vas a bañar a este niño, lo vas a bañar aquí porque viene esta luz, además que a mí me viene bien por que yo meteré la luz por aquí...» y esto a Oriol Maspons le molestó mucho. A mí no me parece mal".

$-¿ Y$ reencuadrar?

(R. Masats, Madrid, 20 de marzo de 2000) -“Como principio no me gusta, pero si hay que

118 Artero, José María, "Pequeña historia de una gran fotografía. Peñaranda de Ramón Masats", en $A F A L$, n² 28, enerofebrero 1961, sin paginar. 
reencuadrar se hace. Pero como forma de enfrentarse a un trabajo y decir: «Bueno, luego ya lo reencuadraré...». Como planteamiento previo, no me gusta. Si luego, por las razones que sean, tienes que reencuadrar, pues no pasa nada. Tú, lo que tienes que tener en cuenta cuando haces una foto, es saber para qué la haces. Es decir, si tú, al hacer la fotografía, la tomas desde muy lejos sabiendo que sólo te interesa un trocito de esta fotografía, pero que lo que tú quieres es luego meterla en la ampliadora, que te salga mucho grano, todo desenfocado y tal... Es decir, la fotografía la tienes que crear en el momento de hacer la fotografía. A mí no me gusta cortar. Hay muchas cosas que no me gustan pero que luego, excepcionalmente, hay cosas que me gustan que van en contra de mi forma de pensar, no digo convencimientos porque no son tan así".

-Entonces eres un poco ecléctico, y picoteas lo que te interesa sin ningún dogma.

(R. Masats, Madrid, 20 de marzo de 2000) -“Dogma no, lo que pasa es que en un noventa por ciento tengo unas muy fundadas opiniones sobre las cosas, y luego hay un diez por ciento que no entra dentro de lo mío pero me gusta ¿Y por qué no? Yo soy una persona que siempre digo que tengo las cosas muy claras, incluidas las dudas ¿Me explico? Por eso pueden existir en ese diez por ciento de dudas, perversiones o desviaciones de lo mío, pero que yo lo asumo y me parece muy bien".

La libertad creativa de Masats no se ceñirá exclusivamente a ser consciente de la subjetividad de la mirada del autor, o a provocar situaciones interviniendo activamente en la realidad. Como ya comentamos, Masats se permitirá el lujo de invertir fotografías, de realizar tomas absolutamente movidas... Incluso realizará fotografías sin mirar por el visor, disparando al azar. Asimismo, manipulará el positivado para aumentar el contraste y perder información en las sombras, utilizará grandes angulares que acentuarán la perspectiva o grandes teleobjetivos que la aplastarán, usará los buñuelos de los puntos de confusión de los objetivos catadriópticos como elementos plásticos... Todo ello para generar nuevas lecturas de la realidad, o para encontrar belleza, composición y armonía en un mundo presuntamente anodino, confuso y cotidiano.

Estos "experimentos" los realizará motivado por la necesidad de encontrar una visión nueva en la propia cotidianidad. Masats explorará en el lenguaje fotográfico, en sus posibilidades y sus límites, de una manera autónoma. Masats ensayará a partir de la revisión de sus propios trabajos, auto-analizándose y dando crédito a los hallazgos de la hoja de contactos, ya sean estos buscados intencionadamente o fortuitos.

Debido a ello, Masats compartirá ese espíritu innovador con otros autores de la época, como William Klein, autor que simultáneamente trabajará (quizás más conscientemente que Masats) en la misma dirección rompedora y vanguardista.

\footnotetext{
“Mi intención era hacer un diario personal. Mi modelo era el Daily News de Nueva York, ese tabloide monstruo de la metrópoli, con sus sensacionalismos, sus escándalos y su política de la edad de piedra, que invadía las calles a partir de las tres de la madrugada. Quería usar prensa, hacer que mi libro se asemejase al Daily News, hacer que fuese a grandes rasgos tan estrepitoso, que tuviese su energía y su vulgaridad. Eso y un toque de mi personal visión del Dadá. Como era obvio, las sutilezas de la técnica fotográfica no me inquietaban. En París, con los amigos gravitaba hacia el antiarte: ¿por qué no hacer antifotografías? 0 por lo menos «anti-buenas» fotografías.

Jugué a ser reportero gráfico, tratando el hecho más trivial como si fuese una gran primicia. Por entonces, 1954, el modelo en fotografía era Cartier-Bresson y el lema, objetividad, elegancia, mesura, distancia; y discreción. Mi proyecto de diario tabloide era muy distinto. Anduve en dirección contraria, dejé caer el mito de la objetividad y provoqué una especie de fotomatón callejero.
}

Fotomatón, reportero gráfico, tabloide, parodia, art brut, antifotografía; todo eso para empezar. 


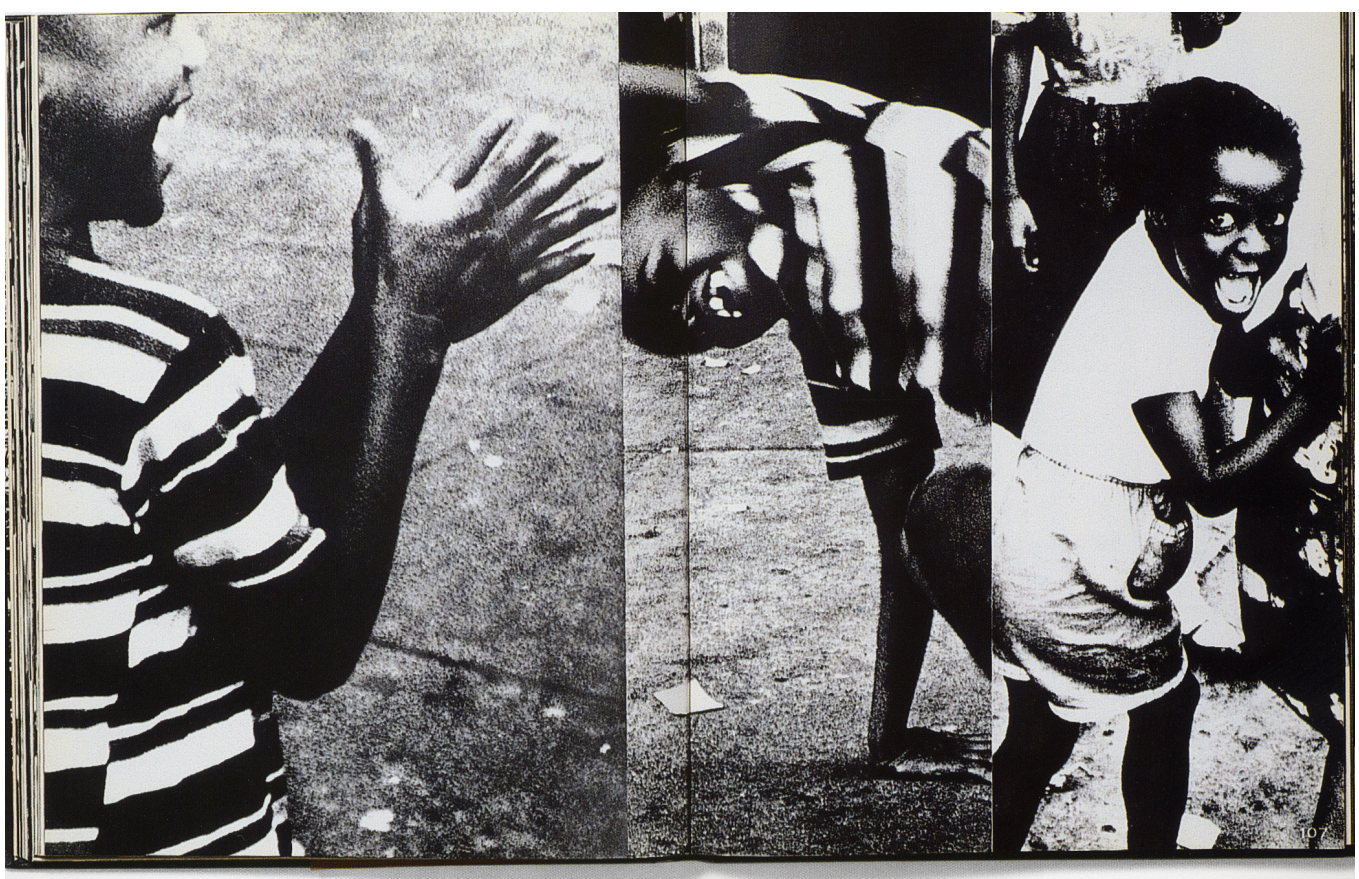

William Klein, New York, 1955, págs. 106 y 107.

Sin que me estorbasen la formación ni los tabúes fotográficos, probé todo. Grano, «movimiento», evasión del encuadre, deformaciones, imágenes accidentales. Disparaba sin apuntar, encuadraba al buen tuntún, exageraba el grano, el contraste, ampliaba con desmesura y, en general, pasaba el proceso fotográfico por la batidora. Un curso acelerado de lo que no hay que hacer en fotografía. La mayor parte de las veces tenía y usaba de cualquier manera todo lo que los fotógrafos de entonces hubieran tirado por la ventana. Pensaba: los pintores se han liberado de las reglas, ¿por qué no los fotógrafos? Tal vez era más fácil para mí, independiente y herético"119.

Aunque no fuera absolutamente general e incondicional la admiración a Klein por parte de toda la generación de Masats, su obra fascinó profundamente a varios fotógrafos de la época. Gonzalo Juanes y Xavier Miserachs recibieron el impacto de la contemplación del libro de Klein, y cada uno asumió su herencia y su influencia en sus respectivas obras. Hay que destacar que, mientras Miserachs y Juanes reconocen explícitamente la influencia de Klein en su trabajo, hay otros autores que coinciden en el uso de la nueva batería retórica de Klein por azar -los desenfoques, las luces quemadas, los desencuadres o los horizontes caídos- y realizan su trabajo sin, ni tan siquiera, conocerlo a él y/o a sus fotografías. Tal es el caso de Masats y su reportaje sobre Los Sanfermines, realizado antes de la llegada del New York a España, pero también es el caso de Manuel Ferrol, que en su magnífico reportaje sobre la emigración -realizado en Galicia en 1956-, utiliza estos "defectos técnicos" para añadir fuerza, dramatismo y realismo a sus imágenes: 


\begin{abstract}
“Desde a perspectiva estrictamente fotográfica, esta recolleita posúe o interés de asumir como elementos narrativos recursos que poderian ser tidos como erros técnicos: rostros e grandes masas desenfocadas, ou movidas; luces queimadas; liñas horizontais ou verticais que deixan de se-lo, caidas; persoas ou faces cortadas; composicións forra de calquer regra etc. Achamos que o crene da cuestión non é enxergar se estes pretendidos defeitos correponden a un planexamento a priori, ou son o resultado das condicións nas que o traballo se fai. 0 cremos suliñabel é o emprego que se fai deses recursos e o resultado obtido. Recursos, aliás, que están a ser usados no documentalismo dos anos 50 polos elementos de avangardia e que en Galiza son descoñecidos. Deteñamo-nos un intre a considerar 0 feito de que o traballo de William Klein da cidade de Nova Ior que é dos años 54-55, acadando a sua publicación no ano 56, o mesmo no que Ferrol fai a reportase presente" ${ }^{\prime 120}$.
\end{abstract}

La opinión de Masats sobre Klein varía a lo largo del tiempo. En un primer momento, descubre perplejo cómo Klein utiliza voluntariamente los defectos tradicionales de la fotografía de reportaje. Realizado en condiciones de trabajo límite, el reportaje acepta los desenfoques y desencuadres, así como los contrastes exagerados y el grano desmedido. Pero todo ello quedaba justificado por la importancia del tema y por las dificultades en el momento de la toma ${ }^{121}$. Sin embargo, Klein no tiene un acontecimiento importante que justifique el uso de tales defectos, como ya comentamos. Por ello, en una primera instancia Masats desconfía de la obra de Klein:

“Cuando hablé con entusiasmo de Klein, Masats de primeras dijo de él que era un «truquista», que hacía reportaje falso e innecesariamente contrastado. Ahora Masats entra por los grupos mirando a la cámara y busca una imagen granulada y defectuosa. Es peligroso esto para Masats. Masats debe limitarse a su maravillosa agilidad y a su intuición para captar el momento oportuno de lo que sea, pero cuando se meta a otear un ambiente, a exaltar un determinado matiz, me temo que los resultados no serán ya de tan primera línea"122.

Esta carta de Gonzalo Juanes a Pérez Siquier recoge la única manifestación de Masats en contra de William Klein, ya que no tarda en comprender que su obra es una nueva manera de entender la fotografía, afín a su propio espíritu joven, contestatario y socarrón. Es una nueva visión del mundo que no será exclusiva de un autor, sino compartida por una masa de jóvenes que se expresa de una forma nueva. Nadie podrá imponer normas, ni restricciones en fotografía después de Klein. Ni tan siquiera el propio Cartier-Bresson. Todas las "chorradas establecidas" (sic) quedan abolidas en aras de la libertad creativa, y ésta es recogida por la juventud europea, en este caso alemana, para regocijo y sorpresa del propio Ramón Masats:

“Lo mejor y más sorprendente de toda la Photokina está aquí. En esta muestra de fotógrafos jóvenes alemanes que presentan sus cosas. Son jóvenes de 12 a 25 años, con una inquietud y un frescor visual extraordinario, que no esperaba yo en la fotografía alemana, por lo general tan ramplona y técnica. Aquí está la fotografía que más me ha impresionado de todo el salón. Es una foto de modas de Max Sayle que se ríe de todas las técnicas y principios y chorradas establecidas (...) Cartier-Bresson ha perdido aquí el cetro y lo han recogido Robert Frank, William Klein y Bruce Davison y su nueva visión ha lanzado a esta juventud por el camino de la explosión de ideas y formas y hacen lo que les da la real gana con el respaldo de unos conocimientos profundos e indiscutibles. Estaría todo el rato hablando de ellos"123.

120 Ferrol, Manuel; Sendón, Manuel; Suárez Canal, Xosé Luis; Vaqueiro Vitor y Beiras, Xosé Manuel, Emigración 1956, Vigo, Centro de Estudios Fotográficos, 1986, sin paginar.

121 Por ejemplo, las expresivas fotos del desembarco de Normandía de Robert Capa están realizadas antes del amanecer, en una playa bajo el fuego alemán... No es el lugar adecuado para trabajar con trípode o con flash.

122 Juanes, Gonzalo, correspondencia con Pérez Siquier (08-04-61), en Terré, Laura, op. cit., pág. 495.

123 Masats, Ramón, “Photokina 60", op. cit., sin paginar. 
La identificación de la juventud con la obra de Klein es el mejor piropo que Masats podía concebir para la obra de un autor. $Y$ todo gracias a la frescura que desprenden sus imágenes, a su rabiosa espontaneidad, a la renuncia explicita a cualquier tipo de reglas académicas y, fundamentalmente, a la experimentación.

-The Family of Man enseñaba, entre otras cosas, que hay un autor detrás, enseñaba la importancia de la maquetación, que llevó a mucha gente a hacer cine, como William Klein...

(R. Masats, Madrid, 4 de septiembre de 2002) -“0 Robert Frank. Ha habido mucha gente que después de fotografía ha hecho cine".

-Tú también, aunque no hayas sido consciente a lo mejor también te ha influido a ti. William Klein en su libro New York también se hace su maquetación, sus textos... Lo hizo todo él. Es una manera de llegar a la autoría completa: que hasta el producto final lo haga todo un único señor.

(R. Masats, Madrid, 4 de septiembre de 2002) -“Sí, la estética del angular y del grano es absolutamente buscada, y la estética del contraste también".

-A él le da igual que el resultado sea más o menos realista. Nueva York no es en blanco y negro ni tiene grano. Esa deformación aparente la hace para potenciar esa visión particular de Nueva York.

(R. Masats, Madrid, 4 de septiembre de 2002) -“Exactamente, la busca. No es que le ha salido así, sino que responde a un planteamiento previo. No es una plasmación directa de la ciudad, en absoluto. Es una impresión subjetiva de lo que él entiende por esa ciudad".

-Con William Klein, comentabas que estás en sintonía, que vibras con él en sintonía. Porque su New York y tus Sanfermines... es imposible que te copiaras porque casi coinciden temporalmente. $Y$ los dos llegasteis a conclusiones similares...

(R. Masats, Madrid, 4 de septiembre de 2002) -“Sí, es verdad, son conclusiones muy parecidas". 


\section{CAPÍTULO 7}

\section{Análisis de una praxis partiendo del propio autor}

\subsection{EN TORNO A LA IMAGEN TÓPICA}

Una de las pocas etiquetas o definiciones que Masats ha aceptado siempre, e incluso se ha auto-impuesto, es que él fotografía tópicos. Da igual que sea fotografía de formas abstractas, fotografía de reportaje o en color: como ya veremos, muchos de los temas que van a aparecer habitualmente en su obra se centrarán en los tópicos. Dada la importancia que adquiere este hecho, conviene desde un primer momento delimitar con precisión el término: por tópico entendemos ese lugar común que la tradición y la cultura popular convierten en cliché fijo y al que se recurre tan frecuentemente que corre el peligro de convertirse en trivial.

¿Cuáles han sido los tópicos de Masats? Depende del lugar que fotografíe, pues Masats es perfectamente consciente de que el tópico depende, y a su vez define, el territorio. Ciertamente es muy interesante comprobar cúal es la visión sobre España de un catalán afincado en Madrid y enamorado de Andalucía. Cuando fotografió Barcelona se centró en Las Ramblas (si le hubiera interesado la arquitectura probablemente habría encontrado otro tópico todavía mayor: Gaudí). Más tarde, cuando recorrió el resto de España, se interesó por los toros, los curas y sus sotanas, los tricornios de la Benemérita, los encapuchados de la Semana Santa, las sevillanas y los trajes de luces, las mujeres de riguroso luto, las paredes de las casas andaluzas...

\footnotetext{
“Poco a poco Ramón Masats fue retratando todos los tópicos españoles, tema fundamental de su obra que llevó también a sus realizaciones audiovisuales, ya que a mediados de los sesenta se pasó de la fotografía a la televisión y el cine: «Me gustan mucho los tópicos, y como español aficionado a los tópicos he hecho toros, Semana Santa..., todos los tópicos de España. Incluso entre el 65 y el 82, que me dediqué a hacer cine, televisión y documentales. Hice una película que se llamaba Topical Spanish, de la que tengo muy mal recuerdo (...) Tuve una mala experiencia con un jefe de producción que era un sinvergüenza, por no decir palabras más gordas. Pero a lo que íbamos: creo tanto en los tópicos que la película se llamaba Topical Spanish»"1.
}

Como vemos, todos estos temas son perfectamente reconocibles e identificables dentro de la iconografía popular. Esa facilidad esconde el peligro de la vulgaridad, por ello, reconoce Masats, hay una tendencia general a evitarlos. Sin embargo él, consciente del riesgo, los asume sin ningún complejo y se aprovecha de la carga cultural y referencial que todos tenemos de ellos.

\footnotetext{
“Masats cree en los tópicos, en esos símbolos de una cultura que definen la idiosincrasia nacional. El símbolo como abstracción visual del concepto, como resumen final del discurso. Ese atajo del discurso verbal es exactamente su fotografía, una especie de concreción visual de literatura y geometría"2.
}

1 Contreras, Eva María, "Ramón Masats: Me gustan los tópicos", en la página web http://www.babab.com/no06/ramon_masats.htm

2 Conesa, Chema, "La memoria construida", en Masats, Ramón; Umbral, Francisco y Conesa Chema, Ramón Masats la memoria construida, Madrid, Dirección General de Archivos y Bibliotecas, Consejería de las Artes, Comunidad de Madrid, 2002, pág. 8. 


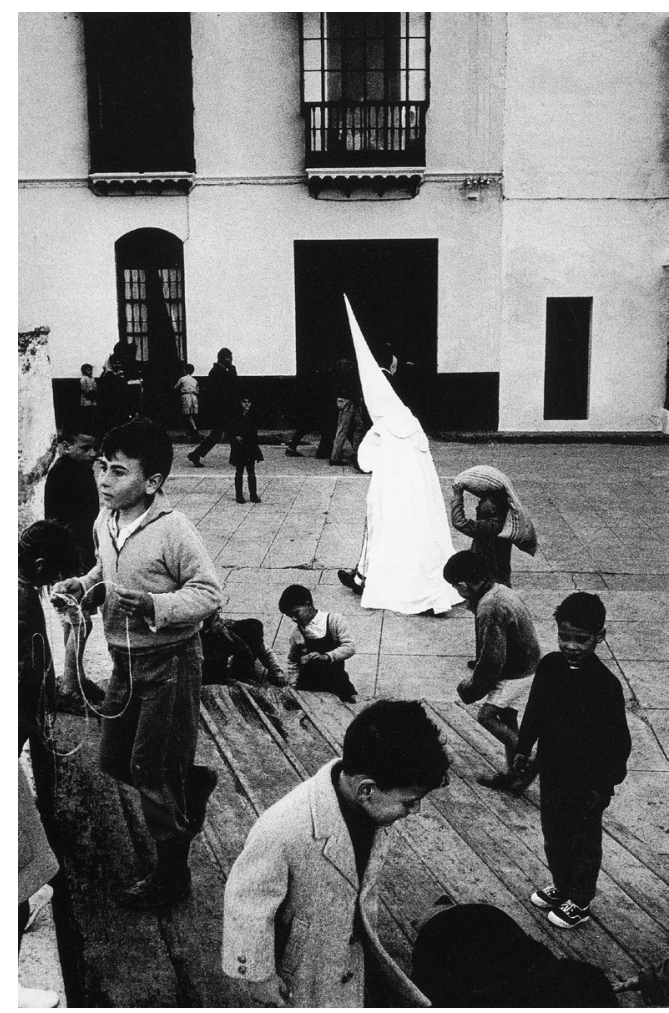

Ramón Masats, “Medina Sidonia (Cádiz)”, 1959.

¿Es posible que este conocimiento y manejo de los tópicos sea una habilidad adquirida gracias a su conocida afición por la literatura? Es el propio Masats quien puede esclarecer la cuestión.

-¿Qué tipo de literatura te gusta?

(R. Masats, Madrid, 4 de septiembre de 2002) -“Yo, es como con la música, me gusta todo lo que me gusta".

- ¿Y cuál es el libro que más te ha gustado. Cuál recomendarías a los amigos?

(R. Masats, Madrid, 4 de septiembre de 2002) -“Aunque es un tópico, pero a mí el libro que más me ha gustado es el Quijote... y Shakespeare. Y no soy nada intelectual, pero el Quijote me lo tuve que leer cuatro veces. Porque hice un documental para Televisión Española. La primera vez lo leí porque no lo había leído. Me encantó. Era solamente para leerme el Quijote, para enterarme de qué iba. Luego ya me lo tuve que leer para ver qué seleccionaba, ya la segunda vez fue para ver qué es lo que iba a utilizar. La tercera vez para concretar más y la última para seleccionar, una vez montada la imagen con el concepto, los textos concretos del locutor... Yo pasaba de Shakespeare, que me lo leí todo. Lo que no tengo es memoria, entonces no me acuerdo de libros importantes. Pero Shakespeare me acuerdo que me lo leí a los diecisiete años, enterito, enterito".

-Entonces te gusta la literatura desde siempre.

(R. Masats, Madrid, 4 de septiembre de 2002) -“Siempre, siempre, yo siempre he sido un lector...Yo iba de visita con mis padres a cualquier casa y no me interesaba nada en absoluto. Sólo me interesaban cosas para leer, que fuera cualquier cosa, recetas de medicina... Es decir, cuando yo digo que para mí lo importante es leer, no es que sea un lector... Necesito leer como el que tiene un vicio y llega un momento que no tiene heroína y se inyecta yeso (por lo visto, 
les da exactamente igual). Yo, si no tengo qué leer, me leo los prospectos de medicina, lo que sea. ¡Hombre me gusta seleccionar! Lo que estoy haciendo ahora en las vacaciones, por una vuelta a Cataluña, es leer a Josep Pla en catalán. Yo siempre he sido un gran admirador suyo. Mi padre me regaló la revista Destino, donde Josep Pla publicaba todas las semanas en castellano, y ya entonces me parecía fantástico. Entonces -no sé que pasó- Destino dejó de publicar a Pla y yo la dejé de comprar. También he leído mucho teatro, a Javier Poncela, he leído mucha ciencia ficción, he leído novela, he leído ensayo. He sido absolutamente disperso. Ahora estoy leyendo unos cuentos de Nabocov".

-Es posible que seas uno de los fotógrafos que más lean en España, ya que te lees varios libros a la semana. ¿Tú crees que la literatura ha podido influir en tu modo de fotografiar? ¿Es posible que tus referencias no sean fotográficas sino literarias?

(R. Masats, Madrid, 4 de septiembre de 2002) -“Es cierto que yo leo mucho, pero no tiene nada que ver con mi manera de fotografiar, que es pura intuición. No estoy de acuerdo. Yo fotografío y compongo según una intuición mía del ritmo que tienen que tener los objetos. No, incluso en la época en la que más he leído yo creo que he hecho peores fotos, porque te planteas cosas, y en el momento en que te planteas cosas ya no eres rápido y si dudas pierdes la foto. No, no estoy en absoluto de acuerdo. A lo mejor... no creo que le haga daño a nadie leer... pero la influencia de la literatura en mi fotografía... no".

$-\dot{\text { A }}$ lo mejor en los temas?

(R. Masats, Madrid, 4 de septiembre de 2002) -“Pero es que mis temas son los tópicos, yo hago los tópicos: los pueblos, los toros... El comisario de mi exposición del Canal de Isabel II es Chema Conesa. Y Chema le ha puesto un título que a mí me gusta mucho. Se llama La memoria construida, en el sentido de que sí hay una memoria, pero está muy construida plásticamente. Tienen una composición todas mis fotografías, que no son estas composiciones, que eso nunca me ha gustado a mí, del triángulo, la fuga mirando para allí... también son muy intuitivas. ¿Puede esta intuición haber sido inconscientemente influenciada por la literatura? Yo considero que muy poco. La literatura enriquece a una persona y posiblemente este enriquecimiento se vea en mis fotografías... pero no lo veo yo. A lo mejor estoy equivocado. Porque uno desde fuera... Yo lo que sí he pensado es que, en un momento determinado, empecé a no ser tan buen fotógrafo (te estoy hablando del año 65) cuando empecé a plantearme si tenía derecho a fotografiar a la gente. Empecé a tener dudas sobre lo lícito que era ese tipo de trabajo en que iba robando la imagen de la gente. Hubo una época en que me quedé un poco desconcertado".

- ¿De eso tiene un poco la culpa la literatura, me estas queriendo decir?

(R. Masats, Madrid, 4 de septiembre de 2002) -“En cierto sentido... posiblemente. Quiero decir que la literatura, inconscientemente, puede haberme hecho como soy. En un sustrato muy bajo. Pero más en la superficie, en un momento determinado, me ha perjudicado. No tanto como digo... pero me ha puesto en duda".

-El tema de los tópicos...

(R. Masats, Madrid, 4 de septiembre de-2002) -“Creo que ha habido una tendencia a huir de los tópicos, porque es muy difícil hacer algo distinto. El sol, los curas, los toros... son los tópicos de siempre. Yo creo que el único tópico moderno es el fútbol... y los turistas. Todo lo demás es la España de siempre".

- ¿Puede que los tópicos te ayuden a generar polisemia? Es decir, no es lo mismo que un señor anónimo cruce la calle, que lo haga un cura o unos nazarenos. El uniforme ya te da una serie de connotaciones que enriquecen muchísimo la foto. Es más fácil a la hora de describir una persona fotografiarla con uniforme que si va de traje gris.

(R. Masats, Madrid, 4 de septiembre de-2002) - “Yo creo que en eso tienes una cierta razón porque el tópico es ambivalente. Es más difícil, pero también es más fácil. La dificultad estriba 
en hacer algo distinto con los tópicos, pero también es más fácil si haces lo de siempre. Aunque creo que con mi ironía... Creo que los tópicos los toco con bastante ironía siempre. Va más en el sentido de descubrir cosas nuevas en los tópicos que no en la facilidad".

En el año 1962, Ramón fue invitado por la Oficina Francesa de Turismo a realizar un reportaje fotográfico en París, junto con un grupo de fotógrafos españoles. El tema que escogió Masats fue, evidentemente, la Torre Eiffel; aunque no se limitó a esos temas, y, una vez allí, también fotografió las calles y las entradas del metro parisino.

(R. Masats, Valencia, 25 de marzo de 2004) -“Esto es de un viaje que hicimos una serie de fotógrafos a París y cada uno hizo lo que quiso. A mí una de las cosas que me gustan mucho son los tópicos. Porque es muy difícil hacer un tópico y darle la vuelta. Es decir, aparte de la dificultad inherente a hacer buenas fotografías, está el tópico y el contra-tópico. Yo elegí la Torre Eiffel, pero luego me salieron fotos paseando por la calle. Digamos que la petición mía de fotografiar la torre se quedó bastante diluida. Fotografié gente esperando para entrar en el metro de París. Hubo una huelga en el metro y estas personas estaban esperando a que se acabara la huelga. Es una imagen no habitual de París".

Aquí está la clave del tratamiento de los tópicos en Masats: el contra-tópico, la ironía, el juego con el contraste entre el tema y su solución formal, la perversión de la tradición iconográfica comúnmente aceptada por la sociedad. Masats consigue generar significados nuevos a partir de estereotipos muy manidos, supuestamente inmutables. Es evidente que para ello hay

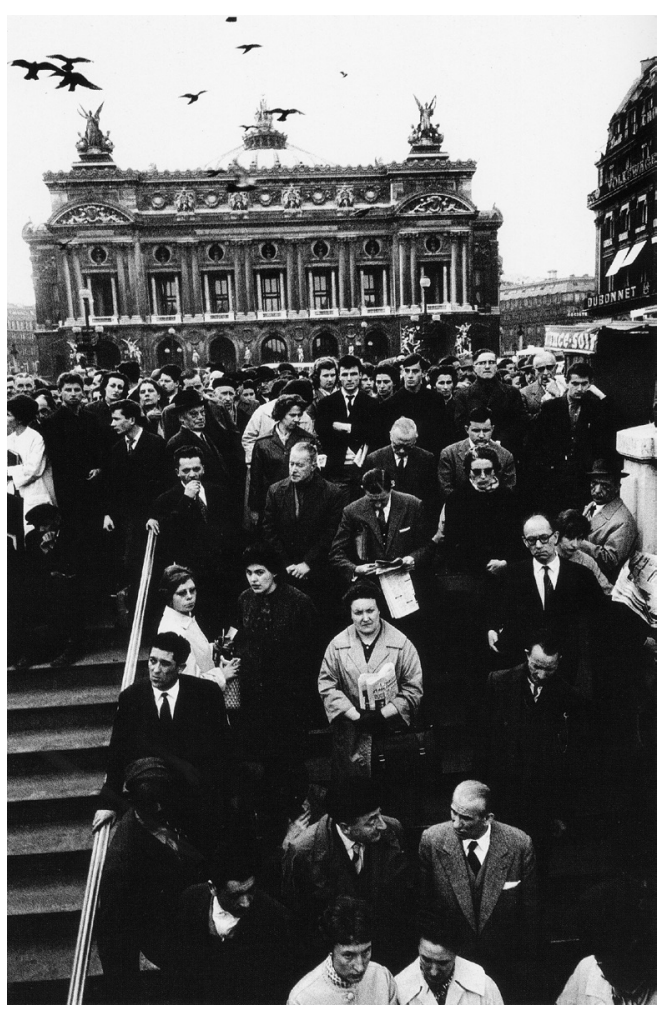

Ramón Masats, “París”, 1962.

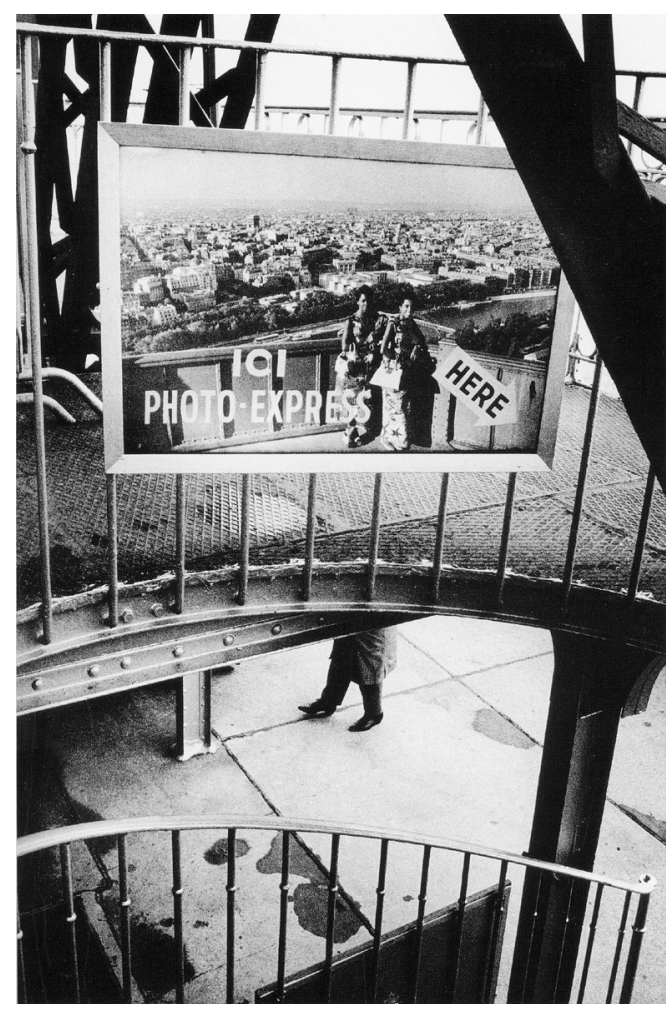

Ramón Masats, “París”, 1962. 
que ser consciente de que nos movemos en el mucilaginoso terreno del lugar común y trabajarlo como un reto añadido a la dificultad de tomar la imagen. Es decir, como un desafío que supone conocer cuáles son los límites de ésta para traspasarlos, quebrantarlos o ampliarlos de un modo premeditado.

(R. Masats, Madrid, 15 de diciembre de 2003) -“Sí, es lo que tengo yo con los tópicos. Los trato de una manera diferente".

Lo que sí está claro es que hay un proceso previo de análisis del tópico para saber como abordarlo. Aquí es, precisamente, donde el argumento del autor intuitivo tan utilizado por el propio Masats se desmorona, ya que ese proceso -que se inicia en la reflexión y que finaliza en la propia realización de la nueva imagen- comporta una gran cultura visual, así como una formación intelectual considerable.

(Koldo Chamorro, Pamplona, 21 de marzo de 2003) -“Yo recuerdo una conversación con Cartier-Bresson que me decía que todas sus imágenes las tenía en la cabeza. Porque si no, no sería comprensible el volumen de trabajo tan importante y tan contundente de Cartier-Bresson. Algo similar también le pasa a Ramón: uno lo puede aceptar o no lo puede aceptar. Yo creo que todo eso trabaja. Uno, como fotógrafo, puede tener su propia idea de lo que es una imagen, pero claro, esa imagen que uno tiene como imagen fotográfica resulta que es una imagen que es esclava de un estereotipo, y ese estereotipo es el que trabaja como referente. Por ejemplo: tenemos la referencia -ahora con la guerra de Irak- del sufrimiento de la sociedad civil. Es la imagen de la Madonna o del descendimiento de Cristo. Son tópicos. Uno, si trabaja desde el punto de vista de la imagen por la imagen, cae inevitablemente en los tópicos, en el estereotipo. La única forma de escaparse del estereotipo es entender por ejemplo, cómo es y cómo se constituye una imagen poética, o cómo es una imagen musical, o cómo determinados escritores, no muchos desgraciadamente, tienen esa capacidad de generar imágenes, es decir que tú, a medida que lees el texto, no lees un texto sino que reconstruyes una imagen. Eso al final afecta, porque a la hora de construir eres más eficaz, porque tienes más economía en los recursos que empleas".

-Pero Masats fotografió mucho los tópicos, él los tiene como tema.

(Koldo Chamorro, Pamplona, 21 de marzo de 2003) - “Vamos a ver... Yo no sé cuál es el diccionario de Ramón. No sé qué es lo que entiende por tópico, yo sé qué es lo que yo entiendo por tópico. Es decir, el que se use un tópico como pueden ser los toros... Evidentemente es un tópico porque es un ámbito cultural muy definido, con una gran personalidad que tú usas como la quieras usar. Otro tópico puede ser la Semana Santa. Pero lo que Ramón hace, es que aprovecha esos espacios culturales muy especializados, pero a la hora de construir, él no construye según el canon establecido de cómo hay que tratar la Semana Santa. Digo en el trabajo personal, no en el trabajo de encargo, que ya es otra historia. Cuando hace el tema de toros no lo fotografía desde el punto de vista de lo que se supone... Y de hecho hay una foto de él que podría ser un estereotipo fotográfico en toros. La foto del toro muriendo en la plaza de Pamplona con la espada clavada. ¿Por qué la consiguió? Porque estaba fuera del concepto del estereotipo. ¿Cuántos millones de toros han muerto, no sé si en las mismas condiciones, con el mismo gesto, la misma secuencia, en España y en Latinoamérica? Pues millones. ¿Quién pilla la foto? Pues alguien que tiene la cabeza suficientemente amueblada para haberla previsto hacer, ayudándose de todos sus conocimientos anteriores".

-Yo le decía que fotografiando tópicos es más difícil hacer algo nuevo, pero también te aprovechas de las connotaciones que pueda tener fotografiar un encapuchado de la Semana Santa o un señor vestido de torero. La misma situación pero con un individuo anónimo, sin "uniforme", puede tener menos interés.

(Koldo Chamorro, Pamplona, 21 de marzo de 2003) -“Evidentemente los lenguajes no verbales, o no claramente verbales, como puedan ser los uniformes, siempre refuerzan la imagen, 


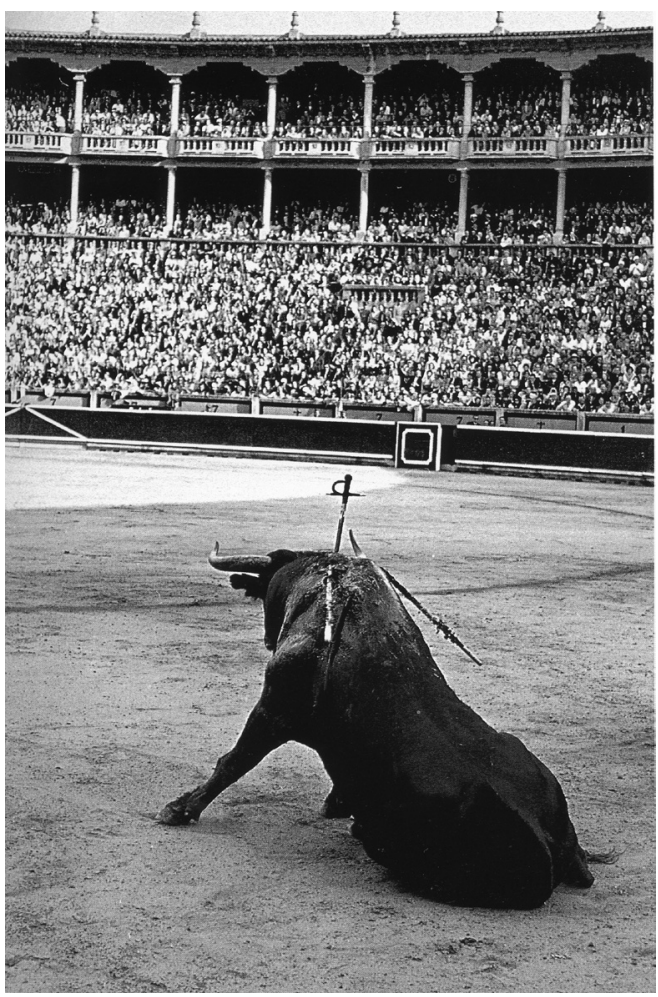

Ramón Masats, "Pamplona", 1960.

pero no son imprescindibles. En la fotografía ha habido mucha tendencia a la categorización de las personas humanas usando precisamente los lenguajes no verbales. Ese recurso tiene una vida: aparece, madura, crece, envejece y desaparece. En lo concerniente a los elementos accesorios, que no son accesorios, porque también son importantes, hay una especie de universalización. Quiero decir que las zapatillas, el chándal... están en todas partes, con lo cual la especialización de la persona desaparece. Hoy en día encontrarte a alguien con un mono de trabajo es una cosa extraña. Salvo que vayas a grandes fábricas, como un astillero, donde la gente tiene que ir con mono. Pero, fuera de lo que es la fábrica, tú no verás a las personas que trabajan en la fábrica irse a almorzar con el mono. No lo verás nunca. Con lo cual desaparece esa especie de personalización de los espacios. Un señor que está laborando en el campo con un supertractor que lleva aire acondicionado, un equipo estéreo... va vestido igual que tú, que vienes de tener un reunión en un despacho. ¿Cómo explicas que ese hombre trabaja en el campo? Es muy difícil".

“Todo eso nos lleva a que los retratos de Masats de esta última etapa han roto los anclajes con el realismo y parecen mas bien sacados de un catálogo de lugares comunes, de tópicos; casi como si la España que interesa a Ramón Masats pudiese reducirse a los objetos que pueblan las estanterías de una de esas tiendas de souvenirs para turistas que abundan en Las Ramblas de Barcelona o en las inmediaciones de la Plaza Mayor de Madrid, llenas de objetos Kitsch que atentan contra el buen gusto pero que, quizá por eso mismo atraen potentemente nuestra atención (...) Ramón Masats sabe que sus películas, al igual que sus fotografías, no van a facilitar un acercamiento histórico a la realidad, por lo tanto, proyecta su imaginario, fuerza los referentes (...) y recurre a los tópicos y al pastiche (...) Mirar para comprender, por lo tanto, la obra de Masats nos obliga a alejarnos de 
lecturas apoyadas en concepciones del realismos modernistas que ya dieron su último suspiro hace medio siglo (...) Las formas populares de cultura han cambiado no sólo los marcos de referencia, sino la propia naturaleza de las obras. Masats ha sido quizá el fotógrafo de la famosa generación de los cincuenta que mejor ha entendido ese cambio"3.

(R. Masats, Barcelona, 17 de noviembre de 2000) - “iCreo que tenemos tantos valores de verdad en España, propios! Yo soy un gran aficionado al flamenco, aunque sé que aquí en Cataluña el flamenco no acaba de llegar. Es decir, creo que somos un país con unos valores, pictóricos, musicales... de todo tipo ¡tan importantes! No le hacemos ningún caso y como unos gilipollas nos dedicamos a copiar lo que se hace fuera. Mas o menos eso podría ser el planteamiento que tuve para querer hacer una película gilipollas [se refiere a la película Topical Spanish].

(Josetxo Cerdán, 17 de noviembre de 2000) -“Yo creo que en fondo se han roto todas las barreras, y la forma que tiene Ramón de ver el país, tiene mucho que ver con la forma que tiene Sisa de ver el país".

(R. Masats, 17 de noviembre de 2000) -“Posiblemente".

(Josetxo Cerdán, 17 de noviembre de 2000) -“Con una mirada muy irónica a todo lo que es nuevo, y con una mirada entre recuperadora y sarcástica del pasado. Eso se ve tanto en tu obra fotográfica como en la película, en su propio título. Hay una sintonía en cuanto a concepción de lo que es la Iberia ésta".

(R. Masats, 17 de noviembre de 2000) -“Está bien visto. No lo había pensado nunca pero está bien. Creo que tienes razón".

(Josetxo Cerdán, Barcelona, 17 de noviembre de 2000) -“Yo soy partidario de lo que dice un colega y es que no hay que hacer caso de lo que dicen los autores de las películas. Los autores normalmente no saben lo que hacen con las películas. Yo creo que Ramón no sabe, o no conoce la dimensión de lo que hizo en su momento. Topical Spanish, para mí, es una película absolutamente necesaria o reivindicable desde un punto de vista de un contexto histórico concreto. Es una película única porque intenta una mezcla entre lo que se está haciendo en aquellos años en Barcelona y lo que se hace en Madrid. Ramón viene de Barcelona y conoce lo que se está haciendo aquí y sin embargo cuando se va a Madrid entra en contacto con una corriente cinematográfica completamente opuesta a lo que se está haciendo en Barcelona, que es el Nuevo Cine Español. El trabaja con gente como Camus, como Saura. Cuando decide hacer una película... sin quererlo, no lo sé; él mezcla lo que tiene de Mediterráneo y lo que ha aprendido de Madrid, de la meseta. Por eso es una película realmente única. Topical Spanish, en ese sentido, es una película que hay que tener en cuenta para poder entender la historia del cine español".

Ahora bien, dentro del trabajo de Masats relacionado con los tópicos existe un grupo de imágenes realmente especial que podemos considerar de "síntesis". En realidad esta denominación no es nuestra, sino que está basada en uno de los pocos títulos con los que el propio Masats ha bautizado a una de sus fotografías: "Síntesis de Colonia". Este título corresponde a una fotografía realizada con ocasión del viaje de Masats a la Photokina de Colonia. Recordemos que el viaje fue parte del premio del concurso que patrocinaba la casa de fotografía Negtor y que Masats ganó en su edición de 1960.

Desde una perspectiva semántica, la síntesis se concibe como suma o reunión de las partes de un todo. Sin embargo, en nuestro caso, dadas las características intrínsecas del medio fotográfico, esta suma debe convertirse paradójica e ineludiblemente en una resta. En fotografía el todo se manifiesta con la máxima potencia una vez liberado de aquellos elementos que no le son propios. 


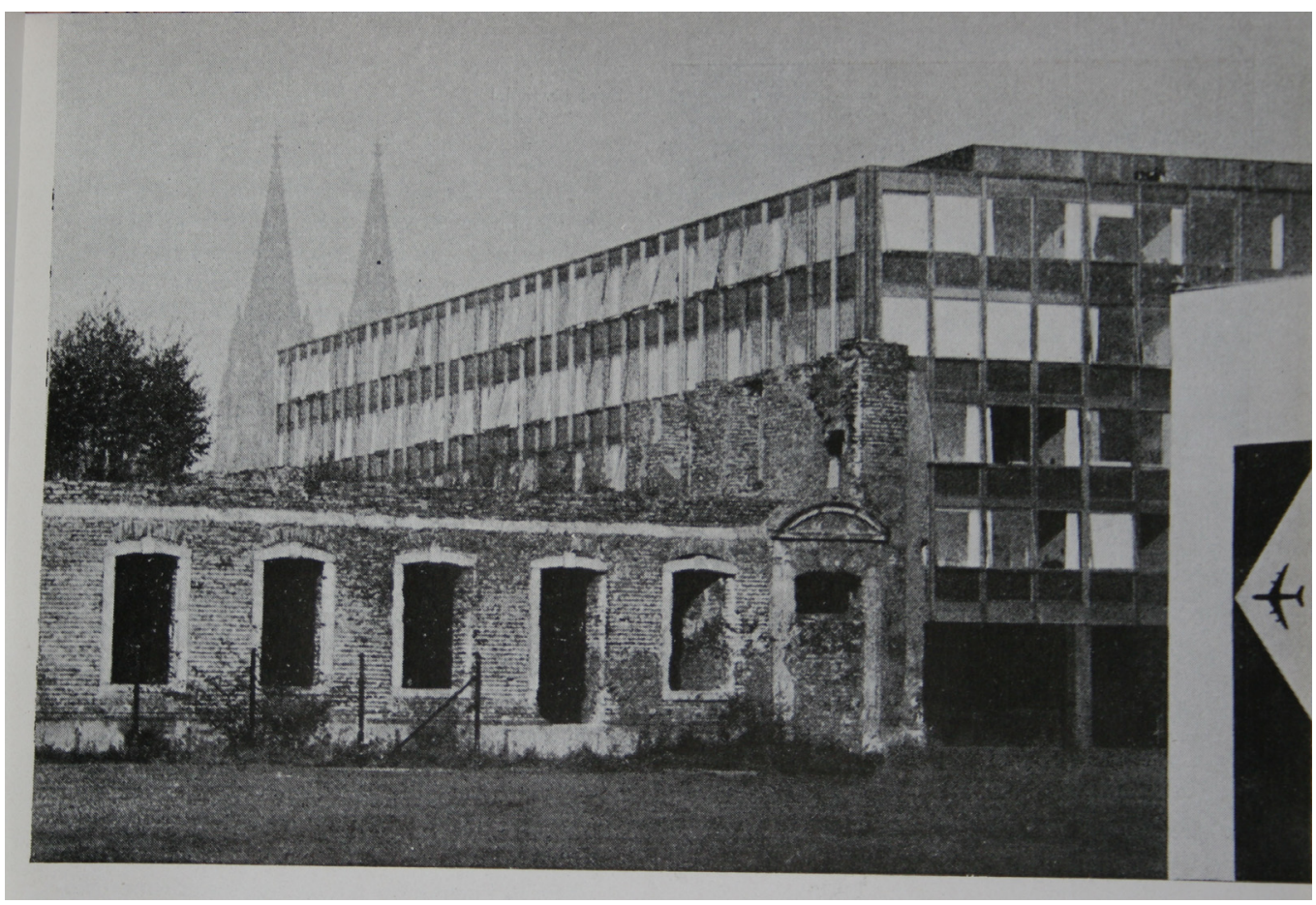

Ramón Masats: “Síntesis de Colonia”, 1960.

“Un sentido innato de selección, en «tempo» (como instante y ambiente) y encuadre, hace de la oportunidad síntesis, de manera que se nos da el todo de una vez en cada caso. A esa «maestría» llega Masats sin sujetarse a «librillo» alguno de reglas que puedan aprenderse. Siente e intuye... y dispara. Eso es todo."

De este modo, la imagen se convierte en un riguroso ejercicio de sustracción de elementos superfluos y accesorios que permite destilar aquellos consustanciales y esenciales, es decir, aquellos realmente imprescindibles para definir el sujeto, el tópico en sí. El título de esta fotografía tomada en Colonia nos confirma la intención analítica de Masats, tal y como demuestra la excelente crítica realizada por Laura Terré:

“Una foto muy buena. Cinco elementos se funden en una misma imagen, componiendo un hojaldre de planos representativos, que a la vez son planos simbólicos, presentando la ciudad en el año 60 , recién salida de su reconstrucción a democracia occidental: en primer plano un cartel blanco que indica en dirección del centro de la imagen, y la flecha indicadora es un avión. El segundo plano es una ruina cuyas puertas y ventanas aparecen totalmente oscurecidas, a pesar de no tener techumbre. Una fábrica grande y racionalista es el tercer plano que queda medio oculto entre la ruina y el cartel del aeropuerto y fuga en perspectiva hacia el fondo de la imagen. El cuarto plano del fondo, idealizado, insinuado por la bruma en un gris aguatinta, recorta las torres de la catedral, único vestigio que consintió mantener en pie el ejército de liberación. Un quinto plano 


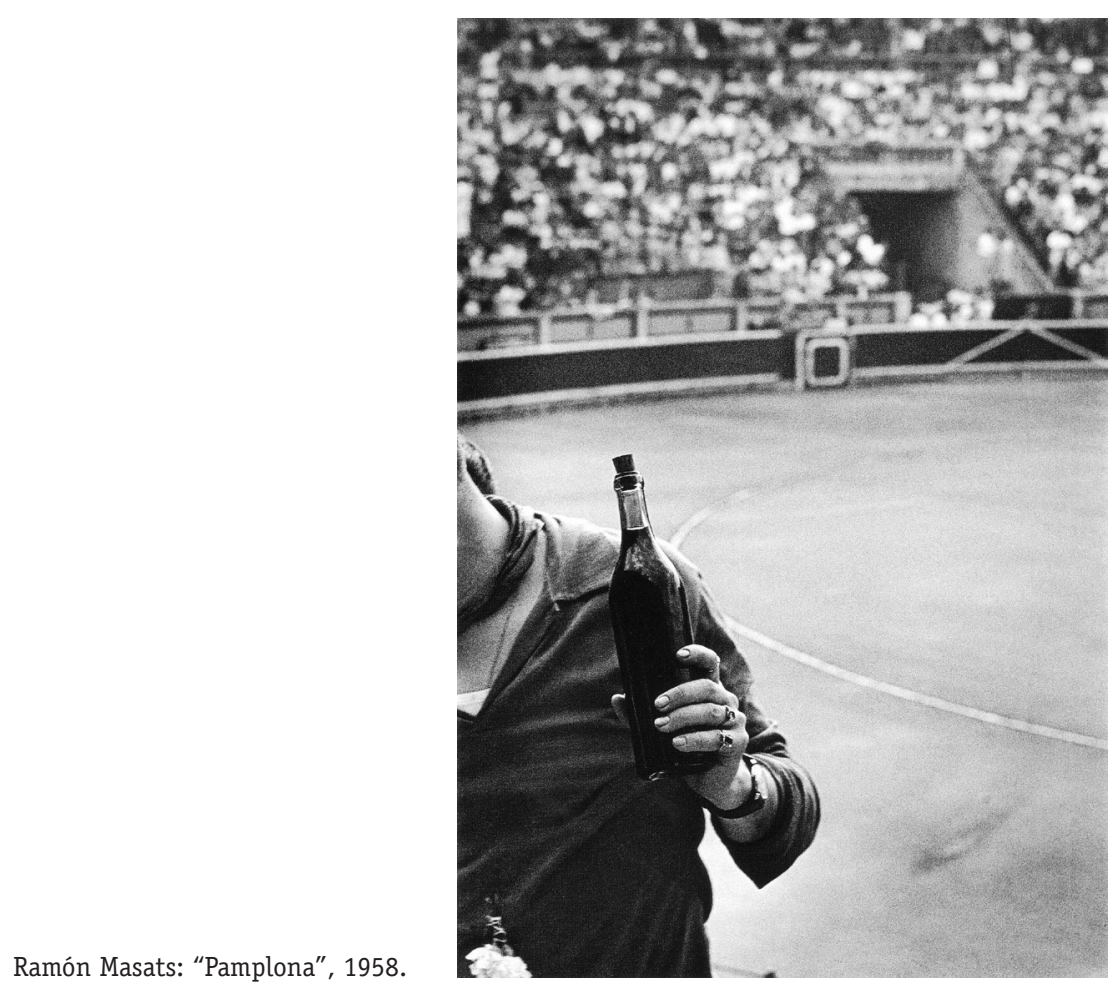

que se despega de todo lo demás, porque se trata de otra vida, de otra forma de existencia, es la naturaleza, como el soporte de la historia, ese suelo poblado de vegetación, que vuelve a ser en cuanto lo dejen" ${ }^{5}$.

Con independencia de esta obra, hemos encontrado varias imágenes más en las cuales el tópico se presenta casi en estado puro: tan concentrado en su propia esencia y tan sintético que surge representado con un mirada absolutamente nueva y original, como si fuera la primera vez que lo contemplamos. Por ejemplo, existe una imagen en su serie sobre Los Sanfermines, que Masats amplió a un tamaño realmente espectacular con ocasión de su exposición antológica, realizada en el Círculo de Bellas Artes de Madrid en 1999. En ella aparece un sujeto que sostiene una botella de vino en una plaza de toros... La composición es muy extraña, pues toda la cara del personaje, toda la cabeza, está cortada fuera del encuadre. Esta composición nos llamó poderosamente la atención, ya que -llevados por nuestra cultura visual, irremediablemente contaminada por la tradición- considerábamos que la composición de esa imagen era errónea, pues le faltaba la cabeza al personaje central... Asimismo, tampoco entendíamos el porqué de su selección y ampliación a un tamaño tan grande. Cuando se lo comentamos a Ramón nos descubrió lo que habíamos tenido delante de los ojos y no habíamos sido capaces de leer. Esa imagen sintetiza la esencia de Los Sanfermines: el vino y la plaza de toros. Cualquier otro elemento -incluida la 


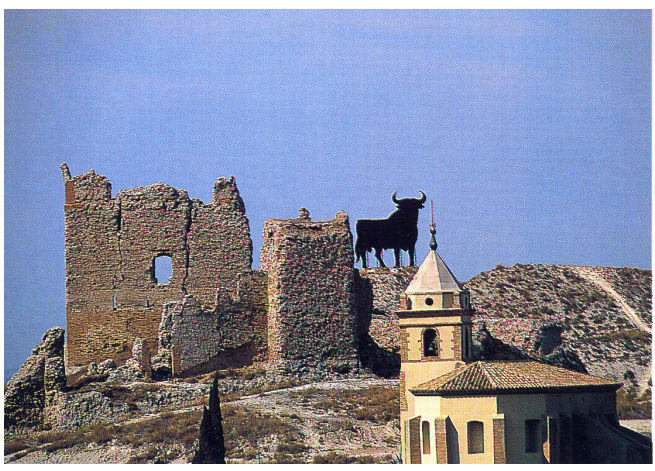

Ramón Masats, “Toro", 1998.

cara del personaje- hubiera corrompido la imagen, distrayéndonos, restándole importancia a los elementos realmente fundamentales. Esa imagen había sido ampliada a un tamaño tan grande porque representaba todo un periodo. Resumía en un solo disparo todo el trabajo que Masats había realizado sobre Los Sanfermines durante casi ocho años - desde 1955 hasta 1963, año de publicación del libro-.

Podemos suponer que las reflexiones que Masats realiza al plantearse estas fotografías han discurrido por deliberaciones parecidas a éstas... ¿Cuál es el denominador común de todas las diferentes manifestaciones de un tópico concreto? ¿Cómo llegamos a su síntesis más íntima? Estas preguntas no son gratuitas, pues estamos convencidos, y el propio Masats nos lo confirma, que este tipo de imágenes van precedidas por meditaciones y reflexiones muy complejas, que una vez más contradice el carácter intuitivo que Masats se empeña en imprimir a su obra.

(R. Masats, Valencia, 25 de marzo de 2004) -“Esto es del último libro que hice, que se llama Toro, y empieza con los tres tópicos de España: el castillo, el toro y la iglesia. ¡Me costó subirme a un monte...! Se ve mucho por la carretera de Zaragoza hacia Barcelona. Esta imagen es de la feria de Sevilla, pero me costó casi un rollo conseguir lo que yo quería. Iba buscando la impresión ésta. Quiero decir que es una foto trabajada. No es casualidad".

Como podemos comprobar en estas declaraciones, Masats ya tiene la imagen previa en su cabeza y sólo le queda construirla, imprimirla, en el negativo fotográfico. Para ello tiene que tomar tres decisiones previas a la exposición de la película fotográfica: pensar cuáles son los tópicos que quiere destacar, encontrarlos y reunirlos en una sola imagen. En el caso concreto al que él mismo aludía debe subirse a un monte, seleccionar una óptica -en este caso un teleobjetivo- que aplaste la perspectiva, alinear todos los elementos básicos del tópico de España, escoger un diafragma lo suficientemente cerrado para tener bastante profundidad de campo... Seguro, asimismo, que necesitó un trípode (que no se dejó en casa o en el coche) para que con ese diafragma tan cerrado, y esa velocidad necesariamente tan lenta, la imagen saliera estable... En el caso de la imagen de feria sevillana, también tiene claro los elementos que debe conectar y cómo hacerlo, aunque deba realizar todo un rollo de 36 diapositivas hasta conseguir ponerle el vestido de sevillana a un caballo.

Este "sintetismo" característico en Masats lo encontramos desarrollado no sólo en sus fotografías, también lo hemos hallado aplicado a una actividad mucho más esporádica en nuestro autor, su faceta literaria (Masats jamás admitirá que estas breves incursiones, siempre obligadas, las consideremos como una faceta suya). Como ejemplo de ello tenemos la suerte de contar con un texto escrito por el propio Ramón Masats sobre la obra de Joan Colom. Es uno de sus pocos textos publicados, y como todos los demás, escrito siempre como encargo. En este caso a petición de Pepe Font de Mora, director de la Fundación Foto Colectania. Del citado texto nos 
Ramón Masats, “Sevilla”, 1982.

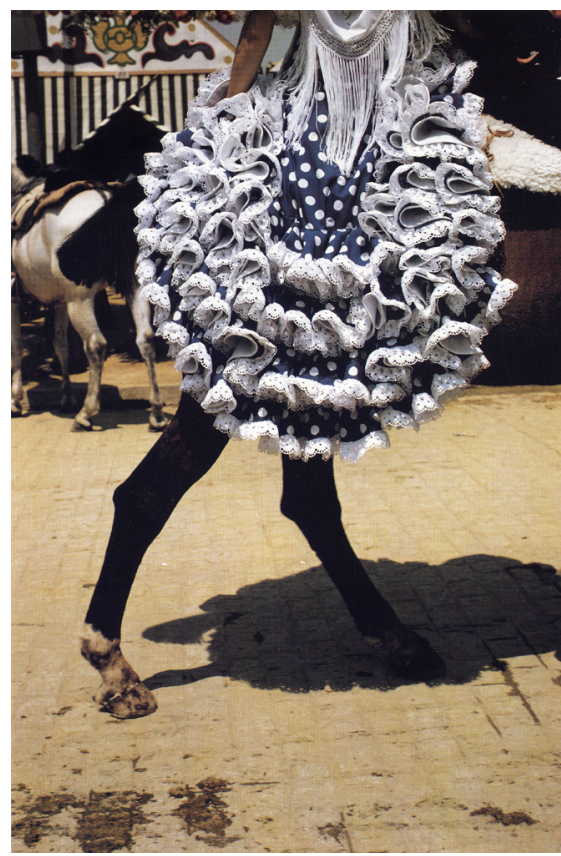

gustaría destacar la síntesis de elementos narrativos, incluso gramáticos, que aparecen en su análisis sobre las fotografías de Colom. El cerebro de Masats funciona con la exactitud de un bisturí, ora para analizar un tópico y transcribirlo a imágenes fotográficas, ora para analizar una obra fotográfica y convertirla en relato escrito. El uso de las palabras no puede ser más preciso, acertado y económico. Masats utiliza un estilo digno de un telegrama.

“A la derecha, circunspectas y moviendo pudorosamente la cola, las [palabras] eruditas:

Denuncia, valentía, arte, cultura, honestidad, utopía, espontaneidad, criterio, visión, realismo, Goya, fetichista, satírico, clandestino, crítico, escándalo, gabardina, obra, subconsciente, intuitivo, testimonio, tacto, naïf, respeto, sociología, plástica, ética, estética y poética.

Irreconciliables y al otro lado, con mucha bulla y ronroneo, las [palabras] pertinentes:

Calle, luminoso, fimosis, gomas, lavaje, bar, taburete, copa, Bonet de San Pedro, hola, tacón, tetas, culo, pelas, habitaciones, escaleras, bombilla, sostén, braga, bidet, toalla, lavabo, cama, 10'.

Escalera.

Blenocol.

Por supuesto, te estoy hablando de fotografía" ${ }^{\text {. }}$

Así es como entiende Masats la fotografía: sencilla, elocuente, directa, potente, concreta, intuitiva, socarrona...

-La foto de la anciana pintando el suelo...

(R. Masats, Madrid, 27 de diciembre de 2006) -“Hace poco estuve en Tomelloso con Publio López Mondéjar. Hicimos una comida con las fuerzas vivas de allí y salió el tema de esta foto: «iHombre, sí. Mi abuela tenía una casa así!». Pero ya no existe nada en absoluto de todo esto. 


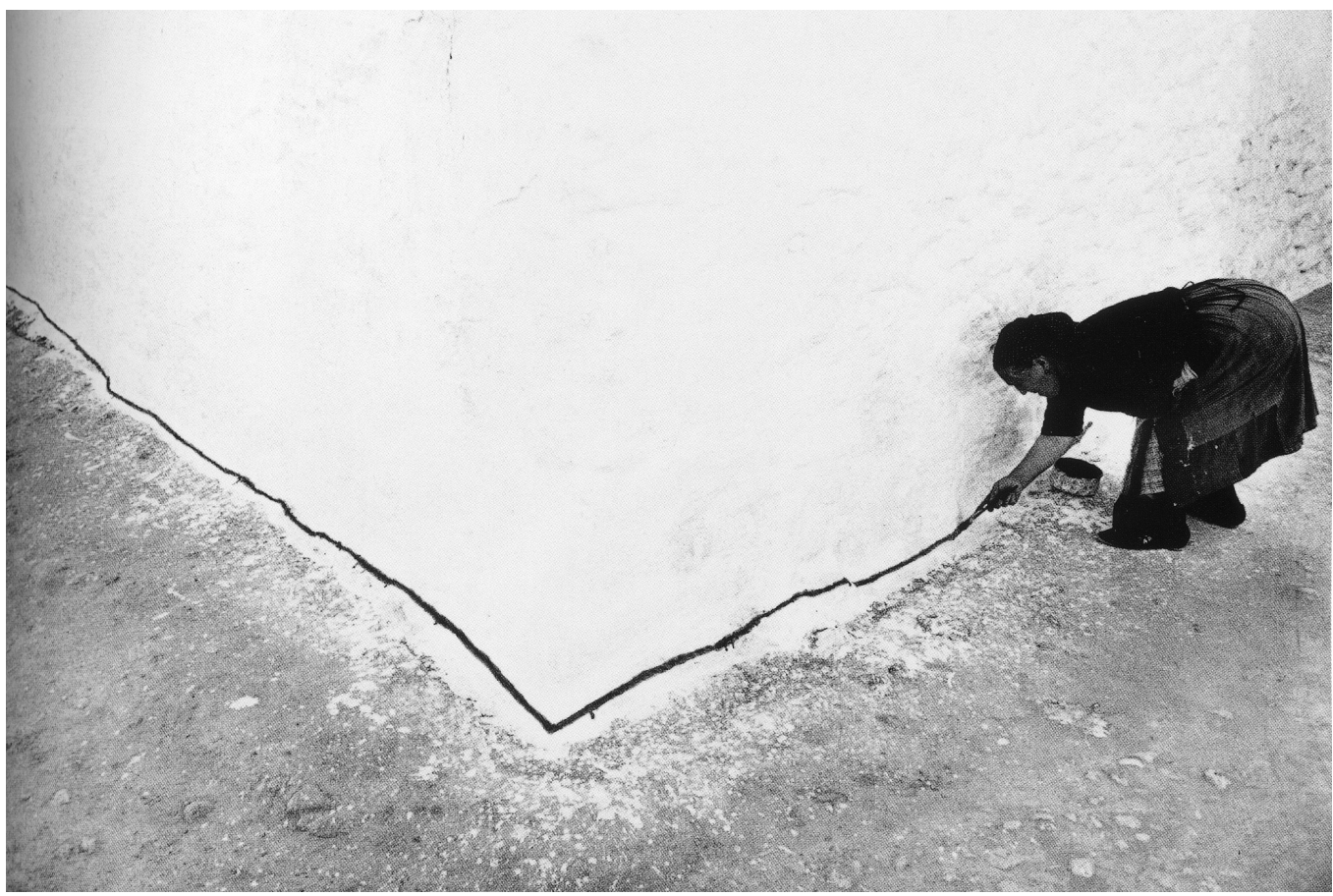

Ramón Masats, “Tomelloso (Ciudad Real)”, 1960.

Yo les pregunté por aquello. ¿Qué significado tenía? Nunca nadie me lo ha sabido decir. Desde luego estético no era. Era de un tipo entre religioso y pagano. Bueno, pues esta ralla protege a la casa... Había muchas casas pintadas de esa manera. Era muy frecuente en las casas de aquella época el que tuviera esta delimitación, no era una excentricidad de esta señora. Lo que pasa es que no estaban la señoras pintando y esta sí. Rafael Sánchez Ferlosio, que está casado con una amiga de Paloma, me pidió que le gustaría tener esta foto. Una noche nos fuimos a cenar a su casa, se la llevé y la mujer se la enseñó a su marido: «iMira que artista es Ramón!», y Rafael dijo, con un criterio cojonudo: «La artista es la señora». ¡Y tiene toda la razón! La gente ha hecho unas maravillosas obras de arte pero sin pretender hacer Arte. Arte con cosas eficientes o con cosas digamos de tipo religioso, pero fuera de la religión, mucho más ancestral. Han hecho cosa maravillosas pero cuando no tienen ninguna pretensión artística".

-Sí, lo importante en tus fotos es que en algunas se puede rastrear temas paganos, iniciáticos, telúricos, mágicos, que rozan la religión, que están en el meollo del asunto.

(R. Masats, Madrid, 27 de diciembre de 2006) -“Posiblemente".

-Parece que, de tanto ir al tópico, y de tanto ir a la síntesis de las cosas, parece que has llegado al origen de las cosas y es uno de los principales dones de estas imágenes. Algo que, aunque está en nuestra memoria colectiva, no somos capaces de entender por qué se hacen, pero están ahí y seguro que un antropólogo sí que le podría dar una explicación más profunda.

(R. Masats, Madrid, 27 de diciembre de 2006) -“Manolo Garrido, con el que hice algunas cosas para televisión, Raíces, también era muy de meterse en la cosa del pueblo... y él ha estudiado mucha antropología y una vez me dijo: «No sé de qué va esto de la ralla, pero, más o menos, debe ser una separación para que el diablo no se meta en la casa...». Pero no lo tenía muy estudiado". 


\subsection{LA LLAMADA FOTOGRAFÍA DE FORMAS}

Como ya hemos comentado, Ramón Masats empezó a hacer fotografías aproximadamente en el año 1952, año en que su familia deja Barcelona (la tienda se la queda un primo) y se va a Tarrasa (donde su padre adquiere un puesto de pesca salada en el Mercado de la Independencia). 1952 también es el año en que Ramón descubre la revista Arte Fotográfico mientras hace el servicio militar en los juzgados militares de Lérida. Las imágenes de estos primeros momentos se caracterizan por ser más abstractas o plásticas que realistas: lo que él mismo llamará sus imágenes "de Formas", que contrastarán con sus otras imágenes de reportaje, más humanistas, directas y dinámicas.

-Hay una contradicción que sería: dinamismo-estaticismo, que son dos facetas tuyas que aparentemente se oponen, pero que están ahí.

(R. Masats, Madrid, 4 de septiembre de 2002) -“Sí, es evidente, y cada vez más. Eso supongo que también lo lleva la edad. El dinamismo va decreciendo y el esteticismo va aumentando".

-Estaticismo, de quieto.

(R. Masats, Madrid, 4 de septiembre de 2002) -“Estático, estético, en mi caso no creo que vayan muy lejanas una cosa de la otra. Esto es cierto. De todos modos, es curioso... Revisando mi archivo me he dado cuenta (he empezado a revisar mi archivo ahora) que hay fotos del puerto de Barcelona, de la Barceloneta, incluso de Las Ramblas, que son muy estáticas y muy estéticas. Es decir, que luego fui evolucionando hacia más dinamismo, hacia Pamplona... Esto es evidente. Pero ahora en el color, últimamente, casi estoy volviendo más hacia lo estático. Es lo que me llama más la atención. Supongo que es la edad, porque no tienes la rapidez. Y también porque el blanco y negro es mucho más rápido que el color. El color tienes que clavar el fotómetro. En diapositiva te equivocas en medio diafragma y no tiene solución, en cambio en blanco y negro te equivocas y no pasa nada".

La primera referencia a estas imágenes de carácter más estático la encontramos en la trascripción del coloquio que Ramón Masats ofreció, con motivo de su triunfo en el V Trofeo Luis Navarro de Fotografía de Vanguardia, ya en la temprana fecha de 1957. Parece ser que el coloquio fue precedido por un breve repaso de su incipiente obra fotográfica y en él aparece recogida la dualidad de estilos que marcará toda la trayectoria fotográfica de Masats: su fotografía más conocida de reportaje (llamada en la ocasión "de marcada tendencia moderna") y sus fotografías de formas abstractas.

“Inició su exhibición con la foto galardonada. Siguieron a ésta otras de su etapa «abstracta» (no figurativa) y a continuación nos mostró las obras de más reciente factura, entre las que se hallaban algunas de carácter puramente «decorativo» (sin anécdota) y varias de marcada tendencia moderna, tal como se entiende el modernismo en fotografía más allá de nuestras fronteras. Quizá lo más «flojo» de sus ampliaciones sea la técnica y la composición"7.

Aunque no nos interesa aquí insistir nuevamente en la disparidad de criterios entre el mundo salonista y Masats, no deja de sorprendernos que el transcriptor del coloquio considere que lo "más flojo" sea la técnica y la composición de sus imágenes, precisamente cuando muchas de aquellas fotografías son auténticas demostraciones del virtuosismo compositivo de Masats.

Con todo, intentar condensar y definir en un solo término todas las fotografías de formales de Masats - por continuar utilizando su propia terminología- es un poco arriesgado, pues dentro de esta ambigua denominación se encuentra un grupo de imágenes muy heterogéneo que, ade-

7 E.V.P., “Coloquios en la A.F.C., con D. Ramón Masats”, en Boletín de la A.F.C., junio 1957, pág. 89. 
más, no se limita a sus primeras fotos, sino que se extiende a lo largo de toda su carrera fotográfica. Las imágenes de formas salpicarán todos y cada uno de sus trabajos: tanto los vinculados a su faceta en blanco y negro o en color, como los relacionados con su etapa como realizador de documentales televisivos. Quizá, el único denominador común presente en este inmenso grupo de imágenes sea el hecho de que todas ellas poseen una gran vocación de experimentación con las posibilidades del medio fotográfico y/o con la mirada del fotógrafo. Por otro lado, estas fotografías no tienen una intención narrativa clara, dirigida y orquestada por nuestro autor -como sucede en su otra línea de trabajo documental-, sino que presentan las imágenes de una manera ambigua, abierta a la libre interpretación del espectador.

Como ya hemos comentado, este tipo de ambigüedad en la obra de Masats no se ceñirá exclusivamente a su obra fotográfica, sino que llegará hasta algunos de los documentales realizados para Televisión Española en los años setenta.

“En la obra de Masats va a imponerse esa mirada desde fuera a lo largo de su trabajo audiovisual de finales de los sesenta y los setenta (...) Ese desplazamiento en la mirada de Masats implica un cambio de actitud: un viaje que lo desplaza desde una posición moderna a otra posmoderna. Ya en algunas de las primeras fotos de Masats se percibe la atracción por romper la unidad humanista de la obra de sus contemporáneos, de introducir un comentario distanciador, que produzca extrañeza, que genere una desfamiliarización del objeto o principalmente el sujeto fotografiado". ${ }^{8}$

Encontramos, por tanto, una gran diversidad de frentes abiertos en su investigación "formal": en ocasiones investigará las posibilidades de la velocidad de exposición, en otras trabajará con el desenfoque y la profundidad de campo, con los puntos de confusión o con la geometría y la composición... Algunas imágenes, las más "decorativas", son fotografías plásticas que buscan sencillamente un deleite visual sin mayores pretensiones: Por el contrario, habrá otras que -sin renunciar a la perfección compositiva- pretenden dar un paso más allá y juegan con la percepción y la representación, engañando al ojo, generando imágenes muy próximas al surrealismo... Posiblemente las palabras que mejor resumen y definen la fotografía de Masats las escribiera Oriol Maspons con ocasión de su crítica a la primera exposición de Terré, Miserachs y Masats, en 1957.

“Este hombre tipo no considera que la belleza resida forzosamente en la corrección de líneas. No le gusta en principio la belleza fácil ni dulzona. Ama la simplicidad en las formas y por esto tiende más a lo románico que a lo gótico. Aborrece lo falso sólo por serlo. Percibe lo ridículo de lo formulario y prefiere lo intuitivo a lo elaborado con refinamiento" ${ }^{\prime \prime}$.

Si bien es cierto que estas palabras no se las dedicó exclusivamente a Masats, y que, en realidad, son un manifiesto personal de su sentir fotográfico, la serie de reflexiones sobre la belleza y la simplicidad de formas, la verdad y la falsedad, lo formulario y la intuición, se enguantan al perfil de Masats con total exactitud. Las fotografías "decorativas" están generadas gracias al interés que siempre ha tenido Masats en buscar y encontrar la belleza entre sujetos sencillos y cotidianos, aparentemente despojados de cualidades plásticas. Esta búsqueda implica una penetrante investigación visual que, mediante una gran limpieza y síntesis compositiva, nos descubre posibilidades sorprendentes en el interior de una realidad aparentemente anodina. Y cuanto más sencillo o humilde sea el objeto retratado, más hermosa será su sublimación fotográfica. No nos

8 Cerdán, Josetxo, op. cit., pág. 157.

9 Maspons, Oriol, "Cómo hacen sus fotografías Terré, Miserachs, Masats", en Arte Fotográfico, n 64, año VI, abril 1957, pág. 294. 
enfrentamos a meros ensayos de composición y forma que podrán ser aplicadas a la fotografía de reportaje (argumento éste, que él mismo planteará más tarde): se trata de imágenes completas y definitivas en las que hay algo más que líneas o geometrías. Generan un juego que Masats establece con el espectador para que éste mire su entorno cotidiano con mayor intensidad. Su objetivo es articular una para-realidad construida exclusivamente a través de medios fotográficos y elaborada con gran ambigüedad y sin necesidad de manipular ni tratar de ningún modo el referente, dado que éste no existe más que en la mente y en su prolongación, el ojo del fotógrafo. Masats, por ello, nos invita a aprender a ver.

(R. Masats, Madrid, 20 de marzo de 2000) -“Fijaos que cosas se pueden hacer en la naturaleza solamente aprendiendo a mirar. Eso es lo más difícil, y eso es lo que tenéis que aprender y eso no os lo puede enseñar nadie. Por muy buen fotógrafo que se sea o por muy buen profesor, nadie os puede enseñar a mirar. Lo único es que tenéis que discernir lo que os interesa".

La mirada fotográfica de la realidad, es lo realmente importante en estas imágenes. Para ponerla de manifiesto hay que asumir cierta disciplina fotográfica, hay que ser conscientes de las limitaciones de la fotografía y seguir una serie de normas de carácter ético. Por ello, la honestidad de Masats y las características del propio medio fotográfico le llevan siempre a descubrir el objeto del que está extraída la imagen. Por muy abstracta que ésta parezca, siempre hay un detalle significativo del referente, del sujeto fotografiado, que aparece en el campo visual. A partir de

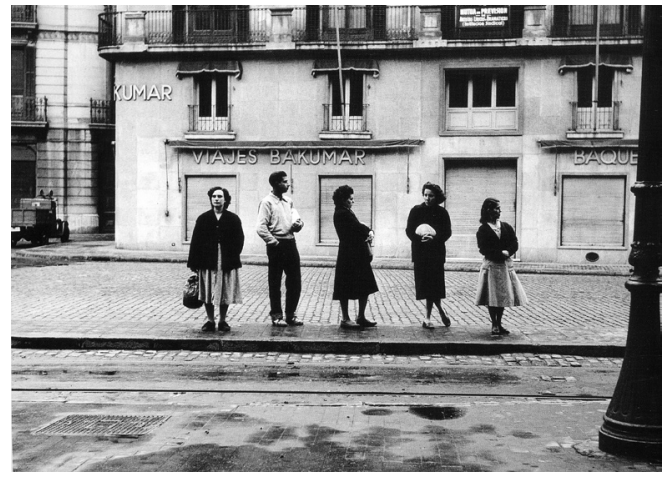

Ramón Masats, "Gente esperando" de su serie "La Rambla", 1956. Publicada en diversas antologías actuales.
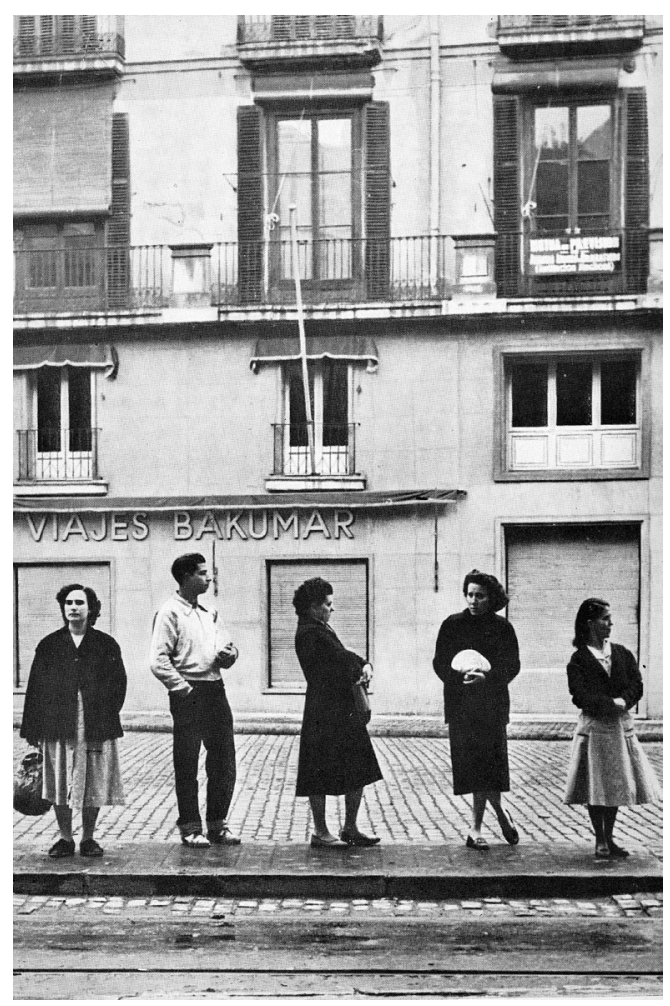

Ramón Masats, "Gente esperando" de su serie "La Rambla", 1956. Publicada en Arte Fotográfico, n 64, abril 1957. 
este detalle podemos reconstruir el proceso de descomposición de la realidad y la posterior creación fotográfica que ha realizado la mirada de Masats. Pero este proceso -en el que la mirada es la única protagonista - le lleva a evitar, en lo posible, la manipulación física de la realidad. No se debe alterar el sujeto fotografiado, pero tampoco el negativo o la copia en el laboratorio (como hubieran hecho los pictorialistas) y ni tan siquiera se considera del todo correcto reencuadrar la imagen en la ampliadora, a menos que uno se vea obligado a ello por cuestiones narrativas, y esto lo hace Masats en muy pocas ocasiones.

(R. Masats, Valencia, 25 de marzo de 2004) -“La foto de la parada de autobuses era vertical y ahora la reproduzco en horizontal. Está hecha con una Rolleiflex de seis por seis. A partir de que en el año 90 han empezado a pedirme cosas mías de blanco y negro, la he revelado en horizontal. Lo que más he trabajado siempre ha sido el $35 \mathrm{~mm}$, y menos alguna foto, siempre he positivado todo el negativo. Es decir, me impongo el rigor de encuadrar lo que necesitas y no dejarlo para reencuadrarlo después en el laboratorio. Siempre ha sido una disciplina muy importante. Tampoco he sido absolutamente riguroso en esto, pero habrá, de las 160 fotos que os voy a enseñar, sólo dos fotos en las que me he visto obligado a reencuadrar. Pero claro... en el seis por seis... Es que el formato cuadrado no me gusta".

Como mucho Masats asume un grano fotográfico evidente (producido por el uso que hace de película de 400 ASA forzada a 800), así como el control del contraste del tono de la imagen fotográfica, realizando tapados y reservas, o utilizando papeles más o menos duros en el laboratorio. Como ya vimos, estas normas nunca supusieron un corsé creativo, y si era necesario, las mismas se vulneraban ya fuera en su periodo en blanco y negro o en su periodo en color. Aunque, como también señalamos, después de pasar por la televisión y el cine se relaja sensiblemente, pues allí aprende a manipular la escena creando situaciones, introduciendo distintos elementos para forzar conflictos, generando imágenes de una manera quizá más artificial:

\section{“¿Fuerza las situaciones para crear las fotografías?}

No, pero están muy buscadas. Sobre todo con los reportajes fotográficos, que pensaba: «Necesito una persona que pase por aquí». Entonces tranquilidad y a esperar. Hice televisión y cine durante 17 años y, cuando volví a la fotografía, no tenía el apoyo de producción. Porque en cine, si necesitas un señor con una carretilla, lo buscan y te lo llevan. Y cuando fotografías nadie te ayuda. Esperas a que se produzca el equilibrio dentro del fotograma y si no sucede, no pasa nada"10.

En un primer momento, sin embargo, toda su potencia creativa se centra en explorar las posibilidades de la mirada, una mirada profundamente fotográfica y, por tanto, usuaria de lentes de diferente distancia focal (especialmente angulares de $20 \mathrm{~mm}$, aunque también teleobjetivos extremos, como un 500mm catadrióptico).

- ¿Trabajas con varios cuerpos a la vez?

(R. Masats, Madrid, 4 de septiembre de 2002) -“Depende del trabajo. He llegado a trabajar con dos Leicas y dos Nikon. Las Leicas (que no son réflex) las llevo normalmente con angulares. Un veintiuno, un treinta y cinco, y un cincuenta. Y las Nikon (que son réflex) las llevo con teleobjetivos".

Masats aprovecha sus características ópticas para manipular las perspectivas de sus imágenes. Juega con la escala, el enfoque y la profundidad de campo como herramientas consustanciales al medio fotográfico. Como ejemplo de investigación en el uso de la profundidad de campo, hay un grupo de imágenes que la utilizan de un modo realmente innovador. Las reglas academicistas aconsejan que las imágenes presenten la máxima nitidez posible y, para ello, recomiendan que aprovechando la 
distancia hiperfocal, todo nuestro cuadro esté enfocado, desde el primer término hasta el más lejano. Caso de no disponer suficiente luz para enfocarlo todo, se deberá enfocar el sujeto situado en primer plano: pues la profundidad de campo es mayor desde el punto enfocado hacia el fondo, que desde en punto enfocado hacia la cámara. De este modo, se acepta que el fondo esté ligeramente rozado de foco mientras el primer término salga nítido. Si se trata de un retrato, el foco debe estar como mínimo en la pupila del ojo del personaje. Si el caso en cuestión es destacar un detalle, éste deberá estar perfectamente nítido mientras que el fondo se desenfocará lo máximo posible para resaltar el sujeto escogido. Como vemos, se trata de potenciar siempre la nitidez del primer término en detrimento del fondo o, por lo menos, conceder al sujeto que queramos destacar el privilegio del enfoque. Masats comprende está "norma establecida" y desmonta la jerarquía de la nitidez, invirtiéndola premeditadamente. Al respecto, nuestro autor posee un numeroso grupo de imágenes en que el fondo queda nítido mientras que el primer término está completamente desenfocado. Podría argumentarse que lo que Masats pretende destacar es el fondo y no el sujeto más cercano, pero no es así. Precisamente, Masats destaca y subraya el primer término desenfocándolo, haciendo vibrar la imagen del sujeto que quiere enfatizar, alterando su percepción normal. De este modo, genera: inquietud, incomodidad y también la frescura de una mirada nueva posada sobre viejos tópicos. Ahora bien, para poder desenfocar nuestro centro de atención sin generar confusión y sin que perdamos el referente, la imagen debe ser límpida, diáfana y clara. Es decir, para evitar el caos, y que con el caos no se genere una imagen sucia -imposible de ser leída-, no debe haber ni un solo elemento que nos distraiga de nuestro centro de atención
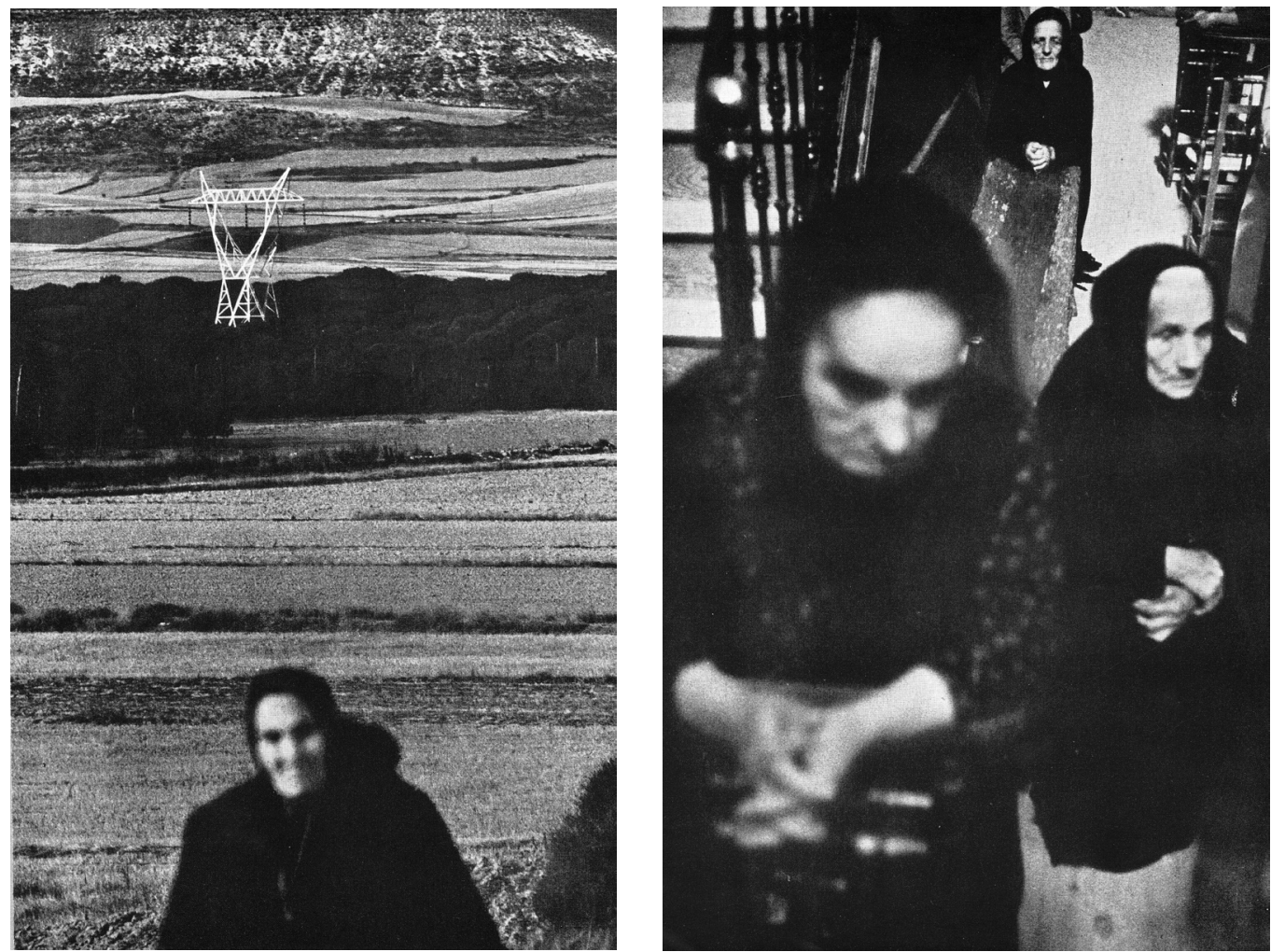

Ramón Masats. Desenfoques aparecidos en su libro Viejas historias de Castilla la Vieja, 1964. 


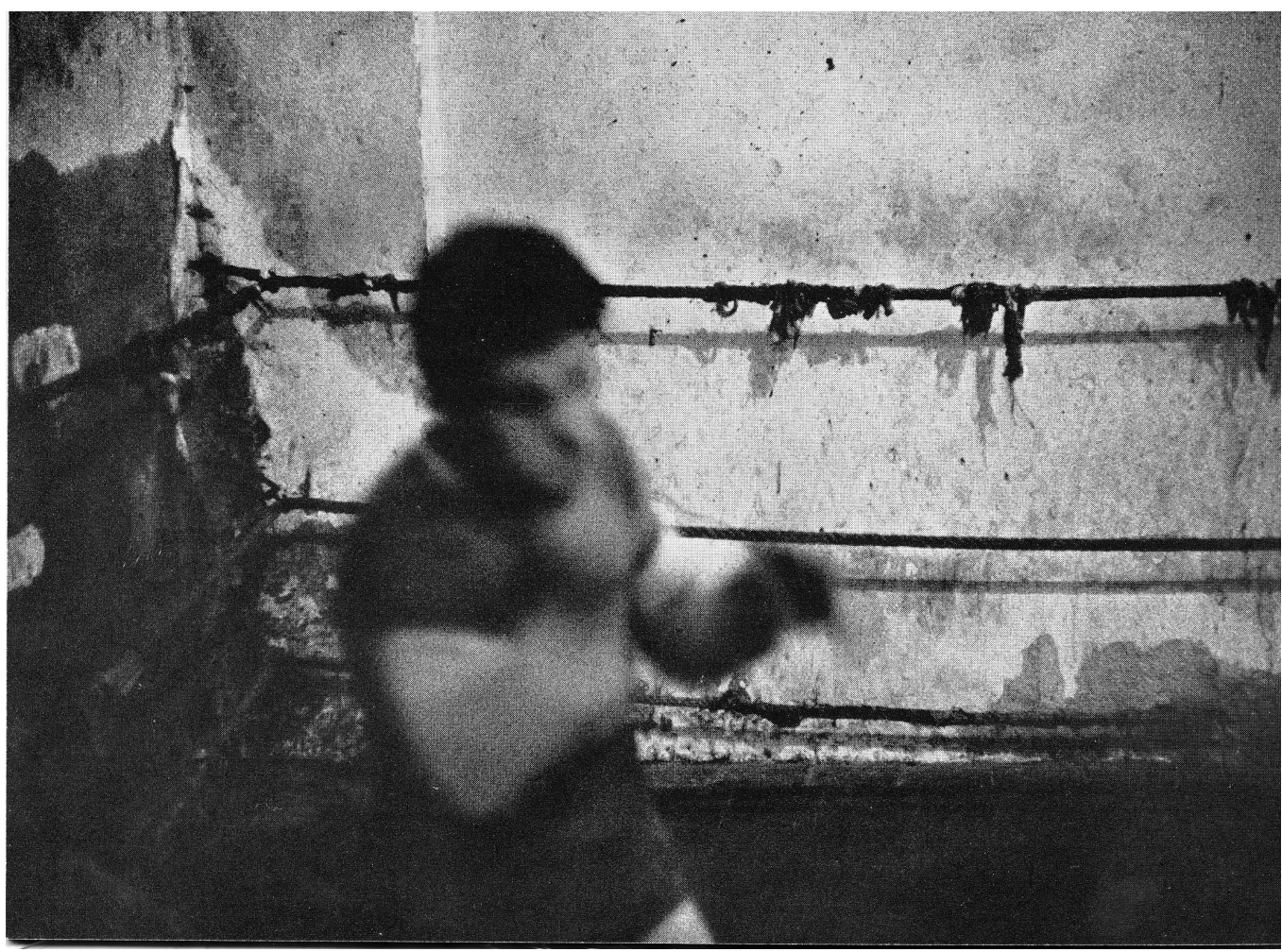

Ramón Masats imagen del libro Neutral Corner, 1962.

desenfocado. Una vez más, cuanto más sencilla sea la imagen, mejor. Cabe destacar, a su vez, que el elemento desenfocado está en todos los casos perfectamente identificado, pues normalmente, Masats utiliza como sujeto borroso un tópico: curas, monjas, ancianas de luto, guardias urbanos, boxeadores... sujetos que a pesar del desenfoque son reconocibles con total claridad. Ya comentamos que para el cerebro es mucho más fácil re-conocer imágenes que le resulten familiares, que abordar imágenes absolutamente nuevas $y$, además, distorsionadas. Sin, por ello, olvidar la utilidad en sí mismo del tópico como generador de significados, tal y como ya pusimos de relieve.

(R. Masats, Madrid, 20 de marzo de 2000) -“Normalmente el zoom lo utilizo para hacer paisajes o para hacer detalles, pero para reportaje humano prefiero cargar la cámara con un $135 \mathrm{~mm} \mathrm{n}^{\circ} \mathrm{f}$ 2, que es mucho más luminoso. El zoom es un 80-200mm nº f 4: o sea, que gano dos diafragmas".

En otras imágenes Masats sí acepta y utiliza la gran profundidad de campo que proporcionan los angulares. Él siempre ha considerado el angular como su principal óptica.

$-¿$ Y por qué un veintiuno?

(R. Masats, Madrid, 17 de julio de 1999) -“Porque es mi objetivo... Muchas de mis fotos están hechas con un veintiuno".

-De los toros no, ¿verdad?

(R. Masats, Madrid, 17 de julio de 1999) -“También, también: El retrato de Paula, la cabeza de toro de Benidorm... mi autorretrato. Bueno no, ése está hecho con un veinte de Nikon. Porque ya sabes que entre el objetivo y el visor hay un pequeño desplazamiento. Era una foto muy complicada y necesitaba que no hubiera ni un centímetro de error de paralaje. Pero vamos, es lo 
Ramón Masats, "Pared y guardia" de su serie "La Rambla", 1956.

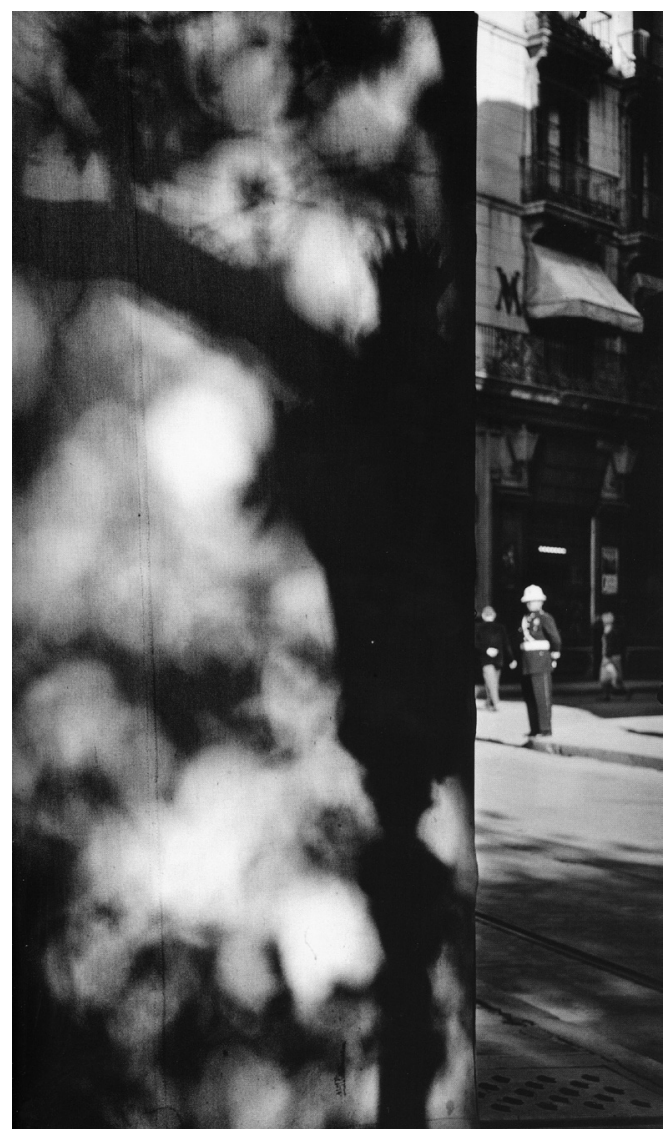

mismo... Y si me voy a Japón me llevaré un veinte de Nikon, por si en algún momento... Es mucho más fácil, por ejemplo, si trabajas con algún polarizador".

(R. Masats, Valencia, 25 de marzo de 2004) -“Aquí podéis ver mi inclinación, casi una obsesión con los angulares. Hoy en día cuando viajo con el Instituto Cervantes sólo llevo una Leica con un $21 \mathrm{~mm}$, no llevo otro objetivo.

Cuando profesionalmente tienes que dar una visión de un pueblo o una ciudad, y tienes unas obligaciones profesionales dadas con un editor, tienes que llevar una amplia gama de objetivos. Pero cuando no necesito mostrar nada y hago lo que me parece, lo hago con el objetivo que me gusta, que es un $20 \mathrm{~mm}$ de Nikon o un $21 \mathrm{~mm}$ de Leica".

Masats conoce las posibilidades de deformación de la perspectiva del angular, pero prefiere no utilizarla de manera exagerada.

(R. Masats, Madrid, 20 de marzo de 2000) -“Bill Brant, compró una cámara en un puesto de material viejo, que sólo tenía un objetivo que deformaba muchísimo, un gran angular, y consiguió unas formas del cuerpo femenino que a mí me gustan mucho. Esas deformaciones son tan deformadas que me gustan... Me parece muy atrevido para aquella época. Fue de los primeros que utilizó de una manera creativa el gran angular, posiblemente ya se utilizara el gran angular para abarcar mucho espacio, pero no para aprovechar las deformaciones. Estoy convencido de que, en el momento en que el fotógrafo que utilizaba el gran angular se acercaba demasiado a un sitio, rechazaba la deformación que el gran angular producía. Posiblemente haya sido el primero que 


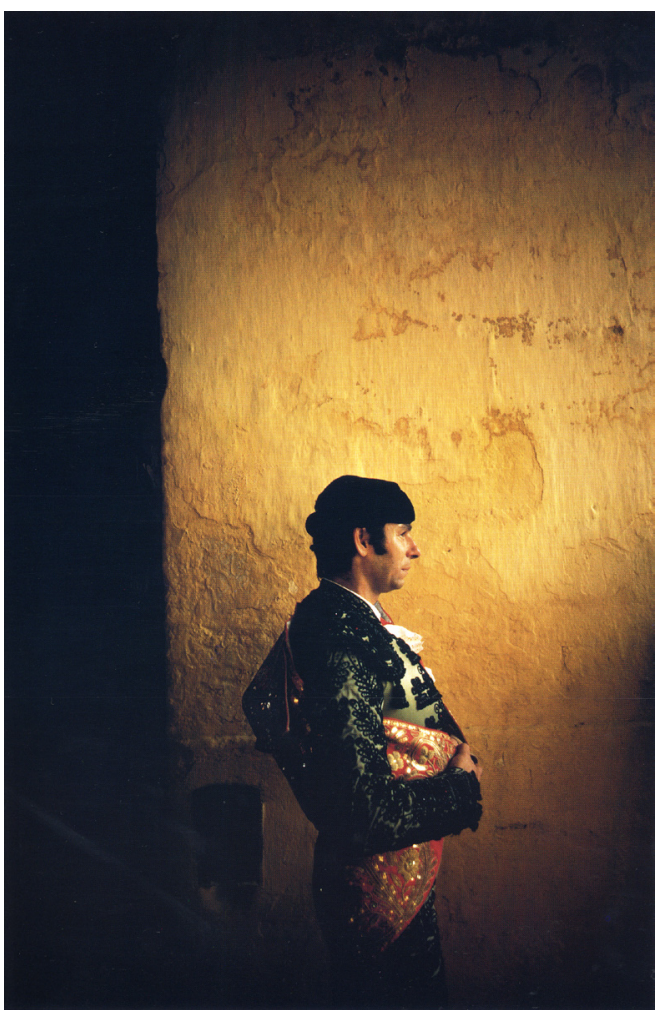

Ramón Masats, “Rafael de Paula”, 1983.

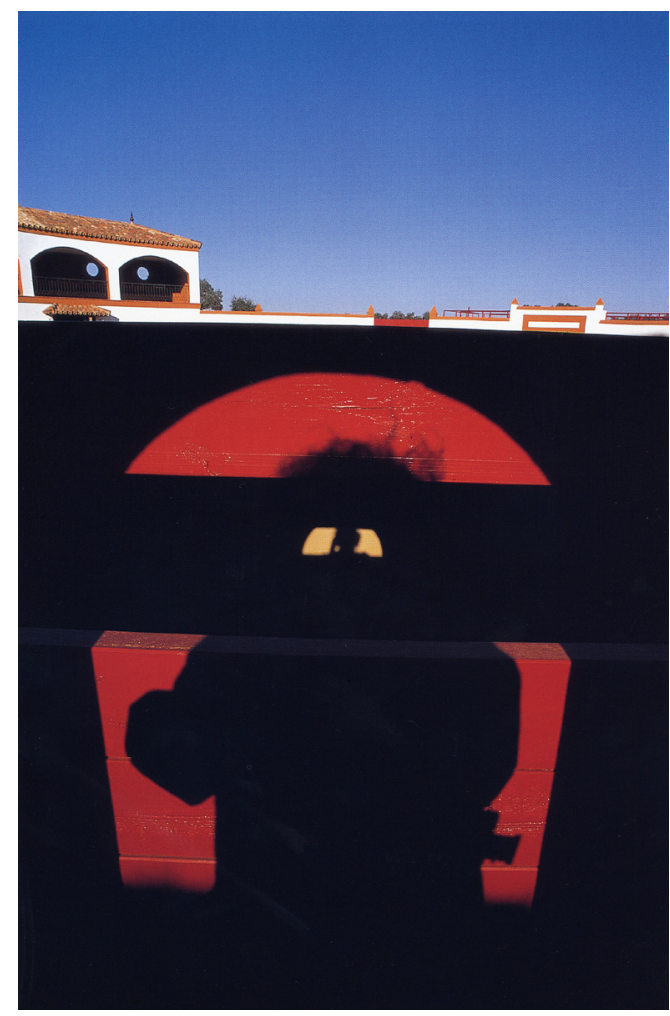

Ramón Masats, “Autorretrato", 1982.

ha utilizado lo que hasta estos momentos se ha considerado como un defecto. Puedes producir cosas muy bellas aprovechando estos defectos".

Por el contrario, su preocupación en el uso de los angulares, se centra en la composición: que todo el encuadre se llene de imagen y no se creen espacios vacíos o muertos en su interior.

-Te vi una ampliación (creo que fue en el Círculo de Bellas Artes) muy saturada, muy contrastada, y con esa utilización del angular tan exagerada... Me recordaba mucho a la fotografía de los años setenta, más que a la de los sesenta, que es cuando estaba fechada. Creo que luego se hará... abusando del angular un poco.

(R. Masats, Madrid, 15 de diciembre de 2003) -“Puede ser".

-Porque normalmente a ti no se te nota que usas el angular.

(R. Masats, Madrid, 15 de diciembre de 2003) -“No se nota mucho, no. No me gusta deformar. Ésta está un poco deformada pero no me gusta deformar con el angular. Es otra cosa: llenar espacios, el tipo de composiciones... Pero no me gusta deformar".

-Además, el angular facilita hacer fotos rápidas.

(R. Masats, Madrid, 15 de diciembre de 2003) -“Sí, claro. Pero es difícil componer en angular para que no te quede todo demasiado lejos y se te llene el fotograma. Es muy difícil. Pero ahora todo lo hago con el veintiuno de Leica. Cuando voy de viaje me llevo una Leica con el veintiuno, un filtro Sky Light, un polarizador y el fotómetro. No me llevo nada más. Y todo lo que hago, lo hago con el veintiuno. Quiero decir que he adaptado mi visión a lo que siempre me ha gustado, que es el veintiuno. Me he comprado un catorce de Tamron, pero ya es demasiado. Sé que no lo voy a utilizar casi". 
Chema Conesa ha encontrado una explicación muy ocurrente a la habilidad de Masats para la ordenación y composición del espacio en sus imágenes.

“En sus años juveniles, Masats no tuvo más remedio que ayudar en el negocio familiar, unos puestos de salazones en el mercado local. Se encargaba del reparto diario, ordenaba en su vehículo los paquetes de tal forma que cupiesen perfectamente cubicados, fue tal su pericia en la materia que aún hoy es capaz de hacer auténticas exhibiciones de cubicaje a simple vista. Es como tener un medidor espacial insertado en el cerebro y que actúa de forma intuitiva"11.

Desde luego la representación del espacio ha sido uno de los principales campos de experimentación formal de Masats:

\begin{abstract}
“Por un lado, busca explorar las relaciones espaciales entre los objetos mediante el establecimiento de correspondencias imposibles y perspectivas forzadas que buscan trabajar los volúmenes, en lo que podríamos ver como un claro impulso de origen velazqueño (...) En el extremo opuesto, hay otra línea de trabajo en la configuración de las imágenes de Masats que busca anular la perspectiva y el efecto de tercera dimensión mediante los caprichosos juegos geométricos que es capaz de detectar el ojo del fotógrafo, la utilización de película de alto contraste y, en su última etapa, el inteligente trabajo con colores, buscando siempre una rotunda y regular saturación de modo que las superficies aparecen desprovistas de profundidad (...) Todo ello tiene que ver con un cierto sentido arquitectónico de la fotografía que cada vez se va a acentuar más en Masats. Como el mismo ha afirmado: «la arquitectura es cierto que para mí es una de las artes más importantes»"12.
\end{abstract}

Otro efecto plástico, fruto de la experimentación formal de Masats, son las imágenes movidas de toros. Fotos, que ya veremos, que considera como un efecto plástico y no como un intento de acercar la fotografía al movimiento del cine.

(Masats, Madrid, 20 de marzo de 2000) -“Esto es de Ernst Haas. Aquí hubo una casualidad. Hice un reportaje de toros con el mismo sistema que él. Yo hice mis fotos y de repente aparecieron en Life las suyas. Las mías como no tenía perras las hice en blanco y negro. Era lo mismo que Ernst Haas, pero él en color. Yo cogí y me guarde lo mío, pero la idea era exactamente la misma. Bueno... ¡Qué le vas a hacer, sino estar muy contento por haber coincidido con Ernst Haas en una idea! Lo que pasa es que tus fotos ya las puedes guardar, porque él... -seré lo suficientemente vanidoso para decir que no creo que fueran mejores- lo único que pasa es que él las hizo en color".

“En lugar de «detener» el movimiento del sujeto con un tiempo breve de exposición, Haas utilizaba un tiempo más lento de forma tal que el modelo continuase moviéndose $y$, por consiguiente, la imagen resultase movida (...) Las imágenes que obtuvo evocan admirablemente el sentido del movimiento y el color las hace muy sugestivas. A principios de los años cincuenta [1954], mientras fotografiaba una corrida en España, Haas se encontró, a medida que caía la tarde, tomando imágenes que cada vez aparecían más invadidas por las sombras. Dada la escasa rapidez de la Kodachrome, se vio obligado a recurrir a tiempos de exposición de $1 / 5$ o, incluso, de $1 / 2$ segundo.

Las imágenes movidas suscitaron su curiosidad y lo alentaron a realizar nuevos experimentos. Al analizar las fotografías descubrió que la vista buscaba siempre en un punto nítido de referencia en la

11 Conesa, Chema, op. cit., pág. 8.

12 Cerdán, Josetxo, op. cit., pág. 164. 


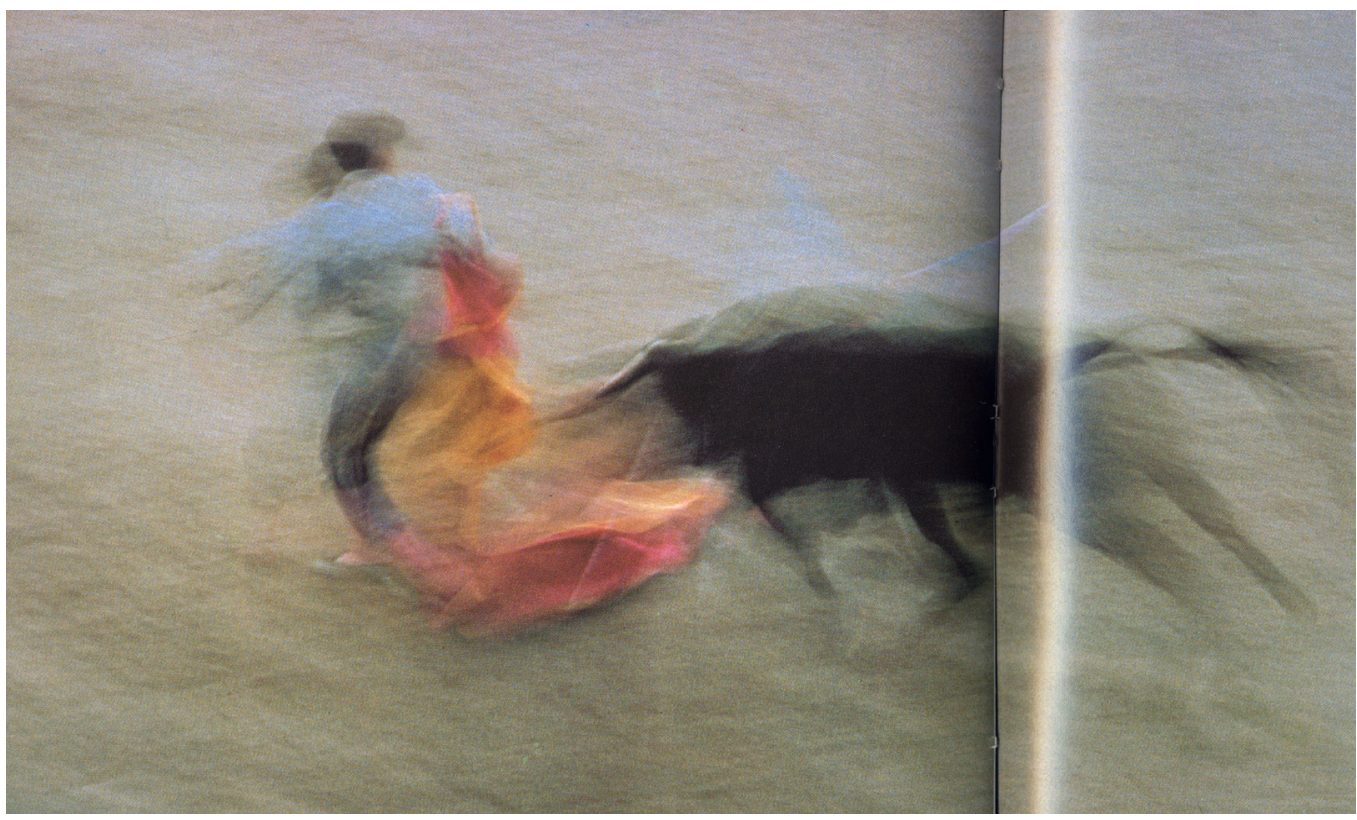

Ernst Haas, “España”, 1954.

zona «movida» de la foto. En teoría, se dijo, aquel punto debía ser la parte más importante de la imagen (...) Life publicó el reportaje de la corrida en julio de 1957 con el título Belleza en un arte brutal [Haas, Ernst, "Beauty in a brutal art", en Life, 29 julio, 1957], tras lo que pidió a Haas que utilizase la misma técnica para fotografiar varias actividades deportivas norteamericanas" ${ }^{\prime 13}$.

Recordemos que la primera vez que Masats dio a conocer su trabajo con fotografías movidas de toros fue con ocasión del V concurso Trofeo Luis Navarro de Fotografía de Vanguardia de la Agrupación Fotográfica de Cataluña, en 1957. Masats, por consiguiente, realizó estas fotos antes del 24 de abril de 1957, meses antes de la publicación del reportaje de Haas en Life. Aunque Masats triunfó con estas imágenes -llevándose el primer premio de aquel concurso con su fotografía del banderillero movido, que en el acta del fallo se llamaba "Tachun 2"- lo cierto es que sorprendió muchísimo a los defensores de la fotografía directa y humanista, que sí apreciaban y conocían su obra de reportaje. Tanto que algunos le acusaron de pictorialista, es decir, de realizar un mero truco óptico, destinado a falsear la realidad.

“Lo premiado de MASATS lo que más le reprocho es no ser sincero; es un truco el hacer un «barrido» a propósito y sin justificación. Queda bonito, pero si me dijeran que es la fotografía de una fracción de un cuadro de Renoir lo creería, porque si a un impresionista se le hubiese ocurrido pintar una corrida, lo hubiera hecho así. Y por ser «modernos» no hay que ser pictóricos de ninguna época. Ni cubistas"14.

13 Campbell, Bryn, "Un color para la naturaleza", en Ernst Haas, Barcelona, Orbis, Colección Los Grandes Fotógrafos, 1990, pág. 6.

14 Anónimo, “De una carta fechada en Barcelona”, en $A F A L, n^{\circ}$ 9, mayo-junio 1957, sin paginar. 
Ramón Masats, “Radiografía del toreo", detalle.

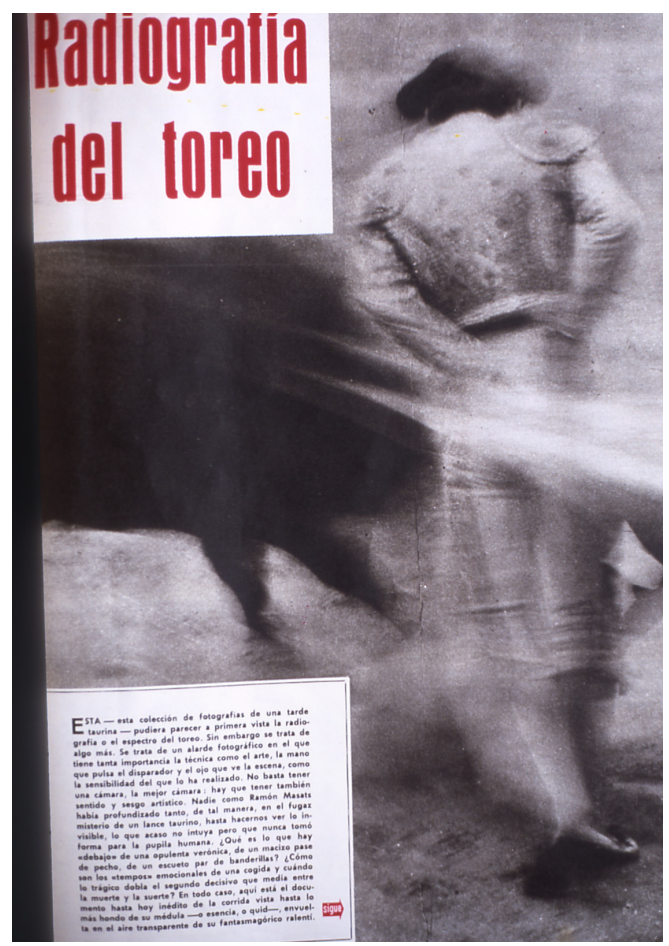

El desconocimiento de sus fotografías más formales por parte de muchos compañeros fotógrafos, unida a la gran calidad de su obra de reportaje, habían situado a Masats, quizá involuntariamente, como uno de los máximos representantes de la fotografía humanista de "marcada tendencia moderna". Por eso esta imagen tan plástica y experimental indignó a algunos críticos que no supieron ver en ella la libertad creativa de nuestro autor:

“La que ganó el Trofeo Luis Navarro, cuyo autor de RAMÓN MASATS, ha producido un huracán de protestas de parte de los amantes de la fotografía que triunfa por esos Salones de España. Sólo ven en ella una fotografía desenfocada y movida" ${ }^{15}$.

No será hasta un par de años más tarde, en 1959, cuando Masats dará a conocer todo su reportaje con cinco imágenes de toros movidas, reportaje que será publicado en Gaceta Ilustrada bajo el título de "Radiografía del toreo"16.

(Koldo Chamorro, Pamplona, 21 de marzo de 2003) -“Ramón, por ejemplo, trabaja con el tema del movimiento. Pero yo no pienso que esté determinado por un concepto meramente plástico sino que está determinado por un concepto fundamentalmente conceptual. Es decir, el tiempo deja tras de sí una huella y la huella es el movimiento. Cuando tú ves esas imágenes (y yo que he conocido bastante a Haas), uno -quizás por cierta comodidad- lo relaciona con Haas. Pero yo no creo que Ramón, en aquel momento tuviera mucha información de lo que estaba haciendo Haas y, por otro lado, yo creo que la reflexión de Ramón está bastante alejada de la de Haas. Haas está más preocupado por los aspectos formales y yo creo que Ramón está más preocupado por... vamos a llamarlo adquisiciones de tipo percep-

15 Bella Costa, José, “Correspondencia con $A F A L^{\prime}$, en $A F A L, n^{\circ}$ 9, mayo-junio, 1957, sin paginar.

16 Masats, Ramón, "Radiografía del toreo", en Gaceta Ilustrada, n 142, 27 de junio de 1959, págs. 23-25. 

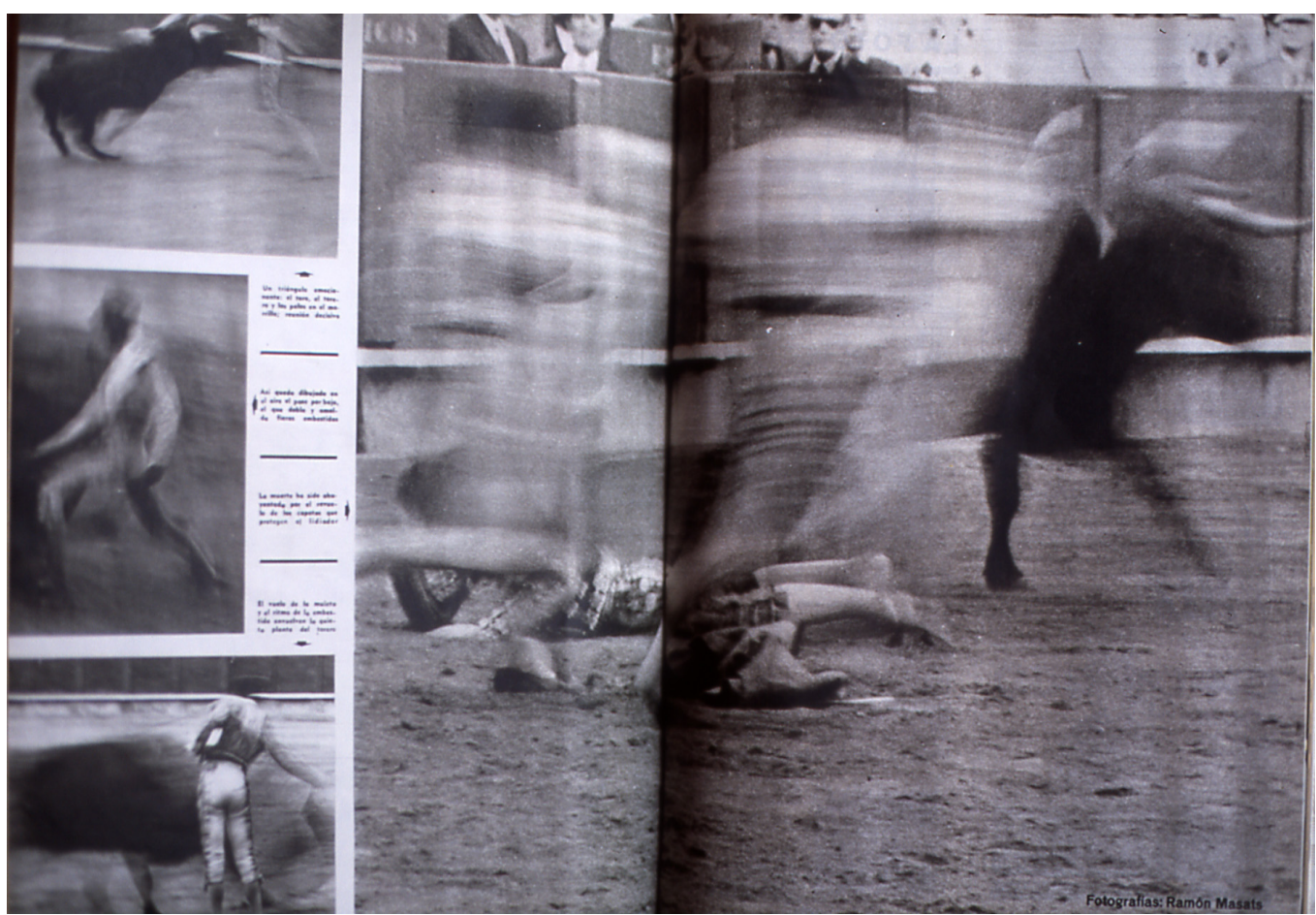

Ramón Masats, "Radiografía del toreo", reportaje publicado en Gaceta Ilustrada n 142, 27 de junio de 1959.

tual y de la experiencia. Es decir, el tiempo. Cómo se valora perceptivamente y cómo uno lo acumula como experiencia. Claro, esto... yo creo que es la parte más importante del trabajo de Ramón".

-¿Tú crees que Ramón tiene alguna concomitancia con Ernst Haas? Sobre todo en su época de color. Le he oído decir que es uno de los fotógrafos en color que más le han interesado. De hecho, estuvo buscando durante bastante tiempo el libro The Creation ${ }^{17}$ de Haas. Yo tengo un ejemplar en casa que había pensado en regalarle... aunque la última vez que estuve en su casa ya lo había encontrado.

(Koldo Chamorro, Pamplona, 21 de marzo de 2003) -“Yo creo que lo más endeble de la obra de Masats es el color, y ello aun teniendo muy buenas imágenes en color. ¿Haas...? Yo creo que no. Haas y Ramón (y los conozco los dos) no tenían entre sí nada, nada que ver. Date cuenta que Haas viene de una familia de músicos. No digo compositores, sino instrumentistas vieneses, en donde toda la parte formal es muy importante... La posición del dedo en el mástil del violín es fundamental... En cambio, Ramón es de otro modo. Siendo Haas un gran personaje, yo creo que es más libre Ramón que Haas. Bastante más libre, más apropiado. Yo veo que las imágenes en color de Ramón que son sólidas están muy, muy, bien".

Masats propone una mirada nada inocente, todo lo contrario: una "mirada construida", cargada de intención, educada, analítica, que se sirve de la simple fotografía como medio de expresión. No es de extrañar que cuando, años más tarde, elabore una lista de sus imprescindibles de la Historia de la Fotografía aparezcan en ella Emmanuel Sougez o Weston, unos maestros que perfeccionaron el arte del saber ver.

(R. Masats, Madrid, 20 de marzo de 2000) -“Esto es de un fotógrafo francés que se llama Em- 
Edward Weston, “Pepper n 30", 1930.

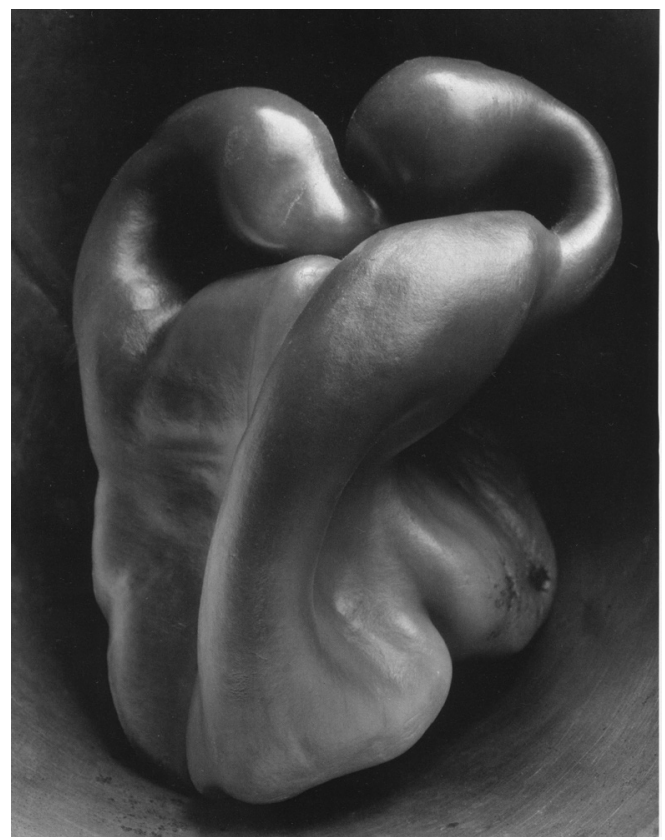

manuel Sougez, que casi está más emparentado con la fotografía americana que vendrá después: Weston, Strand y Ansel Adams. A mí esta foto siempre me ha gustado muchísimo, precisamente por una cosa absolutamente vulgar como es una montón de servilletas. El placer que me produce estéticamente. Es un poco lo que siempre yo he defendido: la belleza que se puede producir con las cosas más ordinarias. Lo único que falta... no tienes ni que montar nada, sólo saber ver la belleza que hay en esto. Y esta es mi opinión sobre la fotografía en gran medida.

En Weston el planteamiento es el mismo. la belleza que hay en las cosas más sencillas. Fijaos en el punto de vista. Cómo ha fotografiado un pimiento, que no es precisamente vulgar. ¡El pimiento en sí ya es de una belleza! Pero cómo ha sabido iluminarlo y cómo ha sabido crear una forma que para mí es fantástica. Y fijaos que yo defiendo que la forma más clara de la fotografía es el reportaje, pero también me gustan muchísimo las formas, tal y como habréis comprobado en algunas de mis fotografías".

Al igual que Weston, en otras ocasiones Masats da una vuelta de tuerca más a sus planteamientos $y$, en el grupo de imágenes de formas más interesante, juega a engañar la mente y el ojo a través de unas representaciones fotográficas que rozan el surrealismo, puesto que buscan no ya la simple belleza, sino la evocación de significados que objetivamente no tienen nada que ver con el sujeto fotografiado, tal y como sucede con la imagen del tronco-sexo de varón de Masats.

“«Muñecos colgantes, feria de Reyes, Barcelona» (1956). Esta fotografía, que estuvo en mi aportación a la primera exposición Terré-Miserachs-Masats, se aparta sobremanera del género que dominaba en los concursos, como la mayoría de las expuestas en la muestra. Es una imagen que provoca asociaciones de ideas, que remite a algo que no está en la foto. Alguna vez he comentado con el pintor Modest Cuixart, que por la misma época realizó una serie de cuadros con muñecos pegados, y con mi colega Oriol Maspons, que también realizó fotos con muñecas o fragmentos de ellas, la curiosa y simultánea atracción que estos objetos ejercían sobre nosotros. Coletazos del surrealismo, probablemente"18. 


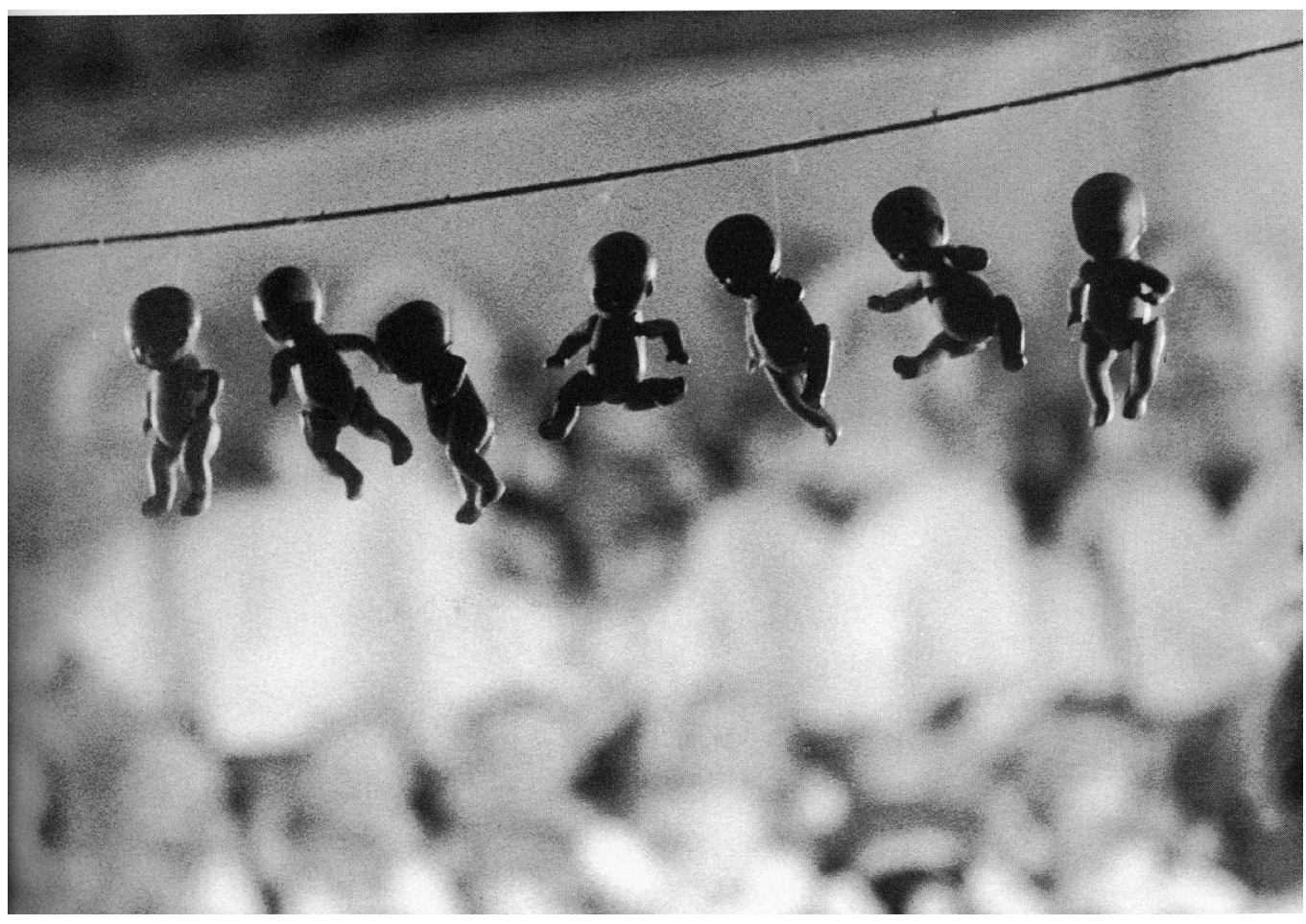

Xavier Miserachs, "Muñecos colgantes, feria de Reyes, Barcelona", 1956.

Desde luego Masats nunca ha pretendido adscribirse al movimiento del surrealismo y tampoco acomete la tarea de explorar el subconsciente, ni los sueños, ni el azar, ni nuestro lado más oscuro. Aunque eso sí, siempre ha defendido su intuición y su instinto como sus principales herramientas de trabajo y, en cualquier caso, tampoco hay que olvidar que estas imágenes son hallazgos visuales, objetos encontrados -filtrados por su ironía y sentido del humor- que admiten interpretaciones ambiguas y que juegan con una evidente pluralidad semántica. En este sentido es cierto que en ocasiones se ha calificado esta imagen del tronco del árbol como "abstracta". Sin embargo, la abstracción utilizada en el contexto del medio fotográfico resulta un concepto ambiguo por dos razones: primero, porque la fotografía analógica está irremisiblemente ligada a la realidad. Como indica el propio Xavier Miserachs a propósito de esta imagen del árbol invertido:

“Completamente de acuerdo contigo en cuanto a los cojones de Masats. No es ninguna fotografía abstracta. La pintura abstracta la acepto, y en algunos casos me gusta. Lo abstracto corresponde a una libertad creativa que no creo que haya alcanzado la fotografía. Lo que sí puede hacer es transmitir impresiones abstractas, detectadas por un fotógrafo muy sensible en lugares no dispuestos al efecto"19.

Y segundo, porque toda imagen fotográfica implica, paradójicamente, una abstracción -tomado el concepto en su sentido más textual- de la realidad: sea por el punto de vista, la

19 Miserachs, correspondencia con Pérez Siquier (01-06-57), en Terré, Laura, El Grupo Fotográfico Afal (1956/1963). Estudio del periodo y aproximación a sus ideas estéticas, tesis presentada en el Departamento de Diseño e Imagen, Facultad de Bellas Artes, Universidad de Barcelona, Barcelona, 1998, pág. 352. 
Ramón Masats, "Sabadell", 1954. Aparecida en la primera exposición colecctiva junto a Terré y Miserachs.

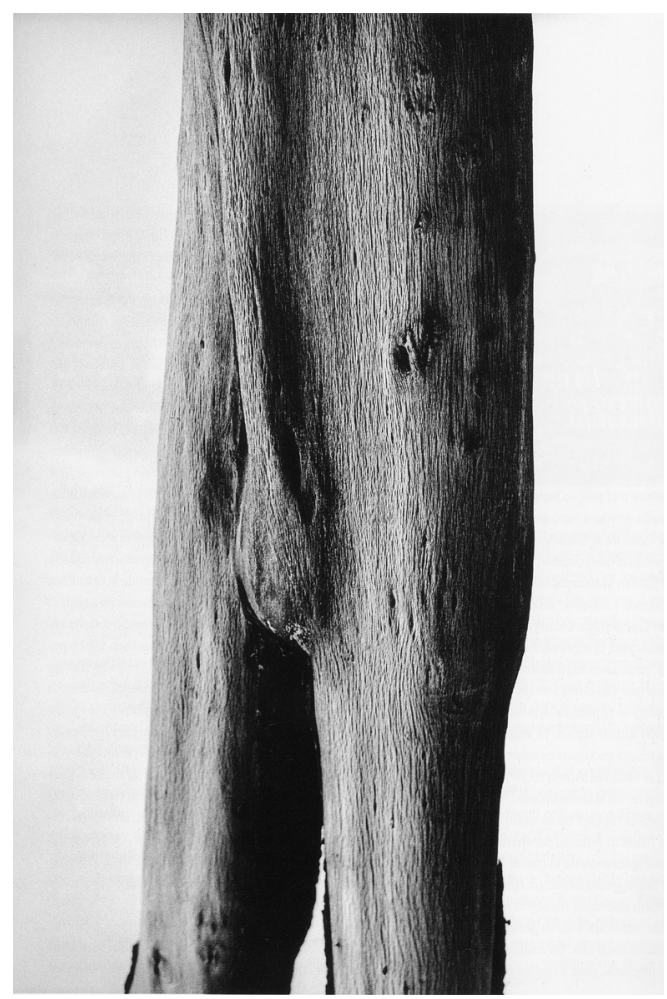

selección del sujeto, la composición, la transformación a un soporte bidimensional, o el cambio de formato, color, tono... Abstracción, sin embargo, que nuestra cultura visual tiende a camuflar u olvidar creando no pocas confusiones.

De cualquier modo, creemos que Masats realmente no pretende "transmitir impresiones abstractas" con esta imagen del árbol invertido. Es más probable que tuviera intención de sorprender e, incluso, escandalizar que de generar "impresiones abstractas". No obstante, sí jugará a simular abstracción, generando juegos de formas y texturas, con otras piezas, como por ejemplo la fotografía del pelaje de una vaca tomada en primer plano y presentada en el concurso de fotografía de animales en el Casino de Comercio de Tarrasa. Aunque tampoco nos cabe ninguna duda de que la finalidad de escandalizar al mundo salonista y de divertirse es similar a la existente en la foto del árbol invertido. En este caso una tradicional, humilde y candorosa vaca es presentada como referente de una imagen abstracta formalmente relacionada con obras artísticas de vanguardia. Una curiosa vanguardia rural que actúa como una buena dosis de provocación al mundo salonista.

“Brotes de hinojo y la pared dibujada. Ilustrando la exposición de París con «Les 30x40». Esta es una de las imágenes más logradas del Masats abstracto/ formalista. La variedad de texturas que crea la luz de los brotes de hinojo no sólo dan profundidad a la imagen, sino que crean una sensación gráfica, de difuminado, como si hubiera sombras y repeticiones que ayudan a fundir el grafismo de la pared, los rasgos gestuales y la reverberación vegetal de las plantas" 20 .

20 Terré, Laura, "Fotografías publicadas en AFAL (por autores)", en Apéndice IV: Vaciado de la revista AFAL, en Terré, Laura, op. cit., pág. 256. 


$$
\text { a }
$$


Ramón Masats, "Brotes de hinojo", publicada en AFAL, $\mathrm{n}^{\circ}$ $22 \mathrm{y} \mathrm{n}^{\circ} 30$, en 1960 y 1961 respectivamente.

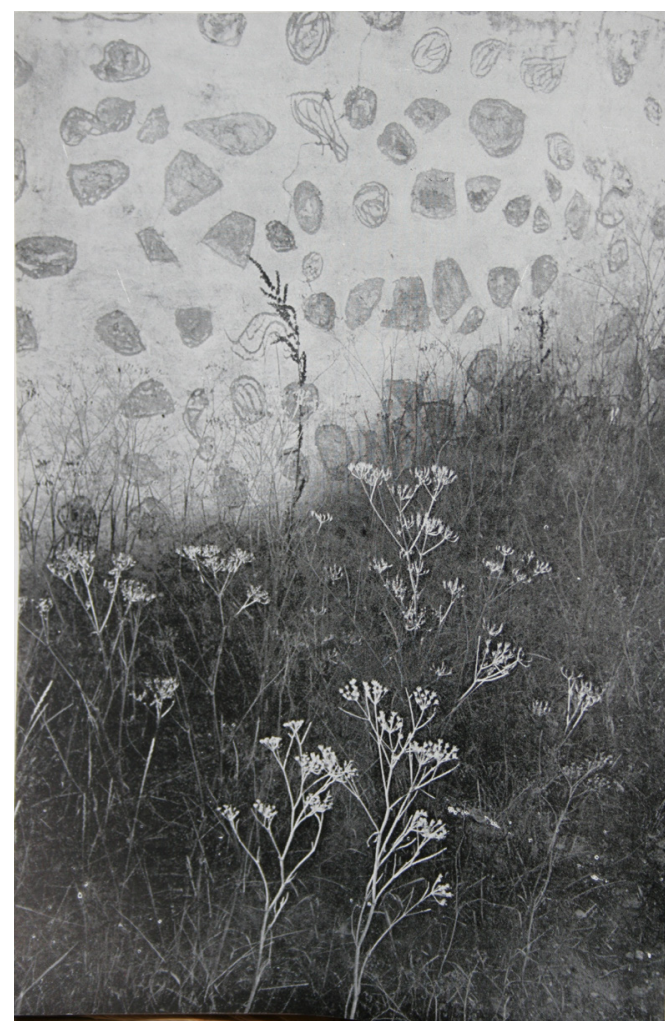

inteligente». $Y$ esto es la base de la mentira y de la vergüenza que esta pasando en una parte muy importante de la fotografía, no sólo en España, sino en todo el mundo".

Masats tiene un gran respeto por ese público con el que juega a descubrir una nueva realidad de una "manera limpia". En este sentido, su humildad y coherencia le obligan a dejar lo más abierto posible los significados de sus imágenes para mantener su riqueza evocadora o connotativa, puesto que Masats es consciente de que cuanto más ambigua, más poderosa es la imagen. Por eso nunca explica o dirige las interpretaciones de sus fotografías con títulos más o menos poéticos o explícitos. Deja pistas, pero éstas siempre son fotográficas, nunca verbales. Con todo, las imágenes de Masats siempre tienen una vocación narrativa: por muy abstractas que resulten, o por muy decorativas que parezcan, siempre se basan en una historia. Ahora bien, mientras que las imágenes de reportaje exponen esa historia de una manera evidente, clara y dirigida; las fotografías de formas, por el contrario, la presentan más sutilmente, aprovechando la sugerencia, la evocación o las posibilidades que como metáfora visual presenta la imagen fotográfica.

“¿Todas las fotos narran una historia?

Creo que sí, pero en las fotos que hago últimamente la gente tiene que sacar la historia, porque yo no la doy. Aunque he hecho fotos que contaban una historia y hacían difícil que el espectador se fuera por otro lado, ahora hago fotos que cada una puede interpretar como quiera. Puede ser más limitado o más amplio"21. 
(R. Masats, Madrid, 15 de diciembre de 2003) -“Normalmente no pongo ningún título. Esto ahora también lo hago".

-¿Por qué?

(R. Masats, Madrid, 15 de diciembre de 2003) - "Yo creo que con esto hay suficiente. Si tienes que explicarlo con un título... Sólo hay, últimamente, una fotografía del Partenón... que sí la titulé diciendo: “¡Geometría coño, geometría!” Que es lo que tiene la piedra aquella y lo que tiene el Partenón. Pero normalmente no lo hago. Pongo el lugar, el año y ya está".

-Entonces dejas la interpretación del público un poco más abierta.

(R. Masats, Madrid, 15 de diciembre de 2003) -“¡Que vean lo que quieran!, ¿No? Y si no hay nada que interpretar es culpa mía. Pero esa culpa mía fotográfica no la voy a corregir dándole un título poético o cualquier chorrada. Esa es mi opinión, vamos".

“La escritura con sus códigos cifrados ordenados adecuadamente produce una información conceptual con una sola significación. Las fotografías pertenecen al mundo mágico de la representación. Son complejos simbólicos que admiten diversas interpretaciones; incluso éstas variarán con el tiempo y con la experiencia en el uso de otras imágenes. Pero es cierto que son universales en la intuición de su entendimiento; todo el mundo cree entenderlas, todo el mundo las usa y está influido consciente o inconscientemente por ellas. Su poder se asienta en la evocación (...) Son liberadoras de experiencias personales (...) y al mismo tiempo, si las imágenes son relevantes, y las de Masats lo son, nos descubren el universo particular de quien las capturó"22.

Posiblemente ésta sea la razón de la legendaria y desesperante parquedad de palabras de Ramón, sobre todo cuando pretendemos analizar o descomponer su trabajo.

\begin{abstract}
“Ramón Masats habla poco, le resulta difícil poner palabras a su universo particular. Comienza las frases por el final y se impacienta ante lo previsible del lenguaje que los humanos empleamos para relacionarnos. Es como si continuamente sintetizara lo esencial de la comunicación, y ésta sucediese siempre un paso más allá de la expresión verbal. Mantener una conversación sobre sus fotografías es como obligarle a hacer un esfuerzo cansino cuando su mente ya ha viajado por ese sendero en ambas direcciones, cuando ya ha librado batallas cuyo botín, la imagen, es la síntesis de todo un discurso"23.
\end{abstract}

Lo que no está en la foto, o no se ve en sí misma provoca una imagen fallida, imagen que no puede intentar arreglarse mediante la palabra. Masats deja al espectador una libertad interpretativa que no aparece únicamente en su obra fotográfica. Una vez más, encontramos que los conceptos que maneja en su faceta como fotógrafo los adapta perfectamente a su obra audiovisual (como veremos en el análisis de su documental Insular) y, en ese sentido, evita dirigir-limitar el significado de sus imágenes con lo que correspondería al pie de foto audiovisual: la voz de un locutor comentarista (voz en off, o voice over, como es denominada por Josetxo Cerdán).

Es muy significativo que cuando Masats realiza una proyección antológica suya, siempre salpica la sesión con divertidos comentarios de sus fotografías de reportaje, pero en cuanto aparecen las fotos calificadas por él mismo como de formas, calla y deja que el público asistente se enfrente a ellas con absoluta libertad. Para ilustrar su actitud ante la teorización de estas imágenes contamos con el testimonio de Jesús García de Dueñas, realizador de Televisión Española y antiguo compañero de Masats. 


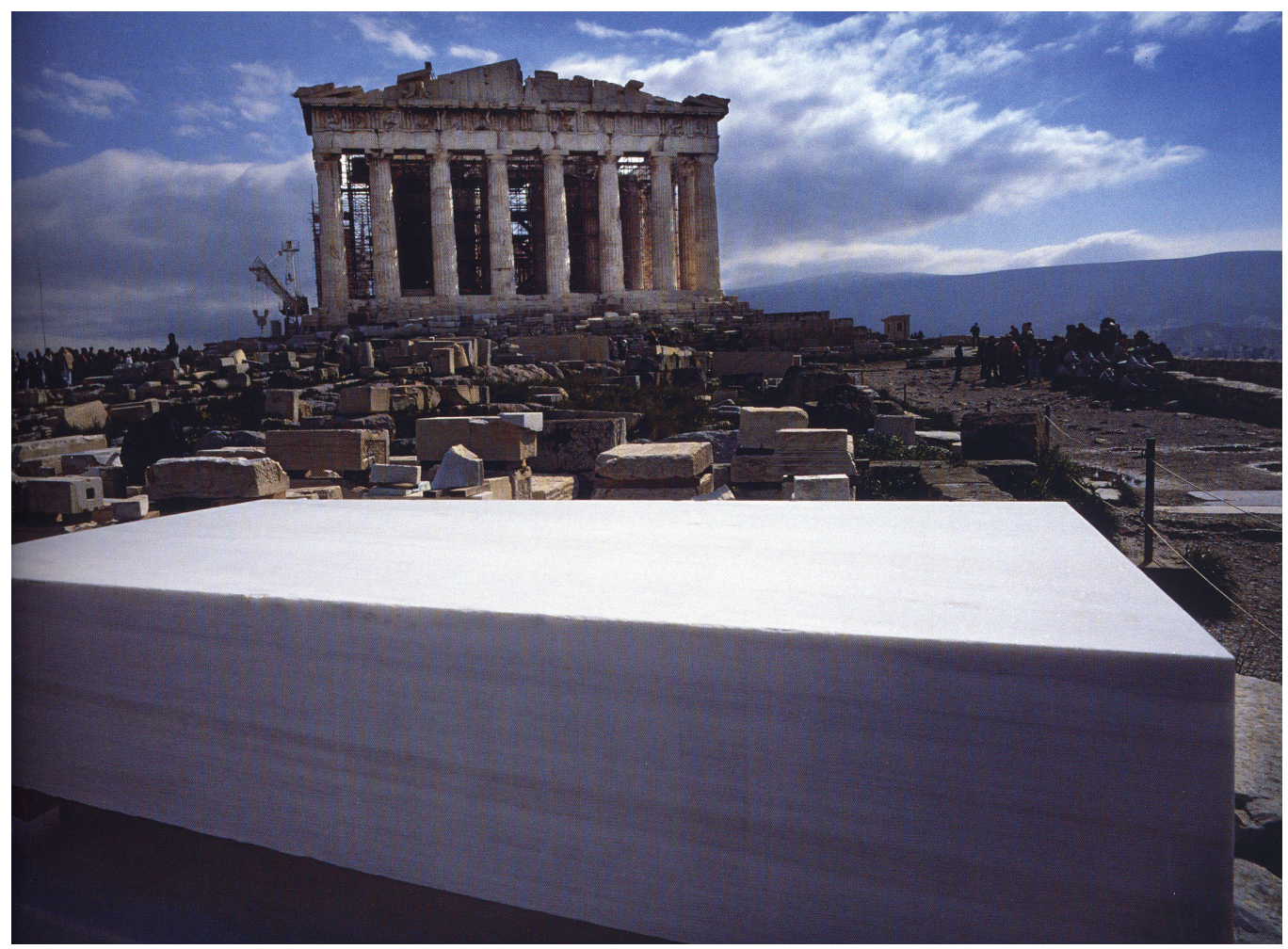

Ramón Masats, “¡Geometría coño, geometría!”, 2003.

(Jesús García de Dueñas, Barcelona, 17 de noviembre de 2000) -“Para situar la perspectiva de Ramón Masats cuando entró en Madrid... o por lo menos cuando yo le vi entrar en Madrid... Yo le vi entrar de una manera aparatosa, como es él. Dentro de esta simplicidad absolutamente tosca y bárbara que tiene su aspecto de personaje abrupto y que da un poquito de miedo. Con esa apariencia tan sólida que los demás no tenemos, ni tendremos nunca y que siempre ha sido envidiable. Entonces él venía de aquel mundo... Les estoy situando a ustedes en una época, en la que, en Madrid... veíamos a Barcelona como un espacio de liberación del que carecíamos en Madrid. Nosotros veníamos a Barcelona porque considerábamos que esto era un espacio de libertad, aunque también padecían ustedes en Barcelona la misma dictadura franquista, pero sin embargo había como una especie de margen que nosotros no teníamos. Entonces él traía, sin saberlo él, sin quererlo y sin pretenderlo (porque él nunca pretende nada, nunca tiene ningún apriorismo, nunca tiene ninguna posición previa, ni teórica en su trabajo... «Voy a hacer esto o voy a hacer lo otro...») ese aire de renovación que nosotros ansiábamos y que necesitábamos. Así es como yo conocí a Ramón y luego no he tenido mucho contacto con él. Nos cruzábamos por los pasillos de televisión... y la verdad es que he pasado treinta años de mi vida sin verle hasta el verano pasado en Santander. Él impartía un curso que daba Ana Müller -la hija de Nicolas Müller- en la Universidad de Santander. Y fui allí porque quería ver a Ramón Masats después de tantos años. Y tuve una experiencia muy singular en el taller de fotografía que impartía que revela muy bien la característica esencial de Ramón como creador. Él hablaba de sus fotografías. Hacía una antología de sus magníficas fotografías a lo largo de los años - delante de una audiencia de jóvenes fotógrafos- y entonces me permití una 
intervención. Quizá llevado por una pedantería obligada de muchos años de ejercer la crítica en muchos sentidos... Y le dije: «Ramón he notado una cosa muy curiosa y es que en todas estas fotografías hay como una especie de pretensión tuya de fotografiar la ausencia. Tú estás retratando instantes que se han producido... pero tú lo que quieres retratar...» Entonces yo mismo me encontré envuelto en esa disquisición absolutamente estúpida y él me cortó rápidamente, me sacó del apuro y me dijo: «iEs un gilipollez lo que estás diciendo! A ver, ¿qué quieren preguntar los demás?».

(R. Masats, Barcelona, 17 de noviembre de 2000) -“¿Ah sí? ¿Eso dije? Te prometo que no me doy cuenta".

(Jesús García de Dueñas, Barcelona, 17 de noviembre de 2000) -“No te das cuenta de esa brusquedad... que forma parte, justamente, del carácter básico de este creador que, como fotógrafo, a mí me parece que ha sido de los mejores que ha habido en España, pero que nunca se ha planteado su trabajo como creador con ninguna clase de apriorismo. Él nunca ha querido hacer las cosas que ha hecho a partir de una concepción intelectual, lo cual no quiere decir que no lo sea aunque le pese. Tiene tal potencia creativa que es capaz de retratar o de interpretar la realidad de acuerdo a una intuición artística absolutamente poderosa, como pocos fotógrafos y cineastas españoles han tenido. Este trabajo hay que hacerlo con absoluta espontaneidad y confiados solamente en lo que nosotros creemos y suponemos que somos, sin pensar en lo que debemos ser. $Y$ eso es lo que tú has hecho a lo largo de tu vida".

(R. Masats, Barcelona, 17 de noviembre de 2000) -“No me acordaba del corte que te di. Lo que pasa es que posiblemente me estabas metiendo en unos tinglados intelectuales que a mí no me convenían. Sobre todo porque me siento perdido y no entiendo nada de lo que dicen, y cuando se ponen así con esas disquisiciones... yo me pierdo. Normalmente la gente me da igual, pero como tenía en frente a gente que venía a aprender fotografía no me interesaba que se viera que soy tonto".

\subsubsection{La Barceloneta y Las Ramblas}

Después de todo lo señalado con respecto a las fotografías de formas, hay que precisar que sí hubo una exposición, un trabajo conjunto, en el que este tipo de imágenes tuvieron una gran importancia. Nos referimos a su exposición sobre Las Ramblas de Barcelona, exposición que realizó junto a Ricard Terré y Xavier Miserachs en los salones de la Agrupación Fotográfica de Cataluña en 1957.

“He aquí, y de izquierda a derecha, a Terré, Miserachs y Masats. Tres fotógrafos a los que une en común la fotografía, mejor dicho, el espíritu con que la practican. Porque la fotografía va del uno al cien, del blanco al negro, y cada fotógrafo escoge el matiz que su capacidad le permite.

Ellos tres emiten en la misma frecuencia de onda. Pretenden adoptar una posición que, aunque no sea siempre dinámica, esté más de acuerdo con el espíritu, no digo de nuestra época, pues es demasiado ambicioso, pero sí al menos del año en que vivimos.

Este solo hecho ya me predispone a hablar de ellos con simpatía. ¿A pesar de ser tus amigos? -añadirá algún irónico-; pues sí, a pesar de eso. Pero al mismo tiempo, su decisión de dar un paso al frente y salirse de esta gran fila en donde dormita la gran afición, les singulariza de tal forma que se hacen merecedores de una crítica más voluntariosa, más constructiva que las jabonosas frases de costumbre. También merecen que no se disparen contra ellos estos cañonazos de polvos de talco perfumado que tanto agradan y que dejan vestido de payaso al más sensato.

Terré, Miserachs y Masats presentan sus obras en una exposición colectiva en nuestra Agrupación Fotográfica de Cataluña. ARTE FOTOGRÁFICO les dedica todas sus páginas ilustradas y a mí me parece muy bien"24. 
-¿Por qué te uniste con Miserachs y Terré y decidisteis hacer una exposición colectiva? No era muy habitual este planteamiento ${ }^{25}$.

(R. Masats, Madrid, 15 de diciembre de 2003) -“Pues igual fue una idea de Oriol Maspons. En aquel momento Oriol estaba absolutamente vivo y era una maravilla de persona. El otro día vi a Terré en una exposición de Barcelona, vino de La Coruña, y estuvimos comiendo con él y con Chema Conesa -que es el comisario de la exposición del Canal de Isabel II que llevé a Pontevedra-, y entonces él me dijo: «¿Tú no te acuerdas cómo nos conocimos?»; «Pues no, no me acuerdo»; -él tiene una memoria fabulosa-; «Pues mira, estaba viendo una exposición en la Agrupación Fotografía de Cataluña y estabais Javier Miserachs y tú comentando unas fotografías, y yo, discretamente, desde un poquito detrás, de modo que no me veíais, iba escuchando lo que decíais y estaba tan de acuerdo con vosotros que me presenté y a partir de este momento formamos un grupo de amigos». Entonces surgió lo de las exposiciones".

La primera exposición de Terré, Miserachs y Masats se inauguró en abril de 1957 en la Agrupación Fotográfica de Cataluña. Poco después, el 7 de mayo del mismo año, se trasladó a los salones de la Real Sociedad Fotográfica de Madrid y, finalmente, el 18 de junio se volvió a exhibir en la sede de AFAL en Almería.

“Pregunto a los tres el porqué de esta exhibición.

Responde Terré que su sentido fotográfico, por afinidad, quedará mejor precisado en esta exposición con sus dos amigos.

Miserachs, más ambicioso, pretende introducir una fotografía que en lugar de ser bonita, sea interesante e inteligente. No creo necesario precisar que una imagen que reúna estas dos cualidades: interés e inteligencia, obtendrá la belleza por añadidura.

Masats, que por lo visto no pretende ser jaleado por las masas, cree que la calidad media de los salones que ha visto es muy baja, y ni su manera de ser ni sus fotografías se adaptan a ellos"26.

- ¿Y por qué escogiste Las Ramblas?

(R. Masats, Madrid, 15 de diciembre de 2003) -“Porque es un tópico y yo creo que entonces ya me gustaban los tópicos".

-Pero anteriormente habías hecho el puerto de Barcelona también...

(R. Masats, Madrid, 15 de diciembre de 2003) -“No exactamente. Lo del puerto de Barcelona eran fotos sueltas que hacía los domingos por las mañanas. Nos reuníamos en un bar, nos hacíamos un desayuno espectacular y luego nos íbamos a hacer las fotos. Tengo muchas fotos de la Barceloneta, que es más o menos el puerto, y del puerto. Pero esto era ir por alli y salir a ver qué... No era un planteamiento de una localización. Sin embargo, las fotos de Las Ramblas eran para una exposición, eran un planteamiento para una exposición y eran el tema de la exposición".

-Es decir que antes de hacer el reportaje de Las Ramblas ya os planteasteis que sería una exposición.

(R. Masats, Madrid, 15 de diciembre de 2003) -“Sí. Estuve... no sé cuantos fines de semana... Aunque me da la sensación de que no le dediqué más de tres o cuatro fines a Las Ramblas. Lo que sí me acuerdo es que estaba trabajando en Tarrasa en la pesca salada y entonces lo debí de hacer los fines de semana, claro. Los temas los tomo con intensidad pero llega un momento en que se me agotan. Entonces ya no me interesa el tema. Es decir, tendría que buscar y rebuscar... y

25 De hecho, luego fue copiado por otros tríos de fotógrafos como Cubaró, Galí y Ontañón que también expusieron colectivamente en la Agrupación Fotográfica de Cataluña en 1958, y Albero, Boada y Bros que lo hicieron por su parte en la Real Sociedad Fotográfica de Madrid en 1960. Asimismo Oriol Maspons y Julio Ubiña formaron un tándem de larga y fructífera carrera profesional que se inició en marzo de 1958 en la Sala Aixelà.

26 Maspons, Oriol, ibidem. 
no es mi estilo. El mío es más bien meterme, imbuirme en la cuestión, hacer fotos rápido y luego dejarlo. No soy un corredor de fondo sino que en esto soy un esprínter".

-Oriol Maspons decía que tu trabajo lo habías hecho en ocho meses.

(R. Masats, Madrid, 15 de diciembre de 2003) -“Ya, pero no se refiere sólo a Las Ramblas. También hice otras cosas. Las Ramblas no las hice en ocho meses, ni mucho menos. Yo estoy convencido de que no las hice en más de tres o cuatro fines de semana".

“En la fotografía objetiva de reportaje el que destaca más de los tres es Ramón Masats Tartera, de 26 años y desde hace 18 meses fotógrafo amateur, cosa que no hubiera sido nunca a no ser que fue agraciado en una tómbola con una cámara fotográfica, con la cual ha podido captar un reportaje admirable de Las Ramblas, vistas a través de sus tipos, de sus detalles reveladores, de sus «badocs»"27.

(R. Masats, Madrid, 15 de diciembre de 2003) - “Esta foto ahora la positivo en horizontal”. -Es decir, que están recortadas.

(R. Masats, Madrid, 15 de diciembre de 2003) -“Claro, es seis por seis. Todas las fotos de Las Ramblas son de seis por seis. Están hechas con una Rolleiflex".

- ¿Es la famosa cámara que le sisaste a tu padre?

(R. Masats, Madrid, 15 de diciembre de 2003) -“No, la primera cámara fue una Kodak instamatic II o algo por el estilo...".

-¿Y qué son "els badocs".

(R. Masats, Madrid, 15 de diciembre de 2003) -“Son los mirones, pero con la boca abierta. El «badoc» es un poco un tonto que mira. Esos que miran embobados".

-Hay tres partes en la exposición: "Els badocs", Las Ramblas propiamente dichas y una última que sería una foto de un picador o un banderillero gordo.

(R. Masats, Madrid, 15 de diciembre de 2003) - “¿Sí? Qué raro. Si no tiene nada que ver con la Rambla ni con el árbol invertido... Lo siento mucho por ti. (Risas)".

“Aportación de Ramón Masats a la TMM

Presenta 28 fotografías, en tres series:

«Els badocs»:

En un kiosco de libros, tapado por un toldo, tres hombres hojean el periódico.

Primer plano del cogote de un anciano con boina y ¿sotana? ¿gabardina ancha?

Un hombre que lleva a una niña a caballito está parado, mirando algo.

Primer plano de grupo de señoras que mira ¿escaparate?

«La Rambla»:

Escaparate de una cuchillería.

Dos ancianos pasean del brazo, la vieja mira hacia un escaparate.

Viejo que pasea con las manos unidas en el pecho.

Perro que duerme junto a unas jaulas de pájaros.

Vieja de espaldas con bastón en el suelo.

Grupo de cinco personas que esperan el tranvía

Árbol ¿al revés? que recuerda un tronco de varón desnudo.

Una vieja que parece coja, va del brazo de un viejo, están de espaldas y esperan a cruzar la calle.

Boca de incendios.

Una árbol con un orificio por el que parece que sale sangre.

27 Anónimo, “Lo que dice el Boletín de Mayo de la A.F.C.: Muestra de Terré, Miserachs, Masats", en AFAL, n0 8, MarzoAbril 1957, sin paginar. 


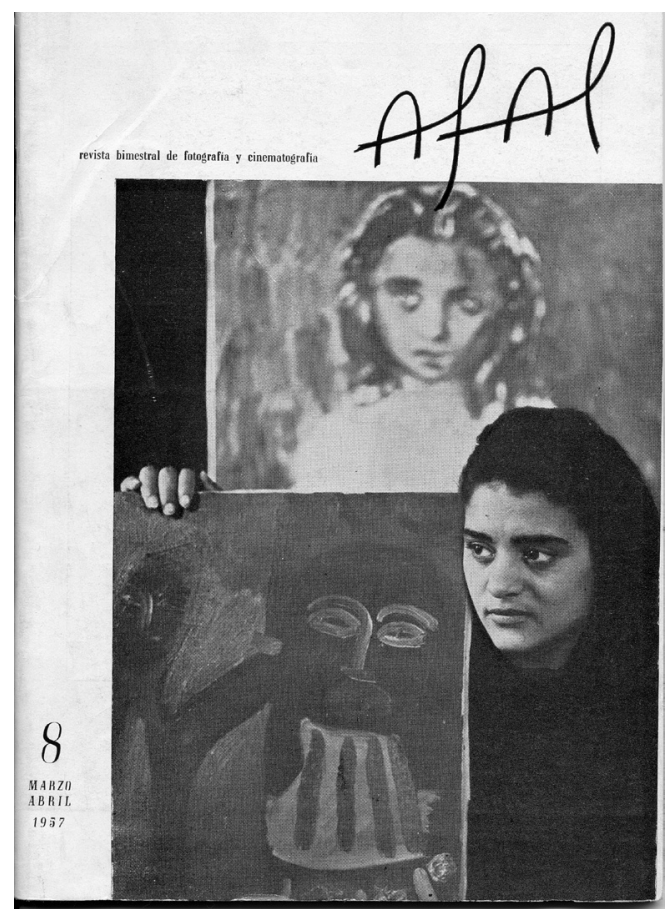

Terré, "Retrato", portada de la revista AFAL dedicada a la exposición.

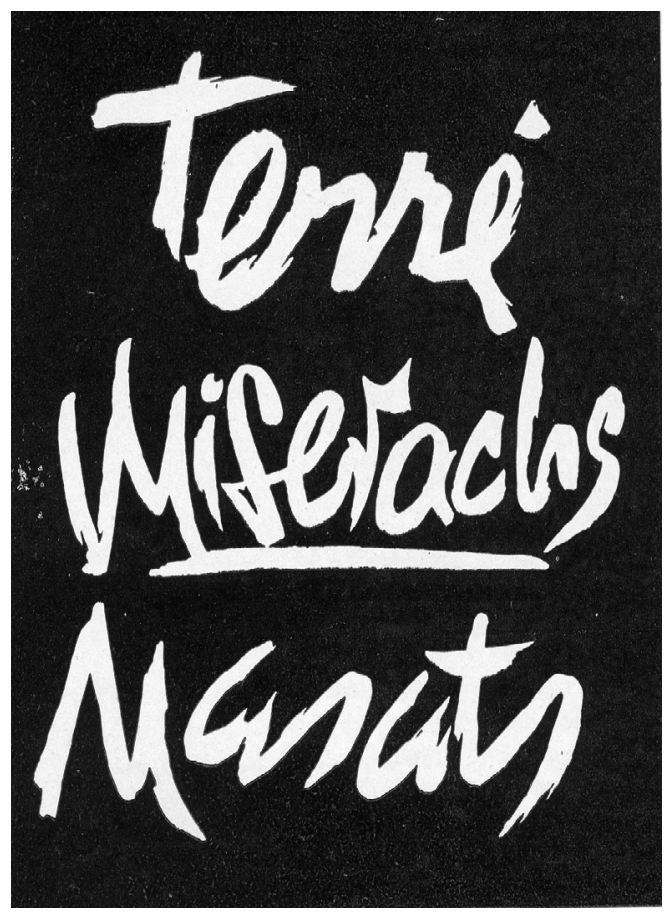

Invitación de la exposición.

Castañera.

Un guardia de tráfico se ve a lo lejos. Toda la composición de la foto, a la izquierda, la llena un primer plano de árbol desenfocado.

Hombre satisfecho que mira pasar a la gente.

Un viejo mira bajo un cartel que anuncia algo con el eslogan «El Manolito».

Equipo de fotomatón callejero sin fotógrafo.

Vieja que vende algo, bajo uno de los leones de Colón.

Vieja que mira de reojo, tiene detrás un aparato de fotografía al minuto.

Vieja que pasa por un ángulo iluminado de la iglesia de Belén.

Limpiabotas anciano.

Hombre oculto por la corona de flores que transporta a su espalda.

Un árbol plátano de la Rambla se ve en primer plano. Parece que sangra.

Hombre que vende lotería, apartado de su silla y su bastón.

Un marinero que lee la prensa subido en una bicicleta.

«Toros» (en realidad una foto suelta):

Picador gordo visto de espaldas"28.

- ¿Tú conocías el libro de Català-Roca sobre Las Ramblas ${ }^{29}$ ?

(R. Masats, Madrid, 15 de diciembre de 2003) -“No".

28 Terré, Laura, op. cit., pág. 335.

29 Català-Roca, Francesc y Romero, Luis, Barcelona, Barcelona, Barna, 1954. 
- ¿Te documentaste de alguna manera, o era simplemente llegar allí y hacer las fotos? Es decir, cuando uno se plantea un reportaje lee un poco sobre el tema...

(R. Masats, Madrid, 15 de diciembre de 2003) -“No, nada. Yo, lo que pasa, es que vivía en Tarrasa en aquellos momentos y para mí Las Ramblas eran Las Ramblas. No necesitaba más información que la que me daban visualmente Las Ramblas. No me documenté. No me interesaba la historia de Las Ramblas, ni su pasado. Lo que me daba Las Ramblas -que era los animales, la parte de debajo de los libros...- todo esto me lo conocía, no en profundidad, pero lo conocía. No necesitaba saber su historia. Era la vida, la gente que había en Las Ramblas lo que me interesaba".

- ¿Y la hiciste quedando con los amigos los fines de semana?

(R. Masats, Madrid, 15 de diciembre de 2003) -“No, Las Ramblas las trabajé sólo. No había ni desayuno compartido con los amigos ni nada".

-¿Cómo te planteaste el reportaje?

(R. Masats, Madrid, 15 de diciembre de 2003) -“Sí, yo iba paseando de abajo arriba y lo que encontraba era lo que fotografiaba".

-Es decir que en ningún momento te planteabas: primero arquitectura, después personas...

(R. Masats, Madrid, 15 de diciembre de 2003) -“No, en aquel momento no tenía ningún planteamiento previo".

- ¿Y cuando paraste?

(R. Masats, Madrid, 15 de diciembre de 2003) -“Cuando ya el tema... (eso es una cosa que me ha seguido pasando en mi vida profesional). Llega un momento en que el tema ya no me da más de sí y tendría que buscar, hacer un esfuerzo y ya no sería la intuición, sería otro planteamiento el que tendría que usar... Y en este momento ya paro".

$-¿ Y$ por qué a la hora de exponer te circunscribiste a un tema concreto y no hiciste una especie de antológica aunque fuera de sólo dos años?

(R. Masats, Madrid, 15 de diciembre de 2003) -“A lo mejor porque me gustaba el ser temático... no lo sé. También podía haber hecho la Barceloneta y el puerto, que ya lo tenía medio acabado...".

-Considero que, como en aquella época ya querías ser profesional, era una manera de demostrar lo que podías hacer con un reportaje completo.

(R. Masats, Madrid, 15 de diciembre de 2003) -“Posiblemente. Sí, puede ser perfectamente por una cuestión mercantilista".

“Masats presenta un buen reportaje de nuestras Ramblas. Se trata de un trabajo inteligente, con cuatro o cinco aciertos fundamentales, que hacen confiar en Masats como un futuro excelente reportero.

El mérito más considerable de su trabajo consiste seguramente en esto mismo: que se trata de un trabajo; se trata del resultado de la lucha del autor frente a un tema determinado y forzado. Aquí es donde se forja el verdadero obrero de la cámara"30.

-Fue tu primer reportaje como amateur, sin ninguna presión por ninguna editorial, pero te lo planteaste como que podía ser un ensayo de lo que podía ser un encargo editorial.

(R. Masats, Madrid, 15 de diciembre de 2003) -“Si”.

“Su cámara es ya profesional. Tiene la malicia del hombre que utiliza la máquina en vez de la pluma para decir cosas a los demás. De los tres expositores de la A.F.C. es el único que quiere pasarse al profesionalismo. Si ello ocurre, no tendremos que felicitar a Masats, sino a la prensa gráfica del país por el hallazgo de esa nueva y valiosa aportación caída prácticamente del cielo" ${ }^{131}$. 
Desde luego, es impresionante leer el texto de Maspons -escrito hace casi cincuenta años- y comprobar como acertó en el augurio sobre el futuro profesional de Ramón Masats.

“En Masats hay madera, parece que la haya, para ser un buen reportero ilustrador. Hace poco, y por Radio Nacional de España en Barcelona, el reportero informador Sáez-Guerrero dijo que la gente estaba ya cansada de ver en los periódicos fotografías de las autoridades a la salida de una iglesia. ¿Por qué no vemos otra cosa? Una de las razones es que los periódicos no acostumbran a publicar más, y otras es que los fotógrafos no hacemos mucho que valga la pena ser publicado, para publicar lo que en reportaje merezca ser visto.

Masats tiene veinticinco años. La fotografía le apasiona. Sólo hay que desear que esta pasión sea más extensa que intensa.

Su vida profesional se desarrolla en el mercado de Tarrasa, en donde vende pesca salada en el negocio de su familia.

Entre el ajetreo de su oficio, Ramón Masats sueña Leica en ristre en viajes y fotografía"32.

-Centrándonos en las fotografías de su exposición no hay ninguna foto que permita una contextualización. No hay ninguna foto que diga que esto son Las Ramblas. Aunque todas las fotos están hechas allí, no hay ningún plano general, ninguna foto que nos sitúe. Tampoco hay prácticamente referencias monumentales...

(R. Masats, Madrid, 15 de diciembre de 2003) -“Es verdad”.

-Digamos que, aunque hay un gran número de imágenes de reportaje, que fueron muy alabadas por la crítica de la época, el conjunto no tiene realmente ninguna voluntad documentalista, a pesar de alguno de los comentarios publicados:

\footnotetext{
“Masats, con tener parecidas reacciones que sus compañeros, parece inclinado más que ellos a la fotografía de reportaje. Su afición es la vida, en lo que tiene de postura anónima o al menos de motivo interesante, que sorprenda. Ve lo que muchos no saben ver en una escena cotidiana. Capta el momento psicológico, la curiosidad simpática, el gesto y el ademán expresivos. La imagen de una parada de autobuses con cinco figuras a cual más elocuente -por no poner otro ejemplo que no sería mejor ni peor- explica lo bastante el acierto de su cámara, donde puede verse armonía, equilibrio, ritmo y gracia"33.
}

(R. Masats, Madrid, 15 de diciembre de 2003) -“A pesar de que esta foto de la mujer que está en esta esquina, está hecha en una iglesia muy importante".

-La de Belén.

(R. Masats, Madrid, 15 de diciembre de 2003) -“Creo que tengo alguna foto, que no sé si expuse, del Liceo... Pero es curioso que no haya ninguna del Mercado de la Boquería, lo cual me hace pensar que las fotos las hacía seguramente en domingo. Tienes tú razón, no hay ninguna foto que sitúe. Si fuera un libro, habría que ampliarlo situando de otra manera. Pero no era mi intención en absoluto. Era más bien... «En este tema obligado, a ver qué es lo que me sale». Eso de que era un ensayo para un posible profesionalismo... a lo mejor sí. Pero era fallido: porque faltaban vistas generales, faltaba una situación y faltaba una serie de cosas imprescindibles...".

-Un japonés no tendría ninguna referencia para situar el lugar...

(R. Masats, Madrid, 15 de diciembre de 2003) -“Absolutamente de acuerdo".

-Hay una crítica de Xavier Miserachs sobre la primera exposición de Las Ramblas que dice

32 Maspons, Oriol, “Cómo hacen sus fotografías Terré, Miserachs, Masats”, op. cit., pág. 336.

33 Díaz, José Andrés, "Lo que dice un crítico de arte de AFAL: Un camino para la fotografía", en AFAL, n 8, Marzo-Abril 1957, sin paginar. 


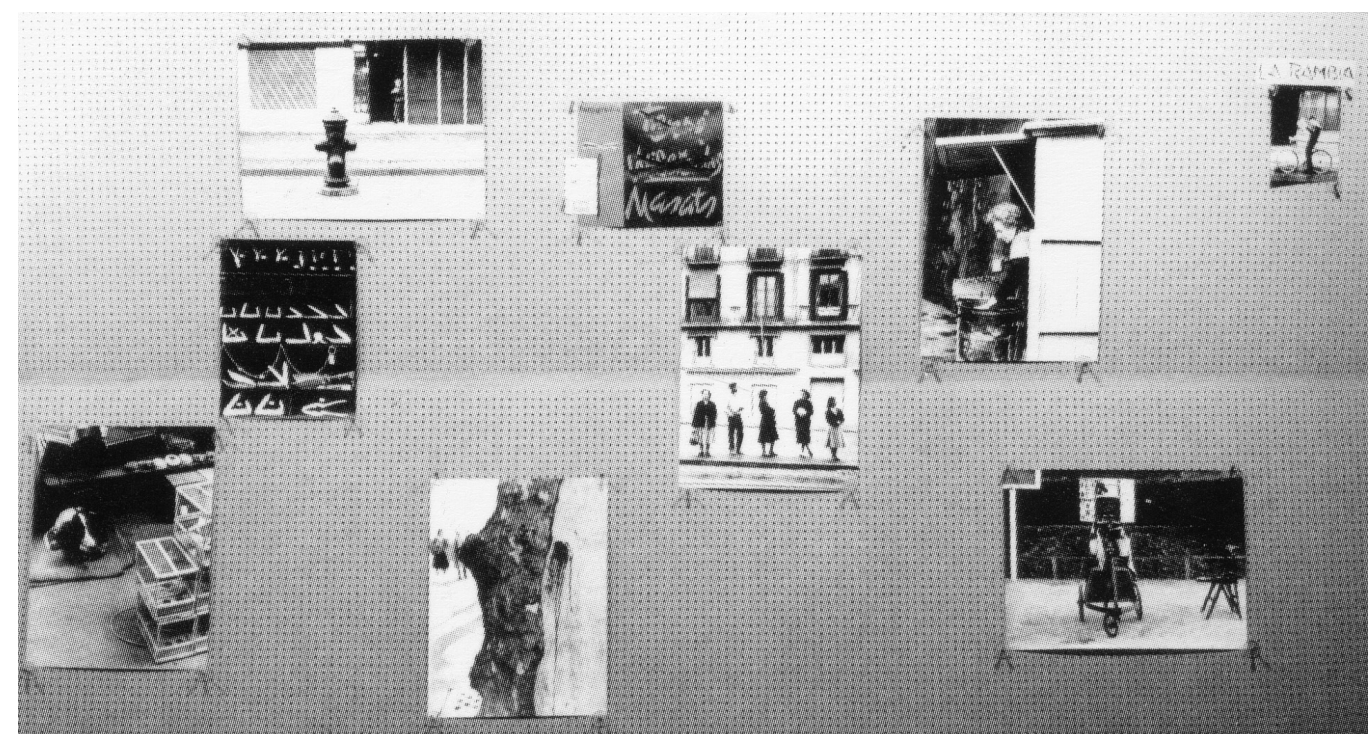

Fotografía de Ricard Terré de parte del material expuesto por Masats. Facilitado por Laura Terré.

que no guías de la mano al espectador, que sólo das pinceladas, dice que es como si describieras a un animal, diciendo que tiene rabo y los dientes grandes, pero que no dijeras qué especie es... aplicado a Las Ramblas.

“Un reportaje tiene que ser ordenado, y hay que llevar de al espectador de la mano para comprender el tema. En el reportaje de Masats falta precisamente esto: un par de fotos fundamentales que definan Las Ramblas en género y especie. Masats nos define Las Ramblas como lo haría de un animal. Decirnos que tiene la cola larga, los dientes gruesos, las alas cortas, pero callando qué clase de animal es (...) En Masats no veis la bomba que vemos los de aquí, porque sólo conocéis de él Las Ramblas. Fue una tontería suya, que ya le advertí, presentar solamente un reportaje en vez de una selección global de su obra. Entonces hubiera sido la bomba, porque tiene mucho y muy bueno. Hace mucho que no lo veo. Desde la exposición. Es lástima que no le conozcáis, porque es muy simpático, aunque tozudo y algo bruto"34.

- ¿Es posible que todavía no tuvieras muy claro cómo plantear la unidad de un reportaje? ¿0, acaso, era que tampoco tuvieras la intención describir Las Ramblas, dado lo conocidas que eran?

(R. Masats, Madrid, 4 de septiembre de 2002) -“Sí, yo creo que fue esto último. Posiblemente tengas razón, posiblemente fuera más a por la foto que no a por el conjunto de Las Ramblas...".

A pesar de este comentario, el boletín de la Agrupación Fotográfica de Cataluña argumenta todo lo contrario, y le llama la atención precisamente la unidad orgánica del conjunto:

“No todas sus fotografías aciertan en la captación de un instante preciso. Otras sí, y magníficamente. Algunas de ellas necesitan estar juntas para hallarles la miga; pero esto no es un tanto en contra, sino una confirmación del sentido orgánico del conjunto" ${ }^{35}$.

34 Miserachs, correspondencia con Pérez Siquier (01-06-57), en Terré, Laura, op. cit., pág. 352.

35 Anónimo, "Lo que dice el Boletín de Mayo ..." Muestra de Terré, Miserachs, Masats", op. cit., sin paginar. 
-No fue una descripción de Las Ramblas.

(R. Masats, Madrid, 4 de septiembre de 2002) -“Posiblemente tengas razón. En aquella época fui a hacer fotos individuales. También tengo muchas fotos del puerto de Barcelona que ahora están saliendo... y en ningún momento quería describir el puerto de Barcelona, sino hacer plástica... Supongo que este planteamiento cambió al pasar a profesional, y que se ha afianzado mucho más después de pasar por el cine y el documental".

-El tema, en realidad, no tenía ningún interés puesto que Las Ramblas estaban muy fotografiadas, pero lo que realmente cobra interés es el tipo diferente de mirada que propicias.

“Un reportaje sobre Las Ramblas de Barcelona y sus personajes no había sido hecho nunca con el estilo de Masats, y quizá sólo una persona que como él, que llega de improviso a la fotografía, podía ver lo que ha visto con ojos nuevos" ${ }^{\prime \prime}$.

(R. Masats, Madrid, 15 de diciembre de 2003) -“Claro. Es que una de las cosas que me gustan de los tópicos es, precisamente, la dificultad añadida que hay sobre una cosa que está muy manida, intentar hacer una cosa distinta... Esto es un reto añadido a la fotografía".

“Si ayer glosábamos la extraordinaria labor producida en el campo fotográfico por Català-Roca, Jacque Leonard o Leopoldo Pomés, hoy queremos señalar el acertado camino, la peculiar manera de «saber ver» de estos tres nuevos valores que se llaman Terré, Miserachs y Masats. Un aspecto inédito de Barcelona, un sorprendente hallazgo de valores plásticos, han sabido captar con vigoroso acento estos tres artistas en esta valerosa imposición de la sensibilidad humana sobre la máquina"37.

-Parece que hay en esta serie una poética interna en donde los ramos de flores caminan solos, donde los árboles sangran o se transforman en sexo de varón... Hay algo de tipismo: aparece la castañera, el limpiabotas, el marinero... pero realmente el conjunto es muy abstracto, vinculado a lo que tú denominas fotografía de formas.

(R. Masats, Madrid, 15 de diciembre de 2003) -"Eso es cierto. Estaba dentro de nosotros".

En realidad hay unas diez o doce fotografías que podríamos considerar de formas, ya que el resto pertenece a imágenes de reportaje. Este porcentaje es tan elevado (cerca del 50\%) que no se pueden considerar como simples imágenes auxiliares. La exposición recoge un momento en que Masats debe plantearse muchas cosas. ¿Se hará profesional? ¿Se decidirá a seguir investigando las posibilidades de la fotografía de formal como ha estado realizando en su trabajo sobre la Barceloneta, o finalmente se decantará por el reportaje? Ésta es la principal característica de las imágenes de esta primera exposición y por ello la hemos situado dentro del presente capítulo. De hecho cuando posteriormente se han reeditado imágenes de esta muestra siempre se han recurrido a las imágenes plásticas como las más representativas. Finalmente, como ya hemos señalado, Masats encontrará un camino intermedio, de ahí que siempre incluya imágenes de formas en sus trabajos, aunque nunca en número o en porcentajes muy elevados (por lo menos hasta llegar a su época en color).

-Es posible que después hayas hecho cosas un poco más descriptivas, pero la obra del principio resulta más plástica. Por ejemplo, en Neutral Corner recoges muy bien el ambiente, al igual que en Los Sanfermines. Pero este primer tema que abordas tiene una intención menos realista.

(R. Masats, Madrid, 15 de diciembre de 2003) -“Sí, posiblemente. Yo estoy diciendo que ahora las fotos que hago en color se parecen muchísimo a lo que empecé haciendo. Es como la pescadilla 
que se muerde la cola. Y claro, mucha gente -como no conocen lo que hacía al principio- no entienden que yo me haya cansado del reportaje. El reportaje ya no me interesa... Como económicamente no necesito hacer lo que no me interesa, estoy como si fuera otra vez aficionado".

No podemos, por ello, coincidir con la lectura que hace Horacio Fernández sobre las imágenes de esta exposición:

“Otras fotografías eran casi abstracciones o, como decía Masats, fotografías no figurativas, compuestas a partir de las sombras de un árbol sobre una pared, manchas y texturas en la corteza de un árbol o la diagonal que dividía la luz y la sombra en el muro de una iglesia. Pero no eran completamente abstractas, ya que las formas eran el marco de pequeñas figuras - un guardia de tráfico, una mujer de negro, unos paseantes- que daban vida a las imágenes. Los ejercicios de composición y análisis de luces que tanto había destacado Maspons no eran sólo acrobacias formalistas: estaban al servicio de la imagen, no eran la imagen. «La fotografía - decía Masats- debe ser humanidad, documento humano, verismo y no falseamiento. (...) El reportaje es pues hijo de nuestra época. Se debe realizar con hondo sentido humano y sin mixtificaciones de índole técnica o de encuadre»" ${ }^{\prime 3}$.

El hombre le sirve a Masats como metáfora de sus abstracciones, donde más que presentarlo lo representa. De ahí que pensemos que el error de Horacio Fernández consiste en no entender la dualidad o la contradicción que existe en la obra de Masats, es decir, en no comprender el binomio que establece el propio Masats entre la fotografía de reportaje humanista y la fotografía de carácter no figurativo.

"Masats hace fotografía no figurativa para ejercitarse en el estudio de volúmenes, luces y principios de composición, que luego aplica al verdadero fin de su afición fotográfica, que es el reportaje. Todas estas consideraciones ha sido él el que me las ha dictado. Yo creo que si la fotografía de intento abstracto sólo ha de servirle de estudio, pierde demasiado tiempo ampliándola a 30x40, aunque he de convenir, que la fotografía no figurativa le sale bien a Masats. $Y$ esto es lo que me asombra: que lo que los otros han hecho después de toda una vida, Masats lo ha hecho mejor en el transcurso de ocho meses, y aun con la mano izquierda, ya que guarda su derecha para el reportaje" ${ }^{\prime \prime 2}$.

-Yo no sé si la declaración que le hiciste a Oriol Maspons -y que él publicó en Arte Fotográficoen donde hablaba de tu "entrenamiento" en la geometría para después hacer reportaje... Realmente, no sé cual de los dos habla en serio o no. Me parece que hay un poco de broma contra los salonistas... Me recuerda a la anécdota de la foto de las manchas de la vaca. Tú le contestaste con ironía a la pregunta de Oriol en la entrevista y él te contesta en el artículo con más ironía y al final no sabes si estas hablando en serio o en broma. Da la sensación de que estés haciendo un guiño al espectador avezado y le estés posicionando contra la Agrupación Fotográfica de Cataluña diciendo...

(R. Masats, Madrid, 15 de diciembre de 2003) - "Yo creo que eso es un poco rebuscado".

-Pero entonces... esas fotos de los árboles sangrando o el sexo invertido... No tienen nada que ver con el conjunto de Las Ramblas, la castañera o el limpiabotas.

(R. Masats, Madrid, 15 de diciembre de 2003) -“Es que yo, si hago un reportaje de Las Ramblas... todo lo que veo en Las Ramblas me vale. Sea un árbol sangrante o sea la castañera. Me vale todo. La castañera es más reportaje y lo otro es más forma. Pero está dentro de mí. Y siempre en los libros, en mis catálogos, siempre ha habido muchas cosas de formas, y mucho más cuando

38 Fernández, Horacio, Variaciones en España. Fotografía y arte 1900-1980, Madrid, La Fábrica, Fundación MARC0, CAAM, 2004, págs. 124 y 126.

39 Maspons, Oriol, “Cómo hacen sus fotografías Terré, Miserachs, Masats”, op. cit., pág. 336. 


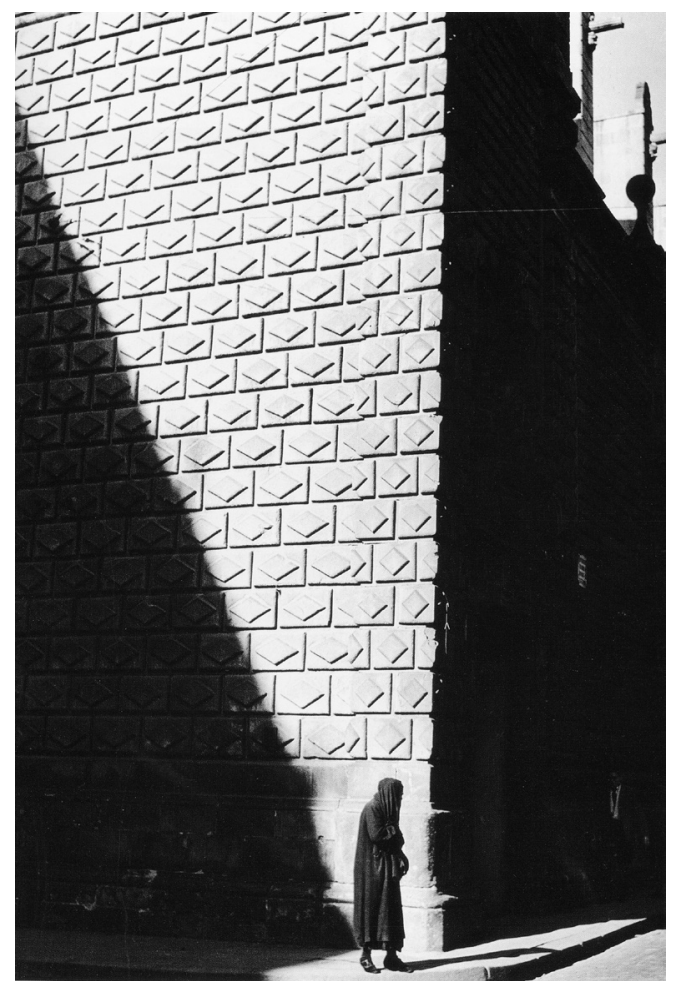

Ramón Masats, "Iglesia de Belén", La Rambla, Barcelona, 1956.

ya he pasado al color. Pero siempre en todos mis trabajos ha habido cosas de formas, incluso en los libros más comerciales siempre encontrarás fotos de esta índole".

- 0 sea que en realidad no tiene ninguna lectura aparte de la mera forma. 0 sea que un árbol sangrante en Las Ramblas no es una crítica a...

(R. Masats, Madrid, 15 de diciembre de 2003) -“A nada. Es pura estética".

-Pura plástica. Un descubrimiento visual.

(R. Masats, Madrid, 15 de diciembre de 2003) -“Exactamente. Y no hay nada más, ni represión, ni franquismo".

“En sus fotografías de tema abstracto podría sospecharse un alma truculenta. No es sólo el árbol al revés -que sólo aceptamos como hallazgo o como diablura si se quiere-, sino también los otros árboles que siempre se nos antojan anatomías. Quien conozca a Masats sabe que no hay tal alma truculenta; por esto confiamos en él mayormente como reportero que como niño terrible" 40 .

A pesar de la excelente acogida de la exposición y de que ésta se considerara como el inicio de todo el movimiento de revolución fotográfica que protagonizó la generación de Masats, lo cierto es que sus fotografías no fueron alabadas incondicionalmente por todo el mundo. Precisamente Gonzalo Juanes fue uno de los más críticos con las imágenes de Masats. Gonzalo Juanes suponía que las fotografías no habían sido bien seleccionadas, que habían sido tomadas sin la necesaria reflexión ni "actividad intelectual". 
“Creo que le falta sensibilidad, la sensibilidad necesaria para seleccionar. Verás, mi manera de ver el problema es esta: una fotografía ambiciosa ha de ser el fruto de una actividad intelectual (...) En la fotografía de reportaje las posibilidades de actividad intelectual quedan desgraciadamente muy disminuidas, no existen. Un reportero con sensibilidad, empieza por seleccionar el ambiente o clima que va a operar, procura captar y saturarse de él, así como (que) este clima no se evapore al pasar al papel sensible. Esta es la primera operación intelectual para ella se necesita sensibilidad claro está. Una vez que ya está en situación ya puede empezar a accionar el disparador, pero no a diestro y siniestro, sino seleccionando al sujeto, sea por su poesía, por su dramatismo, por su desenfado, etc. Verdaderamente esto es muy diferente del reportero vulgar que no comprende climas ni (sabe) de sensaciones furtivas, que no siente impactos, (que) se limita a disparar sobre todo lo que encuentra a su alcance, con la esperanza de obtener, con la colaboración de la suerte una foto salvable, por lo oportuna, rara, sorprendente, espectacular, pero nada más. Pues bien, sospecho que Masats tiene en la exposición dos o tres fotos muy buenas y el resto es una serie de disparos «a ver lo que pasa»"41.

(R. Masats, Madrid, 15 de diciembre de 2003) -“Me han achacado muchas veces que soy mejor fotógrafo que seleccionador de imágenes. Puede ser verdad. Creo que no, pero puede ser verdad. Por ejemplo, en la exposición del Canal de Isabel II Chema Conesa se puso a hurgar en los archivos y ha sacado dos o tres de cosas que yo ni me fijaba en ellas, y cuando las ha sacado Chema sí que me han parecido buenas fotos. Sí, posiblemente tengan razón y no sea muy buen seleccionador".

"Para juzgar el reportaje de "Las Ramblas" de Masats, yo parto del factor tiempo. Es decir, que su importancia está en relación directa a las horas entretenidas en su captación.

Creo, en contra de la opinión de Tous Jové, que el escenario es francamente favorable para la consecución de obras decisivas. Si ha existido oportunidad de poder captar con detenimiento este ambiente, entonces, desde un terreno exigente, su reportaje me parece flojo, pues sólo tres o cuatro obras rebasan la categoría de documento para entrar dentro de un realismo lírico, que es lo que se debe exigir, en estos casos, para que tenga categoría estética.

No obstante, estas tres o cuatro obras, por sí solas me dan un índice muy acusado de su sensibilidad. Estimo pues, que el fallo puede residir, o en el apresuramiento en exhibir un reportaje que todavía no estaba cuajado, o en la falta de experiencia para saber seleccionar las fotografías que lo integran. Ahora bien, Masats, aun siendo todavía una promesa, ha sabido despertarme emociones que hasta ahora no había experimentado con la contemplación de las fotografías más relevantes del salonismo"42.

Una crítica similar es formulada por José María Tous Jové, a quien el citado Pérez Siquier menciona en su análisis:

“Masats no me convenció en su visión de Las Ramblas; claro que escogió un tema que se las trae. Sin
embargo, no dejo de reconocer que cuando tenga una mayor experiencia logrará su meta, pues en su
inquietud revela unas más que notables dotes para el reportaje"43.

Posiblemente, fueran fotos imperfectas, pero eran fotos jóvenes.

“Es muy probable que, ahora, a cualquiera de los tres nos subieran los colores a la cara en caso de contemplar las fotografías que expusimos. Pero lo cierto es que la muestra llamó fuertemente la atención,

41 Juanes, Gonzalo, correspondencia con Pérez Siquier (25-05-57), en Terré, Laura, op. cit., pág. 494.

42 Pérez Siquier, Carlos, "Lo que dice Carlos Pérez Siquier", en AFAL, n 8, Marzo-Abril 1957, sin paginar.

43 Tous Jové, José María, "Lo que dice José María Tous Jové", en AFAL nº 8, Marzo-Abril 1957, sin paginar. 


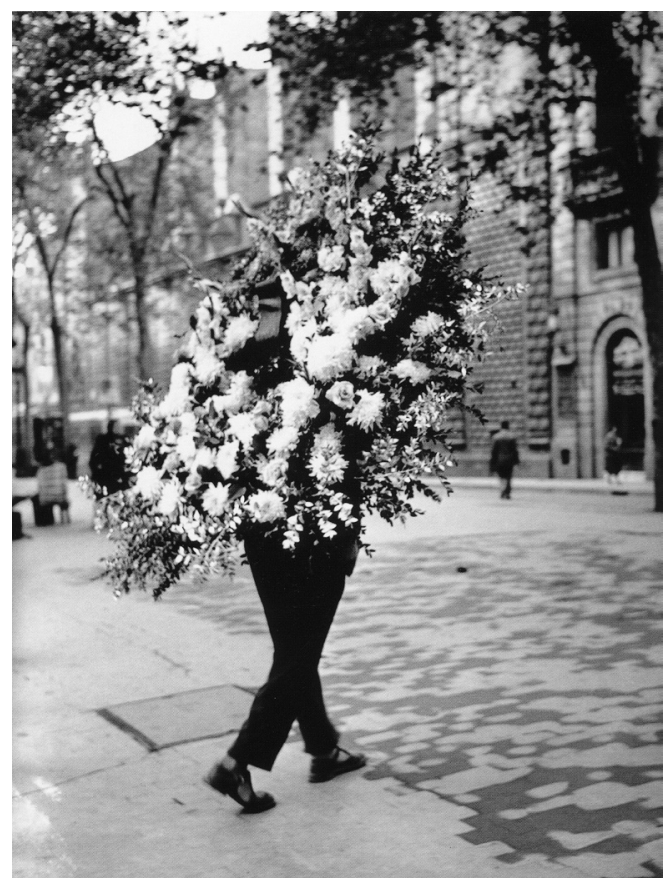

Ramón Masats, "Hombre y corona de flores", La Rambla, Barcelona, 1956.

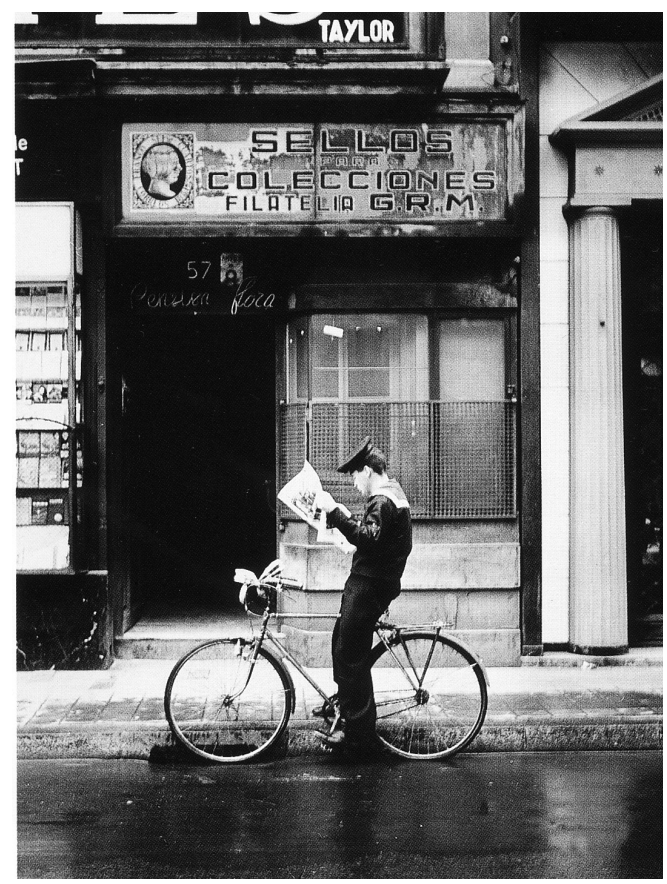

Ramón Masats, "Marinero en bicicleta", La Rambla, Barcelona, 1956.

muy especialmente fuera del círculo de la entidad que nos daba cobijo. El boletín de la AFC dio noticia de ella con un comentario tópico y ecléctico, pero la prensa diaria de Barcelona se hizo amplio eco de la exposición, los semanarios Destino y Revista publicaron artículos sobre ella, y Afal no sólo le dedicó un buen número de páginas sino también se ocupó de que la exposición viajara a Madrid y Almería"44.

-Parece que más que valorar las fotografías lo que se valoró con mayor entusiasmo fue vuestra actitud.

“Me han gustado enormemente las fotos de Terré, Miserachs y Masats, porque en ellas he notado la ausencia de nubes «a lo Gabriel Figueroa», las vacas volviendo del prado y los niños gordezuelos beatíficamente sonrientes. Aparte de esta satisfacción «negativa» me gustan además porque superan en sumo grado los conceptos de «fotografía-documento» y de «fotografía de arte». Son «FOTOGRAFÍAS VIVAS»"45.

(R. Masats, Madrid, 15 de diciembre de 2003) -“Sí, eso es lo que más llamó la atención, la juventud de los tres, el planteamiento de novedad".

44 Miserachs, Xavier, Criterio fotográfico..., op. cit., págs. 185 y 186. Aquí debemos corregir a Xavier Miserachs, pues AFAL jamás se ocupó de que la exposición viajara a Madrid. Todo lo contrario, AFAL compitió con la revista Arte Fotográfico de Ignacio Barceló por la exclusiva y pretendió adelantárseles a la publicación de sus fotografías. Desde luego jamás hicieron ningún trámite para que la exposición se colgara en los muros del enemigo conceptual, la representación misma del salonismo en España, la Real Sociedad Fotográfica de Madrid.

45 Papo, Alfredo, “Lo que dice Alfredo Papo (miembro del Club 49 y del Hot Club)", en AFAL, n0 8, Marzo-Abril 1957, sin paginar. 


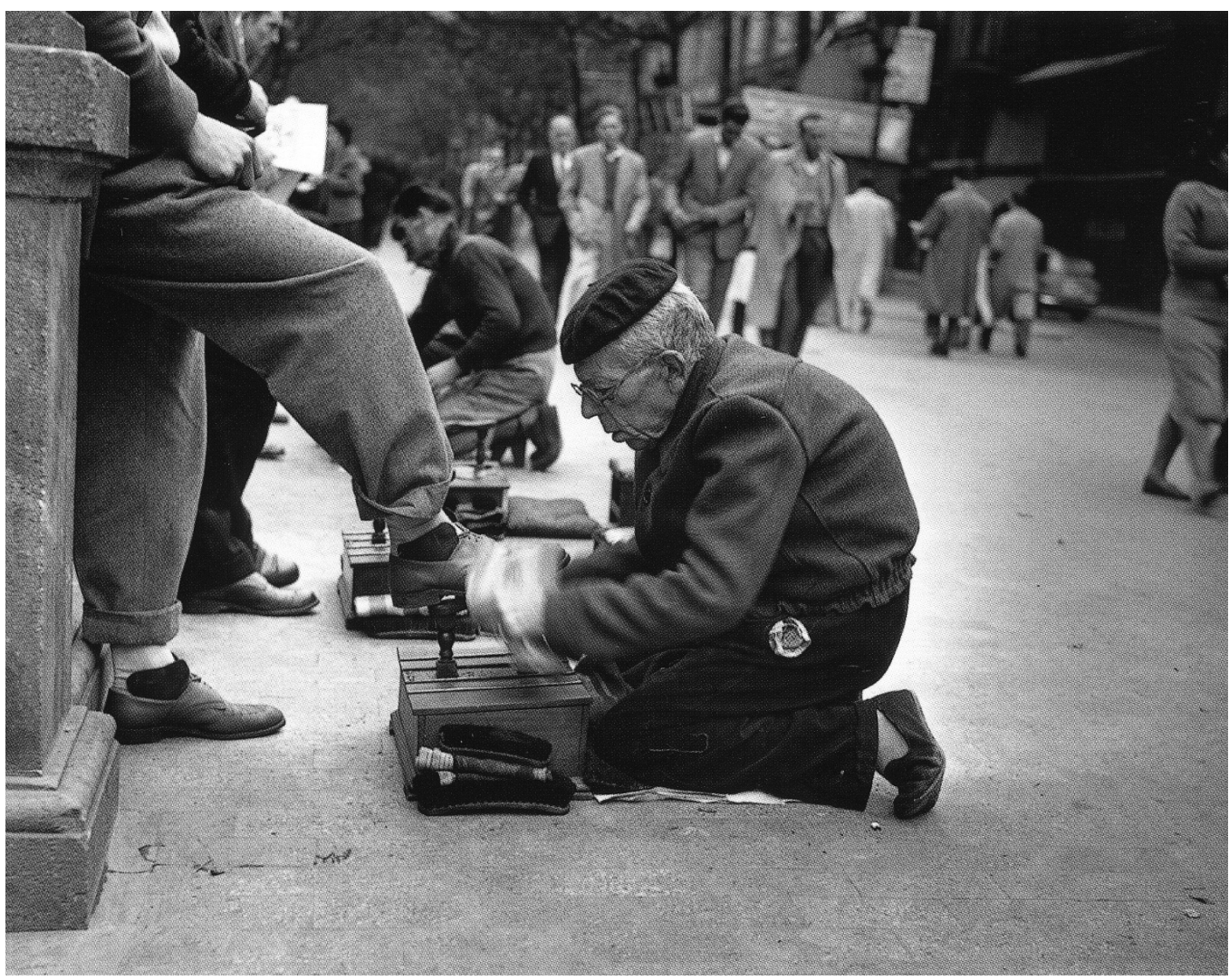

Ramón Masats, "Limpiabotas", La Rambla, Barcelona, 1956.

\section{“¡OBJETIVOS LIBRES...!}

Terré, Miserachs, Masats, han presentado ante nuestros incrédulos ojos una variada gama de valores fotográficos. Podríamos decir que hay de todo: reportaje, fotografía abstracta, «candid-shot» fotografía subjetiva, de vanguardia, retrato, grafismos, composición... ¿Quiénes son estos tres desconocidos? Hace dos años alguno de ellos no sabía ni disparar una cámara. Pecará, pues, de orgullo quien critique estas obras desde su acartonada experiencia de fotógrafo veterano, quien intente comparar, extraer consecuencias, sentar postulados, establecer esquemas, dar normas o formular reglas. ¡Todo se vendrá abajo!

Cada fotografía es distinta a la anterior, hecha bajo diferente impulso, sugerida por una nueva voz interior... ¡No hay fórmulas ni cánones para estas fotografías! Sólo hay lo que pedía Masclet: «¡jos nuevos, virginales! Más sencillez, menos reglas aprendidas, más intuición, más veracidad, más importancia, mayor intensidad... Quiero una sonoridad vibrante y que se dé la nota apropiada... Deseo un canto profundo... ¡Hay que saberse expresar, decir lo que haya que decir y llegar hasta el grito!...¿¿Qué quiero? Menos «composición» y más espontaneidad, menos orden y más frescura; menos procedimientos y menos fórmulas que, sin poder evitar, afectan a las copias de conformismo... ¡Objetivos libres!...»"46. 
Ramón Masats, "Anciana y bastón", La Rambla, Barcelona, 1956.

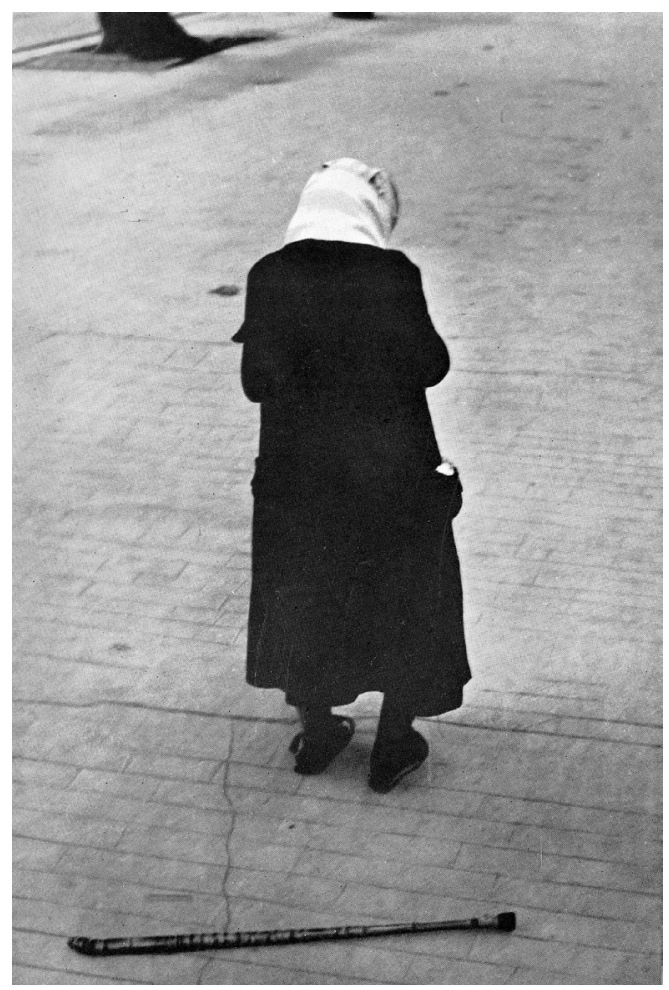

De hecho, cuando un año más tarde de la exposición, otro trío de fotógrafos -en este caso Cubaró, Galí y Ontañón- expone de nuevo en los salones de la Agrupación Fotográfica de Cataluña, repitiendo el mismo esquema de la exposición que nos ocupa, Oriol Maspons arremete contra su falta de originalidad.

\footnotetext{
“No quiero decir con eso que la exposición de T.M.M. fuera un conjunto de perfecciones tales que no valiese la pena ni de intentar superar, sino precisamente por tener el carácter de inicio, de ensayo y casi de atrevimiento (no hay que olvidar que estamos en España), podían pasársele por alto ciertos errores que debieran haber sido superados en ocasiones posteriores (...) además de carecer del factor sorpresa que favoreció a los primeros expositores, se han encerrado en un mimetismo con los tópicos de turno $(\ldots)^{\prime \prime 4}$.
}

Recordemos que, aunque llegó a exponerse en la sede de AFAL, la primera exposición de Terré, Miserachs y Masats se inauguró en abril de 1957 en la Agrupación Fotográfica de Cataluña y un mes después -el 7 de mayo del mismo año- en los salones de la Real Sociedad Fotográfica de Madrid,

- ¿Y por qué lo hicisteis dentro de la Agrupación Fotográfica de Cataluña?

(R. Masats, Madrid, 15 de diciembre de 2003) -“Porque supongo que era mucho más fácil el hacerlo allí. Luego vino lo de Aixelà y fue otro planteamiento. Pero coger una galería y todo eso... Tú ten en cuenta que la fotografía en aquel momento no tenía ningún interés en 
Barcelona. Y si en Barcelona no... ¡imagínate en el resto de España! Lo más fácil fue hacer la primera exposición en la Agrupación Fotográfica. Fue por comodidad".

Realmente había una auténtica preocupación por sacar a la fotografía del endogámico ambiente salonista y aproximarla a la sociedad, llevarla a la calle, a las revistas, a los libros, al mundo de la cultura y al arte.

-Josep Maria Casademont escribió una critica que dice que el equivocarte en el sitio donde vas a exponer es equivocarte en la exposición o, por lo menos, en el planteamiento de la exposición. Señala y que no teníais que haberla hecho allí dentro porque era un entorno hostil.

“Ni siquiera los premios oficiales - con ser su intención de lo más meritorio- habían logrado desmentir esta cruda realidad: en España no existía más fotografía que la de concurso: la mejor o peor llamada fotografía artística, fruto de muy bien intencionadas asociaciones de aficionados pero que no lograban, por más esfuerzos que se hacían para ello -y nos consta que se hacían muchos- adquirir peso específico ninguno en el ambiente culto de la ciudad y del país (...) Ante este desolador panorama y para remediarlo se veían haciendo desde hacía unos pocos años loables intentos que, en ocasiones, partían incluso del seno de estas asociaciones a que antes nos referíamos. La primera exposición de los fotógrafos comentados (Terré, Miserachs, Masats), celebrada hace un par de años, fue uno de estos intentos. Ya entonces la prensa se ocupó de ellos y grandes sectores de público culto empezó a interesarse por esta actividad artística; pero los resultados no trascendieron porque el problema no se había planteado en el terreno conveniente y esto equivalía a plantearlo mal"48.

(R. Masats, Madrid, 15 de diciembre de 2003) -“Tiene razón, pero tú ten en cuenta que en aquel momento nosotros éramos aficionados de allí y la hicimos. Luego conocimos a Casademont y nos ofreció la sala para la segunda exposición, o se lo trabajó Ricard Terré. Porque Ricard Terré era del Hot Club de Barcelona y este se interesaba por cosas nuevas y creo que estaba relacionado con nuestra exposición. Pues sí, estoy de acuerdo, pero visto desde ahora".

“La mostra no tenia altre objetiu que juntar públicament les nostres fotografies i sotmetre-les al criteri públic. En certa manera sabiem que la nostra producció era conscientment $\mathrm{i}$ voluntàriament ben diferent de la «fotografia artística» destinada a guanyar o participar en concursos (...) Així, malgrat ser-ne socis nosaltres mateixos, teníem certa sensació de jugar en camp contrari i, per tant, no va estranyar-nos la fredor i l'asèpsia del comentari publicat al butlletí de l'entitat" 49 .

La animadversión suscitada, sin embargono fue exclusiva de la Agrupación Fotográfica de Cataluña. La Real Sociedad Fotográfica de Madrid también recibió la muestra con absoluta frialdad, cuando no con franco desdén.

“Es de lamentar muy de veras que en esta R.S.F. de Madrid no surja un grupo con afán innovador, savia nueva e ímpetu firme, que renueve esta vieja solera caduca que es incapaz cambiar el sistema (...) Por ello, leyendo los comentarios sobre la fotografía de los tres catalanes (...) alivia pensar que también hay quien, y con la autoridad de un prestigio ganado, opina como yo. En esta R.S.F. ha llegado a decirse que estas fotografías no debían exponerse en estos salones; con esto les digo bastante" ${ }^{\prime \prime 0}$.

48 Anaxágoras (Josep Maria Casademont), "La II de T.M.M. Una muestra de arte vivo", en AFAL, n² 21, noviembre-diciembre 1959, sin paginar.

49 Miserachs, Xavier, Fulls de contactes. Memòries, Barcelona, Edicions 62, 1998, pág. 232.

50 E.G.G., "Muestra colectiva Terré, Miserachs, Masats", en AFAL, n 9, mayo-junio 1957, sin paginar. 
- ¿Fuisteis conscientes de que la exposición actuaba como un hecho contestatario que iba en contra del salonismo.

(R. Masats, Madrid, 15 de diciembre de 2003) -“Un poco sí. Lo que pasa es que lo que teníamos que haber pensado es que era un revulsivo totalmente inútil. Porque allí los únicos que verían la exposición serían los propios salonistas. La exposición si la hubiéramos hecho en otro sitio... posiblemente hubiera venido gente más joven, más acorde con lo nuestro. Pero bueno, lo hicimos allí porque era el único sitio donde podíamos exponer".

\begin{abstract}
“A partir de aquella primer exposición (quizás un poco antes, con la del grupo 30×40 de París), pero siempre dentro del reducido ambiente de las asociaciones amateurs, empezó a hablarse de «fotografía moderna» de «tendencias» y sobre todo de «salonismo», palabra esta última inventada por el excéntrico Oriol Maspons" ${ }^{\prime \prime}$.
\end{abstract}

Esta primera muestra fue considerada como un auténtico hito en la Historia de la Fotografía, aunque no tanto como una promesa de jóvenes valores, sino más bien como la confirmación de una realidad. Terré, Miserachs, Masats representaron la primera manifestación tangible de todo un movimiento nuevo, una reacción fotográfica generacional.

“He aquí la «exposición del año». La primera aportación colectiva española a la fotografía actual que todo el mundo practica... menos nosotros. El más importante signo de vitalidad de nuestra fotografía.

No es pues extraño que se haya levantado una gran polvareda sobre esta «muestra» y el aluvión de críticas y comentarios que materialmente han inundado nuestra Redacción. De entre ellas, sin tiempo para clasificar, comentar o seleccionar, hemos tomado unas cuantas: catalanas unas, almerienses otras, sinceras todas y seriamente impresionadas por el impacto que la Exposición supone en nuestro mundo fotográfico" ${ }^{\prime \prime 2}$.

\title{
Como explicaba el propio Miserachs:
}

“En canvi, la revista AFAL (...) va dedicar un munt de planes a l'exposició, i a més de textos generats a la seva redacció (...) va demanar opinions alienes i va recollir el que havien publicat alguns setmanaris. En conjunt i llegits avui, són una llarga sèrie de benvingudes a un corrent d'aire fresc, a la voluntad de sortir d'un cercle viciós, i em sorprenen més les rúbriques que els continguts. Hi ha comentaris de Català-Roca i Alfredo Papo, i articles d'Arturo Llopis (Destino) i Joan Josep Tharrats $(\text { Revista })^{\prime \prime 5}$.

-Las fotos de la primera Terré, Miserachs, Masats fueron muy bien recibidas en AFAL, que os dedicó unos titulares espléndidos en su revista...

(R. Masats, Madrid, 15 de diciembre de 2003) -“Me da la sensación que en Arte Fotográfico también. Porque aunque la gente siempre habla muy mal de Ignacio Barceló, yo creo que hizo cosas muy buenas para la fotografía. Y a nosotros nos ayudó enseguida. Siempre estuvo de nuestra parte. Arte Fotográfico era una revista muy burguesa, muy tradicional, muy como la Agrupación Fotográfica de Cataluña... pero él veía más allá. A Cualladó, a Paco Gómez, a Oriol Maspons, a Xavier Miserachs y a mí... siempre nos ayudó. Nunca tuvimos en él un enemigo, sino una persona que verdaderamente nos quería. Le hizo mucho daño a AFAL. Porque claro, 
Barceló era un señor mayor y a pesar de este cariño que nos tenía... había una distancia. En cambio cuando aparecieron aquellos locos de Almería, pues por edad y por forma de pensar... nos lanzamos y eso a él le supo mal. Porque no creo que le hiciera mucho daño a nivel de venta de Arte Fotográfico, porque AFAL era muy minoritario, pero sí a nivel de prestigio o a nivel de que habíamos sido ingratos con él. Aunque no era así. Yo siempre le he tenido cariño a Ignacio Barceló porque siempre estuvo con nosotros. Oriol escribía en Arte Fotográfico y decía cosas que estaban muy bien".

-En esta rivalidad entre AFAL y Arte Fotográfico llama la atención cómo reaccionaron con vuestra exposición. Es decir, después del frío recibimiento en la Agrupación Fotográfica de Cataluña cabría esperar que Arte Fotográfico os hubiera tratado igual, ya que se regía más o menos por los mismos criterios estéticos y la misma ideología. Y fue todo lo contrario. Nunca publicó un portafolios tan extenso como el que os dedicó a vosotros tres.

(R. Masats, Madrid, 15 de diciembre de 2003) -“Es que Barceló era un hombre de una apertura intelectualmente fotográfica muy amplia. AFAL era más cerrado, más dogmático. Cerrado en bien, quiero decir que estábamos de acuerdo con sus planteamientos. Pero Ignacio Barceló tenía una amplitud de miras en las cuales cabía toda esa nueva fotografía. Luego me he enterado que Carlos Pérez Siquier se molestó cuando me dieron el Premio Negtor de fotografía, porque había una parte del premio que se concedía a la agrupación fotográfica a la que pertenecías y yo puse la Real Sociedad Fotográfica de Madrid... y eso a AFAL le sentó muy mal, pero era porque para mí AFAL no era la Asociación Fotográfica Almeriense, era una revista. Entonces yo no me di cuenta, y como estaba aquí y tal... Esto le sentó muy mal a Pérez Siquier".

La segunda exposición conjunta entre Terré, Miserachs y Masats fue inaugurada el 14 de marzo de 1959 y permaneció abierta al público hasta el 9 de abril del mismo año en sala Aixelà de Barcelona.

“Aportación de Ramón Masats a la TMMII

Presenta fotografías de la serie Sanfermines y un conjunto de fotos sueltas, en total 24 fotografías, algunas en formatos murales.

«Serie Sanfermines»

1. Hombre empinando la botella de vino entre la gente (formato de más de un metro)

2. Riau-riau. Los mozos y la orquesta vistos desde arriba (formato de más de un metro)

3. Toreando vaquillas. Panorámica

4. Retrato de mozo pecoso con sombrero de copa

5. Aguador en la plaza

6. Una mano se alza, como pidiendo vino entre la gente

7. Cura gordo

8. La barra de un bar

9. Torero descansando

10. Guardia de tráfico y gente descansando

11. Lomo de una vaca y cabeza de otra

12. Cabeza de toro en el matadero

13. Torero dando la capea (en formato de más de un metro)

Fotos sueltas:

14. Mujer sentada al lado de una puerta con escalera al fondo

15. Retrato de María Cuadra

16. Retrato de primer plano de hombre mayor

17. Retrato de hombre con aperos de labranza

18. Dos perros en la era 

19. ¿Tres postes?
20. ¿Ventana?
21. Terraplén blanco y medianera pintada de negro en la que hay una ventana (...)
22. Matas de hierba y pared
23. Pareja (¿novia? ¿primera comunión?) paseando de espaldas por un parque
24. Paisaje de costa" ${ }^{54}$.

- La segunda exposición fue distinta. La sacasteis fuera de la Agrupación Fotográfica Catalana y la llevasteis a la sala Aixelà -que por cierto inaugurasteis vosotros, con música de jazz-. Patrocinada por el Club 49 del Hot Club Barcelona, invitasteis a toda la cultura barcelonesa y tuvisteis mucha más repercusión en los medios. Ya no era una cosa estrictamente fotográfica sino que era una actividad cultural que trascendió el gueto en el que estaban los fotógrafos. Aquí sí que seríais conscientes de que fuisteis un punto de inflexión.

(R. Masats, Madrid, 15 de diciembre de 2003) -“Sí, es cierto".

“La primera mostra dels seus treballs l'havien presentat a l'AFC, però és a través de CLUB 49 que fan una nova posada en escena: tres visions diferents però un mateix esperit. A través de la seva relació amb la gent del Hot Club els autors demanaren a Joan Prats que seleccionés les fotografíes per a la mostra, i el bon ull de Prats li permet de copsar la qualitat de les imatges veient solament els negatius. L'agudesa de Prats, la seva sensibilitat vers la imatge, va impresionar els tres fotògrafs. L'exposició s'acompanyava d’audicions de música de jazz." ${ }^{\prime 5}$

A pesar de que, a priori, las intenciones pudieran ser las mismas en las dos exposiciones, lo cierto es que hay notables diferencias entre ellas. En tan sólo dos años nuestros fotógrafos habían madurado extraordinariamente gracias a una gran cantidad de sucesos que se precipitaron inexorables.

“Dos años más tarde, en primavera de 1959, Terré, Masats y yo repetimos exposición, pero esta vez inaugurando el ciclo que Joseph Maria Casademont programó como responsable de la Sala Aixelà de Barcelona. Nuevamente el interés por la muestra desbordó el ámbito habitual de los certámenes fotográficos. Pero las imágenes que allí expusimos tenían otra madurez, ya no nos provocarían hoy tanto sonrojo. Entre ambas exposiciones habían ocurrido muchas cosas"56.

Una de esas "cosas" a las que alude Miserachs fue, sin duda, la entrada -gracias a Masponsde las influencias fotográficas extranjeras, que ya hemos estudiado. Influencias que no tardaron en hacerse patentes en la producción de nuestros fotógrafos.

-Las fotos estaban colgadas sin paspartú ni marco y con tamaños muy grandes de un metro por metro y medio. ¿Por qué?

(R. Masats, Madrid, 15 de diciembre de 2003) -“No lo sé. Esto eran cosas más bien de Ricard Terré".

- ¿Puede ser que estuvieran inspiradas en The Family of Man?

(R. Masats, Madrid, 15 de diciembre de 2003) -“No te diría que no".

-0 que tuvieran una intención comunicativa, manteniendo con las obras de arte una ambigua relación...

(R. Masats, Madrid, 15 de diciembre de 2003) -“Esto ya es demasiado intelectual para mí.

54 Terré, Laura, op. cit., págs. 339-340.

55 AA. VV., Club 49, Reobrir el joc, 1949-1971, Barcelona, Generalitat de Catalunya, Departament de Cultura, 2000 , pág. 92.

56 Miserachs, Xavier, Criterio fotográfico..., op. cit., pág. 186. 
Yo estoy más próximo a que era un influjo de la exposición-libro de The Family of Man. Por mí parte, porque a lo mejor luego... porque eso lo mangoneaba muy bien... -y digo mangoneo con todo el cariño hacia Ricard Terré- y como nos parecía bien, pues muy bien. Pero yo creo que fue realmente inspirado por The Family of Man".

-Curiosamente, hoy en día se hacen ampliaciones tan grandes para acentuar el concepto de pieza única.

(R. Masats, Madrid, 15 de diciembre de 2003) - "Es que uno de los inconvenientes de la fotografía es el no ser pieza única. Es uno de los más importantes".

-Sin embargo, el que hicierais ampliaciones tan grandes no tenía nada que ver con este concepto.

(R. Masats, Madrid, 15 de diciembre de 2003) -“No".

Como vemos hay una serie de conceptos que son asumidos por Masats de una manera más clara que en la primera exposición: el humanismo, el reportaje... Probablemente, la intención de esta presentación de las ampliaciones fuera subrayar el carácter comunicativo de las imágenes, evitar el marco, omnipresente en la pintura, huir del salón... A pesar de ello, todos estos cambios en su manera de entender la fotografía ya estaban presentes en Masats desde 1957. Recordemos aquel artículo con el que iniciábamos este capítulo en el que ya aparecen reseñadas las fotografías de "marcada tendencia moderna".

“Siguieron a ésta otras de su etapa «abstracta» (no figurativa) y a continuación nos mostró las obras de más reciente factura, entre las que se hallaban algunas de carácter puramente «decorativo» (sin anécdota) y varias de marcada tendencia moderna, tal como se entiende el modernismo en fotografía más allá de nuestras fronteras" ${ }^{\prime 57}$.

Sin embargo, la principal diferencia entre las dos exposiciones que venimos analizando es que en esta segunda Masats y Miserachs ya son profesionales. Como el propio Casademont se apresta a comentar, las fotografías expuestas son imágenes que serán publicadas en libros fotográficos.

“Claro es que no se ha podido prescindir de exponer la muestra en un salón (...) pero no es difícil darse cuenta de que esta circunstancia de lugar es meramente accesoria, si se considera que lo mismo el trabajo de Terré sobre la Semana Santa, que el de Miserachs sobre la Costa Brava, que el sabrosísimo reportaje de Masats sobre las fiestas de San Fermín en Pamplona, no son más que una parte de lo que, en un futuro inmediato, han de ser sendos libros sobre cada una de las materias tratadas" $\$$.

Aunque todavía insistiera un año antes, durante 1958, en sus fotos más abstractas (en las fotografías que Masats seleccionó para el anuario de AFAL), en esta segunda exposición el porcentaje de imágenes de esta índole es menor, casi subsidiario (muy parecido al que después aparecerá en sus libros o artículos), especialmente si lo comparamos con la primera muestra. Aunque este tipo de imágenes Masats siempre las tendrá presentes, no volverá a conceder tanta importancia a los aspectos formales hasta que no llegue su etapa de color, donde prácticamente renunciará al reportaje para concentrarse en las texturas, los colores, las masas y los volúmenes...

Sus fotografías sobre las fiestas de Pamplona cobran tanta importancia en esta segunda exposición que realizaremos un análisis de esta exposición conjuntamente con su libro 
Los Sanfermines, ya que realmente el material visual y expuesto es el mismo.

- ¿Por qué no hicisteis una tercera Terré, Miserachs, Masats?

(R. Masats, Madrid, 15 de diciembre de 2003) -“No lo sé, pero tampoco el hacer tantas Terré, Miserachs, Masats... ya parecería como si fuéramos novios. Ten en cuenta que yo ya me vine a Madrid y Ricard Terré se fue a Vigo. Ya no tenía sentido. Se había acabado el ciclo".

La lectura que se le ha dado a estas exposiciones pasa, inevitablemente, por considerarlas como paradigma de la lucha que mantuvieron estos fotógrafos por exponer fuera del asfixiante ambiente del salonismo. AFAL era muy consciente de las implicaciones y las dificultades que suponía desafiar las estructuras establecidas. Salir del círculo era considerado todo un éxito, por eso apoyó con tanto interés las iniciativas que consiguieron romper con esa espiral endogámica de los fotógrafos aficionados. De modo que, cuando una exposición logró suscitar la atención de los medios culturales españoles, la revista no dudó en dedicarle un número considerable de páginas. Como, por ejemplo, en 1961, con ocasión de la exposición individual que Ramón Masats presentó en la sala del Prado del Ateneo de Madrid.

(Carlos Pérez Siquier, Almería, 27 de abril de 2002) -“En la revista hay un número en el que se dedicó bastantes páginas a Masats como consecuencia de la exposición que se hizo en el Ateneo de Madrid, con algunos textos nuestros, y demás. En aquella época el exponer en el Ateneo fue un buen refrendo para la fotografía, porque la fotografía estaba muy desvalorizada en los medios culturales españoles".

\subsubsection{El regreso a la no figuración en la etapa en color}

Como acabamos de ver, Ramón Masats desarrolló las fotografías de forma en sus primeros años de fotógrafo aficionado. Aunque nunca abandonó completamente esta línea de trabajo, y Masats siempre incluyó alguna de estas imagenes en sus obras fotográficas profesionales, lo cierto es que a partir de 1957 tarea se centró principalmente en el reportaje y en una fotografía de corte humanista, más narrativa y documentalista. Esto fue así hasta 1965. Esta fecha supone una brusca ruptura de Masats con el mundo de la fotografía que durará más de quince años, pues desde 1965 y hasta 1981 Ramón Masats abandonará prácticamente la fotografía como modo de vida (aunque todavía realiza alguna foto para el Ministerio de Turismo) para dedicarse al cine y la televisión. Su vuelta a la fotografía se producirá en 1981, año en que Masats iniciará una larguísima relación profesional con la editorial Luna Wennberg (que poco después pasará a llamarse Lunwerg) y que comenzará con la publicación del libro Nuestro Madrid con textos de Luis Carandell. Ya veremos que esta vuelta a la fotografía será menos drástica que su abandono. Este regreso se puede representar como un largo encadenado que durará varios años, ya que, todavía en 1992, Masats seguirá realizando documentales con ocasión de la Exposición Universal de Sevilla.

La primera característica significativa que queremos destacar de esta nueva etapa es que, debido a las nuevas exigencias editoriales, la vuelta a la fotografía profesional de Ramón Masats se realiza exclusivamente en color.

(R. Masats, Valencia, 25 de marzo de 2004) -“En 1981 cuando volvía a la fotografía hice color, pero no porque me gustara más el blanco y negro antes y me gustara el color después, sino por una razón de tipo editorial. Yo tengo un proveedor de fotografía muy amigo mío, muy profesional y que tiene confianza en mí; y yo he tenido la gran suerte de irme a realizar un trabajo y no saber si lo voy a hacer en blanco y negro o en color. $Y$ el proveedor me ha permitido llevarme blanco y negro y color, y allí, in situ -por una razón que tampoco tengo muy clara en mí- me decido por hacer blanco y negro o color. A partir de 1981 he estado haciendo libros sobre todo. Hasta 1965 lo que más hice fueron reportajes para revistas como Gaceta Ilustrada, entre otras, aunque también hice, me parece que fueron... cuatro o cinco libros en blanco y negro". 
Absolutamente todos los libros de Masats en color son realizados por encargo de Lunwerg Editores. Su obra para esta editorial es muy extensa, tal y como podemos comprobar en el siguiente listado de libros publicados:

-Nuestro Madrid, con texto de Luis Carandell (1981).

-España diversa, con textos de Luis Carandell y José Luis Sanpedro (1982).

-Palacios Reales del Patrimonio Nacional, fotografías de Ramón Masats y Paco Ontañón y texto de Antonio Bonet Correa (1983).

-Monasterios Reales del Patrimonio Nacional, fotografías de Ramón Masats y Andreu Masagué y texto de Óscar Collazos (1984).

-Madrid es más que Madrid, con texto de Luis Carandell (1984).

-Jerez, del ayer al futuro, con texto de Manuel Ríos Ruiz (1985).

- Un Paseo por Madrid (1985).

- El agua de Madrid (1985).

-Al-Andalus. El Islam en España, con texto de Juan Vernet (1987).

-Madrid, con fotografías antiguas de diversos autores y Ramón Masats y textos de Luis Carandell, Daniel Zarza y Publio López Mondéjar (1987).

-Desde el cielo a España, con texto Luis Carandell (1988).

-Del cielo a Madrid, con texto de Luis Carandell (1988).

-Andalucía, con texto de José Manuel Caballero Bonald (1989).

-Sevilla, con texto de Víctor Pérez Escolano (1989).

-Astilleros de ayer a hoy 1877-1991, junto a Cristina García Rodero, Koldo Chamorro, Joan Fontcuberta, Manuel Laguillo y Manel Esclusa. Textos de Publio López Mondéjar y Fernando Quiñones (1991).

-Madrid, Madrid, Madrid, con texto de Luis Carandell (1995).

-Madrid y su comunidad, un mundo diverso. (1996).

-Madrid pasen y vean. (1997).

-Toro, con texto de Joaquín Vidal (1998).

-Andalucía. Cultura y diversidad, con textos de López Guzmán e Ignacio Henares Cuellar (2005).

Sin embargo, a pesar de la impresionante cantidad de libros producidos, la calidad conjunta de todos esos trabajos es muy limitada. Como buen profesional Masats responde a las necesidades y las exigencias del cliente, en este caso la editorial Lunwerg. Todos estos libros (excepto quizás el libro Toro, su proyecto en color más personal) son encargos editoriales (fotografía "mercenaria") realizados con un guión estricto y dirigido a un público general, interesado fundamentalmente en una imagen clásica, turística y poco creativa de España y sus provincias. Son libros "de regalo", aquellos table books que nos comentaba Koldo Chamorro cuando analizábamos la esquizofrenia del autor profesional, es decir, libros suntuosos, caros y de gran volúmen, hechos para colocar encima de las mesitas de los salones y con una utilidad meramente decorativa.

Veamos la opinión que estos trabajos suscita a Carlos Pérez Siquier, teniendo en cuenta que en el momento de esta entrevista Pérez Siquier todavía no conoce los libros antológicos posteriores.

- ¿Y que le parece la fotografía que hace ahora Ramón Masats?

(Carlos Pérez Siquier, Almería, 27 de abril de 2002) -“Ramón y yo hemos tenido que trabajar para el Ministerio de Turismo, para editoriales, sobre todo con Lundwerg, que fue muy amiga de Ramón, pero que le han encargado unos libros con unas características un poco comerciales. Él no tenía una voz propia. Tú ves los libros y dices... un libro sobre Madrid, o un libro sobre Andalucía..., y hay unas cuantas fotos geniales, pero las demás no... Igual que yo. Yo también tengo guías sobre Almería, pero son unas fotos alimenticias. Están hechas con cierto cuidado y con profesionalidad, pero no son las fotos que me definen. Lo diferente entre Ramón y yo está en que yo he procurado separar las fotos que he considerado que quería firmar como autor, y ésas 
tenían una vía, ya que no las mezclaba con las otras. Las otras, tenían un sello eminentemente comercial, hacía lo que me pedían. Yo trabajaba para una agencia de publicidad y eso me ha permitido mantener mi nivel de vida, ése es el trabajo que me daba... Pero el otro trabajo, que no me daba nada, ése lo guardaba yo, y ya empiezo a publicar mis libritos, mis cosas y tal. Además he querido darle siempre mi sello personal, de forma que ya identifican mis fotos: «ésa es una foto de Pérez Siquier».

Antes yo me encontraba muy huérfano, y cuando veía los libros de mis compañeros, que ya tenían de autor, y que fueron buenos al principio, como fueron aquellos de Palabra e Imagen... Aquellos fueron verdaderos libros de autor, esos son los libros que definieron a Ramón, más que los que ha hecho posteriores, mucho más lujosos. Lo que sucede es que en estos últimos las fotografías están mezcladas, ése es su inconveniente. Pero están mezcladas porque él se ha dedicado ha trabajar para Lunwerg, que son muy comerciales. Eso es lo que le daba dinero, pero es que él tenía que vivir. Yo me acuerdo que Ramón una vez me dijo una frase: «Me voy a dedicar a la fotografía», te estoy hablando del año sesenta y tantos, y yo le dije: «¿Pero nada más que a la fotografía? Porque yo estoy en el banco, pero no lo puedo dejar, porque es que si no, no podría... yo tengo que tener una alternativa para trabajar». Y me dijo: «No, no, yo me voy a dedicar, y ya verás cómo salgo adelante». Y efectivamente, salió adelante. Hizo algunas cosas de cine con las que ganó algún dinero, pero tuvo que prestar todos sus esfuerzos haciendo esas fotos, de las que le mandaba Lunwerg y le mandaba el Ministerio. Y claro, a pesar de su gran categoría, le impidió ser todavía más de lo que es. Todavía podía ser mucho más, a pesar de tener esos libros tan buenos y que el resumen final del libro antológico sea estupendo. Tiene tanto talento, que podía haber tenido muchos libros más acojonantes, pero claro, tenía que haber tenido otra cosa alternativa que le diera dinero, alguna renta 0 algo, y haberse dedicado a hacer esos temas. Hubiera sido un fotógrafo todavía mucho más importante de lo que es".

Ahora bien, siendo cierto que la calidad general de estos libros es sustancialmente menor que los realizados durante su época anterior, en blanco y negro, no es menos cierto que hay un gran número de imágenes, diluidas entre las páginas de estos libros, de una gran belleza y plasticidad. El problema que nos plantean estas fotografías es que desaparecen, fagocitadas por el gran numero de imágenes anodinas realizadas con una gran profesionalidad pero sin ninguna "inquietud". Ésta es la dificultad de las colecciones o los grupos fotográficos, puesto que el límite de la calidad la da la peor de las imágenes de la serie. Ésta es la razón por la que no se puede hacer concesiones extrafotográficas sin pagar por ello un alto precio. No cabe duda de que se trata de un problema del editor y no del fotógrafo. En ese sentido aquella maldición del intermediario, ya comentada por Masats, alcanza indiscutiblemente a todo el trabajo reunido en estos libros.

De cualquier modo, nos vemos en la obligación de corregir a Carlos Pérez Siquier: esa recuperación de sus mejores imágenes en color, destiladas una a una de entre la maraña de la mediocridad, sí la ha podido realizar Masats. Por eso hemos situado este subcapítulo aquí, justo después de sus primeras fotografías, porque cuando Masats rescata aquellas imágenes, de las que él sí se considera autor, descubrimos que Masats se ha reencontrado con sus imágenes abstractas, esta vez en color, casi treinta años después de experimentar con ellas en su primera época en blanco y negro.

Es cierto que en ambos periodos Masats maneja los mismos conceptos plásticos y profundiza en los mismos experimentos visuales que ya iniciara con el blanco y negro: juegos con geometrías, texturas, fotos movidas de toros, utilización de sujetos sencillos y humildes como motivos plásticos para descubrir la belleza en la banalidad e, incluso, la investigación con los puntos de confusión utilizados como elementos plásticos y compositivos (elemento éste 


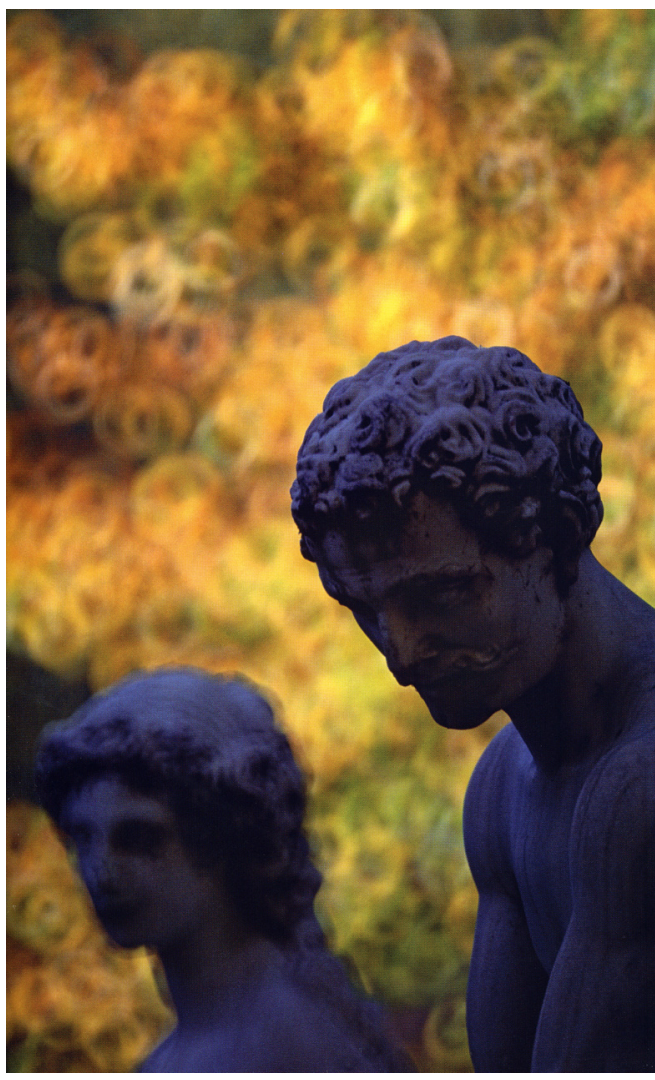

Ramón Masats, “Aranjuez”, 1996.

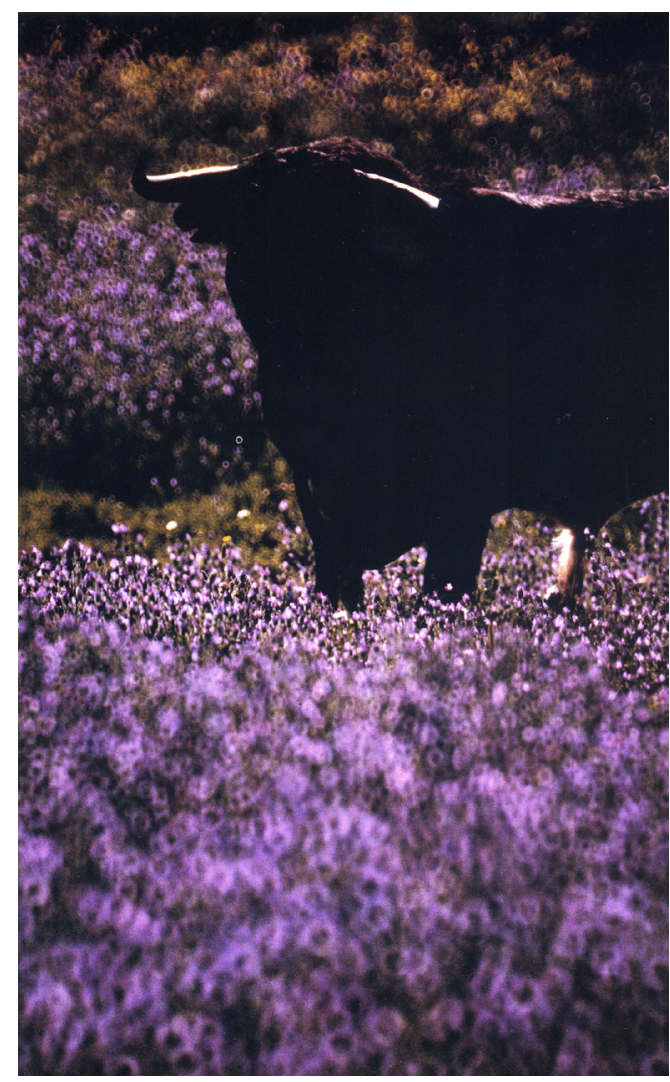

Ramón Masats, "Toro entre las lilas", 1998.

desarrollado exclusivamente en su etapa en color en la que los objetivos catadriópticos, compuestos por lentes y espejos, tienen un característico punto de confusión en forma de círculo hueco que Masats utiliza creativamente en varias imágenes : como su "toro entre las lilas" o en la portada de uno de sus libros sobre Madrid). Sin embargo, aunque desarrolle los mismos conceptos, hay que destacar que Masats nunca podrá mezclar blanco y negro y color a la vez. Cuando piensa en color sus imágenes sólo funcionan en este sentido y se hubieran desvanecido si las hubiera fotografiado en blanco y negro.

“Todos los grandes fotógrafos que empezaron con el blanco y negro han pasado por un trance parecido. Sin embargo, poquísimos, quizá sólo Guy Bourdin, han conseguido dar el salto con la brillantez de Masats. Me refiero a que las fotografías en color de Ramón son inimaginables de blanco y negro (...) Tomemos la fotografía de cuatro cuadrantes de Olvera: dos cuadrantes blancos, dos en colores vivos; dos planos, dos en perspectiva; uno en perspectiva cercana y enjalbegada, el otro en perspectiva lejana y verde. Si pasamos esta espléndida fotografía a blanco y negro no queda prácticamente nada. Es evidente que Masats, cuando tomó la imagen, «pensó» en color. La composición abstracta se sostiene en el color" ${ }^{\prime \prime}$.

59 Tusquets Blanca, Óscar, “Ramón Masats, un testarudo genial”, en Masats, Ramón; Tusquets Blanca, Óscar; López Mondéjar, Publio y Conesa, Chema, Contactos, Madrid, Ministerio de Cultura, Lunwerg, 2006, págs. 22 y 23. 


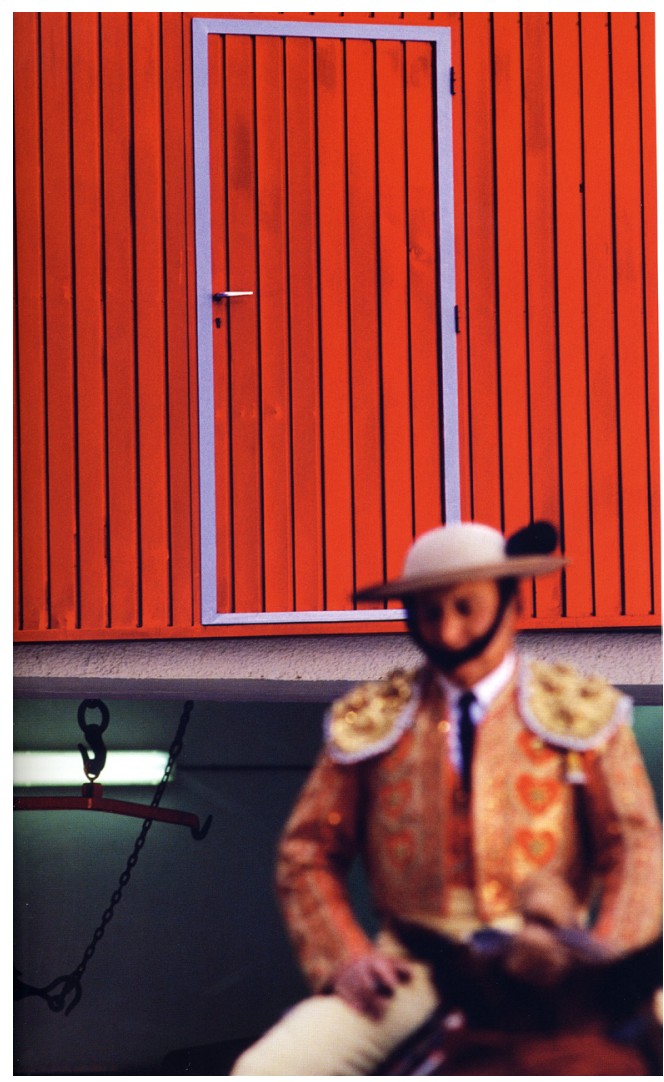

Ramón Masats, “Pamplona”, 1995.

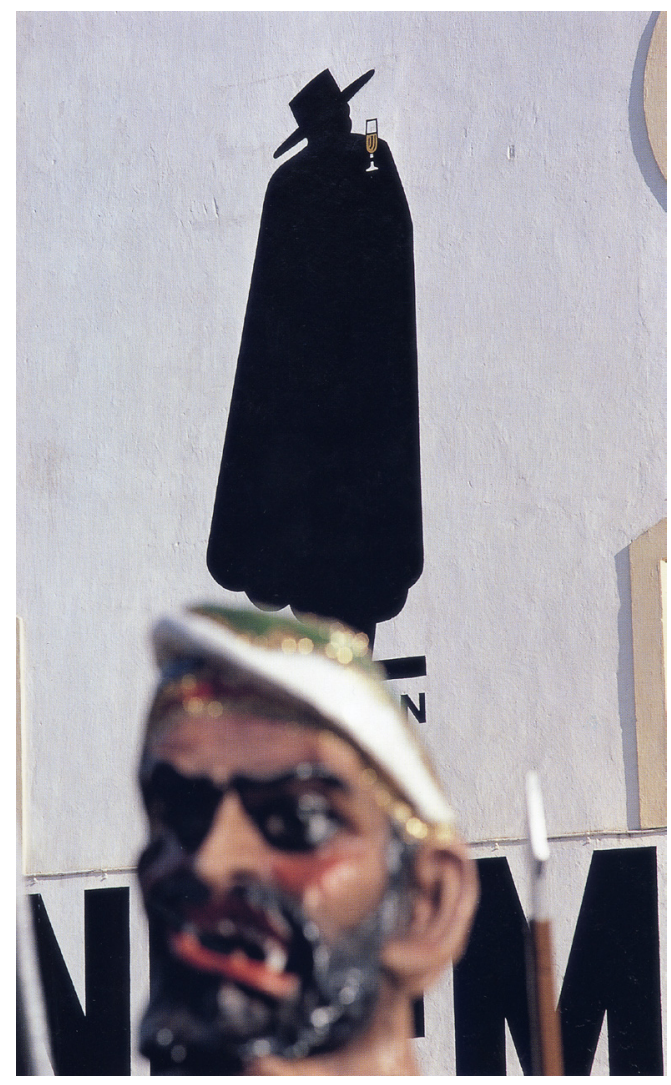

Ramón Masats, “Jerez", 1985.

En general, las imágenes que exploran los aspectos formales no las podemos calificar como una serie o grupo fotográfico. Son imágenes individuales, sueltas, que están concebidas para quedar integradas en estos trabajos como una vía para aumentar la variedad visual, rompiendo la monotonía del conjunto $\mathrm{y}$, a veces, siendo utilizadas incluso como hitos de transición que separan diversas secuencias de los libros. De cualquier modo, no olvidemos que, en realidad, no estaban producidas tan sólo para los libros fotográficos, también estaban previstas para una posterior utilización en exposiciones fotográficas donde el orden de las imágenes no busca la armonía narrativa que exigen los libros fotográficos.

(R. Masats, Madrid, 20 de marzo de 2000) -“Para romper la monotonía de un reportaje, poner detalles más abstractos funcionan muy bien".

-Entonces, sólo funcionan para romper la monotonía, la narrativa de reportaje...

(R. Masats, Madrid, 20 de marzo de 2000) -“No, individualmente también. Funcionan plásticamente. Los reportajes son libros. En color siempre son libros. A mí me gusta poner pequeños detalles en los libros... Aparte de los tópicos que tienes que hacer, de la gente y tal... el ir poniendo detalles un poco estrambóticos... Sí, me interesa".

- ¿Tú, un trabajo cómo lo valoras? Es decir, si ves un libro, ¿valoras el resultado conjunto o cada una de las fotografías por separado? ¿Puede suceder que un libro tenga unas fotos interesantes pero que el resultado final sea mediocre y muy inferior a cada una de sus fotografías sueltas? 


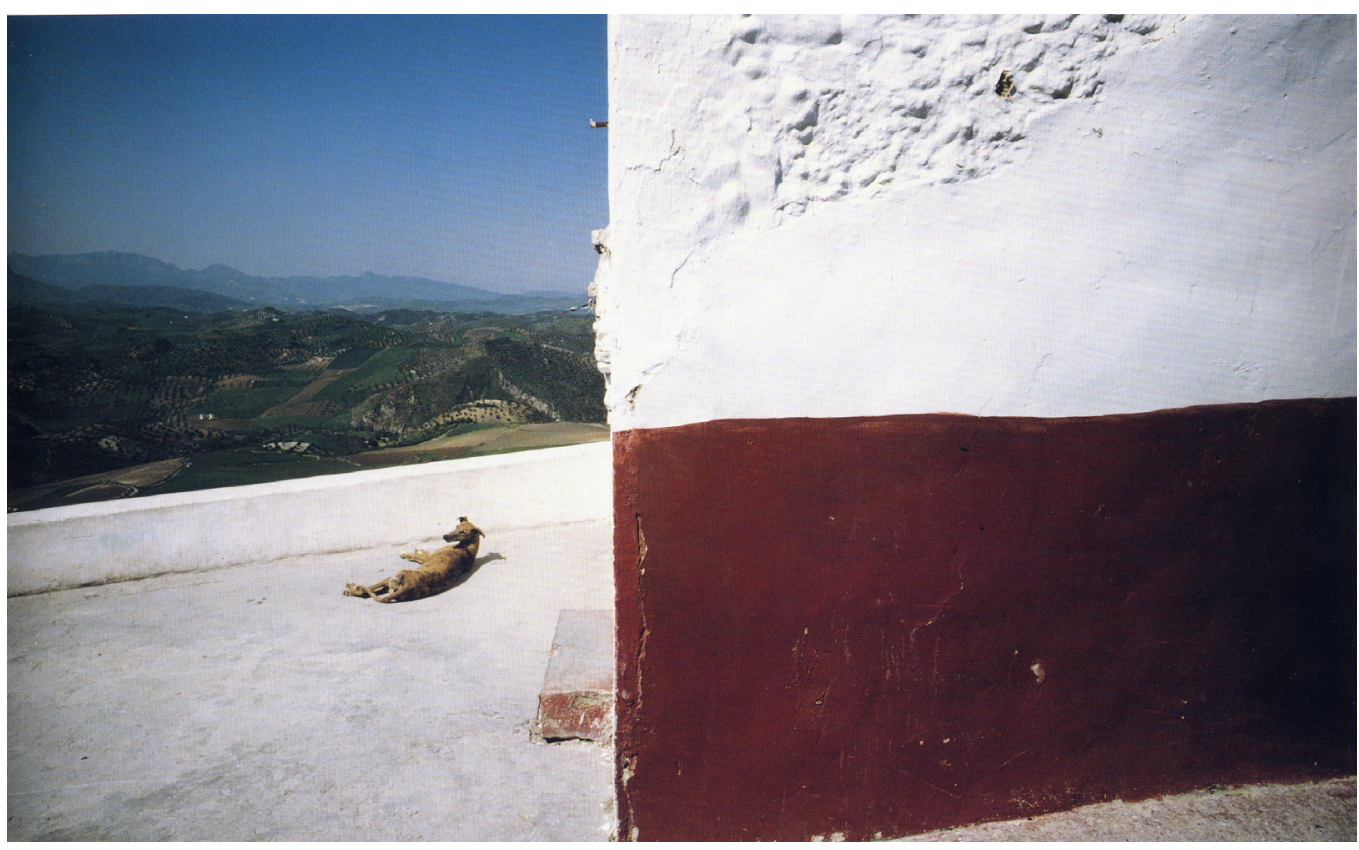

Ramón Masats, “Olvera (Cádiz)", 1988.

(R. Masats, Madrid, 4 de septiembre de 2002) -“Si es un libro yo valoro el conjunto, aunque luego... individualmente, siempre hay dos o tres fotos que las guardo para mis exposiciones. Pero lo que sí, lo que valoro siempre es el conjunto".

-Sin embargo, para las exposiciones...

(R. Masats, Madrid, 4 de septiembre de 2002) -“Cuando estoy trabajando, o estoy haciendo un libro, muchas veces hago fotografías personales, que sé que para el libro no van a valer. Pero sí me valen a mí".

-Pero las exposiciones son recientes.

(R. Masats, Madrid, 4 de septiembre de 2002) -“En color sí, en blanco y negro son ya muy antiguas. Esto siempre ha sido así. Lo que te decía antes de cuando voy a un bautizo. Digamos que un bautizo es igual que un libro. Yo a lo que voy es a reflejar cómo es este bautizo y que quede bien. Que tengan constancia del bautizo los padres. Pero, si durante este hecho hay una foto que yo la veo y me hace click, yo la hago y me la quedo para mí. Me pasa exactamente igual que en los libros. Eso no quiere decir que fotos que aparecen en los libros no pueden ser expuestas, muchas de las imágenes de los libros aparecen después en las exposiciones, individualmente sirven. Con los documentales no puedes pensar en planos aislados y luego pegado uno con otro, sino que es todo un conjunto lo que tienes que pensar".

(R. Masats, Madrid, 20 de marzo de 2000) -“Posiblemente sea más esteticista en color que en blanco y negro, pero me doy cuenta de que mi fotografía es más esteticista por dos razones, que en realidad son la misma. Posiblemente, después de haber estado unos años haciendo cine y documentales, cuando vuelvo a la fotografía en color me la tomo de una manera distinta a como me tomaba el blanco y negro, menos directo y menos de la gente y todo esto; pero aparte de esto, está también la selección que hago de las fotos para publicar. Es decir, hay muchas fotos de gente, que a lo mejor en blanco y negro funcionan pero en color no. Aunque haga muchas 


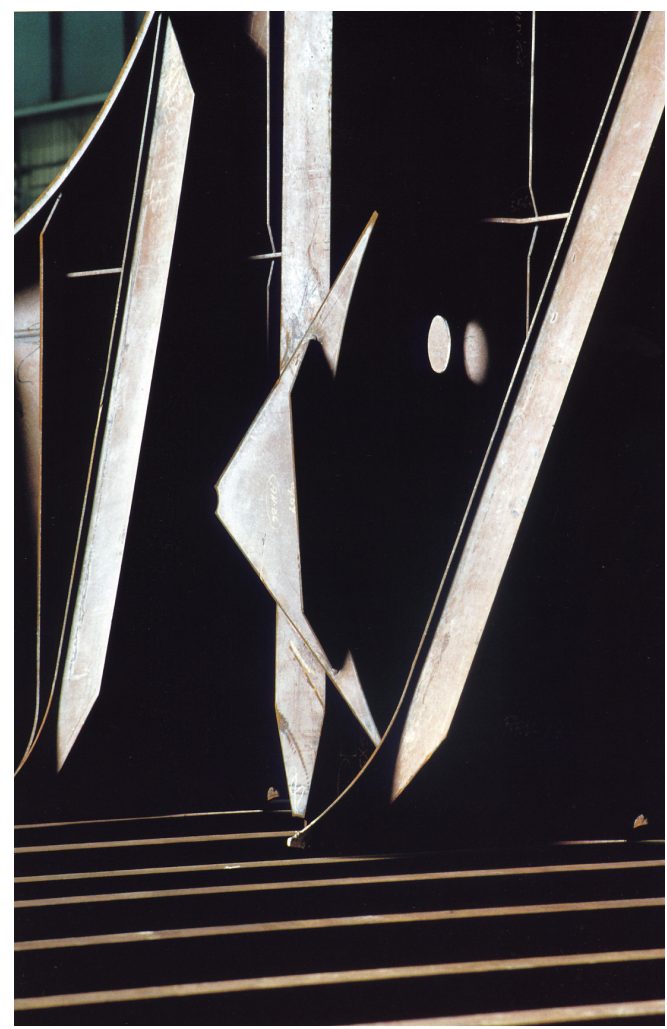

Ramón Masats, “Puerto Real (Cádiz)," 1991.
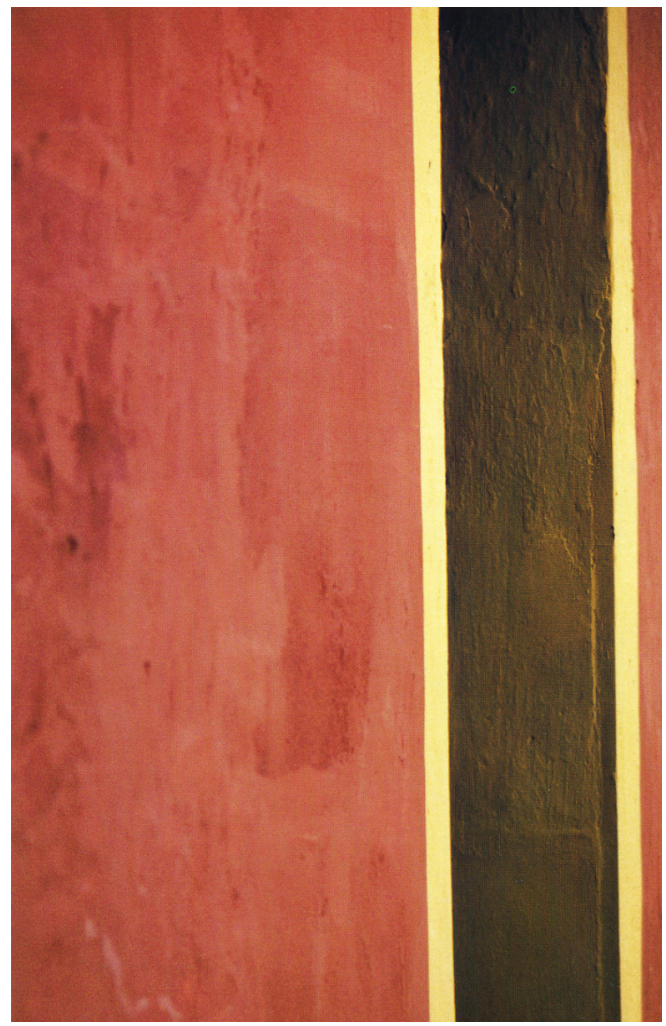

Ramón Masats, “Sevilla”, 1989.

fotos de gente, luego en mis libros no salen porque no las selecciono para ser publicadas. Es el esteticismo dos veces, como fotógrafo y como seleccionador. Hay quién dice que no, que prefiere el blanco y negro...".

La salida que encuentra Masats, como tantos otros, para poder solucionar lo que hemos convenido en denominar como esquizofrenia profesional, esa bipolaridad que se establece entre la realización de una obra mercenaria de subsistencia y, al mismo tiempo, la producción de una obra personal, es editar de un modo diferente. Si es para el cliente, y este cliente no es suficientemente inteligente y/o sensible para aventurarse a ofrecer la interpretación personal, experimental y diferente de la mirada de Masats, éste ofrece lo que se le pide, pero cuando su trabajo se integra en el contexto de una obra más propia, entonces sólo cuenta su opinión.

-Estas fotos del puerto no son las que estaban en el libro de astilleros.

(R. Masats, Madrid, 17 de julio de 1999) -“No, porque en el libro de astilleros había algunas que les gustaban más que éstas. Y claro era un encargo de astilleros. Yo les di lo que a mí me gustaba y les dije lo que me gustaba a mí, y me parece que en algunas me hicieron caso y en otras no. Estaban en su derecho. Lo que pasa es que, cuando yo hago una exposición, decido yo".

(R. Masats, Valencia, 25 de marzo de 2004) -“Curiosamente, en estos últimos momentos, que ya no hago casi nada a nivel profesional, lo que estoy haciendo son formas que es lo que empecé haciendo. Es como una pescadilla que se muerde la cola porque en este momento si me encargan algo de reportaje, lo rechazo. No me interesa. Vuelvo a hacer lo que hacía antes. Veréis 
que mis últimas fotografías en color vuelven a mis principios, que es lo que me pide el cuerpo".

(R. Masats, Madrid, 20 de marzo de 2000) -“Yo, cuando empecé, utilizaba mucho las meras composiciones de formas, puramente plásticas. Luego me hice un fotógrafo mucho más directo, y ahora he vuelto otra vez a la plástica, un poco pictórico... Quizá un poco surrealista, pero no son completamente pictóricas. No sabría definirlo bien, por qué son pictóricas, pero tienen algo más. Siempre procuro que vayan un poco más allá, que no se queden solamente en algo plástico. A veces lo consigo y otras veces no, como en el caso de las paredes. Me gustan mucho las paredes".

(R. Masats, Valencia, 25 de marzo de 2004) -“A mí -dentro del reportaje- siempre me ha gustado el detalle, no sólo el hombre sino también qué cosas hace el hombre. Inconscientemente busco un ritmo, una cosa... No lo voy a llamar arte, porque me parece pedante, al ser inconsciente. Llamarlo arte o no... son discusiones que no me interesan. En las cosas existe también una belleza que a mí últimamente me gusta mucho más que el reportaje, que ya no me...".

-¿Con qué visión hacen las fotografías? ¿Predominan en ella los valores plásticos o los narrrativos?

(R. Masats, Segovia, 20 de octubre de 2004) -“Yo creo que en este momento, mi visión es más estética que al principio. Al principio, en mi caso, yo hacía reportaje mucho más espontáneo y ahora en este momento hago las fotografías más reflexivas. Esto pasa como con todas las cosas. Cuando eres joven tienes potencia y cuando te haces mayor tienes más reflexión... Digo yo. En todos los aspectos".

-En tu caso el color es más irrealista que el blanco y negro?

(R. Masats, Madrid, 20 de marzo de 2000) -“Sí, yo voy por otro lado, quizá más esteta, más surrealista".

-Cuando hacías blanco y negro realizabas junto a las fotos de reportaje más directas alguna foto más abstracta...

(R. Masats, Madrid, 20 de marzo de 2000) -“Sí, esto es evidente, puesto que en las primeras fotos mías de aficionado, había ya muchas paredes y muchas cosas de éstas. Es decir, que no me ha venido con el color, a lo mejor se ha desarrollado más, pero ya me venía esta parte... si queréis llamarla pictórica, aunque yo estoy muy en contra de la fotografía pictórica".

El reportaje humanístico que reportó los mejores trabajos de Masats y que analizaremos en el siguiente capítulo se desvanecerá durante este último periodo. ¿Por qué? Las razones aducidas por Masats para renunciar al reportaje son de índole pragmática y social.

(R. Masats, Madrid, 17 de julio de 1999) -“Lo que pasa es que poco a poco ha ido... Frente a lo que hecho de fotografía de la realidad, se ha ido perdiendo. Últimamente con el color me parece a mí que estoy volviendo a la fotografía de formas, a lo mejor es porque ya no es tan fácil retratar a la gente".

- ¿Se muestra más agresiva ante la cámara?

(R. Masats, Madrid, 17 de julio de 1999) -“Creo que me he ido volviendo más pudoroso con el tiempo. Creo que he ido perdiendo el descaro que tenía antes para enfrentarme a la gente. A lo mejor te planteas... ¿Y si a esta persona la perjudicas por fotografiarla en este momento, aquí...? Llega un momento que me cuesta más retratar a la gente".

-Y esto es por ese pudor que tienes...

(R. Masats, Madrid, 17 de julio de 1999) -“0 a lo mejor es que me gusta menos la gente”.

(R. Masats, Madrid, 20 de marzo de 2000) -“Antes, cuando empezaba, la gente era mucho más receptiva. Era mucho más amable, y ahora es mucho más difícil. La gente es un poco más agresiva, y no considero que sea malo. Tiene la sensación de que la imagen le corresponde más... No lo sé. Es que me molesta fotografiar a la gente. He perdido esta agresividad o espontaneidad". 
(0. Maspons, Barcelona, 20 de octubre de 1999) -“Ramón Masats como Colom, lo que sí se podía decir es que tenían audacia. Ramón tenía hasta chulería. Un día estábamos haciendo fotografías juntos, cuando alguien lo regañó porque estaba haciendo fotos y tal... ¡Ramón se puso chulo y lo amenazó con pegarle un Leicazo! Está claro que no lo hizo, pero lo amenazó".

- ¿Tú crees que hoy en día se podría hacer The Family of Man, exactamente igual que entonces?

(R. Masats, Madrid, 4 de septiembre de 2002) -“Aparte de la desaparición de las revistas ilustradas, hay otro problema que creo que está cambiando mucho la estética fotográfica. Ahora no puedes ir por la calle haciendo Cartier-Bresson porque como te vean una foto publicada te pueden poner un puro que se te enciende el pelo. ¡Huy, si publicas una foto...! Vendrá un abogado, te buscará y buscará lío para que pagues y tal. Es decir, la estética fotográfica la está cambiando la Judicatura, no la evolución de un arte. Tú ves los periódicos, la cantidad de fotos, de gente que tiene que ir con recuadros en la cara. No solamente los guardaespaldas y los guardias civiles y todo esto... Yo creo que menos Ronaldo todo el mundo se tapa la cara. Creo, además, que las editoriales... Publican libros de fotografía, en el extranjero más que aquí, pero van por otro lado. La televisión ha sido la que ha cambiado la fotografía, pero mucha de la culpa de todo esto la han tenido las reclamaciones de los derechos de imagen. No quieren tener problemas. Por eso se van a África y a Sudamérica a hacer reportaje. Para evitar muchos de los problemas que tendrían si tuvieran que fotografiar aquí".

“Lo llamativo de las nuevas fotos de Masats es que renuncian voluntariamente a retratar al hombre y la mujer de la calle en su rutina diaria (...) y en las escasas ocasiones en las que los rostros humanos pasan a ocupar el interés de la cámara, lo harán siempre engalanados para la ocasión, una ocasión que es siempre pública y preformativa. Todo esto nos lleva a que los retratos de Masats de esta última etapa han roto todos los anclajes con el realismo y parecen más bien sacados de un catálogo de lugares comunes, de tópicos" ${ }^{\prime 60}$.

Vamos a ver cómo, después de pasar por Televisión Española y volver a la fotografía en color, se enfrenta al reportaje Masats. Él mismo nos desvela la manera en la que preparó alguna de sus fotografías de reportaje.

(R. Masats, Valencia, 25 de marzo de 2004) -“Normalmente no manipulo. Sí lo he hecho alguna vez, después de hacer televisión. Y es que, cuando estas haciendo televisión, llamas a producción y les pides una viejecita para que salga en un plano por aquí y producción te la facilita. Mientras la viejecita viene se espera el equipo, o hace otro plano en donde no hace falta la viejecita. Eso no se me había ocurrido hacerlo antes de hacer cine y televisión. Es decir, en las fotos de blanco y negro no hay ninguna foto, digamos, preparada. En color hay fotos preparadas pero creo que no lo parecen. Eso sí, procuro que salgan de una lógica. Así, por ejemplo, en esta imagen la chica era la novia de mi hijo. Yo ya tenía todo preparado y me faltaba una esperanza en el futuro. Entonces cogimos a la novia de mi hijo y la tuvimos que preñar. Le pusimos un bombo y venga a pasar hasta que conseguí la foto que yo quería. Puede parecer espontánea pero está verdaderamente preparada".

Sobre esta misma fotografía Óscar Tusquets escribía:

\footnotetext{
“Tomemos ahora una foto totalmente diferente: la de un Madrid modernizado y americanizado. Una chica encinta pasea por un espacio de nuevo urbanismo. Al fondo, delante de unos rascacielos de arquitectura internacional, se ve un muro cubierto de las pintadas que los grafiteros realizan para expresar su individualidad y que en todos los rincones del mundo son idénticas. Esta fotografía se puede ver -o un arquitecto deformado por la geometría puede verla- como una sutil composición de prismas y esferas.
}

60 Cerdán, Josetxo, op. cit., pág. 163. 


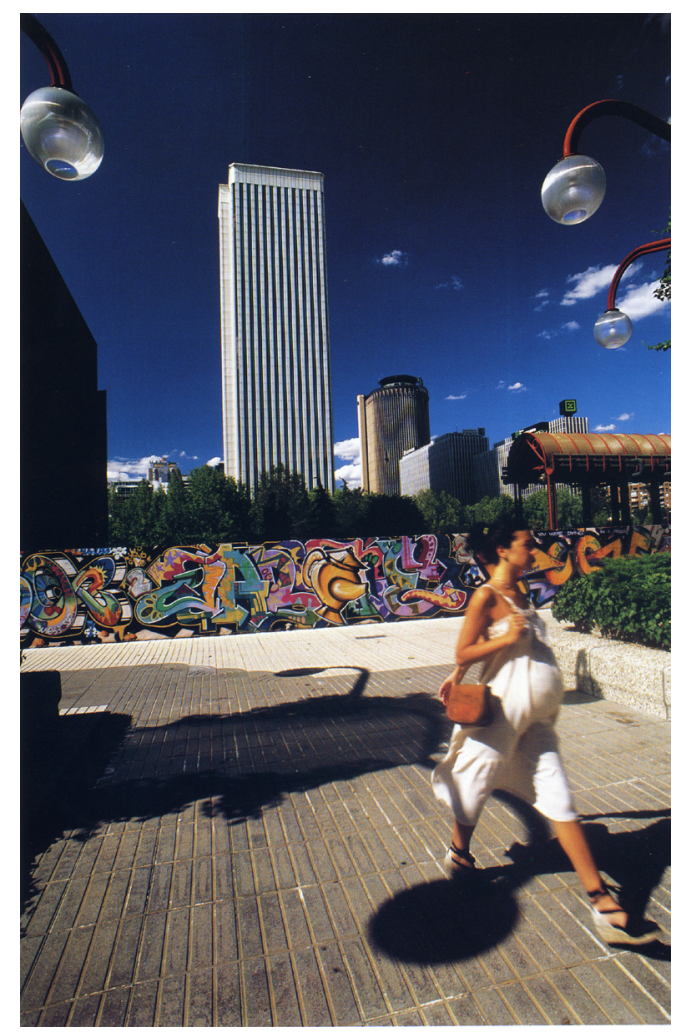

Ramón Masats, “Madrid", 1995.

Prismas, los modernos edificios; esferas, los globos de las farolas de diseño y, en bella metáfora, el bombo de la joven encinta. Pero para la mayoría de los observadores es un retrato del nuevo Madrid. Todo en ella transmite un mensaje de alegría y optimismo. Madrid ya no es aquella ciudad gris, cargada de carácter pero también de miseria y tristeza; Madrid es una ciudad cosmopolita, la más yanki de Europa, menos pintoresca pero también menos mugrienta y casposa, una ciudad que se expresa en tecnicolor. En este caso no es la composición abstracta la que exige el color a Masats: es el tema"61.

Para de evitar esos conflictos legales a los que hemos hecho alusión Masats es incluye a sus familiares y conocidos en sus imágenes de reportaje como si fueran personajes anónimos. Estos personajes son utilizados, como dice Josexto Cerdán, para recrear una vez más los tópicos. Esta preparación de los temas, aunque ya la podíamos rastrear en su etapa en blanco y negro, está mucho más presente en sus fotografías en color.

Al respecto de la fotografía de la mano con los cuernos en Madrid, señala:

(R. Masats, Madrid, 20 de marzo de 2000) -“Esta foto que parece espontánea no lo es. Estos cuernos son de mi hijo llamando cabrón a su padre. No... ya sabéis que es mi ayudante y se me ocurrió que quedaría bien, además es una cosa muy madrileña, y era un libro sobre Madrid. Por ejemplo, tengo una foto en la que sale Paloma, mi mujer. La puse como si viniera de la compra, enfrente de la bestialidad ésa de la televisión. Y claro, aquí está todo preparado, sabiendo cuándo se cerraban los semáforos, porque aquí pasan coches continuamente y tienes que vigilar. Además no es un paso de peatones, es la cúspide de la calle, muy cerca del paso de peatones. Hice muchas 


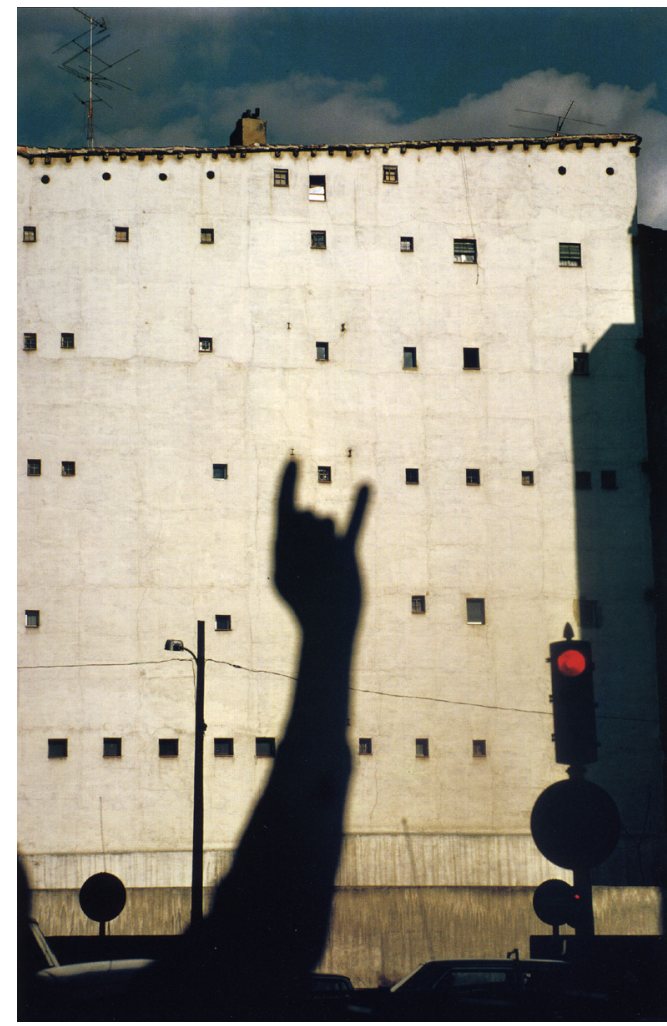

Ramón Masats, “Madrid”, 1985.

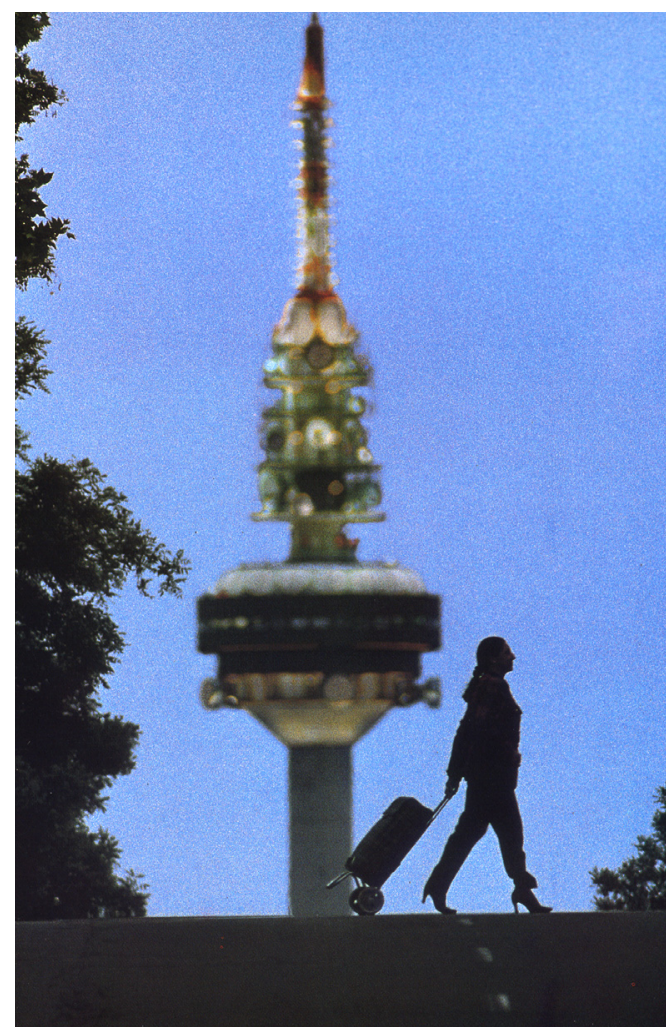

Ramón Masats, “Contraluz en el Pirulí”, 1995.

fotos para que la cogieran en una postura adecuada. Coordinados con una radio portátil, le decía: «Ahora hacia la derecha, otra vez, ahora al revés...». 0 sea, es una foto absolutamente montada. Sucede lo mismo con esta fotografía. Es de un pueblo de Valladolid, donde hice el libro Viejas historias de Castilla la Vieja. Recordaba que era un pueblo con un osario y pregunté donde estaba el osario. Me dijeron que se encontraba muy cambiado. Está mucho mejor, porque hay una pared que cuando fui por primera vez no estaba, y no salió en el libro de Viejas historias de Castilla la Vieja. No tenía una foto, eran sólo calaveras, pero no tenía foto. Entonces, me dijeron que las llaves las tenía el maestro. Fui a la clase, pregunté por el maestro y le dije: «¿No le importaría a usted ponerse aquí?» Y lo que hice fue darle una exposición muy larga, cercana a un minuto. Puse al hombre y hacia los cuarenta segundos le dije: «Márchese por favor», y se marchó. Hice varias tomas, pero todas con el mismo resultado fantasmagórico del hombre ahí, que es lo que yo pretendía, claro".

Como podemos deducir de lo señalado parece que Masats no se ve obligado a amarrarse a una realidad absoluta e inalterable. Aunque no creemos que nuestro autor aceptara en el color estos extremos, es posible que esta laxitud en lo concerniente a la realización de una fotografía socialmente comprometida y, paralelamente, escorada a la investigación en torno a valores plásticos y a la mejor representación del tópico, se deba a una intuida influencia de la postmodernidad, como sugirió Josexto Cerdán. En cualquier caso, nunca será una apología de la mentira y/o al simulacro, tal y como ya veremos.

(R. Masats, Madrid, 27 de diciembre de 2006) -“El libro del Toro lo que pasa es que no es 


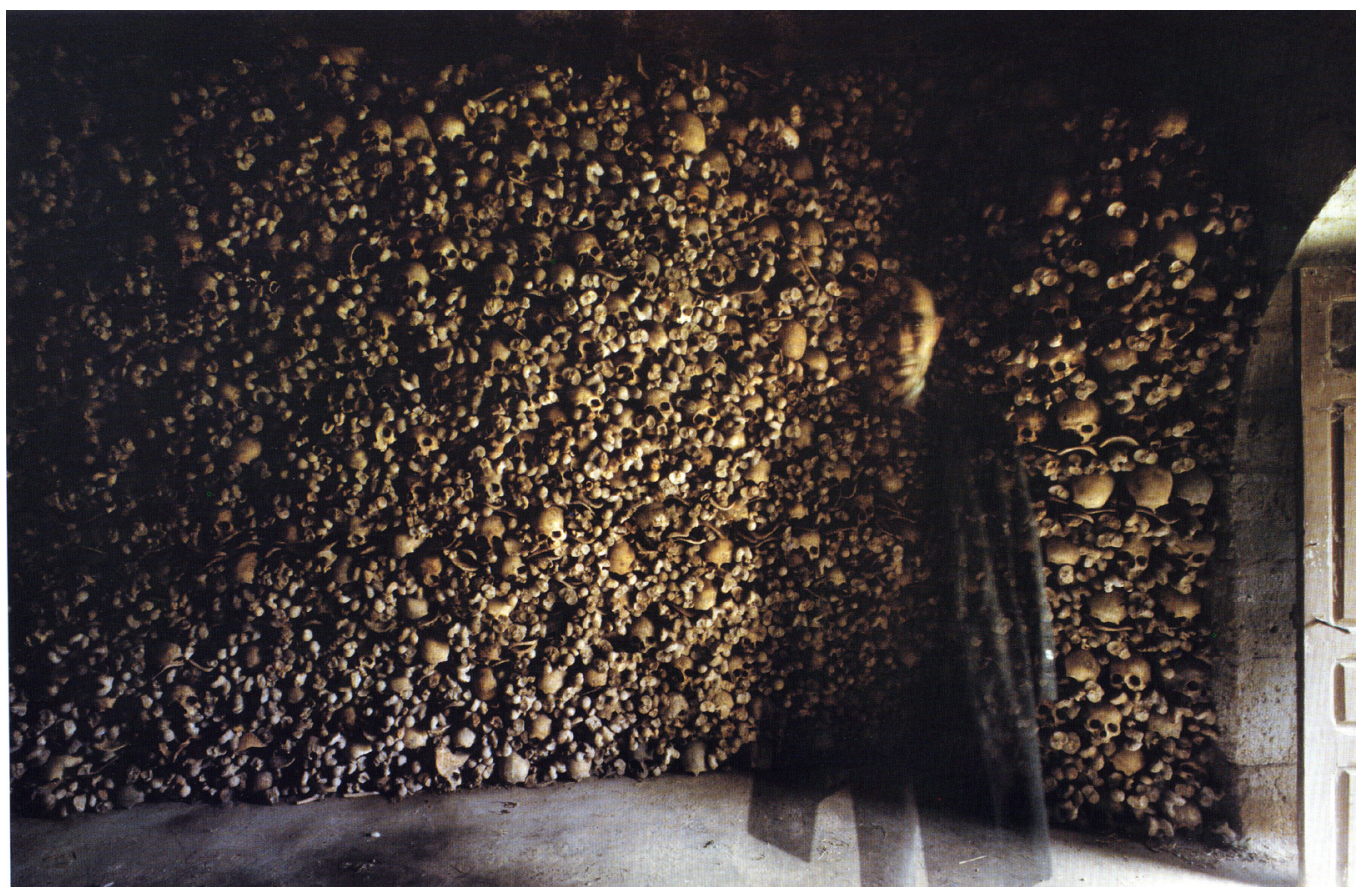

Ramón Masats, “Wamba (Valladolid)”, 1982.

totalmente mío, en el sentido de que... ¿Cómo te explicaría? Propuse hacer el texto a un gran escritor, que era el crítico taurino de El País, que ha sido de lo mejor que ha habido en la crítica taurina reciente. Se llamaba Joaquín Vidal, ha muerto ya. Yo creo que le tuve excesivo respeto a él. En la parte de las corridas del libro estuvimos viendo muchísimas fotos y habían fotos que a mí me gustaban más. Pero me metí demasiado en el criterio de un gran experto. Había fotos que me gustaban a mí, pero que no eran correctas porque el torero no tenía el pie en el sitio, la mano no la tenía baja como era ortodoxo... Entonces él elegía otras fotos -que a mí también me gustaban, si no, no hubiesen estado en la preselección- en la que el gesto taurino era más verdadero".

(R. Masats, Valencia, 25 de marzo de 2004) -“Todo lo que he proyectado aquí me gusta. Muchas fotos que habéis visto, las he hecho mientras hacía trabajos profesionales. Siempre he buscado tiempo para hacer cosas para mí que a lo mejor no se publicaron en su momento. Entonces... sí hay una cosa que he notado en mi fotografía y es que es muy desperdigada. No hay, como en otros fotógrafos, una unidad no sólo temática si no también estilística. Creo que... picoteo mucho".

- ¿Esta falta de coherencia te ha podido perjudicar?

(R. Masats, Valencia, 25 de marzo de 2004) -“Puede ser que me haya podido perjudicar frente a los ojos de otras personas, pero uno es como es y tiene que aceptarse; y ha sido así y estoy contento. Pero no te podría decir si me gustan más los libros... o me gustan las fotos sueltas".

Quizás buscando precisamente esa difícil coherencia en su trabajo, Masats encuentra una solución sorprendente en su exposición antológica Contactos: realizada del 10 de junio al 23 de julio de 2006 en la Real Fábrica de Tapices de Madrid. La misma fue comisariada por Chema Conesa y coproducida con ocasión de su premio Nacional de Fotografía (2004) por el Ministerio de Cultura la Dirección General de Bellas Artes y Bienes Culturales, la Subdirección General de Promoción de las Bellas Artes, Lunwerg y la Real Fábrica de Tapices. 
Folleto de la exposición, 2006.

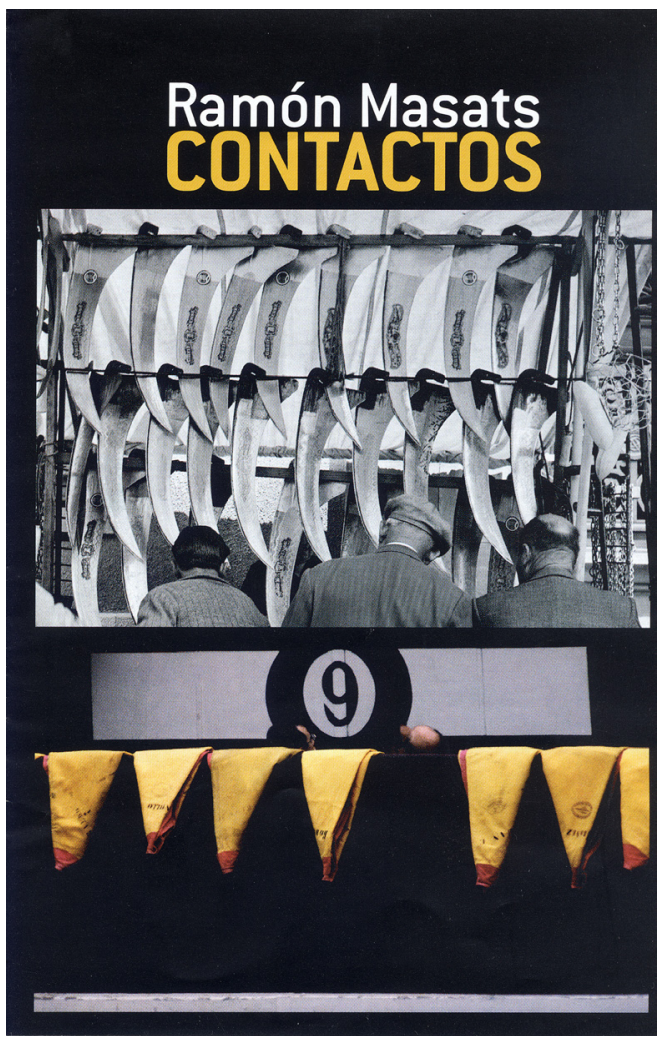

“La historia es entrar en el archivo de Ramón Masats y hacer el siguiente planteamiento: ¿Qué hay en la cabeza de un fotógrafo desde que empieza a hacer fotos, cuando tiene 17 ó 18 años y está empezando, se compra una cámara... hasta que tiene 74 años? La última foto de la exposición está hecha en el año 2006 y es de la exposición que hizo hace menos de un mes en Burdeos...

Entonces, lo que yo puedo ver, es que las fotos iniciales estaban hechas con la misma estructura y con la misma cabeza compositiva y fotográfica que las fotos finales que sigue haciendo todavía. La conclusión es que un fotógrafo, a lo largo de su vida, tiene una forma de mirar que no cambia. Cambian los contenidos, cambia la técnica, cambian los formatos, cambia lo que quieras... pero puedes descubrir que desde el año 54 ó 55 hay una continuidad en la forma de mirar que llega hasta sus fotos del año 2006. Y me he llevado una sorpresa yo mismo, porque no había visto el vídeo que ha elaborado de sus años de televisión, y en ese vídeo están las claves de su forma, de su ritmo, composición y exactitud.

Ramón Masats para mí es una especie de francotirador, donde ve algo que le interesa y hace una foto. Sus negativos nunca son el resumen de un montón de situaciones para llegar a una concreta, sino que dispara y en un par de fotogramas consigue lo que otro está logrando poco a poco, y ves que son fotogramas que poco a poco van creciendo hasta llegar a la foto hecha. Ramón Masats donde pone el ojo pone la bala, en un símil estúpido, pero claro. Y eso mismo sucede desde sus años iniciales hasta sus años finales. Pongo un ejemplo: hay un tríptico donde hay una foto de una vaca que resulta que es un examen, un juego, una propuesta que hace el Círculo de Fotografía del Casino de Tarrasa donde proponen como tema a los aficionados fotografiar una vaca. Él fotografía una vaca y hace un cuadro absolutamente abstracto, y eso lo hace con 17 años, y esa misma mentalidad de cua- 
dro abstracto la extrapola al color 50 ó 60 años después... y eso es lo que a mí me llamó la atención. Este hombre siempre construye de la misma forma aunque cambien el contenido.

Esa, yo creo, es la aportación del lenguaje de Ramón Masats. Es un señor que sincopa y sintetiza todo lo que hace. Cualquier mirada, cualquier expresión gráfica, se trata de hacerlo lo más breve para que siendo lo más breve sea lo más rotundo, lo más directo y lo más esencial posible. Y ese es el resumen que yo he visto en todo esto y eso es lo que resume esta exposición. Fotografías con esa separación de años donde por un lado está el aspecto geométrico, que es así de claro, y en otras está el aspecto irónico de la mirada de Ramón Masats. Ramón Masats es un señor cachazudo que evita las palabras y prefiere que una sola foto defina todo lo que hace, y esa es su gran aportación al lenguaje fotográfico"62.

Las imágenes de más plásticas aparecen misteriosas y sugerentes, aunque esta vez aparezcan agrupadas en dípticos. Unas parejas reunidas en función de una intuición, un pálpito que responde en ocasiones a estructuras formales encontradas cincuenta años más tarde o a relecturas de imágenes completadas a lo largo de toda una vida. Muchas de esas parejas tienen una relación clara mientras que otras son menos evidentes, mucho más complejas. Masats no se ve capaz de explicarlas mejor que como lo exponen las propias fotografías: actitud, ésta, que ha mantenido durante toda su carrera (con escasas excepciones, según hemos podido comprobar).

"«Son sugerencias», explica. «Algunas muy evidentes y otras que probablemente sólo vea yo. Pero me gusta buscar esas relaciones extrañas y poéticas que se dan entre las imágenes». Dispuestas para que cada cual las encuentre o invente como quiera. Son asociaciones libres, a veces muy parciales 0 subjetivas. Siempre muy buscadas"63.

Es muy significativo que en la dedicatoria del catálogo de Contactos utilice una cita de Lou Reed de lo más reveladora, en este sentido.

“Que yo sea el autor de estas canciones no significa forzosamente que sepa de qué van"64.

\subsection{EL REPORTAJE}

Aunque en el epígrafe precedente hemos hecho referencia, debido a cuestiones estrictamente conceptuales, a una etapa cronológicamente mucho más reciente en la trayectoria de Masats -la vinculada con el color-, conviene ahora que retomemos el hilo diacrónico y volvamos al año 1957.

Cuando Masats se va a vivir a Madrid ya tiene claro que el tipo de fotografía que va a desarrollar en la revista Gaceta Ilustrada: el reportaje. Aquellas dudas que se le presentaban meses antes -entre hacer fotos de contenidos más abstractos o fotos de reportaje- y que podíamos rastrear en su primer exposición con Terré y Miserachs, quedará resuelta a favor del reportaje. Aunque nunca abandonará la obra de contenido plástico, es más, como acabamos de observar la recuperará completamente en su etapa de color, lo cierto es que Masats entrará definitivamente en la Historia de la Fotografía como uno de los mejores reporteros de su generación. Recordemos, una vez más, aquellas palabras de Masats que, a modo de manifiesto personal, transcribe

62 Entrevista realizada por el Dr. Pedro J. Lavado Paradinas, Jefe de Servicio de Educación y Difusión, Subdirección General de Promoción de las Bellas Artes del Ministerio de Cultura, a Chema Conesa, comisario de la exposición Contactos de Ramón Masats. Esta entrevista posee un carácter privado y nos ha sido facilitada directamente por el autor, deferencia que agradecemos sinceramente.

63 Yánez, Jara, “Miradas en doble”, en El Periódico, Dominical, 16 de julio de 2006, pág. 51.

64 Reed, Lou, citado en Masats, Ramón; Tusquets Blanca, Óscar; López Mondéjar, Publio y Conesa, Chema, op. cit., pág. 7. 
un miembro de la Agrupación Fotográfica de Cataluña con ocasión de su premio en el V Trofeo Luis Navarro, en el Salón de Vanguardia de la Asociación Fotográfica de Cataluña, en el gran año de Masats, 1957.

“El reportaje -afirma- es arte cuando deja traslucir el «alma» (...) La fotografía debe ser, ante todo, humanidad, o documento humano, verismo, y no falseamiento de la realidad. Ningún otro arte puede captar el momento con tanta autenticidad. El reportaje es pues, hijo de nuestra época. Se debe, por tanto, realizar con hondo sentido humano, y sin mixtificaciones de índole técnica o de encuadre" ${ }^{\prime 65}$.

Estas palabras que apelan a la ética, la autenticidad y la falta de manipulación de la realidad describen la actitud de cómo Masats se enfrenta a la vida para documentarla. En principio, no hay ningún truco técnico, no hay ninguna preparación o planificación previa. Sólo la realidad sometida al análisis irracional e incontrolable de una "supuesta" intuición, que como resultado ofrece una espectacular expresividad y comunicabilidad.

“El arte de Masats, técnicamente hablando, es de una suma simplicidad. Consiste en un objetivo, con una determinada abertura, abierto durante unas fracciones de segundo delante del modelo, delate de un trozo de vida. ¿En qué consiste, por tanto, el misterio de su expresividad? Ni siquiera usa y abusa del claroscuro, de los efectos de luz, de todo eso que, como en las aguafuertes, suele ser dramatismo. Lo suyo es un misterio claro, algo que baña sus obras, sin que sea posible aislarlo, atribuirlo a algo. Un misterio que se respira como el aire, y que convierte la realidad en sueño, en invención (...) A la larga se demuestra que es el hombre el que se vale de la técnica, no la técnica la que lo aplasta (...) La cámara no es sino lo que es la versificación a la poesía"66.

Siempre con sencillez, sin efectismos. Aparentemente sólo hay que estar ahí y apretar el botón en el momento preciso... ¿Cómo hacerlo? Su respuesta siempre apela a una imprecisa ambigüedad: la intuición, el alma, la inquietud, aquello que sólo lo disfruta el que lo tiene, que no se puede explicar, que no se puede transmitir y que no se puede aprender.

(R. Masats, Madrid, 20 de marzo de 2000) -“Fijaos qué cosas se pueden hacer en la naturaleza solamente aprendiendo a mirar. Eso es lo más difícil, y eso es lo que tenéis que aprender y eso no os lo puede enseñar nadie. Por muy buen fotógrafo o por muy buen profesor que alguien sea, nadie os puede enseñar a mirar. Lo único es que tenéis que discernir lo que os interesa".

-Entonces... ¿cómo me enseñarías a ser un buen reportero?

(R. Masats, Madrid, 27 de diciembre de 2006) -“Esto no se puede enseñar. Pero lo principal para un buen reportero es la discreción... No pude dejarme el pelo largo hasta que dejé de hacer reportaje con gente. Con todo, lo principal es llegar a un sitio y, aunque no sepas lo que vas a contar, que te lo diga el mismo hecho. Es decir, ir con una idea preconcebida a un reportaje es muy malo. Más o menos sabes de qué va la cosa y tienes una manera de pensar sobre este hecho, pero hay que dejar que el hecho te impresione y entonces empezar a hacer fotografías. Una cosa que es muy curiosa - pero que comentándolo con Koldo estaba de acuerdo- era que si vas a un sitio y no sabes qué hacer, empieza a tirar fotografías. Aunque sepas que estas fotos no te van a servir para nada, poco a poco te vas calentando, vas viendo cosas a través de la cámara y al final acabas explicando lo que te da el hecho en sí. Sea tu opinión a favor o en contra... Estéticamente, mis composiciones son intuitivas, es una cosa que no se puede estudiar. La armonía dentro del fotograma yo la veo y disparo". 


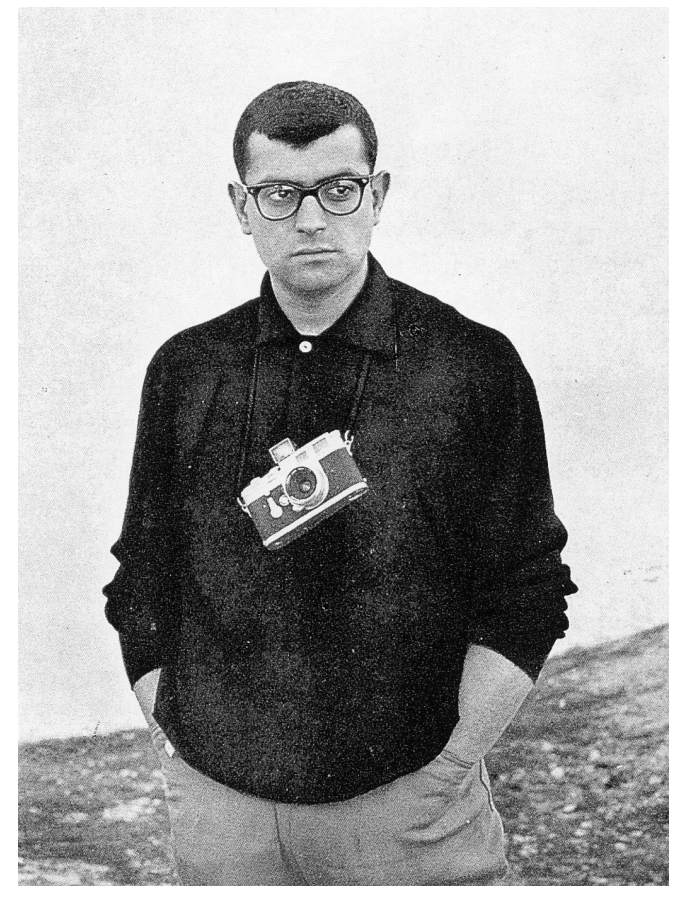

Aspecto de Masats en su época de reportaje. Foto de Paco Gómez, "Ramón Masats", 1960.

-0 sea, que ¿vas buscando o encuentras?

(R. Masats, Madrid, 27 de diciembre de 2006) -“Yo me dejo sorprender. A mí siempre me ha funcionado. Luego, poco a poco, cuando ya vas comprendiendo ya sabes qué fotos tienes que hacer para explicar tu punto de vista. Porque en este momento ya tienes tu punto de vista y entonces buscas las fotografías que puedes necesitar".

"Para su labor de reportero, Masats tiene como imprescindible condición, la intuición genial, su rápida comprensión de ambientes y caracteres, el ojo certero y la mente limpia de telarañas intelectuales que le simplifica la más compleja situación. Pero creemos sinceramente también que otros campos de la fotografía -llámese publicidad, retrato, modas, abstracción, desnudo, etcétera- necesitan de un fondo cultural formado por muchas horas de lectura, de estudio, de meditación, que sólo el tiempo irá decantando y que formará, por sedimentación, la solera necesaria para dotar de trascendencia a la empresa artística"67.

Pese a lo señalado por el propio autor, que somos muchos los que opinamos que la intuición tiene una mala defensa, hasta el punto de que llegamos a contradecir al propio Masats en esta cuestión. En ningún caso pensamos que sus fotografías se generan por casualidad, como él mismo, sin embargo, reconoce.

(R. Masats, Segovia, 20 de octubre de 2004) -“Lo que sí pasaba en aquella época -y sigue pasando hoy en día- es que cuando haces una buena foto en el corazón sientes una cosita que te dice: «Ésta es buena». Yo nunca me he encontrado en el laboratorio con una fotografía que no supiera que era buena. Lo que sí me he encontrado muchas veces es con fotografías que pensaba 
que eran buenas y cuando las he visto en el laboratorio me he dado cuenta de que no eran tan buenas. Pero una, por casualidad, una buena fotografía que yo no me haya dado cuenta en el momento de hacerla, eso no me ha pasado nunca".

(Carlos Pérez Siquier, Segovia, 20 de octubre de 2004) -“A eso es a lo que yo llamaba honestidad. Ese latido... Evidentemente, eran unas fracciones de segundo. Después, quizás, queríamos repetirlas para perfeccionarlas, pero no. Era el momento del latido. Después, en el momento del revelado, te dabas cuenta de que habías acertado".

(R. Masats, Segovia, 20 de octubre de 2004) -“0 no. A veces sentías...”.

(Carlos Pérez Siquier, Segovia, 20 de octubre de 2004) - “iHombre!, te podía fallar técnicamente".

(R. Masats, Segovia, 20 de octubre de 2004) -“No sólo técnicamente. Que lo que veía yo, en el negativo, no era lo que yo esperaba".

(Carlos Pérez Siquier, Segovia, 20 de octubre de 2004) -“Yo, generalmente, si no me fallaba la técnica, en lo que había visto sí acertaba y me daba buen resultado".

(R. Masats, Segovia, 20 de octubre de 2004) -“Pues, felicidades".

\begin{abstract}
“Pocos tan adecuados como Masats para representar una expresión estética de agilidad y veracidad tan acusadas. Todas estas fotos revelan fresca imaginación para analizar la realidad en sus aspectos más característicos, en su momento más expresivo. Un sentido innato de selección, en «tempo» (como instante y ambiente) y encuadre, hace de la oportunidad síntesis, de manera que se nos da el todo de una vez en cada caso. A esa «maestría» llega Masats sin sujetarse a «librillo» alguno de reglas que puedan aprenderse. Siente e intuye... y dispara. Eso es todo. Precisamente, su personalidad es su circunstancia pero presentada con intención no sólo informativa, sino "comunicativa» al espectador de su obra. Para ello; sencillez, agudeza, libre expresión formal y trascendente. La segunda consecuencia importante será, pues, la consagración -aún con el peligro propio de todas las consagraciones- de lo que estamos llamando «fotografía actual» por desentendimiento de lo hecho con frías, asépticas pautas técnicas, compositivas o falsamente sugerentes. Una poderosa corriente de sinceridad fotográfica orea estos paneles murales, sin huir por sistema de normas convencionales; sin fidelidad alguna a ellas tampoco"68.
\end{abstract}

Lo que resulta evidente, es que la realidad -por muy sugerente que ésta sea- no es suficiente per se para realizar una poderosa imagen fotográfica como las realizadas por Masats. La realidad debe ser analizada, deconstruida, limpiada y recompuesta fotográficamente para poder ser comunicada, leída y recordada. Valores plásticos y compositivos, son utilizados por Masats para anclar la imagen, igual que un arquitecto utiliza una estructura y unos cimientos para levantar un edificio. Puede haber belleza, y en Masats la hay a raudales, pero en el reportaje deben primar funciones comunicativas, expresivas, narrativas...

- ¿Hasta que punto es importante la anticipación para captar el momento?

(R. Masats, Madrid, 27 de diciembre de 2006) -“Esto es muy importante. La anticipación en cada foto, pero no el criterio previo sobre el hecho. Éste es uno de los valores que debe tener el reportero".

- ¿Y eso también es intuitivo?

(R. Masats, Madrid, 27 de diciembre de 2006) -“Sí, es una habilidad que tienes o no tienes. Hay que ser rápido. El dedo se te va, aprieta automáticamente".

-Además en aquella época no había motor.

(R. Masats, Madrid, 27 de diciembre de 2006) - “iQué va! Pero nunca he tenido el concepto 


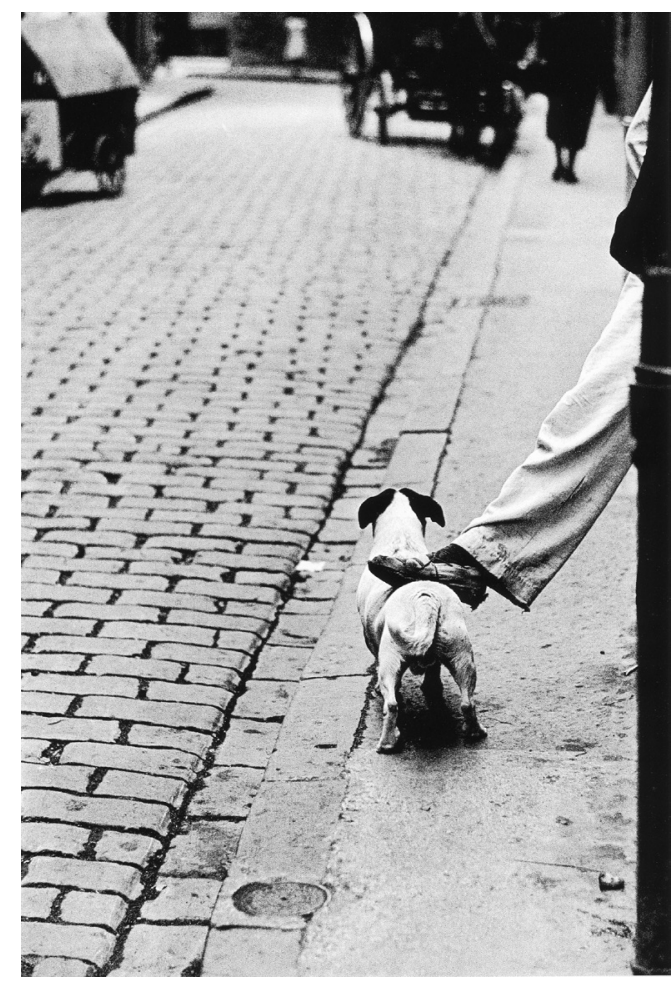

Ramón Masats, “Pamplona”, 1957.

de que había que ahorrar película. Eso desde el principio. A lo mejor es porque nunca he tenido grandes problemas de tipo económico. Cuando me metí en el profesionalismo, si me hubiera ido muy mal, me hubiera vuelto a vender bacalao. De hambre no me iba a morir. Pero nunca he necesitado ahorrar película porque casi todas las fotos de aquella época están hechas con un único disparo. Con una foto ya la tenía. Yo me acuerdo la sorpresa de Koldo Chamorro cuando vio que Los Sanfermines está hecho con noventa rollos. Es decir, que como fui varias veces, en una semana hacía 25 carretes, que es poquísimo. Ahora sí, cuando tiro intento mejorar el encuadre y tiro muchísimo más que cuando empezaba".

-Claro, porque ahora los elementos fotografiados son más estáticos y por eso te permiten tirar más y en aquella época... con cosas tan dinámicas...

(R. Masats, Madrid, 27 de diciembre de 2006) -“Exactamente, y además lo lógico sería que en aquella época fuera mucho más inseguro que ahora, que necesitara tirar más, pero tiraba poquísimo. Casi todas las imágenes son un solo disparo. Por ejemplo, si ves los negativos, la foto del señor con los pies encima del perro es una sola foto. Ahora, no por inseguridad, sino por intentar mejorarlo, pues tiraría tres, cuatro o cinco fotos. Mis fotos son muy de impacto, no son muy sutiles".

-Recuerdo ahora la imagen de la bailarina que está tomando café con el dedito levantado.

(R. Masats, Madrid, 27 de diciembre de 2006) -"Sí, Ludmila Tcherina".

-Eso del dedito es de una gran sutileza.

(R. Masats, Madrid, 27 de diciembre de 2006) -“Sí, pero es una sutileza que la ves enseguida. Tal como está compuesta con las sombras, el señor del bombín a la izquierda y ella como está... fíjate como si miras la foto, rápidamente ves el dedito. Mis fotografías no tienes que mirarlas durante mucho rato para saber de qué van. Por eso digo que son de impacto". 


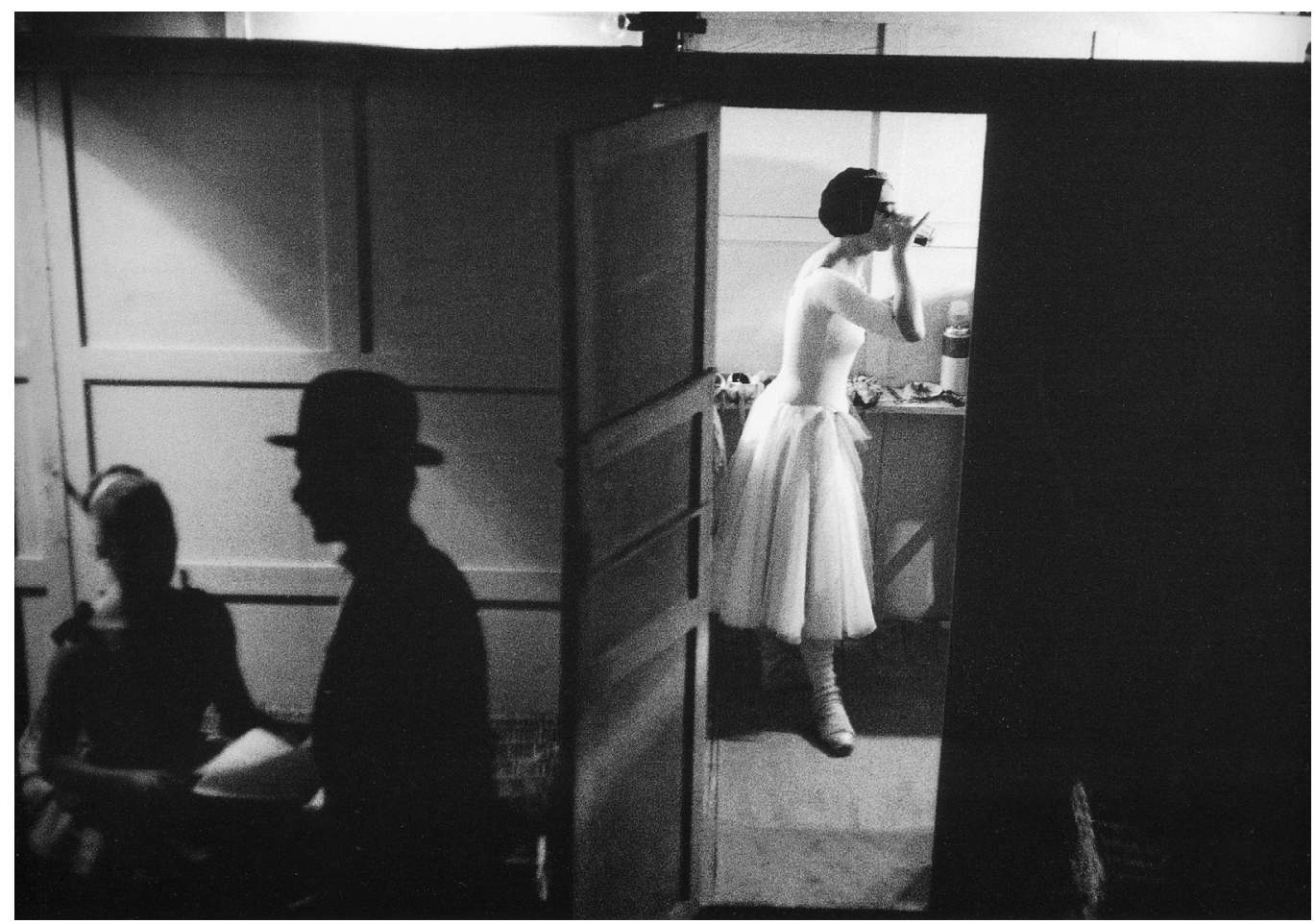

Ramón Masats, “Ludmila Therina”, 1964.

-Es decir que son muy limpias. Lo que no interesa no está, para que no moleste.

(R. Masats, Madrid, 27 de diciembre de 2006) -“Claro. Eso trabajando con angulares es muy difícil. Ahora en el libro de Cuenca he utilizado mucho un $14 \mathrm{~mm}$ de Tamron".

- ¿Por qué crees que se le ha dado tanta importancia a la foto del seminarista?

(R. Masats, Madrid, 27 de diciembre de 2006) -“Porque es la que más impacto tiene. No tienes que ver nada, está todo allí. También se le ha dado mucha importancia ahora porque los curas ya no llevan sotana y por la postura del mismo con todo este negro... Está muy bien compuesta".

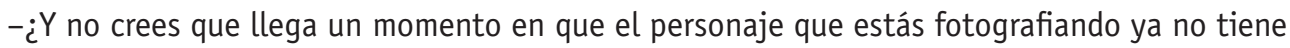
importancia como personaje en sí, y se convierte en un icono, en un concepto, en un símbolo de una época?

(R. Masats, Madrid, 27 de diciembre de 2006) -“Puede ser, la época, la nostalgia... Como foto es muy potente. El jugar con sotana es un anacronismo. No hay cosa más molesta para un tío que va a chutar que jugar con faldas hasta abajo. Supongo que no se las dejarían quitar".

- ¿Y esta foto te la compraron en el MOMA de Nueva York?

(R. Masats, Madrid, 27 de diciembre de 2006) -"La tiene el MOMA de Nueva York pero yo no sé cómo ha llegado allí. De repente vino una amiga mía y me dijo: «He visto tu foto en Nueva York». Pero yo no sé... Ahora las fotos se numeran. En aquella época te venía un amigo y te pedía la foto y se la regalabas. Era un planteamiento completamente diferente, no es que fuéramos menos mercantilistas, porque vivíamos de la fotografía. Ahora me preguntan por qué no empiezo a numerar. Imagínate que alguien me compre la foto número uno, y hay cantidad 


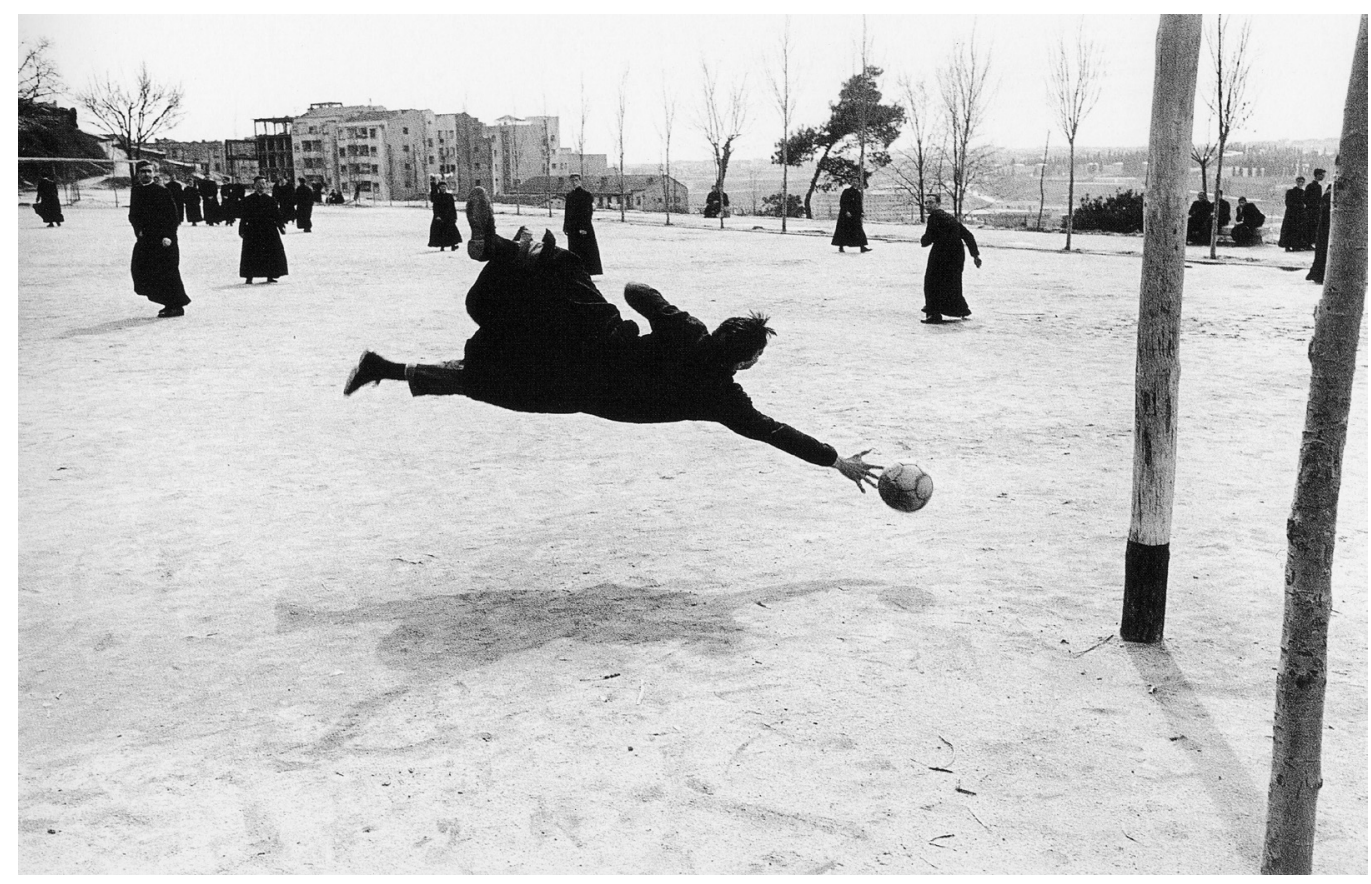

Ramón Masats, "Madrid", 1960.

de gente que ya la tiene. Aparte de que darle valor artístico a una fotografía porque se numere, a mí me parece una aceptación del mercantilismo de las galerías y todo esto, que me parece bien, pero en mi época no se llevaba".

“Ramón Masats es la obsesión por la pureza.

Para quien haya visto sus fotografías, no es necesario decir que sus dotes son las del reportero en el más puro sentido de la palabra. Aquí no hay composición, ni preocupación formal ninguna. Ni añadida ni innata. Porque lo que es innato en Masats es saber captar de golpe el valor del asunto en sí. Lo chusco, lo imprevisto, lo característico, siempre, de un acontecimiento, no escapan a la rapidez que se diría refleja su obturador.

No creemos que piense nunca en dónde un figura causaría mayor efecto plástico; sino simplemente lo que le interesa es «qué está haciendo aquella figura y por qué». Así narra maravillosamente -ingenuamente- lo que sus ojos ven. Sin ánimo de exageración y solamente en su valor anecdótico, podría decirse que Brueghel está a la vuelta de la esquina..."69.

De hecho, las mejores imágenes de Masats, aquéllas que forman parte de nuestra memoria colectiva de la España de los años cincuenta y sesenta, aquéllas especialmente comunicativas, disfrutan de una estructura sólida y segura, un tempo y un ritmo preciso, una frescura que las ha mantenido intactas pese al paso del tiempo.

(Koldo Chamorro, Pamplona, 21 de marzo de 2003) -“Es que cada vez los cambios son mucho más rápidos, casi exponencialmente, con lo cual las fotos caducan. Caducan y sólo se mantienen 
los trabajos que son serios. Todo lo demás... En un plazo de cinco años se puede ver perfectamente el trabajo de un «supuesto», lo que hay de plagio... rápidamente. Y en Ramón yo creo que no. Se mantiene... ¡Ojo! Las buenas imágenes de Ramón, se mantienen perfectamente. Se mantienen e, incluso, mejoran. Eso es una cosa que no se puede decir de todos los fotógrafos. Aunque siempre hay una especie de recuperación nostálgica de fotos viejas. Donde más se ve es en el tema erótico. Las fotos de contenido erótico se las ve viejísimas. Lo que pasa es que tienen esa especie de puntillo nostálgico, romántico... Pero como imágenes son muy cautivas del tiempo. Yo creo que de todas las escrituras fotográficas, la que más rápido envejece es el desnudo. Cuando es malo... Y sobre todo las fotos supuestamente fetichistas y de tratamiento erótico. Todas estas están absolutamente sobrepasadas".

(0. Maspons, Barcelona, 23 de octubre del 2004) -“Al llegar a Madrid Ramón, desde el primer día, entroncó con la gente de cultura, cosa que nosotros en Barcelona también hacíamos. Esto hoy día no sería posible repetirlo. Los fotógrafos nos encontramos con una situación favorable que supimos aprovechar. Además tuvimos la suerte de no ser nada envidiosos como eran, por ejemplo, los directores de arte, que siempre procuraron fastidiarnos porque nosotros ligábamos más. Cuando yo iba a Madrid de vez en cuando, siempre esperaba con curiosidad saber como «respiraría» Ramón, ya que evolucionaba constantemente. Nunca era el mismo. Él siempre fue más de izquierdas que yo, ya que yo era «Gauche Divine» total y él estaba más concienciado. Por ejemplo: un día me empezó a explicar la desgracia que representaba en España lo de los monocultivos: la naranja en Valencia, el aceite en Andalucía, las minas en Asturias, los tejidos en Cataluña y el membrillo no sé donde. Yo le decía que no me parecía mal y él me respondió que yo no entendía nada y que lo mejor para Andalucía sería que arrancasen todos los olivos. Yo luego le decía que cada vez estaba más rojo y comunista. Ramón, al mismo tiempo, es el que sacó mejor partido del trabajo que le daban en los Ministerios, en donde tenía buenos amigos que seguramente eran más fachas que yo. Pero Ramón tenía dos caras, era progre y trabajador. Muy rápido, y cuando tenía un encargo trabajaba de sol a sol, nunca mejor dicho, pues empezaba a las seis de la mañana y trabajaba solo, cual lobo estepario (el título se lo di yo). Sólo aceptó compañía, la de su hijo, años después".

(Koldo Chamorro, Pamplona, 21 de marzo de 2003) -“Es complicado hacer una reflexión con cierta justicia desde el punto de vista histórico. Analizando, ahora, un poco la trayectoria de Ramón, lo primero que destaca, por lo menos para mí, independientemente de los territorios de interés de Ramón, de las estrategias de trabajo, lo que más destaca inicialmente, es que, de algún modo, él, posiblemente de un modo poco consciente, replantea cuál es el ámbito de la fotografía entendida como reportaje. Ahora, de algún modo... claro, el reportaje que es un criterio fundamentalmente taxonómico, es una forma también de poder abordar contenidos de trabajo y de poder reflexionar sobre ellos. De algún modo está enfrentado con lo que se puede entender con la fotografía de autor, con todas las derivaciones que conlleva. Hasta tal punto que, hoy en día, posiblemente, empiece a aclararse que la fotografía de reportaje en realidad no ha existido nunca, ya que es una forma de calificar cierto tipo de discursos. Pero claro, no es que fuera un tipo de discurso, sino que eran un montón de contenidos de discursos completamente distintos. Y a él hay que agradecerle el que lo haya hecho. Yo no sé si él se lo ha planteado. A mí, que me interesa mucho el trabajo de él, y que lo valoro, a mí es la parte que más me interesa de Ramón. Es decir, cómo rompe el pretexto del reportaje y lo convierte en una forma de escritura mucho más amplia".

-¿Por eso a él le da igual que le encarguen un reportaje concreto, puesto que en realidad cuando está fotografiando no es tanto el tema, Los Sanfermines por ejemplo, como la manera de plantearlos? 
(Koldo Chamorro, Pamplona, 21 de marzo de 2003) -“Sí, bueno, evidentemente es muy difícil escaparse de la parte anecdótica porque es un poco la referencia común. Quiero decir que es, de algún modo, lo que hace algo comprensible desde un punto de vista universal aspectos de la cultura. Quiero decir, que la cultura extremeña no es la misma que la cultura castellana, y son territorios colindantes... Pero bueno, independientemente de la parte anecdótica, él lo que intenta es describir ese mundo. Si uno hace un análisis bastante severo de los distintos trabajos de Ramón, lo primero que uno encuentra, una vez hechas las descargas más o menos puntuales, más o menos anecdóticas que sirven para razonar la existencia de una imagen, es que esa imagen tiene unos elementos de construcción terriblemente teatrales. Cuando digo teatrales no lo digo desde el punto de vista de la literatura del teatro, del barroquismo que pueda haber en el teatro, sino de la concepción del mundo como un teatro. Un teatro donde cada ámbito tiene una calificación que es la que permite que ocurran ciertas actividades dentro de ese ámbito. Lo mismo es la actividad, que el propio teatro como teatro. Y donde mejor se ve posiblemente sea en Neutral Corner, y esto remite a Ramón... Yo hace bastante tiempo que no hablo de fotografía desde los géneros. Me parece bastante torpe. Hablo de un tipo de fotografía que se puede llamar de ficción, donde el mundo se reinventa a través de la experiencia y la opinión de uno, y hablo también de una fotografía vinculada a un mundo de no-ficción. Y el mundo de Ramón está muy próximo al mundo de la ficción. Ahora hay autores que se apoyan bastante en esto, como por ejemplo el caso de Sophie Calle, que es una fotógrafa que, en realidad, lo que hace es construir historias donde
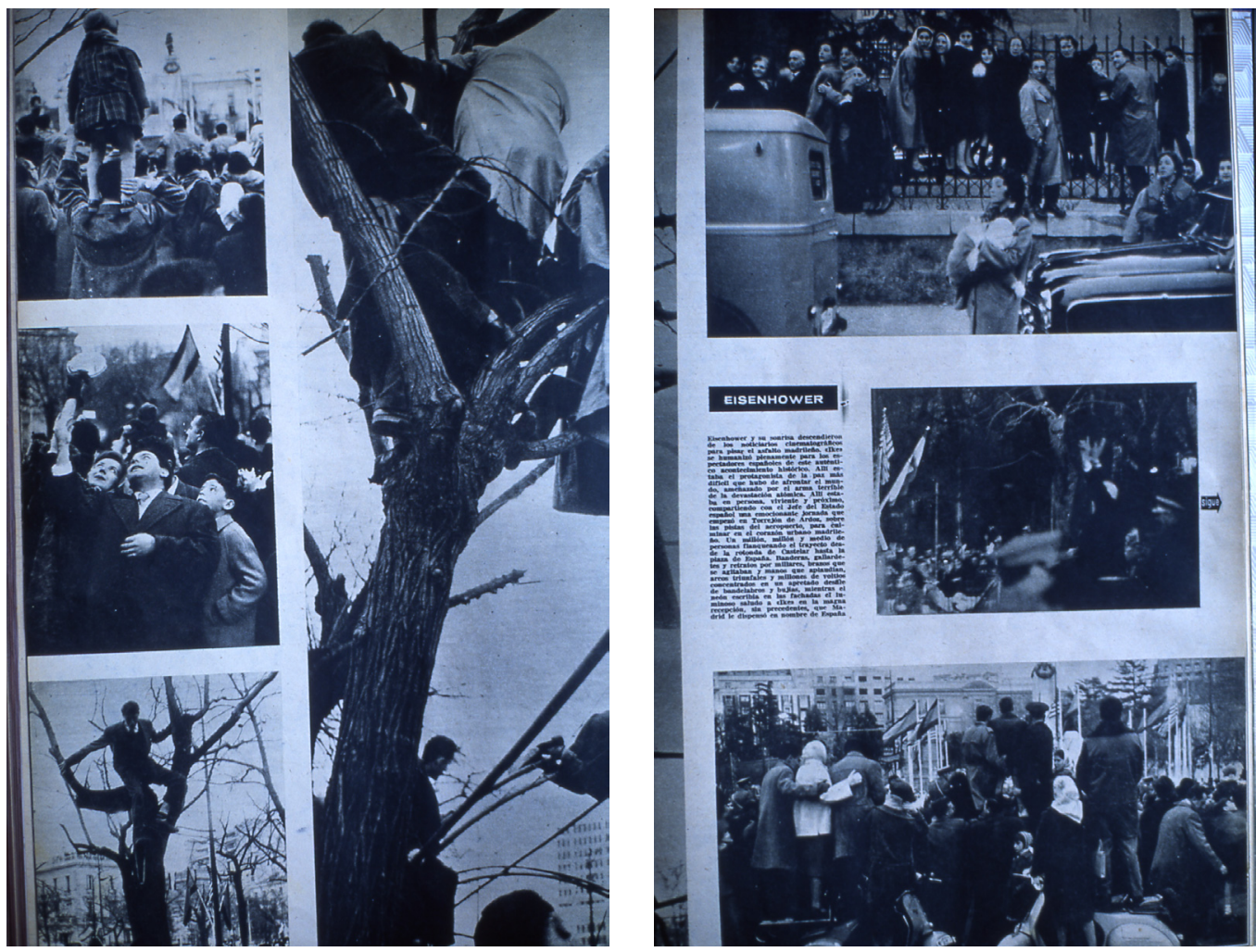

Ramón Masats, reportaje gráfico sobre la llegada de Eisenhower aparecido en Gaceta Ilustrada, n 168,26 de diciembre de 1959, págs. 10-24. 
la imagen visual sustituye a la imagen escrita. Pero la historia escrita existe dentro del discurso del trabajo de Sophie Calle. Ramón no llega a este punto de apoyarse tan descaradamente en la literatura, pero sí está muy próximo a ese concepto de narración. Y estos espacios o ámbitos que yo entiendo tan próximos al teatro son duros, pero no porque sea el tema duro, sino porque están muy descarnados: está muy esquematizado el espacio de escenificación. Claro, él comenta la admiración que tiene por Toni Catany, que es lo contrario de Ramón, por eso no me extraña que le interese tanto el trabajo de Toni. Toni suprime el espacio teatral de representación, porque a él lo que le interesan son los contenidos, representados del modo más tranquilo, y esa tranquilidad tan mediterránea, produce un elemento no estético, fundamentalmente melancólico, donde el nivel de ruido es casi un siseo. No hay una voz que esté por encima de otra. Eso tranquiliza mucho como imagen. En cambio, las imágenes de Ramón son todo lo contrario".

El campo de trabajo de Masats es la realidad, pero una realidad cotidiana, anónima, alejada de los grandes eventos históricos, de las guerras o los conflictos... No deja de parecernos significativo que cuando, en 1959, Eisenhower visita España, Gaceta Ilustrada encargue a Masats fotografiar a las personas que se agolpan ante la comitiva. Lo importante no es tanto el motivo, la anécdota, como los ojos que la interpretan. Ciertamente, no hay ningún encargo de un tema realmente extraordinario en Masats. Revisando los reportajes que Masats realizó para Gaceta Ilustrada entre los años 1957-1964, de los 104 reportajes que hemos encontrado y de las casi 750 fotografías publicadas, hay una enorme cantidad de trabajos de temática aparentemente intrascendente ${ }^{70}$. Así, encontramos muchas curiosidades (como la sección de objetos perdidos, el trabajo de los investigadores privados, una base americana cerca de Madrid, un reportaje sobre la vejez y la longevidad, otro sobre la presencia de visones en el Guadarrama o sobre el hecho de que la orden de San Hermenegildo cumpla cien años...). También tropezamos con cuestiones sobre la actualidad nacional, como el precio de la gasolina, el revuelo que se montó alrededor de un anuncio que demandaba una actriz para una película... Pero, sobre todo, destacan aquellos reportajes que giran en torno a los inicios de lo que después se Llamaría prensa rosa, con extensas páginas dedicadas a deportistas (Di Stefano, Kopa, Puskas, Bahamontes), artistas famosos nacionales (Aurora Bautista, Carmen Amaya, María Jesús Cuadra, Berlanga, Joaquín Rodrigo, el grupo el Paso), actores extranjeros (Charlon Heston, Peter Ustinov, Leslie Carol, David Niven) o eventos dignos de un auténtico paparazzi como la boda de los futuros reyes de España, o la de la Chunga.

- ¿Ustedes buscaban el motivo fotográfico como algo raro, o exótico, o era la vida misma?

(R. Masats, Segovia, 20 de octubre de 2004) -“Hombre, siempre hay algo que te llama la atención y en ese momento haces la fotografía, pero lo haces de la forma que tú querías. El solo hecho de ver algo distinto u original no era ya de por sí un motivo, sino que tú también tenías de poner tu forma, tu sello, tu manita".

(Carlos Pérez Siquier, Segovia, 20 de octubre de 2004) -“Yo creo que lo que puede diferenciar la pintura de la fotografía es que ser fotógrafo identificado es mucho más difícil que coger un pincel. Porque tienes más posibilidades personales de expresión. Como Cartier-Bresson, por ejemplo, que cuando tú ves una foto sabes que es de Cartier-Bresson -aunque él se haya tenido que expresar por un medio mecánico-. La cámara, al fin y al cabo, es un medio mecánico en el que, cuando son fotografías directas, no intervienes".

Esa preponderancia de la autoría, hace que el argumento y la anécdota, en ocasiones, sean un elemento secundario; importante, pero sometido siempre a la visión del autor. Aunque también es cierto que la visión conjunta de toda la obra de Masats de los años cincuenta y sesenta, 


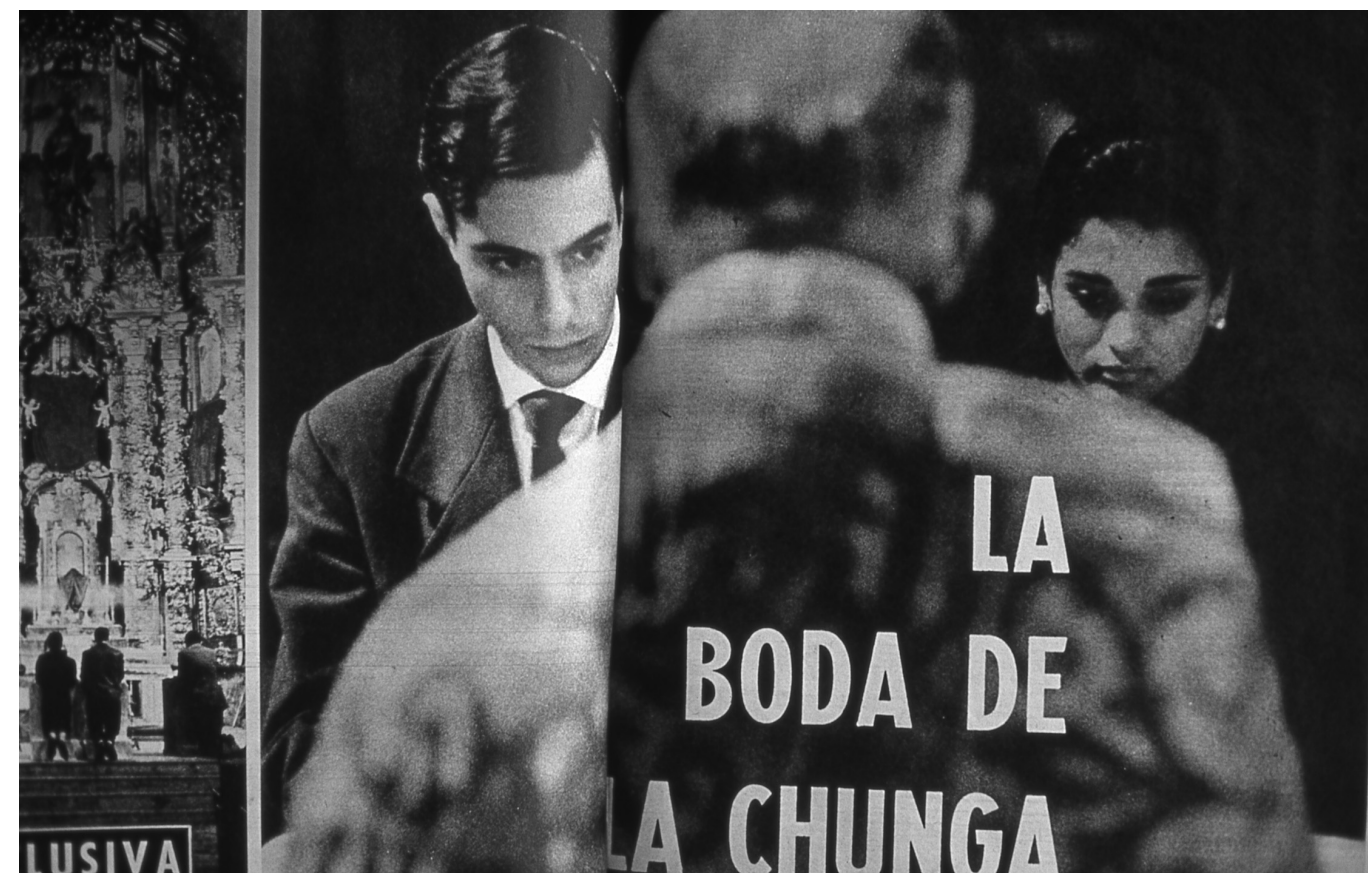

Ramón Masats "La boda de «La Chunga»", en Gaceta Ilustrada, n² 234, 1 de abril de 1961.

la suma de esa enorme y absolutamente inabarcable colección de pequeñas historias, da una idea bastante aproximada de lo que debió ser la sociedad franquista de la época, y eso hoy día cobra mucha importancia, tanta que incluso se ha olvidado que todo ese mundo que reflejan las fotos de Masats está matizado, filtrado y construido por el talento creativo del fotógrafo.

“La suprema suerte de la foto es, en todo caso, dar el viso de que no ha habido mediación entre una y otra cosa, entre el mundo y tú; de que hay un mundo y un instante que se detiene y canta ante nosotros por arte de... No sé qué. Algunos fotógrafos españoles de la renovación lo lograron, y entre ellos, Oriol Maspons, Miserachs, Vielba, Cualladó... Pero, supremamente, Ramón Masats, al que no hacen falta los sermones interpretativos de la Historia"71.

(Carlos Pérez Siquier, Segovia, 20 de octubre de 2004) -“Yo estoy de acuerdo también con Ramón. Creo que no hay que dejarse llevar por el argumento, porque el argumento engaña, y lo que hace muchas veces es ocultar la mediocridad de muchos fotógrafos. El hecho de que tú veas un magnicidio o una gran tragedia... gente llorando, civilizaciones ocultas o perdidas... Te dejas llevar por el argumento y ahí el fotógrafo no ha hecho nada más que poner la cámara. En este momento en que las cámaras tienen motores y te hacen fotos como si estuvieras haciendo cine, seleccionar una foto no tiene mayor importancia. Lo importante es cuando interviene el cerebro y estás buscando las tensiones, los equilibrios, las formas, las luces... una serie de cosas que son las que determinan la obra de arte".

71 Andrés Ruiz, Enrique "El fotógrafo de los Sanfermines", en ABC de las Artes y las Letras, n 754, 15-21 de julio, 2006, pág. 32. 
(R. Masats, Segovia, 20 de octubre de 2004) -“Muy bien, si tú lo dices".

La humanidad, siempre la humanidad. Masats fotografía la historia en minúsculas, siempre a través de él mismo. No le hace ninguna falta fotografiar las grandes tragedias para convertirse en uno de los grandes. En el fondo Masats es incapaz de explicar su fotografía de reportaje porque es incapaz de explicarse a sí mismo, puesto que es él mismo, su mirada, el que aparece retratado en sus fotografías.

"Yo soy bastante intuitivo e irónico, pero no soy nostálgico. Al fin y al cabo uno fotografía como es"72.

-El hecho en sí que estás fotografiando no tiene tanta importancia como tu punto de vista.

(R. Masats, Madrid, 27 de diciembre de 2006) -“No. Ahora acabo de hacer un libro sobre Cuenca. $Y$ en el libro no aparece nadie, solamente las cosas hechas por el hombre pero sin ninguna intención artística. Digamos que la intención artística, aunque sea vanidoso, se la encuentro yo. Lo que necesito es que me saquen, pero en temas tan intrascendentes como una boda o una comunión a veces sale la foto".

(Koldo Chamorro, Pamplona, 21 de marzo de 2003) -“Y ocurre otra cosa de la que también se escapa Ramón. Se supone que cuanto más cutre y más miserable sea el tema, más interesante es el trabajo, y es lo contrario. Y ahí la mejor referencia sigue siendo otra vez Cartier-Bresson. En la medida en que tú te escapas de ese índice de miserias, de estragos y de dolores, es cuando tienes más posibilidades de ser autor, porque si no te conviertes en el tema. Yo conozco, y conozco bien el tema de los fotógrafos de guerra. Son la maldita miseria de la guerra. Larry Burrows, éste que murió en Vietnam en el setenta y dos, él y Griffiths, son los dos únicos y últimos fotógrafos que son identificables como fotógrafos a pesar de que han estado trabajando en guerra. Todos los demás ninguno. Encuentro... por relacionar a alguien con alguien -y siendo contemporáneo de Ramón...- Yo creo que Ramón tiene más relación con Raymond Depardon que con todos los demás. Yo no sé si Ramón es consciente. Yo lo veo. Son dos mundos muy semejantes. No obstante, mantengo la teoría de que uno fotografía en definitiva lo que ama. Porque el trabajo, la obra, viene a ser un autorretrato. No te acuchillas la cara, ni te cortas los dedos, ni te tiras una bomba encima... Y, además, es lo que tienes cerca. Yo puedo sentir una curiosidad terrible por el nacimiento del río Congo, y lo digo con todo cuidado, porque yo soy fundamentalmente africano. Y esto al final está muy bien, y me voy a encontrar maravillas, pero no es algo que tenga yo especialmente cerca. Alguien habrá que esté allí y lo puede fotografiar, si le interesa".

-Pienso que no tienes ningún gran tema de actualidad en tus reportajes: ni fuiste a la guerra y ni siquiera tienes muertos...

(R. Masats, Madrid, 27 de diciembre de 2006) -“Pero a la guerra sí que estuve a punto de ir. Recuerdo que fue en la guerra de Argelia. Yo me fui a Alicante para poder coger un barco para ir a Alger. Fui con otro fotógrafo, Calderón, de Gaceta Ilustrada, y con un periodista, Dominique Lapierre, pero estuvimos intentándolo y nadie nos quiso llevar. Cogimos un taxi y nos fuimos hasta Málaga (una noche entera, con las carreteras que había en aquella época) y en Málaga tampoco lo conseguimos. Fuimos contratados por Gaceta".

-Pero muertos no tienes, que se supone que es un tema de mucho impacto. Tampoco has trabajado con grandes eventos.

(R. Masats, Madrid, 27 de diciembre de 2006) -"Hombre, hay unas fotos de momias...".

-Sí, pero ésas tienen un interés más antropológico. Todo lo que aparece en Gaceta Ilustrada son temas muy sencillos.

72 Pulido, N. "Ramón Masats: «Si se me ha escapado algún mensaje en mis fotos, lo siento»" en $A B C$, 9 de junio de 2006, pág. 56. 


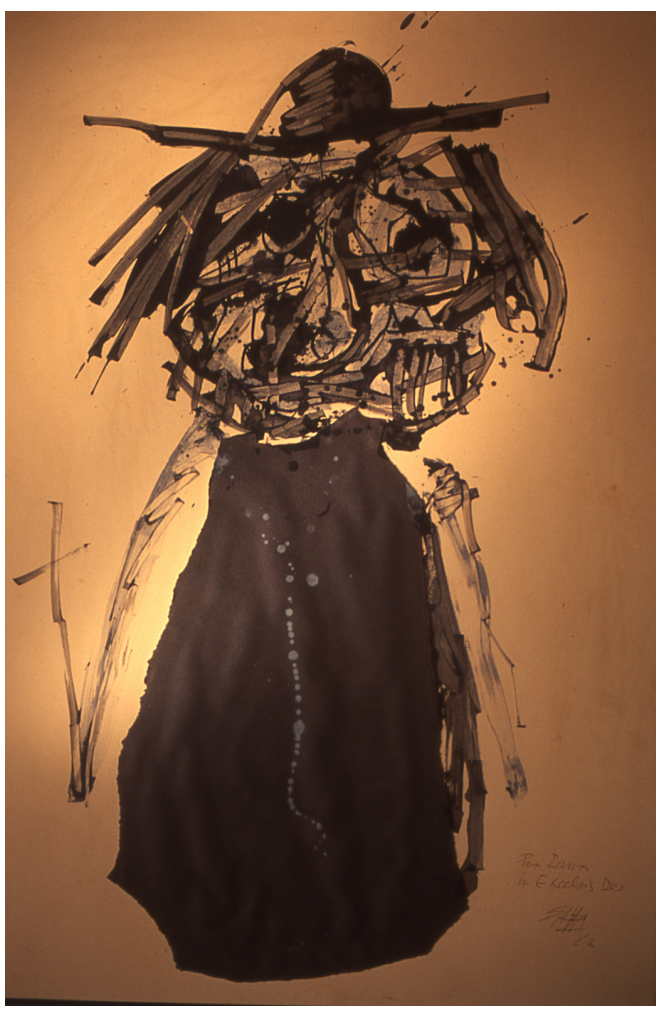

Antonio Saura, "Para Ramón in Excelsis Deo". Obra dedicada a Ramón Masats.

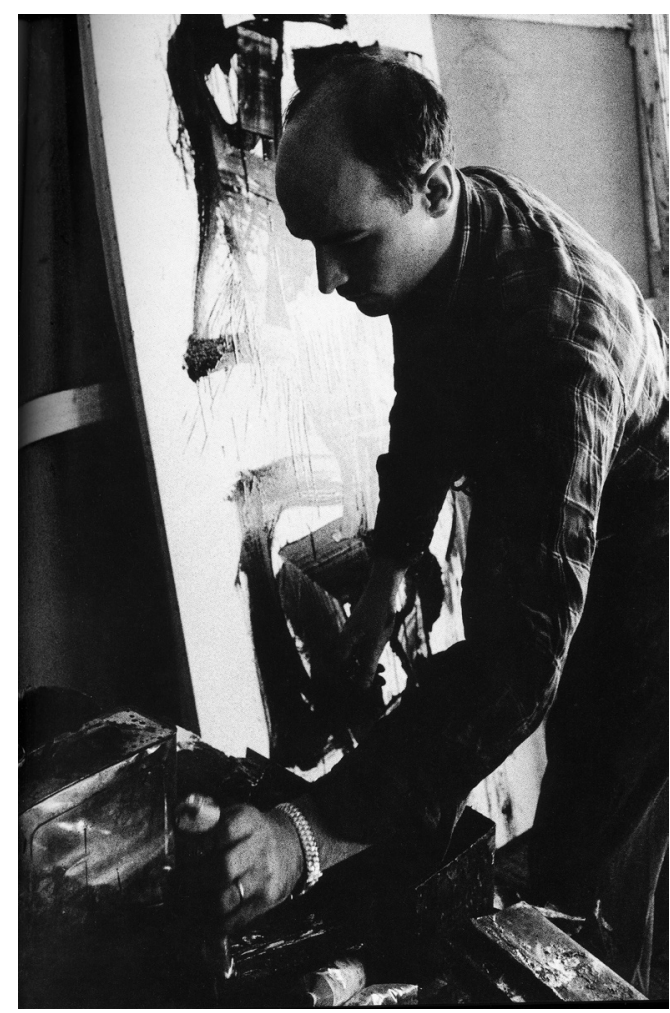

Ramón Masats, fotografía aparecida en el artículo, "Se ha disuelto El Paso", en Gaceta Ilustrada, n 185, 23 de abril de 1960, págs. 29-35.

(R. Masats, Madrid, 27 de diciembre de 2006) -“Hay de todo, yo me he hecho la BBC completa: bodas, comuniones... y también reproducciones de cuadros. Hasta de paparazzi".

-Y actores que venían del extranjero.

(R. Masats, Madrid, 27 de diciembre de 2006) -“Sí, te venía el representante de tal actriz y te la hacía fotografiar bailando flamenco. ¡Very tipical! ¡Unas barbaridades!”

-Son temas del corazón, curiosidades... pero de ahí han salido fotos interesantes. El motivo es casi una excusa.

(R. Masats, Madrid, 27 de diciembre de 2006) -“Sí, yo siempre lo he pensado. Hay fotos del grupo el Paso o de Carmen Amaya que aún se mantienen, las sigo llevando a exposiciones".

(R. Masats, Valencia, 25 de marzo de 2004) -“Éste es Millares. En muchos casos he dado más importancia al estudio y a su obra que a ellos mismos. Esta imagen es de Saura y a él le gustó mucho porque me regaló un dibujo. Es curioso porque yo siempre he tenido fama entre mis compañeros fotógrafos de no saber elegir mis fotos. Esto es una cosa que me lo han dicho muchos compañeros que han visto contactos míos. Yo por supuesto lo he negado y he procurado que no trascendiera mucho, por la cuenta que me tiene. El otro día me llamaron de la galería Malborough de Madrid, porque van a hacer una exposición, precisamente sobre el grupo el Paso y la diseñadora del libro me dijo: "Trae los contactos». Hice contactos de todo lo que había hecho en aquella época y la mujer me fue marcando las fotografías que a ella le interesaban 


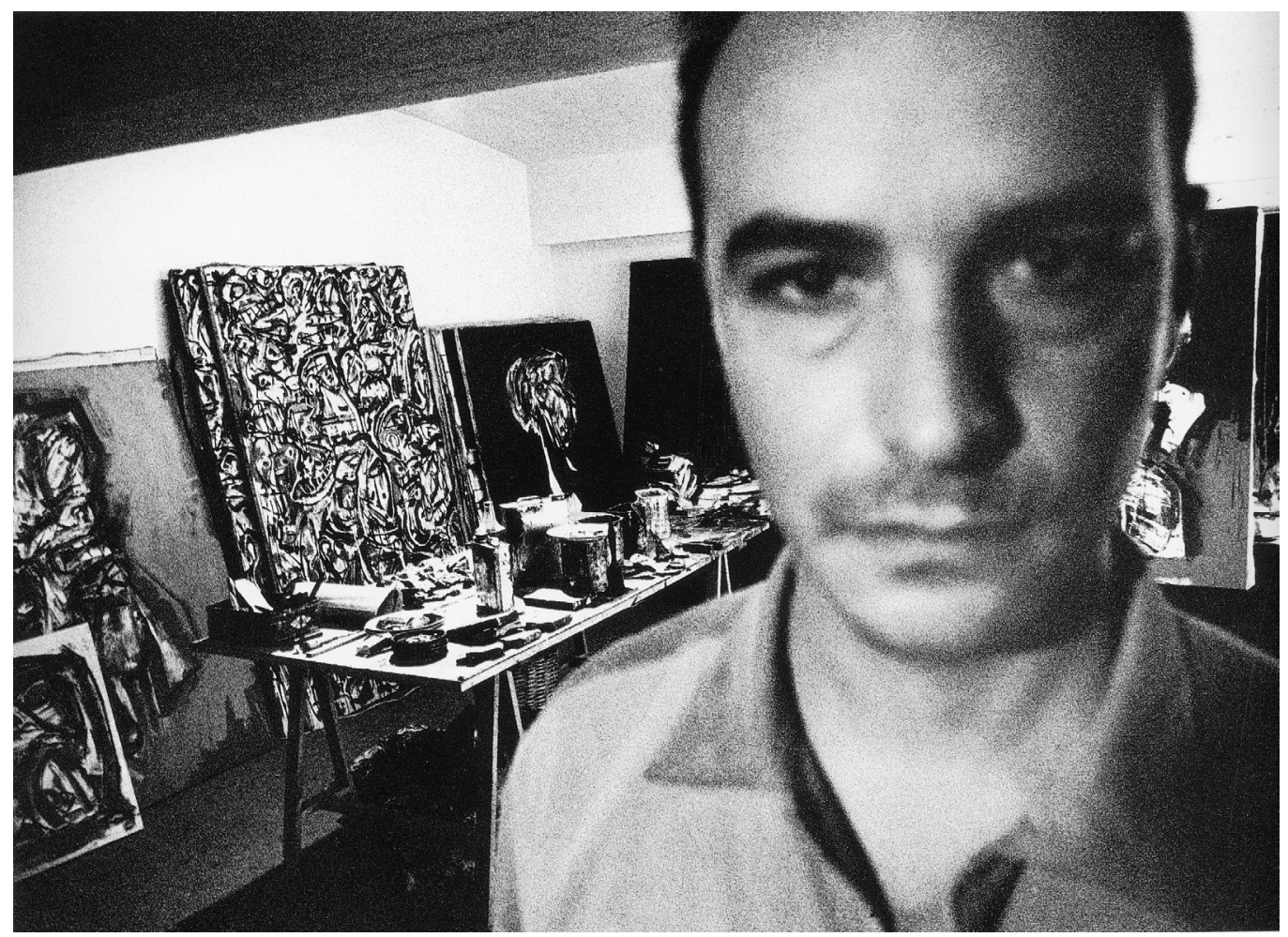

Ramón Masats, “Antonio Saura”, 1962.

para el libro. Y marcó una de Antonio Saura, de este mismo estilo de él, desenfocado y con los cuadros detrás, que cuando la he positivado la encuentro mejor que la que él tiene... Y ahora no sé si ésta va a desaparecer o voy a positivar las dos. Pero me gusta más que ésta. Me descubrió una fotografía en los contactos y he rectificado. ¡Yo creo que debe ser la edad!".

- ¿Y cual es el criterio para saber si una foto es buena o es mala?

(R. Masats, Madrid, 17 de julio de 1999) -“No lo sé, incluso en ello soy muy privado, el que me gusten o no me gusten".

- ¿Enseñas tus fotos a compañeros para que te ayuden a escoger?

(R. Masats, Madrid, 17 de julio de 1999) -“No... ¡Hombre, se las enseño al director de arte! A compañeros se les enseña diciendo: «iMira lo que he hecho...!» si alguna vez nos reunimos, pero cada vez menos. Tú quieres decir por el asesoramiento..."

-Sí, muchas veces, por haber hecho tú las fotos te implicas excesivamente con la anécdota del día en que realizaste las fotos; si te costó mucho la obtención de una en particular, o si te amenazaron al fotografiar tal cosa... y a lo mejor esa foto no tiene tanto valor.

(R. Masats, Madrid, 17 de julio de 1999) -“Yo, para tener perspectiva y no implicarme tanto, las someto al tiempo. Las guardo y de vez en cuando me las miro y el tiempo les va dando su lugar. Pero no las enseño para que opinen, el criterio es mío".

(R. Masats, Valencia, 25 de marzo de 2004) -“Este es Menéndez Pidal. Es uno de los reportajes que más he disfrutado en mi vida, porque el hombre cuando llegué allí... muy amable, muy sencillo. Me dijo: «Usted qué quiere que haga». Y yo le dije: «Lo que usted haría si yo no estuviera 

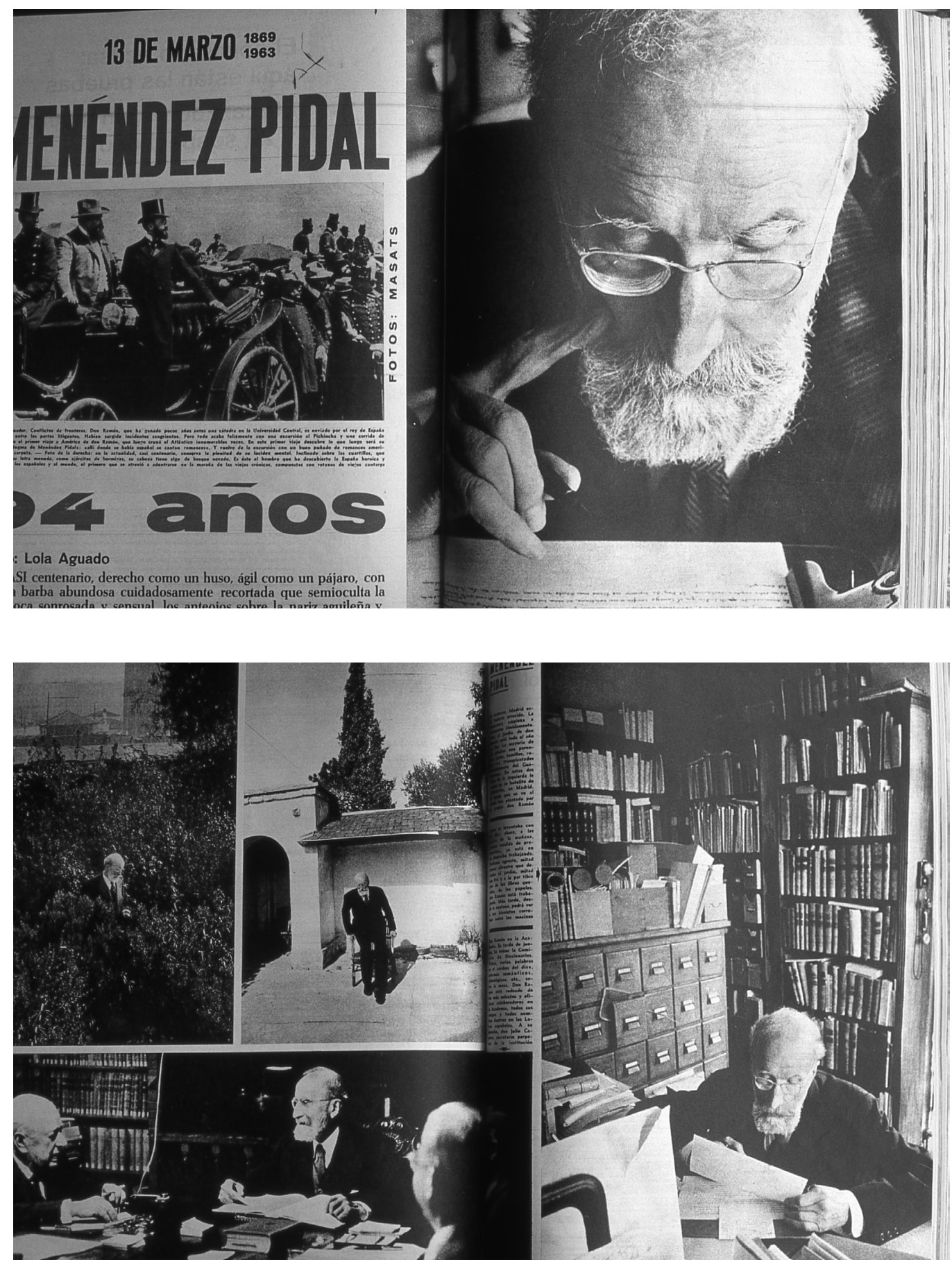

Ramón Masats, “Menéndez Pidal, 94 años", en Gaceta Ilustrada, nº 335, 9 de marzo de 1963, págs. 52-59. 

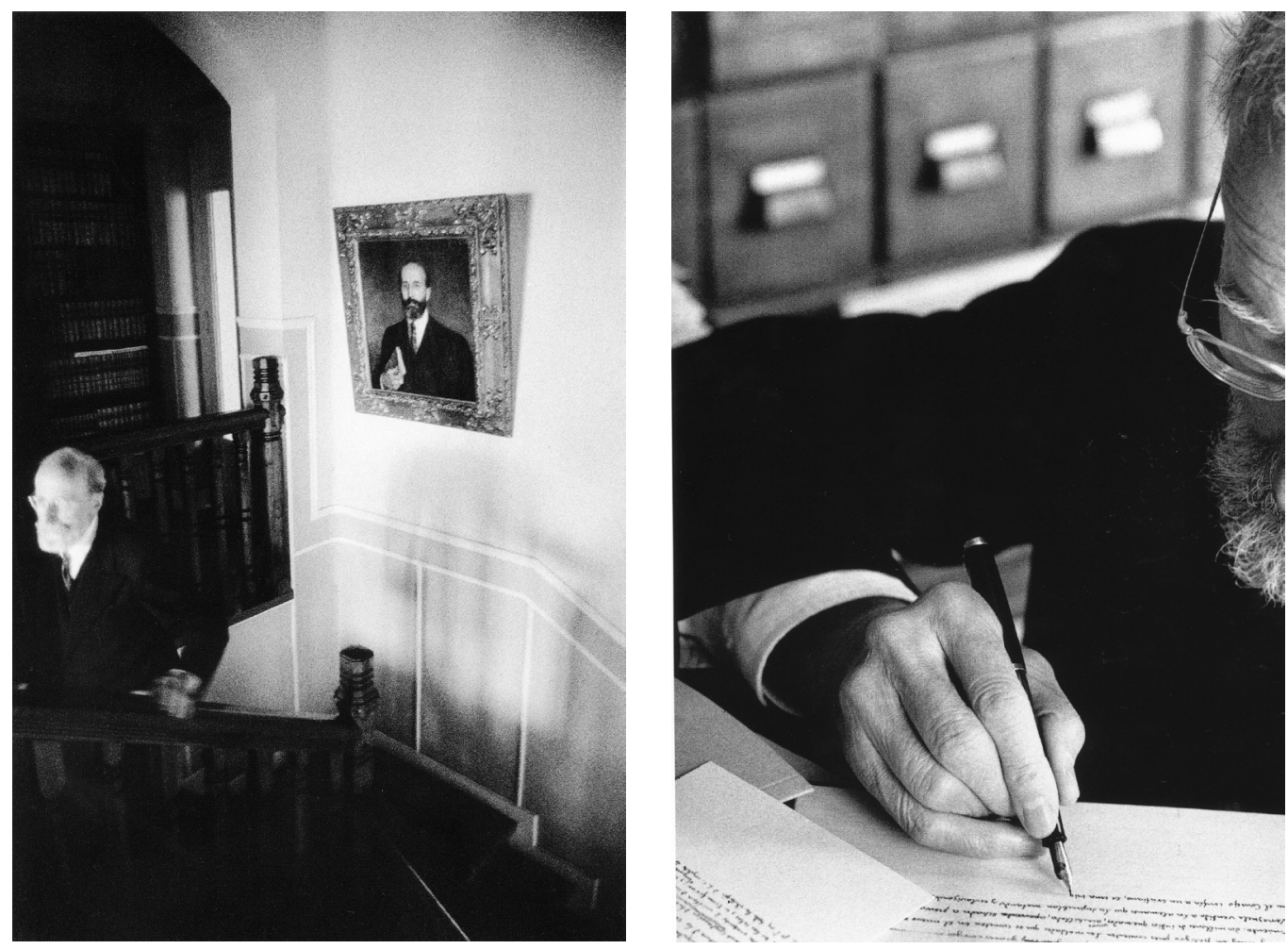

Fotografías del reportaje de Menéndez Pidal que Masats ha recuperado en sus exposiciones antológicas y que no fueron publicadas en su momento en Gaceta Ilustrada.

aquí». Y al hombre no se lo tuve que decir dos veces. La foto de la escalera está posada, pero el hombre... trabajando como si yo no existiera. Y es de los reportajes donde me he sentido más libre. No necesitaba decirle nada. Fue fantástico trabajar con Menéndez Pidal.

Mientras él estaba escribiendo, había en la mesa unos dibujos muy infantiles, pero que yo notaba que aquello no era muy infantil. Y le pregunté: «¿Y eso qué es?» Y me contestó: «Pues mire usted, yo tengo una nieta que es muy pequeña, y por supuesto que no sabe escribir, pero me manda dibujos, y me hace dibujos, y yo la contesto haciendo dibujos infantiles...» ¿Tú te imaginas a don Menéndez Pidal haciendo dibujos infantiles para su nieta? A mí me pareció una anécdota verdaderamente tierna... “

- ¿Cuando ibas a Gaceta Ilustrada qué relación tenías?

(R. Masats, Madrid, 15 de diciembre de 2003) -“La relación con Gaceta Ilustrada era... Eran ellos los que me proponían los temas.

-Es decir, te decían, tal día hay un acto a tal hora. Tú te presentabas allí y te acompañaba un periodista.

(R. Masats, Madrid, 15 de diciembre de 2003) -“A veces sí y a veces no.

-Y luego cogías los carretes y los revelabas en tu casa.

(R. Masats, Madrid, 15 de diciembre de 2003) -“No, en una habitación que había alquilado en un piso frente a la embajada americana, en Serrano 108. Me alquilaron una habitación con derecho a que por la noche podía revelar en el cuarto de baño mis películas y también poner una ampliadora. Y luego quitarlo de día, claro...". 


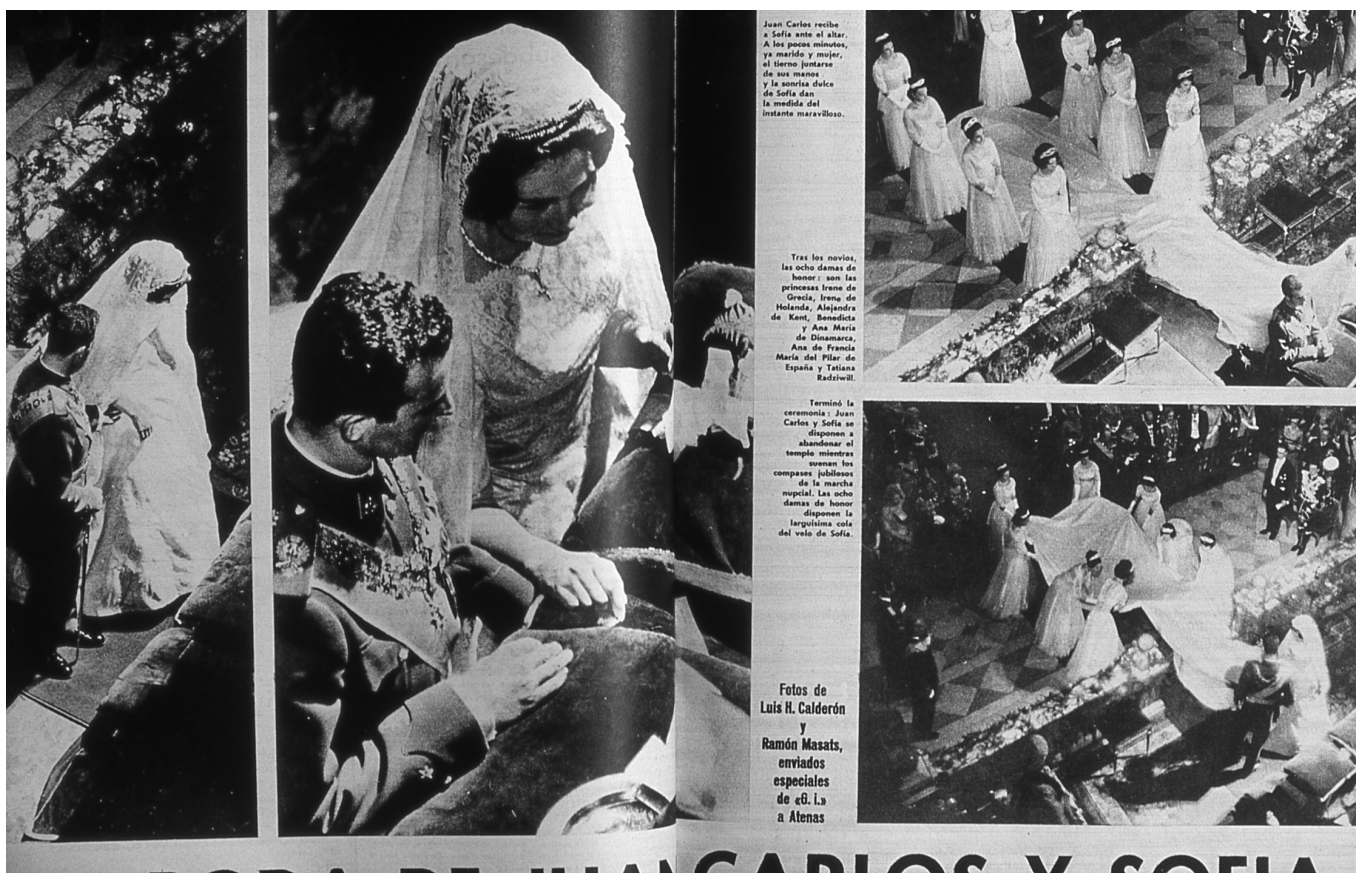

Ramón Masats, “La boda de Juan Carlos y Sofía”, en Gaceta Ilustrada, n² 293, 19 de mayo de 1962, págs. 26-34.

-Entonces les dabas a ellos las ampliaciones.

(R. Masats, Madrid, 15 de diciembre de 2003) -“Claro".

- ¿Pero les enseñabas los contactos y ellos te los seleccionaban?

(R. Masats, Madrid, 15 de diciembre de 2003) -“No, los negativos no. Eso los seleccionaba yo. Ellos no veían ni contactos ni nada. Si necesitaban cinco fotos, yo les entregaba diez o doce para que seleccionaran.

-Luego, discutías con el maquetador...

(R. Masats, Madrid, 15 de diciembre de 2003) -“Alguna vez le decía la intención que tenía en algunas cosas, pero discutir no. Había una relación... No como ahora, que los maquetadores son dioses".

-Entonces se podría decir que tenías una relación estrecha con los maquetadores.

(R. Masats, Madrid, 15 de diciembre de 2003) -“Sí".

-Y que algunas de las páginas las hacías tú.

(R. Masats, Madrid, 15 de diciembre de 2003) -“No. Yo les daba las orientaciones y las hacían ellos. No llegaba a tanto. Yo no creo que hubiera una gran influencia en mi obra de los maquetadores de Gaceta Ilustrada. A lo mejor en la maquetación de mis libros tuvo influencia la maquetación de otros libros... como los de William Klein. Yo creo que ni era mucha mi influencia sobre los maquetadores de Gaceta Ilustrada ni era mucha su influencia sobre mí. Y no es por negarles protagonismo, pero no tengo esa sensación.

-Es que he visto en algunas de las maquetaciones de Gaceta Ilustrada cosas que me han recordado a alguno de tus libros. No sé si era una moda de la época a la hora de maquetar, o como tú estabas supervisándolos todos...

(R. Masats, Madrid, 15 de diciembre de 2003) -“No supervisaba, pero sí les decía cómo veía 
Ramón Masats, "Luis Buñuel", 1964.

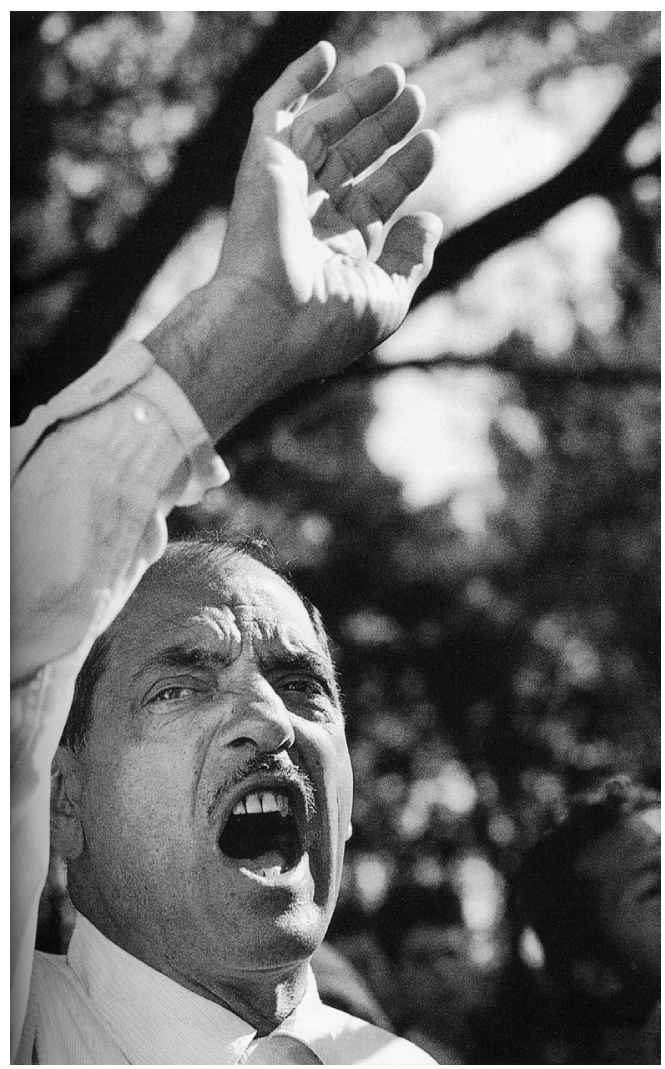

yo la cosa. Y era gente que ya te digo que no eran vedettes como... Alguna vez me decían: «¡Ramón, qué te parece, antes de mandarlo a la imprenta!». Había una colaboración entre el maquetista y el fotógrafo. No como ahora que los maquetistas son dioses y tú sólo haces cositas para que ellos las corten. Ya te he hablado del mundo del intermediario. Los maquetadores son uno de los intermediarios que están jodiendo mucho las cosas. Eran buenos los maquetistas de Gaceta, no eran nada pacatos. No mandaba el texto sino que mandaba la imagen... Se miraban mucho en Paris Macht. Gaceta Ilustrada era un Paris Macth de aquí, de España. Y tenían una colaboración estrecha. Por ejemplo: la boda de Juan Carlos y Sofía la hice para Gaceta y para Paris Match. Me acuerdo que hice la boda... Me fui de Madrid a Atenas pero la vuelta fue por Barcelona. En el laboratorio de Oriol Maspons estaba todo preparado para revelar inmediatamente los carretes. Y se revelaron los carretes, se hicieron contactos, y se hicieron copias para Gaceta Ilustrada y para Paris Match. Es decir, que fue un «pool» que, en este caso, Gaceta colaboró mucho con Paris Macth.

A Luis Buñuel tuve la oportunidad de fotografiar mientras rodaba Viridiana y me miraba mal. No le gustaba nada que un fotógrafo que no fuera de su equipo que estuviera haciendo reportaje por allí. Pero, como yo tenía mucha amistad con los productores, el tío tragó. A mí esta fotografía me gusta porque aunque es una fotografía muy clásica de director, difícilmente se puede adaptar a la forma que podemos imaginar que tenía Buñuel de dirigir. Lo veíamos más pausado... por eso me gusta".

-Era la cotidianidad, la vida misma.

(R. Masats, Madrid, 27 de diciembre de 2006) -“La revista, el semanal filtraba un poco las 
imágenes. No es igual que un periódico diario".

-Tenías más tiempo para hacer los temas.

(R. Masats, Madrid, 27 de diciembre de 2006) -“Un poco más, porque a veces, en el último momento cuando llegaba el cierre se les ocurría una parida y tenías que salir echando leches a hacer la foto. Yo estoy muy contento de esta época porque te da un conocimiento del oficio... Es una variedad que te va formando".

-Tus imágenes eran pequeños retazos de vida de una visión más o menos acertada de lo que sería la sociedad franquista. Lo realmente interesante es tu aportación personal. Hay un punto de equilibrio entre el documento de la época y tu expresión plástica como autor.

(R. Masats, Madrid, 27 de diciembre de 2006) -“Yo lo que pasa es que, por lo que decías del retrato de una época, nosotros (te hablo de la gente que hacía periodismo en aquella época) no éramos conscientes de esto en ningún momento, es decir, no éramos conscientes de que estábamos retratando una época. Luego se puede entender así, pero yo creo que no. No éramos conscientes y además no era nuestra intención el ser testimonio de una época, por lo tanto no la reflejábamos. Al menos, en mi caso, en ningún momento lo pretendí. Lo que es evidente es que a través de los años, poco a poco -al margen de que nuestras fotografías puedan tener un interés plástico- es que sí que se han convertido en una representación de una época. Un época que plásticamente sí la añoro, porque el que se pueda ver una calle de Andalucía, sin ningún coche ni ninguna pintada, blanquísimas y preciosas, está muy bien, pero personalmente no la añoro nada: están mucho mejor ahora porque la gente vive mucho mejor, aunque te llenen las calles de coches y las paredes de pintadas. En ningún momento en mi fotografía hay una representación de la nostalgia. Hay una época pero nada más".

\subsection{EL LIBRO COMO SOPORTE Y UNIDAD NARRATIVA}

\subsubsection{La narratividad de las series fotográficas}

Como ya hemos visto, la influencia de Cartier-Bresson en Masats es muy destacable. Su compromiso ético lo lleva a asumir el utillaje y los modos de trabajar del maestro francés. Desde el uso de la Leica, que gracias a su pequeño tamaño y a la calidad de sus lentes permitió el reportaje fotográfico rápido, dinámico y discreto; hasta la falta de iluminación con flash, incluso en las imágenes nocturnas de Los Sanfermines; pasando por la espontaneidad de sus imágenes, su temática... Ahora bien, hay una serie de elementos absolutamente discordantes entre uno y otro. Habrá que matizar la influencia de su purismo en Masats, de ahí que a continuación comprobaremos cómo existe un desencuentro fundamental en el modo de entender el hecho fotográfico entre ambos autores.

La concepción de Cartier-Bresson del "instante decisivo" lo lleva a considerar el reportaje fotográfico como una imagen única:

“¿Qué es, en realidad, un reportaje fotográfico, un «relato fotográfico»? Algunas veces hay una imagen única, cuya composición posee tal vigor y riqueza, y cuyo contenido expresa tanto, que esta sola imagen es ya una historia completa en sí misma. Pero esto sucede muy raras veces (...) Pero cuando se logra fotografiar tanto la «médula» como el «fulgor» del sujeto, esto es lo que se llamaría un relato fotográfico, y es la página la que se encarga de reunir los elementos complementarios que están dispersos en las distintas fotografías"73.

73 Cartier-Bresson, Henri, "Henri Cartier-Bresson (1948). El instante decisivo”, en Fontcuberta, Joan, Estética fotográfica. Selección de textos, Barcelona, Blume, 1984, pág. 190. 

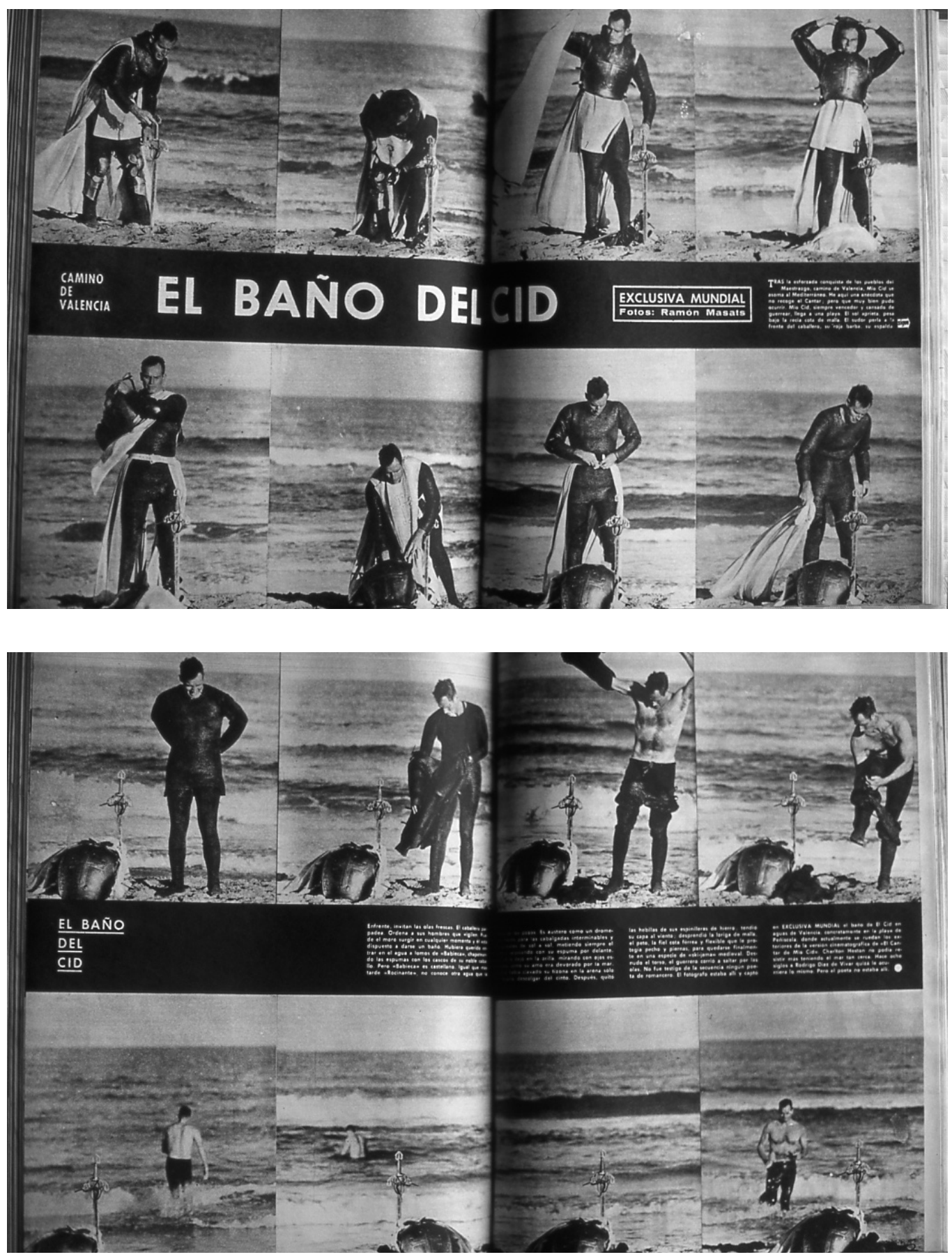

Ramón Masats, “El Baño del Cid”, en Gaceta Ilustrada, nº 231, 11 de marzo de 1961, págs. 50-53. 

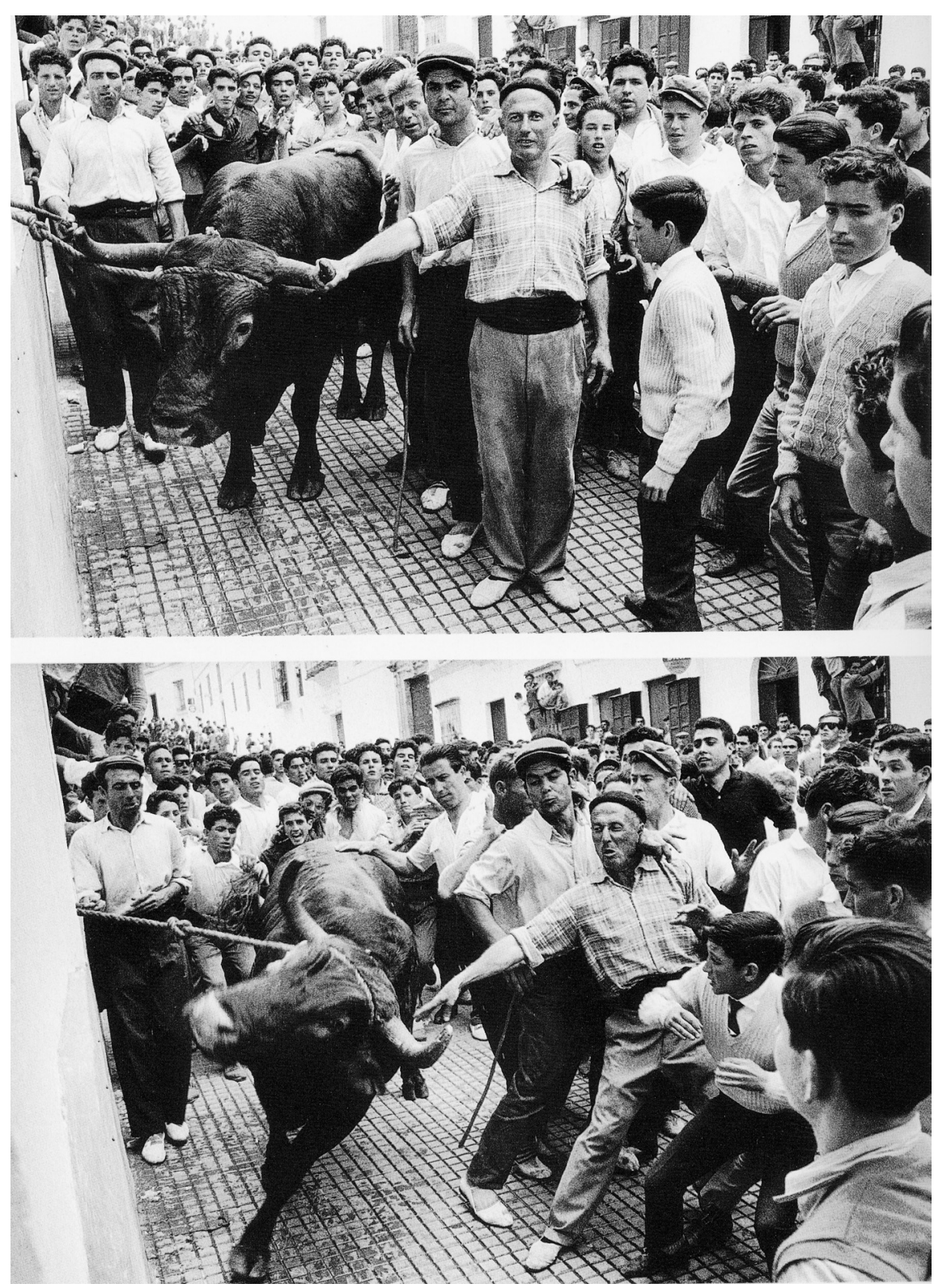

Ramón Masats, “Arcos de la Frontera (Cádiz)", 1959.

Masats, por el contrario, se permite "instantes" de hasta dieciséis fotogramas. De manera que ese ejercicio riguroso y disciplinado que pretende comprimir en un único disparo toda una historia, obviando recursos narrativos exteriores a la mirada y la composición del propio disparo, queda superado en Masats.

-Los dípticos que haces serían el montaje llevado al extremo. Tienes varías fotografías que son dos imágenes. Estoy recordando la del toro que sale rodeado de gente tranquilo en una foto 
$\mathrm{y}$, al revolverse en la foto siguiente, provoca el sobresalto del público.

(R. Masats, Madrid, 4 de septiembre de 2002) -“Sí, pero nunca fueron hechas en el momento de la toma como díptico. Me di cuenta que podían funcionar como díptico posteriormente. Son fotos que vas haciendo en serie y luego, al ver los contactos, ves que funcionan, que se potencian como díptico, pero no están concebidas como tal".

-Sin embargo, la secuencia del baño del $\mathrm{Cid}^{74}$...

(R. Masats, 15 de diciembre de 2003) -“Aquello es una secuencia... Fue una idea previa. Yo fui allí a hacer un reportaje para Gaceta Ilustrada y se me ocurrió la idea de hacer un striptease de Charlon Heston. Había otros fotógrafos por allí que se barruntaban de que había algo... Hablé con el jefe de publicidad y le dije que no dijera nada porque eso era una exclusiva. Un día habló con Charlon Heston y le dijo: "Hoy tenemos un rodaje que no termina tarde y nos podemos ir disimulando...». Él vestido con sus las ropas de la película... Y nos fuimos a una playa que yo ya había seleccionado (no nos siguió nadie) y yo le dije que se quitara la armadura... que hiciera un striptease y que se metiera en el agua. Sí, eso era una idea previa".

-En la del circo también hay una secuencia de una mujer con cuatro expresiones, exactamente con el mismo encuadre.

(R. Masats,15 de diciembre de 2003) -“No me acuerdo de esas fotos".

-Hay una máxima de la Gestalt que dice que el total es más que la suma de las partes que lo componen.

(R. Masats, 15 de diciembre de 2003) -“Sí estoy de acuerdo".

-Cuando ves una serie tuya, ves todo el conjunto y tienes una percepción diferente a si la vieras foto tras foto... Entonces, cuando tú te planteas un reportaje... ¿Lo haces como un conjunto o como fotos sueltas?

(R. Masats, Madrid, 4 de septiembre de 2002) -“Como un conjunto. Siempre que me encargan un libro veo qué cosas hay que fotografiar y pienso, incluso, en qué orden tienen que ir. Hay ideas fotográficas, de dos fotos, que individualmente tendrían un valor determinado y junto con la otra adquieren un valor muy superior. Pienso siempre en el libro, en conjunto".

Masats, como vemos, piensa en términos de secuencia, mientras que Cartier-Bresson se preocupa en perfeccionar el plano único. No existen fotografías que complementen o apoyen un discurso de una categoría superior. Todo se genera en la toma, no hay una hilazón posterior.

“-¿Qué piensa usted de la estética de la dirección artísticas en revistas libros y exposiciones?

-Mi enfoque intuitivo de la fotografía y mi constante preocupación por la imagen única me convierten en un mal diseñador. Encuentro difícil crear una armonía entre fotos distintas. Dejo esto a mis amigos editores, a los directores artísticos con quienes siempre considero el diseño"75.

No es que Cartier-Bresson no tuviera en cuenta la maquetación y la edición, al contrario. Como ya indica en la introducción a su Images à la sauvette, el fotógrafo debería de pensar la posterior paginación mientras realiza las imágenes.

\footnotetext{
“El gran talento del diagramador reside en saber cómo escoger de este cerro de fotos una en particular que merezca una página completa o una doble, y en saber dónde insertar la fotografía chica que va a ser el eslabón indispensable del relato. (Mientras el fotógrafo toma las fotografías para su historia, debería ir pensando en la manera de disponerlas más ventajosamente) $)^{\prime \prime 7}$.
}

74 Masats, Ramón, “El Baño del Cid”, en Gaceta Ilustrada, n² 231, 11 de marzo de 1961, pág. 50 (16 fotos en B/N).

75 Hill, Paul y Cooper, Thomas, Diálogo con la fotografía, Barcelona, Gustavo Gili, 2001, pág. 78.

76 Cartier-Bresson, Henri, op. cit., pág. 200. 


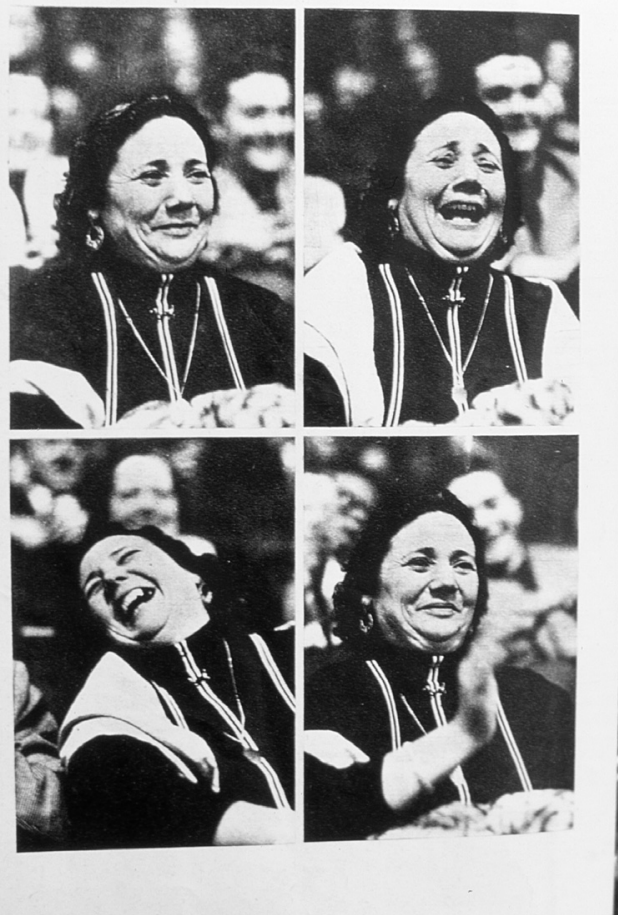

Detalle de la maquetación del reportaje de Ramón Masats y Alfredo Marqueríe (texto), “Otra vez el circo: Un espectáculo que resurge gracias a novedades insospechadas", en Gaceta Ilustrada, $n^{\circ} 70,8$ de febrero de 1958, págs. 23-27.

Es decir, que la maquetación siempre está subordinada a las imágenes, y nunca al revés. No realiza las imágenes pensando en un plano, contraplano o en términos de secuencia cinematográfica, donde un plano pide otro. Cartier-Bresson construye a partir de un montaje en el interior del plano, a veces muy complejo, pero nunca relacionado con la foto anterior y posterior.

“-¿Cuáles le han parecido ser las diferencias estéticas entre tomar fotografías y hacer cine?

-En 1935, cuando estaba en los Estados Unidos, aprendí de Paul Strand los rudimentos y la técnica de la filmación. Ese año no tomé fotografías. Debo también mucho a Jean Renoir, para quien trabajé como segundo ayudante de dirección. Lo que más me gustaba era trabajar sobre el diálogo y nunca tuve relación alguna con el trabajo de cámara o con la iluminación. Pero pensé que no tenía talento para el cine de ficción. He hecho cuatro filmes documentales. En mi opinión, no existe relación entre la fotografía fija y la imagen cinematográfica. En el cine, la fotografía es volátil, como una palabra en un discurso. En la fotografía, se acerca más al monotipo, a la litografía, al dibujo"77.

Por el contrario, Ramón Masats tiene una concepción más amplia del reportaje mucho más cinematográfica, más serial.

-Cartier-Bresson cuenta una historia en un imagen, mientras que Ramón la cuenta en un libro. Ramón pagina, de ahí que tenga una narrativa más cinematográfica.

(Koldo Chamorro, Pamplona, 21 de marzo de 2003) -“Dentro de la actitud, la estrategia de Cartier-Bresson podríamos decir que es la propiedad para la ética. Que no está mal. Es totalmente 

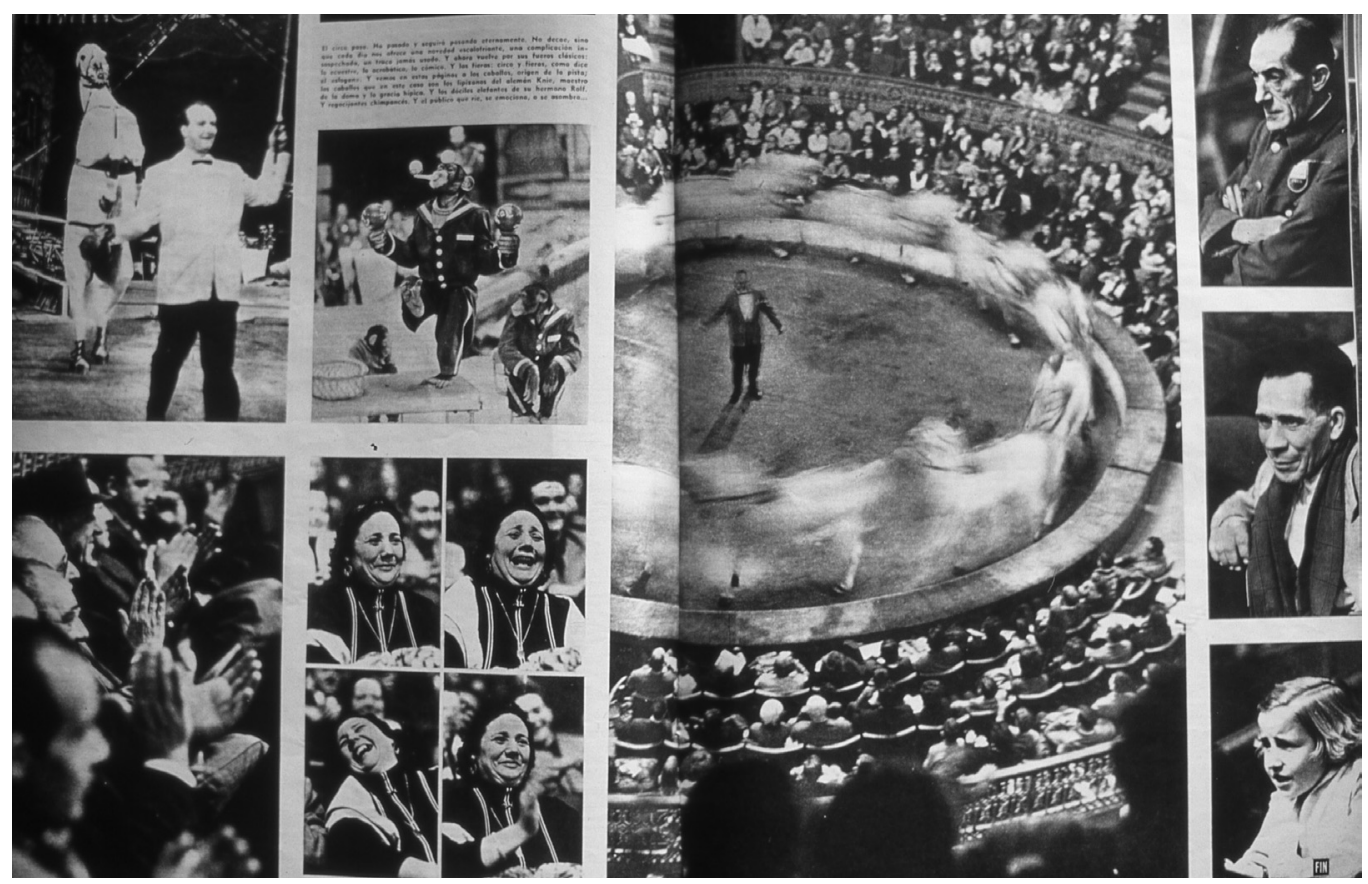

Doble página de la maquetación del reportaje de Ramón Masats y Alfredo Marqueríe (texto), “0tra vez el circo: Un espectáculo que resurge gracias a novedades insospechadas", en Gaceta Ilustrada, n 70, 8 de febrero de 1958, págs. 23-27.

válida e indiscutible. Lo que pasa es que al final ¿qué es lo que ocurre...? Que de Cartier-Bresson te puedes quedar con determinadas imágenes, pero... Yo no tengo ningún libro de mesilla de Cartier-Bresson. En cambio de Ramón, sí; de Raymond Depardon, sí; de Robert Frank, sí. ¿Me explico? Es que... de lo que se trata es de contar historias. Tú puedes contar historias como si fueran un haiku, que de eso tiene mucho Cartier-Bresson. Muchas de sus imágenes son haikus. Pero bueno, los haikus tienen su porqué, pero al final lo que quieres es una historia. Y eso Cartier-Bresson no te lo permite. En cambio otros autores sí. Yo no estoy descalificando para nada, ni poniendo en tela de juicio, a Cartier-Bresson, ni mucho menos. Pero yo estoy más por la vía de contar historias. No tiene que ser un libro de setecientas mil fotos, puede llevar hasta una partitura musical, puede llevar textos de literatura o poesía, y puede llevar incluso tipografías, que hay que cuidarlas al milímetro".

“[La] narración necesita, generalmente, integrarse de diversas imágenes que relatan las evoluciones del hecho, conforme a su importancia, para representárnoslo de una forma más eficaz.

Estamos asistiendo, actualmente, a esta sustitución de la palabra por la imagen, que es capaz de expresar una serie mayor de sugerencias en su tiempo inferior, conforme a las exigencias de nuestro siglo. Los reportajes narrativos de Life, Paris-Match, Tempo, etc., nos muestran una serie de fotografías que cuentan los momentos más culminantes de una historia. Son exigencias de una labor informativa, en la que el fotógrafo tiene necesariamente que documentar la realidad, conforme a su mayor o menor penetración sicológica (...) La fotografía suelta, la imagen solitaria, ha perdido gran parte de su importancia. A veces, se nos presenta como compendio de un hecho. $Y$ es que ha podido sintetizar 
toda su historia (...) Pero es muy difícil conseguir este propósito (...) En estos años, individualmente, nuestros compañeros de Grupo emprenden esta meritoria labor informativa, que consigue encontrar su expresión en Gaceta Ilustrada, la única revista española que, hasta ahora, ha sabido adaptar la arquitectura de sus páginas a la exigencia narrativa.

Parece, pues, que por fin España está reconociendo el valor editorial de la imagen, y se prepara la edición de libros en los que la fotografía es un principal elemento informativo: Masats con San Fermín, Juanes con Asturias, Miserachs con Costa Brava, Terré con Semana Santa, Ontañón con Pueblos de España"78.

El libro o la revista ilustrada se convertirán en la máxima aspiración estética y creativa de los fotógrafos de la generación de Masats, pues estos soportes serán los que mayores posibilidades narrativas y expresivas permitirán. Como ya vimos, las revistas como Life y Look tuvieron una divulgación masiva hasta su desaparición con la llegada de la televisión. El modelo de las revistas ilustradas supuso la evolución de los arcaicos conceptos de la fotografía documental y del fotoperiodismo, lo que posibilitó la imposición del revolucionario concepto del reportaje moderno. La fotografía documental, heredera de los pioneros de 1860 como Maxime du Camp, Charles Marville, Gustave le Gray, Francis Frith, Felice A. Beato y Timothy H. 0’Sullivan, tenía unos claros usos descriptivos, en consonancia con la época de las últimas grandes expediciones de científicos y aventureros, que partían para descubrir y clasificar al mundo, formando así la gran Enciclopedia, donde todo está clasificado y ordenado como instrumento de la ciencia. El fotoperiodismo, por el contrario, va ligado a la noción de "actualidad" y a la exposición de hechos noticiosos que serán explicados con muy pocas imágenes. Las páginas de los periódicos, excesivamente constreñidas desde el punto de vista gráfico y sometidas a demasiadas tensiones de carácter editorial, cederán el paso al nuevo concepto de "reportaje fotográfico" y a sus nuevos formatos, la revista ilustrada y el más ideal de los casos, el libro. El reportaje implica la idea de relato y de discurso. Se basa en un trabajo que exige una mayor dedicación de tiempo, una mayor profundización que la efectuada por el fotoperiodista, ámbito en el que el fotógrafo interpreta la realidad y la reconstruye. Para esta reconstrucción será necesaria una estructura, una serialización que acercará el lenguaje fotográfico al lenguaje cinematográfico y que llevará, en varias ocasiones, a que algunos fotógrafos lleguen a ensayar incursiones en el mundo del cine.

Partiendo de ello, Gabriel Cualladó, reconocerá como modelo a seguir el impuesto por Eugene Smith y considerará sus imágenes como próximas a las de su maestro. En una entrevista concedida a Óscar Berdugo confiesa por qué le gusta llamar a sus reportajes "ensayos fotográficos", igual que Eugene Smith. Cualladó remarca en su modelo fotográfico estos dos conceptos: por un lado, la profundidad y la complejidad del reportaje o "ensayo fotográfico" y, por otro, la estructura secuencial de sus trabajos.

\footnotetext{
“Me considero más cerca de Eugene Smith. Si me preguntan cerca de quién colocaría mis imágenes le citaría a él. A los trabajos que he emprendido, más que reportajes me gusta llamarlos ensayos que es como Eugene Smith solía llamar a sus trabajos. Creo que esa expresión abarca algo más que el simple reportaje, expresa una intención de profundizar y de sugerir mayor número de cosas y de mostrar elementos no perceptibles en un trabajo más superficial. Es lo que he intentado en todos mis trabajos. Desde luego ese intento se queda en nada, si el punto de vista del espectador y la sensibilidad del que lo retrató no coinciden.

-Precisamente observando esos trabajos que tú llamas ensayos, advierto un cierto sentido de secuencia.
}

78 Pérez Siquier, Carlos (El redactor-jefe), “Narración por imágenes”, en $A F A L, n^{\circ}$ 34, enero-febrero, 1962, sin paginar. 
-Efectivamente, cuando he podido los he concebido como un relato con principio y fin. Cada foto tiene su contenido, pero creo que hay que verlas juntas para contemplarlas bien. Por otra parte, siempre me ha interesado la fotografía con presencia humana, que se presta más a esto. A pesar de la fascinación por las fotos de Ansel Adams o de Weston, la presencia del hombre en la fotografía me interesa más. Aquel libro de Steichen, La Familia del Hombre, era como mi libro de cabecera"79.

El concepto de "ensayo fotográfico", según Gabriel Cualladó, no era un mero homenaje a Eugene Smith. Lo que Cualladó pretendía con su "ensayo fotográfico" era un trabajo a un nivel superior al del mero reportaje fotográfico. Expresaba la intención de una mayor profundización y sugerencia en el tema, mucho más elaborado que la superficialidad de un reportaje "gráfico". Y para poder profundizar y sugerir era necesario integrar todas las imágenes en un conjunto, en una secuenciación, en un relato con principio y fin. A pesar del posible interés de cada imagen individual, era necesario contemplar con la suficiente perspectiva todo el conjunto para comprenderlo bien. Exactamente, el concepto de Eugene Smith sobre el "ensayo fotográfico" al que hace referencia Cualladó, es el siguiente:

“-¿Hay una diferencia entre «reportaje gráfico» y «ensayo fotográfico»?

-Creo que un artículo gráfico es un portafolio armado por un director periodístico, mientras que un ensayo debe estar pensado, con cada foto en relación con las otras, de la misma manera que se escribe un ensayo. Quizá la escritura de una pieza teatral sea mejor comparación. Se trabaja sobre las relaciones entre las personas, y se examinan las relaciones que se han hecho, y se ve si deben ser establecidas o reforzadas otras relaciones. Debe haber entre las fotos una coherencia que no creo que usted encuentre en la publicación habitual de un grupo de fotos bajo el nombre de notas gráficas" ${ }^{\prime \prime}$.

Habría que matizar la exclusividad del mérito de Eugene Smith con respecto al uso de la maquetación y la ordenación narrativa-argumental de su "ensayo fotográfico", y reivindicar aquí la espléndida labor realizada por Bernard Quint.

“La publicación de un ensayo fotográfico tan ambicioso como el de Smith [Spanish Village] habría sido un fracaso sin el concurso de un editor gráfico de talento. Smith tuvo a Bernard Quint, uno de los mejores directores de arte de Life, que fue el encargado de seleccionar y ordenar sus imágenes en una secuencia lógica y legible. La tarea del diseñador no fue sencilla, ya que, como Quint recordaría años más tarde, las discusiones con Smith sobre cualquier tema que tratara sus fotos eran cuestiones de vida o muerte (...) Convencerle de que una foto al lado de otra no era lo mismo que presentarla aislada fue una ardua tarea (...) [Quint] Dispuso el diseño como si fuera el de un libro en lugar de estar destinado a una revista, es decir, como si fuera independiente de los demás asuntos tratados en aquel número"81.

Finalmente, se utilizaron las diecisiete fotografías que completan la selección publicada de modo que ninguna repitiera el mismo tamaño, ni se alineara verticalmente u horizontalmente entre sí. De este, modo cada imagen era considerada como una obra individual, como una entidad simbólica independiente. La gran virtud de la maquetación realizada por Bernard Quint del reportaje de Spanish Village, consistió en que todo el ensayo se sostenía visualmente por las relaciones

79 Berdugo, Óscar, "Diálogo con Gabriel Cualladó", en Gabriel Cualladó Fotografías, Madrid, Museo de Arte Contemporáneo, Ministerio de Cultura, 1985, pág 8.

80 Hill, Paul y Cooper, Thomas, op. cit., pág. 246.

81 Fernández, Horacio, op. cit., págs. 110-111. 

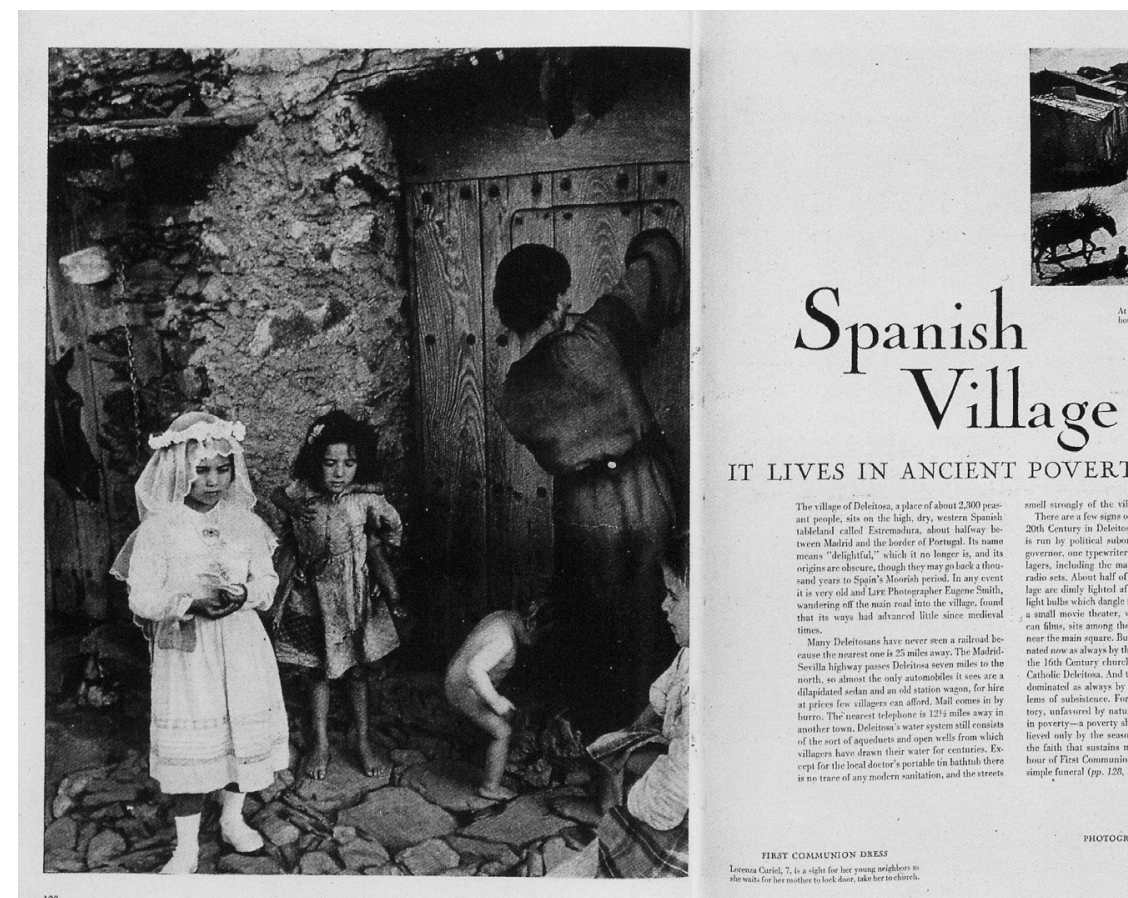

IT LIVES IN ANCIENT POVERTY AND FAITH
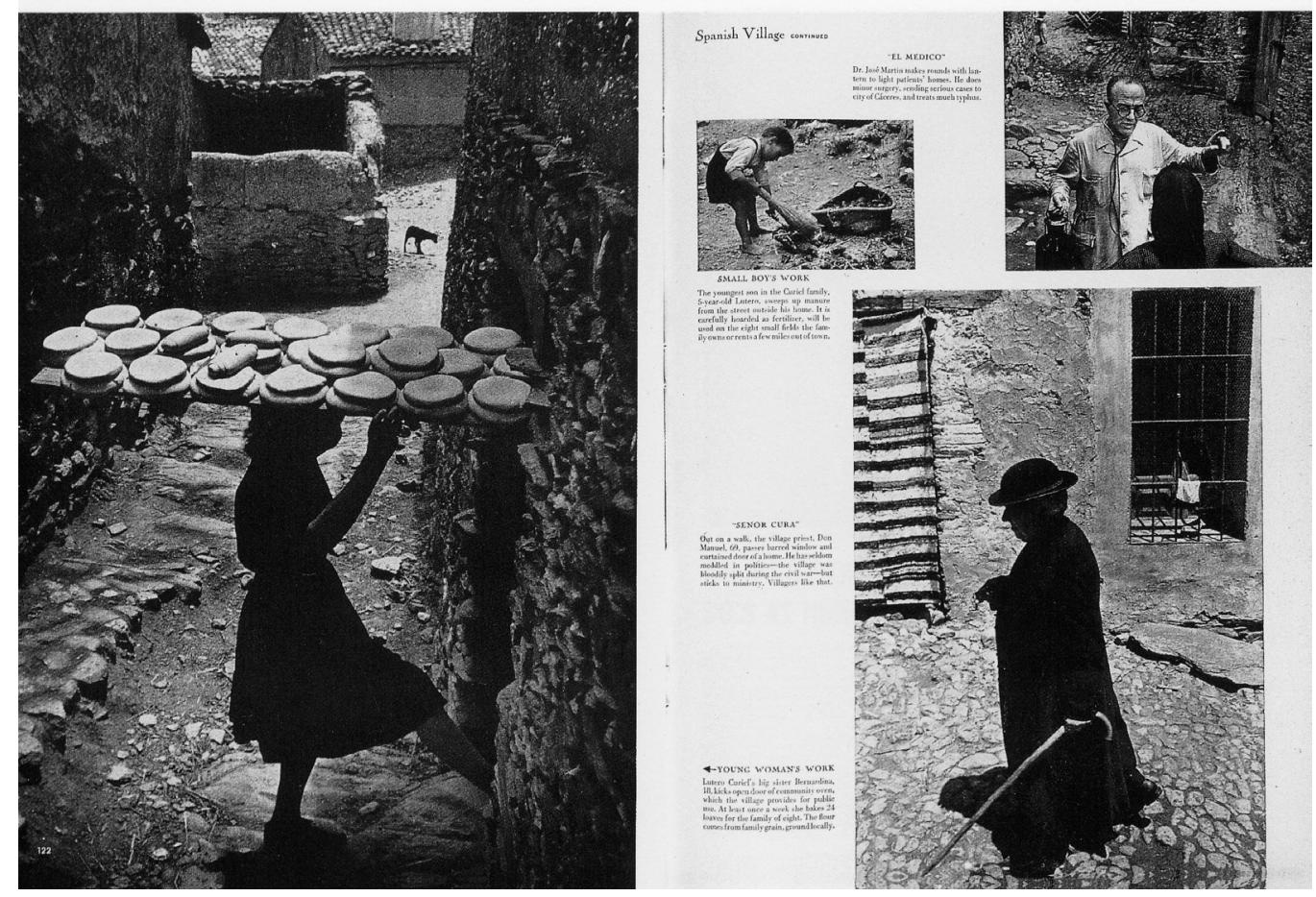

Eugene Smith, "Spanish Village", 1951. 

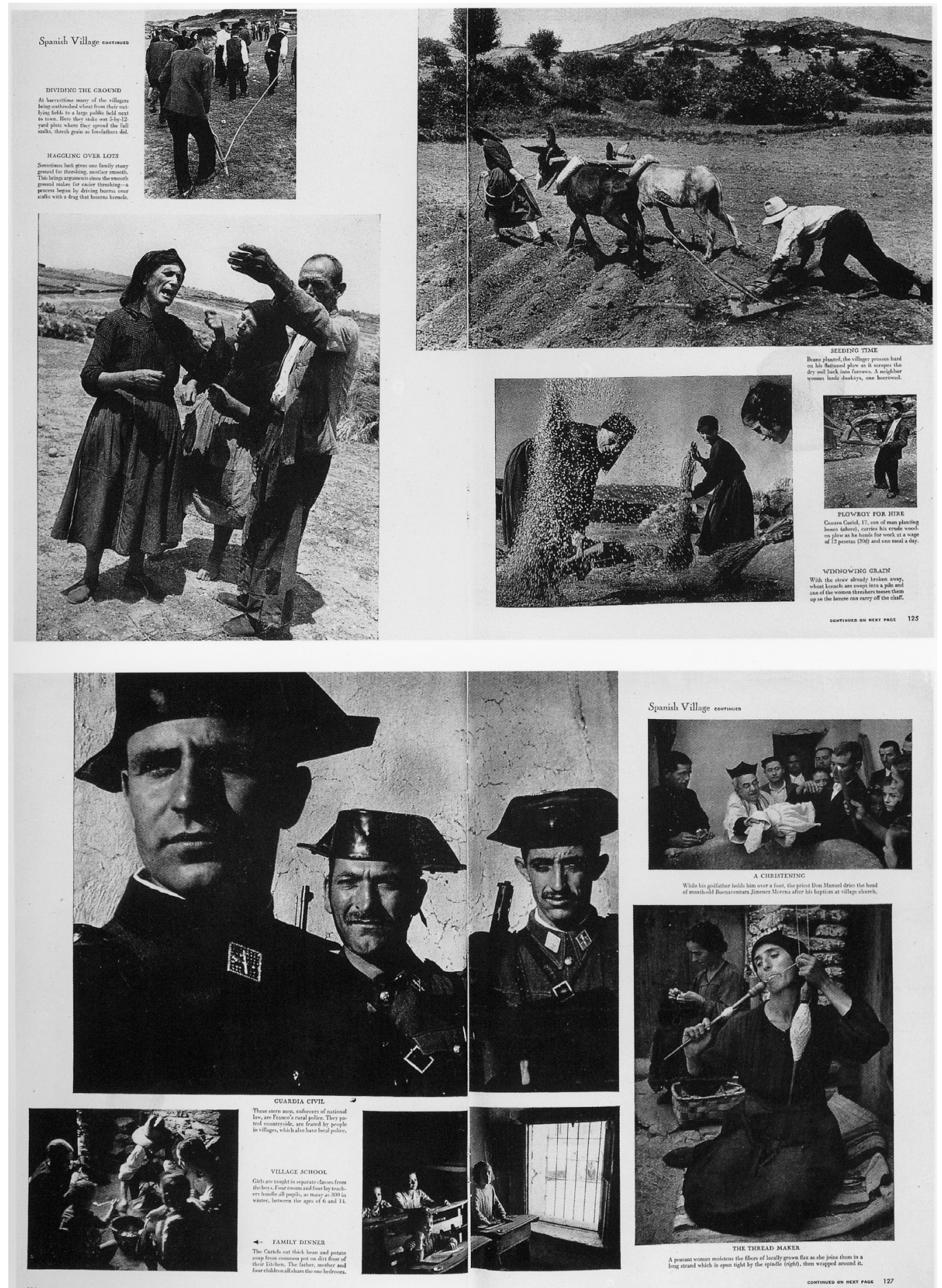

Eugene Smith, “Spanish Village”, 1951. 
geométricas entre las diferentes fotos, establecidas gracias a un juego sutil de sangrías, espacios en blanco y diferentes tamaños de margen, aparentemente sencillos pero de gran complejidad. A pesar de que Ramón Masats no reconoce a Eugene Smith como una de sus influencias más importantes, ese concepto del "ensayo" fotográfico que asume Cualladó, aparece de alguna manera en la obra más personal y elaborada de Masats. Imágenes interrelacionadas unas con otras con coherencia, profundidad y sugerencia.

Masats trabajó en Gaceta Ilustrada, pero él mismo reconoce que Gaceta Ilustrada no era igual que Life.

-¿Tú eras periodista?

(R. Masats, Madrid, 4 de septiembre de 2002) -“Sí, para Gaceta Ilustrada. Para ilustrar un artículo".

-Pero en los periódicos no.

(R. Masats, Madrid, 4 de septiembre de 2002) -“No."

-Es que hay una diferencia entre la fotografía periodística y el reportaje. En uno la actualidad es lo que importa. En el otro hay una profundización en el tema, quizá una interpretación. Tú hacías quizá más ensayo fotográfico, como diría Eugene Smith.

(R. Masats, Madrid, 4 de septiembre de 2002) -“A veces sí y a veces no. A veces hacía noticias para Gaceta Ilustrada. Quiero decir que Gaceta Ilustrada no era Life. Ensayo fotográfico no lo hacía siempre".

Con independencia de ello, el hecho incuestionable se centrará en cómo la obra editorial experimenta en esta época un esplendor inusitado, sobre todo en la década de los sesenta. Como ya vimos, el fotógrafo Català-Roca asumió el papel de pionero de toda una legión de autores que materializaron algunos de los mejores libros de fotografía que se han publicado jamás en la Historia de la Fotografía española.

“Esto explicaría que durante este tiempo la publicación pase a ocupar el papel de unidad expresiva de los fotógrafos y que la historia correspondiente deba efectuarse enumerando títulos de obras editadas"82.

Una vez más el catálogo por excelencia de la época, la "Biblia" de los fotógrafos españoles de finales de los años cincuenta, The Family of Man, tuvo parte de la responsabilidad de esa fecunda explosión bibliográfica que lamentablemente, no tuvo una verdadera continuidad en nuestro país. La contemplación y análisis del mismo sirvió como catalizador de muchos de los conceptos narrativos que desarrollarán con posterioridad Masats y otros autores.

El magnífico catálogo editado demuestra que la selección efectuada posee un alto nivel. Steichen hace un largo viaje preparatorio a través de Europa -para saber si encontrará material en ella, como en los Estados Unidos- y lo encuentra, en efecto. En colaboración con su ayudante Wayne Miller, repasa más de dos millones de imágenes, retiene en primer lugar diez mil y selecciona por último quinientas tres, de sesenta y ocho países distintos. El catálogo está ordenado siguiendo los grandes momentos y los grandes aspectos de la vida humana: nacimiento, amor, trabajo, muerte... Su gran atractivo radica en la brillante edición, ordenación, maquetación y selección, que ilustra perfectamente una filosofía de trabajo por la cual la fotografía sólo cobra sentido pleno editada en una revista y/o un libro, hecho que implica una concepción del trabajo fotográfico que prevé desde el inicio la puesta en página. Aunque realmente las fotos nunca fueron realizadas ex profeso para ese libro y no fueron producto de un encargo, lo cierto es que fueron seleccionadas con ese propósito. Convencido de que la 


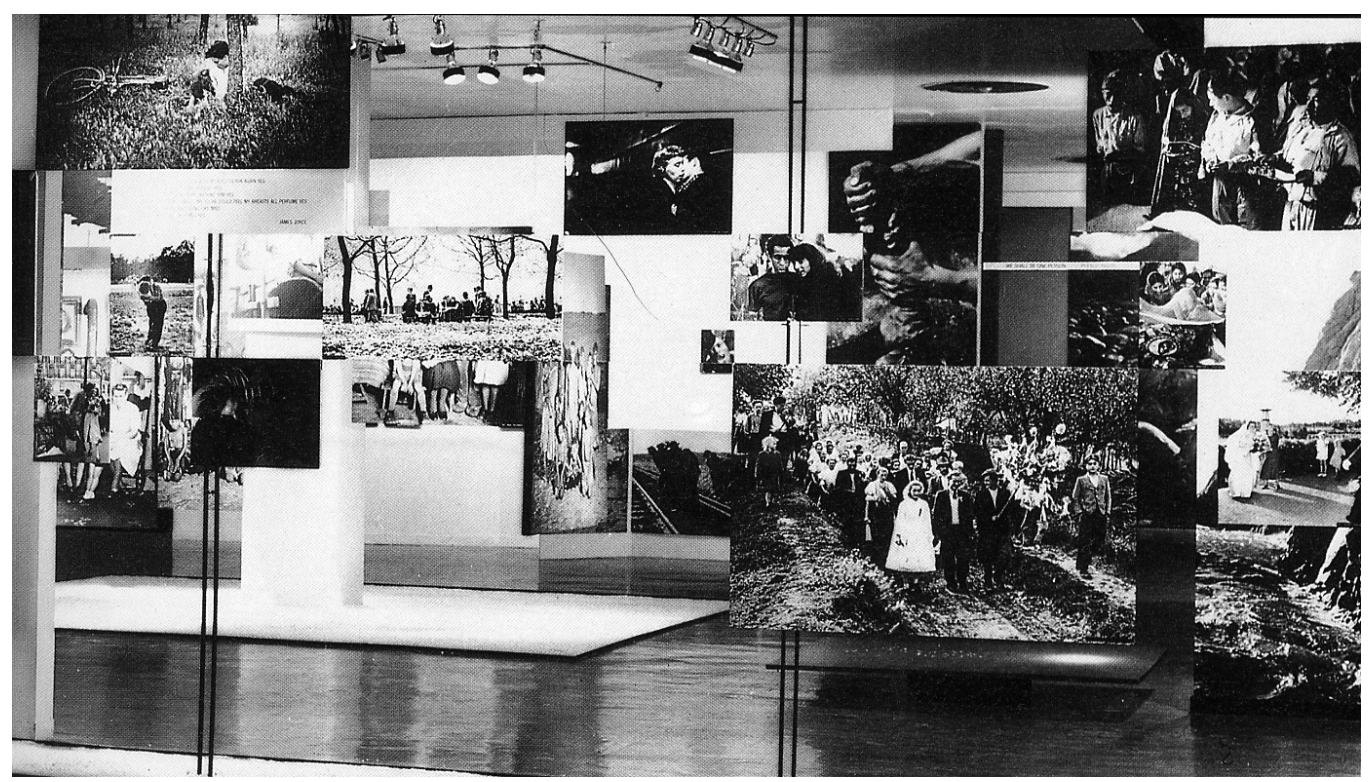

Fotografía del montaje de la exposición The Family of Man.

exposición de fotografía se presta más que ninguna otra a las experiencias de compaginación $\mathrm{y}$, por consiguiente, a la expresión de las ideas dominantes, Steichen asume hasta el límite su papel de maestro de obras, poniendo al servicio de sus ideas humanísticas, como ya vimos, todas las fotografías seleccionadas.

A Masats no le pasó desapercibida en absoluto la paginación del libro y en su particular repaso de la historia de la fotografía, realizada en el curso de fotografía que impartió en el Círculo de Bellas Artes de Madrid, comenta cómo están dispuestas las fotos en el libro:

(R. Masats, 20 de marzo de 2000) -“Ésta es la portada del libro de La Familia del Hombre. He fotografiado unas páginas de dentro para que veáis cómo estaba hecha la composición del libro, que también era bastante novedosa. Estaba muy estructurado por temas: el trabajo, la niñez..."

Esta filosofía afectaba también al diseño físico de la propia exposición. Steichen, de hecho, también concibió la exposición en sí como un libro o, mejor dicho, como una película, con un hilo narrativo que incluía introducción, nudo y desenlace. Ayudado por el arquitecto Paul Rudolph, realizó una magistral distribución de esas obras, manipulando las distancias, los ángulos, los coeficientes de ampliación:

“Las ampliaciones fueron objeto también de una cuidadosa "puesta en espacio» que sustituía la «puesta en página» del libro, de manera que el espectador debía seguir un determinado recorrido de vista y era confrontado con una arquitectura de imágenes de diferentes formatos que actuaban como acentos y puntos de dramatización. Igual que el maquetista decidía el tamaño y la ubicación de la fotografía sobre la superficie de la página, un original destinado a la exposición debía supeditarse a los condicionamientos del espacio" ${ }^{\prime 83}$. 


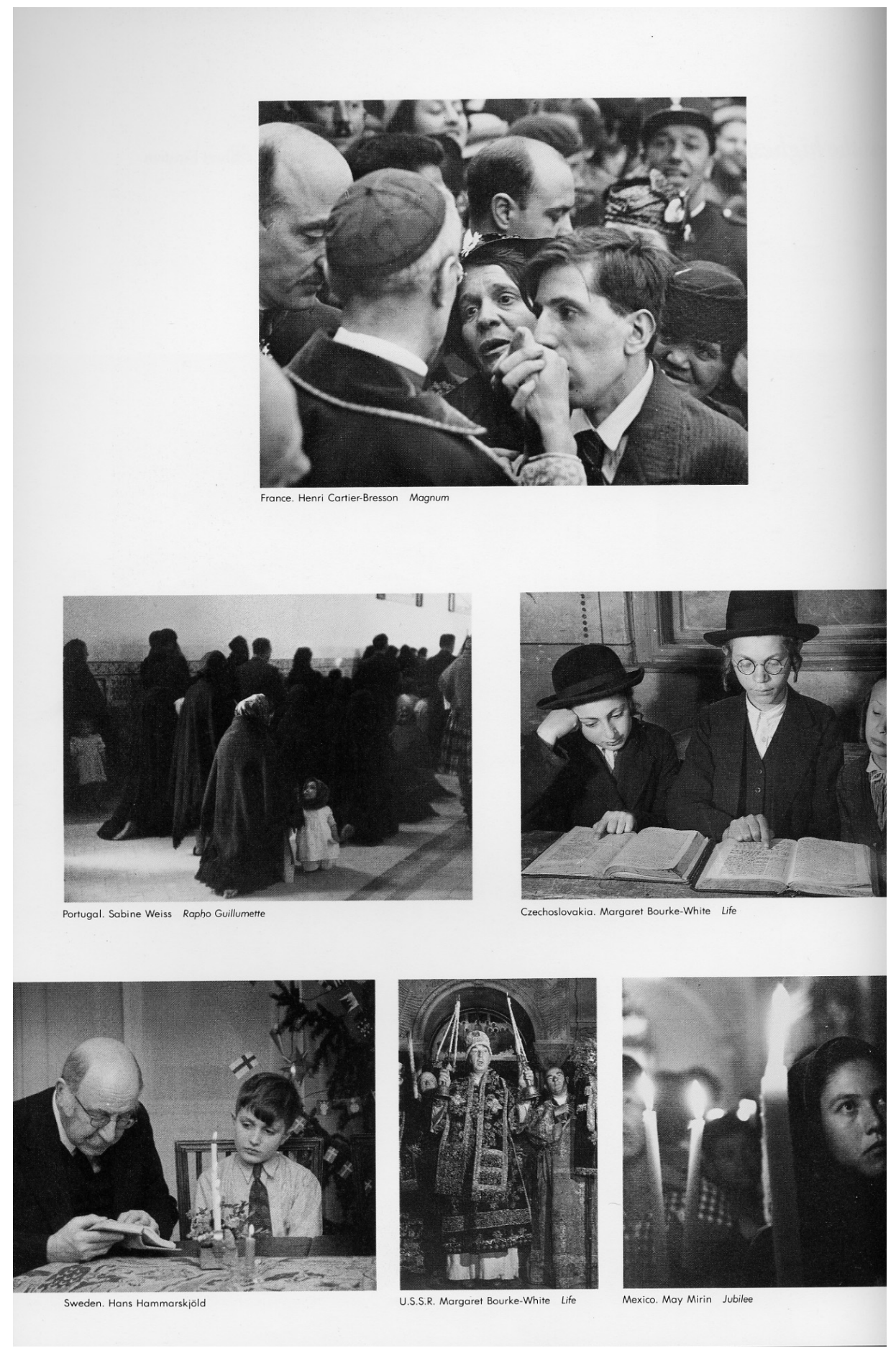

Edward Steichen, The Family of Man, 1955, pág. 158. 

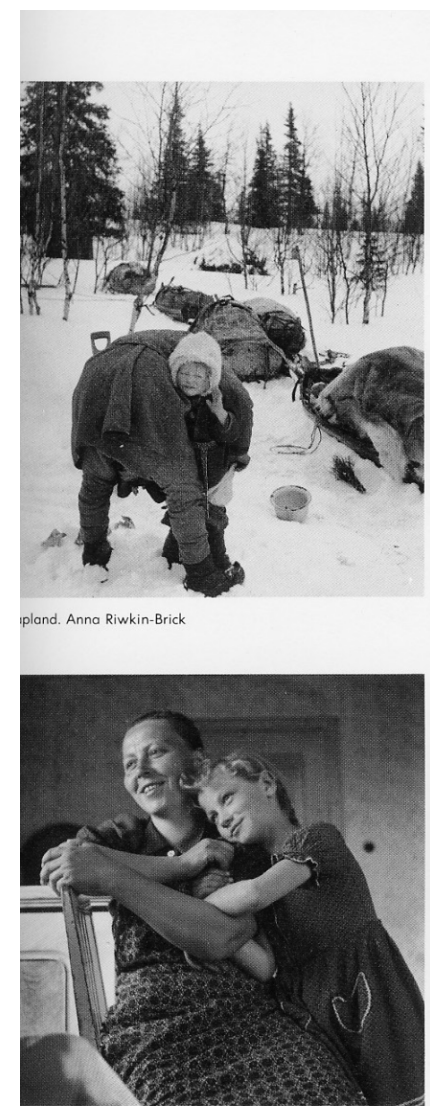

ustria. Ted Castle Magnum, AFSC
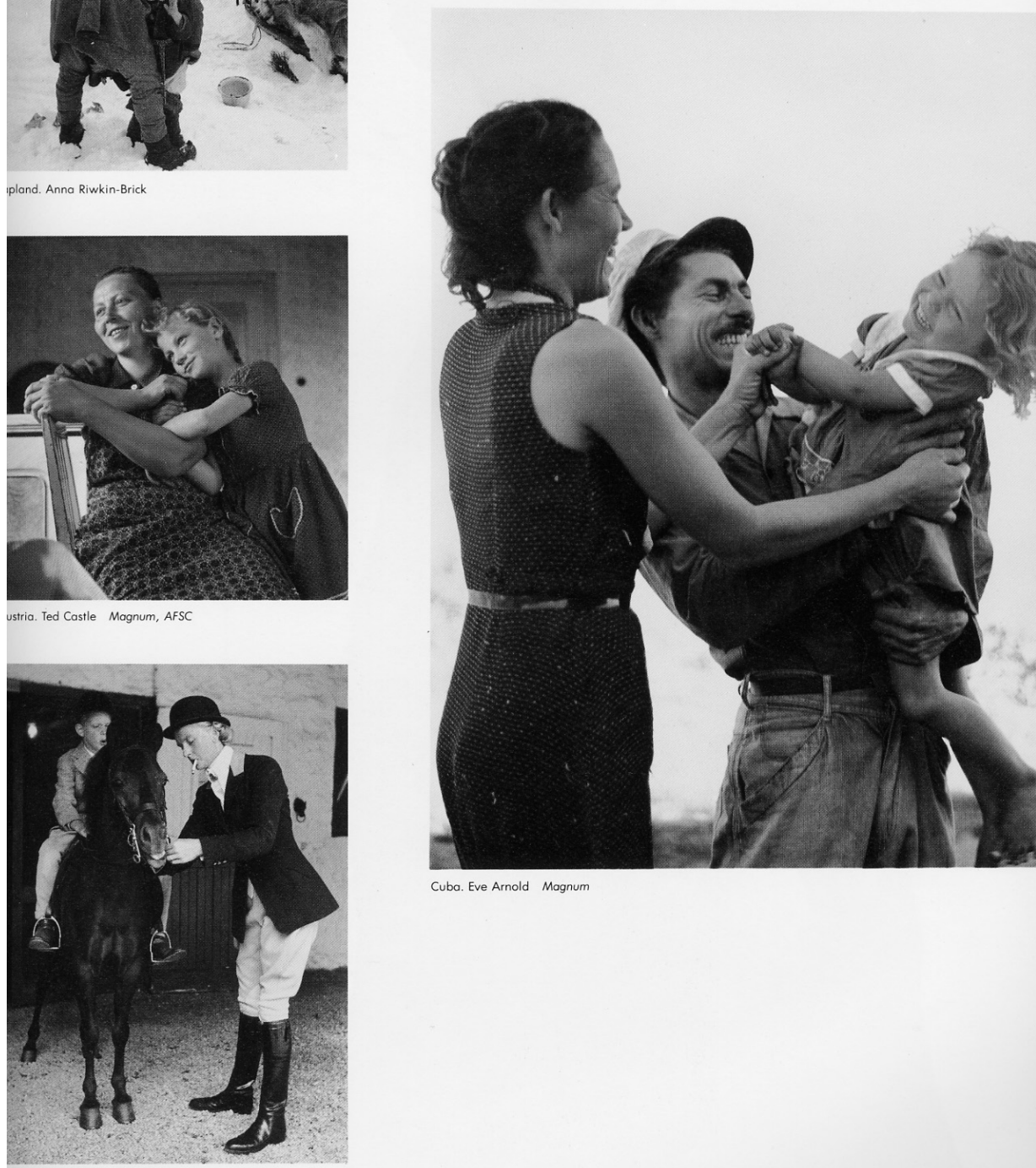

Cuba. Eve Arnold Magnum

S.A. Constantin Joffé Vogue

Edward Steichen, The Family of Man, 1955, pág. 31. 
La idea de Steichen revoluciona el trabajo de su antecesor en el MOMA, Beaumont Newhall. Con la ayuda de su colaborador, centra su fuerza en el montaje de la muestra. Aquí, el libro y la exposición tienen una voluntad explicita de contar, de narrar una historia igual que en el cine, jugando con la escalaridad del plano, con los puntos de vista, incluso con los tiempos de narración:

“Se trata de crear una dinámica similar al montaje cinematográfico, pero en la que la fuerza cinética no sea la del medio fotográfico, estático de por sí, sino la del propio espectador, que se ve situado frente a la cinta que tiene que recorrer en su longitud, aproximándose a los primeros planos y distanciándose de los planos generales hasta conseguir una experiencia final de duración muy similar al obtenido con una película. Un montaje, según la expresión del crítico Marc-Emmanuel Mélon, contra-fílmico (contrefilm), más cinematográfico que fotográfico, desde el punto de vista del resultado final" ${ }^{84}$.

La exposición deja de ser un escaparate aséptico, propio de los museos y las galerías de arte en general, en el que las imágenes se muestran todas iguales, sometidas al marco y al paspartú, como formando parte de un muestrario que puede ser canjeado por un precio estándar. Con todo, Masats no llegó a ver en directo la composición y el diseño de la exposición, puesto que está nunca llegó a España y Nuestro autor no fue a Francia a verla, aunque Oriol Maspons sí, y no cabe ninguna duda de que la explicó a sus amigos con todo lujo de detalles.

A pesar de lo señalado, el mayor impacto en este ámbito provendrá del libro New York de William Klein. Para Miserachs:

“El libro de Klein era -y es- una contundente sucesión de imágenes, ninguna de las cuales era apta para un concurso al uso, pero que, pese a la excelencia que yo les reconocía o atribuía, y a ser directa y viva fotografía de reportaje, tampoco ninguna podía optar a una selección tipo «The Family of Man». Las fotos de Klein parecían carecer de tema concreto, resultaba difícil intuir qué había llevado al fotógrafo a oprimir el obturador de su cámara, pero su lectura y relectura no paraban de ofrecer fascinante y heterogénea información, de despertar asociaciones de ideas, de ofrecer concretísimos punctum entre un aparente caos (...)

El libro New York de Klein llevaba a varias reflexiones, obligaba a relativizar las convicciones previas que pudieran tenerse, ponía en cuestión toda la estética fotográfica. Minimizándose, confiando en el azar, descuidando encuadres y olvidando composiciones, Klein había conseguido un personalísimo conjunto lleno de significantes, al que el lector encontraba concretos significados, parecía que la fotografía y el azar eran capaces por sí solos de comunicar la vida callejera de la gran ciudad, que la idea de «autor» en una serie fotográfica no hacía falta alguna (...) Sin embargo, Klein estaba también escondido por entre sus páginas, lanzando de vez en cuando algún guiño, mostrado alguna leve pista que condujera al lector a la clave de su voluntaria y sofisticada desaparición, que permitiera al lector intuir que azar y brutalismo técnico estaban incluidos en un riguroso y constante ejercicio de estilo"85.

Como vemos Miserachs sigue el mismo argumento antisalonístico. La fotografía bien empleada, comunica, y ahí estriba su verdadera grandeza. Pero, en este caso, el proceso comunicativo no lo lleva a cabo una imagen en solitario, como sería el caso de Cartier-Bresson o las fotografías "sueltas" de The Family of Man. Parece que la potencia de la maquetación y la edición del New York eclipsó el montaje cinematográfico de The Family of Man para Xavier Miserachs. En el libro de Steichen todas las imágenes, fruto de una exhaustiva selección, son impecables. Klein, por su parte, se permite el lujo de utilizar fotografías "comodín", en un alarde de sofisticación. 


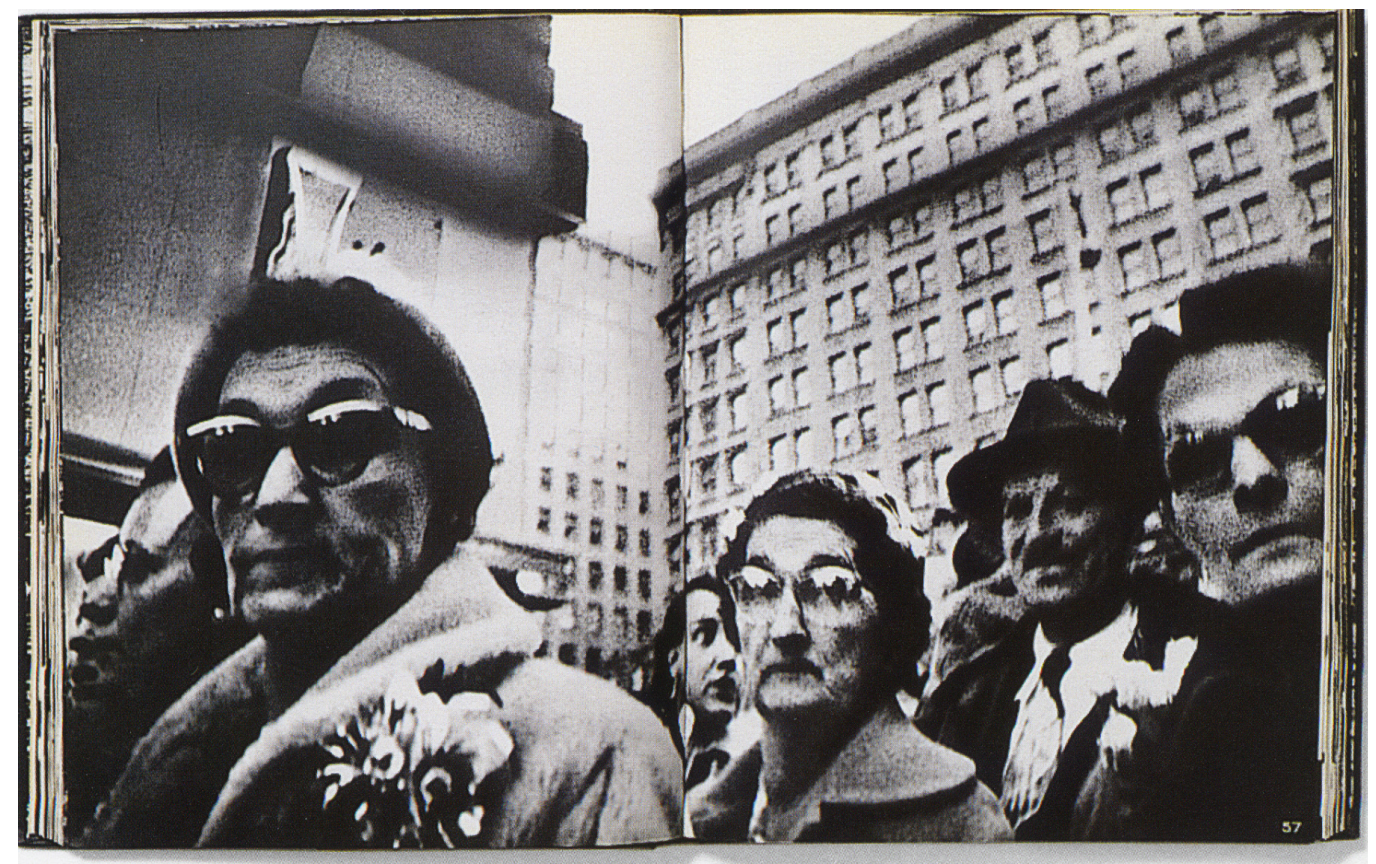

William Klein, “New York", 1955, pág. 57.

De tal modo que Miserachs interpreta que mientras The Family of Man hablaba realmente de la humanidad utilizando un arte comunicativo, en el New York se da una vuelta de tuerca y ese proceso de comunicación es el que se convierte en el propio protagonista de la obra, sacrificando en su articulación incluso los buques insignia de su flota fotográfica:

“En unas páginas se hace evidente el «patrón Klein», no ocurre nada, la imagen parece tomada por azar, aparece gente que no se sabe por qué está allí ni por qué los incluí en la foto, el espacio en que ocurre la escena es totalmente anodino. A la búsqueda de un tema inexistente, la mirada se pasea por la imagen y va descubriendo signos en la indumentaria, en las paredes, en el mobiliario urbano, en los vehículos. El fotógrafo ha propuesto una imagen de la realidad, pero la interpretación va a cargo del lector, quien difícilmente haría el esfuerzo si las viera aisladas, fuera del contexto de un libro, de un discurso" ${ }^{\prime 86}$.

Lo verdaderamente interesante son las posibilidades comunicativas de la fotografía: otra forma de realización que aumentaba las posibilidades expresivas de aquellos fotógrafos que querían superar los meros trabajos de encargo y las asépticas exposiciones. Nuestros jóvenes autores fueron conscientes de la utilización de textos breves, no como elementos descriptivos de las propias fotografías, ni como redundantes pies de páginas, sino como claves, lo más abiertas posibles, que ayudaran mediante la reflexión del espectador a descubrir las verdaderas intenciones de las imágenes, potenciando así su poder comunicativo.

Ya veremos cómo utiliza Masats todos los recursos narrativos que hemos visto. No obstante, no nos gustaría que se llegara a la conclusión de que Masats aprendió literalmente a partir de es- 
tos autores a contar una historia. Pensamos, más bien, que el germen de la narrativa de las series fotográficas subyacía en el contexto fotográfico del Masats de juventud. Las conversaciones con sus compañeros de generación que también estaban realizando sus propios libros, las discusiones con los editores o los jefes de arte de revistas y libros, el análisis de todas las obras que hemos analizado e, incluso, las conversaciones con los escritores con los que trabajó... todo ello creará el caldo de cultivo propicio para que Masats se plantee muchas preguntas y encuentre, siguiendo su intuición e inteligencia, sus propias respuestas.

Lo que no cabe ninguna duda es que Masats constituye un perfecto ejemplo de esta tendencia hacia la publicación de libros. A este periodo corresponden sus mejores trabajos editoriales: en 1962 publicó, con texto de Ignacio Aldecoa, Neutral Corner, para la editorial Lumen; la misma editorial con la que años más tarde, en 1964, publicará Historias viejas de Castilla la Vieja, con textos de Miguel Delibes. En 1963 verá la luz Los Sanfermines, con textos de García Serrano, para la editorial Espasa Calpe. Éste fue su libro más personal, puesto que la idea de realizalo no fue fruto de ningún encargo, como en los otros casos, sino que surgió del propio Masats, que no sólo realizó las fotografías, puesto que también se ocupó de la maquetación, con la que consiguió el Premio Ibarra al libro mejor editado. Por último, Masats también trabajará en una edición de lujo de Don Quijote de la Mancha, para la editorial Alfaguara en 1967.

Este interés por el libro y la narratividad que éste conlleva quedará patente en su posterior salto al ámbito del cine y de la televisión. Dentro de estos medios el montaje -mucho más que el guión, la fotografía o la dirección de actores- ocuparán su atención, hecho que se reflejará en films como Topical Spanish (1970) o en documentales como Insular (1971), integrado este último en el conjunto de trabajos que realizó para TVE entre 1965 y 1981, año en que vuelve a la fotografía. Sin embargo, conviene que no nos precipitemos. De ahí que en las próximas páginas vayamos a centrar nuestra atención en los diferentes libros que Masats realiza.

\subsubsection{Los Sanfermines (1956 - 1963)}

(R. Masats, Valencia, 25 de marzo de 2004) -“Yo trabajaba en una bacaladería del mercado en Cataluña -no me llevaba bien con mi padre- y a partir de un momento determinado, decidí hacerme profesional. Y mi duda era si dedicarme a la forma -al paisaje y todo eso- o dedicarme al reportaje. $Y$ entonces, para ponerme a prueba, me fui a Los Sanfermines -a ver que tal me defendía con el reportaje-. Para mí Los Sanfermines fue una prueba".

-En Los Sanfermines, no hubo encargo.

(R. Masats, Madrid, 15 de diciembre de 2003) -“No".

$-¿$ Y por qué escogiste este tema?

(R. Masats, Madrid, 15 de diciembre de 2003) -“Bueno, es un tópico, evidentemente. Yo ya quería ser profesional y en un momento determinado no sabía si irme con la Rolleiflex a hacer paisajes en plan abstracto a los Pirineos o ponerme a hacer un reportaje-reportaje a Pamplona. Empecé a hacer fotos, lo positivé y empecé a enseñarlo a amigos míos. Les gustaba y vi yo que mi camino era, más bien, de reportaje que no de esteta. Luego vine a Madrid... Yo creo que Los Sanfermines lo hice en tres años. Me da la impresión que lo hice un año siendo aficionado y dos años siendo ya profesional aquí en Madrid, pero no estoy muy seguro."

$-Y$, claro, financiado por tus propio medios.

(R. Masats, Madrid, 15 de diciembre de 2003) -“Completamente, todo".

-Es decir, que fue una apuesta arriesgada... Fue como tu do de pecho... “¡Esto es lo que yo puedo hacer!"... ¿Escogiste Los Sanfermines porque ya los conocías?

(R. Masats, Madrid, 15 de diciembre de 2003) -“No, de oír hablar de ellos en comentarios de prensa... algún documental del NODO o algo por el estilo, supongo. Pero no de alguien que me hablara, y mucho menos alguien del ambiente fotográfico". 


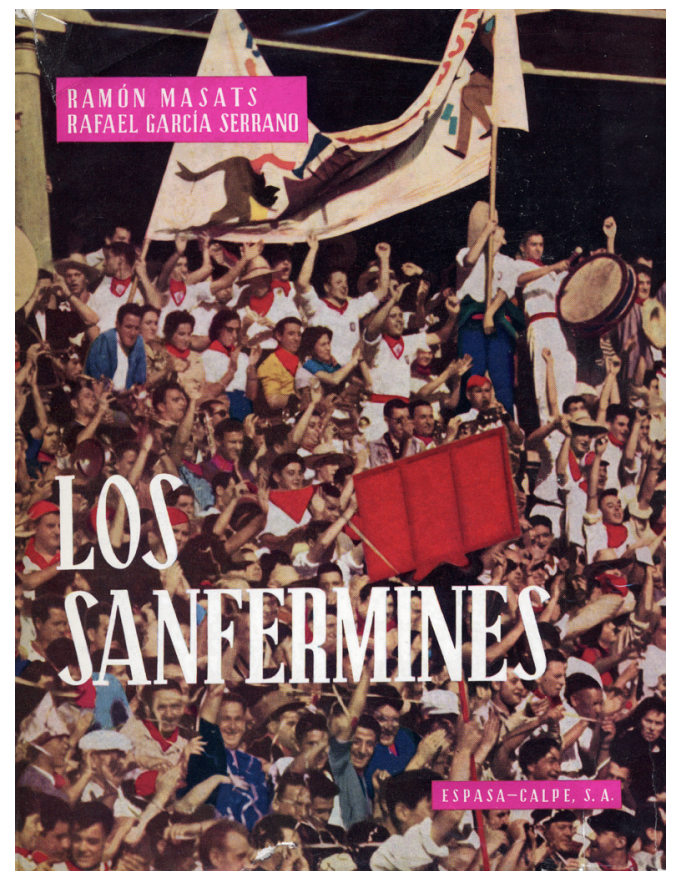

Portada del libro Los Sanfermines, 1963.

“Un año después de la última visita de Hemingway y uno antes de que el excesivo escritor norteamericano se suicidara, la fiesta más internacional de España gracias a "Fiesta" (1926) era un superpoblado universo entregado a la satisfacción de los instintos. La sangre, el alcohol, el sexo y la muerte presidían una celebración en la que el aspecto religioso era menos que una excusa"87.

- ¿Y no te leíste el libro Sangre y arena de Hemingway, o te documentaste de alguna manera? (R. Masats, Madrid, 15 de diciembre de 2003) -“No". - ¿Y cuándo te diste cuenta que a partir de un experimento podías hacer un libro?

(R. Masats, Madrid, 27 de diciembre de 2006) -“Cuando volvía a Barcelona se lo enseñé a Oriol... le gustó mucho y me dijo que tenía que continuar. Luego llegué aquí, a Madrid, y me hice profesional y a la gente que lo enseñé les parecía que podía ser un libro interesante. Y así fue como me animaron".

“Cuenta Cualladó, en unas notas rememorativas muy posteriores (leídas en una Mesa redonda sobre fotografia en el M.E.A.C. en mayo de 1982): «Poco después de esta exposición (se refiere a la de TerréMiserachs-Masats ya comentadas) vino a Madrid Masats con el deseo de abrirse camino en el campo profesional. Como tarjeta de presentación traía un reportaje que había hecho en Los Sanfermines (...) Recuerdo que ese día nos fuimos a un café para ver con detenimiento aquel trabajo. A mí me dejó impresionado la gran belleza de aquellas imágenes" ${ }^{\prime \prime 8}$.

(R. Masats, Madrid, 15 de diciembre de 2003) -“Aún era aficionado cuando me fui a Los Sanfermines. Entonces era fácil. Te estoy hablando del año 1956. Pero me he dado cuenta que tengo una 


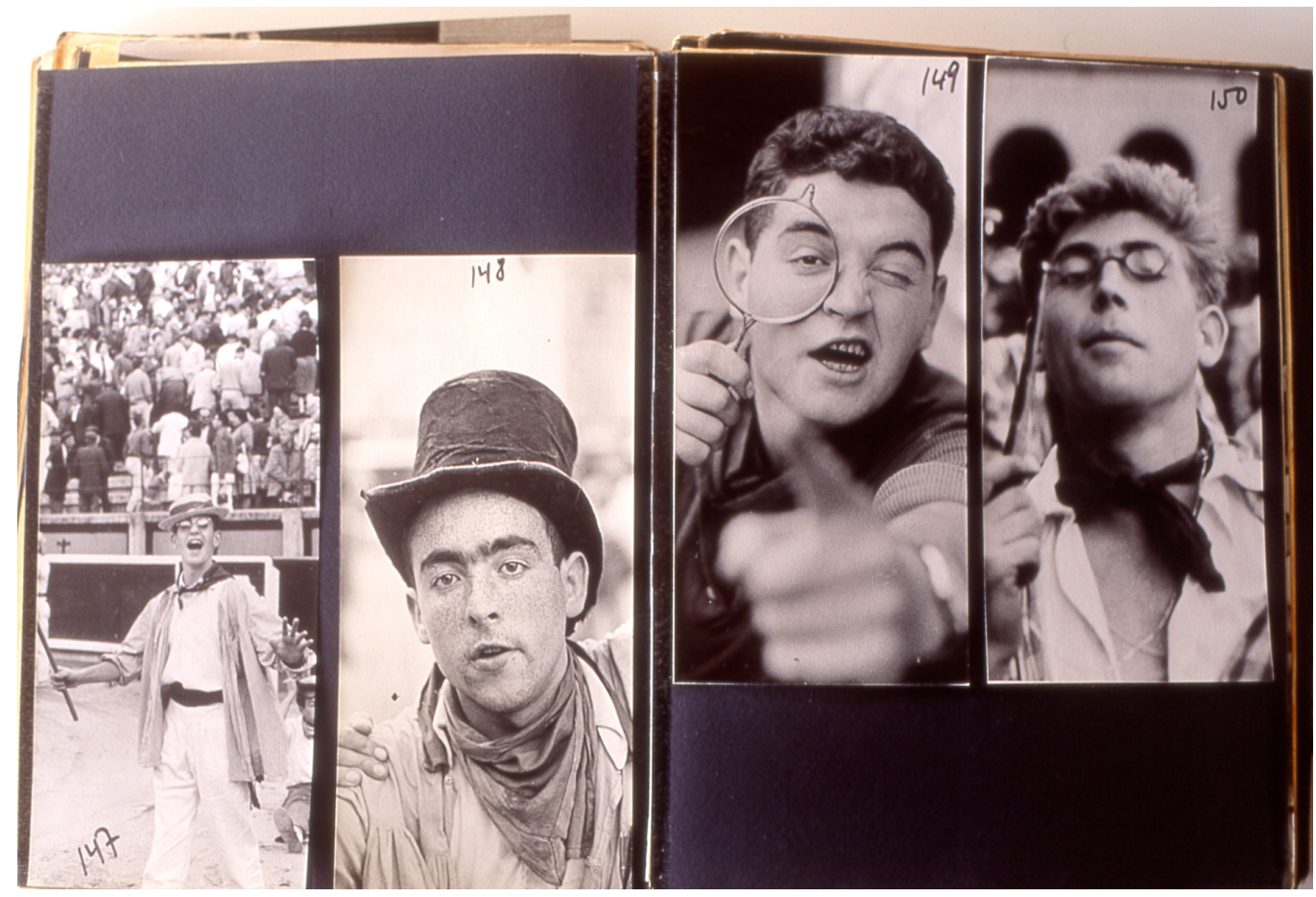

Masats conserva la maqueta original del libro con las fotografías pegadas en cartones a modo de páginas.

serie de lagunas con este libro, porque no me acuerdo cómo fui a Pamplona, no sé si fui en tren o dónde me quedé alojado... No conocía a nadie en Pamplona. Viviría en una casa particular donde me alquilaron la habitación, porque me fui con muy poco dinero. Antes, eso se hacía mucho y ahora también. Pero lo que sí me sorprende fue mi osadía para irme allí. Me fui a la Casa de la Misericordia y me presenté como aficionado que quería hacer un reportaje... Y me dieron permiso para todo: para el callejón de la plaza de toros... tuve permisos para todo. ¡Ahora es absolutamente imposible! Pero me dieron muchas facilidades. Una gente espléndida".

(R. Masats, Madrid, 15 de diciembre de 2003) -“Bueno, ¿sabes que la puesta en página la hice yo?".

-Sí, y te dieron el premio Ibarra al libro mejor editado de 1963.

(R. Masats, Madrid, 27 de diciembre de 2006) -“Yo he conseguido recuperar la maqueta que hice para Los Sanfermines de la editorial Espasa Calpe y tengo una cantidad de vintage... Claro, están las fotos pegadas a unas hojas con el formato exacto del libro. Ahora lo haces con el ordenador y te queda estupendo, pero te estoy hablando de hace casi cincuenta años..."

-El libro de Los Sanfermines está mucho más planificado y explicado que el trabajo de Las Ramblas. Yo no he estado nunca en Los Sanfermines y sí puedo tener una idea de lo que son viendo el libro. Hasta el detalle de la feria de ganado.

(R. Masats, Madrid, 15 de diciembre de 2003) -“Bueno es que esto es parte de la fiesta, evidentemente, y es muy importante. Claro, la feria de ganado era por San Fermín. Los ganaderos corrían los toros que llevaban a las plazas. Hay muchas fiestas que su origen eran las ferias de ganado. Como la feria de Sevilla (que, por cierto, iniciaron un valenciano y un catalán). Allí las casetas de los feriantes eran corrales para los animales y ahora han ido derivando, degenerando o no, en las 


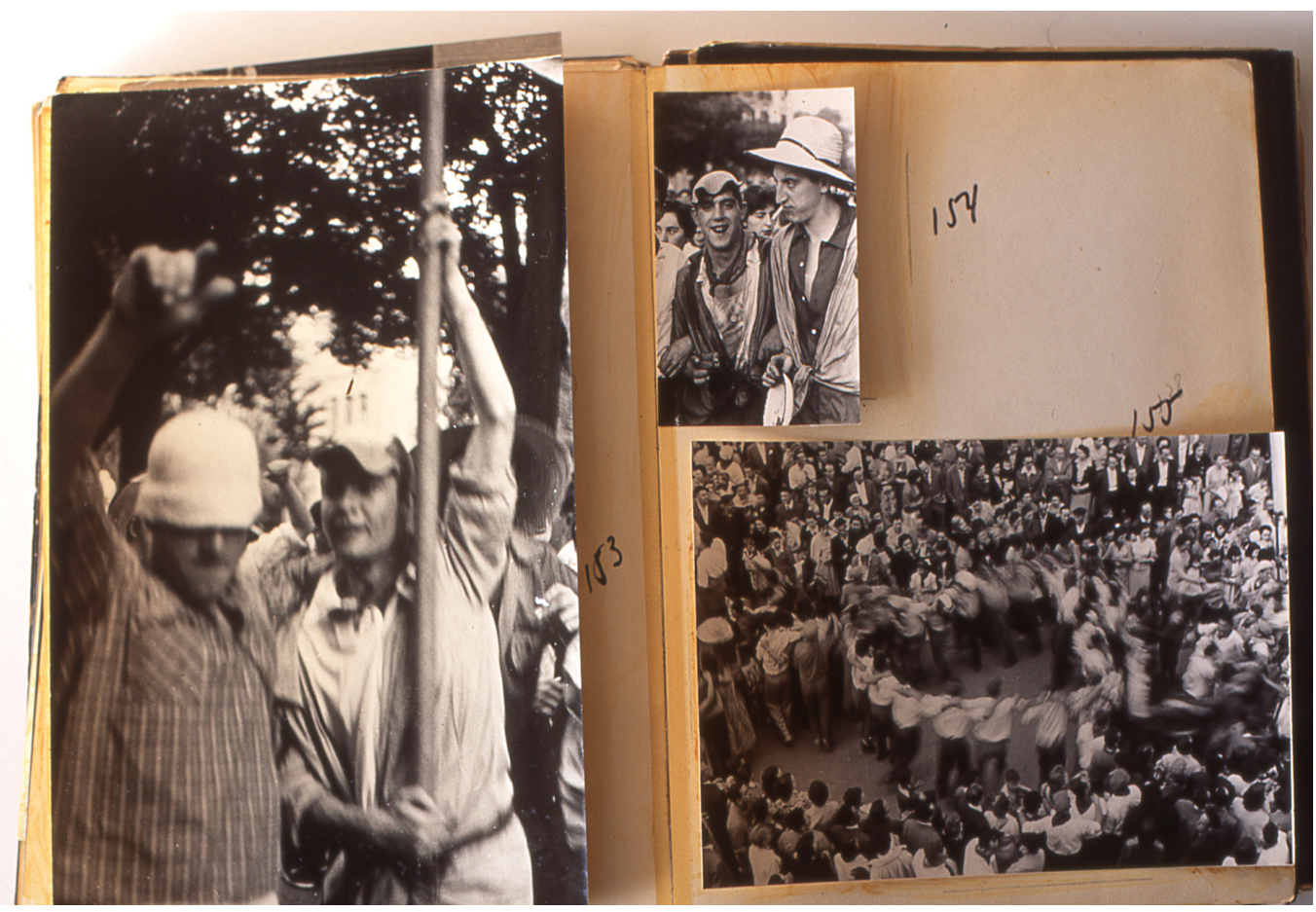

Ramón Masats, maqueta original de las últimas páginas de Los Sanfermines.

casetas de las fiestas. Y de los caballos sólo quedan los carruajes y los que llevan para pasear. El origen de Los Sanfermines era una feria de ganado, por eso le di tanta importancia en el libro.

- ¿Y cuál fue el criterio para ordenar las fotos?

(R. Masats, Madrid, 27 de diciembre de 2006) -“Bueno... tanto en las fotografías, como en los documentales, siempre he tenido un planteamiento muy lineal: es decir, la fiesta empieza con los preparativos, luego los encierros y termina por la noche con el «¡Pobre de mí!». Muy lineal".

-Es decir que no querías captar imágenes de Los Sanfermines, sino que querías contar la historia de cómo son Los Sanfermines a través de una narración muy cinematográfica y temporal: preparación de las fiestas, presentación de los personajes, chupinazo, borrachos, toros y golpes.

(R. Masats, Madrid, 27 de diciembre de 2006) -“Exactamente. Fue mi primer libro como profesional. Es muy cinematográfico, muy documental y lineal".

Este sentido lineal al que alude Masats lo hallamos en la propia estructura del libro ${ }^{89}$. Este se halla dividido en cinco partes: Vispera y vísperas, La noche, El encierro, La mañana, La tarde.

En Víspera y vísperas encontramos los preparativos de las fiestas con la gente comprando en el mercado, así como la primera referencia directa al festejo: un vendedor con pañuelo rojo. Sigue a continuación el vino, las multitudes, el chupinazo, la alegría desatada de los amotinados, las autoridades, la iglesia... y esos detalles que hacen grande este libro, como el de ese niño ataviado de pamplonica que, agotado, se duerme en la iglesia.

La noche es un capítulo dedicado al baile, el divertimento y el alcohol. Está compuesto con algunas de las imágenes más frescas del libro. 


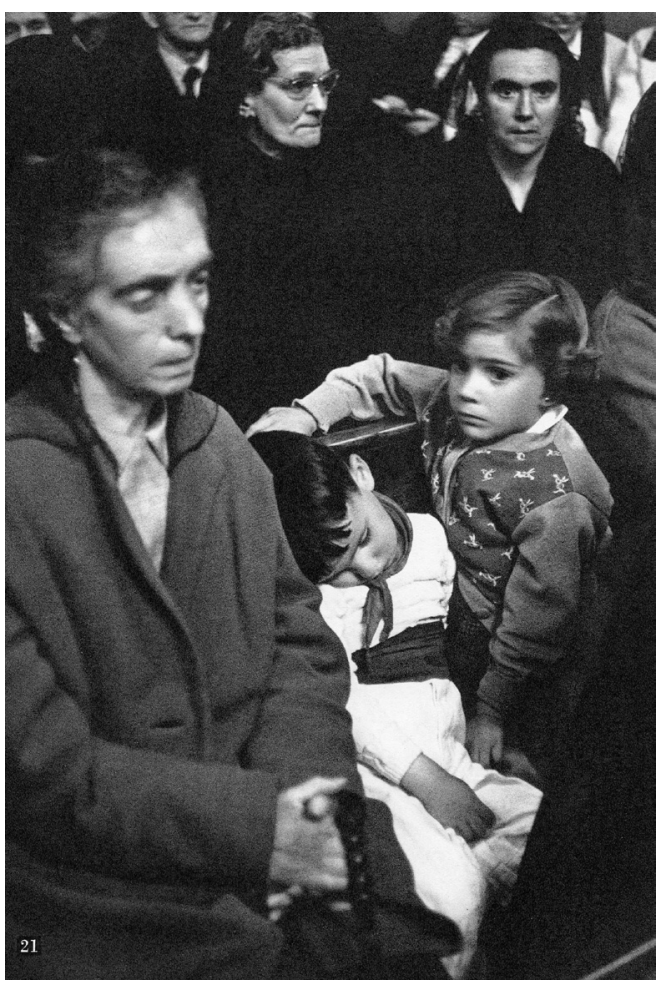

Ramón Masats, "La primera víctima de la fiesta", Los Sanfermines, foto 21.

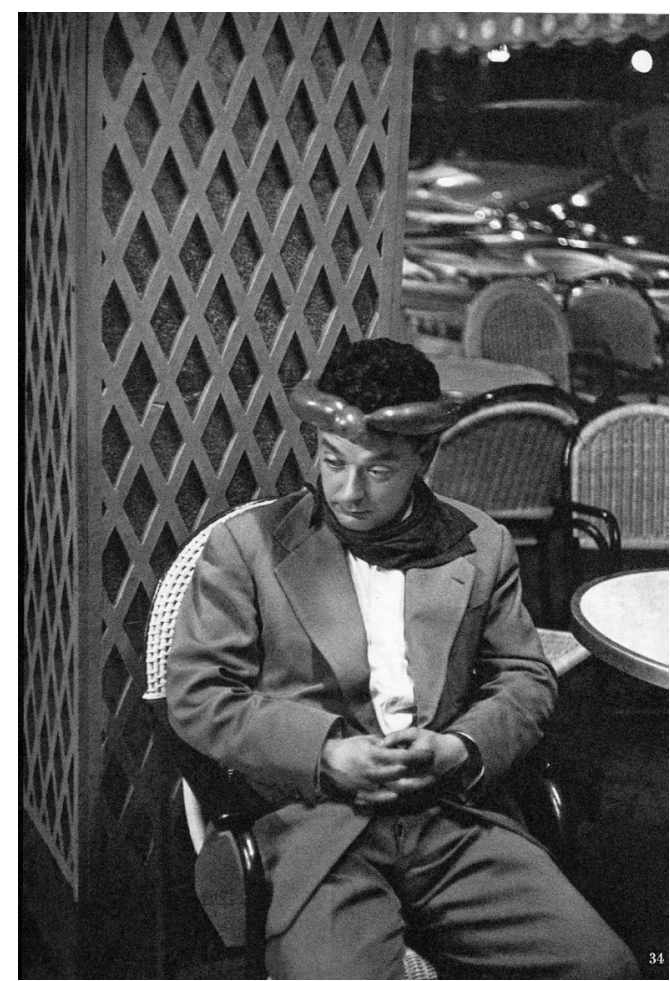

Ramón Masats, "Beatitud", Los Sanfermines, foto 34.

De las 24 imágenes de las que consta El encierro la mitad, precisamente las más impactantes de las cogidas y los tumultos con el toro, son obra de fotógrafos locales: Cine-Foto, J. Galle y Zubieta y Retegui. En el resto, Masats se centra en los preparativos de los mozos, en la danza entre el toro y los mozos de la plaza, los moratones y el agotamiento del final.

La mañana es el capítulo con mayor número de imágenes, 44. Está subdividido a su vez en varios grupos: primero aparecen las imágenes de la feria de ganado, después vuelve la fiesta en la calle, la misa, los gigantes y cabezudos, los niños corriendo y llorando, las procesiones, los corrales que guardan los toros, los concursos en la plaza...

La tarde empieza tranquila y reposada: gente descansando tomando café, escribiendo cartas... un apéndice breve atiende a los pelotaris en un frontón, así como a nuevos borrachos de transición. Tras todo ello empiezan las corridas. La faena en el ruedo es cotejada con el ambiente en las gradas. Una vez más el vino y la ebriedad le sirven a Masats como tema recurrente para ambientar la fiesta, cobrando tanta importancia 0 , incluso, más que la dedicada a los propios toreros y toros.

- Me ha llamado la atención que eres un gran fotógrafo de masas. Te defiendes muy bien con las masas. Y es un tema complicado... Ordenar visualmente el caos es muy complicado. Tienes por lo menos tres reportajes de masas destacables: las fotos de masas de Los Sanfermines, las fotos que hiciste cuando llegó Eisenhower a Madrid (para Gaceta Ilustrada) y luego tienes el reportaje sobre el circo (que también fue publicado en Gaceta Ilustrada). 

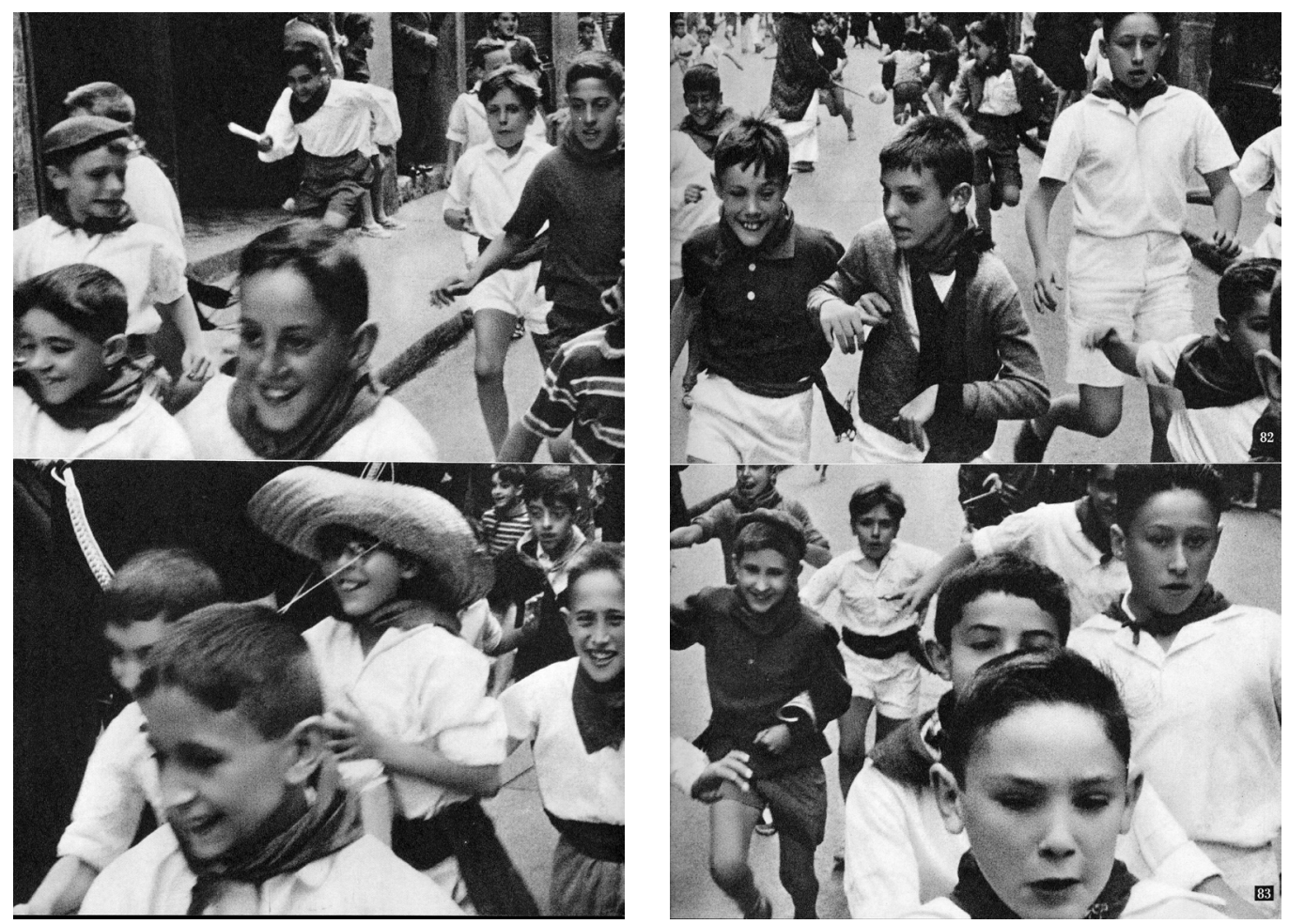

Ramón Masats, "Kilikis al ataque o entrenamiento para el encierro", Los Sanfermines, fotos 82 y 83.

(R. Masats, Madrid, 15 de diciembre de 2003) -“Los Sanfermines son de masas. Puedes individualizar de vez en cuando pero tienes que trabajar la masa. En esto también hay un planteamiento de libro. Ya no era como Las Ramblas...".

-Algunas de las imágenes de Los Sanfermines me recuerdan un poco a William Klein y sus fotografías de los desfiles.

(R. Masats, Madrid, 15 de diciembre de 2003) -“Puede ser. Aquí hay fotos hechas sin mirar, levantando la cámara con los brazos por encima de la cabeza, porque se ve que están hechas en picado, y sin encuadrar ni nada".

-Para dar sensación de multitud y de caos.

(R. Masats, Madrid, 15 de diciembre de 2003) -“Sí, todas estas están hechas así. Con la cámara desde arriba y tirando mucho".

-Este hecho les da mucho dinamismo y mucha fuerza, aunque no se vea ninguna persona concreta ni exista ninguna composición especial. A Cartier-Bresson, por ejemplo, no se le ocurren estas cosas. Todas las fotos tienen el mismo valor. Sin embargo, aquí hay fotos que apoyan otras fotografías y las refuerzan. Sueltas -como las de la masa que has hecho desde arriba- en una exposición no tendrían sentido.

(R. Masats, Madrid, 15 de diciembre de 2003) -“No. Pero entre el follón que crea la página... pues creo que sí".

-También hay fotos bisagra, que ayudan a presentar el tema, organizándolo por momentos... y hay fotografías que enlazan estos momentos. ¿Puede ser?

(R. Masats, Madrid, 15 de diciembre de 2003) -“Puede ser". 

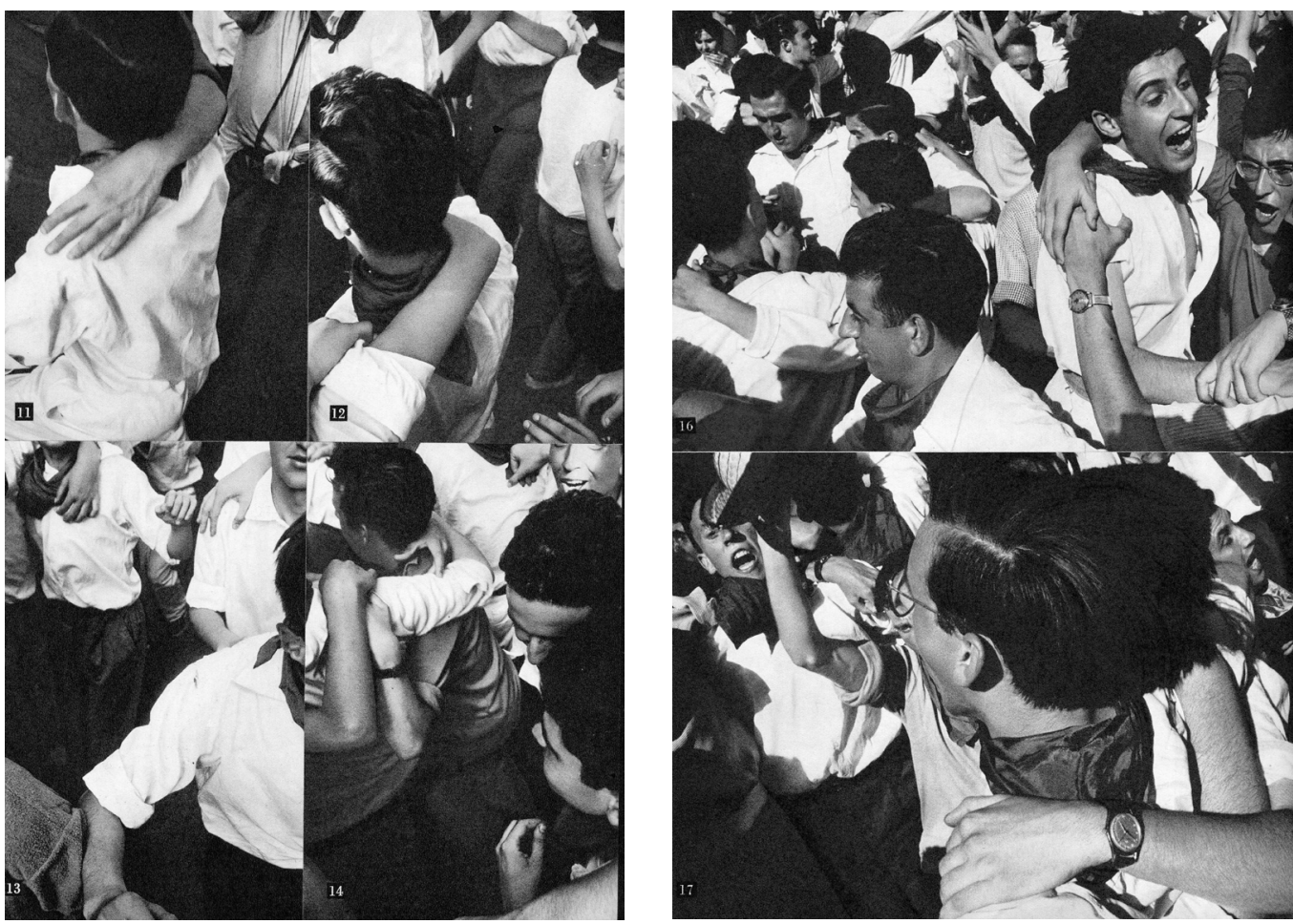

Ramón Masats, “Otros aspectos de la tormenta”, Los Sanfermines, fotos 11-14.

-La maquetación destaca por ser muy narrativa y cinematográfica: hay planos-contraplanos, planos subjetivos... (como cuando se ve a la gente de espaldas asomados a una valla y en la foto siguiente se ve que lo están mirando son lo toros encerrados en una cuadra) eso es un montaje cinematográfico...

(R. Masats, Madrid, 27 de diciembre de 2006) -“Sí, totalmente".

- ¿Puede ser un germen de lo que vendrá posteriormente?

(R. Masats, Madrid, 15 de diciembre de 2003) -“Ten en cuenta que en el 1965 dejé la fotografía para dedicarme a la televisión y el cine. Quiero decir, que ya entonces había un fermento de cine".

-Claro, es que en esta paginación (el toro caído y el uno del público apuntado con una pistola) hay una construcción espacial y narrativa que has generado tú enfrentando las dos imágenes. Porque a lo mejor estaba apuntando a otro espectador o tirándole agua al torero... pero tú lo usas para subrayar al verdugo y su víctima. Que, por cierto, no es el torero sino el público".

En la maquetación que hiciste no estaban contemplados los textos. Pero se aprovecha la estructura que construyes para insertarlos. De hecho están tan claros los grupos de imágenes que casan perfectamente con los pliegos de los textos colocados con posterioridad.

En el tema del dinamismo, que caracteriza al libro, hay otras cuestiones a destacar: por ejemplo, el tema de las fotos movidas, que en este libro hay varias.

(R. Masats, Madrid, 15 de diciembre de 2003) -“Creo que hay una en las fotos de color".

-Sí, sí. También tienes otra en blanco y negro de la gente haciendo un corro. El tema de la foto movida en color lo repites en tu libro de Toro. Tú has hecho muchas fotos movidas siempre: tienes la serie del toreo que publicaste en Gaceta Ilustrada y con la que ganaste el premio Luis 

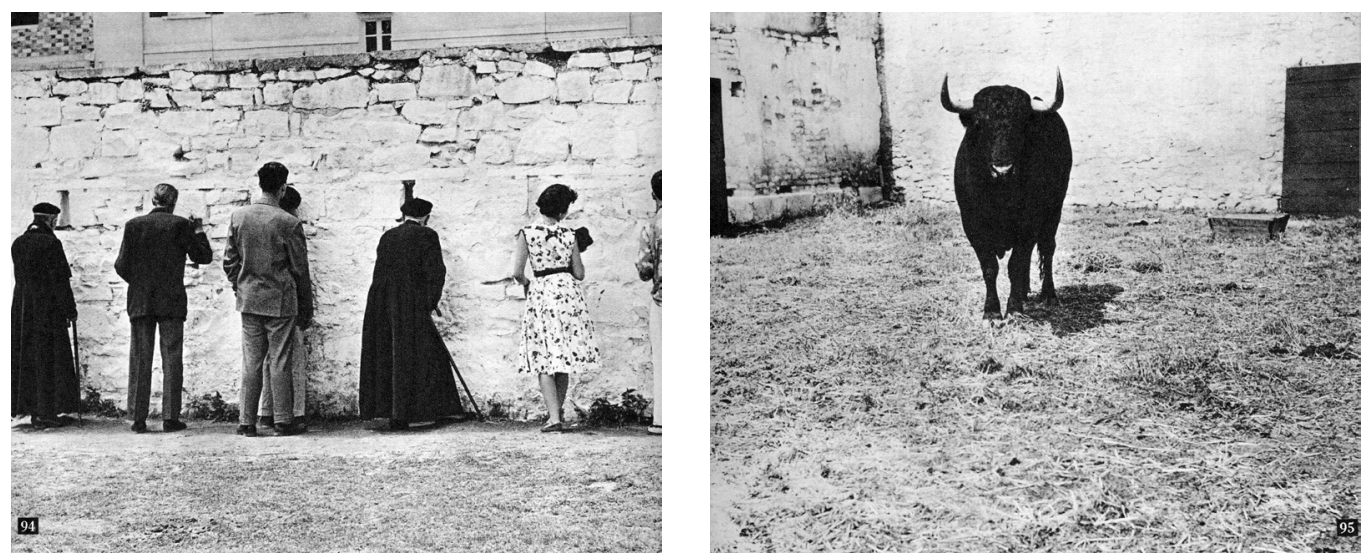

Ramón Masats, “Curiosidad mutua”, Los Sanfermines, fotos 94 y 95. Disposición igual que en la maquetación del libro.

Navarro de Fotografía de vanguardia y que te publicaron en la portada de Afal. Ahora bien, he observado que hay otro tipo de dinamismo en el libro: en las fotografías siempre hay alguien haciendo cosas, gente corriendo, bailando, bebiendo...

(R. Masats, Madrid, 27 de diciembre de 2006) -“Eso es la esencia de Los Sanfermines".

-Y luego la propia paginación también es muy dinámica, fragmentas mucho el espacio...

(R. Masats, Madrid, 27 de diciembre de 2006) -“Eso lo lleva la fiesta. En aquella época yo ya era profesional cuando lo maqueté. Ya tenía cierta experiencia en ver libros... llevaba dos o tres años en Madrid, aunque cuando estaba en Tarrasa también tenía mucha inquietud en ver libros y maquetar...".

-Hoy en día es muy difícil que un fotógrafo se maquete su propio libro. Y la impresión final de un libro depende mucho de la maquetación, por muy buenas que sean las fotos... Es como el director de una película.

(R. Masats, Madrid, 27 de diciembre de 2006) -“Exactamente, puedes tener muy buenos planos pero si no los sabes disponer. Hay una cosa muy difícil que debe hacer un buen director y es suprimir planos: «¿Cómo voy a quitar ese plano que es perfecto, que es una maravilla de plano, que nos costó tanto grabar a todo un equipo?». El director debe ser muy duro para quitarlo en beneficio del ritmo de la película. Normalmente, yo he colaborado bastante en la maquetación de los libros (lo que me han dejado). Pero yo siempre he llevado las fotos a la editorial... Con el Neutral Corner y Viejas historias de Castilla la Vieja no. Eso lo hizo Óscar Tusquets... y lo hizo bien. Pero, normalmente, siempre hablo con el director de arte y le explico la idea. Suelen hacerme caso. No en un cien por cien, pero en un sesenta por ciento sí".

-Considero que en un grupo de imágenes el nivel del conjunto te lo da la peor de las fotografías.

(R. Masats, Madrid, 27 de diciembre de 2006) -“En los libros hay una ventaja con respecto a los documentales y es que no tienes que ceñirte a un tiempo justo, 27 ó 28 minutos. En un libro sale más o menos lo que quieres, puede ser de 90, 100 ó 150 fotos, es más flexible. Aunque sí que hay que ser consciente de ser muy riguroso. ¡Si la foto no funciona, fuera! Es jodido, porque hay que ser muy duro con uno mismo.

-Eres tu peor crítico.

(R. Masats, Madrid, 27 de diciembre de 2006) -“Espero ser mi mejor crítico”.

-¿El último año que te dedicaste al libro cerraste todos los temas que se te habían quedado por hacer o todos los años fotografiabas los mismo temas y luego escogías las mejores imágenes? 

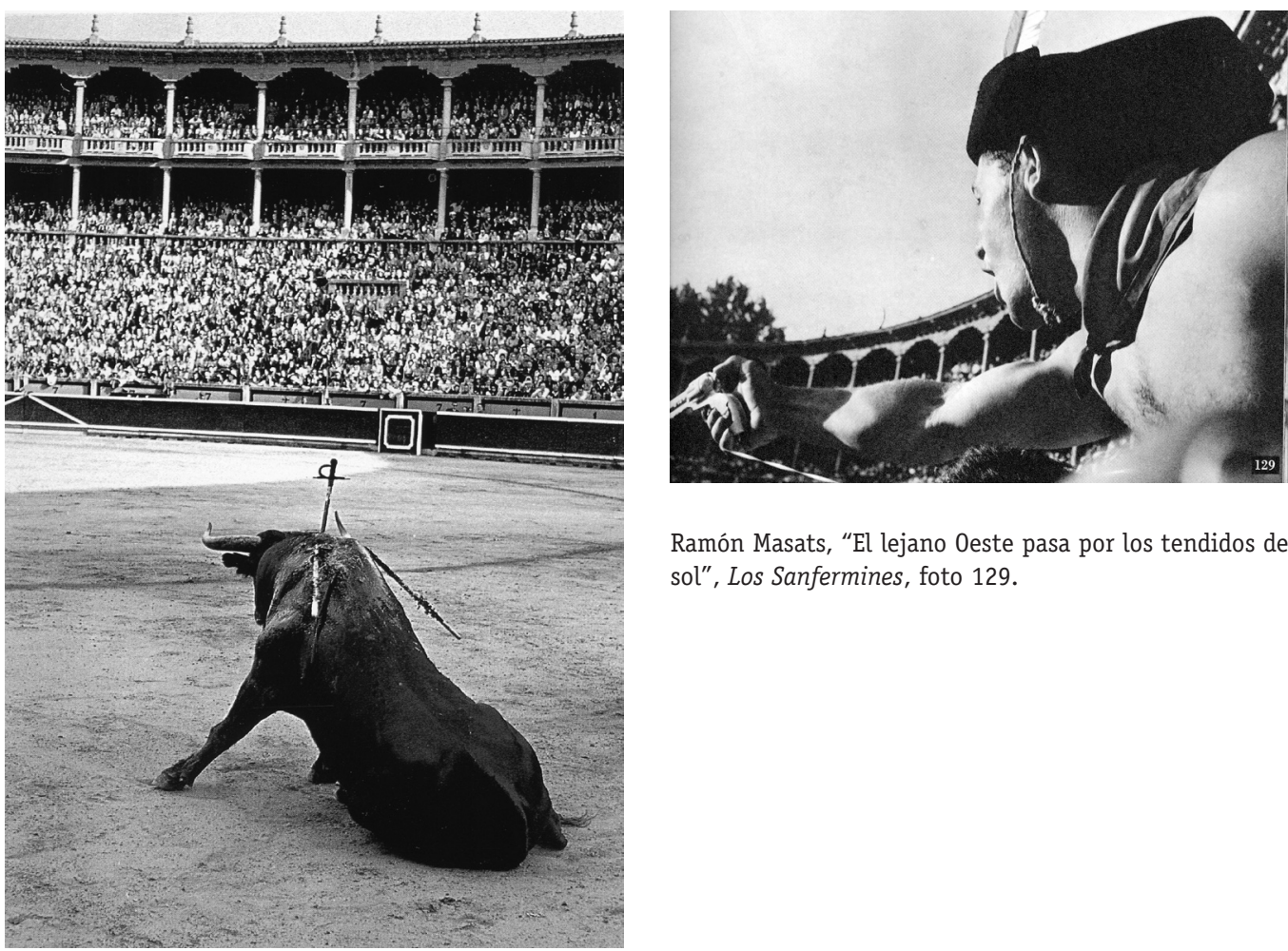

Ramón Masats, “El lejano Oeste pasa por los tendidos de sol", Los Sanfermines, foto 129.

Ramón Masats, "La muerte", Los Sanfermines, foto 128.

(R. Masats, Madrid, 27 de diciembre de 2006) -“Todos los años lo fotografiaba todo". -Es decir, que todos los años volvías a fotografiar los personajes: el callejón, los cabezudos... (R. Masats, Madrid, 27 de diciembre de 2006) -“Sí. Lo hacía en otro sitio 0, por ejemplo, si ya lo tenía por la mañana, lo buscaba por la tarde. Es decir, que procuraba cambiar algo. Pero allí son habas contadas: el chupinazo, el encierro...".

- ¿Es posible que el tono de las fotos de Los Sanfermines sea más amable que el que después asumirás en el resto de tus reportajes, sobre todo en las fotos de Neutral Corner, que son mucho más duras, mas contrastadas?

(R. Masats, Madrid, 27 de diciembre de 2006) -“Sí, es posible".

-Uno de los aspectos más importantes del libro es lo bien integrado que estás en las fiestas. Están fotografiadas desde dentro. No eres un mero espectador que pasaba por allí, sino que das la sensación de que estabas participando.

(R. Masats, Madrid, 27 de diciembre de 2006) -“Sí, claro, claro. Me adoptó una peña de amigos... ¡Es peligrosísimo que te adopte un grupo de gente! Porque si estás con la peña tienes que beber iy como bebas no puedes hacer fotos! Hasta que no les hice entender que no podía beber con ellos... Se quedaban un poco extrañados, pero lo pude mantener mientras trabajaba. Como empieces con uno, otro se puede ofender: o sea que nada, abstemio total. Esto fue uno de los motivos extrafotográficos que me decidió a probar este reportaje: ver cómo podía integrarme con la gente y estar agradable... Porque no fingía, estaba muy bien con ellos, lo que pasa es que en vez de beber hacía fotos. Estaba muy integrado. Me di cuenta de que tenía mucha facilidad 


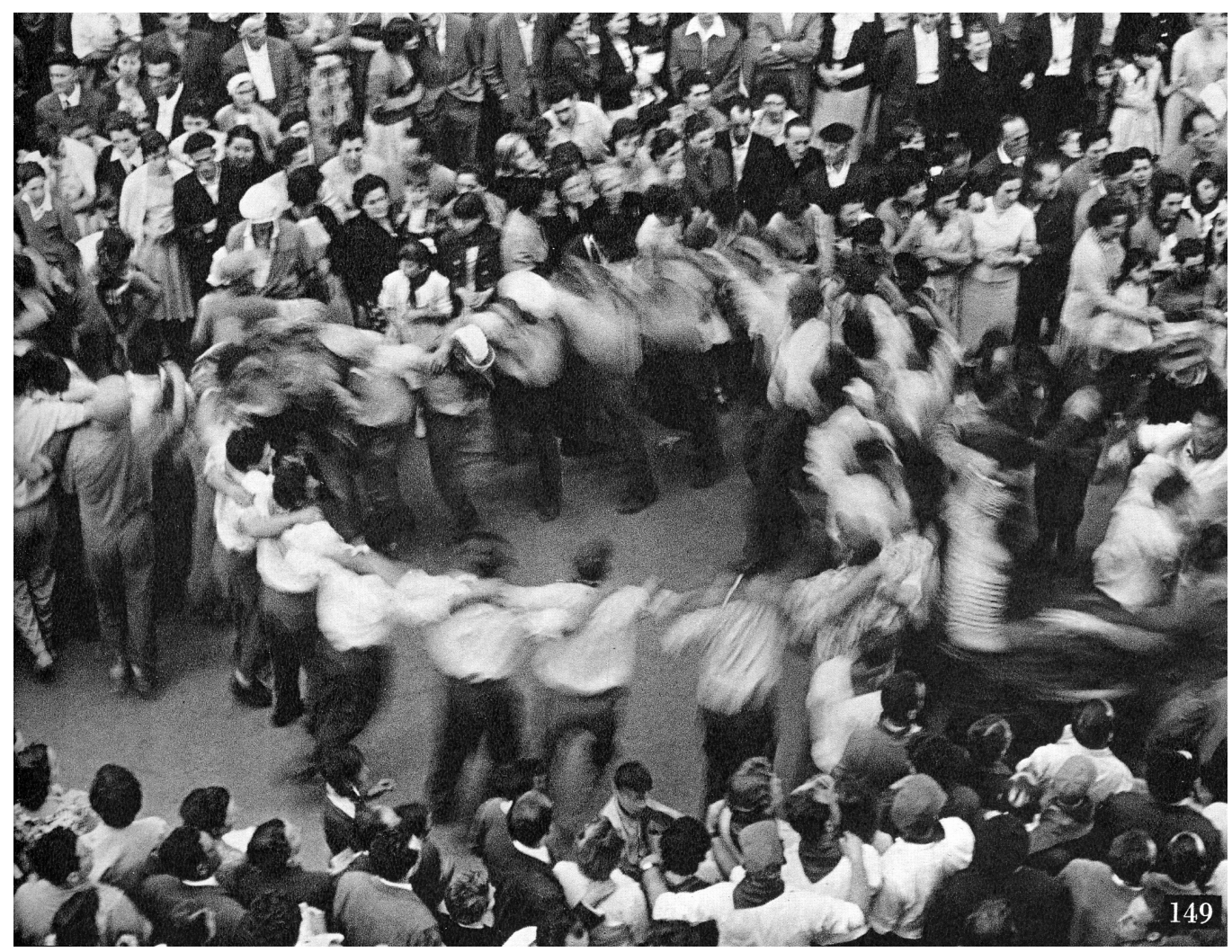

Ramón Masats, “Ciclón", Los Sanfermines, foto 149.

para relacionarme con gente desconocida. Yo tenía mis peñas en Tarrasa y mis amigos, pero en plan profesional fue uno de los motivos que me decidió a hacer reportaje".

- Hablando con Koldo me decía que cuando vas a una fiesta a fotografiar y te presentan como fotógrafo se enciende como una señal de alarma...

(R. Masats, Madrid, 27 de diciembre de 2006) -“Eso en aquella época no pasaba. Ha cambiado muchísimo la forma de reaccionar de la gente, pero no sólo en Los Sanfermines, en todas partes. Pero en aquella época estaban encantados, no había planteamientos de propiedad de la imagen... En aquella época había muchísima más inocencia, era mucho mejor para el fotógrafo. Yo no discuto en absoluto que una persona tenga derecho a su imagen, y por supuesto a un respeto. La gente tiene razón, se han hecho muchas putadas. Pero en aquella época la relación entre la gente y el fotógrafo era muy normal. Ahora este libro no se podría volver a hacer".

-Sabes que hay otro libro hecho por Inge Morath casi al mismo tiempo que el tuyo.

“En el año 1955, -Robert Delpire, un editor emblemático a él se le deben dos libro míticos. El instante decisivo, de Henri Cartier-Bresson, y Los Americanos, de Robert Frank-, publicó Guerra a la Tristeza, un libro, sobre Los Sanfermines, con fotografías de Inge Morath, y texto de Dominique Aubier. El libro, jamás fue publicado en nuestro país"90.

90 Garrido, Lola, “Presentación”, en Morath, Inge, San Fermín, Pamplona, Lola Garrido/Museo de Navarra, 1997, pág. 9. 
(R. Masats, Madrid, 27 de diciembre de 2006) -“Sí, lo he visto publicado muchos años más tarde, creo que lo hicimos a la vez. Es decir, que es posible que coincidiéramos en Pamplona -Parece ser que sus fotos fueron tomadas entre 1953 y 1954.

(R. Masats, Madrid, 15 de diciembre de 2003) - “¿Ella lo hizo antes? Yo creía que a lo mejor habíamos coincidido. De cualquier modo, no tenía ni idea ni conocí el libro de Inge Morath hasta hace un par de años. Para el libro de Toro, que lo hice en el 1998, fui a Pamplona e Inge Morath estaba exponiendo".

-Es que, pensando en tu faceta comercial, Los Sanfermines era un tema muy conocido, no sólo aquí en España si no también en el extranjero.

(R. Masats, Madrid, 27 de diciembre de 2006) -“Sí, yo ya iba a los toros sin ser fotógrafo. Me gustaban los toros. Supongo que eso también se nota: la visión de un aficionado o la visión, por muy bueno que sea, de un fotógrafo que no entiende la fiesta. Lo que sí hay son muchas fotos del encierro que no son mías. Claro, cuando terminé el libro los encierros no estaban. Es muy difícil hacer fotos de los encierros. Entonces les conté el proyecto a unos fotógrafos de Pamplona y me vendieron las fotos. Hay muchas fotos del encierro que no son mías".

-Entonces tú no considerabas realmente el encierro lo más importante...

(R. Masats, Madrid, 27 de diciembre de 2006) -“Es que no hay posibilidad de hacer buenas fotos de encierros. Allí los fotógrafos de Pamplona, que son los que mejores fotos tienen de los encierros, lo que hacen cuando llegan las fiestas es colocar como treinta puestos de fotografía. Cada fotógrafo se reserva treinta, y distribuyen a treinta aficionados a la fotografía con una cámara de fotos cada uno. Porque el encierro es ;zoomm! una cosa que te pasa por delante. No tienes tiempo de nada en absoluto, y si lo pillas lo has pillado y si no te quedas sin nada. Tienes siete posibilidades de que te ocurra algo delante de ti en todas las fiestas. Disparas casi sin mirar y sin motor, porque en aquella época no tenía motor. No se pueden hacer buenas fotos de encierros si no estás...".

-¡Años!

(R. Masats, Madrid, 27 de diciembre de 2006) -“Años y años, y cubierto con treinta fotógrafos de allí. Todo lo demás... la plaza es un hecho que hay allí y yo lo puedo fotografiar, pero el encierro no".

-En el libro es mucho más importante el ambiente que rodea el encierro que el propio encierro.

(R. Masats, Madrid, 27 de diciembre de 2006) -“Eso es lo que yo quería coger, pero no puedes evitar el encierro. Ahora bien, yo les exigí que pusieran los créditos de los fotógrafos de Pamplona en el libro, pero lo hicieron en un sitio que casi no se ve. A mí me extrañó un poco que los pusieran allí detrás. Debían haber aparecido al principio del libro, pero no me hicieron caso y esto es lo que hay. Sin embargo, el señor que ha hecho la versión francesa y el que ha hecho la versión alemana sí tiene su nombre allí, al principio, pero los fotógrafos... detrás. Ellos no me han dicho nada, pero no me parece bien. Cuando lo veo ahora encuentro muchos defectos. La maquetación es mía, pero desde luego eso de poner los textos entre las fotos, en alemán, inglés, francés y castellano después de cada secuencia fotográfica... pues no me ha gustado. Quiero decir, que las traducciones tenían que haber ido al final si les apetecía ponerlas. El castellano puede separar las secuencias, pero las traducciones debían haber ido al final, porque esto te quita del ritmo del libro. Hay muchos errores, pero en aquella época... los libros se hacían... Es una cosa que no decidí yo. Aún así, creo que el montaje de las fotos está bastante conseguido".

-La inclusión de las fotos en color fue una exigencia de la editorial que lo consideró como una novedad técnica del momento pero que no...

(R. Masats, Madrid, 15 de diciembre de 2003) -“Me pidieron alguna fotografía en color, porque pensaban que el color podía aportar más, pero las fotos en color no aportan nada... Hice la portada en color -que no tiene nada que ver con lo que hay dentro del libro-. Hay algunas fotos 
en color que no me interesan en absoluto. En aquel momento yo casi no hacía color. Era una de las primeras cosas que hacía en color, con una Rolleiflex".

(R. Masats, Madrid, 27 de diciembre de 2006) -“Nunca me ha gustado mezclar el color y el blanco y negro, y éste era un libro en blanco y negro. Tuvimos que poner unas fotos en color... No pasa nada, pero era la portada y algunas fotos de dentro... Lo hice el último año, cuando ya estaba decidido hacer el libro porque me lo pidieron desde la editorial".

(R. Masats, Madrid, 15 de diciembre de 2003) -“Hubo un momento en que Koldo Chamorro quería hacer una reedición del libro y una exposición en el Ayuntamiento de Pamplona... -aunque todo eso está parado actualmente- y me preguntó por el número de rollos que hice para el libro. Los conté y le dije que tengo 90 rollos. ¡Poquísimo para hacer un libro 90 rollos!"

-Sí, lo comentamos Koldo y yo cuando lo entrevisté, y me dijo que para aquella época son muchos porque la gente no tiraba tanto. Yo supongo que por la cuestión económica o por la mentalidad... No intentaban buscar la "foto" haciendo fotos y dando vueltas alrededor del tema hasta que encontraban la imagen. Hacían un solo disparo.

(R. Masats, Madrid, 15 de diciembre de 2003) -“Sí, es cierto... Supongo que por las dos cosas, no lo sé. Pero hice muy pocas fotos".

En el libro aparecen 152 fotografías, más la portada.

- ¿Qué acogida tuvo el libro en Pamplona?

(R. Masats, Madrid, 27 de diciembre de 2006) -“Yo creo que no... No se vendió muy bien. Porque a veces la gente me preguntaba que dónde podía conseguir el libro... y la librería de Espasa Calpe de la Gran Vía, a veces lo tenían y a veces no. Hace algunos años fue Koldo por allí y me llamó y me dijo: «Oye Ramón, que tu libro está en oferta. Sí, a mil pelas». "¡Coño, qué me dices!». Me fui por allí y me compré diez o quince. 0 sea, que los estaban vendiendo como saldo. Hay gente que lo quiere reeditar pero yo creo que ese libro no se vendería. No se vendió cuando salió y ahora tampoco se vendería. Lo comprarían tres o cuatro fotógrafos románticos... No tengo mucho interés en reediciones. Si ves lo que hicieron con el Neutral Corner... No vale la pena.

-Allí había otro autor...

(R. Masats, Madrid, 27 de diciembre de 2006) -“Y aquí están los textos de García Serrano, que también me impusieron.

(R. Masats, Madrid, 15 de diciembre de 2003) -“Le enseñé las fotos a una gentes del periódico Arriba -que eran falangistas, pero eran falangistas muy cachondos y me acogieron muy bien- $\mathrm{y}$ me propusieron hacer el texto con Rafael García Serrano -éste si era un falangista radical, aunque yo no tenía ni idea de quién era-. Y claro, te ofrecen hacer el libro, te llevan a la editorial Espasa Calpe... y tú como aficionado...".

-Te dejas llevar.

(R. Masats, Madrid, 15 de diciembre de 2003) -“Claro”.

(R. Masats, Madrid, 27 de diciembre de 2006) -“"Era un falangista recalcitrante de los de «por Dios, por la Patria y el Rey». Pero en aquella época ¿qué podías decir? Además, que yo no sabía quién era García Serrano. Luego me he ido enterando... Que no era mala persona y era buen escritor, pero estaba muy ligado al Régimen y a Franco".

-Bueno, el análisis del libro que te hizo Ignacio Barceló... también está muy condicionado políticamente. En julio de 1958 publicaste un portafolios de ocho fotografías de tu reportaje sobre los San Fermines en la revista Arte Fotográfico. El texto de introducción lo escribió el propio Ignacio Barceló. En él, Barceló, después de arremeter contra el neorrealismo, considerándolo como “un exquisito mal gusto" y "pasado de moda", empeñado "en la creencia de que aquello -la miseria, la tristeza, la cochambre- es fotografía moderna"; alaba la concepción de Masats, y de Terré y Miserachs, que rompen "esta falsa creencia y este falso concepto de fotografía moderna". 


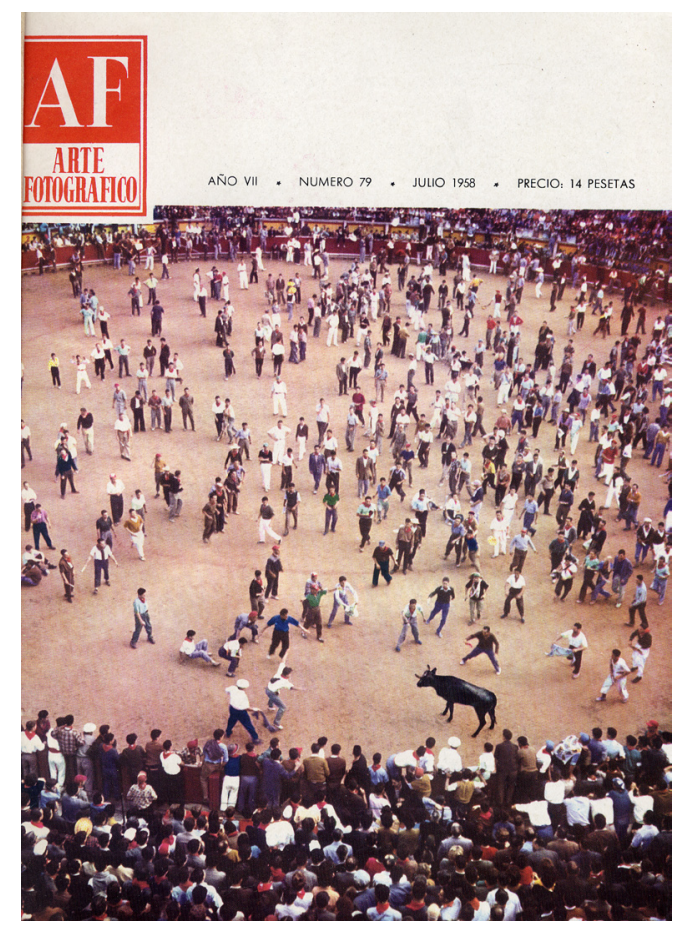

Portada de Arte Fotográfico, nº 79, año VII, julio 1958.

“RAMÓN MASATS, ese fotógrafo inquieto.

Hace poco más de un año que Ramón Masats fue presentado a nuestros lectores desde esta misma página. Entonces Masats era parte integrante de un terceto de fotógrafos que irrumpía en el ámbito fotográfico español con una acusada personalidad y dotados los tres componentes de una nueva manera de «ver» -y sentir-, que rompía con los viejos cánones y hasta con ese neorrealismo de película italiana pasada de moda hace ya tres o cuatro años, que hay quien se empeña en seguir practicando en la creencia de que aquello -la miseria, la tristeza, la cochambre- es fotografía moderna y... española, como si las carteleras de los cines no nos hubieran hartado ya de fotografías de un «exquisito mal gusto», que se empeñan en restregarnos por las narices porque lo creen actual y hasta bello, cuando obras así son -y la frase no es nuestra- una auténtica negación de la belleza.

Terré, Miserachs, Masats -éste es el tercero-, vinieron a romper esta falsa creencia y este falso concepto de la fotografía moderna. Del primero y segundo autor citados hemos visto un limitado número de obras; de Ramón Masats conocemos una producción copiosa en la que hay un notabilísimo porcentaje de obras buenas, de obras muy buenas, ajenas al reportaje, que guarda celosamente y que sólo hemos admirado unos pocos amigos.

Ramón Masats, fotógrafo inquieto, quemó las naves del comercio de Tarrasa hace dos años y se embarcó en otra nave muy marinera, eso sí, pero con la que es muy difícil llegar a buen puerto. Porque Ramón entró en la fotografía, y dentro de la fotografía eligió el reportaje, precisamente por las dificultades que esta especialidad ofrece y a la que ha logrado insuflar ese espíritu nuevo y original que informa sus obras. Con su nave marinera, pero difícil, hace notables singladuras. Sus reportajes, sus obras llegan al extranjero; y no es aventurado augurar su arribada, en un porvenir más o menos inmediato, al gran puerto que Masats sueña, porque Masats es ambicioso, con esa ambición, noble, sencilla, cordial y entrañablemente humana que en la vida le proporcionará amigos de verdad y éxitos merecidos. 
Masats vive en Madrid, y desde las columnas de una revista semanal, a la que fue incorporado por el gran periodista Jiménez Quiles, nos ofrece muestras concretas de su modo de ver y hacer el reportaje de hoy, el reportaje que exige el momento actual y que él practica con indiscutible personalidad. Por ser muy recientes, recordamos un reportaje sobre Los Monegros, hecho en un tiempo «record», que no daba para más pero que fue suficiente para que Masats «viera», con su Leica, aquella zona aragonesa y captara el dramatismo de su sequía a punto de desaparecer por afortunadas obras que se llevan a ritmo acelerado, y aquel otro de la concentración de aquellos valerosos muchachos que en nuestra Cruzada de Liberación fueron alféreces provisionales reunidos en Garabitas, a las puertas de Madrid. Dos reportajes distintos, dramático el primero, profundamente emotivo el segundo. Una muletas caídas al lado de unas sillas y el abrazo fuerte, duro y emocionado de dos viejos camaradas, nos decían al corazón más que la mejor literatura.

Ramón Masats se sintió atraído el año pasado por San Fermín, por todo lo típicamente racial de la sonada celebración del Santo Pamplonica, cuyo eco español y navarro ha atraído fotógrafos de todas las latitudes, que se han visto un poco arrollados por un tema vibrante, vigoroso y tan nuestro que no han comprendido del todo. Masats ha visto San Fermín de modo distinto a los demás. Lo ha visto a su manera, lo ha visto con humor, con el humor finamente captado en casi todas las fotos que ofrecemos a continuación a nuestros lectores y que son una leve muestra de todo lo que Masats tiene seleccionado, quién sabe si para reunirlo en un libro que tendrá -quién lo duda- el éxito que merece este gran reportero español, al que deseamos ver firme en su puesto, personal y sin concesiones a lo fácil, y libre de un profesionalismo que sujeta la fantasía, tan necesaria para la difícil profesión que tan ilusionadamente ha elegido" ${ }^{\prime 1}$.

(R. Masats, Madrid, 27 de diciembre de 2006) -“Ignacio Barceló se portó muy bien con nosotros. Permitió a Oriol Maspons escribir en Arte Fotográfico, nos publicó cosas... y siempre que le ofrecíamos una cosa, pues encantado, y cuando llevábamos tiempo sin ofrecerle nada nos preguntaba a ver que podíamos llevar. Desde luego Ignacio no fue nunca en absoluto como los de Nueva Lente -que lo que querían hacer era intentar destruirnos y todas esas cosas tan pueriles-. Luego, cuando nos metimos en AFAL por estar más de acuerdo ideológicamente, a Barceló le dolió, claro. Lo tomó como una traición. Pero, con toda su cosa de derechismo, Ignacio se portó siempre muy bien con nosotros".

-Lo que sí está claro es que da una lectura muy dirigida políticamente.

(R. Masats, Madrid, 27 de diciembre de 2006) -“Sí, evidentemente. Pero tampoco es una obra muy... En eso que dice del moco y la miseria... es que a mí me ha parecido siempre muy fácil. Me ha gustado más sugerir que no mostrar. Lo cual me ha llevado a que, a veces, algunas de mis fotografías sean un poco ambiguas, porque no he incidido en lo que en aquel momento era muy fácil de hacer: mucha hambre y mucho moco. Tengo mucho respeto a la gente y además no me gustan las cosas fáciles".

-En el libro hay mucho sentido del humor.

(R. Masats, Madrid, 27 de diciembre de 2006) -“Yo siempre he tenido mucha ironía y sentido del humor".

-también observo un gran dinamismo en la paginación y maquetación. Se percibe el influjo de William Klein...

(R. Masats, Madrid, 27 de diciembre de 2006) -“Cuando hice el primer viaje William Klein no había llegado aún a nuestras manos".

-El libro lo publicaste en 1963.

91 Barceló, Ignacio, "Ramón Masats, ese fotógrafo inquieto", en Arte Fotográfico, n 79, año VII, julio 1958, págs. 592-600. 
(R. Masats, Madrid, 27 de diciembre de 2006) -“Sí, pero en el 1960 ya lo tenía terminado. Lo que pasa es que luego, los textos... fue un poco lento. Cuando en las cronologías de los libros ponen Neutral Corner o los otros libros antes que éste de Los Sanfermines no es cierto. Es libro se terminó mucho antes que los otros libros. Lo que pasa es que la editorial lo terminó cuando pudo".

-¿Y por qué no lo hiciste en Lumen?

(R. Masats, Madrid, 27 de diciembre de 2006) -“Porque este libro lo contacté mucho antes aquí, con Espasa Calpe. Fue antes de empezar con Lumen y el libro ya lo tenía comprometido con Espasa Calpe. No había otra posibilidad. Mis colaboraciones con la editorial Lumen fueron muy posteriores, aunque mucha gente meta en la cronología Los Sanfermines después, pero es por la fecha de edición. Los de Lumen se editaron mucho más rápido, pero éste fue mi primer libro".

\subsubsection{La colección Palabra e Imagen de Lumen: una referencia ineludible}

Ramón Masats publicó dos libros en la editorial Lumen, más concretamente en su colección Palabra e Imagen: Neutral Corner (1962) con textos de Ignacio Aldecoa, y Viejas historias de Castilla la Vieja (1964) con textos de Miguel Delibes. Estos dos libros se han convertido en clásicos imprescindibles de la Historia de la fotografía española y son dos de los mejores trabajos que Masats ha realizado nunca. Pero estos no son los únicos libros fotográficos absolutamente fundamentales para la Historia que surgieron de esta colección: La caza de la perdiz roja (1963), fotografiado por Oriol Maspons y también con textos de Miguel Delibes, Toreo de salón. Farsa con acompañamiento de clamor y murga (1963) con fotos del binomio Maspons/ Julio Ubiña y texto de Camilo José Cela, y sobre todo el polémico y desgarrador Izas, Rabizas y Colipoterras (1964) con fotos de Joan Colom y textos de Cela... Todos ellos, y alguno más, se han convertido en los principales referentes de la fotografía española de todos los tiempos... $\mathrm{y}$ todos fueron publicados en esta editorial.

Evidentemente hay otros libros -como el Barcelona en blanc $i$ negre (1964) de Xavier Miserachs o Los Sanfermines (1963) del propio Masats- que están realizados en otras editoriales $^{92}$, pero estas apuestas fueron ocasionales y desde luego no tuvieron un planteamiento tan innovador en su conjunto como el de Palabra e Imagen. Ninguna otra apuesta editorial fotográfica tuvo su continuidad temporal, su coherencia y su trascendencia. También hay que recodar que la misma editorial Lumen realizó otros libros de fotografía fuera de la propia colección Palabra e Imagen y, por ello, y aunque no los vamos a considerar como pertenecientes al mismo conjunto, bien merecen una cita. En función de lo señalado, adoptamos la decisión de remitirnos a los propios responsables editoriales para poder comprender la clave por la cual una sola colección puede generar una cantidad de títulos tal que se hayan convertido en clásicos incuestionables ${ }^{93}$.

Al comentar con Esther Tusquets el boom de la inmensa cantidad de libros fotográficos que se publicaron en aquellos años señala:

(Esther Tusquets, Barcelona, 31 de octubre de 2004) -“Fuera también se hicieron muchos libros de fotografía. Traducimos unos cuantos. Traducimos uno de Richard Avedon, Nada personal-¡fantástico!- y un libro de Cartier-Bresson...".

-De ese libro de Avedon tenéis una edición en catalán...

92 En concreto el libro de Miserachs está editado en Aymá y el de Masats en la ya citada Espasa Calpe.

93 En el momento de plantearnos estas entrevistas todavía no se habían publicado dos libros en los que sí aparece cierta información sobre Palabra e Imagen, inédita hasta ese momento: una biografía de Esther Tusquets y uno de los textos introductorios que Óscar Tusquets realiza para el catálogo de la exposición Contactos de Ramón Masats. Esta información más reciente la hemos utilizado también en las citas que aparecen a continuación. 


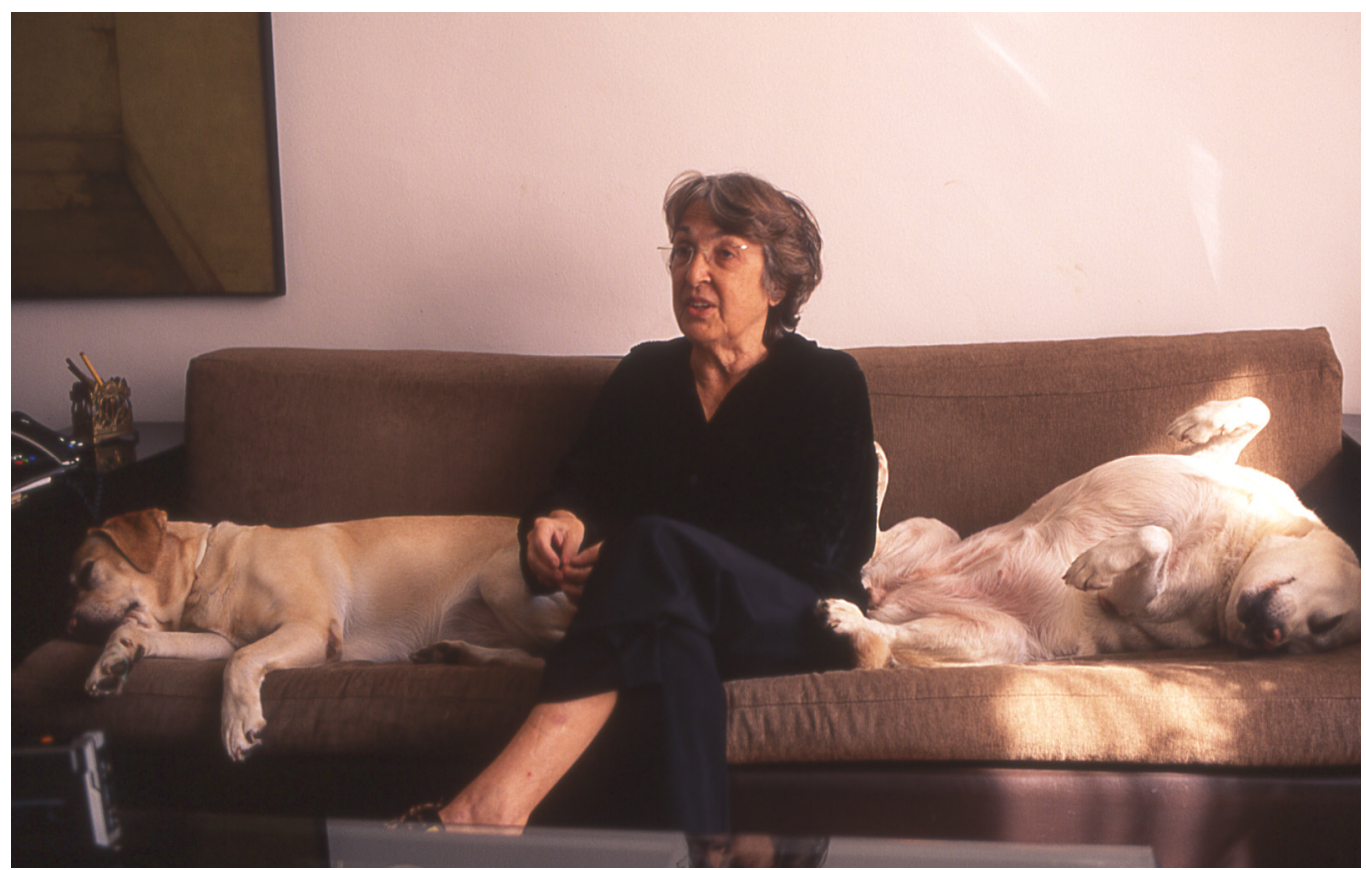

Retrato de Esther Tusquets tomado el día de la entrevista (31 de octubre de 2004).

(Esther Tusquets, Barcelona, 31 de octubre de 2004) -“Sí, Res de personal94, y una edición de bolsillo. Luego hicimos un libro increíble de un fotógrafo japonés, Eikoh Hosoe, presentado por Yukio Mishima que se llama, Killed by roses, Muerto por las rosas ${ }^{95}$. ¿No lo has visto nunca? Es una joya. La edición mundial se acabó vendiendo a unas cantidades fabulosas. Ahora han hecho una segunda edición y quizá valga menos, pero era un libro carísimo. Se empieza por detrás como los libros japoneses. Publicar esto en el año sesenta o sesenta y uno realmente era estar chiflado. Hicimos muy pocos, con un texto en castellano y catalán muy corto. Lumen fue muy bien, pero por casualidad. No entiendo cómo no nos arruinamos en cuatro o cinco años haciendo libros cómo este".

- ¿Y cuál fue el libro que hicisteis de Cartier-Bresson?

(Esther Tusquets, Barcelona, 31 de octubre de 2004) -“Ahora lo estaba buscando, no tengo ninguno de Cartier-Bresson ${ }^{96}$... Creo que era una antología, no lo recuerdo ahora. Hicimos otro libro de un holandés, de eso hace casi cincuenta años, que se llamaba Sweet life ${ }^{97}$, y era también muy duro. Más duro que éste".

A pesar de estas interesantes aportaciones, la editorial Lumen no es una mera importadora de autores extranjeros, sino que mediante la colección Palabra e Imagen se convirtió en la canalizadora de gran parte de la producción nacional de aquellos años. El nutrido conjunto de obras surgidas y la impresionante calidad de los resultados obtenidos nos han llevado a considerar la necesidad de reivindicar esa colección, en tanto que se convirtió en el hito fotográfico más 
trascendente de los años sesenta en España. Ello no es óbice para constatar una gran falta de información sobre la misma. Con el agravante de que consideramos que no ha tenido el reconocimiento que merece, no ya en ámbitos culturales generales, sino especialmente en la propia historiografía fotográfica. En ella aparece como una simple reseña, como una curiosidad, como un experimento o como un epílogo de AFAL.

“Otra actividad editorial que se adelantó a su tiempo fue la colección Palabra e Imagen publicada por Lumen (...) El experimento acabó, igual que AFAL, en entierro; sin el reconocimiento a lo largo de los 70 y 80 de una actividad pionera que aún hoy sostiene una comparación con libros similares"98.

Las referencias a los libros que aparecieron en la colección se limitan a los ya reseñados: los libros de Masats, Maspons y Colom... Ni siquiera aparece una relación completa de los títulos aparecidos.

“Estos libros, a pesar de haber estado bastante silenciados, suponen, por su concepción innovadora del diseño y la realización un intento válido dentro del panorama fotográfico de la época"99.

La mera terminología con la que se describe a toda la colección me parece injusta y limitada: "experimento" y un "intento válido". A su vez la colección aparece mencionada de manera inevitable cuando se habla del currículo de los fotógrafos estudiados, pero nunca como una entidad propia digna de análisis.

“Así casi todos ellos, junto a otros nombres como Jaime Buesa y Colita (Isabel Esteva), colaborarían en la colección «Palabra e Imagen» impulsada por Editorial Lumen, una valiente aventura editorial de los hermanos Óscar y Esther Tusquets, que buscaba una alianza entre la narrativa literaria y la fotográfica. La familia Tusquets adquirió Lumen en 1960, entonces especializada en temas religiosos, y empezaron con literatura infantil; con la colección «Palabra e Imagen» pasaron a la edición para adultos. Algunos títulos se han convertido en clásicos" ${ }^{\prime 100}$.

Vista la paupérrima producción editorial de nuestros días, tanto por su cantidad como por la innovación de sus planteamientos y su calidad, me parece absolutamente necesario analizar en el presente contexto esta colección. ¿Dónde podemos contemplar hoy día una apuesta editorial tan arriesgada como Palabra e Imagen? No hay ni un solo hueco para la experimentación, para la investigación formal y conceptual, ni para la realización de proyectos tan arriesgados y políticamente incorrectos como los suyos.

(Koldo Chamorro, Pamplona, 21 de marzo de 2003) -“Claro, la gran victoria de Ramón y también de Lumen es haber hecho la colección Palabra e Imagen. Es una cosa verdaderamente sorprendente. Ahora mismo, en el mundo, sólo ediciones La Filigrana, son los únicos que están haciendo cosas, no tan buenas, pero que se pueden parecer a esa colección de libros. Los demás son libros de espectáculo. Y eso para los fotógrafos es complicado".

Se ha hablado mucho del milagro de AFAL, quizá sea hora para hablar del milagro de Palabra e Imagen.

-¿Y cómo se le ocurrió la colección Palabra e Imagen?

(Esther Tusquets, Barcelona, 31 de octubre de 2004) -“Casi todas las cosas de mi vida me

98 Santos Manuel, “Fotografía contemporánea española 1970-1990", en AA. VV., Cuatro direcciones. Fotografía Contemporánea Española 1970-1990, Madrid, Museo Nacional Centro de Arte Reina Sofía, Ministerio de Cultura/Lunwerg, 1991, pág. 39. 99 Suárez Canal, Xosé Luis, "Lo caduco y lo nuevo", en AA. VV., Cuatro direcciones..., op. cit., pág. 20.

100 Fontcuberta, Joan, "De la posguerra al siglo XXI", en Sánchez Vigil, Juan Miguel (coordinador), “La fotografía en España. De los orígenes al siglo XXI", SUMMA ARTIS. Historia General del Arte, Tomo XLVII, Madrid, Espasa Calpe, 2001, pág. 418. 
han pasado por casualidad. En aquella época hicimos un libro infantil con Ana María Matute y nos vino a ver un fotógrafo que se llamaba Jaime Buesa, que creo que era un fotógrafo de $L a$ Vanguardia, con unas fotografías de niños en barrios marginales... y fue el primer libro de la colección. Estábamos empezando y no sabíamos muy bien que hacíamos. Mi hermano estaba muy interesado en la imagen y decidimos hacerlo. Se llamaba Estudio de juegos para los niños de los otros. A partir de este primer libro se nos ocurrió la colección. Como la editorial éramos mi hermano y yo... Mi hermano llevaba toda la parte de imagen, toda la cosa visual. Estaba estudiando segundo de arquitectura. Cuando ahora hablan de los editores muy jóvenes me hacen reír, porque cuando empezamos yo tenía veintidós años y mi hermano diecisiete. Se nos ocurrió una colección en la que el fotógrafo colaborase al mismo nivel de importancia que el escritor, que los dos trabajasen sobre el mismo tema y que se llamaría Palabra e Imagen. Yo hice una lista de escritores y mi hermano hizo una lista de fotógrafos. Lluís Clotet también se implicó mucho. Y este fue el planteamiento de la colección".

Parece que una de las claves del éxito de Palabra e Imagen es el entusiasmo y la creatividad de la juventud. Juventud que fuera denominador común en la revolución de AFAL y en toda la contestataria generación de fotógrafos que surgían de las agrupaciones fotográficas pocos años antes.

-Se dejaba mucho en manos de los fotógrafos...

(Esther Tusquets, Barcelona, 31 de octubre de 2004) -“Se daba tanta importancia al fotógrafo como al escritor. Esta era la idea inicial. En algunos libros se partía de las fotografías, en otros libros se partía de los textos y lo ideal hubiera sido que se hubieran hecho a medias, pero eso pasó muy pocas veces. Casi siempre se partió de un lado o del otro".

Así de sencillo y, sin embargo, el mero hecho de considerar al fotógrafo y sobre todo a la fotografía, al mismo nivel que al escritor y su literatura, supone una auténtica revolución conceptual, que va más allá de la mera consideración social, ya que presupone que la fotografía está igualmente capacitada que la literatura para contar historias. Es decir, reconoce a la fotografía su categoría de lenguaje y le da la oportunidad de que se exprese como tal, usando los medios narrativos a su disposición. El principal cometido y función de la fotografía es: relatar, comunicar, expresar, narrar... Recordemos que ese es el sentir de Óscar Tusquets, pero también del propio Masats así como de Miserachs, Maspons, Casademont, Ontañón... Como ya vimos, una única imagen bressoniana tenía significación completa, aunque un grupo de imágenes considerado como unidad podía aumentar la complejidad del texto fotográfico. Pensemos, pues, que en estos libros el juego narrativo es verdaderamente sugerente, ya que la cantidad de posibilidades expresivas que gobiernan las relaciones entre las propias fotos y entre las fotos y los escritos es tan diversa como numerosos son los títulos de la colección. Esta variedad viene imbuida por el espíritu de auténtica investigación narrativa que recorre toda la colección, sobre todo en los primeros números.

“Sabíamos -Oriol nos lo había enseñado- que para Henri Cartier-Bresson, el Papa de la fotografía de
reportaje, no preservar absolutamente el encuadre del negativo era anatema, pero nosotros teníamos
nuestras razones: todas estas libertades estaban justificadas por la relación entre imagen y el texto"101.

Como ejemplo de experimentación y de investigación de las posibilidades comunicativas de la fotografía combinada con la literatura nos ceñiremos, más tarde, al estudio en profundidad de los libros de Masats. Con todo, conviene recordar que el elenco de escritores y fotógrafos participantes en Palabra e Imagen continúa siendo sorprendente en la actualidad ${ }^{102}$ :

101 Tusquets Blanca, Óscar, “Ramón Masats, un testarudo...", op. cit., pág. 18.

102 Hemos ordenado los libros por fecha de publicación dada la determinante participación de Óscar Tusquets en su diseño. Óscar Tusquets abandonó Lumen en 1968 cuando fundó Tusquets Editores, junto con Beatriz de Moura. 


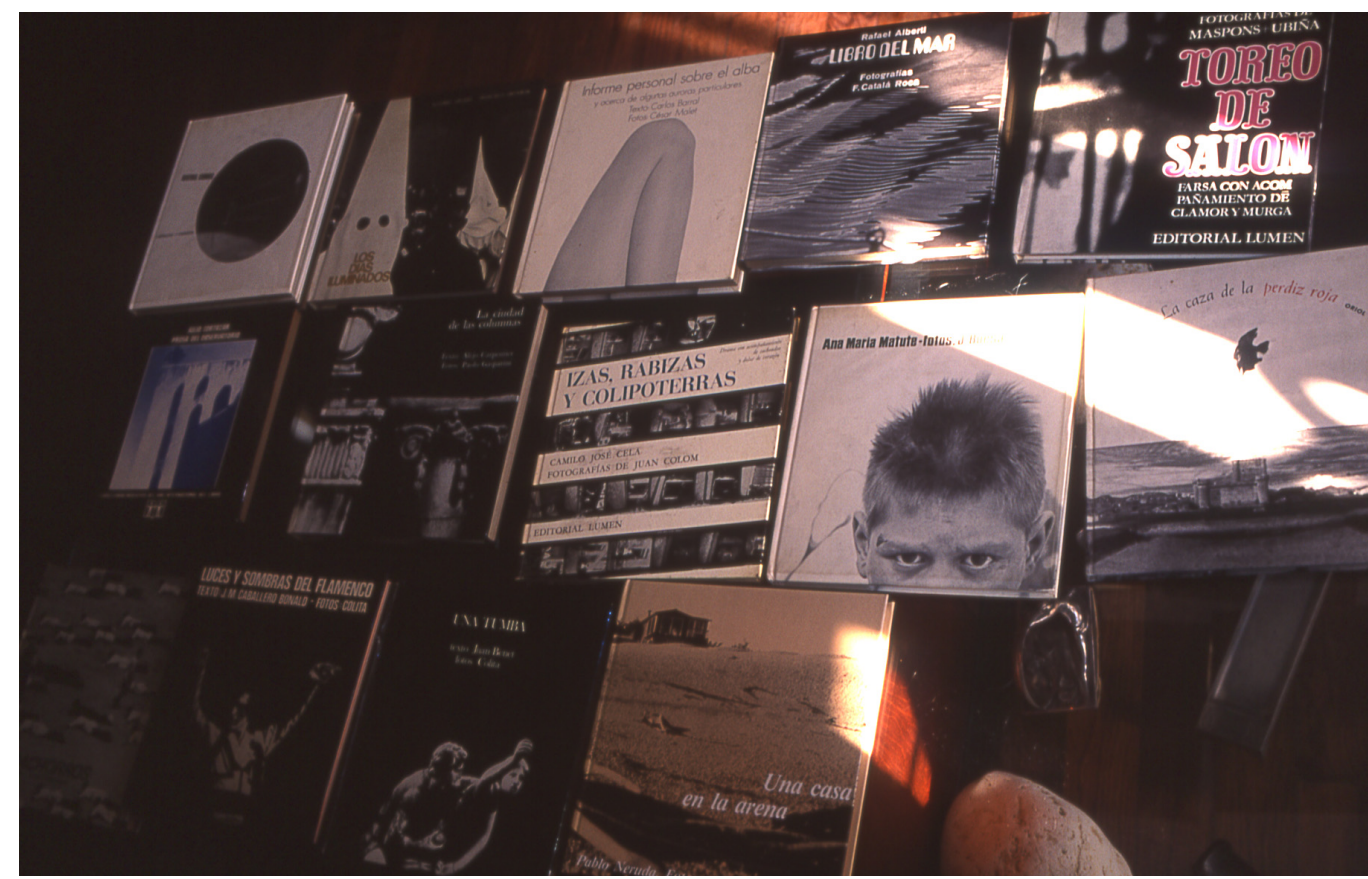

Algunas de las portadas de la colección Palabra e Imagen de la biblioteca de Esther Tusquets.

-Jaime Buesa y Ana María Matute, Libro de juegos para los niños de los otros (1961).

-Ramón Masats e Ignacio Aldecoa, Neutral Corner (1962).

-Oriol Maspons y Miguel Delibes, La caza de la perdiz roja (1963).

-Oriol Maspons, Julio Ubiña y Camilo José Cela, Toreo de salón. Farsa con acompañamiento de clamor y murga (1963).

-Joan Colom y Camilo José Cela, Izas, Rabiza y Colipoterras (1964).

-Ramón Masats y Miguel Delibes, Viejas historias de Castilla la Vieja (1964).

-Francisco Ontañón y Alfonso Grosso, Los días iluminados (1964).

-Xavier Miserachs y Mario Vargas Llosa, Los cachorros (1967).

-Francesc Català-Roca y Rafael Alberti, Libro del mar (1968).

-César Malet y Carlos Barral, Informe personal sobre el alba y acerca de algunas auroras particulares (1970).

-Paolo Gasparini y Alejandro Carpentier, La ciudad de las columnas, (1970).

-Colita y Juan Benet, Una tumba, (1971).

-Julio Cortazar (Fotos) y Antonio Gálvez (colaboración), Prosa del observatorio (1972).

-Colita y José Manuel Caballero Bonald, Luces y sombras del flamenco, (1975).

-Oriol Maspons y Federico García Lorca, Poeta en Nueva York (1976).

-Sergio Larrain y Pablo Neruda, Una casa en la arena (1984).

El calificado como "experimento" tuvo una duración de veintitrés años y un total de dieciséis "intentos válidos". A este listado habría que añadir el proyecto sobre la Chanca de Pérez Siquier (que nos comentó que aunque le hubiera gustado no llegó a publicarse en la colección) y dos encargos inconclusos: uno sobre flamenco (Cualladó recibió un encargo sobre el cante flamenco 
que no pudo atender) y otro sobre España, que Masats tampoco pudo acabar, y del que hablaremos posteriormente. Hay que destacar que la lista de fotógrafos no la realizó Óscar Tusquets en solitario. Éste tuvo la inestimable ayuda de un viejo conocido nuestro, el ubicuo e hiperactivo Oriol Maspons.

“El primero al que osamos abordar, para que colaborar con Delibes en un libro sobre caza, fue Oriol Maspons. De inmediato se entusiasmó con la idea. No sólo realizó aquel y otros libros, sino que, con una camaradería ejemplar que hoy resultaría insólita, nos recomendó a otros fotógrafos: a Xavier Miserachs, Francisco Ontañón y Joan Colom, un desconocido y pintoresco personaje que se dedicaba a robar fotos de putas en el Barrio chino de Barcelona. Pero el fotógrafo por el que Oriol mostraba mayor admiración y el que más calurosamente nos recomendaba era Ramón Masats"103.

(Esther Tusquets, Barcelona, 31 de octubre de 2004) -“En la lista de Óscar estaba: Oriol Maspons, Xavier Miserachs, Català-Roca, Ramón Masats y unos cuantos más. Creo que Masats nos dijo que tenía unos textos hermosos sobre boxeo de Ignacio Aldecoa e hizo Neutral Corner. [En realidad esta afirmación de Esther Tusquets es un error, pues Aldecoa hizo los textos a partir de las fotos de Masats]. Óscar y yo nos fuimos con el «dos caballos» a Madrid a enseñarle la maqueta a Masats para que nos diera su conformidad en cada encuadre. Discutía cada fotografía: cómo se cortaba, cómo se hacía o cómo no se hacía. Éramos muy amigos. Vivía en un piso medio amueblado. Tenía dos niños y una mujer. Todas las mujeres de aquella época cambiaron. Casi todas son ex. Yo conocí a las primeras. Cada vez que íbamos a Madrid cenábamos en su casa o íbamos al cine juntos. Le gustaba mucho el cine. Jugábamos mucho al póquer. Cuando cuarenta años más tarde vendí la editorial dijeron que la había perdido a las cartas. La persona con la que entré en contacto para vender Lumen era un alemán que había conocido jugando al bridge y relacionaron una cosa con la otra y dijeron que había perdido la editorial en una partida de cartas. Lo que no es cierto. Nunca me la he apostado en las cartas. Es una anécdota muy divertida".

Como vemos, prácticamente todos son fotógrafos catalanes. Esta selección no es casual y responde a dos razones. Por un lado, es a sus amigos a los que Maspons recomienda, pero sobre todo, conviene recordar que precisamente fueron los fotógrafos catalanes aquellos que se arriesgaron a emprender el camino de la profesionalización unos años antes. Ello son los que protagonizan esta aventura y Maspons demuestra su confianza en este hecho al recomendarlos a Lumen. Esta generalización tiene su excepción en Joan Colom que nunca dio el salto a la fotografía profesional. El caso de Colom fue distinto porque no tenía que realizar las fotos por encargo, como en el caso del resto de autores. Las fotos ya las tenía hechas y la labor de Maspons fue más bien de descubridor de un talento absolutamente discreto y oculto, tan reservado que hubiera pasado completamente desconocido para la Historia de la Fotografía sin su mediación.

“No recuerdo cómo ni cuándo conocí a Ramón, pero no me extraña haberle conocido porque yo siempre he ido a la caza de los fotógrafos que han ido apareciendo. ¿Quizás en la agrupación?

Yo, por ejemplo, descubrí a Joan Colom, que trabajaba de contable en un gran almacén de venta de ropa de hombre que aún existe que se llama MACSON. Es lo contrario de LOEWE, un almacén cutre y que teóricamente es barato. Por cierto que he de visitarlo porque ando fatal de pantalones.

Colom me enseñó alguna foto de putas. Él las retrataba y las retrata aún casi cada día y tiene 82 años. Pero no las retrataba para hacer crítica social ni leches como querían atribuirle. Él las retrataba porque le gustaban así. Aún es menos pijo que Ramón. Yo, como en aquellos tiempos trataba mucho

103 Tusquets Blanca, Óscar, “Ramón Masats, un testarudo...", op. cit., pág. 15. 
con Esther Tusquets y Camilo José Cela (hice Toreo de Salón con él) y conocía su gusto, no paré hasta lograr que vieran sus fotos. El Colom no tenía ningún interés en que las vieran, ni mucho menos en que las publicaran, pero Esther y yo insistimos y Camilo se interesó mucho también, pues el libro lo tenía ya casi hecho con fichas de su archivo, y se llamaba Izas, Rabizas y Colipoterras.

Cuando salió el libro al que menos gracia le hizo fue al propio Colom ya que temía no poder volver a ver a sus putas. Una de ellas, la llamábamos La Blanca, tenía un amigo abogado y policía. Puso una querella a la editorial. El Colom estaba aterrorizado y arrepentido y tuvimos que ayudarle. Yo me ofrecí a Esther (previo pago de mil pelas) a ir con la puta demandante. A «ocuparme» con ella, y me hizo ilusión, pues desde finalizar la «mili» no había ido de putas. Antes sí, empecé a los 16 años. Después de la mili me dediqué de lleno a las honradas, que da mucho trabajo y sale más caro.

Total, a La Blanca le dije que la había visto en el libro y en seguida me contó lo de la demanda con todo detalle, que es lo que necesitaba saber la Editorial Lumen. Me dio el nombre del abogado etc. etc. No pasó nada porque al parecer lo plantearon muy mal.

Me supo mal que yo, un señorito, le hiciera una putada a una puta. De las mil pesetas de Esther aún me sobró. Nadie podía hacer esta gestión sino yo. Además fue idea mía. Con los abogados nunca hubiesen averiguado nada y no me quiero ni imaginar de lo que hubiera cobrado un abogado por ir de putas por cuenta del cliente.

El Colom quedó acojonado. Imagínate que Esther y yo queríamos mandarlo por Europa para que hiciera fotos del famoso barrio de Saint Pauli del puerto de Hamburgo, cuatro fotos de Pigalle de París, unas cuantas del barrio de Amsterdam (los escaparates) y le dije cómo se tenía que poner en contacto con los macarras que las vigilan. Le hubiésemos acompañado. Yo lo hice con Cantero para Interviú. Nada, un libro precioso y que yo, que conocía la suprema audacia de Colom, ya lo veía hecho. Pero nada. No quiso. El libro se hubiese llamado Europut o Puterop y se hubiese vendido bien en todos los aeropuertos de Europa. ¿Te imaginas a Ramón en estas circunstancias? Él sí lo hubiera hecho. Colom ha hecho su carrera y ha sido premio Nacional de Fotografía. Pero su carrera no dudo hubiese sido otra sin el conocimiento de Esther Tusquets y Camilo José Cela. La publicación de Izas, Rabizas y Colipoterras le colocó ante un horizonte que él no hubiera podido aspirar, porque no hubiese conocido a nadie ${ }^{1104}$.

(Oriol Maspons, Barcelona, 31 de octubre de 2004) -“ ¿Tú te acuerdas de que yo fui de putas por culpa tuya?".

(Esther Tusquets, Barcelona, 31 de octubre de 2004) -“No. Debías ir muchos años antes”.

(Oriol Maspons, Barcelona, 31 de octubre de 2004) - “¡Me hizo una ilusión! Hacía muchos años que no iba y fui con La Blanca a ver como tenía el asunto del pleito. Además la puta aquella era simpatiquísima. ¡Pero hacía más años que no iba de putas!".

(Esther Tusquets, Barcelona, 31 de octubre de 2004) -“La Blanca sería la más guapa del libro. Con otra no lo hubieras hecho".

(Oriol Maspons, Barcelona, 31 de octubre de 2004) -“No, pero me costó menos de mil pelas".

(Esther Tusquets, Barcelona, 31 de octubre de 2004) - “¿Pero te lo pagó la editorial? Me encantaría".

(Oriol Maspons, Barcelona, 31 de octubre de 2004) -“Es que las putas, en aquella época, eran encantadoras, y antes aún más. Buena gente. La droga ha desmoronado el mundo de la puta. Cuando había aquellas casas de putas con aquellos nombres -de eso no se acuerda nadie-: El jardín, El recreo, La gaucha... Mira qué nombres más bonitos de casas de putas. Estaba la jefa de las putas -que era como una madre superiora, como en un convento-, que les mandaba y les decía qué tenían que hacer. Eran simpáticas. Nosotros íbamos a hacer «el florero». Hacer el florero quería decir que cuando ibas no te «ocupabas». Los sábados por la tarde, la primera puta que se 
«ocupaba», la dueña de la casa le hacía un ramo de perejil gordo y se lo ponía a San Pancracio. Y todas las casas de putas tenían a San Pancracio".

(Esther Tusquets, Barcelona, 31 de octubre de 2004) -“¿Y los de florero no hacíais nada?”.

(Oriol Maspons, Barcelona, 31 de octubre de 2004) -“No, rondar a la nenas. ¡Si no teníamos dinero porque valía quince pelas u once...! Pero era divertido porque eran muy simpáticas".

(Esther Tusquets, Barcelona, 31 de octubre de 2004) ${ }^{-}{ } ¿ Y$ a veces te hacían un servicio gratis o no?".

(Oriol Maspons, Barcelona, 31 de octubre de 2004) -“Hombre... sí, alguna vez".

Desde el punto de vista de los contenidos que se recogen en la colección, hay que destacar lo políticamente incorrectos, molestos e incluso provocativos que son esos temas vistos desde una perspectiva actual. Son libros simplemente irrepetibles: crudos, descarnados, críticos, con pocas concesiones a mojigaterías o a sensiblerías bienintencionadas.

“¡A los autores elegidos por mí se les ocurrían unos temas -el boxeo, los toros, las putas, la caza- que no podían sorprenderme más ni gustarme menos!"105.

Desde luego la dureza de alguno de los temas nunca fue un lastre para la publicación de los libros. Más bien al contrario. Alguna de las cicatrices más profundas de la sociedad franquista quedaron retratadas en estos libros por decisión de unos autores auténticos, fueran éstos escritores o fotógrafos...

-Pero los fotógrafos decidían cuáles eran las fotos que les gustaban y la maquetación...

(Esther Tusquets, Barcelona, 31 de octubre de 2004) -“'Lo que pasa es que, como diseñadores, mi hermano y Lluís Clotet eran extraordinarios. Era un privilegio. Aparte de que eran muy respetuosos".

(Oriol Maspons, Barcelona, 31 de octubre de 2004) -“Claro que sí, por eso no nos peleábamos. Y eran muy respetuosos porque les gustaba lo que hacíamos".

(Esther Tusquets, Barcelona, 31 de octubre de 2004) -“De La perdiz roja discutías cada foto. ¡Os he oído discutir cada foto!".

“Ninguno de los dos [Óscar Tusquets y Lluís Clotet] había cumplido veinte años ni tenía experiencia, pero creo que no me ciega la pasión (...) si afirmo que llevaron a cabo un trabajo excepcional (...) partíamos, para bien y para mal, de cero, y eso suponía torpezas, errores, pérdida de tiempo, pero también entrañaba la posibilidad de llegar casi sin darnos cuenta a soluciones inéditas. «Eso no puede ser», decía yo, siempre más conservadora. «¿Y por qué no?», interrogaba Lluís con su aire más inocente, especialista Lluís en poner el gesto de quien no ha roto un plato en su vida. «Porque no se hace nunca». Lluís se encogía de hombros. Óscar se encogía de hombros. Y se hacía. Eso sí, después de haberse discutido muchísimo, porque cada ínfimo detalle se discutía con Lluís durante horas o durante días (ganaba las batallas por cansancio del adversario: llegó a convencernos incluso de que no era preciso, aunque se hiciera siempre, que un libro llevara el título en cubierta, y sin título en la cubierta apareció el primer libro de la colección) [Jaime Buesa y Ana María Matute], y podía haber errores, pero no se debían nunca a la improvisación" ${ }^{106}$.

Como hemos visto el arquitecto Lluís Clotet (1941) dirigió junto a Óscar Tusquets la parte gráfica y de diseño de la colección Palabra e Imagen. El 9 de noviembre de 2004 mantenemos una entrevista telefónica con él. Nos sorprende su memoria, ya que recuerda absolutamente todas las decisiones del diseño gráfico de la colección y, como veremos más tarde, de la maquetación de cada una de las fotos de Neutral Corner de Masats. Lluís Clotet nos confirma que toda la colección 
estaba sometida al criterio del utilitarismo y/o del racionalismo que posteriormente aplicaron al campo de la arquitectura. Como hemos visto en páginas precedentes ese concepto se define dentro de la máxima por la cual si una cosa funciona, es bella de por sí. Es un principio con el que todavía hoy está de acuerdo.

Siguiendo este concepto racionalista se diseñó el tamaño y el formato de los libros, pues las páginas son múltiplos perfectos del pliego de papel (la hoja grande que después se pliega y se corta). De este modo se aprovechaba todo el papel y se aseguraban que no hubiera restos desperdiciados, practicando una ejemplar economía de medios. Otro de los efectos que pretendían al diseñar un formato casi cuadrado era singularizar y destacar la figura del libro entre el marasmo de una librería, pues se trataba de un formato muy novedoso. La colección Palabra e Imagen era especialmente lujosa, incluso cara, y todos esos detalles eran cuidados al máximo.

“El punto más conflictivo iba a ser sorprendentemente el papel. La impresión de las fotos tenía que ser
impecable y requería el mejor couché. Hasta aquí no cabía discusión. Pero ¿y el texto? El texto sería
casi siempre breve, iría por lo tanto en cuerpo grande, no presentaría problema de lectura. De hecho
cualquier papel servía. Pero al decir «cualquier papel», yo no pensaba en una cartulina de embalaje,
rugosa y de color grisáceo, ni remotamente proyectada para libros. ¿No servía? ¡Claro que servía! ¿Que-
daba por ver si alguien compraría unos libros caros, libros de lujo, adecuados para regalo, impresos en
esos papeles que se utilizaban en los mercados para envolver las cerezas o las sardinas"107.

El 6 de enero de 2005 mantenemos una conversación telefónica con Óscar Tusquets en la que también hablamos sobre los dos tipos de papel que utilizaron en la colección Palabra e Imagen. Las razones aducidas para realizar unos libros donde los textos aparecen con letras grandes en un papel mate muy basto y grosero -como si fuera un papel de embalaje- mientras que las fotos se publican en papel brillo de gran calidad, se debe, por un lado, a una función utilitaria: facilitar la lectura de los textos, ya que el papel mate evita los reflejos y permite una mayor legibilidad de las letras. Por otro lado, el mezclar exquisitez con tosquedad correspondía a una moda del diseño de la época. Era un efecto buscado en donde se utilizaban elementos groseros con otros más refinados. Como por ejemplo, joyas hechas con piedras de playa.

-¿En general la colección fue moderadamente rentable para la editorial?

(Esther Tusquets, Barcelona, 31 de octubre de 2004) -“Sí, se vendieron bien las Izas de Camilo José Cela, Los cachorros se vendió bastante, Delibes y su Caza de la perdiz... Sí, no creo que se perdiera dinero, no sé. Era muy divertido este principio de la colección y de la editorial porque todo se hacía en plan absolutamente amateur. Nadie hablaba de pelas. En el mundo editorial de hoy en día sólo se habla de dinero. $Y$ en aquel momento nadie hablaba de dinero. Ni nosotros de ganar ni los autores de lo que cobrarían. Muy poco, tal vez hablamos demasiado poco de dinero..."

- ¿Entonces fueron rentables los libros o no?

(Esther Tusquets, Barcelona, 31 de octubre de 2004) -“No".

-¿Ni para el autor?

(Esther Tusquets, Barcelona, 31 de octubre de 2004) -“Para el autor no sé lo que puede ser rentable, pero no creo. Comparado con lo que deben de cobrar por hacer unas fotos de publicidad... debía de ser una miseria. Lo que pasa es que a todos les hacía mucha ilusión. Ni uno dijo que no. Ni uno. Y de los escritores -que tampoco cobraban gran cosa- tampoco dijo ninguno que no. Los libros que no se llegaron a hacer fueron porque hay cosas que se quedaron por el camino, cosas que no se acaban de hablar... Pero a todos les hacía mucha ilusión la colección y todos decían que sí". 


\begin{abstract}
“A Miguel [Delibes] le importaban los demás (le han seguido importando), y cuando, en nuestra primera entrevista, Óscar le dijo que no nos interesaba lo que se iba a vender, sino lo que a él le apetecía escribir, comprendió sin duda que se hallaba ante unos jovenzuelos tan bien intencionados como insensatos, y empezó enseguida a inquietarse por nosotros y por nuestras dudosas posibilidades de supervivencia"108.
\end{abstract}

Estas declaraciones son muy clarificadoras. Sin duda, otro de los factores que influyeron en la calidad final de la colección fue la libertad creativa de sus autores. Ellos decidían los temas de los libros, a pesar de que personalmente les desagradaran a los responsables editoriales. Los autores disfrutaban de una absoluta confianza por parte de Esther y Óscar Tusquets. Eran considerados profesionales competentes ("autores") que desde luego no escribían ni fotografiaban al dictado de ningún "argumento de venta".

\footnotetext{
“¿Qué eran, pues, los argumentos de venta? Básicamente dos: que se hiciera la versión cinematográfica - a poder ser con Julia Roberts y Ricard Gere de protagonistas- y, por encima de todo, que saliera en televisión. ¿Y si no se hacía por el momento la película y no salía en televisión? Bueno, también valía si se relacionaba con algo de viva actualidad, con un escándalo, con gente famosa... si la autora, por ejemplo, había tenido un lío con un político importante o con el presidente del Gobierno. ¿Servía esto como argumento de venta? A falta de algo mejor... aunque era preferible con el presidente, claro, y si pudiera ser con el rey..." ${ }^{109}$.
}

A pesar de los logros estéticos conseguidosal equiparar fotografía y literatura, lo cierto es que, finalmente, la fotografía nunca pudo superar la concepción de arte menor con respecto a la literatura. Probablemente influyera el que los fotógrafos no fueran conocidos fuera de los círculos especializados. Pensemos que en aquellos años la fotografía empezaba a desembarazarse del salonismo y no interesaba a nadie más que a los propios fotógrafos. Recordemos que fue en 1957, apenas cuatro años antes de la aparición del primer libro de la colección, cuando Terré, Miserachs y Masats realizaron su exposición conjunta, exposición que quizá llamara la atención de una selecta élite de intelectuales y artistas, los más avanzados de Barcelona, extramuros de las agrupaciones fotográficas. Sin duda habría sido excesivo pensar que en tan poco tiempo la fotografía pudiera llegar a un público más amplio, aunque igualmente distinguido, consumidor de una cara y lujosa edición fotográfica.

(Esther Tusquets, Barcelona, 31 de octubre de 2004) -“Se vendía poquísimo, y por descontado los libros se vendían por el escritor y no por el fotógrafo. El intento de dar igual importancia al texto que a la imagen fue inútil".

Óscar Tusquets coincide con Esther en su valoración sobre el éxito de la colección Palabra e Imagen. Fue gracias a los escritores y no por los fotógrafos. Según su opinión, los libros de fotografía no venden, excepto, quizás, los de chicas guapas o los de lugares o paisajes. Cuando editaron el libro de Cartier-Bresson en España, Delphire les confesó que el propio Cartier-Bresson compraba la mitad de la edición, porque si no, Delphire no hubiera podido pagarla. En los libros de arquitectura que él mismo propone a la editorial Lunwerg, actualmente sucede lo mismo. No hacen el libro si no tienen casi toda la edición vendida de antemano.

En 2003, en la Feria del Libro de Valencia había un librero que tenía un ejemplar del Izas, Rabizas y Colipoterras. Estaba en muy buenas condiciones de conservación pero cuando le preguntamos el precio nos dijo que costaba ochenta euros. Nosotros entendimos que como acababan de 
darle el premio Nacional de Fotografía a Colom era normal que hubieran subido tanto el precio del libro que lo consagró, pero cuando le preguntamos al librero el porqué de ese precio, nos contestó -con un brillo en la mirada- que era una primera edición de un libro de Camilo José Cela... Malos tiempos para la lírica. No lo compramos, claro.

- ¿Y por qué cree que el mundo editorial hace menos libros de fotografía?

(Esther Tusquets, Barcelona, 31 de octubre de 2004) -“Porque no se venden. No se hacen por razones económicas".

-¿Pero antes sí se vendían?

(Esther Tusquets, Barcelona, 31 de octubre de 2004) -“Yo creo que hubo una temporada en que es posible que se vendiera más".

(Oriol Maspons, Barcelona, 31 de octubre de 2004) -“Pero en aquella época lo hacíamos un poco como en plan de aventura".

(Esther Tusquets, Barcelona, 31 de octubre de 2004) -“No, no. Lumen era raro. En Lumen lo hacíamos porque estábamos locos. Pero en aquel momento en el extranjero también se hacían más libros de fotos. Se hacían muchos".

(Oriol Maspons, Barcelona, 31 de octubre de 2004) -“Pero yo voy a Kowasa -que es la mejor tienda de fotografía de Europa- y se hacen muchos libros nuevos en el extranjero".

(Esther Tusquets, Barcelona, 31 de octubre de 2004) -“En general es muy difícil vender libros".

-No obstante, se están reeditando muchos libros de la época, como el propio Barcelona en ByN, Neutral Corner o New York de William Klein...

(Esther Tusquets, Barcelona, 31 de octubre de 2004) -“Pero eso no quiere decir que se vendan. No sabéis cuántos se han vendido. No hay ningún control. Hoy en día se venden muy pocos libros y se editan muchísimos. Y eso pasa desde que empecé en los años sesenta hasta ahora. Somos el tercer país productor de libros del mundo, me parece, y de ventas somos el penúltimo de Europa. No se vende y se produce mucho. Salen cincuenta o sesenta mil títulos al año en un país que no se lee".

-¿Y por qué se dejó de hacer la colección?

(Esther Tusquets, Barcelona, 31 de octubre de 2004) -“Básicamente fue cuando Óscar dejó de trabajar para mí y montó Tusquets editores... Y después, bueno... porque las cosas se acaban. Los últimos son menos interesantes. Los últimos en los que no estaba Óscar tienen menos interés".

(R. Masats, Valencia, 25 de marzo de 2004) -“El problema que tuvo la colección Palabra e Imagen es que salió antes de tiempo y no funcionó. Pero la idea era espléndida y hay una gran cantidad de libros de esa colección de grandes fotógrafos y grandes escritores españoles. Era muy interesante".

(Esther Tusquets, Barcelona, 31 de octubre de 2004) -“Un día recibimos un papel que decía que habíamos recibido el León de Venecia. El primer premio del concurso internacional a la mejor publicación, colección o revista relacionada con la fotografía. Nos quedamos muy sorprendidos porque no sabía que participábamos en el concurso, ni sé quien nos presentó".

-¿El premio fue por algún libro en especial o por toda la colección?

(Esther Tusquets, Barcelona, 31 de octubre de 2004) -“Fue por toda la colección. Nos dieron un leoncito y lo tuve que dejar en la editorial cuando la vendí. Me supo muy mal porque fue muy al principio de Lumen".

\subsubsection{Neutral Corner (1962)}

Lluís Clotet diseñó junto a Óscar Tusquets el libro Neutral Corner en 1962. Recuerda a Masats con mucha ilusión y dando todo tipo de facilidades para maquetar el libro. Dio muchísima libertad sin intentar imponer su criterio. Piensa que pocos fotógrafos, actualmente, se prestarían a tanta manipulación como la que sufrieron sus fotos, pero Masats lo aceptó todo. Él y Óscar eran muy jóvenes (estudiantes de segundo curso de arquitectura con apenas veintiún años) y, aunque le 
propusieron cosas muy atrevidas y novedosas, Masats les dejó cortar las fotos y maquetarlas con total libertad, entusiasmado con aquella juventud que tanto reivindicara en sus textos desde Colonia. Lluís Clotet nos comenta que eran muy respetuosos con el autor y siempre se lo consultaron todo. De cualquier manera, casi no habló con Masats. Sólo se estudiaó la maquetación del libro, pero no conversó con él sobre su manera de entender la fotografía o sobre cualquier otro tema. Con el autor de los textos, Ignacio Aldecoa (Vitoria, 1925-Madrid, 1969), sí habló más. Le comentó que le hubiera gustado hacer otro libro de otro deporte más brutal que el boxeo -el ciclismo-. Libro que no se llegó a realizar por su prematura muerte, a los cuarenta y cuatro años de edad.

\begin{abstract}
“Tampoco llegó a hacerse un segundo título que Ignacio proponía para Palabra e Imagen: «Estoy seguro de que el tema de la pesca es excelente - ¿pesca en general?, ¿pesca de río o de mar?- y que podría salir un libro espléndido. Naturalmente a mí me gustaría, o digamos que siento más inclinación, por la pesca en el mar. Pesca laboral y peligrosa, y algunas de cuyas facetas conozco bastante bien. Habría que elegir un fotógrafo, no sólo bueno, sino además con ciertas dosis de osadía»"110.
\end{abstract}

Boxeo, ciclismo, pesca... Como vemos, Aldecoa prestó un gran interés a los oficios más sacrificados y abnegados. Buscaba la aventura épica de personajes comunes y anónimos, enfrentados a ambientes hostiles y a terribles circunstancias. No en vano a Ignacio Aldecoa a menudo se le ha clasificado como representante de la tendencia neorrealista en el marco de la novela de los años cincuenta. Lo cierto es que compartió su interés por Pío Baroja y por el cine neorrealista italiano con los escritores del realismo social, así como su preocupación solidaria, casi enfermiza, por las clases populares más desfavorecidas. Aunque la temática de su obra es variada, el interés por los oficios, la clase media o el éxodo rural a la ciudad es una constante en su trabajo. La obra de Ignacio Aldecoa permite, sin duda, configurar un amplio cuadro de la posguerra española.

\begin{abstract}
“Aldecoa quería escribir la épica de los grandes oficios (así el oficio del mar que sólo pudo cifrar en una obra, Gran Sol), mas asimismo la épica de los oficios humildes: el oficio de maquinista, de cobrador, de pocero, de segador, etc., convencido -y así lo expresó alguna vez- de que la dedicación entrañable de quienes los desempeñaban les confería grandeza cierta (...) Aldecoa compartía con Hemingway no sólo la afición al boxeo, sino también la admiración por ciertas apoteosis del valor, como los toros, sobre los cuales pensó en escribir una novela, y la lucha contra las fuerzas de la naturaleza (Gran Sol) (...) [Neutral Corner] es la historia de un oficio duro, pero ilustre; fuerte pero hermoso; legendario pero trágico"111.
\end{abstract}

La obra de Aldecoa se inició con dos libros de poesía: Todavía la vida (1947) y Libro de las algas (1949). Su trayectoria novelística empieza con El fulgor y la sangre (1954) que, junto con Gran Sol (1957) (Premio de la Crítica 1958), constituye un ejemplo de la llamada novela-reportaje. Otras novelas dignas de mención son: Con el viento solano (1956) y Los pozos. Su producción incluye, además, libros de relatos y cuentos: Espera de tercera clase (1955), Vísperas del silencio (1955), El corazón y otros frutos amargos (1959), Arqueología (1961), Caballo de pica (1961), Cuaderno de Godo (1961), Pájaros y espantapájaros (1963), Los pájaros de Baden-Baden (1965), Parte de una historia (1967) y Santa Olaja de Acero (1968).

110 Tusquets Blanca, Esther, op. cit., pág. 41.

111 Garcia-Posada, Miguel, "El canto, el cuento, la palabra”, prólogo de la segunda edición del Neutral Corner, Madrid, Alfaguara, 1996, sin paginar. 


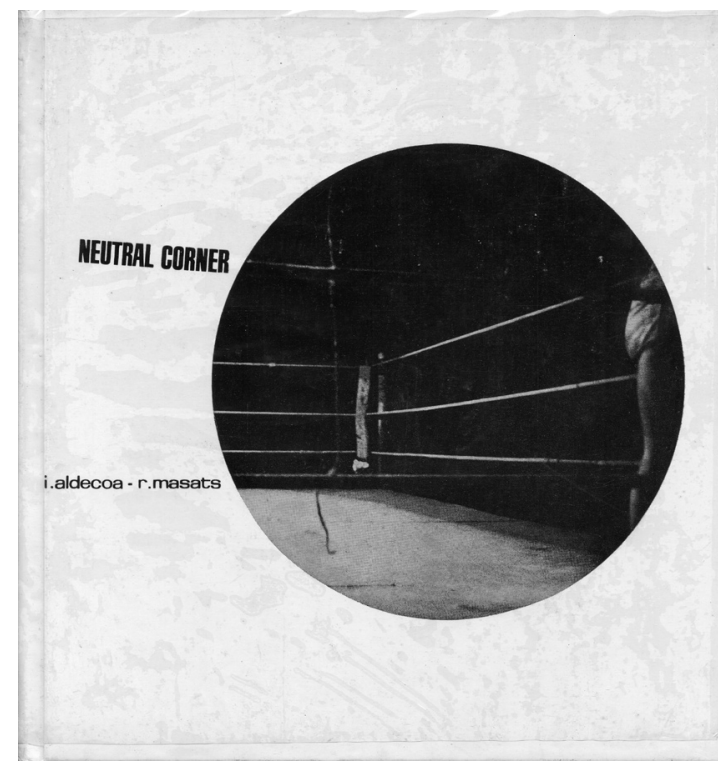

Portada de Neutral Corner.

-Las fotos del Neutral Corner fueron hechas a partir de los textos.

(R. Masats, Madrid, 17 de julio de 1999) -“No, los textos fueron hechos a partir de las fotos. Nos hicieron el encargo, y como yo no conocía el mundo del boxeo, Ignacio me llevó a gimnasios. Me llevó a sitios para que fuera viendo. Llevaba cámara pero casi no hice fotos. Quedaba con la gente para volver y tal... Me dijo «Vamos a hacerlo de esta manera. Tú haces las fotos, luego me las das y yo escribo». Y el resultado para mí es fantástico".

Como vemos la vinculación entre el texto y las fotos es clara y total, aunque en esta obra, tan compleja, habrá que matizar esta afirmación. Pero empecemos por el principio, por la portada del libro.

El libro está encuadernado en tapas duras envueltas en sobrecubierta de plástico. Hablando con Lluís Clotet, le comentamos que analizando el libro hoy día a Masats le llama la atención la portada -con la foto cortada de forma redonda del ring-, pues le parece más lógico que hubiera sido cuadrada. Lluís Clotet me explica que lo que pretende ese gran punto de la portada es subrayar, precisamente, el "neutral corner". El cuadrilátero del boxeo tiene cuatro rincones: dos para los boxeadores, el tercero para el árbitro y el cuarto que no es de nadie. Es la esquina neutral, un punto en el cuadrilátero. Dentro del libro hay una foto muy pequeña, que tiene su negativo al lado y que, para Óscar y para Lluís Clotet, representa ese punto neutral. Ese punto pasó a la tapa. Además, un cuadrado blanco marcado con un punto oscuro dentro se distingue mejor entre el caos de las librerías, hecho que querían cuidar al máximo, puesto que querían mimar el libro al máximo.

\footnotetext{
“¿No se llamaba el libro Neutral Corner? ¿Qué más justificado, entonces, que poner en la cubierta una foto donde apareciese el rincón neutral? Pero la foto de un rincón vacío del ring no tendría mucho gancho aunque fuera de Masats, y muy poca gente entendería la relación con el título. Pero sí se entendería si imprimíamos un cuadrado negro enfrentado a la portada interior. Este cuadrado, que para nosotros era una clara alusión al cuadrilátero visto en planta, lo perforábamos con un disco blanco situado en una esquina, y la foto de la cubierta la recortamos también de forma circular, o sea que el círculo que en el interior se veía en planta, en la cubierta se vería en perspectiva... Y así todo quedaría justificado"112.
} 

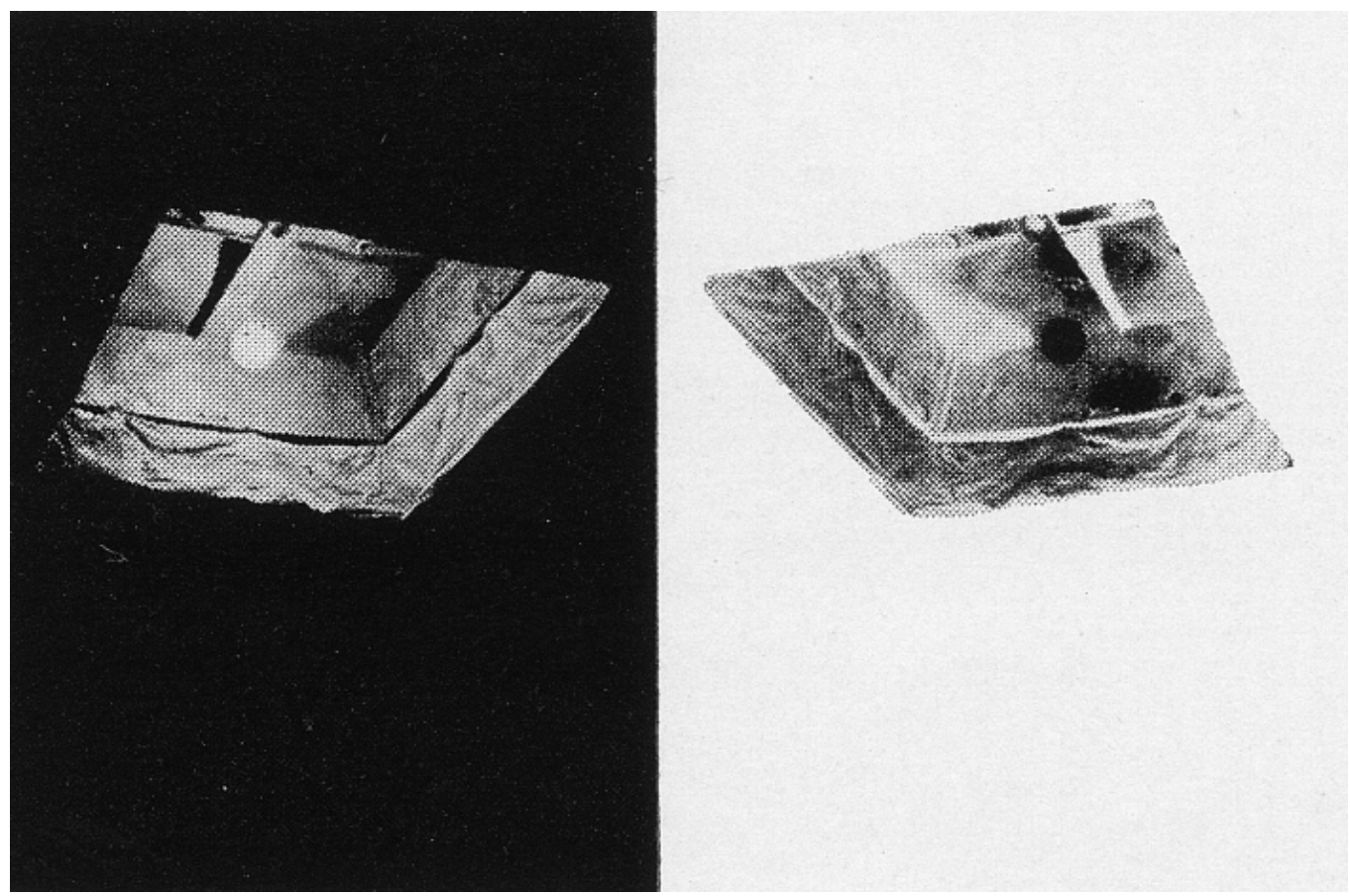

Fotografía que inspiró la imagen del círculo en la portada

Como ya hemos comentado, los libros presentaban dos tipos de papel: uno brillante para que las fotos gozaran de mayor calidad y otro mate, para que los textos se pudieran leer mejor, sin molestos reflejos en su superficie. Esta decisión, eminentemente práctica, complicaba muchísimo la paginación. Todo el libro estaba sometido al orden impuesto por estos pliegos de papel de distinta naturaleza. Al principio y al final del libro, las guardas, los créditos y las hojas de cortesía ocupan los únicos pliegos de cinco hojas de texto. El resto del volumen se somete a un estricto ritmo de geometría que se ordena en grupos de dos hojas de texto, dos hojas con fotos, dos hojas de texto, dos hojas con fotos... Esos moldes físicos condicionan drásticamente los contenidos.

Los textos son necesariamente breves, puesto que los catorce capítulos de los que consta la parte escrita se circunscriben a dieciocho hojas de papel de embalar cerezas (aunque entre el texto portadilla, portada, índice, páginas de cortesía, blancas... hay un total de cuarenta y ocho paginas de este papel basto). Hay capítulos realmente escuetos, de una sola página: como el número uno, el del "neutral corner", donde se permite dejar la otra página de la hoja de papel en blanco. A su vez, hay capítulos que requieren la totalidad de las dos hojas de papel mate, sin embargo, no hay ningún capítulo que traspase esa limitación de las dos hojas (o las cuatro páginas, claro...). Lo que ocurre en la mayoría de los casos es que cada dos hojas se ven ocupadas por dos capítulos, como sucede en los capítulos: 2 "La ley del péndulo" y 3 "The king", 4 "El boxeador que perdió su sombra" y 5 “Break !!!", 6 “El pensador" y 7 “El boxeador fanfarrón” y, por último, en los capítulos 8 "Jaculatorias" y 9 "Un minuto de paz". Todo ello determina una enorme economía de medios y un uso muy acusado de los recursos estilísticos que, por otro lado, resaltan su intensa carga testimonial. Lo cierto es que estas restricciones se ajustan perfectamente al estilo sintético y preciso, casi poético, de la narrativa de Aldecoa. 


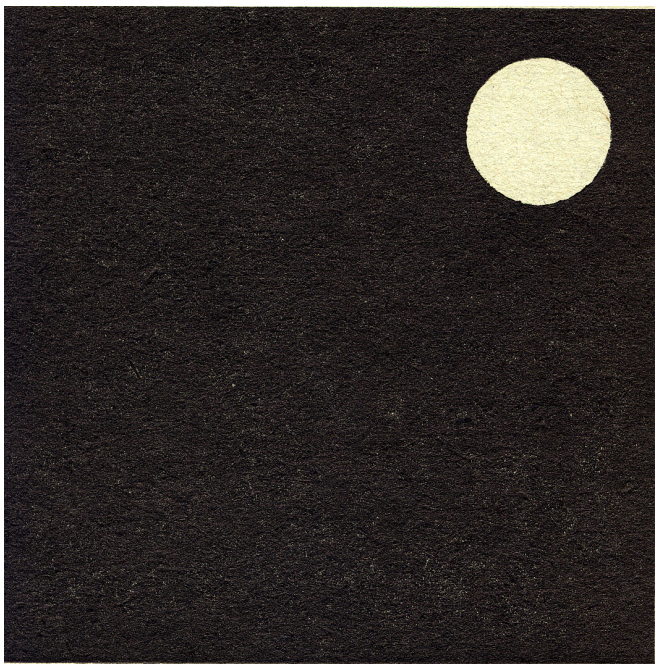

Dibujo que representa el cuadrilátero en la portada interior de Neutral Corner.

"Alienta siempre en Aldecoa una acusada voluntad de forma, que alguna relación tiene con su formación inicial de poeta (...) Aldecoa aportó además a su orfebrería verbal un extremo sentido de la economía expresiva, inducida entre otros factores por la textura narrativa de su discurso. Uno de sus grandes logros reside en la conjunción de la eficacia del relato, siempre ajustado, siempre lacónico, y la honda belleza del estilo"113.

Cuestión aparte suponen las series de fotografías, que, aunque sometidas al mismo ritmo de pliegos -y con un total de 30 páginas de papel cuché- son maquetadas de una manera completamente diferente, atendiendo a su distinta funcionalidad expresiva. Lluís Clotet nos comenta que para relacionar las fotos con los textos la solución que encontraron fue duplicar las fotografías a las que se aludía en el texto, utilizando un tamaño mucho más pequeño. De este modo, las fotos que están directamente relacionadas con el texto se repiten con un formato y con una posición central exacta a las letras del título del capítulo que precede. Por tanto, la relación, la sutura entre estas fotos y los textos, es doble: visual o compositiva (mismo tamaño y misma posición) y en función del contenido de la imagen en sí (es decir, del sujeto fotografiado y su relación significante con el título).

Como ya hemos comentado, estas fotos funcionan como introductorias de los textos que presentan, como cabeceras, pero además, al repetir las fotografías, Clotet y Óscar Tusquets conseguían otro efecto: que pudieran observarse más nítidamente. No obstante, hay que destacar que no todas las fotos menudas tienen su correspondiente réplica a mayor tamaño. La imagen del saco moviéndose en el gimnasio y ese extraño cuadrado de luz con un punto luminoso en un rincón que inspiró el círculo de la portada... sólo están reproducidas en tamaño diminuto. Se deduce, por tanto, que la gran mayoría de las imágenes son relecturas de las grandes. De modo que, por ejemplo, un boxeador enrollado en una toalla en medio de unos radiadores nos puede sugerir, en las fotografías de mayor tamaño, que en los gimnasios hacía mucho frío, dado que eran lugares oscuros, lúgubres y pobres (además, de que compositivamente funciona por simetría con la foto vecina del boxeador haciendo flexiones). Sin embargo, en la reproducción pequeña, la misma foto del boxeador y la toalla da un giro en su significado y representa a un boxeador ab- 


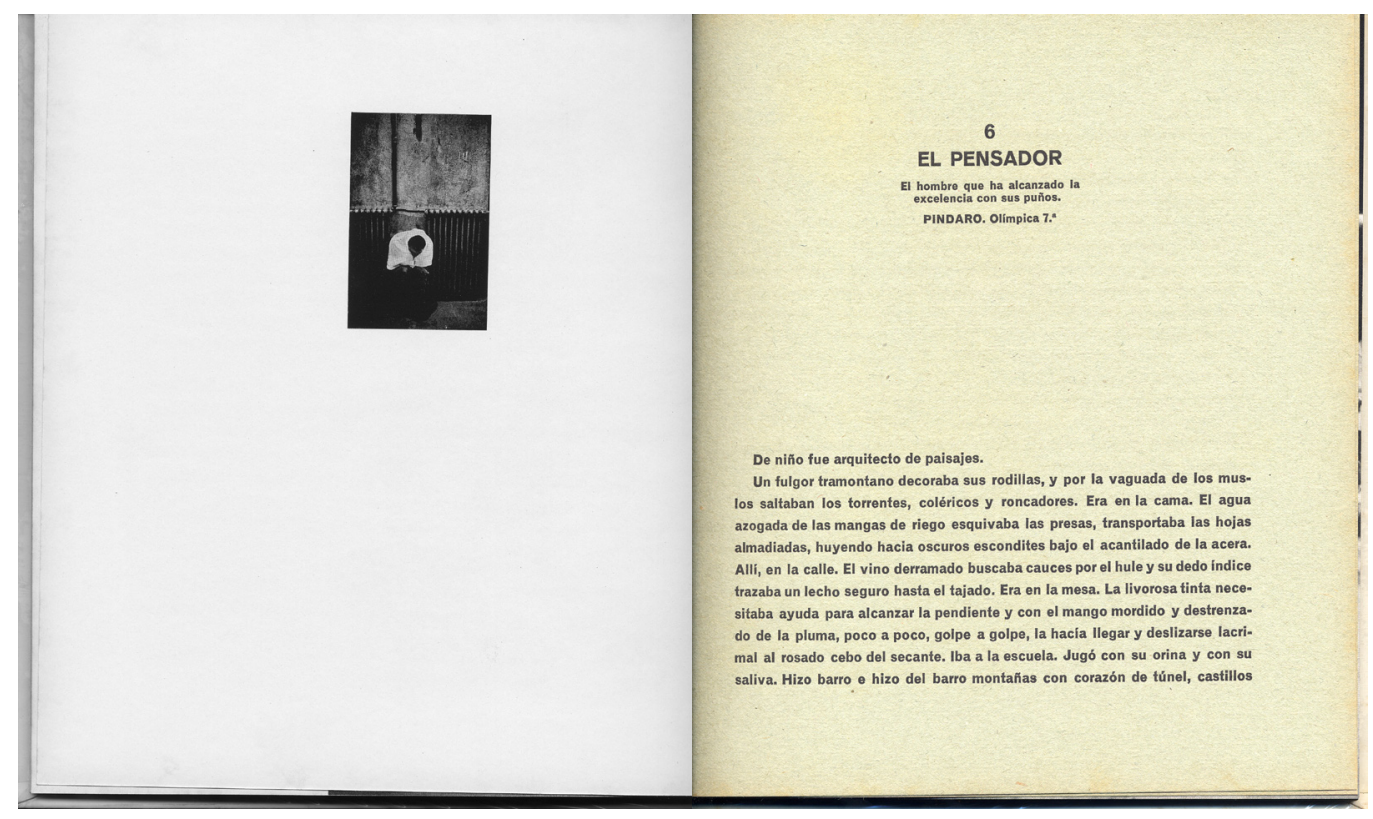

Ejemplo del uso de las imágenes pequeñas relacionadas con el texto, con el mismo tañano y la misma posición que el título, aunque con tipos de papel diferente.

sorto en sus meditaciones y sus sueños, una especie de "pensador". ¿Quizá porque para Aldecoa o para Óscar Tusquets recuerde al pensador de Rodin en su postura? Como vemos, los textos dirigen la lectura de las fotos y las condicionan, limitando su polisemia, a modo de pie de foto.

Otra imagen que se reproduce a dos tamaños y con dos lecturas completamente diferentes es la del boxeador escribiendo, inclinado sobre un pupitre. La primera vez que aparece en el libro lo hace a toda página, abriendo uno de los pliegos de dos hojas de papel cuché y precediendo a una doble página con una foto de los vestuarios. El pliego de fotos anterior también está dedicado a describir el ambiente de los gimnasios, humanizando a los boxeadores... No son las sombras agresivas que nos encontraremos más tarde durante el combate. En estas fotos se reconocen los rostros, las miradas, los gestos. Esta imagen, a su vez, incide en la dificultad que tiene el púgil de coger el lápiz dado lo forzada y constreñida que es su postura, circunscrita a un pupitre demasiado pequeño para su enorme cuerpo. La imagen nos muestra el ridículo papelito que requiere toda su atención y esfuerzo. Es como si las enormes piernas y los pies, calzados con zapatillas deportivas, no correspondieran con el propio tronco superior. Evidentemente, la foto nos habla de la educación del boxeador: sabe leer y escribir, pero no se maneja con soltura dentro de ese minúsculo cuadrilátero. ¿Quizá esa deficiente educación sea uno de los motivos que le han llevado a la practica del boxeo?

“El boxeo era un oficio de pobres. De pobres que querían ganar dinero con él para ser alguien socialmente y redimir así el sufrimiento de sus allegados (...) Son solamente gente humilde que quiere un poco de gloria y un poco de felicidad, y el boxeo es el medio para lograrlas. Éste era, por lo demás, el ambiente que rodeó a los boxeadores españoles de la posguerra, cuando las cuatro cuerdas fueron una metáfora de las clases populares derrotadas en la guerra civil"114. 


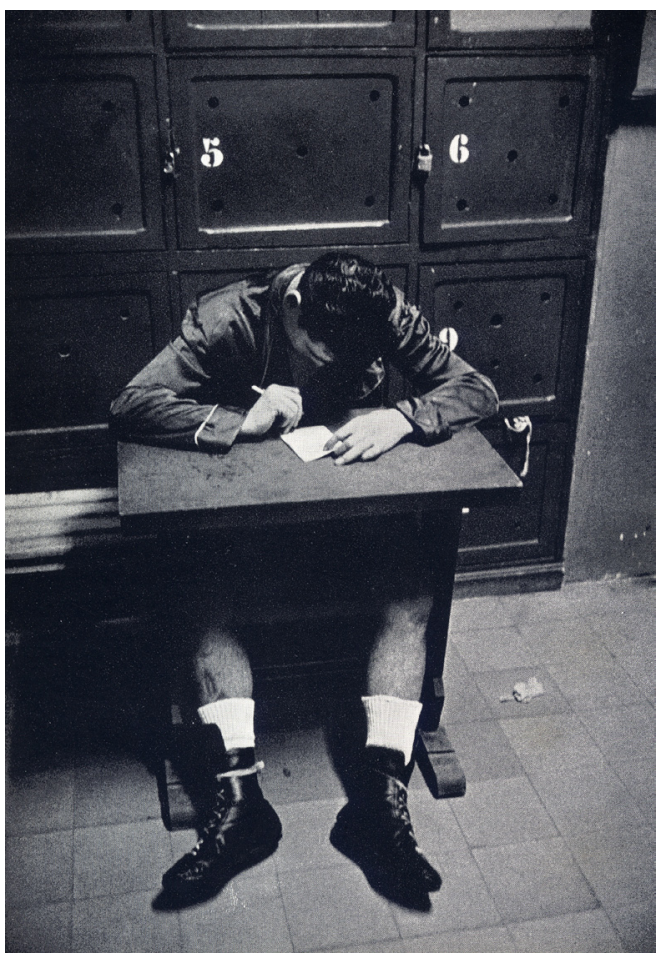

Ramón Masats, imagen extraída del capítulo “Jaculatorias", Neutral Corner.

El título del capítulo que se corresponde con la repetición diminuta es Jaculatorias. La nueva versión de la fotografía que el libro nos ofrece conjetura con el escrito del dichoso papelito. Presume que el púgil está escribiendo sus rezos, breves y fervorosos, a Júpiter, el dios del combate. Ruegos para quebrarle el alma al contrario, para restañar las heridas... oraciones para alcanzar la gloria. Por tanto, se manejan dos niveles de relación entre las fotos y los textos gracias a la disparidad del tamaño de ampliación. Estas dos líneas discursivas, estas particulares reglas de lectura del libro, quedan perfectamente definidas desde su inicio, y obligan al lector a leer la totalidad de imágenes y textos en su correspondiente orden, ya que si estas no se leyeran podría resultar ligeramente confuso el hecho de volver a ver las mismas fotos, mucho más pequeñas, unas páginas más adelante.

Las fotos grandes marcan una línea narrativa más independiente de los textos que las fotos pequeñas. Decir que son absolutamente autónomas sería una temeridad, pero es cierto que estas imágenes de mayor tamaño desarrollan la historia de una manera lineal, cronológica. Las fotografías grandes relacionan unas fotos con otras por medio de la paginación y podrían funcionar perfectamente sin el apoyo de los textos. Las imágenes de mayor dimensión empiezan describiendo el gimnasio, los entrenamientos, los púgiles... para después reproducir el combate. En él se recoge: la presentación de los contrincantes -en una arriesgadísima doble página donde los oponentes se abaten literalmente, el uno contra el otro, al pasar las hojas-, su inicio, los segundos de descanso, las caras de los boxeadores agotadas y desfiguradas -llenas de hematomas y derrames-, la violencia de los golpes y el implacable K.0. final. Evidentemente, las fotos grandes evolucionan de una manera similar a la línea argumental de los textos, pero su contenido es mucho más libre e independiente que lo que sucede en el caso de las fotos pequeñas situadas al final de los pliegos de papel cuché. Como ya hemos 

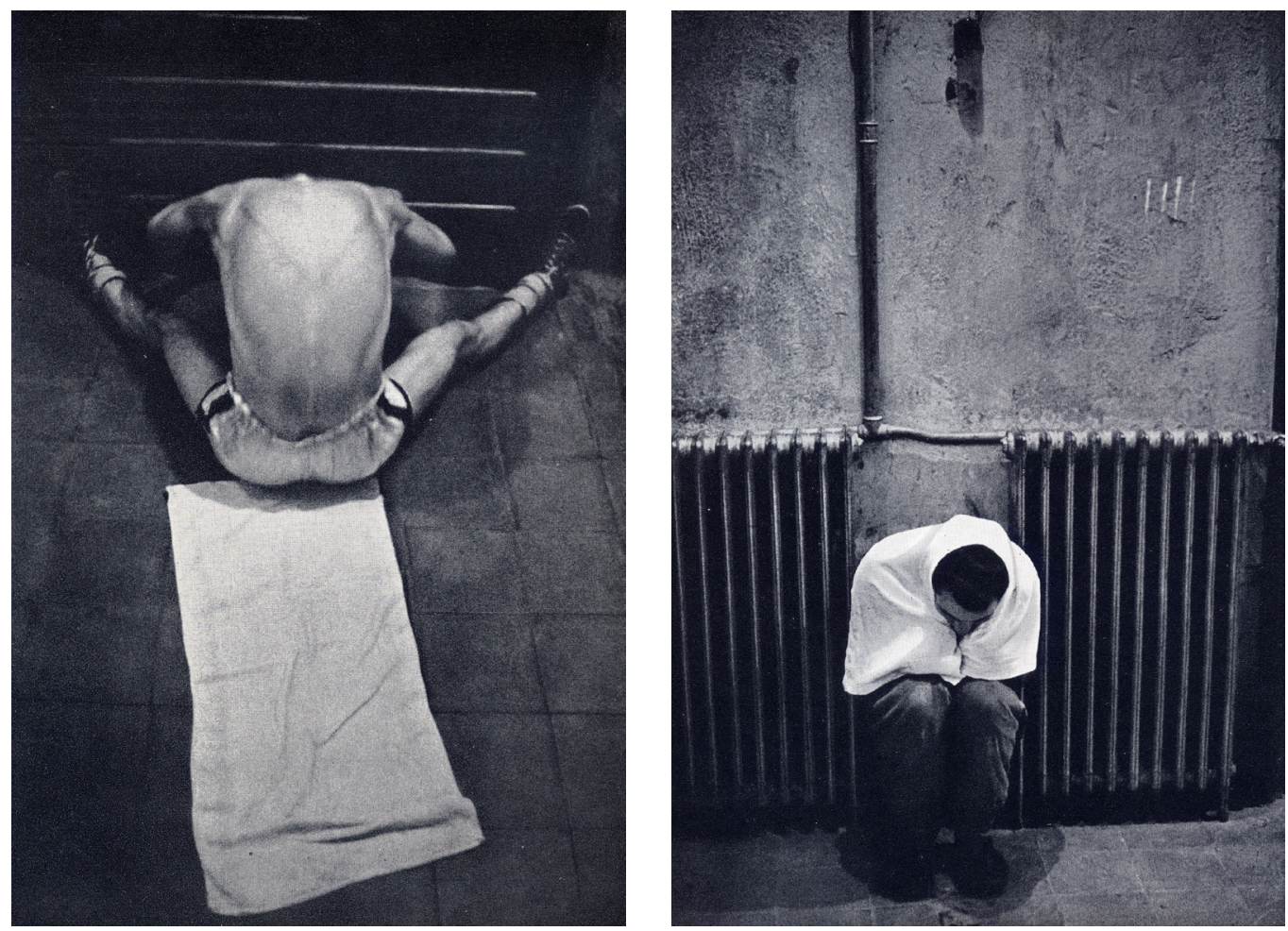

Dos imágenes distintas, una meramente plástica de un boxeador haciendo flexiones y la otra con mayor valor como documento histórico y social donde se ven las condiciones insalubres de los gimnasios.

comentado, éstas sólo dependen de la relación entre las propias fotos. Lo cierto es que todo el libro es armónico y coherente, y forma una unidad creativa asombrosamente imbricada. A ello, sin duda, contribuye la coincidencia de estilos de ambos autores: los dos son analíticos y sintéticos, y plantean su obra del modo más breve, para que en su precisa concisión, sea lo más rotunda, directa y esencial posible.

(Koldo Chamorro, Pamplona, 21 de marzo de 2003) -“Hay otra cosa importante en el tema de Ramón, y es que él está muy próximo... Es decir, el territorio natural de Ramón es la literatura: primero porque a él le gusta leer y, luego, por la forma de contar. Claro, el tema de Neutral Corner funciona tan bien porque está hermanada toda la parte visual y la parte literaria. Es una unidad total, y es una pena que no haya hecho más libros así. Yo, si hubiera sido editor, le hubiera encargado más libros porque son una maravilla, y no hay tanta gente capaz de contar historias con esa intensidad, esa hondura y ese duende".

Sin renunciar a valores plásticos, o gracias a ellos, la lectura del libro constituye un impacto tan áspero como el oficio que retrata. Impacto perpetrado, en parte, gracias al diseño de Óscar Tusquets y Lluís Clotet. A pesar de ello, no debemos olvidar que las imágenes tomadas por Masats poseen un doble interés, ya que junto al riesgo técnico de algunas imágenes, o su propia composición las convierte en arriesgada investigación visual que actúa como el crudo retrato de una época. Cuando años más tarde se revindique este trabajo, se generará una cierta discusión entre cuál de estas dos facetas destacar.

(R. Masats, Madrid, 17 de julio de 1999) -“Por ejemplo, con Publio López Mondéjar, con 


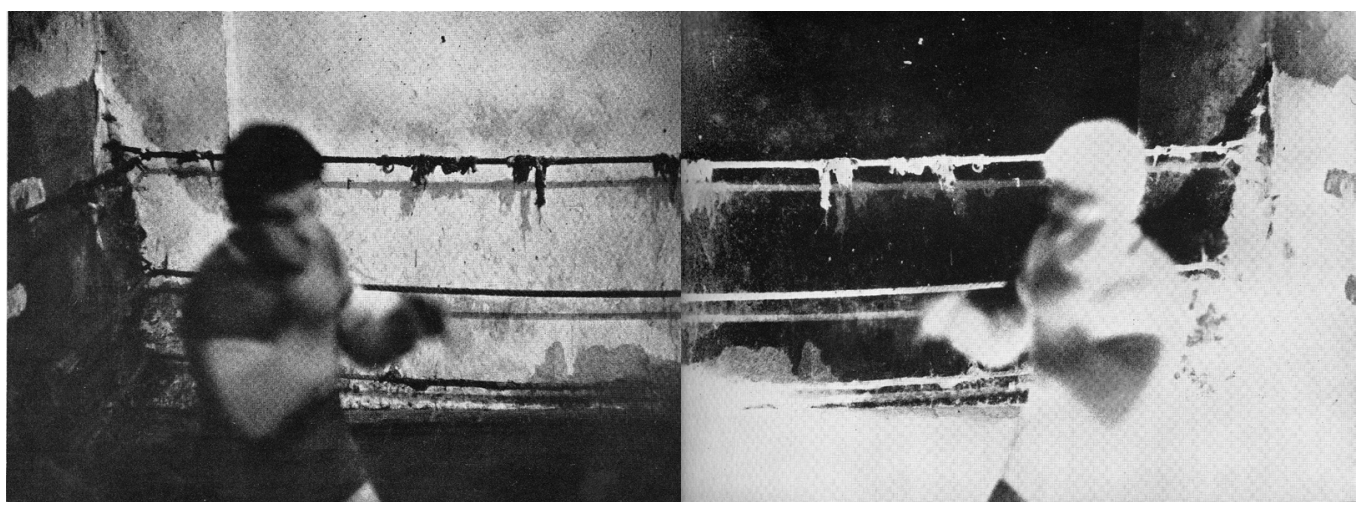

Boxeador haciendo sombra, enfrentado a su negativo.

esta exposición ${ }^{115}$, había en un ochenta por ciento unanimidad sobre lo que teníamos que exponer, en el otro veinte por ciento no. A lo mejor yo iba más a la cosa personal y estética, y él se iba hacia el documento como historiador. Eso está muy claro en dos fotografías del panel de Neutral Corner, que no sé sí recordarás: en una hay un boxeador que está con la toalla entre dos radiadores, y luego hay otro que está haciendo flexiones. Plásticamente me interesa más la foto de las flexiones y a Publio le interesaba más la otra porque te informaba que en el gimnasio hacía frío. En cambio la mía no informa de nada: sólo pone de relieve que hay un señor haciendo flexiones".

En cualquier caso, Neutral Corner constituye un perfecto ejemplo de trabajo en equipo, donde todas las partes involucradas disfrutaron de una excepcional libertad creativa: sin condicionamientos previos, sin más imposición que el propio tema y sin más restricción que el formato mismo de la colección. Masats abordó el boxeo con total independencia, bajo una perspectiva absolutamente personal. Realizó fotos técnicamente muy arriesgadas y vanguardistas (desenfocadas, movidas, demasiado oscuras...) que hubieran escandalizado a un editor más conservador. Aldecoa leyó libremente esas imágenes y amplió sus posibles interpretaciones. Por su parte Lluís Clotet y Óscar Tusquets dispusieron del permiso de los dos autores para jugar con todo ese material a su antojo. Ellos materializaron muchas ideas novedosas, como reproducir una imagen en una página -con un boxeador en el cuadrilátero- y el negativo de esa misma imagen, del mismo tamaño, en la página contraria. En el texto aparece un fragmento que habla de un boxeador que entrena haciendo sombra... y por eso aparece una foto enfrentada a su sombra, su negativo. Éste quizá sea el único ejemplo en el que hay una relación directa entre la foto de mayor tamaño y el texto. Para ser sinceros, la primera vez que nos enfrentamos a esa fotografía nos dio la sensación de que el negativo del boxeador era la imagen que queda en el ojo después de recibir un golpe. Al igual que cuando miramos una luz potente por uno minutos, apartamos la mirada y vemos su negativo en el fondo del ojo... También Clotet y Tusquets articularon la serie del cruce de golpes del combate, dándole ese formato alargado. Al principio pensamos que habían cortado las fotografías para conseguir ese efecto de batería rápida de golpes, pero Lluís Clotet nos explicó que consiguieron esa sucesión tan dinámica no cortando la imagen, sino añadiendo negro a su parte inferior.

115 Se refiere a la exposición retrospectiva Ramón Masats. Fotografías que tuvo lugar en el Círculo de Bellas Artes de Madrid del 16 de Junio al 18 de Julio de 1999, dentro del Festival Internacional de Fotografía PHotoEspaña 99 y del que fue comisario Publio López Mondéjar. 


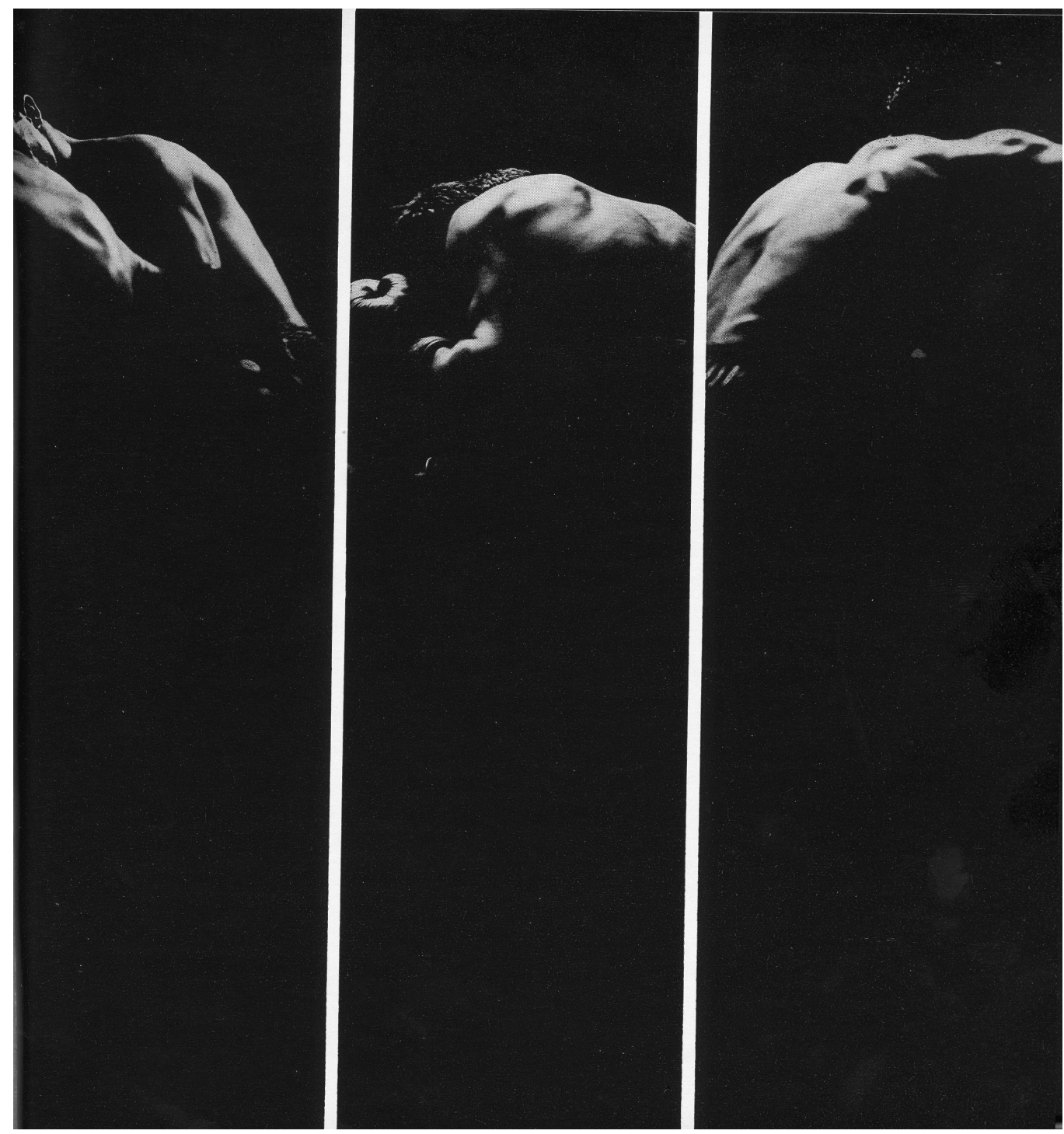

Cruce de golpes del combate donde el dinamismo se logra gracias al formato alargado. Estas proporciones se consiguen no cortando las imágenes si no añadiendo negro en la parte inferior.

-En Neutral Corner la serie del combate, me parece fantástica.

(R. Masats, Madrid, 15 de diciembre de 2003) -“"Esta puesta en página de Neutral Corner es de Óscar Tusquets. ¡Hombre sí, yo positivé esto con la idea de que fuera así! Pero ellos la captaron y la cogieron".

$-¿$ Es el mismo concepto las fotos movidas que las series? ¿Es el mismo concepto con dos soluciones formales diferentes?

(R. Masats, Madrid, 15 de diciembre de 2003) -“Yo creo que cinematográfica es la secuencia. Las fotos movidas no tienen nada que ver. Es una forma de expresar movimiento con una foto quieta... pero no tienen nada que ver con el cine. En cambio la secuencia sí tiene algo que ver con el cine". 


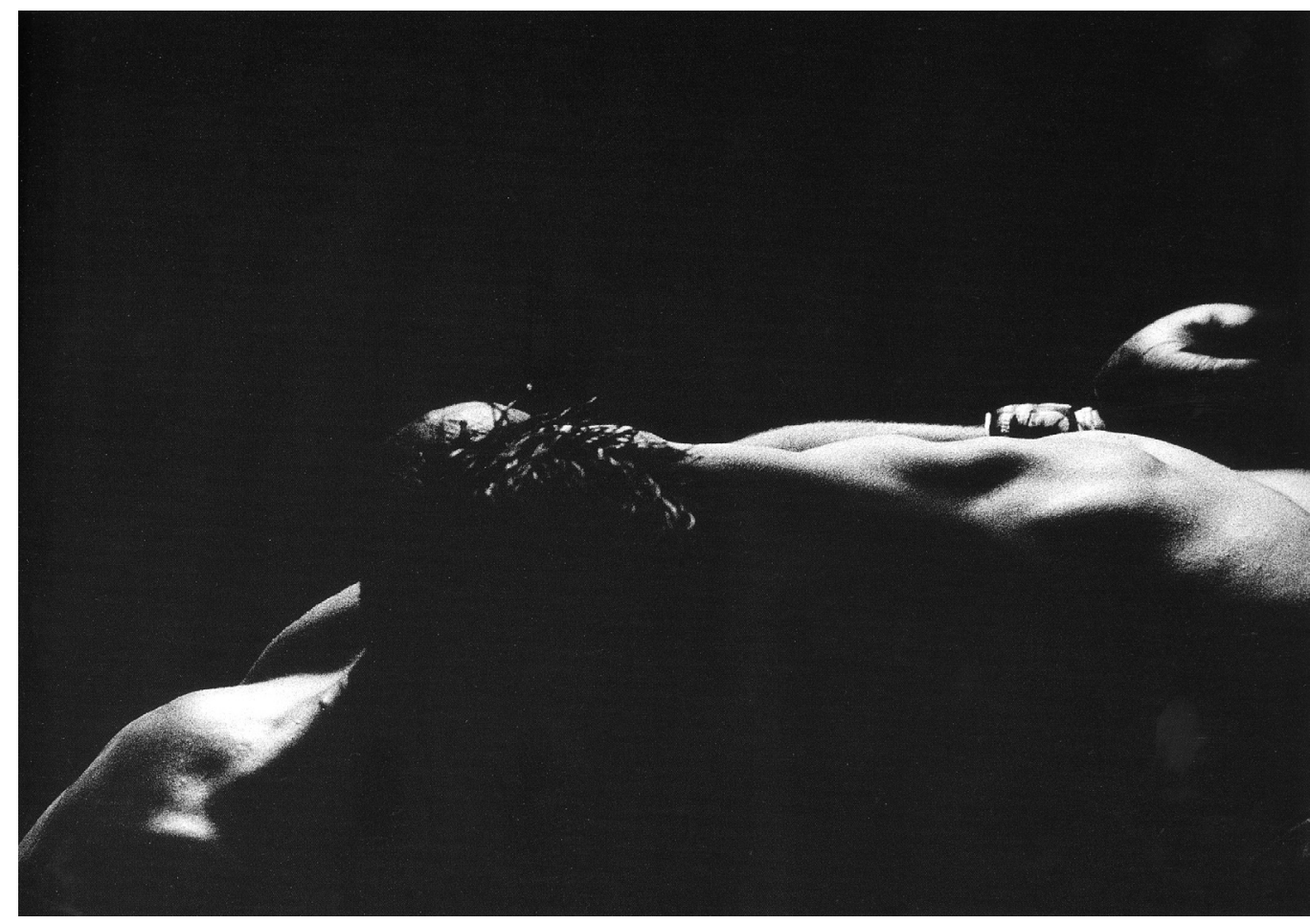

Ramón Masats, imagen extraída de Neutral Corner. Este climax del combate fue publicado a doble página.

-Las fotografías movidas tienen el concepto del tiempo, del movimiento, de la imagen en movimiento, de la acción...

(R. Masats, Madrid, 15 de diciembre de 2003) -“Pero el movimiento puede ser completamente fotográfico, en cambio la secuencia ya es un montaje. Las fotos movidas no las veo como un pre-cine. Las fotos movidas son sólo un efecto plástico, en cambio las series están más relacionadas con el cine. Son "secuencias cinematográficas»".

El clímax de esa secuencia, absolutamente fílmica, se resuelve en la página siguiente, con la soberbia doble página de la silueta del choque de puños. Masats sintetiza el combate a su mínima expresión: negro, dureza, golpe, dolor. A su vez, se jugó con el blanco de los márgenes de la foto. A veces algunas fotos quedaban mejor a sangre -con la foto hasta el borde-, otras con borde blanco, o con el borde negro, dependía... Otras veces recortaban el encuadre de la fotografía para hacerla más dramática. Clotet nos comenta que hay muchas fotos muy interesantes, pero recuerda especialmente una en que aparece el boxeador sentado en su rincón escupiendo agua en un embudo que va a un cubo unido por una manguera. Todo muy aparatoso y dramático. Son hombres fuertes pero que con los guantes se vuelven inútiles, ya que se lo tienen que hacer todo.

Además del material que aparece reproducido en el libro, Masats les dio más originales que finalmente no se llegaron a utilizar. A pesar de ello, Clotet insiste en que respetaban mucho la opinión de los autores y que, como la maquetación era tan especial, se fueron a Madrid a ver a Masats y a Aldecoa para que dieran su beneplácito a la maqueta del libro. 


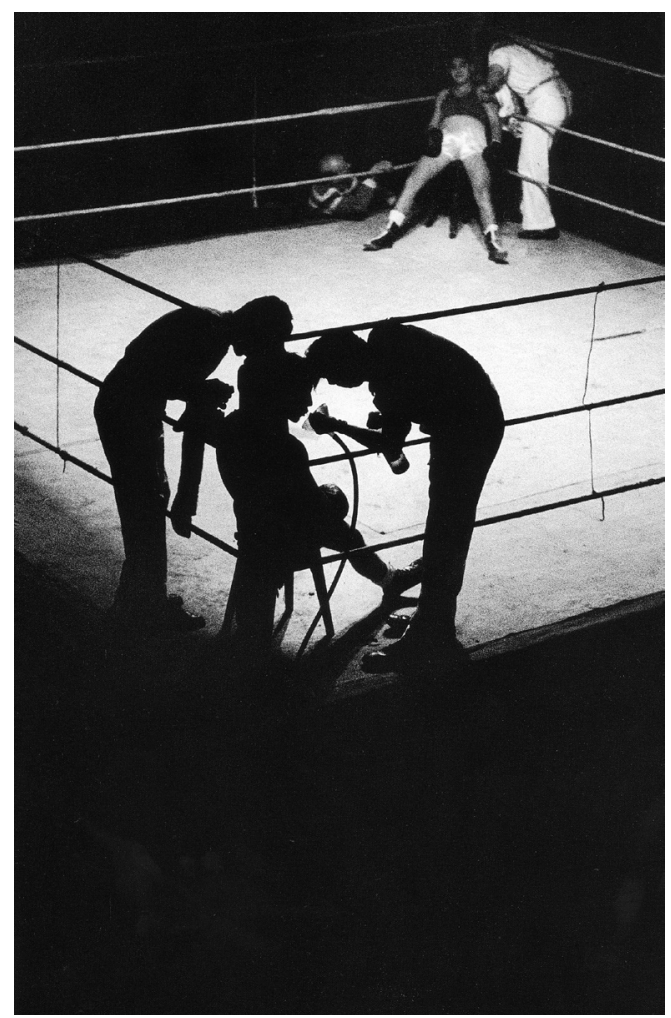

Una de las imágenes que fue aclarada en la imprenta y que Maspons obligó a repetir.

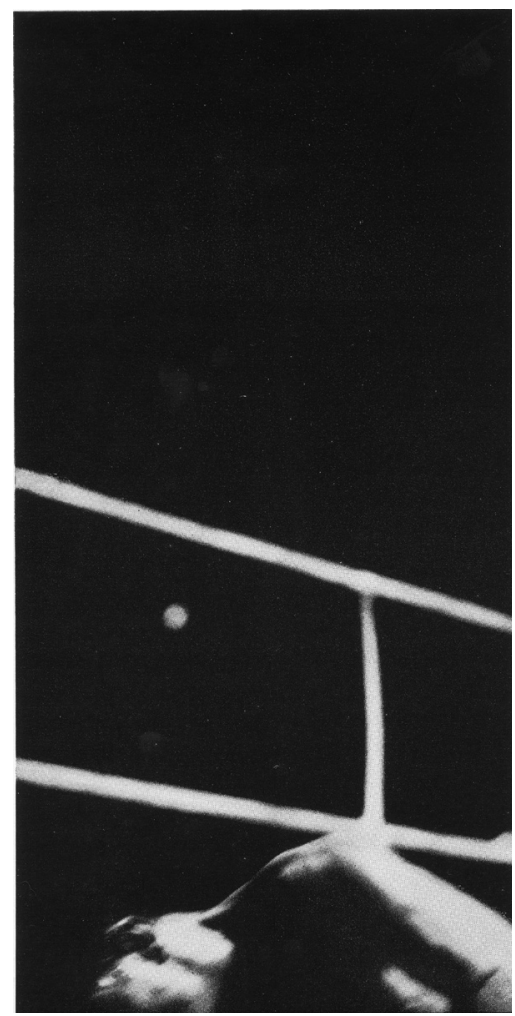

KO final, formato alargado por el negro añadido en la parte superior para acentuar el efecto de caída.

“A pesar del gran respeto que profesábamos por las fotos de Masats, nos atrevimos a proponerle cosas ciertamente arriesgadas: recortar en un círculo la foto de la cubierta, dedicar una doble página a una foto pequeña, repetir fotos en un formato mucho menor, doblarlas simétricamente en negativo y, en un alarde de temeridad agrandar el fondo negro superior de la foto del definitivo y dramático KO para aumentar así el efecto de caída (...) ¿No hablaba éste de boxeadores que peleaban con su sombra? Pues nosotros enfrentábamos al boxeador con su simetría en negativo, peleando con su sombra (...) En aquella época, que a menudo añoro, siempre teníamos nuestras razones, lo malo era que casi nunca conseguíamos que nuestros clientes las compartiesen. Pero Ramón sí las compartió, y juntos hicimos una de esas obras de juventud que te pasas el resto de la vida pensando que no podrás superar ${ }^{\prime \prime 116}$.

Oriol Maspons nos regala una anécdota (en su incomparable estilo) sobre el tiraje de las planchas de las fotos del libro, que nos parece muy significativa para comprender la especial estética que Masats confiere a sus imágenes sobre el boxeo.

(0. Maspons, Barcelona, 20 de octubre de 1999) -“Óscar Tusquets me dijo, «vete a ver si te gustan las pruebas que nos ha hecho S.A.D.A.G». ¡Aquellos imbéciles...! Ramón Masats les entregó las copias y ellos al llegar las fotos, como las vieron muy negras y creyendo que éramos unos chapuceros que no respetábamos la realidad, las metieron en aceite -en platos de acei- 
te- para que quedaran más grises y que tuvieran valores en las sombras. Y se veía más gente en las sombras de las copias... Y a mí no me avisaron hasta después de hecho. ¡Qué desgracia! Cuando vi todo aquello gris, que a este tío se le veía la cara... Masats las quería muy duras. Yo dije, «Yo represento los intereses del fotógrafo y todo esto no sirve». Y ellos decían, «Podemos retocar, refinar». - ¡No, no, ni refinar, ni no refinar! Con todo esto, con todos estos grabados, no se tirará el libro adelante. «iEscuche señor, que nosotros tiramos muy bien y que en esta casa...!». Hubo que volver ha pedirle originales a Masats porque habían aclarado las copias. Era un truco que hacían los grabadores para no tener que tirar duro, porque les molesta. Como la plancha se queda con mucha pintura y aquello lo tienen que poner a secar aparte, no pueden tirar como a ellos les interesa y les gusta. A ellos les interesa que todo quede gris para que no haya cargos de tinta y todo eso... Se repitió, pero el grabador y su ayudante me querían pegar. ¡Me amenazaron!".

En efecto, no se trataba de una cuestión de refinamiento ni de sutileza. Las fotos debían ser aplastantemente oscuras, dramáticas y severas. La legendaria ironía y sentido del humor de Masats desaparece por completo en todo el libro. Los desconchones de la pared y las manchas de humedad -tan fotogénicos pero, a la vez, tan significativos- reflejan una intención crítica; igual que las fotos ya comentadas de los radiadores o del boxeador-escritor. Todas ellas traslucen un contexto social que deriva entre la humildad y la franca pobreza, aunque Masats destila la mayor humanidad y dignidad por las personas retratadas, conmovido por su difícil modo de ganarse el respeto y el sustento.

El combate es el hecho que da sentido a las vidas de los púgiles y al libro mismo. La foto movida de sombras contrapicadas se centra en sus miedos y fantasmas... Masats se propone inducir ese horror en el lector, subirlo al cuadrilátero para que comprenda la tragedia de los boxeadores en toda su extensión. No es sólo pobreza. La lucha da un sentido casi heroico a toda la liturgia del boxeo, pero para ello debe de ser dura, implacable. La crítica deja paso a la energía y al dramatismo. Es una cuestión de restar luz, elementos y valores en las sombras para llegar a la máxima condensación de fuerza. El negro da potencia a la pegada.

(R. Masats, Madrid, 17 de julio de 1999) - “El tema era así, el boxeo era así. Yo sólo reflejaba una realidad. El intuitivo lo que hace es reflejar esta realidad y si esta realidad no le gusta, pues con muchísima más razón. Además, sí estaba un poco influenciado por lo que hablaba con Ignacio Aldecoa, que era una persona muy crítica con el boxeo y a la vez muy cercana al mismo y que le interesaba muchísimo. Algo que es similar a la postura que tengo yo con los toros. Soy crítico desde fuera pero me gustan los toros. Con el boxeo me pasa lo mismo, a pesar de que me parece peor el boxeo que los toros".

- ¿Tú eres consciente de la densidad y la oscuridad de tus positivos?

(R. Masats, Madrid, 15 de diciembre de 2003) -"Claro que soy consciente".

-Gabriel Cualladó también tiene un tono muy oscuro.

(R. Masats, Madrid, 15 de diciembre de 2003) -“Sí, él tiene estos tonos oscuros pero no tan contrastados como yo. Es oscuro, pero no contrastado. Cualladó también se lo ampliaba él, aunque para alguna exposición se lo hacía Juanma Castropietro. A mí también me las amplía para las exposiciones. Aunque las hace como le digo yo... Yo le explico dónde he hecho una reserva o dónde un tapado...".

-Este señor hace las ampliaciones en blanco y negro de casi todas las exposiciones...

(R. Masats, Madrid, 15 de diciembre de 2003) -“Es que es muy bueno, y como fotógrafo también es muy bueno".

-Yo, sin embargo -y por comparación contigo- veo un poco melodramático el tono de Gabriel Cualladó... ¿ ¿Tú qué pretendes conseguir con un tono tan oscuro? 
(R. Masats, Madrid, 15 de diciembre de 2003) -“Yo creo que es impacto. Mis fotos son muy de verlo casi todo en la primera visión, y el contraste que le doy a mis fotos ayuda a ello. Pero este estilo lo tengo ya desde mis primeras fotos. Tal vez menos en Los Sanfermines, pero los demás trabajos ya iban más por este lado".

-Y siempre has intentado dar el mismo tono a todas las colecciones...

(R. Masats, Madrid, 15 de diciembre de 2003) -“Sí, porque normalmente siempre he utilizado la Leica, Tri-X, tirado a ochocientos ASA y revelado diez minutos, a veinte grados, con D-76. Quiero decir que hace muchísimos años que uso...".

- ¿Siempre la misma película?

(R. Masats, Madrid, 15 de diciembre de 2003) -“Sí, siempre la misma película. Lo he intentado con el T-max y no me funciona. No he cambiado en blanco y negro... Me ha llegado a suceder que, haciendo paisajes, tenía tanta luz que trabajaba a 1/1000 y $n^{0} \mathrm{f} 22$, entonces ponía algún filtro para oscurecer un poco la imagen y así no tener que cambiar la sensibilidad de la película. En color sí. En color empecé utilizando el Kodacrome y luego me he pasado al Velvia de cincuenta ASA. Me gustan los colores fuertes, violentos".

-Un poco como el blanco y negro... su equivalente.

(R. Masats, Madrid, 15 de diciembre de 2003) -“Sí, es un poco lo mismo".

-Entonces hay una manipulación del contraste en cuanto a la realidad. Es decir, que la realidad está menos contrastada.

(R. Masats, Madrid, 15 de diciembre de 2003) -“Si".

-Tú inventas una creación fotográfica.

(R. Masats, Madrid, 15 de diciembre de 2003) -“Sí, por ejemplo en el color utilizo mucho el polarizador para saturar más el cielo y los colores".

(Koldo Chamorro, Pamplona, 21 de marzo de 2003) -"Por poner una especie de referencia caligráfica (no de lenguajes): la fotografía ha tenido esa referencia con el grabado. Yo creo que en cierto modo, es bastante coherente porque con el grabado tú puedes hacer una edición de muchos ejemplares y también porque el soporte es en papel y tiene el mismo tipo de problemas de conservación, manipulación... En el grabado hay un tipo de problema que es el negro. El negro mal impreso se convierte en lo que se llama negro ala de mosca, que no es un negro cerrado. Y al fotógrafo, desde el punto de vista de la conclusión de sus imágenes, le ha preocupado siempre el negro. 0 le preocupaba antes, ahora las copias que veo generalmente son negro ala de mosca, que es muy denteroso. Pero en esa época les preocupaba mucho el negro. Le preocupaba mucho a Robert Frank, a William Klein y le ha preocupado bastante a CartierBresson. De hecho, yo creo que la explicación de que Cartier-Bresson haya pasado al dibujo, es porque en el dibujo, por lo menos, él controla el negro. En la copia fotográfica... como no las hace él... Y al final, por muy bien que lo hagas, no lo consigues redondear. El negro con cuerpo es difícil de conseguir. $Y$ buena prueba de lo que digo es que la aparición del margen negro en las copias de Cartier-Bresson es tanto para señalar que él no hace ninguna manipulación, que no corta. Una especie de señalamiento ético como para reforzar el negro en las imágenes. Éste ha sido un problema que siempre han tenido los fotógrafos... Y de hecho puedes entender rápidamente si alguien es un buen fotógrafo simplemente por cómo trabaja el negro. Tanto en la cabeza -a la hora de construir la imagen- como en el negativo al pasarlo a papel. Por ejemplo, y por poner un caso... imágenes sorprendentes, en términos generales sólidas, pero que se quedan un poco espumosas, son las Newton. Siempre están rozando el negro pero no terminan de entrar en el negro".

Después de todo lo apuntado hasta el momento, sólo cabría preguntarnos cuál fue el recibimiento o la importancia real del libro en la historia de la literatura, o de la fotografía, o de esta breve historia mixta... 


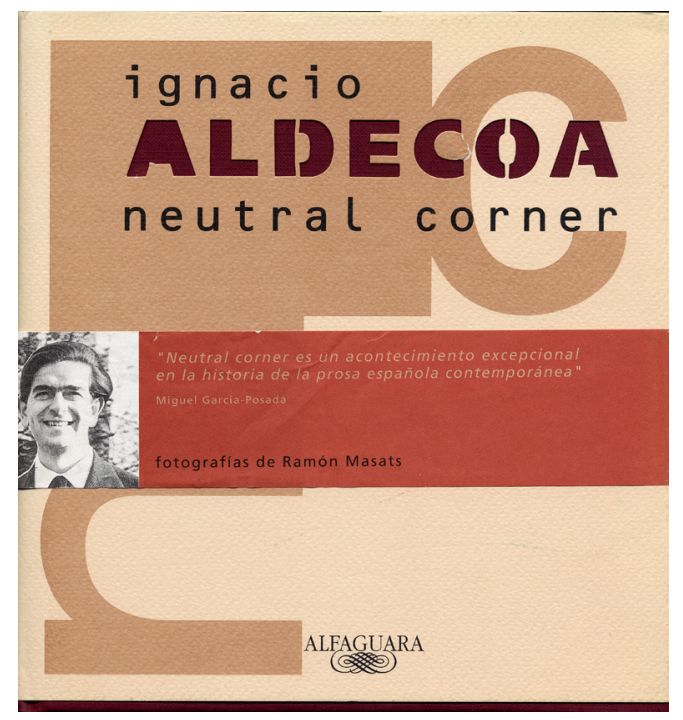

Portada de la segunda edición de Neutral Corner, 1996.

\begin{abstract}
“(...) ni en vida del autor ni después de su muerte esta obra maestra que es Neutral corner ha recibido la atención debida, (...) Se diría que su rareza material (texto acompañado de foto) y, sobre todo, su difícil clasificación han hecho de ella un título incómodo de manejar. La obra desconcertó o produjo sólo tibias reacciones cuando apareció y en la no escasa literatura crítica suscitada por la escritura aldecoana ocupa un lugar secundario. De hecho no se ha reeditado en 34 años; la edición que hoy se publica es la primera desde $1962^{\prime \prime 117}$.
\end{abstract}

En efecto, en 1996 se produce una segunda edición de Neutral Corner. Es curioso que ésta contara con el mismo material, las mismas fotos, los mismos textos y hasta el mismo tamaño y formato. Sin embargo, los resultados serán totalmente dispares, lo que pone en evidencia la espectacular labor de Óscar Tusquets y Lluís Clotet, en detrimento de la realizada por Juan Pablo Rada, responsable de esta segunda edición. Todos los aciertos del primer libro se desvanecen en el segundo. Desde cuestiones meramente formales a otras más profundas, ideológicamente discutibles: desaparecen los dos tipos de papel (y por tanto la voluntad utilitaria), las letras negras, el punto en la tapa, la imagen en negativo, las fotos menudas repetidas en los títulos, la sobriedad y la contención del blanco y negro. Por el contrario, en este segunda ocasión las letras se imprimen en azul, mientras que el color de las hojas discurre entre el marfil y un ñoño crema pastel a juego con unas guardas de color teja, lo que hace que todo el conjunto tenga un carácter cálido y amable. Asimismo desaparece el nombre de Masats en la cubierta, excepto por una pequeña tira de papel que recorre las tapas. Queda, por ello, trastocada la paridad entre fotografía y literatura...

-La segunda edición de Neutral Corner...

(R. Masats, Madrid, 17 de julio de 1999) -“¡iLa segunda edición de Neutral Corner es una mierda! Es que ni siquiera lo considero... Cuando me has hablado de una segunda edición del Neutral Corner... Me parece que fue una estupidez por parte de la editorial que quisieron hacer una cosa muy moderna y fue una tontería. La editorial Alfaguara quería editar los textos de Ignacio Aldecoa -que por cierto son fantásticos- y entonces se encontraron con que faltaban las fotos; y ese planteamiento ya de principio era así: las fotos eran como un pequeño apoyo a los textos de Aldecoa. 


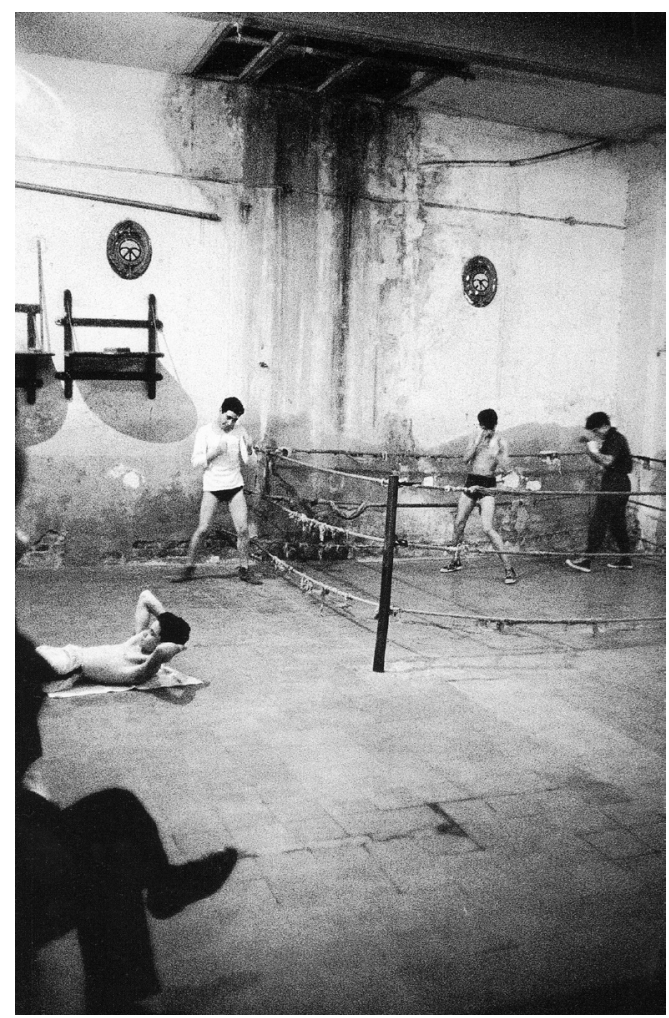

Mancha de humedad de las paredes del gimnasio. Fotografía eliminada en la segunda edición.

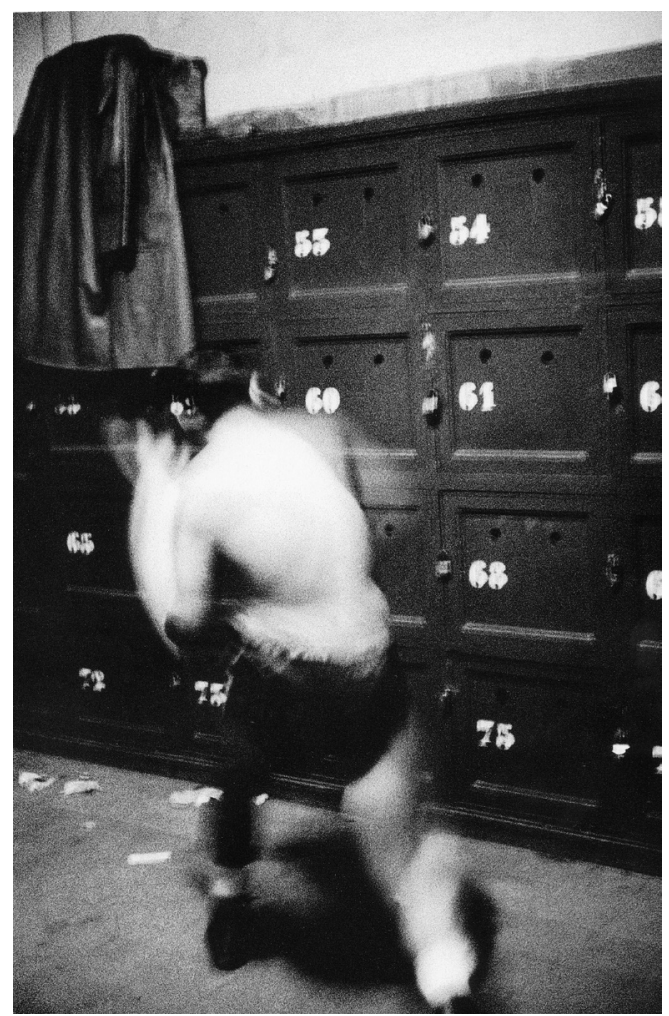

Esta imagen, no publicada en la primera edición, fue recuperada en la segunda.

Entonces me llamó Josefina Aldecoa y me lo propuso y dije, «Hombre por supuesto, siendo para una pequeña ilustración de los textos de Ignacio lo que quieras». Pero luego lo han hecho de una forma tan mal que para mí no... Yo nunca jamás pensé que fuera una reedición de Neutral Corner fotográfica, pero que sí que tuvieran un poco de respeto con las pocas fotos que publicaban".

-Pero es que, además, en el libro ponía que habían eliminado algunas fotos porque las consideraban un anacronismo y yo me quedé perplejo.

(R. Masats, Madrid, 17 de julio de 1999) -“¿Pero eso donde lo has leído?”

-En el propio libro, hay una presentación...

“Hemos renunciado a la reproducción tal cual de todo el libro -texto y fotos- por entender que hubiera sido un anacronismo sin demasiada justificación. Aldecoa concibió su obra al margen de las fotografías. De hecho, él mismo orientó a Ramón Masats en cuanto al alcance de las ilustraciones, por lo demás excelentes, y le enseñó algunos escenarios propicios. Editores Alfaguara, de acuerdo con Masats, con Josefina Aldecoa, viuda del escritor, y con el preparador de la presente edición, ha seleccionado y tratado con los actuales criterios de diseño y composición algunas de las fotografías que ilustraron la edición de 1962. Hemos desechado las fotografías que tenían mayor carga de época"118.

118 Ediciones Alfaguara, "Nota al texto", en Aldecoa, Ignacio y Masats, Ramón, Neutral Corner, Madrid, Alfaguara, 1996, sin paginar. 


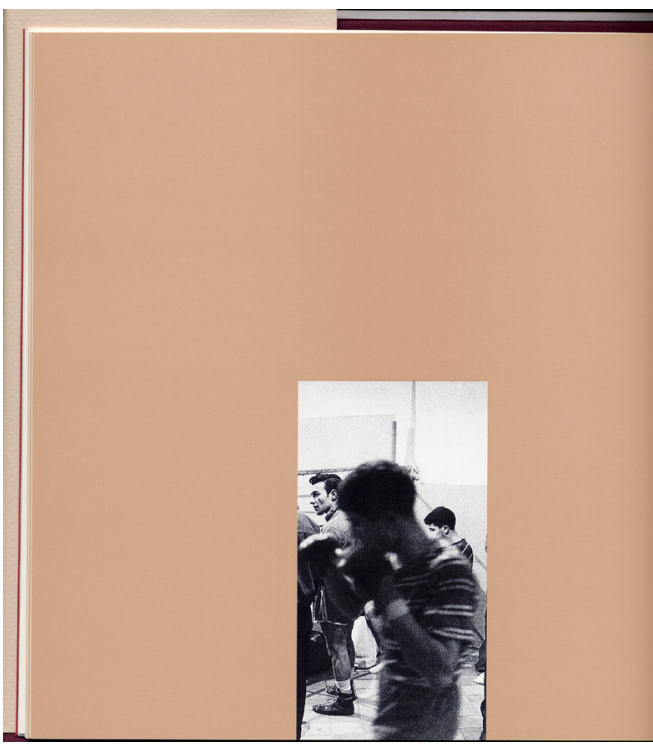

Imagen cortada en la segunda edición.

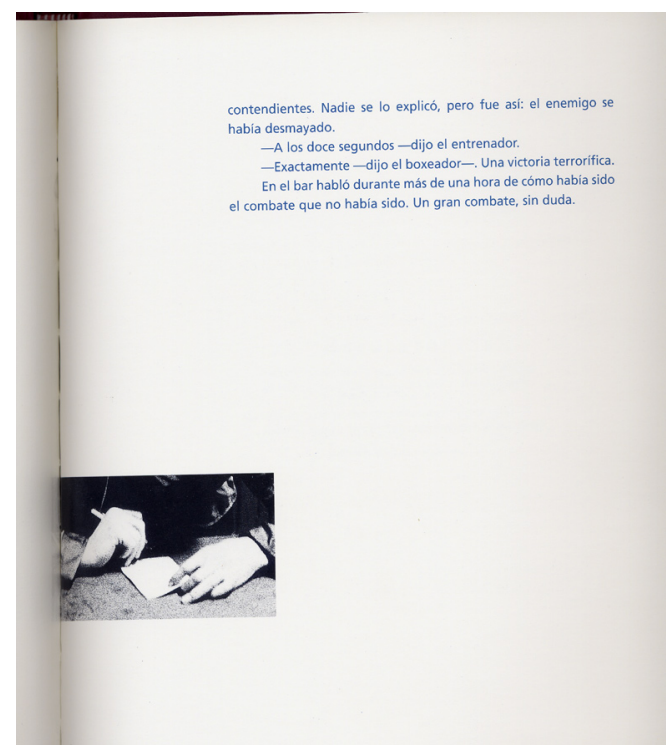

Corte de la imagen del boxeador escribiendo.

Evidentemente una maliciosa curiosidad nos lleva a buscar cuál ha sido el criterio de modernidad. ¿Qué "ilustraciones" (ya el término nos indica cuál es la consideración subsidiaria de las fotos) "por lo demás excelentes", no han pasado esta criba por presentar una "mayor carga de época"? Como ejemplo tenemos la imagen del plano general del gimnasio con la enorme mancha de humedad de la pared, posiblemente la fotografía más crítica desde una perspectiva social. Curiosamente han desaparecido casi todas las paredes con manchas de humedad que aparecían en la primera edición, ya que, o bien se ha suprimido completamente la fotografía, como en este caso, o la imagen se ha reencuadrado para eliminar cualquier señal de penuria. También ha desaparecido la foto del punto de luz sobre el cuadrilátero y su negativo, aunque tengamos que agradecer que se haya recuperado la foto del boxeador golpeando al aire delante de las taquillas, foto que no aparece en el libro original. Cabe destacar que varias fotos se repiten sin ningún criterio: la del péndulo, la del "neutral corner" o las del cruce de golpes. El orden de las fotos es completamente aleatorio, sin un orden cronológico, sin ningún discurso narrativo propio, intercalando los entrenamientos con el combate, y éste con la vuelta al ambiente del gimnasio y los entrenamientos. Las imágenes, por tanto, se limitan a "ilustrar" los textos de una manera directa y simplona.

A pesar de todo ello hay dos defectos especialmente graves en esta edición: la compulsiva e incontrolada obsesión por cortar los precisos y ajustados encuadres de Masats (quizá el corte más grave sea la casi desaparición de la foto del boxeador-escritor, ya que sólo se ve la hoja de papel y las manos, y no se sabe quién escribe ni porqué) y, sobre todo, la falta de negro. Todas las fotos está reproducidas con ese "denteroso gris ala de mosca" que tanto irritara a Oriol Maspons y preocupara a Koldo Chamorro.

(R. Masats, Madrid, 17 de julio de 1999) -“Es que yo me cabreé tanto que creo que ni siquiera me lo he leído. Lo único que podían decir eran estupideces y tú me lo confirmas. Es un libro que me ha dado tanta vergüenza que ni siquiera se lo he regalado a mis hijos y a mis amigos. Josefina Aldecoa no tiene ninguna culpa. Es la editorial, los maquetistas, los 

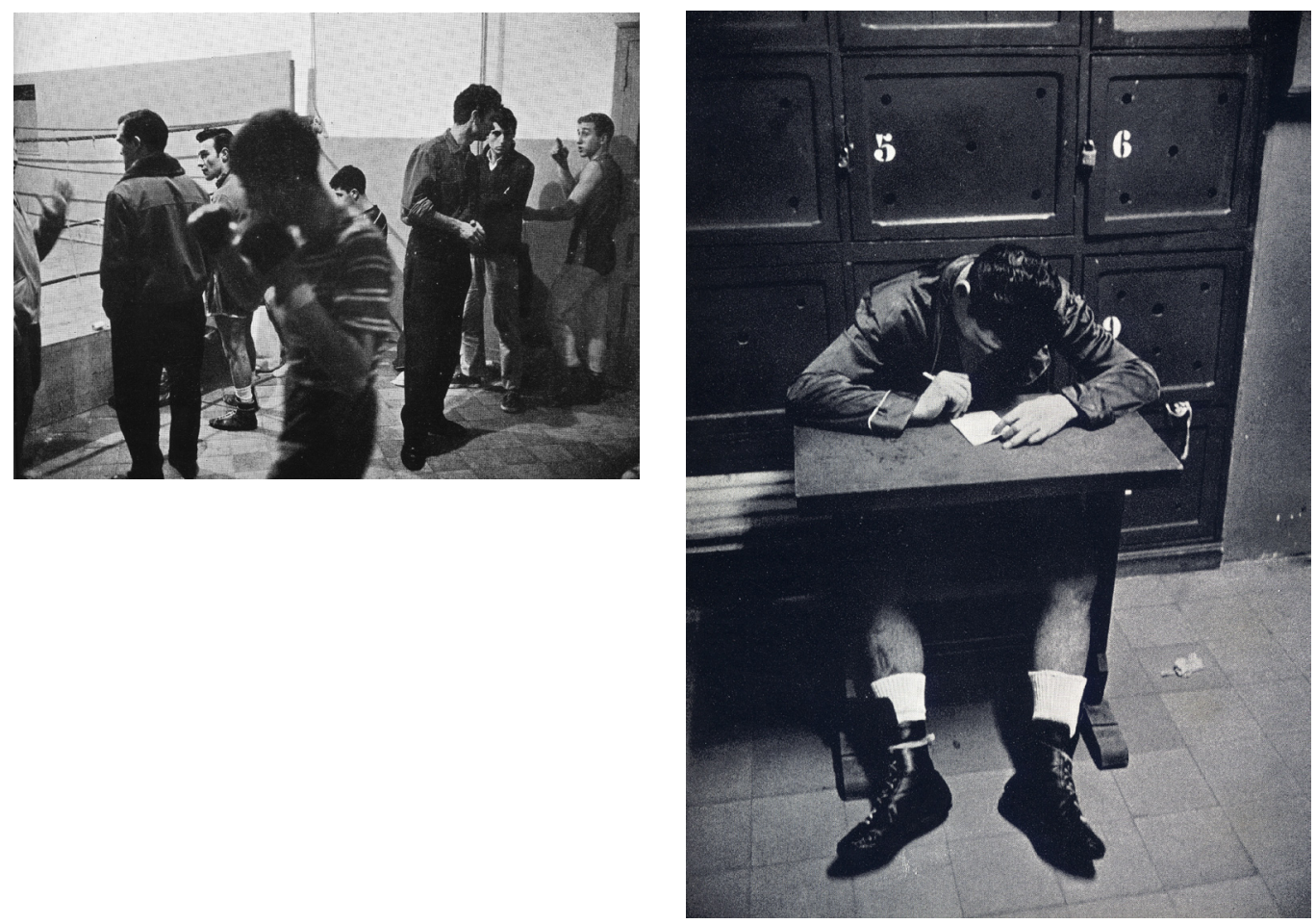

Imagenes a formato completo, tal y como aparecen en la primera edición de Neutral Corner.

genios... Hubo uno que me dijo una vez: «Ramón haces las fotos tan bien encuadradas que no me dejas por donde cortar». Yo amplío todo el negativo, no corto casi nunca".

\subsubsection{Viejas historias de Castilla la Vieja (1964)}

Tras la experiencia de Neutral Corner, Ramón Masats publicó un segundo (y último libro en la editorial Lumen) en 1964: Viejas historias de Castilla la Vieja, con textos de Miguel Delibes (Valladolid, 1920).

(Esther Tusquets, Barcelona, 31 de octubre de 2004) -“Después vino Miguel Delibes que había publicado un libro con grabados en una edición de bibliófilo, y le hacía mucha ilusión publicar este texto en una edición con fotografías. No sé quien pensó en Masats, si Delibes o nosotros. Le encargamos Viejas historias de Castilla la Vieja. Delibes quedó muy contento".

El texto de Miguel Delibes se había publicado anteriormente, en 1960, bajo el título de Castilla $^{119}$. Era una edición de 150 ejemplares ilustrados con grabados al buril de Jaume Pla.

\footnotetext{
“Delibes nos propuso unos textos sobre Castilla, que se habían publicado en edición de bibliófilo, hermosa pero de tirada limitada, acompañados de diecisiete grabados de Jaume Pla.

Escribe en marzo del 62: «Ya sabes, es el mamotreto de los grabados que te enseñé. Julián Marías, Laín Entralgo y varias personas más creen que es lo mejor que he escrito. Esto aparte -aparte también de mi debilidad por estas narraciones- me parece de interés inmortalizar en un bello libro la Castilla de hoy, una Castilla que se nos va un poco cada día. Por una u otra razón, me temo -yo no debería
} 


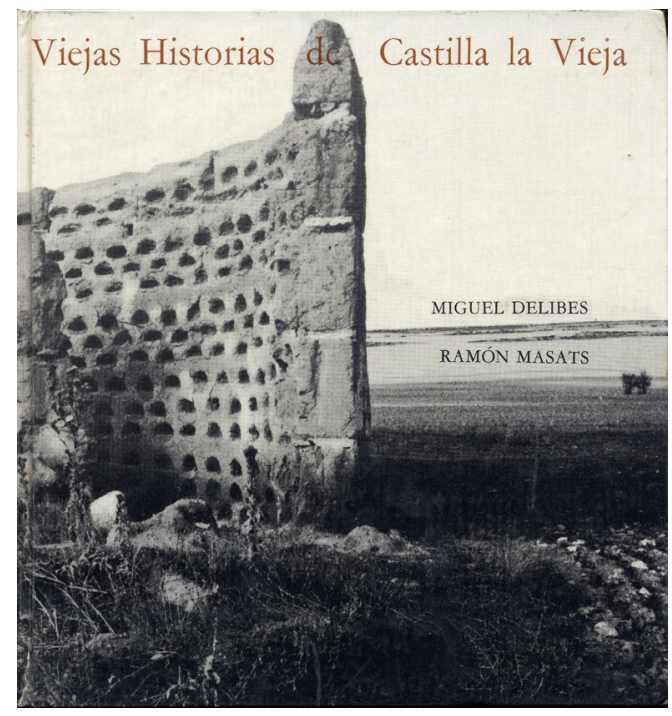

Portada de Viejas historias de Castilla la Vieja.

decir esta monstruosidad, pero decir lo contrario seria insincero- que la Castilla de la siembra al voleo, el arado romano, los gañanes con traje de pana, la trilla con yuntas, los carros hundidos hasta los cubos, etc., durará ya pocos años. Es tremendo, pero cada vez que en la soledad de los páramos oigo trepidar el motor de un tractor se me hiela la sangre. Esto -dicen y hay que creerlo- es el progreso. Y uno debe esforzarse por que estas pobres gentes sean redimidas. Pero ni con toda esta buena intención por delante puedo evitar la melancolía cuando imagino los tesos - pelados hoy- cubiertos de bosques y las hazas borradas por los tractores. ¡Ah, Dios, las máquinas!»"120.

Desde luego hay una cierta relación entre los dos autores con los que Masats colabora en los libros de Lumen. Aldecoa y Delibes comparten las mismas preocupaciones sociales, los mismos compromisos morales con los más débiles; la misma visión humana y comprensiva sobre los problemas de unos antihéroes primarios y bruscos. Delibes, siendo crítico con la pobreza, la marginalidad y un supuesto progreso es, sin embargo, más dulce, menos crudo. Delibes defiende una serie de valores relacionados con el pueblo rural castellano como son la sensación de arraigo y pertenencia a un grupo que se conoce desde siempre, el orgullo de ser de una aldea pequeña, la amistad... Todo ello protagonizado por unos personajes vistos con una profunda simpatía; llenos de una gran humanidad y ternura. Unos personajes que están en simbiosis telúrica con una naturaleza que, aunque alterada y trabajada, no acaba de doblegarse, y esa rebeldía fascina a Delibes. El drama sobreviene cuando la naturaleza se ve marginada, acosada por las máquinas y la modernidad. No debe someterse jamás, ya que todos esos valores, esas personas y esa naturaleza se perderán irremisiblemente unidas por un destino común. Como parece que ese final se precipita inexorable -arrasado por un tractor o por la llegada de la electricidad-, y para evitar que todo el mundo rural se desvanezca para siempre, Delibes se convierte en cronista que "inmortaliza" ese ambiente y ese saber ancestral en sus libros. Aldecoa, sin embargo, nos presenta el entorno de una naturaleza hosca: ausente de cualquier nostalgia, de cualquier amabilidad. Los personajes deben enfrenarse a ella $y$, al sobrevivir, alcanzar su propia dignidad. Esa diferencia en el nivel de aspereza es lo que determina la sintonía entre las fotos y los textos. Masats es implacable, 
rotundo, y esa severidad es más parecida a la percepción de Aldecoa que a la de Delibes. También es cierto que el estilo de Delibes, sencillo y ágil, quizá sea menos directo que el de Aldecoa. Sus textos son más largos, más elaborados, menos sintéticos, y esa falta de condensación también distancia los dos discursos, fotográfico y textual.

(R. Masats, Madrid, 17 de julio de 1999) -"Hice otro libro que se llama Viejas historias de Castilla la Vieja con Miguel Delibes, y aquí primero fue el texto. La editorial Lumen me lo enseñó, y yo me fui a Valladolid a ver a Miguel Delibes y le dije: «Ese texto, circunscríbemelo en un área geográfica», y me dijo: «Mira, es Tierra de Campos». Entonces cogimos el coche nos fuimos a recorrer más o menos la zona y me dijo: «Ésta es el área». Yo ilustré el texto de Delibes. Con Ignacio Aldecoa fue al revés. Quiero decirte que las dos formas yo creo que son válidas. Pero en el caso de Neutral Corner fue al revés".

- ¿Y cuando hiciste las fotos a partir de los textos de Delibes en Viejas historias de Castilla la Vieja, intentaste interpretar literalmente los textos de Delibes?

(R. Masats, Valencia, 25 de marzo de 2004) -“No, literalmente no. En ningún momento pensaba en algún párrafo del libro visualizado. Era el ambiente en donde se desarrollaba lo que él contaba. En ningún momento hay una foto que se pueda decir, eso está en el párrafo tal... No me lo planteé. En cambio, con Aldecoa sí. Los textos los hacía él refiriéndose a la foto".

Efectivamente, la interpretación de Masats sobre Tierra de Campos se centra principalmente en la pobreza, en el estancamiento cultural y social, en la superstición mezclada con una religión omnipresente -poblada de viejas enlutadas-, en el duro y rutinario trabajo en el campo.

(Esther Tusquets, Barcelona, 31 de octubre de 2004) -“Yo he escrito en mis memorias que la imagen de Delibes y la de Ramón no tienen nada que ver. La Castilla de Ramón es muy tétrica, muy negra, son unas fotos muy duras, mientras que el texto de Delibes es nostálgico, de las cosas que echa de menos...".

“El libro, Viejas historias de Castilla la Vieja, es muy hermoso, y espléndidas las fotos. Pero Masats da en ellas, o eso me parece a mí, una imagen negra de la España mesetaria y profunda, que contrasta, creo, con la visión nostálgica y entrañable de los textos, y me sorprende que Delibes, tan receloso con el pobre Maspons, acusado de fotografiar a las perdices fuera de temporada y desde un coche, no pusiera en esta ocasión ningún reparo"121.

Óscar Tusquets considera que las fotos no siguen al texto, que no tienen ninguna relación con el mismo. De hecho, también opina, como su hermana, que había un "desfase" entre la Castilla de Delibes y la de Masats. Delibes más optimista o nostálgico que Masats, mucho más duro y crudo, con mucho talento, dramático y sencillo a la vez. El propio Delibes tiene la amabilidad de confirmarnos su impresión sobre las fotografías de Masats.

- ¿Es cierto que eres un fotógrafo más rural que urbano?

(R. Masats, Madrid, 15 de diciembre de 2003) -“Sí, esto es cierto".

-Sin embargo Las Ramblas es urbano, Los Sanfermines y Neutral Corner también... Quitando Viejas historias de Castilla la Vieja y El Quijote, es todo muy urbano y me parece importante que sea urbano en contraposición con el pictorialismo que es más bien rural. Sabes que hay una tendencia del pictorialismo hacia el campo y su exaltación como un tema bucólico-pastoril y que eso enlaza con la tradición de la Falange que reconoce en el campo el apoyo al levantamiento de la Guerra Civil...

(R. Masats, Madrid, 15 de diciembre de 2003) -“Pero eso depende de cómo lo trates. Yo seré de ciudad o seré de campo, pero bucólico en el campo no he sido nunca".

-Y con lo independiente que eres, ¿qué tal se te da el trabajar en colaboración con escritores? 
Vazladolid, 17 de mayo de 2005

Estimado amigo:

En efecto el trabajo de Masats en "Viejas histo-1

rias" me gustó a pesar de que se apartaba del texto.

Sus dibujos ni se referian a êl ni eran de la tierra.

Con frecuencia eran interiores duros, criticos, refe-

ridos al pasado de Castilla tan oscuro. La libertad

del arte justifica a Masats, siempre que en lugar de

leones no pinte palomas. Su visión de Castilla no rima

ba con la mía pero me gustaba. No hay mäs. En cuanto

a que sea uno de los libros más importantes de nuestra

literatura es opinable.

Un saludo afectuoso

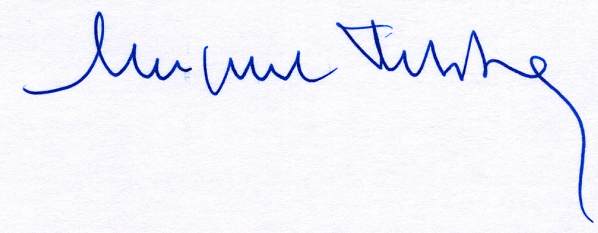

Miguel Delibes, correspondencia con el autor, 17 de mayo de 2005.

(R. Masats, Madrid, 17 de julio de 1999) -“ ${ }$ Ah, muy bien! Porque no se meten en el terreno fotográfico. Hombre, si se lo enseño luego podemos opinar. Quiero decir, que no soy tan rígido para pensar que yo soy Dios y este señor no... Quiero decir que hay fotos que me convencen para quitarlas, aunque haya fotos que no. Pero no soy intransigente, aunque tengo las cosas muy claras no soy intransigente y sobre todo con gente tan inteligente como Delibes o Ignacio Aldecoa. Ser intransigente sería una demostración de mi estupidez y no creo que sea estúpido".

Las fotos del libro que ahora nos ocupa están ordenadas por motivos plásticos. Hemos 

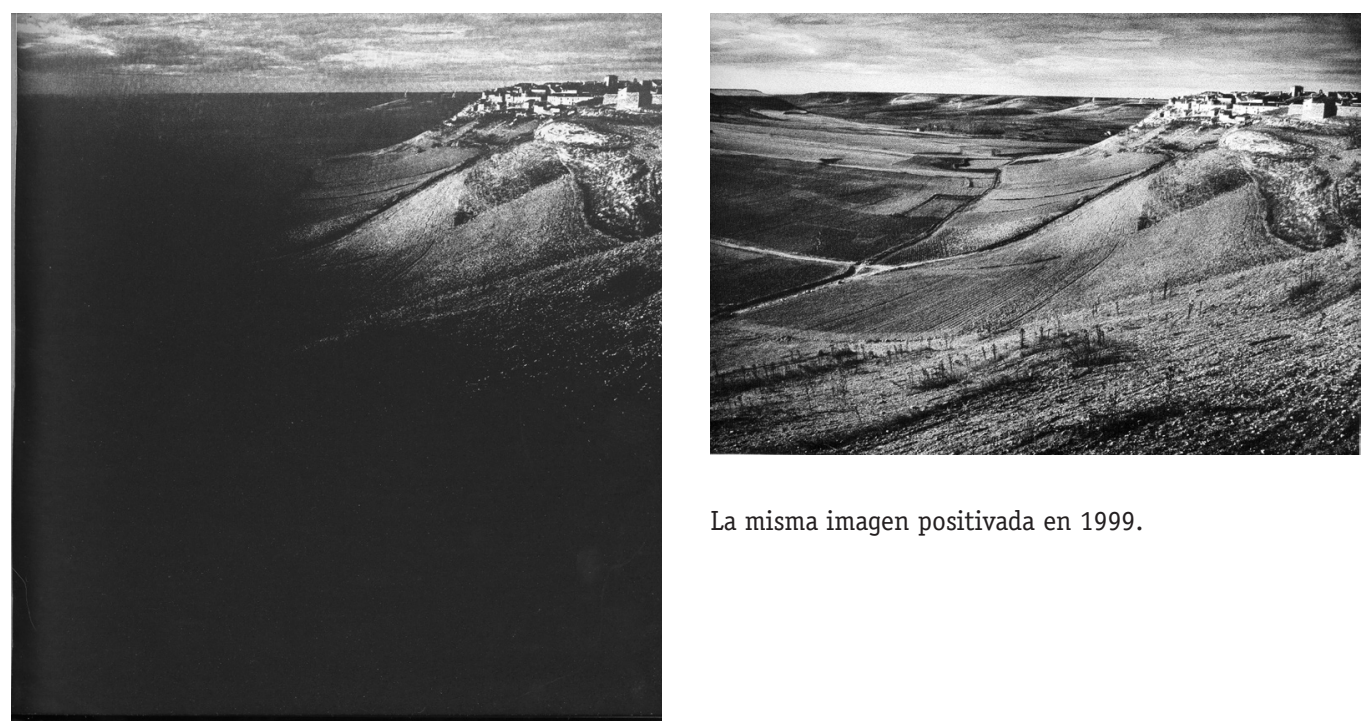

La misma imagen positivada en 1999.

Primera imagen del interior del libro con negro añadido para adecuarlo al formato cuadrado de la colección.

detectado siete conjuntos de imágenes unidas por algunas fotos sueltas que funcionan como bisagra entre un grupo y otro: primero los paisajes exteriores, después los interiores (generales de las estancias), luego los retratos de personas en interiores, un breve grupo de fotografías de temas más amables y menos críticos, se vuelve a los paisajes interiores y se finaliza con varias fotografías del interior de la iglesia.

Hay un total de veintisiete imágenes: las primeras fotografías son una breve serie de paisajes rurales decadentes, donde la presencia del hombre está más intuida que mostrada. La portada reproduce una bella imagen de un palomar medio derruido en medio del paisaje árido de Tierra de Campos. Una vez se abre el libro la primera imagen nos ofrece un paisaje muy sugerente. Esta obra -reproducida a sangre- está tomada desde lo alto de una colina y nos muestra un pequeño pueblo al fondo, rodeado por un oscuro mar de sombras. Parece que la imagen está expuesta con las primeras luces del sol y que los rayos sólo alcanzan la cima de la colina, dejando el valle a oscuras. Sin embargo, años más tarde Masats reproduce esta imagen en su exposición antológica del Círculo de Bellas Artes de Madrid. Allí parece otra fotografía completamente diferente, mucho más luminosa, con las sombras sustituidas por campos de labranza a los pies del pueblo. Comparando los dos formatos, vemos que la imagen está realizada con una cámara de paso universal de $35 \mathrm{~mm}$ y, sin embargo, el formato del libro es casi cuadrado. Una vez más, los diseñadores han repetido -al igual que sucediera con Neutral Corner- el efecto de añadir negro a la fotografía para modificar su formato sin necesidad de cortar la imagen y, para que no se note el añadido, deciden oscurecer toda la imagen excepto el pueblo. Como ya vimos, el negro es un elemento que aporta dramatismo, dureza y fuerza.

La siguiente foto ocupa una doble página, con un plano general partido por la mitad debido a la propia paginación y a la sombra alargada que divide la imagen en dos. En el lado derecho un grupo de viejas casas -con las tejas sueltas- se amontonan en un aparente caos; en el lado izquierdo unos pilares medio derruidos reencuadran, una vez más, el paisaje castellano.

La tercera fotografía que aparece en el libro también es un paisaje, en este caso vertical, donde se intuye un campo oscuro, lleno de rastrojos, en el que al fondo apenas se divisan el perfil 


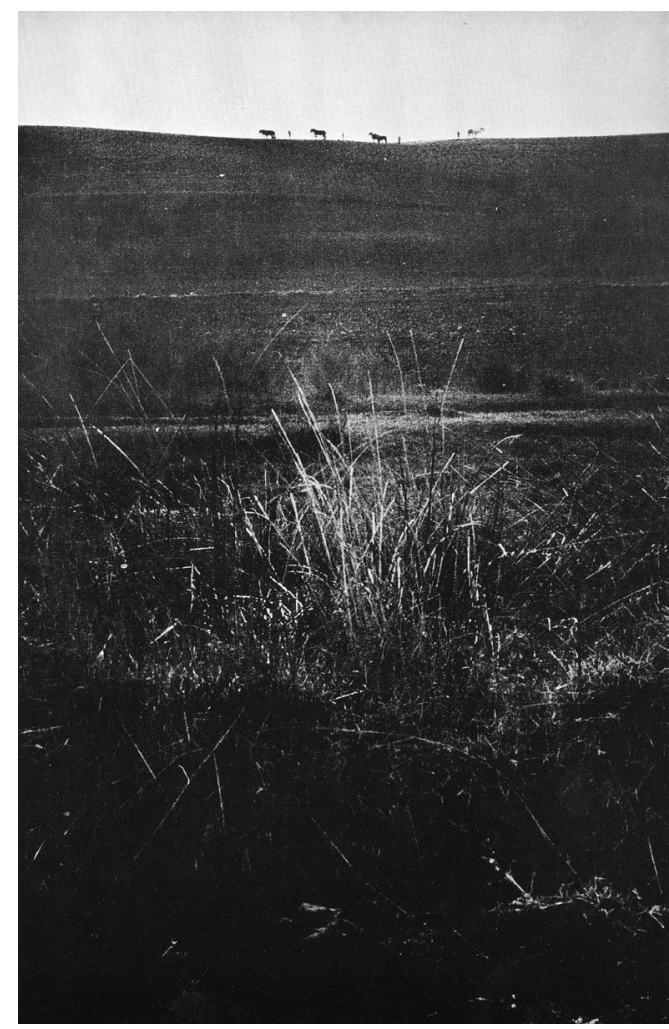

Ramón Masats, imagen extraída de Viejas historias de Castilla la Vieja.

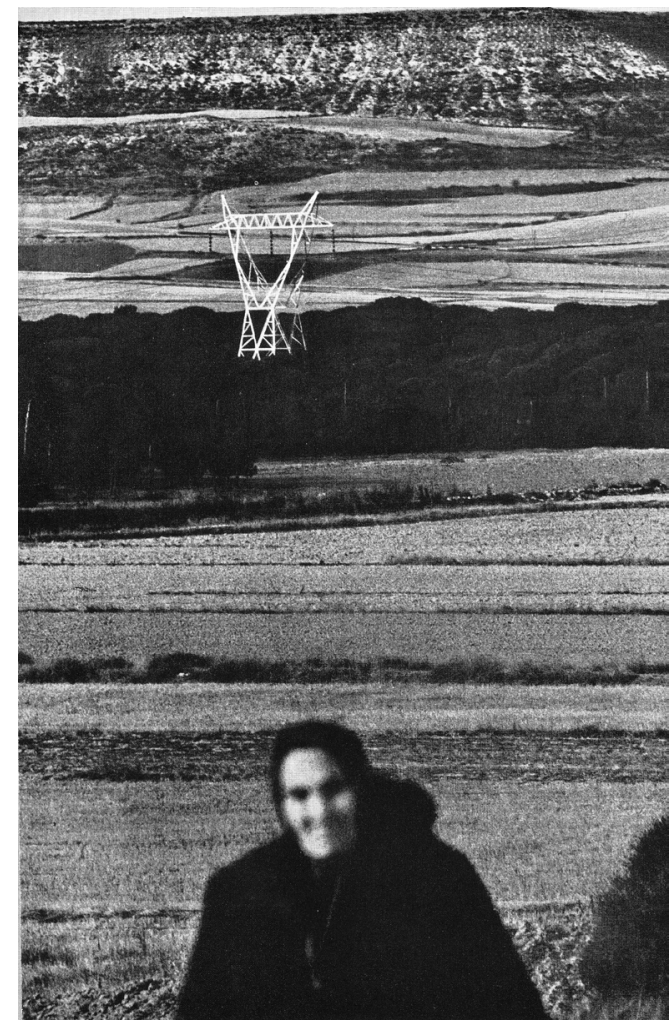

Ramón Masats, imagen extraída de Viejas historias de Castilla la Vieja.

de unos minúsculos arados romanos arrastrados por un animal y empujados por hombre. La escala de los arados y la del hombre es ridícula en comparación con la de la tierra a la que se enfrentan. Una lucha desigual por dominar, por sobrevivir. Tras esta foto nos encontramos con un cruce de caminos en un árido paisaje: no se ve de dónde viene ni se sabe a dónde conduce.

La siguiente imagen, la de la anciana desenfocada con la torre de electricidad detrás, posiblemente, sea la mejor representación de Masats de la amenaza que la modernidad ejerce sobre el paisaje castellano. Se trata, por ello, de una de las pocas imágenes que coincide con la visión más critica de Delibes.

-Compones mucho en profundidad, con todo enfocado. A veces buscas lo contrario, componiendo con muy poca profundidad de campo. Dándole una gran modernidad a temas muy rurales, jugando con el contraste entre el tema y su solución formal.

(R. Masats, Madrid, 15 de diciembre de 2003) -“Sí, es lo que tengo yo con los tópicos. Los trato de una manera diferente".

La señora desenfocada, inquietante, con la torre de luz detrás, reúne en un solo plano -aplastado por un teleobjetivo- dos mundos aparentemente opuestos: la tradición más arcaica - de la anciana vestida de negro con la cabeza cubierta por el luto- y la presencia de la modernidad -metaforizada a través de la electricidad-.

Estos son, prácticamente, todos los paisajes que aparecen en el libro (excepto la última foto, donde aparece un grupo de personas trabajando con un carro en el exterior del cementerio). Como 


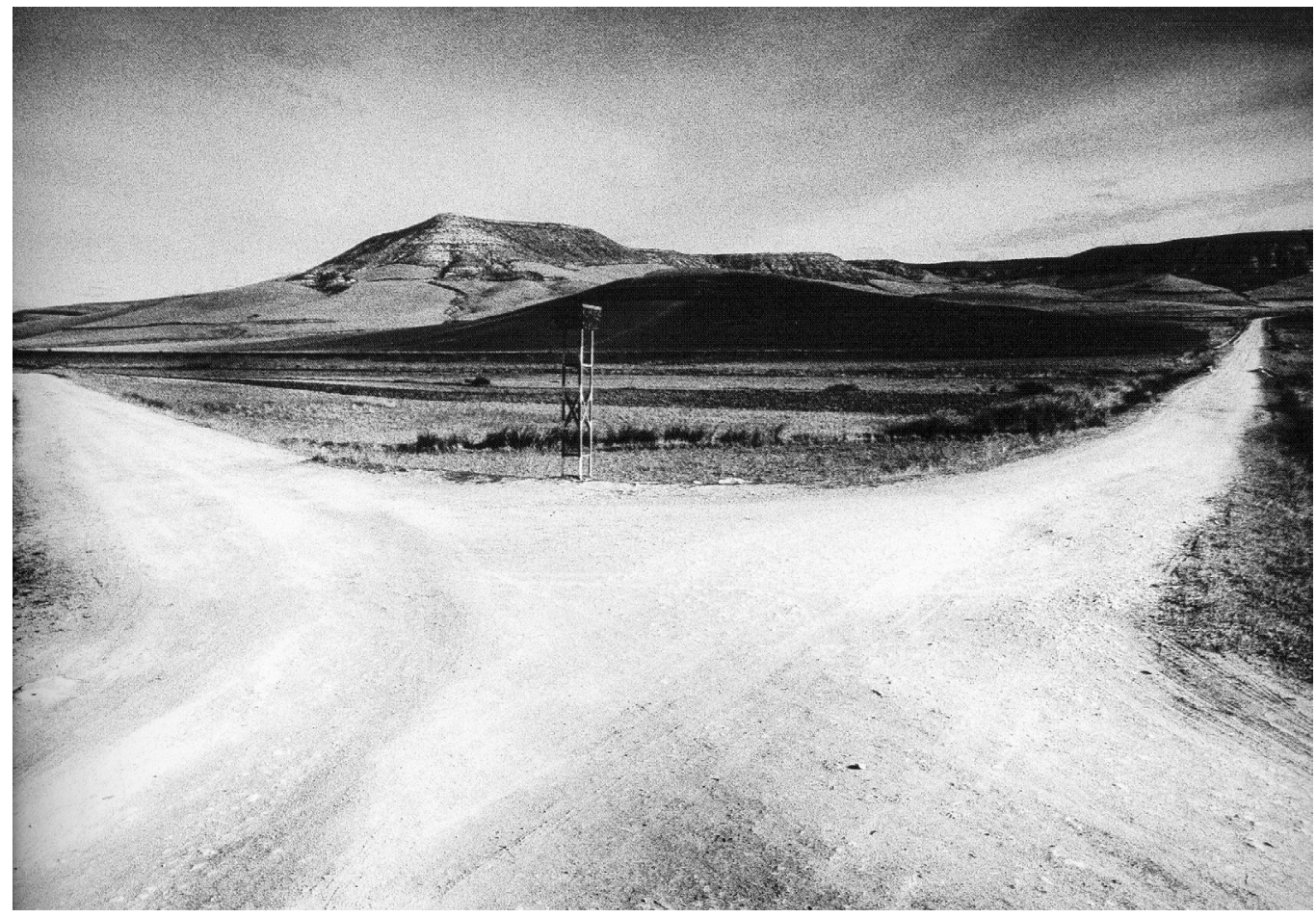

Ramón Masats, imagen extraída de Viejas historias de Castilla la Vieja.

vemos, no hay lugar para la nostalgia de una naturaleza perdida en estas imágenes. No son "fotos de la tierra" desde el punto de vista de Delibes. Ni son nostálgicas, ni bucólicas, ni románticas, ni legendarias, ni heroicas. La visión de Masats nos describe una tierra marchita, dura, difícil, sin un destino claro, invadida por objetos rutilantes, amenazantes, angulosos, anacrónicos.

El libro prosigue con una imagen en la que aparecen cuatro hombres tapados con mantas zamoranas, a cuadros. Es una de las imágenes más poderosas del libro y una de las más famosas de Masats. Realmente la foto que luego se ha recuperado en todas las antológicas de Masats es muy parecida a ésta, pero en ella los hombres ríen, ofreciendo un maravilloso juego de ritmos entre los dientes de las sonrisas y los cuadrados de las mantas. La imagen está llena de ironía ya que, aunque hace un frío mortal, los hombres conservan su sentido del humor y se ríen de sus desgracias. En la foto de Viejas historias de Castilla la Vieja no se ríe nadie.

(R. Masats, Madrid, 15 de diciembre de 2003) -“La siguiente foto es anecdótica. Si no se explica no se entiende. Son toda la gente de un pueblo, todos sus habitantes. Fíjate que la foto tiene cuarenta años. Probablemente estará abandonado hoy en día".

Una imagen de una puerta actúa como prólogo al grupo de imágenes de paisajes interiores, invitándonos a entrar en las casas de estas aldeas rurales. Una anciana, que parece una bruja, nos recibe. Las casas -espartanas y sobrias- están presididas por imágenes religiosas: cristos, vírgenes o crucifijos entre retratos de los antepasados. Las personas que las habitan parecen vacíos borrones, un reloj llena el silencio con su batir y el hilo de luz con de una bombilla ofrece unas sombras de aspecto fantasmagórico a la estancia.

De este conjunto nos gustaría destacar una imagen (tomada con un $35 \mathrm{~mm}$ probablemente) 

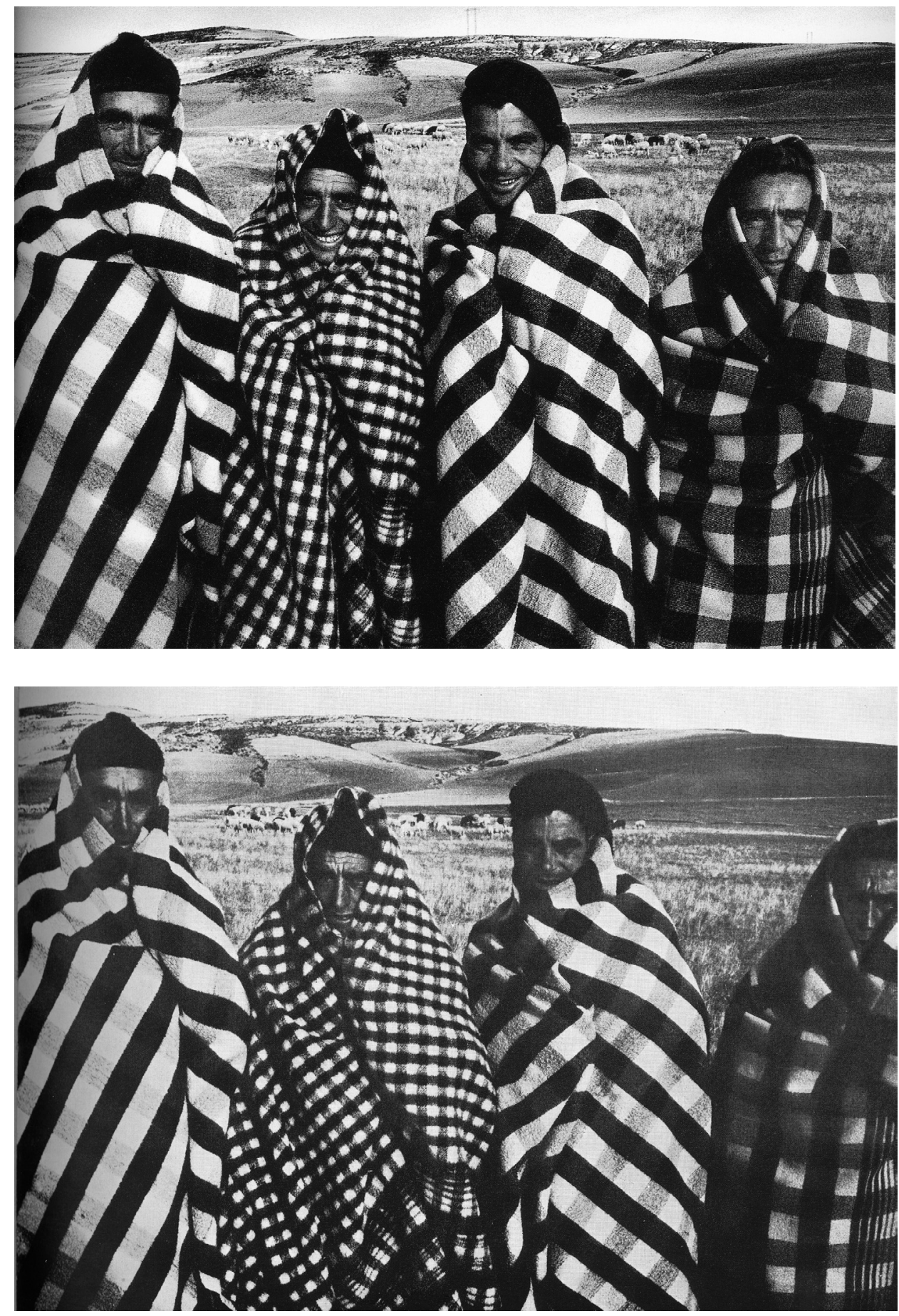

La Imagen superior es la que aparece en las últimas antológicas de Masats mientras que la inferior es la publicada en el libro Viejas historias de Castilla la Vieja. 


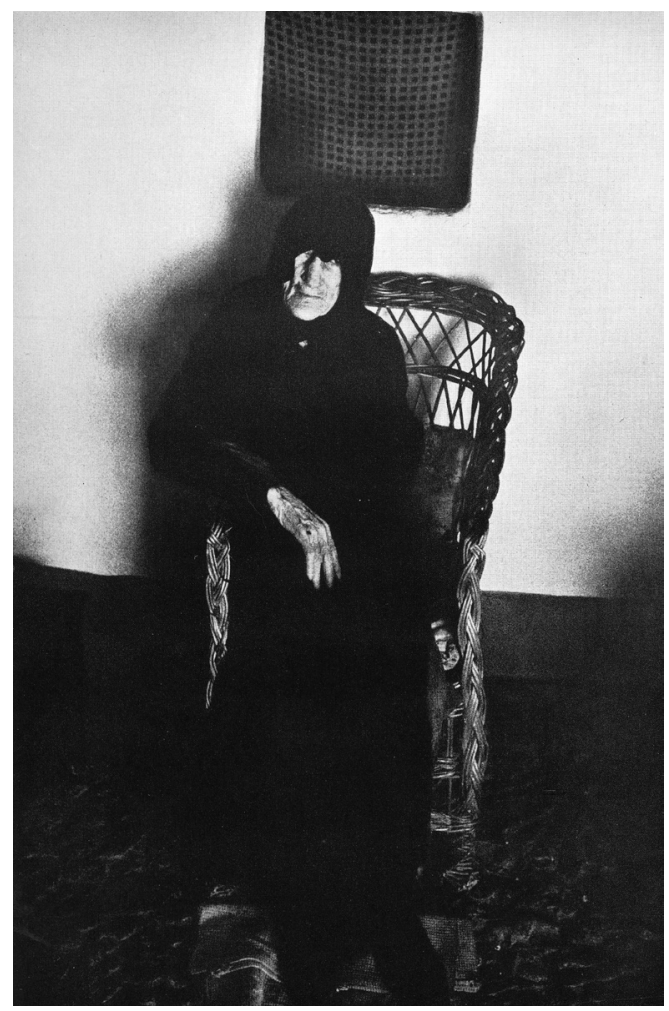

Ramón Masats, imagen extraída de Viejas historias de Castilla la Vieja.

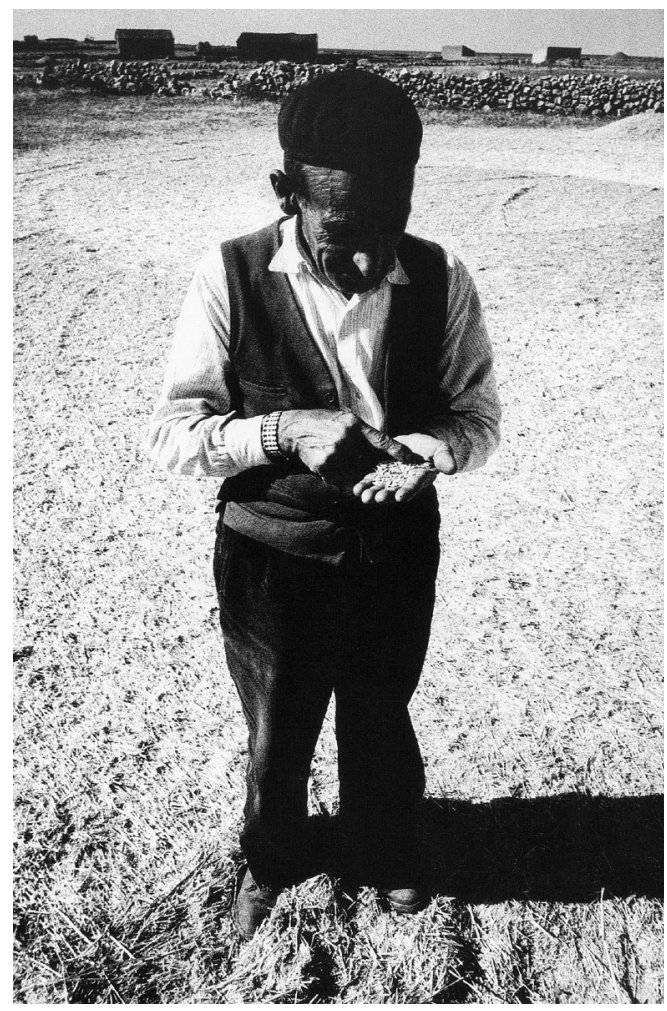

Ramón Masats, imagen extraída de Viejas historias de Castilla la Vieja.

de un campesino, visto en ligero picado, que sobre una era de trigo sostiene un puñado de semillas en la mano. Al observarla, nos molesta el picado y la distorsión que el escorzo produce. La cabeza está en relación a los pies, que son demasiado pequeños. Sin embargo, el punto de vista, tan forzado, destaca las manos y los granos de cereal que el hombre analiza atentamente. Ello permite ver la superficie de trigo sobre la que se asientan los pies del agricultor... Toda su vida se sostiene sobre esa superficie. Su supervivencia depende de ella.

Sólo hay, en todo el libro, cuatro imágenes que podrían recoger el espíritu amable de los textos de Delibes. En la primera, un grupo de jornaleras sonríen, saludando a Ramón Masats desde un camión. La luz, ligeramente en contra, es agradable, las chicas parecen felices. En la segunda imagen un grupo de hombres, con la boina puesta, juega a las cartas en un interior. La tercera nos muestra una perdiz enjaulada, con una mujer sonriendo desdentada, mientras sostiene un vestido. En la cuarta, un grupo de jóvenes bailan agarrados en una habitación vacía de toda decoración. Cuatro fotografías de un total de veintisiete... Es escasa la concesión a Delibes.

Otro grupo de imágenes nos muestra la estancia que representa al poder civil, presidido por retratos de Franco y José Antonio (quizá un salón de plenos de algún ayuntamiento). Junto a la misma, una casa ricamente decorada, pero con los muebles cubiertos con sábanas, como si se trataran de fantasmas de un pasado de mayor esplendor esperando tiempos mejores.

Finalmente, el último conjunto de imágenes del libro consta de tres fotos que toman como referente la actitud de diferentes grupos de personas en la iglesia. La primera, un grupo de ancianas (cabeza cubierta de negro, manos recogidas, semblante triste) avanza hacia la cámara como 


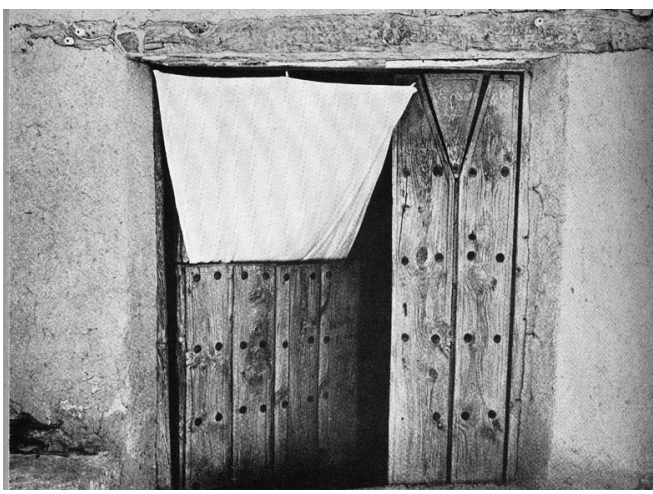

Imagen de formas que a modo de bisagra nos introduce al interior de las casas.

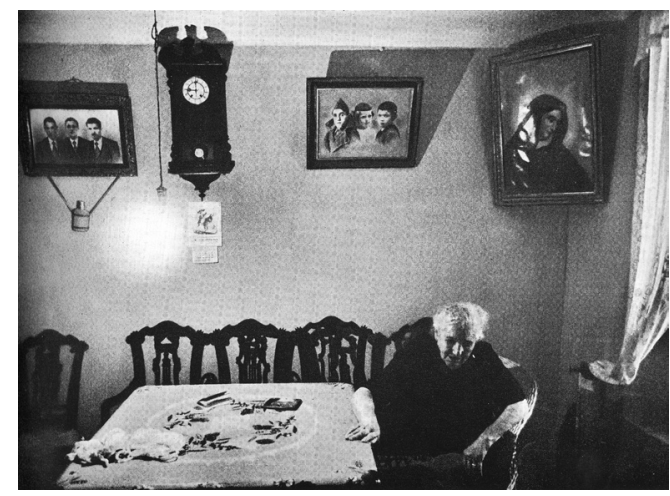

Ramón Masats, imagen extraída de Viejas historias de Castilla la Vieja.

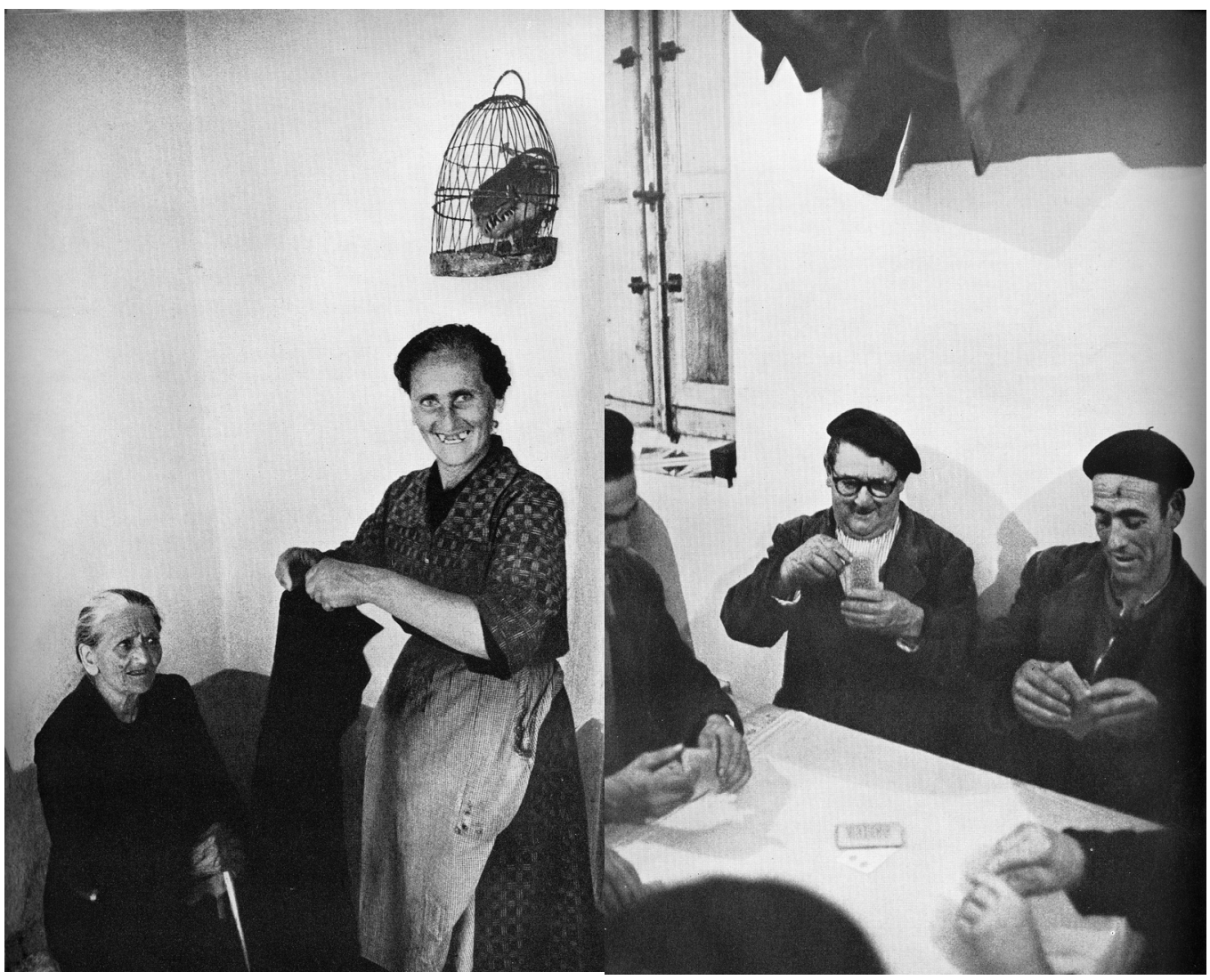

Ramón Masats, imagen extraída de Viejas historias de Castilla la Vieja. 


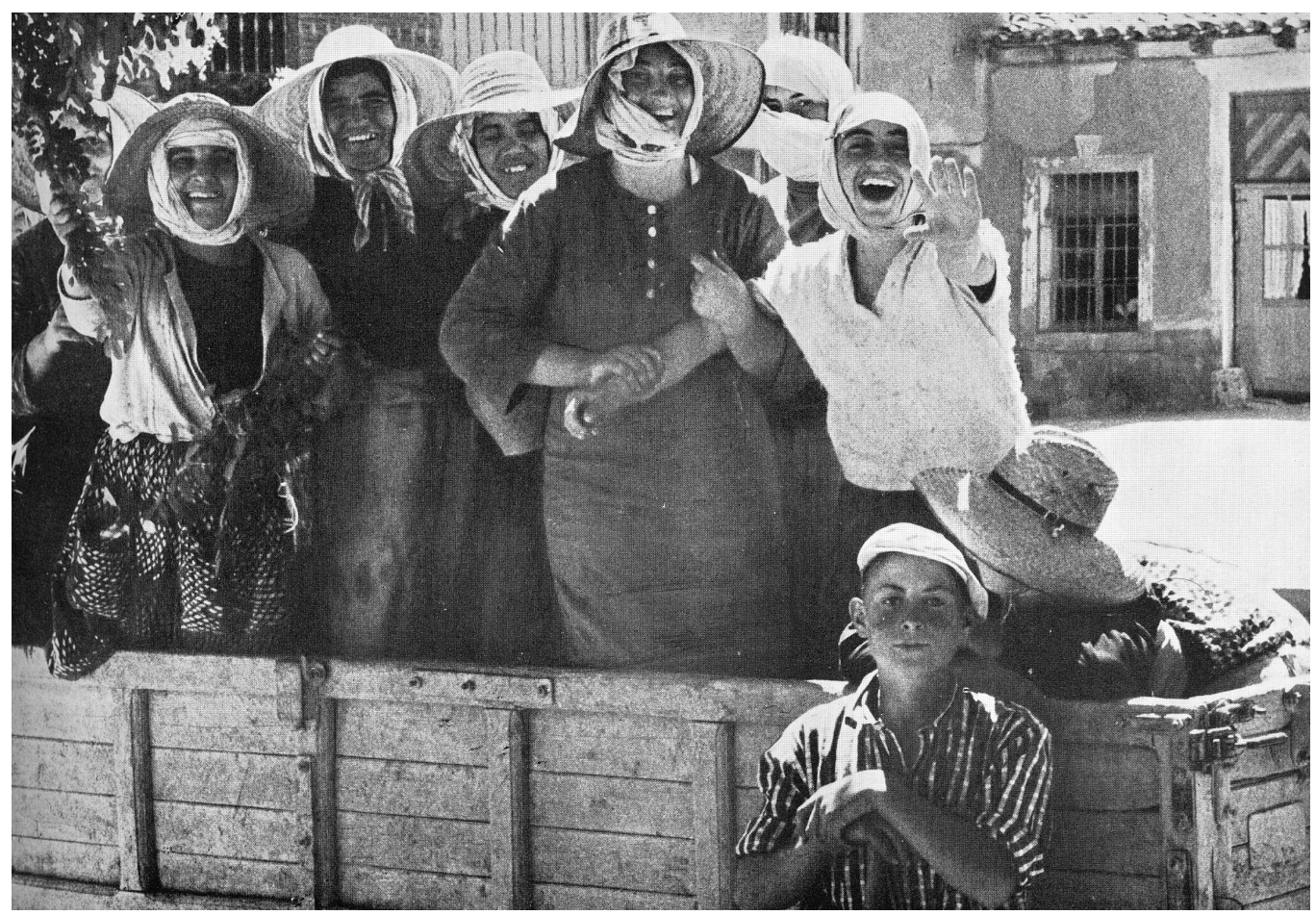

Ramón Masats, imagen extraída de Viejas historias de Castilla la Vieja.

si fueran brujas de un aquelarre. El progresivo y amenazante desenfoque produce, realmente, una gran inquietud. La siguiente está dedicada a una juventud helada de frío que escucha misa con una actitud paciente, como el que espera en una parada de autobús. Su actitud contrasta con la imagen de la página posterior, en donde tres ancianos (uno arrodillado, los otros dos inclinados sobre sus bastones) oran con una devota actitud de respeto. La última imagen del libro es la ya comentada fotografía del paisaje con el cementerio...

Respecto a la maquetación del volumen, ésta conlleva un planteamiento completamente diferente del diseño. Aunque se mantiene el mismo formato y los mismos tipos de papel de toda la colección Palabra e Imagen, el juego de ritmos entre papel-texto y papel-foto de Neutral Corner -donde los textos se ceñían a un espacio dado, entre un grupo de fotos y otro- desaparece en Viejas historias de Castilla la Vieja. Ello se debe en parte a que los textos, un conjunto de diversas historias breves, no pueden sujetarse a dos páginas de papel basto, puesto que, al estar escritos, encontramos capítulos con una extensión más larga o más corta. Por otro lado, como el propio Masats nos comenta, ha realizado sus imágenes independientemente de los textos de Delibes. Las fotos no tienen ninguna interrelación significante con el texto (simplemente, están tomadas en el mismo espacio geográfico), no hay ninguna posible conexión. Ante ello, Óscar Tusquets no fuerza las cosas y deja fluir los dos discursos paralelamente. Aun así, el arquitecto busca cierto orden y el número de páginas de papel mate se agrupa siempre de tres en tres, separadas por páginas de papel cuché (unas veces dos y otras una, alternativamente). Este orden es absolutamente independiente de la capitulación y por ello, a veces, los capítulos se cortan con varias fotos y a veces ni siquiera hay fotografías en un capítulo entero. De hecho, toda esta disposición de hojas parece responder 

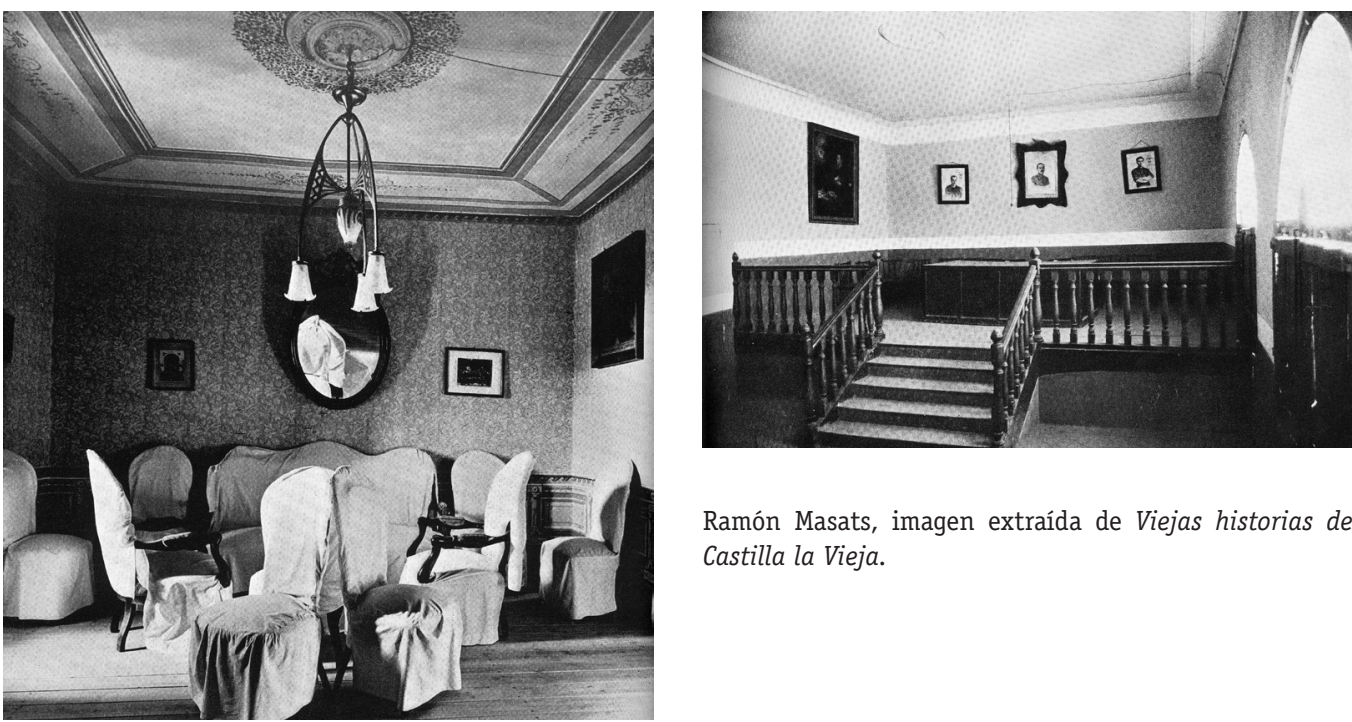

Ramón Masats, imagen extraída de Viejas historias de Castilla la Vieja.

Ramón Masats, imagen extraída de Viejas historias de Castilla la Vieja.

meramente a necesidades de encuadernación más que a cualquier intención narrativa.

Sobre la propia disposición de las fotografías en el interior de la página nos encontramos con un par de imágenes a sangre y dos fotos aparecen a doble página. Asimismo, se juega con los márgenes, igual que en Neutral Corner. Sin embargo, no hay ninguna imagen cortada, ni repetida, ni modificada de ningún modo, excepto el primer paisaje que aparece en el interior del libro, como ya comentamos. Óscar Tusquets nos asegura que la maquetación de Viejas historias de Castilla la Vieja es mucho más sencilla que Neutral Corner porque no le hace falta mayor tratamiento. Las fotos están tan bien construidas que no se necesita reencuadrarlas o cortarlas. Además, Delibes era mucho más ortodoxo. Tusquets parece que se excusa diciendo que, como es un libro publicado muy posteriormente a Neutral Corner, quizá le falte el entusiasmo de la juventud, ese entusiasmo vinculado al empezar y al experimentar. De los dos libros, considera que en Neutral Corner hay mayor participación suya, mayor intervención y experimentación que en el de Viejas historias de Castilla la Vieja, de ahí que considere más personal el primero de ellos.

\footnotetext{
“Dos años más tarde publicábamos Viejas historias de Castilla la Vieja, donde Masats se enfrentaba a un magnífico texto absolutamente representativo de su autor, Miguel Delibes. Un suelto del interior del libro incluía una breve biografía del escritor y del fotógrafo. Al releer esta cartulina amarilleada quedo impresionado por nuestra lucidez juvenil. Decíamos sobre Ramón: «Muy exigente, acepta pocos trabajos y los realiza con responsabilidad. Neutral Corner representó lo mejor de su labor hasta el momento, pero, si entusiasmó a unos pocos, no gustó a la mayoría. Rechaza cualquier tema que no le permita superar este primer libro, hasta que, impresionado por el texto de Delibes, nos da esta visión antiacadémica de los hombres y las tierras de Castilla». Tal como nosotros mismos reconocíamos, la aceptación comercial de estos dos libros fue testimonial, y en el de Delibes motivada, sobre todo, por el prestigio del escritor. Sin embargo han hecho historia. No existe muestra o publicación antológica de Masats que no incluya varias imágenes de ambos"122.
} 

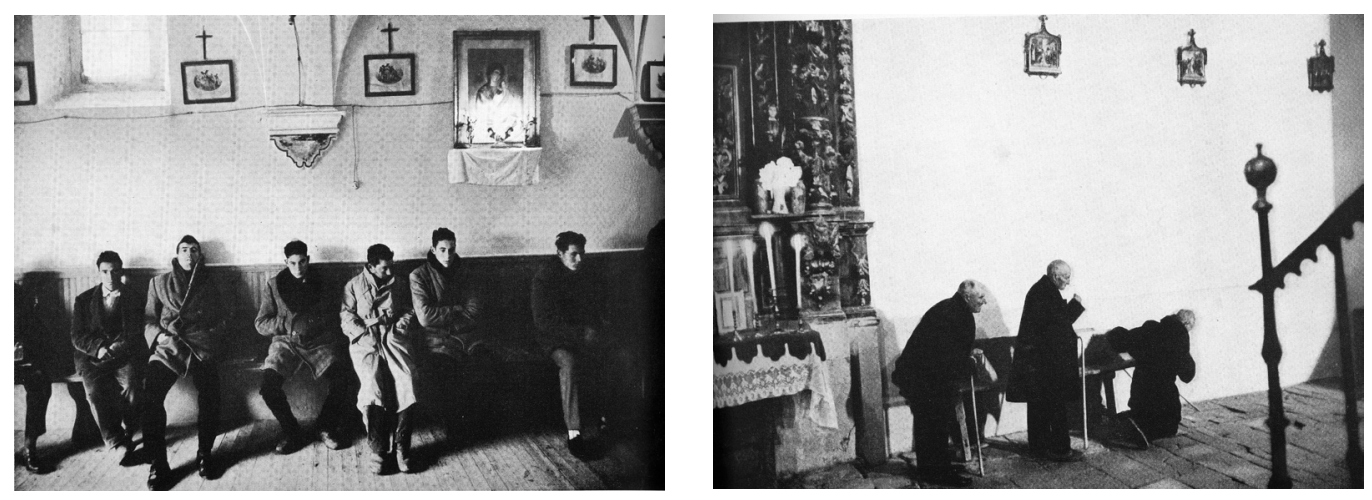

Ramón Masats, imagen extraída de Viejas historias de Castilla la Vieja.

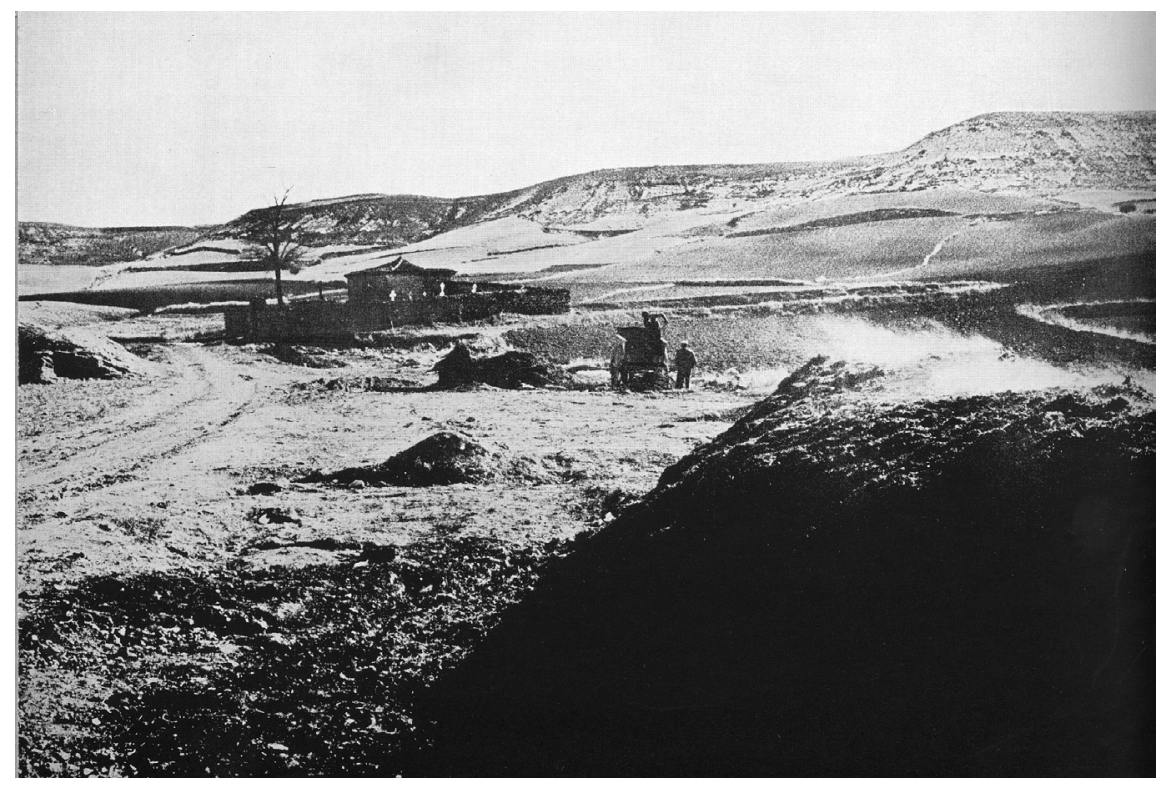

Ramón Masats, última imagen del libro Viejas historias de Castilla la Vieja.

\subsection{Un proyecto descartado}

(Esther Tusquets, Barcelona, 31 de octubre de 2004) -“Posteriormente hablé con Ramón -que estaba haciendo unos carteles para Turismo- y le encargué un libro sobre la España negra. Un libro muy crítico y muy ambicioso. Un libro que no se realizó. Me dijo que no podía compaginar una cosa y otra -sus fotos en color para turismo y las de blanco y negro para nosotros-".

El proyecto se hubiera materializado en Lumen, pero fuera de la colección Palabra e Imagen. Hubiera sido un libro exclusivamente fotográfico, sin la participación de ningún escritor, realizado en riguroso blanco y negro, y con una extensión de unas quinientas fotografías...

Hablar de cosas que nunca existieron siempre despierta la imaginación y excita la fantasía, pero en un trabajo de investigación resulta sumamente peligroso conjeturar cuál hubiera sido el 
resultado de aquel último trabajo con la editorial Lumen y cómo éste hubiera podido influir en la carrera posterior de Masats o en nuestra Historia de la Fotografía. Sin embargo, nos vemos en la necesidad de incluir la anécdota de aquel encargo fallido, no tanto para imaginar lo que hubiera podido ser, como para -a través de los motivos que llevaron a Masats a renunciar al trabajo- conocer mejor el carácter y la personalidad de Masats, así como la consideración que éste tenía de su propia obra y de los encargos que aceptaba y/o renunciaba.

"Muchas de las fotografías realizadas durante aquellos años se hubiesen publicado también en un libro que Ramón nos propuso y nosotros acogimos con entusiasmo. Se trataba de un libro fotográfico sobre España. Así de sencillo y así de ambicioso: dar la visión masatiana de nuestro país. Masats nos mostró varias fotografías que nos dejaron anonadados. Aparte de algunas que aparecían en el libro de Castilla, otras imágenes han quedado para siempre: la del seminarista en acrobática palomita, la de la viejecilla trazando una uve en Tomelloso, la del bruto pisando al perrito en Los Sanfermines, la del toro agonizando solo en el ruedo..."123.

- Hubo un libro sobre España que te propuso Lumen pero que no llegaste a acabar.

(R. Masats, Madrid, 4 de septiembre de 2002) -“Ah sí, sí... Ellos querían hacer un libro sobre España en blanco y negro. Entonces era muy caro viajar por toda España solamente para hacer un libro y no había posibilidad. Pero yo empecé a trabajar para el Ministerio de Información y Turismo. Entonces viajaba para Turismo, y la idea fue, a priori, que yo hiciera las fotos para Turismo pero que aprovechara también para hacer blanco y negro, para el libro de España".

-Las de Turismo ya eran en color.

(R. Masats, Madrid, 4 de septiembre de 2002) -“Eran en color y seis por seis. Entonces, los responsables de Lumen me dieron un dinero que me permitió comprarme un Seat 600 con el que empecé a viajar por toda España. Y me di cuenta de que no era capaz de hacer las dos cosas a la vez. No he podido hacer nunca blanco y negro y color simultáneamente. Me ha sido muy difícil alguna vez que lo he tenido que hacer. Me di cuenta de que el planteamiento era equivocado y que no podía hacer el libro de España. No llegué a hacer ninguna fotografía de aquel libro. Un día cogí el 600 y me marché a Barcelona sin avisarlos -sabía que los iba a encontrar en Bocaccio-. Al encontrarme con Óscar Tusquets le devolví las ochenta mil pelas que me habían adelantado. Y se quedaron muy sorprendidos porque dicen que, hasta aquella fecha, fui el único autor que no había cumplido con un encargo y les había devuelto el dinero. Quiero decir que, por lo visto, había muchos que no hacían el trabajo, pero de devolver el dinero nada. Les devolví el dinero y les dije que no podía hacerlo".

-Pero, ¿no lo pudiste hacer por la incompatibilidad de mezclar Blanco y negro con Color, o por no poder mezclar el trabajo de creación -más personal- con el trabajo de encargo? Te recuerdo lo que Laura Terré señala al respecto:

"Siempre, desde que empezó a dedicarse a la fotografía como profesional, supo que la inquietud, la forma de ver de un fotógrafo amateur, no es la misma que la de un profesional que lleva a cabo los proyectos de encargo. Por ejemplo, en la ocasión en la que Lumen le encargó en el año 62 un libro sobre España (...) no fue capaz de hacer compatibles las dos tareas y tuvo que decir que no al proyecto de Lumen. No era capaz de cambiar el «chip» (sic) que llevaba puesto para las fotos de Turismo: «... fue imposible hacer a una hora fotos para Turismo, y a otra hora fotos para mí. Con lo cual tuve que devolver el dinero a la editorial»"124. 
El propio Masats contradice sus propias palabras y nos confirma todo el capítulo destinado a la esquizofrenia del autor profesional.

(R. Masats, Madrid, 4 de septiembre de 2002) -“Esto no es cierto, porque cuando he trabajado sólo en treinta y cinco milímetros en color, es decir a partir del ochenta y dos con Lunwerg, no he tenido ningún problema en hacer la obra comercial y a la vez, de vez en cuando (porque el tema me llamaba la atención o porque me apetecía) con las mismas cámaras y con las mismas películas, hacer obra personal. No, fue más bien por dos tipos de cámara y por dos tipos de película, color y blanco y negro. Lo que digo yo es que a veces me pongo el chip de color o a veces me pongo el chip de blanco y negro. A partir de aquel momento fui consciente de ello".

Resulta evidente que Masats no podía satisfacer a dos clientes a la vez. Lumen le exigía en su trabajo una visión personal en blanco y negro y con un formato de $35 \mathrm{~mm}$, mientras que el Ministerio de Turismo le exigía una visión más ortodoxa y académica, realizada con una cámara de formato medio y además en color. Si hubiera podido trabajar con el mismo formato y el mismo soporte... quizá hubiera podido compatibilizar los dos encargos, como hará años más tarde en la editorial Lunwerg. Él es un profesional que se debe a su cliente, y si no es capaz de responderle con el nivel que él mismo se impone, renuncia...

“Esta anécdota explica como ninguna el carácter de Masats. Recordándola cuarenta años después, aun tengo dudas de que hiciese bien. Estoy seguro de que el libro hubiese sido la hostia y que hoy sería un clásico indiscutible, como el New York de William Klein o el Nothing Personal de Ricard Avedon, pero Ramón no se veía capaz de hacer lo que él ambicionaba. Ramón es así. Hoy, cuando el común de los artistas más admirados se dedican exclusivamente a incrementar su nivel mediático, su estatus y su cuenta bancaria, este rigor artístico resulta incomprensible y pintoresco, pero entonces, en unos años indiscutiblemente más románticos, me impresionó profundamente. La prueba es que lo recuerdo como si hubiese ocurrido ayer"125.

-El libro inédito de España, ¿lo has hecho después?

(R. Masats, Madrid, 4 de septiembre de 2002) -“No, porque el libro de España que hice para Lunwerg no es el libro que hubiera hecho yo para Lumen. Hubiese sido otro libro completamente distinto".

¿Por qué escogió el trabajo con el Ministerio? Evidentemente por las razones que llevan a un profesional a decidirse por un trabajo o por otro: porque se le pagaría más, porque tendría mayor continuidad laboral, porque podría asegurarse más encargos... Así fue como acabó su relación con la editorial Tusquets y con la Colección Palabra e Imagen, aunque la amistad con Óscar y Esther Tusquets la ha mantenido hasta la actualidad.

(Esther Tusquets, Barcelona, 31 de octubre de 2004) -“Luego lo he visto en Cadaqués muchos veranos. Allí alquila una barca".

- Creo que la barca es suya.

(Esther Tusquets, Barcelona, 31 de octubre de 2004) -“ ¿Ahora es suya? Hace unos años era alquilada. Siempre nos vemos por casualidad. Aunque luego fui a la exposición que hizo aquí, en el Palacio Virreina".

Con Óscar Tusquets también ha mantenido la amistad. Tusquets nos habla sobre la personalidad de Masats. Nos comenta que, cuando charlan de vez en cuando, le pregunta sobre su actividad actual y Masats le dice que se ha retirado; que el único que hace fotos es su hijo Óscar y que él se dedica a hacer un bacalao al pil-pil que le sale estupendo... y luego le da una serie de recomendaciones y recetas de cómo hace el bacalao... Según Óscar Tusquets, eso es falso, ya 
que sigue realizando fotografías por todo el mundo cada vez que, a través del Instituto Cervantes, inaugura alguna de sus exposiciones.

La relación entre Óscar Tusquets y Ramón Masats a pesar del tiempo transcurrido continúa vigente. Y dado que Óscar considera su amigo le pidió un texto -que ya hemos citado en el epígrafe 6.3. al analizar las relaciones entre arte y utilidad- para publicarlo en el Álbum /Enciclopedia de Óscar Tusquets. A su vez, Masats le ofrecera la oportunidad de devolverle el favor y Óscar escribirá en la introducción de su exposición antológica, Contactos, realizada con ocasión de su premio Nacional de Fotografía.

Pocos años después del encargo de aquel libro que nunca vio la luz, en 1965, Ramón Masats rompió con la fotografía para dedicarse al cine y la televisión. Sin embargo, hubo un último libro en blanco y negro, realizado en 1967 y publicado por Alfaguara: Don Quijote de la Mancha, con textos de Martín de Riquer. Masats reconoce que este libro, aunque sí se materializó, resultó fallido. El mismo se realizó en plena producción televisiva y pudo prestarle la atención requerida. Finalmente, se compuso de retales, a base de fotos de archivo.

$-¿$ ¿Por qué no te acaba de gustar el Don Quijote?

(R. Masats, Madrid, 27 de diciembre de 2006) -“Es que está muy mal impreso. Es un libro... ¡Creo que Cervantes se merecía mucho más! Digamos que me dijeron: «Bueno, sí Ramón... pero es que no tenemos mucho dinero. No tenemos mucho tiempo... Mira a ver en el archivo si no tendrías cosas...». Hay muchas fotos en el libro que son de archivo. Fue un libro hecho a base de cortar y pegar. Luego he hecho documentales sobre Don Quijote que han quedado mejor. No lo considero un libro como estos otros, hechos por mí. Fue un poco: «Busca en el archivo y de lo que tengas por ahí... a ver, ¿qué queda? ¿cuatro cosas? Bueno, pues vete una semana... ». Se vino Mario Camus conmigo (que creo que estaba preparando un guión) y no fuimos los dos y estuvimos paseando por allí".

La descripción efectuada por Masats no debe, pese a todo, sorprendernos. Él ya no es fotógrafo en esa época: es director de documentales de televisión.

\subsection{EL ABANDONO DE LA FOTOGRAFÍA Y EL SALTO AL DOCUMENTAL Y A LA TELEVISIÓN: UNA NUEVA INVESTIGACIÓN}

Somos conscientes del hecho de que abordar la faceta documental y televisiva de Masats, supondría iniciar un nuevo trabajo de investigación que debería quedar centrado exclusivamente en la misma. De hecho, la presente tesis tan sólo ha deseado circunscribirse al ámbito fotográfico de su trayectoria, dad la extensión e importancia que éste posee. A pesar de ello, en este breve apartado queremos dejar constancia de la tarea investigadora que todavía queda pendiente de realizar en lo concerniente a la producción artística de Masats. Asimismo, también queremos utilizar estas páginas para profundizar en las motivaciones y circunstancias que llevaron a nuestro autor a tomar la decisión de abandonar la fotografía. Un abandono pasajero puesto que con posterioridad volverá a la misma a través del color, pero que resulta significativo de las nuevas perspectivas profesionales ante las que se enfrenta.

-¿Por qué cree que Ramón dejó la fotografía?

(Carlos Pérez Siquier, Almería, 27 de abril de 2002) -“Quizá porque no le daba tanto que ganar y también porque ser director de cine estaba más considerado que ser fotógrafo".

- ¿Es decir, que fue una decisión meramente profesional o económica?

(Carlos Pérez Siquier, Almería, 27 de abril de 2002) -“Sí, él era siempre honesto en el trabajo y trataba de sacarlo con profesionalidad, no sólo para salir del paso. Pero claro, la fotografía estaba muy mal pagada. Yo creo que de los pocos que ganaban dinero con la fotografía fuimos (en aquella época) los que trabajamos con el Ministerio de Información y Turismo, como 
Ramón Masats y yo. No porque pagaran muy bien la diapositiva (que me parece que la pagaban a seiscientas o setecientas pesetas de los años sesenta) pero es que te compraban doscientas diapositivas... Algunos empezaban con fotografía de prensa con Gaceta Ilustrada -el caso de Oriol- pero tampoco estaba muy bien pagado. Miserachs consiguió meterse en un sector catalán -en el cual él tenía amigos que eran empresarios- y le hicieron encargos de fotografía publicitaria, y consiguió ganar algún dinero. El libro de Costa Brava Show y el Barcelona Blanc i Negre se lo pagaron. No se lo pagaron muy bien, pero se divertía muchísimo, y se permitía hacer sus cosas. Y otro fotógrafo muy acreditado era Leopoldo Pomés, que tenía un estudio de publicidad. Era quizá de los que más ganaba, dentro de los buenos fotógrafos que han quedado después, porque había otros fotógrafos publicitarios que sí ganaron dinero pero hacían otra fotografía más comercial".

- ¿Por qué dejar la fotografía para dedicarse al documental, a la televisión, al cine?

(R. Masats, Madrid, 27 de diciembre de 2006) - “Yo cuando dejé la fotografía para dedicarme al documental y al cine tenía tanto trabajo como antes. Dejé un trabajo por otro y los dos me daban dinero. No fue un planteamiento económico. Yo me pasé al documental más por el montaje que no por otra cosa. Rápidamente, cuando empecé en el cine, quise entrar en una sala de montaje. Para mí eso era muy importante. Más que la fotografía o el movimiento o el sonido (diálogos o música) lo que más me interesaba era el montaje".

$-¿$ ¿ dónde aprendiste a montar?

(R. Masats, Madrid, 27 de diciembre de 2006) -“" ${ }$ Ah, eso no se aprende! Tú vas a una sala de montaje y le dices a un señor que hay allí...".

-No físicamente a cortar y pegar la película, si no ¿dónde aprendiste a montar un plano detrás de otro y que tuviera sentido?

(R. Masats, Madrid, 27 de diciembre de 2006) -“Yo creo que en el cine. Yo veía muchísimo cine, me gustaba mucho, y más o menos así se aprende. Alguna vez, por supuesto, el montador me ha dicho: «Ramón que esto no funciona, que no va a funcionar». «¡Bueno, bueno vamos a dejarlo y mañana lo vemos!». Y mañana no funcionaba. No es que yo llegara allí como Orson Welles diciendo: «iHe descubierto el montaje!». No".

-0 sea que ibas al cine como a una escuela. En vez de disfrutar de la película ibas a analizarla.

(R. Masats, Madrid, 27 de diciembre de 2006) -"Bueno, esto lo hago más ahora que antes". - ¿Lo de analizar?

(R. Masats, Madrid, 27 de diciembre de 2006) -“Sí, mucho más. Como la película no me enganche... empiezo: esto le habrá costado una fortuna a producción... y aquí, ¿esto es una grúa o es un helicóptero?"

- ¡Y te ibas a Francia a ver películas!

(R. Masats, Madrid, 27 de diciembre de 2006) - “ ${ }_{i}$ Hombre, si me iba! Me cogía el tren y me iba a París. Me cogía una pensioncita de lo más barato y me cogía una revista donde venían explicados todos los cines de maravilla. La primera mañana en que yo llegaba allí era sentarme y planificarme las sesiones (porque allí podías ir al cine a las diez de la mañana o a las doce). Entonces decía: «A las doce este cine. Esto está en tal sitio (mapa de París). Entre este sitio y la siguiente película puedo coger el metro y me da tiempo para comerme un bocadillo. Yo me veía de cuatro a cinco películas diarias. Luego me comía cualquier tontería y me metía en la cama a las doce. Y me veía de todo. ¡Buenas películas!"

$-¿ Y$ te ibas de viajes sólo para eso?

(R. Masats, Madrid, 27 de diciembre de 2006) -“Sólo para eso. Viajes de una semana, o cuatro o cinco días. Pero eso ya lo hacía cuando hacía fotografía. Yo me acuerdo de un desprecio que le hice a Xavier Miserachs... ¡No era a él! Xavier Miserachs era un gran aficionado al tenis, y entonces consiguió unas entradas para ir al Roland Garros, iqué era dificilísimo! Fue cuando Turismo de 


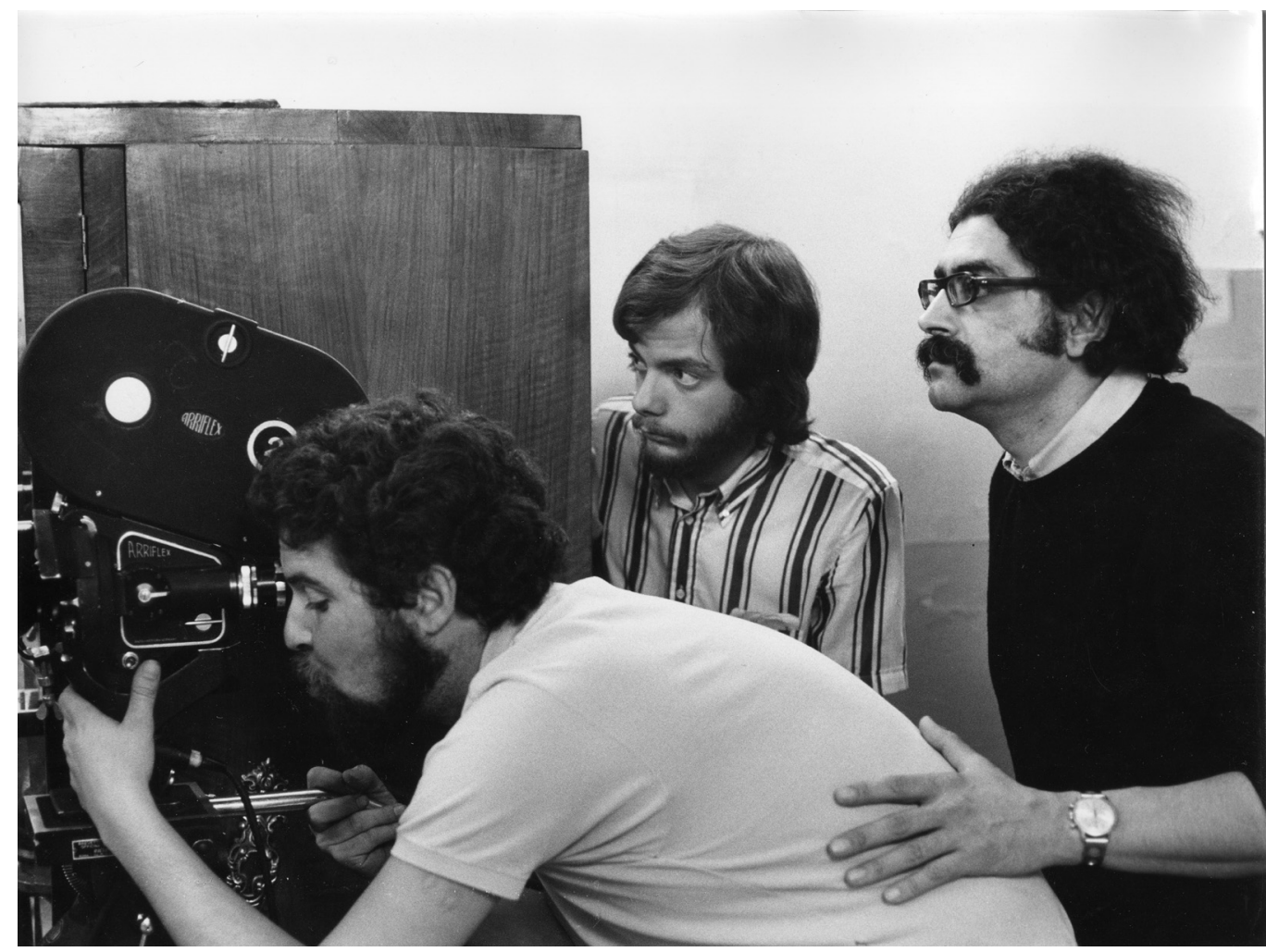

Oriol Maspons y Xavier Miserachs, retrato de Ramón Masats durante el rodaje de la película Topical Spanish, 1970.

Francia nos llevó a unos cuantos fotógrafos españoles invitados a París. Entonces Miserachs me dijo: «Ramón vente al Roland Garros que me apetece que conozcas el mejor tenis que hay en el mundo...». Fuimos y yo a aquello no le veía ninguna gracia y le dije: «Mira Xavier, yo lo siento, pero dentro de media hora ponen una película...» Y el tío se quedó... ¡Después de lo que le había costado la entrada! Para él había sido un detalle que esperaba que yo lo valorara, y me fui al cine".

-¿Qué te aportaba el montaje?

(R. Masats, Madrid, 27 de diciembre de 2006) -“Del montaje me interesaba la interacción entre un plano, el posterior y el anterior. Es decir, la misma armonía que había buscado en un único fotograma que lo tuviera todo el conjunto de planos. Yo, es curioso, siempre he sido muy buen montador. En cambio la cámara yo la he cogido muy poco, he tenido muy buenos operadores. Era el montaje, buscar el ritmo que antes había encontrado en el fotograma. Cuando me metí en el cine (me gustaba muchísimo el cine) estaba con Carlos Saura, con Mario Camus, tenía buenas relaciones".

(R. Masats, Madrid, 17 de julio de 1999) -“Dejé la fotografía en el año 1965, porque llegó un momento que necesité que aquellas imágenes se movieran, pero sobre todo que tuvieran un montaje, una secuenciación y sonido: fuera música o fuera palabra. Entonces lo necesité y tuve la oportunidad por el documental, El que enseña (1965) -el segundo que hice, que va sobre un maestro de pueblo- ganó un Mikeldi de plata: lo premiaron en el Festival de Cine de Bilbao". 
(R. Masats, Madrid, 27 de diciembre de 2006) -“Por cierto, me hizo mucha gracia porque yo tuve que darle el premio a Richard Lester, el director que hizo las películas de los Beatles. A mí me habían dado el mismo premio que a él, pero como él el año anterior no había podido ir a recibir el premio, fue el mismo año que yo. Me tocó a mí darle el premio. Entonces me vine a Madrid y organicé un pase para una serie de amigos. Para que vieran que también me gustaba el cine, pero sin ninguna intención de nada: estaba Mario Camus (Mario Camus fue el productor del documental), Carlos Saura y Salvador Pons. Entonces, cuando finalizó el pase me vino Salvador y me dijo: «¡Chico, me vienes que ni pintado! Me acaban de encargar, esta misma mañana, que monte una serie de documentales sobre España...». Y así fue como empezó todo".

Recordemos que Salvador Pons conoció a Masats en la exposición que Ramón realizó en el Ateneo de Madrid en 1961.

(R. Masats, Madrid, 15 de diciembre de 2003) -“Català-Roca es el que me presentó en Turismo. Hice una exposición en el Ateneo de Madrid y Català-Roca cogió al que entonces era el encargado de Turismo -era amigo suyo y luego fue amigo mío-, Salvador Pons (valenciano de Oliva) y lo llevó a ver mi exposición. Fue Paco Català el que me proporcionó el contacto".

\begin{abstract}
"Salvador Pons, Técnico de Información y Turismo del Ministerio que dirigía Manuel Fraga Iribarne, fue el primer director que tuvo TVE 2. En él se encuentra la semilla que produjo el cambio de rumbo de la historia de la televisión en España. Pons se había bregado en 1965 como comisario del Año Santo Compostelano. El jubileo de ese año se plantea, por vez primera, como una campaña publicitaria de televisión, vallas y otros medios con el fin de potenciar lo que se llamó «turismo social» de los españoles. El éxito le sonríe y en los estertores de ese 1965 se le encarga una nueva campaña que con el título de «Conozca usted España» que se concibe, además de para potenciar el turismo interno, para conseguir un «reforzamiento de los lazos de solidaridad entre las diversas regiones»"126.
\end{abstract}

(Salvador Pons, Denia, 2 de enero de 2007) -“Era una serie de televisión dirigida al interior, a los españoles. Porque yo mantenía una teoría, y la sigo manteniendo: los españoles no conocemos bien nuestro propio país, debido a la gran variedad y diversidad de paisajes y gentes... Yo no tenía ninguna idea de televisión. Yo era funcionario público, si se quiere con la experiencia que produce el haber estado llevando la Sección de Publicaciones de Turismo y luego todo el Ministerio de Información y Turismo durante cinco o seis años... De modo que yo sabía como había que... Pero mi conocimiento técnico -muy importante- del medio audiovisual era muy reducido. Pues tenía el de la curiosidad, la formación universitaria, las lecturas y la observación como espectador... De la gente del mundo gráfico, el único que reunía la doble condición de fotógrafo y hombre que conocía el medio audiovisual... era Ramonet. Ramón era muy amigo, ¡muy amigo!".

- ¿Y por qué cree que Masats dejó la fotografía?

(Salvador Pons, Denia, 2 de enero de 2007) -“Yo pienso que aquello fue una vía que se abrió y abrió. Porque muy pocos entraron. Casi nadie quiso entrar, pero Paco Català-Roca entró -uno de los mejores fotógrafos del país-, aunque los otros no entendieron aquello. Català-Roca llegó a hacer un Conozca usted España sobre Extremadura. Pero Paco Català patinó con Extremadura, que a él le gustaba y conocía, porque había ido a hacer mucha fotografía. No estuvo muy atinado y hubo casi que rehacerlo, y Paco tiró la toalla. En cambio Ramón iba con aquello...".

(R. Masats, Madrid, 17 de julio de 1999) -“Y, más o menos, en aquella época se puso en marcha el segundo canal de televisión [empiezan las emisiones de prueba en 1965, pero oficialmente se estrena en noviembre de 1966]. Esto coincidió con mis ganas de que mis imágenes se movieran. Pero

126 Palacio, Manuel, “Ramón Masats y la televisión”, en AA. VV., Ramón Masats, Ibèria inèdita, Barcelona, L' Alternativa, 2000, pág. 32. 
ten en cuenta que cuando yo he hecho cine o televisión nunca he sido director de fotografía. Es decir, lo que he hecho ha sido dirigir. He seleccionado a operadores que fueran bien con lo que... -porque no todo el mundo funciona bien para todo-. Pero yo nunca he iluminado y muy pocas veces he cogido la cámara. Aunque hice cosas de tipo personal, hasta el año 1982 no volví a hacer fotografía".

(Josetxo Cerdán, Barcelona, 17 de noviembre de 2000) -“La obra de Ramón es mucho más extensa en el terreno audiovisual, dejando aparte su obra fotográfica. Cuando una persona como Manuel Palacio, que se encarga de hacer el capítulo de televisión [del libro Ramón Masats, Ibèria Inèdita, Barcelona, L'Alternativa, 2000] se da cuenta de que Ramón Masats es, poco menos, que la mano derecha de Salvador Pons para montar la segunda cadena de Televisión Española ¡y con todo lo que eso supone....".

(R. Masats, Barcelona, 17 de noviembre de 2000) -“No te diré que no. No soy humilde".

“Cuando lo de Verín llevaba yo un par de años dirigiendo la segunda cadena de TVE, decisión debida ¡Cómo no! al ministro Fraga. Había iniciado, casi un año antes la producción de una serie de documentales para la primera cadena que, con el título de «Conozca usted España», me encargó tras mi actuación durante 1965 como comisario del Año Santo Compostelano, designación asimismo de Fraga. El dedo jupiterino del Ministro decidió, sin excepción, mi carrera en la Casa y a ello debo gran parte de las satisfacciones profesionales que he encontrado a lo largo de la misma.

Cuando en julio de 1966 llegué a Prado del Rey para dirigir TVE 2 llevaba unos meses produciendo los citados documentales. Fraga mantenía que los españoles no conocíamos suficientemente nuestro propio país y que había que estimularlo: le expuse un plan en el que la utilización de TV constituiría la actuación más destacada. Me puse manos a la obra gracias a las relaciones que el excelente fotógrafo Ramón Masats, de mi época de responsable de publicaciones de Turismo, tenía con los directores recién salidos de la Escuela de Cine, especialmente Mario Camus"127.

(Jesús García de Dueñas, Barcelona, 17 de noviembre de 2000) -“Salvador Pons era responsable de Conozca usted España, serie en la que tuvo una importancia esencial Ramón. Conozca usted España nacía, si ustedes recuerdan, de los dictados del Ministerio de Información y Turismo: Fraga Iribarne. Era un eslogan político, tan siniestro como eran todos aquellos. Entonces, Salvador Pons se encontró con que tenía que hacer unos documentales de calidad, para que pusieran en imágenes el mundo de Conozca usted España: el de la maravillosa España del desarrollo".

(Josetxo Cerdán, Barcelona, 17 de noviembre de 2000) -“Cuando Televisión Española va a buscar a sus realizadores a la Escuela Oficial de Cine -no es ninguna novedad- ahí está Ramón como mano derecha de la persona que está dirigiendo ese asunto. Eso es muy importante".

(Jesús García de Dueñas, Barcelona, 17 de noviembre de 2000) -“Quería añadir, para contextualizar esto que acabas de decir... Porque, afortunadamente Ramón ha reconocido, a pesar de su modestia, que él tiene el orgullo de ser responsable de aquello, y que aquello no se hubiera hecho si no hubiera estado allí".

(R. Masats, Barcelona, 17 de noviembre de 2000) -"Sí se hubiera hecho, pero se hubiera hecho de otra manera. No se puede saber cómo hubiera salido".

“La presencia de mi buen amigo Ramón M. Fue importante, decisiva en el arranque de «Conozca usted España» y luego en series de documentales, pero hubo más asesores, había más géneros: música, foIklore, entretenimiento, etc. Pero la lealtad, generosidad y buen oficio de Ramonet fueron proverbiales y eso nunca se olvida"128.

127 Pons Muñoz, Salvador, “Sí, señor ministro", en AA. VV. Manuel Fraga, homenaje académico, Madrid, Fundación Cánovas del Castillo, 1997, págs. 231-232.

128 Salvador Pons Muñoz, correspondencia con el autor, 1 de enero de 2007. 
(Jesús García de Dueñas, Barcelona, 17 de noviembre de 2000) -“Pero Salvador Pons se encontró con un problema y es que los directores posibles que tenía para hacer aquellos documentales eran muy malos. Entonces tuvimos la suerte inmensa, todo el público español y todo el cine español, de que tenía como asesor a Ramón. Ramón le dijo... (no sé si estoy en la integridad de lo que ocurrió, pero puedo decirlo claramente...) «iSalvador no tienes más remedio, macho, que recurrir a la gente de la Escuela Oficial de Cine, que son los que saben!». Bueno... la Escuela Oficial de Cine en aquellos momentos era un nido de rojos, y Salvador tuvo que pasar por ello y llamar a toda aquella gente, llamarnos a todos nosotros -a los que tú conocías, porque eras amigo de todos nosotros- y fuimos los que hicimos aquellos documentales. Eso es importantísimo desde el punto de vista histórico reconocerlo".

(Salvador Pons, Denia, 2 de enero de 2007) -“Y entonces Ramón dijo: "Yo sí tengo un gran amigo que es director de cine: Mario Camus». Mario Camus era director de cine y en el mundillo cinematográfico era muy conocido porque había hecho las películas alimenticias de Raphael. Mario Camus salió de la Escuela de Cine y conocía a toda aquella serie de directores, aspirantes a directores y alumnos aventajados, como era el caso de Claudio Guerín, o gente más talludita como José Luis Borau, que ya era mayor. Con Ramón, en efecto, fuimos distribuyendo los trabajos, lo que íbamos a hacer. Con él yo fui conociendo a toda esta gente. No tiene nada de anecdótico porque formaron todo el plantel de la segunda Ccadena de Televisión Española. Fue trascendente, fundamental. Fue, en efecto, un gran banco de pruebas para lo que después sería el segundo canal de Televisión Española, eso es cierto. Corrió la voz de que una nueva empresa empezaba".

(R. Masats, Madrid, 27 de diciembre de 2006) -“Una de las cosas que hice en la segunda cadena fue incorporar gente joven del cine a la televisión, como Jorge Grau, que empezaron a hacer programas de series de documentales de televisión. Es lo que me encargó Salvador Pons. Él me dijo: «¿Tu experiencia con esta gente... puede servir?». Yo le dije que sí. Todos eran izquierdistas. Salvador era bastante ecléctico. Quiero decir que no era nada tonto y vio que esta gente funcionaba, y le daba igual... Hombre, no había revolucionarios pero sí era gente joven y más bien de izquierdas".

- ¿Y por qué no le servían los realizadores que ya estaban en la primera cadena para montar la segunda?

(R. Masats, Madrid, 27 de diciembre de 2006) -“Es que no había nadie que hiciera documental. Lo único que hacían los realizadores de la primera era teatro televisado o programas como los de Chicho -que no sé en aquellos años qué estaría haciendo- pero, quiero decir, que hacían programas de plató, de estudio multicámara: pones dos cámaras enfrentadas, para el plano y el contraplano y la tercera la pones en medio, que coja los dos por si se levantan (como le dijeron a un amigo mío). Estaba haciendo una obra de teatro y se lo dijeron: «¡Cómo cojones se van a levantar si yo no he dicho que se levanten!». «Bueno, bueno, pero tú ponla en general por si se levantan». ¡Así era la televisión en aquel momento! ¿Comprendes? Estaban haciendo una labor cojonuda, pero eran gente de plató. Documental, que era la orientación que querían darle a la segunda cadena, no existía en la primer cadena".

(Salvador Pons, Denia, 2 de enero de 2007) -“Esa vocación del documental que empezamos con la serie pasaría luego a la televisión. Tuvo un lugar muy importante. No menos de un tercio de nuestra programación eran documentales. La segunda cadena abrió un amplio campo al cine documental del que, evidentemente, ya había tradición... Lo utilizábamos como recurso. Nunca dispusimos de unidades móviles para poder grabar, pero se recorría España de norte a sur y de este a oeste. Toda, sin excepción. Juan Manuel Martín de Blas ha continuado y potenciado este género".

- ¿Y por qué necesitaron recurrir a los directores de la Escuela de Cine?

(Salvador Pons, Denia, 2 de enero de 2007) -“Porque no conocíamos a otros". 
-¿Y los de la primera cadena?

(Salvador Pons, Denia, 2 de enero de 2007) -“Pero es que la serie no pertenecía a Televisión Española, era un producto independiente. Yo, por ejemplo, no tenía sueldo porque yo era un funcionario y cobraba en función de mi categoría como funcionario -quizá tendría un pequeño incremento pero sería un 10 ó un 20\%-. Era una fórmula híbrida. Se trataba de un dinero que, aunque administraba Paco Molero, en realidad que venía de la Dirección General de Radiodifusión, de la que dependía Televisión Española porque era un organismo estatal que estaba integrado funcionalmente en el Ministerio, como en cualquier país totalitario. Por ejemplo, algunas secretarias eran del Ministerio y todo lo demás se pagaban como colaboraciones. La serie no fue una producción de Televisión Española, fue una producción independiente, si cabe llamarla así. Quiero pensar -porque no lo sé bien- que el dinero vino de los presupuestos de Televisión Española, pero fue administrado por un productor -Paco Molero- que nunca trabajó en Televisión Española, que había trabajado mucho con la productora de Samuel Bronston, que como usted sabrá hicieron aquellas superproducciones en España: La caída del Imperio Romano y todas aquellas películas. Aquellas películas desarrollaron mucho la producción en España porque pedían caballos, decorados...".

Algunos de aquellos autores, que Masats ayudó a rescatar de la Escuela de Cine, fueron: Pío Caro Baroja, Jesús Fernández Santos, Mario Camus, Pedro Olea, Claudio Guerín Hill, Francisco Regueiro, Jaime Chavarri, Emilio Martínez Lázaro, Antonio Mercero, Miguel Picazo, Alfonso Ungría, Fernando Méndez Leite, Jesús García de Dueñas, Jorge Grau, Josefina Molina, Antonio Drove, Antonio Giménez Rico, José María Font Espina, Ricardo Franco, Julio Diamante...

(Salvador Pons, Denia, 2 de enero de 2007) - “Casi todos los realizadores se negaron a trabajar con $16 \mathrm{~mm}$ o a manejar ellos mismos las cámaras de televisión. Creo que de los pocos ambidiestros que a veces cogía la cámara estaba Claudio Guerín. Todos en 35mm y en blanco y negro, porque era más económico, era lo que entonces se hacía y la televisión emitía en blanco y negro. Los programas tenían una calidad de imagen muy buena".

-Partiendo de tus modestas intenciones iniciales para experimentar con el montaje llegaste, sin embargo, a dirigir toda una serie...

(R. Masats, Madrid, 27 de diciembre de 2006) -“Bueno, lo único que hacía yo era decir quién podía dirigir cada capítulo y quién podía hacer el guión. Luego me leía el guión y le decía si bien o no. Pero no dirigí toda la serie".

-Eras como un jefe de realizadores.

(R. Masats, Madrid, 27 de diciembre de 2006) -“Sí, pero no hubo ninguna tensión ni ninguna rivalidad entre ellos. Todos se lo tomaban como una oportunidad de creación de media hora, no como una cosa que les solucionara la vida. Ninguno necesitaba realmente el dinero. Todos eran de buena familia porque casi todos salieron de la Escuela de Cine. Eran más jóvenes que la generación de Manolo Summers".

-Actuabas como un director ejecutivo.

(R. Masats, Madrid, 27 de diciembre de 2006) -“Sí, pero eso me llevaba... Cuando venía de rodar y estaba en montaje... si por la mañana estaba en montaje por la tarde me podía dedicar a esto. No era tanto trabajo: era más el golpe de timón, sabiendo más o menos lo que Salvador pretendía. Salvador era un político, que sólo sabía de televisión lo que había visto en la pantalla, pero era un tío inteligente, tenía una cierta sensibilidad. Se trataba de enseñar España. Hicimos una serie de tópicos, que es siempre lo que me ha funcionado: Las Ramblas, esto y aquello. Por ejemplo, hicimos una embajada, que también es España. Hicimos la de Washington y fui a ver cómo funcionaba una embajada por dentro: Una embajada española en Washington (1966). Como era una serie nueva hicimos una presentación, que la hizo Leopoldo Pomés, que en aquel momento ya estaba haciendo cine". 
(Salvador Pons, Denia, 2 de enero de 2007) -“Ramón en lo que ha sido un maestro es en abrir espacios. Digamos... series que yo tenía en la cabeza pero que no sabía cómo hincarles el diente. Hablábamos de estas series en conversaciones que acababan a las tres de la mañana. Chocábamos contra un muro, pero luego encontrábamos una salida. No había base, ni gente, ni medios, lo que había era imaginación creadora y mucho entusiasmo. Yo nunca tuve ni huelgas, ni peticiones de horas extraordinarias, ni plantes... No existían. ¡Éramos tan pequeños! Yo creo que éramos ocho o nueve del staff los que teníamos despacho. Ramón no tenía despacho allí. Estaba como tantos otros. Yo diría que con el estatus de Ramón, como consejeros aúlicos, estaban: Ramón, que tenía el mérito de ser el primero, Pío Caro Baroja, Jesús Fernández Santos, José Luis Borau, Guerín... Era la gente en la que nos apoyábamos. Con Ramón sacamos esta serie de Conozca usted España, no fue el único asesor. No fue el consejero. Fue muy importante, qué duda cabe. Sí fue el primero pero no el único".

Cabe reseñar que todos los autores reseñados disfrutaron de unas condiciones de trabajo realmente excepcionales: disfrutaron de una libertad creativa inaudita en plena Dictadura para desarrollar sus iniciativas y hasta para escoger a sus colaboradores. No sufrieron la censura previa de los guiones. Asimismo, tampoco había nadie que supervisara el material realizado. La censura se limitaba a la obra acabada. La marginalidad y la audiencia minoritaria de los programas de la UHF permitió licencias impensables como hablar de Miguel Hernández.

“Un domingo por la tarde, que la Primera emitía en directo un partido de fútbol de la máxima expectación, programamos a la misma hora un recital de lo que entonces se denominaban los Coros Alexandrov, que eran los mismísimos coros del ejército soviético (advierto que estábamos en los años 67 ó 68) (...) entonando el Volga, Volga, Kalinska y otras canciones, cuyo título ignoro pero que mi oído las recuerda perfectamente de la época de nuestra Guerra Civil"129.

Ni siquiera se sometieron a la soberana autoridad de las audiencias u otras cuestiones de rentabilidad económica.

\begin{abstract}
“Huelga decir que la nueva cadena tenía una cobertura territorial minúscula: y para comprobarlo baste decir que todavía en 1976, diez años más tarde de su estreno oficial, el UHF, apenas cubría el cincuenta por ciento del territorio español (...) Su carácter ultraminoritario tuvo un tangible corolario: los programas de la segunda cadena se movían quedamente en los ambientes políticos del franquismo con lo que permitió que los espacios tuvieran un aumento de los decibles fílmicos, francamente inesperado en la dictadura. Y a más: en la televisión del servicio público y específicamente los programas de «segundas cadenas», en un caso único y extraordinario en todo el audiovisual del siglo XX, actuaban al margen de cualquier requerimiento económico y sin necesidad de contar con el beneplácito del público (...) hacían su trabajo creativo despreocupados absolutamente por las exigencias de circularidad económica obligatoria en toda industria"130.
\end{abstract}

(Salvador Pons, Denia, 2 de enero de 2007) -“La segunda cadena era tratada de una manera un tanto despectiva por parte de Prado del Rey, nos llamaban «la cadenilla», como la de tirar del retrete. Teníamos muy pocos medios, nos dejaron muy pocos estudios. Sólo emitíamos tres horas al día, de nueve a doce, salvo los sábados y domingos que creo que empezábamos a las siete de la noche".

-Tuviste problemas con la censura. 
(R. Masats, Madrid, 27 de diciembre de 2006) -“Lo único que pasó fue que el director de Televisión Española que en aquel momento era Adolfo Suárez, cuando hice el documental sobre Lanzarote, Insular (1972), con música de Luis de Pablo, llamó a Salvador y le dijo: «¡Como vuelvas a hacer otra mariconada como ésta os hecho a Ramón y a ti!». No le gustó nada. Aparte de esto hubo los habituales cortes de censura. En otra ocasión me censuraron un programa que se llamó Apuntes vascos. Quedó muy bien y Televisión Española nos dijo que iría en la serie de Manolo Garrido, Raíces, pero fue a un festival de Irlanda y nunca más se supo. Tenía un tinte izquierdoso, comprensivo para con ETA. Ten en cuenta que Franco aún estaba vivo, y no les gustó nada en absoluto. Dijeron que para un festival estaba bien pero para emitirlo por televisión no. Tampoco era a favor de ETA... Me acuerdo de una anécdota. Hay un grupo de marineros de pueblo que cogen un ataúd y hay uno que baila encima del ataúd. Entonces los estuvimos paseando por todo el pueblo... y al principio no querían hacerlo para nosotros. Dijeron: «Que opine la juventud». Debían de ser de ETA o simpatizantes. Me acuerdo que fui con Manolo Garrido a esa reunión de jóvenes y había bastantes que decían que no había que colaborar con Televisión Española de ninguna manera. Al final los convencí, de lo cual a veces me arrepiento".

- ¿Entonces la censura recortó mucho tu trabajo?

(R. Masats, Madrid, 27 de diciembre de 2006) -“Algunas cosas. Me acuerdo de un plano -que está en la antológica que he montado en la exposición Contactos- en que de un grupo de corderos subía con una panorámica a una cruz de la Falange y luego volvía a bajar a los corderos. Me dijeron que era muy sutil, pero que qué coño me había pensado yo. Pero muchas veces pasaba como con los pintores abstractos, que eran todos de izquierdas, pero como lo que pintaban era abstracto no hacían ningún daño y entonces los llevaban a las bienales y daban una sensación de apertura que le venía muy bien al Régimen. Eso, en un sentido muchísimo menor, porque no tenía ninguna repercusión fuera de los cuatro que veían la segunda cadena, era lo mismo a lo que jugaba el Régimen con nosotros".

-Tampoco había que dar explicaciones por fracasos de audiencia.

(R. Masats, Madrid, 27 de diciembre de 2006) -“En absoluto".

-En realidad teníais más libertad que la que pueda tener un realizador hoy en día, pues no estabais sometidos a la dictadura de la audiencia.

(R. Masats, Madrid, 27 de diciembre de 2006) -“Sí, mucha más”.

-Podíais experimentar.

(R. Masats, Madrid, 27 de diciembre de 2006) -“'Yo nunca he tenido problemas con dirección, salvo los lógicos con la gentuza que llevaba producción, pero si pedía una grúa o un helicóptero me los dejaban".

-Salvador Pons te dio mucha cancha y mucha libertad para dirigir y organizar.

(R. Masats, Madrid, 27 de diciembre de 2006) -“Sí, bueno, él sabía lo que quería, pero me dio mucha libertad. Con Salvador nunca tuve ningún problema, ni castigó nunca a nadie".

\footnotetext{
“No había problemas laborales, nadie exigía nada por trabajar sábados y domingos. Lo que aportábamos a la naciente UHF fue todo el background cultural que habíamos adquirido por la lectura y en la Universidad. Se buscó el talento, la calidad, la excelencia, sin poner barreras a nadie (...) Se podían hacer experimentos, ensayos y así se creó una televisión de vanguardia que rompía moldes anquilosados y aportaba una bocanada de aire fresco en el ámbito cultural televisivo: lo que años más tarde ha venido en denominarse televisión pública. Es justo reconocer que Fraga apoyaba implícitamente esta operación"131.
} 
(Salvador Pons, Denia, 2 de enero de 2007) -“Autonomía, libertad, creatividad, sobre todo gran espíritu creativo. Todo el mundo aportó. Nos reuníamos domingos y hablábamos, discutíamos. Fue la época de mayor satisfacción profesional: muy estimulante, muy estimulante. Éramos muy poco vistos, lo que proporcionaba una gran libertad. Nadie tenía que dar explicaciones de audiencias".

(Jesús García de Dueñas, Barcelona, 17 de noviembre de 2000) -“Por otro lado, Ramón como director de cine, hay que decirlo, creó un estilo personal de cómo se deberían hacer los documentales. No es que tuviera esa pretensión didáctica... porque no la ha tenido nunca ¡Jamás en la vida! Pero la manera de hacer él, de trabajar y de crear el cine... Él creo un estilo de cómo se deberían hacer los documentales, un estilo del que todos hemos chupado rueda... Hay un antes y un después de cómo se han hecho los documentales en Televisión Española, y el que ha seguido esa senda con mayor fortuna y creatividad es Jaime Villa... que es el que yo considero el heredero legítimo suyo".

“Sea como fuere, en los primero años del UHF se creó un estilo colectivo de realización (...) un propio
sistema de representación al servicio de una nueva mirada al país (...) las obras tendrán una duración
de unos treinta minutos (...) unas producciones con elevadísimo componente pedagógico articulado
sobre elementos de la alta cultura -literatura, música, arte, historia, antropología (...) la cultura es-
pañola como espacio simbólico en el que fraguan las llamadas culturas regionales como la catalana. Y
por último, y quizá el aspecto que más choca en la actualidad, las series de TVE eran unos productos
híbridos que utilizan recursos estilísticos de las formas de representación documental pero también de
otras de la ficción: voz expositiva omnisciente y pequeñas dramatizaciones y puesta en escena"132.

-Utilizabais pequeñas dramatizaciones en los documentales.

(R. Masats, Madrid, 27 de diciembre de 2006) -“Esto lo utilice yo por primera vez iperdón! en la serie Si las piedras hablaran con guión de Antonio Gala. Este guión tenía muchos diálogos entre personajes y yo me inventé que tenían que aparecer unos personajes que eran las monjas de clausura, todas cubiertas. Y lo rodaba como en un musical. Por ejemplo, un señor le decía algo a la monja, la monja no sabía nada de esto y bajaba por unas escaleras. En un momento determinado yo le decía: «Párese y vuélvase hacia mí». La monja se volvía. En el montaje, con el diálogo, tenía una explicación porque ella reaccionaba a lo que le decía otro personaje girándose. Pero una monja no lo vio muy claro y se quejó a la madre superiora. Claro, ellas no sabían de qué iba la cosa. Me quedaba muy poco por rodar y tuve que parar el rodaje para ir a Valladolid para hablar con el obispo. Le enseñe el guión, le expliqué qué estaban haciendo las monjas y le gustó la idea. Me dijo: «A mí esto me parece muy original y puede quedar muy bien, pero yo creo que ellas deberían saber qué está haciendo». «Pues tiene usted razón». "¿Y qué hacemos? Si les pide usted que acaben el rodaje...». Porque, como eran de clausura, yo no podía hablar directamente con ellas. Y así fue cómo el obispo dio su permiso".

(Salvador Pons, Denia, 2 de enero de 2007) -“Ramón hizo, a mi juicio, un documental -quizá él no le diera importancia- pero para nosotros tuvo una gran importancia y estuvo muy bien: fue uno sobre la Casa de Alba. En esta serie de Conozca usted España algunas ideas iban a medias entre el ministro Fraga y yo. No es porque yo fuera una persona importante, pero el Ministro Fraga se interesó mucho: «¿Oye, tú conoces a la Duquesa de Alba?». Yo estaba con él como una especie de asesor para asuntos extraordinarios, sin ser director general yo tenía acceso directo al ministro (no he llegado a ser ni siquiera subdirector general), pero él se interesó mucho por la serie. «iTienes que conocer a Cayetana!». Yo hablé con el marido para facilitar el acceso a Ramón, y Ramón, con una gran habilidad... «iPorque esta mujer tiene más títulos reales y más grandezas de España que la propia Reina 
de Inglaterra!». Nunca olvidaré el primer plano del documental porque se aprovechó un concierto de cámara que se organizó en el Palacio de Liria en Madrid, que es la sede de la Casa de Alba. Estaba ella con su marido y sus hijos en el concierto, y en un plano largo, muy lento, que iba recorriendo primero la cara de ella... A su vez, se iban enumerando los títulos nobiliarios: ¡Grande de España, Condesa Duquesa de Olivares...! Unos títulos impresionantes y luego el palacio es precioso. Tiene un retrato de la propia Duquesa de Alba pintado por Goya. Ramón fue un gran rompehielos. Ya le he hablado del programa de la Casa de Alba, porque era un hueso. Pero más hueso fue la serie Si las piedras hablaran, en que yo elegí mentalmente para Ramón el tema que me parecía más difícil, porque la serie se basaba en edificios del Patrimonio Nacional. Recuerdo el dedicado al Monasterio de Tordesillas. (La soledad de una reina. Real Convento de Santa Clara de Tordesillas de 1972). Yo, deliberadamente, sabía que Tordesillas era un monasterio de clausura, muy pequeño. Y yo dije: «Si acertamos en éste, la serie está hecha». ¿Quién se iba a encargar de este primero? Yo no sé si Ramón dijo «yo», o yo le dije a Ramón que lo hiciera. Ramón se fue como se fue Colón a descubrir las Américas: «iA ver que trae éste!» Ramón trajo un programa piloto que a mí me pareció espléndido: ¡el partido que le sacó a las caras!, las escenas a través de las celosías de la clausura... bellísimo, bellísimo. Ramón, sin duda, tenía un sentido plástico y de la idea que partía de la imagen...".

Tal y como apuntábamos al inicio del presente apartado, es evidente que la obra audiovisual de Masats merece un análisis mucho más detallado que el que ofrecemos en estas páginas. Queda, así, abierto un campo que autores como el citado profesor Cerdán han comenzado a abordar. No obstante, de toda esta amplia producción televisiva, deseamos detenernos en un documental que, posiblemente, sea en el que más se hayan desarrollado algunos de los elementos que Masats ya manejó en su faceta fotográfica. Siendo Los Sanfermines el libro más cinematográfico de su bibliografía, éste puede ser uno de los documentales más fotográficos de nuestro autor.

(Josetxo Cerdán, Barcelona, 17 de noviembre de 2000) -“Cuando expuso Ramón en el Circulo de Bellas Artes de Madrid una retrospectiva de toda su obra, hizo un espacio para su obra audiovisual, porque Ramón ha estado casi veinte años haciendo televisión y cortometrajes".

(R. Masats, Barcelona, 17 de noviembre de 2000) -“Dieciocho".

(Josetxo Cerdán, Barcelona, 17 de noviembre de 2000) -“Sí, él escogió una pieza para poner dentro de aquella retrospectiva, una pieza que hizo para Televisión Española que se llama Insular. Se trata de un trabajo de media hora que es una ilustración de diferentes obras de Luis de Pablo pertenecientes a una serie de televisión que se llamaba Intima Armonía".

Insular fue estrenado el 24 de enero de 1972 en la segunda cadena. En dicho documental las imágenes estaban extraídas de Lanzarote

-¿Cómo te surgió hacer el documental sobre Lanzarote?

(R. Masats, Madrid, 15 de diciembre de 2003) -“Fue una proposición de Televisión Española. Me pidieron que hiciera un proyecto sobre visualización de España a través de músicos españoles. Les hice una lista... Me parece que eran doce. No se terminó la serie, pero se hizo Sevilla con Albéniz, la Alhambra con no sé quién... Pero yo no lo hice. Yo me guarde Lanzarote para mí, porque conocía la isla. Ya había hecho documentales sobre Lanzarote. Y lo hice con música de Luis de Pablo".

- ¿Y por qué Luis de Pablo con Lanzarote?

(R. Masats, Madrid, 15 de diciembre de 2003) -“Porque es un poco el caos... y me iba muy bien”.

“En la realización aparece Luis de Pablo, porque a mí entender él me sugiere con su música gran parte de lo que he recogido en Lanzarote, es decir el enorme impresionismo que se produce ante nuestros ojos al contemplar sus pueblos, su cultivos y sus volcanes (...) Creo en la televisión como iniciación para que todos lleguen a comprender la música de nuestros contemporáneos"133. 
(R. Masats, Madrid, 27 de diciembre de 2006) -“Yo ya había hecho un Conozca Usted España sobre Lanzarote. Como Salvador conocía Lanzarote y la música de Luis de Pablo (Salvador luego fue director general de música, es decir que entendía de música), le pareció una buena idea".

(R. Masats, Madrid, 15 de diciembre de 2003) -“Cuando fuimos allí tuvimos muchísimos problemas, porque creo que nunca había llovido tanto en Lanzarote. Pero bueno, me permitieron grabar con todo el material que necesité y no tuve ninguna traba en ese sentido".

- Me he dado cuenta de que a la hora de montar...

(R. Masats, Madrid, 15 de diciembre de 2003) -“El montaje duró dos o tres meses".

"«Insular» consta de seis piezas de ilustran otras tantas composiciones musicales de Luis de Pablo (algunas de ellas entre las más celebres del músico tales como Módulos III, Módulos V e Imaginario II, todas de 1967). Ciertamente es una obra absolutamente admirable en lo que tiene de fijar las correspondencias entre una partitura musical y un determinado diseño cinematográfico. Masats utilizando una película de alto contraste y a base tanto de firmes y vigorosos movimientos de cámara cuanto de una medida configuración de los planos estáticos y de un determinado ritmo de montaje crea visualizaciones que se acoplan modélicamente al sentido rítmico de la música electrónica del compositor bilbaíno"134.

-¡Dos o tres meses para montar Insular? Parece ciencia ficción hoy en día.

(R. Masats, Madrid, 27 de diciembre de 2006) -“Claro, era a capón o a contracapón. Tenía que poner la música y probar con los planos. Ahora éste no funciona... y probar otra vez. El ritmo de montaje tuve que pensarlo en la moviola y tuve tiempo de probar y repetir y corregir. Fue muy largo".

-Llevabas algún tipo de boceto de lo que ibas a grabar.

(R. Masats, Madrid, 15 de diciembre de 2003) -“No, lo que sí sabía eran los temas que quería: turismo, agricultura, volcanes, florecimiento de las plantas... Sabía más o menos la música que iba a poner a cada uno de los bloques. Lo que hicimos en montaje fue seleccionar la música definitivamente y hacer bloques de lo que correspondería a cada música. Es decir, casar cada música con cada bloque temático. Posteriormente con las imágenes ya decíamos: «Esto va en el dos, esto en el cuatro» y se iban metiendo. Rodé mucho. No me pusieron ningún problema".

“El film establece un recorrido que crece a partir de la dialéctica entre la agreste naturaleza volcánica de Lanzarote y las sucesivas huellas culturales, humanas; éstas inicialmente de los pobladores y costumbres casi ancestrales y, según avanza el relato, también otras más recientes como las del turismo. $\mathrm{Si}$ atendemos al último subcapítulo del programa -Imaginario II- Masats cree posible una síntesis integradora de ambos polos, quizá encarnada en el film en la figura de César Manrique: arquitecto y diseñador de artefactos culturales y artísticos que realiza su trabajo en un marco natural"135.

-Los planos finales de los turistas grabados aceleradamente no están pensados a posteriori en la sala de edición.

(R. Masats, Madrid, 15 de diciembre de 2003) -“Sí, claro".

-Entonces sí que llevabas un guión más o menos cerrado.

(R. Masats, Madrid, 15 de diciembre de 2003) -“Sabía lo que quería. Por ejemplo, el hombre que tira del camello, el respeto de no ponerlo en ridículo, dignificándolo con cámara lenta... Todo esto sí lo tenía pensado. Quizá no antes de ir a la isla, pero sí en el momento del rodaje... El respeto al camellero y ridiculizar al turismo: eso estaba rodado así".

-Las puertas abriéndose y cerrándose marcan un ritmo frenético. 
(R. Masats, Madrid, 15 de diciembre de 2003) -“Sí, todo esto estaba estructurado, si no grabar tanto sin un orden hubiera sido un desmadre".

- ¿La fotografía la hiciste tú?

(R. Masats, Madrid, 15 de diciembre de 2003) -“Sólo los angulares. Todo lo demás no, pero los angulares sí. Tenía un buen cámara. Federico Larraya era una maravilla. El montaje también está muy cuidado. No todo el montaje está a golpes y con cambios de plano rápidos. A veces sí y a veces no. Está muy cuidado".

-Sí, unas veces el montaje está más acelerado, otras veces son planos más largos, aunque sean con movimiento... Porque creo que planos fijos... no hay ninguno en todo el documental. Hay mucho dinamismo, lo mismo que sucede en tus libros... Si te hubiera tocado grabar en la Alhambra...

(R. Masats, Madrid, 15 de diciembre de 2003) -“No me hubiera gustado tanto como esto. En cuanto me dieron a escoger ya lo tenía claro. Éste es el documental que me ha gustado más. Sería como el libro de boxeo de los documentales".

Esta comparación del propio Masats entre Insular y Neutral Corner nos es muy útil en este breve análisis, puesto que creemos que hay un grupo de características de este trabajo que lo acercan mucho a su obra fotográfica. Por ejemplo, ya comentamos que en este documental no utiliza la voz en off o cualquier rotulación que explique o redunde en lo que la propia imagen expone.

"Insular es un audiovisual (...) singular no sólo en la carrera de Masats, sino en la propia historia de la televisión española. Lo que más nos interesa ahora es que se trata de una de esas extrañas ocasiones en las que un documental televisivo no recurre a una voice over que fije unívocamente el sentido de las imágenes que se ven en la pantalla (...) La práctica de fijar el sentido de las imágenes de los documentales y noticieros mediante la voice over es un recurso del cual se apropia la televisión desde su nacimiento, pero que en realidad tiene una fuerte tradición en el documental cinematográfico (incluso desde los tiempos del mudo, cuando el lugar de esa voice over lo ocupan los intertítulos escritos en tercera persona). No hace falta insistir en que esa fijación del sentido de la imagen por parte de la voice over (también en tercera persona, en el papel del narrador omnisciente) está evidentemente emparentado con los pies de foto (ya sea en prensa, en una sala de exposiciones o en un libro de reportaje fotográfico) (...) La técnica la repetirá Masats, al menos, en Sisa (1978), capítulo dedicado al cantautor catalán de la serie Yo canto"136.

Por otro lado, hay que recordar que este trabajo fue uno de sus primeros documentales en color. Utilizó película de alto contraste y de gran saturación en los colores, lo que equivaldría a una película fotográfica de blanco y negro forzada un punto para aumentar el contraste, el dramatismo y el negro. Cuando vuelva a la fotografía, a partir de 1981, retomará este tipo de película de gran saturación y contraste para su nueva etapa en color. Usará, al principio, la película Kodachrome de baja sensibilidad y después la Velvia de Fuji de 50 ISO. Recordamos, perfectamente, el disgusto que tenía Masats al contemplar (en diciembre de 2003) los colores desvaídos de la copia de Insular que TVE le había facilitado. No se detuvo hasta que consiguió una copia restaurada que luciera los colores en los que tanto cuidado había puesto él mismo.

El uso de angulares (tan difíciles de componer y que llevo a que el propio Masats se ponga al frente de la cámara) nos recuerda su pasión por el 21 de Leica, o aquel angular Biogon de 38 mm de Hasselblad que Carlos Saura tanto envidiara. Probablemente, el montaje de la paginación heredado de The Family of Man, o de William Klein, que ya se podía rastrear en sus libros o reportajes publicados en Gaceta Ilustrada, aquel intuido interés por la experimentación en la maquetación, culminará en el impresionante montaje cinematográfico de Insular. 
Otra coincidencia que encontramos entre los intereses fotográficos y los fílmicos de Masats la hallamos en el componente humano de su obra. A pesar de la espectacular naturaleza de Lanzarote, Masats no se limita a los volcanes y al caos convulsivo de las erupciones, sino que vuelve, como siempre, a la faceta humana de la isla: la tradición, la cultura y la supervivencia del hombre en un medio agreste, los conflictos entre desarrollo y respeto medioambiental, el equilibrio que encuentra en la figura de César Manrique...

Aunque hayamos destacado este documental como uno de los más relacionados con su faceta como fotógrafo, lo cierto es que los nexos de unión entre ambos aspectos de su obra son realmente prolijos. Entre el 10 de junio y el 23 de julio de 2006 Ramón Masats expuso un resumen de su obra audiovisual con ocasión de su exposición antológica Contactos, realizada en la Real Fábrica de Tapices de Madrid. En realidad, este breve resumen de apenas 25 minutos no recoge ni tan siquiera la mitad de toda su obra televisiva, pues Masats no ha podido encontrar el resto de sus trabajos cinematográficos. La dificultad de disponer de la obra audiovisual de Masats ya quedó suficientemente denunciada por Josetxo Cerdán en la introducción de su estudio sobre la imagen en movimiento de nuestro autor:

\footnotetext{
“Aunque quizá este no es el lugar adecuado, queremos advertir aquí que este texto se ha escrito trabajando sólo con una parte muy pequeña del material audiovisual que Ramón Masats ha realizado a lo largo de su carrera. La consulta del resto del material ha sido imposible o sumamente problemática. Cabe llamar la atención sobre el hecho anómalo de que vivimos en un país en el que resulta imposible trabajar la obra audiovisual de un premio Nacional de Fotografía (Ramón Masats lo fue en 2004) porque ninguna institución se ha preocupado de su preservación, restauración y puesta al servicio de los investigadores a pesar de la, aparente, importancia de su autor"137.
}

A pesar de ello, hemos podido encontrar muchísimas similitudes temáticas en este resumen entre las imágenes en movimiento y sus trabajos como fotógrafo. Así, no debemos olvidar que uno de sus primeros documentales, realizado dentro de la serie Conozca usted España, es sobre Las Ramblas. Masats regresa a sus tópicos sí, pero es que además, prefiere no arriesgarse en un medio que todavía le resulta nuevo, lo que le lleva a revisitar literalmente a viejos conocidos. En la antológica a la que nos hemos referido incluye una imagen de ese documental sobre Las Ramblas, un limpiabotas, que precisamente tiene su equivalente en otro limpiabotas que Masats fotografió e incluyó en su primera exposición fotográfica de 1957. Asimismo, encontramos muchos planos en movimiento que previamente ya habíamos visto en sus fotografías, como los paisajes realizados en Tierra de Campos, o los pastores cubiertos por boina y pañuelo fotografiados con anterioridad, en 1961.

Famosa es la lectura que Masats realiza de su propia obra, autorreferenciándose a sí mismo, en la película Topical Spanish. En la primera secuencia un seminarista que está jugando al fútbol con su compañeros de seminario, aprovecha que el balón ha caído al otro lado de la tapia para fugarse dejando la sotana junto a la pelota, en la misma postura que se advierte en su famosísima imagen del portero seminarista.

Sin embargo, esa correspondencia temática no es unidireccional, es decir, no se realiza únicamente desde la fotografía al cine. Su fotografía en color se verá directamente influida por sus planos de documentales televisivos. Por ejemplo, el osario de Wamba (Valladolid) fue descubierto en su periodo de televisión en blanco y negro y posteriormente fotografiado en color en 1981. Por otro lado, casi todas la imágenes aéreas, que se recuperan en el resumen audiovisual de la exposición Contactos, tienen su equivalencia exacta en sus libros fotográficos en color. Así el Castillo de Bellver de Mallorca, la Sagrada Familia de Barcelona, el Teatro Romano de Mérida, la 
Alhambra de Granada, el Alcázar de Segovia, la Giralda de Sevilla... están publicadas en planos que son realmente idénticos a los utilizados en los audiovisuales y que quedan recogidos en el libro Desde el cielo a España (Lunwerg, 1988). Esta equivalencia en los planos aéreos pueden tener su razón de ser por una cuestión de economía y amortización de las infraestructuras: en varias ocasiones Masats aprovecha el helicóptero para rodar y fotografiar a la vez. Por ejemplo, la imagen del Giraldillo, que abre su libro Sevilla está tomada exactamente en el mismo instante en que lo grabó para un documental que estaba realizando para la Expo de Sevilla de 1992 y que aparece en un plano de la citada recopilación. La posición del sol de atardecer y un pequeño pajaro apoyado en la escultura delatan la simultaneidad de tomas...

Sin embargo, no todas las imágenes se repiten por mera economía de medios de producción. Hay ideas que a Masats le han funcionado en video y las repite en foto fija exactamente igual, con el mismo punto de vista, el mismo encuadre y hasta, parece, la misma óptica. Por ejemplo, la fotografía del Hipódromo de la Zarzuela, que aparece en su Libro España diversa (Luna Wennberg, 1982), es reproducida como imagen en movimiento en esta recopilación de documentales a los que nos referimos. Tiene la misma sensación de dinamismo, el mismo efecto de barrido de colores... Hasta algún chiste - de esos socarrones que tanto le gustan a Masats- tienen su versión fija y en movimiento: hay una secuencia en Contactos dedicada a la Feria de Sevilla. Unas sevillanas se oyen en el audio y en la letra de la música se escucha: -"Sevilla en primavera, gloria bendita" y la imagen que aparece es la de un señor recogiendo estiércol de los caballos de la feria. Masats también se fijó en ese detalle en una foto de su libro España diversa.

Lo más sorprendente es comprobar cómo Masats utiliza las imágenes narrativamente del mismo modo en los libros y en este resumen al que hemos podido acceder y analizar. Por ejemplo, el Giraldillo es utilizado en el documental abriendo y cerrando una secuencia, del mismo modo a como es usado en el libro de Sevilla donde también abre el libro y posteriormente cierra un grupo de imágenes a modo de secuencia. De la misma manera aparecen las esculturas de los toros de Guisando prácticamente al principio del libro Toro (Lunwerg, 1998) y al inicio de la secuencia dedicada al toreo del resumen. De hecho, toda la secuencia del resumen audiovisual dedicada al toreo está estructurada igual que el libro, con la diferencia de que el libro es más optimista y acaba con el nacimiento del novillo y el documental finaliza con un primer plano de la muerte de un toro en la plaza.

En cualquier caso, lo que hemos pretendido resaltar en esta breve aproximación es la inevitable continuidad de las dos facetas creativas de Masats, a veces tan próximas que parece que fotografíe audiovisualmente y dirija sus documentales de un modo fotográfico.

-¿Y por qué dejaste la televisión?

(R. Masats, Madrid, 27 de diciembre de 2006) - “Yo nunca he sido fijo de ningún sitio, no me gusta estar fijo. Los realizadores de Televisión Española no estábamos fijos si no que nos pagaban por documental realizado. Entonces, Pilar Miró -que era del PSOE- y algunos otros -que también estaban politizados- pensaban que desde dentro de Televisión se podía hacer algo para que la Televisión fuera mejor. Los realizadores le pusieron un pleito a Televisión Española en donde, si demostraban que habían estado trabajando durante tanto tiempo, el cien por cien de los casos el juez obligaba a la empresa a hacerte fijo. Y eso es lo que pasó. Yo no lo vi claro, no me gustaba hacerme fijo. Ellos ganaron ese pleito y entraron fijos y empezaron a trabajar. Entonces televisión les encargaba los documentales a los que ya eran fijos. No había más razón que la "artística» para que contrataran a alguien de fuera, como era mi caso. Yo seguí colaborando con Televisión Española pero como coordinador, que era más o menos el mismo trabajo pero con este título. Estuve durante bastantes años trabajando con Manolo Garrido haciendo Raíces, como coordinador. Él me dijo: «Yo hago los guiones, te los enseño, los discutimos, me voy y lo ruedo. Te mando el material y tú lo montas». ¡Perfecto! También llevé la coordinación de un programa que se llamaba Tauromaquia. Aunque allí también dirigía yo, rodé muchas cosas. 
Para concluir este apartado ofrecemos un listado, sin duda alguna incompleto, que debería servir como guía para cualquiera que intente abordar el estudio de la producción audiovisual de Ramón Masats. Esta filmografía introductoria la hemos extraído de la catalogación efectuada por Daniel Sánchez Salas ${ }^{138}$.

“CINE

\section{A) COMO DIRECTOR / GUIONISTA}

-El que enseña

1965

Dirección: Ramón Masats

PRODUCCIÓN PRO ARTIS IBÉRICA S.A. (ESPAÑA)

Producción ejecutiva: María Rezola, Mario Camus. Idea original y Guión: Ramón Masats. Fotografía: Juan Manuel de la Chica. Montaje: Pablo G. del Amo. Sonido: Agustín Peinado. Jefe de Producción: Jesús Sánchez. Ayudante de Dirección: Julián Ibáñez. Ayudante de Fotografía: Hans Burmann. Ayudante de Montaje: Otilia Ramos. Lugar de Rodaje: Nieva (Segovia). Estudio de Sonorización: EXA. Laboratorios: Fotofilm. Negativo: Blanco negro, $35 \mathrm{~mm}$. Formato: Panorámico. Duración: 13 minutos. CORTOMETRAJE DOCUMENTAL.

\section{-Costa Blanca}

1966

\section{Dirección: Ramón Masats}

PRODUCCIÓN X FILM (ESPAÑA)

Guión: Enrique Llovet (comentarios en «off») y Ramón Masats. Fotografía: Juan Manuel de la Chica. Montaje: Luis Diego Álvarez. Jefe de Producción: José Carat. Locución: Víctor Agramunt, Maribel Ramos, Simón Ramírez. Ayudante de Fotografía: Pedro Hueros. Lugares de Rodaje: Jávea, Denia, Calpe, Peñón de Ifach, Altea, Benidorm, Villajoyosa, San Juan, Alicante, Santa Pola, Guardamar, La Mata, Torrevieja, San Javier, Los Alcázares, La Unión, Cartagena, Mazarrón, Águilas, Garrucha, Carboneras, Níjar, Mojácar, Cabo de Gata. Estudio de Sonorización: EXA. Laboratorio: Fotofilm. Negativo: Color, Eastmancolor; 35 mm. Formato: Normal. Distribución: DC Films. Duración: 21 minutos. CORTOMETRAJE DOCUMENTAL.

\section{-Costa del Azahar \\ 1966}

Dirección: Ramón Masats

PRODUCCIÓN: X FILMS (ESPAÑA)

Guión: Enrique Llovet (comentarios en «off») y Ramón Masats. Fotografía: Juan Manuel de la Chica. Montaje: Luis Diego Álvarez. Sonido: Juan Fierbau. Jefe de Producción: José Carat. Locución: Simón Ramírez. Ayudante de Fotografía: Pedro Hueros. Lugares de Rodaje: El Saler, Valencia, La Albufera, Sagunto, Canet, Moncófar, Castellón de la Plana, Benicasim, Oropesa, Torreblanca, Vinaroz, Peñíscola, Benicarló, Delta del Ebro. Estudio de Sonorización: EXA. Laboratorio: Fotofilm. Negativo: Color, Eastmancolor; $35 \mathrm{~mm}$. Formato: Normal. Duración: 11 minutos. CORTOMETRAJE DOCUMENTAL.

138 Sánchez Salas, Daniel, “Obra audiovisual de Ramón Masats”, en AA. VV., Ramón Masats, Ibèria inèdita, Barcelona, L'Alternativa, 2000, págs. 43-50. 
- Las islas de la calma

1966

Dirección y guión: Ramón Masats

PRODUCCIÓN: X FILMS (ESPAÑA)

Fotografía: Juan Manuel de la Chica. Música: Canción popular «Sa llarga» bailado por el grupo folclórico de San José (Ibiza). Montaje: Elena Jaumandreu. Sonido: Jesús Jiménez. Jefe de Producción: José María González Sinde. Locución: Simón Ramírez. Ayudante de Fotografía: Pedro Hueros. Lugares de Rodaje: Mallorca, Menorca, Ibiza y Formentera. Sonorización: Iberson. Laboratorio: Fotofilm. Negativo: Color, Eastmancolor; 35 mm. Formato: Normal. Duración: 34 minutos.

Observaciones: Proyectado, en ocasiones, en dos partes. La primera, con el título Las Islas de la Calma I, comprendía lo referente a la Isla de Mallorca. La segunda parte, titulada Las Islas de la Calma II, comprendía lo referente a las islas de Menorca, Ibiza y Formentera. CORTOMETRAJE DOCUMENTAL.

-Las islas afortunadas

1970

Dirección: Ramón Masats

PRODUCCIÓN NOTICIARIOS Y DOCUMENTALES [NO-DO] PARA LA DIRECCIÓN GENERAL DE PROMOCIÓN DEL TURISMO, CITE (ESPAÑA)

Argumento y guión: José Luis Font. Fotografía: Juan Manuel de la Chica. Montaje: Carmen Frías. Jefe de Producción: Luis Herrero. Locución: Fernando Molero, Rosa María Mateo. Lugares de Rodaje: Lanzarote, La Graciosa, Gran Canaria, Fuerteventura, La Palma, Hierro, La Gomera y Tenerife. Distribución: Noticiarios y Documentales [NO-D0]. Duración: 32 minutos. CORTOMETRAJE DOCUMENTAL.

\section{-El jardín del Edén \\ 1970 \\ Dirección: Ramón Masats \\ PRODUCCIÓN CITE (ESPAÑA)}

Argumento y guión: José Luis Font. Fotografía: Juan Manuel de la Chica. Montaje: Carmen Frías. Jefe de Producción: Luis Herrero. Lugares de Rodaje: Lanzarote, Gran Canaria, Fuerteventura, La Palma, Hierro, La Gomera y Tenerife. Duración: 30 minutos. CORTOMETRAJE DOCUMENTAL.

\section{-Topical Spanish}

1970

Dirección: Ramón Masats

PRODUCCIÓN ESTELA FILMS (ESPAÑA)

Guión: Ramón Masats y Chumy Chúmez. Fotografía: Juan Amorós. Montaje: Teresa Alcocer. Sonido: Roger Sangenis. Asesoría artística y fotografias: Oriol Maspons y Xavier Miserachs. Jefe de Producción: J.M. Cunilles (a.t.c.). Ayudante de Dirección: Ángel González. Secretario de Producción: Félix Tusell. Ayudante de Producción: Manuel Rubio. Operador Segunda Unidad: Juan Manuel de la Chica. Ayudante de Cámara: Benito Rabal. Auxiliar de Cámara: Pedro Doménech. Script: Paquita Vilanova. Regidor: Carlos Frigola. Ayudante de Montaje: Margarita Benet. Maquillaje: Elisa Aspach. Maquillaje srta. Motta: Llongueras. Peluquería: Dolores Soler. Sastra: Marina Rodríguez. Efectos Especiales: Baquero. Jefe Eléctricos: Mariano Cárdenas: Jefe Maquinistas: José Palacio. Intérpretes: Grupo de música pop Los Íberos (Adolfo Rodríguez, Enrique Lozano Pérez, José Castillo), Guillermina Mota, Víctor Petit, José Sazatornill «Saza», Joana Natali, María Zaldíbar, Herminia Navarro, «Pajarito», Elisenda Ribas, Enric Casamitjana, Juan Fernández, Carmen Pradillo, Luis del Pueblo, Marta Mateos, Rosa Flores, Víctor Israel, Luis Quinquer, Jorge Bofia, José M. Bustems, Juan Torres, Miguel Muniesa, Sara Grey, Jacquie Fredin, Alberto Puig Palau, «Tía Leo», Myriel David, Jaime Picas, M. Dolores Ruaix, 
Luis Clotet, Colita, Fernado Forga. Estudios de Rodaje: Kine S.A. Estudios de Sonorización: Estudios Balcázar; Ing. Sonido: José Manc. Estudios: La voz de España; Ing. de Sonido: Jorge Sangenis. Ambientación: Miró. Atrezzo: Artiau. Canciones de Los Íberos: Wayne Bickerton, T. Waddington, Enrique y Wendy Lozano. Canciones de G. Mota: Letra de G. Mota y Ramón Masats. Música de Francesc Bor. Fondos musicales: Maestro Casas Augé. Lugares de rodaje de Exteriores: Barcelona, Los Monegros, Huesca y Cabo de Creus. Lugar de Rodaje de la secuencia de grabación: Estudios de Discos Belter. Laboratorio: Fotofilm. Negativo: Blanco y negro $35 \mathrm{~mm}$. Formato: Panorámico. Distribución: José López-Brea Silva. Duración: 97 minutos. LARGOMETRAJE DE FICCIÓN.

\section{-España de los contrastes}

1974

Dirección: Ramón Masats

PRODUCCIÓN NO-DO (ESPAÑA) PARA SU SERIE «DOCUMENTALES COLOR»

Guión: Eduardo Delgado. Fotografía: Juan Manuel de la Chica, José Luis Sánchez de Blas, Emilio García de Castro, Miguel Melcon Hernando. Montaje: Antonio García Valcárcel. Sonido: Jaime Moreno Rojas. Locución: María del Puy. Laboratorio: Fotofilm. Negativo: Color; 35 mm. Duración: 38 minutos, 46 segundos. CORTOMETRAJE DOCUMENTAL.

\section{-Invierno en España}

1975

Dirección y guión: Ramón Masats

PRODUCCIÓN NO-DO (ESPAÑA) PARA SU SERIE «DOCUMENTALES COLOR»

Fotografía: Juan Manuel de la Chica, Vicente Minaya, José Luis Sánchez de Blas. Montaje: Antonio García Valcárcel. Sonido: Jaime Moreno Rojas. Locución: Rafael Taibo. Laboratorio: Fotofilm. Negativo: Color; 35 mm. Duración: 37 minutos, 38 segundos. CORTOMETRAJE DOCUMENTAL.

-Canarias, un paraíso surgido de las aguas

1977

Dirección y guión: Ramón Masats

PRODUCCIÓN NO-DO (ESPAÑA) PARA SU SERIE «DOCUMENTALES COLOR»

Guión: Eduardo Delgado. Fotografía: Juan Manuel de la Chica. Adaptación musical: Valcárcel. Sonido: Jaime Moreno Rojas. Locución: Xavier Dotu. Laboratorio: Riera, Negativo: Color; 35 mm. Duración: 29 minutos, 40 segundos. CORTOMETRAJE DOCUMENTAL.

-Tras la huella de una aventura (La España de Colón)

1990

Dirección: Ramón Masats

PRODUCCIÓN TOLEDO FILMS (ESPAÑA)

Para: Turespaña (Ministerio de Transportes, Turismo y Comunicaciones). Guión: Salvador Pons Correa (Todelo Productions S.A.). Asesoramiento Histórico: Francisco Morales Padrón, Vicente Cacho. Fotografía: Jorge Herrero. Música: David Garrido Guil, Campos de agua. Montaje: Paz Bilbao. Sonido: Antonio Beoch S.A. Presentador: José Luis Gómez. Locución: José Ángel Juanes. Director de Producción: Salvador Pons Correa. Ayudante de Dirección: Óscar Masats. Ayudante de Producción Andalucía: Jesús Arcos. Ayudante de Cámara: José Villalba. Ayudante de Montaje: Ma Carmen Sánchez. Maquillaje: Ramón de Diego. Eléctrico: José Antonio Oliva. Maquinista: Ernesto Pérez Durán. Lugares de rodaje: Sevilla, Huelva, Córdoba, Salamanca, Granada, Madrid, Barcelona, Canarias. Mezclas: Francisco Peramos. Estudios de Sonorización: Tecnison S.A. Música Archivo: Sintonía A.D.V. Efectos Sonoros: Jesús Peña. Laboratorio: Fotofilm. Negativo: Color: Eastmanco- 
lor; 35 mm. Formato: Pantalla normal. Distribución: Instituto de Promoción del Turismo. Duración: 28 minutos. Metraje: 850 metros. CORTOMETRAJE DOCUMENTAL.

\section{B) Otras tareas \\ -Con el viento solano \\ 1965 \\ Dirección: Mario Camus \\ PRODUCCIÓN PRO-ARTIS IBÉRICA S.A. (ESPAÑA)}

Producción Ejecutiva: Francisco Molero. Argumento: Basado en la novela de Ignacio Aldecoa. Guión: Mario Camus. Fotografía: Juan Julio Baena. Realizador títulos de crédito: Ramón Masats. Música: Antonio Pérez Olea. Montaje: Pablo G. del Amo. Dirección Artística: Antonio Cortés. Jefe de Producción: José Antonio Saínz de Vicuña. Ayudante de Dirección: Federico Canudas. Ayudante de Fotografía: Hans Burmann. Intérpretes: Antonio Gades, María José Alfonso, Vicente escudero, Imperio Argentina, María Luisa Ponte, Erasmo Pascual, Antonio Ferrandis, José Manuel Martín, José Caride, Luis Marín, José Seguera, José Sepúlveda, Luis Torner, Ángel Lombarde, Pascual Costafreda, Francisco Arenzana, María Paz Ballesteros, Fernando Sánchez Polack, Chiro Bermejo, Rafael Hernández, «La Polaca», Luisa Muñoz, Rufino Inglés, Manuel Arbó, Felipe Martín Puertas, Manuel Ayuso, Miguel Palenzuela, Juan Lizarraga, Rafael Seano, José Luis Zalde, María Teresa Dressel, Ricardo Díaz. Lugares de rodaje: Madrid-Griñón (Madrid). Toledo: Talavera de la Reina, Malpica de Tajo, Montearagón, Santa Olalla, Almorox, Escalona. Guadalajara: Cogolludo, Hita. Negativo: Color, Eastmancolor, 35 mm. Formato: Dyaliscope. Distribución: Metro-Goldwyn-Mayer Ibérica S.A. Duración: 92 minutos. LARGOMETRAJE DE FICCIÓN.

CINE

B) Como director / realizador / guionista

\section{SERIE: CONOZCA USTED ESPAÑA \\ -Salamanca \\ 1966}

Director: Ramón Masats

Producción Ejecutiva: Joaquín Sánchez Ortiz. Guión: Luis Cortés. Fotografía: Juan Manuel de la Chica. Montaje: Ana María Romero Marchent. Sonido: Plácido Sáenz. Presentadora: María José Alfonso. Locutor: Alfredo Juderías. Ayudante de producción: Guillermo Alcázar. Ayudante de Fotografía: Nicolás Redondo. Sonorización: Iberson. Laboratorio: Fotofilm. Negativo: Blanco y negro, $16 \mathrm{~mm}$. EPISODIO DOCUMENTAL.

-Una embajada en Washington

1966

Director: Ramón Masats

PRODUCCIÓN X FILMS (ESPAÑA)

Producción Ejecutiva: Joaquín Sánchez Ortiz. Guión: Enrique Llovet. Fotografía: Juan Manuel de la Chica. Montaje: Luis Diego Álvarez. Sonido: Manuel Sánchez Ortiz. Presentadora: Señora Marquesa de Merry del Val. Laboratorio: Riera. Negativo: Blanco y negro, 16 mm. EPISODIO DOCUMENTAL.

-El toro de lidia

1969

Dirección y Guión: Ramón Masats

PRODUCCIÓN TVE Y X FILMS (ESPAÑA) 
Producción Ejecutiva: José María González Sinde. Fotografía: Juan Manuel de la Chica. Montaje: Elena Jaumandreu. Sonido directo: Luis Burgos, Federico García. Locución: Ángel María Baltanás. Negativo: Color, Eastmancolor, 16 mm. Formato: Pantalla normal. Duración: 27 minutos. EPISODIO DOCUMENTAL.

\section{SERIE: LA VÍSPERA DE NUESTRO TIEMPO (PRIMERA ETAPA)}

- La Andalucía de Juan Ramón

Fecha de la primera emisión: 14 de junio de 1967. Segunda Cadena

DIRECCIÓN: Jesús Fernández Santos

PRODUCCIÓN TELEVISIÓN ESPAÑOLA

Realización y Guión: Ramón Masats. Fotografía: Juan Manuel de la Chica. Montaje: Pablo G. del Amo. Locución: Rosa María Mateo y Fernando Rey. Laboratorio: Riera. Negativo: Blanco y negro, 35 mm. Duración: 27 minutos, 5 segundos. Metraje: 738 metros. EPISODIO DOCUMENTAL.

\section{- La Mancha de Cervantes}

Fecha de la primera emisión: 20 de febrero de 1968. Segunda Cadena

DIRECCIÓN: Jesús Fernández Santos

PRODUCCIÓN TELEVISIÓN ESPAÑOLA

Realización y Guión: Ramón Masats. Fotografía: Juan Manuel de la Chica. Montaje: Ana María Romero Marchent. Locución: Joaquín Burgos, Josefina de Luna, Teófilo Martínez, Luis G. del Páramo y Ángel Ter. Laboratorio: Fotofilm. Negativo: Blanco y negro; $35 \mathrm{~mm}$. Duración: 27 minutos. Metraje: 738 metros. EPISODIO DOCUMENTAL.

\section{- Las coplas de Jorge Manrique}

Fecha de primera emisión: 2 de mayo de 1968. Segunda Cadena.

DIRECCIÓN: Jesús Fernández Santos

PRODUCCIÓN TELEVISIÓN ESPAÑOLA

Producción ejecutiva: José María González Sinde. Realización: Ramón Masats. Fotografía: Juan Manuel de la Chica. Montaje: Elena Jaumandreu. Locución: Manuel Dicenta y Maribel Molina. Laboratorio: Fotofilm. Negativo: Blanco y negro; $35 \mathrm{~mm}$. Duración: 26 minutos, 45 segundos. Metraje: 711 metros. EPISODIO DOCUMENTAL.

\section{SERIE: ÍNTIMA ARMONÍA}

-Insular Lanzarote

1971

Fecha de la primera emisión: 24 de enero de 1971

PRODUCCIÓN TELEVISIÓN ESPAÑOLA

Realización y Guión: Ramón Masats. Fotografía: Federico G. Larraya. Música: Luis de Pablo. Laboratorios: Fotofilm, Riera y Madrid Film. Productor: Juan M. Matías. Montaje: José Luis Berlanga. Lugar de rodaje: Isla de Lanzarote. Negativo: Color, $35 \mathrm{~mm}$. Duración: 27 minutos. Metraje: 796 metros. EPISODIO DOCUMENTAL.

\section{SERIE: SI LAS PIEDRAS HABLARAN}

\section{-Apasionado mar. Mallorca}

Fecha de la primera emisión: 6 de noviembre de 1972. Primera Cadena.

Dirección y Realización: Ramón Masats

PRODUCCIÓN TELEVISIÓN ESPAÑOLA

Productor: Alfonso García. Guión: Antonio Gala. Fotografía: Federico G. Larraya. Presentadora: 
Natalia Figueroa. Asesor: Ángel Oliveras. Laboratorio: Madrid Film. Formato: Color; 35 mm. Duración: 26 minutos. Metraje: 711 metros EPISODIO DOCUMENTAL FICCIONALIZADO.

-Dos noticias del mar

EL ESCORIAL (PARTE 1)

Fecha de emisión: 13 de noviembre de 1972. Primera Cadena

Dirección y Realización: Ramón Masats

PRODUCCIÓN TELEVISIÓN ESPAÑOLA

Productor: Alfonso García. Guión: Antonio Gala. Fotografía: Federico G. Larraya. Presentadora: Natalia Figueroa. Laboratorio: Madrid Film. Formato: Color; $35 \mathrm{~mm}$. Duración: 28 minutos. Metraje: 766 metros. EPISODIO DOCUMENTAL FICCIONALIZADO.

-Diálogos de ilustrados

EL ESCORIAL (PARTE 2)

Fecha de la primera emisión: 20 de noviembre de 1972. Primera Cadena

Dirección y Realización: Ramón Masats

PRODUCCIÓN TELEVISIÓN ESPAÑOLA

Productor: Alfonso García. Guión: Antonio Gala. Fotografía: Federico G. Larraya. Presentadora: Natalia Figueroa. Laboratorio: Madrid Film. Formato: Color; $35 \mathrm{~mm}$. Duración: 28 minutos. Metraje: 766 metros. EPISODIO DOCUMENTAL FICCIONALIZADO.

- La soledad de una reina

REAL CONVENTO DE SANTA CLARA DE TORDESILLAS

Fecha de la primera emisión: 27 de noviembre de 1972. Primera Cadena.

PRODUCCIÓN TELEVISIÓN ESPAÑOLA

Productor: Alfonso García. Realizador: Ramón Masats. Guión: Antonio Gala. Fotografía: Federico G. Larraya. Presentadora: Natalia Figueroa. Asesor: Ángel Oliveras. Laboratorio: Madrid Film. Formato: Color; 35 mm. Duración: 27 minutos. Metraje: 738 metros. EPISODIO DOCUMENTAL FICCIONALIZADO.

-Grandeza y ceniza

REAL MONASTERIO DE LAS HUELGAS DE BURGOS

Fecha de la primera emisión: 4 de diciembre de 1972. Primera Cadena.

PRODUCCIÓN TELEVISIÓN ESPAÑOLA

Productor: Alfonso García. Realizador: Ramón Masats. Guión: Antonio Gala. Fotografía: Federico G. Larraya. Presentadora: Natalia Figueroa. Laboratorio: Madrid Film. Formato: Color; 35 mm. Duración: 29 minutos. Metraje: 793 metros. EPISODIO DOCUMENTAL FICCIONALIZADO.

\section{-El largo sueño}

MONASTERIO DE POBLET

Fecha de la primera emisión: 15 de enero de 1973. Primera Cadena.

PRODUCCIÓN TELEVISIÓN ESPAÑOLA

Productor: Alfonso García. Realizador: Ramón Masats. Guión: Antonio Gala. Fotografía: Federico G. Larraya. Presentadora: Natalia Figueroa. Asesor: Ángel Oliveras. Laboratorio: Madrid Film. Formato: Color; 35 mm. Duración: 27 minutos. Metraje: 738 metros. EPISODIO DOCUMENTAL FICCIONALIZADO.

-Un Lunes Santo

PALACIO DE ORIENTE (PARTE 1) 
Fecha de la primera emisión: 12 de febrero de 1973. Primera Cadena.

PRODUCCIÓN TELEVISIÓN ESPAÑOLA

Productor: Francisco García Gárgoles. Realizador: Ramón Masats. Guión: Antonio Gala. Fotografía: Federico G. Larraya. Presentadora: Natalia Figueroa. Asesor: Ángel Oliveras. Laboratorio: Madrid Film. Formato: Color; 35 mm. Duración: 23 minutos. Metraje: 629 metros. EPISODIO DOCUMENTAL FICCIONALIZADO.

-Un pueblo en pie

PALACIO DE ORIENTE (PARTE 2)

Fecha de la primera emisión: 5 de marzo de 1973. Primera Cadena.

PRODUCCIÓN TELEVISIÓN ESPAÑOLA

Productor: Francisco García Gárgoles. Realizador: Ramón Masats. Guión: Antonio Gala. Fotografía: Federico G. Larraya. Presentadora: Natalia Figueroa. Asesor: Ángel Oliveras. Laboratorio: Madrid Film. Formato: Color; 35 mm. Duración: 24 minutos. Metraje: 656 metros. EPISODIO DOCUMENTAL FICCIONALIZADO.

-Palacio Real de Pedralbes. Puerto y Puerta de España

Fecha de emisión: No emitido (censurado).

PRODUCCIÓN TELEVISIÓN ESPAÑOLA

Productor: Francisco García Gárgoles. Realizador: Ramón Masats. Guión: Antonio Gala. Fotografía: Federico G. Larraya. Presentadora: Natalia Figueroa. Asesor: Ángel Oliveras. Laboratorio: Madrid Film. Formato: Color; 35 mm. Duración: 27 minutos. Metraje: 738 metros. EPISODIO DOCUMENTAL FICCIONALIZADO.

\section{-Música en la Córdoba medieval}

Fecha de la primera emisión: 28 de mayo de 1974. Primera Cadena.

PRODUCCIÓN TELEVISIÓN ESPAÑOLA

Productor: Francisco García Gárgoles. Realizador: Ramón Masats. Guión: Arcadio de Larrea, Ramón Masats y Solly Wolodarsky. Fotografía: Federico G. Larraya. Montaje: Magdalena Pulido. Locución Xavier Dotu, Fernando Molero, Rafael de Penagos y María Luisa Rubio. Asesor literario y musical: Arcadio de Larrea. Lugar de rodaje: Córdoba. Laboratorio: Madrid Film. Formato: Color; 35 mm. Duración: 35 minutos, 55 segundos. Metraje: 984 metros. EPISODIO DOCUMENTAL FICCIONALIZADO.

\section{SERIE: LOS RIOS}

-Odiel

1975

Fecha de la primera emisión: 21 de abril de 1976. Primera Cadena.

Dirección y Realización: Ramón Masats

PRODUCCIÓN TELEVISIÓN ESPAÑOLA

Productores: Federico Molina y Miguel Ángel Recuero. Guión: Antonio Burgos y Eduardo Delgado. Fotografía. José Fernández Aguayo Jr. Asesor literario: Pedro de Lorenzo. Lugar de rodaje: Andalucía (Huelva). Laboratorio: Riera. Negativo: Color, 16 mm. Duración: 31 minutos. Metraje: 340 metros. EPISODIO DOCUMENTAL.

-Tinto

1976

Fecha de la primera emisión: 7 de abril de 1976. Primera Cadena. 


\section{Dirección y Realización: Ramón Masats}

PRODUCCIÓN TELEVISIÓN ESPAÑOLA

Productores: Federico Molina y Miguel Ángel Recuero. Guión: Antonio Burgos y Eduardo Delgado. Fotografía. José Fernández Aguayo Jr. Sonido: Jaime Velasco. Montaje: Consuelo López. Locución: Simón Ramírez. Asesor literario: Pedro de Lorenzo. Lugar de rodaje: Andalucía. Laboratorio: Riera. Negativo: Color, 16 mm. Duración: 27 minutos. Metraje: 296 metros. EPISODIO DOCUMENTAL.

\section{-Guadalquivir (parte I)}

Fecha de la primera emisión: 30 de septiembre de 1977. Primera Cadena.

Dirección y Realización: Ramón Masats

PRODUCCIÓN TELEVISIÓN ESPAÑOLA

Productor: Federico Molina. Guión: Antonio Burgos. Fotografía. José Fernández Aguayo Jr. Lugar de rodaje: Andalucía. Laboratorio: Riera. Negativo: Color, $16 \mathrm{~mm}$. Duración: 27 minutos, 25 segundos. Metraje: 297 metros. EPISODIO DOCUMENTAL.

\section{-Guadalquivir (parte II)}

Fecha de la primera emisión: 21 de octubre de 1977. Primera Cadena.

Dirección y Realización: Ramón Masats

PRODUCCIÓN TELEVISIÓN ESPAÑOLA

Productores: Federico Molina y Miguel Ángel Recuero. Guión: Antonio Burgos y Miguel Ángel Recuero. Fotografía. José Fernández Aguayo Jr. Lugar de rodaje: Andalucía. Laboratorio: Riera. Negativo: Color, 16 mm. Duración: 29 minutos, 20 segundos. Metraje: 319 metros. EPISODIO DOCUMENTAL.

\section{-Guadalquivir (grand prix)}

Fecha de emisión: No emitido.

Dirección y Realización: Ramón Masats

PRODUCCIÓN TELEVISIÓN ESPAÑOLA

Productores: Federico Molina y Miguel Ángel Recuero. Guión: Antonio Burgos y Miguel Ángel Recuero. Fotografía. José Fernández Aguayo Jr. Lugar de rodaje: Andalucía. Laboratorio: Riera. Negativo: Color, 16 mm. Duración: 37 minutos. Metraje: 421 metros. EPISODIO DOCUMENTAL.

\section{-Guadalquivir (resumen)}

Fecha de la primera emisión: 20 de abril de 1983. Primera Cadena.

Dirección y Realización: Ramón Masats

PRODUCCIÓN TELEVISIÓN ESPAÑOLA

Productores: Federico Molina y Miguel Ángel Recuero. Guión: Antonio Burgos. Fotografía. José Fernández Aguayo Jr. Lugar de rodaje: Andalucía. Laboratorio: Riera. Negativo: Color, 16 mm. Duración: 59 minutos. Metraje: 628 metros. EPISODIO DOCUMENTAL.

\section{-Guadalete}

1976

Fecha de la primera emisión: 8 de junio de 1978. Primera Cadena.

Dirección y Realización: Ramón Masats

PRODUCCIÓN TELEVISIÓN ESPAÑOLA

Productores: Federico Molina y Miguel Ángel Recuero. Guión: Antonio Burgos y Miguel Ángel Recuero. Fotografía. José Fernández Aguayo Jr. Montaje: Consuelo López Jamar. Locución: Simón Ramírez: Asesor literario: Pedro de Lorenzo. Lugar de rodaje: Andalucía. Laboratorio: Riera. Negativo: Color, 16 mm. Duración: 37 minutos. Metraje: 406 metros. EPISODIO DOCUMENTAL 
SERIE: YO CANTO

-Sisa

Fecha de la primera emisión: 15 de abril de 1978

Dirección: Ramón Masats

Director ejecutivo: Julio Herrero

PRODUCCIÓN TELEVISIÓN ESPAÑOLA

Productor: Emy Arnau. Fotografía: Joan Martí. Sonido: Josep Martret. Montaje: Miguel A. Santamaría. Segunda Unidad de Filmación: Fernando Rosales, Pere J. Ventura. Ayudante de Dirección: Roberto Carugatti. Ayudantes de Fotografía: Agustín Barril y Eduard Monllor. Ayudante de Sonido: Ricard Camprodón. Maquillaje: Josefina Derch. Peluquería: Herminia Lozano. Músicos: Jordi Villaprino, piano; Joaquín Béjar, batería; Xavier Riba, violín; Pere Riera, saxo; Manel Joseph y Dolors Palau, voces; Orquesta estable de «El Molino». Canciones cantadas por Jaume Sisa: Qualsevol nit pot sortir el sol, Cançó de la Font del Gat, Mambo, A Sota L'Alzira, El Seté Cel, El Cabaret Galàctic, Mariquilla Bonita. Lugar de rodaje: Cabaret «El Molino» (Barcelona). Laboratorio: Riera. Formato: Color, $16 \mathrm{~mm}$. Duración: 30 minutos. Metraje: 324 metros. EPISODIO DOCUMENTAL MUSICAL.

\section{SERIE: LOS MERCADOS}

\section{-El bazar de los tres mares/Estambul}

1988

Fecha de la primera emisión: 13 de septiembre de 1993. Segunda Cadena

Dirección: Ramón Masats

PRODUCCIÓN TELEVISIÓN ESPAÑOLA

Productor: Miguel Ojea. Delegado de TVE: José Luis Rubio. Guión: Arturo Ruibal. Fotografía: Lorenzo Cebrián. Montaje: José Luis Matesanz. Sonido: Fauk Asís. Locución: José María del Río. Lugar de rodaje: Estambul. Laboratorio: Fotofilm. Negativo: Color, $16 \mathrm{~mm}$. Duración: 55 minutos, 5 segundos. Metraje: 614 metros, EPISODIO DOCUMENTAL.

\section{C) Como coordinador}

La figura del coordinador en televisión suele equivaler a un cargo de supervisión general por encima del de director y realizador. A día de hoy, no ha sido posible confirmar con la documentación a la que hemos tenido acceso la información de que Ramón Masats ejerció como tal en la serie Conozca usted España, ni su probable coordinación de la serie Tauromaquia en alguna de sus diversas etapas, entre 1969 y 1983. Sí aparece confirmada su coordinación de la serie Raíces, dedicada a las costumbres populares españolas y de la que se llegaron a producir ciento noventa y nueve episodios entre 1972 y 1983. A lo largo de los casi doce años de vida de Raíces, el programa tuvo dos directores, Carlos Serrano y Manuel Garrido Palacios. Los equipos técnicos, lógicamente varían. En la documentación encontrada, Masats aparece como coordinador de manera constante. Sin embargo, él asegura haber ocupado esta labor sólo en el periodo en el que fue director Garrido Palacios. Correspondiente, al parecer, a los dos últimos tercios de la serie". 


\section{CONCLUSIONES}

En las páginas precedentes hemos podido analizar algunas de las facetas del complicado y a veces contradictorio poliedro configurado por Masats, hecho que nos ha permitido entrever partes de sus aspectos más interesantes. A estas alturas de la investigación no cabe ninguna duda de que nuestro fotógrafo es el resultado de su propio contexto histórico, económico, político y social. De unas influencias y de unas experiencias que han determinado su obra y su figura histórica, como no podía ser de otro modo. Ello hace que la intuición alegada en tantos momentos por Masats -y en la que pretende asentar su poética- no sea más que una excusa cómoda con la que evita, por un lado, cansinas explicaciones sobre su obra, que además acotarían y limitarían los significados de la misma y, por otro, un intento de conjurar cualquier concesión interpretativa a la pedantería. A Masats le gusta parapetarse tras declaraciones como: "No tengo nada que decir y lo estoy diciendo. Esto es poesía. Si me contradigo es porque soy muchas personas. La intuición es una forma superior de inteligencia". Sin embargo, el instinto impulsivo e irracional no se sostiene como único argumento hermenéutico. El romántico concepto del creador arrebatado dirigido desde una caprichosa espontaneidad inspiradora es una mera ilusión, puesto que abocaría al autor a una irremediable incapacidad para articular sus propios razonamientos y motivos. A su vez, vincularía inexorablemente lo artístico a la casualidad y al azar, impidiendo a los autores la defensa de sus decisiones y la justificación de sus propias opciones. La espontaneidad artística, por tanto, surge desde el conocimiento y la reflexión, desde la teoría, desde un contexto social, cultural, económico e ideológico concreto.

La contextualización histórica de la figura de Ramón Masats nos ha permitido repasar brevemente el periodo histórico de la dictadura franquista desde esa perspectiva. Después de analizar someramente la estética que domina con posterioridad a 1939 y cómo ésta se aplica a la actividad fotográfica, parece razonable concluir que las estructuras de las asociaciones fotográficas estaban directamente inspiradas por el propio Caudillo. Aquella concepción de la fotografía como mero entretenimiento social y/o deportivo llevado a cabo por los inefables aficionados (el salonismo), o el escueto interés de la fotografía como parte de la industria con aplicaciones técnicas o científicas, reflejaban una voluntad de control de las posibilidades creativas y, sobre todo, expresivas del medio fotográfico. Para los más inquietos en sus veleidades artísticas existía un movimiento, ya extinto en el resto del mundo, que daba alas a su realización personal: el pictorialismo. Gracias a él se negaba cualquier interés artístico a una realidad demasiado cruda, desagradable y de por sí crítica con el Régimen. Como modelo a imitar: Ortiz Echagüe. En este sentido, da igual que éste se aprovechara conscientemente del apoyo del Régimen o que fuera utilizado por él. Lo cierto es que representó al soldado-fotógrafo: un monje, un patriota y un artista que construyó un estereotipo nacional que coincidía exactamente con los ideales franquistas basados en la Tradición, la Patria, el Imperio y Dios. De este modo, controlando las estructuras y dirigiendo el referente -el modelo a imitar- se conseguía fiscalizar la producción fotográfica nacional para que no se repitieran atentados nacionales como el perpetrado por el reportaje de Eugene Smith.

Este opresivo ambiente propició que, quizás por primera vez en nuestra historia, la vanguardia de la pintura, la escultura y el resto de las disciplinas artísticas compartieran una necesidad 
de cambio con la vanguardia fotográfica. Esta coincidencia fue favorecida, en parte, por la relativa apertura del régimen debida al ingreso de España en la 0.N.U. y a la consiguiente recepción de influencias extranjeras que supuso. A ello hay que añadir la inevitable aparición de una generación nueva, joven, que no había vivido la Guerra Civil más que como niños o adolescentes y a los que la retórica y la estética franquista no les aportaba absolutamente nada. Aunque las soluciones estéticas del expresionismo abstracto en pintura y del realismo en fotografía son divergentes y contrapuestas, lo cierto es que ambos movimientos respondieron al mismo tiempo a la necesidad de ruptura con el arte franquista. No deja de resultar asombrosa la coincidencia de fechas, puesto que si en pintura existe el grupo Equipo 57 o el Paso, es en ese mismo (1957) cuando expusieron por primera vez Terré, Miserachs y Masats en una muestra que fue considerada por todos sus coetáneos como el pistoletazo de partida de la revolución fotográfica. Agotado el modelo estético franquista, pintores y fotógrafos sintieron una idéntica ansia cosmopolita, el mismo interés por descubrir qué se gestaba en el extranjero $y$, junto a ello, una comprometida voluntad por reencontrarse con la generación anterior al conflicto civil. En el caso fotográfico hemos estudiado cómo la necesidad de vincularse con una generación anterior podría ser representada por la figura de Luis Navarro (en tanto que conciencia que reivindicaba un cambio en la actitud de los fotógrafos), aunque no cabe ninguna duda de que el padre indiscutible, la figura ejemplar y modélica que subsanó la orfandad de referentes de la generación fotográfica anterior fue Català-Roca.

Por otro lado, los viajes a París de Maspons y sus contactos con las principales figuras de la fotografía francesa (y por tanto mundial), y los artículos y las exposiciones que surgieron de todo ese caldo de cultivo, materializaron esos lazos con el extranjero que caracterizan el momento. Tampoco olvidemos la labor que, en este sentido, realizó AFAL. Todas las exposiciones internacionales de los grupos pictóricos españoles, como Parpalló, El Paso o Equipo 57, plasmadas en los eventos y Bienales desarrolladas en el extranjero, tuvieron su correspondencia en las exposiciones organizadas por AFAL en los mismos años. La principal diferencia entre unas actividades y otras fue que mientras que la pintura abstracta estuvo apoyada por el Régimen a través de su Ministerio de Asuntos Exteriores, la fotografía española llegó a Bélgica (1958), Italia (1958), París (1959), Berlín (1960) o Moscú (1960) sin ningún tipo de subvención o ayuda oficial (aunque haya que reconocer la ayuda del embajador español en París, José Rojas y Moreno, en la realización de la exposición en la Biblioteca Española de París el 4 de diciembre de 1959).

Por lo tanto, cabe concluir que aunque Masats y su generación no tuvieran conscientemente ninguna vocación subversiva o de denuncia explícita de la Dictadura, sí se enfrentaron a las estructuras asociativas y a su particular concepción fotográfica generadas directamente por el franquismo. Fue un enfrentamiento a nivel poético más que político, aunque este posicionamiento estético -el interés por el drama de la humanidad, la realidad de la calle, el compromiso ético- genera unas imágenes que, inevitablemente, tenían que traslucir en sí mismas una ideología crítica: la realidad fotografiada era tozudamente antifranquista aunque los propios autores que producían las imágenes no fueran plenamente conscientes de ello.

Masats siempre ha defendido que para aprender fotografía lo más importante son los amigos, la calle y la biblioteca. La calle hace alusión a ese tránsito solitario que todo fotógrafo debe asumir: la experiencia, la práctica diaria y el oficio. Los amigos y la biblioteca (la mejor biblioteca española de libros de fotografía de la época fue sin duda la de Gabriel Cualladó) se refiere a las influencias, las discusiones, los debates, las teorías compartidas... Desde esta perspectiva, la figura del maestro o el profesor que puede explicar la fotografía de un modo unidireccional no aparece en su reflexión, pues en cuestiones creativas Masats nunca ha reconocido autoridad coercitiva alguna. Para él todo se puede discutir, no hay axioma incuestionable y, por lo tanto, no hay nadie que tenga completamente la verdad última. Además, esa potestad incontestable le recuerda 
demasiado a la estructura autoritaria salonista, de la que ha huido por sistema. Entre amigos, entre iguales, sí se puede discutir para encontrar la manera de superar la norma impuesta y desarrollar el estilo subversivo particular de cada uno. Esa fue la principal misión de las asociaciones fotográficas a las que perteneció Masats, poner en contacto a los fotógrafos, reunirlos en torno a una mesa, aunque fuera en una cafetería alejada de la sede de la propia asociación, para discutir de fotografía, descubrir un autor o un libro nuevo, planear y defender un proyecto común, como una exposición o un anuario... No olvidemos que, al respecto, resulta sintomático el florecimiento de un gran número de grupos y colectivos de muy diversa índole en todo el panorama artístico español del momento, fueran fotográficos o pictóricos. Grupos que surgen probablemente como reacción a la represión política y a la consiguiente falta de información.

Algunas asociaciones fotográficas fueron especialmente fructíferas para Masats, como sucedió con AFAL -gracias a la cual expuso en el extranjero y publicó en sus revistas y su anuario de 1958-, o con la Agrupación Fotográfica de Cataluña -donde Masats conoció a Maspons, Miserachs, Terré y Ontañón, y donde, a pesar de la propia asociación, expuso junto con Miserachs y Terré-. Sin embargo, otras no tuvieron ninguna consecuencia significativa en el desarrollo de la trayectoria fotográfica de nuestro autor, como en el caso de la Real Sociedad Fotográfica de Madrid y, dentro de ella, el grupo La Palangana. Aunque en La Palangana Masats conoció a nuevos amigos como Gabriel Cualladó o Paco Gómez, que sin duda le enseñaron nuevos autores y le ayudaron a reflexionar sobre fotografía, lo cierto es que nunca expuso o publicó nada gracias o junto a ellos. Sin embargo, la Historia de la Fotografía Española habla de La Palangana como antecedente de la Escuela de Madrid, atribuyéndole, en nuestra opinión, una relevancia excesiva, puesto que, como tal, La Palangana nunca editó volumen ni reportaje alguno y sólo expuso -sin la participación de Masats- invitada en el II Salón Internacional de Terrasa en 1963. Reconocer que una provincia periférica, y absolutamente olvidada como Almería, fue la que realmente protagonizó la revolución fotográfica de los años cincuenta y sesenta en España, superando la labor de Madrid y Barcelona, es una tarea que la Historia de la Fotografía Española debe asumir, dejando atrás cualquier tipo de complejos personales o intereses políticos.

Asimismo, creemos que la Historia de la Fotografía debería reconocer y estudiar la labor de Esther y Óscar Tusquets en torno a la colección Palabra e Imagen de la editorial Lumen. El sucinto análisis colateral que hemos realizado de la citada colección sólo pretende señalar un vacío de conocimiento importante. Citar todos los libros de la colección ni siquiera aspira a introducirla, pero nos parecía oportuno reconocer su importancia.

El principal objetivo que nos marcamos cuando iniciamos el presente trabajo de investigación era reivindicar la figura fotográfica de Ramón Masats Tartera. Sin embargo, y aunque se salga estrictamente del objetivo de nuestro estudio, no queremos dejar pasar la oportunidad de destacar un aspecto de Masats completamente extrafotográfico, aunque de gran trascendencia en la historia del audiovisual español. Masats fue el responsable de que Salvador Pons recurriera a la Escuela Oficial de Cine para contratar a los directores que trabajarían en la serie Conozca usted España y que después conformarían la estructura básica de la segunda cadena de Televisión Española. Por tanto, nos gustaría recordar en este breve apéndice que directores de la talla de Pío Caro Baroja, Jesús Fernández Santos, Mario Camus, Pedro Olea, Claudio Guerín Hill, Francisco Regueiro, Jaime Chavarri, Emilio Martínez Lázaro, Antonio Mercero, Miguel Picazo, Alfonso Ungría, Fernando Méndez Leite, Jesús García de Dueñas, Jorge Grau, Josefina Molina, Antonio Drove, Antonio Giménez Rico, José María Font Espina, Ricardo Franco, Julio Diamante... tuvieron su primera oportunidad gracias a nuestro autor.

Volviendo a nuestro objetivo de estudio fundamental -los aspectos fotográficos de Masatsaunque hemos citado los textos que éste ha escrito a lo largo de su vida y nos hemos servido del género de la entrevista para el desarrollo parcial de nuestro trabajo de investigación, lo cierto 
es que difícilmente se podría defender que Masats haya tenido una gran trascendencia en el campo de la argumentación teórica sobre fotografía. Lo que sí se puede plantear es que Masats se vio influido por las teorías recogidas por sus compañeros y amigos. Algunos de sus trabajos son reflejo directo de ellas, pues la especialidad de nuestro autor no se centra en la especulación hipotética sino en la constatación práctica y en la materialización de las imágenes. Contra las teorías, realidades. Sus exposiciones generaron auténticos revuelos a nivel fotográfico precisamente porque consiguieron superar el endogámico círculo fotográfico salonista para irrumpir en la esfera cultural del país. Recordemos que su exposición individual en el Ateneo de Madrid (1961) tuvo una gran repercusión en la revista $A F A L$-con un gran número de páginas dedicadas al acontecimiento-, ya que Masats simbolizó para la dirección de la misma ese salto del mundo del salón al mundo de la cultura que tanto anhelaban y defendían. Masats fascinó a escritores (Delibes, Aldeoa), a pintores (Saura y el resto del grupo El Paso), a cineastas (Berlanga o Camus) y a otros hombres de la élite cultural en un momento en que la fotografía no interesaba a nadie pues era considerada como una mera distracción de diletantes. La figura de Masats se convirtió en uno de los emblemas de toda la generación de AFAL, un referente basado no sólo en la repercusión de sus obras si no, fundamentalmente, en su trayectoria personal.

Masats ha ganado muchos de los más prestigiosos premios en el ámbito fotográfico español: el V Trofeo Luis Navarro de Fotografía de Vanguardia en 1957, el Negtor de Fotografía en 1960, el premio Ibarra al Libro Mejor Editado en 1963 por Los Sanfermines, el premio Especial en Tahormina a su primer documental Prado Vivo en 1964, el premio Miqueldi de Plata al documental El que enseña (1965) dentro del Festival de Cinematografía de Bilbao... y, más recientemente, en 2001, el premio Bartolomé Ros a la Mejor Trayectoria Profesional dentro del Festival Photoespaña, el premio de Cultura de la Comunidad de Madrid (2002) y, para concluir por el momento, el premio Nacional de Fotografía en 2004. Sólo por todo ello su trayectoria ya despertaría un justificado interés. Sin embargo, creemos que un mero listado de premios y honores limitaría el alcance que justifica la reivindicación de su figura. La verdadera importancia de Masats hace referencia a su actitud personal, a la coherencia entre su obra y su propia vida. Después de recordar su palmarés cabe no olvidar los orígenes de Masats como bacaladero. Mientras toda la fotografía española dormitaba, Masats, siguiendo el ejemplo de Català-Roca, Maspons y Miserachs y haciendo gala de una obstinada determinación y una temeraria valentía, renunció a todo y se lanzó al camino de la fotografía profesional. Las razones aducidas para ese salto al vacío son, por un lado, prácticas (la fotografía representa una salida profesional ante el enfrentamiento con su padre) y, por otro, actúan como una respuesta al conflicto que le plantea el hecho fotográfico. Una vez tomada una decisión Masats llega hasta sus últimas consecuencias, por muy radicales que parezcan. En este sentido, Masats llegó a la conclusión de que la fotografía que él defendía y practicaba sólo cobraba su verdadero sentido dentro del contexto del profesionalismo y del utilitarismo. Ni fotógrafosoldado, ni fotógrafo-artista, la nueva figura que Masats reivindica es la del obrero de la cámara, la del modesto artesano profesional: Masats reafirma, por ello, el primum vivere. Sin embargo, para Masats hay que desarrollar el carácter necesario para poder comerciar sin sacrificar ninguna exigencia creativa, consiguiendo conjugar un estilo personal -cuanto más subversivo mejor-con los encargos profesionales: es decir, ser profesional sin renunciar a la autoría, a la experimentación, a un estilo propio lo más innovador posible, evitando la copia y la repetición. De hecho, la sedición es casi una condición para alcanzar la autoría. Masats concluye que la mayoría no tiene por qué tener la razón, que, si es necesario, es mejor elegir la soledad a la vulgaridad y que lo políticamente correcto es totalitario. El concepto que mejor resume todo ello es el de honestidad, el de compromiso con uno mismo.

Esta necesidad del encargo y del cliente no representa obstáculo creativo alguno. Es más, legitima la práctica fotográfica al dotarla de un sentido y una finalidad. Gracias al encargo la 
fotografía es útil y tiene una función: la comunicativa. Masats opina que mientras otros abandonan sus encargos para poder ser libres, nadie se acuerda de ellos. Nos recuerda que Coppola rodó El Padrino para pagar sus deudas, que clientes fueron los Faraones, los Médicis, el Obispo medieval o el Cabildo de la Catedral de Mallorca... y que encargos fueron las Meninas, el Guernica, el Peine del Viento, el Museo Guggenheim... Sin embargo, ello no supone ocultar ni ignorar ciertas dificultades creativas en el campo profesional. Los enemigos naturales del fotógrafo no son tanto los clientes como los intermediarios: el diseñador gráfico (hoy llamado Director de Arte), el fotograbador y el impresor.

El planteamiento para llegar a estas conclusiones se entiende mejor si lo analizamos como una reacción a la fotografía salonista $y$, por supuesto, al tardiopictorialismo. Este ambiente de enfrentamiento, que hemos comentado más arriba, es el que radicaliza la postura de Masats en contra de la posible consideración de la fotografía como una mera afición, un entretenimiento 0 como parte de las artes académicas establecidas tradicionalmente. El pictorialismo fue interpretado por Masats como el resultado de un complejo de inferioridad, mal curado, de la fotografía con respecto a la pintura. Esta interpretación originó, como reacción, una búsqueda de la especificidad fotográfica. Esta necesidad de encontrar un lenguaje purista, propio y genuinamente fotográfico, al margen de cualquier pretensión artística, influirá decisivamente en todas las parcelas de la creación fotográfica de Masats: desde su actitud vital y personal, pasando por la mera concepción y realización de sus imágenes, hasta el propio contexto donde desarrollar el hecho fotográfico (sistema de difusión, comercialización, exhibición pública...). De este modo, casi todas las obras y decisiones de Masats deben analizarse desde estas premisas: ¿qué es verdaderamente fotografía y qué no? ¿Dónde están sus límites? ¿Qué cosas puedo decir con fotografía mejor que con cualquier otro medio de expresión, incluida la palabra? ¿Qué diferencia a un fotógrafo de un artista, a una pintura de una imagen fotográfica? ¿Para qué sirve la fotografía? La respuesta a todas estas preguntas nunca saldrá en forma de palabras de los labios de Masats. Responder a estas cuestiones se encuentra plasmado en sus imágenes y en su actitud, conformando la totalidad de la trayectoria fotográfica de nuestro autor.

La propuesta artística, en ocasiones, no precisa ni tan siquiera ir acompañada de un objeto físico, ya que puede tratarse de una acción, un pensamiento, una reflexión o una intención. Sin embargo, la fotografía necesita de la foto material, de la publicación o la proyección para ser imagen. Debe ser comunicativa, plástica, tener una composición legible y cuanto más sencilla mejor. Fotografía es todo aquello que pueda ser captado gracias a una cámara oscura equipada con una óptica que trabaja, fundamentalmente, mediante luz y plata, y se concreta por medio de un determinado encuadre, obturación, profundidad de campo y momento de exposición. Con esa sencillez se podría resumir la importancia del dominio de la técnica fotográfica en Masats.

Nuestro autor asume que el medio fotográfico es necesariamente limitado. Cuanto mayor sea el ascetismo y menor la cantidad de medios técnicos utilizados, mejor. Cuanto más sencillas y sintéticas las imágenes, mayor nivel de conexión con el cerebro-ojo del fotógrafo, mayor comunicación. Este purismo y sobriedad de Masats lo lleva a practicar una búsqueda analítica en la síntesis de sus imágenes. Para llegar al concepto puro que pretende transmitir, Masats elimina todos los elementos superfluos o anecdóticos de la imagen. Como resultado sus fotos son potentes, directas $\mathrm{y}$, al mismo tiempo, suficientemente ambiguas, pues los elementos primarios -como los de la tabla periódica- son componentes de una gran diversidad.

Cualquier truco o falta de sinceridad son rechazados por él de una manera visceral. Los territorios de campeo del fotógrafo, donde las obras alcanzan rango de imágenes, son los dominios de la mirada, de la interpretación del autor ante el mundo y de los descubrimientos visuales -que podrían partir incluso de una realidad ya conocida, gracias una visión nueva-. Para Masats toda la batería de procedimientos pigmentarios del pictorialismo enmascaran la mirada límpida 
del autor, esconden sus deficiencias o incapacidades, adolecen de una gran falta de honestidad en aras de una supuesta sublimación artística. Puesto que lo importante es la interpretación personal del autor, Masats exige de éste unas cualidades casi espirituales de difícil concreción. Autenticidad, energía, inquietud, integridad, honestidad con uno mismo, intensidad... son también las características que Masats busca en una imagen para considerarla de interés. Exige del autor un compromiso ético, una implicación y una entrega completa.

Es tanta la confianza de Masats en las posibilidades de la mirada del autor que, en un alarde de valentía, el mismo se impone la dificultad de descubrir imágenes nuevas en los temas más manidos y recurrentes que pueda encontrar: los tópicos. Esos hallazgos visuales en los temas más conocidos posibles no hacen más que remarcar esa subjetividad que reclama. Sin embargo, el reportaje documentalista, por realista que se pretenda, está inevitablemente construido y manipulado. La fotografía es un medio de comunicación y expresión, donde lo que en realidad se describe es al propio fotógrafo, y como éste contempla y analiza el mundo. La cámara no opina, el fotógrafo sí. No opina como un supremo artista imbuido por la ventaja de su superior condición, opina, simplemente, porque es la obligación del artesano y porque si no hay participación del autor, la obra no interesa, puesto que queda expuesta de forma fría, rígida e inerme. El documentalismo enciclopedista hace tiempo que quedó superado. Da igual que Català-Roca hubiera fotografiado las Ramblas pocos años antes, ya que se puede volver a retratar el tema una y otra vez en tanto que la visión de los diferentes fotógrafos (de los auténticos fotógrafos) cambia, haciéndonos ver unas Ramblas distintas en cada ocasión.

No obstante, el hecho de que Masats reconozca los límites de la fotografía y se enfrente a ellos de la manera más honesta, no implica que no haya experimentado con todas las posibilidades que el medio fotográfico le brinda. Es más, la calificación de "experimentos casuales" podría no responder realmente al carácter que Masats les brinda. Nuestro autor investiga los extremos de esos límites fotográficos, los extiende, para después asimilar lo hallado y así aumentar su batería de recursos expresivos. Masats logra incorporar a su riqueza estilística lo que un academicismo obtuso podría considerar como un error o como una curiosidad técnica. Sin embargo, ese encuentro está dotado de pleno sentido y significación dentro del discurso narrativo de Masats. Nos parece importante recordar que estas aportaciones a la retórica fotográfica son genuinas de Masats, es decir, que no son fruto de influencia o plagio alguno. El estudio cronológico así nos lo confirma.

En ese sentido, cabe recordar que las fotografías de toros movidos de Masats fueron realizadas antes del 24 de abril de 1957, fecha del fallo del V concurso Trofeo Luis Navarro de Fotografía de Vanguardia de la Agrupación Fotográfica de Cataluña -que precisamente ganó Masats-, mientras que el reportaje de toros movidos en color de Ernst Haas fue publicado en julio de 1957. Recordemos que después del éxito del reportaje de Haas éste se dedicó a experimentar con el movimiento en color en otros campos como el deporte, los rodeos o la naturaleza americana, mientras que cuando Masats conoció el reportaje en color de Haas renunció a desarrollar esa línea de investigación, aunque nunca se resignó completamente y, en ocasiones posteriores, deslizó alguna imagen movida en sus reportajes, como el de Los Sanfermines, para dotarlos de una mayor plasticidad y dinamismo.

Junto a ello, otro de los descubrimientos de Masats que nos gustaría destacar es el atrevido uso del enfoque para centrar la atención del espectador en el propio sujeto desenfocado -precisamente al revés de su uso tradicional-. Masats hace vibrar el objeto principal, lo subraya, desenfocándolo, mientras que el objeto enfocado pasa a un segundo plano carente de fuerza expresiva. No deja de sorprendernos que un recurso tan audaz, funcione de un modo tan natural y sencillo. Asimismo, igualmente atrevido nos parece, situándonos en la España fotográfica de 1956, disparar la cámara de fotos sin mirar por el visor y sin encuadrar. Masats juega con elementos estrictamente fotográficos y llega a una libertad creativa tal que supera la necesidad instintiva 
de encuadrar y componer la imagen, generando unas imágenes completamente caóticas, idóneas para el tema de las fiestas que pretendía retratar.

A su vez, nuestro autor toma conciencia de todos los recursos a su alcance: desde el control del contraste, hasta el tono fotográfico. Recordemos que el negro golpea en la retina como el puño en la cara... Esta toma de conciencia le permite reflexionar sobre su uso tradicional para utilizarlo, subvertirlo o manipularlo en función de sus objetivos e intereses. Esta independencia creativa podría vincularlo con William Klein, que también experimentó con los angulares, el movimiento, el contraste, el encuadre... Sin embargo, recordemos que el famoso artículo de Gonzalo Juanes que dio a conocer en España el primer libro de Klein, New York (publicado en Francia en 1956), no fue publicado en AFAL hasta 1960, cuando Masats ya tiene acabado Los Sanfermines, su obra más personal y donde aplicará muchos de estos hallazgos. Nuevamente no hay influencia directa, pues Masats no conoció el libro hasta esa fecha.

Siendo importantes todos los recursos mencionados, sobre todo porque evidencian perfectamente el carácter inquieto y la voluntad investigadora y transgresora de Masats, nos hemos reservado para el final el que, a nuestro juicio, es el aspecto creativo más importante de nuestro autor: la narrativa cinematográfica aplicada a la fotografía. Como no podía ser de otro modo Masats llegó a la frontera de la fotografía y se encontró con el cine en su mismo linde. Antes de cruzarlo -abandonando la fotografía durante 18 años para hacer una película y dedicarse a realizar y dirigir documentales en Televisión Española- Masats encontró un camino híbrido entre ambos lenguajes.

Desde la perspectiva de nuestro autor, la imagen única fue superada gracias a la lógica profesional. La realización de una única foto presenta varios inconvenientes: no se paga mucho por la misma (a menos que sea la utilizada para una portada), de ahí que no sea rentable desplazarse y perder tiempo fotografiándola. Además, no sólo recuerda demasiado al salonismo (donde se premiaban fotos sueltas), sino que no demuestra ningún control creativo por parte del autor, pues puede haber sido tomada por casualidad... Donde un autor se reconoce realmente es en un reportaje completo, compuesto por un grupo de imágenes. La imagen solitaria pierde vigencia porque, aunque haya podido sintetizar toda una historia, es muy difícil conseguir ese propósito $\mathrm{y}$, sin duda, un grupo es más eficaz, puesto que presenta mayores posibilidades comunicativas y expresivas e implica una mayor idea de relato y de discurso. Esa es la razón por la que todos los fotógrafos de la época, incluido Masats, intentarán publicar en revistas ilustradas o, en el mejor de los casos, en formato libro.

La contribución de Masats representa una evolución y sofisticación de los preceptos estéticos y narrativos que la trascendente exposición The Family of Man ofreció. Masats también reflexiona sobre cómo una imagen independiente no funciona igual cuando se ve acompañada por otra en la misma página. Inevitablemente se establecen una serie de relaciones, un diálogo entre una imagen y la otra, de manera que la suma altera la percepción del conjunto. Masats comprende que la imagen fotográfica, necesariamente estática por su propia naturaleza, cobra un nuevo dinamismo en la mente del espectador. La fusión de las diferentes imágenes y la realización de las series fotográficas generan vacíos que nuestro cerebro rellena -de igual manera que en el lenguaje del cómic-: con ello se crea una falsa apariencia de movimiento entre las diversas viñetas/fotografías. El reportaje fotográfico en su conjunto también presenta un desarrollo temporal, aunque en el caso de Masats siempre sea lineal, ya que éste no suele jugar con saltos temporales. Un reportaje fotográfico es considerado como un todo compuesto de escenas, secuencias y planos. Esta voluntad de construcción de un discurso continuo le lleva a asumir recursos tradicionalmente cinematográficos (plano subjetivo, plano-contraplano, rácord de mirada, etc.). La grandeza de Masats consiste en reinventar un código entero para aplicarlo, como si fuera por primera vez, en un lenguaje nuevo. Aquí reside la vital trascendencia de nuestro autor: Masats amplió las fronteras del lenguaje fotográfico adoptando y adaptando las formas del cine. 
El artificio de Masats es discreto. Su lenguaje se lee con sencillez, por muy complicada que resulte la concepción de su construcción. Todo parece ordenarse de una manera lógica, intuitiva y fácil. Por el contrario, el salonismo resultaba pretencioso, petulante y grandilocuente, aunque sólo fuera por los títulos de sus fotografías. No en balde necesitaba ser pretencioso y confuso como reacción al vacío de sus propias obras: la confusión encubre la ignorancia, la vaciedad o las dos cosas. Como medio de expresión, la fotografía se debe explicar por sí misma, debe ser perfectamente inteligible en todo el proceso comunicativo. Es un contrasentido utilizar un lenguaje de un modo tan críptico que precise de otro lenguaje paralelo -aunque sea la palabra- para justificarlo, entenderlo o interpretarlo. A pesar del reconocido amor de Masats por la literatura éste jamás apoya sus imágenes con presuntuosos textos. La fecha y el lugar de la toma bastan. El resto queda abierto, sometido a la imaginación y a la exégesis del lector. Éste es el sentido en el que deben concebirse todas sus colaboraciones con escritores. Nunca sus imágenes pretenden explicar o ilustrar los textos, nunca los textos interpretarlas literalmente. Ambos discursos trascurren de forma paralela, respetuosa, dialogando, complementándose, sugiriéndose mutuamente, pero nunca cerrando significados. Masats es reservado en sus explicaciones porque considera que sus fotografías son suficientemente comunicativas, sencillas, contundentes de por sí, y, al mismo tiempo, de lectura necesariamente abierta. No hace falta coincidir con la intención que Masats tuvo en el momento de la toma para disfrutarlas y entenderlas. Él es consciente de que, una vez paridas, sus obras son independientes en sus significados: cuanta más polisemia generen, más ricas y mayor valor expresivo poseerán.

No nos extraña que el complicado andamiaje construido por Masats haya pasado inadvertido durante todos estos años. Masats nunca ha teorizado sobre sus descubrimientos y reflexiones. No ha pretendido imponérselos a nadie, entre otras cosas porque Masats es modesto y duda. Desde esta perspectiva, la fotografía de Masats no ha sido más que un intento personal y sincero de dar respuesta a unas preguntas muy íntimas. Ahora bien, de igual manera que nuestro autor no reconoció axioma o maestro alguno, tampoco él ha pretendido constituirse en autoridad dogmática para nadie: -“Cuando enseñes, enseña también a dudar de lo que enseñas. La duda, siempre la duda. Más o menos". 


\section{CRONOLOGÍA}

\section{EXPOSICIONES INDIVIDUALES}

1957 Instituto de Cultura Hispánica, Madrid.

1961 Ramón Masats en los Cuadernos de Arte, Ateneo de Madrid.

1983 Neutral Corner, Galería Raylowski, Valencia.

1984 Primavera Fotográfica de Cataluña, Galería Benet Costa, Barcelona.

1985 Los Sanfermines, Espacio Príncipe de Viana, Pamplona. (Comisario: Koldo Chamorro).

1986 Ateneo de Madrid.

1994 Sobre Miguel Delibes, Universidad de Alcalá de Henares.

1999 Retrospectiva Ramón Masats Fotografía, Círculo de Bellas Artes, Festival de Fotografía Photoespaña, Madrid. (La exposición incluyó la proyección de su documental Insular).

1999 Retrospectiva Ramón Masats Fotografía, Caja San Fernando, Sevilla.

2000 Retrospectiva Ramón Masats Fotografía, Museo de Cádiz. (La exposición incluyó la proyección de su documental Insular).

2000 Ramón Masats, PhotoGalería, exposición sobre el libro Photobolsillo de la Fábrica, Madrid.

2000 Retrospectiva Ramón Masats Fotografí, La Rioja, Burgos, León, Ponferrada, Palencia,

Valladolid y Zamora. (La exposición incluyó la proyección de su documental Insular). 2001 Vintages, Galería Kowasa, Barcelona.

2002 Retrospectiva Ramón Masats Fotografía, Instituto de Cultura La Virreina, Barcelona; Museo

Casa de los Tilos, Granada. (La exposición incluyó la proyección de su documental Insular).

2002 Ramón Masats. El Renuevo, Centro Cultural del Matadero, Huesca.

2002 La Memoria Construida, Canal de Isabel II, Madrid. (Comisario: Chema Conesa).

2002 Retrospectiva Ramón Masats Fotografía, Instituto Cervantes, Moscú. (La exposición

incluyó la proyección de su documental Insular).

2003 La Memoria Construida, León, Valladolid, Burgos, Almería, Sevilla, Granada, Pontevedra y Úbeda.

2003 Retrospectiva Ramón Masats Fotografía, Instituto Cervantes, Atenas, Estambul, Roma, Milán y Bremen. (La exposición incluyó la proyección de su documental Insular). 2003 Ramón Masats, Palau Robert, Barcelona.

2004 Retrospectiva Ramón Masats Fotografía, Instituto Cervantes, Berlín, Toulouse, Varsovia, Oporto y Viena. (La exposición incluyó la proyección de su documental Insular). 2004 La Memoria Construida, Espacio Joaquín Leguina, C.A.M., Madrid.

2004 Ramón Masats Selección, Complejo El Águila, Madrid.

2005 Ramón Masats. Color, Galería Tiempos Modernos, Madrid.

2005 Retrospectiva Ramón Masats Fotografía, Instituto Cervantes, Estocolmo, y Túnez. (La exposición incluyó la proyección de su documental Insular).

200520 Fotografías, SONIMAG, Barcelona.

2006 Retrospectiva Ramón Masats Fotografía, Instituto Cervantes, Munich y Burdeos. (La 
exposición incluyó la proyección de su documental Insular).

2006 Ramón Masats. Contactos, Real Fábrica de Tapices, Ministerio de Cultura, Madrid.

2007 Cuenca en la Mirada, Fundación Antonio Pérez, Cuenca; Sala de Exposiciones Santa Inés, Sevilla.

2007 Ramón Masats. Contactos, La Sala de San Benito, Valladolid.

2007 Ramón Masats. Color, Galería Blanca Berlín, Madrid.

\section{EXPOSICIONES COLECTIVAS}

1956 Agrupación Fotográfica de Cataluña, Bibliothèque Espagnole de Paris. (Organización: Maspons y Les 30x40).

1957 Images Inventées, Galería Aujourd’hui en el palacio de Bellas Artes del Sarre, Bruselas. (Dirección de Otto Steinert).

1957 TMM, colectiva con Ricard Terré y Xavier Miserachs, Agrupación Fotográfica de Cataluña, Barcelona; Real Sociedad Fotográfica, Madrid; AFAL, Almería.

1958 Grupo AFAL, Salón International Albert I de Charleroi, Bélgica.

1959 Photographes d'Espagne \& de France, Bibliothèque Espagnole de Paris. (Bajo patrocinio del embajador José Rojas y Moreno).

1959 La Familia Europea, Alemania.

1959 TMM II, segunda colectiva con Ricard Terré y Xavier Miserachs, Sala Aixelà, Barcelona.

1960 Grupo AFAL, Colegio Beethoven, Berlín occidental; Paulsenschule, Berlín-Steglitz, Munich, Bonn, Moscú. (Organización: Ibero-Amerikanische Bibliothek).

1960 III Bienal Internacional de la Fotografía, Pescara. (Bajo patrocinio de la revista suiza Camera).

1961 Salón del Autorretrato, Alemania. (Comisario: Otto Steinert).

1963 Grupo El Paso, Sala Biosca, Madrid.

1964 Galería Juana Mordó, Madrid. (Junto con Carlos Saura)

1985 Fotografía Catalana de los años cincuenta, Mes de la Foto, París.

1986 Historia de la Fotografía Española, 1950-1986, Sociedad de Historia de la Fotografía Española, Sevilla.

1988 Fotógrafos de la Escuela de Madrid, Museo Español de Arte Contemporáneo, Madrid. 1991 Grupo AFAL 1956-1991, Almediterránea 92, Junta de Andalucía, Almería.

1991 Cuatro Direcciones, Museo Reina Sofía, Madrid.

1992 Tiempo de Silencio, Centre d'Art Santa Mónica, Barcelona; Palais de Tokio, París.

1993 El teléfono en la fotografía, Sala de Exposiciones de Telefónica, Fundación Arte y Tecnología, Madrid.

1993 Imatges escollides. Colecció de Gabriel Cualladó, Instituto Valenciano de Arte Moderno, Valencia.

1995 Europa de posguerra 1945-1965: Arte después del diluvio, Centre Cultural, Sala Catalunya,

Sala Sant Jaume, Fundació "La Caixa", Barcelona.

1995 Galería Du Jour, Mes de la Foto, París.

1999 Galerie Municipale du Chateau d'Eau, Toulouse. (Junto con su hijo Óscar Masats).

2000 Introducción a la fotografía en Cataluña, Museo Nacional de Arte de Cataluña, Barcelona;

Palacio Nacional Luque, Madrid. (Comisario: David Balsells).

2000 España ayer y hoy, Museo Nacional Centro de Arte Reina Sofía, Ministerio de Educación Cultura y Deporte, Madrid.

2002 Espacio Joaquín Leguina, C.A.M.

2004 Fotocolectania, Barcelona. 
2004 Pintores Grupo El Paso, Galería Malborough, Madrid.

2004 Las Ramblas Photoespaña, Madrid. (Junto con Xavier Miserachs y Ricard Terré).

2005 Málaga, miradas de hoy, Sala de Exposiciones Alameda, Málaga.

2005 Diez Miradas, Pabellón de España Expo, Aichi, Japón.

2005 Europa de posguerra 1945-1965: Arte después del diluvio, Fundació “La Caixa", Palma de Mallorca.

2006 Mirades Paral.leles, Museo Nacional de Arte de Cataluña, Barcelona.

2006, AFAL. El Grupo fotográfico 1956/1963, Centro Andaluz de Arte Contemporáneo, Sevilla.

\section{OBRA PERMANENTE}

Museo Español de Arte Contemporáneo.

Colección Centro Nacional de Arte Reina Sofía.

Colección Patronato de Cultura de Alcobendas.

Colección Comunidad de Madrid, Centro de Arte Contemporáneo Dos de Mayo de Móstoles.

Fundación Fotocolectania.

Colección Real Academia de San Fernando.

Colección Centro Andaluz de Arte Contemporáneo.

Museo Nacional de Arte de Cataluña.

\section{PREMIOS}

1957 V Trofeo Luis Navarro del Salón de Vanguardia de la Asociación Fotográfica de Cataluña. 1960 Premio Negtor de Fotografía.

1962 Premio a la Mejor Foto de Rodaje, La caída del Imperio Romano, Inglaterra.

1963 Premio Ibarra al Libro Mejor Editado, Los Sanfermines, Espasa Calpe.

1964 Premio Especial en Tahormina a su primer documental Prado Vivo.

1965 Premio Mikeldi de Plata al documental El que Enseña. Producción: Mario Camus. Festival Internacional de cine documental y cortometraje de Bilbao.

1965 Premio CIDALC, Festival Internacional de cine documental y cortometraje de Bilbao.

2001 Premio Bartolomé Ros a la Mejor Trayectoria Profesional, Festival Photoespaña.

2002 Premio de Cultura de la Comunidad de Madrid.

2004 Premio Nacional de Fotografía.

\section{LIBROS Y OTRAS PUBLICACIONES}

Ver bibliografía específica de Ramón Masats.

\section{CINE Y TV}

Ver filmografía en el subcapítulo 7.5. El abandono de la fotografía y el salto al documental y a la televisión: una nueva investigación.

\section{PARTICIPACIÓN EN JURADOS}

1988 Presidente del premio Fotopress.

2001-2003-2005 Miembro del Premio Fotográfico de Caixa de Terrassa.

2003 Miembro del Festival de Cine Iberoamericano de Huelva.

2005 Miembro de los Premios NotodoFest. 


\section{BIBLIOGRAFÍA}

\section{LIBROS}

AA. VV., Anuario de la fotografía española 1958, Almería, AFAL, 1958.

AA. VV., Manuel Fraga, homenaje académico, Madrid, Fundación Cánovas del Castillo, 1997.

AA. VV., De la foto al fotograma. Fotografía y cine documental: dos miradas sobre la realidad, Madrid, Ocho y Medio/Ayuntamiento de Madrid, 2006.

AA. VV., Ramón Masats, Ibèria inèdita, Barcelona, L'Alternativa, 2000.

AA. VV., Club 49. Reobrir el joc, 1949-1971, Barcelona, Generalitat de Catalunya, Departament de Cultura, 2000.

Artero García, José M. a y Pérez Siquier, Carlos, Anuario de la fotografía española 1973, León, Everest, 1972.

Avedom, Richard y Baldwin, James, Res de personal, Barcelona, Lumen, 1966.

Bonet Correa, Antonio (coordinador), Arte del franquismo, Madrid, Cátedra, 1981.

Bozal, Valeriano, "Arte del siglo XX en España II. Pintura y escultura (1939-1990)", SUMMA ARTIS. Historia general del arte, Tomo XXXVII, Madrid, Espasa Calpe, 1995.

Buesa, Jaime y Matute Ana, María, Libro de juegos para los niños de los otros, Barcelona, Lumen (Palabra e Imagen), 1961.

Calvo Serraller, Francisco, España medio siglo de arte de vanguardia 1939-1985, Madrid, Ministerio de Cultura, Dirección General del Libro y Bibliotecas, 1985.

CampBell, Bryn, "Un color para la naturaleza", en Ernst Haas, Barcelona, Orbis, Colección Los Grandes Fotógrafos, 1990.

Capella, Juli, Álbum/Enciclopedia de Óscar Tusquets, Barcelona, Electa, 2003.

Carr, Raymond, España 1808-1975, Barcelona, Ariel, 1990.

Cartier-Bresson, Henri, El mundo de Henri Cartier-Bresson, Barcelona, Lumen, 1968.

Català-Roca, Francesc y Romero, Luis, Barcelona, Barcelona, Barna, 1954.

Català-Roca, Francesc y Alberti, Rafael, Libro del mar, Barcelona, Lumen (Palabra e Imagen), 1968.

Català-RocA, Francesc, Impressions d'un fotògraf, Barcelona, Edicions 62, 1995.

Charles Baudelaire, Salones y otros escritos sobre arte, Madrid, Visor, Colección la Balsa de la medusa, 1996.

Cirici, Alexandre, La estética del franquismo, Barcelona, Gustavo Gili, Colección Punto y Línea, 1977.

Colita y Benet, Juan, Una tumba, Barcelona, Lumen (Palabra e Imagen), 1971.

Colita y Caballero Bonald, José Manuel, Luces y sombras del flamenco, Barcelona, Lumen (Palabra e Imagen), 1975.

Colom, Joan y Cela, Camilo José, Izas, Rabizas y Colipoterras, Barcelona, Lumen (Palabra e Imagen), 1964.

Cortázar, Julio y Gálvez, Antonio, Prosa del observatorio, Barcelona, Lumen (Palabra e Imagen), 1972.

Delibes, Miguel y Pla, Jaume, Castilla, Barcelona, Edicions de La Rosa Vera, 1960. 
Fontcuberta, Joan, Estética fotográfica. Selección de textos, Barcelona, Blume, Colección bb, 1984. Fontcuberta, Joan, El beso de Judas. Fotografía y verdad, Barcelona, Gustavo Gili, 1997.

Frank, Robert, The Americans, Manchester, Cornerhouse, National Gallery of Art, 1993.

Fusi, Juan Pablo y Palafox, Jordi, España 1808-1996. El Desafío de la Modernidad, Madrid, Espasa Calpe, 1998.

Fusi, Juan Pablo, Un siglo de España, La cultura, Madrid, Marcial Pons, Ediciones de Historia, 1999. Gasparini, Paolo y Carpentier, Alejandro, la ciudad de las columnas, Barcelona, Lumen (Palabra e Imagen), 1970.

Goytisolo, Juan, La Chanca, París, Librería Española, 1962.

HaAs, Ernst y Denoël, The Creation, Suiza, C.J. Bucher Ltd, 1971.

Hernández Sandoica, Elena (Dir.), La España de Franco (1939-1975). Política y sociedad, Madrid, Síntesis, Colección Historia de España 3er. Milenio, 2000.

Hernández Sandoica, Elena (Dir.), La España de Franco (1939-1975). Cultura y vida cotidiana, Madrid, Síntesis, Colección Historia de España 3er. Milenio, 2001.

Hill, Paul y Cooper, Thomas, Dialogue with Photography, Nueva York, Farrar, Straus, Giroux, LLC, 1979 [tr. castellano, Homero Alsina Thevenet, revisado por Joaquim Romaguera i Ramió y Esteve Riambau i Saurí, Diálogo con la fotografía, Barcelona, Gustavo Gili, Colección fotoggrafía 2001 (2a ed.)]. Hosoe, Eiкон y Yuhio, Mishima, Muerto por las rosas, Barcelona, Lumen, 1963.

Juliá, Santos, Un siglo de España. Política y sociedad, Madrid, Marcial Pons, Ediciones de Historia, 1999. Klein, William, New York, Madrid, Lunwerg, 1995 (2a ed.).

Klein, William y Daviron Eric, William Klein habla con Eric Daviron, Madrid, La Fábrica y Fundación Telefónica, Colección conversaciones con fotógrafos, 2003.

Larrain, Sergio y Neruda, Pablo, Una casa en la arena, Barcelona, Lumen (Palabra e Imagen), 1984. Lemàgny, J.C. y Roville, André, Historia de la fotografía, Barcelona, Martínez Roca, 1988.

López Mondéjar, Publio, Las fuentes de la memoria I, Madrid, Lunwerg, 1989.

López Mondéjar, Publio, Las fuentes de la memoria II, Madrid, Lunwerg, 1992.

López MondéJar, Publio, Las fuentes de la memoria III, Madrid, Lunwerg, 1996.

López MondéJar, Publio, Historia de la fotografía en España, Madrid, Lunwerg, 1997.

López MondéJAR, Publio, Ramón Masats, Madrid, La Fábrica y Obra Social Caja Madrid y Tf. Editores, Colección Photobolsillo, 2000.

Malet, CÉsAR y BarRal, Carlos, Informe personal sobre el alba y acerca de algunas auroras particulares,

Barcelona, Lumen (Palabra e Imagen), 1970.

Maspons, Oriol y Delibes, Miguel, La caza de la perdiz roja, Barcelona, Lumen (Palabra e Imagen), 1963. Maspons, Oriol; Ubiña, Julio y Cela, Camilo José, Toreo de salón. Farsa con acompañamiento de clamor y murga, Barcelona, Lumen (Palabra e Imagen), 1963.

Maspons, Oriol y García Lorca, Federico, Poeta en Nueva York, Barcelona, Lumen (Palabra e Imagen), 1976. MASPONS, ORIOL, The Private Collection, Madrid, La Fábrica, 2006.

Mira, EnRic, La vanguardia fotográfica de los años setenta en España, Alicante, Instituto de Cultura "Juan Gil Albert", Diputación Provincial de Alicante, 1991.

Miserachs, Xavier y Vargas Llosa, Mario, Los cachorros, Barcelona, Lumen (Palabra e Imagen), 1967. Miserachs, Xavier, Profesiones con futuro: Fotógrafo, Barcelona, Grijalbo, 1995.

Miserachs, Xavier, Fulls de contactes. Memòries, Barcelona, Edicions 62, 1998.

Miserachs, Xavier, Criterio fotográfico. Notas para un curso de fotografía, Barcelona, Omega, 1998. MoRath, Inge, San Fermín, Navarra, Inge Morath y Lola Garrido, 1997.

Naranjo, Juan; Fontcuberta, Joan; Formiguera, Pere; Terré Alonso, Laura y Balsells, David, Introducción a la

Historia de la Fotografía en Cataluña, Barcelona, MNAC y Lunwerg, 2000.

Olivares, Rosa, 100 Fotógrafos españoles, Madrid, Exit, 2005.

Ollé Pinell, Antonio, El arte de la fotografía, Barcelona, E. Meseguer, Manuales Meseguer, 1954. 
Ollé Pinell, Antonio, Enciclopedia de la fotografía, Barcelona, Gassó Hnos., 1957.

Ontañón, Francisco y Grosso, Alfonso, Los días iluminados, Barcelona, Lumen (Palabra e Imagen), 1964.

Ortiz-Echagüe, José, La España mística, Bilbao, Edición del autor, 1943 (4ª ed., 1964).

Ortiz-Echagüe, José y Vielba, Gerardo, José Ortiz-Echagüe. Sus fotografías, Madrid, Incafo, 1978.

Papo, Alfredo, El Jazz a Catalunya, Barcelona, Edicions 62, 1985.

Pérez Siquier, Carlos, La Chanca, Almería, Junta de Andalucía, Consejería de Obras Públicas y Transportes, 2001.

Prado, Juan Manuel, William Klein, Barcelona, Orbis, Colección los Grandes Fotógrafos, 1990.

Preston, Paul, Franco. A Biography, Harpercollins Publishers, Londres, 1993 [tr. castellana de Teresa Camprodón y Diana Falcón, revisada por Eva Rodríguez Halffter y Enrique Moradiello García, Franco, Caudillo de España, Barcelona, Grijalbo, 2002].

Revenga, Luis, Francesc Català-Roca, Madrid, La Fábrica, Obra Social Caja Madrid y Tf. Editores, Colección Photobolsillo, 1998.

Sánchez Vigil, Juan Miguel (coordinador), “La fotografía en España. De los orígenes al siglo XXI" SUMMA ARTIS, Historia General del Arte, Tomo XLVII Madrid, Espasa Calpe, 2001.

Sougez, MARIE-Loup, Historia de la fotografía, Madrid, Cátedra, 1994.

TÀPIAS, MARIA Dolors, Barcelona Blanc i Negre de X. Miserachs, y el reportaje urbano en la Barcelona de los años sesenta. Tesis doctoral dirigida por Francisco Caja López, Departamento de Diseño e Imagen, Facultad de Bellas Artes, Universidad de Barcelona, Programa "Arte y tecnología de la Imagen", Barcelona, 1991.

TÀPIES, ANTONI, Memòria personal. Fragment per a una autobiografia, Barcelona, Grijalbo, 1977.

Terré, LaURA, El grupo fotográfico Afal (1956/1963). Estudio del periodo y aproximación a sus ideas estéticas. Tesis doctoral dirigida por Francisco Caja López, Departamento de Diseño e Imagen, Facultad de Bellas Artes, Universidad de Barcelona, Programa "Arte y tecnología de la Imagen", Barcelona, 1998.

Tusquets Blanca, Esther, Confesiones de una editora poco mentirosa, Barcelona, RqueR, 2005.

Tusquets BlancA, Óscar, Todo es comparable, Barcelona, Anagrama, 1998.

Tusquets Blanca, Óscar, Más que discutible. Observaciones dispersas sobre el arte como disciplina útil, Barcelona, Fábula Tusquets, 2002.

VAn der Elsken, Ed, Sweet life, Amsterdam, De Bezige Bij, Barcelona, Lumen, 1966.

\section{CATÁLOGOS}

Antología de Emmanuel Sougez (1889-1972), Madrid, Comunidad de Madrid, 1995.

Creació Fotogràfica a Espanya, 1968-1988, Barcelona, Generalitat de Catalunya, 1989.

Cuatro direcciones. Fotografía Contemporánea Española 1970-1990, Madrid, Museo Nacional Centro de Arte Reina Sofía, Ministerio de Cultura/Lunwerg, 1991.

Brassaï, Barcelona, Fundació Antoni Tàpies, 1993.

El carrer. Joan Colom a la Sala Aixelà, 1961, Barcelona, MNAC, 1999.

El Paso 1957-1960, Madrid, Marlborough, 2004.

Emigración 1956, Vigo, Centro de Estudios Fotográficos, 1986.

España años 50. Una década de creación, Madrid, SEACEX, 2004.

Exposición Mundial de la Fotografía, Hamburgo, Gruner + Jahr GmbH, sin fechar.

Francesc Català-Roca, Barcelona, Generalitat de Catalunya, 1997.

Francisco Gómez. La emoción construida, Barcelona, Fundación "La Caixa"/Lunwerg, 1995.

Fotografía pictorialista valenciana, Valencia, Generalitat Valenciana, 1992.

Fotógrafos de la escuela de Madrid, Ministerio de Cultura-M.E.A.C., 1988.

Fotógrafos valencianos años 60, Valencia, Generalitat Valenciana, 1992. 
Gabriel Cualladó Fotografias, Madrid, Museo de Arte Contemporáneo, Ministerio de Cultura, 1985. Gauche Divine, Barcelona, Lunwerg, Ministerio de Educación, Cultura y Deporte, 2000. Gonzalo Juanes... ese declinar de la luz..., Barcelona, Lunwerg, Ayuntamiento de Gijón, 2003. Grupo Afal: 1956-1991, Almería, Almediterránea, Junta de Andalucía, 1991.

Història del Fotoperiodisme a Catalunya: 1885-1976, Barcelona, Generalitat de Catalunya, 1990. Idas y Caos. Aspectos de las vanguardias fotográficas en España, Madrid, Ministerio de Cultura, Dirección General de Bellas Artes y Archivos, 1984.

Imágenes compartidas, Granada, Fundación Caja Granada, 1996.

Imatges Escollides. La col.lecció de Gabriel Cualladó, Valencia, IVAM, 1993.

Joan Colom. Fotografías de Barcelona, 1958-1964, Madrid, Barcelona, Ministerio de Educación, Cultura y Deporte, Lunwerg, 2004.

José Ortiz Echagüe en la colecciones del Museo Nacional de Antropología, Madrid, Ministerio de

Educación, Cultura y Deporte, 2002.

Julio Ubiña, Barcelona, Fundació Caixa de Barcelona, 1990.

La Fotografía Catalana als anys 50-60, Barcelona, Generalitat de Catalunya, 1982.

La fotografía pictorialista en España 1900-1936, Barcelona, Fundación “la Caixa”, 1998.

Leopoldo Pomés, imágenes 1955-1997, Barcelona, Ayuntament de Barcelona, 1997.

Los años jóvenes 1960-70, Alicante, Caja de Ahorros del Mediterráneo, 2004.

L'instant perdut, Barcelona, Fundación “La Caixa”/Lunwerg, 1995.

Nicolás Muller. Instantáneas de una vida, Gijón, Fundación municipal de Cultura, 1985.

Ortiz Echagüe, fotografías 1903-1964, Madrid, Tf. Editores-La Fábrica, Espacio de Cultura, 1998. Otto Steinert, exposición antológica 1950-1960, Almería, AFAL/Dirección General de Bellas Artes, 1960. Pérez Siquier, Barcelona, Fundación "La Caixa"/Lunwerg, 1996.

Resonancias. Brassaï > París / Colom < Barcelona, Barcelona, Fundació Fotocolectania, 2003.

Ricardo Terré. Casa das artes e da historia, Vigo, Ayuntamiento de Vigo, 1991.

Ricard Terré, Barcelona, Lunwerg, 1995.

Robert Doisneau, Barcelona, Fundación "la Caixa", 1995.

Tiempo de silencio. Panorama de la fotografía de los años 50 y 60, Barcelona, Departament de

Cultura de la Generalitat de Catalunya i Fundació Caixa de Catalunya, 1992.

Variaciones en España. Fotografía y arte 1900-1980, Madrid, La Fábrica, Fundación MARCO, CAAM, 2004. Xavier Miserachs. 1 segundo y 25 centésimas, Barcelona, Fundación "la Caixa", 1992.

\section{REVISTAS}

AA. VV., “Terré, Miserachs, Masats", en AFAL, n 8, marzo-abril 1957, sin paginar.

Amestoy, Ignacio, "Ramón Masats. Maestro del reportaje gráfico", en El Mundo. El Mentidero, n 5794, año XVII, domingo, 23 de octubre de 2005.

Anaxágoras (Casademont, Josep Maria), "La II de T.M.M. Una muestra de arte vivo", en AFAL, n²1, noviembre-diciembre 1959, sin paginar.

Andrés Ruiz, EnRique, "El fotógrafo de Los Sanfermines", en $A B C$ de las Artes y las Letras, n 754,

15-21 de julio, 2006, pág. 32.

Anónimo, Sin título, en Arte Fotográfico, n³ 3, año I, marzo 1952, pág. 67.

Anónimo, "Sociedades Fotográficas Españolas", en Arte Fotográfico, nº 18, año II, junio 1953, pág. 304.

Anónimo, "Lo que dice el Boletín de Mayo de la A.F.C.: Muestra de Terré, Miserachs, Masats", en

$A F A L, \mathrm{n}^{\circ}$ 8, Marzo-Abril 1957, sin paginar.

Anónimo, "De una carta fechada en Barcelona", en AFAL, nº 9, mayo-junio 1957, sin paginar.

Anónimo, "Un artículo y una respuesta", en $A F A L, n^{0} 10$, julio-agosto 1957, sin paginar. 
Anónimo, "Su excelencia el Jefe del Estado recibe el nombramiento de «Aficionado de Honor a la fotografía», otorgado por la I Asamblea Nacional de Fotografía, celebrada en Madrid", en Arte Fotográfico, $\mathrm{n}^{\circ}$ 66, año VI, agosto 1957, págs. 602-603.

Anónimo, "ATTENTION «Réalites»!: Esto se ve en París aunque París no sea esto", en Gaceta Ilustrada $n^{0}$ 140, 13 de junio 1959, págs. 46-49.

Anónimo, "AFAL en el mundo", en AFAL, n 19, julio-agosto 1959, sin paginar.

Anónimo, "Salón internacional de fotografía, Mafe-Perutz Galerías Preciados, organizado por la Real Sociedad fotográfica de Madrid", en AFAL, n² 27, noviembre-diciembre 1960, sin paginar.

Anónimo (Josep Maria Casademont), "El VIII Trofeo Luis Navarro y el IX «Aplec» de sociedades catalanas en Seo de Urgel", en Arte Fotográfico, n 115, año X, julio 1961, pág. 583.

Anónimo (Josep Maria Casademont), "Fotografías de Juan Dolcet en la sala Aixelà", en Arte Fotográfico, n 120, año X, diciembre 1961, pág. 1089.

Argilaga, “Los personalismos rebajan el tono”, en Arte Fotográfico, n 65, año VI, mayo 1957, pág. 341.

Argilaga, "Tertulia fotográfica. La realidad «desnuda» no es tema de arte", en Arte Fotográfico, $\mathrm{n}^{\circ}$ 85, año VIII, enero 1959, págs. 33-35.

Arnalte, Arturo, "Ramón Masats. Los grandes fotógrafos españoles con Descubrir el Arte", en Descubrir el Arte, n0 93, año VIII, 2006, pág. 46.

Artero, José María, “Españoles en Moscú", en AFAL, n² 23, marzo-abril 1960, sin paginar.

Artero, José María, "Pequeña historia de una gran fotografía. Peñaranda de Ramón Masats", en $A F A L, \mathrm{n}^{0} 28$, enero-febrero 1961, sin paginar.

Artero, José María (El Director), "Masats 1957-1961", en AFAL, n 30, mayo-junio 1961, sin paginar.

Barceló, Ignacio, "Salones y concursos", en Arte Fotográfico, nº 6, año I, junio 1952, pág. 193.

Barceló, Ignacio, “Aduanas", en Arte Fotográfico, nº 8, año I, agosto 1952, pág. 281.

Barceló, Ignacio, "Trato de favor", en Arte Fotográfico, n³7, año IV, enero 1955, pág. 1.

Barceló, Ignacio, "Ramón Masats, ese fotógrafo inquieto", en Arte Fotográfico, n 79, año VII, julio 1958, págs. 592-600.

Bella Costa, José, "correspondencia con AFAL", en AFAL, nº 9, mayo-junio, 1957, sin paginar.

Casa Palau (Publicidad), "Libros sobre fotografía", en Arte Fotográfico, n 37, año IV, enero 1955, pág. 3.

CatalÀ-Roca, Francisco, "Lo que dice Francisco Català-Roca”, en AFAL, nº 8, marzo-abril 1957, sin paginar.

C.L., "Una nueva faceta utilitaria en la fotografía española", en Arte Fotográfico, n 79, año VII, julio 1958, pág. 611.

Conde Vélez, Luis (Luis Navarro), “El momento fotográfico español”, en Arte Fotográfico, n 12, año I, diciembre 1952, pág. 488.

Conde Vélez, Luis (Luis NavarRo), “Lo nuevo en fotografía”, en Arte Fotográfico, n 14, año II, febrero 1953, pág. 81.

Conde Vélez, Luis (Luis Navarro), “Grandeza y miseria de la fotografía”, en Arte Fotográfico, n 18, año II, junio 1953, págs. 272-273.

Conde Vélez, Luis (Luis Navarro), “El I salón de fotografía moderna”, en Arte Fotográfico, n 18, año II, junio 1953, pág. 295.

Conde Vélez, Luis (Luis Navarro), "El placer puro de la fotografía", en Arte Fotográfico, n 19, año II, julio 1953, pág. 324.

Conde Vélez, Luis (Luis Navarro), “El XII Salón Internacional de Arte Fotográfico", en Arte Fotográfico, n² 20, año II, agosto 1953, pág. 404.

Conde Vélez, Luis (Luis Navarro), "Fecundidad del error", en Arte Fotográfico, nº 21, año II, septiembre 1953, págs. 448-450.

Conde Vélez, Luis (Luis Navarro), "Carta a un aficionado joven”, en Arte Fotográfico, n 22, año II, octubre 1953, págs. 473-475. 
Costa Terradellas, Raimundo, “Salones! Sí...”, en Afal, n 10, julio-agosto, 1957, sin paginar.

Cualladó Candel, Gabriel, "Cómo hago mis fotografías", en Arte Fotográfico, n 69, año VI, septiembre 1957, pág. 736.

De la Fuente Ruiz, Antonio, "La exposición mundial de la fotografía Lucerna (Suiza)", en Arte Fotográfico, nº 7, año I, julio 1952, pág. 267.

DelPIRE, RoBert, “Henri Cartier-Bresson”, en Arte Fotográfico, n 84, año VII, diciembre 1958, pág. 1021.

E.G.G., "Muestra colectiva Terré, Miserachs, Masats" en AFAL, n 9, mayo-junio 1957, sin paginar.

E.V.P., “Coloquios en la A.F.C., con D. Ramón Masats”, en Boletín de la A.F.C., junio 1957, pág. 89.

García, Pilar, "Una muestra fotográfica rescata la historia de Afal en su 50 aniversario", en Ideal,

3 de marzo de 2006, pág. 52.

Gassó Grau, Ernesto, “Carta abierta a don Ramón Masats «Premio Negtor 1960»", en Arte Fotográfico,

n 161, año IX, octubre 1960, pág. 906.

HAAS, ERNSt, "Beauty in a brutal art", en Life, julio 1957.

HieRRo, JosÉ, "Realidad fotográfica y realidad artística", en AFAL, n 30, mayo-junio 1961, sin paginar.

HöPkeR, Thomas, “¿Hacia dónde? Tareas y caminos de la fotografía actual”, en Arte Fotográfico, n

79, año VII, julio 1958, págs. 576-578.

HöPKER, THOMAS, “¿Hacia dónde? Tareas y caminos de la fotografía actual (conclusión)”, en Arte

Fotográfico, n 80, año VII, agosto 1958, págs. 657-660.

Juanes, Gonzalo, "Gonzalo Juanes Cifuentes", en AFAL, n 7, enero-febrero 1957, sin paginar.

Juanes, Gonzalo, "Cómo hago mis fotografías", en Arte Fotográfico, nº 66, año VI, junio 1957, págs. 475-512.

Juanes, Gonzalo, "Anotaciones sobre el New York", en AFAL, n² 24, mayo-junio 1960, sin paginar.

Juanes, Gonzalo, "Moments Preserved (Comentarios a un libro de Irving Penn)", en AFAL, $\mathrm{n}^{0} 35$, marzo-abril 1962, sin paginar.

Juanes, Gonzalo, "La caza de la perdiz roja, de Oriol Maspons", en Imagen y Sonido, n 1, Junio 1963.

Lario, Ores, "Fotografía de la memoria", en Expansión, Fuera de Serie, n 111, 21 de septiembre 2006.

Llopis, Arturo, "Lo que dice Destino: Tres fotógrafos tres estilos", en AFAL, nº 8, Marzo-Abril 1957, sin paginar.

Masclet, Daniel, “Fotografía Española en París”, en Afal, nº 6, noviembre-diciembre, 1956, sin paginar. MASPons, ORIol, "Cómo hago mis fotografías", en Arte Fotográfico, n 45, año IV, noviembre 1955, pág. 692.

MASPONS, ORIol, "Cómo hago mis fotografías, por Daniel Masclet", en Arte Fotográfico, n 49, año V, enero 1956, págs. 32 y 61.

MASPons, ORIol, "Cómo hago mis fotografías, por Doisneau”, en Arte Fotográfico, n 59, año V, noviembre 1956, págs. 823.

MASPONS, ORIol, "Salonismo", en Arte Fotográfico, nº 61, año VI, enero 1957, págs. 3-5.

MAspons, ORIoL, "Cómo hago mis fotografías, por Sabina Weiss", en Arte Fotográfico, nº 62, año VI, febrero 1957, pág. 112.

Maspons, ORIol, “Cómo hago mis fotografías, por Emmanuel Sougez", en Arte Fotográfico, n 63, año VI, marzo 1957, pág. 208.

Maspons, Oriol, "Cómo hacen sus fotografías Terré, Miserachs y Masats", en Arte Fotográfico, n 64, año VI, abril 1957, pág. 294.

Maspons, Oriol, "Carta abierta para D. Raimundo Costa Terradellas", en Afal, n 10, julio-agosto, 1957, sin paginar.

MASPONS, ORIOL, “Cómo hago mis fotografías, por Bernard Valette", en Arte Fotográfico, n 68, año VI, agosto 1957, págs. 648 y 688.

MASPONS, ORIOL, “Cómo hago mis fotografías, por Guy Bourdin”, en Arte Fotográfico, n 70, año VI, octubre 1957, pág. 824. 
Maspons, Oriol, "Cómo hago mis fotografías, por Brassaï", en Arte Fotográfico, n 72, año VI, diciembre 1957, págs. 959 y 1000.

Maspons, ORIol, “Cómo hago mis fotografías, por Henri Cartier-Bresson”, en Arte Fotográfico, n 81, año VII, septiembre 1958, págs. 769-772.

MASPONS, ORIOL, “Cubaro, Galí, Ontañón”, en AFAL, n 18, noviembre-diciembre 1958, sin paginar.

Memba, Javier, "En el estudio de Ramón Masats, el fotógrafo alquimista", en Descubrir el Arte, $\mathrm{n}^{\circ}$ 89, año VIII, 2006, pág. 111.

Miserachs, Xavier, "Oriol y yo hemos ido a París", en AFAL, n 30, mayo-junio, 1961, sin paginar.

Papo, Alfredo, "Lo que dice Alfredo Papo (miembro del Club 49 y del Hot Club)", en AFAL, n 8, Marzo-Abril 1957, sin paginar.

Pérez Siquier, Carlos, "Lo que dice Carlos Pérez Siquier", en AFAL, nº 8, Marzo-Abril 1957, sin paginar.

Pérez Siquier, Carlos y Artero, José María, "The Family of Man”, en AFAL, nº 10, julio-agosto 1957, sin paginar.

Pérez Siquier, Carlos, “Fotografías de Francia”, en AFAL, n²3, marzo-abril 1960, sin paginar.

Pérez Siquier, Carlos (el redactor-jefe), "Narración por imágenes", en $A F A L, \mathrm{n}^{0}$ 34, enero-febrero, 1962, sin paginar.

Pineda, Vicente A., “Trascendencia del creador y servidumbre del actor. Diálogo abierto con Vittorio De Sica", en Arte Fotográfico, n 79, año VII, julio 1958, pág. 623.

Pla Janini, Joaquín, “La fotografía mal llamada moderna”, en Arte Fotográfico, n 48, año IV, diciembre 1955, pág. 745.

Pujol, Aquiles (Josep Maria Casademont), “Fotografía social”, en Arte Fotográfico, n 127, año XI, julio 1962, pág. 662.

Pujol, Aquiles (Josep Maria Casademont), “Que cada palo aguante su vela...", en Arte Fotográfico, $\mathrm{n}^{\circ}$ 130, año XI, octubre 1962, págs. 1040, 1041.

Pulido, N., "Ramón Masats: "Si se me ha escapado algún mensaje en mis fotos, lo siento»", en $A B C, 9$ de junio de 2006, pág. 56.

Rodríguez, Mario, "Mirades paral.leles", en La Vanguardia, 20 de junio de 2006, pág. 47.

Siquier, Pérez y Artero, José Ma " “The Family of Man”, en AFAL, n 10, julio-agosto, 1957, sin paginar.

Sougez, Marie-Loup, “Ramón Masats. Lección de geografía”, en Lápiz, n 41, año V, mayo 1987, págs. 12-15.

Tharrats, Joan Josep, “Lo que dice Revista”, en AFAL, n 8, Marzo-Abril 1957, sin paginar.

Terré, Ricardo, “Fotografía social fotografía libre”, en AFAL, Boletín de información exclusivamente para socios, enero-febrero, 1959, sin paginar.

VARga, André, "Opiniones a distancia, por Miguel Tubau”, en Arte Fotográfico, n 83, año VII, noviembre 1958, pág. 948.

Vielba, Gerardo, "La expresividad de Masats", en AFAL, n³ 30, mayo-junio 1961, sin paginar.

Yánez, Jara, “Miradas en doble", en El Periódico, Dominical, 16 de julio de 2006, pág. 51.

\section{BIBLIOGRAFÍA ESPECÍFICA DE RAMÓN MASATS ${ }^{1}$}

\section{LIBROS}

Masats, Ramón y Aldecoa Ignacio, Neutral Corner, Barcelona, Lumen (Palabra e Imagen), 1962. Masats, Ramón y Serrano García, Los Sanfermines, Madrid, Espasa-Calpe, 1963.

1 Esta bibliografía específica incluye los libros y catálogos publicados por Masats, así como el vaciado de la revista AFAL, Arte Fotográfico, Gaceta Ilustrada y aquellos textos que hemos creído importantes para el desarrollo de nuestro trabajo de investigación. 
Masats, Ramón y Delibes, Miguel, Viejas historias de Castilla la Vieja, Barcelona, Lumen (Palabra e Imagen), 1964.

Masats, Ramón y Carandell, Luis, Nuestro Madrid, Madrid, Luna Wennberg, 1981.

Masats, Ramón; Carandell, Luis y Sanpedro, José Luis, España diversa, Madrid, Luna Wennberg, 1982.

Masats, Ramón; Ontañón, Paco y Bonet Correa, Antonio, Palacios Reales del Patrimonio Nacional, Madrid, Lunwerg, 1983.

Masats, Ramón; Masagué, Andreu y Collazos, Óscar, Monasterios Reales del Patrimonio Nacional, Madrid, Lunwerg, 1984.

Masats, Ramón y Carandell, Luis, Madrid es más que Madrid, Madrid, Lunwerg, 1984.

Masats, Ramón y Ríos Ruiz, Manuel, Jerez, del ayer al futuro, Madrid, Lunwerg, 1985.

Masats, Ramón, Un Paseo por Madrid, Madrid, Lunwerg, 1985.

Masats, Ramón, El agua de Madrid, Madrid, Lunwerg, 1985.

Masats, Ramón y Vernet, Juan, Al-Andalus. El Islam en España, Madrid, Lunwerg, 1987.

Masats, Ramón; Carandell, Luis; Zarza, Daniel y López Mondéjar, Publio, Madrid, Madrid, Lunwerg, 1987.

Masats, Ramón y CarandelL, Luis, Desde el cielo a España, Madrid, Lunwerg, 1988.

Masats, Ramón y Carandell, Luis, Del cielo a Madrid, Madrid, Lunwerg, 1988.

Masats, Ramón y Caballero Bonald, José Manuel, Andalucía, Madrid, Lunwerg, 1989.

Masats, Ramón y Pérez Escolano, Víctor, Sevilla, Madrid, Lunwerg, 1989.

Masats, Ramón; García Rodero, Cristina; Chamorro, Koldo; Fontcuberta, Joan; Laguillo, Manuel; Esclusa, Manel; López MondéJar, Publio y Quiñones, Fernando, Astilleros de ayer a hoy 1877-1991, Madrid, Lunwerg, 1991.

Masats, Ramón y Carandell, Luis, Madrid, Madrid, Madrid, Madrid, Lunwerg, 1995.

Masats, Ramón, Madrid y su comunidad, un mundo diverso, Madrid, Lunwerg, 1996.

Masats, Ramón y Aldecoa Ignacio, Neutral Corner, Madrid, Alfaguara, 1996 (2 ${ }^{\mathrm{a}}$ ed.).

Masats, Ramón, Madrid pasen y vean, Madrid, Lunwerg, 1997.

Masats, Ramón y Vidal, Joaquín, Toro, Madrid, Lunwerg, 1998.

Masats, Ramón; López Guzmán, Rafael y Henares Cuéllar, Ignacio, Andalucía. Cultura y diversidad, Madrid, Lunwerg, 2005.

\section{CATÁLOGOS}

Masats, Madrid, Cuadernos del Ateneo de Madrid, 1961.

Ramón Masats fotografía, Madrid, Lunwerg, Círculo de Bellas Artes, 1999.

Ramón Masats La memoria construida, Madrid, Dirección General de Archivos y Bibliotecas,

Consejería de las Artes, Comunidad de Madrid, 2002.

Ramón Masats, Contactos, Madrid, Ministerio de Cultura, Lunwerg, 2006.

Ramón Masats, Cuenca en la mirada, Cuenca, Diputación Provincial de Cuenca/Lunwerg, 2007.

\section{REVISTAS}

Masats, Ramón y Montero Alonso, José (texto), “Galatea de Extremadura: Una española, «Señorita Pygmalión, 1957»", en Gaceta Ilustrada n 60, 30 de noviembre de 1957, págs. 5-6 (5 fotos B/N).

MASATS, RAMón, “Ahora del cine al teatro: Aurora Bautista vuelve a las tablas: «Réquiem para una mujer»", en Gaceta Ilustrada, n 61, 7 de diciembre de 1957, págs. 26-27 (5 fotos B/N).

Masats, Ramón y Yale (texto), “La gasolina, ¿a peseta?: Maestre Amat, alicantino e inventor", en Gaceta Ilustrada, $\mathrm{n}^{\circ}$ 62, 14 de diciembre de 1957, pág. 9 (2 fotos B/N).

Masats, Ramón y Jiménez Quiles, M. (texto), “Españoles universales: García Sanchiz (novelista) en su rincón", en Gaceta Ilustrada, n² 62, 14 de diciembre de 1957, págs. 16-17 (8 fotos B/N). 
Masats, Ramón y Medina, Tico (texto), “Lo que se pierde, se encuentra: Las cosas que se pierden en Madrid", en Gaceta Ilustrada, n 62, 14 de diciembre de 1957, págs. $26-27$ (7 fotos B/N).

MASATS, Ramón, "Felicidades a los lectores: Seis felicitaciones de navidad para los lectores y anunciantes de «G. I.»", en Gaceta Ilustrada, n 63, 21 de diciembre de 1957, pág. 5 (6 fotos en color).

Masats, Ramón y Castro Viejo, José María (texto), "Así come España en la navidad: Galicia: Bacalao con coliflor, la «Bica», «filloas» y vejiga de cerdo", en Gaceta Ilustrada, n 63, 21 de diciembre de 1957, pág. 11 (2 fotos B/N).

Masats, Ramón y Díaz Cañabate, Antonio (texto), "Así come España en la navidad: Madrid: El besugo, eje de la cena", en Gaceta Ilustrada, n 63, 21 de diciembre de 1957, pág. 17 (1 foto B/N).

MasatS, Ramón y de las Cuevas, José y Jesús (texto), “Así come España en la navidad: Andalucía: La metafísica del polvorón", en Gaceta Ilustrada, n 63, 21 de diciembre de 1957, pág. 25 (1 foto B/N).

MASATS, RAMón, “Don Hilarión, la morena y la rubia, 1957”, en Gaceta Ilustrada, n 64, 28 de diciembre de 1957, pág. portada (1 foto en color).

Masats, Ramón, Maspons, Oriol, y Miserachs, Xavier (fotos), Casamayor, Enrique, y Carpintero, Heliodoro (textos), "Machado: Antonio Machado vuelve a su tierra", en Gaceta Ilustrada, n 66, 11 de enero de 1958, págs 24 y ss. (21 fotos B/N).

MASATS, Ramón, "Cinco de Manresa: Quinielistas millonarios por segunda vez", en Gaceta Ilustrada, $n^{0}$ 67, 18 de enero de 1958, pág. 18 (6 fotos B/N).

Masats, Ramón y Contreras (fotos) “Ataúlfo Argenta: Así quedó el último rincón de este español universal", en Gaceta Ilustrada, nº 69, 1 de febrero de 1958, pág. 36 (5 fotos B/N).

MASATS, Ramón, “La artista alemana Vera Rogge”, en Gaceta Ilustrada, n 70, 8 de febrero de 1958, portada (foto en color).

Masats, Ramón y Mario Herrero, Pedro (texto) “Se necesita una actriz: Un anuncio que movilizó a cientos de muchachas", en Gaceta Ilustrada, n 70, 8 de febrero de 1958, págs. 8-9 (9 fotos B/N).

MaSATS, Ramón, "Arte y milicia: Soldados en el museo del Prado", en Gaceta Ilustrada, n 70, 8 de febrero de 1958, págs. 16-17 (6 fotos B/N).

Masats, Ramón y Marqueríe, Alfredo (texto), “Otra vez el circo: Un espectáculo que resurge gracias a novedades insospechadas", en Gaceta Ilustrada, n 70, 8 de febrero de 1958, págs. 23-27 (12 fotos en B/N, 7 fotos en color).

Masats, Ramón y Yale (texto), "Otro millonario del fútbol: 2.500 .000 por acertar 14 resultados", en Gaceta Ilustrada, n0 70, 8 de febrero de 1958, pág. 40 (6 fotos B/N).

Masats, Ramón y Vega Pico, Juan Manuel (texto), “Españoles universales: El doctor Castroviejo (fotógrafo) en su rincón", en Gaceta Ilustrada, n 71, 15 de febrero de 1958, pág. 42 (5 fotos B/N).

Masats, Ramón, "Color Marroquí: La nueva Sala Marroquí en el Museo del ejercito de Madrid", en Gaceta Ilustrada, n 72, 22 de febrero de 1958, págs. 24-26 (7 fotos en color).

Masats, Ramón, Porras y Rueda, Alfredo (texto), “50 años: Historia de la policía española”, en Gaceta Ilustrada, $\mathrm{n}^{0} 72,22$ de febrero de 1958, págs. 30-42 (12 fotos B/N).

Masats, Ramón y Sancho, Martí (texto), "Sherlock Holmes en España”, en Gaceta Ilustrada, n 74, 8 de marzo de 1958, págs. 38-39 (3 fotos B/N).

Masats, Ramón y Tolcido, Alfredo (texto), "Josefina Baker: La venus de ébano -con muchos más años- de nuevo en Madrid", en Gaceta Ilustrada, n 75, 15 de marzo de 1958, págs. 29-30 (6 fotos en $B / N)$.

Masats, Ramón y ToRres, Enrique (texto), “Nueva visión parroquial: El experimento de La Almunia de Doña Godina", en Gaceta Ilustrada, n 76, 22 de marzo de 1958, pág. 32 (8 fotos en B/N).

MaSATS, Ramón, “Di Stéfano y Kopa”, en Gaceta Ilustrada, n 77, 29 de marzo, pág. portada (1 foto en color).

MASATS, RAmón, “Cuando el árbitro pita: Di Stéfano y Kopa interpretan para «G.I.» las seis faltas más corrientes", en Gaceta Ilustrada, n 77, 29 de marzo de 1958, pág. 33 (6 fotos en B/N). 
Masats, Ramón y Deleyto, José María (texto), “Cuando el toreo es duro: Ángel Monasterio, banderillero.

Un año en el sanatorio", en Gaceta Ilustrada, n 106, 18 de octubre, pág. 54 (2 fotos en B/N). Masats, Ramón, "Carmen Amaya: El mundo en sus pies", en Gaceta Ilustrada, n0 108, 1 de noviembre de 1958, pág. 21 (4 fotos en B/N y 9 fotos en color).

Masats, Ramón y Álvarez Caballero, Ángel (texto), “Vejez y longevidad: La muerte es antinatural antes de los 100 años", en Gaceta Ilustrada, n 110, 15 de noviembre de 1958, pág. 14 (3 fotos en B/N). Masats, Ramón y Sueiro, Daniel, "Legazpi: Frutas y verduras para 2.000.000 de estómagos", en Gaceta Ilustrada, $\mathrm{n}^{\circ}$ 112, 29 de noviembre de 1958, págs. 18 y ss. (13 fotos en B/N y 6 fotos en color).

Masats, Ramón, “María Jesús Cuadra, una actriz española que se ha puesto en el pelotón de cabeza de las actrices europeas", en Gaceta Ilustrada, n ${ }^{0}$ 118, 10 de enero de 1959, pág. portada (1 foto en color).

Masats, Ramón, "María Jesús Cuadra: Una chica de Madrid, cara al triunfo", en Gaceta Ilustrada, n 118, 10 de enero de 1959, pág. 21 (6 fotos en B/N, 5 fotos en color).

Masats, Ramón y Álvarez Caballero, Ángel (texto), “24 horas judiciales por dentro”, en Gaceta Ilustrada, $\mathrm{n}^{0}$ 118, 10 de enero de 1959, pág. 29 (6 fotos en B/N).

Masats, Ramón y Suárez, Marcial (texto), "Berlanga el tranquilo", en Gaceta Ilustrada, n 119, 17 de enero de 1959, págs. 20-23 (9 fotos en B/N).

Masats, Ramón y Fierro, Vicente (texto), "Ladrones de "Seats»", en Gaceta Ilustrada, n 123, 14 de febrero de 1959, págs. 30-32 (9 fotos en B/N).

Masats, Ramón; Vernacci Ruiz, D. (archivo familiar) y Olano, Antonio (texto), "Solana, auténtico y falsificado", en Gaceta Ilustrada, n 132, 18 de abril de 1959, págs. 24-31 (13 fotos en B/N, 4 fotos en color).

Masats, Ramón y G. Herreros, Enrique (texto), "Dior en el palacio de Alba", en Gaceta Ilustrada, nº 132, 18 de abril de 1959, págs. 45-49 (13 fotos en B/N).

Masats, Ramón, "Radiografía del toreo", en Gaceta Ilustrada, n 142, 27 de junio de 1959, págs. 23-25 (5 fotos "movidas" en B/N).

Masats, Ramón y Lorente, José María (texto), “Mikio Oda, Campeón olímpico, entrenador en España”, en Gaceta Ilustrada, n 155, 26 de septiembre de 1959, págs. 26-27 (3 fotos en B/N).

Masats, Ramón y Villagrán, Federico (texto), “S.M. Bahamontes. El «rey» entró en Toledo", en Gaceta Ilustrada, $\mathrm{n}^{0}$ 155, 26 de septiembre de 1959, págs. 30-33 (12 fotos en B/N).

Masats, Ramón, "Lucho Gatica", en Gaceta Ilustrada, n 156, 3 de octubre de 1959, pág. portada (1 foto en color).

Masats, Ramón y Deleito, José María (texto), "Gasolina al corte", en Gaceta Ilustrada, n 156, 3 de octubre de 1959, págs. 16-17 (3 fotos en B/N).

Masats, Ramón y Medina, Tico (texto), "Lucho Gatica", en Gaceta Ilustrada, n 156, 3 de octubre de 1959, págs. 24-29 (14 fotos en B/N, y 6 fotos en color).

Masats, Ramón y Aparicio, Octavio (texto), “Los médicos, un año menos", en Gaceta Ilustrada, n 157 , 10 de octubre de 1959, págs. 14-17 (8 fotos en $\mathrm{B} / \mathrm{N}$ ).

Masats, Ramón; Basabe (fotos); Botán (fotos) y Deleito, José María (texto), “Uno de los 4 del antiguo pasodoble, Vicente Pastor", en Gaceta Ilustrada, n 163,21 de noviembre de 1959, págs. 3438 (17 fotos en $\mathrm{B} / \mathrm{N}$ sin determinar).

Masats, Ramón y Medina, Tico (texto), "Antonio bailó para los Windsor", en Gaceta Ilustrada, n 164, 28 de noviembre de 1959, págs. 18-23 (16 fotos en B/N).

Masats, Ramón; Calderón (fotos); Campúa (fotos); Cifra (fotos) y Gómez Tello, José Luis (texto), “Ike en Madrid. Franco: "España os abre las puertas de su casa»", en Gaceta Ilustrada, $\mathrm{n}^{\circ}$ 168, 26 de diciembre de 1959, págs.10-24 (17 fotos en B/N).

Masats, Ramón y Paniagua, Domingo (texto), “Canta misa a los 57 años”, en Gaceta Ilustrada, n 168 , 26 de diciembre de 1959, págs. 52-54 (5 fotos en B/N). 
Masats, Ramón y Medina, Tico (texto), "Kristine Kaufmann, la mujer bibelot", en Gaceta Ilustrada, $\mathrm{n}^{\circ}$ 170, 9 de enero 1960, págs. 24-25 (1 foto en B/N, 3 fotos en color).

Masats, Ramón y Villagrán, Federico (texto), "Los Barreto, una dinastía en «jazz band»", en Gaceta Ilustrada, $\mathrm{n}^{0} 170,9$ de enero de 1960, págs. 30-33 (8 fotos en $\mathrm{B} / \mathrm{N}$ ).

Masats, Ramón y Gibell, Antonio (texto), "Visones en el Guadarrama”, en Gaceta Ilustrada, n 173 , 30 de enero de 1960, págs. 21-25 (10 fotos en B/N, 5 fotos en color).

Masats, Ramón y Deleyto, José María (texto), "El mejor velódromo de Europa", en Gaceta Ilustrada, n 177, 27 de febrero de 1960, págs. 14-17 (6 fotos en B/N).

MASATS, Ramón, “Estoril 1960. Fernandel, rey del carnaval", en Gaceta Ilustrada, n 178,5 de marzo de 1960 , págs. 52-55 (12 fotos en B/N).

Masats, Ramón, "Del aire a la pista. Colette Duval en el Casino de Estoril baila el charlestón para «G.I.»", en Gaceta Ilustrada, n 179, 12 de marzo de 1960, págs. 58-59 (7 fotos en B/N).

Masats, Ramón y Castillo Puche, José Luis (texto), “¿Sólo Gas?", en Gaceta Ilustrada, nº 182, 2 de abril de 1960, págs. 8-10 (9 fotos en B/N).

Masats, Ramón y Ramírez de Lucas, J. (texto), "Se ha disuelto El Paso", en Gaceta Ilustrada, n 185, 23 de abril de 1960, págs. 29-35 (12 fotos en B/N, 7 fotos en color).

Masats, Ramón, "Ferenc Puskas", en Gaceta Ilustrada, n 196, 9 de julio de 1960, pág. portada (1 foto en color).

Masats, Ramón y Villagrán, Federico (texto), "«Pancho»Puskas primer artillero y segundo cerebro del R. Madrid", en Gaceta Ilustrada, n 196, 9 de julio de 1960, págs. 48-53 (8 fotos en $B / N)$.

Masats, Ramón y A.T. (texto), "Paloma Valdés, se llama Mari Pepa”, en Gaceta Ilustrada, n² 206, 17 de septiembre de 1960, págs. 30 y 31 (4 fotos en B/N).

MASATS, RAMón, "Los 4 primeros premios contestan. Al habla con Ramón Masats, «Premio Negtor 1960»", en Arte Fotográfico, n 105, año IX, septiembre 1960, págs. 800-802.

Masats, Ramón, "Las joyas de Dalí", en Gaceta Ilustrada, n² 213, 5 de noviembre de 1960, págs. 65-67 (6 fotos en color).

Masats, Ramón, "Photokina 60", en AFAL n² 27, noviembre-diciembre 1960, sin paginar.

Masats, Ramón y D. Olano, Antonio (texto), "Paco Camino el torero del año", en Gaceta Ilustrada, $\mathrm{n}^{\circ}$ 222, 7 de enero de 1961, págs. 80-84 ( 6 fotos en $\mathrm{B} / \mathrm{N}$ ).

Masats, Ramón, “Beatriz Lodge", en Gaceta Ilustrada, n²25, 28 de enero de 1961, pág. portada (1 foto en color).

Masats, Ramón y Aguado, Lola (texto), "Una Lodge se quedará en España”, en Gaceta Ilustrada, n 225, 28 de enero de 1961, págs. 30-33 y 35 (3 fotos en B/N y 4 fotos en color).

Masats, Ramón y Alcántara, Manuel (texto), "Galiana no pudo", en Gaceta Ilustrada, n² 226, 4 de febrero de 1961, págs. 48-50 (7 fotos en B/N).

Masats, Ramón, "Charlon Heston: «Mío Cid»", en Gaceta Ilustrada, n² 228, 18 de febrero de 1961, pág. portada (1 foto en color).

Masats, Ramón y Serrano, María Dolores, Tolcido, Alfredo (texto), “El Cid, La gesta en imágenes”, en Gaceta Ilustrada, $\mathrm{n}^{\circ}$ 228, 18 de febrero de 1961, págs. 28-39 (16 fotos en B/N y 7 fotos en color).

MASATS, Ramón, "María Cuadra", en Gaceta Ilustrada, n²229, 25 de febrero de 1961, pág. portada (1 foto en color).

Masats, Ramón, “El Baño del Cid”, en Gaceta Ilustrada, n² 231, 11 de marzo de 1961, págs. 50-53 (16 fotos en $B / N)$.

Masats, Ramón y Moreno Galván, José María (texto), "Un mural de Labra para «G.I.»", en Gaceta Ilustrada, $\mathrm{n}^{0}$ 233, 25 de marzo de 1961, págs. 52-53 (2 fotos en B/N).

MASATS, Ramón, "La boda de «La Chunga»", en Gaceta Ilustrada, n² 234, 1 de abril de 1961, pág. portada ( 1 foto en color). 
Masats, Ramón y Ruiz Castillo, Andrés (texto), "La boda de la Chunga", en Gaceta Ilustrada, n² 234, 1 de abril de 1961, págs. 52-59 (18 fotos en B/N).

MASATS, Ramón, “Raf Vallone", en Gaceta Ilustrada, n² 235, 8 de abril de 1961, pág. portada (1 foto en color).

Masats, Ramón y Vallone, Raf (texto), "Aventura en Peñíscola", en Gaceta Ilustrada, n² 235, 8 de abril de 1961, págs. 52-53 (3 fotos en B/N).

Masats, Ramón, "Masats en el Ateneo de Madrid", en Gaceta Ilustrada, n² 235, 8 de abril de 1961, pág. 58 (3 fotos en B/N).

Masats, Ramón y Heimer, Marc (texto), "Así será el fin del mundo" y "Viernes, 13 de noviembre de 2026: la tierra se hundirá bajo sus habitantes", en Gaceta Ilustrada, n² 236, 15 de abril de 1961, págs. 56-59 y 61 (1 foto en B/N).

Masats, Ramón, "Peter Ustinov, capitán de fragata", en Gaceta Ilustrada, n² 249, 15 de julio de 1961, págs. 34-37 (4 fotos en B/N y 3 fotos en color).

Masats, Ramón y Aguado, Lola (texto), "Joaquín Rodrigo en Aranjuez", en Gaceta Ilustrada, n 252, 5 de agosto de 1961, págs. 30-35 ( 6 fotos en B/ $\mathrm{N}$ y 4 fotos en color).

Masats, Ramón y Izquierdo, Antonio (texto), "Vida de El Viti. El torero del año", en Gaceta Ilustrada, $\mathrm{n}^{0} 262,14$ de octubre de 1961, págs. 40-43, 45 y 47 (11 fotos en B/N).

Masats, Ramón, "María Cuadra”, en Gaceta Ilustrada, n² 265, 4 de noviembre de 1961, pág. portada (1 foto en color).

Masats, Ramón y Figueroa, Natalia (texto), "María Cuadra maniquí de los cuatro grandes de Madrid”, en Gaceta Ilustrada, n² 265, 4 de noviembre de 1961, págs. 70 y 72-73 (7 fotos en B/N y 5 en color).

Masats, Ramón y Agudo, Lola (texto), “Góngora, vivo”, en Gaceta Ilustrada, n² 267, 18 de noviembre de 1961, págs. 66-68 y 70-73 (5 fotos en B/N y 5 en color).

Masats, Ramón y Eguía, Javier (texto), “Franco, 25 años Caudillo”, en Gaceta Ilustrada, n² 274, 6 de enero 1962, pág. 22 (1 foto en B/N).

Masats, Ramón; Maspons, Oriol; Ubiña, Julio (fotos) y Vega Pico, Juan (texto), “El año de dos valientes: El Cordobés y El Viti", en Gaceta Ilustrada, n² 276, 6 de enero de 1962, págs. 56-60 y 62 (7 fotos en $B / N)$.

Masats, Ramón y Figueroa, Natalia (texto), “Fiesta para los Windsor", en Gaceta Ilustrada, n² 279, 10 de febrero de 1962, págs. 32-37 (5 fotos en B/N y 6 fotos en color).

Masats, Ramón, "Elvis Presley no encuentra a la chica que le gusta", en Gaceta Ilustrada, n 279, 10 de febrero de 1962, pág. 47 (1 foto en B/N).

Masats, Ramón, "portada Leslie Caron y David Niven", en Gaceta Ilustrada, n 280, 17 de febrero de 1962, pág. portada (1 foto en color).

Masats, Ramón y Aguado, Lola (texto), "Víctor Martín, violinista prodigio", en Gaceta Ilustrada, n 280, 17 de febrero de 1962, págs. 50-52 y 54 (4 fotos en B/N).

Masats, Ramón, "Lilí baila flamenco. Leslie Caron y David Niven en la Costa del Sol", en Gaceta Ilustrada, $\mathrm{n}^{0}$ 280, 17 de febrero de 1962, págs. 66-67 (2 fotos en B/N y 2 fotos en color).

Masats, Ramón y Serrano, María Dolores (texto), "«Tormenta de verano»: dos millones de pesetas Juan García Hortelano", en Gaceta Ilustrada, n² 287, 7 de abril de 1962, págs. 44-45 (4 fotos en B/N).

Masats, Ramón, Calderón y Villagrán, Federico (texto) "La «helivisión», en la carretera española", en Gaceta Ilustrada, n² 291, 5 de mayo de 1962, págs. 20-24 (12 fotos en B/N).

Masats, Ramón y Medina, Tico (texto), “Alfredo Mañas, «el polvorero»”, en Gaceta Ilustrada, n² 292, 12 de mayo de 1962, págs. $42-47$ (9 fotos en $B / N$ ).

Masats, Ramón; Calderón, Luis y Elías, Casimiro (texto), "La boda de Juan Carlos y Sofía", en Gaceta Ilustrada, $\mathrm{n}^{0}$ 293, 19 de mayo de 1962, págs. 26-34 (11 fotos en B/N).

Masats, Ramón y Aguado, Lola (texto), “Lauro Olmo, el de «la camisa»", en Gaceta Ilustrada, n² 297, 16 de junio de 1962, págs. 56-59 (4 fotos en B/N). 
Masats, Ramón, “El Cid estuvo en Pamplona”, en Gaceta Ilustrada, n 302, 21 de julio de 1962, págs. 38-39 (7 fotos en B/N).

Masats, Ramón y Serrano, Ma Dolores (texto), "Viola, un genio anda suelto", en Gaceta Ilustrada, nº 315, 20 de octubre de 1962, págs. 4-7 (6 fotos en B/N y 3 fotos en color).

Masats, Ramón, "El último «sprint» de Poblet", en Gaceta Ilustrada, n 331, 9 de febrero de 1963, págs. 44-45 (4 fotos en B/N).

Masats, Ramón y Aguado, Lola (texto), "Ha vuelto Sainz de la Maza", en Gaceta Ilustrada, n 331, 9 de febrero de 1963, págs. 48-51 (4 fotos en B/N).

Masats, Ramón, “Soledad Miranda estudia inglés", en Gaceta Ilustrada, n 335, 9 de marzo de 1963, págs. 4-5 (4 fotos en color).

Masats, Ramón y Aguado, Lola (texto), “Menéndez Pidal, 94 años”, en Gaceta Ilustrada, n 335, 9 de marzo de 1963, págs. 52-59 (5 fotos en B/N).

Masats, Ramón y Gibello, Antonio (texto), "San Hermenegildo: una Orden centenaria", en Gaceta Ilustrada, n 340, 13 de abril de 1963, págs. 8-9 (2 fotos en B/N y 2 en color).

Masats, Ramón, (fotos en color), Alcoba (fotos en negro), de Sosa, Luis, Aguado, Lola (texto), “El Escorial: piedra, viento, jaspe y bronce", en Gaceta Ilustrada, n 344, 11 de mayo de 1963, págs. 4-13,15 y 17 ( 5 fotos en color y 8 en $\mathrm{B} / \mathrm{N}$ ).

Masats, Ramón y Aguado, Lola (texto), "Santo Tome de Ávila: gasolina, taller y garaje", en Gaceta Ilustrada, $\mathrm{n}^{0}$ 356, 3 de agosto de 1963, págs. 42-45 (6 fotos en $\mathrm{B} / \mathrm{N}$ ).

Masats, Ramón y Echevarría, María Jesús (texto), "La «Little U.S.A.» madrileña", en Gaceta Ilustrada, $n^{0} 358,17$ de agosto de 1963, págs. 4-13 (15 fotos en B/N y 5 fotos en color).

Masats, Ramón; Lucas, César (fotos) y Aguado, lola (texto), "Antonio Gades es la danza misma", en Gaceta Ilustrada, $\mathrm{n}^{0}$ 391, 4 de abril de 1964, págs. 80-83 (4 fotos en B/N y 6 fotos en color). Masats, Ramón, “Ramón Masats, tiempo de inocencia”, Matador, volumen C, 1997, págs. 26-35. 


\section{RESÚMENES}

\section{CASTELLANO}

El roble en el páramo: la trayectoria fotográfica de Ramón Masats

La presente tesis doctoral aborda la figura y la obra de Ramón Masats en su periodo fotográfico. Desde un punto de vista histórico nuestro autor perteneció a una generación de cambio que revolucionó el panorama fotográfico español a mediados de los años cincuenta, en plena dictadura franquista. La contextualización histórica de nuestra tesis desvela tanto las causas y los motivos como las influencias extranjeras, los principales protagonistas y las entidades (asociaciones, revistas y editoriales) que participaron en ese auténtico choque generacional. Dado su carácter inquieto e hiperactivo, Masats se convirtió en uno de los principales protagonistas de la reyerta pues participó en las exposiciones más polémicas, publicó en todas las revistas fotográficas españolas del momento y perteneció a las tres asociaciones fotográficas en las que surgieron las principales voces discordantes.

En un segundo estadio, nuestra tesis analiza los nuevos conceptos teóricos que se desarrollaron en ese periodo y que Masats interioriza y pone en práctica. Cabe resaltar que esos conceptos teóricos nunca serán verbalizados por Masats. Nuestro autor no es un teórico, es más, siempre ha justificado sus decisiones con la mala excusa de la intuición y el instinto. Sin embargo, en nuestro trabajo queda patente la influencia de sus compañeros de generación y hasta qué punto los mismos desarrollaron cuestiones como la renuncia expresa al pictorialismo, al salonismo y al concurso, en contraposición con el purismo fotográfico. En este sentido, conceptos como la profesionalización, la utilidad del arte, el humanismo, la experimentación o la ética son asumidos por Masats y analizados exhaustivamente en nuestro trabajo.

Por último, abordamos las líneas de investigación planteadas por Masats en su práctica artística. Al respecto, cabe destacar el desarrollo por parte de nuestro autor de los tópicos fotográficos -muy relacionados con las imágenes de síntesis- donde el tema queda tan deconstruido que llega a su sustancia más elemental. Asimismo, Masats experimenta con las formas, la geometría, el enfoque, la velocidad de exposición... y, en especial, con las series fotográficas. La narratividad de éstas le llevarán a considerar el libro fotográfico (pensemos en su Neutral Corner) como una unidad expresiva, generando un lenguaje visual muy similar al del cine. Masats juega con la disposición de sus fotografías en la maquetación de su libro Los Sanfermines (1956-1963), generando planos-contraplanos, planos subjetivos, series de movimiento... un lenguaje que, con toda lógica, finalmente le llevará a explorar en el mundo del montaje cinematográfico y la dirección de documentales audiovisuales, actividad que desarrolló durante casi veinte años. 


\section{VALENCIÀ}

El roure a l'erm: la trajectòria fotogràfica de Ramón Masats

Aquesta tesi doctoral aborda la figura i l'obra de Ramón Masats en el període fotogràfic. Des d'un punt de vista històric l'autor va pertànyer a una generació de canvi que va revolucionar el panorama fotogràfic espanyol a mitjans dels anys cinquanta, en plena dictadura franquista. La contextualització històrica de la tesi desvela tant les causes i els motius com les influències estrangeres, els principals protagonistes $i$ les entitats (associacions, revistes $i$ editorials) que van participar en aqueix autèntic xoc generacional. Atés el caràcter inquiet i hiperactiu, Masats es va convertir en un dels principals protagonistes de la baralla perquè va participar en les exposicions més polèmiques, va publicar en totes les revistes fotogràfiques espanyoles del moment i va pertànyer a les tres associacions fotogràfiques en les qual van sorgir les principals veus discordants.

En un segon estadi, la nostra tesi analitza els nous conceptes teòrics que es van desenvolupar en aqueix període i que Masats interioritza i posa en pràctica. Cal remarcar que aqueixos conceptes teòrics mai no seran verbalitzats per Masats. El nostre autor no és un teòric, és més, sempre ha justificat les seues decisions amb la mala excusa de la intuïció i l'instint. No obstant, en el nostre treball queda patent la influència dels seus companys de generació i fins a quin punt ells mateixos van desenvolupar qüestions com la renúncia expressa al pictorialisme, al salonisme i al concurs, en contraposició amb el purisme fotogràfic. En aquest sentit, conceptes com la professionalització, la utilitat de l'art, l'humanisme, l'experimentació o l'ètica són assumits per Masats $i$ analitzats exhaustivament en el nostre treball.

Finalment, vam abordar les línies d'investigació plantejades per Masats en la seua pràctica artística. Respecte d'això, cal destacar el desenvolupament per part del nostre autor dels tòpics fotogràfics -molt relacionats amb les imatges de síntesi- on el tema queda tan deconstruit que arriba a la seua substància més elemental. Així mateix, Masats experimenta amb les formes, la geometria, l'enfocament, la velocitat d'exposició... i, en especial, amb les sèries fotogràfiques. La narrativitat d'aquestes el portaran a considerar el llibre fotogràfic (pensem en el seu Neutral Córner, 1962) com una unitat expressiva, generant un llenguatge visual molt semblant al del cine. Masats juga amb la disposició de les seues fotografies en la maquetació del seu llibre Los Sanfermines (1956-1963), generant pla-contrapla, plans subjectius, sèries de moviment... un llenguatge que, amb tota lògica, finalment el portarà a explorar en el món del muntatge cinematogràfic $i$ la direcció de documentals audiovisuals, activitat que va desenrotllar durant quasi vint anys.

\section{ENGLISH}

The oak in the moor: The photographic trajectory of Ramón Masats

This present doctoral thesis approaches the figure of Ramón Masats and his works in his photographic period. From a historical point of view our photographer belonged to a changing generation. This generation revolutionized the Spanish photographic scene in the mid fifties, during Franco's dictatorship. The context of our work talks about the causes and reasons and also the foreign influences, the main characters and the associations, magazines and publishers who participated in this generation crash. Masats was one of the main leaders in this revolution because he participated in the most controversial exhibitions, he published in all the Spanish 
photographic magazines of the moment and he belonged to the three photographic associations where the main critical voices were heard.

In the second part, our thesis analyses the new theoretical concepts which are developed in this period. These concepts are used by Masats but he never talked about them. Our photographer isn't a theoretic. He has always justified his decisions using the bad excuse of intuition and instinct. Nevertheless, we have also studied the influence of his generation partners. They developed topics such as renouncing to pictorial photography or photographic competitions in favour of pure photography. We have studied how Masats uses concepts like professional photography, the usefulness of art, humanitarian photography and ethics.

At last, we approached the investigation lines which Masats uses in his own artistic practice. He has developed photographic topics -related to "summary images"- where the subject is so deconstructed that it reaches its elementary substance. Masats experiments with forms, geometry, focusing, the shutter speed... and, specially, with photographic series. He considers the photographic book an expressive unit (e.g. his book Neutral Corner, 1962). Masats has generated a visual language very similar to cinema. He has played with the position of his photographies in the pages of his book Los Sanfermines (1953-1963). He has generated subjective shots, shots-against-shots, movement series... a language that will take to him to explore the world of cinematography assembly and of audio-visual documentary direction. He carried out this activity during almost twenty years.

Jaime Fuster Pérez 